\title{
LA MODERNIZACIÓN Y EL DESARROLLO SOCIO-ECONÓMICO DEL ECUADOR (1950-1970)
}

\author{
Tesis Doctoral realizada por \\ Dña. ARÁNZAZU MORENO NAVARRO, \\ bajo la Dirección del Prof. Dr. D. Jesús Paniagua Pérez
}

\section{UNIVERSIDAD DE LEÓN}

DEPARTAMENTO DE PSICOLOGÍA, SOCIOLOGÍA Y FILOSOFÍA PROGRAMA DE DOCTORADO: HUMANIDADES Y CIENCIAS SOCIALES 2014 


\section{AGRADECIMIENTOS}

Me gustaría que estas palabras sirvieran para expresar mi más sincero agradecimiento a todas aquellas personas que, con su ayuda, han colaborado en la presente tesis, en especial, al Dr. D. Jesús Paniagua Pérez, director de esta investigación, por su orientación, seguimiento y supervisión de la misma, y también, por su generosidad, motivación y apoyo recibido durante estos años.

Quisiera agradecer al equipo de la Universidad de Johns Hopkins por su colaboración en el aporte de los datos necesarios para la realización de la parte empírica de este trabajo.

Un agradecimiento muy especial merece el ánimo recibido de mi familia.

A todos ellos, muchas gracias. 


\section{ÍNDICE:}

\section{LISTA DE ABREVIATURAS Y SIGLAS}

\section{RESUMEN DE LA TESIS DOCTORAL (abstract)}

\section{REFLEXIÓN GENERAL Y METODOLOGÍA}

\section{INTRODUCCIÓN: EL PENSAMIENTO SOCIAL DE AMÉRICA LATINA EN EL SIGLO}

XX: $1-56$

1.1. El desarrollo y el crecimiento económico en el pensamiento social de América Latina y sus principales corrientes teóricas (1950-1970): El nacionalismo, el marxismo ortodoxo, la teoría de la modernización, la teoría de la CEPAL y la teoría de la dependencia. .1

1.2. El pensamiento social en América Latina y su impacto en las corrientes historiográficas del siglo XX: Etapas de la historiografía latinoamericana moderna.

1.3. El pensamiento social en el Ecuador en el siglo XX: La historiografía ecuatoriana antigua y la historiografía ecuatoriana moderna. .29

1.4. La renovación de la historiografía del Ecuador: Principales influencias, contenidos, instituciones y autores representantes.

\section{CAPÍTULO 1: EL DESARROLLO DEL CAPITALISMO Y EL PAPEL DEL ECUADOR EN LA CONFORMACIÓN DE LA ECONOMÍA INTERNACIONAL CAPITALISTA (1880-1930): $57-181$}

1.1. Antecedentes históricos: La evolución geográfica de la Real Audiencia de Quito al Ecuador del siglo XX.

1.2. La importancia de las clases sociales durante la época liberal y su vinculación al mercado mundial (1880-1895): El papel de la burguesía comercial y los terratenientes en el Ecuador.

1.3. Los modos de tenencia de la tierra y la concentración de la propiedad en la Sierra y la Costa ecuatoriana (1880-1895). $85-120$

1.3.1. El problema de la tierra en el Ecuador y su proceso histórico: Formas de producción en la hacienda serrana y modalidades de trabajo 85 
1.3.2. Sistemas de tenencia, modos de producción y formas de trabajo de los grupos pertenecientes a los latifundios de la Costa ecuatoriana: La hacienda cacaotera. 99

1.3.3. La incorporación de la hacienda serrana y costeña al capitalismo mundial. 110

1.4. El nacimiento del capitalismo en el Ecuador: El enclave cacaotero, el modelo agroexportador y la acumulación del capital durante el liberalismo económico (1880-1925).....

1.4.1. El papel del cacao y el sistema capitalista

1.4.2. La consolidación de la burguesía y la decadencia de la clase terrateniente .151

1.5. Inestabilidad económica y el efecto de la política internacional (1915-1930). $168-181$

1.5.1. La crisis económica y las consecuencias de la Primera Guerra Mundial: La declinación del comercio cacaotero y el impacto en la sociedad ecuatoriana. .168

1.5.2. El proceso de industrialización en el Ecuador: Dificultades para sustituir el modelo agro-exportador.

\section{CAPÍTULO 2: LA EXPANSIÓN DEL SISTEMA CAPITALISTA Y EL DESARROLLO DEL COMERCIO EXTERIOR EN EL ECUADOR (1948-1965):

2.1. Nuevas tendencias en la acumulación del capital ecuatoriano: El banano y su auge exportador (1948-1956).

2.1.1. El modelo de desarrollo agro-exportador y sus características.

2.1.2. Circunstancias históricas y políticas del éxito del banano: El papel del Ecuador en el mercado mundial y sus principales socios comerciales. .188

2.1.3. El modelo agro-exportador y el efecto del comercio del banano en la economía ecuatoriana y en la formación social. 206-235

2.1.3.1. El proceso de desarrollo del comercio bananero. .................................................... 206

2.1.3.2. Tenencia de la tierra y grupos asociados a la producción bananera....................... 222

2.1.3.3. La tenencia de la tierra en la Costa y los grupos vinculados durante el auge bananero: La importancia de la pequeña y mediana propiedad. 228

2.2. La pérdida de auge económico y la nueva etapa de dependencia (1956-1970): 236-265 
2.2.1. El estancamiento de las exportaciones bananeras y problemas del modelo de desarrollo agro-exportador. .236

2.2.2. Las acciones imperialistas y la política en América Latina: El efecto de la Revolución Cubana de 1959. 246

\section{CAPÍTULO 3: LAS POLÍTICAS DESARROLLISTAS DE MODERNIZACIÓN Y SU INCIDENCIA EN LA SOCIEDAD Y ECONOMÍA ECUATORIANA DURANTE LA DÉCADA DE 1960: 266-333}

3.1. La política populista y el impacto de la Revolución Cubana en el Ecuador durante el gobierno de Carlos Arosemena (1961-1963): $266-320$

3.1.1. Las medidas populistas y el agro ecuatoriano a comienzos de los años sesenta:..266-320

3.1.1.1. El gobierno de Arosemena y las modificaciones en la estructura agraria: La eliminación del huasipungo y otras estructuras pre-capitalistas. 266

3.1.1.2. Características de la hacienda en la Sierra ecuatoriana durante la década de los sesenta. 285

3.1.1.3. La clase terrateniente y las modificaciones de la agricultura ecuatoriana. 299

3.1.1.4. Las haciendas lecheras en el Ecuador en los sesenta. 311

3.2. El Gobierno de la Junta Militar en el Ecuador (1963-1966): $320-333$

3.2.1. La dictadura militar y la relación con los Estados Unidos (1963-1964): Las políticas de desarrollo asociado

\section{CAPÍTULO 4: LOS PROYECTOS DESARROLLISTAS EN EL SECTOR AGRÍCOLA:} LA LEY DE REFORMA AGRARIA DE 1964:. 334-385

4.1. La modernización del sector agrícola: La Ley de Reforma Agraria (1964): $334-385$

4.1.1. El papel de la Junta Militar en la expedición de la Ley de Reforma Agraria de 1964: Medidas y objetivos económicos, políticos y sociales 334

4.1.2. La supresión del huasipungo y el reparto de tierras: Una comparativa de las entregas anticipadas de huasipungos y la Ley de Reforma Agraria de 1964 .373 


\section{CAPÍTULO 5: EL SECTOR INDUSTRIAL Y SU VINCULACIÓN A LA ECONOMÍA ECUATORIANA: NUEVAS TENDENCIAS EN LA ACUMULACIÓN DEL CAPITAL}

(1960-1973): $386-456$

5.1. La industrialización y su vinculación al sistema capitalista: El papel del estado y de la burguesía moderna en la conformación de un nuevo modo de desarrollo en la economía ecuatoriana (1963-1970). 386

5.2. Una nueva etapa imperialista: El auge del petróleo, el impulso de la industrialización y la subordinación financiera, comercial y tecnológica (1968-1973). 425

\section{CAPÍTUlo 6: ESTUdio DE CASO Y METOdología: EL DESARROLlO Y} CRECIMIENTO ECONÓMICO DEL ECUADOR (1950-1975): $457-543$

6.1. Antecedentes teóricos y principales enfoques del desarrollo económico y humano de una sociedad: El desarrollo y modernización en el Ecuador.

6.2. Teorías del crecimiento y análisis empírico: Determinantes del crecimiento económico ecuatoriano. 491

CONCLUSIONES: EVALUACIÓN DEL PROCESO DE MODERNIZACIÓN Y DESARROLLO DEL CAPITALISMO EN EL ECUADOR (1950-1970): ..................... 544-556

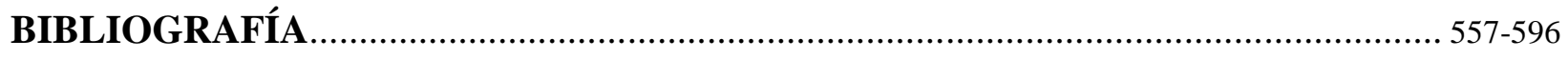

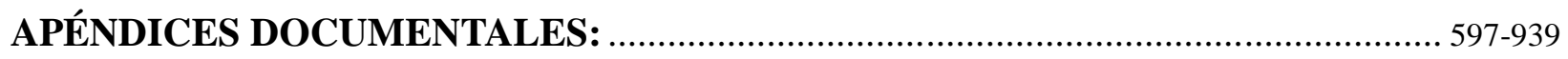

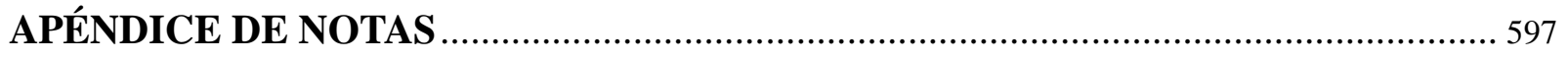

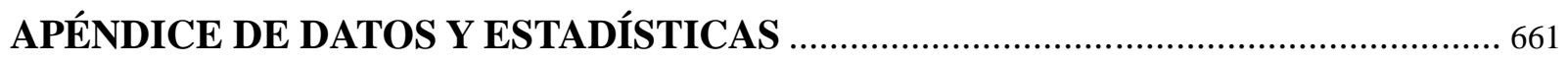

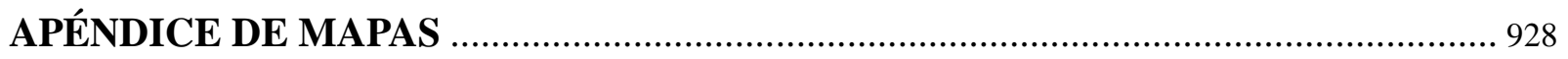




\section{LISTA DE ABREVIATURAS Y SIGLAS}

ACAE: Asociación de Cooperativas Agropecuarias del Ecuador

ADHIEC: Asociación de Historiadores Ecuatorianos

AHC: Archivo Histórico del Guayas

AID: Asociación Internacional de Desarrollo

ANBE: Asociación Nacional de Bananeros del Ecuador

ANCO: Asociación Nacional de Criadores de Ovejas

BID: Banco Interamericano de Desarrollo

CEDEGE: Comisión Ecuatoriana para el Desarrollo de la Cuenca del Río Guayas

CEDOC: Confederación Ecuatoriana de Obreros Católicos

CEN: Corporación Editora Nacional

CENDES: Centro de Desarrollo Industrial del Ecuador

CEPAL: Comisión Económica para América Latina y el Caribe

CIA: Agencia Central de Inteligencia

CIDA: Comité Interamericano de Desarrollo Agrícola

CIH: Centro de Investigaciones Históricas

CLACSO: Consejo Latinoamericano de Ciencias Sociales

CREA: Centro de Reconversión Económica del Austro

CTE: Confederación de Trabajadores del Ecuador

EXIMBANK: Banco de Exportación e Importación

FEI: Federación Ecuatoriana de Indios

FENACLE: Federación Nacional de Campesinos Libres del Ecuador

FENOC: Federación Nacional de Organizaciones Campesinas 
FLACSO: Facultad Latinoamericana de Ciencias Sociales

FMI: Fondo Monetario Internacional

IDIS: Instituto de Investigaciones Sociales

IERAC: Instituto Ecuatoriano de Reforma Agraria y Colonización

IBEC: International Basic Economy Corporation

IIRDUC: Instituto de Investigaciones Regionales de la Universidad de Cuenca

INDA: Instituto Nacional de Desarrollo Agrario

INEC: Instituto Nacional de Estadísticas y Censos

INECEL: Instituto Ecuatoriano de Electrificación

INERHI: Instituto Ecuatoriano de Recursos Hidraúlicos

INIAP: Instituto Nacional de Investigaciones Agropecuarias

ISI: Industrialización Sustitutiva de Importaciones

JUNAPLA: Junta Nacional de Planificación

MAG: Ministerio de Agricultura y Ganadería

OSG: Organizaciones de Segundo Grado

PC: Partido Comunista

PCMLE: Partido Comunista Marxista Leninista del Ecuador

PDC: Partido Demócrata Cristiano

PLPR: Ecuador el Partido Liberal Popular Revolucionario

PSE: Partido Socialista Ecuatoriano

PSRE: Partido Socialista Revolucionario Ecuatoriano

PUCE: Pontificia Universidad Católica del Ecuador

URJE: Unión Revolucionaria de las Juventudes Ecuatorianas 


\section{RESUMEN DE LA TESIS DOCTORAL (abstract)}

La presente tesis tiene como objetivo el análisis y estudio de los principales cambios socioeconómicos ocurridos en el Ecuador durante el desarrollo del capitalismo y su incidencia en el crecimiento de la economía en el periodo comprendido entre 1950-1970.

La revisión del pensamiento social y de las obras de algunos de los autores predominantes de la historiografía ecuatoriana contemporánea nos va a ayudar a responder varios de los interrogantes relacionados con las etapas diferenciadoras, en las que ocurrió la acumulación del capital, la modernización de las estructuras agrarias tradicionales y su inserción en el sistema capitalista, los modelos de desarrollo utilizados por los diversos gobiernos de la época, además de establecer cuál ha sido la contribución de los sectores agrícola, industrial y exterior al crecimiento de la economía ecuatoriana.

Finalmente, esta reflexión de los antecedentes históricos y el análisis de los datos económicos disponibles, no solo nos permitirá elaborar un conjunto de conclusiones finales sobre cuáles han sido los mecanismos de desarrollo más importantes en la sociedad ecuatoriana, sino también tener un mejor entendimiento de la complejidad del problema a estudiar.

$* * * * * * * * * * * * * * * *$

The objective of the present thesis aims at the analysis and study of the major socio-economic changes in Ecuador during the development of capitalism and the impact on its economic growth in the period 1950-1970.

The review of social thought and predominant authors of contemporary Ecuadorian historiography will allow us to answer some of the questions related to the main periods of time when capital accumulation took place in Ecuador. These include the modernization of the traditional agrarian structures, the incorporation of the country into the capitalist system, the development models used by various governments of the time and the contribution of the agricultural, industrial and export sectors to the growth of the Ecuadorian economy.

Finally, the discussion of the historical background and analysis of economic data will give us a better understanding of the complexity of this topic, allow us to establish a hypothesis, and justify the final conclusions related to the main mechanisms of the development of the Ecuadorian society. 


\section{REFLEXIÓN GENERAL Y METODOLOGÍA:}

Al abordar el tema del desarrollo y modernización del Ecuador, es importante realizar una reflexión sobre la evolución de su historia económica, no sólo como un modo de entender el proceso de formación de las relaciones económicas y sociales, sino como un punto de referencia a la hora de proponer soluciones a las dificultades que se puedan encontrar. Con este fin, se establece un conjunto de etapas en el proceso de crecimiento o desarrollo que responde a la interacción entre las causas coyunturales y los cambios estructurales a largo plazo y nos permite analizar cómo se produce el progreso según periodos o áreas geográficas.

Así pues, a modo general, al analizar el concepto de desarrollo, se suele pensar en los cambios producidos en una economía conducentes al incremento del nivel de vida de una población. En el caso de las sociedades capitalistas, este proceso es identificado con el acceso a la modernización y acumulación del capital necesario para aumentar la producción de bienes y servicios y generar un mayor bienestar en la sociedad.

La situación actual del Ecuador es el producto de un proceso histórico, en el que el desarrollo del capitalismo ha tenido un papel fundamental en la aceleración de fenómenos como la globalización del mercado nacional, la urbanización, la eliminación de las formas tradicionales de tenencia de la tierra, la participación del estado en el proceso de acumulación y el desarrollo desigual de la economía y de la sociedad. A su vez, estos fenómenos han sido impulsados por la existencia de fuerzas sociales y políticas que han favorecido a determinadas clases y fracciones, ya que la estructura social ecuatoriana se ha caracterizado desde épocas tempranas por su heterogeneidad y la emergencia de clases antagónicas, las cuales todavía conviven en la actualidad. Teniendo en cuenta estas características económicas y sociales, parece lógico que nos preguntemos cómo se ha llevado a cabo el desarrollo del capitalismo en la sociedad ecuatoriana y cuáles han sido las principales corrientes teóricas que estimularon este sistema.

Precisamente, la revisión de algunas de las teorías fundamentales del pensamiento social de América Latina y de diversas obras pertenecientes a autores representantes de la historiografía ecuatoriana, ha contribuido a la elección del tema de la presente tesis. En este sentido, observamos cómo una parte sustantiva de historiadores y sociólogos se ha caracterizado por su preocupación en especialidades centradas en la cultura ecuatoriana, la historia regional y urbana, el periodo colonial y primeras décadas de la etapa republicana, los héroes de la conquista y de la 
independencia, el estudio del latifundio-minifundio y la hacienda serrana en el Ecuador, entre otros temas, siendo menos habituales las obras centradas en la historia económica del país.

Así, pese al impulso de las diversas corrientes de la época, defensoras de investigaciones de carácter científico, son numerosos los estudios que se han visto condicionados por el desarrollo descriptivo y apenas empírico de la ciencia histórica en el país, quizás, debido a la dificultad para acceder a datos y fuentes estadísticas, hecho que ha sido fundamental a la hora de elaborar esta tesis y aportar datos económicos que muestren el progreso del país.

Se ha de hacer hincapié en los escasos estudios de historia económica relacionados con el Ecuador durante el siglo XX, a excepción del trabajo desempeñado por el Banco Central del Ecuador en la historia económica y la edición de la "Revista Ecuatoriana de Historia Económica", la cual fue discontinuada con el paso del tiempo, y con ello, desapareció de la entidad bancaria este área de interés económico.

La mencionada escasez de datos económicos y estadísticos ha sido un claro obstáculo al análisis de eventos importantes de la historia económica ecuatoriana (la relación entre las economías regionales, los vínculos con el mercado internacional, las etapas de auge y crisis en las economías regionales, etc.), además de suponer un gran impedimento para el entendimiento de otros grandes hechos históricos. En este sentido, la falta de una corriente dentro de la historia económica del país, ha afectado de forma considerable al desarrollo de los estudios históricos debido a la incapacidad para acumular un conjunto importante de conocimientos objetivos sobre el pasado de la economía ecuatoriana.

Por otra parte, a nivel general, dicha cuestión me ha llevado a establecer el propósito del presente trabajo, pues el estudio pormenorizado de las características del proceso de modernización del Ecuador con la ayuda de las fuentes económicas disponibles y la interrelación de los factores sociales, culturales y políticos, ha permitido obtener una visión algo más profunda y causal de las posibilidades de desarrollo y acumulación del capital en el Ecuador entre 1950 y 1970.

De esta forma, al hilo de la idea planteada, al estudiar los rasgos que definen una sociedad y su proceso de acumulación del capital, se pueden apreciar los cambios que de forma paulatina se van produciendo según el grado de desarrollo que alcanzan las condiciones de la producción capitalista. Aquí, la primera pregunta que nos formulamos se refiere a esas posibles condiciones históricas, las cuales no solo contribuyeron al surgimiento del capitalismo en el Ecuador, sino al inicio del desarrollo y modernización del país. 
En este caso, nuestro interés gira en torno a la identificación de diversos momentos históricos en el desarrollo del capitalismo y acumulación del capital en el Ecuador, cuyas diferencias se encuentran en las formas de generación del excedente económico, en los mecanismos de apropiación del mismo y en los beneficiarios y destino de la riqueza acumulada, entre otros factores.

Al realizar esta tarea, llama la atención la existencia de una serie de rasgos comunes en las sociedades latinoamericanas, ya que durante la primera etapa de acumulación de capital (finales del siglo XIX y primeras décadas del XX), estas sociedades se caracterizaron por el uso de un modelo de desarrollo agro-exportador, un débil mercado interno y una escasa industrialización, mientras que la segunda y tercera etapa de acumulación (aproximadamente el periodo 19451970), estuvieron marcadas por un fuerte control estatal y la imposición de un modelo de sustitución de importaciones por industrialización, que perseguía el impulso del desarrollo económico.

La existencia de características afines en dichos países ha constituido otro referente a la hora de elegir este tema, pues además de la necesidad de incorporar datos económicos para explicar el progreso de una economía, el interés de las teorías sociales en América Latina y su preocupación por el desarrollo, me ha llevado a descubrir cómo el pensamiento latinoamericano fue innovador y fomentó el progreso científico en este área del conocimiento a partir de la economía del desarrollo a mediados de los años cuarenta.

La idea de que el estudio de las economías subdesarrolladas (como la ecuatoriana) necesitaba un cuerpo teórico particular que se diferenciara de la teoría económica dominante, surgió a partir de la crisis de la economía neoclásica y la crítica keynesiana, lo cual contribuyó a que el diseño de una teoría económica para los países atrasados, fuera ampliamente aceptado en el campo de las ciencias económicas.

En el caso específico de América Latina, las aportaciones por parte de la Comisión Económica para América Latina y el Caribe durante los años cincuenta, han constituido un modelo a la hora de fomentar el desarrollo del subdesarrollo en la región.

Esta agencia sostenía que América Latina estaba formada por economías nacionales que sólo podían ser comprendidas a través de su inserción en el sistema económico mundial, a partir de una profunda especialización productiva vinculada a la agro-exportación, un escaso desarrollo 
industrial y la importación de bienes de capital procedentes de países desarrollados para satisfacer parte de la demanda interna, tal y como ocurría en el Ecuador.

Para nuestro caso concreto, nos interesa revisar cómo se llevó a cabo el resultado de estos análisis a través de una serie de recomendaciones, las cuales estaban centradas en la eliminación de las insuficiencias de la economía ecuatoriana, una mejor planificación gubernamental del desarrollo mediante el proceso de industrialización, las exportaciones industriales y la reforma agraria.

De este modo, la combinación de estas ideas junto con la identificación de los distintos momentos de acumulación de capital, nos permitirá observar algunas de las limitaciones del sistema capitalista en el Ecuador, demostrándose cómo entre las posibles causas, se encuentra el desarrollo histórico del sistema político e institucional del país.

El contraste y análisis de las diferencias existentes entre una primera etapa, caracterizada por una sociedad tradicional con un sistema de haciendas que dominaba la vida política, económica y social, y un segunda etapa posterior a la década de los cincuenta, en la que se impuso el desarrollismo y los cambios en la sociedad y organización política del país, pone de manifiesto cómo ambos periodos tienen en común la existencia de contradicciones, luchas y alianzas entre las diferentes clases sociales que, buscando imponer su hegemonía en la sociedad para ejercer el control del poder político, no hicieron sino obstaculizar el crecimiento económico y la modernización del país.

\section{METODOLOGÍA:}

Tomando como punto de partida la escasez de trabajos históricos dedicados al estudio de la modernización del Ecuador desde el punto de vista económico, la intención que se persigue en esta tesis, no es otra que la de contribuir al análisis de la historia económica ecuatoriana mediante el uso de una variedad de fuentes estadísticas y económicas, cuya búsqueda ha sido posible gracias a la Universidad de Johns Hopkins y a la Biblioteca del Congreso en Washington D.C, entre otras instituciones.

La combinación de estas fuentes, junto con los elementos históricos disponibles, nos ha permitido lograr una visión más completa del proceso de crecimiento económico en el Ecuador a partir de la evolución del comercio exterior, las reformas del sector agrícola y los avances producidos en el sector industrial durante el periodo 1950-1970. 
Anteriormente, se definía el desarrollo de una sociedad como un conjunto de cambios estructurales que generaban un incremento del nivel de vida de una sociedad, y se afirmaba que en las sociedades capitalistas, este proceso estaba identificado con el acceso a la modernización y la acumulación del capital necesario para aumentar la producción de bienes y servicios y crear un mayor bienestar en la población. Si se parte de la idea de que el crecimiento económico se corresponde con la asociación de la producción industrial y de la innovación técnico-científica, entonces se puede establecer la idea de que este concepto constituye el eje central del proceso de desarrollo de un país.

En el estudio de los modelos de desarrollo del Ecuador (el modelo agro-exportador y el modelo de sustitución de importaciones mediante la industrialización), se va a englobar la problemática existente en relación a la decadencia del comercio exterior agrícola a finales de los años cincuenta, el consecuente agotamiento de la agro-exportación y las reformas de tipo agrario en la década de los sesenta, como factores utilizados para impulsar la transición hacia la industrialización. Así, la Comisión Económica para América Latina afirmaba que la causa principal de la crisis y el atraso de los países latinoamericanos radicaba en el desarrollo hacia afuera que habían tenido dichas economías, es decir, habían sustentado su crecimiento económico en la exportación de bienes primarios agropecuarios o mineros, dejando de lado la producción industrial. Asimismo, esta agencia indicaba que la crisis sólo podría ser superada a través de un desarrollo interior que tuviera como fin la diversificación de la estructura productiva, sustentándose en inversiones nacionales de bienes de consumo y de capital, para lo cual, era necesario abandonar los anacronismos del campo y ampliar la inversión (incluida la extranjera), en tanto se adecuaran los objetivos del desarrollo industrial nacional.

En el Ecuador, la creación de la Alianza para el Progreso fue el instrumento utilizado por la burguesía monopólica industrial y criolla, cuya respuesta económica y política fue la implantación de un conjunto de medidas reformistas para modernizar el capitalismo atrasado ecuatoriano. Entre estas medidas figuraba la aceleración del proceso de industrialización, la realización de una reforma agraria que impulsara el capitalismo e incorporara a las grandes masas campesinas al consumo industrial, y por último, la diversificación de la economía, tomando el desarrollo industrial y las nuevas producciones agrícolas como base del comercio.

Si partimos de la hipótesis en la que se considera el problema del desarrollo ecuatoriano como un problema de crecimiento económico, entendiendo como tal, las restricciones o limitaciones de la 
economía de mercado, sería entonces necesario promover la expansión de la economía de mercado, que viene expresada a través del crecimiento del producto interior bruto (PIB). Para lograr este objetivo, es vital pasar de la producción agropecuaria a la producción industrial, ya que esta funciona como motor del proceso de desarrollo (de ahí la importancia que la industrialización alcanzó en su momento en el Ecuador). De esta forma, a través de la interacción entre tales elementos, se podría impulsar el crecimiento económico, cuyos beneficios distribuidos entre la población, mejorarían significativamente los niveles de vida y la producción del país en cuestión.

Considerando todas estas ideas, nuestro estudio empírico está dividido en dos partes:

En PRIMER LUGAR, en el análisis del desarrollo y la modernización, la revisión de las principales teorías del desarrollo, como ha sido el caso del estructuralismo de la CEPAL, ha puesto de manifiesto que si bien, los proyectos mencionados parecían estar dotados de gran potencial, la realidad de los acontecimientos analizados hasta la década de los setenta, momento de pleno apogeo del desarrollismo, muestran un Ecuador caracterizado por una profunda desigualdad, división política, gran dependencia del capital y tecnología extranjera y altos niveles de analfabetismo, entre otros problemas.

La explicación a este panorama ha de buscarse en la forma en que el Ecuador se integró en el paradigma desarrollista y en cómo los grupos sociales fueron adoptando diferentes posiciones para resolver los conflictos internos, modificando las instituciones sociales y políticas a su antojo y transformando su propia condición a lo largo de dicho proceso de modernización.

Aquí, se han considerado otras teorías políticas y sociológicas del desarrollo que dan gran importancia a los efectos de los factores sociales y políticos mencionados, y permiten explicar los desajustes que establecen la condición de desarrollo o subdesarrollo de un país.

El problema que se expone no se refiere a la exclusión de estos elementos, sino al hecho de que algunas veces se piensa en determinadas sociedades industrializadas y modernas, cuyo fracaso económico puede tener su raíz en la profunda división social y en la naturaleza dictatorial de sus regímenes políticos, como ocurrió en diferentes periodos de tiempo en el Ecuador.

En este sentido, se ha considerado la importancia de otros factores para explicar el concepto de desarrollo como el aspecto humano, la educación y las políticas relacionadas con la libertad de los individuos para tomar decisiones, lo cual pone de manifiesto la necesidad de utilizar la teoría del desarrollo humano debido al fracaso de los planes de desarrollo mencionados en cuanto a 
estabilización, los cuales provocaron el estancamiento de la economía, e hicieron que el peso del ajuste recayera en los grupos más desfavorecidos y pobres.

Para ello, se han tenido en cuenta las ideas de la acumulación de capital humano propuestas por Amartya Sen en su obra "Desarrollo y Libertad" y el Informe sobre el Desarrollo Humano del Programa de las Naciones Unidas para el Desarrollo, en el que se establece el cálculo de un indicador alternativo de desarrollo a nivel mundial, denominado índice de desarrollo humano (IDH).

Este índice está compuesto por el índice de esperanza de vida al nacer, la tasa de alfabetización adulta y la renta real a partir del producto interior bruto, cuyos valores han sido obtenidos a partir de los datos del Banco Mundial. Una vez calculados los índices de cada componente, la determinación del índice de desarrollo humano consiste en el promedio simple de los índices de los tres componentes.

Teniendo como referente las ideas sobre el desarrollo humano, se procederá a calcular dicho índice para el Ecuador y otros países, con el objeto de comparar y establecer una clasificación según los valores mayores y menores del índice de desarrollo humano y ver el lugar ocupado por el Ecuador en el periodo 1960-1980.

Hay que aclarar que la escasez de datos de los años cincuenta ha impedido el cálculo de este índice para dicha década, problema que se plantea también en los sesenta, pese a que se puede calcular el mismo, pero no se incluyen todas las variables seleccionadas. Este obstáculo nos ha llevado a ampliar el periodo desde 1960-1980, puesto que la incorporación de esos datos nos va a ayudar a obtener una idea más precisa sobre la evolución del desarrollo humano en el Ecuador y el puesto que ocupa con respecto a los otros países elegidos.

En SEGUNDO LUGAR, el estudio empírico va a estar centrado en el análisis del crecimiento económico, para lo que se revisarán los posibles factores que han podido ejercer un mayor impacto en el bienestar de una población y determinar el crecimiento de una economía.

Para la elección de estos factores, se han utilizado los estudios realizados por Levine y Renelt ( $A$ sensitivity analysis of cross-country growth regression, 1992) y Durlauf, Johnson y Temple (Growths econometrics, 2005), llevándose a cabo un análisis de correlación y de regresión múltiple.

Una vez analizadas las diferentes variables y clasificaciones, vamos a usar un panel de datos económicos con el que se estimará el modelo dinámico durante el periodo 1950-1980. La falta de 
disponibilidad de datos anuales para algunas de las variables a utilizar, sobre todo de la década de los cincuenta, nos ha obligado a ampliar el periodo de estudio hasta la década de los ochenta. También, en este caso, se podrá observar de una forma más completa el comportamiento de la economía ecuatoriana y determinar cuáles de los factores indicados han ejercido un mayor impacto en su crecimiento.

En nuestro modelo, se utilizará como variable dependiente el crecimiento del producto interior bruto real, cuyos datos proceden de la base Penn World Table Version 6.2 (188 countries, 19502004), compuesta por datos de gasto denominados con un mismo conjunto de precios y una moneda común. En cuanto a las variables independientes, se hará uso de la tasa de crecimiento de la población como promedio de la tasa de crecimiento anual de la población, el precio de la inversión, una medida de apertura de la economía ecuatoriana (promedio de importaciones más exportaciones como porcentaje del PIB), el consumo del gobierno como porcentaje del PIB, la inversión realizada como porcentaje del PIB, cuyos valores también han sido obtenidos de la Penn World Table Version 6.2.

Otras variables independientes son la esperanza de vida al nacer y la población urbana, que han sido obtenidas de la base de datos World Development Data, 2013, el nivel de educación secundaria a partir del estudio de Barro y Lee (International data on educational attainment: Updates and implications, 2000), y el índice de derechos políticos y libertades civiles proporcionado por la Combined Freedom House Index 2013.

Llegados a este punto, se establecen las hipótesis de investigación, para lo cual, se utilizará el manual de Jackson (Statistics: Plain and Simple, 2009) y el de Lehmann y Romano (Testing Statistical Hypotheses, 2008):

- La primera hipótesis (hipótesis nula) establece que la variable dependiente no está influenciada por las variables independientes, es decir, la variabilidad observada en las respuestas es causada por el azar sin influencia de las variables independientes.

- La segunda hipótesis (hipótesis alternativa) se refiere a la contribución significativa de una o más variables independientes a la tasa de crecimiento del producto interior bruto real per cápita del Ecuador.

Finalmente, este análisis nos servirá para apreciar la contribución de las variables al crecimiento de la economía ecuatoriana y cómo esta se ha visto afectada por los altibajos sufridos durante el periodo 1950-1970. 
De todos los factores analizados, se ha de destacar que la desigualdad en la distribución de los ingresos ha sido uno de los elementos que ha limitado el crecimiento de la economía ecuatoriana, ya que tanto en la Sierra como en la Costa, se ha originado un modelo concentrador y excluyente, al encontrarse la mayor parte de los beneficios en manos de un pequeño grupo de personas, mientras que el resto de la población ha vivido con un ingreso mínimo con el que apenas ha podido satisfacer sus necesidades básicas.

Además, los problemas de tenencia de la tierra, la estrechez del mercado interno, la excesiva subordinación con respecto a los capitales foráneos y la dependencia de las exportaciones del sector primario, han originado efectos concentradores en el nivel de ingresos, como se pondrá de manifiesto en esta tesis. 
INTRODUCCIÓN: EL PENSAMIENTO SOCIAL DE AMÉRICA LATINA EN EL SIGLO XX:

1.1) El desarrollo y el crecimiento económico en el pensamiento social de América Latina y sus principales corrientes teóricas (1950-1970): El nacionalismo, marxismo ortodoxo, la teoría de la modernización, la teoría de la CEPAL y la teoría de la dependencia.

Esta tesis tiene como objetivo el análisis y estudio de los principales cambios socio-económicos ocurridos en el Ecuador durante el desarrollo del capitalismo y su incidencia en el crecimiento de la economía en el periodo comprendido entre 1950-1970. La revisión del pensamiento social y de los autores predominantes de la historiografía ecuatoriana contemporánea, nos ayudará a responder las siguientes preguntas: ¿Cuáles fueron las principales etapas diferenciadoras en las que tuvo lugar la acumulación del capital en Ecuador durante el periodo establecido? ¿Cómo se produjo la modernización de las estructuras agrarias tradicionales y su inserción en el sistema capitalista? ¿Qué modelos de desarrollo fueron utilizados por los diversos gobiernos de la época? ¿Cuál ha sido la contribución de los sectores agrícola, industrial y exterior al crecimiento de la economía ecuatoriana?

Cuando se estudia el proceso de desarrollo de una sociedad, es importante realizar una reflexión sobre la evolución de su historia económica, no sólo como un modo de entender el proceso de formación de las relaciones económicas y sociales, sino como un punto de referencia a la hora de proponer soluciones a las dificultades que se puedan plantear. Con este fin, se establece un conjunto de etapas en el proceso de crecimiento o desarrollo económico de una sociedad que responde a la interacción entre las causas y los cambios estructurales a largo plazo, para analizar cómo se produce el progreso según periodos o áreas geográficas.

En este sentido, el interés en torno al concepto de desarrollo como objeto de estudio, surgió tras el final de la Segunda Guerra Mundial (1939-1945), momento en el que se fueron estableciendo algunas disciplinas para el análisis de las sociedades latinoamericanas a partir de las múltiples dimensiones de este concepto. Por aquel entonces, los países de esta región sufrían situaciones de inestabilidad institucional con frecuentes dictaduras militares y democracias ficticias, cuyas economías estaban basadas en la exportación de productos primarios, una escasa industrialización y estructuras de poder formadas por oligarquías anticuadas y con problemas 
sociales, especialmente de marginación. ${ }^{1}$ La comprensión de este complejo conjunto de fuerzas, que dio forma a los países latinoamericanos y que usualmente repercutía en las posibilidades de desarrollo de estas sociedades, se alternaba con la necesidad de establecer un camino que facilitara una mejora de esta situación, de ahí el interés del pensamiento latinoamericano en este tema. ${ }^{2}$ Teniendo en cuenta las características de estas sociedades y asumiendo la existencia de una correlación entre el desarrollo y el crecimiento económico de un país, ¿a qué nos referimos cuándo hablamos del "crecimiento económico"?

El Banco Mundial define este término como la expansión de una economía o los cambios cualitativos que se pueden producir en un país y que son medidos a través del aumento porcentual del producto interior bruto. ${ }^{3}$ Asimismo, considera al desarrollo como la fase de crecimiento de una economía, durante la cual tienen lugar una serie de cambios estructurales conducentes al incremento del nivel de vida de una población. Este proceso es identificado en las sociedades capitalistas, como el acceso a la modernización y acumulación del capital necesario para aumentar la producción de bienes y servicios y generar un mayor bienestar en la sociedad. En este caso, ¿cómo se define el concepto de "modernidad” o "modernización”? ¿cómo se puede explicar el crecimiento y desarrollo de las sociedades latinoamericanas y en particular del Ecuador, si se toma como referencia la idea de "modernización" y de "acumulación de capital"? Existe un amplio debate en torno al surgimiento del concepto de "modernidad", pero si nos guiamos por las ideas de Marx, podemos ubicar su origen en el siglo XVI, al que Fernando Braudel denomina como el largo siglo XVI, al considerar el periodo que comienza en 1450 y que termina en 1650, como parte del mismo. ${ }^{4}$ Es decir, a partir de la expansión del sistema manufacturero capitalista que se da en Europa durante este largo siglo XVI, comienza a

\footnotetext{
${ }^{1}$ Ver la tabla 1 (Dictaduras en América Latina 1945-1965) en el apéndice de datos de la introducción.

${ }^{2}$ Alfredo Falero: El paradigma renaciente de América Latina: Una aproximación sociológica a legados y desafíos de la visión centro-periferia, en "Crítica y teoría en el pensamiento social latinoamericano", Consejo Latinoamericano de Ciencias Sociales (CLACSO), Buenos Aires, agosto 2006, p. 217-280.

${ }^{3}$ Banco Mundial: Más allá del crecimiento, Grupo del Banco Mundial, 2002, www.worldbank.org

${ }^{4}$ Marx habla de esta época como "la era del capital en el siglo XVI" en su obra: "El capital". Esta idea también es compartida por Immanuel Wallerstein en su libro El moderno sistema mundial, Tomo I, Ed. Siglo XXI, México, 1979, y en Immanuel Wallerstein: The West, the Capitalism and the Modern World-System, Review, vol. XV, num. 4, Fall 1992; Fernand Braudel: Expansión europea del capitalismo (1450-1650)", en el libro "Les ecris de Fernand Braudel, Les ambitions de l'histoire", Editions de Fallois, Paris, 1997.
} 
afirmarse también en varios planos de la sociedad las primeras formas características del modo de producción capitalista y las distintas expresiones de la sociedad burguesa moderna. ${ }^{5}$ Aunque vamos a hablar de las clases sociales de América Latina en el capítulo 1, es necesario llevar a cabo una primera aproximación al tema para elaborar una teoría de la historia latinoamericana. De este modo, se podrá tener una idea del estudio de sus peculiares procesos de lucha de clases y, probablemente, se evite el error de trasladar completamente el modelo europeo a América Latina en cuanto al comportamiento de las clases.

Por otro lado, la ausencia de una teoría adecuada de las clases sociales para los regímenes precapitalistas dificulta el análisis histórico, tanto de Europa como de América Latina y otros lugares, especialmente de su periodo colonial y republicano durante el siglo XIX. Así, la teoría de las clases fue elaborada para comprender el mecanismo de funcionamiento del sistema capitalista, en el que se establecieron tres clases sociales: la burguesía, la clase trabajadora y la pequeña burguesía (se incluyen las capas medias asalariadas dentro de la clase trabajadora porque venden su fuerza de trabajo). ${ }^{6}$

En las sociedades industrializadas, la tendencia a la polarización entre dos clases (burguesía y proletariado) tiene una mayor predominancia que en los países coloniales dependientes. Esto justifica la necesidad de profundizar en la estructura de clases de América Latina, donde junto a la burguesía y a la fuerza de trabajo industrial, se encuentra la fuerza de trabajo rural, minera y urbana, un elevado campesinado pobre, una pequeña burguesía rural y urbana, además de las comunidades indígenas. Asimismo, la definición de las clases en América Latina ha de considerar la relación etnia-clase, ya que sería bastante difícil explicar la lucha de clases, el modo de vida y la cultura latinoamericana si se ignora su estudio.

Durante los siglos XIX y XX, se ha dado prioridad a las relaciones de clase sobre las de etnia, especialmente a partir de la segunda colonización de la frontera, pues los despojos de tierra obligaron a los indígenas a la proletarización forzada. En este caso, con la expropiación de las tierras y la venta de la fuerza de trabajo, el tema de la clase se combinó con el problema étnico de las nacionalidades indígenas, al enfrentarse a la clase dominante como opresora de sus etnias y a la burguesía como clase explotadora. De este modo, la relación etnia-clase, a medida que

\footnotetext{
${ }^{5}$ Alfredo Falero, op. cit., p. 217-280.

${ }^{6}$ Ibíd. p. 215-280.
} 
evolucionaba el propio sistema de dominación capitalista, llegó a adquirir nuevas formas, especialmente en el siglo XX, puesto que los conflictos étnicos han venido a ser una expresión procedente de fenómenos clasistas, adquiriendo una dinámica con autonomía propia que influye de manera particular sobre el conflicto de clases. ${ }^{7}$

La situación actual de América Latina y la modernización de sus sociedades constituye un tema que ha de ser abordado desde un punto de vista histórico, en el que el desarrollo del capitalismo ha tenido un papel fundamental en la aceleración de la globalización del mercado nacional, la urbanización, la eliminación de las formas tradicionales de tenencia de la tierra, la participación del estado la acumulación de capital y el desarrollo desigual de la economía y de la sociedad. También, estos fenómenos han sido impulsados por la existencia de fuerzas sociales y políticas que han favorecido a determinadas clases y fracciones, puesto que la estructura social latinoamericana se ha caracterizado desde épocas tempranas por su heterogeneidad y por la aparición de clases contradictorias (burguesía y campesinos), que aún existen en la sociedad actual.

Considerando que uno de los principales objetivos que se persigue es el estudio de la evolución económica de la sociedad ecuatoriana durante el siglo XX, es lógico que nos preguntemos cuáles han sido las principales aportaciones del pensamiento social latinoamericano en relación al desarrollo y a los problemas de inestabilidad y atraso de esta región. Además, al hablar del proceso de modernización del Ecuador, es necesario identificar las diferentes etapas de ese pensamiento en el siglo XX, durante las cuales surgieron diversas teorías centradas en la explicación de estos conceptos.

Por consiguiente, la primera etapa a citar, comprende la segunda mitad del siglo XIX hasta la Segunda Guerra Mundial (1939-1945) y se caracteriza por su pensamiento positivista. La segunda etapa abarca el periodo desde la Segunda Guerra Mundial hasta finales de la década de los setenta, y está definida por una cierta autonomía lograda por el pensamiento latinoamericano y sus distintas corrientes teóricas. Por último, el periodo comprendido entre 1980-1990, en el que el pensamiento latinoamericano sufre un retroceso tras imponerse las ideas conservadoras y neoliberales.

\footnotetext{
${ }^{7}$ Ibíd. p. 217-278.
} 
Hay que señalar que la etapa correspondiente a este proyecto es la que tiene lugar durante los años 1950-1970, momento en que se consolidarán diversos pensamientos que ponen en evidencia la complejidad de la realidad latinoamericana. ${ }^{8}$ ¿Cuáles fueron los rasgos fundamentales que caracterizaban la teoría social de esta época? ¿cuál era el objetivo perseguido teniendo en cuenta las características y los problemas sociales existentes en las sociedades latinoamericanas?

La teoría social en América Latina durante la segunda mitad de los años sesenta y los inicios de los setenta, se caracterizó por estudios relacionados con la problemática de la dependencia y por la incorporación de esta idea al campo del marxismo, lo cual fue una tarea difícil y repleta de contradicciones. A este respecto, se ha de indicar la existencia de varios procesos que marcaron la historia y el camino de las ciencias sociales latinoamericanas en esta década.

Entre estos acontecimientos, hay que destacar el de la Revolución Cubana de 1959, que fue uno de los principales elementos de las teorías del momento, pues profundizó la crisis política del marxismo ortodoxo dominante en América Latina y los problemas fundamentales del capitalismo latinoamericano durante los años anteriores a dicha revolución.

Jaime Osorio indica que el proceso cubano tuvo como efecto una profundización de la crisis política y teórica del marxismo dominante en los partidos comunistas:

Aferrado al evolucionismo en la interpretación de los modos de producción y la alianza del movimiento popular con la burguesía industrial, en aras de desarrollar un capitalismo con vocación revolucionaria que rompiera con los supuestos cotos feudales existentes, esta corriente marxista poco había aportado en las décadas previas a la gesta cubana a la interpretación de los problemas fundamentales del capitalismo latinoamericano... ${ }^{9}$

La Revolución Cubana puso en evidencia la escasa productividad de estas reflexiones y dio paso a una nueva forma de pensar sobre la situación latinoamericana, cuya referencia era el marxismo. Además, fomentó el auge de nuevas asociaciones políticas que enfatizarían el socialismo y la lucha armada, facilitando de este modo, la incorporación de los estudios marxistas de la dependencia en las ciencias sociales de América Latina.

\footnotetext{
${ }^{8}$ Ibíd. p. $216-280$.

${ }^{9}$ Jaime Osorio Urbina: El marxismo latinoamericano y la dependencia, Cuadernos políticos, número 38, Ediciones Era, México, D.F., enero-marzo 1984, p. 40-59.
} 
Tampoco, se puede olvidar las influencias del nacionalismo en el pensamiento social de la época, ya que desde su nacimiento, coincidente con el fin de la época colonial, se fue creando una identidad específica americana, cuya fuente de inspiración fue la ideología liberal de la Revolución Francesa y de la experiencia norteamericana. ${ }^{10}$ Posteriormente, durante los primeros años del siglo XX, el nacionalismo comenzó a incorporar nuevos factores que, aún cuando eran elementos clásicos en la formación del concepto nacionalista (la religión, la raza, y la identidad cultural), llegaron a tener como objetivo su diferenciación, no en cuanto a los países vecinos, sino a un nuevo elemento, el imperialismo, especialmente el norteamericano y el británico.

Aquí, es necesario aclarar que desde mediados del siglo XIX, el pensamiento latinoamericano se ha venido caracterizando por su interés en la modernización y la identidad. En el caso de los aspectos modernizantes, estos van cambiando y se van adaptando según las cuestiones específicas de aquellos países más avanzados. Esto explica el gran interés por seguir el ejemplo de los países más desarrollados (pueden impulsar la modernización) y del mayor énfasis en lo tecnológico y lo mecánico, en perjuicio de lo cultural y lo humanista, además de despreciarse la cultura popular. Este positivismo, favorecedor de la racionalidad científica, propuso el modelo sajón cultural y económico, siendo Inglaterra y Estados Unidos, los países a imitar. ${ }^{11}$

Frente a esto, se observa la existencia de un grupo de autores hispanoamericanos, cuyo objetivo era transformar la sociedad latinoamericana, despojándola de su herencia colonial española, puesto que representaba la causa de todos los males. A esta generación pertenecen los argentinos Esteban Echevarría, Domingo Sarmiento y Juan Bautista Alberdi, el ecuatoriano Juan Montalvo, el mexicano José María Luis Mora y algunos más procedentes de otros países hispanoamericanos. $^{12}$

En cuanto a los elementos propios del proyecto de identidad, se destacan la reivindicación y defensa de los rasgos propios (lo americano y lo indígena), la valoración de lo cultural, lo

\footnotetext{
10 Cayetano Núñez Rivero; María Núñez Martínez: Los orígenes de las grandes corrientes ideológicas latinoamericanas: El socialismo, el nacionalismo y el populismo, UNED, Boletín de la Facultad de Derecho, núm. 26, 2005, p. 1-43.

${ }^{11}$ Ibíd., p. 5-43.

${ }^{12}$ Leopoldo Zea: El positivismo en Hispanoamérica. El positivismo como filosofía para un nuevo orden, Edición digital basada en la tercera edición (Ariel, Barcelona, 1976), diciembre 2003.
} 
artístico y lo humanista, así como la falta de intervencionismo de los países más desarrollados, es decir, la reclamación de la independencia y la liberación.

No obstante, pese a las diversas etapas en las que se combinan los rasgos modernos con los de la identidad, es importante indicar que en cada uno de los movimientos que van surgiendo, existe un destacado sentido de identidad, incluso en aquellos donde parece menos claro. Eduardo Deves indica que el arielismo, el nacionalismo, el paganismo y el latinismo, marcan un afán de reivindicación de lo propio en oposición al sajonismo invasor. ${ }^{13}$

También, en esta línea, el nacionalismo se combina con temas psicológicos, geográficos y étnicos, perdurando en cierto modo, los patrones ideológicos europeos del siglo XIX. De esta manera, aparecen nuevas tendencias que abordan cuestiones como la crisis moral, la decadencia de la nacionalidad y el caudillismo, entre otros, las cuales intentan explicar estos fenómenos a partir de lo hispano, el cual sigue siendo percibido como el motivo de los problemas de las naciones latinoamericanas.

Por otra parte, las modificaciones en el nacionalismo latinoamericano continuaron produciéndose a raíz de la crisis de 1929, ya que esta ocasionó una importante recesión en las exportaciones de los países latinoamericanos y disminuyó las posibilidades de importación de productos industriales para su desarrollo, originando una contracción del mercado interno. ${ }^{14}$ La consecuencia de dichos acontecimientos fue el nacimiento de un nacionalismo de carácter económico y autárquico, que buscaba sustituir los productos extranjeros por los nacionales mediante el desarrollo de una industria protegida y planificada por el estado. De forma paralela, fueron surgiendo movimientos tendentes a la recuperación de la riqueza nacional que se hallaba en manos de empresas extranjeras (norteamericanas y británicas). ${ }^{15}$

Este movimiento recibió un gran impulso durante los años posteriores a la Segunda Guerra Mundial, siendo el desarrollo de una industria nacional y la crisis económica, algunos de los

\footnotetext{
${ }^{13}$ Eduardo Deves Valdés: El pensamiento latinoamericano a comienzos del siglo XX: La reivindicación de la identidad, CUYO, Anuario de filosofía argentina y americana, número, 14, 1997, p. 11-75.

${ }^{14}$ El Ecuador, al igual que la gran mayoría de los países latinoamericanos, se caracterizó por una escasa industrialización y una fuerte tendencia al modelo agro-exportador, cuyo eje de acumulación de capital fue el cacao, para después centrarse en las exportaciones del banano tras la depresión de 1929.

${ }^{15}$ Eduardo Deves Valdés, op. cit. p. 11-75.
} 
elementos que motivaron grandes desplazamientos de la población agraria a las grandes ciudades, hecho que provocó numerosos conflictos sociales y económicos.

Como consecuencia de este proceso y de la ampliación del sufragio, comenzaron a surgir grandes partidos de militantes de ámbito nacional con un carácter diferente a los viejos partidos oligárquicos, ya que incorporaban sectores de la población que habían estado marginados de la actividad política (como era el caso de las comunidades indígenas, las cuales habían estado apartadas de los centros de decisión estatal). Los nuevos partidos tenían como símbolo el antiimperialismo norteamericano y desarrollaban ideologías con rasgos nacionalistas, por lo que su incorporación logró transformar el concepto de estado nacional dándole un carácter más amplio. $^{16}$

Estos acontecimientos fueron impulsados por la Revolución Cubana, que desde un primer momento apoyó al movimiento nacionalista, defendiendo la importancia de los mercados internos, la creación de las instituciones necesarias que aseguraran la estabilidad social y política y la estructuración de un régimen de economía mixta, apoyado en la intervención del sector público y en la creación y distribución de la riqueza. ${ }^{17}$

Los defensores de esta corriente, fieles seguidores de un nacionalismo desarrollista, aceptaban el capitalismo nacional en oposición al capitalismo dependiente, lo que contribuyó a que el aparato estatal se extendiera debido a la influencia de estas ideas en las políticas públicas durante la segunda mitad del siglo XX. ${ }^{18}$

Por otra parte, la producción académica en ciencias sociales se inclinó por un conjunto de nuevas corrientes teóricas de gran importancia para el campo económico, la sociología y las ciencias políticas, como consecuencia de la preocupación que existía en torno al desarrollo. En este

\footnotetext{
${ }^{16}$ Ver el apéndice de notas de la introducción para más información. Fuente: Manuel Alcántara: El origen de los partidos políticos en América Latina, Instituto de Ciencias Políticas y Sociales, WP, número 187, Barcelona, 2001, p. 3-30.

${ }^{17}$ Eduardo Deves Valdés, op. cit., p. 11-75.

${ }^{18}$ Octavio Ianni: Los Estados Unidos y el militarismo latinoamericano, Revista Mexicana de Sociología, Vol, 30 , No 3, Universidad Nacional Autónoma de México, jul-sept, 1968, p. 522-524.
} 
sentido, el pensamiento latinoamericano fue innovador y fomentó el progreso científico, siendo la economía del desarrollo, el eje de este campo de estudio a mediados de los años cuarenta. ${ }^{19}$ El aspecto fundamental que dio continuidad a los diversos enfoques que dominaban esta subdisciplina, fue la convicción de que el estudio de las economías subdesarrolladas (como la ecuatoriana) necesitaba de un cuerpo teórico específico diferente de la teoría económica dominante. La crisis de la economía neoclásica y la crítica keynesiana a sus hipótesis fundamentales en la década de los treinta, contribuyó a la aceptación de una teoría económica diseñada para los países atrasados. ${ }^{20}$

Más allá de estas ideas, las diferencias en la caracterización de este campo de estudio crearon un conjunto de pensadores con ideas distintas. El grupo predominante en el debate internacional estaba formado por algunos economistas anglosajones, los cuales defendían la teoría ricardiana de las ventajas comparativas y los beneficios del comercio internacional. ${ }^{21}$

Según Hirschman, el elemento común era la idea del "beneficio mutuo", es decir, estos autores estaban convencidos de que las relaciones económicas entre los países desarrollados y subdesarrollados podían ocurrir para que ambos resultaran beneficiados. ${ }^{22}$

Dentro de este grupo, hay que señalar la existencia de dos subgrupos teóricos: el primero, que comprendía a los pioneros en la disciplina, entre los que destacaba Rostow, cuya influencia teórica provenía del modelo de crecimiento Harrod-Domar, a través de la cual se establecía la posibilidad de que los países atrasados pudieran incorporarse a una vía de "crecimiento equilibrado" mediante la intervención pública en la coordinación y el impulso de la inversión en la economía. En su obra, Rostow introdujo la versión más extrema de este enfoque, al reducir el

\footnotetext{
${ }^{19}$ Cecilia Nahón, Corina Rodríguez Enríquez, Martín Schorr: El pensamiento latinoamericano en el campo del desarrollo del subdesarrollo: Trayectoria, rupturas y continuidades en "Crítica y teoría en el pensamiento social latinoamericano", Consejo Latinoamericano de Ciencias Sociales (CLACSO), 2006, p. 327-379.

${ }^{20}$ Ibíd., p. 325-379.

${ }^{21}$ La teoría de la ventaja comparativa o principio de resource endowment de David Ricardo, explica la tendencia exportadora del Ecuador en los últimos años del siglo XIX y durante el siglo XX, con respecto al cacao, al banano y al petróleo, productos que determinaron un apogeo sin precedentes en la historia de este país. Ver: José Corsino Cárdenas: Ensayo histórico de la economía ecuatoriana, Biblioteca de Historia Económica, Banco Central del Ecuador, 1995, p. 19.

${ }^{22}$ A. Hirschman: Auge y ocaso de la teoría económica del desarrollo, en El Trimestre Económico, México DF, ${ }^{\circ}$ $188,1980$.
} 
desarrollo nacional a un proceso lineal, universal y dividido en cinco etapas por las que debían de pasar todas las economías nacionales en su camino desde la tradición a la modernidad. ${ }^{23}$

El segundo grupo, formado por economistas como Myrdal y Hirschman, tuvo una mayor afinidad con el pensamiento sobre las ideas de desarrollo que predominaban en este momento en América Latina. ${ }^{24}$ Estos autores expusieron una visión menos armónica del proceso de desarrollo, cuestionando la hipótesis del "crecimiento equilibrado" de los países en vías de desarrollo. Además, sus ideas defendían la intervención gubernamental para la protección de los mercados, el apoyo a la industria y la planificación sectorial de las inversiones, entre otras funciones primordiales. $^{25}$

El campo del desarrollo hizo que la reflexión científica sobre el capitalismo dejara de considerar únicamente a las sociedades más avanzadas, siendo las economías atrasadas, el nuevo centro de atención, en particular, en el nivel latinoamericano. En este sentido, la otra disciplina de las ciencias sociales de esta época fue la "sociología del desarrollo", la cual asumió la continuidad del desarrollo capitalista mundial, intentando demostrar que las naciones tercermundistas eran capaces de superar los obstáculos que impedían su avance y de alcanzar el mismo nivel de desarrollo que los países desarrollados. ${ }^{26}$

Entre las aportaciones a este campo se encuentra la del sociólogo José Medina Echavarría, que introdujo la visión de la sociología en los problemas del desarrollo económico. Hasta el momento, el desarrollo se caracterizaba por un conjunto de ideas dirigidas exclusivamente desde el punto de vista económico, por lo que el trabajo de Medina logró ampliar esa percepción mediante los trabajos realizados por economistas de la Comisión Económica para América Latina y el Caribe (CEPAL), cuyos propósitos explicaremos a continuación. ${ }^{27}$

Por otro lado, hay que señalar la influencia en esta doctrina de la llamada sociología científica durante su etapa de formación, así como la de la teoría de la modernización y su esquema en

${ }^{23}$ W. Rostow: The stages of economic growth, Cambridge University Press, 1980, p. 20-250.

${ }^{24}$ G. Myrdal: Economic Theory and Underdevelopment, London: Duckworth, 1957, p. 10-70; A. Hirschman: The Strategy of Economic Development, Yale: Yale University Press, 1958.

${ }^{25}$ J. Fiori: Estados y modos de desenvolvimiento de las naciones, São Paulo: Vozes, 1999.

${ }^{26}$ Cecilia Nahón, Corina Rodríguez Enríquez, Martín Schorr, op. cit., p. 327-379.

${ }^{27}$ Juan J. Morales Martín: José Medina Echavarría y la sociología del desarrollo, Íconos, Revista de Ciencias Sociales, Núm. 36, Quito, Facultad Latinoamericana de Ciencias Sociales-Sede Académica de Ecuador, enero 2010, p. 133-146. 
relación al campo del desarrollo. ¿En qué consistía esta teoría de la modernización y cómo fomentó el estudio del desarrollo?

La teoría de la modernización, representada fundamentalmente por Talcott Parsons, tenía como base teórica el funcionalismo estructural, siendo su punto principal de partida, la presentación de una división entre dos tipos ideales de sociedades que implicaban los siguientes pares de conceptos: moderno-tradicional, avanzado-atrasado, desarrollado-subdesarrollado. ${ }^{28}$ Esta teoría afirmaba que todos los países atravesaban las mismas fases en su proceso de desarrollo histórico, siguiendo un único camino que permitía pasar de un polo a otro. El uso de diferentes tipos de estructuras sociales proporcionaba información sobre las modificaciones de las formas de organización mediante el análisis de la interacción entre el cambio social y el desarrollo económico. $^{29}$ A través de este sendero, las sociedades podían diferenciarse unas de otras conforme iban superando sus elementos más tradicionales, a la vez que adoptaban las características de las sociedades más avanzadas. ${ }^{30}$

A partir de esta idea, la teoría de la modernización comenzó a investigar de qué forma los países podían pasar de una fase a otra, con el fin de establecer los factores que pudieran facilitar el desarrollo de los países atrasados. Esta investigación implicaba tanto el estudio de los procesos de desarrollo histórico de los países industrializados, como el análisis de las estructuras sociales de las sociedades en vías de desarrollo, lo que permitía establecer cuáles eran los aspectos que podían explicar la ausencia de desarrollo y los requisitos necesarios para fomentarlo.

En esta búsqueda, se incorporó el análisis de los factores culturales, sociales, institucionales y políticos que facilitaban o retrasaban el camino de estos países hacia niveles más avanzados y que se encontraban fuera del análisis de la economía del desarrollo. A la vez, esta incorporación impulsó la elaboración y utilización de nuevas variables de carácter sociológico que comenzaron a complementar al producto interior bruto, al ser utilizadas como indicadores del desarrollo. ${ }^{31}$

\footnotetext{
${ }^{28}$ T. Parsons: El sistema social, Madrid: Alianza, 1966, p. 25-457.

${ }^{29}$ C. Leys: The rise and fall of development theory, London: James Currey, 1996, p. 30-185.

30 Jorge Larrain: Theories of development: Capitalism, colonialism and dependency, London: Polity, 1998, p. 18190.

${ }^{31}$ Cecilia Nahón, Corina Rodríguez Enríquez, Martín Schorr, op. cit., p. 327-379.
} 
Por otra parte, dentro de la economía del desarrollo se puede encontrar la escuela del estructuralismo, que también aportó carácter propio al pensamiento latinoamericano dentro del campo del denominado "desarrollo del subdesarrollo". La característica fundamental de este grupo con respecto a los que predominaban a nivel internacional, fue su rechazo a la teoría de David Ricardo sobre las ventajas comparativas y de los beneficios del comercio internacional, en especial para el caso de las economías subdesarrolladas. Por consiguiente, ¿cuáles eran los rasgos principales del estructuralismo y del desarrollo del subdesarrollo?

Ocampo destaca que el elemento diferenciador del estructuralismo latinoamericano, se encontraba en la forma en que las instituciones y la estructura productiva condicionaban la dinámica económica de los países subdesarrollados y generaban comportamientos diferentes a los de las naciones más desarrolladas. ${ }^{32}$ En contraposición a las ideas de Rostow, este método analítico enfatizaba que las etapas de desarrollo uniformes no existían, ya que el desarrollo tardío de los países de América Latina creaba una dinámica diferente de las naciones que habían experimentado un desarrollo más temprano.

El nacimiento de este campo de estudio (el desarrollo del subdesarrollo) se produjo a mediados del siglo XX, en el contexto de la reconstrucción europea tras la Segunda Guerra Mundial y la creación del sistema internacional de Bretton Woods. Los primeros representantes del campo del desarrollo fueron los mercantilistas, quienes a pesar de no poseer un conocimiento teórico que apoyara sus ideas políticas, expusieron sus sugerencias prácticas con el fin de favorecer el crecimiento económico. Sin duda, Adam Smith con su obra La riqueza de las naciones (1776), fue el primer estudio científico sobre los determinantes del desarrollo capitalista y sobre el papel desempeñado por el estado en este proceso. Las obras de Ricardo y de Marx, entre otros, completaron desde distintas perspectivas los primeros pasos del campo del desarrollo en su pensamiento. $^{33}$

A su vez, Larrain indica que el campo del desarrollo es un concepto vinculado a la discusión y reflexión teórica sobre las causas de la aparición del capitalismo (durante los siglos XVI y

\footnotetext{
32 J. Ocampo: Cincuenta años de la CEPAL, en Revista de la CEPAL (Santiago de Chile), Número extraordinario, 1998.

${ }^{33}$ Cecilia Nahón, Corina Rodríguez Enríquez, Martín Schorr, op. cit., p. 327-379.
} 
XVIII), siendo la economía política, la disciplina encargada del estudio científico de sus leyes. ${ }^{34}$ La novedad de este campo se basaba en los cambios producidos en el estudio sobre el desarrollo, ya que el interés se había desplazado desde las regiones más ricas e industrializadas a las menos desarrolladas.

Entre los aspectos fundamentales incorporados por el desarrollo del subdesarrollo, se encontraba la búsqueda de políticas que potenciaran el desarrollo en un tipo particular de sociedad (las llamadas sociedades en "vías de desarrollo") y el análisis de las causas de los procesos de desarrollo social, económico y político. Además, este nuevo campo no suponía únicamente una simple reflexión analítica, ya que implicaba el diseño de un conjunto de políticas y medidas capaces de facilitar la superación de la situación de subdesarrollo, tal y como ocurrió en los países atrasados con la creación de una considerable cantidad de instituciones estatales, universitarias e internacionales. $^{35}$

En el caso específico de América Latina, se ha mencionado la existencia de una agencia de desarrollo, la cual se destacó por sus principios teóricos y sus ideas de política económica a principios de los años cincuenta. Se trataba de la Comisión Económica para América Latina y el Caribe (CEPAL), la principal institución latinoamericana creada para fomentar el desarrollo del subdesarrollo, además de impulsar el estructuralismo a partir del rechazo de la teoría ricardiana dominante fuera de la región.

El pensamiento teórico y práctico de la CEPAL se caracterizaba por su procedencia vinculada a las ciencias sociales latinoamericanas y por su influencia en el campo del desarrollo del subdesarrollo. Su máximo representante fue su secretario general, Raúl Prebisch, que pertenecía al grupo de economistas keynesianos como Celso Furtado, Aníbal Pinto, Aldo Ferrer y Víctor Urquidi. $^{36}$

Las ideas de esta institución impulsaron la creación de una teoría que lograra comprender las posibilidades de la región y los diferentes caminos que se podían establecer para conseguir su

\footnotetext{
${ }^{34}$ Jorge Larrain, op. cit., p. 18-190.

${ }^{35}$ Cecilia Nahón, Corina Rodríguez Enríquez, Martín Schorr, op. cit., p. 327-379.

${ }^{36}$ Entre sus obras se encuentran: Raúl Prebisch: La CEPAL y los problemas del desarrollo económico en América Latina, Santiago: CEPAL, 1960, v. 2, fascículo 51, 17, en Raúl Prebisch: "Discursos, declaraciones y documentos" 3 v.1952-1963; El desarrollo económico de la América Latina y algunos de sus principales problemas, Santiago: CEPAL, 87 p. E/CN.12/89, 1949.
} 
desarrollo, hecho que implicaba la incorporación de nuevos argumentos intelectuales. Así, en 1949, durante la conferencia de la CEPAL en La Habana, se presentó su informe conocido como el "Manifiesto", aunque no fue hasta 1962, año en que apareció el artículo El desarrollo económico de la América Latina y algunos de sus principales problemas, en el que Prebisch expuso su idea de la relación centro-periferia. ${ }^{37}$

La CEPAL afirmaba que América Latina estaba formada por economías nacionales, que sólo podían ser comprendidas a través de su incorporación en el sistema económico mundial, y que se caracterizaban por una excesiva especialización productiva vinculada a la elaboración de productos agrícolas, un escaso desarrollo de las industrias y la importación de bienes de capital para satisfacer parte de la demanda interna, tal y como ocurría en el Ecuador. La idea de centroperiferia estaba asociada al intercambio desigual procedente del progreso técnico de los centros industriales, su aumento de productividad y su capacidad para establecer los precios de los productos de exportación, frente a la producción agraria y la menor productividad de los países periféricos descritos anteriormente.

Bajo estas circunstancias, la CEPAL tuvo un papel decisivo a nivel regional y pasó a ser un elemento clave en la recomendación de políticas, cuyo propósito consistía en ayudar a los países latinoamericanos para que salieran de la situación de atraso en la que se encontraban. ${ }^{38}$ ¿Cuál fue la propuesta de desarrollo elaborada por esta agencia para los países de América Latina?

Esta propuesta de desarrollo se encuentra estructurada en torno a cuatro elementos fundamentales, los cuales ponen de manifiesto la existencia de una serie de características comunes en el Ecuador y en el resto de América Latina: ${ }^{39}$

El primer punto, caracterizado por el fortalecimiento e impulso del estado del proceso de industrialización por sustitución de importaciones, se venía produciendo en numerosos países de la región como consecuencia de los problemas de la economía mundial después de la Primera Guerra Mundial.

Para los encargados de la CEPAL, este factor constituía el principal mecanismo para la superación del subdesarrollo de las economías latinoamericanas. Así, el estudio económico de

\footnotetext{
${ }^{37}$ R. Prebisch: El desarrollo económico de América Latina y algunos de sus principales problemas, Nueva York: Naciones Unidas, 1949.

38 Alfredo Falero, op. cit., p. 217-280.

${ }^{39}$ Cecilia Nahón, Corina Rodríguez Enríquez, Martín Schorr, op. cit., p. 327-379.
} 
América Latina del año 1949, enfatiza que esta región necesitaba un incremento de la productividad en la producción primaria para poder elevar el nivel de ingresos, además del desarrollo de la industria. ${ }^{40}$

El segundo punto, estaba relacionado con la excesiva concentración de la propiedad de la tierra en manos de las fracciones dominantes, siendo esta característica bastante frecuente en la mayoría de estos países. La concentración de la tierra era un obstáculo al proceso industrializador, que resultaba magnificado por la resistencia presentada por los grandes latifundistas al destinar las ganancias obtenidas de la exportación al sector manufacturero. Esta situación sólo podría ser resuelta a través de una reforma agraria que distribuyera de forma más equitativa la propiedad de la tierra, a la vez que se impulsaba el proceso de industrialización.

El tercer punto, indicaba que el impulso del proceso de industrialización y la superación del subdesarrollo y la pobreza de las sociedades latinoamericanas, debían de producirse a través de la intervención estatal; mientras que el último punto estaba asociado al reconocimiento de que la intervención gubernamental debía asegurar la integración económica latinoamericana. Es decir, para Prebisch, la coordinación regional de la sustitución de importaciones resultaba indispensable para aumentar el comercio intra-regional de bienes industriales y como mecanismo para generar escalas de producción. ${ }^{41}$

Para terminar, la última corriente que analizaremos, se refiere al factor que incidió en la aparición de la dependencia como tema de estudio en las ciencias sociales latinoamericanas. En este sentido, hay que hablar de la creciente integración durante los años cincuenta y sesenta del proceso productivo de las economías de América Latina con el capital extranjero, fenómeno que incrementó las contradicciones sociales en la región. Como consecuencia, este proceso acabó con el deseo de un capitalismo autónomo y el carácter democrático de la burguesía industrial, provocando una crisis en la reflexión de los intelectuales que elaboraron la teoría del desarrollo y la ruptura en el seno de la Comisión Económica para América Latina y el Caribe. ${ }^{42}$

La primera aproximación al concepto de dependencia por parte de los países latinoamericanos, fue su interpretación como un fenómeno externo debido a la situación de subordinación a la que

\footnotetext{
${ }^{40}$ CEPAL: Estudio económico de América Latina, 1949, Nueva York: Naciones Unidas, 1951.

${ }^{41}$ Cecilia Nahón Corina, Rodríguez Enríquez, Martín Schorr, op. cit., p. 327-379.

${ }^{42}$ Ibíd., p. 327-379.
} 
estaban sometidas las economías de la periferia con respecto a los centros desarrollados. La tardía implantación del modelo de sustitución de importaciones debido al agotamiento del modelo agro-exportador en América Latina tras la crisis de 1929 y la Segunda Guerra Mundial, provocó nuevas formas de vinculación frente a los centros industrializados.

Los trabajos de la CEPAL junto con la sociología crítica de raíz marxista (la teoría del imperialismo de Lenin) dieron lugar al nacimiento de la escuela de la dependencia a finales de la década de los sesenta, a la que se unió un grupo de pensadores que revolucionaron el pensamiento social, económico y político de su época. ${ }^{43}$

Las críticas realizadas por los defensores de esta escuela a la teoría de la modernización, se basaban en la afirmación de que las naciones eran partes incompletas de un todo mayor, mientras que la teoría de la modernización concebía al mundo como un grupo de naciones autónomas e independientes. Por otro lado, la teoría de la modernización establecía que los problemas de la periferia se atribuían a su retraso interno y características tradicionales, mientras que la escuela de la dependencia destacaba el comercio, la colonización y las relaciones culturales, políticas y militares que se habían desarrollado entre las sociedades denominadas "modernas" y "tradicionales". 44

Fiori pone de manifiesto la existencia de numerosas versiones académicas sobre la dependencia, que a pesar de representar diferentes proyectos políticos y económicos, tenían en común una deuda con la teoría del imperialismo y una visión de la periferia capitalista en el contexto de una economía mundial y con jerarquías. ${ }^{45}$

\footnotetext{
${ }^{43}$ Se trataba de un conjunto de trabajos que defendían esta postura y se caracterizaban por ser un análisis exógeno, el cual no establecía una relación entre los factores externos e internos en la investigación del atraso de América Latina. Ver las obras de Raúl Prebisch: En torno a las ideas de la CEPAL: Problemas de la industrialización en la América Latina, v. 1, en: French-Davis, Ricardo, comp. Intercambio y desarrollo, México, DF: Fondo de Cultura Económica, 2 v., 1981, p. 143-171 y Estímulo de la demanda, las inversiones y la aceleración del ritmo de crecimiento, en: NU. CEPAL, Estudio económico de América Latina, México, DF: CEPAL, 207 p. E/CN.12/362/Rev.1, 1954, p. 11-23.

${ }^{44}$ Cecilia Nahón Corina, Rodríguez Enríquez, Martín Schorr, op. cit., p. 327-379.

${ }^{45}$ J. Fiori: Estados e modos no desenvolvimento da nações, Sao Paulo: Vozes, 1999.
} 
En tal sentido y siguiendo la caracterización clásica de Palma, vamos a identificar brevemente tres grandes corrientes (aunque no son todas de origen latinoamericano) dentro de la amplia escuela de la dependencia: ${ }^{46}$

La primera corriente tiene como idea fundamental que el subdesarrollo se produce por la dependencia de las economías periféricas respecto a las centrales, por lo que el capitalismo periférico es incapaz de generar un proceso de desarrollo.

El principal representante de esta corriente es André Gunder Frank, el cual indica que las relaciones de dominación establecidas entre lo que denomina como "metrópolis" y "satélites", condicionaban el desarrollo de las fuerzas productivas en las zonas más atrasadas del sistema internacional. ${ }^{47}$ Esto explica que el desarrollo de América Latina estuviera condicionado a una revolución en contra de la burguesía doméstica y del imperialismo mundial, que lograra establecer una estrategia de desarrollo socialista basada en el pueblo y en la independencia económica externa.

En segundo lugar, según Palma, dentro de la escuela de la dependencia hay un grupo, cuya característica común era el análisis de las denominadas "situaciones concretas de dependencia". 48 Este enfoque rechazaba los esfuerzos de construir una teoría general de la dependencia y buscaba comprender la lucha entre la influencia externa y el desarrollo local. Los representantes más importantes son Cardoso y Faletto, que aluden a la forma en que los sectores nacionales dominantes se incorporan a la economía mundial como la causa fundamental del subdesarrollo. ${ }^{49}$ La tercera corriente, representada por economistas como Sunkel y Paz, buscaba reformular el estudio original de la CEPAL, teniendo en cuenta las nuevas teorías del momento y los acontecimientos más recientes de las economías latinoamericanas, además de enfatizar los

\footnotetext{
${ }^{46}$ G. Palma: Dependency and development: A critical overview, en Seers, D. Dependency, 1981, p. 42-43.

${ }^{47}$ A. Gunder Frank: Capitalism and underdevelopment in Latin America: Historical studies of Chile and Brazil, London: Monthly Review, 1967, p. 15-255.

${ }^{48}$ G. Palma, op. cit. p. 42-43.

${ }^{49}$ F. Cardoso, E. Faletto: Dependencia y desarrollo en América Latina, México DF: Siglo XXI, Edit. Siglo XXI, 1969, p. 15-250.
} 
obstáculos al desarrollo nacional que surgían de las condiciones externas a las que estaban ligadas las economías periféricas. ${ }^{50}$

No obstante, hay que señalar que el complicado camino de las economías latinoamericanas durante los años cincuenta, caracterizado por altas tasas de inflación, restricciones externas, una fuerte concentración del ingreso y deterioro del nivel de vida de la población, puso de manifiesto la necesidad de una remodelación del pensamiento de la CEPAL. En ese contexto histórico, y bajo la influencia de la escuela de la dependencia, la CEPAL redefinió parte de sus propuestas, aunque conservó la idea de la contribución del desarrollo de las sociedades latinoamericanas.

En el plano académico, autores como Furtado, indicaron que la acumulación de capital durante la etapa más complicada de la sustitución de importaciones, producía condiciones para la aparición de tendencias al estancamiento. ${ }^{51}$ También, Aníbal Pinto puso de manifiesto cómo la estructura productiva de una buena parte de los países de América Latina, se orientaba hacia ramas de producción con una elevada demanda de importaciones de bienes de capital, lo cual llevaba asociado efectos negativos que indicaban que el crecimiento en América Latina tendía a reproducir la antigua estructura dominante en el periodo agro-exportador. ${ }^{52}$

El resultado de estos análisis fue expresado en un nuevo conjunto de recomendaciones para los países latinoamericanos, cuya finalidad como iremos analizando, consistía en eliminar la insuficiencia económica, mejorar la planificación gubernamental del desarrollo, profundizar el proceso de industrialización, y realizar una reforma agraria. ${ }^{53}$

En definitiva, las ideas expuestas ponen de manifiesto la existencia de una serie de rasgos comunes a las sociedades latinoamericanas, ya que durante la primera etapa de acumulación de capital (finales del siglo XIX y primeras décadas del XX), estas sociedades se caracterizaron por el uso de un modelo de desarrollo agro-exportador, un débil mercado interno y una escasa industrialización, mientras que la segunda y tercera etapa de acumulación (aproximadamente el

\footnotetext{
${ }^{50}$ Osvaldo Sunkel, Pedro Paz: El subdesarrollo latinoamericano y la teoría del desarrollo, México DF: Siglo XXI, 1980, p. 27-370; Celso Furtado: Subdesarrollo y estancamiento en América Latina, Buenos Aires: Editorial Universitaria, 1966, p. 11-129.

${ }^{51}$ Celso Furtado, op.cit., p. 11-129.

52 Aníbal Pinto: Naturaleza e implicaciones de la heterogeneidad estructural, en El Trimestre Económico (México DF) No 145, 1970; Osvaldo Sunkel, Pedro Paz, op. cit. p. 11-129.

${ }^{53}$ R. Prebisch: Hacia una dinámica del desarrollo latinoamericano, Santiago de Chile: CEPAL, 1963, p.13-115.
} 
periodo 1945-1970) estuvieron marcadas por un fuerte control estatal y por la imposición de un modelo de industrialización que perseguía el impulso del desarrollo económico.

En el caso que nos ocupa, el avance del capitalismo en el Ecuador se produjo de forma tardía, siendo su desarrollo similar al de otros países latinoamericanos. Así, por ejemplo, en México, el sistema capitalista experimentó un gran avance en el último cuarto del siglo XIX, una vez rotos algunos de los principales obstáculos del sistema señorial y a través de la construcción de grandes obras públicas, el auge de la exportación y la expansión de la producción para uso interno. De forma paralela al desarrollo urbano, se produjo el avance capitalista rural en la minería, ganadería y de la agricultura, de la cual daban cuenta las haciendas adaptadas al capitalismo y el establecimiento de ranchos. Además, en esta época el predominio capitalista era total a pesar de la presencia de unidades productivas, comunidades y regiones que no operaban dentro de relaciones de producción de esta naturaleza, pero que estaban insertadas en el sistema capitalista por una variedad de mecanismos. Este desarrollo capitalista tardío se fue acelerando durante el siglo XIX gracias al impulso externo, cuyo control estaba en manos de la sociedad burguesa, aunque también hay que considerar otros factores como el auge de la industrialización, la liberalización del trabajo y la proliferación de relaciones capitalistas empresariales. ${ }^{54}$

Al igual que el Ecuador, la economía mexicana se ha asociado con la economía mundial y en particular, con la de Estados Unidos. De este modo, uno de los aspectos a considerar en el marco de una nueva etapa de industrialización, ha sido su vinculación con este último país, pues la necesidad de incrementar la exportación de bienes manufacturados y los mayores requerimientos tecnológicos, han provocado una mayor subordinación del capitalismo mexicano con respecto al imperialismo estadounidense. Asimismo, la Segunda Guerra Mundial fue la coyuntura esperada para México, durante la cual, inició una etapa de industrialización acelerada, en la que el gobierno mexicano asumió el papel de los intereses históricos de una burguesía contradictoria y débil, incapaz de realizar las transformaciones que exigía el desarrollo capitalista del país. Posteriormente, la mayor industrialización alcanzada durante la década de los cincuenta y parte de los sesenta, gracias al elevado ritmo de crecimiento de inversión pública y privada, determinó un fuerte crecimiento de los bienes manufactureros, estableciéndose un mayor vínculo con el

\footnotetext{
${ }^{54}$ Sergio de la Pena: La formación del capitalismo en México, Instituto de investigaciones sociales UNAM, Siglo veintiuno editores, 1975, p. 103-135.
} 
sistema capitalista internacional, en cuyo proceso se manifiesta una polarización social, pues no todo el país logró situarse dentro de dicho contexto. ${ }^{55}$

En definitiva, se puede decir que en estos países, el capitalismo apareció embrionariamente para después expandirse debido a la articulación con el mercado mundial de los centros urbanos y de algunos espacios rurales, ambos integrados por la actividad agro-exportadora. Además, esta actividad fue prácticamente la única fuente de desarrollo del país, llegando a convertirse en el eje del sistema de acumulación de capital.

Las razones por las que el dinamismo de la exportación prescindió de un progreso tecnológico significativo, se debieron por un lado, a la libre disponibilidad de mano de obra, cuya explotación por la vía pre-capitalista determinaba un costo monetario casi nulo, y por otro, a las condiciones internacionales, ya que los productos primarios permitían la apropiación de amplios márgenes de renta al no existir una gran competitividad. ${ }^{56} \mathrm{~A}$ su vez, el escaso desarrollo del capital en la agricultura se tradujo en el lento desarrollo del mercado interno, cuya estrechez dificultó la configuración de estructuras competitivas de mercado en las ciudades. Esas estructuras que lograron actuar como incentivo en Europa, generando la creatividad tecnológica necesaria, no pudieron constituirse en el Ecuador.

Al no existir la motivación de la competencia, el capitalismo ecuatoriano no pudo crear un motor innovador y quedó como un mero mecanismo de reproducción, pasando a ser un factor inherente a su condición de capitalismo dependiente. De este modo, la falta de estructura interna fue un obstáculo frente a la presión competitiva de la industria internacional de bienes de capital. Esto explica el hecho que impidió un desarrollo temprano de la producción de este tipo de bienes en el Ecuador, a la vez que se dejaba la puerta abierta a la importación, ya que conforme aumentaba el desarrollo del país, la necesidad de adquirir bienes de capital era mayor, además de generarse una dependencia de tipo estructural más profunda. En suma, esta caracterización viene a justificar el interés del pensamiento social latinoamericano en diversos mecanismos que permitieran superar el subdesarrollo y la condición de dependencia con el fin de alcanzar su propia autonomía.

\footnotetext{
${ }^{55}$ Ibíd., p. 103-135.

${ }^{56}$ Ibíd., p. 103-135.
} 


\section{2) El pensamiento social en América Latina y su impacto en las corrientes historiográficas del siglo XX: Etapas de la historiografía latinoamericana moderna.}

En términos generales, se puede decir que la historiografía latinoamericana del siglo XX, no sólo se ha caracterizado por su concepción positivista y descripción de los acontecimientos históricos de forma monográfica, sino también por la escasez de una metodología crítica y empirista para interpretar su propio objeto de estudio. Aunque han sido diversos los esfuerzos para convertir la historia en una ciencia que pueda valorar la objetividad y se ha utilizado un mayor número de técnicas en el tratamiento de las fuentes y archivos, se ha de recalcar la falta de datos y estudios de la historiografía de América Latina.

En este sentido, a la hora de hablar de la historiografía, es necesario establecer diversos contextos de tipo social, político, económico y otros generales que determinen una clasificación coherente de las diferentes tendencias y escuelas historiográficas y permitan reconstruir las principales influencias y rasgos propios de la historiografía de cada época. Por consiguiente, esta labor consistirá en el establecimiento de una renovada historia de la historiografía, ni positivista ni completamente monográfica, capaz de elaborar los diferentes modelos explicativos que este campo demanda. La importancia de esta tarea es fundamental, ya que la inserción de las ciencias sociales latinoamericanas en el debate internacional, implicará la realización de un estudio de su desarrollo.

De este modo, teniendo presente la división entre la necesidad de asimilar el desarrollo y avance científico moderno, pero considerando a la vez su propia identidad cultural, las disciplinas científicas que estudian el elemento social en América Latina han pasado a reconstruir con más exactitud el camino recorrido durante el siglo XX. ${ }^{57}$

Con anterioridad, ya hemos señalado el carácter periférico de América Latina, siendo esta situación de periferia del mundo capitalista, una de las causas que permiten explicar ciertos procesos de desarrollo institucional y algunos elementos propios de los estudios históricos latinoamericanos. Atendiendo a ese status periférico y a su atraso económico y social, se puede explicar el desarrollo más lento de varias tareas vinculadas a la actividad cultural.

\footnotetext{
${ }^{57}$ Carlos A. Aguirre Rojas: El largo siglo XX de la historiografía latinoamericana contemporánea: 1870-2025. Puntos de partida para su reproducción, Historia Agenda, Año I. Nueva Época, número 3, México, CCH/UNAM, noviembre-diciembre de 2003, p. 1-50.
} 
La falta de desarrollo de los marcos adecuados para emprender dicha labor, nos ayudará a comprender algunos de los desfases que ha presentado la historiografía latinoamericana respecto a sus equivalentes en Europa. En este caso, podemos referirnos al movimiento de recuperación y organización de los distintos archivos históricos, que en Europa se realiza en el siglo XIX, y que tiene lugar en América Latina durante el siglo XX.

Es necesario aclarar la gran dificultad para poder llevar a cabo la recopilación de estas fuentes y archivos, lo cual se debe en parte, a la escasa atención que los gobiernos han prestado a esta tarea y, por tanto, a una limitada asignación de recursos para la elaboración de archivos y bibliotecas públicas. En este caso, pese a que en el siglo XIX, una buena parte de la documentación se encontraba en manos privadas, conventos y colegios bajo tutela eclesiástica, las posteriores reformas liberales que afectaron a las órdenes religiosas en varios países, ocasionaron una importante dispersión y pérdida de materiales, lo cual fue una gran oportunidad para los particulares interesados en la historia de América a la hora de adquirir libros y otros materiales de gran valor. A su vez, los problemas políticos y otros acontecimientos, hicieron que muchas de esas grandes colecciones bibliográficas se dispersaran y fueran adquiridas por extranjeros, especialmente europeos, aunque con el paso del tiempo también fueron apareciendo los coleccionistas estadounidenses. ${ }^{58}$

Por otro lado, se ha de hablar del proceso de profesionalización de la disciplina histórica mediante la fundación oficial de cátedras universitarias, de la apertura de escuelas de historia dentro de las universidades, de la organización de bibliotecas y secciones dedicadas a este campo, o del nacimiento de revistas de historia y de asociaciones profesionales de historiadores, lo cual ha sido también un proceso que sólo llegó a realizarse en América Latina durante el siglo $\mathrm{XX}^{59}$

Volviendo a la idea de su condición periférica, parece que la historiografía de esta región ha estado sometida a la imposición de ciertos modelos historiográficos elaborados en Europa y Estados Unidos, y que se han proyectado como posibles estructuras explicativas que han de ser el referente de los historiadores a la hora de elaborar la historiografía nacional latinoamericana.

\footnotetext{
${ }^{58}$ Jack R. Thomas: The Role of private libraries and public archives in nineteenth century Spanish American Historiography, Journal of Library History, 9:4, Oct. 1974, p. 334-351.

${ }^{59}$ Carlos A. Aguirre Rojas, op. cit., p. 1-50.
} 
A pesar del fracaso para establecer este proyecto de modernidad occidental debido a los problemas para adaptar los rasgos heterogéneos, se puede decir que la historiografía de América Latina no puede ser comprendida sin esas influencias culturales procedentes de distintos países. Partiendo de este hecho y de la dificultad que implica la investigación de las influencias recibidas, algunos autores han pensado en la idea de una posible periodización general en la formación de la historiografía latinoamericana, la cual abarca el periodo desde finales del siglo XIX hasta la entrada del nuevo milenio y que coincide con las etapas correspondientes a la historiografía europea de esos mismos años. Se trata de un amplio siglo historiográfico latinoamericano, el cual podría ser caracterizado por la asimilación de diversas influencias historiográficas presentes en la cultura latinoamericana. Dicha periodización permitirá la comprensión de los principales momentos de cambio de los estudios históricos de Europa y de América Latina, que se corresponde con las coyunturas sociales globales más importantes de la historia de ambos lugares. ${ }^{60}$

Es importante señalar la existencia de una gran dependencia de la historiografía latinoamericana con respecto de la europea, lo cual se manifiesta en el énfasis para acabar con las culturas existentes y reconstruir sobre las bases europeas, considerando solamente su condición de dependencia.

Esta visión histórica fue dominante en Europa y en América Latina hasta finales del siglo XVIII, a partir de la llegada de los estudios científicos. Desde entonces, comienza a crearse una historia en Europa asociada al discurso científico y una visión eurocentrista con características universales. Es el caso de la Europa de Hegel, Kant y Marx para los cuales, América era un área geográfica que solo pudo incorporarse a la historia gracias a la ayuda europea.

Como vemos, esta historiografía no reconoce las diferencias, sino las supuestas inferioridades, que son explicadas mediante variables científicas que ponen de manifiesto la escasa evolución de la naturaleza y del hombre en América Latina. Asimismo, se llegó a pensar que únicamente durante su prehistoria (a la que se identifica con la etapa pre-hispánica), fue cuando América Latina logró grandes imperios y avances, los cuales suelen ser comparados con los de Europa. Con estas ideas en mente y según la periodización europea, esta región se inserta durante el siglo XVI en una modernidad llena de antagonismos, pues no se trasladó el modelo económico

\footnotetext{
${ }^{60}$ Ibíd., p. 1-50.
} 
capitalista, el de las repúblicas, o el de las universidades científicas, ya que todo esto tendría lugar durante el siglo $\mathrm{XX} .^{61}$

Esta visión eurocentrista será adoptada por una gran cantidad de intelectuales en el siglo XIX, que para defender un proyecto de modernización de tipo europeo, y sin estudiar con detalle la historia latinoamericana, sólo lograrán reproducir dicho eurocentrismo. De este modo, la historia de América Latina ha sido escrita considerando las ideas impuestas y se ha mostrado una historia que ha tenido como referente la cultura dominante de Europa. ${ }^{62}$

Al hilo de la idea planteada, el primer periodo establecido abarca los años 1870 y 1910-1914 y puede ser considerado como una etapa marcada por el trabajo de los ilustrados latinoamericanos y por el auge de la cultura francesa en América Latina. ${ }^{63}$ Este primer ciclo de la historiografía contemporánea es considerado por Aguirre como la "primera hegemonía historiográfica", que ubicará su centro en la Alemania de la Europa Occidental y funcionará como modelo general para el conjunto de las restantes historiografías de Europa y del resto del mundo. ${ }^{64}$ A su vez, este periodo se corresponde con el nacimiento del modo de producción capitalista, los inicios de la industrialización y la modernización de las sociedades de los diferentes países de América Latina, como el Ecuador.

Por otro lado, el ciclo que tiene lugar a posteriori y que se desarrolla entre 1910 y 1945, será una época de transición a causa de las dos guerras mundiales, años en los que se llevó a cabo una reorganización global de la sociedad y de la cultura internacional. Durante esta etapa, tanto en América Latina como en el resto del mundo, se vivieron de manera significativa los impactos producidos a consecuencia de la crisis económica mundial de 1929, el ascenso al poder del fascismo en Alemania y otros países, la revolución rusa o la pérdida por parte de Europa de su

\footnotetext{
${ }^{61}$ Janette G. Yépez, Pedro Rodríguez Rojas: América Latina y la visión de los otros: Breve revisión crítica de la historiografía latinoamericana, Universidad Simón Rodríguez, Venezuela, 2006, p. 2-15.

${ }^{62}$ Carlos A. Aguirre Rojas, op. cit., p. 1-50.

${ }^{63}$ Ver el apéndice de notas de la introducción para más información. Fuente: Carlos Aguirre Rojas: Mercado interno, guerra y revolución de México, 1870-1920, Revista mexicana de sociología, año 52, número 2, México, 1990, p. 180-240; Mario Pozas: El liberalismo hispanoamericano en el siglo XIX, Universidad Centroamericana, José Simeón Cañas. Realidad, Revista de Ciencias Sociales y Humanidades, número 108, abril-junio, 2006, p. 2-16.

${ }^{64}$ Carlos A. Aguirre Rojas, op. cit., p. 1-50.
} 
poder a manos de los Estados Unidos. ${ }^{65}$ Este cambio de hegemonía económica y política, así como la transición de la presencia extranjera en América Latina, se verá reflejado en la historiografía y en el mantenimiento del nacionalismo obsoleto.

A esto se ha de unir la complicada situación que atravesaba la cultura y la razón europea, cuestionada tanto por el psicoanálisis freudiano y la antropología inglesa, como por los aportes del marxismo soviético y la Escuela de los Annales. Aguirre define esta etapa como la "segunda hegemonía historiográfica”, la cual estaba localizada dentro de la cultura francesa.

De forma paralela al surgimiento de la hegemonía francesa, aparece la ofensiva económica, social y política y cultural de los norteamericanos, que tratan de sustituir las influencias culturales europeas con el denominado "americanismo cultural". Por consiguiente, las sociedades latinoamericanas tendrán que adaptarse a los impactos sufridos a nivel internacional y al proceso interno de reorganización y modernización de sus estructuras sociales. ${ }^{66}$

Los efectos producidos en América Latina debido a los procesos globales que terminaron en la Revolución Mexicana en la primera mitad del siglo XX, provocaron una repentina actividad cultural expresada a través de revistas, editoriales y grupos de intelectuales. Estos procesos lograron transformar la cultura latinoamericana, llevándola hacia la búsqueda de su propia identidad y provocando un gran impacto en la historiografía de este periodo.

El tercer periodo, que se establece entre 1945-1968, caracteriza a Europa y a América Latina por su movilidad social, auge económico y una fuerte industrialización, lo que tendrá lugar en América Latina tras la irrupción de la Revolución Cubana de 1959. ${ }^{67}$ La coyuntura perteneciente a los años posteriores a la Segunda Guerra Mundial, fue un periodo expansivo a nivel económico marcado por el crecimiento, recuperación económica y reconstrucción europea impulsada por el Plan Marshall. Una etapa de bonanza económica, manifestada en el Ecuador gracias al banano, que en el ámbito historiográfico, se reflejará en Europa como el proceso de consolidación de la ciencia histórica dentro de la sociedad, y en América Latina como el paso que supondrá la implantación universitaria de esa ciencia de la historia.

\footnotetext{
${ }^{65}$ Luis Vitale: Introducción a una teoría de la Historia para América Latina, Edit. Planeta, Buenos Aires Argentina, 1992, p. 4-164.

${ }^{66}$ Carlos A. Aguirre Rojas, op. cit., p. 1-50.

${ }^{67}$ Terence K. Hopkins, Immanuel Wallerstein: The age of transition. Trajectory of the world system 1945-2025, Editorial Zed Books, New Jersey, 1998, p. 13-226.
} 
En este sentido, dicha etapa se destaca por el proceso de institucionalización vivido por la historiografía, durante el que se fueron sustituyendo los historiadores no profesionales por historiadores de profesión. ${ }^{68}$

A partir de esta profesionalización de la historia, una gran parte de los historiadores latinoamericanos de los años cuarenta y cincuenta, destacó los logros de la modernización de los países latinoamericanos en el contexto de sociedades estables y con un crecimiento económico sostenido, como ya se ha mencionado.

De este modo, durante dicho intervalo de tiempo, se pone fin en Europa a la hegemonía de la cultura germana y se pasa a la nueva dominación cultural francesa, mientras que los fenómenos sociales ganan popularidad y se afirma el movimiento estructuralista dentro de las ciencias sociales. ${ }^{69}$ En este caso, Aguirre no habla de hegemonía historiográfica, sino de una nueva situación de policentrismo en la innovación y descubrimiento de las nuevas líneas de progreso de la historiografía. ${ }^{70}$

El auge económico de los años cuarenta y cincuenta y el marco del aumento del nivel de vida de las clases medias y populares, es donde se origina el carácter desarrollista de la CEPAL y las ideas de una posible integración latinoamericana, lo que en el marco de la historiografía se plantea como el debate sobre la identidad de los estudios históricos.

Del mismo modo que el desarrollismo de la CEPAL dio lugar a las teorías críticas de la dependencia latinoamericana, la historiografía institucional se encontró en la década de los sesenta con los primeros intentos serios de una auténtica renovación historiográfica, los cuales criticaban la vieja historia positivista e historicista e introducían en el debate a las posiciones de la corriente francesa de los Annales y también a los autores marxistas. ${ }^{71}$

Con esto, se incorporaban a la historiografía, las grandes contribuciones de las escuelas de la dependencia que exponían de una manera crítica la situación periférica y subordinada de las distintas sociedades de América Latina. Se trata de un conjunto de trabajos importantes dentro de

${ }^{68}$ Carlos A. Aguirre Rojas, op. cit., p. 1-50.

${ }^{69}$ Francois Dosse: Histoire du Structuralisme, 2 tomos, Editorial La Découverte, Paris, 1991-1992; Carlos Antonio Aguirre Rojas: El legado intelectual de los Annales braudelianos. 1956-1968, en el libro Braudel a Debate, Coedición Fondo editorial Tropykos/Fondo editorial Buría, Caracas, 1998.

${ }^{70}$ Carlos A. Aguirre Rojas, op. cit., p. 1-50.

${ }^{71}$ Luis Vitale, op. cit., p. 4-164. 
los estudios históricos latinoamericanos, que dentro del desarrollismo y de las teorías críticas de la dependencia van a constituir una primera búsqueda de construcción de una identidad específica para la historiografía latinoamericana. Esta búsqueda ha sido expresada a través de debates en torno a la naturaleza de la disciplina histórica dentro de la sociedad latinoamericana, pero también en referencia a su función social y a sus distintos usos políticos. ${ }^{72}$

Al mismo tiempo, la ofensiva norteamericana y la imposición del americanismo cultural va desapareciendo, trasladando sus esfuerzos al plano de la vida cotidiana y de las modas y costumbres.

Por otro lado, en estos años, la historiografía y las ciencias sociales latinoamericanas vivirán un proceso de relanzamiento de la cultura francesa, cuya presencia había disminuido en América Latina en los años anteriores.

El periodo desde finales de la década de los sesenta hasta la entrada del nuevo milenio, se caracteriza por el impacto causado por la revolución cultural de 1968, hecho fundamental a la hora de definir los rasgos de los estudios históricos de los distintos países latinoamericanos. ${ }^{73}$

En términos generales, en Europa y en el mundo occidental, esta etapa se manifiesta como la transición de una situación de hegemonía historiográfica, construida bajo el modelo de un centro fuerte y múltiples periferias hacia un nuevo panorama de policentrismo en la generación de la innovación historiográfica. ${ }^{74}$ Asimismo, la ruptura de 1968, representa el paso de la historiografía positivista a una situación nueva con numerosas visiones históricas.

Hasta los años sesenta, las principales escuelas e instituciones del saber histórico en América Latina, estaban dominadas por la idea de que la historia se hacía solo con textos y que el objetivo

\footnotetext{
${ }^{72}$ Carlos A. Aguirre Rojas, op. cit., p. 1-50.

${ }^{73}$ Sobre la caracterización general de esta revolución cultural de 1968, puede verse la obra de Fernand Braudel: Renacimiento, reforma, 1968: Revoluciones culturales de larga duración, en La Jornada Semanal, núm. 226, México, 10 de octubre de 1993; Immanuel Wallerstein: 1968: Revolución en el sistema-mundo, Tesis e Interrogantes, en revista Estudios sociológicos, núm. 20, México, 1989.

${ }^{74}$ Se ha de tener en cuenta que la historia de los países de Europa occidental y de Norteamérica ha sido estudiada durante un largo periodo de tiempo con los mejores métodos de cada época y se ha usado una base empírica. En América Latina, la situación es muy distinta, ya que en lo que en la historia económica y social no se dispone de una gran cantidad de datos empíricos relevantes, por lo que la adopción de las distintas modas del exterior puede tener consecuencias desafortunadas. Fuente: Magnus Morner: Ensayos sobre historia latinoamericana: Enfoques, conceptos y métodos, Capítulo 1: Historiografía europea occidental y norteamericana: Algunas tendencias recientes, Biblioteca de Ciencias Sociales, Volumen 37, Corporación Editora Nacional, Universidad Andina Simón Bolívar, 1992, p. 6-35.
} 
del historiador, era el de narrar las cosas desde el punto de vista tradicional y positivista. En el plano intelectual, esto reflejaba la realidad del tardío proceso de recopilación y organización de los archivos y de la profesionalización de la disciplina histórica. ${ }^{75}$

Este dominio de la historiografía positivista en los diferentes espacios culturales de América Latina, será cuestionado durante los años sesenta hasta la llegada de 1968, en el que se introducen en Colombia, Ecuador, Chile, Costa Rica, Venezuela, Guatemala y Cuba, las distintas variantes de la historia social, económica, colectiva y estructural, desplegadas en Europa durante todo el siglo XX. A partir de este momento, se inicia para todas estas historiografías un proceso de renovación de sus características más particulares. De igual manera, también en la historiografía mexicana, peruana, argentina, brasileña y uruguaya, entre otras, comienzan a expandirse las nuevas formas de la tarea historiográfica, dejando a un lado los círculos de las élites vanguardistas de la ciencia histórica y de las ciencias sociales latinoamericanas para implantarse paulatinamente en las facultades de historia y en los institutos de investigación histórica. $^{76}$

Como complemento al desplazamiento de la hegemonía del positivismo historiográfico y la acogida de las diferentes posturas historiográficas, la revolución de 1968 representará la difusión de dos elementos claves del pensamiento social e historiográfico: el marxismo y la corriente de historiadores conocida como Escuela de los Annales. ${ }^{77}$

Si la etapa final de la época anterior comenzó a familiarizarse con la renovación asociada al surgimiento de la teoría de la dependencia, la época posterior a 1968, se caracterizará por el auge de las contribuciones de los teóricos de la dependencia.

Por último, la etapa que culmina esta periodización, es la que estamos viviendo en estos momentos, la cual está caracterizada por la búsqueda de una situación abierta a un diálogo multicultural de carácter similar entre las historiografías nacionales del mundo. Esta situación,

\footnotetext{
${ }^{75}$ Carlos A. Aguirre Rojas, op. cit., p. 1-50.

76 Sobre la renovación post-68 de las historiografías latinoamericanas puede verse: Edeliberto Cifuentes: Los Annales y la historiografía centroamericana, en Eslabones, núm. 7, cit.; Marcia Mansor d'Alessio: Los Annales en Brasil. Algunas reflexiones, en Eslabones, núm. 7, cit.; Tulio Halperin Donghi: Un cuarto de siglo de historiografía argentina (1960 - 1985), en Desarrollo Económico, núm. 100, Buenos Aires, 1986.

${ }^{77}$ Para una caracterización más general del papel de esta Escuela ver: Los Annales y la historiografía francesa, Ediciones Quinto Sol, México, 1996; La Escuela de los Annales. Ayer, hoy, mañana, Ed. Montesinos, Barcelona, 1999.
} 
que en Europa comienza a partir del año 1989 y en América Latina tiene lugar en 1994, ofrece una gran movilidad de los historiadores dentro de otros ámbitos y espacios historiográficos diferentes, lo cual ha estado acompañado de múltiples interacciones y de un elevado crecimiento de la información disponible en el desempeño de este oficio. ${ }^{78}$

\section{3) El pensamiento social en el Ecuador en el siglo XX: La historiografía ecuatoriana antigua y la historiografía ecuatoriana moderna.}

Una vez determinadas las etapas de periodización de la historiografía latinoamericana durante los siglos XIX y XX, vamos a realizar ahora un análisis de la evolución del pensamiento social en el Ecuador, la influencia en su historiografía y de cómo los diferentes acontecimientos sociales, económicos y políticos afectaron a la renovación de las instituciones históricas. En este sentido, se partirá de la idea de que aún cuando la historiografía positivista también ha predominado en el Ecuador, su desarrollo ha sido escaso, siendo esto una labor que ha de ser abordada por la historiografía actual. Por consiguiente, ¿cómo se podrían definir las características propias de la historiografía positivista que han obstaculizado la profesionalización de la investigación?

Para responder a esta pregunta, hay que hacer alusión a la importancia que la historiografía tradicional ha venido dando a los protagonistas fundamentales de la historia, es decir, el culto a los grandes personajes y a los denominados héroes de su historia, pues estos han sido descritos como representantes de una voluntad superior (la divinidad) que ha orientado la evolución del proceso histórico a través de dichas figuras. ${ }^{79}$

La historiografía oficial en América Latina forma parte de ese culto del pasado, cuyo fin ha sido la canonización de los héroes de la conquista y de la independencia, estando todavía vinculada a esas ideas de la historiografía del siglo XIX. Los libros de historia constituyen junto con archivos, fiestas nacionales y monumentos, el soporte en el que los gobiernos construyen una idea para mantener el recuerdo de esos personajes. Por esta razón, los gobernantes quieren estar en esa línea de los héroes nacionales, en la que algunas figuras como Bolívar o San Martín ocupan un lugar privilegiado, puesto que juegan un papel fundamental en la constitución de las

\footnotetext{
${ }^{78}$ Carlos A. Aguirre Rojas, op. cit., p. 1-50.

${ }^{79}$ Alejandro Moreano: El discurso historiográfico ecuatoriano como forma narrativa (periodo 1920-50), Proyecto de investigación Historia de la narrativa y narrativa de la historia, Universidad Andina Simón Bolívar, 2003, p. 2160.
} 
identidades nacionales. De este modo, la historia oficial se centra en el establecimiento de dichas divinidades, a la vez que presenta versiones maniqueas del pasado.

El lugar que se les proporciona a estas "grandes figuras" es una cuestión importante a la hora de caracterizar la vida histórica y los procesos que la constituyen. En estos casos, la historia tiene lugar a través de la acción de estas figuras, a las que se alude como si se tratara de héroes:

En todas las épocas de la historia del mundo, hallaremos que los grandes hombres han sido los salvadores indispensables de su tiempo [...] la historia del mundo [...] ha sido la biografía de los grandes hombres. ${ }^{80}$

Así, en América Latina, considerada como un conjunto de naciones republicanas, el culto al héroe se desarrolló en torno a los líderes de la lucha por la independencia. Esto explica la elaboración de una historiografía a partir una visión limitada y llena de prejuicios del pasado, al estar la historia subordinada a las tareas políticas y al protagonismo de los héroes. ${ }^{81}$

Otra característica y gran limitación de la historiografía positivista, ha sido su generalizado empirismo en cuanto a la falta de reflexión histórica por parte de los autores. Esto ha sido un obstáculo en la búsqueda intelectual y a la hora de cuestionar la validez del documento. A este respecto, Jorge Núñez indica:

El mejor resultado de la historiografía positivista ecuatoriana fue un formidable acopio de datos... sobre los mismos temas de siempre convertidos finalmente en verdaderos nudos historiográficos: la conquista, la independencia, el floreanismo, el garcianismo, etc. $^{82}$

Estas reflexiones vuelven a poner de manifiesto la existencia de un contexto caracterizado por la falta de atención prestada a la investigación empírica, así como la necesidad de una renovación de la historiografía ecuatoriana, que debía de centrarse en la búsqueda de un creciente nivel científico de los estudios históricos y en el impulso para la realización de una nueva bibliografía

\footnotetext{
${ }^{80}$ Thomas Carlyle: Los héroes (1840), Madrid: Globus, 1995, p. 2-230.

${ }^{81}$ Alejandro Moreano, op. cit., p. 2-160.

82 Jorge Núñez Sánchez: Historia. Antología: Estudio introductorio: La actual historiografía ecuatoriana y ecuatorianista, FLACSO/ ILDIS, Sede Ecuador, Quito, Ecuador, 2000, p. 7-55.
} 
a través de las diversas aportaciones para enriquecer los conocimientos sobre el pasado ecuatoriano.

Por consiguiente, el desarrollo de una nueva historiografía ecuatoriana es una tarea a largo plazo, que no sólo ha estado marcada por la resistencia presentada por la vieja historiografía, sino por la debilidad institucional y la escasez de recursos.

Ahora bien, ¿cuáles han sido los principales representantes y aportaciones a la historiografía ecuatoriana durante el transcurso de los diferentes acontecimientos socio-económicos que caracterizaron a este país? ¿cómo tuvo lugar la evolución y el paso de una historiografía más tradicional a una más moderna?

Dentro del conjunto de obras de finales del siglo XIX y principios del XX, se encuentra la "Historia General de la República del Ecuador", de gran significación para la historiografía ecuatoriana a pesar de su excesivo énfasis en la época colonial y en la historia eclesiástica. Escrita por Federico González Suárez, arzobispo y renombrado historiador ecuatoriano, esta obra fue el resultado de la primera investigación en fuentes documentales, en oposición a la denominada historiografía de opiniones, la cual era predominante en esos años. ${ }^{83}$ A la vez, este trabajo fue la primera obra de tipo positivista que se escribía en el Ecuador republicano y por lo mismo, marca un momento importante en la evolución de la historiografía ecuatoriana, que durante una larga época fue un referente obligado del modo de investigar y escribir la historia en el país. ${ }^{84}$

También, se debe a González Suárez la creación de la "Sociedad ecuatoriana de estudios históricos americanos" en el año 1908, que reunió a la intelectualidad conservadora de su tiempo, perseguida por las reformas políticas, ideológicas y sociales efectuadas por el liberalismo triunfante. Entre sus socios fundadores figuraban algunos jóvenes discípulos de González Suárez y otros destacados intelectuales de la aristocracia terrateniente como Luís Felipe Borja, Jacinto Jijón y Caamaño, Carlos Manuel Larrea, Aníbal Viteri Lafronte, Juan León Mera y José. ${ }^{85}$

\footnotetext{
${ }^{83}$ Federico González Suárez: Historia general de la República del Ecuador, Imprenta del Clero. Quito, Ecuador, 1894.

${ }^{84}$ Ver apéndice de notas de la introducción para más información. Fuente: Carlos M. Larrea: Federico González Suárez, Quito, Ecuador, Estudio y Selecciones, Biblioteca Virtual Miguel de Cervantes, 1960, p. 15-595.

85 Jorge Núñez Sánchez: Historia. Antología. Estudio introductorio: La actual historiografía ecuatoriana y ecuatorianista, FLACSO/ ILDIS, Sede Ecuador, Quito, Ecuador, 2000, p. 9-45.
} 
El nacimiento de esta Sociedad se produjo de forma paralela al desarrollo del periodo más radical del gobierno del general Eloy Alfaro, durante el cual se promulgó la Constitución de 1906 y se estableció la separación entre estado e Iglesia y la supresión de la religión oficial, a la vez que se promulgó la nueva Ley de Beneficencia en 1908 y se declaró como propiedad estatal todos los bienes raíces de las comunidades religiosas establecidos en la República. ${ }^{86}$ Estas circunstancias llevaron a que el bloque conservador de historiadores buscara refugio en el ámbito de la ciencia y la cultura, con el propósito de establecer las bases para el rescate de su influencia ideológica.

Esta sociedad logró reunir a los investigadores más destacados de la historia, por lo que en 1920, el Congreso de la República le concedió el nombre de Academia Nacional de Historia, a pesar de conservar su carácter social e ideológico original. ${ }^{87}$ Es importante destacar que las aportaciones realizadas por la misma, sirvieron para superar la etapa de una "historia indocumentada" e iniciar una nueva fase de "historia documental", que supuestamente permitía la construcción de la historia a partir de fuentes históricas primarias y se fundamentaba en la investigación de archivo. $^{88}$

De este modo, el pensamiento social que había experimentado grandes cambios entre 1910 y 1930, se fue abriendo a géneros como la crónica histórica y periodística en una época en que la representación política se caracterizaba por su naturaleza crítica. Es decir, la segunda mitad de la década de los veinte transcurrió en medio de reclamaciones por parte de la élite regional agroexportadora que, en ese momento, sufría la transformación de las condiciones de dominación oligárquica ofrecidas por el repliegue del liberalismo que había gobernado el país durante más de una década. ${ }^{89}$ Esto implica la necesidad de analizar el contexto que posibilitó el nacimiento del primer grupo de historiadores a partir de la herencia cultural del liberalismo laico.

\footnotetext{
${ }^{86}$ Jorge Enrique Adoum: Cronología del siglo XX: Cultura y política en Ecuador y el mundo, Quito, Ecuador: Eskeletra Editorial, 2000, p. 11-183.

${ }^{87}$ Decreto publicado en el Registro Oficial No. 23, Quito, Ecuador, 28 de septiembre 1920.

${ }^{88}$ Jorge Núñez Sánchez, op. cit., p. 9-45.

${ }^{89}$ Juan Maiguashca, Lisa North: Orígenes y significado del velasquismo: Lucha de clases y participación política en el Ecuador, 1920-1972, en Rafael Quintero (edit.) La cuestión regional y el poder, Quito, Corporación Editora Nacional/CERLAC-York University/FLACSO, 1991, p. 100.
} 
Además, en esta época, en la que tuvo lugar la incorporación al proceso de acumulación capitalista, la división del trabajo y la consolidación de la sociedad y urbanización de las ciudades, se produjo una fragmentación (ciencia, moralidad y arte) en cuanto a la forma de apreciar el mundo y la marginación de los escritores e intelectuales del momento. ${ }^{90}$

En este contexto, Ángel Hidalgo indica que la ciudad se convierte en el escenario "natural" donde se producen las luchas por ocupar espacios de poder simbólico, al encontrarse en este lugar, las instituciones representantes de la sociedad letrada que se manifestaba en múltiples dimensiones y respondía a diversas motivaciones ideológicas. ${ }^{91}$ De este modo, la existencia de una cultura secular junto a la capacidad de movilidad de organizaciones sociales y culturales, fueron elementos claves para la promoción de nuevas cátedras universitarias, a la vez que organizaban debates en el ámbito público. Así, la vieja intelectualidad de origen burgués, que había predominado en el siglo XIX, daba paso a nuevas agrupaciones procedentes de los sectores medios, los cuales habían recibido la influencia del liberalismo y del discurso nacionalista. ${ }^{92}$ Posteriormente, hacia el año 1930, se crearía el Centro de Investigaciones Históricas de Guayaquil (CIH), hecho que coincidió con la urbanización y el ciclo económico recesivo provocado por la caída de los precios del cacao ecuatoriano en el mercado internacional. La creación de este centro permitiría la conformación de un ámbito del saber historiográfico mediante su correspondiente Boletín del Centro de Investigaciones Históricas.

La idea dominante de los años treinta se basaba en el valor de los documentos históricos y en la idea positivista de la ciencia, cuya metodología se basaba en el análisis de la autenticidad de las fuentes documentales. El historiador de los años treinta fue una figura con una labor parecida a la de un publicista, además de dedicarse a conservar el saber erudito destinado a cumplir una “función social”, la cual consistía en la reconstrucción de la memoria histórica y social de una comunidad. Entre los autores pertenecientes a este grupo y que podían ser calificados como "liberales de vocación positivista", se pueden mencionar Carlos Rolando, pensador progresista y

\footnotetext{
${ }^{90}$ Jorge Núñez Sánchez, op. cit., p. 9-45.

91 Ángel Emilio Hidalgo: El aparecimiento del saber histórico en Guayaquil: El Centro de Investigaciones Históricas (1930-1962), Revista Ecuatoriana de Historia, 31, Quito, Ecuador, Universidad Andina Simón Bolívar, primer semestre 2010 .

92 Carlos Altamirano: Introducción general, en Carlos Altamirano, Dir., Historia de los intelectuales en América Latina. I. La ciudad letrada, de la conquista al modernismo, Buenos Aires, Katz Editores, 2008, p. 15.
} 
de notable interés en temas políticos, sociales y culturales, y los hermanos Robles Chambers, quienes se dedicaron al campo de la genealogía. ${ }^{93}$

La primera labor realizada por el CIH fue la investigación de las obras nacionales y su origen en el Ecuador, dedicándose los historiadores del CIH a la formación de un saber que contribuyera a la elaboración de una historiografía oficial de carácter positivista en la concepción de la historia, pero cercana al pensamiento liberal modernizante. ${ }^{94}$ Además, el papel de esta asociación de historiadores fue estratégico para formar una genealogía de la nación ecuatoriana, cuya base se hallaba en el mito de los héroes y en los relatos destinados a engrandecer el pasado.

Pese al mantenimiento de las estructuras positivistas, hay que decir que esta institución constituiría el eje durante 1930 y 1960 para la creación de una comunidad de historiadores o especialistas en el conocimiento del pasado. Este hecho fue un acontecimiento fundamental en cuanto a la dinámica de formación de una sociedad que vivía un proceso de transición hacia una modernidad entendida como periférica y se caracterizaba por la falta de simultaneidad de los cambios socio-económicos y culturales que tenían lugar en Occidente. ${ }^{95}$

Por otra parte, y a pesar de las dificultades citadas, también se pueden nombrar algunos elementos que favorecieron la renovación historiográfica en el Ecuador, entre los que se encontraba el gran entusiasmo de las nuevas generaciones y el apoyo de algunos historiadores que incorporaban aspectos modernos en sus ideas. En este sentido, hay que señalar que si bien la mayoría de las ideas de los autores tradicionales se caracterizaba por las limitaciones indicadas anteriormente, no se puede pensar que la antigua generación de historiadores abarcara el continente americano en su totalidad. De hecho, existe un grupo de autores que sirvieron de puente entre las diversas generaciones de historiadores ecuatorianos.

Entre los denominados historiadores tradicionales se encuentra José María Vargas, investigador destacado por sus estudios de los diversos campos de la historiografía, Gabriel Cevallos García, historiador y pensador vinculado a la escuela conservadora, Gerardo Nicola, pensador de influencia socialista y pionero en la revisión crítica de las teorías y viejos métodos y el

\footnotetext{
${ }^{93}$ Jorge Núñez Sánchez, op. cit., p. 9-45.

${ }^{94}$ Boletín del CIH: El iniciador de la historia patria, cap.: 1, 1931, p. 7.

${ }^{95}$ Érika Silva Charvet: Identidad nacional y poder, Quito, Abya-Yala, 2004, p. 63-140.
} 
historiador Oswaldo Albornoz Peralta, cuyos trabajos muestran su herencia intelectual del radicalismo liberal y sus propias convicciones marxistas. ${ }^{96}$

Al hablar de la transición y el paso a la historiografía moderna, uno de los momentos más importantes que llevó a la ruptura de la tarea histórica moderna frente a la historiografía tradicional, ha de ser situado en la década de los setenta a partir de las nuevas reflexiones del pasado colonial. De esta forma, se observa que el examen del desarrollo de la historiografía moderna, ha seguido una línea cronológica determinada por la etapa comprendida entre 19701990, sirviendo como referente de periodización, al proporcionar diferentes escenarios en los que algunos enfoques y problemáticas han predominado sobre otros. ${ }^{97}$

Jorge Núñez menciona las aportaciones de Agustín Cueva, renombrado científico social, las cuales se remontan a 1971, año en que publicó su obra de carácter revisionista El proceso de dominación política en Ecuador, centrada en el planteamiento de una síntesis crítica de la historia ecuatoriana y que revelaba el proceso constitutivo de una estructura oligárquica-burguesa en el Ecuador. ${ }^{98}$ Además, incorporaba un enfoque renovador que combinaba una nueva metodología, cuyas perspectivas de estudio se basaban en el análisis del discurso político, llegando a convertirse en el modelo a utilizar por científicos sociales posteriores.

Núñez no atribuye el nacimiento de la historiografía moderna a los historiadores, sino a este sociólogo de izquierdas especializado en Francia. Esto se explica a partir del momento histórico que por aquel entonces vivía América Latina, ya que a pesar de que la Revolución Cubana de 1959 permitió que el socialismo se implantara en esta región, no llegó a influir de manera inmediata en el fortalecimiento de la clase obrera desde el punto de vista de una oleada de revoluciones de campesinos, sino que se manifestó a través de la juventud patriótica, los partidos políticos y el pensamiento de izquierda. ${ }^{99}$

Además, este proceso obedecía a la creación de clases y sistema de antagonismos que la vía junker neocolonial del capitalismo había creado en la mayoría de las formaciones sociales de

\footnotetext{
96 Jorge Núñez Sánchez, op. cit., p. 9-45.

97 Juan Paz, Miño Cepeda: Historiografía económica del Ecuador sobre el siglo XIX y XX en los últimos 25 años, Revista Procesos, Corporación Editora Nacional, 1993, p. 75-115.

98 Jorge Núñez Sánchez: La historiografía ecuatoriana contemporánea (1970-1994), Ediciones de la FAU, Universidad Central del Ecuador, Quito, 1984, p. 5-130.

${ }^{99}$ Fernando Velasco Abad: Ecuador: Subdesarrollo y dependencia, Ed. El Conejo, 1983, p 11-230.
} 
América Latina, marcadas por la dominación imperialista y la supervivencia de estructuras precapitalistas y rasgos represivos del estado. Hasta entonces, la fuerza social y política del desarrollo del pensamiento revolucionario fue la democracia nacional, las corrientes radicalizadas de la iglesia y los viejos partidos nacionales y reformistas de la burguesía, siendo esa base social, el elemento que abriría un camino para el nacimiento y desarrollo de corrientes no-marxistas en el pensamiento ecuatoriano. ${ }^{100}$

A diferencia del carácter conservador de los historiadores de América Latina, los nuevos movimientos intelectuales de América Latina se decantaban por la sociología, la politología y la economía y no prestaban demasiada atención a la historia. Estas circunstancias llevaron a que el Instituto de Investigaciones Económicas de la Universidad Central publicara en 1975 la obra "Ecuador: pasado y presente", la cual pretendía ampliar la versión planteada por Agustín Cueva desde una perspectiva marxista y con ello, ofrecer una visión totalizadora de la historia ecuatoriana. ${ }^{101}$

Guillermo Bustos afirma que el movimiento historiográfico ecuatoriano denominado "nueva historia", tuvo su origen a partir de la segunda mitad de los años setenta. Este se consolidó durante los años ochenta y su objetivo constituía un desafío a la forma en la que se comprendía en ese momento el pasado de la nación. ${ }^{102}$ Los grupos creadores de este nuevo movimiento historiográfico utilizaron los desarrollos alcanzados por la etnohistoria, la historia social y la historia económica, los cuales despertaron un gran interés en el debate internacional sobre el marxismo, la dependencia, el sistema mundial y la historia de las ideas.

Una de las principales aportaciones de la época corresponde al autor Fernando Velasco, cuyos estudios encontraron en el enfoque marxista una fuente de inspiración. Su investigación, influenciada por el debate en torno a la teoría de la dependencia, cuestionaba el carácter feudal

\footnotetext{
${ }^{100}$ Una expresión del conjunto de esa determinación fue el desarrollo en la década de los sesenta de varias corrientes de pensamiento no marxista (nacionalismo revolucionario, teología de la liberación, el anarquismo, etc.) y el surgimiento de la denominada Teoría de la Dependencia.

${ }^{101}$ Jorge Núñez Sánchez, Historia. Antología..., op. cit. p. 9-45.

102 Guillermo Bustos: La producción historiográfica contemporánea sobre la independencia ecuatoriana (19802001): Una aproximación, Procesos, Revista ecuatoriana de Historia, No. 20, Corporación Editora Nacional, 2004, p. 19-36.
} 
que el pensamiento de izquierda liberal proporcionaba a la época colonial, planteando que la formación social colonial estaba definida por su incorporación al sistema capitalista. ${ }^{103}$

Asimismo, la importancia del análisis histórico y de la estructura socio-económica condujo al nacimiento de una nueva corriente historiográfica en la vanguardia intelectual de izquierdas, cuyo énfasis se encontraba en la revisión de antiguas concepciones y en la incorporación de nuevos temas de estudio. Así, la creación del Instituto de Investigaciones Regionales de la Universidad de Cuenca (IIRDUC) o Instituto de Investigaciones Sociales (IDIS) en 1973, ocurrió teniendo como fundamento la investigación histórica, además de impulsar la organización de diversos encuentros centrados en la historia y en la realidad económica y social del Ecuador durante los años posteriores. ${ }^{104}$

A su vez, al hablar de la institucionalidad histórica existente en el Ecuador, es necesario preguntarse cuál ha sido su contribución al desarrollo y promoción de la historiografía moderna y si esta se ha producido de una forma beneficiosa. En el caso de la Academia Nacional de Historia, su vinculación a las ideas sociales e ideológicas tradicionales, hizo que se mantuviera al margen de las nuevas corrientes historiográficas, mostrando una actitud distante y de aparente modernidad:

Estragada por el tiempo y por su propia falta de renovación interna, la Academia ha dejado de ser el alto cenáculo intelectual de antes y ha terminado por convertirse en un reducto de gentes de derechas, algunas sin nivel académico y en ciertos casos, inclusive sin ninguna obra intelectual. ${ }^{105}$

Pese a todo ello, Núñez indica que esta ha mantenido determinadas actividades y ha organizado algunos eventos científicos de importancia, aunque parece que no ha logrado generar una línea de pensamiento histórico, ni tampoco una corriente de acción historiográfica. ${ }^{106}$

\footnotetext{
103 Alejandro Moreano: Introducción. Ecuador: Subdesarrollo y dependencia, en Fernando Velasco Abad. Ed. El Conejo, 1983, p. 9-36.

104 Segundo Encuentro de Historia y realidad económica y social del Ecuador, 17-22 abril, 1978, Fuente: Jorge Núñez Sánchez: La historiografía ecuatoriana contemporánea (1970-1994), Ediciones de la FAU, Universidad Central del Ecuador, Quito, 1984, p. 5-130.

${ }^{105}$ Ibíd., p. 297.

106 Jorge Núñez Sánchez, Historia. Antología..., op. cit. p. 9-45.
} 
Por otra parte, salvo excepciones, se puede decir que durante la década de los años setenta, no se produjo en el Ecuador una clara diferenciación entre el trabajo sociológico y la investigación histórica, debido a la combinación de factores de carácter político. Núñez justifica este hecho haciendo alusión a la carencia de una tradición auténtica de profesionalismo entre los historiadores de la vieja escuela, lo cual se expresaba en la inexistencia de escuelas universitarias de historia y en la ausencia de publicaciones rigurosas y especializadas. ${ }^{107}$ La crisis académica de las universidades nacionales ha impedido la formación de historiadores y el mantenimiento de una política de investigación histórica y de publicaciones coherente. Además, la falta de condiciones para la profesionalización de los historiadores hizo que esta tarea fuera vista como algo recreativo que no necesitaba remuneración alguna.

Esta realidad fue uno de los elementos que llevó a la aparición del sociologismo histórico, el cual no sólo aportaba nuevas ideas y metodologías al campo de la historiografía, sino que se caracterizaba por dejar a un lado la investigación de archivo. Esto se refleja en la carencia de conocimientos paleográficos, fenómeno bastante generalizado en el Ecuador, y en la escasa motivación a la hora de realizar investigaciones. También, se ha de mencionar la situación de los archivos públicos ecuatorianos como ha sido el caso del Archivo Nacional de Historia que, con frecuencia, se ha encontrado a la sombra de otras instituciones. Adicionalmente, el Sistema Nacional de Archivos se ha caracterizado por sus escasos recursos para recoger y catalogar los fondos documentales. ${ }^{108}$

El otro elemento responsable fue el uso de temas de interpretación histórica y el establecimiento de corrientes políticas de izquierda. Este fenómeno, común a todas las ciencias sociales de América Latina, se manifestó en el ámbito de la periodización de la historia del Ecuador, en el cual se destacan diversos grupos de intelectuales que querían revisar las viejas interpretaciones históricas y formular nuevos planteamientos para la acción política. Como resultado, las ciencias sociales ecuatorianas se caracterizaron por el surgimiento de nuevas categorías de análisis histórico y teórico que solían carecer del respaldo de la investigación. Esto explica que más tarde, bajo los impulsos de la naciente escuela historiográfica ecuatoriana, los estudios históricos

\footnotetext{
${ }^{107}$ Jorge Núñez, La historiografía ecuatoriana..., op. cit., p. 297.

${ }^{108}$ Ibíd. p. 297.
} 
tuvieran una mayor autonomía teórico-metodológica, abandonándose el sociologismo, pero conservándose los conocimientos aportados por este último. ${ }^{109}$

A pesar de los intentos de renovación llevados a cabo, el balance de finales de la década de los setenta, muestra un escaso desarrollo de la historiografía positivista ecuatoriana, lo cual se debe en parte a los siguientes factores:

En primer lugar, el énfasis en la recopilación de datos y mención cronológica de los acontecimientos frente al interés por el análisis crítico de su carácter y contenido. Por otro lado, hay que hablar del interés en el estudio de los temas de siempre, así como el ya mencionado culto a los héroes y la biografía, a lo que se ha de unir la falta de conocimientos técnicos de los historiadores nacionales, que ha dificultado el desarrollo de una historiografía positivista. ${ }^{110}$

Por último y en referencia a las características de la enseñanza de historia en el país, se destaca el bajo nivel de los programas de enseñanza, el impulso de la historia ideológica con respecto a la historia científica, el carácter memorístico de la enseñanza, la falta de relación del cuerpo docente con la investigación y la capacitación profesional para los maestros.

En los años ochenta, se cede el protagonismo a proyectos más especializados que reflejan una preferencia por los procesos de ámbitos más regionales y locales y ponen en entredicho los planteamientos anteriores. $^{111}$

Estos cambios muestran un desplazamiento en el marco de reflexión desde la sociología y la economía hacia la historia, comenzándose a elaborar una nueva base metodológica de la tarea histórica profesional, además de establecer un diálogo entre el marco teórico y empírico.

En un principio, estas ideas recibieron su primer impulso de otros países, cuando el debate sobre el carácter feudal o capitalista de la América Latina colonial comenzó a contar con la participación de historiadores como Chevalier, los cuales procedían de medios académicos extranjeros y cuyo interés se centraba en la búsqueda de rasgos particulares en esos sistemas. En esta línea, algunos de los esfuerzos realizados por la historiografía norteamericana llegaron al Ecuador, iniciándose una primera etapa de estudios sobre la historia social y económica de la

\footnotetext{
${ }^{109}$ Ibíd. p. 297.

110 Rosemarie Terain Najas: La historia económica y social sobre la época colonial ecuatoriana. Balance de la producción historiográfica en los últimos 25 años, Revista ecuatoriana de historia No. 5, Corporación Editora Nacional, Quito, 1994, p. 29-45.

${ }^{111}$ Ibíd. p. 29-45.
} 
Audiencia de Quito. Así, en el año 1980, se creó un nuevo espacio dedicado a la reflexión histórica a través de la creación del Encuentro Nacional de Historia, en el que se perseguían los siguientes objetivos: ${ }^{112}$

En primer lugar, se buscaba la creación de una relación más cercana entre los profesores de historia y los investigadores, que facilitara el intercambio de información entre estos dos campos. También, se pretendía ofrecer a los investigadores la oportunidad de acceder a los trabajos historiográficos más recientes para superar los enfoques tradicionales político-institucionales de la historia, además de posibilitar la información sobre estas nuevas orientaciones en cuanto a la historia social, económica, demográfica y otras. Por último, se fomentó la creación de un espíritu crítico entre los profesores a la hora de elaborar programas escolares de historia, proporcionado información relacionada con técnicas de investigación histórica e impulsando su contribución en las tareas de investigación y desarrollo de estudios. ${ }^{113}$

En definitiva, este encuentro tuvo como objetivo la organización de una tercera reunión de historiadores para estimular el desarrollo de la historiografía ecuatoriana con la creación de una Asociación de Historiadores Ecuatorianos (ADHIEC), además de favorecer una profesionalización del trabajo historiográfico, la investigación histórica, la publicación y difusión de sus resultados. ${ }^{114}$

Es importante señalar que una buena parte de la historiografía moderna estuvo dominada hasta bien avanzada la década de los ochenta por temas de pensamiento de principios de los setenta. Además, los debates solían finalizar con la reproducción de los temas clásicos, mientras se utilizaban las referencias de los trabajos realizados en el pasado sobre las estructuras sociales, económicas y políticas coloniales, situación que ponía de manifiesto la falta de una reflexión de carácter actual.

La tendencia al establecimiento de una problemática especializada fue surgiendo durante las décadas de los ochenta y de los noventa, lo cual pasó a ser la mejor forma de contribuir al

\footnotetext{
112 Jorge Núñez, La historiografía ecuatoriana..., op. cit., pp. 295-298.

${ }^{113}$ Ibíd. p. 296-297.

114 Juan Paz, Miño Cepeda: Asociación de historiadores ecuatorianos, Taller de Historia Económica, Facultad de Economía. The.pazymino.com/manifiesto.html.
} 
desarrollo de una historiografía más fundamentada y que reflejaba las transformaciones conceptuales y metodológicas de los últimos tiempos. ${ }^{115}$

La difusión de las ciencias sociales de la región continuó hasta mediados de los ochenta, periodo en el que se produce una decadencia bibliográfica provocada por la crisis económica en América Latina, la caída del marxismo y el abandono de las inversiones culturales y científico-sociales por parte de gobernantes, empresarios e intelectuales. La década de los noventa muestra cómo el debilitamiento de los espacios académicos ha impactado en las perspectivas de profesionalización, produciéndose una situación de estancamiento en la investigación histórica a pesar del esfuerzo realizado para mantener la vitalidad de la reflexión enfocada en temas relacionados con la problemática colonial. ${ }^{116}$

Desafortunadamente, dicho estancamiento se ha extendido hasta el nuevo siglo, pues el estado actual de la bibliografía del país se ha caracterizado por la imposibilidad de mantener la producción nacional y extranjera de estudios ecuatorianos ante la escasez de servicios bibliográficos, encargados de registrar las publicaciones nacionales y ecuatorianistas. ${ }^{117}$

En este caso, se encuentra el Sistema Nacional de Información Bibliográfica del Ecuador, creado en el año 2003, con el que se pueden consultar los catálogos de varias bibliotecas del país, además de los estudios publicados por la FLACSO entre los años 2000 y 2004 (Serie antología de FLACSO), facultad encargada de elaborar los estudios de los años noventa en relación a diversos aspectos del pasado y temas contemporáneos del país. ${ }^{118}$

\footnotetext{
115 Jorge Núñez, La historiografía ecuatoriana..., op. cit., p. 295-297.

116 Rosemarie Terain Najas, op. cit., p. 29-45; Jorge Núñez Sánchez, La historiografía ecuatoriana..., op. cit., p. 296-297.

117 Michael T. Hamerly, John Carter: Bibliografías ecuatorianas: Estado actual y últimos aportes, 2001-2005, Iconos, 2006, p. 175-194.

El último Anuario bibliográfico ecuatoriano del Centro de Investigación y Cultura del Banco Central del Ecuador en Cuenca, fue publicado en 1991 (para el año de 1987). Fuente: Anuario bibliográfico ecuatoriano para el año 19821987, 7 volúmenes, Banco Central del Ecuador, Centro de Investigación y Cultura, 1984-1991.

${ }^{118}$ Michael Hamerly: Más bibliografías ecuatorianas: Las antologías de FLACSO, en publicación: Iconos, Revista de Ciencias Sociales no. 26, FLACSO, Facultad Latinoamericana de Ciencias Sociales, Sede Quito, Septiembre 2006.
} 


\section{4) La renovación de la historiografía del Ecuador: Principales influencias, contenidos, instituciones $y$ autores representantes.}

Como se ha indicado anteriormente, la nueva producción historiográfica ecuatoriana se caracterizó desde sus comienzos por la influencia recibida de diversas perspectivas metodológicas, entre las que destacaba el enfoque marxista. La importancia de esta metodología se hallaba en las diversas contribuciones realizadas a las ciencias sociales, las cuales mostraban una visión estructural de la sociedad y una respuesta al atraso y dependencia de América Latina. ${ }^{119}$ A este respecto, es importante valorar algunas interpretaciones del pensamiento marxista latinoamericano en el ámbito intelectual sobre la combinación entre las ideas socialistas y el humanismo correspondiente a esa teoría.

Aunque algunos de los intelectuales representantes de las ideas marxistas han pertenecido en numerosas ocasiones a partidos de izquierdas, esto no ha dejado de implicar el hecho de que, en determinados momentos y desde la vida académica, hayan expresado ideas alejadas del socialismo soviético y de los partidos comunistas latinoamericanos. ${ }^{120}$

Desde el punto de vista de la modernidad, las propuestas humanistas del marxismo han venido estableciendo una relación armónica con las tradiciones del pensamiento de distintas regiones, culturas y países. En el caso de América Latina, donde el elemento humanista ha estado presente a lo largo de su pensamiento, no parece extraño que el marxismo estableciera una relación con esa herencia. Esto justifica que algunos pensadores procedentes de corrientes diferentes del proyecto socialista llegasen a reconocer desde finales del siglo XIX, el contenido humanista de la obra de Marx y de otros marxistas. ${ }^{121}$ De todas formas, se ha de aclarar que este hecho no implica necesariamente su identificación con todas las obras de tipo socialista.

Por otra parte, algunos de los autores marxistas latinoamericanos más destacados han expresado la necesidad de recuperar a Marx para volver a considerar el valor de su propuesta humanista. Así, durante el auge del fascismo, se destacó el contenido humanista de los proyectos socialistas

\footnotetext{
119 Jorge Núñez Sánchez: Antología de historia, Estudio introductorio: La actual historiografía ecuatoriana y ecuatorianistas, FLACSO, Sede Ecuador, Quito, Ecuador, 2000, p. 9-50.

120 Michael T. Hamerly, John Carter: Bibliografías ecuatorianas: Estado actual y últimos aportes, 2001-2005, Iconos, 2006, p. 175-194.

121 P. Guadarrama González: Razones de confluencia y divergencia entre el pensamiento latinoamericano y el humanismo socialista, en "Islas", n. 110, 1995, p. 16-36.
} 
y del marxismo, mientras que en el periodo después de las guerras mundiales se intensificaron las investigaciones filosóficas sobre las obras de Marx y la enajenación.

En cambio, la década de los sesenta fue bastante importante para la evolución del pensamiento marxista en América Latina. Esto se debió a la Revolución Cubana y a otros elementos internacionales (Che Guevara, Althusser, etc.), que tendrían su impacto particular en el desarrollo del pensamiento marxista en esta región. Para los países latinoamericanos, el proyecto socialista de la Revolución supuso la posibilidad de recuperar el espíritu humanista procedente del marxismo. En tal sentido, esta nueva experiencia motivó el surgimiento de los autores de izquierda que habían sido afectados por la crisis de valores. ${ }^{122}$

Además de las aportaciones marxistas, otras influencias significativas en la historia ecuatoriana han sido las realizadas por la escuela de la historiografía anglosajona, la ya mencionada escuela francesa de los Annales y la escuela latinoamericana de la historia de las ideas, cuyas contribuciones han sido posibles a través de los diversos centros de investigación y de la mano de autores como Arturo Andrés Roig y Leopoldo Zea. También, hay que destacar el alejamiento de las influencias unilaterales y el desarrollo de metodologías que trataban de combinar el uso de recursos técnicos y conceptos procedentes de diversas escuelas. ${ }^{123}$

Entre los autores más representativos de estas asociaciones, figuran algunos historiadores marxistas que estudiaron en las escuelas anglosajonas y que utilizaron en sus trabajos los elementos técnicos de su formación profesional. Este es el caso de Enrique Ayala Mora y de Rafael Quintero, destacadas figuras de gran influencia en la renovación de la historiografía ecuatoriana. ${ }^{124}$ Asimismo, se tendrá en cuenta la perspectiva de otros historiadores marxistas clásicos como Juan Paz y Miño Cepeda, que asimilaron la influencia teórica de la escuela francesa e inglesa de historia social, manteniendo los elementos fundamentales del marxismo

\footnotetext{
${ }^{122}$ Ibíd. p. 16-36; Rosemarie Terain Najas, op. cit., p. 29-45.

${ }^{123}$ Jorge Núñez Sánchez, Antología de historia, op. cit., p. 9-50.

${ }^{124}$ Revisaremos algunas obras de estos autores, entre las que se encuentran: Lucha política y origen de los partidos en Ecuador de Enrique Ayala, Haciendas, capital y lucha de clases andina. Disolución de la hacienda serrana y lucha política en los años 1960-64, Los oligarcas del cacao: Ensayo sobre la acumulación originaria y La hacienda pre-capitalista y la clase terrateniente en América Latina y su inserción en el modo de producción capitalista: El caso ecuatoriano de Andrés Guerrero.
} 
como referente científico. ${ }^{125}$ Por otra parte, es necesario destacar a los historiadores marxistas ortodoxos ecuatorianos, cuyas aportaciones pertenecen a la línea del materialismo y entre los que figuran Elías Muñoz, Oswaldo Albornoz Peralta y Leonardo Espinoza, que no sólo fueron historiadores, sino dirigentes de organizaciones de izquierda. ${ }^{126}$

En esencia, la historiografía de América Latina ha estado sometida a una tendencia basada en la imposición de ciertos modelos historiográficos que fueron elaborados en Europa y Estados Unidos. Estos modelos han sido proyectados de forma permanente como mecanismos del oficio de historiador para las diferentes historiografías nacionales. No obstante, la imposición de estos proyectos de modernidad en América Latina no ha sido una tarea fácil de realizar en lo que corresponde al nivel cultural y de asimilación, llevándose a cabo de manera desigual.

Aunque es difícil comprender la historiografía de América Latina sin esa variedad de influencias culturales e historiográficas, se ha de señalar el problema para analizar los diferentes modos y resultados del proceso de mestizaje cultural al que son sometidos dichos modelos historiográficos y culturales del exterior. En el caso ecuatoriano, no existe una unidad racial o cultural y la disparidad geográfica puede ser notoria, lo cual explica la dificultad para establecer esos modelos. $^{127}$

Por otra parte, no debe olvidarse la influencia del caudillismo, caciquismo y clientelismo en la historiografía ecuatoriana. Con respecto al primero, hay que decir que en América Latina, desde el final de las guerras de emancipación hacia 1826, hasta el afianzamiento de los estados nacionales en la segunda mitad del siglo XIX, se generó el término "caudillo" para referirse a aquellas personas (jefes militares) que habían desempeñado un papel fundamental en la independencia. A pesar de tener una función principalmente militar, los caudillos también ejercieron una función política, pues el prestigio alcanzado durante la guerra, permitió su papel como mensajeros de las ideas del pueblo a los líderes del gobierno, funcionando como un intermediario civil, pero sin ocupar puestos públicos ni obtener cargos administrativos o

\footnotetext{
${ }^{125}$ Algunas de las obras que revisaremos son: La Historiografía económica del Ecuador sobre el siglo XIX y XX en los últimos 25 años y Hegel-Marx: De la filosofía de la historia al materialismo histórico de Juan Paz y Miño Cepeda.

${ }^{126}$ Algunas de las obras que revisaremos son: Ecuador: Luces y sombras del liberalismo de Oswaldo Albornoz Peralta. Fuente: Jorge Núñez Sánchez, Antología de historia, op. cit., p. 9-50.

${ }^{127}$ Rosemarie Terain Najas, op. cit., p. 29-45; Jorge Núñez Sánchez, La historiografía ecuatoriana...op. cit., p. 295297.
} 
gubernamentales. El pueblo confiaba más en sus líderes individuales, legítimos defensores de sus intereses, que en los planteamientos de una determinada institución. Así, tuvo lugar el nacimiento de la figura del caudillo como un prototipo político y social que regía el entorno donde vivía. ${ }^{128}$

En los años posteriores a las luchas por la independencia y durante la etapa del establecimiento de las repúblicas, la forma de gobierno cambió pero los líderes políticos surgieron como herederos del legado caudillista. El caudillismo fue desplazado por una nueva tendencia política denominada "caciquismo", en la que los caciques eran los máximos representantes políticos e inversionistas económicos de una región determinada, con fuerte influencia y apoyo social.

Los caciques abarcaban desde la figura del jefe militar nacional o regional hasta la del terrateniente local, además de compartir su capacidad para ejercer un fuerte poder paternalista sobre un grupo territorial específico. Es decir, los caciques eran figuras con alto poder sobre las personas y los recursos disponibles en una esfera particular de dominación, pudiendo manipular leyes y normas para conseguir sus objetivos. ${ }^{129}$

A pesar de las diferencias existentes entre los caudillos y los caciques, también existen semejanzas que permiten establecer una relación según el grado de autoridad que ejercieron dentro de su propia comunidad.

En primer lugar, ambos son un modelo de enriquecimiento económico que fue empleado en beneficio propio, lo que les permitió ingresar en la burguesía naciente, conforme al poder político alcanzado individualmente. Además, por el carácter que su apellido les otorgó en otros tiempos, poseían linajes políticos semejantes a la aristocracia.

También, podemos referirnos a ellos como categorías sociales a pesar de que su origen tuviera lugar en épocas diferentes. El respaldo popular los llevaba a implicarse en variadas actividades políticas, al tratarse de hombres con méritos adquiridos por sus triunfos y que inspiraban a sus partidarios. $^{130}$

\footnotetext{
${ }^{128}$ Javier Moreno Luzón: Teoría del clientelismo y estudios de la política caciquil, Revista de Estudios Políticos (Nueva Época) Núm. 89, Julio-Septiembre, 1995, p. 191-224; Lariza Pizano: Caudillismo y clientelismo: Expresiones de una misma lógica. El fracaso del modelo liberal en Latinoamérica, en Revista Estudios Sociales, Junio, 2001, p. 75-83.

${ }^{129}$ Javier Moreno Luzón, op. cit., p. 191-224. Lariza Pizano, op. cit., p. 75-83.

${ }^{130}$ Ibíd. p. $75-83$.
} 
Pese a lo dicho, el clientelismo es el factor que une a estas categorías a la hora de buscar seguidores y contribuyentes. La influencia política del cacique depende en gran parte del carisma alcanzado como caudillo, de su poderío financiero y de las redes clientelares que pueda formar y que lo une con las masas. Por ello, el clientelismo fue el elemento que posibilitó el desarrollo del caudillismo y del caciquismo. $^{131}$

El historiador Michael Zeuske al referirse a las clientelas plantea:

Se pueden distinguir dos niveles de clientelas: uno dentro de las unidades militares, que más tarde formará los niveles local y regional (...) y otro nivel formado por altos oficiales de mando, que después constituirá el nivel provincial de las clientelas. Básicamente estos dos niveles se interrelacionaban a través de los coroneles, comandantes y capitanes del ejército libertador, convertidos posteriormente en caciques políticos locales y regionales (...). ${ }^{132}$

Entonces, se puede pensar que la problemática de las redes clientelares es variable porque se adapta al hecho que se persigue. Es decir, el caudillo o cacique se muestra benefactor de los habitantes de una región y estos le proporcionan el apoyo necesario. A partir del apoyo de las élites, esta figura se compromete con los grupos sociales que los apoyan. ${ }^{133}$

Durante las guerras de independencia, se dio prioridad al caudillo militar a la vez que sus relaciones estaban basadas en el intercambio con las redes clientelares que mantenían su status, donde el regionalismo y el prestigio alcanzado, eran los elementos que propiciaron tales hechos. En la época republicana, el cacique pasó a desempeñar el papel principal dentro de las relaciones antes establecidas con sus seguidores, aunque en esta ocasión se basaban en el poderío económico adquirido, permitiéndoles una mayor movilidad en el escenario regional político donde se desarrollaban. ${ }^{134}$

\footnotetext{
${ }^{131}$ Lariza Pizano, op. cit., p. 75-83.

${ }^{132}$ Michael Zeuske: Los negros hicimos la independencia: Aspectos de la movilización afrocubana en el hinterland cubano, Cienfuegos entre colonia y república, en Espacios, silencios y los sentidos de la libertad, Cuba entre 1878 y 1912, Editorial de Ciencias Sociales, 2002, p. 193-234.

${ }^{133}$ Javier Moreno Luzón, op. cit., p. 191-224.

${ }^{134}$ Ibíd. p. 292-224.
} 
Siguiendo con el tema de los campos que han influido en el proceso de creación y desarrollo de la historiografía ecuatoriana, vamos a hablar de la influencia que tanto la literatura como la narrativa han ejercido en el campo de la historiografía, lo cual puede ser estudiado a partir de dos procesos fundamentales que han caracterizado a la modernidad capitalista. ${ }^{135}$

El primero, guarda relación con la correspondencia entre la división del relato mítico en histórico y literario y el correspondiente proceso de separación entre lo político y social y lo público y privado, mientras que el segundo, se refiere a la constitución del pensamiento lógico-racional y de su forma superior, la ciencia, como el eje de la cultura moderna. A partir de estas ideas, Alejandro Moreano explica que los distintos saberes sociales influenciados por la hegemonía de la legitimidad científica, pasaron a convertirse en ciencias sociales hasta alcanzar su independencia de la filosofía. ${ }^{136}$

Por otra parte, Moreano afirma que la historiografía tuvo su origen y desarrollo en el seno de este proceso y no en el de las ciencias sociales, mientras que el desarrollo de la conciencia histórica se forjó con la configuración del estado moderno, asumiendo la narrativa histórica un carácter fundamentalmente político. $^{137}$

Algunos partidarios de las ideas científicas indican que el tránsito de la historia de las artes y de la literatura al de la ciencia fue iniciado durante el siglo XIX, a partir de una corriente historiográfica que se encontraba influenciada directamente por el positivismo. No obstante, durante el siglo XX, la Escuela de los Annales, el marxismo de tipo positivista y las teorías cuantitativas, fueron los movimientos que llegaron a consolidar la tendencia científica de la historiografía, por lo que algunos de estos autores se centraron en el estudio de la conversión de la historiografía en un campo de estudio y en una disciplina científica. ${ }^{138}$

Este nuevo interés contribuyó a impulsar los cambios en cuanto al contenido de los temas a elegir, ya que se fue produciendo un abandono progresivo del drama, la epopeya o la tragedia, y

\footnotetext{
${ }^{135}$ Alejandro Moreano, El discurso historiográfico ecuatoriano..., op. cit., p. 2-160.

${ }^{136}$ Ibíd. p. 2-160.

${ }^{137}$ Ibíd. p. 2-160.

${ }^{138}$ Hayden White afirma a este respecto: Y en efecto, podría argüirse plausiblemente que la transformación de un campo de estudio en una verdadera ciencia, siempre ha ido asociado al abandono de algo parecido al interés por inventar una historia para narrar su objeto de estudio, en favor de descubrir las leyes que la rigen. Fuente: Hayden White: Historiography and historiophoty, en The American Historical Review, Vol. 93, No. 5, Washington, 1988, p. 181.
} 
con ello, de las figuras representativas o héroes individuales, a la vez que se fomentaba una visión de carácter estructural fundamentada en la idea de un proceso sin un personaje determinado. En definitiva, esta separación entre la historiografía, la narrativa y la literatura, puso de manifiesto la existencia de una mayor aproximación al campo de las ciencias sociales. ${ }^{139}$ En este caso, se puede pensar que el proceso en el que la historia siguió su camino de ruptura con la filosofía y la literatura y su reunión con la ciencia, constituyó el segundo momento de la fragmentación del pensamiento mítico, es decir, la emergencia del saber y del discurso científico como eje de la cultura moderna. Ahora bien, nuestro interés se centra en el desarrollo histórico, es decir, en las épocas del "narrativismo" y del "cientifismo" del discurso histórico, así como su correspondencia con las formas dominantes de la literatura narrativa y en las formas de discurso permitidas en cada época. En ese sentido, se pueden establecer las siguientes fases en el desarrollo de la historiografía ecuatoriana: ${ }^{140}$

La primera fase, que se extiende hasta los años cincuenta, se caracterizó por la relación entre la narrativa histórica de ficción, el ensayo y la crítica literaria. La configuración colonial impuesta en el Ecuador fue un obstáculo al desarrollo autónomo del país, puesto que no llegó a producirse la secuencia histórica que permitiera el avance del pasado mítico a la modernidad, con la correspondiente división del relato mítico en histórico y literario y la posterior superposición de la historiografía con las ciencias sociales emergentes. Tampoco, llegó a darse una separación completa de lo público y privado a partir de las relaciones mercantiles.

Posteriormente, los comienzos del siglo XX, se caracterizaron por el surgimiento del liberalismo en el poder, la realización de profundas reformas (la laicización del estado y de la vida social) y la ruptura entre el placismo y el partido alfarista. Así, durante el año 1912, se formaría el llamado régimen plutocrático como resultado del acuerdo entre la oligarquía exportadora-importadora y financiera de la Costa y el latifundismo serrano. En este momento, el liberalismo subió al poder, a la vez que la "sociedad jurídico-literaria", formada por representantes de la aristocracia y de las altas capas medias liberales, expresaba ese proceso mediante las nuevas formas de representación del poder. Aquí, se puede pensar que fueron los poetas, abogados y hombres de letras, los que pusieron de manifiesto las particulares relaciones entre las letras y el saber jurídico

\footnotetext{
${ }^{139}$ Alejandro Moreano, El discurso historiográfico ecuatoriano..., op. cit., p. 2-160.

${ }^{140}$ Rosemarie Terain Najas, op. cit., p. 29-45; Jorge Núñez Sánchez, La historiografía ecuatoriana...op. cit., p. 295297.
} 
del estado, hecho que explica la importancia del papel que desempeñó este último en el nacimiento de la conciencia literaria y lo público. ${ }^{141}$

Tras la primera crisis de la Revolución Liberal, surgió un proyecto histórico social de creación de un estado nacional a partir del movimiento social y cultural de las clases inferiores, que acabó con la formación de organizaciones populares y de la izquierda. Este proceso, que finalizó en la llamada revolución popular del 44, fue el mayor esfuerzo de la época para la construcción de una voluntad nacional-popular desde las clases inferiores.

No obstante, la existencia de una serie de razones (la debilidad política de la clase inferior, el carácter de la burguesía y del estado, entre otros) determinó el fracaso de esa segunda fase de modernización del Ecuador. A este respecto, se ha de indicar que pese a que el proceso cultural anterior mantuvo su forma general (combinación de mito, narrativa, análisis social), se fueron introduciendo cambios en el contenido dado el proyecto nacional de los sectores inferiores.

La década de los cincuenta se caracterizó por la decadencia de la literatura del realismo social, a la vez que se producía un desplazamiento hacia la poesía y el ensayo literario e histórico social, mientras que los años sesenta se destacaron por la lucha de la figura del intelectual y de la forma ensayo y el desarrollo de las ciencias sociales, entre las cuales, la historiografía y la literatura, tenían como objeto la existencia de los personajes, la experimentación del lenguaje y las formas de vanguardia. En este sentido, nos adentramos en la segunda fase, que coincide con la década de los setenta, caracterizada por el lanzamiento del discurso de las ciencias sociales y por el gran esfuerzo de autonomía de la historia y la literatura, y que termina con la crisis de la modernidad y la modernización a finales del siglo XX (la tercera etapa). ${ }^{142}$

Por último, hemos de indicar que las novelas históricas, a través de la polifonía, la intertextualidad y la apertura de la narración histórica al ámbito de lo particular, local y cotidiano, han logrado formular aspectos del pasado nacional que no habían sido incorporados por los tratados históricos tradicionales al ser considerados como irrelevantes. Así, por ejemplo la novela "El general en su laberinto" de Gabriel García Márquez presenta a un Simón Bolívar enfermo y contradictorio al que la gloria se le [ha] salido del cuerpo. En esta novela, se presentan varios pasajes que sirven para mostrar la separación entre el hombre (Bolívar) y su

\footnotetext{
${ }^{141}$ Ibíd. p. 295-297.

${ }^{142}$ Ibíd. p. 295-297.
} 
imagen beatificada (el Libertador), mientras que el autor narra los momentos finales de Bolívar, centrándose en su vida privada y recuerdos, lo que le permite modificar la imagen tradicional de este héroe de la independencia. ${ }^{143}$

Vamos a pasar ahora a analizar cuáles han sido las líneas de investigación de la historiografía ecuatoriana y para ello, comenzaremos haciendo alusión a las notables aportaciones realizadas por la historia política, centrándose su labor en el enriquecimiento temático, al superar la cronología tradicional y dejar a un lado la historiografía partidista. ${ }^{144}$ En este contexto, la publicación de la obra "El poder político en Ecuador" de Osvaldo Hurtado, representa un paso adelante en la consolidación de un estilo de trabajo más ajustado a un marco analítico y basado en la evidencia empírica. ${ }^{145}$

Los temas de estas obras y sus perspectivas de análisis fueron elementos fundamentales que contribuyeron al establecimiento de una nueva forma de abordar la historia política, como ocurrió con el populismo, que logró mantener un espíritu novedoso en el ámbito intelectual. Si bien este tema fue iniciado por Agustín Cueva, posteriormente aparecieron los trabajos de Rafael Quintero, Juan Paz y Miño y los de Juan Maiguashca, quien consideró la diferenciación económica regional y sus consecuencias sociales. ${ }^{146}$

En cierto modo, el análisis realizado por diferentes autores es un indicativo de los numerosos campos de investigación que no han sido explorados, siendo los aspectos de la historia colonial del siglo XVIII los más utilizados. Tampoco, se puede negar el vínculo existente de este tema con los intentos para comprender los antecedentes de la configuración republicana y el impacto en ese contexto de las estructuras que aparecieron de la colonia. Aquí, se encuentran los escritos

\footnotetext{
${ }^{143}$ Gabriel García Márquez: El general en su laberinto, Madrid, 1989, p. 203.

${ }^{144}$ Rosemarie Terain Najas, op. cit., p. 29-45; Jorge Núñez Sánchez, La historiografía ecuatoriana...op. cit., p. 295297.
}

${ }^{145}$ Enrique Ayala Mora considera que la obra El poder político del Ecuador representa una aportación nueva dentro del campo de la literatura social del Ecuador. Fuente: Enrique Ayala Mora: Una relectura de El Poder político en el Ecuador, El poder político en el Ecuador, Debates de Osvaldo Hurtado, vigésimo aniversario, Procesos, revista ecuatoriana de historia, no. 10, Corporación editora nacional, ouko, 1997.

${ }^{146}$ Revisaremos la obra de Rafael Quintero: La cuestión regional y el poder, Facultad Latinoamericana Ciencias Sociales (FLACSO), Biblioteca de Ciencias Sociales, volumen 29, Corporación Editora Nacional, Quito, Ecuador, 1991. 
sobre el auge exportador y los fenómenos de desarticulación regional del siglo XVIII, cuyo estudio sería difícil de entender sin la historia del sector textil y agrario. ${ }^{147}$

En referencia a la historia social, si bien fue promocionada en los años sesenta por las aportaciones de Oswaldo Albornoz Peralta y Jaime Galarza, su desarrollo posterior vino acompañado de la influencia teórica del marxismo, la etnología y la escuela inglesa de historia social.

Entre los autores de la nueva historia social ecuatoriana, podemos destacar a Andrés Guerrero, Manuel Chiriboga, Jorge Núñez, Juan Paz Miño y Milton Luna, apreciándose en sus obras, la mezcla de influencias teóricas y la búsqueda de nuevas metodologías. Por otro lado, el tema de mayor interés para los historiadores ha guardado relación con los sistemas de dominación y las clases dominantes, siendo la historia de la oligarquía, uno de los temas más importantes debido al poder de esta clase en el Ecuador. Entre las contribuciones más destacadas, se encuentran los trabajos historiográficos de Jorge Núñez, que hacen referencia a la oligarquía ecuatoriana, y los de Chiriboga y Guerrero, que tratan sobre las relaciones sociales de las hacienda. ${ }^{148}$

Aunque el desarrollo de la historia de lo social se ha centrado en la narración del pasado ecuatoriano, hay que señalar que la incorporación de nuevos temas de interés y técnicas de investigación contribuyó al abandono del protagonismo de los conquistadores, héroes, dictadores y líderes políticos, llegándose a escribir sobre diversos actores sociales (clases, etnias, masas populares y sectores sociales subordinados). ${ }^{149}$ Asimismo, gracias a la aparición de estas ideas, la historia pasó de ser un escenario político a uno social, en el que el eje histórico ya no serían los conflictos de los líderes, sino los intereses de un pueblo enfrentado en las luchas regionalistas o entre clases. $^{150}$

No se puede olvidar el campo de la historia económica, con respecto a la cual, se ha de hacer hincapié en los escasos estudios llevados a cabo en el Ecuador durante el siglo XX, a excepción

\footnotetext{
${ }^{147}$ Rosemarie Terain Najas, op. cit., p. 29-45.

${ }^{148}$ Revisaremos los trabajos: La historiografía ecuatoriana contemporánea (1970-1994) y La actual historiografía ecuatoriana y ecuatorianista de Jorge Núñez y Los terratenientes costeños en la economía del Ecuador republicano de Manuel Chiriboga.

149 Guillermo Bustos: La producción historiográfica contemporánea sobre la independencia ecuatoriana (19802001): Una aproximación, Procesos, Revista Ecuatoriana de Historia, No. 20, Corporación Editora Nacional, 2004.

${ }^{150}$ Rosemarie Terain Najas, op. cit., p. 29-45.
} 
del trabajo realizado por el Banco Central del Ecuador y la creación de un espacio dedicado a la historia económica y edición de la "Revista Ecuatoriana de Historia Económica", pese a que esta fue discontinuada posteriormente. ${ }^{151}$

La mencionada escasez de datos económicos ha sido un claro obstáculo al análisis de fenómenos importantes de la historia económica ecuatoriana (la articulación entre las economías regionales, las formas de vinculación al mercado internacional, los ciclos de auge y crisis en las economías regionales, etc.), además de suponer un gran impedimento para la comprensión de otros eventos históricos. En este sentido, la falta de una corriente constante dentro de la historia económica del país, ha afectado al desarrollo de los estudios históricos como consecuencia de la incapacidad para acumular una importante cantidad de conocimientos objetivos sobre el pasado de la economía ecuatoriana. ${ }^{152}$

Por otra parte, hemos de mencionar las aportaciones realizadas por los ecuatorianistas extranjeros, cuya preocupación por el conocimiento científico ha estado acompañada por su interés en el estudio de la historia ecuatoriana. El campo de especialización se ha centrado en temas poco utilizados por los historiadores ecuatorianos, como ha sido la historia demográfica y la historia económica. Ahora bien, aún cuando el trabajo de estos autores ha contribuido al análisis de conocimientos de la historia pasada, ofreciendo nuevas perspectivas y metodologías, también se ha caracterizado por una serie de limitaciones. ${ }^{153}$

En el caso de los historiadores europeos, la mayoría de sus trabajos trata sobre la historia del Ecuador y de América Latina, en particular la época colonial, ya que tienen en sus propios archivos las fuentes de dicho periodo y parece que el acceso a las de la etapa republicana es más difícil. No obstante, pese a la existencia de la tecnología que ha facilitado la tarea de investigación, se percibe un distanciamiento mental por parte de los latinoamericanistas europeos en relación a la historia republicana de América Latina. Si bien algunos de los ecuatorianistas norteamericanos han mostrado un espíritu abierto en sus estudios de la historia de América

\footnotetext{
151 Jorge Núñez Sánchez, La historiografía ecuatoriana...op. cit., p. 295-297.

${ }^{152}$ Algunas de las publicaciones del Banco Central que revisaremos son: René Báez: Apogeo y decadencia del modelo agroexportador. Periodo de la segunda posguerra; Patricia Almeida Guzmán, Rebeca Almeida Arroba: Estadísticas Económicas Históricas 1948-1983 y la de la Dirección General de Estadística y Censos: Primer Censo Agropecuario Nacional, 1954. Fuente: Jorge Núñez Sánchez: La historiografía ecuatoriana contemporánea (19701994), Ediciones de la FAU, Universidad Central del Ecuador, Quito, 1984.

153 Jorge Núñez Sánchez, La historiografía ecuatoriana...op. cit., p. 295-297.
} 
Latina, hay un gran número de ellos, cuya visión ofrece ideas preconcebidas, pues no buscan estudiar la historia en su particular marco socio-cultural, sino a partir de los elementos de su propia cultura. $^{154}$

También, existe una acumulación positivista de monografías que no ha llegado a tener gran importancia y ha generado una corriente local conocida como "monografismo" procedente del extranjero. Además, aún cuando dicha acumulación monográfica ha permitido la recopilación de una importante cantidad de información de la historia del Ecuador, su visión reduccionista ha supuesto un obstáculo a la hora de interpretar los diversos periodos de tiempo y eventos de la historia de este país. ${ }^{155}$

Paralelamente, existen numerosos estudios de historiadores ecuatorianistas de buena calidad y auténtica perspectiva científica, que han tenido en cuenta los vacíos dejados por los historiadores ecuatorianos y han enriquecido el trabajo realizado por estos últimos. La falta de continuidad de los historiadores nacionales ha sido causada por la despreocupación y el desinterés de las instituciones ecuatorianas, puesto que no han ofrecido un gran apoyo a la investigación.

Vamos a analizar ahora cuáles fueron las instituciones vinculadas a la renovación de la historiografía ecuatoriana, por lo que tomaremos como referencia el análisis proporcionado por Jorge Núñez, en el que presenta varios grupos de instituciones académicas de promoción científica y las instituciones dedicadas a la investigación. ${ }^{156}$ Por tanto, ¿cuáles fueron las características fundamentales de estas instituciones? ¿en qué se diferencian unas de otras?

En primer lugar, al referirnos a las instituciones académicas, hay que destacar la existencia de dos organizaciones, cuyo trabajo en la enseñanza de la historia ha sido de gran importancia para la formación de una nueva generación de historiadores profesionales, además de impulsar la renovación de la producción historiográfica mediante numerosas publicaciones. Una de estas instituciones es la Pontificia Universidad Católica del Ecuador (PUCE), que ha sido una de las organizaciones académicas más importantes debido a su buen equipo de docentes ecuatorianos y extranjeros, y la otra es la Facultad Latinoamericana de Ciencias Sociales (FLACSO), encargada

\footnotetext{
${ }^{154}$ Ibid. p. 295-297.

${ }^{155}$ Ibíd. p. 295-297.

${ }^{156}$ Ibíd. p. 295-297.
} 
de formar a diversas promociones de historiadores profesionales que han contribuido a la investigación histórica. ${ }^{157}$

De forma paralela al surgimiento de las nuevas tendencias historiográficas, apareció en Guayaquil, un grupo impulsor de los estudios de historia regional, cuyo objetivo era actualizar la antigua tradición historiográfica creada por el Centro de Investigaciones Históricas de Guayaquil. Este grupo intelectual, que pertenece al conjunto de instituciones de promoción científica, alcanzó su expresión institucional en el Archivo Histórico del Guayas (AHC), y es una de las instituciones de promoción de la historia ecuatoriana más activa. La labor del AHC ha sido pionera a la hora de vincular el país a los ecuatorianistas extranjeros y difundir localmente sus estudios, los cuales habrían pasado desapercibidos de no haber sido por su intermediación. ${ }^{158}$

En último lugar, las instituciones de investigación surgieron en varias etapas como expresión del interés científico y de la necesidad de ocupación profesional en el Ecuador. El primer periodo, ubicado entre los años 1972-1982, se caracteriza por el desarrollo de proyectos de investigación histórica bajo motivaciones de tipo ideológico y por una financiación nacional e internacional. El segundo periodo, comprendido entre 1980 y 1984, se caracteriza por los efectos provocados por la crisis y por la falta de interés de los organismos internacionales de financiación en proyectos de ciencia pura (proyectos de difusión histórica), lo cual explica que una gran parte de los centros de investigación privados abandonara la investigación histórica y se concentrara en labores sociológicas más rentables. ${ }^{159}$

Asimismo, hemos de hablar de la promoción de desarrollo cultural llevada a cabo por el Banco Central del Ecuador y la creación de centros de investigación histórica y de difusión cultural (el Centro de Investigación y Cultura, los Museos Arqueológicos, el Archivo Histórico y el Archivo Nacional Audiovisual), los cuales contribuyeron a generar diversas dependencias regionales en el resto del Ecuador y promocionaron los estudios históricos ecuatorianos.

\footnotetext{
${ }^{157}$ Entre las obras correspondientes a estas instituciones figuran: Osvaldo Barsky, Gustavo Cosse: Tecnología y cambio social. Las haciendas lecheras del Ecuador, Facultad Latinoamericana de Ciencias Sociales (FLACSO), 1981; Gilda Farrel, Jorge Fernández, Cristian Sepúlveda: El proceso de industrialización ecuatoriano, Instituto de Investigaciones Económicas, Pontificia Universidad Católica del Ecuador (PUCE), 1983; Osvaldo Barsky: La reforma agraria ecuatoriana, Facultad Latinoamericana de Ciencias Sociales (FLACSO), 1984; Osvaldo Barsky: Los terratenientes serranos y el debate político previo al dictado de la Ley de Reforma Agraria de 1964 en el Ecuador, Facultad Latinoamericana de Ciencias Sociales (FLACSO), 1980.

158 Jorge Núñez Sánchez, La historiografía ecuatoriana...op. cit., p. 295-297.

${ }^{159}$ Ibíd. p. 295-297.
} 
No obstante, la posterior implantación de políticas neoliberales, acompañada de la fragmentación del sistema cultural de la institución, ha provocado frecuentes críticas a los estudios históricos ecuatorianos y, en general, al desarrollo cultural del país. ${ }^{160}$

Otro de los objetivos perseguidos durante el transcurso de este periodo, fue la implantación de diversos centros específicos de investigación, cuya finalidad era la de organizar talleres profesionales (Taller de Estudios Históricos de 1985 y la Fundación de Estudios Históricos de 1989) para poder reunir a jóvenes historiadores procedentes de la FLACSO o la PUCE e impulsar la publicación de libros y revistas especializadas en la historia ecuatoriana. ${ }^{161}$ En este contexto, las instituciones de difusión se han destacado por su labor, ya que a través de sus publicaciones han promocionado el trabajo de estos nuevos historiadores, creando colecciones o bibliotecas editoriales especializadas en historia como la Corporación Editora Nacional (CEN), que cuenta con la publicación de la Biblioteca Básica del Pensamiento Ecuatoriano, el Libro del Sesquicentenario, la Nueva Historia del Ecuador, la Biblioteca de Ciencias Sociales y en última instancia, la Universidad de Guayaquil con la publicación de su Biblioteca Ecuatoriana. ${ }^{162}$

En definitiva, una vez terminado este último balance de las instituciones de investigación más representativas del Ecuador y una vez analizadas las principales corrientes de pensamiento de América Latina y algunos de los principales autores de la historiografía ecuatoriana, cabe preguntarse cómo podríamos relacionar todas estas ideas con la temática seleccionada en nuestro proyecto.

En este sentido, se ha hablado de la preocupación de una parte importante de historiadores y sociólogos por la renovación historiográfica y de su interés en especialidades centradas en la

${ }^{160}$ Ibíd. p. 295-297.

${ }^{161}$ Ibíd. p. 295-297.

162 Algunas de las obras pertenecientes a la Corporación Editora Nacional que revisaremos son: René Báez: Evolución de la dependencia ecuatoriana (1830-1980), Economía Ecuador: 1830-1980, Vol.1, Libro del Sesquicentenario, Corporación Editora Nacional, 1983; Gonzalo Correa Escobar: La economía ecuatoriana de 1830 a 1980, Economía/Ecuador: 1830-1980, Vol.1, Libro del Sesquicentenario, Corporación Editora Nacional, 1983; Manuel Chiriboga Vega: Los terratenientes costeños en la economía del Ecuador republicano, Economía/Ecuador: 1830-1980, Vol.1, Libro del Sesquicentenario, Corporación Editora Nacional, 1983; Iván Fernández Espinosa y Patricio Tobar Robalino: Acumulación de capital 1830-1980. Sus mecanismos de creación y apropiación, Libro del Sesquicentenario. Economía del Ecuador 1830-1980, segunda parte, Corporación Editora Nacional, 1983; Fausto Jordán: El proceso agrario en la Sierra ecuatoriana, Economía/Ecuador: 1830-1980, Vol.1. Libro del Sesquicentenario, Corporación Editora Nacional, 1983; Carlos Larrea Maldonado: Las empresas transnacionales y la economía ecuatoriana durante el periodo bananero, Economía/Ecuador: 1830-1980, Vol.1, Libro del Sesquicentenario, Corporación Editora Nacional, 1983. 
cultura ecuatoriana, la historia regional y urbana, la época colonial y las primeras décadas del periodo republicano, el estudio del minifundio-latifundio y la hacienda serrana en el Ecuador y el análisis del capitalismo y desarrollo de América Latina, entre otros. Sin embargo, hay que señalar que a pesar del impulso de las corrientes de la época defensoras de las investigaciones de carácter científico, existen numerosos estudios limitados por el desarrollo descriptivo y frecuentemente acientífico que ha tenido la ciencia histórica en el país, debido a la clara dificultad para poder acceder a datos y fuentes estadísticas.

Por consiguiente, a partir de las ideas mencionadas y considerando la problemática expuesta, el propósito de esta tesis se centra en el estudio de la modernización del Ecuador a través de la interrelación de los factores económicos, sociales, culturales y políticos, a fin de lograr con los elementos históricos y fuentes económicas disponibles, una visión algo más profunda y causal de las características y posibilidades de desarrollo y acumulación del capital en el Ecuador. 


\section{CAPÍTULO 1: EL DESARROLLO DEL CAPITALISMO Y EL PAPEL DEL ECUADOR EN LA CONFORMACIÓN DE LA ECONOMÍA INTERNACIONAL CAPITALISTA (1880-1930):}

\section{1) Antecedentes históricos: La evolución geográfica de la Real Audiencia de Quito al Ecuador del siglo XX.}

En este primer apartado, se analizará la evolución geográfica del Ecuador durante los siglos de dominación colonial previos a la República, así como el establecimiento de fronteras entre los países con territorios amazónicos y los conflictos de límites que surgieron al respecto. Esto nos permitirá observar la creciente importancia de dichos eventos durante los siglos XIX y XX, debido a su gran influencia en el proceso de constitución de los estados nacionales y en la definición de las fronteras de las áreas amazónicas que pertenecieron a la Audiencia de Quito en el periodo colonial. ${ }^{163}$

En primer lugar, antes de llevar a cabo una síntesis histórica en el establecimiento de las fronteras territoriales de la alta Amazonía, vamos a comenzar con una breve referencia a las primeras décadas de dominación española, caracterizadas por las importantes exploraciones llevadas a cabo como consecuencia de la atracción hacia la explotación aurífera en esa región. Estas exploraciones, organizadas a menudo en las ciudades de Quito y Loja, fomentaron la incorporación de un notable conjunto de territorios a la economía colonial, en los que tuvo lugar un intenso proceso de colonización que terminó con la fundación de varias poblaciones como fue el caso de Baeza, Archidona, Sevilla del Oro y Zamora, así como la creación de varias circunscripciones administrativas que constituyeron los gobiernos de Jaén, Quijos, Macas, Mocoa y Yaguarzongo, y que abarcaban territorios desconocidos en su mayor parte.

La integración a la economía colonial supuso la imposición de un esquema socio-político que estaba basado en la fundación de estas ciudades como centros militares, religiosos y administrativos; la concentración de la población indígena en reducciones, haciendas y obrajes para controlar y explotar su fuerza de trabajo, así como la aplicación de sistemas agrícolas, mineros y manufactureros procedentes de Europa, siendo estos factores, determinantes en el proceso de concentración de la riqueza en manos de los españoles, criollos locales y de la

\footnotetext{
163 Jorge Pérez Concha: Ensayo histórico-crítico de las relaciones diplomáticas del Ecuador con los estados limítrofes, Quito, Banco Central del Ecuador (ed. Orig. 1958-1959), 1979, p. 9-90.
} 
Iglesia. ${ }^{164}$ Ahora bien, ¿cuál fue la disposición geográfica de los territorios dependientes de la Corona española?

En un principio, en el año 1542, Carlos V suscribió una Real Cédula para la creación del Virreinato de Perú, dividido en las Audiencias de Panamá, Lima y Santa Fé, siendo Quito una de sus gobernaciones con jurisdicción sobre Guayaquil y Puerto Viejo. Posteriormente, en el año 1563, la Real Audiencia de Quito fue establecida como una instancia administrativa dependiente de la Corona de España que, por el norte, se extendía hasta Pasto, Popayán, Cali, Buenaventura y Buga, en el actual territorio de Colombia, y por el sur, hasta Piura en el Perú. ${ }^{165}$

Los levantamientos indígenas ocurridos en la zona de colonización a finales del siglo XVI, provocaron un retroceso de dicha frontera, mientras que el siglo XVII se caracterizaría por la presencia de misiones católicas en la alta Amazonía, las cuales acabaron desplazándose hacia las tierras bajas, instalándose en la región de Canelos en el año 1599. ${ }^{166}$

Posteriormente, a mediados del siglo XVII, la monarquía española asignó a los franciscanos la conversión al cristianismo de las gobernaciones de Mocoa y de Quijos, mientras que la de Mainas pasó al dominio de los jesuitas. ${ }^{167}$ A pesar de que estas misiones lograron un gran desarrollo, se ha de indicar que dicha obra misionera no estuvo acompañada de una implantación paralela de autoridad civil y militar colonial y tampoco supuso la incorporación real de la región a la Audiencia de Quito, por lo que una vez expulsados los jesuitas en 1767, los espacios amazónicos ecuatorianos quedaron en una situación de abandono. Los problemas del clero para reiniciar las misiones provocó un aumento de la influencia de los intereses portugueses en estas áreas, lo que unido a las epidemias, fueron factores que terminaron con el control colonial del imperio español en la Amazonía, antes de que se produjera la expulsión de los jesuitas.

Es importante señalar que durante el periodo de dominación española, la Audiencia de Quito ejerció la soberanía sobre los territorios amazónicos, aunque este poder estaba limitado, pues los

\footnotetext{
${ }^{164}$ Nelson Gómez: Organización del espacio ecuatoriano, en Nueva Historia del Ecuador, Vol. 12, 1992 , p. 15-330.

165 En 1739, Quito pasó a formar parte del Virreinato de Nueva Granada, compuesta a su vez por Colombia y Venezuela, pero unos años más tarde volvería a depender del Virreinato del Perú. Ver el mapa 1 en apéndice de mapas. Fuente: Marqués de Lozoya: Historia de España, Tomo V, Salvat Editores, S.A. Barcelona, 1973.

${ }^{166}$ Algunas de las insurrecciones tuvieron lugar en Quijos y en Macas en el año 1578.

${ }^{167}$ Ver el mapa 2 de misiones y fronteras en el apéndice de mapas.
} 
rasgos propios de la selva y el rechazo mostrado por su población nativa, constituyeron un gran obstáculo a la presencia colonial.

El estado de abandono en que se encontraban las posesiones amazónicas y la creciente penetración portuguesa desde el Brasil, llevaron a una reforma administrativa por parte de la Corona española, que quería introducir cambios en la soberanía nacional. ${ }^{168}$ Así, en el año 1802 , el Consejo de Indias llevó a cabo la reformulación de la organización administrativa de la región, a través de la creación del Obispado de Mainas (que incorporaba Quijos y Mainas) y también, con la creación de la gobernación civil y militar de Mainas, realizándose por tanto, el traslado de los espacios amazónicos que dependían de la soberanía de la Audiencia de Quito a la soberanía del Virreinato de Perú. ${ }^{169}$

A continuación, vamos a ver cómo se establecieron las fronteras territoriales en la alta Amazonía durante el siglo XIX, las cuales se vieron afectadas por los problemas causados por las guerras de independencia y los diversos proyectos políticos, al fomentarse el abandono de los espacios selváticos.

En la época republicana, los estados que surgieron a raíz del triunfo sobre el poder colonial hispánico, a efectos de fijar sus límites, decidieron adoptar el principio del derecho romano conocido como uti possidetis, señalando como punto de referencia el año 1810, a partir del cual comenzó a librarse con éxito la lucha independentista. ${ }^{170}$ Dicho principio estimulaba el reconocimiento del estado posesorio en que se encontraban las regiones en el tiempo en que eran colonias y la continuidad del mismo en el momento de la emancipación, permitiendo por tanto, su transformación en estados independientes. De esta manera, el Perú, nació como una república independiente en 1821, mientras que la Real Audiencia de Quito se independizaría de España en

\footnotetext{
168 El 1 de octubre de 1777, España y Portugal hicieron una nueva delimitación de sus colonias en América, despojando a la Audiencia de Quito de $140.000 \mathrm{~km} 2$, los cuales fueron entregados a Portugal (ver mapa 3 en el apéndice de mapas). Fuente: Marqués de Lozoya: Historia de España, Tomo V, Salvat Editores, S.A. Barcelona, 1973.

${ }^{169}$ Ver el apéndice de notas del capítulo 1 para más información y el mapa 4 en el apéndice de mapas.

${ }^{170}$ La doctrina del uti possidetis se desarrolló en el derecho internacional regional de América Latina, como consecuencia de los problemas contenciosos territoriales que surgieron principalmente entre los estados sucesores de España y Portugal en materia de delimitación fronteriza durante los albores del siglo XIX. De acuerdo a los principios del derecho que dieron lugar a las distintas posiciones en torno al uti possidetis, la adjudicación de espacios terrestres en el derecho internacional decimonónico, permitía que esta se realizara mediante las fórmulas del descubrimiento, la ocupación o la conquista. Fuente: Camilo A. Gonzalo: Aplicación del principio uti possidetis juris en América, Universidad Autónoma de Colombia, Facultad de Derecho, Bogotá, 2010.
} 
1822, pasando a formar parte de la Gran Colombia hasta $1830 .{ }^{171}$ La división territorial de la Gran Colombia estableció el Distrito del Sur, que abarcaba los departamentos del Ecuador, con su capital en Quito, y los de Guayaquil y Azuay, con sus capitales en las ciudades de Guayaquil y Cuenca.

Enrique Ayala distingue dos etapas en el proceso de emancipación de los territorios de la jurisdicción de la Audiencia de Quito hasta la conformación de la República del Ecuador. Por un lado, la primera etapa, comprendía tres momentos específicos, siendo el primero de ellos, la Revolución de Quito (1808-1812) seguida del triunfo realista (1812-1820) y de la campaña definitiva para la independencia (1820-1822), mientras que la segunda etapa correspondía a los años de vida del país dentro de la Gran Colombia. ${ }^{172}$

Durante la campaña definitiva, Guayaquil logró su independencia en el año 1820, hecho que impulsó varios movimientos en el interior como fue el de Cuenca, que también declararía su independencia ese mismo año. Posteriormente y a pesar de su éxito, el ejército de Guayaquil sufrió algunas derrotas que lo obligaron a retirarse, a la vez que recibió el refuerzo enviado desde Colombia por Simón Bolívar, junto con una comisión encargada de gestionar la unión de Guayaquil a esta última. ${ }^{173}$ Tras varias batallas, la independencia de lo que hoy es el Ecuador, solamente pudo llevarse a cabo cuando las élites ampliaron la base social de las fuerzas y con la ayuda de Colombia. Esta victoria permitió la resolución de las anexiones de Quito y Cuenca a Colombia, a diferencia del caso de Guayaquil, debido a la resistencia mostrada y a la que Bolívar respondió con la fuerza.

De este modo, como ya señalamos antes, el Ecuador fue incorporado a Colombia con el nombre de Distrito del Sur, a la vez que fue dividido en tres departamentos que seguían las antiguas unidades regionales con capitales en Quito, Guayaquil y Cuenca. ${ }^{174}$

\footnotetext{
${ }^{171}$ La Gran Colombia era un estado federal creado por Simón Bolívar y abarcaba la Nueva Granada (Colombia y Panamá) y Venezuela.

172 Enrique Ayala Mora: Resumen de historia del Ecuador, Independencia y etapa colombiana, tercera edición actualizada, Corporación editora nacional, Quito, 2008, p. 10-90.

${ }^{173}$ Ver el mapa 5 en el apéndice de mapas.

${ }^{174}$ La República de Colombia, que había sido fundada en 1819 como una unión entre Venezuela y Nueva Granada, tenía la expectativa de que Quito también se uniera.
} 
En general, la etapa grancolombiana se caracterizó por una gran agitación en el Distrito del Sur, ya que la guerra de emancipación del Perú, demandó una gran cantidad de sus recursos hasta el fin de la campaña en Ayacucho en 1824. Así pues, la existencia de una presencia administrativa sin definir en los territorios de la alta Amazonía en la época colonial y las modificaciones de su soberanía en el último periodo de dominación española, resultaron en un conjunto de rivalidades por el control político de estos territorios entre el Ecuador, Perú, Colombia y Brasil, para establecer las fronteras sobre las áreas amazónicas que habían pertenecido a la Audiencia de Quito durante la época colonial. ${ }^{175}$

Los continuos conflictos con respecto al control político de la alta Amazonía, surgieron entre Perú y la Gran Colombia, cuando en 1822, el Perú convocó elecciones en las provincias de Quijos y Mainas, provocando fuertes protestas en la Gran Colombia, ya que las provincias de Jaén, Mainas y Quitos dependían de la autoridad de esta última en Quito. Años más tarde, en 1828-1829, estos conflictos llevaron a una guerra por cuestiones territoriales, terminando con la derrota del Perú y la firma del Tratado de Guayaquil en 1829, con el que se establecieron las fronteras de estos territorios de acuerdo con los límites coloniales entre los virreinatos. ${ }^{176}$

A partir de entonces, y una vez que la Gran Colombia estaba prácticamente disuelta, sería cuando el Distrito del Sur se separaría para formar un estado independiente. Ante estas circunstancias, los latifundistas de Quito que mostraban su resistencia a las medidas librecambistas (que perjudicaban la producción textil) y a las reformas igualitarias (que afectaban la estructura jerárquica corporativa), aceptaron la idea de la dictadura de Bolívar. A su vez, en Guayaquil, los terratenientes y comerciantes del puerto que rechazaban la anexión, encontraron algunos beneficios en dichas políticas y medidas librecambistas, manteniendo por tanto, su lealtad a Colombia. Sin embargo, la caída de las exportaciones a finales de los años veinte, llevó a la reactivación del comercio con Lima y al renacimiento de las tendencias autonomistas, acabando

\footnotetext{
175 Jorge Pérez Concha: Ensayo histórico-crítico de las relaciones diplomáticas del Ecuador con los estados limítrofes, Quito, Banco Central del Ecuador (ed. orig. 1958-1959), 1979, p. 50-89.

176 También, se firmó el Protocolo Pedemonte-Mosquero (1830) que fijó la frontera entre el Perú y la Gran Colombia en relación al Amazonas, y que al coincidir con la desintegración política de la Gran Colombia, no llegó a ratificarse.
} 
en la reivindicación de su autonomía, lo que explica el hecho de que las élites dominantes regionales del Distrito del Sur rompieran su vínculo con Colombia. ${ }^{177}$

Al referirse a la fragmentación del país ideado por Bolívar, Enrique Ayala indica:

Al conflicto de intereses entre oligarquías regionales, se unió la inexistencia de una clase social con capacidad para llevar adelante un proyecto nacional que fuera más allá de las presiones localistas y regionales. A estas causas de dispersión interna, se sumó la política de debilitamiento de las potencias capitalistas interesadas en que no se consolidara un gran estado, sino unidades políticas pequeñas, débiles y manejables. ${ }^{178}$

En la caracterización de la República del Ecuador, en mayo de 1830, se acordó la constitución de un estado libre e independiente con los pueblos del Distrito del Sur, a lo que se sumaron los cabildos de Guayaquil y Cuenca resolviendo formar conjuntamente con Quito un país independiente. ${ }^{179}$ Esta decisión no contó con la unanimidad de los terratenientes regionales, pues apoyaban la resistencia militar que tuvo lugar en Guayaquil poco tiempo después de haberse proclamado el nuevo estado.

Asimismo, Enrique Ayala indica que uno de los problemas con los que se encontraron los "padres de la Patria", fue asignar un nombre al nuevo país, puesto que el de la Audiencia de Quito despertaba resistencia entre los representantes de Guayaquil y Cuenca. Finalmente, se optó por el nombre designado por algunos investigadores franceses que habían realizado estudios sobre la línea equinoccial en años anteriores, surgiendo de este modo "el Ecuador". 180

Como veremos en el siguiente apartado, la característica del país en su configuración fue la regionalización, ya que estaba formado por los tres espacios dominantes en el último periodo colonial: la Sierra centro-norte, con Quito como eje, con la mayor parte de la población y la vigencia del régimen de haciendas; la Sierra sur, alrededor de Cuenca, con una presencia

\footnotetext{
${ }^{177}$ Rafael Quintero, Erika Silva: Ecuador: Una nación en ciernes, Tomo I, FLACSO, 1998, p. 34-45.

${ }^{178}$ Enrique Ayala Mora, Resumen de la historia..., op. cit., p. 10-90.

${ }^{179}$ Rafael Quintero, op. cit., p. 43.

${ }^{180}$ En 1736, la Academia de Ciencias de París envió la Misión Geodésica francesa a la zona ecuatorial de Quito para realizar estudios que definieran la forma del globo terráqueo. Algunos de sus representantes eran Pedro Bougher, Luis Godin y Carlos María de La Condomine. Fuente: Germán Rodas: J. de Morainville y el primer dibujo universal de la quina o cascarilla, Boletín del Instituto Francés de Estudios Andinos, año/vol. 32, número 3, Instituto francés de estudios andinos, Lima, Perú, 2003, p. 431-440.
} 
destacada de la pequeña propiedad agrícola y la artesanía; y la cuenca del río Guayas, con su centro en Guayaquil, que experimentó un rápido crecimiento del latifundio cada vez más vinculado a la exportación, a la vez que sufrió una disminución de la pequeña propiedad agrícola. Estas regiones, asociadas económicamente al sur de la actual Colombia, no constituyeron entre ellas un mercado que las articulara, lo que unido a las diferencias en la conformación de las sociedades en cada región, la debilidad y la tardía formación del estado nacional, tuvieron grandes dificultades para lograr la unidad nacional. ${ }^{181}$

Por otra parte, las guerras de la independencia perjudicaron los deficientes vínculos económicos y sociales entre las regiones y disminuyeron el comercio internacional que, con la ruptura colonial, fue orientándose hacia los centros capitalistas, especialmente hacia Gran Bretaña, la cual se constituyó como su principal socio comercial. A su vez, el desarrollo del comercio externo fomentó el crecimiento de la población y de la economía de la Costa, a pesar de que, en un principio, no pudo articular toda la economía del país, pues a finales del siglo XIX, el Ecuador se encontraba dominado por los grandes latifundistas que controlaban el poder regional. Así pues, tras la disolución de la Gran Colombia y con el establecimiento del Ecuador en 1830, continuaron los esfuerzos para poder solucionar la cuestión territorial. No en vano, se ha de señalar la amenaza de una invasión peruana en 1859, la cual puso de relieve la fragmentación de la clase terrateniente y la ausencia de conciencia nacional por parte de los terratenientes regionales. ${ }^{182}$

En efecto, el antiguo conflicto territorial originado por el rechazo del Ecuador a la Cédula de 1802, volvió a ocurrir cuando este exigió a Perú el pago de la deuda contraída por las guerras de la Independencia. El Ecuador negoció su deuda con Inglaterra mediante la cual, Perú debía de entregarle 860.000 pesos, además de ceder los territorios para la explotación por parte de compañías inglesas. En el cumplimiento del plazo de la deuda monetaria no hubo problemas con Perú, pero este no quiso dar los territorios de Canelos y Zamora, al considerarlos de su soberanía. En este caso, al negarse a resolver el conflicto por la vía diplomática, optó por el bloqueo de Guayaquil y declaró la guerra. La crisis diplomática culminó con la firma del Tratado de Mapasingue (1860), con el que se aceptaría la validez de la Cédula de 1802, base de la demanda

\footnotetext{
${ }^{181}$ Rafael Quintero, Erika Silva, op. cit., p. 43.

${ }^{182}$ Ibíd. p. 43-45.
} 
territorial de Perú y con ello, se reconocería la soberanía de este país sobre los territorios coloniales de Quijos, Canelas, Mainas. ${ }^{183}$

El peligro de invasión al Ecuador continuó durante algunos años más, convirtiéndose el puerto principal en un fuerte para resistir la oposición, evitar una nueva incursión peruana y hacer frente a las dos guerras sucesivas con Colombia, país que atravesaba una intensa guerra civil.

Rafael Quintero y Erika Silva recalcan el hecho de que en esta coyuntura, la guerra con Colombia no suponía la defensa de un patrimonio común para la mayoría de la población ecuatoriana, sino la defensa de un poder regional exclusivo de una clase. Esa misma clase, la terrateniente, no logró establecer una política única que se manifestara en un organismo de poder central, pues sus instrumentos de poder se encontraban esparcidos a lo largo del territorio. Esto explica el manejo de una forma más personal de los conflictos, que implicaba una continuación de la inestabilidad del Ecuador respecto a otros estados, así como la intervención en un conflicto interno de otro país, poniéndose de manifiesto la escasez de unión estatal y de las clases terratenientes y por consiguiente, la existencia de una política interior e internacional incoherente. $^{184}$

A pesar del fracaso de las invasiones, estos intentos, que estaban vinculados a la posible constitución de gobiernos regionales, no carecieron de importancia, sobre todo porque al tratarse de un país fuertemente regionalizado, en un momento de crisis un caudillo podía proclamarse jefe supremo si conseguía el apoyo de los núcleos dominantes regionales. ${ }^{185}$

Esta política junto con el escaso apoyo interno recibido, se tradujo en una administración diplomática inconsistente, que fue percibida por Colombia como una debilidad estatal, produciéndose de nuevo el conflicto entre ambos países. No obstante, en el campo diplomático

\footnotetext{
${ }^{183}$ Aún cuando el Ecuador no llegó a contar con el poderío militar suficiente para controlar el territorio peruano, sí que supo beneficiarse de la complicada situación internacional de Perú haciendo uso de la diplomacia. Así, tras la firma del Tratado Pando-Noboa en 1832, por el que reconocía al Perú la posesión de Tumbes, Jaén y Mainas; en 1840, el Ecuador reclamó la fijación de sus límites septentrionales y meridionales justamente cuando el gobierno peruano hacía frente a un grave conflicto con Bolivia. A pesar de esto, la clase dirigente ecuatoriana no siempre actuaría bien, tal y como ocurrió en 1859, cuando adjudicó a sus acreedores ingleses territorios que pertenecían a Perú. La reacción del gobierno peruano fue inmediata, invadiendo Guayaquil para avanzar sobre Quito, lo cual acabó con la rendición del Ecuador, que se vio obligado a reconocer la Real Cédula de 1802 y a firmar el Tratado de Mapasingue. Fuente: Armando Valenzuela: El Perú y sus fronteras geopolíticas, tensiones territoriales y guerra con Ecuador, Centro de Estudios Histórico-Militares del Perú, Lima, Perú, 1998, p. 7-140.

${ }^{184}$ Rafael Quintero, Erika Silva, op. cit., p. 43.

${ }^{185}$ Ibíd., p. 117.
} 
se consideró proponer una alianza con Perú y también con Venezuela, mientras se trataba de llegar a un acuerdo con Colombia.

De forma paralela al pacto con Perú, se pensaba que entre este país y Colombia existía un acuerdo secreto en contra del Ecuador, lo cual alarmó a las clases terratenientes regionales que se unieron al gobierno en el año 1863.

En definitiva, los conflictos bélicos con Colombia fueron un indicativo de los rasgos antinacionales de los proyectos políticos del estado terrateniente, lo cual se agudizó cuando el estado adoptó una forma dictatorial mediante una coalición del clero, la nobleza y el ejército. En el caso de los conflictos con Colombia, esto se puso de relieve mediante la falta de interés de la población en la defensa nacional y de la clase terrateniente para controlar el territorio mediante sus centros de poder.

Por otra parte, hacia finales del siglo XIX, el conflicto de límites apareció unido a los procesos de nacionalización de territorios de la alta Amazonía que desarrollaban los países del área en el marco de la extracción de caucho. Fue entonces, cuando las cancillerías del Ecuador y del Perú firmaron en el año 1887, el Protocolo Espinosa-Bonifaz que sometió las cuestiones de límites pendientes a la decisión del Rey de España, a la vez que comenzaban las negociaciones y la suscripción del Tratado Herrera-García en 1890, por el que se reconocía la soberanía del Perú sobre los territorios del Oriente que comprendían los dos márgenes del Amazonas hasta la desembocadura del Pastaza, mientras que el Ecuador mantenía el acceso al Amazonas a través de los ríos Pastaza, Morona y Santiago. ${ }^{186}$

Aún cuando este tratado fue aprobado por el Congreso ecuatoriano (a pesar de la renuncia a una gran parte de las tierras), se ha de destacar el rechazo por parte del Congreso peruano, al proponer importantes modificaciones que pretendían establecer una precaria salida del Ecuador con respecto al Amazonas, hecho que provocó el fracaso del tratado y el surgimiento de un movimiento nacionalista y militarista en algunas partes del país.

La resolución del conflicto de límites fue retomada tras la firma del Protocolo Valverde-Cornejo (1904), por la cual se pactó la desocupación militar del río Napo a petición del representante del Rey de España. Esta mediación acabó en el año 1910, ya que se pensaba que dicha resolución llevaría a la guerra entre ambas partes.

\footnotetext{
186 Jorge Pérez Concha, op. cit., p. 50-89.
} 
No en vano, algunas informaciones revelaron que el Consejo de España había dictado una medida para dividir el territorio con una línea parecida a la establecida con anterioridad en el Tratado Herrera-García, pero con una mayor reducción de la parte ecuatoriana, hecho que provocó nuevamente un conjunto de rivalidades. ${ }^{187}$

Además de las negociaciones con el Perú, se ha de hablar de la existencia de otros pactos territoriales como fue el Tratado Tobar-Río Branco de 1904, que estableció la frontera entre Brasil y Ecuador, siendo la línea definida, una sección de la frontera entre Colombia y Brasil alejada en tanto en cuanto del territorio ecuatoriano. ${ }^{188}$

Por su parte, para poder consolidar una frontera en el norte, el Ecuador firmó el Tratado Muñoz Vernaza-Suárez (1916), el cual reconocía a Colombia, los territorios en el Caquetá y el Putumayo. Años después, en 1922, Colombia y Perú firmaron el Tratado Salomón-Lozano, con el que Colombia proporcionaba al Perú lo esencial de los territorios que el Ecuador le había cedido antes con el Tratado Muñoz Vernaza-Suárez, quedando este país rodeado por el Perú en la parte oriental.

En el año 1924, el Ecuador y Perú volvieron a iniciar las negociaciones mediante la firma del Protocolo Ponce-Castro Oyanguren, estableciendo un mecanismo con el que se combinaban las conversaciones directas con la intervención del presidente de los Estados Unidos en los temas en los que no se llegara a un acuerdo. Las conversaciones posteriores fueron retrasadas al año 1936 debido a la inestabilidad social y política del momento, por lo que finalmente los representantes de ambos países aceptaron una línea de status quo, renunciando el Ecuador a grandes extensiones respecto a su demanda territorial original.

En 1938, tras varias negociaciones que finalizaron sin llegar a una solución concreta, el Perú, que desde tiempos atrás venía concentrando sus fuerzas militares en la frontera norte, invadió al Ecuador en 1941, dando lugar a una nueva guerra entre estos dos países. Ante estas circunstancias y en un contexto de grandes presiones internacionales, se firmó el Protocolo de Río de Janeiro en 1942, por el cual pasaron al control del Perú amplios territorios, prácticamente hasta la línea de navegación en pequeñas embarcaciones, mientras que la firma de este protocolo

\footnotetext{
${ }^{187}$ Ibíd. p. 50-89
}

${ }^{188}$ Con anterioridad a este tratado, las cancillerías del Ecuador y de Colombia se dispusieron a negociar la delimitación de las fronteras, de ahí que en el año 1894 y por iniciativa colombiana, se llevara a cabo una conferencia tripartita entre el Ecuador, Perú y Colombia a pesar de no obtener resultados concretos. Fuente: Jorge Pérez Concha, op. cit., p. 50-89. 
vendría a crear un verdadero problema nacional en el Ecuador, como consecuencia de los intereses petroleros norteamericanos creados en la Amazonía. ${ }^{189}$

\section{2) La importancia de las clases sociales durante la época liberal y su vinculación al mercado mundial (1880-1895): El papel de la burguesía comercial y los terratenientes en el Ecuador.}

Tal y como el título de este apartado indica, vamos a analizar ahora cuáles fueron las diversas clases sociales que existieron en el Ecuador de finales del siglo XIX durante su incorporación al capitalismo y a la división de trabajo internacional. En el proceso de identificación de estas clases y en la definición de su papel en la sociedad, se verá por un lado, un conjunto de intereses suscitados en torno a las diferencias entre la Sierra y la Costa ecuatoriana, mientras que por otro lado, estudiaremos cómo se fueron creando las relaciones entre estas clases y cómo sus frecuentes luchas por el control del poder político y económico, constituyeron uno de los obstáculos al desarrollo posterior de la sociedad ecuatoriana.

El debate suscitado sobre la naturaleza de los diversos agrupamientos sociales y de las alianzas y conflictos generados en las sociedades, se ha caracterizado por numerosas dificultades entre historiadores y sociólogos a la hora de determinar cuáles son los conceptos y métodos adecuados para clasificar los grupos sociales, circunstancia a la que ya nos hemos referido al hablar de la falta de cooperación entre los estudiosos del tema, y al expresar las diferencias existentes en cuanto a valores y estilos de pensamiento propio.

A este respecto, Magnus Morner indica que la responsabilidad de los historiadores no ha de centrarse en la comprobación de la validez de las teorías utilizadas, sino en la búsqueda de un conjunto de criterios que permita distinguir entre las diferentes clases o grupos sociales, con el objeto de identificar específicamente cuáles han sido los problemas históricos de cada momento. ${ }^{190}$ Considerando estas ideas, ¿cuáles han sido los criterios utilizados para llevar a cabo el análisis de la división de una sociedad en diferentes agrupamientos?

En principio, esta división puede ser explicada a partir de las ideas de algunos de los autores interesados en el tema, los cuales explican los diferentes grupos sociales desde el punto de vista

\footnotetext{
${ }^{189}$ Ver el mapa 6 en apéndice de mapas. Fuente: Jorge Pérez Concha, op. cit., p. 50-89.

190 Magnus Morner: Ensayos sobre historia latinoamericana: Enfoques, conceptos y métodos, Capítulo 3: Clases, estratos y élites: Un dilema del historiador social, Biblioteca de Ciencias Sociales, Volumen 37, Corporación Editora Nacional, Universidad Andina Simón Bolívar, 1992, p. 11-230.
} 
de la desigualdad de las sociedades. James Madison afirmaba que la más común y duradera fuente de discordias, ha sido la diversa y desigual distribución de la propiedad, mientras que Proudhon declaraba que la propiedad era un robo como consecuencia de la diferencia entre el coste del trabajo y los precios capitalistas de bienes o servicios. ${ }^{191}$ Asimismo, en su estudio de las clases sociales, Gonzalo Ortíz indica que este tipo de situaciones ocurre porque los modos de producción establecen grupos que, por su diferente lugar en la práctica económica, pueden apropiarse del trabajo de otros y despojarlos de los frutos de su trabajo. ${ }^{192}$

En términos generales, el surgimiento de las ciencias sociales en el siglo XIX, fue el momento en que el estudio del término "desigualdad" llegó a caracterizarse por sus implicaciones políticas, siendo Marx una de las figuras más importantes en este campo. Su objetivo se centró en explicar la desigualdad a través de la creciente división entre el capital y el trabajo y considerar la asimetría existente entre los propietarios capitalistas de los modelos de producción, como el factor responsable del surgimiento de las clases y de la desigualdad. ${ }^{193}$

Por tanto, la combinación de estas circunstancias permite explicar el hecho de que las cuestiones de formación de clase y estratificación social estén rodeadas de implicaciones políticas que han dificultado la labor de los distintos análisis realizados.

Aunque el concepto de clase ha sido bastante usado en la teoría social, hay que aclarar que no se trata de un término originalmente marxista, ya que el propio Marx reconoció haberlo tomado de diversos autores como Thierry y Guizot y de Ricardo. En este caso, Marx también consideraba que la clase era un concepto relacionado con el proceso de producción. ${ }^{194}$

Asimismo, tomó prestada de la economía clásica, la creencia de que el trabajo constituía el fundamento de todo valor, llegando a la conclusión de que en la sociedad capitalista de su época, la clase trabajadora era explotada por otras clases sociales. El uso de la dialéctica hegeliana también se ve reflejado en la elaboración de su modelo dinámico, en el que se

\footnotetext{
${ }^{191}$ La cita de Madison del número X de El Federalista está tomada de la traducción de Gustavo R. Velasco, Fondo de Cultura Económica, México, 2000, p. 37; Pierre Proudhon: ¿Qué es la propiedad: Investigaciones sobre el principio del derecho y del gobierno, Título del original en francés: Qu'est-ce que la propriété?, Traducción directa de A. Gómez Pinilla, Primera edición, Buenos Aires, 2005.

192 Gonzalo Ortíz Crespo: La incorporación del Ecuador al mercado mundial: La coyuntura socio-económica 1875-1895, Colección Ayora, Volumen IV, Banco Central del Ecuador, 1988, p. 5-285.

${ }^{193}$ Karl Marx: El Capital, México, F.C, 4a.edic, 1966.

${ }^{194}$ Magnus Morner, op. cit., p. 50-160.
} 
mostraba cómo la lucha de clases sobre los medios de producción implicaba una etapa de desarrollo social. $^{195}$

Por su parte, Max Weber definía el concepto de clase para considerar a aquellos grupos sociales que tenían en común las características de que "sus oportunidades de vida" estaban determinadas por la "propiedad" y por las "oportunidades de ingreso", así como por las condiciones del “mercado”. Pero ¿a qué se refería Weber con estos términos? ¿cuál era su definición?

En cierto modo, el establecimiento de estas ideas puede presentar una mayor dificultad debido al carácter relativo de estos términos. ${ }^{196}$ Así, por ejemplo, las "oportunidades de vida" vienen determinadas por los eventos que ocurren en nuestra existencia, por lo que si fuese posible describir con exactitud este término, sería también probable predecir el comportamiento humano. Pero, si las oportunidades de vida se refieren a lo que el destino tiene preparado para cada individuo, podríamos entonces pensar que se trata de un concepto relacionado con otros ámbitos. Con respecto a la palabra "mercado", hay que decir que su definición no es más precisa que la de "oportunidades de vida", pues el mercado está formado por un elevado número de acciones humanas que ocurren en el proceso total del intercambio. ${ }^{197}$

Por consiguiente, independientemente de la forma en que interpretemos estos conceptos, el establecimiento de su definición es un proceso bastante complejo, tal y como ha ocurrido con el concepto de "clase", ya que tras dos siglos de grandes esfuerzos no se ha logrado establecer con éxito una única definición.

Según Morner, la noción de "clase" y de "lucha de clase" ofrecida por Weber, es más flexible que la de Marx, ya que su esquema es más cercano a la compleja realidad social que el de Marx, pero no presenta un modelo claro para el cambio social, al enfatizar el rol activo de la

\footnotetext{
195 Ver las obras de Agustin Thierry: Essai sur l'histoire de la formation et des progress du Tiers Etat, (1850), Editorial: Paris, Garnier frères, 1882; F. Guizot: The History of the origins of representative government in Europe, introducción, traducción y notas de Aurelian Craiutu, Liberty Fund, Indianápolis. Liberty Fund, 2002; David Ricardo: Principios de economía política y tributación (1817), Editorial Pirámide, 2003, Karl Marx y F. Engels: El Manifiesto Comunista (1848), digitalizado para el Marx-Engels Internet Archive por José F. Polanco en 1998, Marxists Internet Archive por Juan R. Fajardo en 1999; Karl Marx y Federico Engels: El Capital, Siglo XXI editores, México, 1867.

${ }^{196}$ Magnus Morner, op. cit., p. 55-145.

${ }^{197}$ Max Weber: Essays in Sociology, traducción e introducción de H. H. Gerth and C. Wright Mills, New York, Oxford University Press, 1970, p. 181.
} 
burocracia como promotor del racionalismo y destructor del estado patrimonial. ${ }^{198}$

En el año 1957, Ralph Dahrendorf intentó revivir el concepto de “clase' y el de "conflicto de clase" mediante una combinación de ideas marxistas y funcionalistas. A su juicio, la base del conflicto de clases en las sociedades industriales se encontraba en las diferencias para acceder a las posiciones de autoridad. ${ }^{199}$ En cambio, en 1966, los estudios de Gerhard Lenski indicaban que el concepto de clase era utilizado para referirse a un conjunto de personas en una sociedad, las cuales estaban situadas en una posición parecida con respecto a alguna forma de poder o prestigio. ${ }^{200}$

En este caso, si la clase implicaba un conjunto de personas pertenecientes a un nivel similar dentro de una sociedad, ¿era posible establecer una equivalencia entre las formas de poder y los estratos o niveles sociales? ¿a qué nos referimos cuando hablamos de los "estratos" o de la “estratificación”?

Al hablar de la posición relativa de los distintos estratos sociales, se ha de mencionar que el establecimiento de los factores y condiciones que la determinan han sido aspectos analizados por el funcionalismo, a la vez que se ha destinado el concepto de clase a determinados usos específicos. Para Talcott Parsons, máximo representante de los sociólogos funcionalistas, la estratificación social debía ser definida como la ordenación diferencial de los individuos humanos que componen un sistema social dado y el orden de superioridad o inferioridad recíproca que guardan sobre ciertos respectos socialmente importantes. ${ }^{201}$

Al igual que los funcionalistas, Lenski opera con distintas dimensiones del sistema distributivo de una sociedad dada, pues la estratificación es esencialmente el proceso distributivo en las sociedades humanas, en el que los valores escasos son distribuidos. Esto explica que se considere la distribución como el resultado del consenso de la sociedad hasta donde concierne

\footnotetext{
${ }^{198}$ Magnus Morner, op. cit., p. 50-160.

${ }^{199}$ Ralf Dahrendorf: Class and class conflict in industrial society, Stanford University Press, Stanford, CA, 1959, p. 3-240.

${ }^{200}$ Gerhard Lenski: Power and privilege: A theory of social stratification, New York: McGraw-Hill book Company, 1966, p.74.

${ }^{201}$ A raíz del funcionalismo, se ha creado un consenso en la sociedad acerca de los valores básicos y un acuerdo general de que la distribución diferencial de bienes puede contribuir al funcionamiento de la sociedad. El análisis de estratificación en la sociedad occidental fue una herramienta sutil, ya que se podía recurrir a diferentes formas de observación y medición a pesar de que los análisis de estratificación carecían de una dimensión histórica. Fuente: Talcott Parsons: Sociological Theory and Modern Society, New York, Free Press, 1967, p. 2.
} 
su carácter diferencial, además de indicar la importancia de la consistencia de clase o de estatus como el causante de las tensiones entre los individuos y la sociedad. ${ }^{202}$

Por último, Poulantzas hizo el intento más completo para entender los criterios marxistas de las clases en la sociedad capitalista, al afirmar que en estas prácticas se encontraba la calidad contradictoria de las relaciones sociales:

Un modo de producción no se reproduce a sí mismo, ni siquiera existe en un estado puro y menos aún, puede periodizarse históricamente como tal. La lucha de clases dentro de la formación social, es el motor de la historia: el proceso histórico tiene en estas formaciones su lugar de existencia. ${ }^{203}$

Esta reflexión, realizada en torno al conjunto de estudios que intentan explicar la complejidad y las diferencias entre las clases sociales, nos ayudará a entender el origen y funcionamiento de las distintas agrupaciones en el Ecuador de finales del siglo XIX, no sólo como un producto mecánico de las relaciones económicas por sí mismas, sino como una consideración del sistema en su totalidad. No obstante, al igual que ha ocurrido con el establecimiento del concepto de "clase social", la tarea relacionada con la identificación de las clases ha sido también un proceso dificultoso. Así, cuando se estudia una sociedad concreta, se observa la existencia de un conjunto de fracciones localizadas en el interior de las diferentes clases.

En este sentido, cuando se habla de los modos de producción de una sociedad, se suele incluir una clase explotadora (clase política e ideológicamente predominante) y una clase explotada (clase política e ideológicamente dominada), aunque también existen sociedades con otros tipos de clases y modos de producción. ${ }^{204}$

$\mathrm{Si}$ consideramos las formaciones sociales donde el capitalismo se encuentra en sus etapas iniciales (como puede ser el caso ecuatoriano durante la etapa 1890-1925), la identificación de las fracciones dentro de la burguesía puede ser una tarea más complicada, puesto que los mismos individuos suelen obtener beneficios mediante diferentes medios. ¿Cuáles son por tanto, los elementos a tener en cuenta a la hora de establecer un análisis de las clases sociales partiendo

\footnotetext{
${ }^{202}$ Gerhard Lenski, op. cit. p.74.

${ }^{203}$ N. Poulantzas: Classes in contemporary capitalism, London, New Left Books, 1975, p. 23.

${ }^{204}$ Magnus Morner, op. cit. p. 45-157.
} 
de la idea de desigualdad?

Gonzalo Ortíz señala que las clases sociales no son estructuras fijas, sino que se encuentran en formación permanente e interactúan entre ellas de modo continuo. Tampoco, se puede olvidar la historia de cada sociedad, porque al estar determinada por diferentes acontecimientos, puede existir un desarrollo desigual de las clases y ser el elemento responsable de las divisiones existentes en una sociedad, ya sean de tipo religioso, racial, tribal, etc. ${ }^{205}$

En el caso que nos ocupa, un rasgo característico de las clases sociales ecuatorianas durante el proceso de independencia, fue su regionalización económica y política, a tal punto de que algunos estudios explican su origen a partir de la localización geográfica y distinguen los centros regionales de Quito, Guayaquil y Cuenca. ${ }^{206}$

En primer lugar, Quito y la Sierra centro-norte, eran espacios que habían sido organizados en torno a la producción de obrajes y que se hallaban en estado de decadencia a raíz de la crisis de los mismos, tras las medidas de libre comercio establecidas por la Corona española. El deterioro de los obrajes, que apareció conjuntamente con la activación económica de la región de Guayaquil, implicó el comienzo de un proceso de desplazamiento del eje de la economía de la Sierra a la Costa. ${ }^{207}$

En este marco crítico para los obrajes, se registró una ruralización relativa de la población y comenzó a consolidarse el complejo de haciendas como unidad productiva agrícola, así como el sector de los hacendados a consecuencia de la apropiación de las tierras de los jesuitas que habían sido expulsados en el año $1767 .{ }^{208}$ Además, el inicio del siglo XIX en Quito, manifestó una intensa actividad de compra-venta de haciendas, lo cual indica la tendencia económica hacia la monopolización de la tierra. ${ }^{209}$

En segundo lugar, la región de Guayaquil, la cual había recibido un gran impulso gracias a la política de la Corona, pues las reformas borbónicas llevadas a cabo fomentaban la

\footnotetext{
${ }^{205}$ Gonzalo Ortíz Crespo, op. cit. p. 5-285.

${ }^{206}$ Manuel Chiriboga: Las fuerzas del poder en 1830, Revista Cultura, Quito, BCE, Vol. II, 6, 1980, p. $171-208$.

${ }^{207}$ Gonzalo Ortíz Crespo, op. cit. p. 5-285.

${ }^{208}$ Víctor González: Razas y clases en la colonia, Guayaquil: Casa de la Cultura Ecuatoriana, 1978 , p.71.

${ }^{209}$ Germán Colmenares: Análisis referido a la estructura agraria de la Sierra norte-central, Quito: FLACSO, 1979, en Rafael Quintero, Erika Silva, op. cit., p. 46.
} 
especialización agro-minera de las colonias y de aquellas que abastecían materias primas para hacer frente al desarrollo manufacturero español. Así, ya desde el siglo XVI, Guayaquil era la pieza fundamental del sistema económico en cuanto a la exportación de tejido y abastecimiento de bienes, hecho que cambiaría a mediados del siglo XVIII, cuando dicho centro pasó a ser un puerto exportador de cacao. ${ }^{210}$

En tercer lugar, la región de Cuenca, que comprendía el Azuay y Cañar, se caracterizaba por un proceso de fragmentación de la propiedad rural, en el que coexistían las grandes haciendas con las pequeñas y medianas propiedades. Asimismo, esta región estaba definida por sus relaciones administrativas con Quito, mientras que con Guayaquil llegó a desarrollar vínculos comerciales y políticos. $^{211}$

Pese a la fragmentación y regionalización que vivían los tres centros de la Real Audiencia de Quito, existían algunos elementos de cohesión entre ellos, siendo su fundamento, la organización jerárquica de la sociedad, caracterizada por un profundo corte étnico-cultural. Así, lo explican Rafael Quintero y Erika Silva cuando afirman que la clase se confundía con la raza en una simbiosis drástica, cuyo elemento diferenciador giraba en torno a la etnicidad. ${ }^{212}$

El peso del factor étnico-cultural creó en el Ecuador, al igual que ocurrió en el resto de los países latinoamericanos, las denominadas "repúblicas", en las que se encontraban la república de los españoles y la de los indios. ${ }^{213}$ Es decir, se trataba de dos comunidades que si bien eran diferentes culturalmente, no poseían autonomía propia, ya que desde el punto de vista de la economía y de la sociedad, la república de los españoles se levantaba sobre la explotación de la república de los indios. ${ }^{214}$

Tras la independencia, en su etapa de transición y abandono del estatus colonial, se planteó el surgimiento de la nación ecuatoriana, tarea de gran complejidad después de tres siglos de

\footnotetext{
${ }^{210}$ Manuel Chiriboga, op. cit., p. 171-208; Michael Hamerly: Historia social y económica de la antigua provincia de Guayaquil 1763-1842, Guayaquil: Publicaciones del Archivo Histórico del Guayas, 1973, p. 11-240.

211 Leonardo Espinoza: Política fiscal de la provincia de Cuenca: Reseña histórica presupuestaria 1779-1861, Segundo Encuentro de Historia y Realidad Económica y Social del Ecuador, Cuenca: s/e, Vol. I, 1978, p. 61-125.

${ }^{212}$ Rafael Quintero, Erika Silva, op. cit., p. 29.

${ }^{213}$ Ibíd. p. 29.

${ }^{214}$ Jorge Trujillo: Los obscuros designios de Dios y del Imperio, Quito, CIESE, 1981, p. 3.
} 
colonialismo. De este modo, en el Ecuador del siglo XIX, la cuestión nacional adoptó las siguientes formas:

La regionalización (con los centros de Quito, Guayaquil y Cuenca) que estaba definida por el conflicto entre las fracciones terratenientes regionales; el corte étnico-cultural (mediante la denominada "república de los blancos" y la de "los indios") como expresión de la lucha entre las clases contradictorias; y la cuestión limítrofe como mecanismo de ausencia de soberanía de ese estado que fue creado sobre la formación social ecuatoriana tras la independencia. En este sentido, el movimiento independentista no llegó a establecer su voluntad para constituir una única clase unificada, sino más bien un estado dividido en una clase en proceso de constitución. A este respecto, Quintero y Silva explican que los elementos que impidieron dicha unificación de clase, tenían su origen en el desarrollo desigual de las diversas vías de constitución del sistema de haciendas en las tres regiones durante el periodo de independencia. ${ }^{215}$

Otra de las formas a considerar, fue la ruptura progresiva de los vínculos económicos y políticos entre Quito y Guayaquil, debido a la política de la Corona que separó a la Real Audiencia del Virreinato de Lima para unirla al de Nueva Granada, ocasionando profundas repercusiones que dificultaron la unificación de los grupos de terratenientes regionales a lo largo del siglo XIX.

No obstante, si bien esos terratenientes desarrollaron desde antes de la independencia algunas relaciones de tipo comercial entre las diferentes regiones, su naturaleza no fue moldeada por el comercio, sino más bien por las relaciones económicas generadas en el espacio de la hacienda y sus fronteras. Esto explica que dicha clase emergente se encontrara más preparada para desarrollar políticas locales, pero también tuvo una mayor dificultad para ajustar sus ideas a nivel nacional. ${ }^{216}$

Asimismo, otra de las características fundamentales de la clase terrateniente ecuatoriana a la hora de desarrollar su comunidad cultural de forma independiente a la indígena, fue su ideología racista y elitista, pues el estado ecuatoriano del siglo XIX, no surgió de la desaparición total del sistema colonial.

Así, en términos de clase, en esas tres regiones existían diversos estados en la constitución de las clases dominantes regionales, pues en la Costa sur, la clase terrateniente con intereses

\footnotetext{
${ }^{215}$ Rafael Quintero, Erika Silva, op. cit., p. 28-29.

${ }^{216}$ Ibíd., p. 29.
} 
comerciales se encontraba en proceso de constitución entre 1830 y 1860, mientras que en la zona de la Sierra, existía una clase terrateniente en diversos grados de desarrollo. ${ }^{217}$

Dentro de la zona serrana, hay que diferenciar la Sierra sur (prácticamente toda la región de Cuenca), que en el siglo XIX, estaba formada por una clase dominante regional procedente de los terratenientes de origen colonial, de los comerciantes o del resultado de la unión de intereses terratenientes y comerciales. Por su parte, en la Sierra norte, se encontraba una clase dominante consolidada que había heredado una acumulación histórica colonial y cuyos intereses económicos estaban ligados a la tierra.

Por otro lado, hay que tener en cuenta la norma general de las sociedades de América Latina, ya que buscaban su integración en el sistema para su continuidad a través de una institución superior, como fue el caso del estado, el cual gozó de funciones administrativas determinadas por el poder de ciertas clases dominantes. Es decir, al hablar de las relaciones de dominación, el principal poder que la clase dominante identifica, es el poder de las relaciones de propiedad y jurídicas existentes. ${ }^{218}$

Esto es lo que se conoce como "el papel de la ideología” y "el poder político", al apoyarse en la capacidad que dichas clases poseen para utilizar el aparato estatal y lograr así sus objetivos políticos. La habilidad y capacidad política combinadas en un bloque es lo que Ken Post define como "alianzas de diferentes fracciones dominantes", las cuales permitirán reproducir esa dominación gracias a su vinculación con el aparato estatal. Bajo estas circunstancias, la principal función del grupo dominante era la de asegurar la reproducción del sistema, dando más importancia a los intereses de las fracciones que compartían el control político. ${ }^{219}$

Volviendo al tema de la ideología, Quintero y Silva aclaran su sentido descriptivo como concepción del mundo y de la vida, al mencionarla como exponente fundamental de la cultura del siglo XIX. Así, la ideología de los terratenientes se encontraba definida por los dos puntos anteriormente indicados, el elitismo y el racismo, y también, por la concepción tradicional de la autoridad, estando ambos ejes determinados por el profundo corte étnico-cultural de la sociedad. En este caso, los criollos y colonizadores consideraban a los indios como seres de naturaleza

\footnotetext{
${ }^{217}$ Gonzalo Ortíz Crespo, op. cit. p. 5-285.

${ }^{218}$ Rafael Quintero, Erika Silva, op. cit. p.27-30.

219 Ken Post: Problems of transition to socialism in underdeveloped capitalist countries, Notes on Lectures, Institute of Social Studies, The Hague, 1976.
} 
inferior, siendo la población blanca, la que concentraría el poder político, operando su sistema en base a la explotación de los indígenas. Aquí, al igual que ocurrió durante la colonia, se observa la coexistencia en una misma sociedad de la denominada "república de los blancos" y la "república de los indios", pues el corte étnico-cultural no pudo ser eliminado con los movimientos independentistas. $^{220}$

De igual forma, la existencia de un estado caracterizado por este corte étnico-cultural pone de manifiesto el tipo de relación entre la clase dominante y la dominada, al existir una jerarquización de clases que permitía que los terratenientes ejercieran su poder sobre las clases inferiores. Este control se reflejaba a través del rechazo en la inserción de la población dominada en la superestructura política nacional, pues el control de los aparatos estatales estaba limitado por la ideología tradicional y los privilegios de la clase terrateniente. ${ }^{221}$

Por otro lado, a partir del racismo y del elitismo, se elaboró el segundo eje ideológico constituido en el fundamento del estado terrateniente del siglo XIX: la idea tradicional de la autoridad. En otras palabras, los diversos grupos de terratenientes regionales exigían su autoridad para gobernar el país a partir de la vía de la herencia cultural y racial heredada de sus antepasados y que se remontaba a los años de la conquista. De esta manera, la combinación de estas características (racismo, elitismo y concepción tradicional de la autoridad) contribuyó a la constitución del fundamento ideológico y cultura del estado terrateniente, que tenía como base económica la explotación del indio, y como base política, una serie de ideas discriminatorias en función de la raza. Esto explica que la cultura resultante fuera un producto dividido y unido de forma artificial a la cultura conquistadora, en el que no se renunciaría a lo nacional por propio interés y por el de los invasores. ${ }^{222}$

Al hilo de la idea planteada, vamos a analizar con más detalle el tema de la caracterización del estado ecuatoriano, en el que la figura de la Iglesia desempeñó un papel bastante importante, ya que se trataba de la institución representativa del papel ideológico que hemos venido comentando hasta ahora.

En principio, durante los primeros años de independencia, tanto la Iglesia como las fuerzas

\footnotetext{
${ }^{220}$ Rafael Quintero, Erika Silva, op. cit., p. 25-30.

${ }^{221}$ Ibíd. p. 79.

${ }^{222}$ Ibíd. p. 79.
} 
públicas estatales, se caracterizaron por un desarrollo desigual (si se compara con el desarrollo de las sociedades capitalistas), a la vez que expresaban las contradicciones existentes al interior de la clase terrateniente. En efecto, mientras que las clases al mando del estado se centraban en la consolidación del aparato represivo a nivel nacional, las clases terratenientes regionales no sólo no crearon dicho aparato, sino que tampoco quisieron fortalecerlo debido a la profunda regionalización de las clases, las cuales acabaron demandando la elaboración de aparatos represivos locales en el interior del sistema de haciendas. ${ }^{223}$

En este caso, la Iglesia ejercía un gran predominio con respecto al resto de instituciones estatales, pues por lo menos poseía un funcionario eclesiástico en casi todas las parroquias y pueblos de la Costa, la Sierra y Oriente, siendo el único centro que mantenía separados a los funcionarios en el ámbito territorial de la formación social. No obstante, su influencia era diferente según las zonas, ya que mientras que en el litoral existía una destacada debilidad de la influencia eclesiástica, en la Sierra, sobre todo en Quito y Cuenca, su influencia era notoria. A diferencia del aparato represivo que respondía a la voluntad de los terratenientes:

La Iglesia era una institución centralizada en todo el ámbito territorial, que respondía a la voluntad unificada de la fracción eclesiástica de la clase terrateniente constituyéndose por otro lado, en un importante aparato de cohesión ideológica del estado terrateniente y fundamentalmente en un poderoso centro de poder. ${ }^{224}$

Sin embargo, los vínculos que la Iglesia mantenía con las fracciones terratenientes regionales no llegaron a consolidarse durante esta época, ya que si bien existían gobiernos que apoyaban dicha relación, otros pretendían acabar con su poder político. Estos conflictos entre la Iglesia y los diferentes gobiernos de los terratenientes deben de ser analizados a partir de los problemas entre una clase terrateniente que no estaba unificada, puesto que dentro de la misma, la fracción eclesiástica había creado aparatos de representación, como fue el caso del cabildo eclesiástico, centro de poder que procuraba convertirse en un organismo de representación en el conjunto de clase.

En definitiva, el carácter del estado durante el siglo XIX, logró su consolidación por el gran peso

\footnotetext{
${ }^{223}$ Ibíd. p. $79-80$.

${ }^{224}$ Ibíd. p. 85.
} 
que la Iglesia había adquirido a nivel ideológico, administrativo y represivo, el cual era mayor que el de otras instituciones de carácter estatal. Esto se puede explicar a partir de la influencia que una fracción de la clase terrateniente (la eclesiástica) ejercía en el estado, llegando a situar a la Iglesia como el centro de un orden intelectual y moral, además de convertirla en institución organizadora del mismo estado. 225

Continuando con el tema de las clases sociales, los estudios de algunos autores nos servirán para corroborar la existencia de una época caracterizada por frecuentes choques de tipo militar, ideológico y político entre las clases sociales procedentes de diferentes ámbitos geográficos, tanto de la Costa como de la Sierra, y que pugnarán por el control del poder, a fin de ganar poder en el nuevo marco dado por el mercado mundial. Así, para el año 1895, la clase terrateniente ya se hallaba en crisis y estaba sometida a los enfrentamientos producidos por el cambio en la sucesión de mando. De este modo, mientras que una parte de los terratenientes de Guayaquil, los partidos de la oposición y la burguesía comercial pasaron a combatir el conservadurismo, otros se unieron a los terratenientes serranos. ${ }^{226}$

En relación a la importancia de esta coyuntura, se observa una importante acumulación de capital con la inserción del Ecuador en las relaciones capitalistas y en la división internacional del trabajo, lo cual nos ayudará a establecer una idea aproximada de la evolución y desarrollo del Ecuador de esta etapa.

Por consiguiente, desde la perspectiva social, se observa a un Ecuador de finales del siglo XIX, definido por la presencia de los terratenientes criollos de la Sierra, los cuales gozaban de una destacada posición económica y de una gran cantidad de tierras adquiridas tras la expulsión de los jesuitas y de los indios tras la independencia. En general, desde las etapas finales de la era colonial (a mediados del siglo XVIII), la clase terrateniente criolla ejercía un firme control de la economía de la Real Audiencia de Quito. Con la decadencia de la mita y la consolidación del sistema de haciendas, el control directo de la mano de obra por parte de la Corona desapareció, quedando su papel limitado a funciones burocráticas. ${ }^{227}$

\footnotetext{
${ }^{225}$ Ibíd. p. 85-86.

${ }^{226}$ Ibíd, p. 85-88.

${ }^{227}$ La mita era una forma de esclavismo que consistía en la adscripción de un número determinado de indios para desempeñar trabajos forzados en las minas, en los lavaderos de oro y en la labranza de las haciendas.
} 
Por su parte, el latifundio se establecía sobre la explotación de los indígenas ligados a la hacienda a través del endeudamiento y la represión, cuya situación fue mantenida tras la independencia aún cuando el poder político quedó en manos de los latifundistas.

Germán Colmenares indica que el monopolio de la tierra en un régimen pre-capitalista no se produjo únicamente a partir de mecanismos puramente económicos, pues la acumulación de propiedades territoriales en manos de unos cuantos fue posible gracias a privilegios institucionales. ${ }^{228}$ La posesión de tierras por la que la Corona española concedía situaciones de poder creadas en América, fue uno de los principales elementos que dio lugar al surgimiento de una clase terrateniente privilegiada, lo cual permitió la consolidación de las grandes propiedades con la independencia y el que los criollos no pudiesen disponer de ellas tan libremente como deseaban. ${ }^{229}$ Pese a estas características, la persistencia de una clase terrateniente en un primer plano no puede ser explicada utilizando solamente los privilegios institucionales, ya que dicha clase gozó de una gran cohesión interna en distintas regiones de América Latina durante un periodo de tiempo bastante amplio. Todo esto y los privilegios institucionales reforzaban el monopolio de la propiedad territorial.

Asimismo, años antes de la independencia, la Corona española estableció nuevas medidas fiscales tras la liberalización del comercio, por lo que los nuevos impuestos y la escasez de capacidad para proveer a las colonias de servicios fundamentales y de productos manufacturados, provocaron profundas repercusiones dentro de la formación social en el Ecuador. En el caso de Quito, se observa la transformación de una economía textil exportadora a una economía agrícola prácticamente separada del comercio internacional, además de una progresiva aceleración de la concentración de riqueza y propiedad y de la modificación de las formas de producción en la Sierra, que se encontraban principalmente en manos de los terratenientes. ${ }^{230}$

Es importante recordar las explicaciones de algunos estudiosos del tema en referencia a la relación comercial entre España y sus colonias en América Latina, ya que a través de un modelo

\footnotetext{
${ }^{228}$ Germán Colmenares: La hacienda en la Sierra norte del ecuador: Fundamentos económicos y sociales de una diferenciación nacional (1800-1870), "Procesos", Revista Ecuatoriana de Historia, No.2, Corporación Editora Nacional, Quito, 1992, p. 5-49.

${ }^{229}$ A fines del siglo XVIII y durante el siglo XIX, las propiedades más extensas y de mayor valor de la región de Quito fueron repartidas entre algunas familias y órdenes religiosas.

${ }^{230}$ Germán Colmenares, op. cit. p. 5-49.
} 
basado en las ideas del mercantilismo liberal inglés, dichos territorios se convirtieron en el centro para el abastecimiento de las materias primas necesarias en la metrópolis, lo que permitía incrementar y diversificar el comercio. ${ }^{231}$ De esta manera, gracias al intercambio comercial, la Península lograría mejorar su agricultura y aumentar el capital, además de impulsar su proceso industrial mediante un pacto con sus colonias, es decir, se pretendía aumentar el comercio libre con la metrópolis mediante la transformación de los territorios de mar en proveedores de materias primas y consumidores de productos manufacturados.

El paso de la dominación española a la dependencia post-colonial, como resultado de cambios en el carácter y en la estructura del sistema económico mundial, supuso la culminación de los conflictos entre fracciones opuestas de las clases existentes en aquel momento: la clase local y la clase extranjera. ${ }^{232}$ En la Audiencia de Quito, el poder colonial español intentó reforzar el control militar y político de las colonias y prohibió la presencia de los nacidos en América en posiciones importantes de la administración estatal para no perder sus privilegios. Esto se sumaba a las frecuentes quejas de la Iglesia, terrateniente e institución clave del régimen colonial, que desempeñaba un papel destacado en la producción de la ideología.

En esencia, la posición hegemónica representada por los terratenientes se encontraba reforzada por la situación de pobreza, que había incrementado la deuda total de los terratenientes y de los miembros de la clase media a la administración colonial. Los terratenientes encargados de recoger los tributos que debían ser pagados por los indígenas, lograron manipular este círculo de mecanismos de extracción de excedentes que articulaba diversas capas de la sociedad colonial, asegurando por tanto, el apoyo de una importante parte del pueblo.

Con la idea de inferioridad del indio y el desprecio a esa parte de la pirámide social, el sistema establecía una clara división entre los mestizos, los indios y las personas de raza blanca, como ya se ha señalado al hablar de las distinciones de raza en las clases sociales. ${ }^{233}$ Por su parte, Celso Furtado habla sobre el poder creciente que la clase terrateniente consiguió tras obtener la independencia: rotos los vínculos con la metrópolis, el poder tendió a desplazarse

\footnotetext{
${ }^{231}$ Pedro Rodríguez Campomanes: Reflexiones sobre el comercio español a Indias (1762), reeditada por Llombart Roca, V. Madrid, 1988, p. 1000-1300.

${ }^{232}$ Germán Colmenares, op. cit. p. 5-49.

${ }^{233}$ Germán Colmenares, op. cit. p. 5-49.
} 
en todas partes hacia la clase de los señores de la tierra. ${ }^{234}$ Aquí, llama la atención el hecho de que la independencia se produjera en el momento en que los terratenientes criollos se habían asegurado la capacidad para mantener su posición privilegiada, ocupando los altos cargos de la administración, el ejército y el liderazgo político. ${ }^{235}$

En definitiva, son estas ideas, las que nos aportan la información necesaria para poder comprender la dinámica del poder terrateniente y la participación de otros sectores (grupos de artesanos, profesionales, pequeños comerciantes, etc.), que giraban en torno a la estructura latifundista con la ayuda proporcionada por el aparato estatal y la acción de la Iglesia.

La posición hegemónica de los terratenientes se mantendrá y se alternará con otros grupos durante el siglo XIX y XX, debido al limitado carácter de las élites serranas que nunca tendrían la capacidad suficiente para movilizar al pueblo y articular proyectos atractivos para las otras agrupaciones sociales. ¿Quiénes fueron los otros grupos de la formación social ecuatoriana? ¿cuáles eran sus intereses y motivaciones? ¿cuáles eran las diferencias con respecto a los terratenientes de la Sierra?

Fernando Velasco muestra cómo una vez obtenida la independencia de España, se fue creando un grupo perteneciente a los sectores ligados al comercio de exportación e importación radicados en Guayaquil, al que denominaba "la naciente burguesía comercial". Paralelamente, indica que durante la época colonial, la importancia de este puerto radicaba en su uso como centro para la construcción de navíos, como exportador de productos tropicales e importador de manufacturas, además de retener el flujo comercial con España, matizando no obstante, la reducida escala de estas actividades y con ello, la conformación de una clase de comerciantes con intereses nacionales y ligada al proceso de producción. ${ }^{236}$

Por su parte, Enrique Ayala se refiere a este grupo como los "terratenientes de la Costa" por su relación con el comercio internacional desde tiempos atrás y una vez obtenida la independencia, lo que supuso el aumento de los intercambios comerciales tras la eliminación de las barreras

\footnotetext{
${ }^{234}$ Celso Furtado: Economic development in Latin America, Cambridge, Cambridge University Press, 1970 , p. 38.

${ }^{235}$ Agustín Cueva: El proceso de dominación política en el Ecuador, Quito, Editorial Universitaria, 1967, p. 28-29.

${ }^{236}$ Fernando Velasco, op. cit. p. 20-220.
} 
coloniales. $^{237}$ Asimismo, el incremento de la demanda externa vino acompañado de una extensión de las plantaciones (especialmente del cacao), que fueron adquiriendo características diferentes a las del latifundio de la Sierra debido a las circunstancias de la región. Así, hacia el año 1904, la Costa ecuatoriana llegó a situarse como el mayor productor y exportador mundial de este producto, hecho que explica la creación de una gran cantidad de haciendas destinadas al cultivo de la denominada "pepa de oro".

Es importante recordar que la prosperidad de Guayaquil no solo se debió a las reformas comerciales borbónicas, las cuales eliminaron los obstáculos impuestos al tráfico de las colonias entre sí y con la metrópoli, sino también al incremento de la demanda procedente de la recuperación demográfica y económica de México, España y del resto de Europa Occidental, principales consumidores de cacao a nivel mundial. ${ }^{238}$ De forma paralela a estos acontecimientos, las autoridades deseaban fomentar las exportaciones del cacao de Guayaquil a través de la disminución de impuestos y derechos aduaneros en el momento de su salida de Guayaquil y con su entrada en cualquier puerto americano a partir de 1776. Pese a esto, se han de señalar algunos problemas en la política proteccionista, pues la Corona deseaba proteger el cacao producido en Caracas y porque Nueva España no podía resistir la competencia de la gran cantidad de cacao de Guayaquil dado su bajo precio. Esto explica la existencia de las numerosas restricciones que fueron impuestas durante casi dos siglos al envío de este producto desde Guayaquil a Acapulco, prohibiéndose en unos casos y limitándose en otros. ${ }^{239}$

En esencia, se puede decir que la combinación de las características mencionadas anteriormente, fue el elemento fundamental que muestra la importancia del papel que el comercio desempeñó en la Costa, pero ¿cuál fue la pieza clave de este entramado que permitió el surgimiento de la burguesía comercial?

Según Andrés Guerrero, la consolidación de la burguesía de la Costa tuvo lugar a mediados del siglo XIX como un efecto de las relaciones capitalistas mundiales, pero sus raíces se remontan

\footnotetext{
${ }^{237}$ Enrique Ayala: Gabriel García Moreno y la gestación del estado nacional en Ecuador, Escenarios Alternativos. Crítica y Utopía, número 5. www.escenariosalternativos.org.

238 Michael Hamerly: Historia social y económica de la antigua provincia de Guayaquil, 1763-1842, Guayaquil, 1973, p. 107 y ss.

${ }^{239}$ Luis García Navarro: El comercio interamericano por la mar del Sur en la Edad Moderna, Revista de Historia, vol. IV, número 23, Caracas, 1965, p.11-55.
} 
en algunos casos a finales de la época colonial. Asimismo, afirma que el marcado carácter regional del capitalismo se ha de situar en la zona húmeda y tropical de la Costa, tras su integración en el mercado y en la división del trabajo mundial en el siglo XIX, a la vez que la serranía ecuatoriana conservaba las estructuras sociales de herencia colonial que apenas habían sido modificadas. ${ }^{240}$

La inserción del país en las relaciones capitalistas mundiales a través del mercado internacional y en la división del trabajo capitalista a escala mundial con la Segunda Revolución Industrial a mediados del siglo XIX, provocó dentro de la formación social una serie de "circunstancias confluyentes" que definieron una vía de acumulación originaria. ${ }^{241}$ Este proceso fue el elemento clave que permitió el nacimiento de la burguesía costeña y que, a finales del siglo XIX, consiguió extender su predominio a la formación social, convirtiéndose en una clase nacional, lo cual explica la importancia de las clases sociales constituidas a partir de la producción del cacao en la Costa ecuatoriana.

En esta línea y en referencia a la acumulación originara, este proceso se llevó a cabo mediante la constitución de elementos del modo de producción capitalista, aunque hay que aclarar que esto no implicaba necesariamente la eliminación y transformación en su totalidad de las sociedades coloniales, ya que a pesar de las modificaciones, lograron conservar una buena parte de los rasgos coloniales.

En la Costa, los factores externos que dieron lugar a la formación del modo de producción capitalista pasaron por la constitución de relaciones de producción no capitalistas en la extracción de la renta de cacao destinada al mercado mundial. Es decir, la acumulación ocurrió a través del capital obtenido con la circulación y comercialización del cacao, adoptando la forma de capital financiero y comercial.

A diferencia de las formas anteriores, el capital financiero generado no era externo a la formación social, pues la forma de producción de la hacienda cacaotera se fue consolidando desde el comienzo como una forma mercantil inserta en la división social del trabajo mundial y en su proceso de reproducción inmediato. ¿Cómo se puede explicar la relación entre el capital

\footnotetext{
240 Andrés Guerrero: Los oligarcas del cacao: Ensayo sobre la acumulación originaria en Ecuador: Hacendados, cacaoteros, banqueros, exportadores y comerciantes en Guayaquil (1890), Corporación editorial, primera edición, agosto, 1980, p. 11-95.

${ }^{241}$ K. Marx: El capital, lib. I, II, III, Siglo XXI, editores, 1867.
} 
y la formación social ecuatoriana?

Esta pregunta se puede contestar atendiendo al concepto de clase social, mediante el cual, Guerrero define un género de burguesía local completamente creado y cuyo fundamento económico no era la acumulación de capital por un mecanismo de producción social, sino un proceso de acumulación de capital con base en las funciones de circulación de la renta de tierra necesarias para su realización en el mercado mundial y para el consumo individual de determinadas clases sociales. Esto justifica la existencia de varios grupos de comerciantes dedicados a la exportación del cacao, a las funciones financieras y de los que se dedicaban a la importación de medios de consumo procedentes de países capitalistas y que abastecían al mercado local. ${ }^{242}$

A partir de la consolidación de la burguesía con la inserción del Ecuador en el sistema capitalista y teniendo en cuenta el papel que desempeñaban los terratenientes en esta sociedad, vamos a pasar a analizar las relaciones existentes entre las distintas clases sociales, considerando también la creciente diferenciación regional entre la Costa y la Sierra y los mecanismos de reproducción del sistema. ${ }^{243}$

Entre los aspectos fundamentales de los sistemas de tenencia de la tierra y de las relaciones entre las clases sociales ecuatorianas se encuentra la lucha de la clase terrateniente para consolidar su poder sobre el pueblo. Aunque dichas fracciones ejercían el control a través de mecanismos relativamente parecidos, se fueron produciendo antagonismos en el control de la mano de obra como consecuencia del auge comercial de la Costa y su integración en el sistema capitalista mundial. De esta forma, mientras que en el litoral se consolidaba la actividad agro-comercial vinculada al mercado externo y se asentaba sobre las diferentes formas de producción, en la serranía, la producción que tenía como destino el mercado interno, seguía dándose al interior de la hacienda, la cual se encontraba organizada según la explotación de campesinos. Este proceso trajo consigo una articulación cada vez más compleja de las dos regiones, pues la acción de la economía costeña sobre el sistema hacendario serrano llegó a profundizar las demandas al iniciarse un nuevo proceso de vinculación de la economía del país

\footnotetext{
${ }^{242}$ Andrés Guerrero, op. cit. p. 11-95.

${ }^{243}$ Enrique Ayala: Lucha política y origen de los partidos en Ecuador Publicaciones Pontificia Universidad Católica Ecuador, Editado por Publitécnica, Quito, 1978, p. 20-335.
} 
con la formación social. ${ }^{244}$.

Ayala habla de las frecuentes tensiones producidas de la diferenciación entre las fracciones terratenientes de la Sierra y de la Costa y establece como principales elementos del conflicto, el control de la mano de obra, siempre escasa en el litoral, y la política proteccionista, que intentaba defender la producción textil serrana. ${ }^{245}$

De esta forma, el flujo de la mano de la Sierra a la Costa, muestra cómo la acción del mercado internacional fue determinante no sólo en la economía costeña, sino también en la formación social. Además, el incremento de las diferencias regionales entre estas zonas tuvo como resultado una diferenciación de los mecanismos de reproducción del sistema, los cuales comenzaron a adoptar características distintas. Así, la oligarquía serrana sustentaba su poder en la explotación de una gran parte de la población, el control del estado y de las instituciones con poder ideológico. Por su parte, la burguesía costeña experimentó un acelerado crecimiento de su poder económico vinculado a los centros capitalistas, ya que no sólo controlaba el comercio internacional, sino que se había convertido en el medio de relación con el exterior y en el núcleo de las divisas y recaudación aduanera.

En consecuencia, aunque ambas fracciones llegaron a controlar la dirección de la sociedad mediante mecanismos relativamente parecidos, los antagonismos existentes fueron creciendo, de ahí que esta etapa se caracterizara por su inestabilidad y por las frecuentes luchas internas que impedían la articulación a nivel nacional de la clase terrateniente debido al desafío permanente de la burguesía comercial, la cual se consolidaría como la clase protagonista tras la Revolución Liberal de 1895.

\section{3) Los modos de tenencia de la tierra y la concentración de la propiedad en la Sierra y la Costa ecuatoriana (1880-1895).}

\subsection{1) El problema de la tierra en el Ecuador y su proceso histórico: Formas de producción en la hacienda serrana y modalidades de trabajo.}

Una de las hipótesis a considerar a lo largo de este estudio, es la de que los sistemas de

\footnotetext{
${ }^{244}$ Carlos Arcos: El espíritu del progreso: Los hacendados en el Ecuador del 1900, en Miguel Murmis "Clase y región en el agro ecuatoriano”, Biblioteca de Ciencias Sociales, Volumen 7, Corporación Editora Nacional, 1986, p. 277.

${ }^{245}$ Enrique Ayala: Gabriel García Moreno y la gestación del estado nacional en Ecuador, Escenarios Alternativos, Crítica y Utopía, número 5. www.escenariosalternativos.org.
} 
tenencia implantados tanto en el Ecuador como en el resto de América Latina (latifundio y minifundio), podrían haber seguido una pauta de modificación distinta tras su inserción en el sistema capitalista, para que el desarrollo socio-económico hubiera tenido lugar de un modo más productivo y eficiente. Es decir, los sistemas económicos característicos de las sociedades latinoamericanas han constituido frecuentemente un obstáculo al desarrollo, por lo que el establecimiento de una reforma destinada a la redistribución de los derechos y beneficios de la propiedad, podría haber estimulado el crecimiento económico y generado oportunidades para el progreso de los grupos menos privilegiados. ${ }^{246}$

La consideración de estas ideas y de los motivos que explican el atraso y escaso desarrollo de la sociedad ecuatoriana, nos llevan a la formulación de las siguientes preguntas: ¿cuáles fueron los principales sistemas de tenencia de la tierra en el Ecuador de finales del siglo XIX y principios del XX? ¿qué tipo de relaciones se desarrollaron entre los grupos dedicados a su explotación? ¿cuáles fueron los modos de producción que predominaron en esta época?

En primer lugar, el estudio de los principales sistemas de tenencia de la tierra en el Ecuador, implicaría llevar a cabo un análisis del concepto de "tenencia de la tierra". Con este objetivo, utilizaremos la definición propuesta por el Comité Interamericano de Desarrollo Agrícola (CIDA) que hace alusión a:

Las relaciones legales y tradicionales entre personas, grupos e instituciones que regulan los derechos al uso de la tierra, traspaso de la misma y goce de sus productos y de las obligaciones que acompañan a dichos derechos. ${ }^{247}$

Por otro lado, al hablar de los países que poseen un escaso desarrollo económico, como es el caso del Ecuador, se ha de explicar la importancia de la tierra y de su papel como una de las principales fuentes de riqueza, pues la distribución de los derechos de propiedad de territorios determina el grado en que las personas y grupos sociales pueden acceder a dichas fuentes de riqueza. Estas consideraciones, junto con las identidades culturales y sociales entre otras, muestran las razones por las que la tenencia de la tierra constituye un factor estratégico en

\footnotetext{
${ }^{246}$ Comité Interamericano de Desarrollo Agrícola (CIDA): Tenencia de la tierra y desarrollo socio-económico del sector agrícola Ecuador, Secretaría General de la Organización de los Estados Americanos-Washington D.C. Publicado por Unión Panamericana, 1965, p. 49-52.

${ }^{247}$ Ibíd., p.51.
} 
el desarrollo agropecuario de un país.

En términos generales, el Ecuador es un país con una economía compleja debido a su dificultosa topografía, la cual ha sido un obstáculo al desarrollo vial. Además, está constituido por economías regionales que poseen los rasgos básicos de las dos principales regiones del país, en las que los factores de producción no se encuentran distribuidos según su productividad. Nos estamos refiriendo a las regiones ya mencionadas, es decir, a la Costa, tradicionalmente orientada hacia el exterior y caracterizada por su auge comercial, y a la Sierra, que ha venido a ser una zona con una tendencia de ritmo lento en el crecimiento interno de su economía. ¿Cuáles podrían ser los factores a considerar a la hora de explicar la importancia de la propiedad de la tierra en el Ecuador?

En principio, podemos atribuir dicha importancia a factores de tipo histórico, los cuales se remontan a la crisis sufrida en el siglo XVIII, de gran repercusión en el imperio colonial hispánico y en la que la propiedad de la tierra se convirtió en la institución clave de la sociedad ecuatoriana. Asimismo, Celso Furtado indica que la decadencia del sistema económico organizado en torno a los polos productores de metales preciosos, tomó la forma de una progresiva descentralización de las actividades económicas y sociales, convirtiendo a la propiedad de la tierra en la institución básica de la sociedad. ${ }^{248}$

A partir de este momento, veremos cómo la acumulación y las luchas surgidas en torno a la disposición de la tierra, será un fenómeno constante que se irá repitiendo con el transcurso del tiempo y que aún perdura en la actualidad. Así, tras la independencia, encontramos un país dominado fundamentalmente por la clase terrateniente, la cual poseía una gran cantidad de tierras, cuyo funcionamiento y organización ha generado una gran diversidad de interpretaciones por parte de los estudiosos de la historia socio-económica del Ecuador.

En relación a esto, en primer lugar, se puede hablar de la hipótesis más tradicional que hace alusión a la estructura social ecuatoriana a partir del funcionamiento y estructura de los latifundios y haciendas, la cual reconoce la existencia de una organización feudal, caracterizada por sus escasas modificaciones. Entre los representantes de esta visión interpretativa se encuentra Jacinto Jijón y Caamaño, que piensa que las relaciones serviles son el elemento primordial de la nueva nación. Por otra parte, se encuentran los sectores activistas

${ }^{248}$ Celso Furtado: La economía latinoamericana desde la conquista ibérica hasta la Revolución Cubana, México, Siglo XXI Editores, 1973, p. 55. 
universitarios que apoyan la "tesis del feudalismo" y entre los que figuran Andrés Guerrero y Rafael Quintero. ${ }^{249}$

En relación a este debate, la CIDA expresa la opinión generalizada de diversos autores en relación al proceso de desarrollo de la tenencia de la tierra en el Ecuador, pues a pesar de presentar un cierto grado de evolución durante el siglo XIX, no se produjo un abandono total de los rasgos heredados de una estructura social y productiva de carácter feudal. ${ }^{250}$ Ahora bien, ¿se podrían aplicar por igual estas conclusiones al proceso de evolución de los sistemas de tenencia de la Sierra y de la Costa? o ¿podríamos hablar de una transformación absoluta del modo de producción pre-capitalista?

Los orígenes de la hacienda durante la colonia y el proceso por el que la tierra se concentró en manos de unos pocos y pudo conservar sus mecanismos de herencias, compras y uso de la fuerza, continuó en el siglo XIX con ritmos diversos en la Sierra y en las zonas del litoral. Así, en la segunda mitad del siglo XIX, la hacienda era la unidad fundamental donde se articulaban las principales estructuras económicas y el poder político e ideológico de la sociedad ecuatoriana.

Al hablar de la hacienda tradicional serrana, Andrés Guerrero señala la complejidad y confusión de sus relaciones de producción, en contraste con las de la forma capitalista del salario. $^{251}$ En otras palabras, la persistencia del elemento arcaico en la estructura social y productiva de la serranía ecuatoriana, fue motivo para la crítica del feudalismo como consecuencia del atraso y de las barreras que obstaculizaban al desarrollo.

Lo importante de este momento histórico, no solo se refiere a la consolidación del latifundio (tendencia que se había manifestado en la serranía desde antes de 1830), sino también a los efectos de este proceso sobre una cierta acumulación de capital.

En efecto, aunque la consolidación de las haciendas tuvo un impacto posterior sobre la acumulación capitalista, dándose con una mayor intensidad en la Costa debido al tipo de

\footnotetext{
249 Jacinto Jijón y Caamaño: Política conservadora, Segundo volumen, Riobamba, Edit. La Buena Prensa del Chimborazo, 1929.

${ }^{250}$ Comité Interamericano de Desarrollo Agrícola, op. cit.,p. 48-90.

${ }^{251}$ Andrés Guerrero: La hacienda pre-capitalista y la clase terrateniente en América Latina y su inserción en el modo de producción capitalista: El caso ecuatoriano, apartado: Formas de trabajo de la hacienda y las relaciones de apropiación de la renta, Ocasional Papers No. 23, Institute of Latin American Studies, University of the Sorbonne, París, 1977, p. 47-72.
} 
producto cultivado que unía a la economía regional con el mercado mundial, también, es cierto que en la Sierra, el fortalecimiento del latifundio se tradujo en una relativa dinamización de la producción mercantil de las haciendas (granos, sombreros de paja, cascarilla, artesanía). ${ }^{252}$

Cabe señalar que en la Sierra central, la circulación de la producción agrícola fuera de su ámbito local fue posible mediante la reestructuración de su sistema de ferias y la mejora en las vías de comunicación a partir de la segunda mitad del siglo XIX. ${ }^{253}$ En este caso, se exportaban de las zonas serranas algunos productos agrícolas como sombreros de paja, cascarilla, suelas y caucho, los cuales eran trasladados de las haciendas hacia el puerto de salida a través de Guaranda (que era el punto de concurrencia del comercio interregional del centro y norte de la Sierra del momento) y de las zonas de Cuenca y Loja, cuya función era la de enviar la producción del interior hacia los puertos de embarque. ${ }^{254}$

Pese a la existencia de estos rasgos, las haciendas tradicionales eran consideradas como los sistemas de tenencia dominantes en la Sierra, al ser la principal unidad de producción, pues de sus actividades dependía la economía de una buena parte de la población ecuatoriana. ${ }^{255}$ Asimismo, la importancia de la hacienda no se limitaba a su papel económico, puesto que su importancia en el contexto político había logrado sobrepasar su peso durante un largo periodo de la historia ecuatoriana. ${ }^{256}$

A la vez que las haciendas constituían la forma dominante de ocupación y explotación de la tierra en la región interandina, su formación se remontaba a las tierras otorgadas como compensación de servicios durante la época de la conquista en una zona poblada. Estas compensaciones incluían tanto las tierras como los servicios personales de los indígenas que se encontraban vinculados al estado, al clero, a los conquistadores y terratenientes, creándose de este modo, un patrón de relaciones de servidumbre que ha poseído vigencia durante el siglo XX (a través de instituciones como el huasipungo u otras similares), pese a sus modificaciones

\footnotetext{
${ }^{252}$ Rafael Quintero, Erika Silva, op. cit. p. 160-167.

${ }^{253}$ R. J. Raymond y Rosemary Bromley: Cambios de los días de feria en la Sierra central del Ecuador durante el siglo XIX, Revista del Archivo Histórico del Guayas, Guayaquil, 1976, p. 7-32.

${ }^{254}$ Agustín Cueva: El proceso de dominación política en el Ecuador, Ed. Critica, Quito, 1973, p. 25-45; Oswaldo Hurtado: El poder político en Ecuador, Edcs. PUCE, Quito, 1977, p. 20-400.

${ }^{255}$ M. Hamerly, op. cit. p. 21-185.

${ }^{256}$ Agustín Cueva, op. cit. p. 26-45.
} 
a lo largo del tiempo.

De acuerdo con González Prada, en el Ecuador, la hacienda no sólo se constituyó como un sistema socio-económico, sino que vino a mostrar una imagen de modernidad que complicó aún más el problema indígena. ${ }^{257}$ Esta imagen reflejaba las ideas de una clase terrateniente dominante que, tras haber suavizado las diferencias de los pueblos indígenas una vez obtenida la independencia, buscó su incorporación como sujetos étnicos diferentes y oprimidos. ${ }^{258}$

Esta imagen se legitimó en los círculos intelectuales, de ahí que el indigenismo literario de Ecuador intentara poner de manifiesto una realidad que había pasado a convertirse en el eje central del debate nacional. Esta interpretación contraria de la historia de las repúblicas andinas, la incorporación del indígena y su realidad, ha sido un tema tratado por críticos como Antonio Cornejo-Polar, quien afirma que:

Leer indigenismo es leer la extrema contradicción de naciones que no pueden decirse a sí mismas, por su propia y desgarrada condición heteróclita, más que en reflexiones y ficciones que al intentar resolver el problema nacional, lo que hacen es repetirlo. ${ }^{259}$

De esta forma, la narrativa andina de los primeros años del siglo XX, fue elaborada como un conjunto de relatos heterogéneos que reproducían un conflicto sin resolver. En el caso ecuatoriano, la paradoja de una constitución liberal que buscaba la igualdad de todos los ciudadanos, pospuso el debate sobre el régimen servil de la hacienda hasta finales de los años treinta, al identificar al indígena como un grupo atrasado. ${ }^{260}$

Andrés Guerrero clasifica las formas de trabajo existentes en las haciendas en tres grandes grupos, según las principales obligaciones y derechos correspondientes. ${ }^{261}$

\footnotetext{
${ }^{257}$ Manuel González Prada: Nuestros indios (1904), en Horas de lucha, n. 31-32, Quito, 1905, p. 2-3.

${ }^{258}$ Andrés Guerrero señala que, en un primer momento, los indígenas fueron considerados tributarios del estado, mientras que a finales del siglo XIX, pasaron a ser sujetos étnicos, siendo administrados por configuraciones de poder locales y regionales. Fuente: Andrés Guerrero: Una imagen ventrílocua: el discurso liberal de la desgraciada raza indígena a finales del siglo XIX, en Blanca Muratorio, ed. Imágenes e imagineros: representaciones de los indígenas ecuatorianos, siglos XIX y XX, FLACSO, Quito, 1994, p. 200-201.

${ }^{259}$ Antonio Cornejo-Polar: Escribir en el aire: Ensayo sobre la heterogeneidad socio-cultural en las literaturas andinas, Editorial Horizonte, Lima, 1994, p. 207.

${ }^{260}$ Ibíd. p. 206.

${ }^{261}$ Andrés Guerrero, La Hacienda pre-capitalista..., op. cit. p. 45-80.
} 
El primer grupo, formado por varias modalidades de trabajo, se caracterizaba por una cantidad específica de jornadas de trabajo que los campesinos estaban obligados a desempeñar en los cultivos organizados por el terrateniente, obteniendo el acceso a ciertos medios de producción (tierra, agua, etc.). Dentro de este grupo, se encontraba el trabajo yanapero y del huasipunguero, en el que los campesinos estaban obligados a entregar una parte del producto obtenido en las tierras trabajadas.

El segundo grupo, constituido por partidarios o por arrendatarios, se caracterizaba por una relación en la que el hacendado ponía la tierra y algunos medios de producción, mientras que el campesino aportaba su fuerza de trabajo, dividiéndose la producción obtenida en partes fijadas con anterioridad. Por lo general, los socios del terrateniente eran campesinos externos a la gran propiedad, los cuales pertenecían a la pequeña burguesía de los pueblos cercanos.

El tercer grupo, formado por un grupo de trabajadores asalariados, eran los empleados que recibían una paga mensual en dinero, aunque también recibían un pago en especies o en usufructo de tierras y pastizales.

Dentro de este grupo, el nivel más alto lo ocupaban los administradores, que solían pertenecer a la clase terrateniente. El segundo nivel estaba representado por funcionarios medios que procedían de la pequeña burguesía. Para estos dos niveles sociales, el salario monetario formaba la base de su remuneración, siendo los beneficios en especies o medios de producción de carácter secundario. El último nivel dentro de este grupo de empleados, los mayordomos, estaba encargado de las tareas de ejecución y control del trabajo, así como de la represión directa y recibía una remuneración monetaria complementaria a la posesión de tierras y pastizales.

Los ayudantes mencionados no se diferenciaban demasiado de los huasipungueros, siendo elegidos entre dicho grupo en numerosas ocasiones. En conjunto, estos funcionarios pertenecían al denominado aparato de dirección de la hacienda, es decir, la estructura compuesta por un conjunto de funciones económicas (dirección, organización y control del proceso productivo) y de dominación política-ideológica (coacción) del campesinado indio. ${ }^{262}$

Por último, hay que destacar la existencia de otro grupo asalariado, los denominados "peones", libres o sueltos, temporales o permanentes, quienes vendían su fuerza de trabajo a las

${ }^{262}$ Ibíd. p. 40-80. 
haciendas. Estos trabajadores recibían un jornal en dinero, exceptuando algunas tareas específicas como las cosechas, donde se les entregaba un complemento en especies. Los peones formaban un tipo particular de proletariado que vivía dentro de la hacienda y que presentaba características determinadas, pues estaba vinculado a los huasipungueros por relaciones de parentesco.

De esta forma, el hacendado sometía al productor inmediato interno (el huasipunguero) o externo (yanaperos, partidarios y arrendatarios con obligaciones de trabajo, minifundistas, etc.) implantando relaciones de dominación extra-económicas, que le permitían ejercer económicamente su derecho de monopolio sobre la tierra y obtener trabajo extra en la forma de jornadas trabajadas por campesinos indios en sus cultivos (renta territorial en trabajo).

Todas estas ideas explican la razón por la que el huasipungo constituía la pieza fundamental del sistema, ya que sustentaba todo el proceso de producción de la hacienda tradicional de la Sierra, en tanto que era el elemento clave de la apropiación de trabajo extra y de la explotación del productor inmediato.

A este respecto, Enrique Ayala afirma que las relaciones serviles, sobre todo en el caso de la Sierra, fueron de gran importancia, pero a la vez piensa que no se ha de abandonar la idea de que las estructuras agrarias existieron solamente en relación a una sociedad más amplia de la cual eran parte. ${ }^{263}$ Por esta razón, los trabajos científicos privilegian el análisis de la complicada articulación de este tipo de relaciones productivas al interior de la formación social del Ecuador.

A su vez, este mismo autor acepta como hipótesis de trabajo, la enunciada por Guerrero y Quintero, y considera que en la etapa colonial no se dio un modo de producción dominante al interior de la formación económica-social. Así, en los años posteriores a la independencia, la transición colonial dejó paso a la consolidación de las relaciones capitalistas de producción. Por otra parte, reconoce el establecimiento del sistema de haciendas en la Sierra tras la independencia, ya que el colapso minero en la región andina y la consecuente crisis de la producción textil en Quito, provocaron el auge de la producción agrícola al mismo tiempo que aumentaba el valor de la tierra. Todo esto tuvo lugar durante las últimas décadas de dominio colonial, en las que las oportunidades para fomentar el desarrollo industrial fueron

\footnotetext{
${ }^{263}$ Enrique Ayala Mora, Lucha política y origen..., op. cit. p. 20-335.
} 
desapareciendo para favorecer a la metrópoli y a otras potencias europeas, de ahí que al obraje no le sustituyera ninguna actividad de tipo industrial. ${ }^{264}$

A su vez, estos acontecimientos originaron el desalojo de las comunidades indígenas a las que no sólo se les despojó de las tierras, sino que también fueron obligadas a vincularse al sistema de la gran propiedad agraria establecido con la ampliación de las fronteras agrícolas. De esta forma, los indígenas se vieron obligados a concertarse, comprometiéndose con un propietario que les pagaba una remuneración por adelantado. Fernando Velasco explica que esta forma de vida se mantuvo entre las diferentes generaciones de indígenas como consecuencia de la gran cantidad de tributos y obligaciones que tenían y que, a largo plazo, implicaron una acumulación de la deuda con su patrón que se perpetuaba de padres a hijos, uniéndolos al latifundio de por vida. ${ }^{265}$

Siguiendo con la polémica generada en torno al modo de producción de la hacienda tradicional, caracterizado por la articulación de sus rasgos feudales y capitalistas, vamos a ver ahora cómo se llevaba a cabo su funcionamiento. En este sentido, el destacado carácter de la combinación de tales rasgos, aseguraba la reproducción del modo de producción de la hacienda en su forma específica, a la vez que el capitalismo se esforzaba por disolverlo con el objeto de llegar a imponerse en su totalidad. ${ }^{266}$

A este respecto, no se puede olvidar el debate de los modos de producción de América Latina, en el que autores como Gunder Frank, hablan del capitalismo universal. Otros estudiosos del tema defienden el carácter feudal y dual de las sociedades latinoamericanas, hecho que resultará en la formulación de cuál fue la clase de articulación predominante en la América Latina de finales del siglo XIX.

Ya vimos en la introducción, la posición adoptada por Gunder Frank en su análisis de América Latina y cómo esta supuso el inicio del debate. Frank afirmaba que el capitalismo existía en América Latina desde la época de la conquista y que todas las diferentes estructuras productivas desde la colonia eran el resultado del proceso de expansión del mercantilismo,

\footnotetext{
${ }^{264}$ Ibíd. p.20-335.

${ }^{265}$ Fernando Velasco: La estructura economía de la Real Audiencia de Quito. Notas para su análisis, Publicado en "Ecuador: pasado y presente", Instituto de Investigaciones Económicas de la Universidad Central, 1976, p. 80.

${ }^{266}$ Gonzalo Ortíz Crespo, op. cit. p. 130.
} 
capitalismo y del imperialismo. Además, la existencia de un mercado importante constituía el factor diferenciador decisivo entre el capitalismo y el feudalismo, ya que el sistema capitalista era un modo que abastecía al mercado, mientras que el feudalismo tenía como base una economía cerrada. ${ }^{267}$

Diversos autores han argumentado que los errores de la concepción de Frank, se encontraban en el hecho de que su perspectiva ideológica le obligaba a omitir las relaciones de producción de su definición del capitalismo. ${ }^{268}$ Por su lado, la posición que Frank intentaba criticar también tenía sus fallos, pues dicha interpretación mantenía que las sociedades latinoamericanas poseían una estructura dual, donde determinados sectores pudieron modernizarse y desarrollarse con el impulso del mundo capitalista, mientras que otros habían quedado reducidos a una economía aislada feudal o pre-capitalista.

En su examen de las relaciones de producción, Laclau concluye que el modo de producción feudal ha estado ampliamente presente en América Latina a lo largo de su historia:

Teniendo en cuenta que la relación económica fundamental del capitalismo se basaba en la venta de su fuerza de trabajo por parte del trabajador libre, solo quien creyese que este era el factor dominante en América Latina del siglo XVI, podría considerar al continente como capitalista. No fue este el caso, ni en la propia Europa de esa época. Al revés, desde entonces, ha sobrevivido en América Latina, un modo de producción basado en características muy diferentes de las capitalistas. ${ }^{269}$

También, afirma que el carácter pre-capitalista de las relaciones dominantes de producción en estos países, no solo era incompatible con la producción para el mercado mundial, sino que llegó a intensificarse por la expansión de este último.

A partir de estas ideas y asumiendo que la inserción en las relaciones capitalistas no supuso una

\footnotetext{
${ }^{267}$ Andre Gunder Frank: Capitalismo y subdesarrollo en América Latina, Instituto del Libro, Editorial de Ciencias Sociales, 1970, p. 35-300.

268 Laclau afirma que esta posición ha sido mantenida por desarrollistas burgueses y partidos comunistas de América Latina, ya que la izquierda latinoamericana surgió como el ala izquierda del liberalismo, estando determinada su ideología por las categorías básicas del siglo XIX. En estos casos, no era posible la aplicación a la historia latinoamericana de las cinco etapas pseudo-marxistas (comunismo primitivo, esclavitud, feudalismo, capitalismo y socialismo) como algunos de estos partidos demuestran. Fuente: E. Laclau: Feudalismo y capitalismo en América Latina, de la publicación del Centro de Estudios de Economía Política, Buenos Aires, 1971 , p. 67.

${ }^{269}$ Ibíd. p. 67.
} 
transformación radical del sistema pre-capitalista de la hacienda y de sus modalidades de trabajo, ¿cómo tuvo lugar la articulación de los diferentes modos de producción en la misma?

El análisis de la combinación y de los antagonismos entre las formas pre-capitalistas y capitalistas y de cómo cada uno de estos modos llegó a convertirse en una condición para la existencia del otro, será utilizado para explicar con más detenimiento la evolución de la hacienda y de las modalidades de trabajo y su inserción en las relaciones capitalistas en el siglo XX. Estos aspectos constituyen un requisito para realizar un análisis histórico en una sociedad, además de ser uno de los puntos más importantes en el estudio de los modos de producción. Así, al analizar la combinación de estas relaciones se ha de tener en cuenta que el trabajo se encontraba subordinado al latifundio a través de la represión y al capital mediante el salario.

Guerrero indica que la familia extensa del huasipungo era el lugar donde esta articulación inicial se daba al nivel de producción, aunque fue después, cuando el progreso del capitalismo comprimió las condiciones de reproducción de dicha familia para lograr un conjunto de trabajadores libres, pero que estaban obligados a vender su fuerza de trabajo. ${ }^{270} \mathrm{Si}$ los trabajadores poseían este tipo de obligación, ¿cómo se puede hablar de ellos en términos de libertad? ¿cuáles eran los beneficios que los terratenientes podían obtener de estas situaciones?

Los terratenientes usaron diversos mecanismos con este fin para poder contar con mano de obra cuando fuera necesario y de esta manera, no estaban obligados a crear nuevos huasipungos. Es decir, la reproducción ampliada de las relaciones pre-capitalistas fue bloqueada por los hacendados ante la imposición de una nueva racionalidad económica, precisamente a causa de la articulación de la hacienda con el modo de producción capitalista. ${ }^{271}$ No obstante, este proceso habría de tomar muchos años, ya que cuando finalmente se dictó la Ley de Reforma Agraria y Colonización de 1964 como resultado de la estrategia modernizante iniciada por un sector del latifundio serrano, la combinación de los modos de producción todavía estaba vigente a pesar de que el modo de producción capitalista

\footnotetext{
${ }^{270}$ Andrés Guerrero, La hacienda pre-capitalista..., op.cit. p. 40-85.

${ }^{271}$ Oswaldo Barsky: Iniciativa terrateniente en el pasaje de hacienda a empresa capitalista. El caso de la Sierra ecuatoriana (1959-1964), Quito: CLACSO 1978.
} 
predominaba en el nivel de formación social. ${ }^{272}$ Es decir, la penetración capitalista en la hacienda no implicó la eliminación de las relaciones pre-capitalistas, como veremos posteriormente.

Entonces, si la familia del huasipungo experimentaba las relaciones pre-capitalistas y capitalistas entre sus propios miembros, era porque el hacendado tenía también un papel doble de terrateniente y capitalista, siendo el ritmo de transformación del hacendado diferente entre la Costa y la Sierra.

En la Sierra, el proceso se caracterizó por su lentitud debido al bajo nivel de desarrollo de las fuerzas productivas y del volumen de inversión de capital, así como por la disponibilidad del capital a través del proceso de acumulación y la consolidación del monopolio de la tierra en manos de los hacendados. ${ }^{273}$ Este proceso, característico ya del siglo XVIII, recobró fuerza desde mediados del siglo XIX, y habría de durar hasta el siglo XX.

Precisamente, a partir de este proceso de expansión de la propiedad hacendaria y de la represión de los indígenas, fue que se produjo la acumulación primitiva del capital en la hacienda. Se podría argumentar que este fuera el único modo posible de acumulación en la hacienda, dada la baja composición de capital y de otros factores internacionales, pero la verdad es que esto favoreció a los hacendados.

El principal mecanismo del que disponían los hacendados para incrementar su producción, no venía de la inversión del capital, sino del aumento del volumen de fuerza de trabajo y de la extensión de tierra. Así, la articulación entre las relaciones pre-capitalistas y capitalistas a los niveles del huasipungo y la hacienda explica la contradicción de la supervivencia de las

\footnotetext{
${ }^{272}$ La primera ley ecuatoriana de reforma agraria impuesta en 1964, incorporó las ideas principales de los anteproyectos que habían sido debatidos durante los gobiernos de José María Velasco Ibarra (1960-1961) y Carlos Arosemena (1961-1963). Hay que señalar la conversión de los huasipungueros en propietarios de sus parcelas y el estímulo a la colonización, mientras que la redistribución de tierras quedaría restringida a situaciones especiales que únicamente habrían de presentarse en el caso de las haciendas estatales. Esta ley fue expedida en un contexto de crisis política caracterizado por la agitación popular, el derrocamiento sucesivo de ambos presidentes y las presiones del gobierno norteamericano que pretendía fomentar un conjunto de reformas para evitar una repetición de la situación cubana. Asimismo, las protestas agrarias y la concentración en la liquidación del huasipungo, serían una muestra de que los factores políticos y el ascenso de las luchas campesinas desempeñaron un papel importante en la creación de esta ley. Fuente: Andrés Guerrero: Hacienda, capital y lucha de clases andina, Quito, Editorial, El Conejo, 1983, p. 86-114; Agustín Cueva: The process of political domination in Ecuador, New Brunswick: Transaction Books, 1982, p. 46-50.

${ }^{273}$ Para incrementarlo era necesario disponer de nuevas técnicas e insumos proporcionados por el mercado internacional o doméstico, lo cual fue posible tras la Revolución Industrial, la integración del país en el mercado mundial y la acumulación de divisas para pagar las importaciones.
} 
haciendas pre-capitalistas en la Sierra en su condición de atraso hasta el siglo XX. Si bien ambos modos de producción constituyeron un negocio para el terrateniente, esto tuvo graves consecuencias para el país a la hora de establecer el tipo o modelo de desarrollo histórico, pues este proceso necesario para la acumulación consideró al sector agro-exportador como el eje de su economía. ${ }^{274}$

Hasta ahora, se ha hablado del papel desempeñado por la Sierra ecuatoriana a lo largo del siglo XIX como espacio económico, social y político, al encargarse desde un primer momento del abastecimiento de alimentos para el mercado interno y ser la reserva de mano de obra de los latifundios a través de formas precarias. En este sentido, es necesario preguntarse cuáles fueron las actividades desarrolladas que fomentaron la importancia de esta región a nivel nacional, teniendo en cuenta la división entre la Sierra centro-norte y la Sierra sur debido a sus características diferenciadoras. $^{275}$

Tras la crisis de la producción minera de Potosí y las Reformas Borbónicas del siglo XVIII, la Sierra centro-norte se especializó en la producción textil, a la vez que siguió estando unida a los mercados de producción de oro de Nueva Granada durante el siglo XIX. De forma paralela, esta región comenzó a dedicarse a la producción agropecuaria, buscando sin éxito una salida al mercado internacional al no poder encontrar los productos y medios necesarios. De esta manera, la zona agropecuaria central estaba vinculada a Guayaquil, mientras que la ciudad de Quito era el mercado principal de la zona norte, generándose así, la creación de círculos espaciales de producción y cooperación. $^{276}$

La Sierra centro-norte era la región más importante del naciente país en 1830, [...] estaba integrada por las provincias de Imbabura, Pichincha y Chimborazo [...] La ciudad de Quito, además de ser la capital de la República, era el centro económico,

\footnotetext{
${ }^{274}$ Andrés Guerrero, La hacienda pre-capitalista..., op. cit. p. 40-80.

${ }^{275}$ Pablo Ospina: Esquemas para una breve historia del espacio ecuatoriano, en Sara Báez, Pablo Ospina y Galo Ramón: Una breve historia del espacio ecuatoriano, Quito, Camaren-IEE, 2004, p. 66-67.

${ }^{276}$ Ibíd., p. 67.
} 
político y administrativo de la región. Le seguían en jerarquía dos ciudades importantes, Ibarra y Riobamba, como capitales de provincia... ${ }^{277}$

La Sierra centro-norte se caracteriza por una población significativa y a diferencia de la Costa sur, descentralizada. A inicios del siglo XX, Riobamba, Ambato y Guaranda cuentan con una población similar a la de Quito. Durante este periodo se destaca el crecimiento de Ambato, que se convirtió en el centro de los intercambios interregionales entre la Costa, la Sierra y la alta Amazonía... ${ }^{278}$

A pesar del dominio terrateniente, la hacienda había perdido la capacidad de producción anterior a causa de las políticas de libre comercio impulsadas por España, los altos impuestos y un conjunto de desastres naturales y sociales que habían logrado perjudicarla:

La crisis era tal, que en el siglo XIX, el mercado principal de las haciendas era Quito y eran los quesos frescos, los que lograban la mayor rentabilidad, cuestión que mostraba la restricción de los mercados de la hacienda. A ello, habría que añadir la actividad textil que, a pesar de estar muy golpeada, se mantenía en unas cuantas haciendas de la Sierra Norte; la cría de mulas en Chimbo, la producción de frutas de Ambato, la producción de sal en Tomabela y Salinas de Ibarra, la de cabuya y sus elaborados en la Sierra central y el algodón y aguardiente en los valles... ${ }^{279}$

Por su parte, la Sierra sur, formada por las provincias de Cuenca y Loja, estaba vinculada al mercado del norte peruano, aunque los problemas fronterizos constituyeron un gran obstáculo para la creación de un espacio nacional. En el caso de Cuenca, la explotación de la quina, le permitió establecer su propio lazo con los mercados internacionales, creando de este modo, una articulación privilegiada con Guayaquil y desarrollando esfuerzos importantes para abastecer a Puerto Bolívar. Es necesario señalar que el apogeo de la quina coincidió con la declinación de las relaciones comerciales con el Perú, debido al conflicto limítrofe de 1859.

\footnotetext{
${ }^{277}$ Galo Valarezo, Víctor Torres: El desarrollo local en el Ecuador: Historia, actores y métodos, Ediciones AbyaYala, Quito Ecuador, 2004, p. 114.

${ }^{278}$ Pablo Ospina, op. cit., p. 67.

${ }^{279}$ Galo R. Valarezo, Víctor Torres, op. cit. p. 116.
} 
Por último, si bien la explotación de la quina se producía en las grandes propiedades, a diferencia de la Sierra centro-norte, caracterizada por la alta concentración de la propiedad de la tierra, en la Sierra sur, las grandes haciendas estaban acompañadas de una amplia red de pequeñas y medianas propiedades rurales independientes. Estas propiedades estaban dedicadas a la extracción de oro y a la producción de artesanías de oro, confección de sombreros de paja toquilla y a la producción agro-ganadera para abastecer a Cuenca y Guayaquil, compitiendo las clases más altas de Cuenca con los pequeños y medianos productores en el campo agropecuario, a la vez que ejercían el papel de agentes intermediarios de tipo comercial con respecto a la producción artesanal. $^{280}$

\subsection{2) Sistemas de tenencia, modos de producción y formas de trabajo de los grupos pertenecientes a los latifundios de la Costa ecuatoriana: La hacienda cacaotera.}

Vamos a pasar ahora, a examinar los sistemas de tenencia, los modos de producción y las modalidades de trabajo de los grupos vinculados a los latifundios del litoral ecuatoriano, para que de esta forma, tengamos un conocimiento más completo de las diferencias existentes entre esta región y la Sierra, y de su funcionamiento a partir de su inserción en el sistema capitalista. En primer lugar, al hablar del latifundio costeño, hemos de referirnos al momento de su consolidación, el cual fue posterior al asentamiento de la hacienda serrana. Las razones que explican estas diferencias, pueden ser localizadas en la naturaleza de su constitución, que en el caso de la Costa, tuvo lugar a raíz del apogeo del comercio a mediados del siglo XVIII y en el que la producción de ciertas plantas tropicales como el tabaco, el algodón, el arroz y el cacao cobraron una gran importancia. Además, durante la colonia, la Costa era una región agrícola secundaria en la que predominaba la pequeña propiedad, la cual coexistía con las tierras comunitarias indígenas, de ahí que la consolidación de su latifundio ocurriera en una época posterior a la de la Sierra. ${ }^{281}$ De todos modos, es importante recordar que su producción tuvo que hacer frente a diversos problemas de competitividad como fue el caso del cacao procedente de Venezuela, hecho que acabó favoreciendo un sentido más comercial y capitalista de su agricultura.

En cuanto al principal producto, el cacao, que permitió el apogeo de la Costa a través de su

\footnotetext{
${ }^{280}$ Ibíd. p. 116-118.

${ }^{281}$ Michael Hamerly, op. cit. p. 21-185.
} 
comercio, se ha de señalar que su cultivo se remonta al siglo XVI, pero no fue hasta el año 1740, en que comenzó a aumentar de forma permanente, sobre todo durante las primeras décadas del siglo XIX, en las que la producción cacaotera fue aún mayor. La economía de la Costa, que estaba vinculada al comercio internacional, no solo logró experimentar un fenómeno de crecimiento permanente, sino que provocó la aparición de la denominada "burguesía comercial", caracterizada por sus conflictos con la tradicional oligarquía latifundista, como ya se ha comentado.

La necesidad de incrementar la producción de cacao durante el siglo XIX, vino acompañada por la tendencia a la extensión de las fronteras agrícolas en la zona de la Costa y por la concentración territorial, pero también fue una medida para obstaculizar el acceso a las tierras libres por parte de los inmigrantes serranos. ${ }^{282}$ La escasez de mano de obra de la Costa obligó a los terratenientes a buscar otros métodos de control de la fuerza de trabajo y aunque el concertaje logró permanecer hasta comienzos del siglo $\mathrm{XX}$, dicho mecanismo no fue establecido como la relación básica de producción predominante en esta zona. Por tanto, ¿cuáles fueron las principales modalidades de trabajo en el latifundio de la Costa?

Ayala explica que el latifundio del litoral se basaba en el trabajo excedente extraído al cultivador dependiente, siendo la redención, la principal forma de explotación a su interior. $^{283}$ En ella, el tiempo de trabajo del productor directo estaba dividido, pues cultivaba el lote asignado por el hacendado, del que conseguía lo necesario para sobrevivir, además de encargarse de la plantación y cultivo de los cacaotales para la hacienda, los cuales eran entregados cuando estaban listos para la producción.

De esta forma, la producción de la hacienda cacaotera se caracterizaba por su división interna, en la que una parte atendía a las demandas del mercado externo y la otra se hacía cargo del mercado interno y del consumo doméstico.

Si bien el mecanismo de la redención fue la forma más económica utilizada por el terrateniente para ampliar sus propiedades, las condiciones del mercado de trabajo fueron los elementos fundamentales para introducir las relaciones monetarias, al imponerse la necesidad de contratar mano de obra pagando un salario al trabajador. Esto no solo agudizó

\footnotetext{
${ }^{282}$ Galo Valarezo, Víctor Torres, op. cit. p. 116.

${ }^{283}$ Enrique Ayala Mora, Lucha política y origen..., op. cit. p. 20-335.
} 
las diferencias existentes entre la Costa y la Sierra, sino que puso de manifiesto la apertura y consolidación de las relaciones capitalistas, las cuales coexistían con las formas típicamente pre-capitalistas. ${ }^{284}$

Por otra parte, para conocer el proceso seguido por la hacienda pre-capitalista hay que resolver otras cuestiones de carácter histórico, como es el caso del salario. Si bien el pago de un salario era un tema incluido en las leyes españolas que regían en la colonia, ¿en qué momento apareció el trabajo asalariado en las haciendas del litoral ecuatoriano?

Anteriormente, se dijo que la acumulación originaria en la Costa ecuatoriana tuvo lugar a través de la hacienda cacaotera como una forma de producción particular, la cual ayudó en la constitución de las relaciones de producción capitalista en otros ámbitos sociales. También, se ha mencionado cómo los factores externos que provocaron la formación del modo de producción capitalista, pasaron por la creación de relaciones no capitalistas en la renta de cacao destinada al mercado mundial.

En consecuencia, teniendo en cuenta estas ideas, vamos a profundizar en el funcionamiento de la hacienda cacaotera dentro del sistema capitalista para tener una mejor idea de cuáles fueron las modalidades de trabajo de los grupos vinculados a estos latifundios y del origen del trabajo asalariado en la Costa.

A finales del siglo XIX y siguiendo el mismo camino que otros países de América Latina, se observa en el Ecuador un rápido desarrollo de las haciendas cacaoteras y una creciente especialización del cacao, cuyo volumen de exportaciones llegó a duplicarse en un periodo de veinte años, pasando a representar el $70 \%$ del total de las exportaciones. ${ }^{285}$

\footnotetext{
${ }^{284}$ Ibíd. p. 20-335.

${ }^{285}$ Andrés Guerrero, Los oligarcas del cacao..., op. cit. p. 11-95.
} 
Gráfico 1: Exportaciones de cacao. Total de exportaciones nacionales (1881-1898)

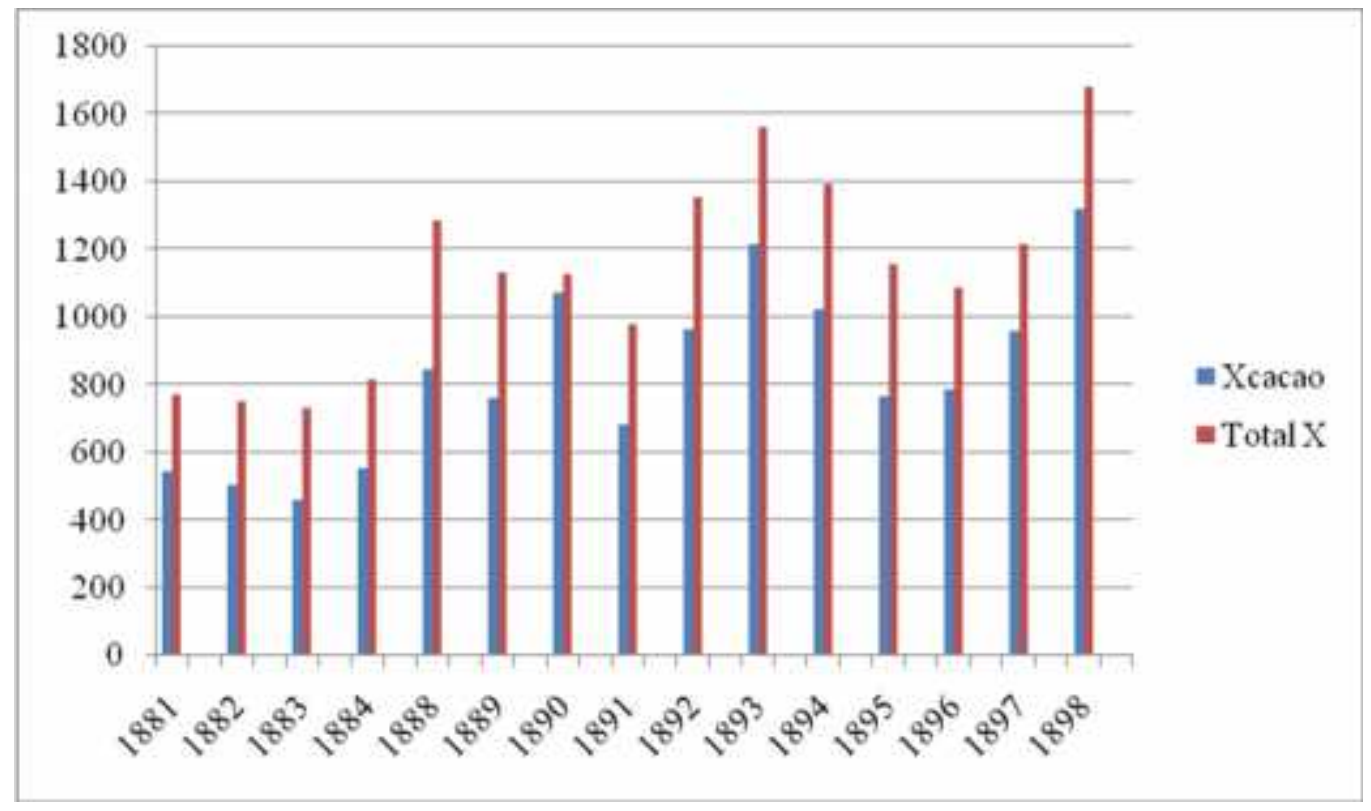

Elaboración propia a partir de los datos de la tabla 5.

La serie azul representa las exportaciones de cacao en el periodo 1881-1898, mientras que la serie roja, representa las exportaciones totales a nivel nacional para dicho intervalo de tiempo.

Fuente: Parliamentary Papers, Consular Reports, Ecuador, en Luis Carbo: Historia Monetaria y Cambiaria del Ecuador, Banco Central del Ecuador, 1953, p. 447-448.

El desarrollo de la producción del cacao, puede ser explicado mediante la existencia de unas mejores condiciones de producción en la Costa ecuatoriana, si se compara con otras áreas. Es decir, la producción de cacao se ubicaba principalmente en el litoral, concretamente en la cuenca del río Guayas, y se caracterizaba por la existencia de bosques naturales, que eran despejados y destinados a la producción del cacao, a la vez que las condiciones naturales eran favorables para el cultivo del árbol en las llamadas huertas regulares. ${ }^{286}$ Estas características son

\footnotetext{
${ }^{286}$ La producción de cacao en el Ecuador se puede llevar a cabo mediante las huertas regulares, las cuales se levantan preparando un terreno apto, especialmente en los bancos, por el desmonte acostumbrado, dejando en pie, si los hay, algunos árboles de sombra. Los árboles se siembran en orden quincuncial, haciendo los huecos a la distancia de dos o tres varas y depositando en cada uno de ellos cuatro o cinco semillas frescas de cacao. Al mismo tiempo, se siembran las plantas que deben proporcionar sombra a las plantas del cacao. Entre los cuidados que recibe la huerta cargadora, se encuentra el de rozarla una vez por año (normalmente en la estación de verano) y en esta ocasión, se cortan las ramas superfluas y plantas parásitas que puedan impedir el crecimiento del árbol. Fuente: Theodor Wolf: Geografía y geología del Ecuador, Geografía botánica y zoológica, capítulo I. Public. Gobierno de la República, 1892.
} 
interpretadas en el mercado mundial mediante la obtención de rentas convertidas en mayores beneficios.

En lo que se refiere a la parte interna, las rentas diferenciales resultantes de la localización geográfica y de la fertilidad de la tierra implicaban dos hechos importantes. En primer lugar, constituían una de las herramientas de la especialización del aparato agropecuario en los cultivos que podían disponer de dichas rentas, mientras determinaban las zonas de expansión de la frontera agrícola. En segundo lugar, la extensión territorial de las relaciones de producción resultantes de la inserción en el mercado internacional estaba delimitada por el espacio geográfico, en el que se llevaba a cabo la apropiación de dichas rentas diferenciales. ${ }^{287}$

La combinación de estas circunstancias puso de manifiesto la incapacidad de la clase terrateniente para alcanzar un carácter nacional en el plano económico y político, a pesar de que los terratenientes cacaoteros lograran abrir las fronteras y monopolizar las tierras de acceso más fácil, permitiendo la consolidación de esta clase social. Las cifras catastrales muestran que a principios del siglo XX, existían aproximadamente 4.837 fincas y unos sesenta millones de árboles de cacao (Tabla 2: Concentración de la propiedad de las haciendas cacaoteras, 1909), siendo las grandes provincias cacaoteras Los Ríos, El Oro y Guayas, las que presentaban mejores condiciones de transporte gracias a la red fluvial que permitía llevar la producción al puerto de Guayaquil. ${ }^{288}$

Los datos de la tabla 2 aportan una idea aproximada de la multipropiedad, al tomarse como referente una investigación realizada por algunos de los hacendados con respecto a sus propiedades en la guía agrícola, comercial e industrial en $1909 .^{289}$ No en vano, estas estadísticas muestran cómo el cultivo del cacao en el Ecuador se llevaba a cabo como una actividad de la propiedad terrateniente, aunque no se puede hacer una comparación con la pequeña producción campesina de tipo familiar independiente, ya que apenas existe información de las provincias cacaoteras más destacadas. Partiendo de estas afirmaciones,

\footnotetext{
${ }^{287}$ Andrés Guerrero, Los oligarcas del cacao..., op. cit. p. 11-95.

${ }^{288}$ La tabla 2 se encuentra en el apéndice de datos del capítulo 1. Fuente: GUIA: El Ecuador, Guía comercial, agrícola e industrial de la República, 1909, Guayaquil, 1909, en Andrés Guerrero, Los oligarcas del cacao..., op. cit. p. 11-95.

${ }^{289}$ Ibíd., p. 11-95.
} 
¿cómo se pueden explicar las relaciones de trabajo entre los grupos vinculados a los latifundios cacaoteros de la Costa ecuatoriana?

Andrés Guerrero identifica dos formas de trabajo existentes en las haciendas cacaoteras de finales del siglo XIX y primeras décadas del siglo XX. Estas formas, representadas en dos figuras del trabajador directo, sembradores y peones, estaban vinculadas a una cierta división social y técnica de trabajo interna al proceso productivo del cacao. ${ }^{290}$

La composición de las plantaciones de cacao podía llevarse a cabo mediante la eliminación y limpieza de la maleza de los bosques tropicales, despejándose los terrenos con fuegos para luego, sembrar las semillas de cacao y crear una huerta regular. ${ }^{291}$ Este método, que solía ser el más frecuente, constituía una forma particular de inversión no capitalista, al implicar una reproducción ampliada del proceso productivo cacaotero mediante la apropiación de una renta en productos trabajada por un grupo doméstico campesino. ${ }^{292}$ Además, a través de esta forma, los hacendados conseguían ampliar sus fronteras agrícolas y creaban sus plantaciones mediante la forma de trabajo de sembradores. Por tanto, ¿en qué consistió el trabajo realizado por los sembradores en las plantaciones de cacao? ¿qué tipo de pago recibía el sembrador a cambio de su trabajo durante dicho periodo de tiempo? ¿cuáles fueron los cambios ecológicos provocados en el paisaje agrario ecuatoriano?

En relación a esta última pregunta, con el auge cacaotero se crearon las bases para una posterior integración del espacio nacional y el desarrollo de su mercado interno, integrándose este proceso de cambios con la llegada del ferrocarril, el establecimiento del sistema financiero, el crecimiento de las ciudades, la comercialización de la agricultura y una producción urbana y rural orientada exclusivamente al mercado. La combinación de todos estos elementos y los cambios producidos en la vinculación de la propiedad y los recursos al mercado, tuvieron un gran impacto en los paisajes de diversas regiones ecuatorianas.

En el caso de la hacienda tradicional serrana, en las cercanías de Quito y en los valles de la Sierra central, la llegada del ferrocarril condujo a la progresiva expansión del área cultivada, a la lenta introducción de técnicas más intensivas de cultivo, a la incipiente adopción de relaciones salariales de producción, a la delineación más detallada de los límites de las haciendas y a un

\footnotetext{
${ }^{290}$ Ibíd., p. 11-95.

${ }^{291}$ T. Wolf: Geografía del Ecuador, Leipzig, 1892, p. 25-598.

${ }^{292}$ E. Parodi: La decadencia del cacao en Ecuador, Le materiel colonial, junio 1937, p. 4-5.
} 
acceso cada vez más restringido de los indígenas al uso de recursos de las haciendas, como aguas y pastoreo. ${ }^{293}$ Por su parte, la introducción del eucalipto (de origen australiano) llevada a cabo por García Moreno, indujo un progresivo cambio en el paisaje serrano, ya que los bosques naturales restantes irían desapareciendo de los valles, no sólo para abastecer las necesidades energéticas de las ciudades y del propio ferrocarril, sino para preparar los terrenos para pastos y cultivos ante la expansión del mercado.

La reorganización de los espacios para intensificar la producción de alimentos y las modificaciones en cuanto al acceso de recursos, estuvo marcada por la integración de regiones a través del ferrocarril y carreteras, por el aumento de la población y la creciente separación y diferenciación entre los espacios rurales y urbanos. Por un lado, se creó un nuevo proceso de especialización productiva, pues la producción fue reorientada hacia la creciente demanda urbana, creándose espacios dedicados a la ganadería, producción de hortalizas, granos, leche, leña y carbón. Además, se alteraron los sistemas de rotación y de barbecho, así como las estrategias tradicionales de fertilización de los suelos y modalidades de uso de la mano de obra, como ya hemos mencionado antes. ${ }^{294}$

Los sistemas agrícolas fueron orientados a las necesidades externas del mercado, de ahí que se aumentaran las áreas cultivadas y se acelerara la deforestación, quedando los suelos desprotegidos de la erosión. El uso tradicional formado por la ganadería, la agricultura y los bosques, que había formado paisajes bastante heterogéneos, acabó dividiéndose en explotaciones ganaderas o agrícolas en perjuicio de otros espacios, los cuales habían sido reservados a bosques, páramos y pastos naturales en otras épocas.

De este modo, el paisaje fue transformándose en pastizales artificiales para carne y leche y cultivos de cereales y hortalizas para la ciudad. Esta especialización de la producción modificó las relaciones sociales en el campo, afectando las formas tradicionales de los distintos grupos sociales en relación al uso de los espacios y los recursos, por lo que las haciendas comenzaron a tener límites. En este caso, a principios del siglo XX, las tierras destinadas a la producción de las familias ampliadas del hacendado y los campesinos fueron dedicadas a producir bienes de consumo en masa, mientras que los bosques cercanos a Quito se convirtieron en madera de

\footnotetext{
${ }^{293}$ Pilar Pérez: Cuando los montes se vuelven carbón: La transformación del paisaje en los alrededores de Quito, Tesis de maestría, Quito, FLACSO, 1995, p. 109.

${ }^{294}$ Ibíd. p. 109.
} 
construcción para espacios urbanos en expansión. Teniendo en cuenta que la leña fue la fuente fundamental de energía en el país, se puede tener una buena idea del gran proceso de deforestación provocado en la Sierra. ${ }^{295}$

Asimismo, con el boom del cacao y la incorporación de las nuevas técnicas de navegación a vapor, las condiciones cambiaron radicalmente, convirtiéndose las zonas del interior en espacios deseados para la producción. Esto explica que dichas tierras dejaran de estar en manos de los indígenas, generándose un proceso de concentración territorial y de despojo social, acompañado de la transformación del espacio cultivado dedicado al monocultivo que condujo a desequilibrios, pues los ecosistemas se hicieron más vulnerables. ${ }^{296}$

Según Carlos Larrea, aproximadamente treinta familias de Guayaquil se apropiaron de la gran mayoría de la producción y extendieron su inversión al capital comercial y financiero, combinando las relaciones de producción propias de los métodos no capitalistas con el pago de salarios con niveles cercanos a la subsistencia. Esto indica el hecho de que Guayaquil llegara a atraer una importante migración sobre todo de la Sierra, transformándose a principios del siglo XX en la principal ciudad del país, y procurando la articulación del país al mercado internacional a través de una economía de enclave. ${ }^{297}$

En referencia al trabajo en las plantaciones de cacao, la familia campesina realizaba todas las tareas que giraban en torno al cultivo de este producto, como era el caso de la siembra y cuidado de las plantas durante su periodo improductivo, lo cual duraba aproximadamente entre cuatro y siete años. Una vez que la huerta regular comenzaba a producir, se convertía en “cargadora” y el sembrador tenía que entregar el cultivo a los hacendados. ${ }^{298}$

Esta forma de trabajo comprendía una relación de carácter monetario, determinada a partir del costo de la plantación. Sin embargo, Guerrero dice que dicha forma de trabajo era una modalidad de apropiación de una renta en productos que se presentaba bajo la forma de un

${ }^{295}$ Ibíd. p. 109.

${ }^{296}$ Pablo Ospina, op. cit. p. 59.

${ }^{297}$ Carlos Larrea: Hacia una historia ecológica del Ecuador, Quito: Corporación Editora Nacional, Universidad Andina Simón Bolívar, Eco-Ciencia, 2006, p. 49-50; Alberto Acosta: Breve historia económica del Ecuador, 2da, ed. Quito: Corporación Editora Nacional, 2006, p. 38.

298 C. Wiener: 1879-1882: Viaje al río de las Amazonas y a las Cordilleras, en El Ecuador visto por los extranjeros, Biblioteca Ecuatoriana Mínima, México, 1950, p. 341-470. 
conjunto de árboles de cacao en producción, a pesar de la apariencia de una simple relación monetaria. La subsistencia y reproducción de la familia campesina estaba basada en los cultivos realizados por el grupo doméstico para su autoconsumo y en los adelantos monetarios que el hacendado entregaba al sembrador unos años más tarde como pago final en el momento de entrega de la huerta cargadora. Aquí, en el proceso de trabajo, se aprecia la existencia de una relación económica y técnica para la creación de una huerta de cacao, así como la forma de trabajo del campesino. ${ }^{299}$

Además, el proceso productivo entre la preparación de la huerta y la recogida de la primera cosecha unos años más tarde, requería el cultivo de plantas, cuyo fin era el de proporcionar sombra (consideradas como "materia prima auxiliar") a las matas de cacao. A su vez, estos cultivos auxiliares eran utilizados por la familia campesina para llevar a cabo otros procesos productivos temporales, al tiempo que cultivaban el cacao, cumpliendo de ese modo, una doble función en el proceso de producción inmediato: por un lado, aportaban sombra a las nuevas plantas y por otro, se incorporaban a la economía de subsistencia de la familia campesina del sembrador como catch crops hasta el momento de entrega de las plantaciones:

... el espacio intermedio entre los lugares plantados de cacao se consagra al cultivo de bananas, mandioca, maíz, diversos tipos de frijoles y otras plantas alimenticias. Estos cultivos intermedios son por lo general, plantados uno detrás de otro, hasta que crezca el árbol de cacao. ${ }^{300}$

La especialización de la economía de la hacienda costeña en el cacao (consecuencia directa de las relaciones capitalistas mundiales), no sólo se reflejaba en la producción para el mercado, sino que llegó a introducirse en la reproducción económica de la familia del trabajador directo.

Por una parte, la variedad de cultivos intermedios se encontraba delimitada por su carácter auxiliar en el desarrollo de las matas de cacao, y por otra parte, la familia campesina del sembrador carecía de una actividad artesanal doméstica. Estos aspectos ponen de manifiesto que la actividad económica destinada a la subsistencia del trabajador directo, se encontraba

\footnotetext{
${ }^{299}$ Andrés Guerrero, Los oligarcas..., op. cit., p. 11-95.

${ }^{300}$ A. Norero: El cacao y su cultivo, Madrid, 1910, p. 41.
} 
incorporada a la división social del trabajo, la cual había sido impuesta por el capitalismo. De esta forma, la familia campesina debía pasar por el ámbito de circulación mercantil para poder adquirir los productos necesarios y satisfacer de esta manera, su consumo individual. ${ }^{301}$ ¿Se podría hablar en este caso de una relación determinada por la subordinación en la hacienda al igual que ocurría en la Sierra?

La forma de trabajo del sembrador implicaba la posesión por parte de la familia campesina de un fondo de consumo y reserva, que usaba para mantenerse durante la primera etapa de desmonte, mientras se preparaban los cultivos destinados al autoconsumo. Este fondo serviría de complemento a los medios de subsistencia obtenidos en los cultivos intermedios, durante el tiempo necesario para que la planta de cacao alcanzara la etapa productiva. ${ }^{302}$

Además, esos fondos de consumo adoptaban la forma de adelantos en dinero que otorgaba el hacendado a sus sembradores, los cuales le permitían insertarse en el mercado de bienes de consumo y adquirir los medios complementarios de subsistencia. Precisamente, fueron esos avances monetarios, los factores que procuraron la incorporación de la familia campesina en el mercado.

Esta modalidad social tenía como base el endeudamiento de la familia campesina y la subordinación dentro de la hacienda, hecho que explica la articulación de los mecanismos precapitalistas y capitalistas en el latifundio del litoral. ${ }^{303}$

La familia debía de pasar por la mediación de las relaciones capitalistas para conseguir su reproducción económica y obtener una parte de su fondo de reserva, lo que implicaba el mecanismo monetario de endeudamiento, que eran los avances o adelantos. En última instancia, el acceso a los medios de producción y de estos fondos constituye la base de las relaciones políticas e ideológicas que supeditaban al campesino a la hacienda, obligándole a entregar al terrateniente parte del trabajo familiar en forma de una renta en árboles de cacao. ${ }^{304}$ Vamos a pasar ahora al estudio de la segunda modalidad de trabajo en la hacienda cacaotera, la cual estaba representada por los peones. Al hablar de las características de las haciendas

\footnotetext{
${ }^{301}$ Andrés Guerrero, Los oligarcas del cacao..., op. cit. p. 11-95.

${ }^{302}$ Ibíd. p.11-95.

${ }^{303}$ Ibíd. p. 11-95.

${ }^{304}$ Ibíd. 11-95.
} 
cacaoteras, dijimos que la mayoría de los trabajos que constituían la formación de los huertos y cosechas eran desempeñados por los sembradores. De forma paralela, existían otros trabajos complementarios a las plantaciones que implicaban actividades de podas anuales, deshierbe, etc., las cuales eran realizadas por un grupo de jornaleros, los peones, que además de poseer una casa y un huerto en las haciendas, recibían a cambio un jornal por día de trabajo realizado. $^{305}$

Guerrero aclara que las tareas de poda y cosecha, transporte y secado, eran desempeñadas por las cuadrillas de peones que estaban a cargo de uno de los mayordomos funcionarios del aparato de dirección de la hacienda. ${ }^{306}$ ¿Implican entonces las afirmaciones de Guerrero que la forma de trabajo de los peones se llevaba a cabo en grupo, o se trataba de un tipo de trabajo individual? ¿cómo se llevaba a cabo su reproducción económica? ¿estaba el peón insertado en las relaciones capitalistas?

A diferencia de Wiener, que habla de trabajadores individuales, Guerrero identifica la existencia de un grupo doméstico, aunque aclara que algunas tareas eran realizadas por trabajadores individuales, los cuales eran los peones.

En cuanto a la reproducción económica de la familia del peón, hay que decir que esta no tenía lugar únicamente a partir del jornal, ya que en determinados casos, los peones poseían algunos espacios agrícolas y de pastoreo, donde realizaban un proceso de producción de subsistencia. Además, el aparato familiar del peón disponía de algunas actividades económicas de tipo agropecuario y realizaba un proceso de producción autónomo, a través del cual obtenía una parte de sus medios de subsistencia. ${ }^{307}$

Por último, los peones estaban insertados en las relaciones capitalistas, pues el pago monetario les permitía ir al mercado y comprar los bienes necesarios para sobrevivir. Sin embargo, hay que señalar que el jornal recibido no era suficiente para adquirir todo lo que les hacía falta, debido a la existencia del mecanismo de endeudamiento del trabajador directo. En este caso, la forma de endeudarse era diferente al de los sembradores, ya que no representaba un fondo de consumo

\footnotetext{
${ }^{305}$ C. Wiener, op. cit. p. 467.

${ }^{306}$ L. A. Martínez: A la Costa, reedición sin fecha, ed. Andes, en Andrés Guerrero: Los oligarcas del cacao: Ensayo sobre la acumulación originaria en el Ecuador: Hacendados cacaoteros, banqueros, exportadores y comerciantes en Guayaquil, Quito, Ecuador: Editorial El Conejo, 1980, p. 170-171.

${ }^{307}$ Ibíd. p.170-171.
} 
y de reserva para el proceso productivo autónomo, de ahí que una parte del fondo de reproducción del trabajador no estuviera comprendido en el jornal, obligando al peón a solicitar adelantos que constituían la base de la sujeción del trabajador a la hacienda.

\subsection{3) La incorporación de la hacienda serrana y costeña al capitalismo mundial.}

Hemos comentado cómo las últimas décadas del siglo XIX se caracterizaron por una acelerada consolidación del modo de producción capitalista y por una significativa dinamización comercial y avance en el proceso de modernización del estado ecuatoriano. Aunque en el próximo apartado se estudiarán con más detenimiento cuáles fueron los factores que impulsaron el establecimiento del capitalismo en este país, nos corresponde analizar ahora, cómo se llevó a cabo la inserción de la hacienda serrana y del litoral en el modo de producción capitalista y cuáles fueron los cambios producidos. ${ }^{308}$

Continuando con el tema de la penetración del capitalismo en las formas de producción y en la subordinación de los diversos elementos del proceso al capital, hemos de recordar que el establecimiento de este proceso no ocurrió mediante la implantación de una única vía ni tampoco, a través de la disolución inmediata de las relaciones de producción ya existentes, sino que el proceso de producción pre-capitalista quedó sometido al capital para lograr una mayor acumulación de la renta. Andrés Guerrero explica dicha articulación haciendo alusión al establecimiento de una relación de complementariedad entre el capital y las relaciones de producción pre-capitalistas, en la cual, el proceso de producción anterior no permanecía sin alterar, sino que era transformado por el modo capitalista. ${ }^{309}$

¿Cómo se llevó a cabo esta transformación de las formas pre-capitalistas en las haciendas ecuatorianas? ¿afectó este proceso por igual a las haciendas situadas en la Sierra y en la Costa? La situación agraria en América Latina pone de manifiesto la existencia de una gran cantidad de ejemplos de subordinación de las formas de producción pre-capitalistas al capital. Aquí, se pueden encontrar relaciones de producción capitalistas con una forma de trabajo asalariada, y relaciones pre-capitalistas con una variedad de formas de trabajo precarias (como es el caso del huasipungo).

\footnotetext{
${ }^{308}$ Enrique Ayala, Lucha política..., op. cit., p. 201.

309 Andrés Guerrero: Haciendas, capital y lucha de clases andina. Disolución de la hacienda serrana y lucha política en los 1960-1964, Del apartado: Las formas de penetración capitalista en la hacienda, editorial El Conejo, Quito, 1983, p. 7-140.
} 
También, es importante recordar la complejidad de las relaciones de producción de la hacienda tradicional serrana y sus formas de trabajo, en particular, si estas se comparan con el carácter homogéneo del trabajo asalariado capitalista. Aunque estas formas manifestaban el efecto del capitalismo en la hacienda, hay que aclarar que cada una era única en cuanto al tipo de salario en dinero y al conjunto de derechos y obligaciones.

En referencia al proceso de producción inmediato de las haciendas serranas tradicionales, se ha hablado de sus rasgos y formas de trabajo obligatorio, que eran expresión de ciertas relaciones de producción y de apropiación de una renta en trabajo. De esta forma, el hacendado sometía al productor inmediato interno o externo a la gran propiedad, implantando relaciones de dominación extra-económicas que le permitían ejercer económicamente su derecho de monopolio sobre la tierra y obtener trabajo extra en forma de jornadas devengadas por campesinos indios en sus cultivos (renta territorial en trabajo). ${ }^{310}$ Ahora bien, además de la fuerza de trabajo del productor directo ¿qué otros elementos constituían la base del proceso de producción de las haciendas durante el siglo XIX?

Al hablar de las haciendas tradicionales, se dijo que la producción estaba basada en la utilización de formas sencillas de cooperación y de división de trabajo típicas del sistema feudal. Además, se utilizaban herramientas manuales simples y se realizaba un seguimiento de las normas tradicionales en los cultivos y en la cría de ganado ovino y vacuno, los cuales eran métodos de la agricultura extensiva y mostraban el bajo nivel de desarrollo de las fuerzas productivas en la Costa y en la Sierra ecuatoriana.

Es cierto que ya se había incorporado el trabajo asalariado en algunas haciendas de la Costa, mientras que en determinadas haciendas de la Sierra, los terratenientes habían comenzado a mejorar sus mecanismos para cultivar, pero hay que señalar que básicamente las haciendas no recibieron ningún tipo de inversión hasta años posteriores.

Asimismo, pese a la introducción de esta estrategia modernizante, las haciendas continuaron manteniendo el proceso tradicional de producción, puesto que las innovaciones aumentaban la productividad en algunas partes fundamentales, siendo el resultado de esta combinación, la maximización de las ganancias.

Teniendo en cuenta la descripción de la hacienda tradicional, ¿cómo se podría explicar la

${ }^{310}$ Andrés Guerrero, Los oligarcas del cacao...op. cit. p. 11-95. 
introducción de este tipo de innovaciones y el mantenimiento de los rasgos pre-capitalistas? y más aún ¿cómo se explica la obtención de un beneficio máximo?

Andrés Guerrero indica que el proceso de producción pre-capitalista es compatible con cierto grado de desarrollo de las fuerzas productivas, sin que se tenga que llevar a cabo una profunda transformación de dicho proceso. Esto explica que la inserción de la hacienda en el capitalismo para el abastecimiento de bienes y el uso de instrumentos tecnológicos modernos no implicara la modificación obligada del proceso de trabajo, ni tampoco de las relaciones de producción. $^{311}$

Como ya se mencionó con anterioridad, la mentalidad tradicional de los terratenientes fue el factor responsable del rechazo a la innovación y la falta de un comportamiento poco empresarial, al obstaculizar la integración de la hacienda en el sector moderno de la economía. Sin embargo, Andrés Guerrero no critica el arcaísmo de la hacienda desde el punto de vista de la falta de capacidad empresarial de los hacendados, sino que alude a una racionalidad económica, mediante la cual, el terrateniente conseguía maximizar las ganancias sin grandes cambios.

Quizás, el punto crucial de esta argumentación pueda ser explicado cuando se comparan el huasipungo y la hacienda, pues la principal característica de la hacienda (la apropiación de la renta de la tierra en trabajo) era la forma fundamental de apropiación de la renta por parte del hacendado y la existencia de una relación de explotación-dominación. Por tanto, a partir de esta relación extraeconómica se justifica su condición pre-capitalista. ${ }^{312}$

En cambio, en comparación con el capitalismo, las relaciones de dominación se producían en el proceso productivo inmediato, configurándose de este modo, una determinada forma económica. Guerrero explica su carácter especial al hablar de la existencia de dos elementos separados en el proceso de producción, siendo uno de ellos, la hacienda (plustrabajo), y el otro, la parcela del huasipungo (trabajo necesario). ${ }^{313}$

La parcela del huasipungo puede ser entendida como parte de los derechos que recibían los huasipungueros, ya que estos tenían acceso a una parte de tierra fija dentro de la hacienda,

\footnotetext{
${ }^{311}$ Andrés Guerrero, Haciendas, capital..., op. cit. p. 5-140.

${ }^{312}$ Ibíd. p. 5-140.

${ }^{313}$ Ibíd. p. 5-140.
} 
además del disfrute de los pastizales naturales para una cantidad limitada de ganado. Esto implicaba la división de las haciendas en varias partes, pues por un lado, se encontraban las tierras cultivadas directamente por el propietario, mientras que por el otro, se hallaban las tierras en posesión de la familia huasipungo, que normalmente era un conjunto de lotes desparramados en tierras de segunda calidad y en las laderas del latifundio. Bajo estas circunstancias, ¿cómo se aseguraba la reproducción material de la familia huasipungo?

Antes de responder a la pregunta sobre la reproducción material de la familia huasipungo, nos interesa explicar el concepto de la familia huasipungo, ya que era un tipo de estructura familiar con origen en las relaciones de producción de la hacienda y que, por su función en la reproducción de la fuerza de trabajo, servía como un doble eje en cuanto a la subordinación del trabajo a la gran propiedad y de supeditación formal del trabajo al capital. Por su parte, en el huasipungo, la parcela de tierra, además de ser el medio de producción fundamental del trabajador, era el lugar donde vivían los miembros de esta forma particular de familia, a la que podían pertenecer personas que estaban fuera del círculo de familia nuclear. ${ }^{314}$

Esta familia realizaba un conjunto de actividades agrícolas, pecuarias y artesanales de tipo doméstico, estando vinculada su importancia a las características de la hacienda y a los derechos proporcionados al productor. En este caso, tanto la producción agrícola como la pecuaria del huasipungo, solían estar asociadas para conservar la fertilidad de la parcela y como base de la actividad artesanal doméstica. ¿Qué papel desempeñaba el salario en base a la reproducción de la familia huasipungo?

Al hablar de las actividades agropecuarias y artesanales antes descritas, hay que referirnos al ingreso monetario y a la venta de trabajo de los peones libres o sueltos, miembros en su mayoría de la familia huasipungo. Es decir, la base de la reproducción material de estas familias estaba dada por la actividad productiva de la familia huasipungo, aunque el nivel de ingresos podía ser diferente.

De esta manera, el ingreso monetario salarial llegó a adoptar el carácter de salario complementario, en el sentido de que su reproducción material no dependía del mismo en su totalidad, como ocurría con el trabajador directo capitalista, sino que servía de complemento gracias a la actividad económica autónoma de la familia. Por esta razón, se piensa que el

\footnotetext{
${ }^{314}$ Ibíd. p. 5-140.
} 
salario percibido por los miembros de la familia huasipungo, no podía definir un trabajo asalariado completamente, ni tampoco un verdadero conjunto de trabajadores proletarios, al encontrarse la base de su reproducción en el aparato productivo de la familia. Sin embargo, Guerrero señala que la familia ampliada del campesino indio, no garantizaba totalmente las condiciones materiales de su reproducción, ya que se encontraba en un proceso de supeditación formal a las relaciones de producción capitalistas. ${ }^{315}$

Continuando con los mecanismos empleados en las formas de producción, es necesario hacer referencia a la represión económica, la cual se basaba en el monopolio de la tierra como medio de producción y lograba su eficacia por medio de una serie de medios políticos e ideológicos, entre los que se pueden citar los aparatos administrativos y represivos de las haciendas y los del estado y la Iglesia. Esta última, al ser uno de los principales terratenientes de la época, poseía un gran papel político y económico e imponía directamente su poder e ideología sobre la mayoría del pueblo. Aunque la violencia era empleada a menudo, no se puede pensar en este mecanismo para explicar la reproducción permanente de las relaciones de dominación.

Relacionado con este tema, se encuentra la obra "Huasipungo" de Jorge Icaza, que hace alusión al debate político de los intelectuales de las primeras décadas del siglo XX, en referencia al concertaje y a las distintas estrategias utilizadas para controlar a los indios. Esta lectura pone de manifiesto el diálogo establecido entre la novela y la etapa del Ecuador de 1890, llevando a cabo una representación de los elementos marginales, así como de la violencia empleada por la clase terrateniente liberal serrana para contener al indio huasipunguero. ${ }^{316}$ De forma paralela, se aprecia la combinación de los dos sistemas culturales diferentes (el indígena y el blancomestizo) que dominaron hasta finales del siglo XIX, momento en que la narrativa lo incorporó como un tema de interés nacional. ${ }^{317}$

"Huasipungo" narra el tema de la explotación del indio ecuatoriano por el terrateniente, la

\footnotetext{
${ }^{315}$ Ibíd. p. 5-140.

316 Jorge Icaza: Huasipungo, Cátedra, Madrid, 1934.

${ }^{317}$ Andrés Guerrero se refiere a la ventriloquia política como una modalidad inédita de la representación cuando se habla de la integración de la imagen del indio al estado. En este caso, varios agentes blanco-mestizos hacen referencias y escriben en nombre del indio acerca de su opresión y degradación. Ver: Andrés Guerrero: Una imagen ventrílocua: El discurso liberal de la desgraciada raza indígena a fines del siglo XIX, p. 240, en Blanca Muratorio, ed. Imágenes e imagineros representaciones de los indígenas ecuatorianos, siglo XIX y XX, FLACSO, Quito, 1994, p. 200-201.
} 
Iglesia, los políticos y los países extranjeros, y presenta la miseria y atraso del indio ante la indiferencia mostrada por los terratenientes.

El marco histórico se centra en el paso de la colonia al estado independiente, el cual no produjo grandes cambios en el Ecuador, puesto que el sistema de haciendas de la Sierra era similar al de la época feudal, siendo el concertaje la forma de trabajo aplicada. Recordemos que el concertaje era un contrato de servicios personales, a través del cual, el hacendado pagaba el trabajo por adelantado y creaba una deuda con el trabajo concierto. El terrateniente solía emplear la amenaza de prisión por dicha deuda para que el trato se cumpliera, por lo que el indio podía emplear a su familia para completar dichas tareas.

La dificultad para incorporar a los indios a la sociedad constituyó un tema de gran interés después de 1895, tras el decreto expedido por el gobierno de Eloy Alfaro (1895-1901) para proteger a la raza indígena. La inclusión de los indígenas en el proyecto nacional fue algo nuevo para las clases dominantes, pues se buscaba equiparar el trabajo del indio al del jornalero con el objetivo de facilitar la adaptación social. La transformación de la imagen del indio en trabajador de la hacienda serrana durante las primeras décadas del siglo XX, impulsó la entrada del país en el mercado internacional, rasgo propio de las naciones desarrolladas.

Jorge Icaza relata los cambios en la hacienda de la familia Pereira, en la que se observa esa relación indio-obrero en la conversación de la primera parte de la novela: ${ }^{318}$

- Los indios se aferran con amor ciego y morboso a ese pedazo de tierra que se les presta por el trabajo que dan a la hacienda. Es más: en medio de su ignorancia lo creen de su propiedad. Usted sabe, allí levantan la choza, hacen sus pequeños cultivos, crían a sus animales.

- Sentimentalismos. Debemos vencer todas las dificultades por duras que sean. Los indios... ¿Qué? ¿Qué nos importan los indios? Mejor dicho... Deben... Deben

\footnotetext{
${ }^{318}$ Antonio Cornejo Polar habla sobre la irrupción de un agente externo para que el mundo indígena pasara a ser el trasfondo de una obra literaria. En el caso de la obra Huasipungo, las modificaciones de la hacienda de la familia Pereira y la posterior llegada de los inversionistas estadounidenses para la construcción de nuevos caminos, determinan el punto de partida de modernidad en un país con características arcaicas. Fuente: Antonio Cornejo Polar: Escribir en el aire: Ensayo sobre la heterogeneidad socio-cultural en las literaturas andinas, Centro de Estudios Literarios “Antonio Cornejo Polar”: Latinoamericana Editores, Lima, Perú, 2003.
} 
importarnos...claro... ellos pueden ser un factor importante en la empresa. Los brazos... el trabajo... ${ }^{319}$

Este diálogo muestra a la hacienda como un espacio en el que conviven varios grupos sociales rodeados de múltiples conflictos. Icaza narra esta historia haciendo uso del sistema establecido en la hacienda tras la independencia, y expone los deseos del indio huasipunguero por conservar su parcela de tierra y las instituciones que pretenden arrebatarla. ${ }^{320}$

Por otra parte, se observa cómo los indios de la hacienda de Alfonso Pereira son apreciados como fuerza laboral, lo cual explica el hecho de que desde el principio de la obra, su valía quede reducida al beneficio económico obtenido de sus "brazos". ${ }^{321}$ Por este motivo, el accidente del personaje Andrés Chiliquinga (se queda cojo) puede interpretarse como el resultado del sometimiento del indígena a manos del sistema autoritario, es decir, al analizar el momento en el que se produce el accidente, se observa que por un acto involuntario (consecuencia del desasosiego causado por los abusos de poder), el hacha acaba partiendo el pie de Chiliquinga: ${ }^{322}$

En uno de aquellos arrebatos, al asegurar con el pie el tronco que patinaba en el fango y descargar el hachazo certero —endemoniada fuerza que flagela-, la herramienta transformada en arma - por acto fallido- se desvió unas líneas y fue a clavarse en parte en la carne y en los huesos del pie del indio. ${ }^{323}$

Además de criticar la falta de preocupación por parte de las clases dominantes, Icaza denuncia el rechazo a los indígenas a través del "cholo" (Gabriel Rodríguez), personaje que intenta imitar a la sociedad blanco-mestiza, a la vez que insiste en dejar a un lado su herencia indígena. En la novela, la forma de mirar del capataz presenta un rasgo diferente, por lo que el autor decide

\footnotetext{
${ }^{319}$ Jorge Icaza, op. cit. p. 66. Abya-Yala, Quito, 2004, p. 253-283.

${ }^{321}$ Ibíd. p. 253-283.

${ }^{322}$ Ibíd. p. 253-283.

${ }^{323}$ Jorge Icaza, op. cit. p. 107.
}

${ }^{320}$ En su análisis sobre el Ecuador postcolonial, Mercedes Prieto indica que el tema de la liberación de los trabajadores conciertos fue un elemento clave en la discusión sobre la modernización de la nación a principios del siglo XX, ya que pese a los cambios producidos, los indios seguían siendo explotados en las haciendas. Fuente: Mercedes Prieto: Liberalismo y temor: Imaginando los sujetos indígenas en el Ecuador postcolonial, 1895-1950, 
caracterizarlo como un ser horrible (está tuerto) y violento (lleva a cabo los castigos a los indígenas). A pesar de que no se explican las razones de esta incapacidad, Icaza destaca que Rodríguez es un chagra picado de viruela, cara de gruesas y prietas facciones, mirada desafiante con su único ojo, que se abría... al responder o al interrogar a las gentes humildes. ${ }^{324}$

Con respecto a este diálogo, hemos visto cómo el sistema de representación de los intelectuales liberales ecuatorianos, fue elaborado sobre la base de un proceso de exclusión e inclusión del indio, ya que por un lado, se pretendía incorporarlo al aparato estatal como ciudadano y al sistema económico como jornalero campesino, mientras que por otro, la clase dominante intentaba presentarlo como un ser vengativo y violento. A partir de aquí, Icaza intenta contrarrestar una representación que ignoraba la situación de las haciendas, a través de sus imágenes del cholo y del indio como alternativas a las existentes dentro del discurso liberal. ${ }^{325}$ Una vez analizada la novela de Jorge Icaza y sus implicaciones, vamos a pasar ahora a ver cuáles eran las razones que explican la persistencia de un sistema social como el descrito en el Ecuador.

Quizás, la explicación a esta pregunta puede hallarse en la forma en la que el poder de clase se imponía sobre la formación social, es decir, la manera en que se obtenía dicha hegemonía. El papel de la Iglesia en este proceso fue decisivo a lo largo de todo el proceso histórico del Ecuador, lo cual explica que la lucha política entre las diferentes fracciones de las clases dominantes estuviese centrada en la definición de las relaciones entre la Iglesia y el estado.

Asimismo, hay que pensar que la base legal de este sistema tenía un carácter arcaico y correspondía a una situación de tipo feudal, pues el derecho de propiedad sobre la tierra estaba ligado a la estructura legal del país. Pese a esto, la propiedad de la tierra fue creada en el Ecuador con anterioridad y bajo ideas legales diferentes.

\footnotetext{
${ }^{324}$ Ibíd., p. 97.

${ }^{325}$ Otra obra literaria que trata de reflejar la situación de las haciendas y la denuncia al sistema de esclavitud es "Matalaché" de Enrique López, en la que se expone la relación entre la joven patrona (María Luz) y el e sclavo (José Manuel Soto), así como los prejuicios sociales de una sociedad colonial en tránsito a una república. Esta novela, que gira en torno a la hacienda "La Tina" ubicada en Piura (Perú), critica el trato cruel de los patrones a los trabajadores, pues estos tenían que desempeñar trabajos forzosos durante once horas sin apenas recibir alimentos. También, se vuelve a poner de manifiesto la existencia de las barreras raciales, ya que la relación mantenida entre María Luz y José Manuel transcurre en una sociedad representada por los prejuicios y la desigualdad, que justificaba el autoritarismo de los terratenientes de las haciendas y el rechazo hacia las personas diferentes a ellos (mestizos, esclavos, indígenas, etc.). Fuente: Enrique López Albújar: Matalaché, Biblioteca Peruana, Peisa, Lima, 1983.
} 
Recordemos que el sistema feudal constituía una forma de organización política basada en la regulación de relaciones personales a través de instrumentos contractuales. Así, un hombre libre se encomendaba a la protección de otro, comprometiendo su lealtad y su servicio a cambio de un beneficio, ya fuese un cargo, un territorio o feudo. De este modo, el protector se convertía en señor del protegido y recibía el nombre de vasallo. ${ }^{326}$

Uno de los efectos más importantes del feudalismo fue la forma que el dominio territorial llegó a asumir en las áreas a las que se extendió, puesto que la mayor parte de la propiedad inmueble de la época pasaba a incorporarse como beneficio a las relaciones de vasallaje, produciéndose una fragmentación de la propiedad raíz entre diversos titulares (enfiteusis): la persona en la que se originaba el beneficio (y que por lo tanto, era fuente del derecho del vasallo y mantenía un derecho sobre el feudo), y el que la recibía en beneficio, adquiriendo las facultades de uso y goce. $^{327}$

A diferencia del sistema feudal, una vez alcanzada la independencia política, se buscó la independencia jurídica con el propósito de desvincularse de la normativa española que seguía siendo aplicaba, puesto que conservaba su tradición cultural en el derecho romano. No obstante, pronto surgiría entre los juristas, políticos e intelectuales de los nuevos estados, la pretensión de reformar el viejo derecho heredado, el cual sería sustituido por una legislación nacional formulada bajo la forma de códigos al estilo moderno. De esta forma, durante la primera mitad del siglo XIX, el modelo más prestigioso fue el código napoleónico; que fue adoptado como imagen para afirmar la independencia de los nuevos estados, y mediante el cual, se planteaba el concepto de propiedad como libre y única: La propiedad es el derecho de gozar y disponer de las cosas del modo más absoluto, siempre que no se haga un uso prohibido por las leyes o reglamentos. ${ }^{328}$

La situación derivada de las interrelaciones de individuos con diferentes funciones y restricciones en el uso del suelo, poseía un mayor parecido con las concepciones del derecho

\footnotetext{
${ }^{326}$ Marco A. Checa Cobo: Régimen de la propiedad de la tierra en el Ecuador, Universidad Católica del Ecuador, Quito Ecuador, 1973, p. 11-343.

327 José Antonio González Martínez: La enfiteusis: aspectos básicos de esta institución, Revista de la Facultad de Ciencias Sociales, Jurídicas de Elche, Volumen I, Número 4, 2009, p. 251-267.

${ }^{328}$ Artículo 544, Código de Napoleón, en Eduardo Novoa Monreal: La evolución del Derecho de propiedad ante los actuales textos constitucionales latinoamericanos, en Estudios de Derecho económico, serie I, número 1, Instituto de Investigaciones Jurídicas de la UNAM, México, 1980, p. 41-73.
} 
medieval, ya que la libre disposición del propietario sobre la tierra regía en aquel solo para los efectos de autoridad derivados de la condición del terrateniente, pues algunas de las relaciones habían sido adaptadas del periodo Inca. En las Leyes de Indias, y en contraste con el derecho romano o con las concepciones modernas del derecho de propiedad, la tierra era interpretada como un bien sujeto a un conjunto de derechos de distintas personas, las cuales se encontraban categorizadas dentro de clases o estamentos. Así, el Código Civil, vino a significar en cierta forma, una aspiración que reforzaba el punto de vista de los terratenientes que constituían el sector dominante en el ambiente social, político y económico de la época de su promulgación. ${ }^{329}$ En esencia, estas ideas vuelven a poner de manifiesto la importancia de las características y la posición ocupada por los terratenientes en las sociedades de América Latina, al ser elementos fundamentales que conformaban el debate en torno al problema agrario y al desarrollo del capitalismo dependiente de estos países.

El estudio de dichos elementos permite aclarar algunos rasgos del funcionamiento de la hacienda y de la clase terrateniente, con el objeto de lograr un mejor entendimiento de las transformaciones que tuvieron lugar en la estructura social de la Sierra y de la Costa y de cuáles fueron sus principales tendencias dentro del modo capitalista. En referencia a esto, aunque ya hemos revisado la relación de la hacienda serrana y el huasipungo y la posición de los terratenientes dentro del sistema capitalista, todavía nos falta analizar el comportamiento de las haciendas de la Costa bajo estas circunstancias.

Enrique Ayala indica que el litoral fue el lugar donde las relaciones dominantes se establecieron definitivamente, consolidándose sobre otras formas con las que coexistían. De esta manera, la burguesía comercial logró ejercer el control de la economía ecuatoriana, a partir del cual comenzó a planear la implantación de un nuevo orden y la rearticulación de los rasgos precapitalistas de la estructura social. ${ }^{330}$ Según Ayala, ¿cuáles fueron los factores que aceleraron las relaciones salariales en la Costa de acuerdo con el modo de producción capitalista?

El análisis del incremento sostenido de la exportación de productos tropicales, en especial del cacao, indica que el aumento de la demanda de este producto, el bajo aprovechamiento del suelo y la necesidad de mano de obra, fueron algunos de los factores responsables que llevaron

\footnotetext{
${ }^{329}$ Marco A. Checa Cobo, op. cit. p. 11-343.

${ }^{330}$ Enrique Ayala Mora, Lucha política..., op. cit. p. 20-335.
} 
a la ampliación de las fronteras agrícolas y que contribuyeron a acelerar la aplicación de las relaciones salariales. Ayala indica que de todos estos factores, la escasez de mano de obra, fue el motivo fundamental para que los terratenientes pagaran un salario en efectivo, pues a la larga lo recuperaban al implantar mecanismos que les permitían conservar el control y acceder a gran parte de ese dinero en circulación. ${ }^{331}$

Por su parte, Guerrero dice que el estudio de las modalidades de trabajo de la hacienda cacaotera, sus mecanismos de reproducción, su inserción en las relaciones capitalistas y los correspondientes mecanismos de endeudamiento, nos permitirán analizar las características sociales de los terratenientes cacaoteros como clase. ${ }^{332}$ Pese a que el origen del grupo se remonta al siglo XVIII como resultado de las relaciones capitalistas (aunque también se ha de atribuir su nacimiento a la época colonial), ¿qué posición ocupaba este grupo dentro de la sociedad si se tiene en cuenta su situación tanto en el proceso de producción inmediato a través de la apropiación de la renta, como en el proceso de circulación y distribución capitalista?

Al igual que ocurría en la hacienda serrana, en el proceso de producción inmediato de la hacienda costeña, la clase terrateniente cacaotera se caracterizaba por la apropiación de la renta de productos y trabajo. Anteriormente, vimos cómo el hacendado cacaotero ampliaba su proceso de trabajo y sus cultivos a partir de la renta que obtenía al obligar a las familias campesinas y a los peones a trabajar. Además, la relación entre los sembradores y peones con el hacendado, se presentaba como una relación monetaria, es decir, se producía un pago por la huerta de cacao, los adelantos y jornales, que eran formas de relación monetarias. No obstante, se aprecia una relación de dependencia con respecto de los patrones, la cual se daba a través del creciente endeudamiento para evitar que los trabajadores se escaparan incumpliendo sus contratos en algunos casos. ${ }^{333}$

Wiener explica que la permanencia de esta dominación estaba basada en el endeudamiento, ya que se trataba de una forma de ejercer el control del terrateniente sobre los medios de

\footnotetext{
${ }^{331}$ Carlos Wiener, op. cit. p. 467.

${ }^{332}$ Andrés Guerrero, Los oligarcas del cacao... op. cit. p. 11-95.

${ }^{333}$ Ibíd. p. 11-95.
} 
producción y subsistencia. ${ }^{334} \mathrm{El}$ control permitía la existencia de una relación de dominación que supeditaba a la familia del trabajador directo a la hacienda y le permitía la apropiación de la renta en productos y en trabajo, mientras que la supervivencia ocurría cuando el campesino (sembrador o peón) se sometía a la dominación del hacendado. Así, el sembrador estaba obligado a expandir el terreno agrícola y cultivar el cacao mediante el cual, llevaba a cabo su proceso de autosubsistencia, a la vez que el peón era contratado en la hacienda y a cambio recibía un jornal para sobrevivir.

Como vemos, los dos tipos de campesinos estaban sujetos a la hacienda mediante el endeudamiento y para obtener el fondo en dinero tenían que dirigirse a su hacendado, lo cual reflejaba la existencia de una relación personal. Es decir, no se producía una relación en la que el trabajador directo podía disponer de su fondo de consumo mediante una relación estrictamente salarial como ocurría con el capitalismo. ${ }^{335}$

En definitiva, si bien este sistema de avances llegó a constituir una forma de circulación y distribución inherente a las relaciones de apropiación de la renta en las haciendas cacaoteras de la Costa, también se observa dentro de este ámbito de circulación, la penetración del capitalismo en el seno del proceso de producción, puesto que dichos avances permitían al peón y al sembrador comprar los productos necesarios para su consumo individual. Esto explica que la inserción del Ecuador en las relaciones capitalistas internacionales en el siglo XIX, tuviera como resultado la creación de una forma comercial de producción especializada en el cacao como se verá a continuación.

\section{4) El nacimiento del capitalismo en el Ecuador: El enclave cacaotero, el modelo agro- exportador y la acumulación del capital durante el liberalismo económico (1880-1925).}

\subsection{1) El papel del cacao y el sistema capitalista.}

En los apartados anteriores, hemos hablado de la inserción del Ecuador en las relaciones capitalistas internacionales durante las últimas décadas del siglo XIX, así como de los cambios ocurridos en las haciendas tradicionales de la Sierra y la Costa en cuanto al modo de producción, las relaciones entre clases sociales y las modalidades de trabajo. A partir de

\footnotetext{
${ }^{334}$ Carlos Wiener, op. cit. p. 467.

${ }^{335}$ Andrés Guerrero, Los oligarcas del cacao...op. cit. p. 11-95.
} 
estas ideas y teniendo en cuenta que el propósito de este trabajo es el análisis de la modernización del Ecuador, pasaremos ahora a un estudio más detallado de cuáles fueron los factores fundamentales que posibilitaron el desarrollo y acumulación del capital durante esta época.

En relación al concepto "acumulación de capital" se ha hecho mención a la interrelación existente entre los conceptos de crecimiento económico y desarrollo de un país, a lo que se ha de unir su papel como factor impulsor de la modernización de las sociedades. En este sentido, la acumulación de capital constituye un proceso de creación y apropiación de la riqueza social mediante las formas capitalistas de producción, así como una forma de incrementar esa riqueza mediante su consumo en la producción.

Iván Fernández y Patricio Tobar indican en su obra:

Las relaciones capitalistas de producción no aparecen espontáneamente ni están plenamente constituidas, sino que se van imponiendo gradualmente frente a formas anteriores de producción como resultado de transformaciones económicas, sociales, políticas e ideológicas, por lo que el análisis del proceso de acumulación de capital en un país particular, cubrirá aquel periodo histórico en que las formas de producción capitalistas comienzan a surgir y a desarrollarse. ${ }^{336}$

Al hilo de la idea planteada, se puede entonces afirmar que las características que asume el proceso de acumulación de capital, se irán modificando de acuerdo al grado de desarrollo que vayan alcanzando las condiciones de la producción capitalista. Por consiguiente, ¿cuáles fueron las condiciones históricas para el surgimiento del capitalismo en el Ecuador y el inicio del desarrollo y modernización del país?

Andrés Guerrero indica la existencia de diversas vías adoptadas por la acumulación originaria en cada formación social, aunque deja claro la necesidad de identificar rasgos generales y comunes en determinados contextos históricos, tal y como ocurrió en América Latina. ${ }^{337}$ Por otro lado, Marx advierte que este movimiento comprende un conjunto de procesos históricos

\footnotetext{
336 Iván Fernández Espinosa, Patricio Tobar Robalino: Acumulación de capital 1830-1980. Sus mecanismos de creación y apropiación, Libro del Sesquicentenario. Economía Ecuador, Segunda parte, 1830-1980, Corporación Editorial Nacional, Inter-Americal Defense College library, 1983, p.117-131.

${ }^{337}$ Andrés Guerrero, Los oligarcas del cacao..., op. cit. p. 11-95.
} 
diversos para cada uno de los elementos del modo de producción capitalista, los cuales pertenecen a una misma etapa, mientras que su aparición se encuentra fuertemente imbricada. ${ }^{338}$ En el caso ecuatoriano, se pueden identificar distintos momentos históricos en el desarrollo del capitalismo y acumulación del capital, cuyas diferencias se encuentran en las formas de generación del excedente económico, en los mecanismos de apropiación del mismo y en los beneficiarios y destino de la riqueza acumulada, entre otros factores. A partir de aquí, corresponde establecer las diferentes etapas en las que se analizará la evolución del proceso de acumulación del capital y desarrollo del capitalismo, así como la incidencia en el crecimiento a través del estudio de los principales sectores de la economía ecuatoriana.

Además, el análisis realizado de la sociedad ecuatoriana durante los últimos años del siglo XIX, nos ayudará a establecer ese conjunto de etapas en las que ocurrieron algunos de los eventos más importantes que marcaron la primera mitad del siglo $\mathrm{XX}$, siendo su estudio necesario para poder entender los cambios políticos y socio-económicos ocurridos a posteriori.

La primera etapa que podría identificarse en el nacimiento del capitalismo ecuatoriano, abarcará aproximadamente el periodo comprendido entre los años que siguieron a la Revolución Liberal de 1895 y las primeras décadas del siglo XX. Su estudio nos permitirá conocer por un lado, cuál fue el modelo de desarrollo empleado que facilitó el asentamiento del capitalismo, así como el impacto ocasionado en la Costa y en la Sierra, y por otro, el papel que desempeñó el cacao como centro de riqueza del país, el comportamiento de las clases sociales con respecto al mismo y la evolución de la economía ecuatoriana en el mercado internacional. ${ }^{339}$ Osvaldo Albornoz describe al Ecuador de principios del siglo XX, como un país fundamentalmente agrario en el que la tierra constituye un factor económico de primer orden, siendo el campesinado el producto de un largo proceso histórico con origen en el colonialismo español en América Latina, y cuya explotación obedecía exclusivamente a las necesidades de consolidación del capitalismo mundial en plena expansión. ${ }^{340}$ Aquí, se puede apreciar la visión historiográfica tradicional que ha venido rechazando la combinación de lo prehispánico y lo colonial, como si la historia hubiera llegado a América Latina tras la conquista

\footnotetext{
${ }^{338}$ K. Marx: El capital, tomo I, Vol. 3, Ed. Siglo XXI, 1975.

${ }^{339}$ Iván Fernández Espinosa, Patricio Tobar Robalino, op. cit., p.117-131.

${ }^{340}$ Oswaldo Albornoz Peralta: Ecuador: Luces y sombras del liberalismo, Editorial El Duende, Quito, Ecuador, 1989 , p. 12-179.
} 
de los europeos. Al no reconocerse el intercambio recíproco que ocurrió entre ambas culturas, se estaría renunciando a comprender la importancia de una serie de factores sociales de la cultura indígena, los cuales fueron usados por los españoles, como fue el caso de minería y agricultura, pues de no haber contado con los adelantos tecnológicos metalurgia y con sus conocimientos para localizar las minas de oro y plata, habría sido bastante difícil crear una economía de exportación en un periodo de tiempo tan breve. La convivencia de las dos culturas (la europea y la indoamericana) produjo un proceso de desestructuración y formación que se prolongó durante siglos en esta fase de transición de la historia latinoamericana, ya que mientras el imperio español trataba de eliminar los elementos sociales indígenas, se fueron incorporando instituciones precolombinas como la mita.

En referencia a la conformación de las primeras bases del capitalismo en el Ecuador, ya sabemos que el eje central fue la producción y exportación del cacao en la parte central de la Costa, siendo estos elementos, los encargados de cumplir el papel de vincular el contexto agrícola al comercio internacional durante las primeras décadas del siglo XX.

La orientación de la agricultura costeña al mercado externo respondió desde un comienzo a las fluctuaciones del sistema capitalista internacional, siendo el carácter dependiente de su producción y su especialización, los factores cruciales en la transformación de las relaciones productivas, los cuales predominarán durante las diversas etapas por las que ha transcurrido la economía de la Costa. ${ }^{341}$

Iván Fernández y Tobar Robalino coinciden con las ideas de Albornoz y aclaran:

Si bien la producción cacaotera se remonta al periodo colonial, será recién en el lapso antes indicado, ya en la época Republicana, cuando el desarrollo del capitalismo europeo y norteamericano en el marco de la división internacional del trabajo, crea la demanda de cacao que permitirá al país desarrollar su cultivo y vivir un intenso proceso de acumulación de capital. ${ }^{342}$

\footnotetext{
${ }^{341}$ Francisco Pareja Cucalón: Comercio de exportación en la economía pre-petrolera, Libro del Sesquicentenario, Corporación editora nacional, III Economía/Ecuador 1830-1980, primera parte, 1983, p. 386.

${ }^{342}$ Iván Fernández Espinosa, Patricio Tobar Robalino, op. cit. p. 117-131.
} 
A pesar de que las exportaciones de cacao ecuatoriano se iniciaron durante la época colonial, no fue hasta el desarrollo del sistema capitalista cuando se aceleró la demanda de este producto y una mayor acumulación (no porque no se intentara, sino porque existieron numerosas trabas para no perjudicar el cacao procedente de Venezuela). ${ }^{343}$ ¿Se podría considerar al capitalismo como el único factor responsable del auge comercial del cacao y de los inicios de modernización ocurridos a finales del siglo XIX y comienzos del XX?

Ya, a principios del siglo XX, se advierte que la Costa ecuatoriana ocupa la posición de mayor productor y exportador de cacao, habiéndose creado en el siglo XIX, grandes haciendas destinadas casi exclusivamente al cultivo de la denominada "pepa de oro". Por consiguiente, es aquí donde se aprecian los primeros síntomas de modernización del Ecuador como consecuencia de la inserción del país en las relaciones capitalistas a través del mercado mundial. Sin embargo, la modernización ha de considerar también que la creación de la riqueza acumulada en la época, tuvo como base el uso intensivo de los trabajadores asalariados procedentes de la Sierra y de la Costa norte:

Los despojados por la expansión de la gran propiedad, fueron seguramente los primeros reclutados, al igual que los esclavos liberados, pero evidentemente resultarían insuficientes. La crisis del campesino-artesano serrano y costeño y la durísima legislación terrateniente ejercida sobre él, generarían las condiciones para una violenta expulsión de los trabajadores, parte significativa de la cual, migrando hacia la Costa, permitió a la clase terrateniente reclutar un inmenso contingente de brazos. Solo ese aporte sustantivo de energía vital explica el rapidísimo crecimiento de la producción,

\footnotetext{
${ }^{343}$ Según Eric Wolf, para obtener el máximo beneficio posible de sus posesiones americanas, la Corona española impulsó una especialización atendiendo a sus recursos naturales y ventajas comparativas. En este contexto, el gobierno fomentó el comercio de productos americanos hasta bien entrado el siglo XVII, decisión que llevó a que Caracas iniciara el comercio de cacao de manera regular a partir de la década de 1620. De esta manera, el cacao venezolano logró imponerse consiguiendo que la Corona prohibiera el comercio en el Pacífico, además de obtener la exclusividad comercial desde la segunda década del siglo XVII. Para acabar con la hegemonía venezolana, Guayaquil mantuvo numerosas luchas legales y también hizo uso del contrabando, lo que permitió mantener su comercio del cacao con irregularidad durante el periodo que duró la prohibición. Fuente: Jesús Hernández: El fruto prohibido. El cacao de Guayaquil y el mercado novohispano, siglo XVI-XVIII, Universidad Autónoma de Tamaulipas, EHN 39, julio-diciembre 2008, p. 43-79; Eric Wolf: Pueblos y culturas de Mesoamérica, Traducción de Felipe Sarabia, México, Editorial Era, 1985, p. 167.
} 
que pasaría de un promedio de 123.389 quintales de cacao entre 1841 y 1850 a 817.707 quintales entre 1911 y $1920 .^{344}$

Entonces, se ha de hablar de la mano de obra como una fuente de capital fundamental, la cual se fue creando y acumulando durante este periodo gracias a la labor de los trabajadores en la preparación del cacao. En este caso, es lógico que pensemos que a nivel económico, la existencia de los núcleos de producción capitalista fue una gran influencia en las otras formas de producción del país (artesanales y comunales), las cuales se vieron implicadas en una relación de producción e intercambio de mercancías y fuerza de trabajo, pasando a convertirse en agentes dinámicos de la sociedad ecuatoriana.

Entonces, considerando el papel desempeñado por los trabajadores y su contribución a la modernización y acumulación de capital, ¿se podría hablar de otros factores que contribuyeron a impulsar el proceso de acumulación durante esta etapa?

Hamerly indica que las exportaciones de cacao recibieron varios impulsos, los cuales llegaron a ser la causa para que dicho producto lograra ocupar un puesto de gran importancia en las exportaciones del Ecuador. Así, aunque la producción de cacao creció durante el siglo XVIII, el principal cambio tuvo lugar entre 1788 y 1820, cuando las exportaciones se duplicaron y empezaron a contribuir entre la mitad y los tres cuartos del total del ingreso extranjero de la Audiencia de Quito. ${ }^{345}$

En relación a estas contribuciones, Guayaquil vio gravadas sus exportaciones de cacao con motivo de la construcción de la nueva catedral de Cuenca, ya que debido a los cambios en la organización administrativa y eclesiástica, esta provincia dejó de pertenecer al obispado de Quito y pasó a depender de la recién creada diócesis de Cuenca. En este sentido, el ascenso político de Cuenca tuvo lugar en 1779 con la creación de su propio obispado, gracias a la idea propuesta originalmente por el obispo de Quito Juan Nieto Polo en 1752, la cual se puso en marcha dividiendo el área Sur y Occidental del obispado de Quito en las regiones de Guayaquil, Loja, Zaruma, Jaén de Bracamoros, Macas y Alausí. ${ }^{346}$

\footnotetext{
${ }^{344}$ Michael Hamerly, op. cit. p. 67.

${ }^{345}$ Ibíd. p. 67-69, 102-105.

${ }^{346}$ Ibíd. p. 67-69, 102-105.
} 
La creación del nuevo obispado se caracterizó por sus numerosos conflictos, pues para lograr la sede episcopal, Cuenca tuvo que competir con el rico puerto de Guayaquil, que también aspiraba a esa sede. El triunfo alcanzado por Cuenca guardaba relación con los intereses de la Corona española, que ansiaba tener un obispado en el sur de Quito para consolidar su jurisdicción sobre los grandes territorios de la Amazonía, amenazados por la expansión portuguesa. ${ }^{347}$

Si bien la posesión de la nueva sede episcopal llegó a aportar grandes beneficios para Cuenca, sobre todo por causa de los tributos que el obispado recibía anualmente, en especial de la región de Guayaquil, el punto de discordia entre las élites regionales sería el aspecto económico. Es decir, las quejas por parte de los propietarios del puerto fueron numerosas, puesto que deseaban poseer su propio obispado, además de convertirse en un órgano para la promoción de los intereses porteños. El principal motivo de conflicto giró en torno a la construcción de la catedral de Cuenca, ya que el obispo designado, José Carrión y Marfil, planteó un ambicioso proyecto que incluía un seminario y casas episcopales:

Llega el primer Obispo de Cuenca, don José Carrión y Marfil, malagueño de nacimiento, y como primer paso piensa en la construcción catedralicia, un seminario y casas episcopales. La primera se plantea que sea semejante a la ostentosa de su Málaga natal... ${ }^{348}$

De acuerdo con la tradición, los hacendados cuencanos procuraron que los indios se hicieran cargo del pago de la mayor parte de la construcción, mientras que las diversas provincias del obispado aludían a la pobreza con el fin evitar la contribución para la obra. En la provincia central, el cabildo de Cuenca llevó a cabo una distribución de aportes entre los propietarios blancos y los tributarios indios, según la cual, los primeros debían proporcionar 1.861 pesos, mientras que los indios debían aportar 4.000 pesos (más del doble). Por su parte, en la provincia de Loja, las autoridades y propietarios se negaron a contribuir, a menos que el rey permitiera la producción y exportación de cascarilla (quina) de segunda y tercera clase, mientras que la villa

\footnotetext{
347 Jesús Paniagua Pérez: Noticias socioeconómicas del Austro Ecuatoriano en el proceso de la nunca construida catedral de la colonia de Cuenca, Separata del anuario Jurídico y Económico Escurialense, XXVI, Vol. I, San Lorenzo del Escorial, 1993, p. 519-520.

${ }^{348}$ Ibíd. p. 516.
} 
minera de Zaruma ofreció la cantidad de 200 pesos. $^{349}$ De este modo, solo quedaba la rica provincia costera de Guayaquil, pero la clase propietaria y las autoridades locales alegaron su pobreza motivada por el precio del cacao y establecieron una contribución dividida entre los diversos distritos, que proporcionaba un total de 1.847 pesos. ${ }^{350}$

Al encontrarse con esta situación, el obispo Carrión y Marfil tuvo que elaborar otro plan, pero siempre intentando que la obra se realizara sin perjudicar a los indios. De este modo, pudo negociar el apoyo de los hacendados de Loja y de los cacaoteros de Guayaquil, presentado sus reivindicaciones económicas a la Corona a cambio de obtener una parte de los beneficios estipulados. En el caso de Loja, apoyó sus encargos de libre exportación de cascarilla de inferior calidad, y le pidió al rey la contribución de un peso por cada carga exportada para la construcción de la catedral. En cuanto a Guayaquil, también favoreció las reivindicaciones de los hacendados y comerciantes del puerto, con el fin de poder lograr la libre exportación de su cacao a México y España, que hasta el momento, estaba prohibida debido a la oposición del monopolio cacaotero de Caracas, ejercido por la Compañía Guipuzcoana. En este caso, propuso que se le permitiese exportar a México veinte mil fanegas de cacao, además de las ya autorizadas al puerto.

El resultado obtenido con este plan fue bastante diferente, pues por un lado, la Corona no autorizó la exportación de cascarilla de Loja de segunda y tercera calidad, pero por otro, sí permitió la libre exportación del cacao de Guayaquil, aunque limitando el tributo para la catedral de los cuatro reales por fanega solicitados por el obispo a solo dos reales, según real orden del 24 de agosto de 1789. ${ }^{351}$ Esta cantidad, que comenzó a cobrarse el 3 de febrero de 1790, aportó grandes beneficios para la prelatura cuencana, pues para el 6 de octubre de 1796, había recibido una cantidad total de 84.122 pesos por cuenta del impuesto cacaotero. ${ }^{352}$

A pesar de las protestas de los productores y comerciantes de Guayaquil, que pensaban que el tributo perjudicaba sus intereses, este continuó vigente durante algunos años más, y aún cuando fue eliminado finalmente por real orden del 18 de agosto de 1800, la lentitud de la burocracia

\footnotetext{
${ }^{349}$ Ibíd. p. 519-520.

${ }^{350}$ Ibíd. p. 518-520.

${ }^{351}$ Ibíd. p. 518-520.

${ }^{352}$ Ibíd. p. 518-520.
} 
colonial llevó a que este se siguiera cobrando hasta el 27 de enero de 1802, fecha en que el total de lo recolectado ascendía a la cifra de 146.474 pesos. No obstante, lo sorprendente de esta situación es que la catedral de Cuenca no llegó a ser construida. ${ }^{353}$

Continuando con los elementos que promocionaron la acumulación de capital, hay que destacar el factor de especialización extrema al que nos hemos referido, siendo el cacao, el producto dominante en la economía ecuatoriana hasta comienzos de la década de 1920. Así, la ruptura de los lazos coloniales con España terminó con las restricciones comerciales impuestas por la Corona, produciéndose una expansión de las exportaciones de cacao que ya, para 1820-1841, superaba los niveles alcanzados durante la era colonial. Por otra parte, a pesar de que se exportaban otros bienes tropicales, hacia 1850, el cacao representaba el 50\% del total de las exportaciones, mientras que durante el periodo 1875 a 1920, esa proporción se elevó al 75\%. ${ }^{354}$ El gráfico 2 (Producción anual de cacao en el Ecuador) muestra los niveles de producción desde 1871 hasta 1900, a la vez que confirma el aumento gradual de este producto durante este intervalo con algunas variaciones. Llama la atención el año 1879, en el que tuvo lugar un aumento repentino de la producción, alcanzándose la cifra de 322.578 quintales con respecto al año anterior, en el que la cifra alcanzada fue de 105.734 quintales. ${ }^{355}$

Por otra parte, a pesar de la disminución de la cantidad producida a mediados de esa década, la producción anual promedio para el periodo 1879-1888 es de 276.240 quintales, incrementándose el promedio anual a 365.750 quintales, durante $1889-1898 .^{356}$

\footnotetext{
${ }^{353}$ Ibíd. p. 537.

${ }^{354}$ Francisco Pareja Cucalón: Comercio de exportación en la economía pre-petrolera, Libro del Sesquicentenario, Corporación editora nacional, 1983, III Economía/Ecuador 1830-1980, primera parte, 1983, p. 386.

355 Informes del Ministerio de Finanzas. Tomado de Luis Carbo: Historia Monetaria y Cambiaria del Ecuador, Banco Central del Ecuador, 1953, p. 447-448.

${ }^{356}$ Ibíd. p. 447-448.
} 
Gráfico 2: Producción de cacao (1890-1900)

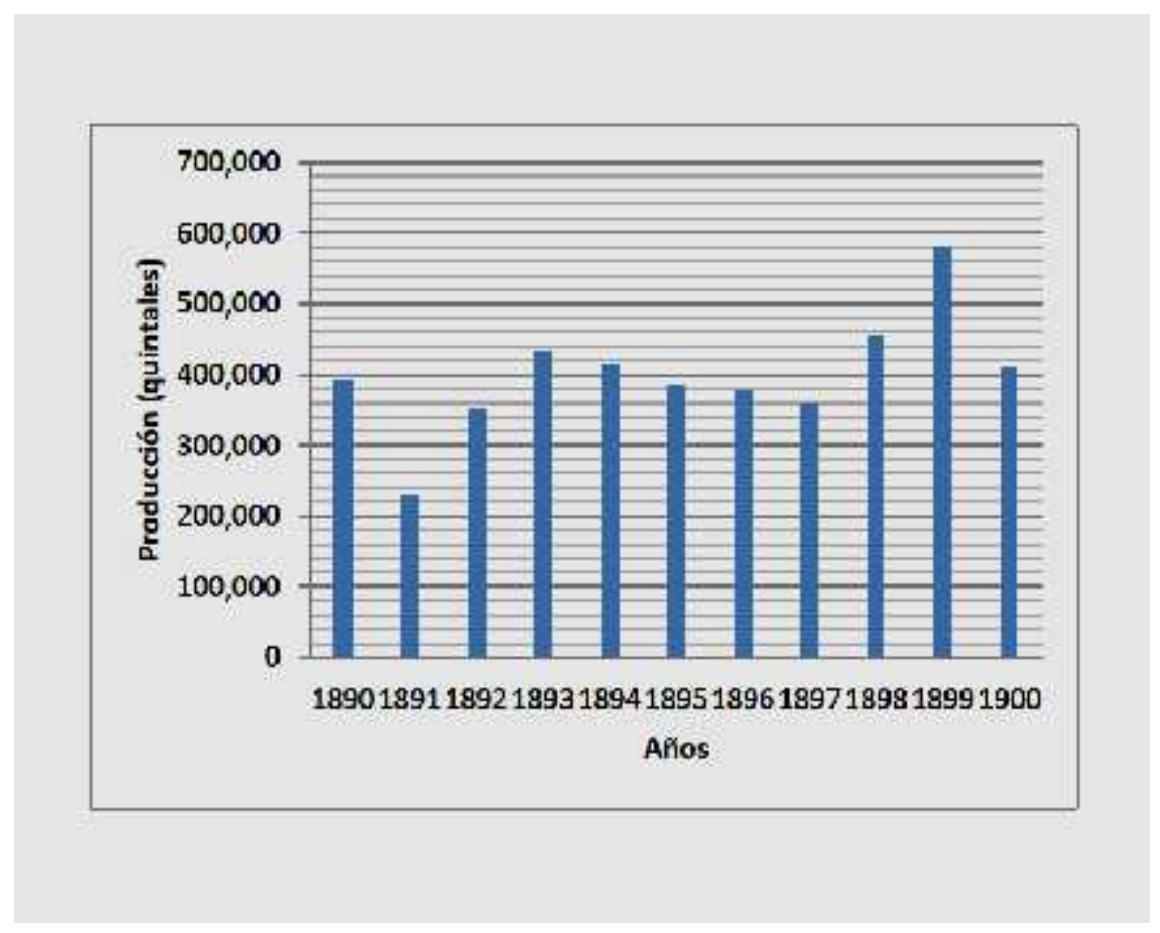

Elaboración propia a partir de los datos de la tabla 3.

Fuente: Informes del Ministerio de Finanzas. Tomado de Luis Carbo: Historia Monetaria y Cambiaria del Ecuador, Banco Central del Ecuador 1953, p. 447-448.

De forma paralela, en la Tabla 4 (Valor declarado de importaciones y exportaciones ecuatorianas) se presenta el promedio anual y la evolución de las exportaciones (e importaciones) en el intervalo comprendido entre 1871-1900. Se puede observar que el periodo comprendido entre 1879-1888, fue bastante significativo debido al incremento de las exportaciones, sobre todo en $1879 .{ }^{357}$

Comparando esta etapa con la siguiente década (1889 -1898), se aprecia un incremento en el volumen como consecuencia del aumento de las exportaciones de cacao (excepto el periodo 1895-1897), representando entre un 60\% y $80 \%$ del total de los ingresos percibidos por el Ecuador (Ver Tabla 5: Ingresos por cacao). ${ }^{358}$

\footnotetext{
${ }^{357}$ Las tablas 4-5 se encuentran en el apéndice de datos del capítulo1.

${ }^{358}$ Luis A. Carbo, op. cit., p. 447-448; Carlos Wiener, en H. Toscano, op. cit. pp. 453 y ss.
} 
A finales del siglo XIX, el Ecuador era el mayor productor mundial de cacao, posición que venía gozando desde hacía algún tiempo y que todavía iba a conservar hasta 1910, momento en que dejó de ser el principal productor internacional al ceder su hegemonía a Brasil. Sin embargo, este país seguiría produciendo una importante parte del total mundial (aproximadamente un 15\%) hasta la crisis de 1920, tal y como se muestra en los gráficos $3 \mathbf{y}$ 4. 359

\footnotetext{
${ }^{359}$ Michael Hamerly, op. cit. p. 121.
}

Estos gráficos han sido realizados con la información de las tablas 6 y 7 (producción y valor del cacao 1900-1909 y 1910-1919). Estas tablas se encuentran en el apéndice de datos del capítulo 1. 
Gráfico 3: Producción de Cacao (1900-1909)

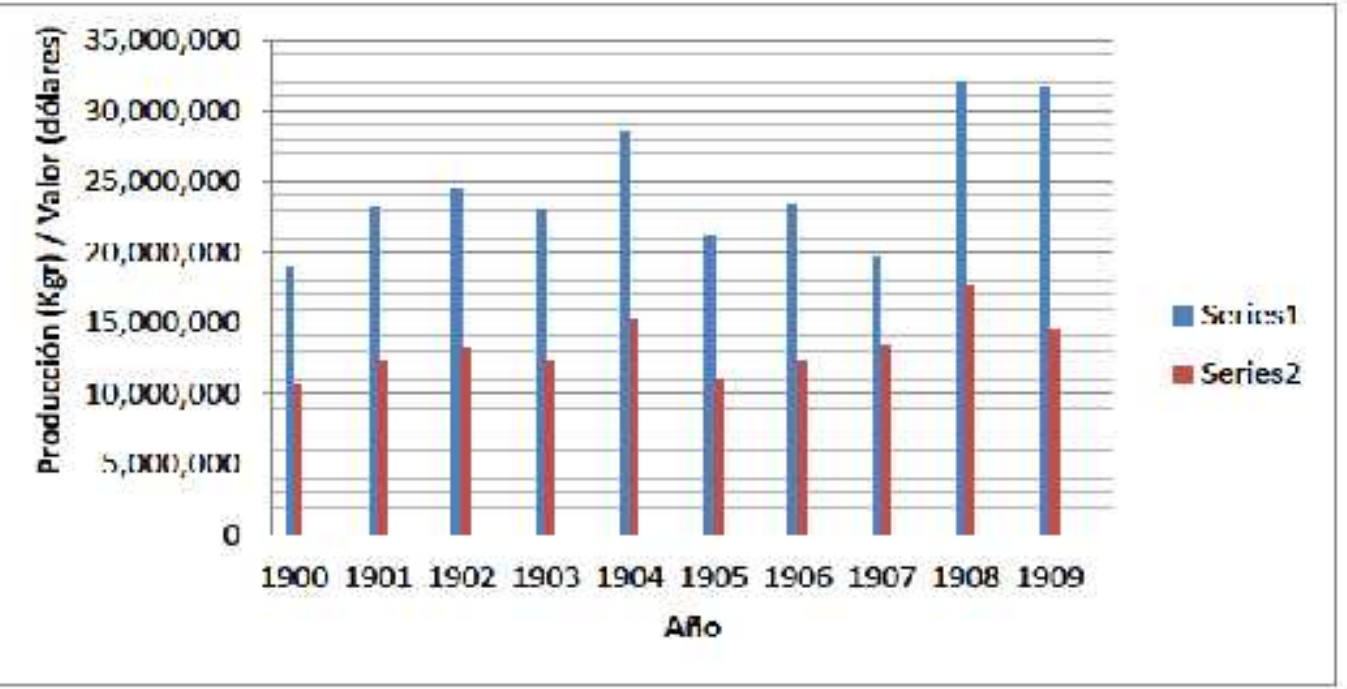

Elaboración propia a partir de los datos de la tabla 6.

La serie 1 representa la producción (en kilogramos) y la serie 2, el valor (en dólares).

Fuente: Banco del Ecuador: Crónica comercial e Industrial de Guayaquil en el primer siglo de la independencia, 1820-1920, La economía del Ecuador en los últimos setenta años (1906-1976), Biblioteca ecuatoriana, 1977. 
Gráfico 4: Producción de Cacao (1910-1919)

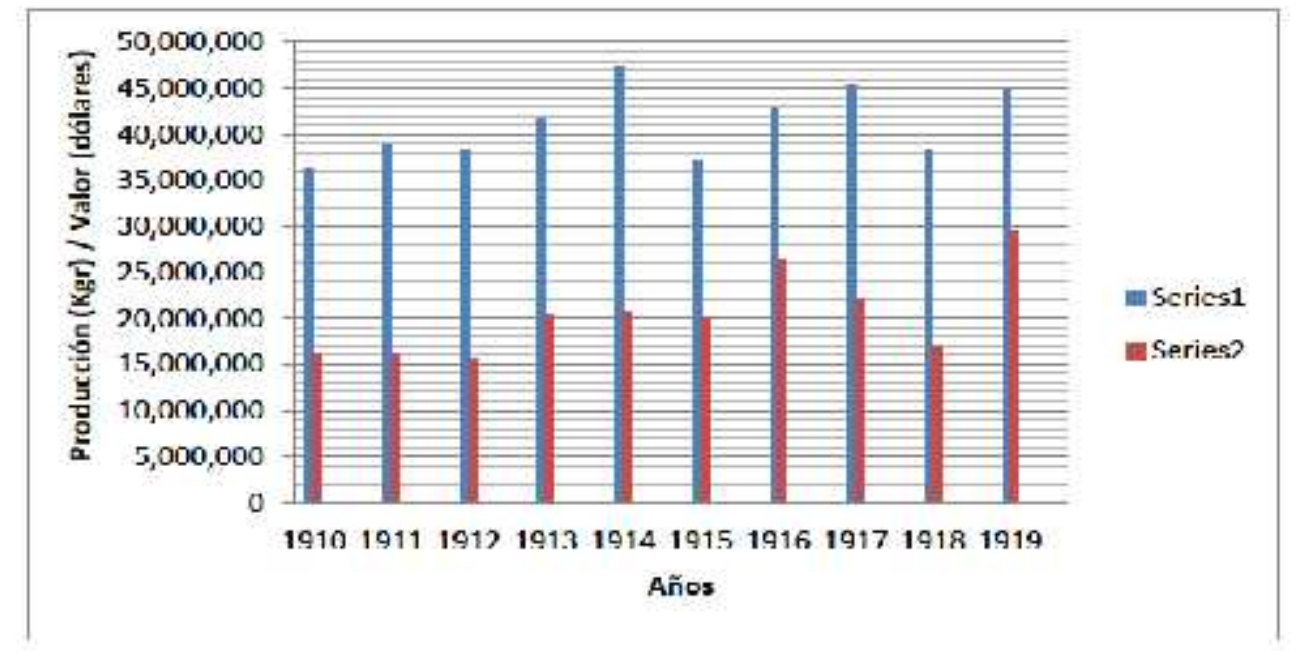

Elaboración propia a partir de los datos de la tabla 7.

La serie 1 representa la producción (en kilogramos) y la serie 2, el valor (en dólares).

Fuente: Banco del Ecuador: Crónica comercial e Industrial de Guayaquil en el primer siglo de la independencia, 1820-1920, La economía del Ecuador en los últimos setenta años (1906-1976) Biblioteca ecuatoriana, 1977.

El motivo fundamental que permitió que el Ecuador mantuviera una posición líder en el mercado internacional, con etapas de alta demanda entre 1870 y 1920, se debe al tipo de cacao producido, ya que se trataba de una variedad de cacao amarillo resistente a las enfermedades y de alta productividad.

Además, se ha de señalar la combinación de dos hechos de gran importancia que afectaron a la tecnología del consumo de cacao y que alteraron de forma permanente la estructura de la demanda. El primero, se refiere a los cambios que condujeron a una mayor demanda del producto elaborado, diversificando su sabor y su forma de utilización, mientras que el segundo, fue la innovación en el proceso de comercialización de algunos subproductos. 
Sin duda, estos adelantos tecnológicos constituyeron la clave del cambio de estructura de la demanda, ya que se produjo un aumento del consumo de cacao en los países industriales. Como resultado, las exportaciones de cacao ecuatoriano se duplicaron en el decenio 18951905, y de nuevo en los siguientes años hasta el inicio de la Primera Guerra Mundial. ${ }^{360}$

Por su parte, Ortíz Crespo afirma que la estructura del comercio del cacao mostraba las características de la integración del Ecuador al mercado mundial de una forma clara, siendo destacable la posición ocupada por Guayaquil, al exportar el 95\% del cacao del Ecuador, el $90 \%$ del café que producía y aproximadamente un $60 \%$ de la producción de caucho y cuero (Ver tablas 8 y 9 (Producción Café y Caucho 1880-1909). ${ }^{361}$ Bajo estas circunstancias, ¿cuáles fueron las características que permitieron al puerto de Guayaquil poseer el monopolio del comercio de exportación? ¿cómo se llevaba a cabo la comercialización del cacao en la Costa?

En principio, además del largo proceso de especialización que se había llevado a cabo en esta zona, se ha de pensar en su geografía, pues la falta de caminos existentes hizo que los ríos se convirtieran en los únicos medios de transporte y de comercio. Esto explica que el asentamiento de la población y el cultivo al interior de la Costa, tuvieran lugar en las cercanías de los ríos, siendo la abundancia e interconexión de las vías fluviales, los factores fundamentales que permitieron el retraso en la construcción de caminos y líneas férreas. Así, la combinación de estas vías en Guayaquil, puerto fluvial y marítimo nos ayuda a entender la posición privilegiada de dicho puerto, al tener el control del cacao y otros cultivos.

A su vez, las formas de comercialización del cacao pusieron de manifiesto una inclinación hacia la concentración a nivel del mercado mundial y al interior de la República. Es decir, los campesinos que mantenían relaciones de siembra con los hacendados, se encontraban obligados a vender sus productos a precios impuestos por el terrateniente que, por lo general, eran bastante bajos. Sin embargo, los campesinos independientes disponían de varias opciones, ya que podían vender su producción a un terrateniente cercano que pagaba cantidades escasas o al

\footnotetext{
360 José Corsino Cárdenas: Ensayo histórico de la economía ecuatoriana, Capítulo 2: El ciclo del cacao, Banco Central del Ecuador, Biblioteca de Historia Económica, Vlumen VI, Quito, 1995, p. 33-59.

361 Estas tablas se encuentran en el apéndice de datos del capítulo 1. Fuente: Gonzalo Ortíz Crespo: La incorporación del Ecuador al mercado mundial: La coyuntura socio-económica 1875-1895, Banco Central del Ecuador, Colección Isidro Ayora, Volumen IV, apartado: "Nuevas formas de concentración: el sistema comercial", 1981.
} 
intermediario que tampoco ofrecía buenos precios. Con esta estructura, en la que no había demasiados canales de mercadeo, los campesinos eran explotados fácilmente por los intermediarios, lo que indica que la cadena comercial del cacao fuera una práctica en una estructura de monopolio donde los lazos familiares se combinaban con las relaciones comerciales.

Otros elementos que contribuyeron a la consolidación del cacao y a su comercialización a nivel global, fueron aquellos que ejercían una gran influencia en la demanda. Así, el crecimiento de pedidos de alimentos a nivel internacional, resultado de un aumento de las tasas del crecimiento económico y demográfico de los países, logró favorecer el comercio de productos como el té, el café y el cacao. Esto se puede observar en los gráficos 5 y 6 (Exportaciones generales 19001909 y 1910-1919), en los que aunque solamente se presentan las cifras de las exportaciones totales y no se puede apreciar la contribución de estos productos, vemos cómo estos valores permanecen al alza de forma constante. 
Gráfico5: Exportaciones generales (1900-1909)

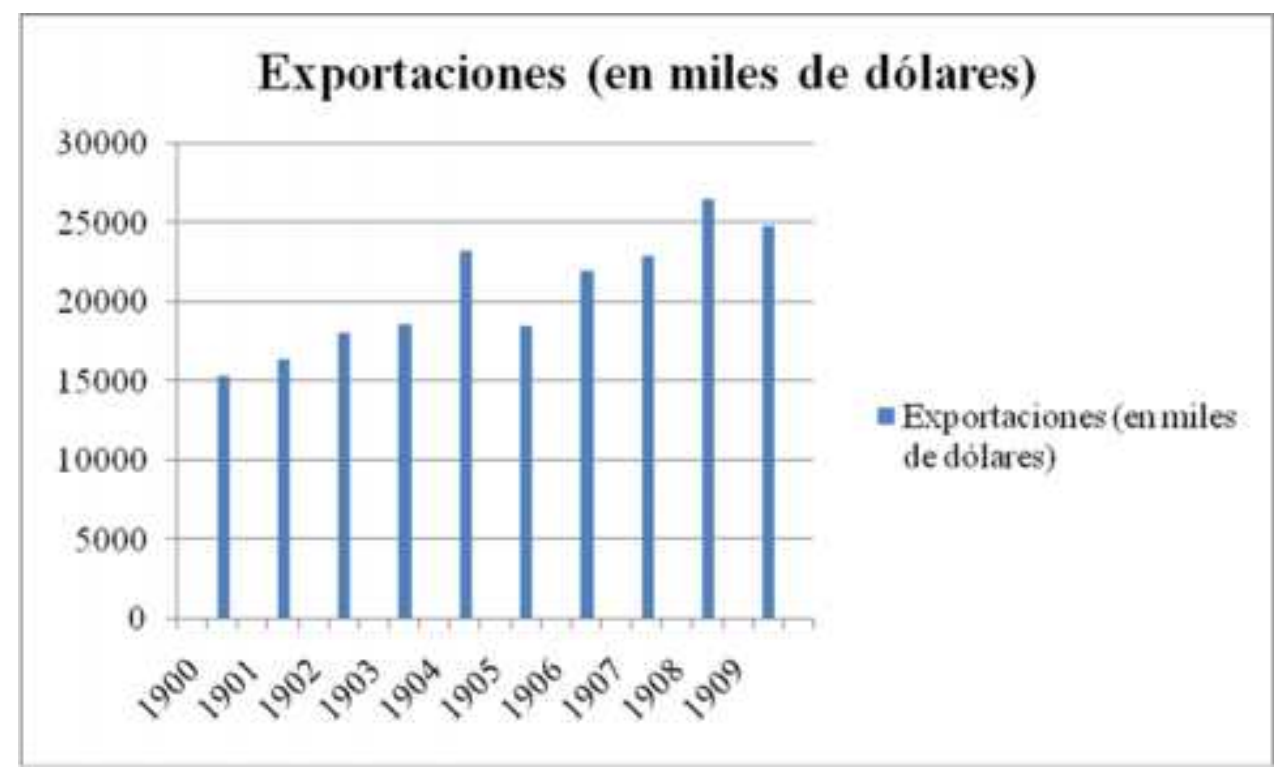

Elaboración propia a partir de los datos de la tabla 10.

Fuente: Banco del Ecuador: Crónica comercial e Industrial de Guayaquil en el primer siglo de la independencia, 1820-1920, La economía del Ecuador en los últimos setenta años (1906-1976), Biblioteca ecuatoriana, 1977. 
Gráfico 6: Exportaciones generales (1910-1919)

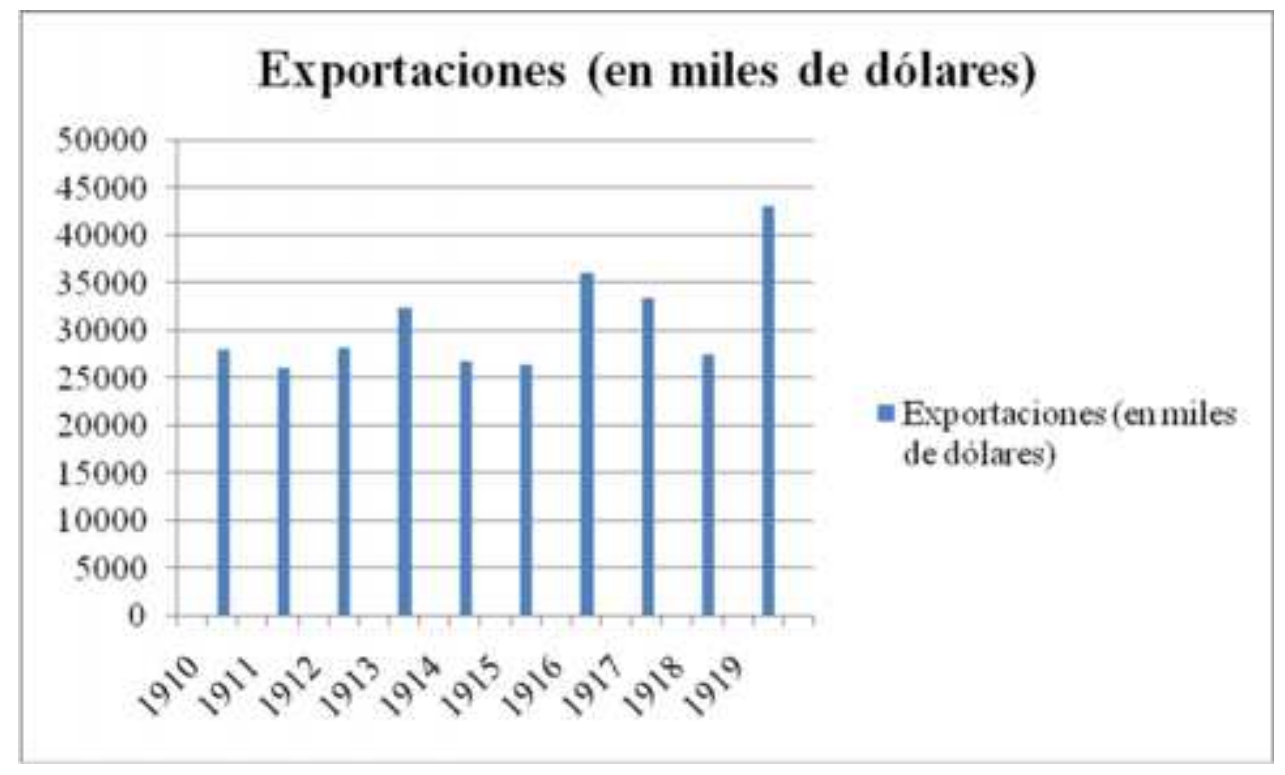

Elaboración propia a partir de los datos de la tabla 11.

Fuente: Banco del Ecuador: Crónica comercial e Industrial de Guayaquil en el primer siglo de la independencia, 1820-1920, La economía del Ecuador en los últimos setenta años (1906-1976), Biblioteca ecuatoriana, 1977.

Otro factor que estimuló considerablemente la prosperidad de este negocio (ver gráficos $\mathbf{7} \mathbf{y}$ 8) fue el precio del cacao, que fue incrementándose paulatinamente como consecuencia del aumento de la demanda. ${ }^{362}$ Además, a la vez que aumentaba este precio, los costes del transporte disminuían, pues los antiguos barcos de vela estaban siendo reemplazados por barcos de vapor, permitiéndose una nueva relación entre los precios y el transporte que implicaba una internalización de los costos marítimos y mayores beneficios.

En cambio, Fernando Velasco se refiere a una bajada de los precios del cacao ecuatoriano al tener que competir con las colonias de los países centrales, lo cual supuso una explotación de

\footnotetext{
362 Precios del cacao durante la década 1870-1879: A principios de la década, se vendía el cacao a un precio de $\$ 9,20$ a $\$ 9,60$ el quintal, mientras que a finales de la misma, el precio pasó de $\$ 12,80$ a $\$ 17,60$.

Precios del cacao durante la década 1880-1889: En 1880, el precio del cacao era de $\$ 13,60$ el quintal, cifra que se fue incrementando durante este periodo (a excepción del año 1882 que disminuyó a \$12) hasta llegar a los \$20,40. Fuente: Gonzalo Ortíz Crespo: La incorporación del Ecuador al mercado mundial: La coyuntura socio-económica 1875-1895, Banco Central del Ecuador, Colección Isidro Ayora, Volumen IV, apartado: "Nuevas formas de concentración: el sistema comercial”, 1981.
} 
bajo nivel técnico que acabó obstaculizando el dinamismo de la economía nacional. ${ }^{363}$

Asimismo, la aparición de firmas extranjeras contribuyó a impulsar el comercio del cacao, al facilitar el contacto entre los comerciantes extranjeros de Guayaquil y los centros mundiales. Estas compañías, procedentes en su mayoría de Inglaterra y de Estados Unidos, desempeñaron un papel fundamental en la construcción del ferrocarril y en la dotación de servicios públicos en América Latina, pues con el desarrollo de las líneas férreas se buscaba vender la producción del interior, mientras que los países latinoamericanos podían obtener divisas para cubrir las deudas que habían contraído en la construcción del ferrocarril.

En el caso ecuatoriano, serán los capitales norteamericanos y británicos quienes desarrollen el tendido de líneas férreas, la instalación de líneas telefónicas y telegráficas, la explotación de minas de Portovelo y la explotación de petróleo en Santa Elena:

Es así como la Guayaquil and Quito Railway construye el ferrocarril (1897), la South Americana Development Company explota las minas de oro en Portovelo (1899); y la Ancon Oilfields los yacimientos de petróleo (1911). ${ }^{364}$

Velasco hace hincapié en la importancia de las pautas comerciales establecidas a nivel mundial, al ser los exportadores ecuatorianos un eslabón de la cadena que vinculaba al país con el mercado mundial. En este caso, al actuar en la periferia del complejo del comercio internacional, estaban sujetos a los términos de intercambio fijados por los grandes centros, los cuales utilizaban su ventajosa posición y servicios informativos para determinar los precios. $^{365}$

\footnotetext{
${ }^{363}$ Fernando Velasco: Ecuador: Subdesarrollo y dependencia, Apartado "Liberalismo y cacao", Edit. El Conejo, primera edición, 1981.

${ }^{364}$ Oswaldo Hurtado, El poder político..., op. cit. p. 87.

${ }^{365}$ Fernando Velasco, op. cit. p. 11-220.
} 
Gráfico 7: Exportaciones de cacao (1900-1909)

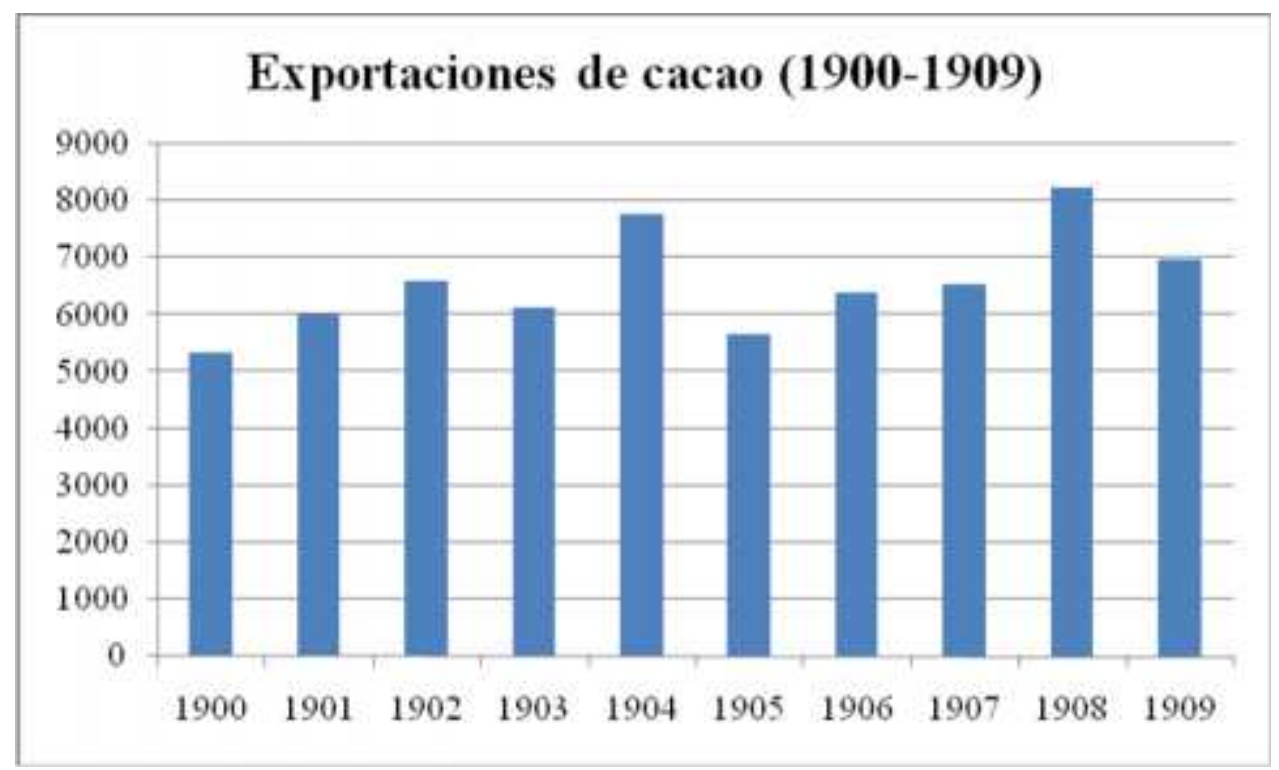

Elaboración propia a partir de los datos de la tabla 13.

Fuente: L. A. Rodríguez: The search for public policy: Regional politics and government finances in Ecuador, 1830-1940, University of California Press, Bekerley, 1985, p.191; L. J. Weinman: Ecuador and cacao: domestic responses to the boom-collapse monoexport cycle, University of California, Los Angeles, 1970, p. 360; L. A. Carbo: Historia monetaria y cambiaria del Ecuador, Banco Central del Ecuador, Quito, 1953, p. 68. 
Gráfico 8: Exportaciones de cacao (1909-1919)

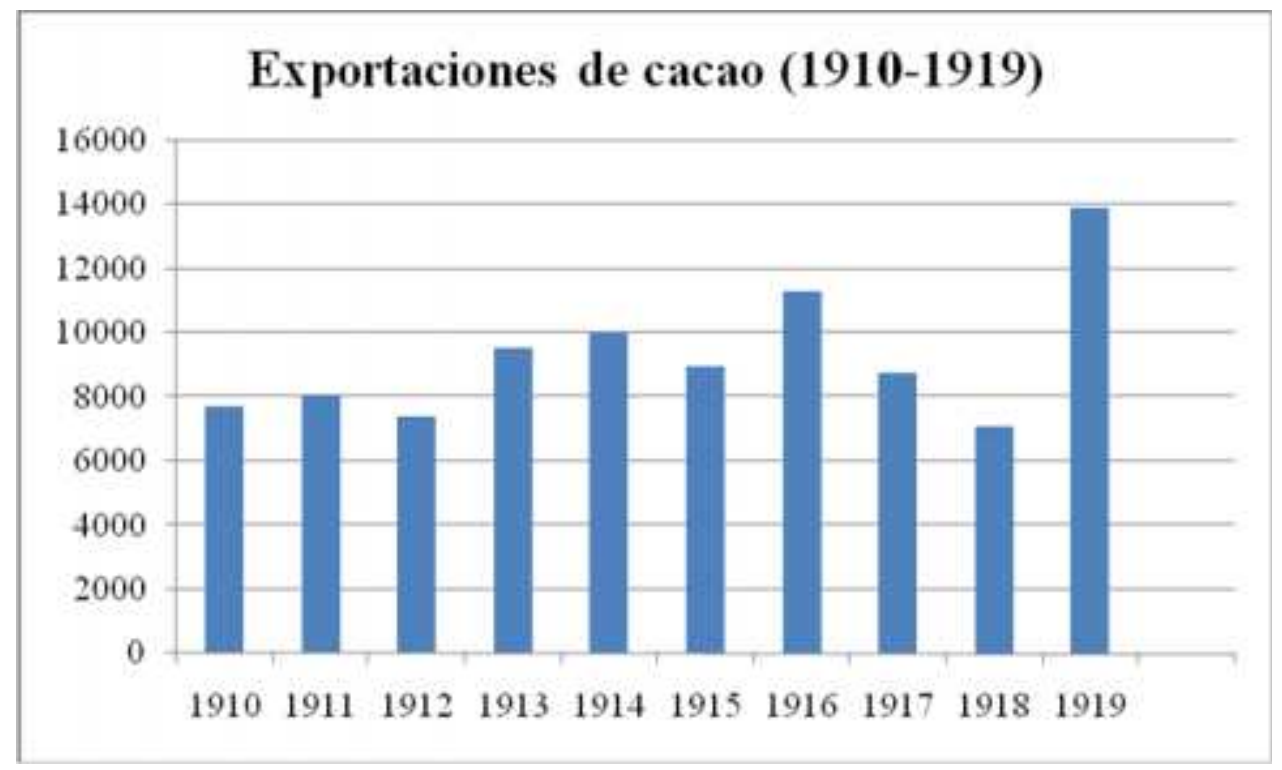

Elaboración propia a partir de los datos de la tabla 13.

Fuente: L. A. Rodríguez: The search for public policy: Regional politics and government finances in Ecuador, 1830-1940, University of California Press, Bekerley, 1985, p.191; L. J. Weinman: Ecuador and cacao: domestic responses to the boom-collapse monoexport cycle, University of California, Los Angeles, 1970, p. 360; L. A. Carbo: Historia monetaria y cambiaria del Ecuador, Banco Central del Ecuador, Quito, 1953, p. 68.

Cuando nos referimos a la relación entre el auge del comercio cacaotero del Ecuador y el sistema capitalista internacional, se ha de establecer una conexión con la Revolución Industrial, ya que fue la pieza angular que permitió la incorporación de los avances tecnológicos y de la organización del trabajo, posibilitando el aumento de producción en este país, pese a su tardía incorporación. A este respecto Celso Furtado indica:

Durante el siglo comprendido entre los años veinte del siglo XIX y la Primera Guerra Mundial, se implantó un esquema de división internacional del trabajo y tomó forma un sistema de economía mundial. Las actividades económicas de una parte creciente de la población mundial, pasaron a comportarse como elementos interdependientes de un conjunto articulado. ${ }^{366}$

${ }^{366}$ Celso Furtado, op. cit., p.46. 
La combinación de estos factores fue fundamental en el establecimiento de la división internacional del trabajo, cuya posición hegemónica era ocupada por Inglaterra, a la vez que el resto de los países se especializaba en la producción de materias primas o de manufacturas. Los resultados obtenidos permitieron un aumento de los ingresos y una mayor demanda de productos tropicales (entre los que figuraba el cacao), lo cual justifica que el Ecuador se convirtiera en productor de materias primas y consumidor de bienes de capital importados. Además, las innovaciones tecnológicas aplicadas a los medios de transporte, las cuales ocurrieron en el paso hacia una segunda fase de la Revolución Industrial, favorecieron la inserción de amplias zonas geográficas al sistema mundial.

La demanda acelerada de comestibles novedosos y lujosos como fue el caso del cacao, café y té y el aumento del consumo de azúcar, constituyeron nuevos fenómenos que acabaron poniendo de manifiesto un conjunto de cambios sustantivos en las estructuras sociales. Esto se refleja en el año 1559, momento en que los "comestibles no europeos" representaban menos del 9\% del valor total de las importaciones a Inglaterra, aumentando dicha proporción hasta alcanzar un 35\% en el año $1800 .^{367}$ Ese consumo de productos importados, junto con el uso de bienes y productos domésticos, será lo que contribuya a modelar patrones culturales con características propias, los cuales servirán para construir un tipo de identidad nacional en el siglo XX. ${ }^{368}$

Por su parte, también se ha de mencionar el debate originado en relación al impacto de la expansión de ultramar en las economías de Europa y su modernización, pues la demanda y el comercio trasatlántico de estas mercancías tuvieron efectos económicos profundos. Según De Vries y Kenneth Pomeranz, las compañías comerciales coloniales y las utilidades procedentes del comercio de esclavos y de las economías de plantaciones con mano de obra esclava, estimuladas por la demanda europea de comestibles tropicales, fueron una condición necesaria para la industrialización y despegue económico europeo. ${ }^{369}$ Además, la atracción hacia el tabaco, azúcar, cacao, café y té, pudo haber motivado a los empleados a trabajar más para disponer de dinero

\footnotetext{
${ }^{367}$ Ibid. p. 46.

368 Benjamin Orlove: Living importance to imports, p. 7-8, en: Arnold J. Bauer (ed), The allure of the foreign: Imported goods in postcolonial Latin America, Ann Arbor, University of Michigan Pres, 1997, p. 1-30.

369 J. De Vries: The economy of Europe in an age of crisis, 1600-1750, Cambridge: Cambridge University Press, 1976, p. 141; Kenneth Pomeranz: The Great Divergence: China, Europe and the making of the modern world economy, Princeton: Princeton University Press, 2000, p. 194; S. Mintz: The sweetness and power: The place of sugar in modern history, New York: Penguin Books, 1985, p 10-275.
} 
suficiente a fin de pagar sus nuevos hábitos. De este modo, el nuevo aprecio por los productos tropicales americanos estimuló el comercio en Europa y en sus colonias. ${ }^{370}$

No obstante, se ha de aclarar que a pesar del creciente énfasis en la importancia de los "comestibles de lujo" para las transformaciones en la cultura y la economía de Europa, los académicos no han sabido reconocer la importancia del cacao en lo referente a las importaciones tropicales.

En el siglo XVIII, el café y, en particular, el té, sobrepasaron al chocolate en términos de las cantidades importadas, siendo este último producto, la primera bebida estimulante consumida por los europeos en cantidades significativas. ${ }^{371}$ Este hecho suele ser ignorado incluso en los estudios más recientes sobre la llegada de bebidas estimulantes a Europa, pues se suele asumir que el cacao llegó a este continente después del café. ${ }^{372}$

En el caso de la Península Ibérica, el cacao tuvo una presencia importante en la década de 1590, extendiéndose hacia el norte a partir de 1620. Por su parte, el consumo de café no se afianzó en Inglaterra hasta la década de 1650, a pesar de que los comerciantes ingleses participaron en su comercialización en el mercado interasiático en décadas anteriores, mientras que esto ocurrió en España hacia finales del siglo XVIII. ${ }^{373}$ La noción generalizada que dice que el consumo del café llevó al consumo de chocolate es anacrónica, puesto que parece que el chocolate ayudó a introducir el café, creando un apetito por bebidas estimulantes calientes, oscuras, amargas y endulzadas. Al igual que las bebidas cafeinadas que aparecieron después, el chocolate

${ }^{370}$ J. De Vries: Between purchasing power and the world of goods: Understanding the household economy in Early Modern Europe, en J. Brewer y R. Porter (Eds.) "Consumption and the World of Goods" London: Routledge, 1993, p. 85-132.

${ }^{371}$ J. Goodman: Excitantia: Or how Enlightment Europe took soft drugs, en: J.Goodman, P.E. Lovejoy y A. Sherrat (Eds.), "Consuming habits: Drugs in history and anthropology” London: Routledge, 1995, p. 126.

${ }^{372}$ Davidson sugiere que el chocolate fue aceptado en el momento en que se hizo una analogía con el café, de manera que pudo entonces ser encasillado como una bebida lujosa con cualidades estimulantes. Fuente: A. Davidson: Europeans. Wary encounter with potatoes, tomatoes and other New World foods, p. 3 En: N. Foster y L. Cordell (Eds), Chilies to chocolate: Food the Americas gave the world, Tucson: University of Arizona Press, 1992, p. 3; S. Mintz: The sweetness and power: The place of sugar in modern history, New York: Penguin Books, 1985, p. 111.

${ }^{373}$ Los primeros encuentros de los europeos con el café ocurrieron a finales del siglo XVI, en las regiones que estaban bajo el control otomano. No obstante, no fue hasta mediados del siglo XVII, cuando se comenzó a importar este producto para el consumo europeo. En el caso español, la hegemonía del chocolate continuó hasta finales del siglo XVIII, cuando el café comenzó su ascenso. Fuente: B. Cowan: The social life of coffee: The emergence of the British Coffeehouse, New Haven: Yale University Press, 2005, p. 58-60; C. Kany: Life and manners in Madrid 1750-1800, Berkeley: University of California Press, 1932, p. 151. 
probablemente aumentó la demanda de azúcar debido a que los dos productos se consumían conjuntamente, de ahí que se haya de considerar la creciente popularidad del azúcar a partir de la difusión de las bebidas estimulantes. ${ }^{374}$

Vamos a pasar a continuación a estudiar cuáles fueron los principales países que demandaban el cacao y que mantenían una relación comercial con el Ecuador.

Osvaldo Hurtado afirma que el principal comprador del cacao ecuatoriano fue Inglaterra, pero aclara que en los datos históricos, Gran Bretaña aparecía fundamentalmente como comprador, asumiendo un papel menos importante como vendedor. ${ }^{375}$ Los gráficos 9 y 10 (Principales Socios Comerciales del Ecuador: Importaciones y Exportaciones) muestran otros socios comerciales del Ecuador, entre los que se destacaban España, Francia, Alemania y los EE.UU. ${ }^{376}$

\footnotetext{
${ }^{374}$ Sidney Mintz, op. cit. p. 150.

${ }^{375}$ A finales de siglo, Gran Bretaña satisfacía buena parte de su demanda de cacao con la producción de sus colonias. Fuente: Osvaldo Hurtado: El poder político en el Ecuador, Quito, Ediciones de la Universidad Católica, 1976.

${ }^{376}$ Los gráficos 6 y 7 han sido elaborados a partir de los datos obtenidos de la tabla 12 y representan valores en miles de dólares. Esta tabla se encuentra en el apéndice de datos del capítulo 1.
} 
Gráfico 9: Principales Socios Comerciales del Ecuador: Importaciones (1889)

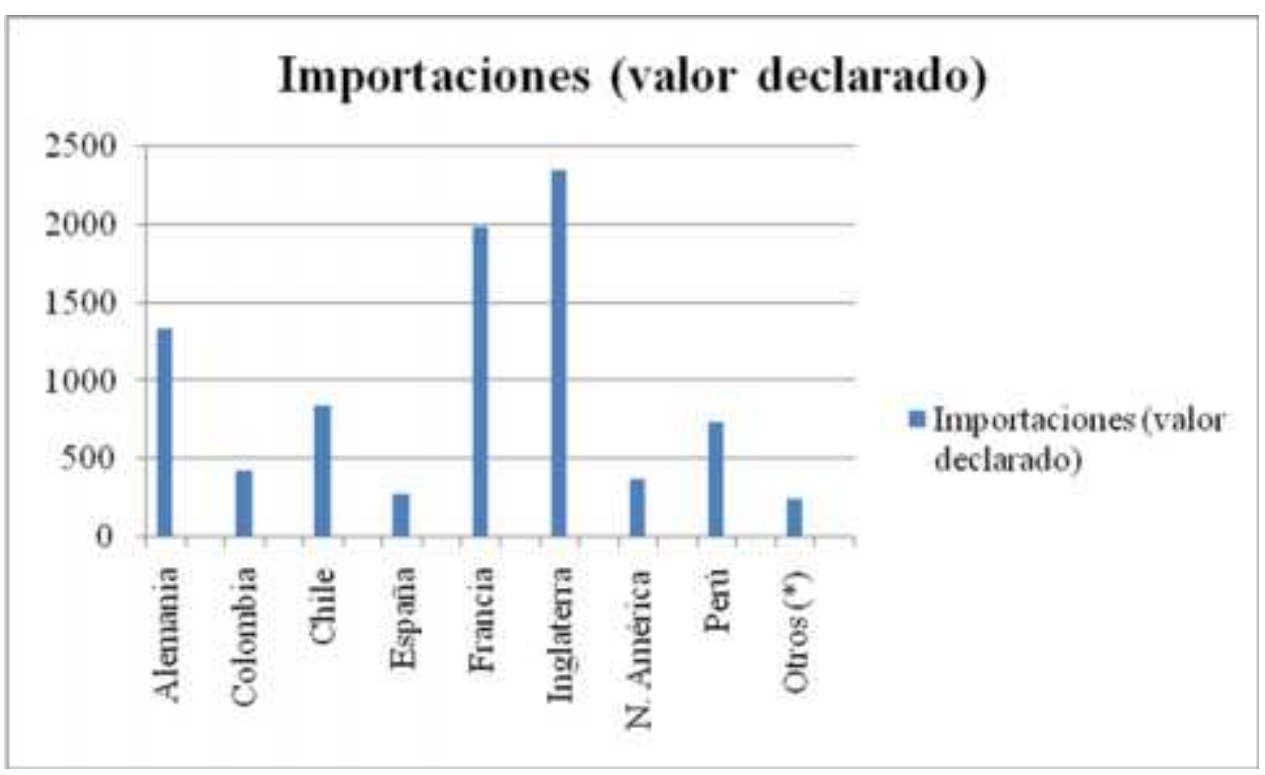

(*) Esta partida incluye Bélgica, Cuba, China, Holanda, Italia, Suiza, Argentina, Centroamérica, México y Uruguay.

Fuente: La Nación, Guayaquil, 25 de septiembre de 1890, no. 3382. 
Gráfico 10: Principales Socios Comerciales del Ecuador: Exportaciones (1889)

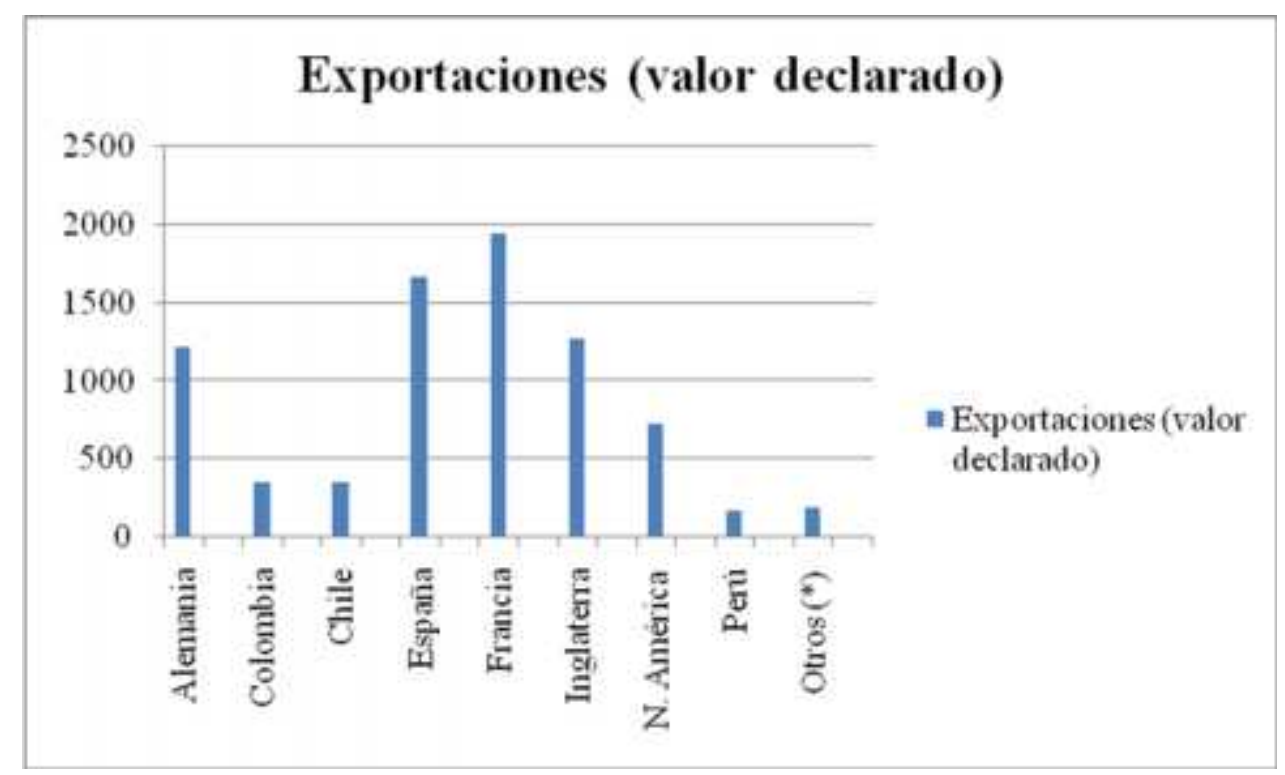

(*) Esta partida incluye Bélgica, Cuba, China, Holanda, Italia, Suiza, Argentina, Centroamérica, México y Uruguay.

Fuente: La Nación, Guayaquil, 25 de septiembre de 1890, no. 3382.

Oswaldo Albornoz se refiere a esta época como el periodo de la "penetración imperialista" e indica que a pesar de que este fenómeno no llegó a alcanzar los niveles de otros países latinoamericanos, tampoco pasó desapercibido a los intereses nacionales. ${ }^{377}$ De todas formas, desde antes de que se iniciara la etapa imperialista del capitalismo, las naciones desarrolladas como era el caso de Inglaterra, empezaron a penetrar en el Ecuador utilizando los préstamos onerosos, los tratados de navegación y el comercio como medios para poner de manifiesto su presencia.

Recordemos que la independencia de las colonias españolas originó una rivalidad entre Estados Unidos e Inglaterra para obtener el control marítimo y comercial del continente latinoamericano. Así, a partir de 1812, surgiría en Inglaterra un gran interés en la inversión en América Latina, el cual dio lugar al establecimiento de diversas compañías que querían explotar la minería y el comercio, crear líneas navieras, vender motores a vapor y establecer colonias de agricultores en esas tierras.

${ }^{377}$ Oswaldo Albornoz Peralta, op.cit., p.108-109. 
En el caso que nos ocupa, la relación comercial del Ecuador con Gran Bretaña se inició oficialmente con el apoyo crediticio que algunos banqueros londinenses ofrecieron al movimiento liderado por Simón Bolívar para financiar la compra de barcos, armas y el mantenimiento de las tropas. Como ejemplo, se encuentra la sociedad formada en 1820 por José Antonio Muñoz, un alto militar del ejército de Bolívar, y el inglés, William Henderson, establecido en Chile. ${ }^{378}$

También, se ha de hablar del transporte marítimo con el que los barcos ingleses navegaron por la Costa ecuatoriana transportando bienes y llevando productos ecuatorianos a otros países.

A este respecto, se ha de hablar del "Primer Tratado de Navegación y Comercio entre Gran Bretaña y la Gran Colombia”, establecido en 1825 por el gobierno de Gran Bretaña para evitar que Estados Unidos monopolizara el comercio de las antiguas colonias españolas, tras el acuerdo comercial establecido con los países de la Gran Colombia en 1822. De esta manera, mediante la firma del tratado, los productos ingleses (textiles y manufacturas) de mayor calidad que los procedentes de Estados Unidos, comenzaron a invadir Venezuela, Colombia y Ecuador.

No obstante, tuvieron que pasar muchos años, concretamente hasta 1839, para que el Ecuador, ya separado de la Gran Colombia, firmara el primer tratado de Amistad, Comercio y Navegación con Gran Bretaña, ampliándose en 1854 y 1889, las relaciones comerciales entre ambos con estos nuevos tratados. ${ }^{379}$

Por otro lado, también se ha hablar de la llegada de las primeras multinacionales británicas a partir de 1819, cuando empresas bancarias y de comercio, como Gibbs, Crawley \& Co., abrieron oficinas en Guayaquil. Estas compañías cumplieron un destacado papel en la financiación del comercio guayaquileño, especialmente en el comercio exterior ecuatoriano.

Otros ejemplos de la penetración del imperialismo se manifiestan con el establecimiento de la Central \& South American Cable Company, que inició la instalación submarina del cable en la costa del Pacífico en América del Sur, inaugurándose este servicio en Guayaquil en el año 1882. También, las inversiones procedentes de la Ecuador Telephone Company Limited para la instalación de la primera central telefónica "Empresa Ecuatoriana de Teléfonos" en $1888 .{ }^{380}$

\footnotetext{
${ }^{378}$ Ibíd., p. 108-109.

${ }^{379}$ Guillermo Arosemena: La Gran Bretaña en el desarrollo económico del Ecuador, 1820-1930, Selected Work, Embajada de Inglaterra en Ecuador, enero 1991, p. 13-140.

${ }^{380}$ Oswaldo Albornoz Peralta, op. cit., p. 108.
} 
En cuanto a las obras de infraestructura, se encuentra la construcción del ferrocarril, en la que participaron un conjunto de profesionales, contratándose los servicios ingleses y de otros países en su mayoría, al no existir agentes especializados en carreteras ni ingenieros mecánicos. ${ }^{381}$ Volviendo al tema del comercio del cacao, Albornoz señala la imposición de precios insignificantes a la "pepa de oro" por parte de estos compradores y habla de una ganancia mínima para el Ecuador, aunque no muestra los datos económicos relacionados con estas cantidades:

Desde mucho tiempo atrás, ya se había deformado nuestra economía mediante el monocultivo del cacao, que se transformó en el principal producto de exportación y que, como es lógico, se convirtió en el objetivo principal de la explotación extranjera. Los compradores imponían precios irrisorios para la pepa de oro, inclusive valiéndose de métodos sui generis como aquel de la consignación, que consistía en el envío de los cargamentos de cacao sin ninguna negociación previa, para que luego se vendieran a los precios del mercado, que no eran otros, sino los convenientes a los consignatarios y agentes. Los beneficios para el país, de esta manera, resultaban mínimos. ${ }^{382}$

Asimismo, el comercio importador que se encontraba vinculado al capital extranjero, constituía otra reserva de las fuerzas pro-imperialistas, ya que se trataba de los representantes y agentes de las empresas y monopolios de diversas potencias, como era el caso de EE.UU, Inglaterra, Alemania y Francia. ${ }^{383}$

Enrique Ayala también considera a Inglaterra como principal socio comercial del Ecuador, puesto que con su consolidación como eje de la división del trabajo y la mejora de los transportes marítimos, poseía la capacidad para establecer una vinculación estrecha con zonas más alejadas, entre las que se encontraba el Ecuador. ${ }^{384}$

Hacia finales de siglo, el control que Inglaterra ejercía sobre el comercio ecuatoriano se vio

\footnotetext{
${ }^{381}$ Guillermo Arosemena, op. cit. p. 13-140.

${ }^{382}$ Oswaldo Albornoz Peralta, op. cit. p. 108.

${ }^{383}$ Para 1880, el capitalismo entró en su fase superior o imperialista, lo cual significaba una mayor demanda de materias primas por parte de EE.UU y Europa. Fuente: Washington Macías: Ecuador: De la agro-exportación a la industrialización asociada 1830-1986, Colección problemas socio económicos del Ecuador, 1983.

${ }^{384}$ Enrique Ayala Mora, Lucha política..., op. cit. p. 20-300.
} 
reforzado con la suscripción del mencionado Tratado de Amistad, Comercio y Navegación, cuyos términos de igualdad y reciprocidad concedían enormes ventajas a los intereses británicos. ${ }^{385}$ Este acuerdo establecía privilegios con respecto a cualquier aspecto relacionado con el comercio y navegación, por lo que se concedía a Inglaterra la calidad de nación más favorecida. ${ }^{386}$ Pese a estas ventajas, la presencia inglesa en el Ecuador no llegó a ser en forma de monopolio, pues el mercado británico se abastecía de los productos tropicales que poseía en sus colonias, en donde contaba con abundante fuerza de trabajo y costos reducidos. Dadas estas circunstancias, buena parte del papel dinamizador lo cumplirían los EE.UU y otros países como Francia, Alemania y España, que mantenían estrechos vínculos comerciales con el Ecuador.

Con respecto a la relación entre Estados Unidos y el Ecuador, en un principio, esta tuvo como eje central los temas de la diplomacia y los conflictos internos ecuatorianos, pero a finales del siglo XIX se observa el establecimiento de una mayor relación comercial entre ambos países. ¿Cuáles fueron los factores específicos que impulsaron el aumento de la presencia comercial de los EE.UU y de otras naciones? ¿cómo se podrían describir los cambios producidos en el Ecuador que favorecieron el desarrollo del capitalismo después de la Revolución de 1895 ?

Manuel Chiriboga considera al impulso procedente del mercado exterior como el factor responsable de la modificación radical de la estructura de acumulación, particularmente de la Costa, cuyo impacto llegaría a perdurar hasta la actualidad. ${ }^{387}$

Estas transformaciones contribuyeron al afianzamiento de la hegemonía de la burguesía costeña, ya que mediante la construcción del Canal de Panamá (al que Ayala también se refiere), se facilitó la venta de los productos agrícolas costeños en el mercado mundial, integrando a la economía ecuatoriana en la red internacional del capitalismo (especialmente del norteamericano). Por su parte, la construcción del ferrocarril Guayaquil-Quito estableció un nexo más dinámico en el interior del país y logró deshacer el poder de la aristocracia y las

\footnotetext{
${ }^{385}$ Banco del Ecuador: Crónica comercial e Industrial de Guayaquil en el primer siglo de la independencia, 18201920, en La economía del Ecuador en los últimos setenta años (1906-1976), Biblioteca ecuatoriana, 1977.

${ }^{386}$ Oswaldo Albornoz: Del crimen de El Ejido a la Revolución del 9 de julio de 1925, Tall. Gráf. de Editorial Claridad, 1969, p. 45.

387 Manuel Chiriboga: Los terratenientes costeños en la economía del Ecuador republicano, en Libro del Sesquicentenario: Economía', CEN, Quito, 1982, p. 239-254.
} 
relaciones de producción semi-feudales de la Sierra, a través del traslado de fuerza de trabajo hacia la Costa, en donde las relaciones de producción capitalistas eran las predominantes. $^{388}$

Al igual que Chiriboga, Albornoz señala la importancia del ferrocarril del sur, al convertirse en un mecanismo que vinculaba la Sierra y la Costa y que logró acabar con el gran aislamiento feudal de las provincias, convirtiéndose en un factor indispensable para la producción. ${ }^{389}$ Así, se fueron reemplazando algunos de los productos comprados en el exterior por los procedentes de la hacienda serrana, impulsándose la monetarización del campo y la erosión de las estructuras pre-capitalistas de la Sierra. ${ }^{390}$

En ese nuevo contexto, la economía serrana, especializada en la producción para el consumo doméstico, comenzó a perder importancia, a la vez que la Costa fue adquiriendo un nuevo papel como eje agro-exportador y centro de la economía nacional proveedora del cacao. Así, la imposición del denominado modelo de crecimiento hacia afuera o modelo agro-exportador (cuyas características examinaremos en otro apartado), ocurriría paralelamente a la inserción del Ecuador en el mercado internacional, el cual ya había pasado a su etapa de capitalismo monopólico en los primeros años del siglo XX. ${ }^{391}$

Paralelamente, después de la Revolución Liberal de 1895, se establecieron una serie de objetivos para introducir un conjunto de cambios económicos como el desarrollo de una infraestructura que facilitara la incorporación del capitalismo e impulsara el comercio del cacao. $^{392}$ En este caso, el 4 de noviembre de 1898, para aumentar los intercambios

\footnotetext{
${ }^{388}$ Según Fernández y Tobar: El estado, cuyos ingresos dependían directamente de las exportaciones y de los préstamos de los bancos privados orientó la inversión pública al favorecimiento del proceso de acumulación privada, sobre todo a través de la construcción de infraestructura vial y ciertos servicios básicos en la ciudadpuerto Guayaquil. Fuente: Iván Fernández Espinosa, Patricio Tobar Robalino, op. cit. p. 117-131.

${ }^{389}$ La campaña anti-ferrocarril fue realizada por la derecha liberal para impedir la consolidación y avance de Alfaro, que vio en la finalización de esta obra un gran triunfo, con el que conseguiría elevar su prestigio para convertirse en fuerza política. Fuente: José Raúl Gangotena: La inversión en el Ecuador 1830-1980, Apartado IV. El liberalismo 1895-1925, Libro del Sesquicentenario. Economía Ecuador, segunda parte, 1830-1980, Corporación Editorial Nacional, Inter -Americal Defense College Library, 1983.

${ }^{390}$ Ramón Ojeda: Efectos del ferrocarril en la agricultura y la ganadería, Revista de la Sociedad Nacional de Agricultura, Vol. IX, Nil 66, Quito, 1925, p. 35.

${ }^{391}$ Oswaldo Albornoz Peralta, Ecuador: Luces y sombras...op.cit., p. 108-125.

${ }^{392}$ Ibíd. p. 108-125.
} 
comerciales y ayudar a la burguesía comercial, se dictó la Ley sobre Moneda Nacional que permitía la adopción del talón oro y la liberalización del comercio de las fluctuaciones de cambio. Además, el Congreso aprobó una ley de carácter anti-imperialista para impulsar el comercio y con la que solamente se podía aplicar el trato de nación más favorecida sobre la base de la más estricta reciprocidad, impidiéndose la aprobación de un tratado comercial que Estados Unidos quería imponer.

El incremento del volumen de producción y sus requerimientos de comercialización como consecuencia de estas leyes, llevaba aparejado el desarrollo de actividades comerciales y bancarias como campo particular de inversión y acumulación de capital, siendo un ejemplo de ello, las casas comerciales y los bancos de emisión y crédito. ${ }^{393}$ Entre las funciones desempeñadas por las casas comerciales, se encontraba su papel como intermediarios entre plantadores y compradores en el mercado internacional, a la vez que también se encargaban de realizar el resecado, almacenaje y embalaje final del cacao para su transporte a EE.UU y Europa. Las ganancias asociadas a este tipo de actividades, al igual que las de los grandes propietarios de las plantaciones, eran notablemente elevadas, siendo estos grupos los que llegarían a apropiarse de la riqueza creada durante este primer periodo de acumulación de capital en el Ecuador.

Se puede decir que el resultado de la imposición de estas medidas, se vio reflejado en un aumento de las rentas fiscales y de las exportaciones e importaciones, así como en la creación de nuevas industrias, compañías comerciales y de la ampliación del sistema financiero durante las primeras décadas del siglo XX. El auge cacaotero y las transformaciones económicas y políticas a nivel de la sociedad ecuatoriana en su conjunto, fueron los elementos que dieron paso a la consolidación de las relaciones capitalistas y del proceso de acumulación de capital, lo que supuso un gran avance para el desarrollo del capitalismo y el abandono del retraso que caracterizaba al país.

Así, estos comerciantes constituían el grupo de actividad más numeroso con 153 firmas, de las cuales, había veinte grandes casas comerciales que controlaban el 57\% del capital dedicado a la distribución de bienes importados en el mercado local, y tenían un promedio de capital de 241.000 sucres. Asimismo, aproximadamente la mitad de las firmas eran comercios medianos y

${ }^{393}$ Andrés Guerrero, Los oligarcas del cacao..., op. cit. p. 11-95. 
pequeños y su capital no pasaba de los 22.000 sucres. $^{394}$

La participación de los grandes comerciantes se encontraba en los bancos, en los que solían ocupar algunos de los cargos más altos (presidencia del directorio del Banco del Ecuador, vicepresidencia en el Agrícola y Comercial y en el Territorial).

Por último, también, existían algunas casas exportadoras extranjeras como la Andrean Trading Co., la American Trading Co. de Guayaquilla y la Casa Tagua, filial de la Tagua Handellschaft, de capital alemán. ${ }^{395}$

La tabla 14 muestra las casas exportadoras más importantes para el año 1905, las cuales conformaban un grupo donde se concentraba el capital portuario. Algunas de estas casas estaban constituidas por los hacendados más influyentes del país, como era el caso de los exportadores Guzmán y Reyre, los cuales figuraban entre los mayores exportadores de cacao de la época (declaraban capitales de 1.000.000 sucres cada uno), al igual que Aspiazu, Caamaño y Rhode con 800.000 sucres; mientras que el resto de los exportadores declaraban capitales entre 700.000 y 250.000 sucres. $^{396}$

\subsection{2) La consolidación de la burguesía y la decadencia de la clase terrateniente.}

El objetivo fundamental de este apartado se basa en el estudio de los conflictos internos y alianzas establecidas entre las clases dominantes de la sociedad ecuatoriana, en su lucha por el control del poder político y económico a finales del siglo XIX y principios del XX. Para ello, se puede establecer como punto de referencia la Revolución Liberal de 1895, a partir de la cual, la hegemonía política de la que gozaban los latifundistas serranos, entró en una fase de deterioro y declinación, mientras se consolidaba la burguesía agro-exportadora de la Costa ecuatoriana, que logró cimentar su poder en el auge de la producción y exportación del cacao y en las políticas de libre cambio.

Hemos visto cómo el progresivo establecimiento del modo de producción capitalista a finales del siglo XIX, tenía como eje dinamizador de la economía nacional a la región costeña,

\footnotetext{
394 A. Norero: Equatore Moderno, vol. 1, Roma, 1908, en: Andrés Guerrero: Los oligarcas del cacao..., op. cit. p. 73.

${ }^{395}$ Ibíd. p. 72-80.

396 Esta tabla se encuentra en el apéndice de datos del capítulo 1. Fuente: A. Norero: Equatore Moderno, vol. 1, Roma, 1908, en: Andrés Guerrero, Los oligarcas del cacao...op. cit. p. 73.
} 
caracterizada por el predominio de sus relaciones salariales sobre las formas tradicionales. De este modo, el control que la burguesía comercial ejerció sobre la economía ecuatoriana, supuso el primer paso para la preparación y establecimiento de un nuevo orden con el que se pretendía rearticular los rasgos serviles de este sistema mediante la división internacional del trabajo.

Además, tras varios años de expansión, la burguesía comercial poseía la capacidad para controlar todo el bloque en poder y someter sus intereses al resto de los grupos y fracciones dominantes. Con este control económico, la burguesía costeña tenía en mente hacerse con el dominio del poder político, hecho que provocaría una mayor tensión al interior del bloque en el poder, pues la fracción serrana intentaba mantener su participación política. ${ }^{397}$

A su vez, los deseos de la burguesía se vieron favorecidos por el fracaso de los gobiernos que se sucedieron después de la administración garciana (1859-1875), por el descontento generado entre los sectores populares y por la incapacidad del sector terrateniente a la hora de imponer un proyecto alternativo al proyecto burgués. 398

Bajo estas circunstancias, ¿cuáles eran los beneficios que la burguesía del litoral podría obtener al hacerse con el control del poder político?

En un principio, para los exportadores liberales que deseaban aumentar las exportaciones, su plan estaba asociado con la transformación de las instituciones y de las leyes. De este modo, el control del estado a través del acceso de la legislación, el dominio de la mano de obra y su desvinculación del latifundio serrano, representaba el control de la inversión pública y de los instrumentos de política, así como la oportunidad de unir la Costa y la Sierra para tener un mayor acceso a esta última desde un punto de vista económico. Fernando Velasco muestra que las razones que motivaron el enfrentamiento entre los sectores políticos asociados al latifundismo serrano y los liberales poseían un matiz ideológico, lo que explica la persistencia de la lucha. Dicho carácter estaba marcado por la acción de la Iglesia, la cual pertenecía al sector latifundista, por lo que el triunfo liberal dependía de la pérdida de sus posesiones y de la

\footnotetext{
${ }^{397}$ Enrique Ayala Mora: Lucha política y origen de los partidos en Ecuador, Capítulo quinto: Hacia el predominio agro-exportador. Apartado 1: Inserción en el mercado mundial: Capitalismo y cacao, las fracciones en pugna, Pontificia Universidad Católica, Editado por Publitécnica, Quito, 1978.

${ }^{398}$ Para más información sobre García Moreno, ver el apéndice de notas del capítulo 1.
} 
posición privilegiada de la que gozaba desde la época colonial. ${ }^{399}$

De esta forma, el poder en manos de la burguesía exportadora y banquera implicaría una integración total en las relaciones capitalistas internacionales, además de un aumento de las exportaciones de cacao como consecuencia del acceso de la Costa a la mano de obra de la Sierra y a una mayor absorción de productos tropicales en los países centrales. Esto refleja en cierto modo, el que esta etapa se caracterizara por la dinamización del comercio y los avances de la modernización del estado.

El resultado del auge comercial cacaotero se vio traducido en un incremento notable de la población de la Costa, convirtiéndose Guayaquil en la mayor ciudad del país a finales del siglo XIX. Enrique Ayala señala que la consecuencia de este aumento fue una mayor exigencia en la acumulación de capital y, por tanto, un incremento de la explotación de masas (en especial en la región del litoral) y tensión entre las fracciones dominantes que pugnaban por el control de la mano de obra. ${ }^{400}$ Ante estas circunstancias, ¿cuál fue el impacto ocasionado en la estructura de población sobre la que se asentaban las haciendas serranas y las plantaciones del litoral?

Hemos analizado cómo estas formas organizativas en el área rural, las cuales eran simples unidades de producción, extendían su presencia a la sociedad ecuatoriana del momento. Es importante destacar que ambas formas estaban vinculadas a un control de la población relativamente rígido, es decir, la hacienda serrana necesitaba un elevado número de mano de obra para lograr su acumulación, de ahí que cualquier incremento en la producción dependiera de la población.

Anteriormente, se vio cómo la ausencia de tecnología en las haciendas tradicionales se justificaba con la obtención de una mayor rentabilidad a partir del uso extensivo de la mano de obra y tierra. En este caso, los elementos que impulsaban dicho proceso eran la renta conseguida por el terrateniente y las ventajas en términos de coste y beneficio que requerían el uso de una mayor cantidad de población. ${ }^{401}$ Esto llevaba al mantenimiento de un gran número

\footnotetext{
${ }^{399}$ Fernando Velasco Abad, op. cit. p. 30-230.

${ }^{400}$ Enrique Ayala Mora, Lucha política..., op. cit. p. 200-350.

${ }^{401}$ Simón Pachano: Sobrepoblación relativa: Un acercamiento al caso del campesinado serrano, Revista Ciencias Sociales, número 12, Universidad Central, Quito, 1979, p. 110-136.
} 
de trabajadores ligados al sistema hacendario bajo las modalidades analizadas, estando estos sujetos a las determinaciones del terrateniente y a sus necesidades de acumulación y de poder. En las plantaciones de la Costa, el peso de las relaciones no capitalistas de control fue menos evidente, pero sus resultados fueron parecidos.

De esta forma, lo esencial de dichas formas organizativas se mantuvo en lo referente a la dinámica de la población y la problemática del empleo, mientras que los mecanismos de control se fueron debilitando una vez entrado el siglo XX. Es este momento, se manifiestan algunos indicios de cambio y modernización, para lo cual se necesitaba la combinación de otros elementos que actuarían como factores determinantes y que serán revisados en otro capítulo. ${ }^{402}$ En definitiva, se puede asumir que la existencia de una estructura poblacional tan rigurosa se justificaba en el excesivo control del campesinado por parte de las diferentes fracciones, pero ¿cuáles fueron las iniciativas llevadas a cabo por ambos grupos para mantener dicho control ante la creciente necesidad de mano de obra en el litoral? ¿cuáles fueron las consecuencias de estas acciones para la burguesía comercial y los terratenientes?

Entre las iniciativas emprendidas por las fracciones dominantes para ganar la batalla, se encuentra la constitución de la "Sociedad de Agricultura" en 1875 (a la que Ayala considera como una agrupación clasista) por parte de los latifundistas de la Costa, cuyos objetivos estaban centrados en la obtención de mano de obra y en la eliminación de impuestos, como era el caso del diezmo. ${ }^{403}$

La polémica generada en relación al diezmo manifestaba una vez más las contradicciones existentes, ya que por un lado, los exportadores cacaoteros y pequeños propietarios rurales, luchaban por la supresión de este impuesto y otros aranceles, mientras que el gran latifundismo serrano intentaba mantenerlo. ¿Cuáles eran las razones que pueden explicar la actitud de defensa de la oligarquía tradicional?

La respuesta puede ser nuevamente de tipo ideológico, debido a que una buena parte de las

\footnotetext{
${ }^{402}$ Enrique Ayala Mora, Lucha política..., op. cit., p. 200-330.

${ }^{403}$ A este respecto, se establece la Sociedad Agrícola sobre las bases siguientes: 1. Objetivos: proteger los intereses agrícolas, estudiar sus necesidades y procurar remedios.... 2. La Sociedad Agrícola... no se ocupará jamás de política. Se pondrá en relación con las autoridades sólo por asuntos de creación o reformas de las leyes que le conciernen. 3. Todo agricultor será admitido como socio, por su condición, sin distinción alguna de nacionalidad, creencias, partidos ni opiniones... Fuente: Actas de Instalación, El Comercio, Guayaquil, 16 de Noviembre de 1875, No. 56, en ibíd., p. 150-330.
} 
tierras en manos de la oligarquía serrana pertenecían a la Iglesia, la cual permitía su uso y disfrute a cambio de una pequeña cantidad, por lo que es lógico que estos defendieran el mantenimiento del diezmo. En cambio, la defensa de este impuesto estaba justificada por los terratenientes, al tratarse de contribuciones de tipo eclesiástico (imposiciones decimales) con las que se podían mantener instituciones de beneficencia caracterizadas por su independencia del poder central. ${ }^{404}$

En relación a esto, se ha de señalar que en el Ecuador hay cuatro instituciones que expresan las políticas estatales de salud desde la colonia hasta el presente: la beneficencia, que existió desde la colonia hasta 1925; la asistencia pública, que se inicia con la Revolución Juliana y finaliza en 1969; la sanidad, que también comienza durante la colonia pero se modifica significativamente en el siglo XIX, y el Ministerio de Salud, creado en 1969. Los acontecimientos que marcan la vida económica, social y política del país, así como los procesos internos de estas instituciones permiten establecer una periodización de estas últimas.

En la etapa que nos ocupa, la jerarquía eclesiástica ejercía el control de instituciones de beneficencia y salud como los hospitales, orfanatos, casas asistenciales e incluso cementerios.

La caridad de los benefactores individuales y la Iglesia desempeñaron un papel fundamental en la vida de los establecimientos de beneficencia, pero estos recursos siempre fueron controlados por el estado; incluyendo las limosnas que estaban sujetas a un ordenamiento de carácter estatal. ${ }^{405}$

En un principio, durante la colonia, la Corona española asumió la responsabilidad de hacerse cargo de las necesidades de salud de sus colonias de un modo hospitalario. La razón por la cual se asistía a los enfermos, pobres y discapacitados, se debe al marco económico y social de la época, es decir, se vivía la etapa de acumulación originaria del capital, hecho que llevaba aparejado la profundización de las desigualdades económicas y sociales, la expansión de la población pobre y el incremento de sus problemas, por lo que el estado colonial debía dar una respuesta a las necesidades de españoles e indios en América porque dependía de las colonias americanas.

\footnotetext{
${ }^{404}$ Ibíd. p. 125-330.

405 Alba Moya: Instituciones de salud en el Ecuador. La beneficencia, en: Geografía de la Salud en el Ecuador. Tomo II, volumen 2, CEDIG, 1995, p. 1-49.
} 
La financiación de los hospitales durante la colonia procedía en gran parte de los fondos de la Hacienda Real y del tesoro recolectado por las cofradías y hermandades a las que la Corona encargaba solicitar limosna. De igual forma, los mecanismos utilizados para financiar los hospitales fueron múltiples y experimentaron algunas modificaciones a lo largo del tiempo.

Algunos de estos incluían impuestos como era el noveno y medio de la mitad de los diezmos (es decir el duodécimo del diezmo), asignado mediante la Cédula Real del 29 de octubre de 1570, y que en 1578, el Virrey Toledo impuso a todos los indios para que tuvieran hospitales. ${ }^{406}$

Pese a que las principales ciudades y pueblos tenían hospitales, no siempre contaron con la protección de las autoridades locales o con las ayudas económicas estatales. De hecho, muchos de ellos surgieron y se mantuvieron gracias a las contribuciones de personas caritativas. En el caso del Ecuador, además del Hospital San Juan de Dios de Quito y de Guayaquil, se abrieron hospitales en pequeñas áreas como ocurrió con el hospital de Sigsig, cercano a un centro minero, y el de Tomebamba, creado en $1556 .^{407}$

En el siglo XIX, tuvieron lugar algunos acontecimientos relacionados con la ruptura de los vínculos coloniales y la conformación de una nueva unidad política. Esto implicaba la constitución del territorio independiente, la centralización del poder político y la formación de la nueva identidad.

Como vemos, las modificaciones económicas y políticas realizadas en el Ecuador a partir de la segunda mitad del siglo XIX, afectaron a su perfil institucional. Además, las relaciones Iglesiaestado y el desarrollo del mercado interno e internacional determinaron la financiación y el papel ideológico desempeñado por las instituciones de beneficencia.

El cambio de poder político producido con la independencia no modificó la relación de la Iglesia con los hospitales durante los primeros años, pero en 1835, el gobierno central declaró ilegal el ejercicio de la medicina por parte de algunas comunidades religiosas. No obstante, la Iglesia siguió llevando la administración de los hospitales, ya que fue el principal mecanismo del saber médico hasta mediados de siglo. Aquí, es importante destacar que durante el gobierno de García Moreno (1869-1875) se consolidó el poder de la Iglesia, el cual había estado vinculada al control del estado mediante el Patronato Real hasta el momento, y después de la Independencia a los

\footnotetext{
${ }^{406}$ I. Estrada: El Hospital de Guayaquil, 2a. ed. Archivo Histórico del Guayas, Guayaquil, 1974, p. 13.

${ }^{407}$ Ibíd. p. 13.
} 
gobiernos republicanos mediante el Patronato (declaración por la que se subordinaba la Iglesia Católica al estado a cambio de su protección).

De esta forma, el Patronato Real se comprometía a cubrir los gastos de los religiosos, cuya función era la de evangelizar a los indígenas y mantener hospitales y orfanatos, a la vez que la Iglesia recibía parte del diezmo (10\% de los ingresos procedentes de los tributos de la tierra que recaudaba la Corona). No obstante, a finales del siglo XIX, la Iglesia comenzó a perder los privilegios económicos y políticos que poseían desde la colonia, tras la eliminación del diezmo. Además, con la promulgación de la Ley del Patronato, el estado pudo controlar otra vez a la Iglesia, lo cual fue un paso fundamental para que los gobiernos liberales elaboraran leyes que les permitieran privar al clero de los beneficios económicos que eran transferidos a las instituciones de beneficencia. ${ }^{408}$

La erradicación del diezmo implicaba una pérdida del mecanismo de endeudamiento, con el que se controlaba la mano de obra que, como se ha indicado, era difícil de retener. Asimismo, al tratarse de un impuesto a la producción, resultaba más beneficioso entregar la décima parte de lo que se producía que pagar un tributo, ya que los latifundios serranos no eran cultivados en su totalidad.

Por otro lado, conforme la burguesía comercial iba adquiriendo un mayor poder, el latifundismo serrano experimentaba una profunda crisis como consecuencia de la división interna dentro de sus propias filas al crearse un grupo de tendencia modernizante, cuyas ideas se inclinaban a la adopción del sistema capitalista. ¿Cuáles fueron las razones para que se produjera esta división en la oligarquía tradicional?

Esta pregunta puede ser explicada aludiendo a las expectativas que los nuevos grupos habían generado en torno a la posibilidad de exportar algunos productos serranos, debido a la mejora de las vías de comunicación internas y al establecimiento de relaciones cercanas a los mercados externos.

Este sector, formado en su mayoría por terratenientes aferrados a las formas de producción arcaicas, era consciente de la pérdida del control de su sociedad. Asimismo, el auge del intercambio comercial implicaba un flujo cada vez mayor de excedentes desde la Sierra al litoral, lo que explica que la capacidad de acumulación de los bancos costeños fuera superior

\footnotetext{
${ }^{408}$ A. Pareja Diezcanseco: Ecuador: La República de 1830 hasta nuestros días, Ed. Universitaria, Quito, 1979, p. 234-235.
} 
a la de los serranos. A raíz de esto, la banca de Guayaquil acabó absorbiendo al Banco de Quito, consolidándose su control sobre el sistema fiscal y la economía ecuatoriana:

El auge cacaotero y el papel estratégico que empieza a desempeñar el sector exportador y su influencia directa e indirecta sobre una serie de variables económicas, va a fortalecer notablemente el grupo social vinculado al ejercicio del comercio exterior, grupo que en asocio con banqueros y otros comerciantes que provenían de sus propias filas, logra establecer ciertas formas de autoridad y de poder capaces de lograr el consentimiento y obediencia relativos de otros grupos sociales. $^{409}$

De esta forma, además del enfrentamiento por el control del campesinado, aparecieron nuevos motivos de conflicto, pues el deseo por parte de la fracción modernizante del latifundismo serrano de mejorar las comunicaciones internas, se vio traducido en el apoyo a la construcción del ferrocarril, hecho que implicaba el endeudamiento externo del país.

Los terratenientes tradicionales abogaban por la cautela en este asunto y solo optaron por la financiación procedente de los organismos públicos para llevar a cabo esta obra de gran envergadura, lo cual dejaba claro su rechazo a la propuesta de obtener capital extranjero. No obstante, Ayala aclara que la existencia de tal preocupación no era por el endeudamiento externo, sino que se basaba en el miedo a una mayor vinculación con los centros capitalistas, ya que la construcción del ferrocarril aumentaría el comercio de la Sierra con el exterior, provocando la implantación del patrón oro y la caída de las reservas de los bancos de Quito, que eran los centros de acumulación latifundista. ${ }^{410}$

Bajo estas circunstancias, si las acciones de los latifundistas serranos estaban centradas fundamentalmente en la defensa del peso del poder ideológico, el control de las masas y la fuerza de los bancos de Quito, a la vez que la burguesía se articulaba a una amplia tendencia liberal en su mecanismo de ascensión al poder, ¿cómo se logró resolver esta situación caracterizada por enfrentamientos constantes? ¿cuáles fueron los cambios que tuvieron lugar en el país?

\footnotetext{
${ }^{409}$ Pedro Moncayo: El Ecuador de 1825 a 1875, sus hombres, sus instituciones y sus leyes, Segunda Edición corregida, anotada y documentada por C.E.M. y L.F. V., Quito, Imprenta Nacional, 1906, p. 132.

${ }^{410}$ Enrique Ayala Mora, Lucha política..., op. cit. p. 150-330.
} 
La presión ejercida por el partido liberal representado por la burguesía exportadora y banquera, llegó a su punto final con el enfrentamiento que le dio la victoria tras la Revolución Liberal liderada por el general Alfaro en 1895. La creación de un nuevo marco político permitió acabar con el aislamiento en la Sierra, al aprobarse finalmente la construcción del ferrocarril del sur, además de impulsar el crecimiento de las exportaciones de cacao, produciéndose la integración del país en el sistema capitalista mundial de forma definitiva.

Desde un comienzo, la burguesía emprendió una serie de transformaciones encaminadas a llevar a cabo tareas nacionales para su expansión capitalista y para reivindicar los intereses nacionales, pero pronto abandonaría su línea radical para volver a aliarse con los terratenientes serranos y crear un régimen burgués-terrateniente. ${ }^{411}$ Es decir, el triunfo de la Revolución Liberal no supuso una modificación sustancial de la estructura económica del país, ya que realmente nunca llegó a ser el objetivo económico-político de la burguesía agrocomercial bancaria. Este grupo centró sus intereses en el control del poder del estado para impulsar el modelo agro-exportador a través de una serie de medidas económicas y jurídicas, que favorecían la exportación y la importación de productos y las operaciones bancarias destinadas al fortalecimiento de la burguesía en su conjunto. ¿Cuáles fueron por consiguiente, los cambios que se llevaron a cabo en la estructura económica y productiva del país después de la Revolución de 1895 ?

En el apartado anterior, consideramos algunos de los objetivos perseguidos con la Revolución de 1895, entre los que se encontraban la introducción de una serie de cambios económicos y el desarrollo de la construcción de una infraestructura material que facilitara la incorporación del capitalismo y favoreciera a los distintos sectores de la burguesía. Albornoz explica que uno de los beneficios obtenidos y que afectaron a la agricultura, fue la abolición del diezmo, el cual representaba el clamor general de los agricultores desde los primeros años de la República, al tratarse de una carga feudal que obstaculizaba su desarrollo. ${ }^{412}$

Por otro lado, la problemática en torno a la enajenación de las tierras del clero (enemigo del partido liberal), fue uno de los grandes temas a debatir durante la Revolución Liberal. En

\footnotetext{
411 Rafael Quintero: La cuestión regional y el poder, Facultad Latinoamericana Ciencias Sociales (FLACSO), Biblioteca de Ciencias Sociales, volumen 29, Corporación Editora Nacional. Quito, Ecuador, 1991, p. 15-275.

${ }^{412}$ Oswaldo Albornoz Peralta, Ecuador: luces y sombras...op. cit. p. 12-179.
} 
realidad, el gobierno liberal no llevó a cabo una reforma agraria y tampoco modificó el régimen de la propiedad agrícola privada, aunque sí llegó a transferir la propiedad territorial del clero mediante la Ley de Beneficencia de $1908 .{ }^{413}$ Por consiguiente, ¿cuál fue el destino final de estas propiedades? ¿se logró llevar a cabo una reforma de la estructura productiva que posibilitara el reparto de las tierras?

Ya hemos visto cómo el proceso de crecimiento de las ciudades latinoamericanas a finales del siglo XIX y principios del XX, estuvo caracterizado por un incipiente desarrollo industrial, la demanda de trabajo urbano, inmigración del campo a la ciudad, el aumento de la población, el ingreso de la clase obrera a la escena política, el populismo, los levantamientos indígenas, la crisis económica y los problemas entre etnias.

En general, en el Ecuador, las transformaciones más importantes del régimen de Alfaro estuvieron relacionadas con la promoción de la economía liberal, las transformaciones jurídicopolíticas, los cambios ideológico-culturales y las políticas sociales. En materia económica, Alfaro promocionó las industrias ecuatorianas, alentó el comercio, incentivó la agro-exportación del cacao, contribuyó al desarrollo de la banca gracias al apoyo del Banco Comercial y Agrícola de Guayaquil, reformó la educación, impulsó la obra pública mediante la construcción de carreteras y puentes, y llevó a cabo la construcción del ferrocarril Guayaquil-Quito, que una vez finalizado en 1908, no solo integró a las dos regiones más importantes del Ecuador, sino que permitió mercantilizar la tierra, ampliar el trabajo asalariado y desarrollar el comercio regional. Esto explica que las reformas realizadas manifiesten el carácter revolucionario del liberalismo alfarista, pues estuvieron orientadas a cambiar las estructuras heredadas.

En cuanto a la transformación ideológica y cultural, se ha de decir que la extensión de la educación laica fue una de las políticas sociales más radicales emprendidas por el gobierno de Alfaro, cuyos esfuerzos fueron dirigidos a la formación de maestros, la construcción de locales y creación de empleo.

La inserción a la vida ciudadana, el uso de la luz eléctrica y la creciente actividad en las ciudades, reconfiguraron la vida y el paisaje de las ciudades latinoamericanas en las primeras décadas del siglo XX. En términos generales, parece que la transformación de la ciudad va abandonando los valores históricos de la ciudad, al tiempo que se elimina todo aquello que está

\footnotetext{
${ }^{413}$ Para más información del trasfondo político de esta medida, consultar la obra de Alfredo Pareja: La lucha por la democracia en el Ecuador, Quito, Ed. Ruminahui, 1956, p. 57.
} 
fuera de lo municipal.

Un ejemplo de esta nueva tendencia se encuentra en la dinámica arquitectónica, urbanizadora y sociocultural de Quito durante el periodo de 1910-1930, para la profundización de su modernidad. La estructura de la ciudad sufre modificaciones como consecuencia de los adelantos que los gobiernos liberales van introduciendo: la culminación del ferrocarril (1908), que intensificó la comunicación entre la Sierra y la Costa y permitió el transporte de materiales pesados (hierro, cemento, etc.), la constitución de la compañía Quito Electric Light and Power (1906), las obras de canalización y agua potable (1908) y la preocupación por la sanidad y la medicina. ${ }^{414}$

Por otro lado, la banca serrana se consolida en esta época con grandes capitales privados, llegándose a convertir en uno de los mayores productores de la arquitectura moderna. ${ }^{415}$ Simultáneamente, se va configurando una nueva etapa formada por un conjunto representado por capas medias asociadas al desarrollo del aparato estatal y al sector bancario, una clase trabajadora que adquiere la identidad de pueblo, y un grupo de terratenientes modernizados.

Guillermo Bustos indica que uno de los hechos más destacados en el crecimiento de Quito, es su forma longitudinal y su imagen segregacionista, siendo el propósito del proceso de modernización de la ciudad, la eliminación de todo elemento que pusiera de manifiesto sus rasgos indígenas o rurales. ${ }^{416}$ Así, las clases sociales con mayor poder adquisitivo se fueron desplazando desde el centro hacia la región norte (de un Quito moderno), mientras que los barrios marginales se encontraban localizados en el sur de la ciudad.

En definitiva, la modernización de América Latina en el periodo 1880-1940, generó en la constitución de los estados nacionales, distintos modos de representación simbólica, entre los que se encuentran el modernismo, el regionalismo, el realismo crítico y el vanguardismo. De este

\footnotetext{
${ }^{414}$ Pablo Aguilar: Arquitectura y modernidad 1850-1950, Quito, Museo Municipal Alberto Mena Caamaño, 1995 , p. 44.

${ }^{415}$ Ibíd. p. 44.

${ }^{416}$ Guillermo Bustos: Quito en la transición: actores colectivos e identidades culturales urbanas: 1920-1950, Enfoques y estudios históricos: Quito a través de la historia, Quito Municipio de Quito, 1992, p. 176.
} 
modo, imaginarios urbanos y rurales, regionalistas y cosmopolitas expresaron las tensiones y conflictos entre las experiencias periféricas de la provincia y los espacios urbanos. ${ }^{417}$

De este conjunto, la obra de Pablo Palacio destaca el impulso vanguardista que buscó novedosas maneras para representar la nueva imagen de la ciudad. Los vanguardistas latinoamericanos realzaron la gran ciudad y realizaron fuertes críticas con respecto a los logros del proyecto de la modernidad, mostrando la vida moderna en conflicto con sus ambigüedades y contradicciones. Como ejemplo, se puede citar a José Carlos Mariátegui, el cual no dejó nunca de exponer el espíritu revolucionario de la ciudad y la posibilidad de experimentar cambios: en contraste con el campo, la ciudad, en cambio, ha alojado perennemente un fuerte afán de creación. ${ }^{418}$

Palacio propone una nueva forma de ver la ciudad a través de nuevas perspectivas y combinaciones de lecturas como es el caso de sus "Obras Completas", en las que se abordan de temas relacionados con la vida diaria de las ciudades ecuatorianas. ${ }^{419}$

Por otro lado, cuestiona los gobiernos injustos e ineficaces mediante un conjunto de voces narrativas y textos fragmentados, siendo la prosa el mejor medio para la combinación de estas ideas. De igual modo, se observa la crítica a la sociedad en el contexto político o moral mediante la exposición de la trama, la cual aparece desdibujada y centrada en la vida interior de los personajes.

A su vez, Palacio aborda los temas de contenido social, pobreza, política y economía en su novela "Débora", en la que explora los espacios suburbanos y los barrios, a la vez que describe los bandos de la sociedad ecuatoriana:

Los gemebundos son los legítimamente heridos: Viejos fieles a lo viejo. Los neogemebundos son los revolucionarios del lápiz o de la pluma. Han hecho malabares con las palabras o han torcido las líneas, pero sobre la base de los recuerdos. ${ }^{420}$

\footnotetext{
${ }^{417}$ Pablo Aguilar, op. cit., p. 44.

418 José Carlos Mariátegui: Invitación a la vida heroica, Textos esenciales, Lima, Fondo Editorial del Congreso del Perú, 2005, p. 246. Beatriz Sarlo habla sobre esta vanguardia y se pregunta sobre la modernidad en las sociedades periféricas, en las que conviven un conjunto de elementos residuales junto a programas renovadores. Fuente: Beatriz Sarlo: Una modernidad periférica, Buenos Aires 1920 y 1930, Buenos Aires, Nueva Visión, 1999.

${ }^{419}$ Pablo Palacio: Obras Completas, Editorial Universidad de Costa Rica, 2000.

${ }^{420}$ Pablo Palacio: Débora, en Obras Completas, Editorial Universidad de Costa Rica, 2000, p. 129.
} 
De esta forma, Palacio hace alusión al desconcierto provocado por la necesidad de tener que afrontar un nuevo mundo en constante cambio y lleno de contradicciones, el cual representa la modernidad (los neogemebundos son los revolucionarios, del lápiz o de la pluma, en contraposición a los elementos viejos fieles a lo viejo). ${ }^{421}$

En la novela "Vida del ahorcado", hay que destacar los textos fragmentados, el cambio de voces y los altibajos en la voz del narrador. Esta novela se manifiesta en contra de la explotación y de la injusticia, recurriéndose para ello, a la ironía o a la violencia, a la vez que este tema es tratado como una crítica a los intelectuales asociados al poder. El segmento "Hambre" es una muestra clara de estos procedimientos:

El gobierno de la República ha mandado insertar en los grandes rotativos del mundo esta convocatoria escrita en concurso por sus más bellos poetas: ¡Atención!, Subasta pública. Atención, capitalistas del mundo:

El Chimborazo está en pública subasta. Lo daremos al mejor postor y se admiten ofertas en metálico o en tierra plana como permuta. Vamos a deshacernos de esta joya porque tenemos necesidades urgentes: nuestro súbditos están con hambre, por más que tengan promontorios a la ventana. Hoy es el Chimborazo, mañana será el Carihuairazo y el Corazón; después el Altar, el Illiniza, el Pichincha. ¡Queremos tierra plana para sembrar caña de azúcar y cacao! iQueremos tierra para pintarle caminos! ${ }^{422}$

Otro tema reflejado en estas obras, es el contraste entre lo urbano y lo rural para situar a los personajes y mostrar los cambios en el Ecuador de principios de siglo XX, en el que los personajes luchan para encontrar un espacio en el que puedan sentirse bien. Con la frase "no se halla", el autor realiza una interpretación de la sociedad del momento sobre cómo las ciudades han sido diseñadas para poner en orden los objetos y la gente.

Esto mismo se refleja en la novela "Un hombre muerto a puntapiés", en la que el narrador relata cómo el protagonista, llamado Ramírez, ha sido agredido a puntapiés en la calle, mientras intenta reconstruir la historia y explicar las razones que llevan a este desenlace.

\footnotetext{
${ }^{421}$ Ibíd. p. 129.

${ }^{422}$ Ibíd., p. 149.
} 
Este texto incorpora varios elementos que se repiten en la novela, como es el caso de la escena urbana, los asuntos cotidianos, los personajes agobiados y el humor de los narradores que critican las instituciones y reglas del orden social. De este modo, el protagonista de la novela se mueve en una ciudad caracterizada por sus calles concurridas y gente desconocida, a la vez que la ciudad requiere el conocimiento de algunas normas de orientación y capacidad para reconocer los elementos pertenecientes al centro y a las afueras. ${ }^{423}$

Regresando al tema de las reformas llevadas a cabo durante el periodo liberal, es importante decir que pese a que el objetivo propuesto era crear una economía empresarial, transformar la economía campesina e intentar cambiar la condición indígena, las pocas medidas tomadas por los gobiernos, no lograron cambiar el sistema económico vigente. Es decir, las estructuras agrarias básicas y la explotación de los trabajadores rurales dentro del régimen de las haciendas, continuaron vigentes en la historia ecuatoriana durante décadas. También, el retraso de soluciones frustró las mismas bases del liberalismo, mientras que la dominación de la oligarquía acabaría con este proyecto, que fue erradicado definitivamente tras el asesinato de Eloy Alfaro el 28 de enero de 1912 . $^{424}$

En relación al reparto de tierras, hay que decir que estas quedaron en manos del estado en un primer momento, y nunca se llevó a cabo un reparto de las mismas entre los campesinos, pues se temía crear un precedente que permitiera una ampliación de la reforma hacia la propiedad laica. De esta forma, se aseguró la existencia del latifundio con sus rasgos feudales para los terratenientes, los cuales se beneficiaban mediante la explotación de los indígenas.

Además, al no tener la producción de la Costa como destino final el consumo interno, la presencia de las relaciones capitalistas salariales en la Sierra era fundamental para permitir el abastecimiento del mismo. Sin embargo, las relaciones pre-capitalistas en la Sierra podían seguir vigentes, siempre y cuando no llegaran a vincular jurídicamente al campesino a la hacienda y se permitiera la migración desde la serranía hacia el litoral. En este caso, la existencia de los campesinos serranos en las plantaciones de la Costa ejercía una presión de los salarios a la baja, de forma que la burguesía podía obtener un mayor beneficio y acumular más

\footnotetext{
423 Pablo Palacio: Un hombre muerto a puntapiés, en "Obras Completas", Editorial Universidad de Costa Rica, 2000, p. 7-13.

424 Ministerio Coordinador del Desarrollo Social: Eloy Alfaro: Pensamiento y políticas sociales, Cassolutions Publicidad, Quito, 2012.
} 
capital.

Por otro lado, la falta de interés de la burguesía para reformar el sistema agrario, puede ser explicada teniendo en cuenta los antecedentes históricos y el peso de los terratenientes y latifundios en América Latina. Esto se aprecia en las débiles medidas empleadas para acabar con los abusos de los terratenientes, ya que una reforma agraria completa habría acabado con el apoyo de estos grupos al general Alfaro. Asimismo, una redistribución consecuente de la tierra habría procurado acabar con las bases de la dominación burguesa, pues su producción cacaotera se generaba en estos grandes latifundios. Albornoz afirma que la omisión de la reforma agraria, supuso el cierre al desarrollo acelerado del país y a una rápida industrialización que hubiera podido detener la penetración imperialista. Desde entonces, la transformación de la economía latifundista tendría lugar lentamente a través de la vía junker, que mantenía la gran propiedad agraria y los rasgos semifeudales según la conveniencia de los terratenientes, los cuales irían perdiendo el carácter de tales, para convertirse en capitalistas agrarios. Esta vía implicaba a su vez la existencia de una alianza entre la burguesía triunfante y los terratenientes derrocados y por tanto, el establecimiento de un estado burgués-terrateniente. ${ }^{425}$

Tras el asesinato de Alfaro (28-01-1912) y teniendo como base económica y social la omisión de la reforma agraria, se estableció un pacto entre la oligarquía liberal y el conservadurismo terrateniente, que bajo el dominio de los primeros, pretendía mantener el statu quo de la tierra y la explotación del pueblo. Esta alianza, que se había venido forjando desde tiempos atrás para acabar con el alfarismo, se consolidaría finalmente con la implantación de dicho pacto durante la segunda administración del general Plaza (1912-1916). ${ }^{426}$ Entonces, ¿cuáles fueron las implicaciones en el desarrollo de la economía ecuatoriana a raíz de la alianza entre conservadores y liberales?

En principio, hay que señalar la estabilización obtenida en materia política y en el sistema productivo, hecho que contribuyó a la unificación de las fuerzas de los sectores de la clase dominante bajo la dirección de la burguesía exportadora y bancaria de Guayaquil, a la vez que se conseguía el compromiso entre exportadores costeños y terratenientes serranos con la hegemonía del placismo.

\footnotetext{
${ }^{425}$ Oswaldo Albornoz Peralta, op. cit. p. 12-179.

${ }^{426} \mathrm{Su}$ mandato comprendió el periodo de 1901 a 1905.
} 
De este modo, la Revolución Liberal acabó siendo una transformación jurídica- política, que no sólo no llegó a afectar de forma decisiva la estructura de producción de la Sierra, sino que el sistema económico quedó condenado al esquema tradicional de exportación de productos agrícolas, en los que se tenía una ventaja comparativa por la situación geográfica. ${ }^{427}$

El establecimiento del statu quo de la tierra y de la vía junker como medio de introducción del capitalismo en el campo, fue un mecanismo que implicaba una lenta modificación de la economía latifundista en capitalista. En este caso, los campesinos apenas tenían derechos, siendo los beneficios exclusivos para los terratenientes que pasaron a ser capitalistas agrarios, al dejar de ser prioritarios sus intereses por la tierra.

Además, la permanencia del latifundio implicaba el mantenimiento de los métodos atrasados de cultivos y del bajo nivel de vida de los campesinos e impedía la acumulación de capitales, al obstaculizar la formación de un amplio mercado nacional. Así pues, la existencia de estos factores junto con la penetración imperialista impulsada por la alianza liberal conservadora, fueron algunos de los causantes del retraso socio-económico de la región.

En relación a los modos de producción, Marta Harnecker explica que en América Latina no se llegó a establecer el feudalismo con sus características político-jurídicas propias, sino las formas modificadas de la base económica general apoyada en la explotación servil. ${ }^{428}$ La existencia de formas intermedias entre los modos de producción, basadas en la servidumbre y en el trabajo asalariado, que surgieron en la masa campesina de los países latinoamericanos, es explicada a través de las relaciones de producción "semi-serviles”, ya que las razones jurídicas que unían al siervo a la propiedad fueron eliminadas, al venderle o entregarle la tierra. ${ }^{429}$

No obstante, es importante aclarar que a pesar del surgimiento de este nuevo tipo de relación, el campesino creaba una deuda, pues su producción no le permitía obtener los bienes necesarios para su subsistencia y la de su familia, por lo que se veía obligado a trabajar las tierras del terrateniente, recibiendo a cambio un pago en forma de tierras, productos y dinero. De esta manera, conforme el dinero pasaba a ser la parte fundamental del salario y la tecnología

\footnotetext{
${ }^{427}$ Fernando Velasco, op. cit., p. 15-200.

${ }^{428}$ Marta Harnecker: Los conceptos elementales del materialismo histórico, Siglo XXI, 2007, p. 163.

${ }^{429}$ V. I. Lenin: El desarrollo del capitalismo en Rusia, en Obras Completas, tomo 3, en: Marta Harnecker: "Los conceptos elementales del materialismo histórico”, Siglo XXI, 2007, p. 163.
} 
desplazaba la maquinaria rudimentaria, estas relaciones de producción se fueron convirtiendo en capitalistas. Es decir, aparece la denominada "vía junker de desarrollo capitalista" o la transformación de las antiguas haciendas feudales en haciendas capitalistas, en contraposición a la "vía americana", en la que el reparto de propiedades a los campesinos de forma apropiada constituye el rasgo fundamental, puesto que les permite transformarse en pequeños productores independientes y diferenciados de los capitalistas agrarios y del proletariado agrícola. ${ }^{430}$

Por su parte, la alianza entre las diferentes clases, a la que Albornoz considera de "contenido clasista y económico", generó un acercamiento de las ideologías en base a concesiones recíprocas. Es decir, mientras que los conservadores llegaron a aceptar determinados principios burgueses, la burguesía dejaba a un lado algunas de sus ideas de carácter más radical, siendo el objetivo común, el mantenimiento de la explotación de los campesinos a través de la instauración de un régimen de fuerza. ${ }^{431}$ En cambio, Velasco explica el acuerdo entre los diversos sectores de la clase dominante a partir del auge económico que se prolongó hasta el año 1920. Su idea parte del incipiente nivel de lucha entre clases, que eliminaba la presión para un cambio, y la existencia de factores ideológicos pre-capitalistas, que proporcionaban un notable prestigio a la aristocracia serrana. ${ }^{432}$

En cierto modo, la existencia de estos factores pudo facilitar el fin de los conflictos entre la burguesía comercial y los terratenientes de la Sierra, por lo que el desarrollo de las fuerzas productivas no logró crear un ambiente contradictorio demasiado importante como para liberar el mercado vinculado a las grandes haciendas. A la vez, la bonanza económica tampoco supo estimular la transformación del sistema, debido a la falta de capacidad por parte de la burguesía comercial para aprovechar el auge de la acumulación de capital.

En definitiva, estas circunstancias posibilitaron el mantenimiento de dicha alianza hasta bien entrada la década de los años treinta, consolidándose la unidad entre liberales y conservadores, con la excepción de que, a diferencia de los años anteriores, el control estaría en manos de los terratenientes en su paso hacia la clase capitalista.

\footnotetext{
${ }^{430}$ Ver el apéndice de notas del capítulo 1 para más información.

${ }^{431}$ Oswaldo Albornoz Peralta, op. cit. p. 12-179.

${ }^{432}$ Fernando Velasco, op. cit., p. 15-200.
} 


\section{5) Inestabilidad económica y el efecto de la política internacional (1915-1930).}

\subsection{1) La crisis económica y las consecuencias de la Primera Guerra Mundial: La declinación del comercio cacaotero y el impacto en la sociedad ecuatoriana.}

Con la llegada de la Primera Guerra Mundial (1914-1918), las exportaciones del cacao ecuatoriano entraron en una época llena de dificultades, creándose el marco necesario que daría lugar al comienzo de la crisis económica. La caída de los precios y la disminución de la demanda del cacao, la excepcional situación geográfica de otros países competidores respecto a los centros de consumo y la aparición de plagas que mermaron las plantaciones, fueron algunos de los factores responsables de la declinación de las exportaciones ecuatorianas. La combinación de estos acontecimientos y el impacto generado por la crisis en la sociedad ecuatoriana, constituirán el objeto de reflexión de este apartado, a partir del cual, se podrán analizar las acciones emprendidas por las fracciones dominantes para evitar el desastre económico.

Manuel Chiriboga hace alusión a la crisis económica de las primeras décadas del siglo XX:

A partir de 1910, la tendencia ascendente de los precios del cacao en el mercado mundial se transforma en una descendente. La sobreproducción mundial buscada por los propios monopolios chocolateros, se cristalizó en el rapidísimo crecimiento de la producción de cacao en el noroccidente africano, bajo dominio colonial. El derrumbe de los precios alteraría toda la estructura de acumulación establecida en el Ecuador y la relación entre los diversos agentes intervinientes.

El elevado nivel de la oferta mundial del cacao ecuatoriano, unido al hecho de que su producción y exportación se encontraba bajo el control de grupos nacionales, fue un elemento clave que terminó dando a estos grupos el control del poder monopólico en el mercado internacional. Por consiguiente, a medida que otros productores fueron insertándose en el mercado, como fue el caso de Ghana, Brasil y el Caribe, el poder monopólico del Ecuador comenzó a declinar. Así, el cierre de los principales puertos de acopio (Hamburgo y Londres) con la caída de los precios, provocó un descenso de su cuota de producción mundial,

\footnotetext{
${ }^{433}$ Manuel Chiriboga Vega, Los terratenientes costeños..., op. cit. p.239-254.
} 
que pasó de un $18 \%$ en 1902 a un $11 \%$ en 1922, mientras que la participación del cacao en el total de las exportaciones también disminuiría, pasando de un $77.3 \%$ en 1914 a un 46,2\% en 1925, como se refleja en el gráfico 11. Esto se debe a que después del término de la guerra, los países europeos prefirieron comercializar con sus colonias, provocando el consiguiente aumento de la dependencia ecuatoriana con respecto del mercado estadounidense. ${ }^{434}$

Gráfico 11: Porcentaje exportaciones cacao en las exportaciones nacionales (1914-1925)

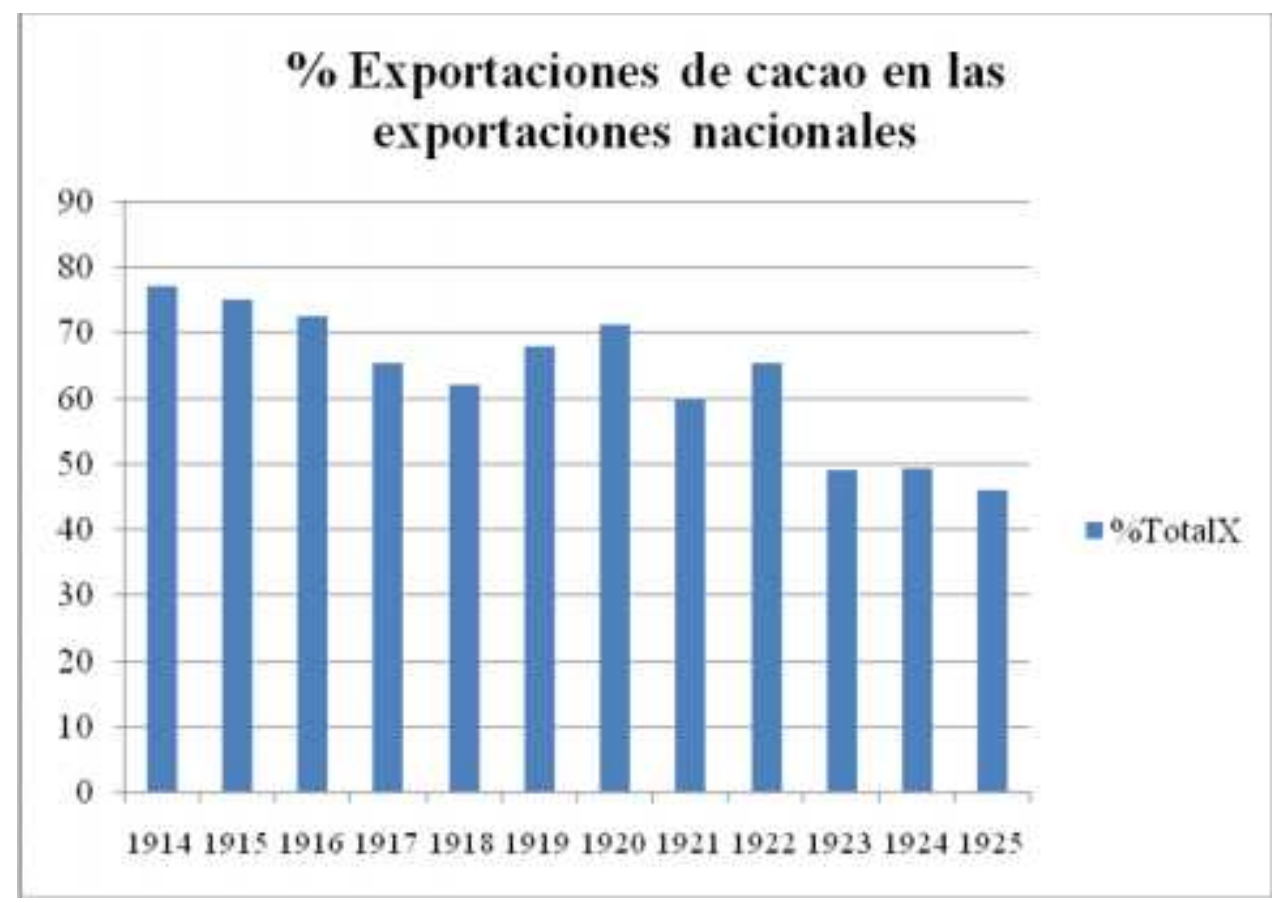

Elaboración propia a partir de los datos de la tabla 13.

Fuente: L. A. Rodríguez: The search for public policy: Regional politics and government finances in Ecuador, 1830-1940, University of California Press, Bekerley, 1985, p.191; L. J. Weinman: Ecuador and cacao: Domestic responses to the boom-collapse monoexport cycle, University of California, Los Angeles, 1970, p. 360; L. A. Carbo: Historia monetaria y cambiaria del Ecuador, Banco Central del Ecuador, Quito, 1953, p. 68.

Aquí, se ha de aclarar que la menor participación ecuatoriana en el valor de las exportaciones, no implicó necesariamente una reducción local de la producción cacaotera, ya que en el periodo

\footnotetext{
${ }^{434}$ Francisco Pareja Cucalón, op. cit. p. 388.
} 
señalado, hubo en la Costa un crecimiento sostenido de la producción de cacao (ver gráficos $\mathbf{3}$ y 4), entrando el Ecuador en una fase de sobreproducción que no le permitiría a la burguesía exportadora lograr su sueño de controlar el precio del cacao. ${ }^{435}$ La guerra causó un efecto desastroso en la agro-exportación de cacao, ya que no solamente cerraron los puertos mencionados anteriormente, sino que el transporte por mar comenzó a presentar problemas debido a los cambios en la orientación del sistema naviero hacia el transporte de las necesidades de los países en conflicto, mientras que existían numerosas dificultades en el giro de letras de cambio. Estos problemas fueron algunos de los motivos que provocaron la bajada del precio del cacao y su almacenamiento en Guayaquil, llegando a acumularse sus reservas en grandes cantidades en las casas exportadoras.

Para poder limitar estos efectos negativos, se organizó en el año 1911, la Asociación de Agricultores protectores del cacao con el apoyo financiero del estado, con el objetivo de influir sobre el precio internacional del cacao mediante la manipulación de existencias.

Ante las graves dificultades que afectaban a los hacendados cacaoteros y a la fracción comercial de la burguesía, la Asociación de Agricultores protectores del cacao, con la colaboración del Banco Comercial y Agrícola y durante la presidencia de Leónidas Plaza (1912-1916), intervino comprando y almacenando grandes stocks del producto para poner fin a las pérdidas iniciales debido a la depresión de los precios pagados por los exportadores a los productos. ${ }^{436}$ Además, esta asociación contrató créditos con bancos privados, pues durante esos años, dichos bancos tenían el control de la política económica, gozando por tanto, de la facultad para emitir billetes. ${ }^{437}$

En este sentido, la administración de Plaza logró fortalecer el compromiso entre los exportadores de la Costa y los terratenientes de la Sierra. No obstante, el gobierno central

\footnotetext{
${ }^{435}$ Gerardo Aceituno: La acumulación de capital en la formación social ecuatoriana, en Aceituno et al. Ecuador, Historia y Acumulación de Capital, Cuenca, F. de Ec., 1978, p. 47-153.

${ }^{436}$ Mario Canessa Oneto: La Banca del Ecuador: Una explicación histórica, Escuela Superior Politécnica del Litoral, 1958, p. 1-5.

${ }^{437}$ La propuesta para que los países tuvieran Bancos Centrales, surgió en la Conferencia Internacional de Bruselas en 1920, por lo que a finales de 1925, el Ministro de Hacienda de la Junta de Gobierno (Luis Dillon) preparó la creación del Banco Central del Ecuador, lo que llevó a numerosos conflictos entre el poder del estado y el de la Banca de la ciudad de Guayaquil. En este sentido, el Banco Central no fue creado para competir con la Banca Comercial, pero su presencia logró modificar las reglas del juego en cuanto al poder político del país. Fuente: Ibid. p. 1-6.
} 
dependía de los créditos de las entidades financieras privadas, las cuales controlaban el poder político, de ahí que la burguesía agro-exportadora y financiera o bancocracia, poseedora de dicho poder, pretendiera adecuar la política económica para adaptarla a las necesidades del momento, sin que esto afectara al proceso de reproducción del capital, hecho que implicaba trasladar las pérdidas a las mayorías populares. ${ }^{438}$

Francisco Pareja afirma que el coste de adquirir y mantener existencias de la "pepa de oro", junto con la participación del estado en política y la dependencia de este último en el sistema bancario privado, fueron los responsables de que el desastre exportador se convirtiera también en financiero. A su vez, la crisis de las exportaciones hizo que numerosas haciendas y plantaciones no pudieran hacer frente a las deudas que habían contraído con el sistema bancario, por lo que algunas de ellas fueron embargadas al vencerse los créditos hipotecarios y otras fueron vendidas para poder cubrir sus gastos de producción. ${ }^{439}$

De forma paralela, este problema fue empeorando cuando el creciente deterioro económico afectó al proceso productivo, creándose las condiciones para la rápida expansión de las plagas (la monilia y la escoba de la bruja), que acabaron arruinando a un numeroso grupo de hacendados.

Con respecto al criterio de que la crisis del cacao ocurrió como consecuencia de las plagas, algunos autores, entre los que destacan Luis Carbo, justifican su origen en el funcionamiento del capitalismo mundial. Es decir, se puede pensar que al estar orientada la agricultura costeña hacia el mercado externo, esta se vio expuesta a las fluctuaciones del sistema capitalista.

Este hecho indica que el carácter dependiente de su producción, así como la extrema especialización de cacao hasta la década de 1920, fueron los determinantes de las sucesivas etapas por las que transcurrió la economía de la Costa, además de ser los elementos cruciales a la hora de transformar las relaciones productivas dominantes en la región. ${ }^{440}$

En relación a la situación de la Sierra, hay que destacar su mejor adaptación a la crisis, pues a

\footnotetext{
${ }^{438}$ L. Weinman: Ecuador and cacao: Domestic Responses to the Boom-Collapse, Monoexport Cycle, University of California, Los Ángeles, 1970, p.188-92.

${ }^{439}$ Francisco Pareja Cucalón, op. cit., p. 388-389.

${ }^{440}$ Ya vimos cómo en el año 1850, el cacao ya representaba el 50\% de las exportaciones totales, acentuándose esta especialización extrema de la economía exportadora durante los años siguientes. Así, hacia 1908, la proporción era de un 63\%, y para 1920, cuando se presentó la crisis definitiva, el cacao representaba el $75 \%$ de las exportaciones. Fuente: Ibíd., p. 388-390.
} 
diferencia de la Costa, no dependía de la comercialización del cacao, siendo su producción principalmente artesanía textil y alimentos destinados al consumo local. ${ }^{441}$

En este sentido, un informe sobre el cacao ecuatoriano elaborado por Luis A. Carbo en 1917, indica el impacto causado por la guerra en el mercado del cacao:

La escasez de vapores, los altos fletes y seguros, las dificultades respecto a cambios y letras, son ya bastante conocidos. Posteriormente, se fue agravando la situación: con la prohibición o restricciones dictadas por Inglaterra y Francia contra la importación de cacao, con la mayor escasez de vapores para su transporte a Europa, con las acumulaciones de cacao en los centros de producción y consumo, con la carestía del azúcar en los países europeos y con el proyectado impuesto americano al cacao, equivalente a 7,50 sucres el quintal... ${ }^{442}$

Es el mismo Carbo, el que apunta al incremento de la producción mundial y a los problemas enumerados, como los principales responsables de que la burguesía comercial costeña se viera obligada a vender a consignación la mayor parte de su cacao. Así, en el periodo 19131916, la Asociación de Agricultores vendió el 87\% del cacao a consignación, lo que en términos económicos significaba depender de los grupos comerciales del exterior y del Banco Comercial y Agrícola, ya que durante esos años había adelantado a la Asociación de Agricultores aproximadamente 23 millones de sucres. También, la volatilidad de los precios del cacao (que pasaron, en el primer trimestre de 1920, de un máximo de 26,75 centavos de dólar por libra a 12 centavos a finales del mismo año y a un mínimo de 5,75 en 1921) y la disminución del volumen de las exportaciones, provocaron una caída del valor de las mismas, como se puede observar en el siguiente gráfico: ${ }^{443}$

\footnotetext{
${ }^{441}$ Galo Abril-Ojeda: Auge exportador y desarrollo en Ecuador, en: Trayectorias divergentes: comparación de un siglo de desarrollo económico latinoamericano y escandinavo, Magnus Blomström y Patricio Meller, Coordinadores, Santiago de Chile: Cieplan, 1990.

${ }^{442}$ Luis A. Carbo, op. cit. p.465.

${ }^{443}$ Ibíd. p.464-465.
} 
Gráfico 12: Exportaciones de cacao (1900-1925)

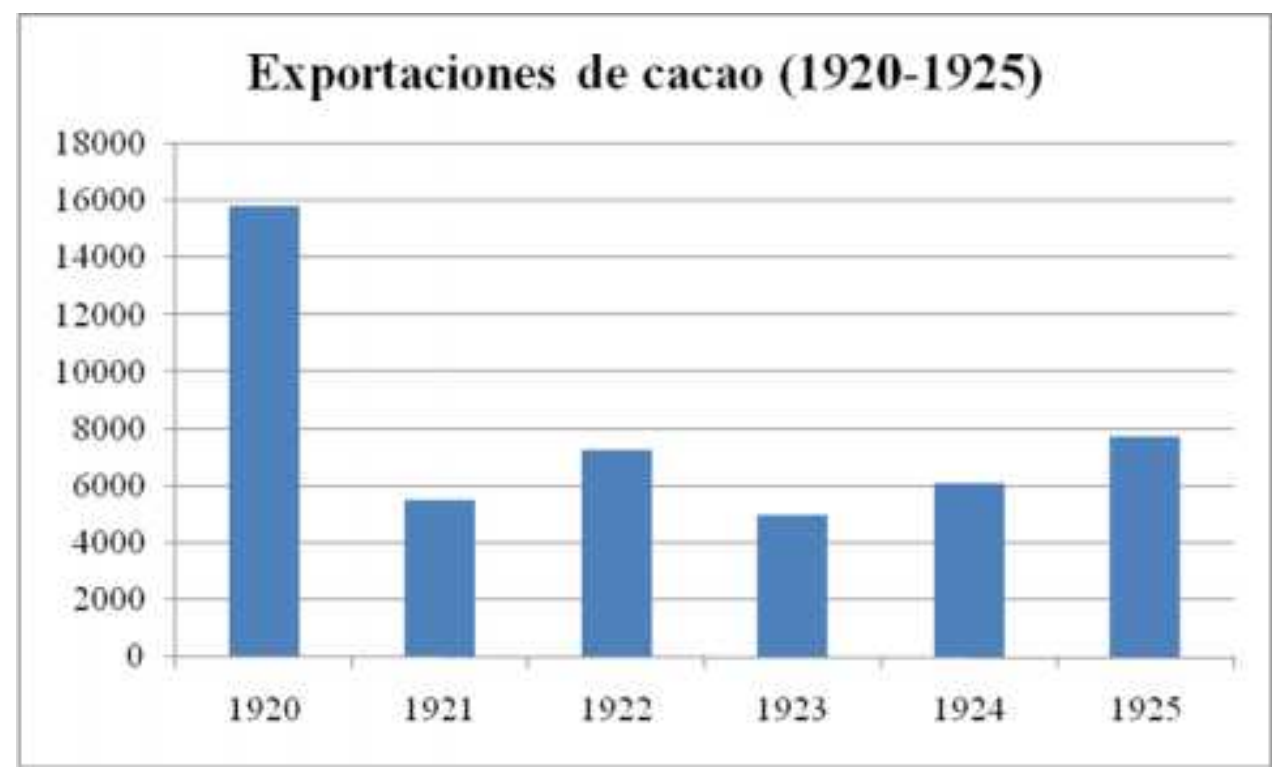

Elaboración propia a partir de los datos de la tabla 13.

Fuente: L. A. Rodríguez: The search for public policy: Regional politics and government finances in Ecuador, 1830-1940, University of California Press, Bekerley, 1985, p.191; L. J. Weinman: Ecuador and cacao: domestic responses to the boom-collapse monoexport cycle, University of California, Los Angeles, 1970, p. 360; L. A.Carbo: Historia monetaria y cambiaria del Ecuador, Banco del Ecuador, 1953, p. 68.

De igual forma, la tabla 15 (Exportaciones desde 1900 a 1969) refleja una disminución del promedio de exportaciones de dólares, lo cual tuvo una profunda influencia en el estancamiento general de la economía y graves retrocesos en las zonas productoras de la Costa, hecho que explica que la crisis tuviera un origen de tipo estructural. ${ }^{444}$

Ante esta situación, el estado recurrió a los bancos de Guayaquil y al Banco Comercial como mecanismos de financiación, tras la disminución de los ingresos que recibía de las exportaciones de cacao. Este intervalo de tiempo, al que los historiadores ecuatorianos denominaron "plutócrático" o de la "bancocracia", se caracterizó por una política de emisión incontrolable por parte de las entidades bancarias, siendo sus acciones apoyadas por el

\footnotetext{
${ }^{444}$ Esta tabla se encuentra en el apéndice de datos del capítulo 1. Fuente: Osvaldo Barsky, Gustavo Cosse: Tecnología y cambio social: Las haciendas lecheras del Ecuador, Facultad Latinoamericana de Ciencias Sociales (FLACSO), USDA National Agricultural Library, Capítulo II: El patrón de desarrollo económico y el rol del sector agropecuario en relación al proceso de conformación del estado, apartado "La declinación del cacao y la expansión inicial del estado", 1981.
} 
estado para poder afrontar la crisis, pero ¿cuáles fueron los resultados obtenidos al aplicar esta política monetaria durante la denominada "bancocracia"?

Los efectos de estas medidas no tardaron en manifestarse, ya que el país entró en un periodo inflacionario con grandes repercusiones de carácter social. Este proceso afectó a buena parte de las clases trabajadoras y a los grupos urbanos que, a pesar de haberse desarrollado en torno al comercio y al sector financiero, tenían una situación precaria. ${ }^{445}$ También, los hacendados de la Sierra que no habían participado de la bonanza de las exportaciones y el sector manufacturero serrano sintieron el impacto del proceso inflacionario.

Ayala muestra que en este marco de descontento popular, el control del poder de la burguesía comercial y bancaria llegó a debilitarse seriamente, mientras que el latifundismo serrano iniciaba la lucha para retomar su antigua posición. ${ }^{446}$ A su vez, aclara que la división del poder plutocrático se explica por la presión que ejercían los nuevos grupos, los cuales reclamaban un espacio dentro de la nueva escena social y política. Es decir, los sectores medios, fortalecidos por la implantación del estado laico, luchaban contra la dominación oligárquica e intentaban ampliar su reducida cuota de poder político. ${ }^{447}$

Chiriboga coincide con estas ideas y añade que la caída de precios fue el factor principal que alteró la estructura de acumulación establecida en el Ecuador, así como la relación entre los diversos agentes. A partir de aquí, los bancos y las casas comerciales buscaron transmitir la crisis hacia la producción a través de políticas inflacionarias, las cuales acabarían golpeando al sector más tradicional y atrasado de la clase terrateniente y a la masa de trabajadores. ${ }^{448}$ Llegados a este punto, el descontento político y social se generalizó rápidamente en contra del gobierno liberal, siendo el resultado el golpe militar del 9 de julio de 1925, más conocido como la Revolución Juliana. Esta revolución puede ser entendida como un intento del ejército y de diversos grupos civiles para iniciar un proceso de democratización y modernización del estado y el país. Pero, ¿qué se consiguió con la Revolución Juliana? ¿cuáles fueron realmente

\footnotetext{
${ }^{445}$ Los miembros de estos grupos fueron los encargados de organizar los sindicatos y combatir al sistema con todos los medios intelectuales a su alcance.

${ }^{446}$ Enrique Ayala Mora, Resumen de historia..., op. cit. p. 12-44.

${ }^{447}$ Ibíd. p. 12-44.

${ }^{448}$ Manuel Chiriboga Vega, op. cit. p. 239-254.
} 
los objetivos establecidos?

El movimiento juliano expresó una nueva realidad que se había ido conformando en el país, de forma que la legislación social procuraba incorporar la redistribución de excedentes a los sectores de trabajadores, mientras que las medidas económicas estaban dirigidas a los grupos financieros comerciales costeños. ${ }^{449}$ No en vano, dicho movimiento, estaba impulsado por la pequeña burguesía, que al no disponer de los medios de producción fundamentales, pretendió servir a los sectores populares y reorientar la vida económica del país sin modificar la estructura productiva y tampoco la estructura de clases de la sociedad. Por consiguiente, únicamente logró debilitar el poder de la burguesía costeña, fortalecer el latifundismo serrano e iniciar un proceso de institucionalización del estado ajustado a las nuevas formas de dominación que lideraba Estados Unidos. Esto justifica el que no se introdujera ninguna reforma sustancial que modificara la concentración de la tierra, eliminara los privilegios de la banca y mejorara las condiciones populares.

Además, la carencia de una base económica y la debilidad de la pequeña burguesía para enfrentarse a la burguesía bancaria de Guayaquil, fue suficiente para que estuviera al amparo del gamonalismo serrano, principal beneficiario del julianismo. Por otro lado, los cambios sociales ocurridos tras la Revolución, fueron proyectados en la esfera política, produciéndose una reagrupación de las viejas fuerzas y la creación de otras nuevas.

Al referirse a esto, Ayala ubica el surgimiento de los partidos políticos modernos del Ecuador en el año 1925, durante el cual se reconstituyó el Partido Conservador Ecuatoriano, mientras que en 1926 se fundó el Partido Socialista Ecuatoriano. Los militares julianos incluyeron en su programa algunas ideas socialistas e inclinaciones hacia los trabajadores, pero su paso por el poder trajo una serie de innovaciones que favorecieron a los sectores medios, principalmente a la burocracia, e impulsaron la modernización estatal. Por su parte, el socialismo se constituyó en el polo de influencia ideológica más dinámico del Ecuador, pues en cierto sentido, implicaba la continuidad del radicalismo liberal y la base de la lucha por el

\footnotetext{
${ }^{449}$ Para más información de la Revolución Juliana, ver el apéndice de notas del capítulo 1. Fuente: Juan J. Paz, Miño Cepeda: La fundación del Banco Central del Ecuador y su significado histórico a los 75 años, Taller de Historia Económica, Noviembre 2002, Año II- Número 2, 2002; Juan J. Paz, Miño Cepeda: La Revolución Juliana: Nación, ejército y bancocracia", Abya-Yala, Quito, Ecuador, 2002; Guillermo Arosemena: La Revolución Juliana: Evento ignominioso en la historia de Guayaquil, Archivo Histórico del Guayas, Guayaquil, 2002; Rafael Quintero: El mito del populismo: Análisis de los fundamentales del estado ecuatoriano moderno (1895-1934)”, FLACSO, Quito, 1980, p. 242.
} 
laicismo, especialmente en la educación, donde la izquierda socialista tuvo gran influencia. ${ }^{450}$ En definitiva, aunque la Revolución Juliana acabó con la dominación liberal y la división liberal-conservadora llegó a suavizarse en términos políticos, ambos partidos mantuvieron su importancia en el proceso posterior. Además, en esta época, el estado se configuró como un espacio a disposición de las diversas fracciones dominantes y no como un ámbito de mediación entre la sociedad civil y el ejercicio del poder.

Asimismo, la inexistencia de una fracción burguesa interesada en la ampliación del mercado interno y la falta de integración de los campesinos en la economía monetaria, parecen ser algunos de los elementos fundamentales que justifican la inexistencia de un sistema político adecuado. Si bien el crecimiento de los servicios y de la industria y de algunas actividades semiartesanales provocó un aumento de los sectores de trabajadores, la mayor parte de la fuerza de trabajo era campesina. Por consiguiente, una vez terminado el periodo de bonanza cacaotera, el país entró nuevamente en un proceso de inestabilidad política, que duró hasta finales de la década de los años cuarenta. ${ }^{451}$

\subsection{2) El proceso de industrialización en el Ecuador: Dificultades para sustituir el modelo agro-exportador.}

Con anterioridad, se ha analizado cómo el desarrollo del capitalismo en el Ecuador no llegó a adquirir una dinámica similar a la que tuvo lugar en Europa, sino que su aparición ocurrió de forma repentina y solamente se expandió como consecuencia de la articulación al mercado mundial de los centros urbanos y de algunos espacios económicos rurales, que se encontraban integrados en la agro-exportación. Esta actividad, al ser prácticamente la única fuente de desarrollo de la economía ecuatoriana, pasó convertirse en el eje del sistema de acumulación, con lo que a finales del siglo XIX, la agro-exportación junto con la infraestructura de transporte fueron absorbiendo lentamente el progreso tecnológico.

Se puede observar que la falta de avances técnicos en el dinamismo de las actividades exportadoras, se debió en parte a la gran disponibilidad de la mano de obra, que como ya se

\footnotetext{
${ }^{450}$ Enrique Ayala Mora, Resumen de historia..., op. cit. p. 12-44.

451 Osvaldo Barsky, Gustavo Cosse: Tecnología y cambio social: Las haciendas lecheras del Ecuador, Facultad Latinoamericana de Ciencias Sociales (FLACSO). USDA National Agricultural Library. Capítulo II: El patrón de desarrollo económico y el rol del sector agropecuario en relación al proceso de conformación del estado, apartado: La declinación del cacao y la expansión inicial del Estado, 1981.
} 
ha dicho, estaba supeditaba a una explotación de tipo pre-capitalista y tenía un costo monetario casi nulo. ${ }^{452}$ Por otro lado, también se ha de aludir a las condiciones internacionales en cuanto a los productos primarios, pues al no existir una gran presión competitiva, era posible la apropiación de amplios beneficios. Entonces, ¿qué papel desempeñó la industrialización en el desarrollo de la economía ecuatoriana y en la acumulación de capital?

Sabemos que desde la época colonial, existieron algunas industrias de importancia entre las que figuraban la industria textil y la industria naval debido a la importancia de los astilleros de Guayaquil durante los dos últimos siglos coloniales, pues tenían mayor actividad que el resto de los puertos en la costa del Pacífico y de Europa. ${ }^{453}$

La relación entre la geografía y el desarrollo económico en Guayaquil se muestra a partir del impacto que tuvo el aprovechamiento de la riqueza maderera de sus bosques, los cuales eran regados por la red hidrográfica del Guayas:

Dado el carácter desértico de la Costa peruana, las maderas de Guayaquil se convierten ya desde los primeros tiempos de la colonia en el principal material de construcción de las ciudades costeras... ${ }^{454}$

Aquí, hay que destacar que una buena parte de las maderas no fueron exportadas en bruto, sino que a menudo eran aserradas y labradas en Guayaquil, en donde se desarrolló una notable industria de aserraderos y de carpintería y ebanistería. Como consecuencia, llegó a ser el astillero más importante del Pacífico americano debido a la amplia disponibilidad de materia prima para la construcción naval. ${ }^{455}$

Con la independencia, surgieron otro tipo de industrias que se fueron creando dentro de las limitadas perspectivas del mercado interno, produciéndose su expansión de una manera irregular

\footnotetext{
${ }^{452}$ Ver el apéndice de notas del capítulo 1 para más información.

${ }^{453}$ Para más información de la industria textil en el Ecuador, ver el apéndice de notas del capítulo 1.

${ }^{454}$ Lawrence Clayton: Los astilleros de Guayaquil colonial, Guayaquil, Archivo Histórico del Guayas, 1978, p. 12175; Nick Mills, Gonzalo Ortíz: Economía y sociedad en el Ecuador postcolonial, Cultura, Revista del Banco Central del Ecuador, vol, II, número 6, Quito, 1980, p. 17-270.

${ }^{455}$ M. Luisa Laviana: Guayaquil en el siglo XVIII, Recursos naturales y desarrollo económico, Escuela de estudios hispano-americanos de Sevilla, 1987, p. 10-300.
} 
como resultado del gran poder de las fracciones del bloque dominante. ${ }^{456}$

La combinación entre oligarquía mercantil y terrateniente (al mantener el esquema latifundistatradicional y estimular la importación de artículos industriales desde los países metropolitanos) fue la responsable de organizar una economía de rasgos agro-exportadores, terratenientes y financieros. Es decir, se creó un estado reestructurado según las clases sociales dominantes en el país, lo cual explica la dificultad a la hora expandir el mercado interno y llevar a cabo un proyecto industrializador. ${ }^{457}$

En tales condiciones, las posibilidades para plantear una política industrial progresista y popular, que hubiera vulnerado los intereses de los latifundistas, eran mínimas. No se concibe la industrialización sin un mercado interno y no es posible crear este en un país agrícola sin atentar contra los propietarios de la tierra. ${ }^{458}$ Tampoco, se tocaron los intereses del artesanado, que gozaba de gran poder, a diferencia de otros países en América Latina, donde tuvieron lugar rebeliones contra el comercio libre, como fue el caso de Colombia. ${ }^{459}$

Así, en Europa y Japón se proyectó un desarrollo equilibrado entre la industria y la agricultura, mientras que en el Ecuador, este proceso tuvo como base un desequilibrio continuo que impedía a la agricultura constituirse como una fuente de estímulos para las innovaciones de origen industrial.

Por otra parte, la estrechez y el lento desarrollo del mercado interno ecuatoriano dificultaron la configuración de estructuras competitivas para impulsar la creatividad tecnológica. Esta circunstancia justifica la compleja situación que enfrentaba el capitalismo ecuatoriano a la hora de reproducir las fuerzas innovadoras endógenas, hecho que llegó a convertirse en un factor inherente a su condición de capitalismo dependiente.

A su vez, se observa que este tipo de economías, en las que no había un mercado interno significativo, no existieron suficientes posibilidades para la aparición de una producción capitalista de bienes de capital, sobre todo si se trataba de economías abiertas al mercado

\footnotetext{
456 Gonzalo Correa Escobar: La economía ecuatoriana de 1830 a 1980, Libro del Sesquicentenario, Corporación editora nacional, III Economía/Ecuador 1830-1980 primera parte, 1983, p. 13-30.

457 José Moncada: Panorama general de la economía en el Ecuador republicano, Libro del Sesquicentenario, Corporación editora nacional, III Economía/Ecuador 1830-1980 primera parte, 1983, p. 51.

${ }^{458}$ Fernando Velasco, op. cit. p. 184.

${ }^{459}$ Para más información de las organizaciones artesanales, ver el apéndice de notas del capítulo 1.
} 
internacional, cuya actividad fundamental era la agro-exportación. No obstante, Sandoval Moreano hace referencia al desarrollo de la industria textil, al indicar que parte de los ingresos procedentes de las exportaciones de cacao y de otros productos tropicales, permitían la generación de empleo manufacturero industrial, pues a pesar de que los grupos exportadores lograban cierta acumulación de capital, la contradicción de intereses entre la oligarquía exportadora y la burguesía industrial, no permitía la incursión en actividades industriales, a menos que estuvieran relacionadas con la producción agrícola. ${ }^{460}$

Velasco señala que el crecimiento de la industria textil se produjo a partir de la inexistencia de factores estructurales que pudieran impedirlo, puesto que el nivel de desarrollo del mercado interno aseguraba la demanda de una adecuada cantidad de tejidos. En la tabla 17 (Evolución de las importaciones por grupos de artículos, 1928-1930 y 1948-1950) se muestra una disminución de las importaciones de textiles en el periodo 1948-1950 con respecto a 19281930; mientras que en la tabla 18 (Variaciones en las importaciones de textiles, 1928-1930 y 1948-1950), se aprecia dicha sustitución de importaciones, al desglosarse esta partida en materia prima, productos semi-elaborados (hilados) y productos acabados (tejidos $\mathrm{y}$ confecciones). ${ }^{461}$

A su vez, Cristian Sepúlveda indica que el proceso de industrialización que tuvo lugar en América Latina a partir de la Gran Depresión, está caracterizado por la aparición de una nueva etapa de acumulación, en la que la vieja economía agro-exportadora logró abrirse paso a su conversión en economía industrial. Esta transición, que perduró hasta el inicio del periodo de posguerra, encontró como elemento principal, la crisis de reorganización estructural que el mercado mundial vivió y cuyos efectos se manifestaron en un aflojamiento de las relaciones de dependencia. Por consiguiente, consideraremos este periodo de integración de América Latina al mercado internacional, como el momento clave, en el que se pudo configurar el contexto de las nuevas formas y orientaciones adquiridas por el progreso tecnológico a escala social. ${ }^{462}$

\footnotetext{
460 Fabián Sandoval Moreano: La fuerza de trabajo en el Ecuador Republicano, Libro del Sesquicentenario. Corporación editora nacional, III Economía/Ecuador 1830-1980 primera parte, 1983, p. 51-70.

${ }^{461}$ Estas tablas se encuentran en el apéndice de datos del capítulo 1. Fuente: CEPAL: El desarrollo económico del Ecuador, México, N.U., 1954, p. 27-28.

${ }^{462}$ Cristian Sepúlveda: Estado y fases de acumulación dependiente en el desarrollo capitalista chileno, Berlín
} 
La gran crisis de la plantación cacaotera y la subordinación del trabajador a la gran propiedad, acabó provocando un creciente proceso de pauperización. Es decir, las plantaciones comenzaron a eliminar mano de obra, que en las grandes ciudades tenía que hacer frente a un mercado de trabajo limitado por la falta de centros manufactureros, lo cual generó serios problemas de desempleo y protestas populares.

Estos hechos permiten entender cómo el proceso de industrialización llevado a cabo en la actividad textil, logró fortalecerse en la Sierra, al estar ligada al latifundio serrano y basarse en una legislación proteccionista. En este caso, si bien la división técnica del trabajo era bastante precaria, esta nueva demanda de mano de obra tendía a generar un nuevo grupo social ligado al capital a través de relaciones salariales.

A este respecto, se ha de mencionar la creación de un espacio de acumulación en la modernización capitalista de la agricultura, en la eliminación de las formas precarias de tenencia de la tierra, en la expansión de la frontera agrícola y políticas estatales de fomento, generándose un proceso de disolución de la economía terrateniente. ${ }^{463}$

Por otro lado, la Gran Depresión provocó una disminución de la capacidad de importación en el Ecuador, a la vez que se produjo un descenso de inversión extranjera y de los flujos importados de tecnología incorporada en los equipos. Frente a este hecho, la intervención del estado en la asignación de las divisas, condujo a que la industria desplazara a las actividades agroexportadoras como principales sectores de absorción del progreso técnico.

Sin embargo, a pesar de los planes para establecer este nuevo modelo de desarrollo, la situación financiera del Ecuador continuó empeorando durante los años treinta como consecuencia de la gran crisis internacional del capitalismo.

El deterioro de la fuerza de trabajo debido a la escasa industrialización, la cual no pudo absorber la mano de obra urbana, junto con las escasas transformaciones del mercado interno, llevaron a que el estado siguiera usando el modelo exterior de exportación: con las sucesivas devaluaciones y a la superexplotación del campesinado, se mantiene el viejo modelo de

Occ. Mimeo, 1978, p. 262.

${ }^{463}$ Cristian Sepúlveda, Gilda Farrell, Jorge Fernández: Estrategias de desarrollo rural y economías campesinas: Hacia la formación de una nueva política tecnológico-ocupacional, en Estructuras agrarias y reproducción campesina, Lecturas sobre transformaciones capitalistas en el agro ecuatoriano, Ed. IIE-PUCE, 1982, p. 35-270. 
crecimiento en base a las exportaciones tradicionales... ${ }^{464}$

Por su parte, la burguesía criolla continuó manteniendo su política de importación de productos sustitutos, que además de provocar un déficit en la balanza comercial, fomentaba un estrangulamiento de la producción nacional. El impacto ocasionado por esta política antinacional (en la producción agrícola de consumo interno y en la manufacturera) fue notable, pues la importación de diversos productos (harina, trigo, queso, embutidos, galletas, chocolate, jabones, etc.) desplazaba continuamente a la producción nacional, mientras favorecía a la economía imperialista norteamericana, que buscaba colocar sus excedentes en el mercado internacional recurriendo a la política del dumping. De esta forma, en el periodo 1929-1942, la balanza comercial ecuatoriana alcanzaba un déficit aproximado de 182 millones de sucres, el cual solo pudo ser cubierto con la venta de reservas de oro por parte del Banco Central. ${ }^{465}$ ¿Cuáles fueron las razones que explican el mantenimiento de este tipo de políticas que impedían a la vez el desarrollo de la economía ecuatoriana?

Bajo estas circunstancias, hemos de pensar que la escasez de condiciones estructurales internas, no sólo implicaba la eliminación de los estímulos necesarios para impulsar la producción, sino que además dificultaba su supervivencia frente a la presión competitiva de la industria mundial de bienes de capital. Por otro lado, se observa que la implantación de este tipo de políticas ocurrió porque no llegó a existir un grupo interesado en impulsar la formación de un sector industrial que liderara la economía nacional. ${ }^{466}$

En otras palabras, la disminución del capital necesario para fomentar la industrialización, junto con el reducido tamaño del mercado interno y la ausencia de un grupo de industriales capaces de impulsar un conjunto de medidas para ampliar el mercado interno, fueron algunas de las causas que posibilitaron la supervivencia de las políticas mencionadas. ${ }^{467}$

\footnotetext{
${ }^{464}$ Fernando Velasco, op. cit. p. 181.

${ }^{465}$ Washington Macías, op. cit. p. 20-159.

466 Cristian Sepúlveda: El proceso de industrialización ecuatoriano, en "Progreso científico-tecnológico, acumulación y políticas económicas en América Latina, El caso de América Latina”, Instituto de Investigaciones Económicas, Pontificia Universidad Católica del Ecuador, Publicaciones IIE, PUCE, primera edición, 1983 , p. 254.

${ }^{467}$ Fernando Velasco, op. cit. p. $180-183$.
} 


\section{CAPÍTULO 2: LA EXPANSIÓN DEL SISTEMA CAPITALISTA Y EL DESARROLLO DEL COMERCIO EXTERIOR EN EL ECUADOR (1948-1965):}

\section{1) Nuevas tendencias en la acumulación del capital ecuatoriano: El banano y su auge exportador (1948-1956).}

\subsection{1) El modelo de desarrollo agro-exportador y sus características.}

El proceso de desarrollo económico del Ecuador durante el siglo XX, se ha caracterizado por la implementación de dos modelos económicos sustancialmente diferentes, cada uno con sus propias políticas macroeconómicas y de sector agropecuario asociadas. El primer modelo aplicado, el modelo agro-exportador, vino a constituir el motor del desarrollo económico ecuatoriano desde la época colonial hasta finales de la década de los cincuenta del siglo pasado, mediante la exportación de minerales y productos agrícolas de limitado procesamiento, siendo el cacao, uno de los más destacados, como ya se ha indicado. ${ }^{468}$

El énfasis en el segundo modelo, la industrialización por sustitución de importaciones, surgió principalmente como consecuencia de los problemas existentes y de las limitaciones a la hora de organizar una economía de mercado debidamente articulada. Para ello, el pensamiento de la CEPAL concentró sus esfuerzos en la búsqueda de teorías que lograran sustentar la autosuficiencia a través de la sustitución de las importaciones y la planificación estatal, haciendo su aparición en el Ecuador en el año 1954.

El rechazo de la tecnocracia con respecto a los grupos dominantes de la Costa y el control que estos ejercían en el desarrollo de la economía, fue motivo suficiente para que se impulsara la nueva doctrina, que vino a constituirse en un incentivo para el traspaso del dominio político a manos del estado. Si bien la institucionalidad de la planificación llevó consigo la promoción de la sustitución de importaciones durante la década de los cincuenta y buena parte de los sesenta, este proceso comenzó a caracterizarse por su simplicidad, al basarse fundamentalmente en

\footnotetext{
468 Durante el siglo XVI y XVII, la minería y la exportación de oro y plata a España eran las principales actividades económicas, junto con las exportaciones de textiles. Posteriormente, la economía ecuatoriana pasó por una fase de transición, aumentando su dependencia con respecto a la agricultura y ganadería, siendo la agricultura el factor dominante de la economía hasta el siglo XVIII. Los principales cultivos incluían cereales y tubérculos de la Sierra, tabaco, café, cacao, caña de azúcar y madera de la cuenca tropical del río Guayas, cerca de Guayaquil. Además, el cacao y el tabaco se convirtieron en importantes productos de exportación en las últimas décadas del siglo XIX. Fuente: Morris D. Whitaker, Dale Colyer, Jaime Alzamora: El rol de la agricultura en el desarrollo económico del Ecuador, en "Un diagnóstico del sector agrícola del Ecuador", U. S. Department of Agriculture, National Agriculture Library, 1990, p. 27.
} 
industrias de bienes de consumo inmediato (particularmente de bebidas y alimentos), lo cual implicaba procesos tecnológicos relativamente simples, como se verá más adelante.

Al referirse a estos modelos, Francisco Swett indica que la historia económica del Ecuador ha estado condicionada por una diversidad de factores, los cuales han dificultado el establecimiento de un modelo de desarrollo que demuestre continuidad en el tiempo y que pueda ser definido como un conjunto congruente y sistemático de política económica, apoyado en una filosofía reconocible y con objetivos claramente determinados. ${ }^{469}$ Es decir, la inestabilidad política, característica de la historia republicana, ha sido el principal elemento que ha imposibilitado la formación de un cuerpo coherente de doctrina y práctica.

Con anterioridad, se vio cómo los primeros veinte años del siglo $\mathrm{XX}$, presenciaron un continuo crecimiento de las exportaciones agrícolas lideradas por el cacao, y cómo se originó un balance positivo en las cuentas corrientes comerciales anuales, al ser el valor de las exportaciones superior al de las importaciones. Posteriormente, el periodo de la posguerra (la década de los cincuenta) será el que marque la plena vinculación de la economía ecuatoriana al sistema capitalista internacional, y con ello, el inicio de un proceso de penetración del capitalismo en todos los niveles de la formación social, ubicándose su comienzo en la etapa del denominado modelo de desarrollo agro-exportador. En efecto, el alza de los precios del café y del cacao y la acelerada expansión de las exportaciones del banano, van a constituir la base de un proceso de acumulación interno, que vendrá acompañado de importantes cambios en el conjunto de la sociedad.

Por consiguiente, teniendo como referencia el modelo agro-exportador, el Ecuador llegó a especializarse en la producción y exportación de determinados bienes agropecuarios, a la vez que importaba productos manufacturados, siendo este, el mecanismo de vinculación al mercado capitalista mundial. En cambio, hay que aclarar que contrariamente a lo que sucedió en otros países latinoamericanos, cuyos procesos de industrialización sustitutiva se iniciaron entre los años treinta y cuarenta, en el Ecuador, se mantendrá el modelo agro-exportador como única alternativa de acumulación capitalista pese a los intentos de promoción industrial en los años

\footnotetext{
${ }^{469}$ Francisco X. Swett: Modelos de desarrollo del Ecuador, Libro del Sesquicentenario, Economía Ecuador, segunda parte, 1830-1980, Corporación Editora Nacional, 1983, p. 73-81.
} 
cincuenta. ${ }^{470}$ Es cierto que, tras la crisis de 1929 y una vez reorganizados los mercados y la producción, algunas economías latinoamericanas (como fue el caso de Argentina, Brasil, etc.) lograron acumular numerosas divisas, mientras se beneficiaban de la defensa automática del mercado interno provocada por la guerra. En este sentido, dichos países parecían hallarse en condiciones de unirse al denominado ciclo de sustitución de importaciones y transformaciones estructurales. ${ }^{471}$

En el caso del Ecuador, a principios de la década de los cincuenta, las posibilidades de dinamizar la economía nacional se basaban fundamentalmente en las actividades agrícolas de exportación, mientras que la base industrial fue iniciada de forma más lenta debido a la existencia de un mercado interno bastante reducido. Estas diferencias determinaron las peculiaridades del proceso de acumulación capitalista en la formación social ecuatoriana, así como las situaciones que explican el proceso de urbanización, las características del estado y la dominación social. Entonces, ¿cuáles fueron las circunstancias políticas y económicas que llevaron a la adopción del modelo de desarrollo económico agro-exportador? ¿cuáles eran algunas de sus principales características?

En referencia a la primera pregunta, hemos de remontarnos a las últimas décadas del siglo XVIII, momento en el que algunos países europeos (Inglaterra, Francia y Alemania, entre otros) vivían la Revolución Industrial, el desarrollo de las fuerzas productivas del mercado nacional e internacional y, en general, el desarrollo del capitalismo mundial. Es decir, fue el proceso de industrialización que tuvo lugar tanto en dichos países europeos como en EE.UU, el factor clave que provocó el incremento de la demanda de materias primas latinoamericanas y generó un comercio rentable para la clase burguesa de la época si se tiene en cuenta el bajo coste de la mano de obra existente en América Latina.

$\mathrm{Al}$ referirse al modelo de desarrollo agro-exportador, Gonzalo Ortíz afirma que su incorporación en el Ecuador tuvo lugar en la época colonial española, durante la cual se enfatizó la venta de productos agrícolas al exterior como elemento clave para el desarrollo nacional. ${ }^{472}$ Sin embargo,

\footnotetext{
${ }^{470}$ Iván Fernández Espinosa, Patricio Tobar Robalino, op. cit. p. 117-131.

${ }^{471}$ Ver el apéndice de notas del capítulo 2 para más información. Fuente: Junta Nacional de Planificación: Evolución histórica del comercio exterior ecuatoriano 1950-1970, Oficina de Publicaciones, Ecuador, 1975; F. H. Cardosso, E. Faletto: Dependencia y desarrollo en América Latina, Siglo XXI, Editores, México 1972, pp. 4,5 y ss.

${ }^{472}$ Gonzalo Ortíz Crespo, op. cit.p. 5-285.
} 
el mayor auge de las exportaciones del país ocurriría en el último cuarto del siglo XIX, momento en que se elaboró de forma oficial dicho modelo, el cual llegó a regir hasta la década de los sesenta y buena parte de los setenta.

En una economía como la ecuatoriana, caracterizada por la extendida vigencia de relaciones de producción atrasadas, el núcleo de actividades unidas a la agro-exportación vino a constituirse en la clase de su crecimiento y disposición. Anteriormente, se habló de cómo este modelo era la mejor opción de la burguesía costeña, al asegurar su control económico y político en el país y al impulsar su producto principal (el cacao), pues no tenía que depender de grandes inversiones para su producción, dada la naturaleza de este cultivo, las adquisiciones gratuitas de tierra y el bajo costo de la fuerza de trabajo. ${ }^{473}$

En relación a la segunda pregunta, las características del modelo agro-exportador, hemos de diferenciar entre características externas e internas. ${ }^{474}$ Comenzando con las primeras, hay que indicar que este modelo se ha caracterizado en lo externo, por orientar al país hacia una especialización como productor y exportador de bienes primarios de origen agropecuario, a la vez que se ha convertido en importador de bienes industrializados.

Asimismo, ha condicionado la economía ecuatoriana a las decisiones de los centros hegemónicos capitalistas, como ocurrió durante el periodo bananero tras la crisis de producción de América Central. En este sentido, hay que aclarar que la subordinación se ha expresado a través de las políticas monetarias, el endeudamiento externo, el saqueo de los recursos naturales y el deterioro en los términos de intercambio, siendo la deuda externa, uno de los problemas más importantes a resolver, pues su elevada cantidad y respectivos intereses han sido una amenaza para el desarrollo.

El tercer rasgo viene definido por la implantación de un comercio desigual, ya que ha impuesto unos precios bajos a los productos ecuatorianos, mientras que los importados se han caracterizado por una tendencia creciente. Este comercio desigual supone el deterioro en los términos de intercambio de la economía de los países pobres en beneficio de los países desarrollados, ya que se han de entregar más productos a cambio de los bienes que se importan.

\footnotetext{
${ }^{473}$ Ibíd. p. 5-285.

${ }^{474}$ Washington Macías, op. cit. p. 12.
} 
En cuanto a las características internas, hay que hacer referencia a la frecuente reinversión de capital en las actividades agro-exportadoras, lo que ha generado una tendencia permanente al monocultivo (como ocurrió con el caso del cacao y luego con el banano). Así, a lo largo de la historia, la producción ecuatoriana se ha enmarcado dentro de la teoría de la especialización de acuerdo a la ventaja comparativa, puesto que la dotación de recursos naturales ha favorecido a la actividad agrícola, mientras que la base de las exportaciones se ha asentado sobre el monocultivo, suscitándose diversas bonanzas del cacao, banano y otros productos en general. ${ }^{475}$ No en vano, el monocultivo ha sido un rasgo bastante negativo para el Ecuador debido a la gran dependencia existente de un único producto, cuyo precio ha sido fijado en la mayoría de los casos por los centros hegemónicos capitalistas. Además, los momentos de crisis del producto exportable han provocado una crisis global en todo el país, mientras que los beneficios obtenidos en la época de auge han sido repartidos entre unos pocos.

Esta tendencia a la mono-exportación ha constituido un fenómeno constante en la historia ecuatoriana, pues en el caso del auge del banano, se pondrá de relieve cómo la dependencia de un único producto hizo peligrar la soberanía nacional tras la delegación por parte del estado del control del negocio bananero a compañías extranjeras, hecho que refleja la vulnerabilidad de la economía ecuatoriana de los años cincuenta. ${ }^{476}$

También, como resultado del monocultivo, se ha de hablar de la escasa diversificación de la producción, la cual ha afectado a la oferta de bienes, y se ha tenido que recurrir a la importación de productos que podían haber sido producidos en el país, mientras que el uso de la tierra no ha sido llevado a cabo de una manera adecuada y racional.

A su vez, hay que señalar la ejecución de políticas estatales favorables a la consolidación del modelo de desarrollo agro-exportador y de la burguesía agro-comercial bancaria, las cuales han acabado perjudicando a otros sectores sociales y actividades económicas. En este sentido, ya analizamos la devaluación monetaria que tuvo lugar al caer el precio del cacao, los préstamos del del Banco Central al sector agro-exportador y la ejecución de obras de infraestructura fundamentales para su fortalecimiento. Además, la rentabilidad obtenida por la burguesía con la producción agro-exportable fue uno de los factores que mermó las posibilidades de desarrollo

\footnotetext{
${ }^{475}$ Francisco X. Swett, op. cit. p.73-81.

${ }^{476}$ Washington Macías, op. cit. p. 12.
} 
manufacturero y el lento progreso de las fuerzas productivas, pues la industrialización no tenía cabida en los esquemas de la burguesía como proyecto económico. Paralelamente, para los terratenientes serranos este proyecto tampoco fue posible, ya que para llevarlo adelante tenían que transformar la estructura latifundista y acabar con las relaciones precarias que constituían la fuente de sus ingresos. ${ }^{477}$

Otra de las características, se refiere a la especialización de la Costa en la agro-exportación y de la Sierra en la producción de bienes para el consumo interno, creándose un comportamiento regional diferente expresado en el tipo de relaciones sociales de producción. Es decir, se produjo un aumento de las relaciones salariales en las plantaciones costeñas, a diferencia de las haciendas serranas, en las que predominaban las relaciones serviles.

Por último, se ha de hablar de la dependencia del presupuesto estatal en cuanto a los beneficios del comercio exterior, pues durante las primeras décadas de la República se obtenían a través de las aduanas aproximadamente entre el $30 \%$ y el $40 \%$ de los ingresos del estado, mientras que en la época de auge del cacao (y después con el banano), las aduanas pasaron a constituir la base de los ingresos fiscales. ${ }^{478}$

Tras este breve análisis de las características del modelo agro-exportador, vamos a estudiar ahora cuál fue el impacto que este modelo de desarrollo económico tuvo en la sociedad ecuatoriana durante la primera mitad del siglo XX.

Teniendo en cuenta que el patrón de desarrollo del Ecuador estuvo orientado casi en su totalidad hacia el exterior, es lógico que se piense que los centros dinámicos externos fueron los que determinaron la existencia de una tendencia de crecimiento tanto a nivel global, como regional y local. ${ }^{479}$ Así, en los inicios de la República, la Sierra fue la región más dinámica debido a su herencia colonial y su articulación con España. Más tarde, la reorientación del comercio exterior hacia otros países europeos y EE.UU. a partir de la exportación de los productos de la Costa, impulsó la formación de un nuevo centro económico en la región litoral. Como consecuencia, se creó la modalidad de la Sierra y de la Costa, las cuales eran diferentes en cuanto a estructura económica y social y existía en ellas una concentración destacada del ingreso. Este hecho dio

\footnotetext{
${ }^{477}$ Ibíd. p. 12.

${ }^{478}$ Esta tabla se encuentra en el apéndice de datos del capítulo 2.

${ }^{479}$ Lionel López Pinto: Distribución del ingreso en la economía ecuatoriana 1830-1980, Libro del Sesquicentenario. Economía Ecuador, segunda parte, 1830-1980, Corporación Editora Nacional, 1983, p. 155-164.
} 
lugar a un modelo de desarrollo excluyente, ya que una buena parte de los beneficios generados en el crecimiento pertenecían a la burguesía comercial a diferencia del ingreso mínimo que los campesinos recibían y que los condujo a la marginación económica, social y política (ver la tabla 1: Diferencias en el ingreso mensual por clases sociales, 1950 y 1956). ${ }^{480}$ Bajo estas circunstancias, ¿cuáles fueron las causas y los orígenes de este fenómeno de concentración del ingreso?

Para responder esta pregunta, hay que hacer alusión a la formación de la sociedad ecuatoriana y al tema de cómo la propiedad de los medios de producción se encontraba en manos de unos cuantos. Es decir, se destaca el régimen de tenencia de la tierra heredada de la época colonial y que perdura durante la República, como uno de los factores responsables de la división entre un pequeño grupo con ingresos más altos y un amplio grupo de menores ingresos.

La disparidad social es otro de los factores responsables que corresponde a la gran dependencia de la economía ecuatoriana de las exportaciones agrícolas, que vinculadas al sistema de tenencia y a determinadas formas organizativas del proceso de producción, causaron también efectos concentradores. Así, el cacao, el café, el arroz y el banano, constituyeron los principales productos de exportación tras la independencia, permitiendo la obtención de las divisas necesarias para la compra de bienes de capital y manufacturas, a la vez que hicieron posible la consolidación del pequeño grupo agro-exportador, dueño de las plantaciones de la Costa, y del grupo comercial-importador constituido por los grandes comerciantes. Estas agrupaciones, que se apropiaron de la mayor parte del ingreso procedente de estas actividades, fueron responsables de que el fenómeno de concentración incidiera en el sistema de tenencia y en el bajo ingreso de los asalariados que, en su mayoría, era población serrana que había emigrado hacia la Costa en busca de empleo y mejores salarios y que no podían ser ofrecidos por la artesanía o la agricultura de la Sierra.

\subsection{2) Circunstancias históricas y políticas del éxito del banano: El papel del Ecuador en el mercado mundial y sus principales socios comerciales.}

Tal y como se ha ido indicando hasta el momento, durante las primeras décadas del siglo XX, el crecimiento de la economía ecuatoriana estuvo condicionado por la evolución del sector externo y por su dependencia de un número reducido de productos agrícolas de gran inestabilidad. A este

\footnotetext{
${ }^{480}$ Rafael Quintero, Erika Silva, op. cit. p. 59.
} 
respecto, también se ha hablado de cómo la crisis de los años treinta dificultó la realización de los productos agrícolas ecuatorianos en el exterior, provocando no sólo la caída de los precios del cacao, sino el estancamiento económico y social de la región, cuyos efectos depresivos vendrían a marcar su evolución durante la década de los cuarenta. ${ }^{481}$ Esta crisis se vio reflejada en la decadencia de las exportaciones y en la dificultad para importar, provocando que numerosos países latinoamericanos iniciaran un proceso de industrialización basado en la sustitución de importaciones.

La tabla 2 (Relación de precios de intercambio y capacidad del Ecuador para importar (19281949) muestra cómo el deterioro de los términos de intercambio en el Ecuador, generó una pérdida en la capacidad de importar durante el período 1930-1939, lo que unido a la presión de las obligaciones externas, determinaría la tendencia al desequilibrio. ${ }^{482}$

La decisión de mantener el modelo de crecimiento basado en las exportaciones tradicionales, caracterizado por su escaso dinamismo y por las ventajas derivadas de la situación geográfica; nos llevará al análisis de dicho modelo a partir de la incorporación de un nuevo producto (el banano) y al estudio de la rearticulación de la economía ecuatoriana al mercado mundial.

El mantenimiento de la agro-exportación se puede atribuir al aprovechamiento de ciertas coyunturas ofrecidas por el mercado mundial, las cuales permitieron diversificar las exportaciones y adquirir cierta competitividad a través de sucesivas devaluaciones y de la explotación de la mano de obra por parte de hacendados y latifundistas. ${ }^{483}$ Estas devaluaciones, reflejadas en el gráfico 1, ponen de manifiesto la disminución de los precios de los productos de exportación durante el periodo 1927-1940, así como el hecho de que aún cuando el modelo de

\footnotetext{
${ }^{481}$ Fernando Velasco Abad, op. cit. p. 179-200.

${ }^{482}$ Esta tabla se encuentra en el apéndice de datos del capítulo 2. Fuente: F. Cardoso, E. Faletto: Dependencia y desarrollo en América Latina, segunda edición, México, Ed. Siglo XXI, 1970, p. 54-130.

${ }^{483}$ El café se convirtió en el principal sustituto del cacao en 1934, ya que se trataba de un producto de gran interés para el Ecuador, pues sus áreas de cultivo se extendían en una amplia zona de la Costa y en algunos valles bajos de la Sierra. No obstante, la insuficiencia de técnicas de cultivo y los obstáculos para el aprovechamiento de este cultivo en las variedades adecuadas, llevaron a su reemplazo por el arroz, cuya exportación se incrementaría a causa de la Segunda Guerra Mundial. Fuente: Gonzalo Correa Escobar: La economía ecuatoriana de 1830 a 1980 , Libro del Sesquicentenario, primera parte, III Economía/Ecuador 1830-1980, primera parte, Corporación editor Nacional, 1983, p. 79.
} 
desarrollo basado en las exportaciones logró sobrevivir, su poder dinámico se vio disminuido sustancialmente, a tal punto que la exportación decreció en un nivel significativo. ${ }^{484}$

Gráfico 1: Índices de precios de productos de exportación (1927-1940)

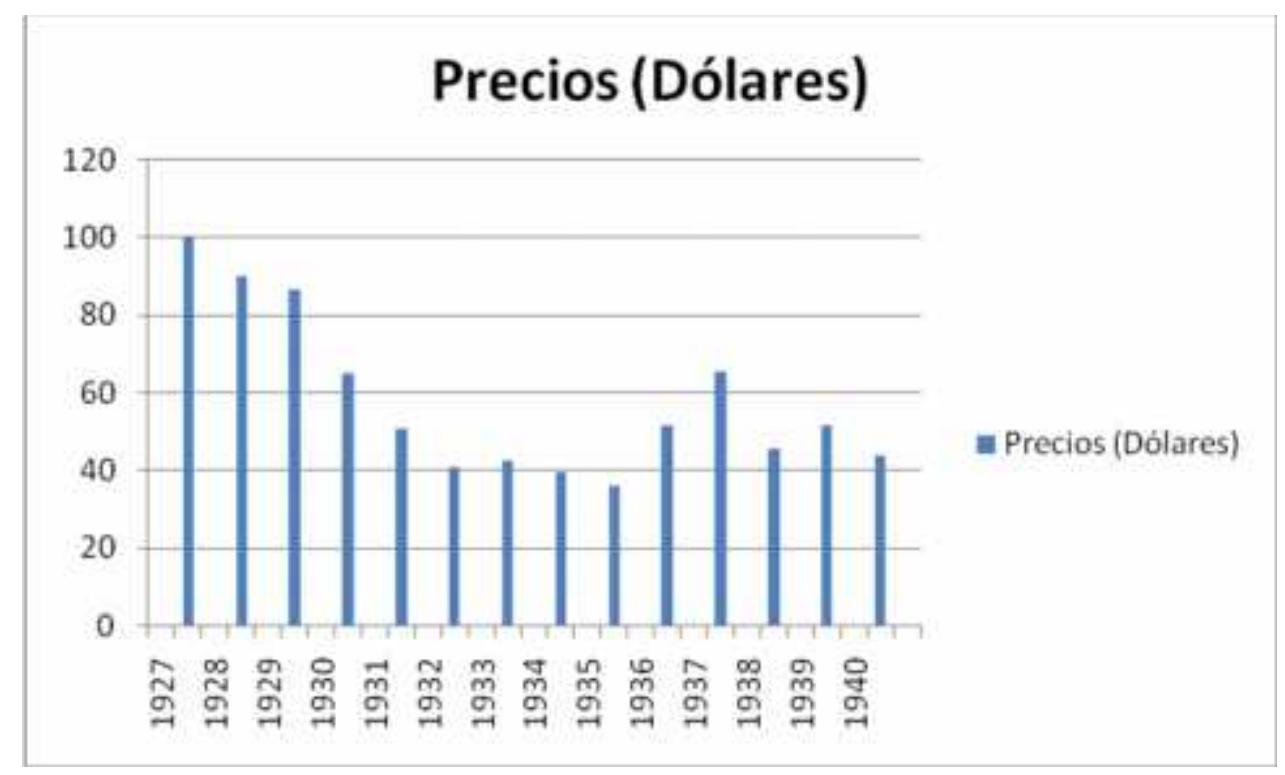

Elaboración propia a partir de los datos de la tabla 3.

Fuente: H. Heiman: Estadísticas de las exportaciones del Ecuador, 1940-1942 (con series históricas anteriores), Tabla 78, Quito, Ministerio de Economía, 1943-1945.

En estas condiciones, el estancamiento de la economía avivará las contradicciones sociales, empeorando la situación de la pequeña burguesía y de los trabajadores. Esta lucha tendrá lugar entre las diversas clases sociales y los diversos sectores de la clase dominante, expresándose en lo político, mediante sucesivos cambios de gobierno, y en lo económico, a través del aumento de los precios, puesto que los sectores pugnaban por una mayor cuota del excedente producido. ${ }^{485}$ En definitiva, a pesar de las dificultades estructurales para diversificar la economía y de los numerosos problemas manifestados durante las crisis políticas que tuvieron lugar entre $1930 \mathrm{y}$ 1948, el sistema productivo pudo ser ajustado para seguir usando el modelo de crecimiento hacia

\footnotetext{
${ }^{484}$ Fernando Velasco Abad, op. cit. p. 187.

485 Luis Carbo indica que, en el periodo 1938-1948, el índice de precios casi llegó a cuadriplicarse. Para ello, establece la referencia con respecto al índice de precios base 1937:100, a partir de la cual, observa la evolución de la siguiente forma: 1938:101, 1943:168, y 1948:395, Fuente: Luis Carbo: Historia monetaria y cambiaria del Ecuador, Quito, Imp. del Banco Central, 1953, p. 595.
} 
afuera. Este periodo de inestabilidad política se refleja en la tabla 4 (Cronología de presidentes en el Ecuador 1931-1948), en la que se muestra una relación de los diferentes presidentes durante las décadas de los treinta y cuarenta. ${ }^{486}$

A su vez, en el plano político, esta etapa se caracterizó por una extremada inestabilidad a consecuencia de las continuas luchas entre los diversos sectores de la clase dominante, además de la irrupción del Partido Socialista por parte de los sectores medios y del surgimiento de la figura de Velasco Ibarra $^{487}$. En referencia al plano económico, se ha de destacar la importancia que este llegó a adquirir, la cual fue en aumento después de la caída de Velasco.

Las posibilidades de expansión del sector externo durante la Segunda Guerra Mundial, sirvieron de incentivo para buscar una fórmula que consiguiera los mismos resultados. De esta manera, se propuso un programa que incluía la reorganización del sistema de fomento para la agricultura, la revisión del sistema tributario y la protección industrial, siendo los partidarios de este movimiento, los que llevaron a Galo Plaza al poder en las elecciones de 1948. Por tanto, ¿cuáles fueron los elementos que contribuyeron a la dinamización del sector externo y a la reactivación de la economía ecuatoriana durante este nuevo gobierno? ¿cuáles fueron los principales socios comerciales del Ecuador?

Se pueden destacar dos coyunturas que favorecieron la consecución de dichos objetivos, siendo la primera, la guerra de Corea (1951-1953), pues había venido incrementando de nuevo la demanda de los productos tradicionales como el cacao y el café y también del banano.

El gráfico 2 muestra las exportaciones de estos productos y su participación en el total exportado, siendo el banano, el más importante de estos, ya que su contribución al total de exportaciones pasó de 19,9\% en 1951 a 31,3\% en 1953; mientras que el cacao representaba un $31,2 \%$ en 1951 y un $20,6 \%$ en 1953 , siendo las contribuciones del café de $27,2 \%$ en 1951 y

\footnotetext{
486 Universidad de Georgetown: República del Ecuador, Political database of the Americas, Center for Latin American Studies, 2009.

${ }^{487}$ Ver el apéndice de notas del capítulo 2 para más información. Fuente: Agustín Cueva: El proceso de dominación política en el Ecuador, Planeta, Quito, 1997; Rafael Quintero: El mito del populismo en el Ecuador, FLACSO, Quito, 1980; Juan Maiguashca, Lisa North: Orígenes y significado del velasquismo: Lucha de clases y participación política en el Ecuador, en Rafael Quintero (comp.), La cuestión regional y el poder, Corporación Editora Nacional, FLACSO, CERLAC, Quito, 1991.
} 
24,9\% en 1953. En segundo lugar, se encontraba la posibilidad de sustituir a los productores centroamericanos de banano en el abastecimiento del mercado norteamericano. ${ }^{488}$

Gráfico 2: Exportaciones de banano, cacao y café (en miles de sucres)

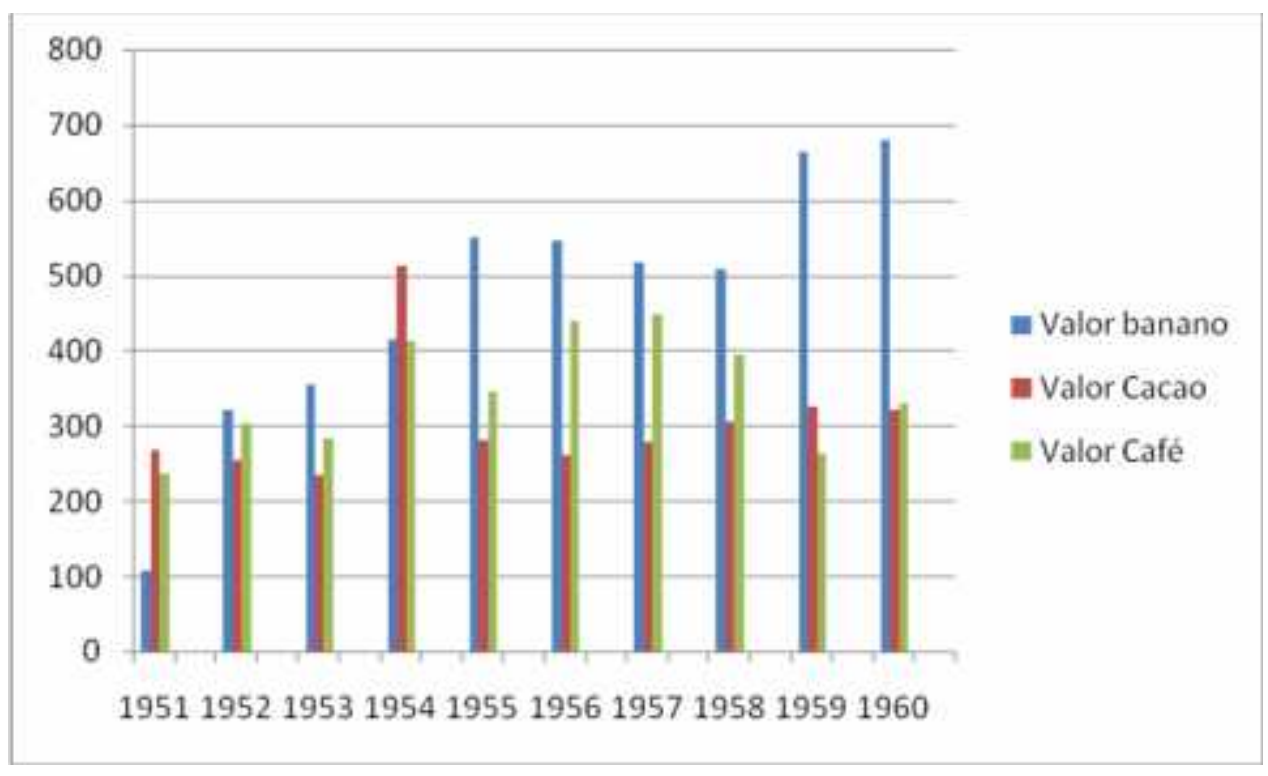

Elaboración propia a partir de los datos de la tabla 5.

Fuente: Junta Nacional de Planificación: Plan General de Desarrollo, T.I. Libro 1, Quito, 1963, p. 66 .

Como resultado de la combinación del aumento de la demanda externa y de la política de fomento, el banano pasó a ser el principal producto de exportación, contribuyendo al auge del comercio exterior ecuatoriano. Asimismo, la expansión exportadora, responsable de dinamizar la vinculación externa del país, tuvo su origen en una coyuntura internacional estimulada por los incrementos de los precios y de las exportaciones de banano, como podemos apreciar en la tabla 6 (Ecuador: Exportaciones de banano 1948-1960). ${ }^{489}$ A su vez, el gráfico 3 refleja las altas contribuciones del sector agropecuario durante el periodo indicado, que llegó a generar ingresos

488 Germánico Salgado: La economía del Ecuador en los últimos setenta años, Libro del Sesquicentenario, Economía Ecuador, segunda parte, 1830-1980, Corporación Editora Nacional, 1983, p. 116.

489 Esta tabla se encuentra en el apéndice de datos del capítulo 2. Fuente: Carlos Larrea: Estructura social, apropiación del excedente y desarrollo desigual en el Ecuador. Una primera aproximación, Mimeo, Quito, 1978. 
de divisas de más del $80 \%$, a diferencia de los otros sectores, que no sólo muestran sus bajas contribuciones, sino que estas fueron descendiendo progresivamente.

Gráfico 3: Composición de las exportaciones 1950-1970 (porcentajes a precios corrientes)

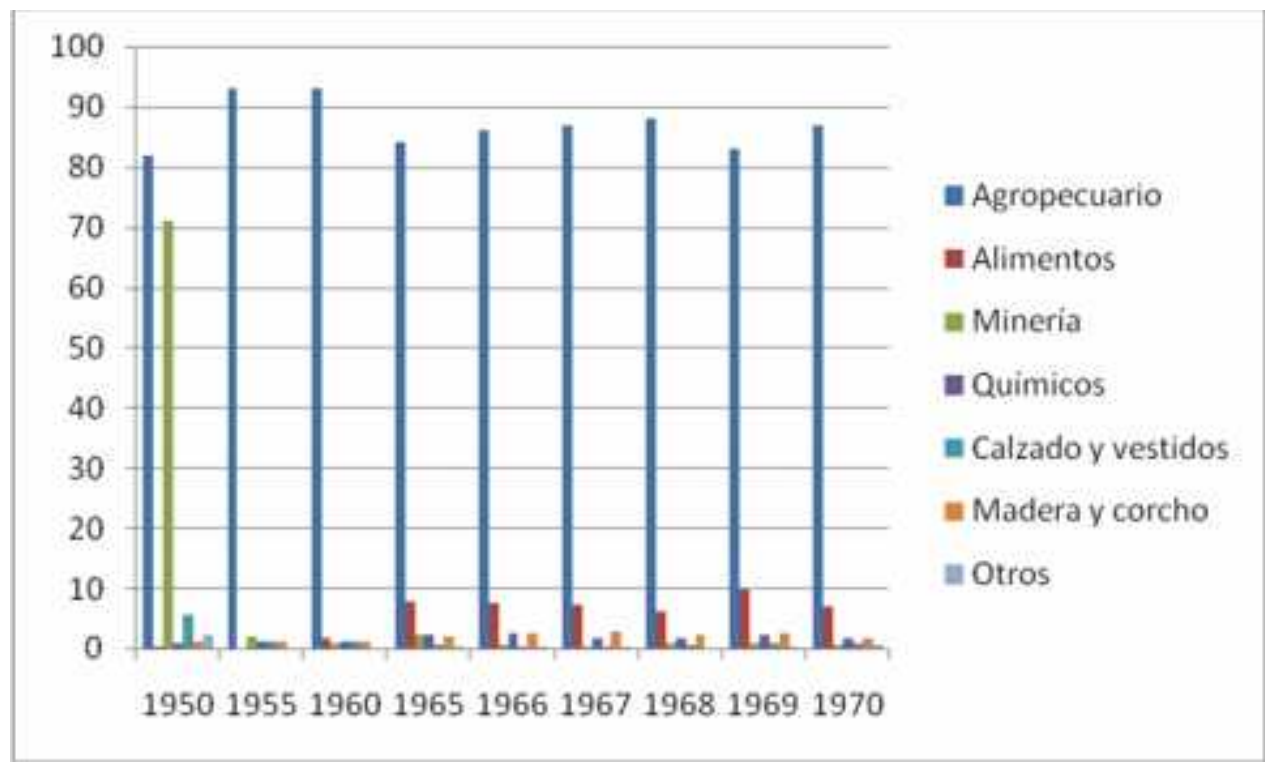

Elaboración propia a partir de los datos de la tabla 7.

Fuente: Anuario de Comercio Exterior y Boletines del Banco Central, Tomado de: Evolución Histórica del Comercio Exterior Ecuatoriano 1950-1970, JNP.

En cuanto a los socios comerciales del Ecuador, hay que decir que Estados Unidos llegó a convertirse en el principal proveedor de divisas, aunque también mantenía relaciones comerciales con algunos de los mercados tradicionales (Alemania Occidental, Japón, Chile y Colombia) como refleja la tabla 8 (Destino de las exportaciones). Esto pone de manifiesto la gran dependencia de la economía ecuatoriana en relación a los escasos productos de exportación disponibles y en cuanto al bajo número de países compradores. ${ }^{490}$

Comparando la situación del Ecuador con otros países del entorno, como es el caso del Perú, también se observa un carácter liberal de las políticas comerciales peruanas, especialmente en los años cincuenta y comienzos de los sesenta, debido en parte a un bajo nivel arancelario, la ausencia de controles cambiarios, una industria pequeña y ligada al sector exportador, y una

\footnotetext{
${ }^{490}$ Esta tabla se encuentra en el apéndice de datos del capítulo 2. Fuente: Junta Nacional de Planificación: Evolución histórica del comercio exterior ecuatoriano 1950-1970, Oficina de Publicaciones, Ecuador, 1975, p. 28.
} 
economía abierta al comercio exterior, en la que las exportaciones eran el motor del crecimiento, siendo algunos de sus principales socios comerciales Estados Unidos y Alemania, seguidos de Reino Unido, Bélgica y Holanda.

En relación a la composición de las exportaciones peruanas, se ha de indicar los cambios que tuvieron lugar durante los años transcurridos desde principios del siglo XX, pues la plata, producto de exportación fundamental a lo largo del periodo colonial y durante el siglo XIX, desapareció del grupo de las primeras exportaciones del país en el siglo XX, dejando paso al azúcar, que llegó a convertirse en el producto dominante de las exportaciones desde 1895 hasta 1920, a pesar de perder fuerza posteriormente. Otros productos destacados fueron el caucho, que fue importante hasta el inicio de la Primera Guerra Mundial, el petróleo, el algodón y el cobre, que dominaron las exportaciones peruanas en vísperas de la gran crisis del capitalismo mundial (ver la tabla 9 Principales productos de las exportaciones peruanas 1927-1950). ${ }^{491}$

A lo largo del periodo de crisis, la composición de las exportaciones fue sufriendo variaciones, pues el cobre y el algodón se situaron entre los productos más afectados, pero a partir de 1933, el algodón comenzó a recuperarse. Posteriormente, tras la Segunda Guerra Mundial (1939-1945), los primeros puestos en el ranking de las exportaciones peruanas experimentaron algunas modificaciones a favor de los sectores controlados por el capital nacional, siendo el algodón y el azúcar, los principales animadores de las exportaciones, junto con otros productos con presencia de capital nacional, como el plomo, el zinc y la pesca (ver las tablas 9 y 10 Principales productos de las exportaciones peruanas 1927-1950, Exportaciones del Perú 1927-1950). ${ }^{492}$

Regresando al tema del comercio ecuatoriano, entre los factores que favorecieron el intercambio comercial entre el Ecuador y Estados Unidos, se encontraba el tamaño de mercado, que proporcionó la capacidad adecuada para absorber una destacada variedad de productos, en concreto, los de primera necesidad, pese a que los inversores norteamericanos también se

\footnotetext{
${ }^{491}$ Esta tabla se encuentra en el apéndice de datos del capítulo 2. Fuente: Dirección de Estadística del MHC, Extracto Estadístico del Perú, 1931-1933, p. 67 y 117; Anuario Estadístico del Perú 1948-1949 y 1951. Elaboración propia.

${ }^{492}$ Estas tablas se encuentran en el apéndice de datos del capítulo 2. Fuente: Dirección de Estadística del MHC, Extracto Estadístico del Perú, 1931-1933, p. 67 y 117; Anuario Estadístico del Perú 1948-1949 y 1951; Junta Nacional de Planificación: Evolución histórica del comercio exterior ecuatoriano 1950-1970, Oficina de Publicaciones, Ecuador, 1975.
} 
interesaron en otras fuentes de explotación, como posteriormente ocurrió con el petróleo, sobre todo a partir de 1968.

Entre los principales productos de exportación a este país, se encuentra el banano, cuyas ventas pasaron de seis millones de dólares corrientes en 1950, a casi veintidós millones en 1970; el café, que tuvo un crecimiento sostenido debido a la ampliación de las cuotas de exportaciones; y el cacao, en el que las exportaciones tendieron a decrecer, llegando a su nivel más bajo en 1969, en que apenas se logró vender un equivalente a cuatro millones de dólares (Ver la tabla 11: Productos principales de exportación a EE.UU). ${ }^{493}$

En esencia, el auge exportador fue el elemento que dio un gran estímulo a la economía ecuatoriana y vino a atenuar los problemas sociales y políticos que habían mantenido a la sociedad en un estado de caos:

Entre 1940 y 1952, las exportaciones se elevaron de 10 a 79 millones de dólares, mientras las importaciones subieron de 11 a 56 millones de dólares. La reserva monetaria evolucionó de 79 millones a 591 millones de sucres para el mismo periodo, mientras que las operaciones de crédito de la banca fiscal y privada exhibían asimismo un incremento vertiginoso a partir de $1948 .^{494}$

Estas condiciones de aparente bonanza económica, permitieron el apoyo crediticio por parte del estado a la política de colonización, expandiéndose la frontera agrícola en la Costa, principalmente con plantaciones y fincas bananeras. Pese a todo esto, la producción bananera solamente creció cuando el estado ecuatoriano se inclinó por una política para impulsar su cultivo tras las negociaciones con la United Fruit durante la presidencia de Galo Plaza en $1949 .^{495}$

Como hemos visto, la presencia imperialista norteamericana en el Ecuador se consolidó con el auge cacaotero a comienzos del siglo XX, pero el carácter atrasado del país, la estrechez del

\footnotetext{
${ }^{493}$ Esta tabla se encuentra en el apéndice de datos del capítulo 2. Fuente: Junta Nacional de Planificación: Evolución histórica del comercio exterior ecuatoriano 1950-1970, Oficina de Publicaciones, Ecuador, 1975.

${ }^{494}$ Gonzalo Abad Ortíz: El proceso de lucha por el poder en el Ecuador, Tesis de maestría, El Colegio de México, 1970, p. 37.

495 Para más información sobre Galo Plaza, ver el apéndice de notas del capítulo 2. Fuente: Carlos de la Torre, Mireya Salgado: Galo Plaza y su época, Introducción, FLACSO, Ecuador, 2008, p. 11-26.
} 
mercado interno y su tardía incorporación al mercado internacional, hicieron que la inversión capitalista extranjera no estuviera presente en grandes cantidades antes de 1948.

Con el término de la década de los cuarenta, los capitalistas norteamericanos mostraron un mayor interés en este país y comenzaron a colaborar con mayor detenimiento con los gobiernos de la época, siendo su objetivo primordial la exportación bananera. Entre las inversiones norteamericanas más importantes de esta época, se encuentran las procedentes de la United Fruit, las cuales aumentaron la producción del banano cuando el estado ecuatoriano adoptó una política para impulsar su cultivo y se llegó a un acuerdo con la dicha compañía.

Existen varios elementos que explican la decisión de invertir en el Ecuador, ya que por un lado, la United Fruit, que había penetrado en el Ecuador en la década de los veinte, no solo debía hacer frente a las diversas enfermedades que acabaron por deteriorar sus plantaciones centroamericanas, sino que también se encontró con condiciones climáticas adversas. A esto, se ha de añadir la aparición de regímenes de tendencia nacionalista, que acabaron desplazando el interés de los inversores norteamericanos hacia los del gobierno de Plaza, cuyo principal objetivo estaba centrado en el progreso económico del Ecuador y la expansión norteamericana. ${ }^{496}$ Además, al ser el aumento de la producción exportable el problema principal, Plaza no llegó a enfrentarse a ningún grupo económico y estos, en consecuencia, respetaron su gobierno. No en vano, es importante recalcar el hecho de que las políticas desarrollistas de Plaza no se centraron en ningún aspecto de la estructura interna del país y, por tanto, el verdadero trasfondo de la problemática se mantuvo alejado como futura amenaza. Así, en referencia a la agricultura, el gobierno emprendió programas de mecanización a los que sólo podían aspirar algunos productores privilegiados, mientras que el problema de la tenencia de la tierra, principal obstáculo al desarrollo del sector agrícola, no fue mencionado, al igual que ocurrió con la distribución del ingreso. En otras palabras, nunca se tuvieron en cuenta las dificultades y el atraso del mercado interno, lo que permitió que el gobierno de Plaza gobernara en paz, ajustando los grupos que componían la clase dominante y renovando la vinculación con la economía central.

En estas circunstancias, el rápido crecimiento del banano hizo posible un desarrollo capitalista poco común en esta época, a la vez que las exportaciones permitieron superar la crisis económica

\footnotetext{
${ }^{496}$ Rafael Quintero, Erika Silva, op. cit. p. 7-40.
} 
del sector agro-exportador producida con el cacao. La fiebre del denominado "oro verde" convirtió al banano en el principal producto de exportación del Ecuador, de cuyas posibilidades dependió hasta comienzos de los setenta.

De esta manera, durante varias décadas, el Ecuador, como país dependiente, pasaría a ser el principal proveedor del banano en el mundo, ya que las condiciones mencionadas, hacían que para 1948, la presidencia de Plaza fuese un ideal para EE.UU, pues podría implantar el modelo desarrollista que necesitaba.

En el plano socio-económico, este gobierno también estableció una pauta desarrollista acorde con los intereses norteamericanos, involucrando al país en planes de ayuda técnica, programas de crédito agrícola gubernamental y convenios de asistencia económica a través de agencias para racionalizar el proceso de exportación bananera en el Ecuador. Así, el crecimiento económico dependiente fue considerable en los años posteriores a 1948, pues las concesiones bananeras aumentaron de 37.000 acres a 370.000 acres de 1948 a $1954 .{ }^{497}$

Además, entre las formas gubernamentales de asistencia, se contó con la concesión de tierras estatales a la United Fruit y a aquellos ecuatorianos dispuestos a colaborar con la compañía imperialista. Esa apropiación de territorios por parte de las compañías extranjeras, acusaba la incapacidad del estado para controlar su propio territorio, revelando su carácter no soberano en la medida en que la soberanía era arrebatada por un poder extranjero.

En referencia a la United Fruit, ya en 1934, había adquirido la antigua hacienda cacaotera de Tenguel, localizada entre las provincias de Guayas y El Oro, la cual fue transformada en un enclave de 100.000 hectáreas, mientras que sus propiedades alcanzaban las 225.000 hectáreas a comienzos de los años cuarenta. ${ }^{498}$

Según Patricio López, la variación de explotación desde el clásico enclave extranjero de producción directa hacia productores independientes que proveían a las multinacionales, no sólo respondió a la iniciativa del gobierno, sino también a la experiencia de la United Fruit con los fenómenos de disputa y apropiación territorial con comunidades locales campesinas. En efecto, desde 1938, la United disputó sin éxito la implantación de comunidades campesinas, y su

\footnotetext{
${ }^{497}$ Ibíd. p. 7-40.

${ }^{498}$ Ver el mapa 1 (Hacienda Tenguel-Balao en el Ecuador) en el apéndice de mapas del capítulo 2. Fuente: J. P. Deler: Ecuador: Del espacio al estado nacional, Centro de Investigación y Cultura, Banco Central del Ecuador, 1987.
} 
correspondiente apropiación de tierras dentro de los bordes de su propiedad en Tenguel, apoyada por los recursos legales de un estado caracterizado por un poder central distante e inestable, y autoridades locales con alto grado de autonomía y rechazo a la presencia extranjera. ${ }^{499}$ Precisamente, entre 1946 y 1948, los encargados de la United Fruit constataban la incapacidad y la falta de voluntad estatal para asegurar sus derechos de propiedad, lo que ponía en peligro la seguridad de la producción directa. ${ }^{500}$

Mientras las estructuras de fomento se consolidaban, la respuesta del gobierno fue bastante rápida, creándose la Comisión de Orientación y Crédito para el banano, organización gubernamental semi-autónoma, relacionada con el sistema de bancos de fomento, que diseñó una agresiva estrategia de impulso a la producción a partir del fomento crediticio. Así, hasta mediados de 1949, había asignado 15 millones de sucres a 922 dueños de explotaciones bajo la forma de préstamos que fueron, en más de tres cuartas partes, inferiores a 20.000 sucres y de ellos, los más importantes no pasaron de 50.000 sucres. $^{501}$

A su vez, los propietarios se habían beneficiado de diversas regulaciones que permitían la reclamación de tierras baldías en zonas de hasta 50 hectáreas, conformando un núcleo de pequeños propietarios que aprovecharon el margen de crédito bananero ( 4 sucres por planta sembrada). Mediante esta medida, para 1949, se dio crédito para 10.705 hectáreas trabajadas, las cuales estaban distribuidas en las provincias de Esmeraldas (3.653 hectáreas), Los Ríos (2.457 hectáreas), Manabí (1.709 hectáreas), Guayas (1.354 hectáreas) y Cañar (320 hectáreas). ${ }^{502}$

Mientras surgían las grandes propiedades extranjeras destinadas al cultivo del banano, el latifundio en manos de una clase terrateniente costeña siguió ejerciendo una gran importancia en el agro. En 1962, el 50\% de la tierra dedicada al cultivo del banano en la provincia de El Oro pertenecía a cuatro familias, lo que muestra una estructura de la tenencia de la tierra que no había cambiado demasiado con el auge bananero. Es cierto que se produjo un aumento de la mediana

\footnotetext{
499 Patricio López: La normalidad excepcional: Una panorámica de la política económica del gobierno Plaza Lasso (1948-1952), en “Galo Plaza y su época”, FLACSO, 2008, p. 86-89.

500 Steve Striffler: In the shadows of state and capital. The United Fruit company, popular struggle and agrarian restructuring in Ecuador, 1900-1995, Duke University Press, Durham \& London, 2002, p. 73.

501 J. P. Deler: Ecuador: Del espacio al estado nacional, Centro de Investigación y Cultura, Banco Central del Ecuador, 1987, p. 257.

${ }^{502}$ Ibíd. p. 257.
} 
propiedad, ya que para 1965, el $87 \%$ de las propiedades dedicadas al cultivo del banano tenían menos de 100 hectáreas, pero esta situación no mostraba el hecho de que las unidades mayores de 100 hectáreas ocupaban el 50\% de las tierras bananeras, encontrándose estas en las provincias del Guayas y Los Ríos. ${ }^{503}$

El mapa 2 (Zonas bananeras en el Ecuador (década 1960) señala las zonas bananeras desarrolladas desde la Cuenca del río Guayas hacia el norte y al sudeste, casi al límite con el Perú. Esta ampliación de la frontera agrícola no sólo obedecía a la lógica estatal de fomento agrícola impulsada durante el gobierno de Galo Plaza, sino que vino acompañada de un amplio movimiento de toma de tierras que agrupaba a un conjunto de campesinos. ${ }^{504}$

Posteriormente, a diferencia de su predecesor, la administración de Velasco Ibarra (1952-1956) llevó a cabo un programa de mayor interés en la realización de obras concretas. Así, Velasco usó el excedente del auge exportador para la construcción de carreteras, escuelas y otras obras públicas, tal y como se muestra en la tabla 12 (Inversión real en obras de infraestructuras y transporte 1948-1965). ${ }^{505}$ Además, la continuación de la bonanza del sector externo que la guerra de Corea había permitido y la creciente demanda estadounidense fueron algunos de los factores fundamentales para un consenso político, gracias al cual, Velasco pudo conducir su gobierno y terminar en paz su periodo constitucional.

Retomando el tema de la recuperación de las exportaciones nacionales, vamos a pasar ahora a analizar cómo el banano, hasta ese entonces de escasa importancia, logró encauzar la economía ecuatoriana y dejar a un lado la larga crisis provocada por la caída de la actividad cacaotera, a la vez que se integraba a los mercados internacionales, fortaleciéndose así, una economía capitalista dependiente y un paulatino proceso de urbanización. ${ }^{506}$

Gonzalo Abad explica el sistema económico ecuatoriano, definiéndolo como una modalidad de la economía de enclave: la economía agro-exportadora. En su estudio, se muestra la existencia de

\footnotetext{
${ }^{503}$ Steve Striffler, op. cit. p. 48-50.

${ }^{504}$ Este mapa se encuentra en el apéndice de mapas del capítulo 2.

${ }^{505}$ Esta tabla se encuentra en el apéndice de datos del capítulo 2. Fuente: Patricio Almeida Guzmán, Rebeca Almeida Arroba: Estadísticas económicas históricas (1948-1983), Fuentes para la Historia Económica del Ecuador, Serie Estadísticas Históricas Vol. 1, Banco Central del Ecuador, Quito, 1988, p. 333.

506 César Montalvo: La estructura vertical del mercado bananero para el Ecuador y el carácter limitado de las reformas de comercio internacional, en Revista Tecnológica Espol, vol. 21, número1, 2008, p. 165-179.
} 
una sociedad dependiente, donde el sistema económico y el sistema político se hallan interrelacionados, siendo la producción una prolongación directa de la economía central en un doble sentido. Es decir, la conexión de la economía central con la sociedad dependiente, se da principalmente a través del sistema de poder, ya que este define las condiciones en que se articula el enclave. ${ }^{507}$

En este sentido, se puede hablar de una segunda etapa de acumulación de capital, que puede ser ubicada desde finales de la década de los cuarenta, más concretamente en el año 1948, y que abarcará toda la década de los cincuenta y parte de los sesenta. ${ }^{508}$

Además, al igual que en el periodo anterior, el dinamismo de acumulación de capital dependía también del mercado internacional, al que la economía ecuatoriana se encontraba subordinada. Por consiguiente, los cambios ocurridos en la estructura del capitalismo internacional y en los mercados mundiales incluyeron la posibilidad de una nueva forma de vinculación con el capitalismo, en la que tuvo lugar el ajuste del capital imperialista y la formación de mecanismos para la integración de las economías atrasadas o dependientes a la acumulación imperialista.

De esta manera, la dirección del desarrollo capitalista moderno en el Ecuador, comienza a definirse a partir del crecimiento de las exportaciones de banano, las cuales permitieron a los diferentes gobiernos de la década de los cincuenta impulsar el desarrollo y encauzar una parte de las divisas hacia el sistema productivo, además de aplicar una política caracterizada por la atracción al capital externo y al crédito (especialmente para cultivos tropicales) y otras medidas de tipo administrativo según las necesidades de modernización institucional de la nueva situación en el país. ${ }^{509}$

Igualmente, este proceso de expansión del capitalismo se fundamentaba en la ampliación de la frontera agrícola del litoral mediante relaciones de producción capitalistas ligadas a la producción de banano, café y cacao; así como en la formación de una destacada suma de capital comercial y financiero, una mayor producción industrial alrededor de las ciudades de Quito y Guayaquil, la cual estaba sustentada en el incremento de la capacidad de importación de bienes del mercado mundial capitalista y en la exportación de productos agrícolas tropicales. La

\footnotetext{
${ }^{507}$ Gonzalo Eduardo Abad, op. cit. p. 50-400.

${ }^{508}$ Iván Fernández Espinosa, Patricio Tobar Robalino, op. cit. p. 117-131.

${ }^{509}$ Ibíd. p. 117-131.
} 
configuración de todos estos elementos permitió profundizar la acumulación originaria de capital, así como una importante expansión de las fuerzas productivas. Esta situación del país, ligada a la situación internacional por su papel político en los centros imperialistas y a los efectos dinamizadores de la guerra de Corea, implicaba el impulso de las relaciones con el capitalismo internacional. $^{510}$

A partir de aquí, la expansión económica puede ser explicada mediante el papel desempeñado por las exportaciones bananeras y el mercado interno, el cual se fue ampliando con el desarrollo del capitalismo en el litoral y en la Sierra, donde la agricultura comienza a reflejar una relativa diferenciación y modernización. Por otra parte, se da también entre 1948 y 1960, un débil proceso de instalación de industrias en la Costa y en la Sierra, teniendo como base ese crecimiento, la formación de una destacada cantidad de capital financiero y la creación de los principales centros urbanos del país como eje de concentración de grandes cantidades de trabajadores.

No en vano, el crecimiento que se da en el Ecuador tiene características propias de su situación estructural, siendo una de ellas, la complejidad y contradicción del mercado capitalista, pues no todos los sectores sociales pasaron por el proceso de ampliación del mercado interno. En este ámbito, se puede entender el hecho de que las clases dominantes del Ecuador no conformen un bloque uniforme y que surjan entre ellas contradicciones, producto de la diversidad de intereses por apropiarse del excedente generado en el país. ${ }^{511}$ Por otro lado, la escasez de unidad de las clases dominantes no podrá ser superada en esta coyuntura, ya que la división regional de dichas clases se fue acentuando con el paso del tiempo.

Teniendo en cuenta estas ideas, se podría decir que la dinámica internacional del capitalismo y su impacto en el Ecuador, se llevó a cabo mediante el paso del capitalismo de libre competencia al capitalismo monopólico, y de este, al capitalismo monopolista estatal. Además, el estado en su conjunto, se adaptará a los intereses de la fracción burguesa agro-exportadora, cuya hegemonía se consolidará, aliándose con el sector terrateniente tradicional y el sector comercial importador, con quienes compartirá los beneficios generados en el proceso de modernización capitalista. En

\footnotetext{
${ }^{510}$ Rafael Quintero, Erika Silva, op. cit. p. 7-39.

511 José Moncada: La economía ecuatoriana en el siglo XX. Algunos elementos relativos a la génesis, apropiación y utilización del excedente económico, primera edición, Quito, Ed. III.UC. 1980, p. 47.
} 
este caso, el estado comienza a desempeñar un papel importante en la acumulación a través del Banco Central y otros organismos similares a los norteamericanos. ${ }^{512}$

El estudio de estos hechos pone de manifiesto la importancia del impulso económico de los años cincuenta conseguido con el auge bananero (principal fuente de acumulación del capital del momento) y de su posterior declinación en los sesenta, ya que serán estos factores, los que nos ayudarán a entender cómo ocurrieron algunas de las transformaciones sociales y económicas más importantes de la historia del desarrollo ecuatoriano. Entonces, partiendo del auge económico representado por el banano, ¿cuáles fueron los factores externos e internos que facilitaron la repentina irrupción en el mercado mundial de un proveedor marginal?

Osvaldo Barsky y Gustavo Cosse indican que el aumento espectacular en la producción y exportación del banano en la primera mitad de los años cincuenta, se debió a varias circunstancias, como la fuerte crisis en la producción bananera de Centroamérica causada por plagas y ciclones. ${ }^{513}$

Para aprovechar esta situación, el gobierno de Plaza apoyó con créditos a las pequeñas y medianas explotaciones bananeras y promocionó la construcción de infraestructuras (caminos y obras portuarias) para el transporte de este producto (tal y como ya vimos en la tabla 12 (Inversión real en obras de infraestructuras y transporte 1948-1965), aunque estas tuvieron un mayor auge durante la presidencia de Velasco Ibarra.

En su estudio, René Báez hace referencia a la expansión del capitalismo norteamericano después de la Segunda Guerra Mundial y a los efectos directos producidos en la economía ecuatoriana y en su modelo agro-exportador. Tradicionalmente proveedora de productos agrícolas al capitalismo central, la nueva coyuntura confirmará esa función del aparato productivo ecuatoriano, dándole un empuje desconocido desde la época del cacao. ${ }^{514}$ Báez define este momento histórico como la inauguración de un nuevo momento de la dependencia neocolonial del Ecuador, esta vez bajo la presión del capitalismo estadounidense; siendo los datos económicos utilizados, los que mostrarán cómo Estados Unidos llegó convertirse en el principal

\footnotetext{
${ }^{512}$ Lucas Pacheco: La politica económica en el Ecuador Republicano, Libro del Sesquicentenario, segunda parte, 1830-1980, Corporación Editora Nacional, 1983, p. 103-113.

${ }^{513}$ Osvaldo Barsky, Gustavo Cosse, Tecnología y cambio social..., op. cit., p.29-31.

${ }^{514}$ René Báez: Apogeo y decadencia del modelo agro-exportador: Periodo de la segunda posguerra, Colección Isidro Ayora, vol. II, Banco Central del Ecuador, 1980, p. 28-42.
} 
socio comercial del Ecuador (ver tablas 13, 14 y 15: Exportaciones por países compradores 1950-1965)..$^{515}$

También, Iván Fernández y Patricio Tobar se refieren al papel que este país desempeñó, sobre todo en cuanto al tema de la acumulación de capital. En este sentido y a diferencia del cacao, la tenencia de la tierra ya no era motivo suficiente para que los propietarios se quedaran con la riqueza bananera, pues esta no llegó a caracterizarse por una gran concentración como sucedió con el cacao. ${ }^{516}$ Así, durante esta época, a la vez que se desarrollaba un número considerable de grandes, medianos y pequeños propietarios con un peso significativo en la producción, fueron surgiendo los enormes latifundios para las plantaciones bananeras, cuyo control directo estaba en manos de las compañías norteamericanas de la fruta, United Fruit y Standard Fruit Company, las cuales desempeñaron un destacado papel en el auge bananero durante los años cincuenta. De este modo, dichos autores consideran que el auge bananero fue posible gracias a la necesidad de impulsar una rápida ampliación de la frontera agrícola para la producción de banano, partiendo de un menor costo y también con las estrategias de las grandes transnacionales que controlaban el mercado mundial de la fruta.

A su vez, Carlos Larrea y Francisco Cucalón, a diferencia de Báez, explican que los factores externos que llevaron a que el Ecuador se convirtiera en uno de los primeros exportadores mundiales de banano (después de un largo periodo de inserción marginal en la economía internacional), fueron el resultado de la combinación de las plagas y ciclones que afectaron a la producción exportable centroamericana durante la posguerra, y del incremento de la demanda del banano en los mercados de Estados Unidos y Europa. ${ }^{517}$

Además, mencionan el asesoramiento técnico e intervención directa de la compañía norteamericana United Fruit para la comercialización y producción de la fruta que tuvo lugar

\footnotetext{
${ }^{515}$ Estas tablas se encuentran en el apéndice de datos del capítulo 2. Fuente: Patricio Almeida Guzmán, Rebeca Almeida Arroba: Estadísticas económicas históricas (1948-1983), Fuentes para la Historia Económica del Ecuador, Serie Estadísticas Históricas Vol. 1, Banco Central del Ecuador, Quito, 1988.

${ }^{516}$ Iván Fernández Espinosa, Patricio Tobar Robalino, op. cit., p. 117-131.

517 Carlos Larrea Maldonado: Las empresas transnacionales y la economía ecuatoriana durante el periodo bananero, III Economía/Ecuador 1830-1980, primera parte, Libro de Sesquicentenario, Corporación Editora Nacional, 1983, p.255-267.
} 
durante el gobierno desarrollista de Plaza, al imponerse como objetivo la rehabilitación económica del país. ${ }^{518}$

Con estas ideas, y una vez analizados los factores que dieron lugar al auge bananero en el Ecuador, vamos a pasar a realizar una pequeña comparación entre la economía de exportación basada en el cacao y en el banano, partiendo de la existencia de una economía de enclave, tal y como propone Gonzalo Abad. ${ }^{519}$ En este caso, es importante señalar un gran parecido entre una época y otra, ya que durante ambas, el desarrollo de la producción se mantuvo en manos nacionales y apenas hubo grandes inversiones directas extranjeras en la economía ecuatoriana, siendo la deuda externa pública en cierto modo insignificante. Para 1949, la deuda del país procedía de la adquisición de acciones de la antigua Guayaquil y de la Quito Railway Company, así como los préstamos para financiar la construcción del transporte vial; mientras que en los sesenta, los préstamos externos aumentarían (ver gráficos 4 y 5) para llevar a cabo los programas de construcción de carreteras. Es decir, el carácter dependiente de la economía ecuatoriana estaba relacionado con el hecho de que su crecimiento era una continuación de la economía internacional, sobre la cual, no podía ejercer influencia. Esto explica que la suerte económica del Ecuador estuviera en manos de la demanda externa y no dependiera de la demanda doméstica.

\footnotetext{
${ }^{518}$ Francisco Pareja Cucalón, op. cit., p. 392-394.

${ }^{519}$ Gonzalo Eduardo Abad, op. cit. p. 30-400.
} 
Gráficos 4 y 5: Deuda externa por sector público 1948-1957 y 1958-1967 (millones de dólares)
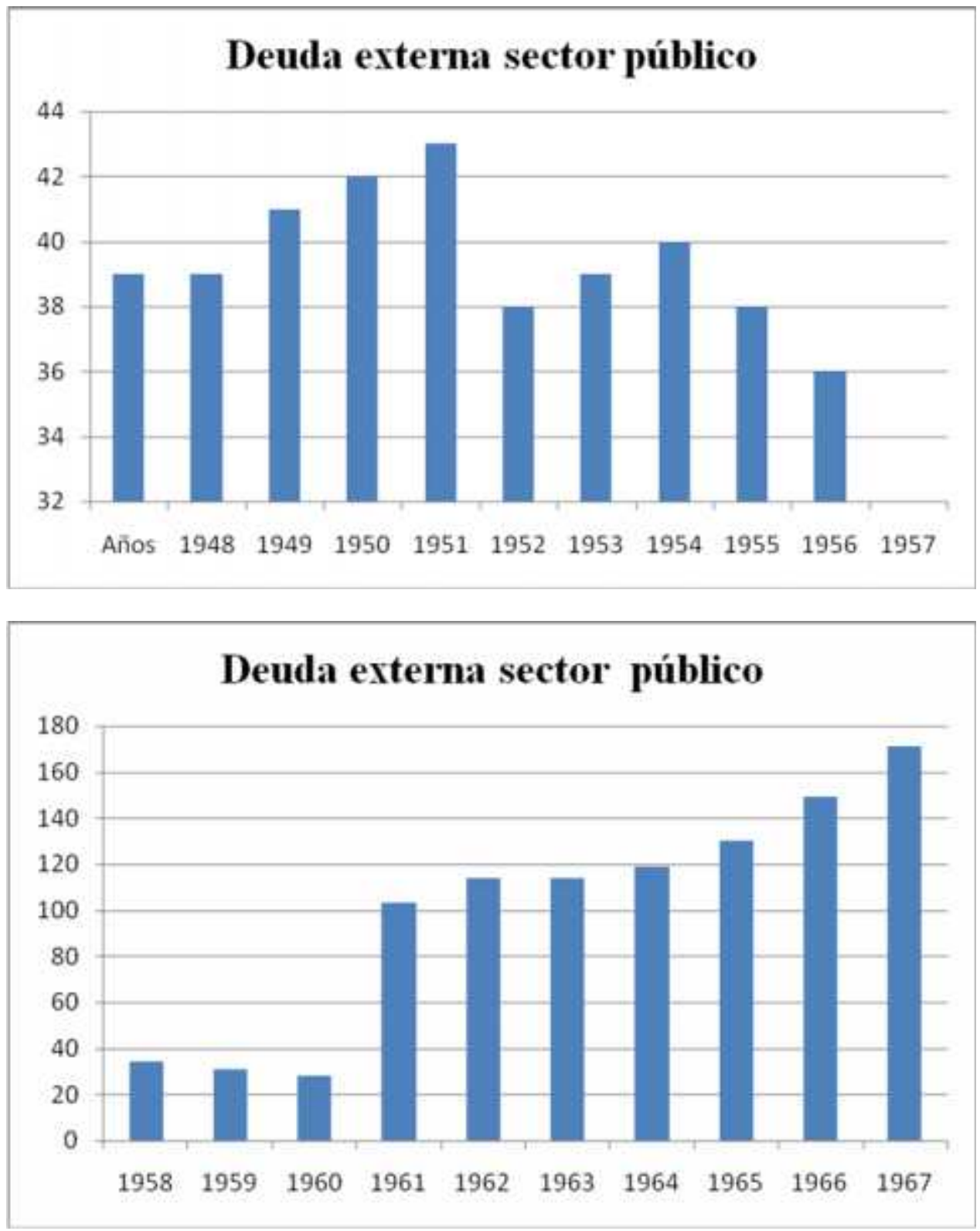

Elaboración propia a partir de los datos de la tabla 16.

Fuente: Patricio Almeida Guzmán y Rebeca Almeida Arroba: Estadísticas económicas históricas (1948-1983), Fuentes para la Historia Económica del Ecuador, Serie Estadísticas Históricas Vol. 1, Banco Central del Ecuador, Quito, 1988, p. 466.

Por otro lado, ya se ha indicado cómo las exportaciones de cacao eran el fruto de una agricultura no capitalista basada en grandes haciendas, a diferencia de la producción del banano, que 
implicaba el desarrollo de una agricultura capitalista basada en explotaciones medianas, siendo una importante parte del excedente generado repartido entre las multinacionales. ${ }^{520}$ En último lugar, hay que destacar que el boom bananero no gozó de una duración tan prolongada como ocurrió con el cacao, ya que las exportaciones de banano llegaron a su apogeo en 1955, estancándose durante varios años, para incrementarse nuevamente a partir de 1959 (ver tabla 6: Exportaciones de banano 1948-1960), hasta que gradualmente fueron perdiendo su importancia hacia el año 1973, cuando el petróleo pasó a constituir la base de la economía exportadora. ${ }^{521}$ En definitiva, y aunque se hablará más adelante de las consecuencias económicas y políticas del estancamiento de las exportaciones bananeras, es importante destacar algunos elementos estructurales comunes que han caracterizado a estos fenómenos, pues en los dos casos, el Ecuador estableció una alta dependencia del mercado americano, a la vez que la composición de sus exportaciones se encontraba dominada en su mayor parte por un único producto, siendo la difusión de las enfermedades lo que acabó destruyendo las plantaciones de cacao y de banano.

\subsection{3) El modelo agro-exportador y el efecto del comercio del banano en la economía ecuatoriana y en la formación social.}

\subsubsection{1) El proceso de desarrollo del comercio bananero.}

Hasta ahora, hemos explicado cómo el sector externo ecuatoriano se caracterizó durante la primera parte de la década de los cincuenta, por un creciente dinamismo que no había conocido desde la época del cacao. Asimismo, se ha hecho referencia al papel hegemónico que Estados Unidos adquirió después de la Segunda Guerra Mundial (1939-1945) dentro del capitalismo internacional, y al incremento en la demanda de bienes de consumo (banano, cacao y café), mientras que el resto de su producción exportable tenía como destino los países europeos. De forma paralela, si bien la expansión de las exportaciones se debió a la próspera vinculación externa del país y a su dependencia de dichos mercados, también se ha de indicar el aprovechamiento de la coyuntura internacional; siendo la combinación de estos factores un

\footnotetext{
${ }^{520}$ Según un informe de 1960 de la Junta Nacional de Planificación, el precio internacional del banano se distribuía de la siguiente manera: un $27,6 \%$ era percibido por el productor, un $17,7 \%$ por los responsables de su comercialización interna y el 54,7\% restante quedaba en manos de los exportadores. Fuente: Francisco Pareja Cucalón, op. cit. p.393-396.

${ }^{521}$ Esta tabla se encuentra en el apéndice de datos del capítulo 2.
} 
elemento fundamental que nos ayudará a entender el efecto del auge bananero y la evolución de su comercio.

Por otra parte, es necesario señalar que el comienzo de este periodo supondrá una transformación del nivel de desarrollo de la economía local, hecho que se vio reflejado en el aumento del producto interior bruto y de las inversiones de carácter público. Así, durante la década de los cincuenta, se intenta incrementar el papel del estado en el manejo del proceso económico y racionalizar los mecanismos de inversión, crédito y gasto público. Hasta ese momento, la debilidad del estado, como factor de organización de la sociedad civil, y su falta de recursos, había dificultado los intentos a la hora de establecer organismos dedicados a la planificación.

La coyuntura del auge bananero generó una gran diferenciación social y económica que estableció la necesidad de adoptar mecanismos para canalizar las inversiones. En referencia a esto y durante el gobierno de Galo Plaza, la implantación de políticas desarrollistas para satisfacer los intereses norteamericanos se vio favorecida por las ideas de la CEPAL, las cuales contribuyeron a identificar los problemas de la estructura económica y social. ${ }^{522}$

El ingreso de divisas por las exportaciones de banano y el aumento de la deuda externa, permitieron comenzar un modelo de desarrollo basado en la industrialización sustitutiva de importaciones (ISI), tal y como fue propuesto por la Comisión Económica para América Latina y el Caribe. ${ }^{523}$

Esto requería una participación activa del estado en el desarrollo económico, sobre todo en lo concerniente a la promoción y planificación de las inversiones en sectores estratégicos. Pese a esto, el estado ecuatoriano aún no estaba preparado para liderar una fuerte intervención en la actividad económica debido a la precariedad de sus instituciones y del sistema económico, siendo necesario un cambio, el cual fue iniciado durante la presidencia de Galo Plaza (19481952) y continuado por Velasco Ibarra (1952-1956), al que sucedería Camilo Ponce Enríquez (1956-1960).

En esta etapa, se creó un conjunto de organismos de control como la Junta de Planificación, inaugurada en 1954 y encargada de promover tres planes de desarrollo: el Centro de Desarrollo Industrial del Ecuador (CENDES), el Instituto Ecuatoriano de Electrificación (INECEL) y la

\footnotetext{
522 Osvaldo Barsky, Gustavo Cosse, op. cit. p. 30-31.

${ }^{523}$ Marco Naranjo Chiriboga: Dolarización oficial y regímenes monetarios en el Ecuador, Colegio de Economistas de Pichincha, Quito, 2005, p. 22-275.
} 
Comisión Nacional de Valores. Estas instituciones permitieron un fuerte crecimiento de la inversión industrial, que pasó de 15,6 millones de sucres promedio entre 1953 y 1957 a 867 millones entre 1969 y $1972 .{ }^{524}$ No obstante, es importante recordar que aún cuando los ingresos obtenidos por el estado permitieron llevar a cabo numerosas inversiones en infraestructura, se originó una creciente dependencia de las importaciones de bienes de capital y un elevado déficit de la balanza de pagos.

Siguiendo con el tema del impacto del auge bananero en el desarrollo económico del Ecuador, hemos señalado la importancia del incremento de las exportaciones, pues la expansión de la economía se encontraba ligada al comportamiento de las mismas. Aquí, se ha de aclarar que si bien el auge bananero ocurrió principalmente durante la etapa 1948-1964, el comercio de este producto comenzó a adquirir importancia a partir de 1927, manteniéndose un nivel creciente en sus exportaciones a pesar de las diversas crisis sufridas. Así, el impacto causado por la Primera Guerra Mundial provocó un descenso de las exportaciones bananeras, produciéndose su recuperación con el establecimiento en los años treinta de una división bananera perteneciente a la United Fruit Company en la provincia de Guayas.

En el gráfico 6, que muestra los ingresos generados por las exportaciones bananeras entre 19271947, se pueden observar las variaciones a consecuencia de la crisis económica ocurrida al término de la Primera Guerra Mundial y con la depresión de los años treinta, en la que las exportaciones bananeras ecuatorianas alcanzaron el nivel más bajo de ingresos. ${ }^{525}$ Superada la crisis, en el año 1934, las exportaciones bananeras comienzan a recuperarse alcanzando una cifra de 258.000 dólares, a partir de la cual, se incrementan las exportaciones hasta su nueva caída con la Segunda Guerra Mundial (1939-1945). ${ }^{526}$

\footnotetext{
${ }^{524}$ Enrique Ayala Mora, Sonia Fernández: Ecuador: Las raíces del presente, compilación de los suplementos especiales del diario La Hora, Universidad Andina Simón Bolívar-Taller de Estudios Históricos-La Hora, Quito, 1995. Ver también: Osvaldo Hurtado: El poder político en el Ecuador, Ediciones de la Universidad Católica, Quito, 1977, p. 272-279.

${ }^{525}$ El nivel más bajo de ingresos corresponde al año 1932, durante el cual se exportaron 324.387 racimos equivalentes a 40.000 dólares.

${ }^{526}$ Es importante establecer las diferencias entre el plátano y el banano, pues el plátano es un fruto procedente del árbol de la familia de las Platanáceas, con forma alargada, corteza lisa y amarilla y mide aproximadamente entre diez y quince centímetros de longitud. El banano es una planta de la familia de las Musáceas y parecida al plátano, pero con la hoja más ovalada, el fruto es más redondeado e igualmente comestible. Fuente: Diccionario de la Real Academia de la Lengua Española, www.rae.es
} 
Gráfico 6: Exportaciones de banano y plátano (1927-1947) (miles de dólares FOB)

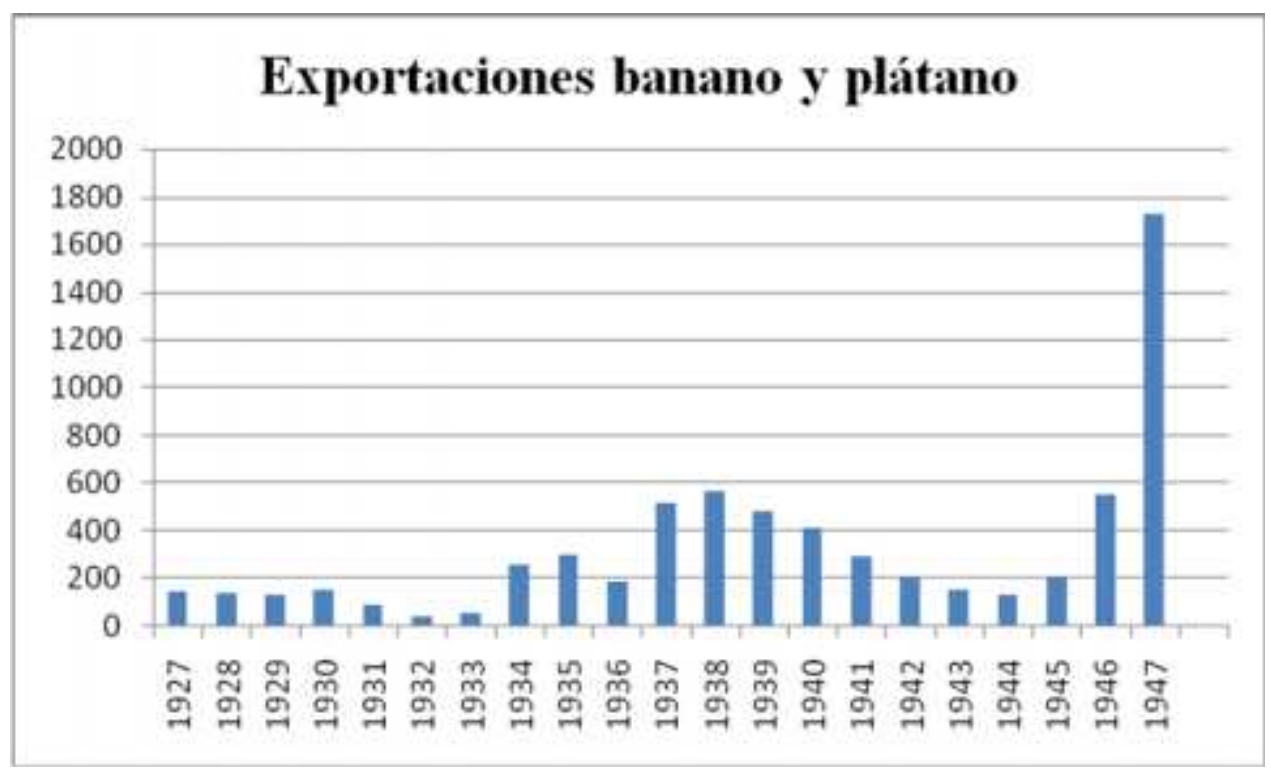

Elaboración propia a partir de los datos de la tabla 17.

Fuente: Carlos Larrea, El Banano en el Ecuador, Corporación Editora Nacional, 1997.

En el gráfico 7, se puede apreciar el aumento del producto interior bruto en el periodo 19271939, en el que se pasa de una cifra de 79 millones en 1927 a 113 millones de dólares en 1939, mientras que en la etapa 1940-1947, se registra inicialmente una cifra de 148 millones y en 1947, se obtienen 360 millones de dólares. 
Gráfico 7: Producto interior bruto del Ecuador (1927-1947)

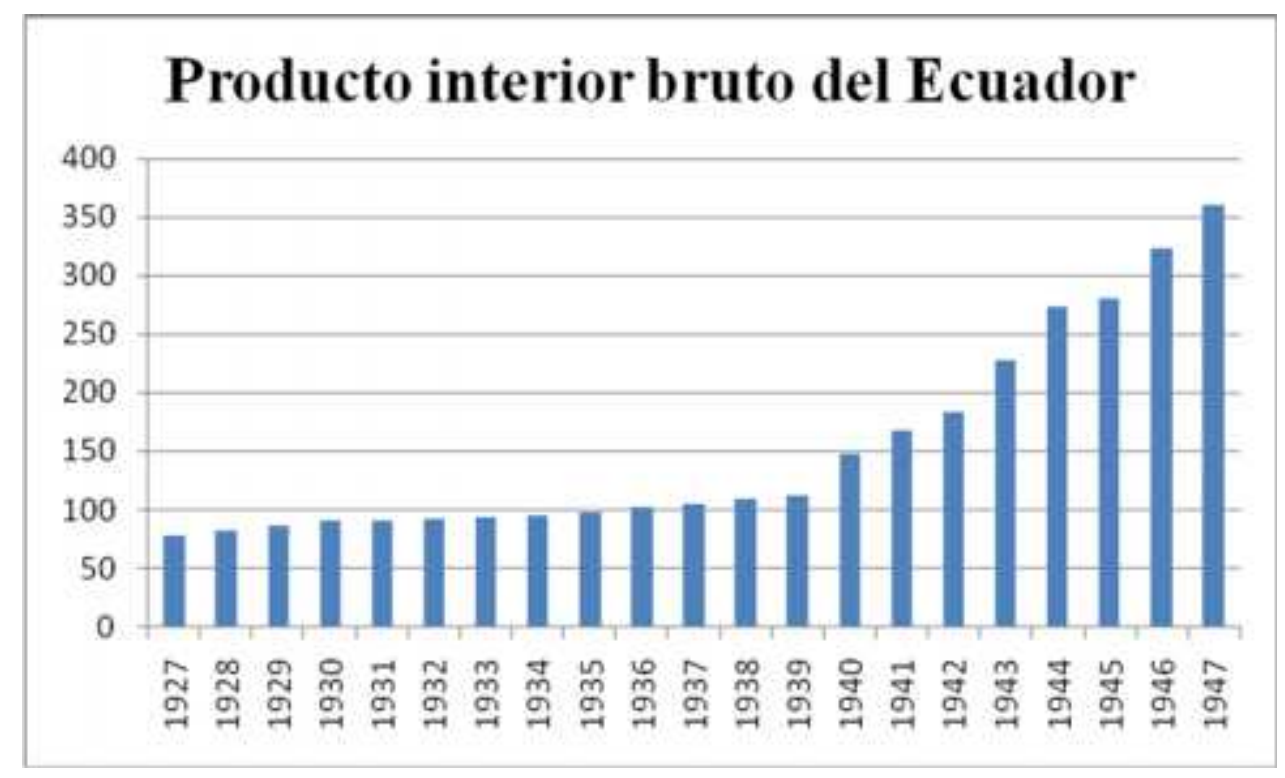

Elaboración propia a partir de los datos de la tabla 18.

Fuente: Banco Central del Ecuador: Setenta años de información estadística 1927-1947, 1997.

La etapa que sigue a estos años, es la correspondiente al auge bananero y abarca el periodo 19481965, en el que la economía ecuatoriana es parte de un largo proceso de crecimiento sostenido. El gráfico 8 muestra el incremento progresivo del producto interior bruto, que si bien en 1948, se situaba en los 460 millones de dólares, en 1965, llegó a alcanzar la cifra de 1.151 millones de dólares, siendo el sector agropecuario, el que mayores contribuciones realizó al producto interior bruto, seguido del sector manufacturero y de las actividades comerciales (Ver tablas 20, 21 y 22 : PIB por clase de actividad económica 1950-1964). ${ }^{527}$

Dentro de esta etapa, el periodo de mayor crecimiento de las exportaciones fue el correspondiente al quinquenio 1950-1954, que comienza con la cantidad de 7.854 millones de dólares para situarse en 27.671 millones de dólares en 1954. A partir de 1955, a consecuencia de la caída de los precios del cacao y del café, se observa un ritmo de crecimiento más lento de las exportaciones, que a pesar de los altibajos, logrará mantenerse hasta la crisis del banano a

\footnotetext{
${ }^{527}$ Estas tablas se encuentran en el apéndice de datos del capítulo 2. Fuente: Patricio Almeida Guzmán y Rebeca Almeida Arroba: Estadísticas económicas históricas (1948-1983), Fuentes para la Historia Económica del Ecuador, Serie Estadísticas Históricas Vol. 1, Banco Central del Ecuador, Quito, 1988, p. 53-70.
} 
mediados de los años sesenta. (Ver las tablas 23 y 24: Valor de las exportaciones de productos principales. Estimaciones de la producción y exportación del banano, 1948-1965). ${ }^{528}$

Gráfico 8: Producto interior bruto del Ecuador (1948-1965)

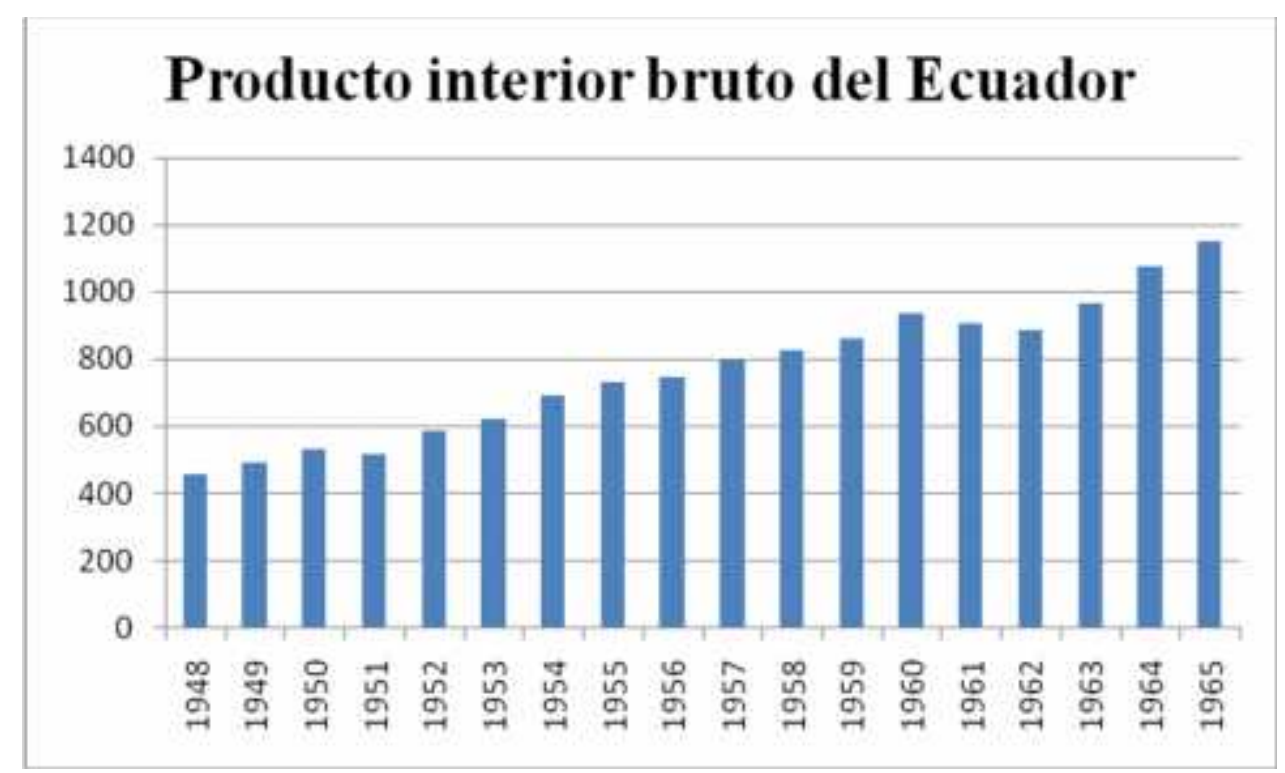

Elaboración propia a partir de los datos de la tabla 19.

Fuente: Banco Central del Ecuador: Setenta años de información estadística 1927-1997, 1997.

Siguiendo con el tema de la expansión bananera, anteriormente atribuíamos su origen a la coyuntura internacional, cuyo estímulo venía dado por el incremento de precios del mercado mundial y de la demanda de banano por parte de Estados Unidos y Europa Occidental. A este respecto, Fernando Velasco indica que la presencia de estos elementos se agudizará a partir de 1950, pues el precio del racimo, que tenía un valor de 12,32 sucres hasta el año 1949, se incrementará hasta llegar a la cantidad de 18.46 sucres en $1952 .{ }^{529}$

No obstante, también alude a la decadencia de las plantaciones bananeras de Centroamérica, afectadas por el "mal de Panamá" como el principal factor que contribuye a la incorporación del

\footnotetext{
${ }^{528}$ Estas tablas se encuentran en el apéndice de datos del capítulo 2. Fuente: Patricio Almeida Guzmán y Rebeca Almeida Arroba: Estadísticas económicas históricas (1948-1983), Fuentes para la Historia Económica del Ecuador. Serie Estadísticas Históricas Vol. 1. Banco Central del Ecuador, Quito, 1988, p.53-70.

${ }^{529}$ Fernando Velasco Abad, op. cit., p. 179-20.
} 
Ecuador en el mercado mundial. ${ }^{530}$ De esta manera, tras la crisis de los años treinta, el sistema capitalista de la economía norteamericana, genera una tendencia de carácter comercial que busca la incorporación de los sistemas productivos de su área de influencia.

A su vez, la existencia de condiciones ecológicas favorables para el cultivo del banano y su demanda en el mercado internacional, junto con las acciones de la burguesía exportadora que estaba dispuesta a crear un modelo político que asegurase la vinculación dinámica del sector externo, no constituían una condición suficiente para que el Ecuador dejara de ser un proveedor marginal. Es decir, únicamente con la crisis centroamericana, la United Fruit Company pudo integrar la producción bananera del Ecuador al mercado mundial a partir del año 1949.

De esta coyuntura, según Velasco, logrará beneficiarse el sector exportador gracias al gobierno de Galo Plaza (1948-1952), cuya preocupación central fue la captación de inversiones extranjeras para la agricultura, originándose de este modo, la denominada "fiebre del banano", 531 Ante esta perspectiva, uno de los elementos claves del proceso de cambio socio-económico fue el flujo de capital extranjero, el cual cobró mayor importancia a partir de la segunda mitad de los años sesenta, pero llegó a manifestarse en los cincuenta mediante los préstamos e inversiones. Considerando la situación de otros países latinoamericanos, es evidente que la afluencia considerable de capital extranjero hizo posible la incorporación tardía de la economía ecuatoriana al mercado mundial, el cual estaba liderado por las empresas transnacionales (como era el caso de la United Fruit Company). Es decir, ya en los años sesenta, el Ecuador, a pesar de sus reducidas dimensiones, comenzó a ser apreciado como mercado de reserva de materias primas y mano de obra, ya que hasta entonces, había sido un país prácticamente incomunicado a nivel interno, con un mercado interior reducido, una población pequeña y una economía con un lento proceso de expansión.

La tabla 25 (Ecuador: Entradas de capital extranjero. Promedios y cifras anuales en millones de dólares estadounidenses 1951-1965) ofrece una visión general de las principales tendencias

\footnotetext{
530 El mal de Panamá es un tipo de enfermedad producida por el hongo Fusarium oxysporum f. sp. cubense. Se trata de una de las amenazas de extensión internacional más graves de las plataneras y causante de cuantiosas pérdidas económicas. Este patógeno que ataca las raíces e invade el sistema vascular de la platanera, impide su normal alimentación y ocasiona una progresiva deshidratación, amarillamiento de la hoja y muerte de la planta. Fuente: Inpla S.A.: Investigación para la agricultura, inpla.es. Puede verse la obra de H. David, Thurston: Enfermedades de cultivos en el Trópico, Turrialba, Costa Rica, 1989, p. 16-17.

531 Fernando Velasco Abad, op. cit. p. 179-180.
} 
en materia de capitales extranjeros al Ecuador. Aquí, para 1951-1955, se destaca el paso de un promedio de inversión extranjera de unos tres millones de dólares y de una cantidad de préstamos inferiores a siete millones de dólares a valores cercanos a los veinte millones de dólares anuales entre 1961-1965. ${ }^{532}$

Ante estas circunstancias, las exportaciones nacionales lograron expandirse teniendo como principal base el banano, el cacao y el café, al ser sus contribuciones al total de las exportaciones, las más destacadas entre todos los bienes de carácter primario y secundario de acuerdo con las tablas 26 y 27 (Exportación total por rama de actividad, 1948-1963). ${ }^{533}$ Por su parte, el gráfico 9 muestra que el crecimiento de las exportaciones fue bastante elevado durante los primeros años de la década de los cincuenta, al estar impulsado por los altos precios de los mercados internacionales, mientras que entre 1955-1958, se produce una pérdida del dinamismo y del valor de las exportaciones, al acentuarse el deterioro de los términos de intercambio con el término de la guerra de Corea.

\footnotetext{
${ }^{532}$ Esta tabla se encuentra en el apéndice de datos del capítulo 2. Fuente: Estudios e informes de la CEPAL: La presencia de las empresas transnacionales en la economía ecuatoriana, Publicaciones de las Naciones Unidas, Santiago de Chile, 1984, p. 13.

533 Estas tablas se encuentran en el apéndice de datos del capítulo 2. Fuente: Patricio Almeida Guzmán y Rebeca Almeida Arroba: Estadísticas económicas históricas (1948-1983), Fuentes para la Historia Económica del Ecuador, Serie Estadísticas Históricas Vol. 1. Banco Central del Ecuador, Quito, 1988, p. 472-476.
} 
Gráfico 9: Exportaciones totales (1948-1965) (Miles de dólares FOB)

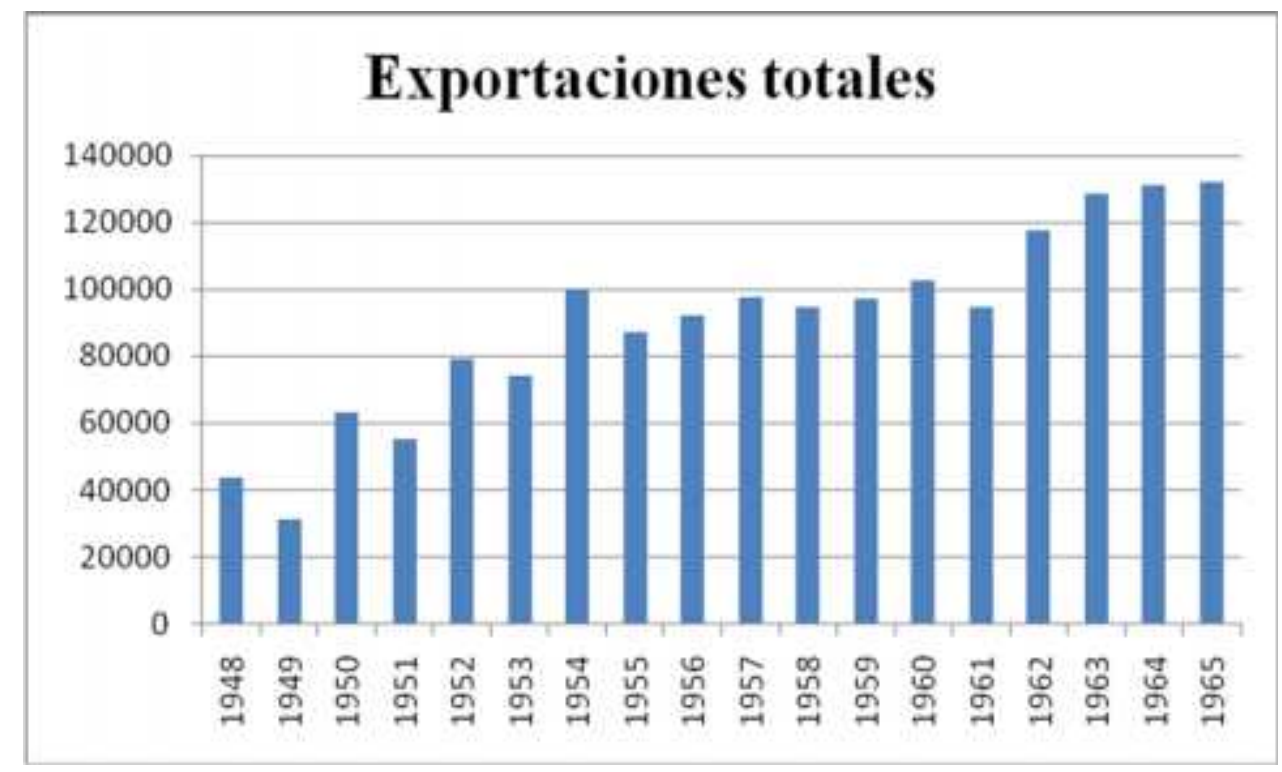

Elaboración propia a partir de los datos de la tabla 28.

Fuente: Patricio Almeida Guzmán y Rebeca Almeida Arroba: Estadísticas económicas (19481983), Fuentes para la Historia Económica del Ecuador, Serie Estadísticas Históricas Vol. 1. Banco Central del Ecuador, Quito, 1988, p. 471.

De este modo, al cambiar las condiciones internas y externas, el modelo agro-exportador adquirió unas características especiales, dependiendo del tipo de vinculación del país al mercado mundial. A este respecto, Velasco alude al informe El desarrollo económico del Ecuador, presentado ante el gobierno por la International Basic Economy Corporation (IBEC), para definir un modelo de desarrollo asociado a la economía, basado en la consolidación y diversificación del sector exportador de productos primarios y en la dinamización del sector agropecuario, a la vez que se encargaba de producir para el mercado interno y el sector industrial. ${ }^{534}$

Dicha dinamización implicaba la adopción por parte de la agricultura serrana de nuevas tecnologías, así como la mejora de la raza bovina, de los fertilizantes utilizados y sistemas de

\footnotetext{
${ }^{534}$ Para más información sobre la International Basic Economy Corporation (IBEC), ver el apéndice de notas del capítulo 2. Fuente: Emmanuella Scarpellini: Nelson A. Rockefeller's International Basic Economy Corporation and the Introduction of Supermarkets to Italy, Researcher in Contemporary History University of Milan, Italy, 2001.
} 
irrigación, del coste y de la calidad industrial, para lo que se ha de destacar la importancia de la política de inversiones extranjeras. ${ }^{535}$

En definitiva, estos objetivos venían a proponer una mayor participación del Ecuador en el mercado internacional (en calidad de exportador de productos primarios y de importador de manufacturas), a partir de la modernización de los sectores encargados de satisfacer las necesidades nacionales y de la incorporación del capital extranjero, lo cual explica el crecimiento repentino de las importaciones, al pasar de los 58,5 millones de dólares en 1952 a los 100,2 millones de dólares en el año 1954, cifra que continuará aumentando durante las décadas posteriores (gráfico 10: Importaciones totales 1952-1965) y que nos muestra una estructura de las importaciones propia de aquellos países, en los que la industrialización se produjo de forma tardía, como ocurrió en el Ecuador. ${ }^{536}$

${ }^{535}$ Luis Carbo, op. cit., p 330-334.

${ }^{536}$ Patricio Almeida Guzmán, Rebeca Almeida Arroba, Estadísticas económicas históricas..., op. cit., p. 491. 
Gráfico 10: Importaciones totales (Tipos de bienes: materias primas, bienes de capital y bienes de consumo) (miles de dólares CIF)

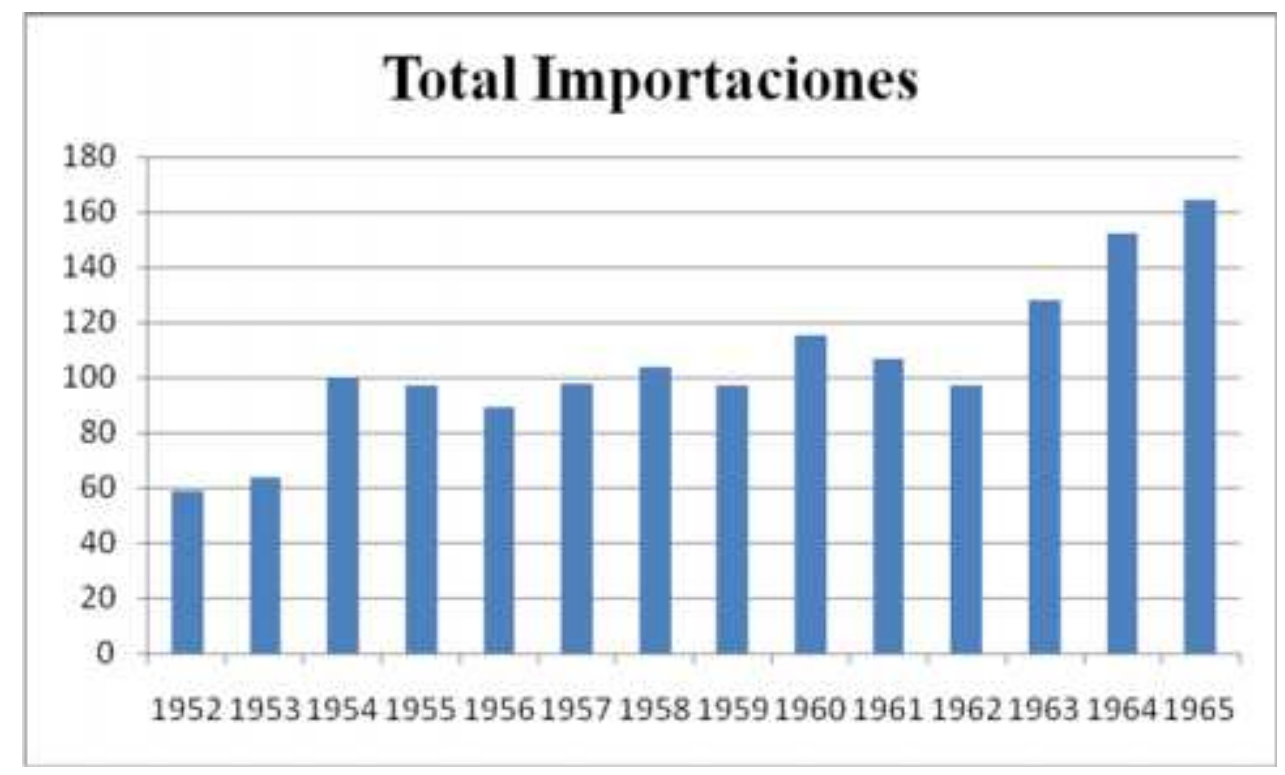

Elaboración propia a partir de los datos de la tabla 29.

Fuente: Patricio Almeida Guzmán y Rebeca Almeida Arroba: Estadísticas económicas históricas (1948-1983), Fuentes para la Historia Económica del Ecuador, Serie Estadísticas Históricas Vol. 1. Banco Central del Ecuador, Quito, 1988, p. 491.

Por otro lado, tras la notable inversión en las plantaciones de fruta estimulada por el estado a través del Banco de Fomento, se organizó un sistema de comercialización que llevó al banano a constituir más del $60 \%$ de las exportaciones del Ecuador. Además, bajo la influencia de la CEPAL, se estableció la Junta de Planificación y Coordinación Económica en 1954, planteando una estrategia de cambios en la tenencia de la tierra para dinamizar el sector agropecuario, ampliar el mercado y permitir la sustitución de importaciones. Por su parte, la inversión estatal se concentró de forma progresiva en el saneamiento ambiental y desarrollo urbano, así como en la canalización de una parte significativa del ahorro privado hacia la industria de sustitución, lo cual incrementaría el endeudamiento externo. ${ }^{537}$ Según la Junta de Planificación, entre 1959 y 1961, si bien se ingresó la cifra aproximada de 3.518 millones de sucres por inversiones directas,

\footnotetext{
537 José Raúl Gangotena: La inversión en el Ecuador 1830-1980, Libro del Sesquicentenario, Economía Ecuador, segunda parte, 1830-1980, Corporación Editora Nacional, 1983, p. 145-147.
} 
empréstitos y otros medios, la cifra abonada para atender la deuda pública y otras utilidades se situó en 4.719 millones de sucres. ${ }^{538}$

En este caso, durante las décadas de los cincuenta y sesenta, con el auge de la producción bananera y los precios de bonanza del café y del cacao, se fomentaron las relaciones capitalistas de producción costeñas a expensas de la mano de obra procedente del latifundio serrano. ${ }^{539}$. En este sentido, la mayor acumulación de capital con el auge del banano, generó un desplazamiento de una gran masa de capital desde la agro-exportación hacia la industria, ampliándose el reducido mercado interno del sector de manufacturas y estimulándose la migración de la mano de obra hacia la Costa, siendo esta combinación esencial para que Guayaquil se convirtiera en un centro de crecimiento industrial entre $1950-1955 .{ }^{540}$ En otras palabras, el aumento de la producción exportable implicó un crecimiento de la frontera agrícola, provocando la incorporación de extensas zonas de las provincias de Esmeraldas, Pichincha, Manabí y El Oro.

El plan vial de la Costa y los procesos de colonización, junto a otras actividades económicas relacionadas con el comercio en los puertos (Guayaquil fundamentalmente), provocaron grandes movimientos migratorios hacia esas zonas que se incorporaban a la economía agro-exportadora, reduciéndose de este modo, la población de la Sierra, tal y como se puede apreciar en la tabla 30: Población del Ecuador según regiones y provincias (censo de 1950 y 1962). ${ }^{541}$

A su vez, la economía de exportación suponía la incorporación de nuevos elementos para el análisis del mercado interior debido al tipo de modernización capitalista en el Ecuador. En términos generales, se puede hablar de una pequeña ampliación del mercado interno y del avance en cuanto a su integración nacional, dado que el aumento de la frontera agrícola, las nuevas vías de comunicación, la urbanización en Quito y Guayaquil y el uso de nuevas técnicas en determinadas haciendas serranas, implicarían el aumento del circuito de mercancías y la formación de una economía nacional de mercado.

\footnotetext{
${ }^{538}$ Ibíd. p 145-147.

${ }^{539}$ Lucas Pacheco, op. cit. p.103-113.

${ }^{540}$ Washington Macías, op. cit., p. 61-66.

${ }^{541}$ Esta tabla se encuentra en el apéndice de datos del capítulo 2. Fuente: Primer Censo de Población, 1950, Segundo Censo de Población 1962 y Per. Censo de Vivienda.
} 
Por otro lado, esta ampliación podría repercutir en el sector industrial y agrícola, en el sentido de que el aumento de la población seguiría vinculado a actividades del agro, siendo su demanda de bienes de consumo satisfecha con su propia producción, o en el caso de mayor demanda, vía importaciones por las divisas que generaba la agro-exportación como ocurrió en realidad. ${ }^{542}$ En estas condiciones, se puede interpretar que la demanda de bienes manufacturados era muy pequeña $y$, por consiguiente, el sector industrial seguía teniendo el mismo problema de estrechez del mercado interno.

En definitiva, nos encontramos con una estructura agraria para el consumo interno caracterizada por una gran rigidez, la cual contaba con un lento proceso de acumulación en manos de la fracción terrateniente, cuyas ideas constituían un obstáculo al desarrollo capitalista de la formación social. La expansión de la economía agro-exportadora será el comienzo de los cambios del sector agrícola tradicional en los años cincuenta y sesenta, dándose una progresiva penetración capitalista en este sector y un proceso de pauperización de los trabajadores del campo.

A continuación, vamos a pasar a analizar la relación que tanto el Ecuador como otros países de América Latina mantenían con las compañías transnacionales United Fruit y Standard Fruit, oligopolios que ejercían el control de la mayor parte del mercado mundial.

Carlos Larrea indica que durante 1951 y 1953, el 80\% de las ventas de fruta en Estados Unidos estaba en manos de las transnacionales, las cuales lograron asumir el control de las dos terceras partes de las exportaciones latinoamericanas en el año $1964 .{ }^{543}$ Ya, en el año 1946, la United Fruit dominaba el $85 \%$ de las tierras aptas para el cultivo del banano de exportación en Centroamérica y era propietaria del $73 \%$ de los barcos bananeros destinados al mercado norteamericano. ${ }^{544}$ A su vez, los intereses que estos oligopolios poseían en los países centroamericanos eran diferentes, ya que mientras que en Guatemala, Honduras, Panamá y Costa Rica, las compañías controlaban el proceso desde las grandes plantaciones hasta la distribución

\footnotetext{
${ }^{542}$ Rafael Quintero, Erika Silva, op. cit., p. 7-126.

543 Carlos Larrea Maldonado: Las empresas transnacionales y la economía ecuatoriana durante el periodo bananero, III Economía/Ecuador 1830-1980, primera parte, Libro de Sesquicentenario, Corporación editora Nacional 1983, p. 255-267.

${ }^{544}$ Ibíd. p. 255-267.
} 
en los mercados consumidores, en el resto de los países centroamericanos que exportaban a EEUU antes de la guerra, sus intereses tenían un carácter más limitado.

La participación de estos oligopolios en el Ecuador fue diferente y menos importante que la de sus enclaves centroamericanos. Así, en 1964, estas negociaron únicamente el 30\% de las exportaciones bananeras del país, mientras que el resto correspondía en gran medida a otras empresas. Asimismo, en el Ecuador, la actividad bananera era más intensiva en el empleo de mano de obra que en los enclaves de América Central, pero los salarios eran menores y la tecnología disponible era menos eficiente en el cultivo y en la comercialización de la fruta (las tablas 31, 32 y 33 muestran que los salarios en el Ecuador eran más bajos que en algunos países centroamericanos durante la etapa 1950-1974). ${ }^{545}$

Además, la mayoría de la producción no tenía su origen en las grandes plantaciones extranjeras, sino que procedía de numerosos propietarios medianos nacionales, mientras que la infraestructura vial y de los puertos, al igual que una buena parte del apoyo financiero para la actividad bananera, fueron elementos proporcionados por el estado y no por estas compañías.

A este respecto, Velasco indica que tras las acciones impulsadas por la United Fruit Company, los grupos exportadores buscaron la expansión de la producción nacional, de ahí que entre 1948 y 1950, el gobierno asignara altas cantidades al fomento bananero mediante la Comisión de Orientación y Crédito para el banano y del sistema nacional de Bancos al Fomento (ver la tabla 34: Créditos concedidos por los bancos de fomento para el cultivo del banano 1944-1951), a la vez que las firmas exportadoras comenzaron a establecer plantaciones en las grandes áreas, proporcionando facilidades crediticias a los productores nacionales. ${ }^{546}$ Teniendo en cuenta estas ideas, ¿cuáles fueron los factores que impulsaron las actividades y el interés de las transnacionales en los países centroamericanos y el Ecuador?

Para responder esta pregunta, vamos a basarnos en la teoría estructural del oligopolio de Bain y Sylos Labini, según la cual, existen factores de tipo tecnológico que, con independencia de las

545 Estas tablas se encuentran en el apéndice de datos del capítulo 2. Fuente: Carlos Larrea: El sector agroexportador y su articulación en la economía ecuatoriana (1948-1972): Subdesarrollo y crecimiento desigual, en Lefeber (ed.) Economía política del Ecuador: Campo, región, nación, Quito, Corporación Editora Nacional, 1985; Fondo Monetario Internacional: Estadísticas financieras internacionales, vol. XXIX, no. 5, Washington D.C, mayo de 1976; Chiriquí Land Co., Informe, Op. cit. (Panamá), Contraloría General de la República, op. cit, cuadro Mimeo; Frank Ellis, cit. Banco Central del Ecuador, Boletín anuario no. 5, Quito, 1982.

${ }^{546}$ Esta tabla se encuentra en el apéndice de datos del capítulo 2. Fuente: CEPAL: El desarrollo económico del Ecuador, México, 1954, p. 170; Fernando Velasco Abad, op. cit. p. 179-180. 
preferencias de los consumidores, permiten crear barreras a la movilidad de capital en ciertas ramas de la economía, posibilitando el control estable de la mayor parte del mercado de un producto, estando dicho control en manos de un número reducido de empresas. ${ }^{547}$

Bain indica que las barreras económicas a la entrada de nuevos productores, son medidas por el mayor precio que puedan lograr las firmas existentes, apareciendo estas trabas económicas mediante la combinación de los siguientes factores:

En primer lugar, las economías de escala pueden ser de gran importancia, por lo que si un nuevo productor desea competir, habrá de proveer una parte significativa del mercado. Aquí, nos referimos a las economías de escala como una situación, en la que el costo promedio a largo plazo de una compañía va disminuyendo con el aumento de la producción, es decir, se genera una economía de escala cuando al crecer la producción bajan los costos unitarios.

El segundo elemento, se refiere al hecho de que las firmas existentes poseen ventaja en cuanto a la diferenciación de sus productos, lo cual únicamente puede ser superado mediante gastos en la promoción de ventas por parte de los nuevos competidores.

En último lugar, otra posible combinación ocurre cuando las firmas existentes poseen ventajas en el control de materias primas y de conocimientos especializados, y tienen acceso a recursos financieros que impliquen mayores costos para cualquier competidor nuevo.

En el caso del mercado bananero, las grandes economías de escala se dieron en el transporte internacional del producto, en la eficiente coordinación e integración vertical del proceso desde la plantación hasta la distribución en los países consumidores, en las campañas publicitarias que permitieron diferenciar los productos, en el control de las tierras más adecuadas para el cultivo del banano y en las presiones políticas ejercidas sobre los débiles gobiernos centroamericanos que posibilitaron el control de dichas empresas en el mercado mundial. Además, las firmas líderes mencionadas poseían menores costes de producción y dominaban una buena parte del mercado, pudiendo manipular los precios y las cantidades ofertadas para eliminar a las empresas pequeñas y menos eficientes y extender su influencia de este modo.

De acuerdo con estos autores, las firmas líderes en un mercado tienen como objetivo maximizar su ganancia en el largo plazo, permitiendo solamente la existencia de las empresas medianas y

\footnotetext{
547 J. Bain: Barriers to new competition, Cambridge: Harvard University Press, 1956, p. 87; P. Labini, Sylor: Oligopoly and technical progress, Cambridge: Harvard University Press, 1962, p. 158; Carlos Larrea Maldonado, Las empresas transnacionales..., op. cit. p. 255-267.
} 
pequeñas cuando el costo de su eliminación no es compatible con dicho objetivo. De esta manera, en este periodo, los cambios ocurridos a nivel internacional tuvieron lugar cuando los costes comparativos de producción de los países que pudieron conservar sus posiciones, se mantuvieron a niveles rentables respecto a los precios internacionales, lo que explica el motivo por el cual, los países desplazados sufrieron una relación desfavorable de costes que imposibilitó su permanencia en el mercado internacional. ${ }^{548}$

El incremento de los costes a consecuencia de los fenómenos citados, hizo que las transnacionales replantearan sus estrategias regionales, abandonando los intereses secundarios que habían mantenido en esos países de Centroamérica, mientras desarrollaban a gran escala las exportaciones de fruta en el Ecuador, el cual se convirtió en su nuevo centro de operaciones secundarias. Así, en la Costa existían amplias zonas donde las plagas no causaron un gran impacto y en las que no había peligro de ciclones, lo que unido a la concentración geográfica de la producción, permitió a las compañías el empleo de grandes barcos para la distribución de la misma. La construcción de infraestructura por parte del estado y su control nacional, dejaron la puerta abierta a las transnacionales para que comercializaran sin contratos estables con los productores, y mantuvieran precios bajos para poder quedarse con una buena parte del excedente.

Carlos Larrea señala que el bajo salario de los trabajadores ecuatorianos respecto a América Central, fue el factor encargado de compensar la desventaja derivada de una tecnología menos eficiente y una desfavorable localización frente a los principales mercados (exceptuando el caso de Estados Unidos). ${ }^{549}$

Las ventajas expuestas de la producción ecuatoriana, entre las que se encuentran sus condiciones naturales, permitieron que los costos de producción fueran inferiores a los de los enclaves centroamericanos hasta 1964, fomentándose de esta forma, las pequeñas y medianas empresas que competían con las grandes multinacionales y que operaban desde el Ecuador. ${ }^{550}$

\footnotetext{
${ }^{548} \mathrm{El}$ aumento de los costes causados por las plagas y huracanes, la imposibilidad de aprovechar las economías de escala en el transporte marítimo y su inferioridad tecnológica frente a los grandes enclaves. Fuente: J. Bain, Barriers to new..., op. cit. p. 87; P. Labini, Sylor, Oligopoly..., op. cit., p. 158; Carlos Larrea Maldonado, Las empresas transnacionales..., op. cit. p. 255-267.

${ }^{549}$ Carlos Larrea Maldonado, Las empresas transnacionales..., op. cit. p. 255-267.

${ }^{550}$ Ibíd. p. 255-267.
} 


\subsubsection{2) Tenencia de la tierra y grupos asociados a la producción bananera.}

Al referirnos a la diversidad de los sistemas de tenencia en la Costa ecuatoriana, es necesario destacar el papel desempeñado por los distintos procesos históricos de ocupación de la tierra en este país. Así, al margen de una generalización sobre los rasgos de los recursos agrícolas, el litoral ecuatoriano se ha caracterizado por un proceso único de ocupación de la tierra con características históricas e institucionales homogéneas, a diferencia de lo que ha sucedido en la Sierra. La naturaleza de este mecanismo se refiere a las diversas fronteras agrícolas, de las cuales, las más antiguas tienen aún características tradicionales, ausentes en otras zonas de ocupación más reciente. En este sentido, el rasgo más común de los distintos momentos de este proceso, se encuentra en el impacto del mercado, particularmente del externo, que ha causado una gran influencia en la configuración de la Costa. ${ }^{551}$

De acuerdo con Silverman, esta caracterización conduce el análisis en dos direcciones: en primer lugar, alude al estudio del proceso histórico, con el que la agricultura del litoral ha estado vinculada de forma diferente al mercado exportador en diversos periodos, y en segundo lugar, se refiere a la elaboración de tipologías que definen y clasifican la variedad de las formas agrarias de la Costa. ${ }^{552}$

Se ha de aclarar que el tema de la localización de la producción agrícola del litoral supuso varios tipos de ajuste a los costos de transferencia, a la vez que fomentó decisiones alternativas en la orientación de la producción a un nivel distinto del de la región interandina.

Por tanto, a la hora de establecer un criterio que permita distinguir entre los sistemas de tenencia en el litoral, se ha de tener en cuenta una serie de elementos fundamentales como las diversas oleadas de ocupación a través del tiempo y el impacto de la demanda externa, siendo la combinación de estos factores, la encargada de establecer y modificar los sistemas de tenencia y las características de los grupos vinculados a ellos. En el caso de la Costa, estos factores no sólo suscitaron cambios en la producción, sino que durante el auge del cacao y posteriormente del banano, plantearon distintas situaciones de tenencia, así como una transformación de las

\footnotetext{
${ }^{551}$ Marilyn Silverman: Variabilidad agraria en la Costa ecuatoriana, en Clase y región en el agro ecuatoriano, Proyecto FLACSO-CERLAC II, Corporación Nacional Editora, Quito, 1986, p. 9-175.

${ }^{552}$ Ibíd. p. 9-175.
} 
instituciones existentes, de ahí que este apartado esté centrado en el análisis de los nuevos sistemas de tenencia generados con el banano. ${ }^{553}$

El auge del banano trajo consigo una serie de situaciones que causaron grandes impactos en la agricultura y en la economía de la Costa, pues desde ese momento, las áreas de ocupación más antiguas donde las haciendas y las grandes plantaciones contribuían a las exportaciones de la etapa pre-bonanza, pasaron a un segundo plano. En este sentido, la clasificación establecida por la CIDA, muestra una división de las explotaciones bananeras en explotaciones medianas (de 26 a 100 hectáreas), pues las que poseían un tamaño inferior, no estaban completamente incorporadas al mercado debido a la imposibilidad para cubrir el mínimo de producción demandada (ver la tabla 35: Distribución de la superficie bananera según la clasificación por tamaño de las explotaciones). ${ }^{554} \mathrm{~A}$ su vez, esta clasificación señala que el dominio de las propiedades pequeñas y medianas en la producción de banano de exportación, fue un hecho poco probable en América Latina debido a las grandes explotaciones de los países centroamericanos. Por consiguiente, ¿cuáles fueron las razones que permitieron la existencia de propietarios medianos y pequeños dedicados al cultivo del banano en el Ecuador?

Aunque en el siguiente apartado, veremos con más detalle cómo el cultivo del banano dio lugar a la formación de una nueva clase agrícola compuesta por profesionales procedentes de diferentes ámbitos, nos interesa analizar ahora algunas de las principales razones para llevar a cabo dichas inversiones, entre las que se encuentran los altos rendimientos obtenidos por los primeros cultivadores y la posibilidad de adquirir tierras baratas por parte de los nuevos grupos.

De este modo, a partir de 1948, las compañías decidieron apoyar los intentos del gobierno y de los propios agricultores en la ampliación de los cultivos del banano, ya que el país contaba con numerosas ventajas comparativas como la ausencia de plagas, mano de obra barata y la existencia de zonas húmedas que hacían menos urgente las inversiones en sistemas costosos de irrigación. Esta posibilidad de disminuir los costos y de conseguir beneficios dio lugar al comienzo de la "fiebre del banano", la cual se extendió entre terratenientes, campesinos, comerciantes y profesionales de otros ámbitos.

\footnotetext{
${ }^{553}$ Comité Interamericano de Desarrollo Agrícola, op. cit. p. 407-416.

${ }^{554}$ Esta tabla se encuentra en el apéndice de datos del capítulo 2. Fuente: Comité Interamericano de Desarrollo Agrícola, op. cit. p. 412.
} 
Por otro lado, Carlos Larrea apunta a la baja productividad obtenida por la variedad ecuatoriana Gros Michel (no sobrepasaba los 400 racimos por hectárea) y a la creciente demanda de las compañías exportadoras, como algunos de los factores que propiciaron el ingreso y la participación de pequeños campesinos que se encontraban alejados de carreteras y puertos de embarque. $^{555}$

Asimismo, las fincas productoras generadas en torno al complejo agro-exportador bananero, se constituyeron sobre las ruinas de las antiguas haciendas cacaoteras o en tierras vírgenes ocupadas por colonos, dispersándose dichas fincas en distintas provincias con características sociales, geográficas y ambientales diversas. Por consiguiente, como consecuencia de la destrucción de las plantaciones de cacao, se dio una reversión hacia la agricultura de subsistencia al interior de las anteriores haciendas destinadas al cultivo del cacao, en las que una buena parte de los antiguos sembradores y peones permaneció como arrendataria. El desarrollo de esta economía en tierras previamente ocupadas por haciendas cacaoteras, continuó prácticamente sin modificaciones hasta la década de los sesenta, ya que según el censo de 1954, en ese año había cerca de 18.500 pequeños arrendatarios y colonos, cada uno con lotes de un tamaño promedio de 20 hectáreas o menos. $^{556}$

Junto a las clases agrarias dominantes que participaban en la actividad bananera, también se encontraba un grupo de campesinos, cuyas características sociales y económicas eran variadas. Dentro de este grupo, se puede hablar de los productores bananeros que conformaban un sector social con características de las formas de producción campesina y de la economía capitalista, siendo su cultivo inferior a 20 hectáreas. Además, en la fase agrícola del banano de agroexportación se aprecia esta diferenciación social de los productores, no sólo por la oposición y competencia entre pequeña y gran propiedad, sino también por las diferencias económicas entre el campesinado. Por ello, no solo hay que destacar el predominio de la pequeña y mediana propiedad como rasgo social esencial de la configuración agraria de esa rama productiva, sino

\footnotetext{
555 Se trataba de una variedad que producía racimos gruesos, simétricos y de considerable peso, cuyo promedio se calculaba alrededor de 80 libras, aunque su límite superior se situaba entre 130 y 140 libras. Fuente: J. Cueva: Comercialización del banano ecuatoriano, Quito, AECA, 1964. Ver también: Carlos Larrea, Malva Espinosa, Paola Charbet: El banano en el Ecuador: Transnacionales, modernización y subdesarrollo, FLACSO, Biblioteca de Ciencias Sociales, volumen 16. Quito, Corporación Editorial Nacional, 1987, p. 118.

${ }^{556}$ Francisco Pareja Cucalón, op. cit. p. 392-394.
} 
que también hay que incluir a los dueños de las grandes plantaciones con vínculos oligárquicos y pequeños campesinos. ${ }^{557}$

Aunque en el Ecuador, el cultivo del banano en torno al enclave transnacional no tuvo lugar hasta finales de la década de los cincuenta y principios de los sesenta, se puede apreciar un creciente control del cultivo nacional por parte de las transnacionales. Ya hemos mencionado cómo durante la década de 1930, la United Fruit Company instaló una división bananera en la provincia del Guayas; siendo la cantidad producida bastante significativa en 1957, pues tenía 3.071 hectáreas dedicadas al cultivo del banano. ${ }^{558}$ A su vez, en 1948 la Fruit Trading Corporation, con sede en Panamá, inició la compra de varias haciendas en la provincia de Esmeraldas, dedicando alrededor de 7.000 hectáreas al cultivo del banano. ${ }^{559}$

Las grandes plantaciones coexistieron junto al enclave de los primeros años en las provincias de El Oro, Los Ríos y Guayas; correspondiendo el $26 \%$ del banano sembrado a propiedades mayores de 500 hectáreas para el año 1954. De hecho, el $50 \%$ del área sembrada de la provincia de El Oro, perteneció a varias familias hasta la primera Ley de Reforma Agraria. ${ }^{560}$

En contraste, en la provincia del Guayas, la producción bananera estuvo monopolizada por las grandes explotaciones, pues para 1963, el 15\% de los terrenos registrados en la Dirección Nacional del Banano correspondían a plantaciones mayores de 500 hectáreas. ${ }^{561}$ Es importante matizar el énfasis que se le ha dado a la existencia de los pequeños y medianos productores, pues la mayor parte del control lo tenían las grandes compañías extranjeras y los latifundios en manos de una clase terrateniente costeña. ${ }^{562}$

\footnotetext{
${ }^{557}$ Carlos Larrea, Malva Espinosa, Paola Charbet, op. cit. p. 118-119.

558 S. May, G. Plaza: The United Fruit Company in Latin America, Washington, National Planning Association, 1958, p. 170.

${ }^{559}$ Ver el apéndice de notas del capítulo 2 para más información. Fuente: Pablo Aníbal Minda: La tenencia de la tierra en la provincia de Esmeraldas, en "Identidad y Conflicto: La Lucha por la tierra en la zona norte de la provincia de Esmeraldas”, Escuela de Antropología Aplicada, UPS-Quito, Ediciones Abya-Yala, 2002, p. 23-30.

${ }^{560}$ Carlos Larrea, Malva Espinosa, Paola Charbet, op. cit. p. 117.

561 M.R. Redclift: Agrarian reform and peasant organization on the Ecuadorian Coast, Universidad de Londres, The AthoIonc Press, 1978, p. 48-50.

562 Ver el apéndice de notas del capítulo 2 para más información. Fuente: Instituto Interamericano de Ciencias Agrícolas: La planificación y el desarrollo agrícola e institucional en Ecuador, Dirección Regional para la zona Andina, apartado 478, Lima-Perú, 1969, p. 54; M. Cuvi, Carrión: Oferta tecnológica en la producción de banano en
} 
Según Redclift, el $50 \%$ de la tierra dedicada al cultivo del banano en la provincia de El Oro pertenecía a cuatro familias, lo cual pone de manifiesto que la estructura de la tenencia de la tierra solamente había cambiado superficialmente con el auge bananero. No en vano, sí que es verdad que se produjo un aumento de la mediana propiedad como hemos señalado; pues para 1965, el $87 \%$ de las propiedades destinadas a cultivar este producto tenían menos de 100 hectáreas; aunque esta situación no reflejaba el hecho de que las unidades mayores de 100 hectáreas ocupaban el 50\% de las tierras bananeras situadas en las provincias del Guayas y Los Ríos. $^{563}$

Aquí, se aprecia cómo la tenencia de la tierra en la Costa estaba caracterizada por la presencia del latifundio dominante en 1954, ya que el monopolio de la tierra estaba compartido por la propiedad imperialista y los grandes hacendados que tenían un total de 650 propiedades mayores de 500 hectáreas, las cuales representaban a su vez, el $41.4 \%$ del territorio costeño censado. En ese mismo año, había 241 propiedades de más de 2.500 hectáreas que sobrepasaban el millón y medio de hectáreas e igualaban a la propiedad de 329.000 pequeños y medianos propietarios.

A esta concentración de la tierra que muestra una auténtica vigencia del latifundio, se ha de añadir un bajo desarrollo tecnológico agrícola, un gran porcentaje de la población campesina sometida a relaciones de producción atrasadas y el frecuente asedio destructor de las comunidades indígenas en beneficio del latifundio. La concentración de la tierra en pocas manos ponía de relieve la existencia de doscientos grandes terratenientes latifundistas (que poseían un millón seiscientas mil hectáreas), mientras que en el extremo de la pobreza se hallaban 251.000 propiedades con una extensión menor de cinco hectáreas y 92.000 parcelas de menos de una hectárea. $^{564}$

Esta gran concentración de la propiedad muestra los rasgos estructurales propios del retraso social mantenido por la política terrateniente, la cual reclamaba la propiedad de tierras baldías y

el Ecuador, Quito, FLACSO, 1984. (Mecanografiado); Paola Sylva: Los productos de banano, en: El banano en Ecuador: Transnacionales, modernización y subdesarrollo, FLACSO, volumen 16, 1987.

${ }^{563}$ M.R. Redclift, op. cit., p. 48.

${ }^{564}$ Censo agropecuario de 1954. 
era dueña de enormes haciendas, donde las características feudales se mantenían bajo la forma de huasipungos, aparcería y otras formas de explotación. ${ }^{565}$

En referencia a las tierras, es importante recordar el papel desempeñado por la Iglesia durante esta época y el poder de la clase terrateniente asociado al régimen de haciendas. Esto ocurrió de forma particular en la Sierra, pues el papel de Iglesia en economías especializadas en la producción para el mercado externo, era diverso en aquellos lugares donde la producción se basaba en relaciones precarias.

Enrique Ayala indica que las relaciones de concertaje en la Sierra requerían de la presencia de la Iglesia, mientras que en la Costa, las propias relaciones económicas no necesitaban la fuerza ideológica de la Iglesia. En este caso, las relaciones pre-capitalistas requerían de un mecanismo extraeconómico de consolidación a partir de un conjunto de características ideológicas desarrolladas al margen del control del aparato eclesiástico, relaciones de vecindad, etc. ${ }^{566}$

Por otro lado, hay que tener en cuenta que la Iglesia fue el primer terrateniente del país durante el siglo XIX, pues aún cuando las regulaciones coloniales habían desaparecido, tanto las diócesis como las órdenes religiosas, lograron intensificar la adquisición de propiedades, manteniéndose así como rentistas. De este modo, la Iglesia añadió a sus compromisos estatales, la identificación de intereses con las clases latifundistas serranas. ${ }^{567}$

Por esta razón, es necesario analizar el énfasis unilateral dado a la producción bananera en la Costa, el cual ha dado una imagen errónea del verdadero panorama agrario del litoral, pues la concentración de la propiedad agraria no supuso un cambio de forma significativa.

En último lugar, hay que señalar que el régimen de vida en las haciendas bananeras se caracterizaba por el ausentismo del propietario, puesto que la naturaleza de las operaciones para la comercialización del banano requería su presencia en la ciudad durante varios días. En conjunto, la existencia de estos rasgos en los nuevos empresarios puede ser entendida si se piensa

\footnotetext{
${ }^{565}$ En el capítulo 1, vimos cómo el huasipungo era un pedazo de tierra que el terrateniente entregaba al indio para que realizara trabajos agrícolas o de pastoreo en beneficio del terrateniente. Fuente: Efrén Avilés Pino: Definición de huasipungo, en Enciclopedia del Ecuador, Academia Nacional de Historia del Ecuador, 2012.

El sistema de aparcería consistía en la entrega de la tierra al trabajador agrícola para su cultivo, adquiriendo al mismo tiempo, la obligación de entregar al terrateniente la mitad de la cosecha. Fuente: Pedro Saad, op. cit., p. 9-18.

${ }^{566}$ Enrique Ayala Mora: La relación Iglesia-Estado en el Ecuador del siglo XIX, Procesos: Revista ecuatoriana de historia, II Semestre, 1994, p. 91-115.

${ }^{567}$ Ibíd. p. 91-115.
} 
en un proceso que combinaba los elementos de frontera agrícola y de bonanza. Asimismo, la tecnología empleada por la mayoría de terratenientes, finqueros y campesinos fue bastante simple, pues la selección de las tierras y los mecanismos de acceso a las zonas de producción carecían de una tecnología desarrollada.

\subsubsection{3) La tenencia de la tierra en la Costa y los grupos vinculados durante el auge bananero: La importancia de la pequeña y mediana propiedad.}

El resultado de las modificaciones llevadas a cabo con el desarrollo del capitalismo ecuatoriano durante la década de los cincuenta, llegó a originar una serie de variaciones en cuanto a la estructura social de las clases dominantes, así como un nuevo perfil social y político para las clases inferiores en el contexto de una mayor movilización política nacional, lo que dio lugar a un empeoramiento de las contradicciones de clase. Por consiguiente, teniendo en cuenta estas ideas, vamos a pasar a revisar con mayor detenimiento cuáles fueron esos grupos de diferentes propietarios que lograron beneficiarse de la actividad bananera durante los años cincuenta y sesenta.

En principio, se puede decir que la enorme riqueza creada con el auge bananero se llevó a cabo mediante la acción de dos sectores beneficiarios, pues por un lado, se encontraban los grandes y medianos propietarios de las plantaciones, y por otro, las compañías exportadoras, entre las que figuraban las empresas transnacionales, principalmente las estadounidenses, que fijaban los precios de la fruta y asignaban determinados cupos a los productores para subordinar a los medianos y pequeños propietarios a sus intereses. ${ }^{568}$

Ya vimos cómo el cultivo del banano generó una nueva clase agrícola que, en cierto modo, pudo modificar la distribución del ingreso. Esta nueva clase estaba constituida por militares jubilados, empleados, comerciantes y artesanos, los cuales se convirtieron en propietarios de las tierras entregadas a un valor bajo para el cultivo del banano, permitiéndose de esta manera, una democratización entre los propietarios agrícolas y la existencia de una clase media. ${ }^{569}$

Francisco Pareja afirma que la expansión de la producción bananera generó una serie de cambios económicos, sociales y políticos de gran magnitud, siendo sus efectos más directos, la expansión

\footnotetext{
${ }^{568}$ Iván Fernández Espinosa, Patricio Tobar Robalino, op. cit. p. 117-131.

${ }^{569}$ Lionel López Pinto: Distribución del ingreso en la economía ecuatoriana 1830-1980, Libro del Sesquicentenario, Economía Ecuador, segunda parte, 1830-1980, Corporación Editora Nacional, 1983, p. 162.
} 
de la frontera agrícola, el desarrollo de una agricultura capitalista en la Costa y el crecimiento de una nueva clase media. De este modo, el cultivo del banano tuvo lugar en las zonas más húmedas de la Costa, en las áreas antes ocupadas por las haciendas cacaoteras y también en tierras que no habían sido incorporadas a la agricultura, lo cual explica la expansión de la frontera agrícola mediante la apropiación de nuevas tierras para uso productivo. ${ }^{570}$

Así, a diferencia de la Sierra, donde la clase terrateniente había ocupado una gran mayoría de las tierras, en el litoral, había un alto porcentaje de terrenos baldíos, existiendo por tanto, la posibilidad de realizar una expansión profunda de la frontera agrícola. Así, el área original de producción comercial del banano, la zona de Babahoyo-Naranjal, fue extendiéndose hacia el norte; articulando una nueva red urbana en la Costa central y norte que tenía como eje las ciudades de Quito y Guayaquil. Esta colonización era una forma de inversión capitalista para estos sectores de la pequeña burguesía, lo que manifestaba la heterogeneidad de la propiedad costeña, al haber aparecido la burguesía agraria media como nueva categoría social.

En referencia a la utilización de tierras desocupadas para el cultivo del banano, se ha de matizar su importancia, pues la producción se pudo llevar a cabo lejos del control de los terratenientes tradicionales de la Costa, permitiendo la generación de nuevas relaciones de producción. Aunque estos pequeños y medianos propietarios representaban una nueva clase agrícola, se caracterizaban por el mantenimiento de sus raíces en la ciudad de Guayaquil y en otras zonas. Además, la predominancia del elemento de clase media condujo a una auténtica democratización de la clase de propietarios agrícolas, al haber desaparecido la asociación tradicional de la posición de hacendado o propietario de una hacienda con distinción de fortuna. ${ }^{571}$ Es decir, esta nueva fracción mostraba antagonismos con respecto a la clase terrateniente no capitalista a través de su propio origen y posición, mientras que también estaba contradictoriamente ligada a un proceso de comercialización controlado por las grandes compañías bananeras imperialistas.

Por otro lado, el auge económico de la expansión bananera, no solo reavivó la penetración del capitalismo en la forma de producción de la hacienda serrana y costeña, sino que también desintegró las estructuras pre-capitalistas, agudizando a su vez, las contradicciones entre el campesinado indígena y los terratenientes que lograron mantener los huasipungos, mientras que

\footnotetext{
${ }^{570}$ Francisco Pareja Cucalón, op. cit., p. 392-394.

571 C. Herrera Vascónez: Algunos datos sobre la producción y comercialización de banano en el mundo y particularmente en el Ecuador, Guayaquil, REV-VAG, Doc. No. 021-ST, 1965.
} 
en las ciudades, particularmente en Guayaquil, la población era movilizada para reivindicar las estructuras políticas de la burguesía. Esto también tenía su origen en el deterioro de la producción y distribución de la riqueza, debido a la disminución de los precios de bienes de exportación por el control de la producción bananera por monopolios en el mercado mundial.

En su obra, Iván Fernández habla de la alianza establecida entre los grupos agro-exportadores y la clase dominante, y de cómo pudieron beneficiarse del excedente económico de las exportaciones con la ayuda del estado. Esta alianza se puso de manifiesto en la política económica de comercialización interna, que fue abandonada al libre juego de la oferta y demanda sin la intervención estatal, mientras que la comercialización externa se encontraba favorecida por una política tributaria, arancelaria y monetaria (devaluación de 13 a 15 sucres), que llevaría a un fortalecimiento económico de los grupos exportadores. ${ }^{572}$

Llama la atención el papel del estado en esta época, pues se constituyó como un medio para incentivar las actividades económicas, creando para ello, las condiciones materiales y sociales necesarias para su reproducción. Además, el control gubernamental se hacía en la inversión para impulsar el sector externo, lo cual manifestaba su débil posición política al servicio de la clase asociada a dichos intereses.

Volviendo a la producción bananera exportable durante los años cincuenta, se ha de mencionar cómo llegó a estructurar una matriz de acumulación capitalista más amplia que abarcaba numerosas zonas de la Costa y de la Sierra y estaba basada en una estrecha vinculación con el mercado mundial, además de estar sustentada en las políticas públicas de fomento agropecuario del estado burgués-terrateniente. ${ }^{573}$

Como se mencionó anteriormente, el estado se encontraba ligado a las posibilidades de acumulación que el sector agrario permitía al conjunto de los sectores productivos. La inversión pública para la producción agrícola (especialmente de banano) se llevó a cabo por medio de los créditos concedidos por el sistema de bancos, que pasaron de 330.000 sucres en 1944, a más de 17 millones de sucres entre 1949 y $1950 .{ }^{574}$

\footnotetext{
572 Iván Fernández: Estado y desarrollo capitalista en el Ecuador, Nueva sociedad, Número 45, NoviembreDiciembre, 1979, p. 12.

573 Ocupaba territorios de las provincias costeñas de Esmeraldas, Los Ríos, Guayas, El Oro, Manabí, pero abarcaba también las provincias serranas de Pichincha, Cotopaxi, Bolívar y el Cañar.

${ }^{574}$ Iván Fernández, op. cit. p. 12-13.
} 
Asimismo, este esfuerzo crediticio para favorecer la producción agrícola de exportación fue acompañado de un plan de colonización y de inversión en infraestructura para dinamizar la región del litoral.

El plan vial de la Costa fue la obra fundamental del estado en este periodo, gracias a ello, el transporte de la fruta a los puertos de exportación se hizo en mejores condiciones y el proceso de colonización se amplió en forma considerable (zonas como Santo Domingo y Quevedo nacieron prácticamente en esta década). ${ }^{575}$

Además, la inversión pública que pasó del $25 \%$ en 1950, al 37\% en 1959, fue destinada a infraestructura vial (carreteras y puertos), lo cual nos da una idea de la política de inversión pública y de cómo los sectores sociales y económicos se beneficiaban de la acción gubernamental. ${ }^{576}$

En la Costa, la producción y exportación bananera permitieron la reconversión de la estructura agraria anterior y la disminución de los latifundios, proceso que ya había comenzado con la crisis de la hacienda cacaotera a través de la venta de la tierra para financiar la modernización o para solucionar las demandas campesinas. Esta lenta reducción del latifundio costeño, iniciada en los años cuarenta, estuvo acompañada de un fuerte incremento de la pequeña y mediana propiedad, por lo que para principios de los sesenta, la distribución de la tierra destinada al cultivo del banano representaba un predominio de la mediana extensión. En la producción bananera no se constituyó una estructura agraria pre-capitalista, sino que a partir de las características de la nueva colonización, se desarrolló una burguesía agraria media, se extendió el área de pequeños campesinos independientes y se generó un numeroso grupo de trabajadores rurales, mientras que a comienzos de los sesenta, aproximadamente un 50\% de la población costeña involucrada en la producción agrícola estaba integrada por trabajadores asalariados. ${ }^{577}$

También, Fernando Velasco habla de la importancia de la pequeña y mediana propiedad cuando se refiere a la presencia de un nuevo grupo social que logró desplazar a los productores tradicionales, lo cual se explica en virtud de la ampliación de la frontera agrícola.

\footnotetext{
${ }^{575}$ Ibíd. p. 12-13.

${ }^{576}$ Ibíd. p. 12-13.

${ }^{577}$ Comité Interamericano de Desarrollo Agrícola, op. cit., p. 407-416.
} 
En este caso, la producción bananera fue incorporando tierras que anteriormente no habían sido explotadas, lo que unido a los créditos, creó buenas perspectivas para los grupos emergentes. Es decir, con la expansión del banano se abrió la frontera agrícola del Ecuador y se impulsó la ocupación de la zona del interior de la Costa, lo que se vio favorecido por la construcción vial porque logró romper el aislamiento entre determinadas áreas. ${ }^{578}$ Así, las fíncas medianas y pequeñas se convirtieron en el eje de este negocio de exportación, mientras aparecía un grupo medio de agricultores, transportistas e intermediarios, que pudo haber promocionado una nueva estructura de poder en la economía y política ecuatoriana. Entre las razones que impidieron que esto ocurriera, se encuentran la inestabilidad de la actividad bananera, pues los avances técnicos en su cultivo, especialmente la difusión de variedades resistentes a las plagas, impusieron el cultivo de la gran hacienda bananera, mientras que el pequeño o mediano agricultor se encontraba sometido a la explotación de una serie de intermediarios y exportadores. ${ }^{579}$

A su vez, la expansión de la actividad bananera fue realizada a partir de nuevas formas de trabajo, siendo las relaciones salariales impuestas en la mayor parte de la región. No obstante, hay que aclarar que este proceso no tuvo lugar de igual forma para todos los productos de exportación, pues en el caso del arroz, se continuó aplicando la aparcería.

La difusión de estas relaciones salariales y la alta productividad de la tierra en las fincas bananeras, fueron algunos de los factores que desempeñaron un papel considerable en la acumulación de capital y el rápido desarrollo del capitalismo en la Costa, a lo que también se ha de añadir la aparición de los nuevos grupos sociales que no tenían una vinculación con la clase terrateniente. De forma paralela, la riqueza generada por la demanda mundial del banano, arroz, cacao y café, fue utilizada como fondo de consumo destinado a la adquisición de bienes sofisticados, el cual fue satisfecho mediante la importación de bienes de capital, de ahí que el sector importador se convirtiera en uno de los principales beneficiarios del auge bananero.

Por otra parte, a nivel de la sociedad ecuatoriana, el dinamismo del banano produjo una ampliación del mercado interno y la comercialización de la producción de la hacienda serrana, creándose un importante espacio para la capitalización de la renta de los terratenientes serranos, así como un nuevo mecanismo de acumulación de capital a nivel interno mediante la formación

\footnotetext{
${ }^{578}$ Fernando Velasco Abad, op. cit. p. 179-200.

${ }^{579}$ Germánico Salgado: La economía del Ecuador en los últimos setenta años, 1906-1976, Guayaquil: Departamento de Publicaciones, Facultad de Ciencias Económicas, Universidad de Guayaquil, 1978, p. 103-145.
} 
de trabajadores en la ciudad y un proceso de urbanización. Es decir, el impulso de la producción bananera y de otros bienes tropicales tuvo gran impacto en el mercado de trabajo, provocando la migración Sierra-Costa, tal y como se refleja en la tabla 36 (Emigración e inmigración en el Ecuador por provincias, años 1950 y 1962). ${ }^{580}$

Esta ampliación de la frontera agrícola se debía por un lado, a la política de fomento agrícola impulsada por el gobierno de Galo Plaza, y por otro, al amplio movimiento de toma de tierras que agrupaba a los campesinos. ${ }^{581}$ En este contexto, el campesinado agrícola constituido como grupos de asalariados se unió políticamente mediante grandes movilizaciones a finales de la década de los cincuenta. ${ }^{582}$

No obstante, el desarrollo capitalista en el agro costeño, también estuvo acompañado de algunas de las formas características del viejo régimen latifundista. Así, en numerosos casos, los asalariados agrícolas, de los cuales aproximadamente el 20\% tenía una relación laboral estable, estaban sometidos a un conjunto de restricciones sobre su jornal, como el pago parcial en vales de la tienda o almacén de la hacienda, la negación de derechos laborales vigentes en las leyes sociales como el libre tránsito, la organización, carencia de protección del seguro social, etc. ${ }^{583}$ Al mismo tiempo, se aprecia cómo la estructura de producción en la que se estableció el auge bananero, incorporaba una serie de elementos novedosos, ya que el tamaño medio de la finca, dispersaba de forma considerable la oferta del producto y consolidaba un amplio sector de intermediarios nacionales, encargados de una serie de actividades entre las que figuraban la cosecha y el embarque controlado por las compañías extranjeras. Además, mientras que la actividad fundamental de las plantaciones pequeñas y medianas era el cultivo del banano, para las grandes haciendas pertenecientes en su mayor parte a compañías extranjeras, el cultivo del banano no era precisamente la actividad más importante, pues sus operaciones principales

\footnotetext{
${ }^{580}$ Esta tabla se encuentra en el apéndice de datos del capítulo 2. Fuente: Patricio Almeida Guzmán, Rebeca Almeida Arroba, Estadísticas Económicas..., op. cit.p. 444-447.

${ }^{581}$ Ver el apéndice de notas del capítulo 2 para más información. Fuente: Astrid Martínez: Planes de desarrollo y política agraria en Colombia: 1940-1978, Ed. Universidad Nacional de Colombia, 1986.

${ }^{582}$ Ver el apéndice de notas del capítulo 2 para más información. Fuente: Oswaldo Albornoz: Las luchas indígenas en el Ecuador, Editorial Claridad, S.A. Guayaquil, Ecuador, 1971, p. 80-85.

${ }^{583}$ La concentración de estos asalariados en algunas empresas y grandes plantaciones agrícolas estaba por encima de los 300 y 400 hombres, llegando a superar el millar en la hacienda Tenguel de la United Fruit. Fuente: Pedro Saad: La cuestión agraria, en obras escogidas, tomo IV Guayaquil, Editorial Claridad, 1971, p. 12.
} 
estaban centradas en la comercialización del banano, a partir del control monopólico que ejercían sobre el mercado mundial. Esto nos indica que la mayor parte del precio final era absorbido por estos sectores, siendo mínima la porción que el productor recibía. ${ }^{584}$

A este respecto, Velasco afirma que en el control de la producción durante la primera década del auge bananero, coexistían un sector de enclave vinculado a la economía central y un sector controlado a nivel nacional, el cual estaba subordinado al del enclave mediante mecanismos de comercialización. La presencia del capital extranjero en el sector productivo permitió alcanzar un precio más alto, ya que el sector nacional se beneficiaba de los precios del enclave, aunque también determinaba la escasa participación del productor en el precio final. ${ }^{585}$

Además, las grandes haciendas de las compañías extranjeras poseían un conjunto de privilegios en la comercialización y exportación de la fruta a diferencia de los pequeños y medianos productores, que apenas podían beneficiarse de los adelantos tecnológicos y de las economías de escala, pues dependían del control de las compañías exportadoras. Así, la gran burguesía oligárquica, los terratenientes y las empresas imperialistas obtenían grandes beneficios en el negocio bananero, de ahí que la burguesía agraria media defendiera sus intereses reclamando contra los monopolios norteamericanos conforme se acentuaban las contradicciones de clase.

La lucha de clases derivaba fundamentalmente del deterioro de la producción y distribución de la riqueza entre las clases sociales, debido al control monopólico de la producción bananera en el mercado mundial, cuyo margen del precio de exportación fue de un 54,7\%, quedando apenas un $27,6 \%$ para el productor y un $17,7 \%$ para la comercialización interna. ${ }^{586}$ Por otro lado, la tabla 37 (Ingreso mensual por clases sociales -1950 y 1956) muestra la disparidad de ingresos entre las clases sociales, siendo las trabajadoras las más perjudicadas, si se comparan con las propietarias y con la burguesía pequeña. ${ }^{587}$

\footnotetext{
584 Según la Junta Nacional de Planificación, en 1960, el productor percibía aproximadamente un 27,6\% del precio de exportación, quedando un $17,7 \%$ como margen bruto de comercialización interna y un 54,7\% como margen bruto de comercialización del sector exportador. Fuente: Junta Nacional de Planificación: Plan General de Desarrollo Económico y Social, T.I. Lb.I, Quito, 1963, p. 68.

${ }^{585}$ Fernando Velasco Abad, Ecuador, op. cit., p. 179-200.

${ }^{586}$ Rafael Quintero, Erika Silva, op. cit. p. 67.

587 Reinaldo Torres Caicedo: Los estratos socio-económicos del Ecuador, Quito, JUNAPLA, 1960, p. 30; Proyecciones de Torres Caicedo, Quito, JUNAPLA, 1960, p. 30.
} 
Por otra parte, teniendo en cuenta que la mayor parte de las exportaciones ecuatorianas tenía como destino Estados Unidos (su cifra se encontraba alrededor del 50\% y el 65\%), el resultado fue la gran vulnerabilidad del país y de la nueva fracción social como consecuencia de la fuerza económica y política del imperialismo. Así, este sector de la burguesía ecuatoriana planteó acabar con los obstáculos que el estado ecuatoriano imponía a la exportación de productos agrícolas a los países socialistas. ${ }^{588}$

En estos años, para remediar dicha vulnerabilidad, apareció una propuesta del Partido Demócrata Cristiano, fundado en noviembre de 1964 en Guayaquil, según la cual, se proponía escapar de la situación de dependencia, de los intereses económicos y monopólicos y de las clases sociales que se beneficiaban de esa dependencia, ya que la eliminación del imperialismo implicaba deshacerse de las relaciones de poder:

El país deberá escapar de su actual dependencia con respecto a los Estados Unidos, promoviendo un más activo intercambio comercial con los otros países, especialmente con los europeos y socialistas, particularmente estos últimos que ofrecen las mejores perspectivas, por no estar sujetos a acuerdos internacionales y por no haber saturado sus posibilidades de compra. ${ }^{589}$

De esta forma, mientras la penetración imperial aumentaba en el agro costeño a través de la asesoría técnica de la "Asociación Internacional de Desarrollo" (AID) y se golpeaba a la producción nacional de la Sierra y de la Costa con la intervención estadounidense en el mercado, la burguesía agraria media no logró crear un grupo agrario nacional. Esto puede deberse a su propio fraccionamiento regional, a la debilidad de los industriales, o porque en ese contexto de descontento y de lucha por una reforma agraria, prefirió elegir la defensa de los intereses nacionales buscando la vía del compromiso con la oligarquía. 590

\footnotetext{
${ }^{588}$ Rafael Quintero, Erika Silva, op. cit. p. 67.

589 Ver el apéndice de notas del capítulo 2 para más información. Fuente: Osvaldo Hurtado: Dos mundos superpuestos, Quito, INEDES, 1969, p. 111; Enrique Ayala, Rafael Quintero: Teorías e ideologías sobre el estado en Ecuador: 1948-1984, en “El estado en América Latina”, Edit. Siglo XXI, 1990, p. 400-402.

${ }^{590}$ Pedro Saad, op. cit. p. 17.
} 


\section{2) La pérdida de auge económico y la nueva etapa de dependencia (1956-1970).}

\subsection{1) El estancamiento de las exportaciones bananeras y problemas del modelo de desarrollo agro-exportador.}

Ya se ha visto cómo el desarrollo de la modalidad de acumulación capitalista de esta segunda fase, dependía del incremento continuo de las exportaciones, la obtención de precios altos en el mercado mundial y mantenimiento de los términos de intercambio favorables, siendo fundamental la combinación de estos elementos para que el sector ecuatoriano volviera a tener el dinamismo de la época del cacao. Este motor de acumulación que giraba alrededor de la exportación de productos agrícolas tropicales, encontró límites al desarrollo capitalista que le impedían repartirse en el ámbito geográfico y económico del país, restringiéndose al espacio agrario que permitía captar rentas diferenciales a nivel del mercado internacional y la ampliación de la frontera agrícola. ${ }^{591}$

Si bien es verdad que esta matriz facilitó el desarrollo del capitalismo en todo el país, las condiciones internacionales y locales favorables a este tipo de crecimiento económico cambiaron muy pronto, ya que a partir de 1955, y por motivos ajenos al control nacional, se aprecia un estancamiento de las exportaciones bananeras como consecuencia de una disminución de la demanda y alteración de los precios, los cuales mostraban tendencias negativas con el término de la guerra de Corea, a la vez que se saturaban los mercados de banano, las plagas incrementaban los costos de producción y había menos tierras vírgenes fértiles.

La tabla 38 (Exportaciones de banano y relación de intercambio 1951-1960) muestra esta pérdida de dinamismo de las exportaciones bananeras, así como el problema del deterioro de los términos de intercambio, cuyos efectos negativos llegaron a cancelar lo que parecía haber sido

La Asociación Internacional de Desarrollo o AID fue creada en 1960, con el objetivo de dar asistencia a los países más desfavorecidos al ofrecerles préstamos libres de interés (para la provisión de servicios sociales básicos y la dirección de apoyo a presupuestos), asistencia técnica y asesoría en políticas públicas. Esta asociación es financiada por países ricos y los préstamos son realizados a aquellas naciones que no pueden solicitarlos a través del Banco Internacional de Reconstrucción y Desarrollo. Fuente: Bretton Woods Project: Asociación Internacional de Desarrollo, Índice de instituciones, 2008.

${ }^{591}$ Fernando Velasco Abad, op. cit. p. 201-130. 
una base permanente de estímulo gracias al desarrollo hacia afuera. ${ }^{592}$ Esta disminución de la demanda afectará decisivamente a toda la economía, pues durante la etapa 1955-1959, el aumento de la demanda global se produjo más lentamente a consecuencia de la disminución de la inversión pública. ${ }^{593}$ Como resultado, aún cuando el sector exportador continuó siendo el sector más dinámico de la economía, no llegó a tener la misma vivacidad del periodo 1950-1954, provocando una serie de efectos en la economía ecuatoriana, sobre todo a partir de la segunda mitad de los años sesenta, cuyo estudio realizaremos a continuación.

Entre las razones que explican estos cambios se puede destacar la reiniciación de la actividad comercial en las plantaciones centroamericanas, en las que existían mayores posibilidades de obtener beneficios gracias al reducido coste de transporte y a las técnicas más modernas aplicadas tanto en el procesamiento como en la comercialización de la fruta, lo que provocó un alejamiento por parte de las multinacionales que operaban en el Ecuador, y con ello, la pérdida de su hegemonía en el mercado mundial.

Pese a que las transnacionales fueron las que contribuyeron al auge bananero ecuatoriano, en ese momento, pasaron a ser competidoras de la principal exportación nacional a los Estados Unidos, siendo los resultados obtenidos desfavorables como era de esperar. Ante estas condiciones, los sectores exportadores comenzaron a buscar nuevos mercados donde realizar sus exportaciones tradicionales a pesar de la dificultad para encontrar un mercado tan valioso como el estadounidense, que era capaz de ofrecer un crecimiento dinámico y sostenido de las exportaciones. Además, se produjo una profunda transformación del mercado bananero internacional, llevándose a cabo una expansión de las zonas básicas de operaciones de las multinacionales en Centroamérica, a la vez que impulsaba la exportación bananera de Filipinas hacia Japón.

Esta segunda crisis del modelo agro-exportador muestra el agotamiento de las estructuras tradicionales, por lo que a partir de aquí, se plantea la realización de determinados cambios para estabilizar el sistema. También, se ha de hablar del aumento considerable de población como se puede observar en el gráfico 11 (Población total estimada 1950-1969), así como del incremento

\footnotetext{
592 Esta tabla se encuentra en el apéndice de datos del capítulo 2. Fuente: Germánico Salgado: El Ecuador y la integración subregional", Exportaciones, Volumen, Quito, UNTAL, 1969, p. 64; Junta Nacional de Planificación: Plan General de Desarrollo, Valor y relación de intercambio, Libro I, Volumen I, Quito, 1963, p. 62 y 66.

593 Esta tasa paso de $22.6 \%$ en el primer quinquenio a $6.6 \%$ en el segundo. Fuente: Germánico Salgado, op. cit. p. 49.
} 
de las migraciones del campo a la ciudad, las cuales llegaron a provocar grandes concentraciones en Guayaquil y Quito, con el reclamo de asistencia estatal para aliviar la aguda crisis económica tras las devaluaciones monetarias del sucre y el elevado nivel de precios a finales de la década de los cincuenta.

Como se ha mencionado, ciudades como Guayaquil y Esmeraldas (ver la tabla 30: Población del Ecuador según regiones y provincias -censo de 1950 y 1962- y la tabla 39: Crecimiento de principales centros urbanos), experimentaron un crecimiento urbano superior al crecimiento demográfico total del Ecuador, al igual que una concentración nacional urbana en la región del litoral. $^{594}$

Entre 1950 y 1962, la migración interna neta desde la Sierra fue de 280.477 personas. De ellas, el $96 \%$ se radicó en la Costa. La población económicamente activa en el agro de esta región se elevó de 222.957 personas en 1950 a 351.585 en 1962. La población del litoral, que significaba el 40,5\% del total nacional en 1950, llegó al 47,5\% en $1962 .{ }^{595}$

Aquí, cabe destacar que este proceso de urbanización supuso una cierta masificación de la sociedad urbana del Ecuador, pues al igual que ocurrió en otros países de América Latina desde los años veinte y treinta, la aparición de la marginalidad urbana llegó a convertirse en un gran problema en los años cincuenta. Este proceso de urbanización afectó sobre todo a Guayaquil y Quito, pues la primera se había convertido desde finales del siglo XIX en la ciudad más grande del país, sobrepasando a la capital y llegando a los 45.000 habitantes en 1890. En 1950, Guayaquil poseía el 7,7\% de la población total del país; en 1962 tenía el 11,4\%, y en 1974 pasó a un 25,9\% de la población total del país. Al compararla con Quito, vemos que su participación fue del $6,6 \%$ en $1950,7,9 \%$ en 1962 y $18,8 \%$ en $1974 .^{596}$

\footnotetext{
${ }^{594}$ Censos nacionales 1950 y 1962 en Carlos Larrea y Renato Landín: Estructura social, crecimiento económico y desequilibrios internos en el Ecuador: El caso de las exportaciones de banano y cacao en la Costa Sur, Centro de cómputo de FLACSO, 1987, edición digital, idl-bnc.idrc.ca.

595 Carlos Larrea: El sector agroexportador y su articulación con la economía ecuatoriana durante la etapa bananera (1948-1972), 1985, en Louis Lefeber, ed. Economía Política del Ecuador. Campo, Región, Nación, Quito: CEN-CERLAC- FLACSO, p. 35-90.

${ }^{596}$ Censos nacionales 1950 y 1962 en Carlos Larrea y Renato Landín, op. cit., edición digital idl-bnc.idrc.ca
} 
Gráfico 11: Población total estimada (1950-1069) (miles de personas)

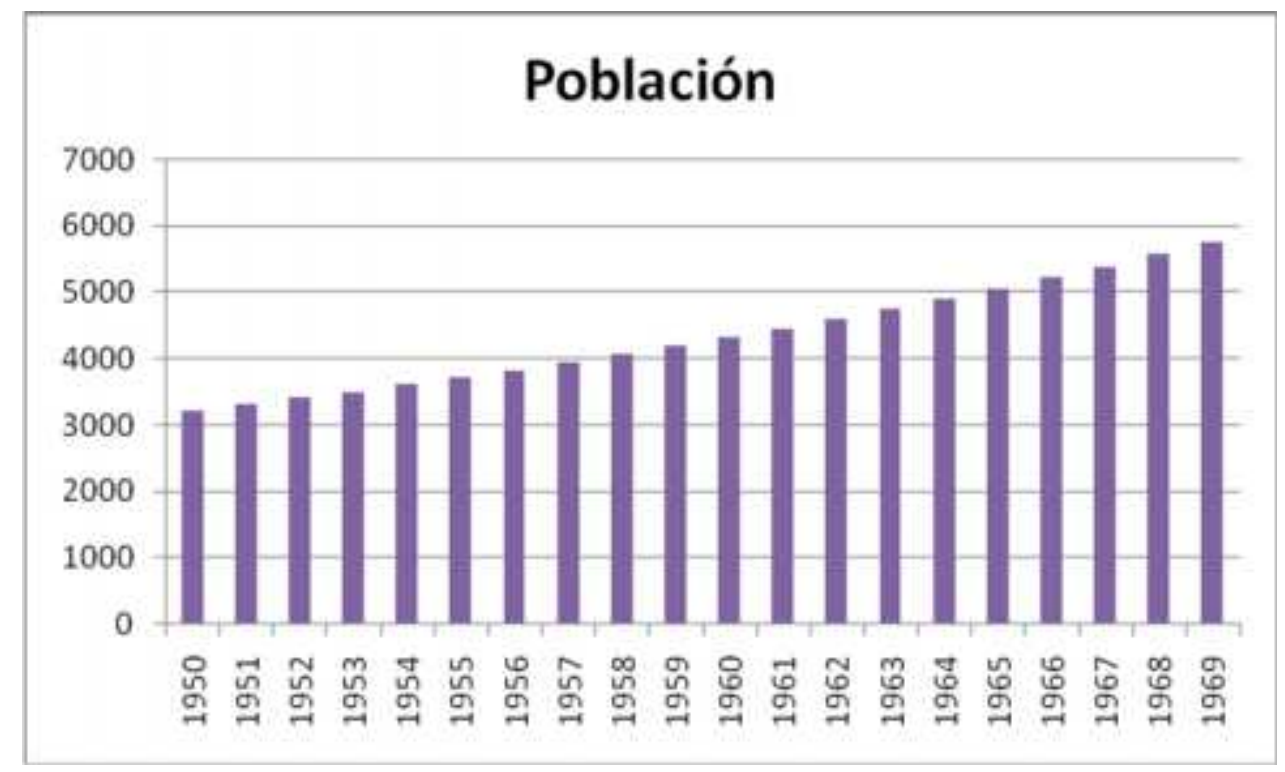

Elaboración propia a partir de los datos de la tabla 42.

Fuente: Patricio Almeida Guzmán y Rebeca Almeida Arroba: Estadísticas económicas históricas (1948-1983), Fuentes para la Historia Económica del Ecuador, Serie Estadísticas Históricas Vol. 1, Banco Central del Ecuador, Quito, 1988, p. 4.

El empeoramiento de la situación económica y agudizamiento de los problemas sociales, no sólo se produjo a partir de la declinación del auge bananero, sino también con el descenso de las cotizaciones del cacao y del café, siendo los sectores populares, los primeros en sufrir el impacto de la crisis, produciéndose huelgas y reclamos que finalizaron en una masacre en Guayaquil en 1959:

La recuperación de las plantaciones centroamericanas, el retiro de las compañías extranjeras que fundamentalmente se mueven en la esfera de la comercialización del producto, la caída de los precios de los productos de exportación, el deterioro de los términos de intercambio, producirán una nueva crisis en la economía, que repercute drásticamente sobre los sectores populares. ${ }^{597}$

\footnotetext{
${ }^{597}$ Patricio Ycaza: Movimiento obrero, estado y modernización capitalista en el Ecuador (1960-1983), Editorial Rafael Perugachi, 1985, p. 13.
} 
El debilitamiento de la coyuntura determinó la subida del producto interior bruto al $1 \%$ entre 1955-1960, reduciéndose la inversión pública a un ritmo del 4\%, en tanto que la inversión privada disminuía en términos absolutos. El cuadro depresivo de la época fue empeorando ante los inflexibles requerimientos de divisas para la industrialización sustitutiva y por el pesado servicio a la deuda externa a la que se acudía de forma recurrente (Ver la tabla 40: Ecuador: Evolución de la Deuda Externa (1950-1970). ${ }^{598}$

Ante estas circunstancias y para poder remediar el déficit externo y los retos planteados por la sociedad, los gobiernos de la época acudieron a los préstamos internacionales en lugar de aplicar medidas que hubieran afectado a la estructura de tenencia de la propiedad y a la incipiente industria y a otras áreas de la economía. Así, la economía ecuatoriana comenzó a estancarse como consecuencia de la dependencia comercial, financiera y tecnológica a que habían llevado los años del auge bananero.

Igualmente, la pérdida del auge bananero perjudicó la alianza de clases capitaneada por la oligarquía de la Costa y produjo graves problemas de pauperización y desempleo, poniendo de manifiesto una estructura productiva anacrónica, cuyos problemas principales (debilidad de la industria, predominancia de las formas pre-capitalistas en la agricultura, etc.) habían sido ignorados por los gobiernos de la época.

Así, a comienzos de los sesenta, los intentos para reactivar el modelo agro-exportador mediante la aplicación de diversas políticas tuvieron muy poco éxito. La devaluación del sucre (de 15 a 18 por dólar) llevada a cabo por Velasco Ibarra en 1961 y las reducciones de impuestos fiscales a las principales exportaciones realizadas durante su presidencia y la de Arosemena (1961-1963), fueron simples medidas monetarias y fiscales destinadas a mantener los niveles de acumulación de los monopolios agro-exportadores, pero no estaban diseñadas para resolver la crisis global del sistema. $^{599}$

A pesar de los problemas, el gobierno de Arosemena (1961-1963) no modificaría el esquema económico, ya que el cambio estaba motivado por conflictos políticos internos y por una agitación popular que rebasó todo límite por parte de la burguesía, teniendo que hacer frente a la

\footnotetext{
${ }^{598}$ René Báez: Apogeo y decadencia del modelo agro-exportador: Periodo de la segunda posguerra, texto tomado de René Báez: "Dialéctica de la economía ecuatoriana", Colección Isidro Ayora, Vol. II, Quito, Ecuador, Banco Central, 1980, p. 28-42.

${ }^{599}$ Ver el apéndice de notas del capítulo 2 para más información. Fuente: Pablo Cuvi: Velasco Ibarra: El último caudillo de la oligarquía, Instituto de Investigaciones Económicas, 1977, p. 230-233.
} 
agresividad de los intereses petroleros y latifundistas y a los intentos de gobierno de los industriales. ${ }^{600}$ De este modo, la presidencia de Arosemena lograría impulsar una política nacionalista burguesa, cuyo objetivo era favorecer una política agraria encargada de debilitar el poder del gran latifundismo. ${ }^{601}$

Los problemas del sector exportador llevaron al gobierno de la Junta Militar (1963-1966) a plantear un modelo de desarrollo asociado, el cual se definía por una mayor diferenciación de la estructura económica y una industrialización por sustitución de importaciones. A este respecto, ya existían intereses industriales que buscaban una representación política, mientras que los exportadores querían transferir sus inversiones a un sector productivo, y de este modo, apoyar el modelo desarrollista.

No obstante, se ha de aclarar que la existencia de rezagos pre-capitalistas era un obstáculo al proceso de industrialización debido al bajo nivel de consumo, la estrechez del mercado interno y la presencia de grandes latifundios en manos de un número limitado de terratenientes. Es decir, todos estos elementos constituían un complemento del cuadro depresivo que afectaba a la economía ecuatoriana.

En este sentido, el Censo Agropecuario de 1954 pone de manifiesto la existencia de 241 propiedades en el Ecuador mayores de 2.500 hectáreas (ver tabla 41: Latifundios en el Ecuador Censo de 1954). ${ }^{602}$ Dentro de estas, hay varias que pertenecen a una misma persona o a una misma corporación, por lo que el número de latifundistas en esa época era menor que el número indicado de propiedades.

En el caso de la provincia del Guayas, la propiedad estaba altamente concentrada debido a la existencia de la United Fruit, que en el Ecuador operaba con el nombre de "Bananera del Ecuador" y tenía las haciendas de Villanueva, Milagro, Venecia, San Carlos con decenas de millares de hectáreas cada una.

\footnotetext{
${ }^{600}$ Ver el apéndice de notas del capítulo 2 para más información. Fuente: Juan J. Paz, Miño Cepeda: La economía en los gobiernos de José María Velasco Ibarra (1960-1961) y Carlos Julio Arosemena (1961-1963), Monografías, Archivo Histórico del Taller de Historia Económica, No. 01, PUCE, 2006.

${ }^{601}$ Washington Macías, op. cit. p. 66-69.

${ }^{602}$ Banco Central del Ecuador, Ministerios de Economía, Banco Nacional de Fomento: Primer Censo Agropecuario Nacional, 1954, Impreso en los talleres gráficos de la Dirección General de Estadística y Censos, Ministerio de Economía, Quito, Julio 1956.
} 
Otro de los mayores latifundistas era el estado ecuatoriano, que no solo tenía tierras baldías (con millones de hectáreas), sino que también tenía grandes haciendas (como las de Asistencia Pública) que mantenía con sistemas feudales de explotación.

También, ya sabemos que otro de los grandes latifundistas era la Iglesia y como ejemplo se puede citar el caso de la Curia de Guaranda, la cual se fue adueñando de decenas y centenares de miles de hectáreas, incluyendo la población de Zapotal.

Por último, se encontraban los grandes bancos (el Banco de Fomento) que fueron quedándose con las tierras embargadas por las hipotecas y cuentas que los campesinos no podían pagar. En la provincia de Esmeraldas, por ejemplo, se denunció la existencia de tres mil juicios contra los campesinos de dicha provincia, los cuales corrían el riesgo de perder sus pequeñas pertenencias:

En definitiva, la tierra ecuatoriana está acaparada en pocas manos, no sirviendo para nada las grandes mayorías, sino que la mantienen al servicio de unos pocos grandes señores terratenientes que hacen de ella un instrumento de explotación de las grandes masas campesinas. ${ }^{603}$

A su vez, los problemas de la acumulación bananera llevarán a la crisis de los medianos y pequeños productores y la subsistencia de las grandes plantaciones de banano, por lo que no es de extrañar que la recuperación de las plantaciones centroamericanas llevara aparejada una disminución del ritmo de crecimiento de las exportaciones ecuatorianas y una nueva etapa de crisis en la acumulación capitalista de los años sesenta.

Carlos Larrea explica cómo a partir de 1965, las exportaciones ecuatorianas comienzan a ser desplazadas de sus principales mercados, reduciéndose a la mitad las ventas a Estados Unidos entre 1964-1973, mientras que en el caso europeo la disminución fue menor. ${ }^{604}$ A su vez, el estancamiento en el volumen de exportaciones, provocó una disminución de la capacidad adquisitiva e inestabilidad en el corto plazo, lo que vino acompañado por una declinación de los mercados tradicionales y del japonés en los años setenta.

Esta situación puede ser explicada a partir del cambio producido en la estructura de costes comparativos a nivel internacional tras la introducción por parte de las transnacionales de nuevas

\footnotetext{
${ }^{603}$ Pedro Saad, op.cit., p. 36-37.

${ }^{604}$ Carlos Larrea, op. cit. p. 12-50.
} 
variedades, como fue el caso del Cavendish, que lograría disminuir los costes de la United Fruit en Honduras. ${ }^{605}$ Es decir, mediante un cambio total en las técnicas del cultivo y a través de la investigación tecnológica, las transnacionales pudieron desarrollar nuevas variedades en sus plantaciones.

Según Frank Ellis, para el intervalo 1960-1964, los costes de la United Fruit bajaron de un promedio de 2,54 dólares por caja, a 1,40 para el periodo 1965-1970, perjudicando esta estructura de costes a la variedad ecuatoriana Gros Michel. ${ }^{606}$

Además, aún cuando el Ecuador pudo conservar algunas ventajas comparativas derivadas de las condiciones sociales, como fue el pago de bajos salarios, no logró mantener las ventajas procedentes de sus condiciones naturales, pues el menor desarrollo del mal de Panamá en las plantaciones bananeras del Ecuador desapareció como ventaja, al igual que ocurrió con la ausencia de ciclones gracias a la mayor resistencia que el Cavendish presentaba. ${ }^{607}$

Las variedades nuevas lograron rendimientos por hectárea cuatro veces superiores a los tradicionales y sobre todo fueron menos vulnerables a los ciclones y resistentes a las plagas. Ante la nueva situación, las ventajas relativas del país, perdieron significación y la relación de costos comparativos se tornó desfavorable para el banano nacional. En los años siguientes, las transnacionales extendieron la participación de sus enclaves en el comercio mundial y desplazaron parcialmente al Ecuador de los mercados tradicionales. Esta nueva situación es funcional para los oligopolios que, desde 1965, han empleado al Ecuador como proveedor marginal y abastecerlos de reservas frente a

605 Tipo de banano con menos sabor que el Gros Michel, al que sustituyó por ser más resistente al mal de Panamá, aunque en la actualidad también es atacado por ese mal, ya que se ha producido una alteración en ese hongo. Para producción de tipo de banano. Fuente: Pedro Arias: La economía mundial del banano, 1985-2002.

${ }^{606}$ Frank Ellis: Las transnacionales del banano en Centroamérica, Educa, Costa Rica, 1983, p. 188.

El comercio internacional de banano se basa principalmente en la exportación de bananos del tipo Cavendish. El Cavendish sustituyó al Gros Michel en el comercio internacional debido a su resistencia a la enfermedad de Panamá y a su mayor productividad (hasta 60 toneladas por hectárea en plantaciones modernas. Fuente: FAO: La economía mundial del banano 1985-2002, Organización de las Naciones Unidas para la agricultura y la alimentación, Roma, 2004 , p. 7. 
eventuales desastres naturales, conflictos políticos o laborales que imposibilitaron su abastecimiento regular. ${ }^{608}$

Como vemos, la insuficiencia de estímulos externos y la inexistencia de tecnología que propiciara el despegue industrial autónomo, fueron algunos de los factores que limitaron las posibilidades para un crecimiento independiente. Esto explica que el fracaso de las reformas impuestas por los diferentes gobiernos determinara la continuación del modelo agro-exportador, que buscaba dar cauce a su proceso industrial mediante una legislación proteccionista (Ley de Fomento de 1964) a la que intentaron resistirse exportadores e importadores. ${ }^{609}$ Dicha oposición derivó en agudos conflictos políticos entre 1965 y 1966 (la guerra del arancel, la huelga de los comerciantes de Guayaquil, etc.), que vinculados al estrangulamiento financiero al que había conducido la política de desarrollo subordinado al imperialismo y la supuesta modernización del país, culminaron con la caída de la Junta Militar en $1966 .{ }^{610}$

El régimen provisional de Clemente Yerovi (1966) buscará restablecer el equilibrio con medidas clásicas y monetarias, las cuales no fueron sino remedios temporales que tampoco pudieron dar solución a una crisis de raíces estructurales y profundas, teniendo el Ecuador que hacer frente a numerosos desajustes de la balanza de pagos de las finanzas públicas, como veremos más adelante. ${ }^{611}$

Para mejorar la competición internacional de la fruta ecuatoriana, los productores ecuatorianos comenzaron a sembrar y exportar banano Cavendish a partir de 1967, y a pesar de que llegaron a contar con el apoyo del gobierno, no lograron revertir la relación de costes comparativos. ${ }^{612} \mathrm{La}$

\footnotetext{
${ }^{608}$ Carlos Larrea, op. cit. p. 12-50.

${ }^{609}$ La primera ley de promoción industrial fue aprobada en 1957 y fue modificada sucesivamente durante el periodo 1962-1973, con el fin de incrementar los incentivos y orientar el desarrollo industrial. Fuente: José Moncada: $L a$ Economía ecuatoriana en el siglo XX, Instituto de Investigaciones Económicas, Universidad Central del Ecuador, 1980, p.58.

${ }^{610}$ Ver el apéndice de notas del capítulo 2 para más información. Fuente: Carlos Larrea, op. cit. p. 12-50; Efrén Avilés Pino: La Junta Militar de Gobierno, en Enciclopedia del Ecuador, 2012.

${ }^{611}$ Ver el apéndice de notas del capítulo 2 para más información. Fuente: Efrén Avilés Pino: Clemente Yerovi, en Enciclopedia del Ecuador, 2012.

${ }^{612}$ FAO: La economía mundial del banano 1985-2002, Organización de las Naciones Unidas para la agricultura y la alimentación, Roma, 2004. Este estudio muestra que el costo del banano Cavendish ecuatoriano en 1969, era de 92 dólares, mientras que el costo del banano de Costa Rica era de 90 dólares.
} 
tabla 43 (Superficie de bananos Gros Michel y Cavendish en el Ecuador 1965-1976) muestra una disminución paulatina de la cantidad de tierra destinada al cultivo del Gros Michel, que pasó de una superficie de 146.233 hectáreas en 1967, a 47.067 hectáreas en 1972, frente a las 53.927 hectáreas que por aquel entonces representaba el Cavendish. ${ }^{613}$

Asimismo, el cambio de variedad no sólo implicaba una transformación de la distribución espacial de la producción bananera y de la estructura de la tenencia de la tierra, sino también una reducción de la superficie sembrada y una concentración geográfica y económica de los productores, pues la mayor sensibilidad de la nueva variedad durante su transporte interno, llevó a la modificación de las técnicas de preparación, imponiéndose la necesidad de concentrar el área bananera cerca de los puertos. ${ }^{614}$

A su vez, los exportadores volvieron a recurrir a la eliminación de los impuestos a las exportaciones para favorecer los productos agrícolas ecuatorianos en el mercado internacional. Este plan se pudo llevar a cabo debido a la debilidad organizativa y política de los productores, la falta de un movimiento sindical entre los obreros agrícolas bananeros y la influencia sobre las políticas estatales que los exportadores demostraron tener, recayendo las consecuencias de este plan en los productores, sobre todo los pequeños, que se vieron afectados por las políticas de precios y la inestabilidad de la demanda, mientras que los trabajadores vieron cómo sus salarios disminuían, tal y como muestra la tabla 44 (Salarios mensuales de los trabajadores bananeros 1952-1976). ${ }^{615}$

En definitiva, la existencia de estos problemas económicos y sociales, junto con la reducción de la superficie y la concentración de la producción en la Costa sur, ponen de relieve las razones por las que el banano dejaría de ser la actividad agrícola más importante del litoral, dando paso a cultivos agro-industriales para el mercado interno, principalmente las oleaginosas. Entre estas oleaginosas, se puede citar la soja, que fue cultivada fundamentalmente en las áreas liberadas con el desplazamiento del cultivo de banano hacia la provincia de El Oro. Así, Quevedo y sus

\footnotetext{
${ }^{613}$ Esta tabla se encuentra en el apéndice de datos del capítulo 2. Fuente: María A. García: Análisis estadístico de la producción bananera en el Ecuador, Escuela Superior Politécnica del Litoral, Guayaquil, Ecuador, 2000 , p. 52-86.

${ }^{614}$ Ver el apéndice de notas del capítulo 2 para más información. Fuente Frank Ellis: Las transnacionales del banano en Centroamérica, Editorial Universitaria Centroamericana, 1983, p. 80-82; J. Cueva: Comercialización del banano ecuatoriano, Quito, AECA, 1964.

${ }^{615}$ Esta tabla se encuentra en el apéndice de datos del capítulo 2. Fuente: Carlos Larrea, op. cit. p. 12-50.
} 
alrededores habían sido hasta entonces, las zonas bananeras por excelencia, pero con la generalización del "mal de Panamá" que afectaba a la variedad Gros Michel, y la sustitución de ésta por la variedad Cavendish, la producción bananera de la zona de Quevedo entró en crisis.

La producción de soja fue iniciada en 1973, cuando se sembraron 1.227 hectáreas, siendo la superficie sembrada de 33.325 hectáreas en 1982, de las cuales el 65\% se concentró en la zona mencionada. A su vez, el sorgo comenzó a sembrarse en 1979 en una superficie aproximada de 2.500 hectáreas, mientras que el maíz de grano amarillo se producía en varias provincias del país (Manabí, Los Ríos y Guayas en la Costa; Laja Pichincha y también en la Amazonía), siendo la superficie nacional sembrada con ese grano de 77.000 hectáreas para $1969 .{ }^{616}$

De esta manera, la crisis de la actividad bananera, las acciones desarrollistas llevadas a cabo por los gobiernos de la época para promover el crecimiento de la industria, la diversificación de la estructura productiva y la expansión del mercado interno, junto con las exportaciones de petróleo que reemplazaría al banano como primer producto de exportación, fueron algunos de los factores fundamentales que redujeron la importancia estratégica de la exportación de productos agrícolas en el Ecuador.

\subsection{2) Las acciones imperialistas y la política en América Latina: El efecto de la Revolución Cubana de 1959.}

Las características del proceso económico ecuatoriano que hemos analizado hasta ahora, tenderán a reflejarse de manera directa en el ámbito político de finales de los años cincuenta y durante la década de los sesenta. Así, la vigencia del patrón agro-exportador como modelo de desarrollo económico, estableció una estructura social y cierta dinámica de poder, pues en la esfera política, lo habitual era el control directo del poder ejercido por los grupos vinculados al sector agro-exportador. ${ }^{617}$ De este modo, las fluctuaciones del sector externo moldeaban las diversas formas que la dominación política asumía en cada etapa del desarrollo histórico de la sociedad ecuatoriana, de ahí que se piense en el auge bananero como el elemento responsable de la estabilidad y funcionamiento de una democracia más o menos liberal entre 1948 y 1960. La caída del modelo agro-exportador, el énfasis del desarrollo industrial y el inicio de la producción

\footnotetext{
616 María Cuvi, Rafael Urriola: Oleaginosas, cereales y agroindustria en la Costa ecuatoriana, en "Transformaciones agrarias en el Ecuador", CEDIG, 1988, p. 95-107.

${ }^{617}$ Agustín Cueva, El proceso de dominación..., op. cit. p. 95-105.
} 
y exportación del petróleo, generaron importantes cambios en el funcionamiento de la estructura de poder, que también se vio afectada por la ruptura del sistema de dominación de Estados Unidos en Cuba, como se estudiará después.

En el plano internacional, América Latina se vio afectada por el triunfo de la Revolución Cubana en 1959, hecho que acabó rompiendo el esquema de la sociedad respecto a la imposibilidad de una revolución socialista. Paralelamente, generó un gran impacto en el marco intelectual, social y político de las sociedades latinoamericanas, al pasarse de una fase popular democrática a una etapa socialista a partir de la década de los sesenta. El éxito de este movimiento creó un conjunto de problemas desde el momento en que la operación liderada por Fidel Castro no se limitó a eliminar la dictadura de Fulgencio Batista y a establecer una democracia, sino que tuvo como objetivo impulsar un proceso de profundas transformaciones políticas, económicas y sociales, a la vez que buscaba poner fin al dominio estadounidense sobre la isla. ${ }^{618}$

Dadas las ideas del momento, estos cambios, que implicaban el abandono de la economía de mercado y del modelo político liberal, derivaban hacia el socialismo, pues la revolución que pretendía acabar con el ideal democrático-liberal y el cuestionamiento a la hegemonía norteamericana, fue la causa que había conducido a la intervención de EE.UU en Guatemala. ${ }^{619}$ A su vez, existía una gran dificultad para evitar que dicha controversia se desvinculara de las contradicciones de la Guerra Fría, ya que la confrontación entre EE.UU y la Unión Soviética apenas dejaba espacio para posiciones intermedias. ${ }^{620}$

En aquel momento, la mayoría de los gobiernos latinoamericanos tenía una orientación conservadora o no poseía un gran espacio de autonomía en relación con EE.UU (ver tabla 45: Presidentes en los países latinoamericanos (1950-1960), por lo que las medidas de reforma social impuestas por Cuba, tales como la reforma agraria y la reforma urbana, la intervención del estado en el sector empresarial y bancario, así como las confrontaciones con la Iglesia católica,

\footnotetext{
${ }^{618}$ Patricio Ycaza, op. cit., p. 13-15.

${ }^{619}$ Ver el apéndice de notas del capítulo 2 para más información. Fuente: Hugo Murillo Jiménez: La intervención norteamericana en Guatemala en 1954. Dos interpretaciones recientes, Escuela de Historia y Geografía, Universidad de Costa Rica, Anuario de Estudios Centroamericanos, 11 (2), 1985, p. 149-155.

${ }^{620}$ Gabriel Aguilera Peralta: Cuba y la OEA Apuntes de una larga y complicada relación, Revista Nueva Sociedad, No 223, septiembre-octubre de 2009, p. 1-11.
} 
en aquel entonces muy conservadora, contribuyeron a la reacción negativa de los gobiernos del continente. $^{621}$

En cuanto a EE.UU, el factor fundamental del conflicto, fue la decisión de expropiar las empresas norteamericanas que se encontraban en Cuba, lo que dio lugar al establecimiento de medidas económicas como contrapartida, tales como la congelación de la cuota azucarera y el embargo comercial, situación que ponía de relieve la negativa de EE.UU, que no estaba dispuesto a ceder en la lucha contra la Unión Soviética, y la postura de las empresas norteamericanas, que se negaban a perder su control del mercado cubano. ${ }^{622}$

A la vez, las ideas comunistas era contrarias a las políticas impuestas por la mayoría de los gobiernos latinoamericanos, que no sólo se encontraban alineados con EE.UU, sino que muchos de ellos estaban gobernados por dictaduras que tenían a la población sometida a la miseria, lo que hacía más atractiva la idea de un cambio radical. En cualquier caso, lo cierto es que el gobierno estadounidense dejó clara su postura y su carácter opuesto a la Revolución Cubana, realizando diversos esfuerzos para provocar un cambio de régimen, los cuales incluían el aislamiento diplomático, político y económico de la isla, el apoyo a movimientos armados contrarrevolucionarios que realizaban sabotajes y organizaban guerrillas y finalmente, la invasión de Bahía de Cochinos. ${ }^{623}$

En el caso específico del Ecuador, los efectos de esta revolución y su coincidencia con el agotamiento del estado ecuatoriano y los problemas de la sociedad, permiten entender la gran influencia que dicho movimiento tuvo en este país. Aquí, es importante recalcar el impacto que la Revolución Cubana tuvo en el desarrollo de la izquierda ecuatoriana, pues incluía un conjunto de fuerzas enfrentadas al estado, a la vez que tenía como objetivo transformar la sociedad, que sufría los efectos del estancamiento de las exportaciones y del aumento del nivel de precios.

\footnotetext{
${ }^{621}$ Enciclopedia Salvat, Países de América Latina, Salvat Ediciones Ecuatoriana S.A., Tomo VIII, Barcelona, 1980.

${ }^{622}$ Ver el apéndice de notas del capítulo 2 para más información. Fuente D. Rich, M. Kaplowitz, Michael: New opportunities for US-Cuban trade, Universidad de John Hopkins, abril, 1992, p. 1; J. Luis Rodríguez, G. Carriazo, George: La erradicación de la pobreza en Cuba, La Habana: Editorial Ciencias Sociales, 1990, p. 3; F. López Segrera: Cuba: Capitalismo dependiente y subdesarrollo (1510-1959), La Habana: Editorial Ciencias Sociales, 1981, p. 187; José Acosta: Cuba: de la neocolonia a la construcción del socialismo, Economía y Desarrollo, Núm. 19, La Habana, 1973, p. 64; F. López Segrera: Dependencia y subdesarrollo, Revista de la Biblioteca Nacional José Martí, septiembre-diciembre 1969, Núm. 3, p. 110; Leo Hubennan y Paul Sweezy: Cuba, anatomía de una revolución, Anuario Azucarero de Cuba 1960, (La Habana: 1961), p. 59.

${ }^{623}$ Ver el apéndice de notas del capítulo 2 para más información. Fuente: Revista el Militante: La Revolución Cubana: Pasado, presente y futuro, noviembre 2004, p. 16-22.
} 
En este contexto, las simpatías por la Revolución Cubana en el Ecuador de los años sesenta, llegaron a producir frecuentes oposiciones, pues los acontecimientos democráticos se convertirían en hechos subversivos dentro de un marco político delimitado por un estado oligárquico. Las reclamaciones manifestaban el desacuerdo de la sociedad, lo cual fue percibido por la reacción y el imperialismo como un alejamiento intencionado con respecto a las formas sociales establecidas. $^{624}$

Teniendo en cuenta la gran influencia que Estados Unidos ejercía en el Ecuador como socio comercial y el papel imperialista de las transnacionales durante la fase bananera, se puede entender la amenaza que dicha revolución representaba para el gobierno estadounidense y su relación con el Ecuador y el resto de los países latinoamericanos.

En efecto, siendo la lucha contra el comunismo una de las principales preocupaciones de la política exterior de EE.UU durante la Guerra Fría, es lógico que no quisiera un acercamiento entre América Latina y la Unión Soviética. No obstante, esta demanda no impediría la desaparición de los partidos políticos de izquierdas, los cuales habían crecido durante la guerra, ganando prestigio gracias a sus vínculos con la Unión Soviética, al ser percibida en ese momento como una aliada de EE.UU y de los otros países en la lucha contra el fascismo.

Los líderes latinoamericanos y ecuatorianos, fieles aliados de EE.UU durante la Segunda Guerra Mundial, especialmente al proveer las materias primas a precios más bajos que los del mercado, pensaban que tras la finalización del conflicto, podrían recibir algún tipo de ayuda por su lealtad. En su lugar, la elaboración del Plan Marshall, con el que se otorgaron 12.400 millones de dólares en subvenciones para la reconstrucción de Europa, supondría un duro golpe para los países latinoamericanos, que no podían entender cómo EE.UU entregaba esta gran cantidad a Japón y Alemania, sus enemigos del eje, mientras ellos no recibían nada. Además, los líderes de estos países creían que EE.UU ejercía una gran presión en asuntos concernientes a sus intereses e ignoraba sus preocupaciones, especialmente las relacionadas con una disminución de los aranceles y el establecimiento de precios justos para sus exportaciones, así como sus deseos de obtener asistencia para el desarrollo económico. ${ }^{625}$

\footnotetext{
${ }^{624}$ Rafael Quintero, Erika Silva, op. cit. p. 224.

${ }^{625}$ Ronn Pineo: Ecuador: Relaciones exteriores a la luz del bicentenario, Quito, FLACSO, Colección Bicentenario, 2009, p. 297-331.
} 
Este punto de vista comenzó a manifestarse en el año 1947, cuando los delegados de América Latina y Estados Unidos se reunieron para la Conferencia Interamericana para el Mantenimiento de la Paz y la Seguridad del Continente, en la que Estados Unidos pretendía negociar un tratado de seguridad colectiva anticomunista con América Latina, mientras que los delegados latinoamericanos intentaron aprovechar esta oportunidad para negociar el Plan Marshall para América Latina. ${ }^{626}$

A pesar del fracaso de estas negociaciones, el Ecuador estaba dispuesto a aceptar la formación de una alianza militar antisoviética, aunque también aspiraba a conseguir un acuerdo intrahemisférico, es decir, apoyaba la idea de la defensa mutua, no sólo en contra de los ataques extrahemisféricos, sino también en los casos en los que ocurrieran problemas con otros países del continente, como el que había tenido lugar entre Ecuador y Perú en $1941 .{ }^{627}$ Esta medida, que encontraría poco apoyo, serviría para prevenir futuras invasiones peruanas, a la vez que pretendía revisar las implicaciones territoriales de la incursión anterior.

Posteriormente, en 1948, en la reunión de la Conferencia Panamericana, el Ecuador volvió a solicitar el establecimiento de mecanismos más eficaces que evitaran la guerra entre los países latinoamericanos, además de abordar el tema de los términos de intercambio para las exportaciones.

Si bien, en el periodo de 1948 a 1958, Estados Unidos proporcionó asistencia económica a estos países, se ha de destacar que una parte considerable de la ayuda recibida tenía el carácter de préstamo, al igual que ocurría con la asistencia militar, aunque esta también era proporcionada bajo la forma de subvenciones. Así, desde 1945 a 1957, EE.UU entregó a América Latina 2.600 millones de dólares en forma de créditos y subvenciones militares y económicas, aunque solamente el 2\% del total (48,5 millones de dólares) fue destinado al Ecuador. La fuente principal de ayuda económica para el Ecuador fue el Banco de Exportación e Importación

\footnotetext{
${ }^{626}$ Ver el apéndice de notas del capítulo 2 para más información. Fuente: Pedro F. Salas: El Tratado Interamericano de Asistencia Recíproca de Río de Janeiro (1947), Editorial Jurídica de Chile, 1962 y Pan American Union: "IX Conferencia Internacional Americana, Bogotá, 1948: Convención Interamericana sobre concesión de los derechos políticos a la mujer", Washington, D.C, Unión Panamericana, 1948.

${ }^{627}$ La guerra de 1941 culminó con la victoria total de las tropas peruanas, la ocupación de dos provincias ecuatorianas y la firma del Protocolo de Río de Janeiro en 1942, que establecía los límites entre el Ecuador y Perú. No obstante, las negociaciones en torno a la guerra y paz entre estos países dependieron principalmente de la acción mediadora de Argentina, Brasil, Chile y Estados Unidos, pues estos gobiernos firmaron como garantes del tratado (el Protocolo de Río) hasta que la frontera entre esas naciones quedara definitivamente demarcada. Fuente: Jorge Domínguez: Disputas fronterizas en América Latina, Foro Internacional 177, jul-sept. 2004, p. 357-391.
} 
(Eximbank), cuyos préstamos fueron utilizados para financiar la amplia gama de proyectos (autopistas, suministro de agua para Quito y otras poblaciones, pavimentación de las calles, construcción de nuevas facilidades en Guayaquil, aeropuertos para Quito y Guayaquil, etc.) a los que nos hemos referido con anterioridad. ${ }^{628}$

Ya hemos señalado como el imperialismo y las acciones de los gobiernos de la época, a pesar de la ayuda estadounidense, generaron el malestar social y representaron una pérdida de la libertad de acción para este país. A este respecto, Galo Plaza (1948-1952) comprometería todavía más la soberanía del país negociando con el Fondo Monetario Internacional en 1949, el establecimiento de un conjunto de medidas estrictas de política monetaria a cambio de créditos que, aún cuando podían ser usados para obras de infraestructura, debían de contar con la aprobación de dicha institución. Es decir, el Eximbank controlaba los proyectos de obras públicas y en el caso de que estos no se desarrollaran de la forma en que el Banco quería, este amenazaba con retirar el crédito.

En los años cincuenta, la política monetaria tuvo un carácter de estabilización, puesto que su objetivo central era que el crecimiento de la economía nacional tuviera el mínimo de inflación. Sin embargo, la Ley de Régimen Monetario establecida en 1948, incorporaba los instrumentos keynesianos de política monetaria y fiscal que se resumían en la búsqueda del orden financiero internacional, el fomento de la producción y el empleo y el desarrollo del aparato productivo, a fin de crear condiciones monetarias y crediticias favorables al crecimiento de la economía. ${ }^{629}$ Esta teoría correspondía a la corriente monetarista del keynesianismo y fue difundida por el Fondo Monetario Internacional, con el propósito de adecuar la legislación monetaria ecuatoriana y adaptarla a las exigencias del nuevo orden económico surgido al término de la Segunda Guerra Mundial.

\footnotetext{
${ }^{628}$ El Export-Import Bank de Estados Unidos (Eximbank) fue fundado por el Congreso de los Estados Unidos en 1934 y establecido como una agencia gubernamental independiente en 1945. Su propósito es "apoyar en el financiamiento y el fomento de las exportaciones”. Desde su origen, el Eximbank ha apoyado las exportaciones estadounidenses con más de cuatrocientos mil millones de dólares, además de ayudar a los países exportadores con financiación de corto, medio y largo plazo, a clientes internacionales con capacidad de crédito de los sectores privado y público, así como con garantías de capital de trabajo. Fuente: Michael R. Czinkota, Ilkka A. Ronkainen: Marketing Internacional, Ed. Cengage Learning, octava edición, 2007, p. 378-380.

${ }^{629}$ Eduardo Larrea Stacey: Evolución de la política del Banco Central del Ecuador 1927-1987, Quito, Banco Central del Ecuador, 1990, p. 90-92.
} 
De este modo, mientras que el estado impulsaba la producción exportable a través del crédito procedente del Banco Nacional de Fomento y de la Comisión de Orientación y Crédito para el Banano, la política fiscal fue orientada a promover la expansión y diversificación productiva, a la vez que la inversión pública desempeñaba un papel estratégico en la integración entre la Costa y la Sierra y en la ampliación del mercado interno. El estado se convirtió en el motor de la inversión y promotor del crecimiento de la demanda de bienes y servicios, al disminuir el papel de la inversión privada que pasó del 74\% en 1950 al 57\% en 1960, mientras la inversión pública ascendió del $26 \%$ en 1950 al $43 \%$ en $1960 .{ }^{630}$ Además, fue un mecanismo de negociación entre la burguesía agro-exportadora y financiera con el latifundismo serrano, y constituía el vínculo para la internacionalización de la economía.

Las fuentes para esta expansión fiscal fueron el crecimiento de las exportaciones y el crédito internacional, sobre todo a mediados de la década de los cincuenta. ${ }^{631}$ La financiación externa tenía su origen en las instituciones financieras internacionales, las cuales promocionaban el desarrollo en los países subdesarrollados. De este modo, la misión del Fondo Monetario Internacional, que visitó el país durante el Gobierno de Galo Plaza en 1949, consistiría en crear una política basada en la libre circulación de capitales y bienes.

No en vano, una vez obtenidos los préstamos, el Ecuador dejó de lado estas estipulaciones y aplicó su propio criterio, debido en parte a que el Eximbank ejercía un gran control en los proyectos de obras públicas que patrocinaba el Ecuador. Como ejemplo, se puede citar el proyecto de construcción de la vía Manta-Quevedo en 1950, para el cual, se necesitaba la aprobación del Eximbank, además de tener que aceptar un plan detallado sobre la forma de utilización de fondos, concediendo al Banco la aprobación de los planos de construcción. En el momento en que la construcción no se llevaba a cabo de la forma en que el Banco deseaba, este amenazaba con retirar el crédito.

El empeoramiento de la situación económica con la pérdida de fuerza del boom bananero vino acompañado de la agudización de los problemas sociales, siendo los sectores populares los primeros en sufrir la crisis, dando lugar a huelgas que acabaron con una masacre en Guayaquil en 1959. Durante este año, el gobierno de Camilo Ponce (1956-1960) comenzó a solicitar

\footnotetext{
630 Junta Nacional de Planificación y Coordinación Económica: Desarrollo y perspectivas de la economía ecuatoriana, en Plan general de desarrollo económico y social, Quito, Citado por Miño, 1963, p. 120.

${ }^{631}$ Wilson Miño: Breve historia bancaria del Ecuador, Quito: Corporación Editora Nacional, 2008, p. 25-190.
} 
préstamos internacionales con el propósito de aprovechar los recursos financieros, solucionar las demandas de la sociedad y hacer frente a los déficits externos, pero no se tuvo en cuenta un conjunto de medidas que afectara la estructura de tenencia de la tierra y de la incipiente industria. ${ }^{632}$

En la medida en que la inestabilidad aumentaba, el Ecuador se veía obligado a pedir préstamos al Fondo Monetario Internacional, contratando nueve créditos contingentes o stand by en junio de 1961, junio de 1962, julio de 1963, julio de 1964, julio de 1965, julio de 1966, abril de 1969, septiembre de 1970, siendo el último de esta serie, en julio de 1972, unos días antes de que se comenzaran las exportaciones de petróleo. Estos préstamos fueron concedidos a cambio del establecimiento de un estricto programa de austeridad fiscal, una política de crédito restrictiva y la devaluación de la moneda, que según el FMI debió haber sido realizada por el gobierno de Camilo Ponce y que contribuyó a la desestabilización del gobierno de Velasco Ibarra (19601963) provocando una prolongada etapa de inestabilidad. ${ }^{63}$

Por otro lado, durante el gobierno de Camilo Ponce, se solicitó un préstamo de quince millones de dólares para la construcción de carreteras en la Costa y otras obras de infraestructura, a cambio de proporcionar a las corporaciones multinacionales mayor libertad y aceptar mayores exigencias en cuanto a la política fiscal. Los préstamos correspondientes al periodo 1963-1966, fueron obtenidos tras la implantación de las medidas anteriores, el aumento de los precios de la gasolina y de las tarifas de electricidad y el despido de doscientos empleados en la planta eléctrica de Quito. ${ }^{634}$

Por supuesto, tanto el Fondo Monetario como Estados Unidos mantenían la idea de que el Ecuador había provocado la imposición de este tipo de medidas, pues en algunas ocasiones, las agencias de cooperación de los EE.UU reclamaban que el Ecuador utilizaba los fondos de los préstamos en formas no autorizadas. A menudo, el gobierno ecuatoriano no solo no disponía del dinero necesario para contribuir con su parte de los costos de los proyectos financiados por el exterior, sino que la descentralización de la burocracia ecuatoriana obstaculizaba la existencia de

\footnotetext{
${ }^{632}$ Ver el apéndice de notas del capítulo 2 para más información. Fuente: Efrén Avilés: Camilo Ponce Enríquez, en Enciclopedia del Ecuador, 2012.

${ }^{633}$ Alberto Acosta: Breve Historia Económica del Ecuador, Corporación Editora Nacional, Quito, 2002, p. 109.

${ }^{634}$ Ronn Pinneo: Las relaciones entre Ecuador y Estados Unidos durante la Guerra Fría, FLACSO, 2009, p. 309312.
} 
un grupo de personas a cargo de dicho proyecto. Un ejemplo de esto, fue el préstamo solicitado para financiar la extensión de líneas de agua potable en Quito durante los años cincuenta, para el que el Eximbank demandó que la Hacienda municipal le enviara un informe mensual que explicara los beneficios generados por el agua potable. La razón por la que el Banco llegó a tomar esta decisión, fue porque el gobierno de la ciudad dejó de depositar las rentas obtenidas en el Banco Central del Ecuador, tal y como se había acordado previamente. Como resultado, una buena parte de los préstamos nunca fue utilizada, de ahí que el Eximbank desistiera en su intento de trabajar con este país, por lo que los créditos que llegaron al Ecuador no llegaron a ser tan cuantiosos como los que otros países de América Latina recibieron y tampoco se ajustaron a las necesidades del país. Los créditos del Eximbank destinados a América Latina alcanzaron entre 1962 y 1982, la cantidad de 10.000 millones de dólares, de los que 64,4 millones fueron para el Ecuador que acabó recibiendo menos que Paraguay, Jamaica y Perú, entre otros países. El total de los préstamos concedidos por el gobierno de los Estados Unidos a Ecuador fue de 661 millones de dólares, es decir, el $2 \%$ del total latinoamericano. ${ }^{635}$

La victoria de Velasco Ibarra en las elecciones de 1960 no fue suficiente para enfrentar la crisis estructural de la sociedad ecuatoriana, iniciándose al poco tiempo un gran deterioro del gobierno velasquista. Además, se ha de mencionar el papel de Cuba durante los primeros años de los sesenta, pues llegó a ser un poderoso elemento entre los países socialistas y el Ecuador, el cual no quería romper relaciones con la isla y se oponía a la acción estadounidense en contra del régimen de Fidel Castro. Aquí, nos encontramos ante una época de gran agitación en la que aparecieron movimientos nacionalistas antiestadounidenses que expresaban ideas de carácter nacional-popular a nivel de la sociedad civil, frente a lo cual, el velasquismo optó por convertirse.

Es importante destacar el impacto de la Revolución Cubana en el desarrollo de la izquierda ecuatoriana y de todas las fuerzas interesadas en transformar la sociedad, caracterizada por enfrentamientos dirigidos a un estado inmerso en una gran crisis política:

Este fue el efecto de dicha revolución, ya que el desbordamiento del estado ecuatoriano por parte de la sociedad adquirió el carácter de un rompimiento del acuerdo social y fue estigmatizado o percibido por la reacción y el imperialismo como una desviación

\footnotetext{
${ }^{635}$ Ibíd., p. 311.
} 
intencionada con respecto a las normas sociales establecidas en nombre del "fidelismo", al que veían como inspirador de un fenómeno. ${ }^{636}$

En este contexto, las simpatías por la Revolución Cubana crearon una gran oposición, como fue el caso de la respuesta de intelectuales como Jorge Icaza y Benjamín Carrión, que llegaron a proponer la imitación de la revolución en el Ecuador, con el fin de acabar con la dominación estadounidense. En cuanto a los movimientos culturales, hay que hablar del Tzantzismo que agrupaba a una joven intelectualidad y criticaba la razón occidental, a la vez que buscaba las "raíces auténticas" mediante su propia auto-identificación:

Su nacimiento, rodeado del clima de rebelión existente, se produjo justamente en la casa de un pintor cubano, René Alis, en 1962, y allí mismo estos artistas asumieron su papel de "reductores de cabeza" evocando las prácticas culturales de una etnia oriental caracterizada por su vocación guerrera: los Shuar, más nombrados en esa época como jíbaros. $^{637}$

Las condiciones de agitación política y social y la idea de una revolución latinoamericana con el triunfo cubano, hicieron que los tzantzicos entraran en contacto con sectores populares y adoptaran una postura marxista.

Aquí, cabe recordar un fenómeno ideológico de importancia, pues algunos políticos, cuya afiliación original no había sido de izquierdas, pasaron a ser seguidores de Fidel Castro, ejerciendo desde sus altos cargos una gran influencia en la política interna y externa del país. ${ }^{638}$ Este fue el caso del Dr. Araujo Hidalgo, ministro de gobierno de Velasco, que llegó incluso a visitar Cuba y a entrevistarse con Fidel Castro, y Jorge Chiriboga Guerrero, alcalde de la ciudad de Esmeraldas. ${ }^{639}$

Como en otros países latinoamericanos, la Revolución Cubana en el Ecuador provocó el debilitamiento del imperialismo norteamericano, que acabó manifestándose a través de

\footnotetext{
${ }^{636}$ Rafael Quintero, Erika Silva, op. cit. p. 222.

${ }^{637}$ Ibíd. p. 223.

${ }^{638}$ Gastón Godoy: El caso cubano y la OEA, Madrid, Artes Gráficas, 1961, p. 20-98.

${ }^{639}$ Rafael Quintero, Erika Silva, op. cit., p. 226.
} 
movilizaciones populares. La política de Estados Unidos, centrada en aislar a Cuba, trató de forzar una ruptura de relaciones diplomáticas, a la que el gobierno de Velasco Ibarra y el de Arosemena Monroy se opusieron.

No obstante, los primeros meses de gobierno de Velasco Ibarra se caracterizaron por un empeoramiento de las condiciones de vida de las masas, que vieron cómo los precios de los artículos de consumo popular aumentaban (el arroz, las patatas, la manteca, etc.) mientras que los salarios seguían intactos. Frente a esto, la movilización popular que tuvo lugar durante el periodo 1960-1963, se caracterizó por movimientos de campesinos indios que demandaban la disolución de la hacienda y de las formas precarias de trabajo en la Sierra, mientras que en la Costa se fueron tomando las propiedades en las áreas arroceras.

Aquí, se ha de aclarar que estas manifestaciones no sólo eran de la izquierda, sino que la derecha también se defendía, intentado ejercer presión en los sectores medios a través de la influencia de la Iglesia:

Todas estas movilizaciones traducían, en cierta manera y pasando por mediaciones reivindicativas inmediatas, las modificaciones de la estructura social y económica producidas por la acumulación capitalista en base a la exportación bananera, al mismo tiempo que el agotamiento del modelo de acumulación. ${ }^{640}$

En este caso, el contexto en que tuvieron lugar las movilizaciones estaba determinado por dos factores. Por un lado, las clases dominantes vivían una situación de crisis debido al debilitamiento de las condiciones de su reproducción económica, su transición (clase terrateniente no capitalista) y su nuevo papel (capital agrario), mientras que por otro lado, estas transformaciones crearon el marco adecuado para el nacimiento de un movimiento popular, cuyo sector más conflictivo era el agrario de la Sierra y de la Costa:

Las luchas campesinas también adquieren un nivel más alto (...) Ante la indiferencia de los poderes públicos para resolver los problemas de la vida de las masas agrarias, los

${ }^{640}$ Ibíd. p. 224. 
campesinos aceleran la ocupación de tierras, que se están produciendo en todo el país, especialmente en el litoral. ${ }^{641}$

Pedro Saad también se refiere a la reacción popular frente a las oligarquías, y pone como ejemplo el caso de Quevedo, que reclamó una administración municipal al servicio del pueblo, el caso de Esmeraldas, donde las masas exigieron en la calle atención al problema del abastecimiento de agua potable, el de Limones, donde se hizo frente a un consejo antipopular, y por último, el de Manabí, donde se luchaba por el progreso provincial.

Las masas no buscan ya soluciones momentáneas, no confían en los departamentos estatales y municipales encargados de resolver sus problemas y quieren hallar la salida de todos, incluso la acción directa si es necesario. ${ }^{642}$

Los profundos cambios agrarios de esta revolución fueron interpretados como una reforma agraria a partir de la cual, los sectores del campesinado ecuatoriano pudieron comprender la necesidad de defender su propia política agrícola ligada al movimiento obrero y a los partidos políticos revolucionarios.

Un ejemplo del pueblo de Cuba, en lucha por su independencia nacional, por su progreso, por la democracia, por el destino de América Latina, es un acicate para el pueblo ecuatoriano, y para todos los pueblos del continente, en la lucha por su independencia y soberanía y por destruir la dominación feudal e imperialista. ${ }^{643}$

Por su parte, la intensa actividad de EE.UU para desestabilizar el gobierno de Velasco, se manifestó de múltiples formas, penetrando en numerosas instituciones de poder del estado ecuatoriano para incidir en el conjunto de la sociedad civil. Las expresiones políticas estadounidenses fueron efectivas en varios ámbitos, siendo fundamentales para el ejército y los

\footnotetext{
${ }^{641}$ Pedro Saad, op. cit. p. 116.

${ }^{642}$ Ibíd., p. 117.

${ }^{643}$ Ibíd. p. 118-119.
} 
grupos de los latifundistas, a los que se vinculó la presión de los exportadores de Guayaquil que impulsaban un cambio de mando a favor del vicepresidente del gobierno Arosemena Monroy. ${ }^{644}$ De este modo, y conforme la política se inclinaba hacia la derecha, Velasco fue perdiendo el apoyo de la izquierda, a la vez que las protestas a nivel nacional continuaban. A todo esto, se unieron los bajos niveles de precios para el cacao, el café y el banano, así como la disminución de su producción y la habilidad de la clase dominante para trasladar la crisis a los sectores populares a través de la subida de los precios. A su vez, la elevada tasa de desempleo de la clase trabajadora y la devaluación monetaria terminaron con los débiles vínculos del gobierno, dando lugar a la caída del gobierno de Velasco Ibarra.

Tras el derrocamiento del presidente Velasco Ibarra (7-11-1961) mediante un golpe de estado, el vicepresidente Arosemena (1961-1963) asumió la presidencia expresando la necesidad de defender posiciones independientes en el área internacional y de modernizar la sociedad ecuatoriana, aún cuando carecía de una plataforma adecuada. En su intento para demostrar la independencia política, Arosemena volvió a establecer las relaciones con Polonia y Checoslovaquia, países miembros del bloque socialista, y viajó a la URSS con la intención de reiniciar las relaciones pese a la oposición de EE.UU. Asimismo, su gobierno expresó su voluntad de cooperar en la creación de un frente popular para agrupar los sectores democráticos, antiimperialistas y antigolpistas, siendo esta declaración de gran importancia, ya que ponía de manifiesto el reconocimiento de que la alianza entre terratenientes y burguesía comercial bancaria había fracasado. ${ }^{645}$

En realidad, este hecho fue el elemento fundamental que permitió a Arosemena mostrar su apoyo a Cuba:

Es así como en las movilizaciones a favor del mantenimiento de relaciones diplomáticas con Cuba y contra las presiones norteamericanas, afinadas en sectores de la burguesía, se halla una adhesión al proceso histórico que vivía dicho país, sentido a nivel popular

\footnotetext{
${ }^{644}$ Tras la caída del cuarto gobierno velasquista, en 1961, Carlos Arosemena Monroy pasó a ejercer la presidencia, en la que se mantuvo durante el periodo 1961-1963. Su acción de gobierno tuvo un carácter progresista y de defensa de las libertades públicas, siendo alguno de sus principales logros, el impulso dado a la educación pública, la fundación de numerosos colegios, las campañas de alfabetización, la defensa de los derechos de los maestros y la creación de dos nuevos centros de enseñanza terciaria, la Universidad Laica Vicente Rocafuerte y la Universidad Católica, en Guayaquil. Fuente: Efrén Avilés: Carlos Arosemena Monroy, en Enciclopedia del Ecuador, 2012.

${ }^{645}$ Ronn Pineo, op. cit., p.314.
} 
como una afirmación nacional anti-norteamericana y luego, una identificación enraizada en la frustración nacional por la pérdida de los territorios amazónicos con el conflicto fronterizo peruano en $1941 .{ }^{646}$

Este último aspecto, utilizado por Velasco para ganar el voto popular, fue también la base de apoyo popular por el gobierno de Arosemena. Efectivamente, el Protocolo de Río de Janeiro que había sido diseñado para acabar con el conflicto ecuatoriano-peruano sobre las fronteras entre ambos países, era percibido por el pueblo y por la izquierda como una imposición norteamericana. Así, su gobierno intentaría negociar el apoyo a Cuba mediante la discusión de dicho tratado a nivel internacional.

En este contexto, algunos sectores dominantes que sentían la amenaza de las tensiones sociales, aprovecharon para llevar a cabo la iniciativa de modernizar el agro, que era la zona más atrasada del país. Los terratenientes que proponían esta reforma como solución a los problemas, pretendían imponer la denominada Alianza para el Progreso con el apoyo de los EE.UU y de otros países, por lo que el tema agrario quedaría vinculado al problema internacional, abarcando a su vez, aspectos relativos a la soberanía del estado y a la cuestión territorial y nacional.

A su vez, se elaboró el primer Plan General de Desarrollo Económico del Ecuador dirigido a promover la industrialización del país, que a pesar del impulso externo y las exenciones tributarias, presentaba numerosas limitaciones debido al escaso desarrollo capitalista y a las marcadas relaciones de dependencia.

De forma paralela a estos acontecimientos, se percibía al comunismo como una ideología que dificultaría la instrumentalización para realizar reformas orientadas a modernizar la estructura económico-social. Finalmente, el gobierno de Arosemena, incapaz de fomentar cambios revolucionarios, acabó perdiendo el apoyo popular y fue derrocado por un golpe militar, al no disponer de la plena confianza de la clase oligárquica y de los políticos estadounidenses, pese a que rompió sus relaciones con Cuba.

En cierto modo, se puede pensar que la complicada situación que tuvo que afrontar este gobierno fue lo que puso fin a este gobierno, pues la sociedad ecuatoriana exigía cambios profundos (sobre todo en el agro), siendo urgente el establecimiento de políticas que hicieran realidad esa necesidad.

${ }^{646}$ Rafael Quintero, Erika Silva, op. cit. p.228. 
Uno de los problemas esenciales de los sectores modernizantes en el Ecuador de los sesenta, fue la disolución de las formas pre-capitalistas en la agricultura de la Sierra y también en algunas zonas de la Costa para algunos cultivos. No en vano, la imposibilidad de poder llegar a un acuerdo entre las clases llevó a una situación de neutralización de las fracciones dominantes, debido a las continuas luchas sociales y al contexto de crisis de un gobierno que no sólo había sido rebasado por la sociedad civil, sino que se encontraba sometido a presiones internas y externas, y por tanto, carecía de fuerza política para realizar las reformas propuestas. ${ }^{647}$

El análisis de esta situación repercutió en distintos niveles de la estructura social, sobre todo en las formas de dominación y funcionamiento del estado. En el agro serrano y en el litoral, la penetración del capitalismo mediante la ampliación de la red vial, las migraciones a las ciudades y a la Costa, fue acabando con el dominio de la clase terrateniente sobre la población, provocando una desintegración de la trilogía del poder local (terrateniente, párroco y teniente político). Así, la clase terrateniente era desplazada por la burguesía, aunque seguía controlando algunas partes del estado como el Parlamento y las gobernaciones. La estructura clientelista y su forma de poder, el paternalismo, fue perdiendo su control, pues la masa campesina dependía cada vez menos del terrateniente para su reproducción económica y social conforme se iba insertando en el sistema capitalista.

A este respecto, la significación de dicho fenómeno implicó que las clases dominantes tuvieran que hacer frente a la necesidad de reconstruir nuevos organismos políticos, ideológicos y culturales de integración de las masas populares. Así, en 1961, se constituyó el Partido Liberal Popular Revolucionario (PLPR), y en 1964, se crearon el Partido Comunista Marxista Leninista del Ecuador (PCMLE) y el Partido Demócrata Cristiano (PDC). En este sentido, los partidos políticos tradicionales, cuyos puntos en común eran la religión, la vinculación estado-Iglesia, el paternalismo clientelar y el caudillismo se fueron debilitando, lo cual ocasionó la pérdida de identidad política entre conservadores y liberales, al sufrir una desintegración en cuanto a composición de clase.

Las movilizaciones populares de 1959, que terminaron en la masacre de Guayaquil durante la presidencia de Camilo Ponce, ponían de manifiesto esta situación de debilitamiento del poder político, como consecuencia de los cambios de las clases dominantes y de sus instrumentos de

\footnotetext{
${ }^{647}$ Ibíd. p. 228-231.
} 
control. El problema de la ruptura diplomática con Cuba y la necesidad de establecer reformas estructurales en el agro, fueron los puntos fundamentales que polarizaron el juego de las fuerzas políticas y agudizaron las contradicciones de las fracciones dominantes. ${ }^{648}$

Por otro lado, hay que señalar que durante la Guerra Fría, el extremo de la derecha encontró un aliado en Estados Unidos, pues los líderes ecuatorianos sabían que se podía culpar a los defensores del comunismo para justificar sus acciones. Bajo estos ideales, el gobierno ecuatoriano apoyó la justicia social como parte de un plan de lucha contra el comunismo, lo que facilitó el establecimiento de la dictadura militar de 1963, y que con la ayuda de Estados Unidos, llegaría a lograr algunos de los objetivos propuestos mediante la prohibición de partidos políticos progresistas y de sindicatos de izquierda, el encarcelamiento de golpistas, el asesinato de intelectuales, etc.

A su vez, el triunfo de la Revolución Cubana fomentó la formulación de la Doctrina de Seguridad Nacional en los países de América Latina, la cual sirvió de elemento impulsor en la elaboración de las teorías orientadas a explicar procesos políticos de cambio. Un ejemplo destacado fue la llamada "teoría de la dependencia", que como ya hemos visto, planteaba que la dependencia externa de la región era un factor negativo que apoyaba el subdesarrollo. Asimismo, se retomaron las doctrinas marxista-y la propia doctrina revolucionaria cubana, enunciada principalmente por Ernesto Che Guevara, cuyas formulaciones proporcionaron argumentos para legitimar diversos movimientos armados en varias zonas de la región. ${ }^{649}$

Así, apareció la denominada era revolucionaria de América Latina, basada en la ideología de las juventudes de clase media y de numerosos grupos sociales, siendo Cuba el punto de referencia de las "vanguardias revolucionarias":

Además del viejo militarismo y la ideología político-militar estadounidense, los militares latinoamericanos acudieron a los principios desarrollados en Francia para confrontar los movimientos de independencia en Indochina y Argelia. Los franceses habían creado la doctrina de la guerra revolucionaria y tácticas de contrainsurgencia, elementos que fueron fundamentales para la elaboración doctrinaria y su aplicación práctica. Sobre

\footnotetext{
${ }^{648}$ Ibíd. p. 229-231.

${ }^{649}$ Ver el apéndice de notas del capítulo 2 para más información. Fuente: Michael Lowry: El pensamiento del Che Guevara, Editorial Siglo XXI, 1985.
} 
estas bases, los militares construyeron la Doctrina de Seguridad Nacional, que sirvió para legitimar un militarismo de nuevo cuño. ${ }^{650}$

El planteamiento de la Doctrina de Seguridad Nacional se desarrolló de la misma forma en que Estados Unidos abordaba los problemas sociales de la región latinoamericana. Es decir, desde los años cincuenta, las políticas norteamericanas hacia América Latina estuvieron determinadas por la concepción de inestabilidad regional, siendo el comunismo el factor que constituía la causa principal de dicha situación, la cual era considerada como la principal amenaza para la seguridad del hemisferio.

La Doctrina de la Seguridad Nacional afirmaba que el mundo contemporáneo estaba dividido en dos fracciones irreconciliables, el occidente cristiano y el oriente comunista. Este enfrentamiento se manifestaba mediante la subversión interna que permitía el desarrollo del conflicto sin el riesgo de una guerra, en el que los países latinoamericanos eran objeto de subversión interna, pues formaban parte del bloque político occidental. ${ }^{651}$

Además, se mantenía la idea de que a partir de la seguridad del estado, se garantizaba la de la sociedad, por lo que el control militar era necesario para poder conseguir este objetivo. En este caso, si bien la Doctrina de Seguridad Nacional estableció como enemigo principal al comunismo internacional, cuyo epicentro era la Unión Soviética y Cuba, se había de entender que a Estados Unidos le correspondía mantener el enfrentamiento contra dichos países. Las naciones latinoamericanas debían de enfrentar al enemigo interno, materializado en el comunismo, por lo que junto con las guerrillas, dicho enemigo podía ser cualquier grupo o persona que tuviera ideas opuestas a las de los gobiernos militares apoyados por Estados Unidos. ${ }^{652}$

Durante los años sesenta, la pobreza fue añadida a dicha situación de inestabilidad, lo que aclara el hecho de que gobierno de Kennedy (1961-1963) diseñara dos estrategias complementarias, que serán analizadas más adelante: la Alianza para el Progreso para combatir la pobreza, y los

\footnotetext{
${ }^{650}$ Gabriel Aguilera Peralta: Cuba y la OEA: Apuntes de una larga y complicada relación, Revista Nueva Sociedad No 223, septiembre-octubre de 2009.

${ }^{651}$ E. de Jesús Velásquez: Historia de la doctrina de la seguridad nacional, Universidad Autónoma del Estado de México, Convergencia, enero-abril, año 9, número 27, Toluca, México, 2002, p. 11-39.

${ }^{652}$ Francisco Leal: La doctrina de seguridad nacional: Materialización de la Guerra Fría en América del Sur, Revista de Estudios Sociales, número 15, junio 2003, p. 74-87.
} 
programas ampliados de contrainsurgencia (Fuerzas Especiales del Ejército y la Oficina de Ayuda para la Seguridad Pública) contra la subversión. ${ }^{653}$

La Alianza para el Progreso, iniciativa con la que se intentó dar un giro en la política estadounidense de la Guerra Fría hacia América Latina, pretendía llevar al semi-continente a un desarrollo económico autosostenible siempre y cuando aceptara la guía norteamericana. En este caso, Estados Unidos mostraría el camino a estos países, ayudándoles a establecer las bases sociales y económicas adecuadas, sobre las cuales podrían consolidar una democracia, y de forma paralela, se podía prevenir la expansión del comunismo en Latinoamérica y el surgimiento de casos similares al cubano.

Para lograr estos objetivos, la Alianza presentó una ambiciosa agenda de diez años que buscaba fomentar la industrialización, eliminar la mala distribución del ingreso, llevar a cabo reformas agrarias, aumentar la tasa de escolaridad y acabar con el analfabetismo, entre otras cosas.

Con el fin de revisar el proyecto, se organizó una reunión en Punta del Este, Uruguay, en el año 1961, a la que acudieron los presidentes latinoamericanos, y en la que el gobierno estadounidense se comprometía a aportar 20.000 millones de dólares para la Alianza. No obstante, dos años después de su lanzamiento, este programa comenzó a ser percibido como un fracaso, a consecuencia de los escasos resultados obtenidos y por la intranquilidad sobre la forma de desembolsar el dinero. Es decir, todas las propuestas latinoamericanas para emplear los fondos debían ser examinadas por un Consejo formado por nueve expertos, originando sus procedimientos un considerable rencor:

El pueblo de Estados Unidos pensaba que su generosidad no había sido apreciada, mientras los latinoamericanos generalmente resentían las restricciones que se ponían sobre el uso de fondos, al igual que la actitud condescendiente de los funcionarios americanos... ${ }^{654}$

${ }^{653}$ Lars Schoultz: National security and United States Policy toward Latin America, Princeton University Press, 1987, p. 11-20.

${ }^{654}$ Jerome Levinson, Juan de Onís: The Alliance that lost its way: A critical report on the Alliance for Progress, en Michael Larosa y Frank O. Mora: Neighborly Adversaries: Readings in U.S. Latin American Relations, Lanham: Rowman \& Littlefield Publishers, In., 1999, p. 179-191. 
Aún cuando la ayuda total de los Estados Unidos a América Latina ascendió a la cantidad de 22.300 millones de dólares durante los años sesenta, esta cuantía no llegó a tener un impacto real. Además, existían otros problemas, pues los fondos que llegaron, solían ser asignados a la adquisición de mercancías americanas, generalmente vendidas a precios no competitivos, o eran depositados en bancos americanos como pago de la deuda externa latinoamericana. ${ }^{655}$

En cambio, existen algunos programas de la Alianza que fueron beneficiosos, como fue el caso del Cuerpo de Paz en el Ecuador, que ayudó a los necesitados y contribuyó a mejorar la imagen que el pueblo tenía de los americanos. A pesar de esto, la mayoría de los objetivos sociales y de desarrollo de la Alianza se vieron completamente eclipsados por la agencia militar y anticomunista del programa, pues los políticos estadounidenses prestaron más atención al problema del comunismo en América Latina.

Pese a la implementación de estos nuevos mecanismos, siguió primando la idea que consideraba los problemas sociales como parte de la conspiración comunista. De esta forma, se ignoraron las necesidades básicas del desarrollo y las aspiraciones de autonomía de las naciones y se frenaron muchas políticas reformistas atentando contra los regímenes considerados de izquierda. ${ }^{656}$ Posteriormente, la Junta Militar de 1963 tenía como base una ideología anti-comunista e inició su mandato vinculado a una contradicción histórica. Es decir, el golpe militar respondía a una estrategia que pretendía acabar con el estatus capitalista, pero que garantizaba a su vez, la realización de los objetivos de la denominada Alianza para el Progreso, cuyo contenido consistía en la expansión del capitalismo dependiente latinoamericano mediante la modernización de algunas de sus estructuras. En el caso del Ecuador, la viabilidad del capitalismo requería modernizar la estructura agraria, sustituir el modelo de desarrollo agro-exportador y fomentar el desarrollo industrial desde el gobierno, aún cuando no había un sector empresarial capaz de mantener este proceso. Aunque este proyecto de modernización exigía el apoyo de las capas medias y de los sectores populares, llegó a desempeñarse gracias a la acción de los sectores que

\footnotetext{
${ }^{655}$ Ibíd. p. 179-181.

${ }^{656}$ Ver el apéndice de notas del capítulo 2 para más información. Fuente: Jorge Tapia Valdés: La doctrina de la seguridad nacional y el rol político de las fuerzas armadas, en Juan Carlos Rubinstein (comp.), El estado periférico latinoamericano, Buenos Aires, Eudeba, 1988, p. 241.
} 
estaban a favor de la campaña anti-comunista. De este modo, el denominado "desarrollismo" se implantaba en el país a través de una dictadura represiva. ${ }^{657}$

El carácter modernizante del nuevo gobierno perseguía también el establecimiento de su proyecto como mecanismo neutro para poder unificar a importantes sectores medios y encontrar un grupo de apoyo. El resultado fue la formación de una alianza entre la oligarquía importadora, con gran afán modernizante, y sectores populares, sometidos a la miseria y represión política.

El gobierno militar además de plantear un modelo de desarrollo asociado en base a la industrialización por sustitución de importaciones, llegó a comprometer la capacidad de libertad y decisión del país, renunciando a su soberanía sobre 200 millas del mar territorial al llevar a cabo una enorme concesión petrolera a la Texaco-Gulf en la región amazónica (1.500.000 hectáreas) y mediante la formulación de un plan decenal que contenía una reforma agraria, tributaria, educativa y administrativa. ${ }^{658}$

Sin embargo, la industrialización requería la modernización del aparato estatal, siendo esto posible gracias a la creación de organismos encargados de la planificación y ejecución de los proyectos industriales. Además, la promulgación de la Ley de Reforma Agraria dictada el 11 de julio de 1964, pese a que no afectó al sistema de tenencia de la tierra, sirvió para que se ampliara el mercado interno, elemento indispensable para el desarrollo industrial, ya que al liberar fuerza de trabajo de la Sierra pudo crear las condiciones favorables para la transformación del sistema de haciendas y convertir a los campesinos en potenciales consumidores de productos industriales. De esta manera, la presencia de la Junta Militar determinaría el comienzo de una nueva etapa de crecimiento del capitalismo ecuatoriano, que se caracterizaría por la tecnificación del aparato estatal, por una tendencia creciente del capital extranjero en la economía, el fortalecimiento de los grupos industriales y el debilitamiento del control de los sectores agroexportadores en la estructura de poder, aún cuando el sector externo seguía siendo la base financiera de este crecimiento dependiente.

\footnotetext{
${ }^{657}$ Rafael Quintero, Erika Silva, p. 229-235.

${ }^{658}$ Patricio Ycaza, op. cit., p. 13-20.
} 


\section{CAPÍTULO 3: LAS POLÍTICAS DESARROLLISTAS DE MODERNIZACIÓN Y SU INCIDENCIA EN LA SOCIEDAD Y ECONOMÍA ECUATORIANA DURANTE LA DÉCADA DE 1960:}

\section{1) La política populista y el impacto de la Revolución Cubana en el Ecuador durante el gobierno de Carlos Arosemena (1961-1963):}

\subsection{1) Las medidas populistas y el agro ecuatoriano a comienzos de los años sesenta:}

\subsubsection{1) El gobierno de Arosemena y las modificaciones en la estructura} agraria: La eliminación del huasipungo y otras estructuras pre-capitalistas.

Uno de los problemas principales del proceso de modernización en el Ecuador de la década de los sesenta, tuvo como fundamento la eliminación de las formas pre-capitalistas agrícolas que, como ya sabemos, constituían el elemento clave para el funcionamiento de la estructura social agraria tanto en la Sierra como en el litoral del país. Así, el debate generado a nivel político en relación a los proyectos de liquidación del precarismo y de reforma agraria, se iniciará a partir de 1959, año en el que comenzaron las entregas anticipadas de huasipungos por parte de una fracción terrateniente, y que continuaron hasta la creación de la primera ley de Reforma Agraria de $1964 .^{659}$

Este periodo es bastante significativo en relación al desarrollo de la cuestión agraria ecuatoriana, sobre todo si se tiene en cuenta el papel desempeñado por el triunfo de la Revolución Cubana, al marcar un momento de gran agitación social y política en América Latina. En el caso ecuatoriano, las consecuencias fueron bastante destacadas, saliendo a relucir el problema agrario al primer plano del debate público, además de aparecer propuestas que atribuían la causa del atraso económico y social a las relaciones sociales de la Sierra ecuatoriana, lo cual llevó a plantearse la necesidad de una reforma agraria a nivel nacional.

De forma paralela, se fue produciendo el afianzamiento de algunas fracciones de terratenientes que no querían seguir compartiendo los recursos de las haciendas con los campesinos, y comenzaron a pensar en el paso a las relaciones salariales para alcanzar el desarrollo agropecuario. Esta estrategia, además de encabezar la liquidación de las relaciones precarias,

\footnotetext{
659 Algunas de las obras que tratan el tema de la entrega de huasipungos son las de Leon Zamosc: Luchas campesinas y reforma agraria: Un análisis comparado de la Sierra ecuatoriana y la Costa atlántica colombiana, Publicación: Agricultura y Sociedad, 1990; Osvaldo Barsky: Iniciativa terrateniente en la re-estructuración de las relaciones sociales en la Sierra ecuatoriana: 1959-1964, en: "El problema agrario en el Ecuador", Antología de las Ciencias Sociales, Publicación ILDIS, 1988, p. 107; Piedad Peñaherrera de Costales, Alfredo Costales Samaniego: Historia social del Ecuador: Reforma agraria, vol. 4, Editorial Casa de la Cultura Ecuatoriana, 1971.
} 
implicará la consolidación de una estructura empresarial en las haciendas, que no solo se proponía afrontar el tema de la abolición del huasipungo, sino que también pretendía absorber las reivindicaciones planteadas por las organizaciones campesinas. ${ }^{660}$

No obstante, el fraccionamiento económico y político de los hacendados dificultaría el establecimiento de un proyecto de carácter suprarregional, al requerir el consenso de los terratenientes modernizantes de la Sierra y de la Costa en el marco de un régimen democrático. Tampoco, la burguesía logró imponer un proyecto de modernización que ofreciera una rápida salida a la crisis, creándose como resultado, una situación de neutralización de las iniciativas políticas de las fracciones dominantes. ${ }^{661}$

Por consiguiente, al abordar esta cuestión y considerar la tensión generada entre las diferentes fracciones sociales y cómo se fue creando una estructura de cambios, analizaremos por un lado, algunos de los rasgos de la política agraria hasta la caída de Velasco Ibarra en 1961, así como el proceso de debate sobre el reparto de tierras y eliminación de relaciones precarias durante el gobierno de Carlos Arosemena (1961-1963), y por otro lado, la relación entre los gobiernos mencionados y las Cámaras de Agricultura.

El tema de la reforma agraria en el Ecuador y las presiones para llevar a cabo dichas modificaciones, comienza a manifestarse en el gobierno de Camilo Ponce (1956-1960) durante el cual, aparece una serie de planteamientos para resolver el problema de la falta de tierra de los campesinos mediante la vía de la colonización y la parcelación de las haciendas estatales. ${ }^{662}$

A este respecto y antes de analizar la política agraria de esta época, es importante recordar brevemente cómo tuvo lugar el proceso de apertura de la frontera agrícola con la expansión colonizadora en el Ecuador.

En principio, se puede decir que el proceso de colonización ecuatoriano comenzó hace aproximadamente unos doscientos años a través de flujos ocasionales que, de forma progresiva, fueron consolidando las propiedades. Para ello, el estado intervino con su capacidad legislativa

\footnotetext{
${ }^{660}$ La idea de abolición del huasipungo ya había sido planteada de forma oficial por la Secretaría General de la Administración Pública el 30/12/1961. Fuente: Osvaldo Barsky: Los terratenientes serranos y el debate político al dictado de la Ley de Reforma Agraria de 1964 en el Ecuador, en "Ecuador: Cambios en el agro serrano", FLACSOCEPLAES, Quito, Abril 1980, p. 133-207.

${ }^{661}$ Rafael Quintero, Erika Silva, op. cit. p.221-238.

${ }^{662}$ Osvaldo Barsky, Los terratenientes serranos..., op. cit. p. 133-207.
} 
con el fin de solucionar los problemas relacionados con la ocupación y reversión de tierras baldías, transferencias de posesión y de dominio, entre otros.

A partir de aquí, se observa que la institucionalización de este proceso ocurre mediante la colonización y con la acción legislativa del estado. Así, las leyes promulgadas por los gobiernos nacionales regularon la ocupación de las tierras baldías, las cuales fueron ocupadas por campesinos, terratenientes, agro-exportadores, hacendados serranos, militares y burócratas. ${ }^{663}$

Con el paso del tiempo, el proceso de colonización fue adoptando diferentes características debido a la integración de las necesidades de acumulación del capital en los distintos momentos del desarrollo desigual de la formación social ecuatoriana. También, se fue configurando según los intereses hegemónicos del estado que, bajo la presión terrateniente, permitió la consolidación de las grandes propiedades serranas (orientadas a la producción de consumo interno con modalidades de producción pre-capitalistas) y costeñas (destinadas a la agricultura de exportación y en las que existía el concertaje y la sembraduría a pesar de que las relaciones salariales predominaban) en perjuicio de los productores campesinos. ${ }^{664}$

A este respecto, ya vimos con anterioridad, cómo a diferencia de los orígenes coloniales de la hacienda serrana, la hacienda de la Costa recibió el impulso procedente del auge del cultivo del cacao, que comenzó a cobrar fuerza a partir del siglo XVIII, siendo este proceso, el resultado de la concentración de tierra tras la ampliación de la frontera agrícola y la desposesión de los pequeños agricultores. Posteriormente, tras la caída del mercado cacaotero en los años veinte, aparecieron un conjunto de pequeños propietarios y finqueros, los cuales fueron ganando el control de las tierras como resultado de la división de la gran propiedad y el ajuste al sistema precarista existente en las antiguas haciendas.

A partir de estas ideas, vamos a retomar la discusión sobre la legislación de los procesos colonizadores, para lo que es importante señalar cuáles fueron algunas de las principales medidas de colonización establecidas en el país y las razones que llevaron a su creación en el siglo XX.

\footnotetext{
${ }^{663}$ Ver el apéndice de notas del capítulo 3 para más información. Fuente: Franklin Canelos: Colonización y vías de desarrollo: El caso de la parroquia Pedro Vicente Maldonado, FLACSO, Ecuador, 1980.

${ }^{664}$ Ver el apéndice de notas del capítulo 3 para más información. Fuente: Juan J. Paz, Miño Cepeda: La época cacaotera en Ecuador, Boletín del Taller de Historia Económica, Pontificia Universidad Católica del Ecuador, Facultad de Economía, Quito, no. 3, marzo/abril de 2011, p. 2-3.
} 
En principio, se ha de destacar la Ley de Tierras Baldías y Colonización del 12 de Mayo de 1936, la cual constituía uno de los instrumentos legales de mayor importancia, puesto que limitaba la extensión de las entregas y pretendía establecer una colonización basada en la pequeña propiedad como mecanismo para acabar con el latifundio.

En cuanto al contexto social que motivó la expedición de esta ley, Osvaldo Albornoz señala los levantamientos indígenas que habían tenido lugar en el periodo 1927-1941, y que estaban relacionados con el control de tierras por parte de los terratenientes y los abusos cometidos contra los indígenas. ${ }^{665}$

La Ley de Tierras Baldías y Colonización tuvo lugar en un periodo de tiempo histórico durante el cual, la fracción terrateniente agro-exportadora fue perdiendo su influencia en el poder como consecuencia de la crisis cacaotera. Además, esta ley surgió en un momento de gran presión por parte de las movilizaciones campesinas para rescatar sus tierras, a la vez que reclamaban el establecimiento de relaciones salariales en las haciendas serranas.

A su vez, mientras que se producía la decadencia de la fracción agro-exportadora, la crisis del capitalismo en la década de los treinta motivaba los comienzos de industrialización del país y la conformación de una situación que limitaba la tendencia a la concentración latifundista de la tierra, especialmente de la tierra baldía, cuya colonización se daba en vinculación a la expansión de las superficies cultivadas de bienes agro-exportables. Al mismo tiempo, se planteaba la colonización campesina como medio de escape a la demanda campesina para acceder a la tierra y eliminar las relaciones pre-capitalistas de producción.

El surgimiento de las plantaciones bananeras durante la década de los cuarenta trajo consigo la recuperación del auge de la Costa, así como la concentración de tierra y expansión de la frontera agrícola. El dinamismo bananero posibilitó la acumulación interna de capital, la ampliación de la producción industrial y el fortalecimiento del mercado interno, creando algunas posibilidades para la modernización de la agricultura serrana y la consolidación de un aparato estatal más moderno. En este caso, ya analizamos cómo el estado asumió un papel más intenso dentro de la economía, asignando recursos a otros sectores, realizando inversiones en obras públicas y aumentando el crédito agropecuario. Este crecimiento y ampliación del mercado interno, fue un gran incentivo para renovar la producción en las haciendas de cacao y arroz en la Costa, al

\footnotetext{
${ }^{665}$ Para más información de los levantamientos, ver el apéndice de notas del capítulo 3. Fuente: Oswaldo Albornoz, Las luchas indígenas..., op. cit. p.84-96.
} 
tratarse de un proceso de transformación en las haciendas serranas, en particular, en aquellas en las que se dio prioridad al ganado lechero.

Por su parte, en la Costa, los terratenientes que llevaban a cabo renovaciones en sus haciendas, intentaron contratar únicamente mano de obra asalariada, hecho que llegó a ocasionar enfrentamientos con los precaristas arroceros. También, en la Sierra, el sector de hacendados modernizantes comenzó a privilegiar el uso de relaciones salariales frente a la renta en trabajo. Esto ocurriría luego en la zona centro-norte cuando los huasipungos fueron eliminados y los huasipungueros recibieron dichas tierras u otros lotes de tierras baldías más pobres, perdiéndose en ambos casos, los derechos de acceso a los recursos naturales de la hacienda, tal y como estudiaremos a continuación. ${ }^{666}$

No obstante, el proyecto de la colonización en tierras baldías requería la centralización de las políticas estatales, por lo que era necesario que los organismos públicos continuaran reconociendo iniciativas privadas de colonización o de simple posesión de tierras. Esta práctica hizo que Velasco Ibarra (1952-1956) introdujera varias disposiciones a la Ley de Tierras Baldías y Colonización (Decreto número 455, 3-03-1954), mediante las que se pretendía impulsar una colonización que permitiera el mantenimiento de las formas precapitalistas de explotación en la Sierra, ante las demandas y luchas campesinas. ${ }^{667}$ A su vez, el establecimiento de esta política implicaba el establecimiento de un orden de la colonización, encargándose al Ministerio de Economía, el trámite de denuncias y solicitudes de tierras baldías, así como la resolución sobre conflictos relacionados con la posesión de tales tierras.

Posteriormente, ya durante el gobierno de Camilo Ponce Enríquez (1956-1960), se decretó la ley para la creación del Instituto Nacional de Colonización, promulgado el 6 de junio de 1957, con el propósito de impulsar una colonización ordenada que fomentara la expansión de la producción y el aumento de la productividad necesario para el desarrollo de la economía ecuatoriana.

\footnotetext{
${ }^{666}$ Alain de Janvry, Pablo Glikman: Encadenamientos de producción en la economía campesina del Ecuador, Publicado por el Fondo Internacional de Desarrollo Agrícola y el Instituto Interamericano de Cooperación para la Agricultura, 1991, p. 55-65.

${ }^{667}$ Ver el apéndice de notas del capítulo 3 para más información. Fuente: Osvaldo Barsky: Iniciativa terrateniente en la reestructuración de las relaciones sociales en la Sierra ecuatoriana: 1959.1964, en Revista Ciencias Sociales, Vol. II-No.5, Quito, 1978.
} 
El Instituto Nacional de Colonización, que comenzó a funcionar en agosto de 1957, estaba encargado de establecer algunas de las siguientes funciones para centralizar la política colonizadora:

1. Levantar un inventario de las tierras baldías y de propiedad particular aptas para la colonización;

2. Planificar la distribución de la población rural;

3. Elaborar el Plan Nacional de Colonización;

4. Resolver denuncias de tierras del estado y controversias entre adjudicatarios;

5. Ejecutar los planes y proyectos de colonización;

6. Promover la inmigración de colonos y prestar asistencia técnica, social y financiera a los colonos;

7. Llevar a cabo los trámites del proceso de parcelación de las tierras, siendo la fórmula para financiar las parcelaciones la siguiente: un 15\% a cargo del Instituto, un 60\% para el Banco Nacional de Fomento y un 25\%, que era la mitad de lo que exigían las leyes vigentes de por aquel entonces. $^{668}$

Esta estrategia pretendía establecer un programa para la entrega de tierras baldías a los campesinos precaristas fundamentalmente (ver la tabla 1: Concesión de tierras baldías realizada por el estado 1948-1959). ${ }^{669}$ Así, para finales de 1959, el gobierno de Camilo Ponce gestionó la posibilidad de financiar un programa de recolonización y reasentamiento de los grupos campesinos localizados en las haciendas administradas por la Asistencia Social, mediante el cual, los terratenientes pretendían desviar la presión campesina de las tierras serranas y trasladar a los campesinos a zonas deshabitadas que carecían de acceso y servicios. ${ }^{670}$

A partir de este año, tiene lugar el proceso de entrega anticipada de huasipungos para eliminar las relaciones precarias, pues estaban consideradas como la causa del retraso social y económico

\footnotetext{
${ }^{668}$ Ver apéndice de notas del capítulo 3 para más información. Fuente: Banco Nacional de Fomento: Historia del Banco Nacional de Fomento, www.bnf.fin.ec.

${ }^{669}$ Esta tabla se encuentra en el apéndice de datos del capítulo 3. Fuente: Osvaldo Barsky, Los terratenientes serranos..., op. cit. p. 133-207.

${ }^{670}$ El primer antecedente legal de este consenso fue el Decreto de Ley de Emergencia, expedido en julio de 1959 por el gobierno de Camilo Ponce, que confería al Instituto Nacional de Colonización la facultad para llevar adelante las parcelaciones. Fuente: Osvaldo Barsky, Los terratenientes serranos...., op. cit. p. 143 -147, en: Ecuador: Cambios en el agro Serrano, Osvaldo Barsky, Quito, FLACSO, CEPLAES, 1980, p. 133-206.
} 
del país. La situación de la población huasipunguera en la estructura agraria serrana en el año 1960, se refleja en la tabla 2 (Composición de la población agrícola de las provincias de la Sierra, 1960) y muestra un total de 264 familias en el Ecuador de 1960, de las cuales, 174 eran propietarias de tierras, 19,7 eran familias huasipungueras, 8 eran arrendatarias y 12,9 eran familias partidarias o aparceras. ${ }^{671} \mathrm{La}$ situación de los huasipungueros en la relación con la hacienda se veía afectada por la familia ampliada del huasipungo, que incluía como fuerza disponible a los arrimados, pues vivían en las parcelas del huasipungo y trabajaban en las haciendas como peones. Por otro lado, se observa la extrema pobreza de las familias huasipungueras, que tenían como promedio entre 0,5 y 2,2 hectáreas de labranza, siendo estas tierras de baja calidad y de gran irregularidad topográfica, como se aprecia en la tabla 3 (Clasificación por tamaño de la superficie total y de labranza de los huasipungueros en el total de la Sierra ecuatoriana). ${ }^{672}$

Frente a esta perspectiva, no es de extrañar que el problema agrario se situara en un primer plano del debate público y se consideraran las relaciones precarias de la Sierra ecuatoriana como una de las causas principales del atraso económico del país.

Además, esta situación coincidió con el paso progresivo a las haciendas ganaderas y el establecimiento de las relaciones salariales, puesto que los terratenientes comenzaron a observar una menor rentabilidad al tener que compartir los recursos de las haciendas con los precaristas.

La firmeza de este sector permitió que figuras como el antiguo presidente del país, Galo Plaza, y otras como Emilio Bonifaz, crearan una propuesta alternativa del sector que permitiera su inclusión en un proceso de cambios. ${ }^{673}$ Este mecanismo para acabar con las relaciones precarias, no solo implicará la consolidación de una estructura empresarial de las haciendas, sino que además centrará su atención en la eliminación del huasipungo. No en vano, hay que señalar que

\footnotetext{
${ }^{671}$ Esta tabla se encuentra en el apéndice de datos del capítulo 3. Fuente: Comité Interamericano de Desarrollo Agrícola, op. cit. p. 17.

${ }^{672}$ Esta tabla se encuentra en el apéndice de datos del capítulo 3. Fuente: Osvaldo Barsky: La reforma agraria ecuatoriana, Biblioteca de Ciencias Sociales, Volumen 3, FLACSO, Corporación Editora Nacional, Quito, 1984, en Segovia, artículo en El Comercio, 5 de marzo de 1962.

${ }^{673}$ Para más información de Emilio Bonifaz y Galo Plaza, ver el apéndice de notas del capítulo 3. Fuente: Osvaldo Barsky, La reforma agraria..., op. cit. p. 106; Carlos de la Torre, Mireya Salgado: Introducción. Galo Plaza y su época, FLACSO, Fundación Galo Plaza, 2008.
} 
no todos los proyectos de entrega anticipada de tierras fueron elaborados cuidadosamente, como ocurrió con el de Galo Plaza, que trató de crear un plan de desarrollo campesino.

En cuanto a los mecanismos para acabar con las relaciones de trabajo precarias, Osvaldo Barsky menciona la existencia de varias iniciativas establecidas por los terratenientes como el desalojo de los precaristas, el acceso de estos a tierras en poder las haciendas y la entrega de los huasipungos, siendo esta última, la que analizaremos a continuación. ${ }^{674}$

El mecanismo de entrega de huasipungos comenzó cuando algunos terratenientes dieron por terminada la relación con los huasipungueros, básicamente mediante la entrega de una parcela de tierra, la cual podía ser el huasipungo ocupado por los campesinos. Al no existir una legislación específica de esta materia, el Ministerio de Previsión Social y Trabajo se acogió al Reglamento sobre expropiación y adjudicación de tierras (Decreto 184 de 1938), que era la forma legal adoptada para la entrega de huasipungo. Este reglamento acordaba la intervención del Ministerio en la venta y entrega a través del establecimiento de un acuerdo en una de las notarías del cantón al que perteneciera dicho inmueble.

Las primeras adjudicaciones de tierras se llevaron a cabo en la hacienda de Guachalá (Cayambe) y en algunas provincias del norte y centro de la región serrana del Ecuador, como ocurrió con Imbabura, Pichincha, Carchi, Cotopaxi, Chimborazo y Bolívar; a la vez que implicaban la ruptura de la mayoría de las relaciones precarias y de los derechos de acceso de los antiguos huasipungueros a los recursos de la parcela (leña, agua, pastos, etc.). En estas circunstancias, los campesinos no podían beneficiarse realmente de las tierras recibidas, pues carecían de riego y tenían un bajo índice de productividad (ver las tablas 4 y 5: Entregas de huasipungos por años 1959-1964 y Entrega de huasipungos por provincias). ${ }^{675}$

Asimismo, la política del cuarto gobierno de Velasco Ibarra (1960-1961) mantuvo un conjunto de elementos similares, enfocándose parte de su programa en la necesidad de realizar reformas en el agro, ya que era el punto de mira de distintas clases sociales. Es decir, en un contexto interno caracterizado por una multitud de problemas y ante posibles conflictos sociales, algunas

\footnotetext{
${ }^{674}$ Osvaldo Barsky, La reforma agraria..., op. cit. p. 67-78.

${ }^{675}$ Estas tablas se encuentran en el apéndice de datos del capítulo 3. Fuente: Lucía Salamea: La transformación de la hacienda y los cambios en la condición campesina, en "Ecuador, cambios en el agro serrano", FLACSO, CEPLAES, 1980, p. 251-300.
} 
fracciones dominantes organizaron un plan para modernizar el agro, al tratarse de la zona más atrasada del país.

En el estudio de Leon Zamosc, se hace alusión a las figuras políticas mencionadas y se analizan las ideas de Barsky y el papel desempeñado por los terratenientes modernos a la hora de impulsar las entregas anticipadas de tierras como respuesta al desarrollo de las fuerzas productivas y del mercado. ${ }^{676}$ Además, se añade que la mayor parte de las entregas tuvieron lugar en las provincias del norte de la Sierra, es decir, en las áreas donde se encontraban las haciendas lecheras más modernas. ${ }^{677}$

Pese a que Zamosc considera que la investigación de Barsky tiene un valor incuestionable, pone en duda su tesis principal, pues la mayor parte de las entregas se efectuaron en las tres provincias del norte de la Sierra, principalmente en Pichincha, a la cual correspondía casi el $60 \%$ del total, siendo dicho reparto bastante reducido, al afectar a un $15 \%$ del conjunto total de huasipungueros de la Sierra. ${ }^{678}$ En otras palabras, los datos de las entregas de huasipungos manifiestan la iniciativa llevada a cabo solo por una parte de terratenientes, ya que no fue un comportamiento general de esta clase. Además, estas cifras por separado no aportan información suficiente que aclare las razones que llevaron a los terratenientes a realizar dicho reparto de tierras.

En este contexto, además de la iniciativa terrateniente propuesta por Barsky, también se encuentran las ideas planteadas por Andrés Guerrero, que considera como elemento fundamental de la reforma, la presión ejercida por el campesinado; así como las de Miguel Murmis, que afirma que fueron los agentes externos (el desarrollo de la tecnología) y su interés en la agroindustria, los que exigieron una reforma agraria a través del aparato estatal. ${ }^{679}$

\footnotetext{
${ }^{676}$ Leon Zamosc: Luchas campesinas y reforma agraria: Un análisis comparado de la sierra ecuatoriana y la costa atlántica colombiana, Publicación: Agricultura y Sociedad, 1990, p. 216.

${ }^{677}$ Miguel Murmis explica la iniciativa de entregas anticipadas de tierras como una estrategia de carácter defensiva, ya que el sector moderno quería convertirse en una fracción agraria de la nueva burguesía y mantener de este modo, el control de la producción de leche en un territorio que estaba limitado por la existencia de suelos de mejor calidad y localización. Fuente: Miguel Murmis: El agro serrano y la vía prusiana de desarrollo capitalista, en Miguel Murmis et al, Ecuador: Cambios en el agro serrano, Quito, FLACSO, 1980; León Zamosc, op. cit. p. 216.

${ }^{678}$ Leon Zamosc, op. cit. p. 216.

${ }^{679}$ Andrés Guerrero, Haciendas, capital...op. cit.p. 5-140; Miguel Murmis: El agro serrano y la vía prusiana de desarrollo capitalista, en "Ecuador: Cambios en el agro Serrano" Osvaldo Barsky y Miguel Murmis (Eds.). Quito: FLACSO-CEPLAES, 1980.
} 
Siguiendo la idea planteada por Murmis y atendiendo a las características de las formas de trabajo de la Sierra ecuatoriana de principios de los sesenta, era necesario llevar a cabo una reforma de las mismas que fuera acorde a las exigencias del capitalismo. Esto implicaba la utilización de maquinaria en las grandes propiedades, lo cual se alternaría con la estrategia de marginalización de campesinos. ${ }^{680}$ En este sentido, el desarrollo capitalista fue entendido como una idea acorde con el pensamiento de los terratenientes, ya que estos podían seguir manteniendo los beneficios del sistema anterior, además de los derivados de la falsa promesa a los campesinos porque no implicaba grandes concesiones.

En este caso, Murmis afirma que la aplicación de las nuevas tecnologías en las haciendas hizo que los terratenientes se plantearan la reorganización de la hacienda en función de una evaluación de sus propios intereses económicos y no de una presión sea ésta estatal o campesina ${ }^{681}$ Así, con el reparto de los huasipungos y la promoción de la Ley de Reforma Agraria, los terratenientes podían conservar sus propiedades que, con la ayuda de la tecnología, gozaban de gran productividad y no tenían que compensar a los huasipugueros por su trabajo, además de poder acceder a mano de obra asalariada pagando precios muy bajos.

El razonamiento de Murmis, al igual que el de Barsky, tiene un sentido de tipo económico, sobre todo si se consideran los beneficios obtenidos por los terratenientes y la expansión de mercado lograda. No obstante, también se ha de valorar la posición de Guerrero, al considerar que la iniciativa del reparto de tierras y de reforma agraria pudo haber ocurrido a partir de los conflictos políticos que tuvieron lugar a principios de los años sesenta.

Las transformaciones de la estructura social agraria no podian ser explicadas sin tener en cuenta la escena política, los conflictos y antagonismos sociales que componen la coyuntura de los años 1960-1964, el problema que formula la retardada intervención del estado con la Ley de Reforma agraria (1964); en fin, todos aquellos elementos que constituyen lo político de un momento histórico dado. Además, recordaba que aquellos años fueron extremadamente conflictivos: el ejemplo de la Revolución Cubana recorría y removía el ambiente político latinoamericano, el fantasma (o la realidad) de las

\footnotetext{
${ }^{680}$ Miguel Murmis: El agro serrano y la vía prusiana de desarrollo capitalista, en Ecuador: Cambios en el agro serrano, Osvaldo Barsky y Miguel Murmis (Eds.), Quito: FLACSO-CEPLAES, 1980, p. 11.

${ }^{681}$ Ibíd. p. 21.
} 
guerrillas foquistas asustaba a las clases dominantes (burguesas y terratenientes), las manifestaciones populares que paralizaban Quito y al país continuamente, los enfrentamientos con las Fuerzas Armadas que disparaban sin titubear el temor que invadía a los hacendados serranos de que sus indios se volvieran levantiscos, insolentes, reclamones, endoctrinados. ${ }^{62}$

Las razones expuestas por Guerrero explican la necesidad de realizar una reforma agraria, puesto que destaca el papel desempeñado por las luchas campesinas, las cuales movilizaron a miles de huasipungueros y llegaron a convertirse en el eje de las protestas por las reformas sociales. Por eso, este autor rechaza la idea de la iniciativa terrateniente y la entrega de tierras voluntaria como elemento único para la elaboración de una ley de reforma agraria, pues los problemas y conflictos de la época fueron razón suficiente para que la clase terrateniente intentara buscar una salida rápida a través de la entrega de los huasipungos.

Por otra parte, teniendo en cuenta los problemas de unificación de las clases sociales, la necesidad de una reforma agraria supuso una gran ruptura en el sistema, en tanto que los hacendados tradicionales (tanto de la Sierra como de la Costa) se resistían a tal propuesta, mientras que la clase modernizante proponía una reforma estructural como mecanismo de escape a las tensiones sociales, a la vez que seguía el modelo planteado por la Alianza para el Progreso y contaba con el apoyo de los Estados Unidos. ${ }^{683}$ Como consecuencia, el problema agrario quedaría vinculado de forma internacional, mientras se incluían aspectos relacionados con la soberanía del estado y la cuestión territorial, poniéndose de manifiesto el tema de la cuestión nacional. ${ }^{684}$

\footnotetext{
${ }^{682}$ Andrés Guerrero, Haciendas, capital..., op. cit. p. 11.

${ }^{683}$ Recordemos que los principales objetivos de la Alianza para el Progreso se fundamentaban en el crecimiento del ingreso per cápita, el reparto equitativo del ingreso, la diversificación de las estructuras económicas para lograr una menor dependencia de los productos primarios, la aceleración del proceso de industrialización, el incremento de la producción y productividad agrícola y llevar a cabo una reforma agraria integral. A estos objetivos, se le unían otros de tipo social como la erradicación del analfabetismo y la mejora del sistema de educación, la construcción de viviendas populares y el aumento de la tasa de esperanza de vida al nacer. En último lugar, se buscaba consolidar los acuerdos de integración económica mediante un mercado común latinoamericano y el desarrollo de programas de cooperación. Fuente: Orlando Aguirre: La Alianza para el Progreso y la promoción del desarrollo en América Latina, historiadeamericalatina.files.wordpress.com/2011/07/clase-20_alianza-para-el-progreso.pdf

${ }^{684}$ Ver el apéndice de notas del capítulo 3 para más información. Fuente: Alejandro Moreano: El escritor, la sociedad y el poder, en "La literatura ecuatoriana en los últimos treinta años (1950-1980)", Quito, El Conejo, 1983,
} 
Además, esto volvió a mostrar que uno de los problemas más importantes para la modernización del Ecuador de los años sesenta, era la disolución de las llamadas formas pre-capitalistas en la agricultura, que constituían la base del funcionamiento de la estructura social agraria de la Sierra y de la Costa para algunos cultivos. Así, los problemas de atraso y el precarismo de los campesinos, desencadenaron una nueva oleada de movilizaciones indígenas en las haciendas estatales y tomas de tierras en las zonas arroceras, que finalmente lograron llevar el problema del agro al primer plano de la escena política. ${ }^{685}$

La abolición del precarismo fue el punto de coincidencias de distintas fuerzas sociales. Las diferencias entre estas, comenzaban a partir de las formas específicas de abolición y, por supuesto, acerca de los contenidos más generales de una Ley de Reforma Agraria. No es de extrañar entonces que en apenas dos años, seis proyectos de abolición del huasipungo se pongan en discusión: de la Comisión Nacional de Reforma Agraria designada por Velasco Ibarra, el elevado por el gobierno de Arosemena al Consejo Nacional de Economía, del Instituto Indigenista Ecuatoriano, de la Confederación de Trabajadores del Ecuador, de la Cámara de Agricultura de la I Zona y finalmente un proyecto de Alfredo Pérez Guerrero presentado en la Cámara de Diputados. ${ }^{686}$

Fernando Velasco también hace alusión a los problemas de agitación social en el campo a partir de 1960, año en que comenzó a incrementarse el número de sindicatos, huelgas y demandas de la mano del Partido Comunista a través de la Federación Ecuatoriana de Indios en la Sierra y la Federación de Trabajadores Agrícolas del Litoral. ${ }^{687}$

En este contexto, Velasco considera que la reforma agraria no solo ha de ser interpretada desde el punto de vista económico a partir de la incorporación del capitalismo, sino que también hay que tener en cuenta las contradicciones sociales impulsadas por dichos cambios. Así, la presión de las

p. 112; Rafael Polo: Los intelectuales y la narrativa de la nación mestiza en el Ecuador en la década de 1950, Universidad Andina Simón Bolívar, 1998.

${ }^{685}$ Ver el apéndice de notas del capítulo 3 para más información. Fuente: Rafael Quintero y Erika Silva, Ecuador: Una nación..., op. cit., p. 227-230; Agencia Latinoamericana de Información: Movimiento campesino, alainet.org/publica/diversidad/movcampesino.html

${ }^{686}$ Osvaldo Barsky, La reforma agraria..., op. cit. p. 130.

${ }^{687}$ Fernando Velasco Abad: Reforma agraria y movimiento campesino indígena de la Sierra, segunda ed. Quito: Editorial El Conejo, 1983, p. 77. 
clases más bajas hizo que algunos miembros de la élite defendieran una modificación de la propiedad que pusiera fin a la lucha de clases, instituciones y relaciones de trabajo obsoletas, que suponían un obstáculo para la modernización del país.

Muchos terratenientes concedieron tierras a sus trabajadores sólo después de protestas como la marcha de la FEI en 1961 sobre Quito. En total, de 1959 a 1963 hubo 3.019 casos de terratenientes liquidando huasipungos por iniciativa propia. En esencia, los sectores elitistas empezaron pronto a promover la legislación de reforma agraria porque funcionaría como una válvula de escape para las acciones de protesta rurales. ${ }^{68}$

De esta forma, en 1961, se creó mediante decreto ejecutivo, la denominada Comisión Nacional de Reforma Agraria, cuya función era la de elaborar un proyecto para establecer dichos cambios agrarios. No en vano, y pese a la insistencia en el tema, solamente se llegaron a incluir algunas de las haciendas públicas en el proyecto presentado al Senado, a la vez que se planeaba presentar las medidas de colonización como parte de la reforma agraria.

A este respecto, Barsky indica que la Comisión Nacional de Reforma fue únicamente una herramienta encargada de retrasar el establecimiento de medidas importantes relacionadas con la estructura agraria, cuyo objetivo primordial era canalizar las presiones que se reflejaban desde los diferentes sectores. ${ }^{689}$ Es decir, mediante esta estrategia de Velasco Ibarra en su papel de mediador de intereses antagónicos, se pretendía evitar el enfrentamiento de las diferentes fracciones propietarias y mantener su imagen de protector de los grupos marginados:

Surge nuevamente Velasco como el único caudillo capaz de manipular los sentimientos antiimperialistas y anti-oligárquicos de los sectores populares, para mantener la dominación oligárquica e imperialista en el gobierno. ${ }^{690}$

¿En qué consistía el intento de reforma del agro llevado a cabo por dicha Comisión? En principio, el proyecto elaborado por la Comisión Nacional de Reforma Agraria, aún cuando dejaba fuera de los alcances a un conjunto de precaristas (yanaperos) y limitaba los beneficios de

\footnotetext{
${ }^{688}$ Fernando Velasco Abad, Reforma agraria..., op. cit., p. 82.

${ }^{689}$ Osvaldo Barsky, Los terratenientes serranos...op. cit. p. 133-207.

${ }^{690}$ Pablo Cuvi: Velasco Ibarra: El último caudillo de la oligarquía, Instituto de Investigaciones Económicas, 1977, p. 253.
} 
los huasipungueros, contemplaba algunas de las cuestiones primordiales a la hora de abordar el tema de las relaciones precarias:

En primer lugar, se puede citar la entrega de las parcelas de huasipungo mediante acuerdos privados, con los que se adjudicaban tierras de escasa calidad y cantidad a los precaristas a cambio de lo estipulado para los huasipungueros por fondo de reserva, vacaciones y horas extraordinarias. Este proyecto permitía que los precaristas fueran propietarios de la tierra de forma directa, por lo que sus deudas debían de ser eliminadas.

Otra de las cuestiones a debatir, era el acceso a otros recursos de la hacienda (pastos, leña y agua), pues permitía a los huasipungueros la cría de animales de forma independiente. No en vano, en las entregas anticipadas, los terratenientes eliminaron esta posibilidad de acceso a la hacienda, ya que tenían pensado deshacerse de cualquier vínculo que pudiera afectar la posesión de la tierra.

En tercer lugar, se ha de hacer referencia a la adjudicación de los páramos, ya que la entrega de estas tierras serviría para complementar la posibilidad de un mecanismo de reproducción de la parcela campesina.

Por último, esta iniciativa tenía como objetivo incrementar el tamaño de las parcelas, definirlas como explotaciones de tipo familiar, y evitar el despojo de tierra mediante la prohibición de su venta o con el gravamen de la misma.

Este proyecto, presentado al Congreso en septiembre de 1961, no llegó a ser revisado ante el rechazo total manifestado por las Cámaras de Agricultura y la gran agitación generada por parte de algunos sectores latifundistas que veían amenazadas sus posesiones. ${ }^{691}$

El incremento del malestar entre la población hizo que estos sectores y otras fuerzas económicas y políticas, acabaran con el gobierno de Velasco Ibarra, asumiendo el gobierno el vicepresidente del momento, Carlos Arosemena, que también intentaría impulsar un programa para redistribuir la tierra, como veremos a continuación. ${ }^{692}$

\footnotetext{
${ }^{691}$ La fracción terrateniente ligada a la producción lechera había sido la responsable de impulsar la entrega de tierras de los huasipungueros, además de favorecer la reforma agraria. La otra fracción terrateniente, cuantitativamente dominante, estaba en contra de dicha reforma. No obstante, este periodo se caracterizó por la eliminación de los huasipungos mediante la venta de terrenos y con el término de contratos o la disminución de derechos; siendo el $15 \%$ de las parcelas-huasipungo entregadas a las familias huasipungueras a través de lo que se conoce como la "iniciativa terrateniente", que tuvo lugar con anterioridad a la Ley de Reforma Agraria de 1964. Para más información ver: Fernando Velasco, Reforma agraria..., op. cit. p. 74.

${ }^{692}$ Andrés Guerrero, Haciendas capital..., op. cit. p. 51-86.
} 
Así pues, durante la presidencia de Arosemena (1961-1963), el centro político de la reforma agraria fue el establecimiento de su definición y alcance. A su vez, la escena política quedó marcada por una de las manifestaciones urbanas más grandes de campesinos indígenas en la historia ecuatoriana, en la que aproximadamente unos doce mil huasipungueros y comuneros invadieron las calles de Quito de manera pacífica en diciembre de $1961 .{ }^{693}$ Este suceso fue de gran importancia, pues el tema de la transformación de la estructura agraria de las haciendas serranas, era un hecho que no podía seguir siendo ignorado.

A partir de 1962, la cuestión de la reforma del agro estaba centrada en torno al tipo de transformación necesaria y se planteaba si la liquidación del precarismo era algo beneficioso para los campesinos o para los terratenientes. La discusión giraba en torno a dos aspectos, puesto que por una parte, se debía de tener en cuenta un eje constituido por la entrega del huasipungo y las condiciones establecidas en dicha entrega; mientras que por otra parte, se debatía sobre la situación en la Sierra, en cuanto que en la Costa, el precarismo tenía menor importancia y se limitaba a sectores finqueros y sembradores, además de existir una frontera agrícola en expansión y relaciones de tipo salarial. ${ }^{694}$

Frente a la posibilidad de que los militares asumieran el poder político, y en el intento de fortalecer su gobierno, Arosemena intentó regularizar las movilizaciones campesinas que habían sido impulsadas principalmente por la Federación Ecuatoriana de Indios (FEI). ${ }^{695}$

Para ello, aprovechó la coyuntura favorable, al realizarse el tercer Congreso de la Federación Ecuatoriana de Indios en Quito (16-18 de diciembre de 1961). Entre los puntos de debate planteados en este evento, se encontraba el de la reforma agraria, al cual Arosemena respondió asumiendo su compromiso de elaborar un proyecto de abolición del huasipungo, aunque se ha de

\footnotetext{
${ }^{693}$ L. Linke: Ecuador's politics: President Velasco's Fourth Exit, the World Today, Vol. 18, 2, 1962, p. 65-75.

${ }^{694}$ Osvaldo Barsky, Alex Barril, Gustavo Cosse, Jorge Morandi, Humberto Vinueza: El proceso de transformación de la producción lechera serrana y el aparato de generación-transferencia en Ecuador, FLACSO, Proyecto Cooperativo de Investigación sobre tecnología agropecuaria en América Latina, Documento Protaal, núm. 40, 1990, p. 233-248.

${ }^{695}$ Ver el apéndice de notas del capítulo 3 para más información. Fuente: M. Becker, S. Tutillo: Historia agraria y social de Cayambe, FLACSO, Abya-Yala, 200, p. 138-139.
} 
aclarar que esta propuesta únicamente tenía como objetivo el establecimiento de pequeñas medidas destinadas a los terratenientes más atrasados. ${ }^{696}$

El proyecto presentado por Arosemena no incluía a los arrimados, finqueros y cosechadores de la Costa ni tampoco a los yanaperos, ya que carecían de fondo de reserva y trabajaban en algunas ocasiones como jornaleros para poder acceder a los pastos y al agua de la hacienda. Estas insuficiencias fueron mostradas por la Federación Ecuatoriana de Indios:

El proyecto de decreto señala que la entrega de los huasipungos a los huasipungueros se haría mediante el pago del precio de la tierra según el valor comercial de los últimos cuatro años, tomando como base para dicho cálculo, la liquidación del fondo de reserva (un mes de sueldo por año al que tenían derecho los huasipungueros al cesar de trabajar en la hacienda). El valor de la liquidación del fondo de reserva, será pagado a base del mismo terreno que los huasipungueros hayan ido ocupando en la proporción que arroje la liquidación. Y la liquidación del fondo de reserva arrojará un valor tan pequeño que, en la mayoría de los casos, no permitirá a los huasipungueros convertirse en dueños de toda la extensión de los actuales huasipungos, tendrían que quedar endeudados por la cantidad restante de la tierra, con lo cual no podrían pagar con el valor de la liquidación del fondo de reserva. ${ }^{697}$

Por otro lado, se indicaba la posibilidad de que los huasipungueros recibieran un conjunto de tierras diferentes a las estipuladas, tratándose de terrenos en peores condiciones. A todo esto, se ha de añadir que el proyecto no contemplaba el uso de pastos, agua, leña y otros recursos de gran importancia para la economía del huasipunguero, así como la eliminación de otras formas de producción existente en la Sierra como era el caso de la aparcería o el sistema de trabajo de los

\footnotetext{
${ }^{696}$ Ver el apéndice de notas del capítulo 3 para más información. Fuente: Federación Ecuatoriana de Indios: III Congreso de la Federación Ecuatoriana de Indios y Gran Concentración de la Sierra para exigir la Reforma Agraria Radical y Democrática, e-archivo ecuatoriano, www.yachana.org/earchivo/fei/ en: El Comité Ejecutivo Nacional, La Comisión Nacional Campesina de la CTE, III Congreso de la Federación Ecuatoriana de Indios y Gran Concentración de la Sierra para exigir la Reforma Agraria Radical y Democrática, Mañana 2, no. 96 (December 7, 1961).

${ }^{697}$ Diario El Comercio, años 1959-1964, 3 de enero de 1962, en Osvaldo Barsky: La reforma agraria ecuatoriana, Corporación Editora Nacional, Biblioteca de Ciencias Sociales, Volumen 3, 1984, p. 123-160.
} 
arrimados. Tampoco, favorecía a los campesinos de la Costa que, bajo los sistemas de los finqueros, sembradores y arrendatarios de parcelas, estaban sometidos a altas rentas. ${ }^{698}$

En definitiva, podemos observar cómo este proyecto, que había sido preparado para satisfacer los intereses de los terratenientes, había ignorado algunos de los puntos fundamentales a tener en cuenta en la reforma, como era el caso de la entrega gratuita del huasipungo, el acceso a ciertos recursos de la hacienda y la eliminación total de las prestaciones personales, siendo por tanto, una simple legalización de entregas que los terratenientes llevaron a cabo por su cuenta. En cierto modo, lo que se pretendía con estas entregas, era situar a los huasipungueros en tierras de peor calidad y más pequeñas que las ocupadas, eliminándose los recursos de los que habían venido gozando hasta el momento.

En un principio, la política establecida por Arosemena acabaría por aceptar la subordinación a las presiones de la Cámara de Agricultura de la Primera Zona, pues las continuas declaraciones para ajustar las leyes sobre el huasipungo y llevar a cabo una reforma agraria, podrían implicar la adopción de las propuestas del organismo de los terratenientes. A pesar de esto, el gobierno de Arosemena abandonaría de forma indefinida este proyecto, para poder ganar tiempo y espacio político y terminar su mandato. Con esto, podría participar en manifestaciones campesinas para luego ceder rápidamente a las presiones de la mayoría de los terratenientes que lideraban en ese momento la Cámara de Agricultura. ${ }^{699}$

Osvaldo Barsky se refiere a los meses de diciembre de 1961 y enero de 1962, como dos momentos de cambio fundamentales de la situación económica ecuatoriana, a partir de los cuales se puede entender mejor el comportamiento de la fracción terrateniente que dirigía la Cámara de Agricultura de la Zona I, la cual agrupaba a los hacendados del centro y norte de la Sierra.

Los problemas de la sociedad y las numerosas luchas populares que acabaron poniendo fin al mandato de Velasco Ibarra, junto con la posterior administración de Arosemena y su interés para realizar cambios en el agro, fueron aprovechados por los dirigentes de la Cámara a través de su estrategia que ponía de manifiesto la madurez política de los dirigentes del sector pertenecientes al grupo más moderno. ${ }^{700}$

\footnotetext{
${ }^{698}$ Ibíd. p. 123-160.

${ }^{699}$ Osvaldo Barsky, La reforma..., op. cit. p. 120-160.

${ }^{700}$ Ibíd. p. 134-139.
} 
En lugar de oponerse a todo tipo de modificaciones, tal y como ocurría con la Cámara de Agricultores de la tercera zona (sur de la Sierra: Loja, Azuay y Cañar), su actitud era la de cooperar para el establecimiento de una ley que incluía sus propios intereses. Además, esta actitud generada a raíz de los problemas sociales, tenía como objetivo instrumentar los proyectos gubernamentales, adaptándolos al tipo de cambios que dicha fracción estaba dispuesta a asumir. De este modo, se mantuvo el apoyo a la iniciativa mencionada a pesar del anuncio de Arosemena en cuanto a la abolición del huasipungo. En este caso, Barsky habla de la contraofensiva terrateniente, pues a la convocatoria del Congreso Indigenista de la FEI, los terratenientes respondieron convocando al Congreso de Agricultores de la Primera Zona para el 19 de enero. De forma paralela, una comisión de la Cámara se reunió con Arosemena y con el Consejo Nacional de Economía para analizar el proyecto de abolición del huasipungo y posponer su puesta en marcha hasta la celebración del congreso, a lo que el gobierno accedió.

La posterior celebración del Congreso de Agricultores se llevó a cabo con la presencia de doscientos delegados miembros de la Cámara como representantes de las distintas provincias de la Sierra y el Oriente, y la delegación de la Cámara de Agricultura de la Segunda Zona que agrupaba a los productores de la Costa.

Las reflexiones realizadas durante este congreso fueron bastante complicadas, al no poder llegar a un acuerdo sobre la abolición del huasipungo. Esto se debió a la diferencia de opiniones, pues existía un sector mayoritario que estaba de acuerdo con la entrega, pero también había una minoría que mostraba su rechazo. A la vez, junto al sector mayoritario, se ha de hablar de otro grupo que quería entregar los huasipungos y adoptar resoluciones adicionales para mejorar las condiciones de vida de los indígenas de la Sierra.

Finalmente, a pesar de que todos los participantes llegaron a un acuerdo con el que se aceptaba la abolición del huasipungo como parte integrante de la reforma agraria, la ofensiva de la Cámara consiguió retrasar dicha medida como consecuencia de los continuos ataques al gobierno de Arosemena. Como consecuencia, el problema agrario continuaría presente, iniciándose nuevamente la discusión de los proyectos de Reforma Agraria en 1962. ${ }^{701}$

${ }^{701}$ Ibíd. p. 137. 
Así, el debate sobre el problema se reavivó con la discusión de la Cámara de Diputados de un proyecto elaborado básicamente por Alfredo Pérez Guerrero, que era el Rector de la Universidad Central en aquel momento: ${ }^{702}$

En líneas generales, el proyecto tendía a favorecer a los precaristas, sobre todo, a los huasipungueros, partidarios, colonos, sembradores y arrendatarios, es decir, a aquellos que ocupaban tierras de las haciendas. Los yanaperos, si bien seguían gozando de los beneficios que tenían hasta la sanción de la futura ley, no tenían acceso a tierras por vía de este proyecto. Otro punto importante es que el decreto tendía a garantizar la estabilidad de los precaristas y la percepción de salario, a cambio de su trabajo. Además, hacia retroactivo a 1961, el derecho a reclamar la parcela y la relación laboral, dado los desalojos de precaristas que se venían produciendo desde los últimos años. ${ }^{703}$

En definitiva, se trataba de un proyecto favorable para la mayor parte de los precaristas existentes, en el que la concesión hecha a los propietarios consistía en proporcionarles la diferencia entre el valor de la tierra y la liquidación hecha al precarista, lo cual era realizado por el estado en un periodo de veinte años.

A pesar de los diversos ataques que este plan sufrió, la Cámara de Agricultura de la Primera Zona mantuvo su apoyo a la abolición del huasipungo, pero únicamente a partir de sus requerimientos, es decir, aplicándolo solo a los huasipungueros y manteniendo las desventajas para los precaristas que hemos visto hasta ahora.

Esta lucha, que se prolongó a lo largo del gobierno de Arosemena, fue aumentando a través de manifestaciones y continuas movilizaciones en el campo por parte de los huasipungueros y los campesinos costeños. ${ }^{704}$ Estos acontecimientos, unidos a la continua presión ejercida por la derecha local y el imperialismo, obligaron a que el gobierno cambiara su posición política de reivindicaciones populares, lo cual provocó una situación cercana al vacío de poder. De esta

\footnotetext{
${ }^{702}$ Ver el apéndice de notas del capítulo 3 para más información.

Fuente: Efrén Avilés: www.enciclopediadelecuador.com, miembro de la Academia Nacional de Historia del Ecuador, 2012.

${ }^{703}$ Osvaldo Barsky, La reforma..., op. cit. p. 137-138.

${ }^{704}$ Ver el apéndice de notas del capítulo 3 para más información. Fuente: Oswaldo Albornoz, Las luchas..., op. cit., p. 117-123.
} 
forma, el gobierno de Arosemena, incapaz de cumplir con las reformas que hubieran consolidado el apoyo popular, se encontró con la resistencia de los terratenientes a cargo del poder, consiguiendo que los sucesivos proyectos de Ley de Reforma Agraria o de entrega de huasipungos se paralizaran.

En suma, el periodo descrito llegó a caracterizarse por un debate donde los gobiernos del momento, tanto el de Velasco Ibarra como el de Arosemena, más que impulsar un proyecto representativo de un sector fueron acercando posiciones según las relaciones de fuerza entre los distintos sectores. Esto generó un estado de indefinición que provocó la toma del control del poder por parte de los militares, quienes establecieron las nuevas reglas del juego del problema agrario.

Asimismo, los cambios económicos y sociales que fueron apareciendo en el Ecuador, tuvieron lugar gracias a las clases sociales que actuaban conforme a sus exigencias, llevando a cabo acciones de forma consciente. Esto explica que el plano de lo político quedara definido como un espacio de juego de intereses y no como un campo de conflictos sociales, en el que intervenían fuerzas, cuya conciencia de los cambios iba adoptando un carácter parcial y atrasado. ${ }^{705}$

\subsubsection{2) Características de la hacienda en la Sierra ecuatoriana durante la década de los sesenta.}

Con anterioridad, se ha visto cómo la conformación de la estructura de la Sierra ecuatoriana durante el siglo XIX, se llevó a cabo mediante un complejo sistema de incorporación de la mano de obra indígena a los diferentes mecanismos creados por los colonizadores en el proceso de generación de excedentes. Este proceso tuvo como resultado la configuración de la hacienda como eje estructurador de la sociedad agraria serrana durante el periodo republicano, existiendo un conjunto de campesinos y comunidades independientes que estaban ligados a las haciendas a través de diversos mecanismos.

Se trataba de amplias extensiones que permitían a sus propietarios ceder parte de sus tierras o recursos para la extracción de renta en trabajo y aportaban lo fundamental de la producción al mercado en la Sierra. Asimismo, sabemos que la hacienda tradicional se apoyaba en un conjunto de formas de trabajo que podían ser de tipo precario o salarial, las cuales mostraban una dependencia hacia el terrateniente o una relación de carácter capitalista.

\footnotetext{
${ }^{705}$ Andrés Guerrero, Haciendas capital..., op. cit. p. 51-86.
} 
A partir de estos elementos, se observan las diferentes combinaciones en las que se podía incluir la hacienda para la organización de su sistema productivo y la maximización de sus ingresos, pero ¿cuáles eran las estrategias agrarias aplicadas en la clasificación de las haciendas de esa época?

Una de las primeras observaciones sobre las estrategias agrarias del sector hacendado, consiste en una tipología de la especialización de la producción de las haciendas de mediados del siglo XVIII en la Audiencia de Quito, en la que se encuentran las haciendas de sembradío, las haciendas de ganado mayor, los rebaños y obrajes (fabricas rurales de telas) en la Sierra norte. ${ }^{706}$ La desaparición de los obrajes durante el siglo XIX, debido a la imposibilidad para competir con los cambios generados por la Revolución Industrial, hizo que las haciendas agropecuarias asumieran el control, a la vez que se entraba en una etapa de expansión territorial y la aplicación de una agricultura extensiva apoyada en el uso de la tierra y mano de obra barata. Ahora bien, ¿se podría aplicar esta tipología y los rasgos de explotación social y económica mencionados a las haciendas de los años cincuenta y sesenta? ¿cuáles habrían sido sus principales rasgos de haberse abandonado la herencia colonial $?^{707}$

Hasta comienzos de la década de los sesenta, la economía ecuatoriana estuvo representada por la hacienda tradicional, la cual constituía la figura dominante de la producción agropecuaria en la Sierra y en gran parte de la Costa. Unos años antes, en la región de la Costa, se llevaron a cabo algunos cambios debido a las inversiones de la United Fruit Company en las plantaciones de banano que lograron extender las relaciones salariales.

Leon Zamosc indica que las haciendas de esta época, representaban el elemento central de la organización socio-económica ecuatoriana, siendo las relaciones de subordinación con los campesinos su método de reproducción. ${ }^{708}$ En este sentido, las haciendas se encontraban

\footnotetext{
${ }^{706}$ Charles C. Crissman: La agricultura en los Páramos: Estrategias para el uso del espacio, Consorcio para el Desarrollo Sostenible de la Ecorregión Andina, Num. 1, 2003.

707 Miguel Murmis, Jose Bengoa, Osvaldo Barsky: Terratenientes y desarrollo capitalista en el agro, ediciones CEPLAES, 1982, p. 93-98.

708 Ver las obras de: Eduardo Archetti: Burguesía rural y campesinado en la Sierra ecuatoriana, en Ecuador Archetti, Campesinado y estructuras agrarias en América Latina, Quito, CEPLAES Editores, 1981, p. 17-22; CIDA: Ecuador: tenencia de la tierra y desarrollo socio-económico del sector agrícola, Washington: Comité Interamericano de desarrollo agrícola, 1965, p. 45-181; Andrés Guerrero: La hacienda precapitalista y la clase terrateniente en América Latina y su inserción en el modo de producción capitalista: El caso ecuatoriano,
} 
vinculadas a las comunidades de huasipungueros y allegados, es decir, la economía al interior de la hacienda, mientras que hacia afuera, esta se encontraba ligada a los campesinos que pertenecían a otras comunidades minifundistas.

Los terratenientes daban parcelas a arrendatarios que pagaban en efectivo y a partidarios que pagaban con parte de la cosecha. Los arreglos más importantes, sin embargo, eran con los sitiajeros y varios tipos de yanapas, que se obligaban a trabajar para la hacienda a cambio del derecho a usar ciertos recursos como pastos, aguas, leña y caminos. $^{709}$

Zamosc también señala la existencia de relaciones de producción precarias a comienzos de los sesenta, y la existencia de huasipungos en las haciendas más modernas situadas en el norte y centro de la Sierra:

Aún tomando en cuenta el desarrollo capitalista y la importancia que pudiera tener la mediana propiedad en los lugares de mayor mercantilización, puede concluirse que la articulación entre haciendas y economías campesinas subordinadas, y más particularmente la extracción de rentas en trabajo, era el ingrediente fundamental del proceso de formación socioeconómica en la Sierra. ${ }^{710}$

Según Fernando Guerrero y Pablo Ospina, nunca existió un único tipo de hacienda tradicional en estos años, pues en cada región del país las haciendas tradicionales se articulaban conforme a los mercados y poseían diversos sistemas de captación de mano de obra. A pesar de esto, todas las haciendas se basaban en diferentes formas de cobro de una renta en trabajo o en especias a comunidades de campesinos a cambio de poder usar los recursos de la hacienda o sus recursos. ${ }^{711}$ En el Ecuador, la gran propiedad se transformó y desarrolló sus fuerzas productivas, integrando su producción al mercado y asentando su organización en relaciones plenamente salariales,

universidad de Glasgow, Occasional papers, no. 23, 1977, p. 4-16; Fernando Velasco: Reforma agraria y movimiento campesino indígena en la Sierra, Quito: Ediciones Latinoamérica, 1983, p. 41-62.

${ }^{709}$ Leon Zamosc, op. cit. p.207.

${ }^{710}$ Ibid. p.209.

${ }^{711}$ Fernando Guerrero Cazar, Pablo Ospina Peralta: El poder de la comunidad: Ajuste estructural y movimiento indígena en los Andes ecuatorianos, CLACSO, 2003, p. 9-11. 
siendo el factor responsable de esta dinámica, la agro-industria a través de las empresas transnacionales.

Así pues, la importancia de abordar los cambios que tuvieron lugar en las haciendas de la Sierra, está determinada por un proceso como el señalado anteriormente, pero donde el factor dinamizador externo no aparece y la iniciativa desempeñada por la burguesía terrateniente modernizante, es la encargada de procurar el desarrollo de la agro-industria.

Las características de esta iniciativa a nivel estructural y el tipo de repercusiones que este proceso tuvo en el agro serrano, marcaron una profunda diferenciación al interior de la burguesía terrateniente serrana y determinaron la modernización de las haciendas localizadas fundamentalmente en la zona central, siendo todo esto posible gracias a la producción de leche, que se convertiría en un producto fundamental, como veremos en el siguiente apartado. ${ }^{712}$

El periodo donde se aprecia con más claridad las diferencias mencionadas, es el que se desarrolla en la primera mitad de la década de los sesenta, pues a partir de 1959, comenzaron las entregas voluntarias de los huasipungos, que como se ha dicho, fue una medida ligada a la iniciativa de una de las fracciones terratenientes para liquidar el precarismo.

Por su parte, Jose Luis Ortíz habla del proceso de cambio en el sistema de hacienda y de la presencia dominante de empresas agrícolas basadas en el trabajo asalariado en la serranía ecuatoriana, a la vez que pone de manifiesto la capacidad de respuesta de una fracción terrateniente para atender los condicionamientos del mercado nacional y de un conjunto de incidencias en la estructura productiva y en el sistema de relaciones sociales. ${ }^{713}$

Este autor también menciona el proceso que tiene lugar a partir de 1959, en el que se aceleran las relaciones capitalistas en el campo y la existencia de una fracción terrateniente dentro de un nuevo bloque de clases dominantes, a partir de lo cual, podremos apreciar el fenómeno de modernización y los efectos que tuvieron lugar en la organización campesina.

Los cambios experimentados en el agro serrano muestran la presencia de un conjunto de representantes de la fracción modernizante de terratenientes en este proceso, siendo las características de las unidades productivas que accedieron a dicha modernización, las que nos permitirán entender las razones que llevaron a la entrega anticipada de los huasipungos y a los

\footnotetext{
${ }^{712}$ Osvaldo Barsky, Iniciativa terrateniente...op. cit. p. 15-65.

713 Jose Luis Ortíz: Formas de organización rural en el Ecuador. Marco histórico (la comunidad campesina), en "Enfoque: Ecuador, Estudios de la realidad nacional", Fundación Eugenio Espejo, Guayaquil, mayo 1983, p. 69-93.
} 
cambios de las relaciones sociales. ${ }^{714}$ En este caso, dicho fenómeno ocurrió en una buena parte de las haciendas serranas, al convertirse en ganaderas y lecheras y también, porque la eliminación de las relaciones pre-capitalistas y el crecimiento del poder de la fracción terrateniente mediante su participación directa en la elaboración de los proyectos de ley de Reforma Agraria, pasaron a ser los objetivos fundamentales.

Así, la iniciativa terrateniente, elemento dinamizador del proceso, y posteriormente, las políticas agrarias gubernamentales, fueron un conjunto de factores fundamentales en el tamaño de las unidades productivas y en la forma de utilización de la mano de obra. Como consecuencia, se observa la disminución de la fuerza de trabajo gracias las inversiones modernizadoras que favorecieron el incremento del capital constante y que procuraban el ahorro de mano de obra. A partir de aquí, la transformación de las haciendas agrícolas en unidades productivas modernas, llevó al uso creciente de mano de obra asalariada y al abandono del sistema anterior de mano de obra campesina subordinada. $^{715}$

Regresando al análisis de la realidad de la tierra en el Ecuador, vamos a ver ahora uno de los modelos de latifundio-minifundio, desarrollado por Rafael Barahona, en el que se establece una tipología de las haciendas ecuatorianas en la Sierra ecuatoriana, la cual es definida utilizando los siguientes criterios: ${ }^{716}$

1) La coexistencia de varias empresas en una hacienda y el carácter de su desarrollo.

2) El acceso de los campesinos a los recursos de la hacienda.

3) La modalidad de pago de la empresa patronal.

El informe de la CIDA en relación a la tenencia de la tierra en la región interandina para los años sesenta, muestra un esquema global de lo que ha venido a llamarse la "trama institucional de la

\footnotetext{
${ }^{714}$ Osvaldo Barsky: Los terratenientes serranos y el debate político previo al dictado de la Ley de Reforma Agraria de 1964 en el Ecuador, en "Cambios en el agro serrano", publicación de CEPLAES y FLACSO, abril 1980.

715 Jose Luis Ortíz se refiere a este proceso como una versión empobrecida de la agricultura capitalista y la degradada agricultura andina, como consecuencia de los problemas resultantes de las condiciones de subsistencia de la población en el campo y de la pérdida cultural. Para más información ver la obra de José Luis Ortíz, Formas de organización... op. cit. p. 56-58.

716 Rafael Barahona: Una tipología de haciendas en la Sierra ecuatoriana" en Oscar Delgado (comp.) Reforma Agraria en América Latina, proceso y perspectivas, Fondo de Cultura Económica, México, 1965. También, se puede consultar Andrés Guerrero: La hacienda precapitalista y la clase terrateniente en América Latina y su inserción en el modo de producción capitalista: El caso ecuatoriano, Ed. Escuela de Sociología, Universidad Central, Quito, 1974; Jaime Galarza: El yugo feudal, Edic. Solitierra, 1973.
} 
región”, en el que se puede apreciar cómo los vínculos de interdependencia continuaban vigentes entre los diversos sistemas de explotación agrícola durante esta época. ${ }^{717}$

Los criterios empleados para llevar a cabo la clasificación de los sistemas de tenencia de la tierra, son elementos de análisis que se refieren a la coexistencia de varias empresas dentro de una misma hacienda y su carácter relativo de desarrollo, por lo que el nivel básico está representado por la hacienda tradicional corriente. ${ }^{718}$

En este caso, la investigación llevada a cabo por Barahona con respecto a la realidad de la serranía ecuatoriana de los años sesenta, indicaba la existencia de nuevas formas de tenencia que emergieron del nivel de hacienda tradicional corriente a partir de la transformación positiva y mediante la desintegración, como veremos a continuación (ver Tabla 6: Tipos de haciendas: Tipología Barahona, 1963): $: 19$

- El primer sistema, el tradicional infra o infra-tradicional, en el que los terratenientes tenían un menor poder pero continuaban utilizando los elementos gamonalistas de la potestad señorial para recaudar la renta. Además, en la práctica no existían actividades empresariales del propietario, siendo la economía campesina predominante en estas haciendas, por lo que los cultivos carecían de extensión, importancia económica y dotación de ganado. Ante estas circunstancias, la fuerza de trabajo por parte de la empresa patronal era mínima, limitándose a mantener un sistema administrativo destinado al cobro del tributo y renta.

Los elementos que conformaban estas haciendas estaban constituidos por las áreas de minifundio o las de las comunidades indígenas que no tenían tierra de forma significativa, y que al estar rodeadas de haciendas y grandes terrenos para el pastoreo extensivo, estaban forzadas al sitiaje (ver Tabla 7: Hacienda Tradicional infra).

- En segundo lugar, las haciendas tradicionales en desintegración, caracterizadas por un fuerte asedio interno y por la escasez de actividad de la empresa patronal como consecuencia de la desintegración de la autoridad patronal, a causa de la presión de los

\footnotetext{
${ }^{717}$ Comité Interamericano de Desarrollo Agrícola, op. cit. p. 35-150.

${ }^{718}$ Jose Luis Ortíz, Formas de organización..., op. cit. p. 56-58.

${ }^{719}$ Las tablas 6-10 se encuentran en el apéndice de datos del capítulo 3. Fuente: Rafael Barahona: Una tipología de haciendas en la Sierra ecuatoriana, en "Reforma Agraria en América Latina, procesos y perspectivas", Oscar Delgado, comp. Fondo de Cultura Económica, México, 1965.
} 
trabajadores que exigían un salario. Estas situaciones fueron provocadas por un aumento de la población de las haciendas mediante crecimiento vegetativo o con la acogida de campesinos desarraigados (ver Tabla 8: Hacienda Tradicional en desintegración).

En el caso de que las haciendas pertenecieran a instituciones de la Universidad Central, estas eran controladas por sus trabajadores, hecho que provocaba el cese de actividad de la empresa patronal, ya que las iniciativas de los trabajadores colocaban a los patrones frente a una situación que no podía ser resuelta ni con el uso de la fuerza, ni a través de la vía económica. Por otro lado, la base de la explotación era la economía campesina, pero no la economía campesina de los minifundistas externos a la hacienda, sino la economía dominante de los propios trabajadores de las haciendas, que iba forzando una paulatina disminución de las operaciones por cuenta del propietario.

- En tercer lugar, la hacienda tradicional corriente, caracterizada por la coexistencia de varios tipos de explotaciones dentro de la unidad y diversas formas de pago, ya fuera en recursos o en salarios (ver Tabla 9: Hacienda Tradicional corriente).

- Por último, la hacienda moderna emergente, que era una empresa fuertemente capitalizada, donde existía un firme control de los recursos por la empresa patronal, en la que se incrementaban de forma considerable los obreros asalariados y se instrumentaba el proceso de eliminación de los precaristas, aunque aquí, es necesario aclarar la permanencia de algunos rasgos característicos de los otros tipos de haciendas (ver Tabla

\section{0: Hacienda Moderna).}

El tema de la hacienda, la situación de los indios y los problemas derivados del reparto de la tierra en los años cincuenta y sesenta fueron una constante en la literatura ecuatoriana de la generación de autores de los años treinta. Así, en el cuento de Icaza, El nuevo San Jorge, se muestra al indio como un ser explotado por los blancos y mestizos, a los que llama cholos y se vuelve a poner de relieve una imagen típica del latifundista, exagerando su papel para mostrar su mensaje de denuncia. $^{720}$

\footnotetext{
${ }^{720}$ Este cuento pertenece a la obra Seis relatos, Quito, Casa de la Cultura Ecuatoriana, 1952, la cual fue publicada posteriormente bajo el nombre Seis veces la muerte, Buenos Aires, Editora Alpes, 1954.
} 
En el cuento Mama Pacha, también perteneciente a la obra Seis veces la muerte, Icaza retrata al teniente político como una figura incapaz de dirigir el gobierno y que mantiene a cholos y miembros de la oligarquía acostumbrados a las preferencias incondicionales de su autoridad: ${ }^{721}$

- Busquen al criminal...

- iSr... Sr...!

-¿Pero quién?

-iEl Teniente Político!

- Cierto! El Teniente Político.

-Que nos sea útil en este trance.

- Que sirva para algo.

- Que desquite las multas y los impuestos.

-Que nos defienda.

-Pero que sea pronto.

- -El Teniente Político! ¡El Teniente Político! $!^{722}$

Asimismo, en este cuento se observa un cambio en el teniente político, pues del servicio del patrón blanco se pasa al del cholo con dinero. No obstante, este cambio es solo aparente, ya que su actitud servil al poder de los terratenientes sigue siendo igual.

Por otro lado, y siguiendo con Icaza, se aprecia su crítica en el primer tomo (El juramento) de su última novela Atrapados, en el que presenta una autobiografía formada por varios eventos de carácter político. ${ }^{723}$ Tal y como el título de este tomo sugiere, Icaza pone de manifiesto un plan para vengarse de su tío Enrique, al que considera como el típico latifundista ecuatoriano, del cura, de los gringos y de los chullas que se aprovechan de la situación de necesidad de su madre. De igual forma, Icaza ataca la corrupción, la hipocresía y la forma en que varios personajes pretenden dedicarse a la vida política para beneficiarse.

En esta novela, el teniente político también sufre un cambio, hecho que se manifiesta cuando el cacique Teodoro Segovia queda sorprendido cuando la autoridad rural ya no actúa como su

\footnotetext{
${ }^{721}$ Jorge Icaza: Mama Pacha, en Seis veces la muerte, Buenos Aires, Editora Alpes, 1954, p. 35.

${ }^{722}$ Ibíd. p. 81.

${ }^{723}$ Jorge Icaza: Atrapados: Tríptico, vol. 1: El Juramento, Editorial Losada, 1972.
} 
sirviente incondicional: Cuando Teodoro reclama justicia al teniente político se da cuenta de que ya no era el tipo incondicional, duro e inhumano con los indios y con ciertos cholos, al gusto de cualquier cacique... ${ }^{724}$

Por otro lado, la crítica en el papel del teniente político se mantiene en la novela de Icaza, al que describe como una figura con una actitud siempre lista al zarpazo abusivo y que usa para maltratar a la gente pobre y a los indios: ${ }^{725}$

Se encontró rodeado por las personas ante quienes no podía usar ni su máscara ni su tono profesional, fuerte, y altanero. Los dueños de la tierra, los ministros de Taita Diosito, los comerciantes, las honorables madres de familia.... ${ }^{726}$

No faltaba nunca el Teniente Político, generalmente algún cholo, ex-mayordomo o exsirviente de casa grande, con botines de becerro sucios y despellejados las puntas, vestido de casinete remendado el culo y los codos, camisa de cuello pringoso, boca hedionda a peras podridas, piel morena, lustrosa de sebo. ${ }^{727}$

Aquí, vemos como el teniente es uno de los miembros que mantiene una actitud de desprecio con respecto al indio, al tiempo que es víctima del latifundista. Esto es uno de los aspectos principales de la crítica de Icaza, pues este personaje es el mecanismo usado por el latifundista para abusar del indio ecuatoriano.

Tras el fin de la narrativa de la generación de los treinta, se abre un periodo que, a primera vista, no pudo superarse con escritores como Alfredo Pareja Diezcanseco (1908-1993) y tampoco por el mismo Jorge Icaza con la publicación de su novela El chulla Romero y Flores (1958). ${ }^{728}$

Uno de los aspectos reflejados por la literatura ecuatoriana de estos años es el de la dictadura y la forma de crear conciencia sobre la necesidad de un país libre e independiente políticamente. A

\footnotetext{
${ }^{724}$ Ibíd. p. 161.

${ }^{725}$ Ibíd. p. 87.

${ }^{726}$ Ibíd. p. 87.

${ }^{727}$ Ibíd. p. 14.

${ }^{728}$ Escritor ecuatoriano, cuya narrativa se caracteriza por describir la historia y la evolución de la sociedad del Ecuador y por su vinculación con el realismo. Entre sus obras se encuentran El muelle (1933); Hombres sin tiempo (1941); Las tres ratas (1944); El aire y los recuerdos (1959) y Los poderes omnímodos (1964); Las pequeñas estaturas (1970) y Ensayos de ensayos (1981). Fuente: Alfredo Pareja DíezCanseco, en biografíasyvidas.com.
} 
través de la novela, los autores intentan reconocer el poder del pueblo, rechazando a las clases dominantes de la burguesía o élite militar, de ahí que estas obras se centren en temas relacionados con la libertad y el trabajo colectivo.

Alfredo Pareja Díezcanseco es uno de los autores que refleja el despotismo jerárquico que buscaba la unidad política con el apoyo de las clases dominantes. En sus obras, se refiere al Ecuador como un país atrasado, en el que la agricultura era la actividad dominante y estaba en manos de una clase oligárquica, la cual no era sino un obstáculo para establecer las bases políticas y económicas del país:

Recuerda el campo: trabajan los hombres desde las seis de la mañana en rudas faenas, comen mal, uno o dos platos, no saben leer, no saben nada, no perciben jornales sino en víveres con precios escandalosos que fija el patrón y siempre están debiendo al amo y heredan los hijos y los nietos las deudas, verdadera familia de esclavos. ; $Y$ dicen que no hay problema social en el Ecuador! ${ }^{729}$

Además, pone de manifiesto los problemas de inestabilidad social y política, y critica la facilidad con la que se podía acceder al poder y manipularlo según su parecer:

... en este país, cualquier gusano disuelve congresos y se hace jefe supremo, dictador, o Presidente Constitucional, rompiendo la Constitución, que así está hoy de desgraciada y ridícula nuestra patria, vergüenza y calamidad por obra de los canallas... ${ }^{730}$

El reconocimiento de estas obras es posterior a la división cultural de los sesenta, lo cual fue posible con el surgimiento de poetas e intelectuales procedentes de la sociología y la filosofía, que contribuyeron en términos de análisis y producción de poesía. Así, en Quito se publicaron algunas revistas como Letras del Ecuador de la Casa de la Cultura Ecuatoriana (Pucuna, La bufanda del sol, Indoamérica, Ágora, etc.), con que se expresaban los poetas del ya mencionado movimiento Tzántzico.

Este grupo utilizó la poesía para desafiar la cultura oficial, mientras intentaba provocar efectos políticos y culturales con sus recitales, de ahí la importancia que adquirió como forma de

\footnotetext{
${ }^{729}$ Alfredo Pareja Díezcanseco: Don Balón de Baba, Quito, Casa de la Cultura Ecuatoriana, 1960, p. 130.

${ }^{730}$ Ibíd. p 437.
} 
expresión pública. A este respecto, Alejandro Moreano considera que los recitales tzántzicos expresaban las ideas de los poetas de sumarse al pueblo en su lucha por encontrar la voz propia, libre, auténtica, total, en una sociedad también total y libre y que estaba caracterizada por un régimen tradicional basado en las haciendas: ${ }^{731}$

- Para mañana, ¡no!

- Hasta entonces nos habrán mutilado.

- ¡Tiene que ser ahora... ${ }^{732}$

En el año 1963, al mismo tiempo en que la dictadura militar tomaba el poder en el Ecuador, la revista Pucuna publicó “el duro arte de la reducción de cabezas" (Pucuna, N 3, Quito, de julio de 1963) como muestra del rechazo hacia una sociedad temorosa de los acontecimientos que tuvieron lugar con la Revolución Cubana.

La denominada "reducción de cabezas" implicaba la eliminación de la vieja generación y la apertura del mundo cultural local a los grandes debates que tenían lugar en otros países de América Latina, Europa y Estados Unidos. De esta forma, en 1965, Alejandro Moreano declaraba:

La necesidad histórica del movimiento en la degradación a la que se había sometido a la literatura, al haberla convertido en diversión refinada del señor feudal (los hacendados de la Sierra y sus descendientes) o para la pequeña burguesía, en un mecanismo de ascenso social y carrera política, oficio para ganarse una reputación. Se hizo, pues, necesaria la rebelión [y] acabar con la falacia de nuestros cancilleres-poetas, cónsulespintores, embajadores-prosistas. La actitud tzántzica era la impugnación absoluta de la concepción misma que sobre el arte tenía la vieja guardia literaria. ${ }^{733}$

Según Alejandro Moreano, la ruptura de los tzántzicos era parte de un proyecto político revolucionario y de una crítica a la cultura ecuatoriana. Así, la literatura debía de comprometerse

\footnotetext{
${ }^{731}$ Alejandro Moreano: Los presentes. Tzántzicos, en La bufanda del sol, № 2, Quito, agosto, 1965, p. 5-65.

732 Alfonso Murriagui, poeta tzántzico, VII-8-63, en Carlos Arcos Cabrera: La caja sin secreto: Dilemas y perspectivas de la literatura ecuatoriana contemporánea, Quorum, Revista de pensamiento iberoamericano, no. 14, primavera, Universidad de Alcalá, 2006, p. 187-210.

${ }^{733}$ Alejandro Moreano, op. cit. p. 5-65.
} 
con la revolución a partir de la aparición de los movimientos de izquierdas y su etapa de ascenso político. $^{734}$

En el proceso de fragmentación, llama la atención la crítica realizada a la novela indigenista y en particular, a Jorge Icaza. A este respecto, Agustín Cueva hace alusión a la compleja relación entre arte, literatura y mestizaje en su revista Indoamérica y parte de la idea de que el surgimiento de la novela indígena coincide históricamente con la llegada del capitalismo, formándose una totalidad social, ámbito propicio para que florezca la novela. ${ }^{735}$

No obstante, no se puede olvidar que el establecimiento del sistema capitalista ecuatoriano se produzco de forma parcial, al sobrevivir las formas pre-capitalistas en la hacienda y al no poderse eliminar la presencia de dos culturas (en particular en la Sierra).

En este marco, la división de clases del capitalismo se sobrepuso a la fragmentación cultural, hecho que tuvo una gran repercusión en la manera en que los individuos se percibían los unos a los otros: Los miembros del uno (de los grupos culturales) ven a los del otro como elementos poco diferentes entre sí. ${ }^{736}$ Esta situación de tipo cultural y de dominación eliminaba el concepto de individualidad y creaba un problema a la narrativa: el de la externalidad del narrador.

Para Cueva, este es el principal problema de la narrativa indigenista, lo cual explica la dificultad del escritor a la hora de captar la idea del mundo que tienen los personajes indios, ya que las palabras y las diferentes técnicas no son suficientes para describir los obstáculos construidos sobre la dominación cultural y el racismo. Esto justifica que la narrativa indigenista establezca los acontecimientos de la sociedad con la reconstrucción de voces (la de los indios) y conserve la distancia con respecto al grupo extraño.

Es una literatura que mira a los personajes autóctonos, es decir: que le es exterior. En ellos, más que encontrar otro yo actual, el relatista intuye un alter ego potencial. No es una literatura comprensiva, sino una literatura explicativa... no ha querido comprender

\footnotetext{
${ }^{734}$ Ibíd. p. 5-65.

735 Agustín Cueva: Reflexiones sobre la novela indigenista, Indoamérica, año I, No 2, marzo abril, Quito, Ecuador, 1965, p. 121-122.

${ }^{736}$ Ibíd. p. 121.
} 
al patrón ni ponerse en el lugar del peón indio, sino explicar sus mutuas relaciones... Es más que nada una literatura de acción. ${ }^{737}$

Volviendo al tema de la hacienda, Rafael Barahona indica que esta clasificación muestra una relación estrecha que existía entre las posibilidades de desarrollo del movimiento campesino, así como la actitud de las clases propietarias. Por consiguiente, frente a las clases propietarias ausentistas o que mantenían sistemas de producción basados en el empleo de gran cantidad de fuerza de trabajo, el camino "campesino" no solo podía encontrar una línea de resistencia inferior en la propia unidad productiva, sino también a nivel de la sociedad. ${ }^{738}$

En cambio, el proceso adquiría rasgos diferentes si se producía una actitud moderna, pues los terratenientes eran los que realizaban el proceso de cambio. Esto se debía a que las relaciones sociales existentes, que durante un periodo considerable habían sido el eje de la obtención de excedentes, habían pasado a ser un obstáculo en una etapa más reciente, particularmente en las haciendas denominadas modernas emergentes, aunque también se han de considerar otros elementos responsables del cambio como la presión social, la política y la ideología. ${ }^{739}$

Barsky y Cosse (ver tabla 11: Tipos de haciendas y procesos en la Sierra ecuatoriana Baharona, Barsky y Cosse-) plantearon la necesidad de distinguir dentro de lo que Barahona llama haciendas modernas emergentes, dos tipos de unidades: por una parte, aquellas que poseían un sostenido proceso de acumulación en la explotación (utilizaban tecnología punta) en relación a las condiciones nacionales, y por otra, las haciendas que ya habían acabado con las relaciones no capitalistas de producción, reemplazándolas por relaciones salariales (y su posterior conversión a la ganadería lechera), pero que contaban con un proceso de inversión de capital menos significativo. ${ }^{740}$

Este último tipo de explotación tuvo lugar mayoritariamente en la Sierra y se desarrolló atendiendo al modelo de haciendas tradicionales corrientes y de las haciendas infra. La viabilidad

\footnotetext{
${ }^{737}$ Ibíd. p. 121.

${ }^{738}$ Rafael Barahona, Una tipología de haciendas..., op. cit. p. 688-696.

${ }^{739}$ Ibíd. p. 688-696.

740 Esta tabla se encuentra en el apéndice de datos del capítulo 3. Fuente: Osvaldo Barsky, Gustavo Cosse: Tecnología y Cambio Social..., op. cit. p. 40-75.
} 
de este modelo es fundamental, ya que nos ayudará a comprender cómo el proceso de transición analizado no se limitó a una reducida fracción de las haciendas, sino que abarcó una parte importante de las mismas.

El informe CIDA establece también una recapitulación de los rasgos fundamentales de los sistemas de tenencia y pone de relieve la existencia de una mayor diversidad en la Costa con respecto a la Sierra como consecuencia de los procesos históricos de ocupación de las tierras. ${ }^{741}$ Por tanto, ¿cuáles fueron las principales diferencias entre el sistema de tenencia en la Sierra y en la Costa en este periodo?

Al margen de la naturaleza de los recursos agrícolas, la Costa parecía carecer de un proceso único de ocupación de la tierra, con caracteres institucionales e históricos homogéneos (de forma contraria a lo que ocurría en la Sierra). Aquí, el proceso se refiere a las sucesivas fronteras agrícolas, de las cuales, las más antiguas tenían rasgos tradicionales, y que estaban ausentes casi por completo en áreas de ocupación posteriores. También, se observa que el rasgo común se localiza en los incentivos, es decir, el impacto del mercado, particularmente del externo, el cual ejerció una gran influencia en el establecimiento de situaciones distintas de las existentes en la Sierra. En este caso, ¿cuáles son los criterios utilizados a la hora de establecer una clasificación de los sistemas de tenencia de la Costa ecuatoriana?

Para aclarar esta pregunta y establecer un criterio que permita distinguir entre los diversos sistemas de tenencia en la región costeña, se ha de partir del análisis de los movimientos de ocupación en distintas zonas y del efecto de la demanda exterior. En el pasado, la combinación de estas circunstancias ha permitido la creación y alteración de los sistemas de tenencia y de las características de los distintos grupos de personas vinculadas a ellos.

De este modo, mientras que en la Sierra las modalidades de cultivo y crianza permanecieron iguales (con algunas excepciones como el caso del desarrollo de la ganadería), la Costa, recibió el impacto de la demanda externa que provocó cambios en la producción y generó nuevas situaciones de tenencia, además de modificar las instituciones existentes. ${ }^{742}$

\footnotetext{
${ }^{741}$ Comité Interamericano de Desarrollo Agrícola, Tenencia de la tierra..., op. cit. p. 40-150.

${ }^{742}$ Ibíd. p. 40-150.
} 


\subsubsection{3) La clase terrateniente y las modificaciones de la agricultura ecuatoriana.}

Hasta el momento, hemos hablado de las relaciones precarias en el agro ecuatoriano y del interés mostrado por una fracción de terratenientes en cuanto a la abolición del huasipungo, así como de los intentos de los diferentes gobiernos de finales de los cincuenta y principios de los sesenta para llevar a cabo una reforma agraria. Este proceso de diferenciación social, que tuvo lugar dentro de la clase terrateniente y que comenzó a partir de 1959 con las entregas voluntarias de los huasipungos y la eliminación de las relaciones pre-capitalistas en el campo, adquirió una gran importancia en esta época, al surgir una nueva categoría de hacendados modernistas que pretendía impulsar un proyecto global de reformas agrícolas.

En consecuencia, ¿cuál fue el origen de las transformaciones de la estructura social agraria serrana en esta época? ¿cuáles fueron las razones para que dicha fracción de terratenientes quisiera impulsar la reforma agraria?

Las investigaciones relacionadas con los cambios que el agro serrano experimentó, demuestran que fue la iniciativa terrateniente el factor inicial a partir del cual, comienza en 1959, el proceso de transformación aludido, a través del paso a la ganadería y a las relaciones salariales.

A este respecto, el aumento de la demanda de la leche y sus derivados fue el responsable de crear un conjunto de posibilidades para los sectores agrarios más avanzados, dándose las condiciones de mercado necesarias para estimular la diferenciación de una serie de unidades que comenzaron una rápida transformación en empresas agropecuarias. Este tipo de desarrollo capitalista fue parte de su propia dinámica, al constituir una forma concreta donde el capital penetró en la agricultura, permitiendo a su vez, la existencia de un grupo social interesado en ciertas líneas de producción y zonas aptas. ${ }^{743}$

Dicho fenómeno ocurrió ante todo en las haciendas serranas, en las que la eliminación de las relaciones precarias se manifestó mediante la supresión del huasipungo, el aumento del poder de la fracción terrateniente y con la participación directa de sus representantes en la elaboración de los proyectos de Reforma Agraria. ${ }^{744}$

\footnotetext{
${ }^{743}$ Osvaldo Barsky, Gustavo Cosse, op. cit. p. 49-60.

${ }^{744}$ Jose Luis Ortíz, op. cit. p. 56-60.
} 
Por consiguiente, el estudio del papel de los sectores modernizantes dentro de las clases rurales altas de la Sierra será fundamental para poder comprender las medidas estatales del agro, la importancia de estas estrategias en el contenido de las leyes y los procesos que tendrán lugar con la Ley de Reforma Agraria de $1964 .^{745}$

En este sentido, vamos a centrarnos en el proceso de diferenciación de los terratenientes serranos realizado por Miguel Murmis, José Bengoa y Osvaldo Barsky, en el que parten de su comportamiento a nivel de las unidades productivas, sus organismos corporativos y de sus expresiones políticas e ideológicas, a la vez que establecen una clasificación, en la que se especifica el término "fracción" para explicar las actitudes frente a los procesos de cambios planteados (liquidación de relaciones precarias y reformas agrarias). ${ }^{746}$

En primer lugar, se puede hablar de la fracción que llevó a cabo importantes inversiones en tecnología y mecanización avanzada, teniendo como soporte la producción lechera, al ser el elemento fundamental de su ingreso. Galo Plaza fue el representante más destacado de este sector, siendo los objetivos de su proyecto la liquidación de las relaciones precarias, la colonización agraria y la industrialización del país para absorber el excedente demográfico procedente de la Sierra.

En Galo Plaza, vemos un tipo de proyecto de los sectores terratenientes más avanzados. El proyecto, inspirado en la experiencia cubana y planteado por diversos grupos locales, ponía como centro la división del latifundio y su entrega a los campesinos. El que aparecía a través de la Alianza del Progreso, establecía una estrategia de reforma agraria en función de la relación establecida entre tenencia de la tierra y desarrollo. ${ }^{747}$

Al considerar el desarrollo como el avance de una economía más capitalista, la reforma agraria era interpretada como un mecanismo para aumentar la productividad agrícola, distribuir los ingresos, ampliar el mercado interno y liquidar las formas más atrasadas con el propósito de producir cambios sociales en el agro y evitar situaciones que hicieran peligrar la estabilidad del sistema en su conjunto.

\footnotetext{
${ }^{745}$ Andrés Guerrero, Haciendas capital..., op. cit. p. 51-80.

${ }^{746}$ Miguel Murmis, José Bengoa, Osvaldo Barsky, op. cit. p. 93-98.

${ }^{747}$ Osvaldo Barsky, La reforma..., op. cit. p.61.
} 
No en vano, si bien el proyecto de esta fracción planeaba repartir los huasipungos entre los campesinos (para lo que se elaboró cuidadosamente un proyecto de transformación), el mismo Plaza sabía que esta estrategia de entrega no iba a ser suficiente. Al ser eliminadas las relaciones con la hacienda, un conjunto de elementos que la hacienda proporcionaba a los huasipungueros (leña, pastoreo de animales, etc.) fueron suspendidos, por lo que aquellos campesinos minifundistas que no tenían ingresos extra quedaban en numerosas ocasiones por debajo del nivel de subsistencia. Esta situación explica la existencia de diversas propuestas destinadas a complementar los ingresos de los campesinos, y se articularan medidas para ayudar a los trabajadores y poder cumplir con las exigencias del proceso productivo. ${ }^{748}$

En todo caso, la ruptura de las relaciones precarias no podía esconder a los trabajadores la pérdida de una serie de beneficios que antes podían obtener, tal y como muestra el informe de la CIDA:

El cambio generado con la entrega de los huasipungos significa que los exhuasipungueros devienen en minifundistas con títulos de propiedad; o sea que están lejos de constituirse en productores agrícolas independientes. ${ }^{749}$

De esta forma, al permanecer como mano de obra disponible, volvía a ponerse de manifiesto su subordinación a la empresa patronal pero esta nueva relación era diferente, pues los trabajadores debían de incorporarse al mercado laboral, mientras que el patrón contrataba únicamente la fuerza laboral que necesitaba.

En definitiva, bien puede decirse que la medida de adjudicar los huasipungos tiene un valor dual; permite al patrón absorber solamente la mano de obra que necesita, y comporta una reducción en el monto de capital invertido en contratar mano de obra que podrá ser destinado a las inversiones que más convengan a la explotación. ${ }^{750}$

También, Jose Luis Ortíz afirma que la iniciativa terrateniente se tradujo en un conjunto de factores incidentes en el tamaño de las unidades productivas y en la forma de uso de la mano de

\footnotetext{
${ }^{748}$ Miguel Murmis, José Bengoa, Osvaldo Barsky, op. cit., p. 93-98.

${ }^{749}$ Comité Interamericano de Desarrollo Agrícola, op., cit. p. 451.

750 Ibíd. p. 451.
} 
obra. Es decir, se observa la disminución de la mano de obra como consecuencia de las inversiones modernizantes que favorecían el incremento del capital. ${ }^{751}$

En cuanto a la estrategia de desarrollo de la producción de los Plaza, se ha de mencionar el impulso de la ganadería ovina para la producción de lana y la ganadería bovina para la producción de leche.

La existencia de amplias extensiones en la serranía ecuatoriana, que por motivos ecológicos (como la altura) eran adecuadas para ciertas producciones, impulsó el desarrollo de una destacada ganadería bovina en el Ecuador, ya que tanto los hacendados como los campesinos poseían en estas áreas importantes rebaños.

Para mejorar la calidad de la lana, la familia Plaza impulsó la creación de la Asociación Nacional de Criadores de Ovejas (ANCO), presidida durante varios años por Galo Plaza. ${ }^{752}$ La labor de ANCO se centraba en la importación de animales de pedigrí para obtener lana superior a la producida por el ganado criollo dominante en la Sierra, para lo que se usaron mecanismos de financiación internacional y nacional.

En el desarrollo de la ganadería lechera, el elemento distintivo de la fracción terrateniente modernizante fue el cruce y la mejora constante de ganado criollo con ejemplares Holstein Friesian: ${ }^{753}$

Consciente de las buenas aptitudes ecológicas de los valles del callejón interandino, y frente a un mercado nacional en expansión con un déficit permanente de leche que obligaba a su importación, Plaza perfiló las perspectivas del desarrollo lechero en 1959.,"754

\footnotetext{
${ }^{751}$ Jose Luis Ortíz, op. cit.p. 56-60.

${ }^{752}$ Ver el apéndice de notas del capítulo 3 para más información. Fuente: Oswaldo Barsky, La reforma agraria..., op. cit., p. 100.

${ }^{753}$ Dentro del grupo de vacas de raza Holstein-Friesian, caracterizadas por la producción de altos niveles de leche, se pueden distinguir las norteamericanas, con una alta capacidad de acomodación a un sistema en establo y elevados requerimientos nutritivos, y las neozelandesas, cuyos niveles de producción son menores y están mejor adaptadas a un sistema bajo en bienes, dependiendo su alimentación de pastos y forrajes verdes. Fuente: B. Horan, J.F. Mee, M. Rath, P. O'Connor, P. Dillon: The effect of strain of Holstein-Friesian cow and feed system on reproductive performance in seasonal-calving milk production systems, Animal Science 79, 2004, p. 453-468.

${ }^{754}$ Miguel Murmis, Jose Bengoa, Osvaldo Barsky, op. cit. p. 117.
} 
Esta iniciativa llevaba a cabo por Plaza comprendió dos niveles principales. El primero de ellos, fue el de garantizar la importación de ganado Holstein con la ayuda del estado y mediante su puesto como presidente del Banco de Fomento. El otro aspecto importante de su labor fue la difusión de diferentes componentes tecnológicos relacionados con la mejora del ganado lechero, utilizando para ello, sus haciendas como modelo de desarrollo tecnológico.

Este proceso de cambio en las haciendas de la zona central de la Sierra ecuatoriana permitió que los hacendados se convirtieran en el sector más consolidado dentro de los terratenientes serranos, en el que los Plaza lograron situarse en el eje de un proceso re-articulador en el agro de la Sierra, siendo la leche el producto principal. ${ }^{755}$

La segunda fracción, representada por Emilio Bonifaz, estaba compuesta de haciendas que también habían desarrollado su paso a la producción lechera, pero poseían un bajo nivel de inversiones en cuanto a mejora genética y mecanización.

A diferencia de Plaza, Bonifaz expresó de forma más clara los intereses de un conjunto de terratenientes, quienes sabían que su conversión a la nueva situación social era un proceso de gran riesgo con el que se establecían relaciones de subordinación a las otras fracciones propietarias de capital. De esta manera, consideraba que la modernización subordinada implicaba la pérdida de poder, pues el aparato gubernamental nacional asumía un destacado papel en el control del agro.

Estos elementos llevaron a la elaboración de un conjunto de argumentos de tipo defensivo, tendentes a evitar medidas estatales en contra de la fracción terrateniente representante. Para ello, se valió de la desigualdad en la distribución de la tierra en la Sierra, al intentar demostrar que las medidas de redistribución no solo no alterarían la situación, sino que también provocarían graves daños, pues se pensaba que la causa de la pobreza y de la erosión tenía su origen en la gran presión de los minifundistas sobre la tierra. ${ }^{756}$

Pese a esto, Murmis, Bengoa y Barsky consideran que las acciones llevadas a cabo por dicha fracción constituían el modelo oportuno a seguir, ya que el proceso de entrega anticipada de huasipungos en 1959, pudo haber sido consecuencia de la reducción de los precaristas existentes en ellas (en comparación con los Plaza, que lo hicieron en 1962). Así, estas entregas ponían de

\footnotetext{
${ }^{755}$ Ibíd. p. 117.

${ }^{756}$ Ibíd. p. 117.
} 
manifiesto el creciente número de hacendados que comenzaron a adoptar una estrategia similar, al poder reestructurar las haciendas sin tener que invertir una fuerte suma de capital, al tiempo que se iban eliminando las relaciones precarias, pues no afectaban la supervivencia de la hacienda de una forma decisiva. ${ }^{757}$

Por otro lado, estos autores recalcan que los planteamientos de Bonifaz eran similares a los de Plaza a la hora de hacer frente a las reivindicaciones de los campesinos y poder evitar la fragmentación del eje social que configuraba dicha estructura. No obstante, pese a que sus propuestas (sobre todo en cuanto al reparto de fertilizante gratuito a los indígenas) pretendían elevar el nivel de vida de los campesinos para evitar peligrosas presiones sobre las tierras, su planteamiento de abolición de los huasipungos impedía el uso de elementos (tierras, aguas, pastos y leña) como ocurría con las otras propuestas de los terratenientes.

La tercera fracción, mayoritaria a nivel de la Cámara de Agricultura de la Primera Zona hasta 1964, estaba expresada en los planteamientos de su presidente Marco Tulio González, a través de diferentes situaciones. ${ }^{758}$ Por un lado, estaban los hacendados que habían iniciado un camino similar al de Bonifaz, mientras que por otro, existía un grupo que estaba a la espera de organizar los cambios planteados, así como aquellos propietarios de unidades con problemas de tipo ecológico para realizar cambios rápidos de sus estrategias productivas. Así, para este grupo, la limitación en el tamaño de las haciendas podía poner en peligro la cantidad de excedentes que venía obteniendo, pero coincidía con las fracciones anteriores en cuanto a la eliminación de las relaciones precarias. ${ }^{759}$

En último lugar, se encontraba un conjunto de terratenientes, cuya estrategia productiva consistía en el uso intensivo de mano de obra precaria y en el desarrollo de la agricultura como dominante, a la vez que rechazaba cualquier cambio en el agro que pudiera afectar las relaciones precapitalistas o restringir el tamaño de sus propiedades. Esta fracción estaba formada por los

\footnotetext{
${ }^{757}$ Ibid. p. 117-119.

758 Marco Tulio González fue Ministro de Educación Pública durante la segunda presidencia de Velasco Ibarra (1944-1947). Fuente: Juan J. Paz, Miño Cepeda: La economía en el gobierno de José María Velasco Ibarra, Taller de Historia Económica, Facultad de Economía, PUCE, boletín electrónico, Quito, número 1, Año VII, 2005.

${ }^{759}$ Miguel Murmis, Jose Bengoa, Osvaldo Barsky, op. cit. p. 98.
} 
organismos de la zona sur de la Sierra y su posición era minoritaria dentro de los del centro y norte. $^{760}$

Otra clasificación realizada por Carlos Marchán y Carlos Arcos, plantea la existencia de dos fracciones en el estudio de los hacendados serranos: una progresista y otra arcaica. ${ }^{761}$ Dicha diferenciación fue retomada posteriormente por Osvaldo Barsky, al manifestar que la división entre terratenientes tenía su origen en la ampliación del mercado interno después de la llegada del ferrocarril a principios del siglo, pues fue entonces, cuando una fracción modernizante de los hacendados serranos comenzó a transformar las relaciones de trabajo. ${ }^{762}$ El mayor interés comercial de la Sierra llevó a la transformación de las tierras agrícolas en pastizales y de su uso para la explotación ganadera, por lo que aún cuando dichas explotaciones requerían una considerable inversión de ganado, la utilización de mano de obra era escasa, lo cual manifestaba la baja rentabilidad del huasipungo.

A partir de estas ideas, Barsky define a la fracción progresista como un grupo caracterizado por su racionalidad económica empresarial, que promovía relaciones de trabajo salariales en la unidad productiva y ejercía un control directo de la propiedad. Esta fracción, propietaria de haciendas ganaderas, con un alto nivel de inversión y escasa fuerza de trabajo, fue capaz de hacerse con la representación de la clase hacendera serrana mediante la Cámara de Agricultura, impulsando un proyecto de desarrollo capitalista de modernización del agro serrano que pasaría a convertirse en la Ley de Reforma Agraria de $1964 .{ }^{763}$ En cambio, en la fracción tradicional, con sus relaciones de trabajo precarias en las haciendas, el estado sería el responsable de obligar a modernizar sus unidades productivas, al carecer de un proyecto de desarrollo capitalista.

Asimismo, Barsky apunta a la especialización de las haciendas en la rama ganadera lechera en determinados valles (Machachi, Cayambe y algunos más), ya que recibían la influencia del mercado urbano de Quito, el cual era uno de los factores responsables del proceso de diferenciación entre terratenientes, además de originar dicha fracción modernizante.

\footnotetext{
${ }^{760}$ Washington Macías, Problemas socio-económicos del Ecuador, primera edición, Ecuatextos, Ecuador, 1983, p.115-220.

${ }^{761}$ Carlos Arcos, Carlos Marchán: Apuntes para una discusión sobre los cambios en la estructura serrana, Pontificia Universidad Católica del Ecuador, 1976, p. 54.

762 Osvaldo Barsky: Iniciativa terrateniente en la reestructuración de las relaciones sociales en la Sierra ecuatoriana: 1959-1964, Revista de Ciencias Sociales, Vol. II, número 5, 1978, p. 117.

${ }^{763}$ Ibíd., p. 91-123.
} 
Miguel Murmis recoge las conclusiones de Barsky e indica que el caso de la Sierra ecuatoriana constituye un proceso de carácter único en América Latina, en el que la diferenciación social dentro de la antigua clase terrateniente tenía lugar por determinaciones de origen interno al proceso productivo, pues la formación de un grupo de terratenientes modernizadores podía conducir a la modificación de las estructuras agrarias en un sentido capitalista. ${ }^{764}$

De esta forma, Murmis pretende acabar con el esquema a partir del cual, los terratenientes tradicionales eran considerados como una clase social incapaz de modernizarse. Además, la iniciativa de dicho sector modernizante implicaba el término de las relaciones de producción precapitalistas dentro de las haciendas, la formulación de algunos proyectos y leyes de reforma agraria y el arrastre del resto de fracciones de la clase terrateniente a un proceso de cambio. ${ }^{765}$

El planteamiento de Barsky y Murmis estaba basado en la expansión del mercado de productos lácteos, fundamentalmente en Quito, ya que los cambios tecnológicos del proceso productivo en algunas haciendas habían provocado una especialización de las mismas en dicha rama de producción, abandonándose así, el sistema tradicional de una variedad de cultivos agrícolas combinados y que modificaban la racionalidad económica de la acumulación de estas haciendas. En este caso, el mantenimiento de la forma de trabajo huasipunguero era incompatible con la modernización, siendo necesario el cambio a las relaciones salariales con las que se sustituían a los huasipungueros por peones. ${ }^{766}$

En segundo lugar, la clase terrateniente entró en un proceso de diferenciación social, ya que los cambios tecnológicos y las relaciones de producción en las haciendas permitieron modificar la naturaleza de dicha clase terrateniente, apareciendo de esta manera, una fracción terrateniente capitalista. Así, el grupo modernizante de terratenientes se originó como una fracción de clase que elaboraba sus proyectos económicos, políticos e ideológicos de disolución de la forma del huasipungo, a la vez que intentaba incluir a la clase de hacendados en el proyecto modernizante, impulsándola a nivel estatal. ${ }^{767}$

\footnotetext{
${ }^{764}$ Miguel Murmis: Sobre la emergencia de una burguesía terrateniente capitalista en la Sierra ecuatoriana como condicionamiento de la acción estatal, en Revista de Ciencias Sociales, Volumen II, número 5, Quito, 1978, p. 5-55. 
La transformación de la estructura agraria serrana de los años sesenta tiene sus raíces en factores de tipo económico como es el caso de la expansión del mercado lechero, el cambio tecnológico, la especialización de las haciendas en una rama de producción y el nuevo interés económico de los terratenientes.

Barsky y Murmis coinciden en que el impulso inicial se produjo en el marco político, por lo que en el momento en que se produjeron manifestaciones campesinas, estos adoptaron una forma funcional a la iniciativa de la fracción modernizante a consecuencia del carácter reformista de las organizaciones políticas que lo motivaban. De este modo, los estudios de Barsky muestran la tendencia a especializarse en la leche en algunas haciendas situadas en algunos valles cercanos a Quito. $^{768}$

No en vano, Murmis vuelve a referirse al punto central de Barsky en un estudio posterior, mediante el cual los terratenientes llegaron a plantearse la reorganización de la hacienda según sus propios intereses económicos, sin tener en cuenta la presión ejercida por el estado o los campesinos. ${ }^{769}$ Esta iniciativa es mostrada por Barsky con la propuesta de una ley de reforma agraria, las discusiones posteriores a raíz del proceso de entrega anticipada del huasipungo, y con el análisis de las ideas de figuras importantes entre los hacendados. ${ }^{770}$

En este sentido, se ha de considerar la influencia del estímulo en los hacendados, las relaciones de producción resultantes de esa iniciativa y hasta qué punto esta propuesta supuso una ampliación de la producción y un desarrollo de las fuerzas productivas.

Murmis señala que el vínculo entre estos tres aspectos no es obvio, ya que la existencia de la iniciativa terrateniente no tenía que implicar una alteración de las relaciones de producción en el sentido de desarrollo del capitalismo, ni tampoco de la tecnificación y expansión de las fuerzas productivas. Así, una respuesta terrateniente podría haber sido el endurecimiento de las medidas feudales o un alejamiento de las actividades empresariales. ${ }^{771}$

En relación a la iniciativa terrateniente, cabe señalar el papel fundamental de las oportunidades de mercado, las cuales estaban ligadas a la urbanización de Quito y a la expansión de las capas medias. Barsky muestra que tal iniciativa se encontraba en los grupos que controlaban el proceso

\footnotetext{
${ }^{768}$ Osvaldo Barsky, Iniciativa terrateniente..., op. cit. p. 91-123.

${ }^{769}$ Miguel Murmis, El agro serrano..., op. cit. p. 10-25.

${ }^{770}$ Osvaldo Barsky, Iniciativa terrateniente..., op. cit., p. 91-123.

${ }^{771}$ Miguel Murmis, El agro serrano..., op. cit. p. 10-25.
} 
de producción agropecuaria, frente a los casos en que el impulso del mercado estaba en los grupos capitalistas más cercanos a este. La iniciativa de los que tenían el control de esos enlaces, como la comercialización o el procesamiento, podía hacer menos obvia la actuación de los terratenientes que no estuvieran involucrados en el cambio. Además, desde el momento en que esos otros sectores fuesen empresas capitalistas con altas concentraciones de capital, el carácter de la formación tendría un menor alcance. En este caso, en lugar de tratarse de una respuesta de empresas no organizadas sobre la base de relaciones de producción capitalistas, nos encontraríamos frente a una respuesta elaborada por eslabones capitalistas en el marco de dicha mercancía. Pese a esto, Barsky insiste en que los terratenientes llevaron su iniciativa hasta la organización de eslabones intermedios. ${ }^{772}$

Aquí, se ha de considerar que el procesamiento de la leche necesitaba de capitales relativamente pequeños, a la vez que permitía eslabonamientos hacia adelante a partir de los empresarios agrícolas. ${ }^{773}$ Con respecto a esto, el dinamismo empresario de los terratenientes ha sido afirmado por Barsky, al exponer a su vez, en qué medida el proceso puede entenderse como el resultado de la presión ejercida por parte del estado o del movimiento campesino. ${ }^{774}$

Por su parte, Andrés Guerrero rechaza la idea de la existencia de varias fracciones dentro de los terratenientes y explica que los hacendados estaban constituidos en un "bloque monopólico", en el cual, la figura del hacendado tenía dos lados económicos: el terrateniente, representante de las relaciones de producción extra-económicas, y el capitalista, exponente de relaciones de producción salariales. ${ }^{775}$ Además, sostiene que en la producción se imponía la figura terrateniente, dejando a un lado la idea de que la clase terrateniente serrana fuese capaz de realizar un proyecto de desarrollo económico capitalista o de modernización de sus unidades productivas.

\footnotetext{
${ }^{772}$ Osvaldo Barsky, Iniciativa terrateniente..., op. cit. p. 90-123.

${ }^{773}$ Para más información sobre los eslabonamientos, ver el apéndice de notas del capítulo 3. Fuente: A. Hirschman: Enfoque generalizado del desarrollo por medio de enlaces, con referencia especial a los productos básicos, en El Trimestre económico, número 173, México, enero-marzo, 1977.

${ }^{774}$ Osvaldo Barsky, Iniciativa terrateniente..., op. cit. p. 90-123.

${ }^{775}$ Andrés Guerrero, La hacienda pre-capitalista..., op. cit. p. 47-72.
} 
Esto justifica que solo se considerara al estado como el responsable de la eliminación de las formas de tenencia de la tierra tradicionales y promotor de las relaciones de trabajo salariales. ${ }^{776}$ Este conjunto de ideas analizadas hasta el momento, nos permite apreciar las diferencias entre los planteamientos de Guerrero y los de Murmis y Barsky, ya que estos últimos reconocen un grupo de hacendados modernizantes que apoyaba un modelo de desarrollo capitalista del agro, así como la existencia de un grupo de propietarios tradicionales que no tenía un plan de capitalización de sus unidades productivas, y que constituían un obstáculo para el desarrollo capitalista.

Carlos Marchán retoma estos planteamientos y establece que ambos núcleos de la fracción terrateniente poseían un proyecto de desarrollo capitalista, pero estos eran diferentes debido a las variadas condiciones de producción. En el caso del núcleo modernizante, el desarrollo del agro era incompatible con la presencia de formas de trabajo precario, mientras que para el grupo tradicional, el huasipungo se adaptaba a una racionalidad capitalista para maximizar los beneficios y minimizar el coste de producción. ${ }^{777}$

Además, explica que al imponerse el proyecto del grupo ganadero, la decisión del estado en el establecimiento de la reforma agraria a nivel nacional, supuso para el núcleo modernizante la creación de una política agrícola coherente, mientras que para la fracción tradicional, dicho proceso suponía una política agraria irracional. Es decir, se pretendía imponer por la fuerza de la ley un proyecto capitalista de relaciones de trabajo asalariadas, en contra de la lógica económica de estas haciendas, que únicamente querían maximizar sus ganancias y que afirmaban que los cambios no tenían lugar mediante la creación de normas jurídicas, sino por el desarrollo económico. La respuesta a la reforma agraria por parte del núcleo tradicional acabó con la venta de una gran parte de sus tierras y con el traslado de capitales hacia otros sectores de la economía. $^{778}$

Andrés Guerrero muestra la existencia de una serie de dificultades en la consideración de las fracciones modernistas como el motor de las transformaciones agrarias en cuestión. Así, en el

\footnotetext{
${ }^{776}$ Andrés Guerrero: Renta diferencial y vías de disolución de la hacienda pre-capitalista en el Ecuador, Revista de Ciencias Sociales, Vol. II, número 5, 1978, p. 52.

777 Carlos Marchán Romero: El panorama agrario de la Sierra centro-norte 1550-1982, III Economía / Ecuador: 1830-1980, primera parte, Libro del Sesquicentenario, Corporación Editora Nacional, 1983, p. 201-207.

${ }^{778}$ Ibíd. p. 201-207
} 
plano económico, la idea de que estas fracciones aparecen gracias a la especialización de sus haciendas en la rama lechera mediante las oportunidades ofrecidas por el mercado, la introducción de cambios tecnológicos y el abandono de las relaciones de producción huasipungueras, deja sin explicación varios aspectos complejos que, según Guerrero, han de ser analizados. ${ }^{779}$

Por un lado, el impulso del mercado, la incorporación de nuevas tecnologías y la especialización productiva en la rama lechera, no tenían por qué repercutir de forma directa en las relaciones sociales, ni tampoco llevar a la abolición del huasipungo. En este caso, podían presentarse varias alternativas, cuyos parámetros consistían en el mantenimiento de las relaciones sociales sin grandes modificaciones, y también, en el paso del trabajo asalariado y la entrega de los huasipungos. Estas variantes, a las que Guerrero denomina como "situaciones de transición desigual", no han de conducir necesariamente a la implantación de relaciones capitalistas en las haciendas, pues son situaciones de transición que se establecen según el tipo de hacienda y suelen minimizar los conflictos.

Desde el punto de vista del terrateniente, la estabilidad partía de la explotación de las familias ligadas a la hacienda, mientras que para la comunidad huasipungo, esto significaba el mantenimiento de sus estructuras de reproducción y vida social, de ahí que esta forma lograra sobrevivir dentro del capitalismo ecuatoriano durante este periodo. Por otro lado, en determinados casos, en una misma hacienda se alternaba la modernización y especialización parcial en la rama lechera en algunas partes, mientras que otras seguían dedicadas a los cultivos de cereales o tubérculos con formas de trabajo tradicionales, es decir, en una misma hacienda había situaciones de transición desiguales, según los pisos andinos (piso alto y piso bajo). ${ }^{780}$ Por último, en relación a la estructura de los grandes terratenientes, estos estaban conformados en torno a organismos familiares de una manera más o menos vinculada. Los rasgos interiores de esta clase se basaban en el parentesco, al tiempo que existían lazos comunes a la existencia de

\footnotetext{
${ }^{779}$ Andrés Guerrero, La hacienda precapitalista..., op. cit.p. 47-72.

${ }^{780}$ Para más información de los pisos altos y bajos, ver el apéndice de notas del capítulo 3. Fuente: CONDESAN Problemática en zonas ganaderas alto andinas, en Instrumentación de políticas con influencia en la ganadería y la pobreza en zonas alto andina en Perú, Ecuador y Bolivia. Análisis de las condiciones en Ecuador, Pablo López Buitrón, apéndice I del Informe final del proyecto Andean Hub of the pro-poor livestock policy initiative, PR number 24333, 23 de febrero 2003, p. 2-3.
} 
una clase social (identificación interna y barrera de diferenciación frente a otras clases, percepción del mundo basada en elementos comunes, etc.).

Quizás, el aspecto más interesante de este tipo de formación social puede ser el hecho de que los vínculos de parentesco funcionaban como normas de unión de clase, existiendo una estrecha relación con la estructuración en grupos familiares. Un aspecto relacionado con este último, es el de la multipropiedad, no sólo porque la estructuración familiar intervenía directamente en la transmisión hereditaria de las propiedades, sino porque consolidaba el hecho de que la clase se agrupaba en torno a la familia y controlaba las unidades productivas. ${ }^{781}$

\subsubsection{4) Las haciendas lecheras en el Ecuador en los sesenta.}

Ya hemos visto cómo las características del proceso de desarrollo de la economía ecuatoriana y los diferentes momentos en los que tuvo lugar la acumulación de capital, fueron factores que repercutieron en el mercado nacional de la demanda de alimentos hasta la década de los sesenta. En este contexto, la discusión de la reforma agraria y sus diferentes propuestas abrieron el camino para llevar a cabo una vía alternativa de desarrollo que reformara las grandes haciendas, permitiendo una integración más rápida en el proceso de capitalización y una acelerada modernización de las unidades productivas tradicionales mediante el paso de la agricultura a la ganadería. Así, los periodos de expansión de la producción lechera comenzaron a adquirir gran importancia, sobre todo a partir de las acciones desempeñadas por la fracción modernizante para establecer una reforma agraria que impulsara dicho sector.

Teniendo en cuenta estas ideas, vamos a analizar ahora el cambio de la actividad agrícola a ganadera, el desarrollo de las fuerzas productivas en las haciendas lecheras del Ecuador anterior a la Reforma Agraria de 1964 y el principio del proceso de modernización del agro serrano a través de la estrategia elaborada por el sector moderno de terratenientes.

Al hilo de la idea planteada, al analizar la historia ganadera del Ecuador, es importante ubicar sus orígenes en el siglo XVI, momento en el que las haciendas comenzaron a especializarse en la crianza del ganado ovino, debido a la necesidad de materia prima para los obrajes, y en animales de transporte y carga que permitían el desplazamiento por los caminos de herradura. Si bien esta

\footnotetext{
${ }^{781}$ Andrés Guerrero, La hacienda precapitalista...op. cit. p. 47-72.
} 
actividad vinculada a la producción agrícola era predominante, la producción de ganado bovino de carne o leche se encontraba en un segundo plano. ${ }^{782}$

Posteriormente, la crisis de los textiles a finales del siglo XVII y principios del XVIII y la disminución de la demanda de la lana, provocaron un desplazamiento hacia las actividades agrícolas. Esta etapa coincide con la gran importancia adquirida por las haciendas tradicionales, pues la gran mayoría de sus actividades de carácter agrícola estaba organizada sobre la base del control de las tierras, que como ya sabemos, poseían un bajo nivel de mecanización y por el uso de una gran cantidad de mano de obra. ${ }^{783}$

En este contexto, Osvaldo Barsky y Gustavo Cosse explican que la producción lechera era una actividad secundaria en la mayoría de las haciendas, pues la demanda existente se correspondía con un mercado interno bastante pequeño, a lo que se le ha unir la gran dificultad de los medios de comunicación para conectar los centros poblados de mayor tamaño con la producción.

Aquí, se aprecia cómo la especialización de dicho producto se encontraba vinculada a la expansión del mercado y al desarrollo de las obras de infraestructura que permitiera acabar con los problemas de comunicación entre la Sierra y la Costa y dentro de las distintas partes de la serranía ecuatoriana. ${ }^{784}$ Ahora bien, ¿cuáles eran las principales zonas del Ecuador que se dedicaban a la ganadería durante esta época?

Rafael Quintero y Erika Silva hacen referencia a la Sierra centro norte, en concreto, la cuenca lechera de las provincias de Pichincha y Cotopaxi (ver mapa División del Ecuador, Sierra Centro Norte), en las que se llevó a cabo su transformación en unidades empresariales eficientes, caracterizadas por la introducción de métodos modernos de gestión y tecnificación en torno a la leche y derivados, y que generaron hacia la década de los setenta del siglo XX, la agro-industria más importante del país: La producción comercial de leche en esta subregión, data de principios

\footnotetext{
782 Osvaldo Barsky, Alex Barrill, Gustavo Cosse, Jorge Morandi, Humberto Vinueza: El proceso de transformación de la producción lechera serrana y el aparato de generación-transferencia en Ecuador, Proyecto cooperativa de investigación sobre tecnología agropecuaria en América Latina, Documento Protaal, número 40, FLACSO, 1980, p. 52-80.

${ }^{783}$ Ibíd. p.52-80.

${ }^{784}$ Osvaldo Barsky, Gustavo Cosse, Tecnología y Cambio..., op. cit. p. 40-75.
} 
de siglo, concretamente a partir de 1910, en la microzona de Guaytacama, perteneciente a una provincia de renombrado cuño latifundista, Cotopaxi. ${ }^{785}$

La incorporación del ferrocarril a comienzos del siglo XX, lograría impulsar la producción ganadera-lechera en los hacendados, al atravesar algunas de las zonas estratégicas de la Sierra y fomentar el desarrollo de los primeros procesos industriales de transformación que generaron importantes envíos de derivados de la leche hacia Guayaquil, que para esta época, se había convertido en el principal centro consumidor del país. De este modo, las haciendas tradicionales de relaciones pre-capitalistas de producción, comenzaron a desarrollar sus fuerzas productivas alrededor de la producción lechera.

Junto al impulso generado por el ferrocarril, se ha de considerar la mejora genética de las razas y las inversiones destinadas a la construcción de acequias de agua que permitieron ampliar los pastos naturales e iniciar un proceso de implementación de pastos artificiales con pastos extranjeros y leguminosas. ${ }^{786}$

Además de la mejora de un conjunto significativo de animales, este proceso constituyó la base de la expansión posterior para la implantación de las primeras agro-industrias del sector en el interior de algunas haciendas. A pesar de esto, hay que señalar que en una buena parte de las haciendas, la ganadería bovina era bastante simple debido a una baja calidad genética y al uso de técnicas de manejo demasiado rudimentarias, lo que ponía de manifiesto las restricciones para aplicar las mejoras a un número limitado de haciendas. ${ }^{787}$

Posteriormente, a finales de la década de los cuarenta, el auge bananero pudo consolidar este proceso de desarrollo con el que se originó una diferenciación al interior de los sectores terratenientes, que también alcanzaron un carácter regional dentro de la Sierra como hemos visto. Así, mientras que la mayoría de las haciendas continuó vinculada a la producción agrícola, manteniéndose para ello, el sistema de cesión de tierras y recursos naturales a los campesinos, la

\footnotetext{
${ }^{785}$ Este mapa se encuentra en el apéndice de mapas del capítulo 3. Fuente: Rafael Quintero, Erika Silva, op. cit. p. 39.

${ }^{786}$ Ramón Ojeda: Efectos del ferrocarril en la agricultura y ganadería, en Pensamiento agrario ecuatoriano, ed. Carlos Marchán, Banco Central del Ecuador, Corporación Editora Nacional, 1986, p. 646-656.

${ }^{787}$ Osvaldo Barsky, Alex Barrill, Gustavo Cosse, Jorge Morandi, Humberto Vinueza, op. cit. p. 52-80.
} 
transición de unidades agrícolas a pecuarias, posibilitó el desarrollo de mecanismos para realizar el cambio de las relaciones sociales. ${ }^{788}$

En este contexto, vamos a ver cómo el proceso de modernización en el agro serrano implicó una verdadera transformación de la organización interna de las haciendas, además de una reestructuración del proceso productivo, pero antes es necesario analizar las características en que se desenvolvió la producción agropecuaria serrana durante la década de los cincuenta y sesenta.

Según Alex Barril, para los años cincuenta, la actividad agrícola en la Sierra ecuatoriana era dominante con respecto a la producción pecuaria. ${ }^{789}$ El Censo Agropecuario de 1954 muestra que el número estimado de explotaciones (tabla 13: Número estimado de explotaciones y superficie según el uso de la tierra) en el Ecuador era de 344.234, de las que 259.569 se encontraban en la Sierra, siendo la superficie total censada de 3.020.000 hectáreas (tierras de labranza y otras tierras). ${ }^{790}$

A su vez, la tabla 12 (Número de explotaciones y superficie de la Sierra ecuatoriana por estratos de tamaños, año 1954) muestra una estructura de la tierra bastante polarizada para el año 1954, ya que había 259.169 propiedades en la Sierra, de las que 162.153 eran menores de cinco hectáreas, con una superficie total de 341.700 hectáreas. En el otro extremo, había 2.368 explotaciones entre 100 y 500 hectáreas con una superficie total de 471.100 hectáreas y 389 explotaciones de más de 1.000 hectáreas, con una superficie total de 1.242 .900 hectáreas. ${ }^{791}$ Esta situación pone de manifiesto la diversidad existente en el sistema productivo, caracterizado por la presencia de un sector minoritario que concentraba el agua y la tierra y un sector mayoritario que poseía escasos medios de producción y una gran cantidad de fuerza de trabajo.

\footnotetext{
${ }^{788}$ Ramón Ojeda, op. cit.p, 646-656.

${ }^{789}$ Alex Barril, op. cit. p. 211-245.

${ }^{790}$ Las tablas 13-22 se encuentran en el apéndice de datos del capítulo 3. Fuente: Ministerio de Economía, Dirección General de Estadística y Censos: Censo Agropecuario Nacional 1954, Quito, 1956.

${ }^{791}$ Censo agropecuario de 1954.
} 
La actividad agrícola estaba basada en la producción de alimentos, cuyo destino era fundamentalmente el mercado interno, siendo los cultivos principales el maíz, el trigo, la cebada y las patatas como se puede observar en la tabla 14 (Producción agrícola 1954). ${ }^{792}$

Las propiedades menores de diez hectáreas que ocupaban 496.400 hectáreas, el 16,5\% de la superficie agrícola de la Sierra, producían el 38,7\% del volumen total producido. En cambio, las propiedades mayores de 500 hectáreas que ocupaban 1.472.200 hectáreas, el 48,7\% de la superficie, aportaban solo con el 17,2\% de la producción agrícola total. $^{793}$

Estos datos ponen de relieve una escasa utilización del suelo de las grandes propiedades debido a una explotación extensiva con formas de trabajo pre-capitalistas. ${ }^{794}$

Por su parte, la producción pecuaria era secundaria, siendo el número estimado de explotaciones totales de 163.019 y 1.215 .900 cabezas de ganado vacuno, de las que 136.020 explotaciones y 786.300 cabezas de ganado vacuno pertenecían a la Sierra (Tablas 15-19: Ganado vacuno). A su vez, para el año 1954, la leche producida ascendía a la cantidad total de 718.400 litros, de los que 511.200 correspondían a la Sierra (Tablas 20, 21 y 22: Producción pecuaria). ${ }^{795}$

El uso de tecnología en la ganadería estaba vinculado a los procesos agrícolas, los cuales se realizaban con técnicas bastante simples y con abundante mano de obra. En la producción de leche, el problema técnico se centraba en la cuestión genética y en las técnicas deficientes en el manejo de ganado y pastos y tampoco existía un sistema de clasificación para el ganado vacuno:

De 544 visitas realizadas a 288 predios productores de leche en la Sierra, el 73\% de ellos merecían la calificación de pésimas las condiciones higiénicas en las cuales se realizaba la ordeña. La comercialización se hacía directamente a Quito en un 20\%, después de tres o cuatro horas de la ordeña, y en un $40 \%$ después de 14 a 18 horas de la ordeña. El

\footnotetext{
792 Ministerio de Economía, Dirección General de Estadística y Censos: Censo Agropecuario Nacional 1954, Quito, 1956.

793 JUNAPLA: Censo Agropecuario de 1954.

${ }^{794}$ Alex Barril, op. cit. p. 211-245.

795 Ministerio de Economía, Dirección General de Estadística y Censos, Censo Agropecuario Nacional 1954, Quito, 1956.
} 
transporte se hacía en camiones, junto a la carga habitual de estos: ruedas, llantas, aceite de motor, etc. ${ }^{796}$

Además, el uso extensivo del suelo y la complicada la topografía de los terrenos, son factores que también explican el bajo uso de maquinaria en las tareas agrícolas.

La tabla 23 (Tipo de tracción usada en las actividades agrícolas según tamaño de las explotaciones, 1954) nos da una idea del incipiente proceso de mecanización en el Ecuador, en particular, en la Sierra. ${ }^{797}$ Así, de las 343.948 explotaciones existentes en el país en 1954, solamente 394 utilizaban tracción mecánica en las labores agrícolas, mientras que 190.092 usaban únicamente tracción animal y 140.004 incorporaban la fuerza humana en el trabajo agrícola. $^{798}$

Si bien se observa una mejora en la incorporación de maquinaria en el proceso productivo agrícola (ver Tabla 24: Maquinaria agrícola en el Ecuador entre 1959-1962), en el número de trilladoras, tractores y sembradores a partir de 1959, no se puede decir lo mismo para la actividad pecuaria, pues no hay gran evidencia en cuanto al uso de equipos en los inventarios globales de maquinaria. $^{799}$

En relación al uso de tecnología de tipo biológico en la producción pecuaria, vamos a considerar las razas animales y sistemas reproductivos debido al vínculo establecido con la mejora genética y la producción. De este modo, a partir de dicha etapa, el sector productor lechero se centrará en el tema de la genética, asistiéndose a un proceso de organización decisivo de la actividad, al que contribuye la creciente importación de animales de esta raza por parte de países como Estados Unidos y Canadá:

El incremento del ganado lechero de la Sierra constituye uno de los hechos de mayor importancia entre los ocurridos en las últimas décadas en la producción pecuaria; sus

\footnotetext{
796 J. Villagómez, 1954, tomado de Osvaldo Barsky, Alex Barrill, Gustavo Cosse, Jorge Morandi, Humberto Vinueza: El proceso de transformación de la producción lechera serrana y el aparado de generación-transferencia en Ecuador, FLACSO, marzo de 1980, p. 448-449.

${ }^{797}$ Censo Agropecuario de 1954, JUNAPLA y FAO, 1960.

${ }^{798}$ Esta tabla se encuentra en el apéndice de datos del capítulo 3. Fuente: Osvaldo Barsky, Ecuador, cambios..., op. cit. p. 215.

799 Esta tabla se encuentra en el apéndice de datos del capítulo 3. Fuente: Departamento Estimaciones Agrarias, Dirección Nacional de Agricultura y Ministerio de Fomento, 1963.
} 
principales rebaños fueron transformados y mejorados con la introducción de sangre pura, de gran pedigrí, especialmente de la raza overo-negra de Estados Unidos y de Canadá. ${ }^{800}$

A su vez, el esfuerzo para mejorar la calidad genética del ganado adquirió un carácter básicamente privado, siendo la presencia de ganaderos ecuatorianos en los Estados Unidos y de técnicos norteamericanos en el Ecuador, los mecanismos que facilitaron la transmisión de las técnicas para el cruce de ganado y control lechero.

Asimismo, en la década de los cincuenta, comenzó a llevarse a cabo una separación de terneros para la alimentación artificial, con el objetivo de incrementar los niveles de leche para su venta. Aquí, se ha de señalar que cuando los hacendados tomaron el control de las etapas de adopción de tecnologías procedentes de los grandes centros de producción lechera mundial, se inició un proceso bastante importante en cuanto a la presencia del sector privado en las instituciones estatales encargadas de la tecnología. ${ }^{801}$

Teniendo en cuenta estos cambios, se puede comprender cómo estas décadas constituyeron un elemento clave en el desarrollo del agro serrano, al crearse la iniciativa terrateniente como un proceso por el cual, algunas de las fracciones crearon un conjunto de estrategias para eliminar las relaciones pre-capitalistas de producción y obtener altos beneficios. ${ }^{802}$

La existencia de una estructura agraria tradicional, no solo era un obstáculo para lograr un desarrollo capitalista, sino que impedía el aumento de la producción y de los ingresos conforme iba aumentando la población en las ciudades y el mercado de consumo interno.

En este marco, el sector modernizante, caracterizado por su fuerte poder político, inició la entrega de los huasipungos a los campesinos como una forma de desarrollar su estrategia de cambio del sector e impulsó los primeros debates que mostraban cómo la estructura agraria impedía la formación de un mercado interno necesario y constituía un freno a las posibilidades de desarrollo y acumulación de los sectores urbanos de la clase dominante. ${ }^{803}$

\footnotetext{
${ }^{800}$ Secretaría de la Comisión Económica para América Latina: El desarrollo económico del Ecuador, Naciones Unidas, México, enero de 1954, p. 88.

${ }^{801}$ Ibíd. p. 88.

${ }^{802}$ Alex Barril, op. cit. p. 211-245.

${ }^{803}$ Ibíd. p. 211-245.
} 
La elaboración de esta estrategia incluía un doble efecto, ya que se pretendía recuperar las mejores tierras (una buena parte de los huasipungos no fueron entregados en el lugar donde estaban, sino en zonas apartadas de peor calidad) para iniciar el cambio de actividad productiva, mientras se pretendía apaciguar los conflictos sociales de la época. ${ }^{804}$

Rafael Quintero y Erika Silva explican que las condiciones ecológicas, la vinculación con el mercado mediante el ferrocarril que atravesaba la zona, las crecientes ganancias obtenidas por los envíos de mantequilla, queso y ganado a la Costa y la escasez de mano de obra como consecuencia del movimiento migratorio hacia el litoral, fueron algunos de los factores que hicieron posible la eliminación de las relaciones pre-capitalistas en Guaytacama y la transformación de las haciendas en empresas ganaderas, lo que dio lugar al primer complejo agro-industrial en la mayor parte de la provincia. ${ }^{805}$

Esta tendencia, que se fue extendiendo por toda la región centro norte del Ecuador, motivó la aparición de diversas formas de asociación y apoyo de una clase terrateniente regional en proceso de conversión en burguesía terrateniente. En efecto, el desarrollo de la ganadería de leche se expandió hacia las provincias de Pichincha, Imbabura y Carchi, creándose las condiciones para la eliminación de las relaciones pre-capitalistas en cuanto al resto de la Sierra y del país. ${ }^{806}$ Dicha situación explica que esas provincias registraran la proporción más significativa de entrega de huasipungos antes de la Reforma de 1964 (ver la tabla 25: Porcentaje de huasipungos entregados y de superficie entregada en 1959). ${ }^{807}$

Además, dicha iniciativa no se limitó únicamente a una racionalidad económica para aumentar las ganancias, sino que se implantó en la sociedad de forma global, llevando al sector a tener una fuerte presencia en la discusión en la reforma del agro para impulsar desde el aparato estatal, la liquidación de las relaciones no salariales de producción, a la vez que buscaba reforzar el proceso de modernización iniciado por las fracciones más fuertes. De este modo, se fue elaborando un proceso para impulsar el desarrollo de las fuerzas productivas y el cambio en las relaciones

\footnotetext{
${ }^{804}$ Ibíd. p. 211-245.

${ }^{805}$ Rafael Quintero, Erika Silva, op. cit. p. 202.

${ }^{806}$ Ver el apéndice de notas del capítulo 3 para más información. Fuente: Ibíd. p. 202-203; Carlos Arcos, Carlos Marchán: Guaytama y Cusubamba: dos modalidades de desarrollo de la agricultura serrana, Revista Ciencias Sociales, Quito, UCE, Vol. II, 5, 1978, p. 13-51.

${ }^{807}$ Rafael Quintero, Erika Silva, op. cit. p. 201.
} 
sociales de producción, las cuales lograron imponerse debido a la fuerte influencia social y política del sector modernizante, tal y como se estudiará en el siguiente capítulo con la Ley de Reforma Agraria de $1964 .^{808}$

Por su parte, Barsky y Cosse hablan de dos elementos utilizados por la fracción modernizante para eliminar las relaciones no salariales en sus haciendas, los cuales se encontraban en dos tipos de niveles: un nivel micro en la unidad productiva y un nivel macro, que incluía el plano social, político e ideológico. ${ }^{809}$

En relación al primer nivel, se ha de aludir a la expansión del mercado de productos internos a raíz del aumento de los ingresos ocasionado por el incremento de la demanda de productos como la leche y sus derivados. Esto también se vio favorecido al producirse las condiciones de mercado necesarias para estimular la diferenciación de un conjunto de unidades productoras de leche y cebada, mientras se generaba un creciente tránsito para su consolidación como empresas agropecuarias de tipo capitalista. Es decir, este tipo de desarrollo, diferenciado por ramas o zonas, tuvo lugar como consecuencia de la penetración del capital en el agro. ${ }^{810}$

A partir del crecimiento de la demanda de los productos mencionados, la fracción modernizante comenzó a realizar inversiones, a la vez que desplazaba a los trabajadores de las tierras otorgadas para que se adaptaran a los nuevos procesos y mejorar las condiciones de productividad. En este caso, los hacendados plantearon como estrategia repartir las tierras que tenían una situación ecológica peor, en las que el tipo de producción del campesino creaba una demanda de mercado con beneficios más bajos.

De este modo, las relaciones paternalistas anteriores fueron utilizadas con la intención de crear una parcela de pequeños campesinos situados alrededor de las haciendas, la cual constituía una reserva de mano de obra y servía para consolidar al nuevo personal asalariado que continuaba ligado al hacendado mediante relaciones extraeconómicas. ${ }^{811}$

Por último, el segundo nivel vuelve a hacer referencia a los hacendados que deseaban eliminar las relaciones precarias, e introduce los cambios demandados por los sectores nacionales y la

\footnotetext{
${ }^{808}$ Ibíd. p. 201.

${ }^{809}$ Osvaldo Barsky, Gustavo Cosse, Tecnología y Cambio Social..., op. cit. p. 47.

${ }^{810}$ Ibíd. p. 47.

${ }^{811}$ Ibíd. p. 54-55.
} 
Alianza para el Progreso. Este grupo participó en las modificaciones de la estructura agraria y en la elaboración de la primera Ley de Reforma Agraria de 1964, mostrando al resto de los hacendados el mecanismo para reorganizar el sistema de trabajo de sus unidades y contribuir de este modo, a las nuevas condiciones de desarrollo del país.

De esta manera, a mediados de la década de los sesenta, se acelera el cambio en la estrategia de producción en la Sierra, a través de la cual la actividad ganadera-lechera logró desplazar a la actividad agrícola gracias al proceso de modernización de las unidades productivas y a las crecientes inversiones de capital. ${ }^{812}$

\section{2) El Gobierno de la Junta Militar en el Ecuador (1963-1966).}

\subsection{1) La dictadura militar y la relación con los Estados Unidos (1963-1964): Las políticas de desarrollo asociado.}

En el análisis del periodo comprendido entre 1960-1964, señalamos cómo la lucha de clases dentro de las haciendas, la cuestión cubana y la entrega de huasipungos antes de la Reforma Agraria de 1964, fueron factores que contribuyeron en gran medida a dar forma a las características políticas y económicas de la sociedad ecuatoriana de esta época. Si bien, hasta el momento, hemos profundizado en mayor medida en la estructura de la hacienda y los proyectos de reforma que implicaban la eliminación de las relaciones precarias y la abolición de los huasipungos, vamos a continuar analizando el impacto de la Revolución Cubana y las medidas aplicadas, teniendo en cuenta el carácter del desarrollo asociado ecuatoriano y su relación con los Estados Unidos.

En este contexto, las movilizaciones populares de 1959 y la matanza en Guayaquil bajo el gobierno de Camilo Ponce (1956-1960), vinieron a exponer la situación de debilitamiento del poder político, consecuencia de las modificaciones de las clases dominantes y de sus mecanismos de control. ${ }^{813}$ El problema de la ruptura diplomática con Cuba y la necesidad de

\footnotetext{
${ }^{812}$ En este caso, se encuentran las provincias del centro y norte de la Sierra (Pichincha, Imbabura, Cotopaxi y Carchi), las cuales contribuyeron con un alto porcentaje en las entregas de tierras a los huasipungueros, al tratarse de zonas en las que por su condición ecológica, transporte y cercanía a mercados, habían desarrollado un proceso más avanzado de transición a la producción lechera. Fuente: Osvaldo Barsky: Iniciativa Terrateniente en la estructuración de las Relaciones Sociales en la Sierra Ecuatoriana, Revista de Ciencias Sociales No.5, Quito, 1978.

${ }^{813}$ Camilo Ponce Enríquez fue presidente del Ecuador desde 1956 hasta1960. Asumió la presidencia de la República en 1956, iniciando una administración de derechas que fue muy discutida por los partidos de centro y de izquierda, al ser el primer presidente católico del país después de más de cincuenta años de gobiernos liberales. Entre sus
} 
establecer reformas estructurales en el agro, fueron los elementos finales que agudizaron las contradicciones al interior de las fracciones. ${ }^{814}$ Esta etapa vino a marcar un símbolo de la crisis que caracterizó a la sociedad ecuatoriana hasta el inicio de la exportación petrolera, pues a nivel económico, el debilitamiento de la exportación bananera llevó a la reformulación del patrón de acumulación, orientándolo hacia la industrialización con la intervención del estado. ${ }^{815}$

Aquí, se ha indicar cómo a partir de 1960, se inicia un segundo periodo de planificación en el Ecuador, en el que la Junta Nacional de Planificación asumió una gran cantidad de tareas para programar el desarrollo del país, entre las que se pueden citar el control y la evaluación de la ejecución de los planes, la coordinación de la política económica, la asesoría del sector público en la contratación de financiación externa, la coordinación de la asistencia técnica, etc. La asignación de este conjunto de tareas, mostraba cómo los planes de las primeras etapas se iban acomodando al proceso y cómo los grupos sociales que se beneficiaban de dicha acción, fueron aumentando el número de tareas, cuya atención era difícil de satisfacer. ${ }^{816}$

Dicha dificultad provenía de la poca experiencia por parte de la Junta de Planificación, a la vez que se encontraba en el número tan limitado de técnicos disponibles para cubrir una gran variedad de campos de acción y tampoco existía demasiada información estadística que pudiera hacer frente a las distintas necesidades.

A su vez, se ha de hablar de otros obstáculos en el papel de la planificación del Ecuador, relacionados con el proceso de industrialización y el dinamismo económico que el sector exterior había tenido hasta entonces. En efecto, el proceso de industrialización sustitutiva y el auge del sector externo habían determinado la aparición de nuevos grupos sociales que luchaban por tener una mayor participación en la elaboración e implementación de las decisiones.

A esto se ha de añadir el problema presentado por el crecimiento de la población (ver Tabla 26 Población total del Ecuador estimada por regiones -1955-1965) a partir de 1960, pues la

logros, hay que destacar el gran impulso a las construcciones escolares que contaban con edificios nuevos y modernos en todo el país. Fuente: Efrén Avilés Pino: Dr. Camilo Ponce Enríquez, en Enciclopedia del Ecuador, Academia Nacional de Historia del Ecuador, 2012, www.enciclopediadelecuador.com

${ }^{814}$ El Ecuador rompió relaciones con Cuba en 1962, como consecuencia de la presión por parte del gobierno estadounidense sobre Arosemena, mientras se producía la ruptura con la entonces Checoslovaquia y Polonia. Fuente: Germán Rodas Chaves: La izquierda ecuatoriana. Aproximación Histórica, segunda edición, Edic. Abya-Yala, 2000, p. 72.

${ }^{815}$ Andrés Guerrero, Haciendas capital..., op. cit. p. 86.

${ }^{816}$ Rafael Quintero, Erika Silva, op. cit. p.221-238. 
solución impuesta con la expansión de las exportaciones y el proceso de industrialización sustitutiva no había sido suficiente: ${ }^{817}$

Un esquema de análisis que confiaba en el simple crecimiento, la superación de todas las dificultades económicas y sociales del país, ya no podía tener una estricta correspondencia con una realidad en la cual se presentaba una creciente diversificación social y la emergencia de nuevos grupos. En otras palabras, que la planificación del Ecuador ya no podía continuar con las mismas características de simple acompañamiento y racionalización del proceso económico, sin siquiera avizorar nuevas y diferentes tendencias de evolución económica-social. ${ }^{818}$

Por otro lado, a nivel social surgió la necesidad de replantearse las alianzas entre las clases en el poder, mientras que a nivel político existió una mayor inclinación para modernizar el estado.

Así, al abordar el tema de la Revolución Cubana, ya hablamos de la importancia de la influencia política que este fenómeno tuvo en el Ecuador y en el resto del continente, al originar la ruptura en el control que Estados Unidos había tenido desde tiempos atrás, además de los numerosos movimientos populares ocasionados. En este momento, tanto el gobierno de Velasco como el de Arosemena, intentaron renegociar la situación de dependencia con respecto a Estados Unidos, comenzando sus mandatos con cambios diferentes de las ideas de las clases dominantes.

Los acontecimientos de los años sesenta presentaron las contradicciones del desarrollo capitalista del país a través de varios acontecimientos. La irrupción de la Revolución Cubana como movimiento social de estructuración campesina que demandaba la realización de una reforma agraria, se dejó sentir en los sectores políticos internos creando numerosos conflictos, mientras que Estados Unidos planteaba un conjunto de estrategias para eliminar esta influencia en América Latina. Es decir, este país preparó un conjunto de acciones de tipo económico y militar que pretendía acabar con dicha revolución, aislándola del resto de países con el impulso de gobiernos que fomentaban la organización de grupos ultra derechistas y fortaleciendo a los cuerpos represivos estatales, mientras se establecían mecanismos para aliviar la presión y revueltas populares, como fue el caso de la reforma agraria. Así, ya a principios de 1961, el

\footnotetext{
${ }^{817}$ Patricio Almeida Guzmán, Rebeca Almeida Arroba, Estadísticas económicas..., op. cit. p.5.

${ }^{818}$ José Moncada Sánchez: Historia económica, planificación y socialismo en el Ecuador, Pensamiento Socialista, Ediciones La Tierra, Quito, 2008, p. 182.
} 
imperialismo norteamericano y los movimientos anticomunistas denunciaban las posibles infiltraciones comunistas en el gobierno, además de defender al ejército y los valores tradicionales del país. ${ }^{819}$

A partir de este momento, y tras la Conferencia Interamericana celebrada en 1961 en Punta del Este (Uruguay), las medidas de política agraria propuestas por Estados Unidos comenzaron a ser adoptadas por una buena parte de países latinoamericanos. ${ }^{820}$ El tema de las relaciones diplomáticas con Cuba fue uno de los principales puntos políticos de Estados Unidos, sobre todo desde que las administraciones de Velasco Ibarra y de Arosemena presentaron algunos obstáculos a sus planteamientos, a la vez que las masas populares se inclinaban por la ideología impuesta por la revolución como forma de rechazo anti-imperialista y anti-estadounidense. Para estos gobiernos nacionalistas, romper relaciones con Cuba significaba acabar con el apoyo popular del que gozaban, lo que suponía una modificación de sus políticas y la imposición de la derecha. ${ }^{821}$ Aunque estos acontecimientos fueron fijando el conflicto coyuntural e impulsaron los regímenes populistas de Velasco Ibarra (1960-1961) y Arosemena (1961-1963), hay que hablar de la relación existente entre la política y la práctica económica, ya que aún cuando se plantearon demandas de independencia nacional frente a la estrategia de aislamiento a la Revolución Cubana, en las acciones económicas, se atendía a las ideas de Estados Unidos y se buscaba su colaboración para ampliar el mercado de exportaciones.

Si bien la cuestión cubana como problema de la coyuntura fue desapareciendo de la escena política a finales de 1962, el tema de la reestructuración de las relaciones en el campo permaneció como un gran reto en la sociedad y política ecuatoriana. De ahí, la importancia a la hora de analizar conjuntamente ambos eventos, ya que sería bastante difícil comprender la

\footnotetext{
${ }^{819}$ Ver el apéndice de notas del capítulo 3 para más información. Fuente: Rafael Quintero, Erika Silva, op. cit. p.221-238; Germán Rodas Chaves: La izquierda ecuatoriana. Aproximación histórica”, segunda edición, Edic. Abya-Yala, 2000, p. 73-74.

${ }^{820}$ En esta conferencia se aprobaron diversas recomendaciones como la necesidad de programar el desarrollo de los países de la región latinoamericana para lograr un crecimiento autosostenible. La elaboración de un plan se convirtió en una condición inevitable para obtener financiación internacional. Fuente: José Moncada Sánchez, op. cit. p. 180183.

${ }^{821}$ Rafael Quintero, Erika Silva, op. cit., p. 220-239.
} 
entrega anticipada de los huasipungos y la posterior reforma del agro si no se analiza previamente la lucha de las clases y movimientos populares de la coyuntura 1960-1964. ${ }^{822}$

Andrés Guerrero explica cómo la política de reforma agraria fue utilizada en otros países como mecanismo para disminuir la presión social de los países dominados. Así, tras la Revolución China (1948), donde la mano de obra fundamental era el campesino, Estados Unidos llevó a cabo una política mundial de reformas agrarias para eliminar las crecientes contradicciones sociales originadas por el desarrollo económico de la postguerra. En este momento, el imperialismo comenzó a apoyarse en las clases dominantes más atrasadas, asentadas en relaciones precapitalistas pero insertas en un modo capitalista que restringía la base política de sustento de dominación. ${ }^{823}$ De este modo, se fue creando una política con la que se intentaba acabar con aquellos sectores o clases sociales dominantes tradicionales, con el objetivo de fomentar la reestructuración de las relaciones de producción en el campo.

A raíz de la Revolución Cubana, se planteó la necesidad de aplicar políticas de este tipo en América Latina, con las que el gobierno estadounidense logró impulsar la ya mencionada Alianza para el Progreso a través de una serie de medidas reformistas que debían ser aplicadas en un plazo de cuatro años (1960-1964).

Hay que recordar que la reforma agraria era parte de una vieja demanda de los partidos de izquierdas, pues todavía existía una visión de los problemas latinoamericanos, en la que se combinaban los rasgos feudales en el campo, el capitalismo y la consolidación de una burguesía anti-imperialista y una clase media revolucionaria que manipulaba a la clase obrera sin estudios y sin una forma de pensar clara.

Como ya sabemos, el tema de la reforma agraria estuvo presente tanto en el gobierno de Velasco como el de Arosemena, en los que la burguesía y algunos sectores de las clases terratenientes fueron cobrando conciencia de que debían sacrificar algunos intereses agrarios para mantener el status quo político, a la vez que la derecha local y el imperialismo presionaban a los gobiernos para que cambiaran su posición política de reivindicaciones populares. ${ }^{824}$

\footnotetext{
${ }^{822}$ Andrés Guerrero, Haciendas capital..., op. cit. p. 7-139.

${ }^{823}$ Ibíd. p. 7-135.

${ }^{824}$ Rafael Quintero, Erika Silva, op. cit. p. 221-245.
} 
El fracaso de ambos gobiernos y la situación de neutralización cercana a un vacío de poder durante el mandato de Arosemena, al ser incapaz de cumplir con las reformas prometidas que hubieran consolidado el apoyo popular, acabó con el golpe de estado militar del 11 de julio de 1963 debido al alto nivel de enfrentamientos. ${ }^{825}$

No obstante, además de los problemas sociales, se ha de mencionar el papel que Estados Unidos desarrolló en la caída del gobierno de Arosemena y la motivación por parte del nuevo gobierno militar para adoptar una política acorde con el gobierno norteamericano, pues el origen del golpe estaba en las necesidades de financiación exterior. También, se ha de añadir el discurso pronunciado por Arosemena en una cena, a la que acudió el almirante Wilfred MacNeil, en la que dijo: El pueblo de Ecuador y el de Estados Unidos gozan de relaciones cordiales, pero éstas sólo existen entre los dos pueblos. El gobierno de Estados Unidos explota a América Latina y explota al Ecuador. ${ }^{826}$ Unas horas después, el ejército trasladó a Arosemena a Panamá, quedando el poder en manos de la Junta Militar. ${ }^{827}$

De esta manera, la Junta Militar justificaba las razones que llevaron al final de una autoridad civil para poder mantener el status quo y las instituciones del capitalismo, las cuales habían sido amenazadas por el reciente desarrollo de la sociedad civil. A partir de estas ideas, si la intención del nuevo gobierno era obstaculizar las ideas difundidas por la Revolución Cubana y evitar el alejamiento del sistema político de su forma tradicional, ¿cuáles fueron las acciones que se plantearon para el cumplimiento de dichos objetivos? ¿qué fracciones apoyaron estas medidas? ¿qué tipo de reformas pretendía llevar a cabo la Junta Militar con la ayuda de Estados Unidos? ¿qué tipo de beneficios obtuvo Estados Unidos?

El régimen autoritario, cuyo origen se encontraba en la estrategia del capital monopólico, contó con el apoyo de importantes fracciones de las clases dominantes regionales, que ante el levantamiento de los grupos populares, usaron la represión para bloquear sus exigencias. ${ }^{828}$

\footnotetext{
${ }^{825}$ Recordemos que la Junta Militar, que gobernó desde 1963 hasta 1966, estaba formada por Ramón Castro Jijón, Marcos Gándara Enríquez, Luis Cabrera Sevilla y Guillermo Freire Posso. Fuente: J. S. Fitch: The military coup d'etat as a political process, Ecuador, 1948-1966, Universidad de Johns Hopkins, University Press, 1977, p. 117.

${ }^{826}$ Esta frase ha sido reproducida múltiples veces, por ejemplo en Osvaldo Albornoz Peralta: Las compañías extranjeras en el Ecuador, Quito, Abya-Yala, 2001, p. 187.

${ }^{827}$ Rafael Quintero, Erika Silva, op. cit. p.221-238.

${ }^{828}$ Ibíd. p. 221-238.
} 
El sector dominante en la alianza que, en un principio, promocionó la dictadura, estaba formado por la fracción modernizante de la clase terrateniente serrana. De este modo, la composición del gobierno manifestó el apoyo de la clase terrateniente y de la burguesía, pues los miembros del gobierno fueron escogidos para ocupar las diferentes divisiones de los partidos conservador y liberal. $^{829}$

Además, en el caso del Ecuador, la supervivencia del capitalismo requería modernizar la estructura agraria, sustituir el modelo de desarrollo agro-exportador y fomentar el desarrollo industrial, aún cuando no hubiera un sector empresarial capaz de realizar este proceso. Pese a que este proyecto de modernización exigía el apoyo de los sectores medios y populares, llegó a existir gracias a la acción de los grupos a favor de la campaña anti-comunista. De este modo, el denominado desarrollismo, corriente ideológica reaccionaria pero modernizante, se implantó en el país a través de una dictadura represiva. ${ }^{830}$

Aunque esta irrupción militar constituyó el primer golpe de estado institucional de tipo militar en el estado, se ha de aclarar que el primer gabinete de la Junta Militar (1963-1966) fue una alianza entre el placismo y el poncismo, al tratarse de un gobierno de colaboración antagónica entre la derecha y el grupo placista, ya que los objetivos perseguidos por los dos grupos eran completamente diferentes. Por un lado, los placistas eran impulsores de los programas reformistas, y por otro, los poncistas defendían el status quo y gozaban de su influencia en el gobierno militar. ${ }^{831}$

El producto de esta alianza tuvo como resultado el establecimiento de una política reformista, basada en un Plan decenal de desarrollo (1964-1973), que condicionó desde ese momento, la evolución política y económica del país, a la vez que el gobierno militar ilegalizaba los partidos comunistas ecuatorianos y ejercía una gran represión en contra de los movimientos que representaran una ideología izquierdista. Para realizar esta tarea, el gobierno militar contó con la

\footnotetext{
${ }^{829}$ P. Agge: Inside the company: CIA diary, Gran Bretaña: Penguin Books LTD, 1975.

${ }^{830}$ Patricio Ycaza, op. cit.p. 7-40.

${ }^{831}$ El Plan de Desarrollo propuesto por la Junta Militar pretendía una mejora de la distribución del ingreso y del crecimiento económico mediante una reforma de tipo agraria, tributaria y administrativa, a lo que los poncistas se opusieron. Esto llevó a que la colaboración antagónica entre placistas y poncistas no durara más de un año, abandonando el poncismo el gabinete en julio de 1964, unos días antes de ser expedida la Ley de Reforma Agraria. Fuente: César Verduga: Desarrollo del capitalismo en el agro ecuatoriano e intervenci6n estatal: Un esbozo preliminar en "El problema agrario", ILDIS, 1988, p. 518.
} 
ayuda de gobierno de Estados Unidos, poniendo de manifiesto el abandono de la actitud nacionalista mediante el establecimiento de políticas acordes con la posición norteamericana. ${ }^{832}$ La estrategia global de Estados Unidos se basaba en el establecimiento de un conjunto de acciones para impedir la repetición del ejemplo cubano en el resto del continente, mediante la organización de la contrainsurgencia, encargada de desencadenar la guerra interna contra la subversión en los países latinoamericanos, y la ya mencionada Alianza para el Progreso, estrategia destinada a desarrollar las economías atrasadas que tenían como referencia las teorías formuladas por Rostow. ${ }^{833}$

Los planes de la Alianza para el Progreso, diseñados por el gobierno de los EE.UU en respuesta al reto planteado por la Revolución Cubana, pretendían establecer un programa de reformas encaminadas a corregir los atrasados sistemas agrícolas (distribución de los grandes latifundios feudales), tributarios, administrativos y de educación, además de intentar promover la mejora de los servicios sanitarios y acabar con las contradicciones y el descontento campesino para modernizar el país, abriendo paso a la industrialización. ${ }^{834}$

Además, con este programa, Estados Unidos pretendió resolver por la vía reformista las contradicciones antagónicas existentes en el seno de las sociedades latinoamericanas, ofreciendo de este modo, una alternativa a la vía socialista que había aparecido con la Revolución Cubana. Esta alianza también pretendía conseguir con la vía del consenso, la consolidación de la hegemonía norteamericana en esta región, además de introducir los cambios apropiados que los intereses del capital monopólico requerían de la estructura social de los países latinoamericanos. $^{835}$

\footnotetext{
${ }^{832}$ Ver el apéndice de notas del capítulo 3 para más información. Fuente: Bertha García Gallegos: Ecuador: Democratización y Fuerzas Armadas: El contexto histórico, social y político de una relación ambivalente, en "La Administración de la defensa en América Latina. Análisis nacionales", Instituto Universitario General Gutiérrez Mellado-UNED, 2008, p. 1-2.

${ }^{833}$ El tema de la industrialización se tratará con más detalle en el capítulo 5. No obstante, se puede decir que ya en el gobierno de Carlos Arosemena se elabora el primer Plan General de Desarrollo Económico (1961), el cual tenía como objetivo promover la industrialización del país, que a pesar del impulso externo y las exenciones tributarias expedidas, surgió con los problemas propios de las condiciones internas del desarrollo capitalista dependiente. Fuente: Patricio Ycaza, op. cit. p. 5-40.

${ }^{834}$ René Báez: Teorías para el subdesarrollo, Editorial Diógenes S.A., México, primera edición, 1975, p. 73.

${ }^{835}$ César A. Bravo: Historia del Ecuador: De la década de los 1950 a la década de los 70, Colegio de Abogados del Azuay, editorial Gráficas Hernández, Cuenca, 1995, p. 15-190.
} 
De esta forma, el gobierno de la Junta Militar anunció un plan decenal que fue presentado por la Junta Nacional de Planificación en 1963 e implicaba una reforma de la estructura de tenencia de tierra y expansión de la frontera agrícola, una reforma tributaria y de la administración pública, además de buscar el desarrollo industrial. Algunos de los objetivos generales de este plan se centrados en el aumento del crecimiento del producto interior bruto en un $3.15 \%$ per cápita durante un periodo de diez años, a partir del cual se imponía una inversión bruta de 41.000 millones de sucres. Asimismo, dicho plan pretendía mantener constante la relación de ocupación respecto a la población total para lograr una mejora gradual en la distribución del ingreso y elevar la tasa de educación de la población e intentar de este modo, acabar con el analfabetismo en la población adulta. ${ }^{836}$ (Ver tablas 26, 27 y 28: Población alfabeta y analfabeta (1950-1965), Número de alfabetizados por provincia (1948-1965). ${ }^{837}$

La presencia de la Junta Militar determinó el comienzo de una nueva fase en el modo de crecimiento del capitalismo ecuatoriano, en cuanto a que se caracterizó por una mayor implicación del aparato estatal en la economía, una tendencia creciente del capital extranjero, el fortalecimiento de los núcleos industriales y un menor control de los grupos agro-exportadores, aún cuando el sector exterior seguía siendo la base de este crecimiento dependiente.

Además de impulsar el modelo de desarrollo vía industrialización por sustitución de importaciones, el gobierno militar suscribió un modus vivendi secreto mediante el cual, renunciaba a su soberanía sobre las 200 millas del mar territorial y establecía una enorme concesión petrolera a la Texaco-Gulf en la región amazónica (1.500.000 hectáreas). ${ }^{838}$

Como se ha mencionado, el plan decenal estaba dividido en varias etapas, correspondiéndole a la Junta Militar, la elaboración de las bases para que el modelo pudiera funcionar adecuadamente. Así, en las cuestiones internas, tenía la misión de iniciar la reforma del agro a través de un cambio en la estructura de la tenencia agraria, a la vez que la reforma tributaria dependía de la inversión bruta total. A partir de entonces, los objetivos del plan dependerían de un mecanismo para incrementar los ingresos del sector externo para que este siguiera siendo el elemento más importante de la economía.

\footnotetext{
${ }^{836}$ Rafael Quintero, Erika Silva, op. cit. p. 233-237.

${ }^{837}$ Estas tablas se encuentran en el apéndice de datos del capítulo 3. Fuente: Patricio Almeida Guzmán, Rebeca Almeida Arroba, Estadísticas económicas..., op. cit. p. 397-398.

${ }^{838}$ Patricio Ycaza, op. cit. p. 5-40.
} 
El dinamismo generado sería el resultado del aumento de las exportaciones y de la estabilización de la relación de los términos de intercambio, así como de la afluencia de capital extranjero y de la utilización de la capacidad de endeudamiento del estado para afrontar la inversión bruta. Esto explica la importancia de la relación con Estados Unidos, al ser el principal mercado de exportación para el Ecuador. ${ }^{839}$

Por su parte, la reforma administrativa contemplaba la creación de la Secretaría Técnica de Administración que, al estar dotada de una mayor capacidad que la indicada en el propio plan, entró en conflicto con otros mecanismos administrativos, acabando con las posibilidades de avance para la implantación de la reforma administrativa en el Gobierno Central y en el sector público nacional. ${ }^{840}$

Pese a esto, en materia de reforma tributaria se lograron resultados destacados en cuanto a los objetivos previstos en el Plan decenal, como fue el caso de la unificación de los impuestos aplicados a las exportaciones de banano, café y cacao y de la producción y consumo de cerveza y cigarrillos. También, se eliminaron algunos impuestos de tipo provincial y local que gravaban la producción, la movilización y el consumo de productos primarios, cuyo rendimiento neto solía ser negativo. $^{841}$

José Moncada señala que las medidas aplicadas significaban una racionalización del complejo sistema tributario del país, en el que mientras que no se tocaran significativamente los intereses de los grupos sociales, tales políticas gozarían de un alto nivel de aprobación. Sin embargo, destaca que cuando se pretendió modificar el arancel de importación para procurar recursos suficientes al sector público, mejorar la distribución del ingreso y contribuir a que la tributación fuera una herramienta eficiente de política económica para neutralizar las variaciones de la

\footnotetext{
${ }^{839}$ Ibíd. p. 5-40

${ }^{840}$ La Secretaría Técnica de Administración fue creada mediante el Decreto 240 publicado en el Registro Oficial 33, el 20 de agosto de 1963, siendo uno de los objetivos impuestos, la necesidad de centralizar la responsabilidad en la ejecución de las reformas estructurales y procedimientos administrativos del sector público, con el propósito de dar eficiencia a la maquinaria administrativa y posibilitar la realización de las reformas socio-económicas de la Junta Militar. Fuente: Ley Orgánica de Administración Financiera y Control, Decreto Supremo, No. 1429, RO/337 de 16 de mayo de 1977.

${ }^{841}$ Patricio Ycaza, op. cit. p. 5-40.
} 
economía, entonces aparecieron numerosos intereses que hicieron prácticamente imposible su ejecución. ${ }^{842}$

En cuanto a la reforma de la estructura de tenencia de la tierra y expansión de frontera agrícola, se ha de mencionar que el documento presentado por la Junta Militar como parte del Plan decenal, contenía procedimientos de trabajo de gran interés para llevar a cabo una política de reforma agraria, como veremos en el capítulo siguiente con más detenimiento.

No obstante, en la cuestión agraria, la clase terrateniente serrana consiguió limitar este problema a un único aspecto centrado en la entrega del huasipungo, logrando desviar las reivindicaciones campesinas más importantes que ponían en peligro el mantenimiento de las relaciones precapitalistas en las haciendas y la propiedad de la tierra. La defensa del monopolio y tenencia de la tierra fue un punto crucial que obtuvo el consenso general de la clase terrateniente a la hora de impedir la aprobación de una ley de reforma del agro. Por otro lado, los hacendados adoptaron una estrategia en contra de la ley mediante el control de organismos estables y otras instituciones encargadas de la reglamentación legal de una nueva estructura agraria y su ejecución. ${ }^{843}$

De esta manera, las dos variantes populistas se caracterizaron por establecer políticas para responder a la movilización campesina y a las acciones de los grupos que deseaban una modernización que no implicara un gran costo económico y social. Esto explica que a nivel político, los elementos fundamentales estuvieran centrados en la cuestión agraria (vías para la modernización capitalista, movimiento campesino y fracturas en la forma hacendaria y tradicional) y en los elementos de debilitamiento del sector externo para buscar una salida que permitiera el crecimiento económico y la creación de un lugar rentable para la reinversión del excedente obtenido. ${ }^{844}$

En definitiva, la dictadura tuvo un acentuado carácter represivo y anti-izquierdista, a la vez que fue un intento de centralizar el espacio nacional en lo referente al aparato estatal, al tiempo que atacaba a los sectores más avanzados de la sociedad civil. Este intento autoritario, elaborado con la ayuda imperialista y de las clases dominantes, demandó el término del orden jurídico, siendo

\footnotetext{
${ }^{842}$ José Moncada Sánchez, op. cit. p.27-45.

${ }^{843}$ Luis F. Verdesoto: El análisis de algunas características sobresalientes de la evolución en los últimos treinta años del sistema político ecuatoriano, del libro "Enfoque: Ecuador. Estudios de la realidad nacional" Fundación Eugenio Espejo, Guayaquil, 1983, p. 21-49.

${ }^{844}$ Ibíd. p. 21-49.
} 
el objetivo de la represión, impedir la unificación del movimiento de masas y crear un clima de confianza para afianzar la política imperial en el país. ${ }^{845}$

En nuestro país, el fascismo como proyecto político llegado desde fuera, ha sido incubado en organizaciones de extrema derecha desde los años treinta. Hubo momentos en que incluso adoptó la forma de un contramovimiento, aunque incipiente, pero nunca se enraizó en la sociedad lo suficiente como para aislar al estado. La originalidad histórica de la dictadura militar de 1963-1966, radica en haberse constituido en el vehículo institucional que permitió al proyecto fascista tener presencia decisiva en el estado sin que llegue a desarrollarse, de manera acabada, un régimen de excepción para esos años. $^{846}$

Luis Verdesoto indica que la intervención militar de 1963, permitió al grupo dominante superar la debilidad de la estructura social y adoptar un proyecto de modernización que consistía en la aplicación de la Alianza para el Progreso. Con esto, no solo se proponían las reformas señaladas, sino que también se pretendía aprovechar la coyuntura para desarrollar el proceso de industrialización en términos de un modelo de desarrollo para la clase dominante. De esta forma, se logró definir una vía de modernización agraria y la consolidación de la presencia del estado en la economía, desempeñando una labor en las condiciones económicas para la industrialización con un carácter social. ${ }^{847}$

Junto al aumento de la inversión industrial y de la creación de las condiciones para la transferencia de excedente, el estado creó una nueva fracción de clase dentro del núcleo dominante. Sin embargo, la industrialización por sustitución de importaciones no llegó a originar novedades importantes con respecto a otros países de América Latina, aunque hay que indicar que sus proposiciones crearon algunos conflictos con los sectores económicos tradicionales, a

\footnotetext{
${ }^{845}$ La supeditación a la estrategia norteamericana implicó la ejecución de un tipo de política antinacional que se manifestó en varios aspectos. Así, ya se ha comentado cómo en los tres años de dictadura militar, la Junta renunció al ejercicio de la soberanía ecuatoriana sobre el mar territorial al suscribir un "Protocolo Secreto" con el gobierno de los EE.UU mediante el cual, se autorizaba a los buques pesqueros norteamericanos a operar en el mar en un límite de 200 millas. Además, la embajada norteamericana intervenía directamente en la designación de los funcionarios estatales, estableciendo con el gobierno militar convenios que perjudicaban la soberanía nacional. Fuente: Rafael Quintero y Erika Silva, op. cit. p. 239-297.

${ }^{846}$ Ibíd. p. 240.

${ }^{847}$ Luis F. Verdesoto, El análisis de algunas..., op. cit. p. 21-49.
} 
pesar de que dicho proceso surgió ligado a ellos y como respuesta a una forma de acumulación en decadencia, de la cual fue su principal beneficiario. ${ }^{848}$

Por su parte, Tobar y Cisneros explican la Alianza para el Progreso como una estrategia que respondía a la necesidad del imperialismo norteamericano para hallar nuevos mercados donde invertir sus capitales e introducirse en los nuevos sectores de las economías dependientes. ${ }^{849} \mathrm{~A}$ este respecto, la Junta Militar confiaba en la ayuda de Estados Unidos para obtener la financiación externa que necesitaba, pues el principal producto de exportación, el banano, no contaba con las condiciones necesarias para aportar ingresos suficientes.

José Moncada indica que en la etapa comprendida entre 1950-1960, la dependencia exterior del Ecuador estaba centrada en el control que el capital extranjero ejercía sobre los sectores productores de materias primas, mientras que en el periodo de 1960-1970, el capital extranjero se introdujo en el país y se difundió en otros sectores provocando la desnacionalización económica. ${ }^{850}$ En este contexto, se han de entender las políticas públicas y el desarrollo asociado, puesto que ponían de manifiesto una industrialización controlada por la hegemonía del capital extranjero.

Así, en el plano económico, el seguimiento imperialista por parte de la Junta Militar implicó que entre 1964 y 1966, las diversas formas de ayuda económica alcanzaran la cifra de 84,5 millones de dólares y la asistencia militar a 9,3 millones de dólares. ${ }^{851}$ A esto, se ha de unir el papel desempeñado por el Banco Interamericano de Desarrollo (BID), que pasó a ser el agente financiero internacional del país en octubre de 1963, por lo que la obtención del crédito externo ya no estaba en manos del control nacional. ${ }^{852}$

Además, el proyecto industrializador requería impulsar la modernización del aparato estatal porque carecía de la capacidad para convertirse en la entidad responsable del proceso de

\footnotetext{
${ }^{848}$ Ibíd. p. 21-49.

${ }^{849}$ Bayardo Tobar, Ramiro Cisneros: Industrialización dependiente del Ecuador, Revista Economía, Quito, (IIEUCE) 68,1968, p.14-15.

${ }^{850}$ José Moncada: Las perspectivas de evolución del Ecuador hacia fines de siglo, en G. Drekonja et al., Ecuador Hoy, Bogotá: Siglo XXI, 1978, p. 91-133.

${ }^{851}$ Gonzalo Abad Ortíz, op. cit. p.130.

${ }^{852}$ El Banco Interamericano de Desarrollo fue fundado en el año 1959, con el objetivo de reducir la pobreza y la desigualdad y lograr el desarrollo de manera sostenible en los países de América Latina y el Caribe. Además de préstamos, ofrece donaciones, asistencia técnica y lleva a cabo diversas investigaciones. Fuente: www.iadb.org.
} 
industrialización, y porque en la medida en que el bloque dominante, pese a ser compensado con la política estatal, opuso resistencia al conjunto de reformas arancelarias elaboradas para fomentar el desarrollo industrial.

De esta manera, a la oposición de la burguesía comercial de la Costa, se sumaría el rechazo generalizado contra la dictadura militar, manifestado a través de los movimientos estudiantiles, la huelga general declarada por la Confederación de Trabajadores del Ecuador (CTE) y la Confederación Ecuatoriana de Obreros Católicos (CEDOC), que acabarían poniendo fin a la dictadura militar y dando paso a un nuevo gobierno civil dirigido por Clemente Yerovi (30/03/1966-16/11/1966), cuya figura se encontraba ligada a numerosos grupos económicos de Guayaquil. ${ }^{853}$

${ }^{853}$ Ver apéndice de notas del capítulo 3 para más información. Fuente: Ramón Galo: Indios, crisis y proyecto popular alternativo, Centro Andino de Acción Popular, Quito, 1988. 


\section{CAPÍTULO 4: LOS PROYECTOS DESARROLLISTAS EN EL SECTOR AGRÍCOLA: LA LEY DE REFORMA AGRARIA DE 1964:}

\section{1) La modernización del sector agrícola: La Ley de Reforma Agraria (1964):}

\subsection{1) El papel de la Junta Militar en la expedición de la Ley de Reforma Agraria de 1964: Medidas y objetivos económicos, políticos y sociales.}

En el capítulo anterior, analizamos cómo en la década de los sesenta fueron apareciendo una serie de factores que generaron una discusión en torno a la necesidad de llevar a cabo una reforma del agro ecuatoriano. ${ }^{854}$ En este contexto, la caída de las exportaciones del banano, la consiguiente recesión y los conflictos entre clases crearon una gran inestabilidad política y social como consecuencia de la desigualdad en el reparto de la propiedad, puesto que las grandes haciendas controlaban la mayor parte de la tierra y todavía existían relaciones de producción precapitalistas en la agricultura ecuatoriana.

Ante este escenario, con la preocupación por el avance del comunismo en la región, la intervención de la Alianza para el Progreso, la presión por parte de campesinos, los cambios que empezaban a gestarse al interior de la clase terrateniente y la entrega anticipada de tierras, se dictó la Ley de Reforma Agraria y Colonización de $1964 .{ }^{855}$

En un principio, la iniciativa de entrega de tierras fue un elemento de gran importancia para que, en un marco social y económico como el descrito, en el que la cuestión agraria era un asunto de primera orden para el desarrollo del país, las transformaciones impulsadas debían de permitir el

\footnotetext{
${ }^{854}$ En los años sesenta, se inició el intervencionismo estatal de tipo desarrollista en el Ecuador debido a las reacciones continentales frente a la Revolución Cubana (1959), la expansión de las estrategias norteamericanas para evitar la influencia del comunismo y las nuevas ideas sobre el desarrollo económico impulsadas por la Comisión Económica para América Latina. La Junta Militar que gobernó Ecuador entre 1963-1966, estableció un conjunto de políticas entre las que se encontraban la planificación estatal, el crecimiento de la inversión pública en obras y servicios, la reforma agraria para eliminar el antiguo régimen de haciendas y el trabajo precario en la agricultura y la industrialización sustitutiva de importaciones. Fuente: Juan J. Paz, Miño Cepeda: Ecuador: Una democracia inestable, Pontificia Universidad Católica de Ecuador, HAOL, Núm. 11, 2006, p.89-99.

${ }^{855}$ En el capítulo anterior, vimos cómo el Censo de 1954, reflejaba una extrema polaridad de la estructura agraria y la alta concentración de la tierra en pocas manos, a lo que se había de añadir la agudización de los problemas sociales y la desigualdad económica. Así, frente a las 241 propiedades mayores de 2.500 hectáreas, existían 329.000 propiedades medianas y pequeñas, de las que 251.000 tenían una extensión menor de cinco hectáreas y 92.000 contaban con una extensión menor de una hectárea. Fuente: Gustavo Cosse: Reflexiones acerca del estado, el proceso político y la política agraria en el caso ecuatoriano 1964-1977, en "Ecuador, cambios en el agro serrano", CEPLAES,-FLACSO, 1980.
} 
manejo de las tensiones y conflictos, a la vez que se llevaba a cabo el proceso de eliminación de las relaciones precarias y el establecimiento de una racionalidad completamente capitalista.

En efecto, al hablar del proceso de modernización en el Ecuador, se ha de abordar el tema agrario y su carácter pre-capitalista, debido al papel desempeñado por el sector primario a la hora de abastecer las necesidades de consumo interno y la exportación, y la existencia de una elevada masa de mano de obra indígena y campesina, cuyo potencial productivo no era utilizado completamente. La permanencia de las relaciones de producción tradicionales se reflejaba en las carencias tecnológicas, en la falta de educación de la población y en su estado de retraso; mientras que la ausencia de una racionalidad acumulativa en el agro ponía de manifiesto por otro lado, la caducidad del sistema de hacienda, que era un obstáculo al desarrollo de la economía nacional. $^{856}$

Desde esta perspectiva, los factores mencionados impedían el paso hacia prácticas capitalistas que debían de concordar con las demandas a nivel internacional. Así, la penetración del capitalismo en las haciendas serranas debía de ir por el camino de las transformaciones graduales de las relaciones de renta en trabajo en las haciendas, situación que tenía como prioridad la división de la clase terrateniente. Por consiguiente, en 1964, la Ley de Reforma Agraria y Colonización rompió con el relativo bloqueo de la transición al capitalismo, obligando la intervención estatal a disolver las relaciones huasipungueras de trabajo y otras formas similares. $^{857}$

A partir de estas ideas, considerando la cuestión agraria en lo que se refiere a la estructura de la hacienda serrana y el carácter de las transformaciones en la Sierra durante esa época, vamos a estudiar a continuación, cuál fue el papel del estado bajo la influencia de la Junta Militar, así como el impacto de las políticas desarrollistas que fueron impulsadas en el agro serrano, centrándonos para ello, en la primera Ley de Reforma Agraria del 11 de julio de 1964.

En el estudio del sector agrario ecuatoriano, se ha de tener presente la gran influencia que el proceso político ha ejercido a lo largo de la historia del país. En este sentido, como consecuencia de la permanencia de las relaciones pre-capitalistas, las diferencias entre la Costa y la Sierra y la

\footnotetext{
${ }^{856}$ En relación al atraso técnico de la agricultura ecuatoriana, los datos de la CEPAL indican que en 1952, había un tractor por cada 900 hectáreas de tierra cultivada, lo cual significaba un porcentaje prácticamente inexistente de mecanización de la agricultura ecuatoriana, sobre todo, si se tiene en cuenta que este número de tractores estaba concentrado en las grandes empresas imperialistas. Fuente: Pedro Saad, op. cit. p. 3-27.

${ }^{857}$ Andrés Guerrero, Haciendas, capital..., op. cit. p. 5-40.
} 
tardía constitución de una fracción burguesa, no se pudo organizar un sistema político adecuado para organizar los conflictos con estabilidad.

Esta situación hizo que, en los momentos fundamentales, el nivel de consenso requerido que exigía costosas negociaciones entre la tecnocracia, los partidos políticos y los militares para fomentar un conjunto de transformaciones en el país (como el caso del agro), se viera obstaculizado por fuerzas con gran poder:

Esto muestra como el proceso social-político transcurre en dos niveles. Los sectores reformistas de las Fuerzas Armadas, la tecno-burocracia y otros sectores que se expresan fundamentalmente a nivel del aparato estatal y de la estructura jurídico-política, no tienen demasiados problemas para aprobar una ley agraria. Pero, cuando la misma está en vías de ejecución, esta no puede realizarse sin el apoyo de las clases dominantes. ${ }^{858}$

Según Gonzalo Abad, el estado ecuatoriano dirigido por la Junta Militar, asumió una forma híbrida en relación a dos tipos extremos de militarismo característicos de América Latina. El primero hace alusión a la forma de intervención tradicional en la manera en que un militar cuenta con suficiente apoyo para ser presidente, instala un estado militar tradicional en sociedades fundamentalmente agrarias y concede favores a la oligarquía nativa, compañías extranjeras y sus lugartenientes. El segundo tipo hace referencia al denominado estado burocrático-autoritario, cuyos rasgos centrales consisten en la exclusión estructural de las organizaciones políticas y gremiales, la reformulación del sistema de representación corporativa y la implantación de un modelo económico que reduce la redistribución del ingreso y se orienta a beneficiar a los sectores de la alta capitalización asociada al capital internacional. ${ }^{859}$

La estructura del estado ecuatoriano de esta época estaba formada por una cúpula de militares, políticos y empresarios, mientras que los sectores populares no llegaron a desempeñar un papel significativo en el diseño de la política. De este modo, independientemente de los conflictos y

\footnotetext{
${ }^{858}$ Gustavo Cosse, Reflexiones..., op. cit. p.419-420.

${ }^{859}$ Gonzalo Abad, op. cit. p. 142-143.
} 
acuerdos establecidos, este tipo de estado no llegó a adquirir la capacidad suficiente para favorecer una orientación predominante de las Fuerzas Armadas. ${ }^{860}$

Además de los conflictos entre la sociedad política y la civil, que hacía que esta segunda se enfrentara al poder estatal sin apenas mediaciones, se ha de mencionar la existencia de un periodo de numerosas contradicciones entre fracciones de clases dominantes. Es decir, las acciones de modernización planeadas por el estado, entre las que se encontraba la reforma del agro, enfrentaron a una amplia alianza de diversas fuerzas políticas, que fueron acabando con la reducción de su base de apoyo. De esta manera, el gobierno militar ejercía su poder conteniendo las acciones de los partidos tradicionales, pero no contaba con el poder suficiente para independizarse debido a que estaba formado por un mayor número de civiles que de militares. ${ }^{861}$ Esta estructura expresaba la denominada "alianza antagónica" de los sectores de Galo Plaza y Camilo Ponce, los cuales apoyaban la ruptura institucional y defendían el fin del gobierno de Arosemena, a pesar de tener proyectos diferentes. Para el poncismo, una vez neutralizado el sindicalismo y la izquierda, lo importante era mantener el statu quo. Para el placismo, la corriente desarrollista más importante del país, lo fundamental era establecer un conjunto de cambios que eliminara las posibles amenazas para la modernización de la sociedad ecuatoriana.

En esta situación, el gobierno creó la ley agraria y logró permanecer en el poder el tiempo suficiente para llevar a cabo las reformas planificadas, pese a que en mayo de 1964, se rompió la alianza indicada como consecuencia de los intentos del poncismo para deshacerse de los militares y evitar la Ley de Reforma Agraria.

Aquí, se aprecia cómo el caso ecuatoriano constituye un proceso de generación de consenso en relación a las transformaciones, el cual fue creado a partir de un nivel de la sociedad política (militares, partidos políticos, tecno-burocracia y representantes del sistema internacional), pero no logró alcanzar a una buena parte de las fracciones de las clases dominantes. Ante la incapacidad de establecer un sistema político que facilitara ese consenso fragmentado, la Junta

\footnotetext{
${ }^{860}$ En el caso de otros países de América Latina, como ocurrió en Perú, el régimen militar liderado por el General Velasco Alvarado (1968-1975) expresaba de forma diferente el estado militar, al tratarse de una intervención de tipo autoritario. No obstante, el contenido de esa intervención era diferente al de América Latina en la década de los sesenta, pues se establecía una reforma agraria que eliminaba el gamonalismo y permitía expandir el sector estatal de la economía, mientras que el estado trataba de conducir la movilización social de ciertos sectores. En comparación con el caso ecuatoriano, se observa que el régimen parecía menos dependiente de las fuerzas políticas y sociales y fomentaba transformaciones más profundas en el agro. Fuente: Gonzalo Abad, op. cit. p.143.

${ }^{861}$ Rafael Quintero, Erika Silva, op. cit. p. 240-244.
} 
Militar asumió la implantación del proceso de modernización, al que las clases dominantes afectadas se oponían. ${ }^{862}$

Así, durante la presidencia del gobierno militar, se establecieron algunas medidas que llevaron a la mencionada alianza entre diversos sectores de las clases dominantes, tal y como ocurrió con los latifundistas tradicionales y los sectores ligados al comercio de exportación-importación. Por un lado, la reforma agraria estaba en contra de los intereses de los terratenientes tradicionales expresados en el poncismo, y por otro, los intentos para unificar el sistema tributario y eliminar la descentralización presupuestaria regional y provincial, generaron la oposición de sectores dominantes (como los de Guayaquil). ${ }^{863}$

Miguel Murmis explica la falta de autoridad de esta alianza a la hora de liderar el proceso de modernización capitalista a cargo de la Junta Militar, y hace alusión a la escasa importancia que la iniciativa terrateniente tuvo en la liquidación del trabajo precario, el cual estaba reducido al norte de la Sierra. ${ }^{864}$

También, apunta a la imposibilidad de establecer una alianza con otras fracciones de clase dominante, en la medida en que entre ellas no existía un acuerdo o la necesidad de ceder posiciones. Ante todo, este hecho se establece a partir de la oposición de importadores y banqueros a las medidas impulsadas por el gobierno militar, que constituían un conjunto de iniciativas como la reforma del agro. A esto, se ha de añadir el poder de los sectores agrarios modernizantes del placismo, los cuales desempeñaron un papel clave en la discusión de la Ley de Reforma Agraria. Así, desde un primer momento, la supervivencia de la política agraria se originó de forma comprometida por el hecho de ser parte de una serie de transformaciones dentro de un complicado contexto político y social.

En este sentido, la ausencia de poder de los terratenientes modernizantes o de algún proyecto burgués modernizador para establecer una alianza social y lograr el desarrollo capitalista condujo a que las Fuerzas Armadas ocuparan ese espacio social y político con las características anteriormente mencionadas. No obstante, aquí se ha de volver a indicar la interpretación de este proceso como un acuerdo fragmentado, sobre todo en el panorama agrario, pues a pesar de que la

\footnotetext{
${ }^{862}$ Gonzalo Abad, op. cit. p. 147-149.

${ }^{863}$ Ibíd. p. 147-149.

${ }^{864}$ Miguel Murmis: Sobre la emergencia de una burguesía terrateniente capitalista en la Sierra ecuatoriana como condicionamiento de la acción estatal, Revista de Ciencias Sociales, Vol. II, número, 5, Quito, 1978.
} 
Junta Militar podía emprender la reforma agraria, carecía del apoyo suficiente para asegurar su marcha. ${ }^{865}$

Las discusiones parlamentarias previas al comienzo del gobierno militar, ponen de relieve la existencia de un elevado apoyo a las transformaciones agrarias, entendidas a partir de la erradicación del trabajo precario. Sin embargo, cuando se trató de llevar adelante esas transformaciones, estaba claro que el apoyo político no expresaba el favor social necesario, situación que reflejaba la incapacidad de la estructura política para expresar las contradicciones de la sociedad civil, y por consiguiente, para hacer posible ciertas transformaciones. En este caso, y como explica Gustavo Cosse, el acuerdo a nivel de partidos y Parlamento no era demasiado relevante para expresar la correlación de fuerzas existentes, es decir, la ruptura entre lo político y lo social hizo que el consenso al primer nivel no fuese reconocido, dejando entrever la inexistencia de una estructura de representación en el país. ${ }^{866}$

A este respecto, Rafael Quintero y Erika Silva indican que el gobierno estaba compuesto por los distintos miembros (terratenientes y burguesía) que representaban las subdivisiones del partido conservador y liberal, además de los militares defensores de la Alianza para el Progreso y de las ideas anticomunistas y pro-norteamericanas. Pese a esto, en realidad, los sectores de la burguesía y la tecnoburocracia social vinculada a la Junta Militar, solo fueron simples agentes utilizados para apoyar el proyecto autoritario militar, los cuales eran convocados con la excusa de participar en la creación del supuesto plan reformista del régimen. Esta situación explica los problemas que fueron surgiendo cuando dichas clases sociales dejaron de apoyar a la Junta, ante la imposibilidad de llegar a un acuerdo para cubrir sus demandas sociales. ${ }^{867}$ También, lo refleja César Verduga cuando dice:

\footnotetext{
${ }^{865}$ Gonzalo Abad, op. cit. p. 147-149.

${ }^{866}$ Gustavo Cosse, op. cit. p. 418-421.

${ }^{867}$ Rafael Quintero, Erika Silva, op. cit. p. 243.
} 
En un inicio, este sueño de poder de las clases medias, fantaseado por la tecnoburocracia y profesionales independientes convertidos en empleados públicos, se tradujo, a nivel ideológico, en la pantalla reformista del régimen. ${ }^{868}$

Además, el proyecto autoritario de la Junta tenía como objetivo intervenir en los procesos legales limitando los derechos políticos y civiles de la población, y de este modo, crear un clima adecuado para reafirmar la política imperialista. Entre las reformas realizadas, se encontraban la del Código Penal, la represión legal de las organizaciones populares y la de la Ley de Educación Superior eliminando la autonomía universitaria.

Siendo la dictadura militar un intento de centralizar vertical y coercitivamente el espacio nacional, tanto en lo referente al aparato del estado, como a través de una política integracionista (uno de cuyos puntales fue la ley de reforma agraria que se tradujo en cubrir áreas territoriales integrándolas a la producción), sus políticas fueron dirigidas a fortalecer al estado, al mismo tiempo que golpeaba a los sectores más avanzados de la sociedad civil. ${ }^{869}$

Por su parte, la reforma del agro cambió la modalidad histórica de incorporación de la cuestión política como hecho regional, pues las modificaciones en la Sierra ecuatoriana tuvieron un mayor impacto. ${ }^{870}$ La cuestión agraria apareció en el campo político, al tiempo que se crearon varias propuestas políticas y una tendencia social general en la cual, todas las clases y fracciones de clases estaban inmersas de formas diferentes, implicando prácticas políticas diversas sobre los modos de desarrollo capitalista del agro. ${ }^{871}$

Además de esto, llama la atención el hecho de que la cuestión agraria fuera interpretada como un asunto de tipo nacional, al incorporar todo el marco territorial de la formación social y concentrar las exigencias de varios sectores urbanos y rurales. Precisamente, este carácter puso de relieve la

\footnotetext{
${ }^{868}$ César Verduga: Política económica y desarrollo capitalista en el Ecuador contemporáneo, Quito: Escuela de Sociología, UCE-Quito, segunda edición, 1977, p. 46.

${ }^{869}$ Rafael Quintero, Erika Silva, op. cit., p. 242.

${ }^{870}$ Al hablar de los cambios en la Sierra ecuatoriana, nos referimos al paso de las relaciones pre-capitalistas a salariales como se ha estudiado en el capítulo 3.

${ }^{871}$ Rafael Quintero, Erika Silva, op. cit. p. 239-317.
} 
falta de una formación nacional ecuatoriana, ya que mostraba los problemas políticos entre las fracciones dominantes para asumir el desafío de la sociedad civil y buscar una solución a un problema tan importante como el agro.

Pedro Saad indica que la burguesía pretendía resolver esta situación mediante la vía de la colonización de las tierras baldías y la parcelación de los latifundios. Sin embargo, aún cuando los campesinos hubieran podido acceder a una parcela de tierra, la falta de créditos y ayuda técnica, los habría llevado a perder dicha propiedad a corto plazo. ${ }^{872}$

Por su parte, la lucha de los sectores agrarios en la Sierra y en la Costa estaba centrada en algunos aspectos reivindicativos. Así, la Federación Ecuatoriana de Indios (FEI) planteaba como proyecto de reforma agraria, la entrega gratuita de la tierra al campesino, la eliminación de las relaciones pre-capitalistas, la entrega de propiedades del huasipungo, diversos mecanismos de ayuda al agricultor (crédito y asistencia técnica), el aumento de los salarios y una garantía de los derechos laborales. ${ }^{873}$ Es decir, las demandas del movimiento campesino querían acabar con el latifundio en la Sierra y en la Costa y pugnaban por una vía campesina de transformación agraria.

A este respecto, aunque ya se ha analizado con más detalle el papel de los terratenientes en el proceso de entrega de tierras previo a la Ley de Reforma Agraria, no se puede olvidar la participación del campesinado que, en cierta forma, se ha visto reducida al ser comparada con los movimientos de otros países de América Latina, tales como el mexicano y peruano, en los que la extensión y organización del movimiento ha sido mucho mayor en la manera en que se fueron apropiando el espacio nacional. ${ }^{874}$

Por su parte, Barraclough y Collarte señalan que la reforma agraria pretendía evitar un conflicto con las masas campesinas, las cuales buscaban eliminar el latifundio en la Sierra y en la Costa. ${ }^{875}$ Esta estrategia implicaba dos ideas que parecían opuestas al incluir por un lado, la idea de la

\footnotetext{
${ }^{872}$ Pedro Saab, op. cit. p. 23.

${ }^{873}$ Para más información de la FEI, ver el apéndice de notas del capítulo 4. Fuente: Ibid. p. 3-26.

${ }^{874}$ Rafael Quintero y Erika Silva dicen que aún cuando el movimiento campesino en el Ecuador no tuvo la misma fuerza que en otros países, no puede olvidarse su impacto en la sociedad. Ver el apéndice de notas del capítulo 4 para más información. Fuente: Rafael Quintero, Erika Silva, op. cit., p. 239-244.

${ }^{875}$ S. Barraclough, J. Collarte: Tenencia de la tierra y desarrollo socio-económico del sector agrícola, Ecuador, Resumen del Informe del CIDA, FLACSO, 1976, p. 359.
} 
iniciativa terrateniente, y por otro, la de la existencia del movimiento campesino, cuyas acciones no fueron las responsables de que la clase dominante planificara un reajuste de fuerzas mediante una reforma del agro. Así, el movimiento campesino logró vincular su lucha con otros sectores como el artesanado, el movimiento estudiantil y los intelectuales urbanos, creando una alianza con el incipiente proletariado urbano de la Costa y de la Sierra.

La lucha de los estratos populares agrarios en Sierra y Costa se centraba en varios puntos que eran privilegiados según la región. Así, la FEI y otras organizaciones planteaban como proyecto de reforma agraria: entrega gratuita de la tierra al campesino, destrucción de relaciones pre-capitalistas, entrega en propiedad del huasipungo, medios complementarios de ayuda al agricultor como crédito y asistencia técnica, defensa de la comunidad india como potencial base de constitución de modernas cooperativas agrícolas, alza de salarios, garantía de los derechos laborales. ${ }^{876}$

A pesar de esto, el aumento del acuerdo popular no logró acabar con la acción de las clases dominantes regionales en el estado, las que comprendiendo el peligro en que se encontraban sus intereses, decidieron elaborar varios proyectos para poner fin al movimiento que defendía la reforma agraria.

Finalmente, ante este panorama, el 11 de Julio de 1964, se dictó la primera Ley de Reforma Agraria y Colonización y la Ley de Tierras Baldías y Colonización (28-09-1964), creándose también, el Instituto Ecuatoriano de Reforma Agraria y Colonización (IERAC) encargado de ejecutar dicha reforma. ${ }^{877}$ Los organismos encargados de elaborar la política agraria, como fue el caso del Consejo Ejecutivo del IERAC, estaban formados por terratenientes que actuaban a través de los miembros de las Cámaras de Agricultura, mientras que los representantes laborales fueron designados directamente por la Junta Militar. Además, los hacendados de la Sierra y Costa, incluso aquellos vinculados por sectores más tradicionales, fueron tomados en cuenta para presidir el Ministerio de Agricultura y el IERAC. ${ }^{878}$

\footnotetext{
${ }^{876}$ Pedro Saad, op. cit. p.23.

${ }^{877}$ Para más información sobre el IERAC, ver el apéndice de notas del capítulo 4. Fuente: Osvaldo Barsky, Gustavo Cosse, Tecnología..., op. cit. p. 40-75.

${ }^{878}$ Ver el apéndice de notas del capítulo 4 para más información. Fuente: J.F. Uggen: Peasant mobilization in Ecuador: A case study of the Guayas Province, Tesis doctoral, Universidad de Miami, 1975, p. 206-207.
} 
El contenido de la Ley de 1964, lejos de reflejar los deseos de los campesinos, recogía las ideas sobre la reforma agraria, formuladas en la reunión de ministros de la Organización de los Estados Americanos en Punta del Este (Uruguay) en 1961, y que coincidían con el programa Alianza para el Progreso, impulsado en América Latina por los Estados Unidos.

El dictado de esta ley fue desde el punto de vista del contenido, una continuidad de una gran cantidad de aspectos contemplados en los proyectos anteriores, como fue el caso de los proyectos elaborados por la Junta Nacional de Planificación, la Comisión Ecuatoriana de la Alianza para el Progreso, el Partido Liberal, el Consejo Nacional de Economía, y la Comisión de la Cámara de Diputados. ${ }^{879}$

En este contexto, la promulgación de la primera ley de reforma por parte de la dictadura militar, incluía diversos proyectos de reforma agraria de los terratenientes y, en ese sentido, implantó una vía autoritaria y oligárquica de cambios en el agro, que favorecía los intereses de los hacendados:

El carácter oligárquico y antipopular de la Ley de Reforma Agraria de 1964, ha sido mostrado en varios estudios. Con la excepción de la erradicación del trabajo precario (huasipungo y yanapa) planteado por el movimiento campesino, ninguna otra reivindicación del movimiento fue tomada en cuenta. ${ }^{880}$

Pese a que la reforma agraria y la colonización eran dinámicas distintas, estaban unidas de forma indisoluble en la práctica. ${ }^{881}$ Así, si bien ya existía una Ley de Tierras Baldías y Colonización expedida en 1936 y un Instituto Nacional de Colonización creado en 1957, la Ley de 1964 establecía dos novedades fundamentales: la incorporación de la reforma agraria con un objetivo

\footnotetext{
${ }^{879}$ Osvaldo Barsky, Los terratenientes serranos..., op. cit. p. 133-206.

${ }^{880}$ Rafael Quintero, Erika Silva, op. cit. p. 259; Miguel Murmis, El agro serrano..., op. cit. p. 7-50, 1980, P. Saad: La reforma agraria, en La Reforma agraria democrática, Guayaquil, Edit. Claridad, 1976, p. 27-110, F. Velasco: Reforma agraria y movimiento campesino indígena de la Sierra, Quito, Edit. El Conejo, 1979.

${ }^{881}$ F. Brassel, S. Herrera, M. Laforge: ¿Reforma agraria en el Ecuador? Viejos temas, nuevos argumentos, SIPAE, Quito, 2008, p. 18.
} 
marcado de cambio estructural del agro y la articulación de la reforma agraria con la colonización como dos facetas de una misma acción. ${ }^{882}$

La estructura de la tenencia de tierra en Ecuador es herencia (...) que ha perpetuado de producción y modalidades de relaciones sociales que hoy son absolutamente anacrónicas y opuestas a los ideales (...). De acuerdo al Censo de 1954, en 1.369 explotaciones, es decir, en 0,4\% del total, se concentra el 45,1\% de la superficie. En cambio, (...) el 73,1\% de las explotaciones tiene tan solo el 7,2\% de la superficie. ${ }^{883}$

Se ha concebido a la Reforma Agraria y a la Colonización (...) considerando que su acción (en singular, como único fenómeno), debe estar encauzada a poner en marcha un (...) proceso de cambio de la defectuosa estructura de la tenencia de la tierra y promover una racional expansión de la frontera agrícola. ${ }^{884}$

Para la realización de un proceso de Reforma Agraria (...) se han concebido (...) medidas coadyuvantes y complementarias. (...). Entre ellas, se destaca la Colonización, como política conducente a absorber los desplazamientos demográficos (...). ${ }^{885}$

En este sentido, la reforma agraria y la colonización han sido dos partes de una misma política, ya que buscaban una mayor integración nacional por medio de acciones dirigidas por el estado, con las que se pretendía incorporar a los campesinos marginados a la sociedad y unir las amplias zonas vacías al territorio nacional. ${ }^{886}$

Así pues, la reforma agraria destacaba la existencia de tierras con un elevado número de mano de obra, a diferencia de las tierras baldías, que tenían pocos habitantes y debían ser colonizadas, es decir, se pretendía ofrecer una imagen coherente para que las tierras abandonas y atrasadas se

\footnotetext{
${ }^{882}$ Pierre Gandard, Hubert Mazurek: Treinta años de reforma agraria y colonización en el Ecuador (1964-1994): Dinámicas espaciales, en Dinámicas territoriales: Ecuador, Bolivia, Perú Venezuela, Estudios de Geografía, vol. 10, CGE/Corporación Editorial Nacional, Pontificia Universidad Católica del Ecuador, PUCE, Quito, 2001.

${ }^{883}$ Exposición de motivos de la Ley de Reforma Agraria de 1964, párrafo 3.

${ }^{884}$ Ibíd. párrafo 5.

${ }^{885}$ Ibíd. párrafo 7.

${ }^{886}$ Para más información del proceso de colonización, ver el apéndice de notas del capítulo 4. Fuente: O. Barsky et al: Políticas agrarias, colonización y desarrollo rural en el Ecuador, Quito, OEA-CEPLAE, 1982, p. 63-65.
} 
integraran a la modernidad y a la economía. A su vez, la colonización destacaba que las zonas con mucha población estaban junto a predios grandes y de escasa productividad agrícola.

En la mayoría de los casos, este contraste se basaba más en el empleo de mano de obra precaria que en los nuevos modos de tecnificación del agro, por lo que la reforma agraria estaba obligada a buscar una solución a estas importantes restricciones al desarrollo, juntando los objetivos sociales y económicos en un mismo movimiento político. ${ }^{887}$

Por su parte, Fernando Velasco indica que uno de los objetivos perseguidos con la Ley de la Reforma Agraria, fue la búsqueda de la ampliación del mercado interno mediante la implantación de las relaciones salariales en el campo y la eliminación de los rasgos feudales que todavía existían. No obstante, hay que aclarar que el mercado urbano contaba con mayor probabilidad de crecimiento que el mercado rural, expandiendo el gobierno militar el poder de compra de los sectores medios, en especial, el de los sectores vinculados a la burocracia. ${ }^{888}$

El Ecuador necesita modificar la estructura de su economía y convertirse en un país agrario-industrial, porque de otro modo, nuestra economía seguirá siendo una economía débil y retrasada. Pero el desarrollo industrial requiere forzosamente la creación de un mercado interior que absorba los productos industriales y requiere forzosamente la producción de materias primas necesarias para la industria. Si no resolvemos estos dos problemas, no estaremos en condiciones de ir a la transformación radical de la estructura económica del país. Por eso, tiene importancia vital, examinar todo el problema agrario del Ecuador como parte de la transformación de la vida nacional. ${ }^{889}$

A través de estas acciones, la Junta Militar buscaba aumentar el apoyo social y político que recibía, a pesar de que estos sectores ya no contaban con los mismos mecanismos políticos de épocas anteriores con los que solían lograr una participación efectiva. Además, los militares que actuaban en nombre de la burguesía industrial, no pudieron y tampoco quisieron apoyarse en las masas campesinas para lograr su programa de reformas, por lo que impulsados por sus ideas

\footnotetext{
${ }^{887}$ Ibíd. p. 63-65.

${ }^{888}$ Fernando Velasco Abad, op. cit. p. 30-220.

${ }^{889}$ Pedro Saab, Obras..., op. cit. p. 30.
} 
políticas y tratando de asegurar los beneficios de los inversionistas, reprimieron duramente a los organismos de los trabajadores y a los movimientos políticos de izquierda. ${ }^{890}$

Mediante su mecanismo de represión, la Junta Militar ilegalizó al Partido Comunista (PC) del Ecuador, mandó encarcelar a más de doscientos líderes políticos, persiguió y asesinó a algunos dirigentes de la Confederación de Trabajadores del Ecuador (CTE) y puso en marcha una campaña antiobrera con la que impedía que los trabajadores ejercieran sus derechos básicos (establecimiento de una jornada de trabajo definida y estable, el pago de utilidades de las empresas y de sus bienes, etc.). ${ }^{891}$

A esto, Rafael Quintero y Erika Silva añaden que la represión ya se venía produciendo con anterioridad al golpe de estado. ${ }^{892}$

Inclusive desde antes del golpe, el aparato represivo había creado ciertas zonas del país donde ya no regían las leyes de la República sino la voluntad de uno u otro jefe militar. Eran los casos del campo lojano, manabita y ciertas haciendas costeñas. En estos lugares, el batallón Febres Cordero asesinó a cerca de 1.500 campesinos y trabajadores... ${ }^{893}$

De este modo, la adopción de medidas reformistas en el agro fue vista como un mecanismo para obtener mayores niveles de productividad y eficiencia entre los trabajadores agrícolas. Para ello, se eliminarían las modalidades tradicionales de tenencia de la tierra y se liberaría la mano de obra indígena de la hacienda para proporcionar trabajadores a las empresas industriales, generar mercado interno e integrar a los habitantes del campo en el capitalismo. Se buscaba instaurar un

\footnotetext{
${ }^{890}$ Para más información del programa industrial de la Junta Militar, ver el apéndice de notas del capítulo 4. Fuente: Cristóbal Kay: Reforma agraria, industrialización y desarrollo: ¿Por qué Asia Oriental superó a América Latina?, Debate agrario: análisis y alternativas; publicación trim. del Centro Peruano de Estudios Sociales, Lima, 2002, p. 4594.

${ }^{891}$ Ver el apéndice de notas del capítulo 4 para más información. Fuente: Lazar Jeifets, Víctor Jeifets: Los orígenes del Partido Comunista del Ecuador y la Tercera Internacional, Revista Izquierdas, año 3, número 6, 2010, América Latina en movimiento: Movimiento sindical, La Riqueza de la Diversidad, alainet.org/publica/diversidad/sindicalismo.html, Efrén Avilés: "Dr. Carlos Alberto Arroyo del Río", Enciclopedia del Ecuador, www.enciclopediadelecuador.com, 2012.

${ }^{892}$ Rafael Quintero, Erika Silva, op. cit. p. 241-242.

${ }^{893}$ Ibíd. p. 242.
} 
sistema más dinámico y modificar las condiciones de vida de la población agraria con la creación de mayores oportunidades de ingreso, educación, salud y modernización. ${ }^{894}$

La Ley de Reforma Agraria de 1964 recogía bastantes elementos establecidos en los proyectos elaborados por distintas comisiones, pero señalaba un momento diferente en la discusión del problema agrario: la puesta en marcha del primer intento estatal para modificar la estructura de la propiedad territorial a través de la elaboración de un proyecto modernizante. Paralelamente, se pretendía parar el movimiento campesino y encaminar sus demandas hacia los objetivos propuestos en ese proyecto modernizante. ${ }^{895}$

De acuerdo con la Ley de Reforma Agraria, el IERAC estableció un conjunto de prioridades para su acción, siendo el objetivo principal, la erradicación de las formas de trabajo precario (huasipungueros, aparceros y otras formas). De este modo, en primer lugar, se intervendrían las haciendas del estado para después pasar a las propiedades semi-públicas o privadas con fines sociales, y por último, las propiedades privadas. ${ }^{896}$

El proyecto del IERAC contemplaba la entrega de tierras o fincas familiares de cinco hectáreas como promedio en la zona baja y, entre quince y veinte hectáreas en la zona intermedia y alta. Los beneficiarios serían los huasipungueros, los partidarios con residencia en la hacienda y un pequeño número de jornaleros (arrimados) que trabajaban permanentemente en la hacienda.

En el caso de las haciendas administradas por la Asistencia Social, el objetivo fundamental que perseguía el IERAC, no solo consistía en la eliminación de las relaciones precarias, sino que pretendía dotar a los trabajadores beneficiados de los recursos mínimos para establecer explotaciones racionales, capaces de absorber la mano de obra familiar, producir alimentos e integrarse al mercado. Para que esta política tuviera éxito, se necesitaban haciendas con tierras

\footnotetext{
${ }^{894}$ Augusto Varas, Fernando Bustamante: Fuerzas Armadas y Política en Ecuador, Quito: Ediciones Latinoamérica, 1978 , p. 63.

${ }^{895}$ Para más información de los propósitos de la Ley de Reforma Agraria de 1964, ver el apéndice de notas del capítulo 4. Fuente: Marco Jaramillo Pavón: La economía campesina y la reforma agraria en el Ecuador, en Economía/Ecuador: 1830-1980, Libro del Sesquicentenario, Tomo III, Corporación Editora Nacional, 1983, p. 159185 .

${ }^{896}$ Comité Interamericano de Desarrollo Agrícola: Tenencia de la tierra y desarrollo socio-económico del sector agrícola: Ecuador, capítulo V, Unión Panamericana, 1965, p. 506.
} 
suficientes para el establecimiento de fincas familiares; requisito indispensable que no siempre cumplían las haciendas intervenidas. ${ }^{897}$

Las adjudicaciones se efectuaron en las tierras de antiguos y nuevos asentamientos de la Sierra y de la Costa, pasando los predios a manos del IERAC. En efecto, se inició este programa teniendo como base los reasentamientos campesinos, las haciendas del estado, de la Asistencia Social, y de la Iglesia, entre otros organismos.

La tabla 1 (Adjudicación de tierras del sector privado, la Asistencia Social, el estado y otros organismos, diciembre de 1967) muestra el grupo de los predios intervenidos que pasarían a ser objeto de reasentamiento entre las familias de esa zona. De los cuarenta predios que aparecen en el cuadro, quince pertenecían al sector privado, uno a la Iglesia, seis al estado, otros quince a la Asistencia Social, y tres de ellos a otras instituciones, pasando a ser propiedad del IERAC por negociación, reversión o expropiación. ${ }^{898}$

En los promedios de las diferentes provincias se ha observado una notable diferencia en el nivel familiar: mientras los predios de la Sierra no pasaban de las seis hectáreas (Pichincha, Imbarura y Chimborazo), en la Costa, la cifra variaba entre diez y veinte hectáreas (El Oro y Guayas). ${ }^{899}$

Así, a través de la Ley de Reforma Agraria de 1964, se pretendía modernizar la actividad agropecuaria, a la vez que se buscaba preservar en lo fundamental, la estructura concentradora de la tenencia y uso de la tierra, cuestión que vino confirmándose durante la vigencia de esta Ley durante varios años. Es decir, existía una clara intención de mantener a la población trabajadora subordinada al capital, en cuanto a que era una reserva de mano de obra.

Marco Jaramillo destaca que la entrega de lotes individuales a los campesinos, no constituyó el problema fundamental, siendo la eliminación de los huasipungueros y de otras formas precarias, un modo de liberar mano de obra para dar paso a la modernización de la actividad agropecuaria, que ya sentía la presión de una elevada demanda de productos agrícolas: Desde ese punto de vista, la aplicación de la Reforma Agraria en el Ecuador puede considerarse un éxito. No así, se

\footnotetext{
${ }^{897}$ Informe del Instituto Nacional de Colonización, 1963-1964, p. 65-66.

${ }^{898}$ Esta tabla se encuentra en el apéndice de datos del capítulo 4. Fuente: Archivo de Providencias de adjudicación de tierras. Sección de evaluación y estadísticas, 1968. En Alfredo Costales y Piedad Costales: Historia Social del Ecuador: Reforma Agraria, Edit. Casa de la Cultura Ecuatoriana, Quito, 1971, p.-59.

${ }^{899}$ Ibíd., p.59.
} 
entendió que dicho proceso debía transformar la estructura de tenencia de la tierra y la estructura de poder correspondiente. ${ }^{900}$

Por su parte, Osvaldo Barsky afirma que la Reforma Agraria fue una medida que vino a moldear la combinación entre el tipo de cambios que los sectores urbanos y modernizantes del agro deseaban implementar, a lo que Gustavo Cosse añade. ${ }^{901}$

La ley se propone modernizar el agro, induciendo la racionalización empresarial de las explotaciones de baja productividad e incorporando las transformaciones a la amplia dotación de tierras públicas no explotadas y de la Asistencia Pública, generalmente agregadas a particulares. ${ }^{902}$

Pese a esta modernización, la ley tenía una mayor inclinación a proteger las haciendas tradicionales, las cuales pudieron adaptarse a las nuevas condiciones productivas ofreciendo su apoyo a la constitución de corporaciones agrícolas para que las tierras ociosas pudieran evitar la expropiación, a la vez que se daba un plazo de tres años a las haciendas ineficientemente explotadas para hacerlas productivas. ${ }^{903}$

En su estudio de la reforma agraria, Galo Viteri afirma que la Ley de 1964 se limitó únicamente al reconocimiento de los huasipungos y no a la necesidad de repartir la propiedad de forma equitativa entre los campesinos. Esto explica la distribución de tierras de baja productividad y la adjudicación de títulos individuales, lo que llevó a incrementar la comercialización de la tierra. También, habla de la importancia del papel desempeñado por la fracción de terratenientes que

\footnotetext{
900 Marco Jaramillo Pavón: La economía campesina y la reforma agraria en el Ecuador, en Economía/Ecuador: 1830-1980, Libro del Sesquicentenario, Tomo III, Corporación Editora Nacional, 1983, p. 159-185.

${ }^{901}$ Osvaldo Barsky, Los terratenientes serranos..., op. cit. p. 133-206.

${ }^{902}$ Gustavo Cosse, op. cit. p. 405.

${ }^{903}$ Para más información de la Ley de Reforma Agraria de 1964, ver apéndice de notas del capítulo 4. Fuente: César Verduga, Gustavo Cosse: Algunas consideraciones sobre las políticas estatales para el agro ecuatoriano (19641970), en Proyecto Cooperativo de Investigación sobre Tecnología Agropecuaria en América Latina (PROTAAL), Facultad Latinoamericana de Ciencias Sociales (FLACSO), documento número 29, 1978, p. 5-9. También, se ha consultado el Informe del Instituto Nacional y Colonización, 1963-1964, p. 29-43.
} 
apoyaba la reforma agraria a la hora de aprobar dicha ley, cuya necesidad era aceptada por una variedad de sectores políticos y sociales. ${ }^{904}$

Según este autor, existen algunos estudiosos del tema, como Luis Macas, que piensan que la Ley de Reforma Agraria de 1964, se debió a la exigencia de las comunidades de campesinos y a la presión externa para reformar el agro que, en aquellos momentos, existía en América Latina. ${ }^{905}$ Por su parte, Nina Pacari dice que las reformas en el agro tenían un objetivo de tipo político, ya que con ellas, se pretendía detener las movilizaciones de campesinos y su estructuración organizativa, teniendo como punto de mira la amenaza de la Revolución Cubana de 1959, que buscaba extenderse en América Latina y provocar numerosas revueltas sociales. ${ }^{906}$

Viteri apoya la tesis de Gustavo Cosse en cuanto a la existencia de otros factores que llevaron a una discusión para la reforma del sistema agrícola ecuatoriano: ${ }^{907}$

- El primero de estos factores, la presión internacional, incrementada tras la reunión de la Organización de Estados Americanos (OEA) en Punta del Este en 1961, y la aprobación del programa Alianza para el Progreso, pues la ayuda económica que el Ecuador recibía de Estados Unidos dependía de dichas transformaciones agrarias.

- En segundo lugar, se ha de hacer referencia a los estudios e investigaciones que algunos organismos internacionales llevaron a cabo y que ponían de manifiesto las deficiencias y la necesidad de acabar con las estructuras precarias de las haciendas. Este fue el caso del Comité Interamericano de Desarrollo Agrícola (CIDA), cuya labor fue primordial en la generalización de la problemática agraria y la urgencia de su transformación. A esto, se ha de sumar los estudios que manifestaban los problemas sociales de las haciendas terratenientes en cuanto a analfabetismo, baja esperanza de vida, etc.

- En tercer lugar, la importancia de los sectores tecnoburocráticos que, en los años cincuenta, empezaron a referirse a la necesidad de una reforma agraria. Fue el caso del

\footnotetext{
904 Galo Viteri Díaz: Reforma agraria en el Ecuador, editado por eumed.net, www.eumed.net/libros/2007b/298, 2007, p. 12.

905 Luis Macas: La tierra para los pueblos indígenas en el Ecuador, Boletín ICCI-ARY Rimay, Año 6, No. 58, enero del 2004, p. 1, en Galo Viteri Díaz, op. cit. p. 12.

906 Nina Pacari: La tenencia de tierras y rublos indígenas, en Latinoamérica agraria hacia el siglo XXI, CEPLAES, Quito, 1993, p. 392.

${ }^{907}$ Gustavo Cosse, op. cit. p. 398-399 en Galo Viteri Díaz, Reforma ..., op. cit. p. 4-5.
} 
Censo de 1954, al mostrar la disparidad tan extrema en el agro y la gran concentración de tierra en pocas manos.

- En cuarto lugar, los levantamientos del movimiento campesino, que pese a no poseer una estrategia nacional y tener numerosas limitaciones en sus reivindicaciones, no podían ser ignorados en su totalidad.

- Por último, se menciona el proceso de transformaciones registradas en las haciendas de la Sierra en la segunda mitad de la década de los cincuenta: el 15\% de los huasipungueros recibieron predios por el proceso de entrega de tierras por iniciativa terrateniente, lo cual a su vez representaba el 15\% del total de hectáreas en régimen de huasipungo. ${ }^{908}$

A este respecto, Galo Viteri aclara que aún cuando dichas transformaciones no fueron suficientes para modificar la estructura agraria, sí que tuvieron una importancia significativa para que las modificaciones fomentadas por el estado fueran viables.

Así, a partir de estas consideraciones, la Junta Militar puso en marcha la primera Ley de Reforma Agraria en 1964, a lo que Viteri añade la existencia de los planes de desarrollo que buscaban acabar con la pobreza del campo, impulsar la integración social y aumentar los niveles de productividad, entre otros objetivos propuestos:

Estos planes han definido a la Reforma Agraria como un conjunto de acciones simultáneas relativas a la distribución, tenencia y uso de la tierra en el contexto de proyectos de desarrollo rural integral. Han considerado a la Reforma Agraria, junto con el fomento agropecuario, como dos elementos actuantes que permitirán lograr un verdadero proceso de cambios en el agro con impactos de alcance nacional en todos los sectores de la economía. ${ }^{909}$

Por otra parte, dichas disposiciones ponían de manifiesto la inexistencia de una política orientada a afectar la tierra de los grandes latifundios durante el gobierno de la Junta Militar. ${ }^{910}$ Tal fue el

\footnotetext{
${ }^{908}$ Ibíd. p. 5.

909 Plan Integral de Transformación y Desarrollo 1973-1977; Plan Nacional de Desarrollo 1980-1984; Plan Nacional de Desarrollo Económico y Social 1989-1992, en Ibíd. p. 8.

910 Frank Brassel, Patricio Ruíz, Alex Zapatta: La estructura agraria en el Ecuador: Una aproximación a su problemática y tendencias, en: “¿Reforma Agraria en el Ecuador?, Viejos temas, nuevos argumentos”, Publ. Sipae, agosto 2008 .
} 
caso de las haciendas ociosas de la Costa, en las que el finquero arrendaba una parcela al terrateniente, al contar con la protección de la ley cuando estaba estipulado que los finqueros debían de pagar por la tierra y los arriendos atrasados o verse sometidos al desalojo por los terratenientes. ${ }^{911}$ Las consecuencias se reflejan en el débil crecimiento del sector agrícola, que apenas creció a una tasa anual de 0,8\% entre 1965 y 1970, tras cinco años con la Ley de Reforma Agrícola. $^{912}$

En su mayor parte, el alcance de la reforma agraria venía dado por los límites de la tenencia de la tierra. Teniendo en cuenta este criterio, la ley favoreció a la clase terrateniente de la Sierra y la Costa mediante arreglos legales para que los grandes latifundistas pudieran protegerse de posibles afectaciones durante mucho tiempo.

A consecuencia de esto, 10 años después de expedida la Ley de Reforma Agraria, en 1974, el $2.1 \%$ de las propiedades agropecuarias tenían bajo su control el $48 \%$ de la superficie agrícola del país, lo que significaba una leve variación con lo registrado en el censo de 1954, a pesar de las optimistas evaluaciones de la ley por parte de algunos investigadores. $^{913}$

En este sentido, la Ley concedió un plazo de tres años a las haciendas ineficientes explotadas para que fueran productivas, y también favoreció la creación de corporaciones agrícolas como la Sociedad en Predios Rústicos, mediante la cual, las tierras ociosas o con baja productividad podían escaparse de la expropiación. ${ }^{914}$

\footnotetext{
${ }^{911}$ Pedro Saad, La reforma..., op. cit. p. 27-110.

912 Manuel Chiriboga: La pobreza rural y la producción agropecuaria, p. 96, en: M. Chiriboga et al: El mito del desarrollo, Quito, Editorial El Conejo, 1982, p. 93-130.

${ }^{913}$ Rafael Quintero, Erika Silva, op. cit. p. 260.

914 Artículo 28 de la Ley de Reforma Agraria y Colonización de 1964, Informe del Instituto Nacional de Colonización, 1936-194, p. 33.
} 
La explotación agropecuaria y forestal podrá también hacerse mediante la Sociedad en Predios Rústicos, que se contratará de acuerdo con las modalidades propias de la sociedad civil de derecho y las disposiciones que siguen... ${ }^{915}$

Pedro Saad también indica cómo los hacendados de la Costa se vieron favorecidos por la Ley de Reforma Agraria, ya que las haciendas ociosas fueron protegidas cuando los finqueros tenían que pagar por la tierra y los arriendos atrasados y de no hacerlo, habrían sido desalojados por los terratenientes. $^{916}$

La ley es ampliamente generosa con los terratenientes, rebasando en materia de máximos a todos los proyectos de ley presentados desde 1960. El proyecto del Partido Liberal fijaba el máximo de los predios en 100 has. en Sierra y 200 en la Costa, aunque de hecho contenía tales ambigüedades, que haciendas de mayor tamaño tenían una mínima afectación. El proyecto del presidente Arosemena fijaba como máximo 600 has. en la Sierra y 900 has. en la Costa; el Proyecto del Consejo Nacional de Economía fijaba un máximo de 730 has. Por otro lado, la JUNAPLA aconsejaba afectar las tierras que excedían de 200 has. en la Costa y de 100 has. en la Sierra. Estas demandas resultaron radicales comparadas con los máximos establecidos en la Ley, los que alcanzaban en la Costa 2.500 has. más 1.000 de sabanas y pastos naturales y 800 has. en la Sierra más 1.000 has. para páramos. ${ }^{917}$

También, Fausto Jordán habla de estas concesiones realizadas a favor de los terratenientes y afirma que el objetivo de la Ley de 1964 consistía:

\footnotetext{
915 Artículo 94 de la Ley de Reforma Agraria y Colonización de 1964, Informe del Instituto Nacional de Colonización, 1936-194, p. 41.

${ }^{916}$ Pedro Saad, La reforma..., op. cit. p. 27-110, Rafael Quintero, Erika Silva, op. cit., p. 260.

${ }^{917}$ Ibíd. p. 260.
} 
En preservar de la eventual afectabilidad a las haciendas de alta productividad.... Al mismo tiempo, concedió un plazo de tres años para que esas unidades y haciendas adquieran condiciones de no afectabilidad. ${ }^{918}$

De este modo, a través de la vía legal, la reforma agraria pudo favorecer y proteger a los terratenientes de la Sierra y de la Costa de posibles afectaciones durante largos periodos de tiempo.

Además, la protección a los grandes latifundios privados pudo lograrse tras el establecimiento de políticas que tendían a priorizar otros regímenes similares a la reforma agraria. Así, se daba énfasis a la expropiación de las tierras estatales, mientras que en el caso de las tierras privadas se optó por la reversión sobre la expropiación, pues no había que pagarle al estado por las tierras revertidas. ${ }^{919}$

Una vez analizado el marco jurídico sobre el que se asentó la política agraria de la Junta Militar, vamos a pasar a estudiar las políticas estatales del agro a partir de la aplicación de la Ley de 1964. Para ello, seguiremos el esquema establecido por Manuel Chiriboga, en el que se estudia la política campesina, la política de fomento, y la ya mencionada política de tierras, cuya articulación dependía del grado de conflictividad social existente y de la relación entre las diversas fuerzas sociales. ${ }^{920}$

En relación a la política campesina y los aspectos socio-políticos de modernización en el campo, se observaba la necesidad de realizar cambios culturales en el mundo indígena para superar las condiciones de pobreza, analfabetismo y exclusión, aplicándose nuevas fórmulas para integrarlo a la sociedad nacional.

Entre los programas de desarrollo rural aplicados desde la segunda mitad del siglo, se encontraba el desarrollo de la comunidad como estrategia de integración indígena y campesina entre 1954 y 1963. Este programa llegó a la población rural con el Programa Andino para el Desarrollo de los

\footnotetext{
${ }^{918}$ Fausto Jordán: Reforma agraria en el Ecuador, en Proceso agrario en Bolivia y América Latina, Edit. CIDESUMSA, Biblioteca virtual CLACSO, 2003, p. 289-290.

${ }^{919}$ Ver el apéndice de notas del capítulo 4 para más información. Fuente: Gustavo Cosse, Reflexiones..., op. cit.; S. Barraclough, J. C. Collarte: Tenencia de la tierra y desarrollo socio-económico del sector agrícola, Ecuador, Resumen del Informe del CIDA, Quito, FLACSO, 1976, p. 356.

${ }_{920}$ Manuel Chiriboga: El estado y las políticas hacia el sector rural (1979-1989), en: "Ecuador Agrario", Quito, ILDIS-El Conejo, 1984, p.94-141.
} 
Grupos Indígenas, introducido por Naciones Unidas a través de la Misión Andina para el Ecuador. Posteriormente, entre 1964 y 1975, se introdujeron propuestas de desarrollo rural, combinadas con metodologías del enfoque de desarrollo de la comunidad, que incluían proyectos de desarrollo y colonización para lograr el paso de los trabajadores agrarios a una tendencia capitalista. $^{921}$

La acción de la Misión Andina del Ecuador desempeñó un papel muy importante como nueva política estatal hacia el campesinado, al ser desarrollada para acabar con la influencia de la izquierda en el campo y centralizar sus proyectos en la población indígena de las comunidades aisladas y con altos niveles de pobreza.

De este modo, ya para 1963, la Misión Andina había operado en unas setenta comunidades de la Sierra, en particular, en las provincias de Imbarura, Tungurahua, Chimborazo, Cañar, Azuay y Loja, mientras que para 1969, la Misión había llegado con sus programas a unos 130.000 campesinos serranos. $^{922}$

Entre las actividades emprendidas por la Misión se encontraba la mejora de la disponibilidad de alimentos y de las condiciones de vida, así como la enseñanza de oficios, siendo el elemento fundamental del enfoque, la formación de líderes campesinos a través de cursos de capacitación. Por otro lado, la Misión Andina, como iniciativa de política estatal hacia el campesinado, tenía el objetivo de eliminar la influencia de las federaciones campesinas con una orientación de izquierda. Esta iniciativa estaba relacionada con el tipo de política agraria de la Junta Militar, puesto que no solo pretendía evitar la amenaza de una revuelta campesina y trataba de no antagonizar a los terratenientes más poderosos de la Sierra y de la Costa, sino que también buscaba obtener su apoyo para sacar adelante las reformas en el agro. ${ }^{923}$

En relación a la política de tierras, la Junta Militar estableció una estrategia doble mediante la cual y a nivel del estado, hizo que los organismos responsables de la política de tierras, como era el caso del IERAC, se encargaran del control en la mediación entre el movimiento campesino y

\footnotetext{
${ }^{921}$ Dichos proyectos de desarrollo de la comunidad fueron establecidos por la Misión Campesina, organismo privado fundado por las Naciones Unidas en 1956, que pasó a denominarse Misión Andina del Ecuador (MAE) en 1963, durante el gobierno de la Junta Militar. Posteriormente, a partir de julio de 1970, esta entidad pasó a formar parte del Ministerio de Previsión Social y Trabajo como institución pública. Fuente: Paola Sylva: La organización rural en el Ecuador, Quito, Cepp - Abya Yala 1991, p. 42-43.

${ }^{922}$ Ibíd. p. 42-43.

${ }^{923}$ Ibíd. p. 42-43.
} 
el estado; mientras que a nivel de la sociedad civil, estableció vínculos con la central sindical CEDOC, controlada por el sector de la derecha y el clero conservador, cuyo objetivo era aislar al sector de la izquierda del movimiento campesino. ${ }^{924}$

Siguiendo la primera estrategia, la Ley de Reforma Agraria estableció que los diferentes tipos de tierras afectadas pasaran primero al poder del estado representado por el IERAC, quien a su vez, procedería a adjudicarlo al beneficiario correspondiente. ${ }^{925}$ De la misma manera, los artículos 53 y 178 de la ley, situaban a las cooperativas agrícolas bajo control directo del IERAC, a la vez que las solicitudes de todas las cooperativas debían ser aprobadas por dicho Instituto, lo cual implicaba el control por parte del gobierno en la formación de las organizaciones campesinas. ${ }^{926}$

El IERAC dará preferencia a las adjudicaciones a los campesinos tenedores de tierras en precario, sean arrendatarios, aparceros, sitiajeros, arrimados, colonos, sembradores, finqueros y otros similares residentes en las zonas intervenidas. ${ }^{927}$

El Ministerio de Previsión Social en el plazo de sesenta días a partir de la vigencia de esta Ley, enviará al IERAC la nómina e información completa de las Comunas y Cooperativas agrícolas establecidas con fines de adquirir tierras, las mismas que podrán ser controladas por el IERAC. ${ }^{928}$

Según Rafael Quintero y Erika Silva, detrás de todas esas medidas, se encontraba la intención política de la dictadura militar de crear un pacto militar-campesino para neutralizar al movimiento campesino, haciéndolo incondicional a las políticas estatales. Además, en ausencia

\footnotetext{
${ }^{924}$ Para más información sobre la Confederación Ecuatoriana de Obreros Católicos (CEDOC), ver el apéndice de notas del capítulo 4. Fuente: Jaime Durán: Movimientos sociales en Ecuador en 1970: Unidad y crisis de las centrales sindicales, en: Los movimientos populares en América Latina, Edit. Siglo XXI, Universidad de las Naciones Unidas, 1989; CEPEP: Las luchas campesinas 1950-1983. Movilización Campesina e historia de la FENOC, Quito, Centro de Educación Superior Popular (CEPED), Serie Movimiento Social, 1985, p. 8; Francisco Chiodi: Ecuador, capítulo III, en La educación indígena en América Latina: México, Guatemala, Tomo I, P. EbiAbya Yala, UNESCO/OREALC, 1990, p. 354.

${ }^{925}$ S. Barraclough, J. Collarte, op. cit. p. 357-358.

${ }^{926}$ J.F. Uggen, op. cit. p. 210.

927 Artículo 53 de la Ley de Reforma Agraria y Colonización de 1964, Capítulo V: De los adjudicatarios. Fuente: Informe del Instituto Nacional de Colonización, 1963-1964, p. 36.

${ }^{928}$ Artículo 178 de la Ley de Reforma Agraria y Colonización de 1964, Título X: Disposiciones Transitorias. Fuente: Informe del Instituto Nacional de Colonización, 1963-1964, p. 48.
} 
de clases dominantes hegemónicas nacionales, el ejército era el único aparato de poder que podía llevar adelante una política de este tipo. ${ }^{929}$

Este mecanismo autoritario de cambios en el agro, basado en este proyecto de pacto militarcampesino, tuvo como consecuencia un aumento de la represión policial y militar que era considerada como legal por la Ley de Reforma Agraria de 1964 en varios de sus artículos. Así, por ejemplo, el artículo 168 señalaba que las personas que se hubiesen apoderado de los predios por medios violentos, serían excluidas de los beneficios de la Reforma Agraria, mientras que el artículo 169, prohibía la invasión de tierras:

El IERAC llevará un Registro de quienes hayan ocupado o llegaren a ocupar la tierra violenta o clandestinamente, los que podrán ser excluidos de los beneficios de esta Ley, en especial del de compra y adjudicación de tierras del IERAC sin perjuicio de las responsabilidades civiles y penales. ${ }^{930}$

La fuerza pública intervendrá cada vez que fuere necesario para hacer cumplir los fallos y demás decisiones del IERAC. Especial empeño pondrá en impedir la ocupación de tierras que no fueren previamente autorizadas. ${ }^{931}$

El tercer elemento de la política agraria de fomento estaba centrado en la concesión de crédito, para lo cual, la Sección de Desarrollo Agropecuario de la Junta de Planificación estudió el problema de los bajos ingresos en el sector, que impedían al agricultor incrementar sus ahorros y destinarlos a nuevas inversiones. ${ }^{932}$ Para ello, utilizó una serie de instrumentos como la investigación, las políticas de precios y la educación agropecuaria, mediante los cuales, se pretendía impulsar el desarrollo de este sector:

\footnotetext{
${ }^{929}$ Rafael Quintero, Erika Silva, op. cit. p. 245-260.

${ }^{930}$ Artículo 168 de la Ley de Reforma Agraria y Colonización de 1964, Título IX: Disposiciones Generales. Fuente: Informe del Instituto Nacional de Colonización, 1963-1964, p. 47.

931 Artículo 169 de la Ley de Reforma Agraria y Colonización de 1964, Título IX: Disposiciones Generales. Fuente: Informe del Instituto Nacional de Colonización, 1963-1964, p. 48.

932 Ver el apéndice de notas del capítulo 4 para más información. Fuente: 25 Años de Planificación. JUNAPLA Edición, Selección y Notas: Dr. Germánico Salgado. Director Técnico de JUNAPLA. Econ. Eduardo Santos Alvite 1979, Secretaría Nacional de Planificación y Desarrollo, www.planificacion.gob.ec.
} 
El crédito agropecuario en las zonas de colonización y reforma agraria será otorgado por los Bancos del Sistema de Crédito de Fomento, que coordinarán con el IERAC la asistencia técnica y elaborarán conjuntamente, los programas de crédito en las zonas referidas, dando prioridad a la concesión de créditos de capacitación a campesinos de escasos recursos. ${ }^{933}$

Ante esta situación, un incremento del crédito agropecuario para técnicas de cultivo podía ser beneficioso, siempre y cuando se realizara con los instrumentos mencionados y con el establecimiento de las condiciones adecuadas en cuanto a las cantidades, plazos y oportunidades. De este modo, se podría romper el círculo de bajos ingresos, ahorros e inversiones que seguían existiendo en el sector agropecuario.

En los años 1960-1967, el Banco Central, el Banco Nacional de Fomento y algunos bancos privados concedieron a las diferentes actividades económicas las cantidades de crédito que se reflejan en el gráfico 1 (Crédito del sistema bancario por actividades, 1960-1967). Como puede apreciarse, en relación con las demás actividades, la agricultura recibió una proporción muy baja del crédito bancario entre 1960 y 1967, teniendo el comercio un mayor acceso a dicho crédito. ${ }^{934}$

\footnotetext{
933 Artículo 112 de la Ley de Reforma Agraria y Colonización de 1964, Capítulo III: Del crédito de la reforma agraria. Fuente: Informe del Instituto Nacional de Colonización, 1963-1964, p. 43.

${ }^{934}$ Ver el apéndice de notas del capítulo 4 para más información. Fuente: Juan J. Paz y Miño Cepeda: La fundación del Banco Central del Ecuador y su significado histórico a los 75 años, capítulo V, Taller de Historia Económica, número 2, Noviembre 2002, Banco Nacional de Fomento, Historia, www.bnf.fin.ec; Guillermo Guerra: La Planificación y el Desarrollo Agrícola e institucional en Ecuador, IICA, Dirección regional para la Zona Andina, apartado 478, Lima-Perú, junio, 1969, p. 64-65.
} 
Gráfico 1: Crédito del sistema bancario por actividades (1960-1967):

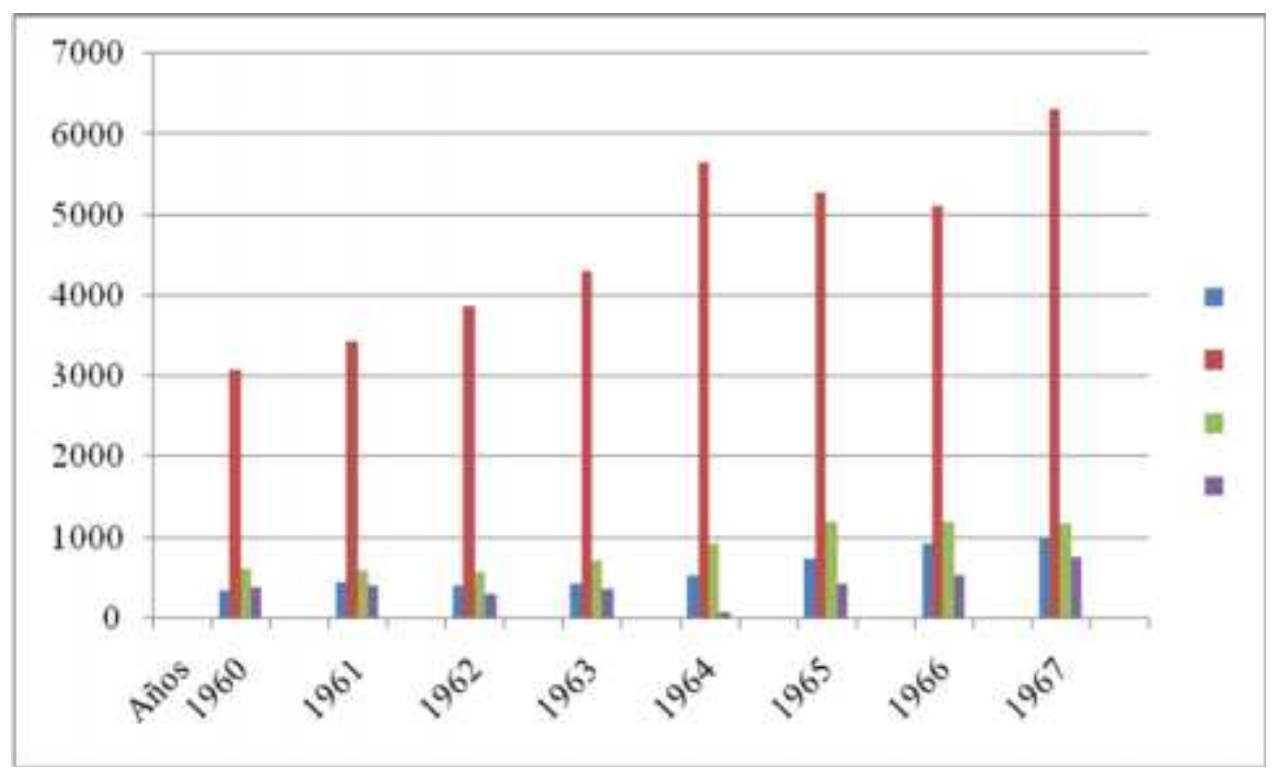

El color azul representa el valor del crédito destinado a la agricultura; el color rojo corresponde al comercio; el color verde representa la industria; y el color morado representa otras actividades.

Elaboración propia a partir de la tabla 2.

Fuente: Sección Programación Financiera y Banco Nacional de Fomento, en: Secretaría General de Planeación y Económica de la Junta Nacional de Planificación y Coordinación: El crédito agropecuario en el periodo 1964-1967, documento núm. 08-03, 1968, p. 3.

En los años 1960-1963, el crédito hacia el sector agropecuario no muestra una tendencia clara, es decir, aumentó en 1961, en relación al año anterior, pero disminuyó en 1962 y luego volvió a incrementarse en el año siguiente. Por el contrario, a partir de 1964, con el Plan de Desarrollo existió una tendencia creciente de la financiación institucional con respecto del agro.

En la tabla 3 (Crédito otorgado por el sistema bancario para la agricultura 1960-1967) se puede observar el crédito destinado a la agricultura para 1960-1967 (según el tipo de banco). Así, en el intervalo de tiempo anterior a la formulación del Plan de Desarrollo hasta el año 1964, el Banco Nacional de Fomento era la institución a través de la cual, se orientaba el volumen más alto de recursos financieros destinados a la agricultura, pasando esa posición a los bancos 
privados en los años 1965-1967. A la vez, el Banco Central mantuvo un lugar intermedio entre las dos instituciones mencionadas durante 1964-1967. ${ }^{935}$

La razón por la que los bancos privados asumieron esta nueva posición, se debió a la Ley de Reforma Agraria y Colonización de 1964, que establecía la obligación de conceder créditos al sector agropecuario en un porcentaje del $15 \%$ de los depósitos a la vista y a plazo. Como resultado, el crédito de la banca privada al sector primario se incrementó considerablemente desde el año 1964 hasta 1967: ${ }^{936}$

Los bancos privados obligatoriamente invertirán en crédito agropecuario un porcentaje no menor del $15 \%$ de los depósitos a la vista y a plazo. La Superintendencia de bancos reglamentará y controlará el cumplimiento de esta obligación. ${ }^{937}$

No obstante, se ha de indicar que si bien los bancos privados crearon las condiciones necesarias para mantenerse dentro de los límites fijados por la Ley, en algunos casos, la banca se pasó por alto lo establecido en esta Ley de Reforma Agraria, a la par que la Superintendencia de Bancos, como organismo encargado del control de esas disposiciones, no exigió el cumplimiento de las mismas.

Teniendo en cuenta esta situación, vamos a analizar cuáles fueron las metas establecidas en cuanto a la concesión de créditos y cuáles fueron las cantidades que realmente recibió el agro en el periodo 1964-1967.

De forma global, las necesidades planeadas de crédito para el desarrollo de los programas de cultivo y especies ganaderas durante la vigencia del Plan de Desarrollo y el crédito concedido por el sistema bancario aparecen en el gráfico 2 (Metas del Plan de Desarrollo y Crédito Agropecuario concedido por el sistema bancario, 1964-1967). En principio, parece que las metas de crédito fueron superadas, pero se ha de tener en cuenta que las cantidades de crédito

\footnotetext{
${ }^{935}$ Esta tabla se encuentra en el apéndice de datos del capítulo 4. Fuente: Sección Programación Financiera y Banco Nacional de Fomento, en: Secretaría General de Planeación y Económica de la Junta Nacional de Planificación y Coordinación: El crédito agropecuario en el periodo 1964-1967, documento núm. 08-03, 1968, p. 4.

${ }^{936}$ Ibíd. p. 4.

937 Artículo 113 de la Ley de Reforma Agraria y Colonización de 1964, Capítulo III: Del crédito de la reforma agraria. Fuente: Informe del Instituto Nacional de Colonización, 1963-1964, p. 43.
} 
concedido, no solo incluían créditos del Banco Nacional de Fomento, sino también los préstamos del Banco Central y de los Bancos Privados:

Para conocer el verdadero cumplimiento de las metas, se debería de comparar estas con los créditos concedidos por el Banco Nacional de Fomento por constituir créditos a la producción e inversión agropecuaria como prevé el Plan de Desarrollo. ${ }^{938}$

Gráfico 2: Metas del Plan de Desarrollo y Crédito Agropecuario concedido por el sistema bancario, 1964-1967 (en millones de sucres):

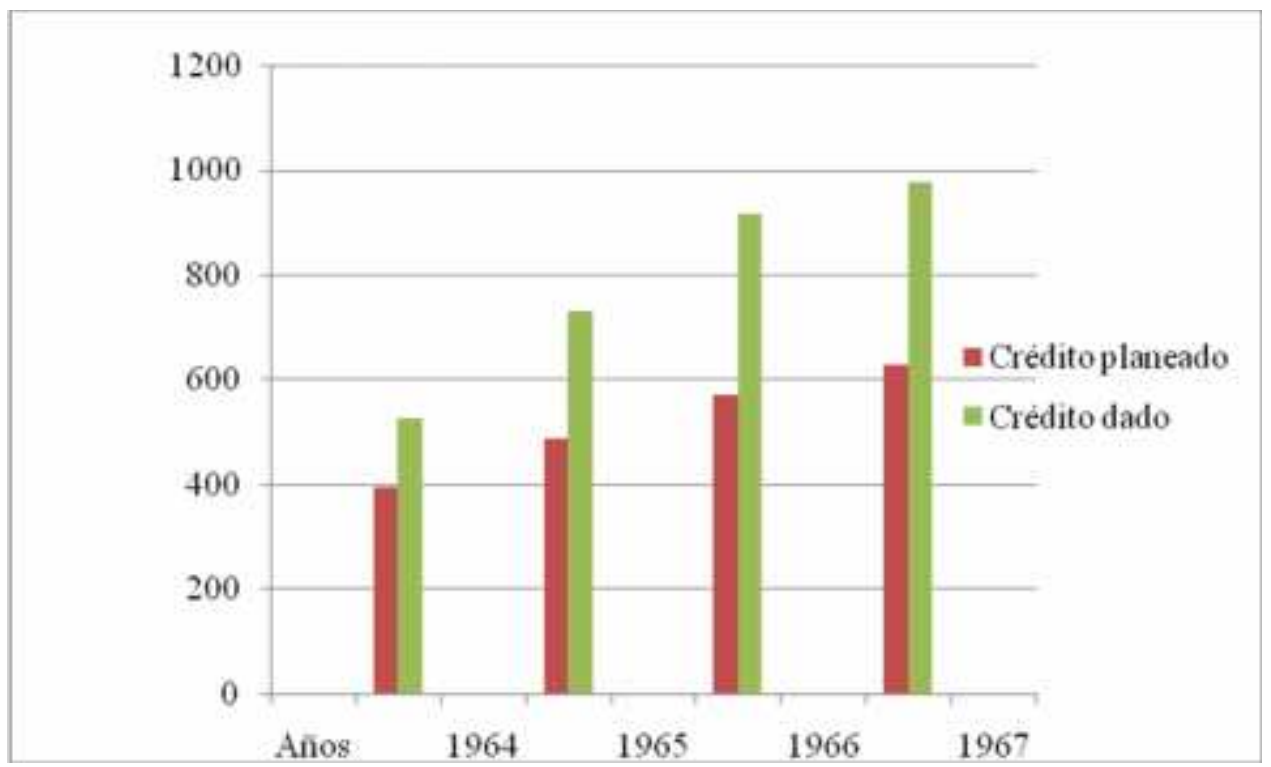

Elaboración propia a partir de los datos de la tabla 4.

Fuente: Plan de Desarrollo y Sección Programación Financiera en: Secretaría General de Planeación y Económica de la Junta Nacional de Planificación y Coordinación: El crédito agropecuario en el periodo 1964-1967, documento núm. 08-03, 1968, p. 11.

Al no disponer de la información correspondiente al crédito original por plazos, se ha de considerar la información de la tabla 5 (Comparación de las metas del Plan con el crédito concedido por el Banco Nacional de Fomento, 1964-1967), que muestra cómo la diferencia entre

\footnotetext{
938 Secretaría General de Planeación y Económica de la Junta Nacional de Planificación y Coordinación: El crédito agropecuario en el periodo 1964-1967, documento núm. 08-03, 1968, p. 12.
} 
las metas y las realizaciones iba más allá de lo establecido, siendo los créditos concedidos más bajos de lo planeado inicialmente. ${ }^{939}$

También, en el gráfico 3 (Necesidades según el Plan de Desarrollo y nuevos créditos concedidos por el Banco Nacional de Fomento, 1964-1967) se observa cómo las necesidades según el Plan de Desarrollo eran bastante mayores que los créditos concedidos por el Banco Nacional de Fomento en el periodo 1964-1967.

Gráfico 3: Necesidades según el Plan de Desarrollo y nuevos créditos concedidos por el Banco Nacional de Fomento, 1964-1967 (en millones de sucres):

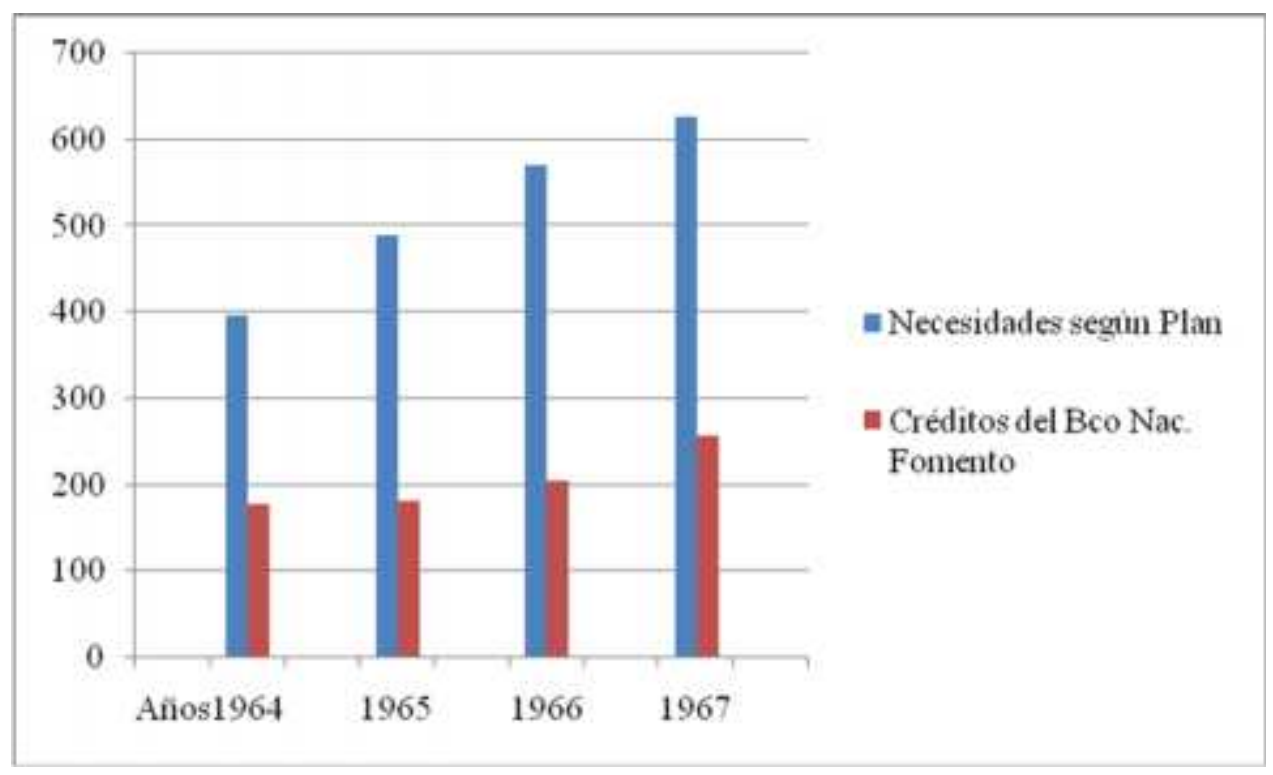

Elaboración propia a partir de los datos de la tabla 6.

Fuente: Plan de Desarrollo y Banco Nacional de Fomento, en: Secretaría General de Planeación y Económica de la Junta Nacional de Planificación y Coordinación: El crédito agropecuario en el periodo 1964-1967, documento núm. 08-03, 1968, p. 13.

Con respecto a la política de créditos, la Junta de Planificación puso de manifiesto que una mejor orientación del crédito bancario habría implicado la intervención de la banca privada en los créditos de producción a corto plazo, por lo que el Banco Nacional de Fomento podría haber satisfecho en mayor medida los requerimientos de crédito a medio y largo plazo del sector

\footnotetext{
${ }^{939}$ Estas tablas se encuentran en el apéndice de datos del capítulo 4. Fuente: Programa de Desarrollo Agropecuario y Banco Nacional de Fomento en: Secretaría General de Planeación y Económica de la Junta Nacional de Planificación y Coordinación: El crédito agropecuario en el periodo 1964-1967, documento núm. 08-03, 1968, p. 12.
} 
agropecuario. Para que esta institución hubiera podido llevar a cabo así su política de crédito, debería de haber dispuesto de recursos financieros apropiados, además de haber mantenido una política más ágil para los préstamos: ${ }^{940}$

Con el objeto de que el crédito que recibe el agricultor sea oportuno y suficiente, debería establecerse una estrecha vinculación entre el sistema de crédito de la banca privada y el Banco Nacional de Fomento; además, deben ser revisadas las condiciones en las que se presenta la oferta de crédito por parte de la banca privada que son inconvenientes para promover el desarrollo del sector, especial referencia debe hacerse de la tasa de interés demasiado elevada- y de los plazos excesivamente cortos a los que se conceden préstamos. $^{941}$

Continuando con el tema de la política de fomento, otro aspecto importante era el relacionado con la infraestructura productiva, a la vez que se pretendía garantizar el desarrollo capitalista de las grandes y medianas propiedades, para lo que se fortaleció y amplió la red institucional que había sido creada antes del ascenso de los militares al poder. ${ }^{942}$

De esta manera, en 1964, se creó el Ministerio de Agricultura y Ganadería (MAG) como una parte del antiguo Ministerio de Fomento, en 1965, la Comisión Ecuatoriana para el Desarrollo de la Cuenca del Río Guayas (CEDEGE), y posteriormente, en 1966, se creó el Instituto Ecuatoriano de Recursos Hidráulicos (INERHI) para encauzar la política de riego. ${ }^{943}$

A partir de 1964, la política agraria de los gobiernos continuó impulsando la política de fomento, que fue bastante útil para los hacendados modernos o en vías de transformación:

\footnotetext{
${ }^{940}$ Plan de Desarrollo y Banco Nacional de Fomento en: Secretaría General de Planeación y Económica de la Junta Nacional de Planificación y Coordinación: El crédito agropecuario en el periodo 1964-1967, documento num. 0803, 1968, p. 13. Manuel Chiriboga: El estado y las políticas hacia el sector rural (1979-1989), en: "Ecuador Agrario", Quito, ILDISEl Conejo, 1984, p. 94-141; Instituto Nacional Autónomo de Investigaciones agropecuarias: Tecnología para el desarrollo agropecuario, Corpoiniap, 1995; Rubén Suárez: El sector eléctrico ecuatoriano como fuente de bienestar social, FLACSO, Quito, 2010.

${ }^{943}$ Para más información de las instituciones nacionales y regionales, ver el apéndice de notas del capítulo 4. Fuente: Ministerio de Agricultura y Ganadería, Historia, www.mag.gob.sv;Ley de creación del Instituto Ecuatoriano de Recursos Hidráulicos, capítulo 1: Finalidades y funciones, artículo 1, faolex.fao.org, M. Chiriboga, El estado..., op. cit. p. 94-141; O. Barsky, Los terratenientes... op. cit. p. 133-206.
} 
Toda esta compleja red institucional de fomento agropecuario tendió a servir a la mediana y a la gran propiedad agropecuaria, a impulsar su conversión en empresa capitalista utilizadora de tecnología moderna. La dispersión institucional y legal permitió a diversos núcleos propietarios optar con facilidad los aparatos estatales especializados. ${ }^{944}$

En referencia a la política de tierras de la dictadura militar, ya se ha visto cómo el IERAC inició en algunas zonas y consolidó en otras, un proceso de transformaciones agrarias basándose en una línea de afectación territorial bastante limitada, y centrando su esfuerzo en el apoyo a la política de colonización de tierras baldías más que en una reforma agraria.

En la tabla 7 (Distribución de las hectáreas adjudicadas por periodo, régimen y región, 19641977) se puede apreciar que, a lo largo del periodo analizado (1964-1977), la colonización fue el régimen predominante. Así, el porcentaje asignado por colonización fue del 71\% para 1964-1967 y del 75,5\% para 1967-1971, frente al porcentaje de tierras adjudicado en régimen de reforma agraria (parcelación en haciendas privadas, en predios de la Asistencia Pública, entrega de huasipungos y eliminación de otras formas precarias) que para 1964-1967, fue del 29\% del total de adjudicaciones y del 24,5\% para 1967-1971. ${ }^{945}$

En cuanto a la distribución de la tierra por hectáreas se calculan los siguientes datos: de las 292.867 hectáreas correspondientes a 1964-1966, la cantidad de 84.931 fue distribuida con la reforma agraria, mientras que 207.936 hectáreas correspondieron a la colonización. Para 19671971, de las 380.238 hectáreas disponibles, 93.158 fueron distribuidas por la reforma agraria y 287.080 por la colonización. ${ }^{946}$

Para el tamaño promedio adjudicado por familia, la tabla 8 (Promedio de hectáreas por familia adjudicadas por tipo de afectación. Año y región, 1964-1970) muestra que la dimensión del promedio adjudicado con la colonización es bastante más grande que con la reforma agraria. Asimismo, el gráfico 4 (Número de familias beneficiadas y hectáreas adjudicadas en

\footnotetext{
${ }^{944}$ Manuel Chiriboga, El estado... op. cit. p. 116.

${ }^{945}$ Esta tabla se encuentra en el apéndice de datos del capítulo 4. Fuente: Estadísticas de Adjudicaciones IERAC, en Gustavo Cosse, Reflexiones..., op. cit. p. 424.

${ }^{946}$ Esto también se puede observar en las tablas 10 y 11 (Adjudicación legalizada de tierras en Colonización, por provincias 1964-1967 y 1968-1971) y en las tablas 12 y 13 (Adjudicación legalizada de tierras en Reforma Agraria, 1964-1967 y 1968-1971), las cuales se encuentran en el apéndice de datos del capítulo 4.
} 
colonización y reforma agraria, 1964-1971) indica un mayor reparto de hectáreas con la colonización, siendo mayor el número de familias afectadas con la reforma agraria para 19641971 (ver también tablas 10 y 11: Adjudicación legalizada de tierras en Colonización, por provincias, 1964-1967, 1968-1971, y tablas 12 y 13: Adjudicación legalizada de tierras en Reforma Agraria, por provincias, 1964-1967, 1968-1971). ${ }^{947}$

Gráfico 4: Número de familias beneficiadas y hectáreas adjudicadas en Colonización y Reforma Agraria (1964-1971):

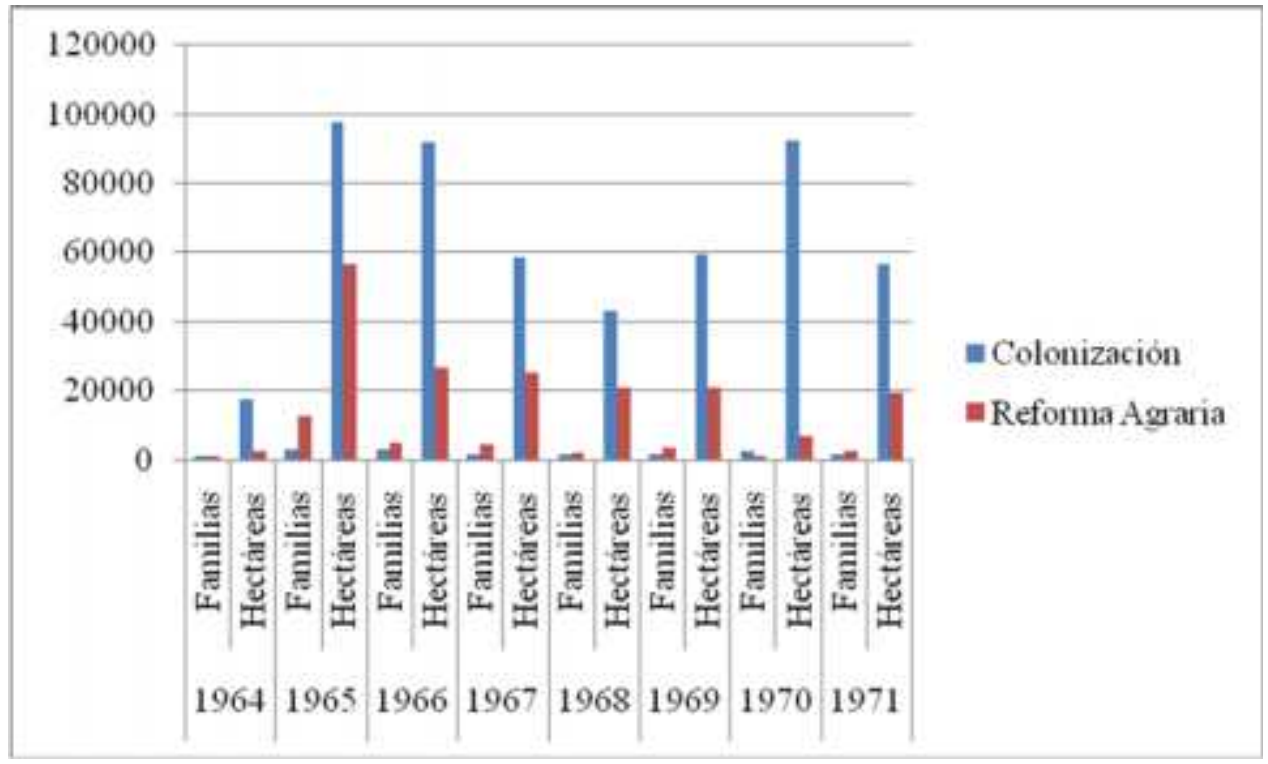

Elaboración propia a partir de los datos de la tabla 9.

Fuente: Patricio Almeida Guzmán, Rebeca Almeida Arroba: Estadísticas Económicas Históricas 1948-1983, Serie estadísticas históricas, Vol. 1, Banco Central del Ecuador, 1988, p. 33.

En el régimen de la reforma agraria, a pesar de que la entrega del huasipungo fue de gran importancia, los campesinos recibieron un lote pequeño al igual que ocurrió con la entrega de tierras colectivas o comunas indígenas, en las que el promedio de hectáreas por familia era también muy reducido. En cambio, en la aplicación del régimen de colonización en la Sierra, la Costa o el Oriente, la dotación de tierras era superior.

\footnotetext{
947 Todas estas tablas están en el apéndice de datos del capítulo 4. Fuente: Patricio Almeida Guzmán, Rebeca Almeida Arroba: Estadísticas Económicas Históricas 1948-1983, Serie estadísticas históricas, Vol. 1, Banco Central del Ecuador, 1988, p.34-39.
} 
Aquí, interesa anotar que esta orientación estaba prefijada en la Ley de 1964, es decir, el artículo 42 establecía que el IERAC podía determinar en cada zona la extensión de la unidad agrícola familiar o el tamaño mínimo del lote a entregar: ${ }^{948}$

La extensión es aquella que conforme a la naturaleza de la zona sea suficiente para que, explotada en condiciones de razonable eficiencia, mediante el trabajo del propietario y su familia sea capaz de suministrar ingresos adecuados para su sostenimiento, para el pago de las deudas organizadas en la compra, aprovechamiento de la tierra y para la progresiva mejora de la explotación, la vivienda y el nivel de vida. El trabajo familiar puede ser completado con el empleo de mano de obra extraña en ciertas épocas de labor agrícola, si la naturaleza de la explotación así lo requiere. ${ }^{949}$

De tal manera, la ley exponía dos situaciones atendiendo al agente social que ocupara las tierras distribuidas. La primera, referida a los huasipungueros, buscaba la entrega del predio, independientemente de su tamaño. En este caso, la ley mantenía los derechos de tránsito, agua y leña, que eran fundamentales para los antiguos huasipungueros en el momento en que estos pasaran a ser trabajadores asalariados de la hacienda. La segunda situación comprendía todos los regímenes restantes como el de reforma agraria (parcelación de haciendas privadas y públicas, reversión, etc.) y de colonización. Además, parece que la reforma agraria trataba de fomentar la instalación de productores familiares capitalizados. ${ }^{950}$

Según Osvaldo Barsky, con la Reforma Agraria de 1964, se crearon una serie de situaciones en las que los campesinos fueron haciéndose con las haciendas tradicionales, llegando a adquirirlas de forma parcial o total mediante movimientos que generalmente fueron apoyados por medidas de tipo estatal. ${ }^{951}$ Un ejemplo de esto fue la provincia de Cañar, situada al sur del Ecuador, en la que se dio una combinación de campesinos que venían de comunidades alejadas de las haciendas y de aquellos campesinos, que con la Ley de Reforma obtuvieron algunos lotes de tierras y en la

\footnotetext{
948 Artículo 42 de la Ley de Reforma Agraria y Colonización de 1964, Capítulo III: De la integración al minifundio. Fuente: Informe del Instituto Nacional de Colonización, 1963-1964, p. 34.

${ }^{949}$ Rafael Quintero, Erika Silva, op. cit. p. 239-270.

${ }^{950}$ Ibíd. p. 239-270.

${ }^{951}$ Osvaldo Barsky, La reforma agraria... op. cit. p. 367.
} 
que el alto régimen de minifundios y la escasez de eficiencia dieron lugar a una alta tasa de migración.

Aquí, Barsky señala que esta provincia estaba caracterizada por una alta concentración de la tierra en pocas haciendas que pertenecían a particulares, a la Curia o Asistencia Pública, y en las que los huasipungueros o aparceros no recibían un salario. Con la reforma agraria, la expropiación de las tierras públicas generó una fuerte expansión de minifundios, mientras que las explotaciones capitalizadas familiares de subsistencia tenían una baja presencia. ${ }^{952}$

Por su parte, en la provincia de Carchi, el norte de la Sierra constituye otro ejemplo de consolidación de un grupo de campesinos según el tamaño de la parcela recibida y su nivel de integración al mercado, lo cual permitió alcanzar un nivel superior al de subsistencia.

En esta zona, la eliminación de las relaciones precarias, como el huasipungo, fue de gran importancia y las formas seguidas por los campesinos para acceder a la tierra fueron variadas, pues recurrieron a la compra por su precio de mercado a través del mecanismo de las cooperativas. ${ }^{953}$ En el centro del país, en la provincia de Tungurahua, la escasez de haciendas y de relaciones de carácter pre-capitalistas provocaron la presencia de un número importante de campesinos que, al estar alejados de la problemática campesina, pudieron hacer uso de tierras y valles con ventajas ecológicas en la producción de algunos tipos de frutas (moras, peras, etc.) con un alto precio de mercado y constituirse como un sector de productores familiares capitalizados. También, Barsky hace alusión a la provincia de Loja, situada al sur de la Sierra, en la que los arrimados tenían algunas obligaciones con los productores de la hacienda y como contrapartida contaban con acceso a parcelas de veinte hectáreas. Estas tierras se caracterizaban por unas condiciones ecológicas bastante desfavorables, y tampoco recibían la protección del estado, lo cual acabó provocando una alta tasa de migración hacia el resto del país. ${ }^{954}$

Gustavo Cosse indica que la adjudicación de tierras no contó con el apoyo suficiente de otras políticas, como las de asistencia técnica y crédito, para que estos productores pudieran acceder al ciclo de acumulación. A pesar de esto, destaca que dicho proceso logró instalar una cantidad importante de productores vinculados al mercado y con un tipo de articulación al sistema de

\footnotetext{
${ }^{952}$ Ibíd. p. 371.

${ }^{953}$ Ibíd. p.368.

${ }^{954}$ Ibíd. p. 367-368.
} 
haciendas bastante diferente al del antiguo huasipunguero. La importancia de esto radicaba en la conformación de la estructura de clases en el campo y en la dinámica social y política; siendo esa realidad, la que llegó a marcar el proceso social y agrario posterior, al ser un elemento central en la estructuración de alianzas y movilizaciones sociales. ${ }^{955}$

En el gráfico 5 (Volumen de hectáreas adjudicadas por año, subperiodo y región, 1964-1971) se observa nuevamente el proceso de entregas y su intensidad durante los años 1964-1971, en los que la reforma agraria recibió menos impulso que la colonización, siendo la región de la Sierra, la que experimentó una dinámica mayor.

Gráfico 5: Volumen de hectáreas adjudicadas por año y región con la Reforma Agraria y Colonización (1964-1971):

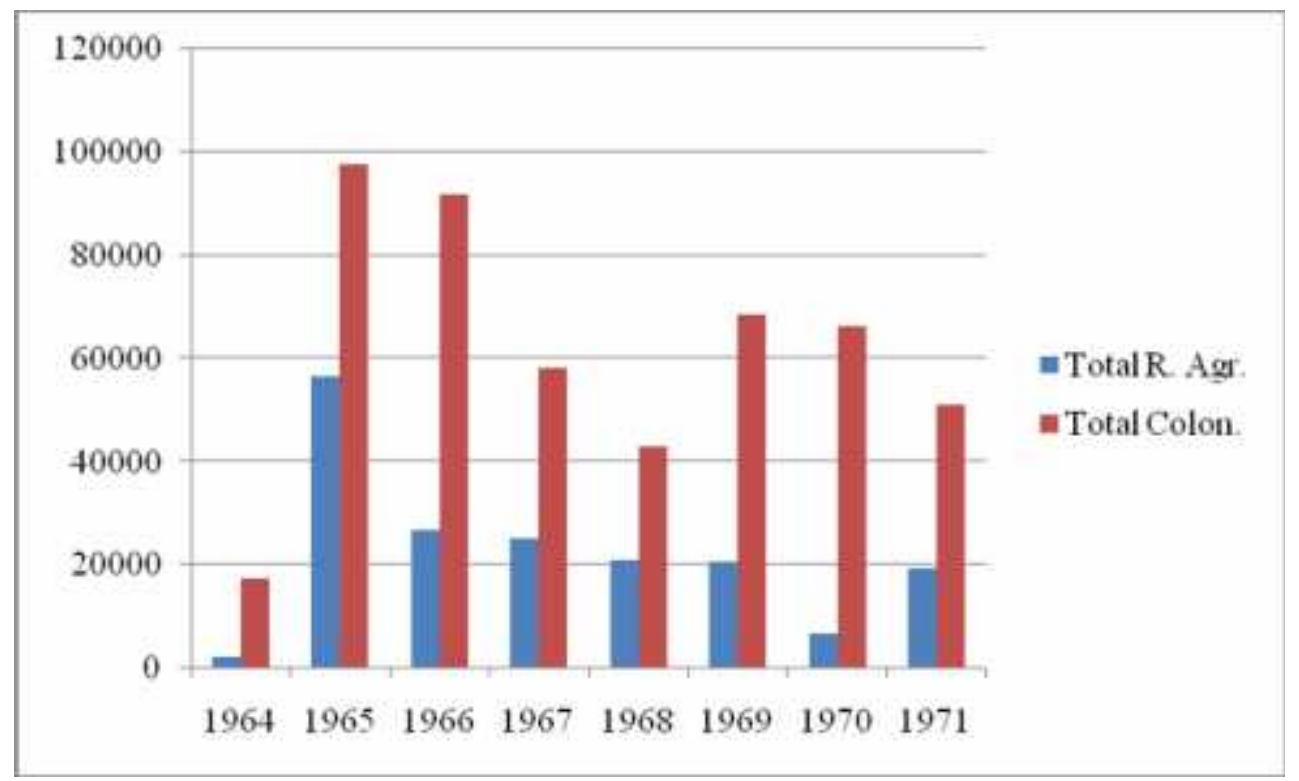

Elaboración propia a partir de los datos de la tabla 14.

Fuente: Estadísticas Adjudicaciones IERAC en Gustavo Cosse: Reflexiones acerca del estado, el proceso político y la política agraria en el caso ecuatoriano 1964-1977, en Ecuador, cambios en el agro serrano, CEPLAES-FLACSO, 1980, p. 426.

El gráfico 6 (Número y superficie de las explotaciones de la Sierra, Costa y Oriente, 1954 y 1968) permite observar el crecimiento del número de unidades entre 1954 y 1968 en la Sierra, el

${ }^{955}$ Gustavo Cosse, Reflexiones... op. cit. p. 423-425. 
Oriente y la Costa ecuatoriana. El número de predios de menos de una hectárea aumentó en 113.698 unidades; los de 1-5 hectáreas aumentaron en 103.994 respectivamente, mientras que los de 5-10 hectáreas se incrementaron en 31.137 unidades. En los tramos superiores, los cambios fueron menores pero no menos significativos: los predios entre 10 y 20 hectáreas aumentaron en 13.125 unidades mientras que los de 20-50, lo hicieron en 10.557 hectáreas. ${ }^{956}$

Gráfico 6: Número de explotaciones de la Sierra, Costa y Oriente (1954, 1968):

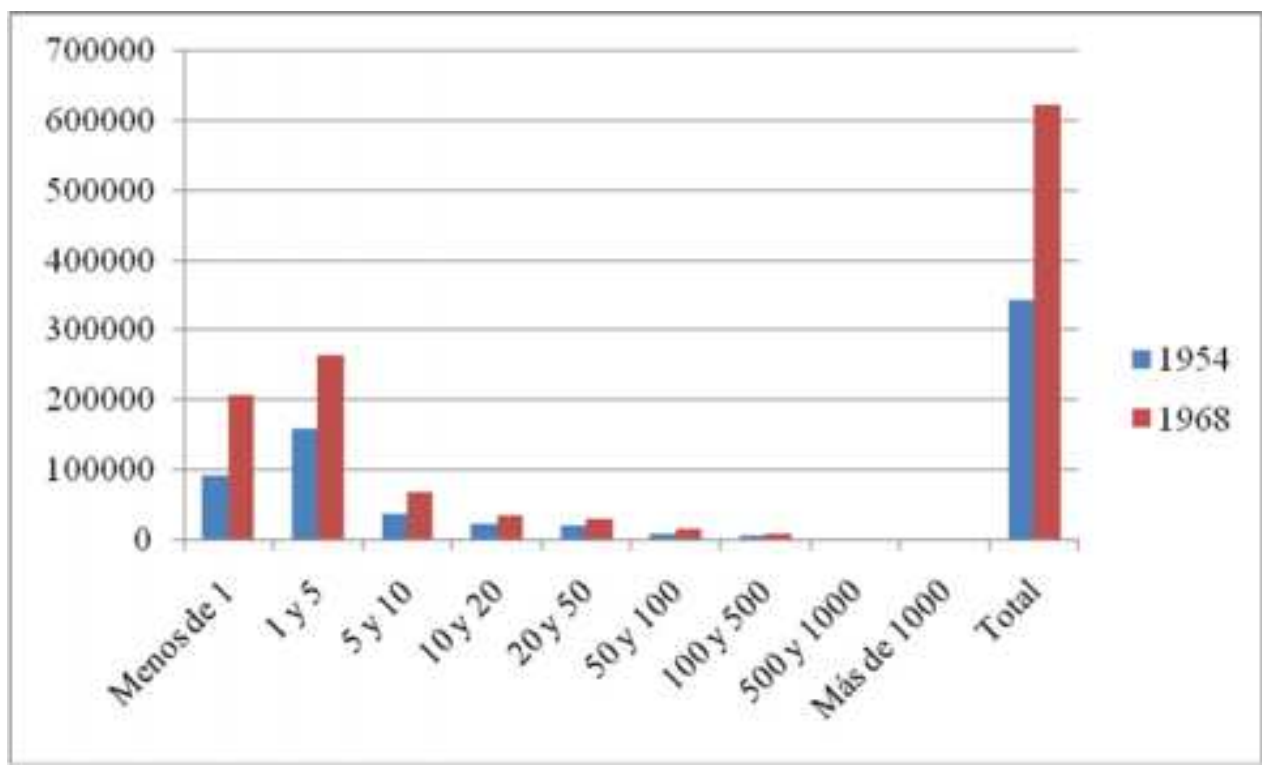

Elaboración propia a partir de los datos de la tabla 15.

Fuente: Patricio Almeida Guzmán, Rebeca Almeida Arroba: Estadísticas Económicas Históricas 1948-1983”, Serie estadísticas históricas, Vol. 1, Banco Central del Ecuador, 1988, p.47.

Este cuadro no solo muestra un mayor número de predios, en el que la superficie de los pequeños se incrementó sensiblemente, sino que también indica una disminución de los de más de 1.000 hectáreas en 351 unidades. Asimismo, el tramo de productores medianos (20-50 hectáreas) sufrió un ascenso importante de su superficie en 336.455 hectáreas, al igual que ocurrió con el de los productores grandes, al aumentar su superficie en 395.284 hectáreas. ${ }^{957}$

\footnotetext{
${ }^{956}$ Estas tablas se encuentran en el apéndice de datos del capítulo 4. Fuente: Patricio Almeida Guzmán, Rebeca Almeida Arroba: Estadísticas Económicas Históricas 1948-1983, Serie estadísticas históricas, Vol. 1, Banco Central del Ecuador, 1988, p.47.

${ }^{957}$ Ibíd. p. 47.
} 
En definitiva, parece claro que no puede hablarse de un cambio radical de la estructura agraria a nivel nacional tras la reforma de 1964. Se destaca una mayor cantidad de predios y superficies en los segmentos pequeños y medios y algunos cambios de los más grandes, al igual que también se observa la consolidación de un sector de minifundios inviable económicamente y que correspondía a los ex-huasipungueros en la Sierra.

En cuanto al impacto regional de la Ley de Reforma Agraria, se ha de decir que fue diferido cuando se comparan sus resultados entre la Costa y la Sierra, y también, al analizar sus efectos dentro de cada una de las regiones por provincias. Esta situación estaba determinada por una serie de características locales y regionales que conformaban la parte social sobre la que recaían los efectos de las acciones del estado en el agro, tales como la configuración de la tenencia de la tierra, la existencia de economías campesinas vinculadas o no a movimientos campesinos, la incidencia de las relaciones pre-capitalistas, la concentración de la tierra y la importancia histórica de la hacienda tradicional en cada región. ${ }^{958}$

Las tablas 12 y 13 (Adjudicación legalizada de tierras en Reforma Agraria por provincias, 1964-1967 y 1968-1971) muestran una mayor adjudicación de tierras en la Sierra, que ascendía a la cantidad total de 140.559 hectáreas, en comparación con la Costa, en la que se repartieron 38.259 hectáreas entre apenas 2.340 familias. ${ }^{959}$

Además, para las provincias de la Sierra, estas tablas muestran un mayor reparto en las provincias de Carchí, Imbabura, Pichincha y Cotopaxi (Sierra norte). Aquí, es importante recordar el proceso de entrega anticipada de tierras iniciado por las fracciones terratenientes desde finales de los cincuenta y cómo su producción logró impulsar la agroindustria en torno a la producción de leche y sus derivados.

Por su parte, la estructura de tenencia de la tierra de la Sierra centro sur, constituida por las provincias de Tungurahua, Bolívar, Chimborazo, Cañar y Azuay, sufrió menores transformaciones con la reforma agraria. ${ }^{960}$

En síntesis, la política de tierras de la Junta Militar se concentró en una serie de reivindicaciones formuladas por el movimiento campesino, entre las que se encontraba la liquidación de las

\footnotetext{
${ }^{958}$ Rafael Quintero, Erika Silva, op. cit. p 239-270.

${ }^{959}$ Patricio Almeida Guzmán, Rebeca Almeida Arroba, Estadísticas..., op. cit. p.38-39.

${ }^{960}$ Rafael Quintero, Erika Silva, op. cit. p. 239-270.
} 
formas pre-capitalistas, y que no llegó a cumplir de forma íntegra, pues solo fueron abolidos el huasipungo y la yanapa en la Sierra, manteniéndose otras formas de trabajo precapitalista como la aparcería.

A este respecto, Carlos Espinosa afirma que si bien la reforma agraria iniciada en 1964, no tuvo la profundidad esperada, sí logró un mayor impacto en la transformación de las relaciones sociales en el campo y la estructura de tenencia de la tierra: Para 1969, unas 25.000 familias campesinas habrían recibido la tierra a través de la reforma agraria y unas 10.000 a través de la colonización, estos resultados correspondian a la mitad de los objetivos propuestos. ${ }^{961}$ En cambio, según Fausto Jordán, esta reforma podía haber sido más radical si hubiera existido un movimiento nacional encargado de representar los intereses de los campesinos sin tierra y las agrupaciones indígenas sin carácter nacional, cuyas demandas estaban ligadas al huasipungo. ${ }^{962}$ A pesar del bajo impacto en el acceso a la tierra, Espinosa afirma que los campesinos que se beneficiaron de la reforma agraria pudieron formar cooperativas de nuevos propietarios rurales, que fueron legalizadas y establecieron un vínculo directo con el estado. ${ }^{963}$

Osvaldo Barsky indica que las cooperativas fueron un mecanismo utilizado por los campesinos para adquirir grandes extensiones de tierra en un solo acto, apareciendo estas asociaciones de forma aislada en la década de los cincuenta, aunque fue en el periodo 1964-1971 cuando tuvieron un mayor auge:

El objetivo declarado era el de obtener tierra, generalmente en manos de las haciendas, por lo cual, se hizo habitual que una vez cumplida aquella etapa adquisitiva se

\footnotetext{
${ }^{961}$ C. Espinosa: Historia del Ecuador en contexto regional y global, Editores, España, 2010, p. 644.

${ }^{962}$ Para más información de las organizaciones comunitarias, ver el apéndice de notas del capítulo 4. Fuente: Fausto Jordán, Reforma agraria..., op. cit. p. 6; Dirección de Organizaciones Populares, MAG, en Hernán Carrasco: Democratización de los poderes locales y levantamiento indígena, en "Sismo étnico en el Ecuador. Varias perspectivas", CEDIME, 1993, p. 134; Luis A. Tuaza: Cansancio Organizativo, en "Repensando los movimientos indígenas", FLACSO, Ministerio de Cultura del Ecuador, 2009, p. 126; Luciano Martínez Valle: Las organizaciones de segundo grado como nuevas formas de organización de la población rural, en "La construcción de la democracia en el campo latinoamericano", CLACSO, Consejo Latinoamericano de Ciencias Sociales, 2006, p. 109.

${ }^{963}$ C. Espinosa, op. cit. p. 654.
} 
procediera a la parcelación de las propiedades de la cooperativa y que sus funciones fueran reducidas a una mínima expresión. ${ }^{964}$

Un ejemplo de esto es la hacienda Pesillo, ubicada en la provincia de Pichincha, en el Cantón Cayambe, que fue dividida en dos cooperativas por el IERAC, en el año 1966. Estas cooperativas, denominadas "Atahualpa" y "Simón Bolívar", eran parte de un programa piloto desarrollado y gestionado por campesinos locales con la idea de que este modelo contribuyera a su integración y a una mejora de su estilo de vida. ${ }^{965}$ Además, también se pretendía establecer un programa de reforma agraria que impidiera la división de las grandes haciendas en pequeñas empresas agrícolas, de ahí que se impulsaran las cooperativas constituidas por las antiguas familias del huasipungo y arrimados mediante un acuerdo de tipo informal con un huasipunguero ya establecido. ${ }^{966}$ A pesar de esto, dichas cooperativas no llegaron a funcionar bien porque el gobierno no supo tener en cuenta las necesidades de los campesinos y tampoco se preocupó de la preparación de los dirigentes, lo cual acabó generando problemas de administración. ${ }^{967}$

Otro caso fue el de la hacienda San Vicente de Pusir y Anexas, situada en el sur de la provincia de Carchi en los Cantones Montúfar y Espejo, en las que se contemplaba la parcelación de unas 2.800 hectáreas a favor de 188 familias campesinas, las cuales debían de recibir unidades agrícolas familiares de 10-16 hectáreas cada una, aunque se tenía previsto la creación de una estructura cooperativa como respuesta a los problemas ocasionados por el reasentamiento de campesinos. ${ }^{968}$ De esta manera, se pretendía fortalecer las pequeñas economías de los reasentados y mantener la hacienda como una unidad mejorada mediante el establecimiento de

\footnotetext{
${ }^{964}$ Osvaldo Barsky, La reforma..., op. cit. p. 369.

${ }^{965}$ De acuerdo con el informe elaborado por el Instituto Nacional de Colonización, algunos de los problemas de la Hacienda Pesillo estaban relacionados con el mal uso de los recursos naturales (tierra y agua), la baja producción, los sistemas precarios de tenencia de la tierra, la falta de conocimiento técnico, los bajos ingresos y una elevada presión demográfica. Fuente: Instituto Nacional de Colonización, 1963-1964, p. 70.

${ }^{966}$ Marc Becker, Silvia Tutillo: Historia agraria y social de Cayambe, FLACSO, Abya-Yala, 2009, p. 213-214.

${ }^{967}$ Pablo Guaña, Pedro Camino y Quimbia Ulco: Inti Raymi Cayambi: La fiesta sagrada del sol en la mitad del mundo; la fiesta de San Pedro en Cayambe, Cayambe: CICAY/Museo Cayambe, 1992, p. 116.

${ }^{968}$ Instituto Nacional de Colonización, 1963-1964, p. 70.
} 
diversos servicios de abastecimiento, comercialización, técnicos y de desarrollo de la comunidad, entre otros. $^{969}$

Por otro lado, pueden observarse los efectos en la estructura agraria en la expansión de la frontera agrícola, pues numerosas zonas comunales se extendieron hacia los páramos y se fueron dividiendo en minifundios inviables, a la vez que se convertían en áreas étnicas, mientras las zonas de valles se transformaban en haciendas agro-industriales modernas.

En definitiva, la aplicación de la reforma agraria como mecanismo de política pública para el desarrollo rural, no tuvo el impacto esperado debido a su escaso carácter distributivo. Además, si bien la reforma agraria fue la respuesta a presiones de distintos sectores, finalmente, fueron los hacendados, los encargados de llevar a cabo dicho proceso, que lejos de acabar con la desigualdad social y ayudar a la clase campesina, contribuyó a diversificar las formas de acumulación de la clase terrateniente.

\subsection{2) La supresión del huasipungo y el reparto de tierras: Una comparativa de las entregas anticipadas de huasipungos y la Ley de Reforma Agraria de 1964.}

En el capítulo anterior, ya nos referimos a la entrega anticipada de tierras iniciada en 1959, la cual fue avanzando de modo progresivo hasta 1964, año en que entró en vigencia la Ley de Reforma Agraria y Colonización. A partir de aquí y teniendo en cuenta que uno de los objetivos que se proponía la reforma agraria era la abolición de las formas precarias, en este apartado, vamos a analizar cómo se llevó a cabo el proceso de eliminación de huasipungos, estableciendo una comparativa entre la iniciativa anticipada de 1959 y las entregas producidas tras la implantación de la Ley de 1964.

Recordemos que la liquidación de los huasipungos y el reparto de tierra realizada, se produjo según la antigua ley de expropiaciones y adjudicaciones de tierras que había sido dictada en el año 1938, y a través de la cual, el Ministerio de Previsión Social y Trabajo, convertido en el órgano ejecutor de estas entregas, actuaba al amparo de dicha ley haciendo posible la liquidación de las deudas de trabajo a los huasipungueros (fondos de trabajo y vacaciones no gozadas). ${ }^{970}$

\footnotetext{
${ }^{969}$ Informe del Instituto Nacional de Colonización 1963-1964, p. 50.

${ }^{970}$ Artículo 67, capítulo II, primer párrafo de la Ley de expropiaciones, en: Alfredo Costales, Piedad Peñaherrera Costales, Historia social..., op. cit. p. 114-118.
} 
De este modo, si las entregas comenzaron en el año 1959 y se fueron acentuando en años posteriores, se puede observar como para 1964, se habían efectuado entregas para 3.019 familias beneficiarias que recibieron un total de 9.303,33 hectáreas, según muestra la tabla 16 (Relación entre la población huasipunguera y la superficie ocupada en hectáreas con la entrega de huasipungos desde 1959 a 1964). ${ }^{971}$

Además, en este periodo, la masa de trabajadores agrícolas era de un total de 400.974 habitantes, cifra repartida entre huasipungueros, comuneros, partidarios y ayudas, es decir, los precaristas agrícolas del país. De esta cifra, los huasipungueros representaban el 15,5\% de los precaristas en ese momento, lo que refleja cómo las entregas voluntarias resultaban insignificantes, pues una buena parte de huasipungueros, no recibían el beneficio de las parcelas de labranza. ${ }^{972}$

La tabla 17 (Entrega de huasipungos por provincias 1959-1964) muestra un análisis más detallado de la distribución de tierra desde 1959 hasta 1964, siendo la provincia de Pichincha, en la que se llevó a cabo el mayor número de entregas con 1.760 beneficiarios, a quienes se les repartió un total de 4.945 hectáreas. ${ }^{973}$

\footnotetext{
${ }^{971}$ Esta tabla se encuentra en el apéndice de datos del capítulo 4. Fuente: Censo Agropecuario de 1954 actualizado a 1959, por el IEAG. Departamento de Cuestiones Sociales del Ministerio de Previsión Social y Trabajo, 1964. Elaboración: Instituto Ecuatoriano de Antropología y Geografía, División Antropología Social y Cultural, 1964.

${ }^{972}$ Alfredo Costales, Piedad Peñaherrera Costales, op. cit. p. 116-117.

${ }^{973}$ Departamento de Cuestiones Sociales del Ministerio de Previsión Social y Trabajo, 1964, en: Ibíd. p. 117.
} 
Gráfico 7: Entrega de huasipungos por provincias (1959-1964):

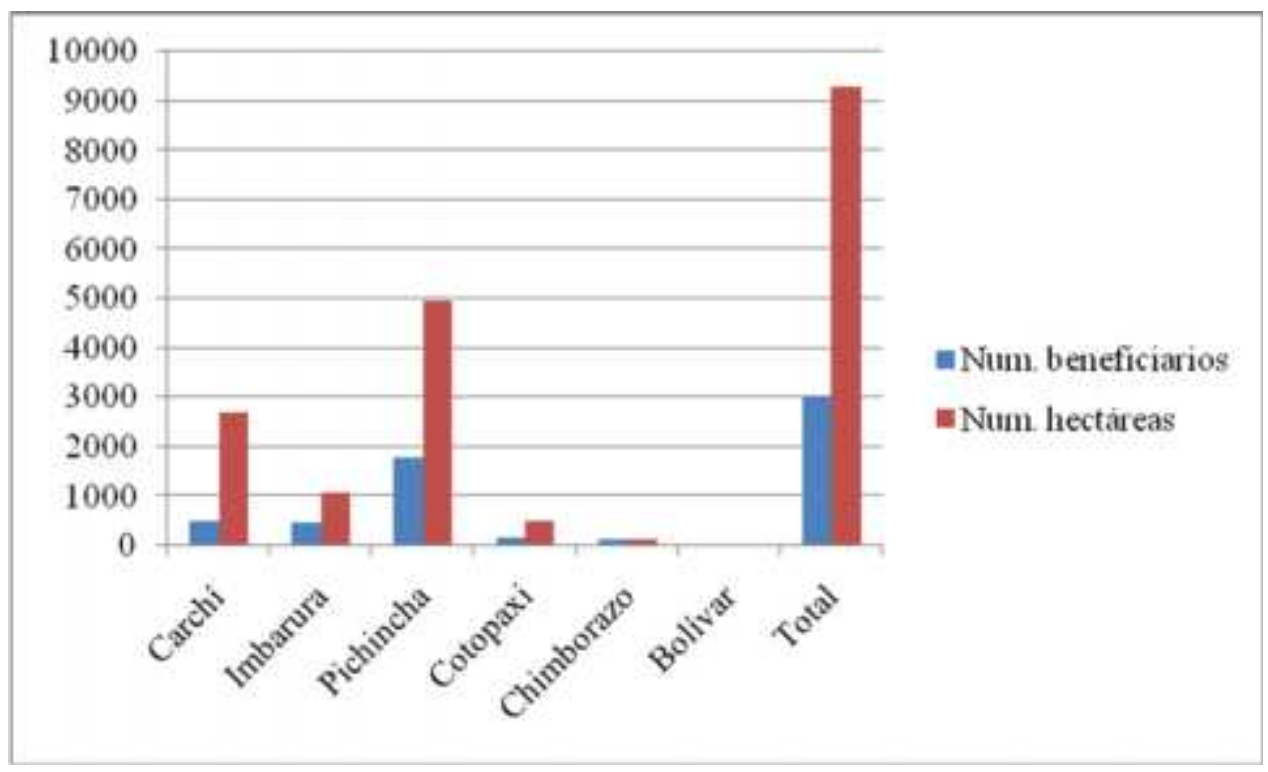

Elaboración propia a partir de los datos de la tabla 17.

Fuente y elaboración: Departamento de Cuestiones Sociales del Ministerio de Previsión Social y Trabajo, 1964, en: Piedad y Alfredo Costales: Historia Social del Ecuador, Reforma Agraria, edit. Casa de la Cultura Ecuatoriana, Quito, 1971, p. 117.

De forma paralela, de las diez provincias de la Sierra, se realizaron entregas anticipadas en seis de ellas. Así, en Loja, Cañar, Azuay y Tungurahua, no se llevó a cabo este proceso hasta la promulgación de la Ley de Reforma Agraria de 1964 debido a varias razones: en el caso de Loja, la modalidad del arrimado era diferente en relación al problema de fondo, a la vez que su parentesco con el huasipunguero solo existía en cuanto al precarismo. En Tungurahua, el número de huasipungos era mínimo, por lo que se decidió retrasar las entregas, mientras que en el caso de Cañar y Azuay, se habían detenido dichas entregas debido a la presencia del minifundio. ${ }^{974}$ En este proceso, la desproporción demográfica, variable de peso que determinaba los efectos de la entrega de huasipungos, y la disponibilidad real de tierra de labranza, fueron elementos que desempeñaron un papel de gran importancia (tabla 16: Relación entre la población

\footnotetext{
${ }^{974}$ Ibíd. p. 117.
} 
huasipunguera y la superficie ocupada en hectáreas con la entrega de huasipungos desde 1959 a 1964). ${ }^{975}$

La proporción hombre-tierra entre los huasipungueros era la siguiente: para 1959, había 19.665 cabezas de familia que representaban una población de 88.209 personas, con una cifra de 60.800 hectáreas, lo que significaba un promedio de 0,7 hectáreas por persona. ${ }^{976}$

Además, al liberarse del paternalismo feudal y al perder parte del bien, desaparecieron los beneficios que antes se han comentado, como era el acceso al pasto, agua y leña, y que en suma, permitían sobrellevar el huasipungo.

Desde el punto de vista de la tierra, la parcela que había sido un minifundio de explotación, pasó a ser un minifundio de propiedad con absoluto dominio. Además, las entregas que ocurrieron en la mayoría de las haciendas, se realizaron considerando el número de beneficiarios (cabezas de familia), el valor catastral de la tierra y los años de servicio prestados por el huasipunguero. ${ }^{977}$

De todo esto, llama la atención que solo se tuviera en cuenta al cabeza de familia como beneficiario, excluyendo a la familia agrícola, la cual se vio obligada a abandonar la zona para no complicar el fenómeno de la presión demográfica y la división de la tierra. ${ }^{978}$

Por otro lado, la Tabla 18 (Entrega de los huasipungos por provincias, según los espacios de tenencia. Número de beneficiarios y valor en sucres 1959-1964) referida a los espacios de tenencia y al número de beneficiarios, muestra las siguientes anomalías: ${ }^{979}$

- De los 3.019 huasipungueros beneficiados, se adjudicó a 299 familias una cantidad de 87,10 hectáreas, que era equivalente a un $0,9 \%$ de la superficie total para el intervalo de 0-5 hectáreas. Es decir, los beneficiarios recibían una parcela muy pequeña con la que apenas podían sobrevivir a un nivel de autoconsumo.

\footnotetext{
975 Esta tabla se encuentra en el apéndice de datos del capítulo 4. Fuente: Censo Agropecuario de 1954 actualizado a 1959, por el IEAG. Departamento de Cuestiones Sociales del Ministerio de Previsión Social y Trabajo, 1964. Elaboración: Instituto Ecuatoriano de Antropología y Geografía, División Antropología Social y Cultural, 1964.

${ }^{976}$ Ibíd. p. 10-30.

${ }^{977}$ Piedad Peñaherrera, Alfredo Costales, op. cit. p. 118.

${ }^{978}$ Ibíd. p. 120.

${ }^{979}$ Esta tabla se encuentra en el apéndice de datos del capítulo 4. Fuente: Datos obtenidos del Departamento de Cuestiones Sociales del Ministerio de Previsión Social y Trabajo. Elaboración: Instituto Ecuatoriano de Antropología y Geografía, en Ibíd. p. 119-120.
} 
- Los espacios intermedios estaban representados en el siguiente orden: las parcelas de 510 hectáreas correspondían a la cantidad de 2,1\% con 189,33 hectáreas, las de 10-20, el 4,3\% con 395,52 hectáreas, y las de 20-50, el 5,1\% con 474,06 hectáreas, lo cual tampoco implicaba los elementos necesarios para la supervivencia de las familias beneficiarias.

- Por último, para las parcelas de más de 50 hectáreas, los datos indican que 1.608 beneficiarios recibieron 8.057 hectáreas, implicando un promedio de 5,01 hectáreas por beneficiario. Aún cuando este promedio parece bastante aceptable, se ha de tener en cuenta que no todas las tierras eran de labranza y se entregaron sectores de páramos destinados al pastoreo.

Además, pese a que el huasipunguero llegó a ser propietario, su tenencia de la tierra significaba un apoyo económico limitado por la autoridad del patrón. En su caso, las condiciones socioeconómicas no mejoraron, pues los antiguos huasipungueros tenían que conseguir a través de los intermediarios, los medios agrícolas y semillas que necesitaban, pagando altos precios por ellos, mientras que tampoco existía un programa complementario educativo y cultural que los ayudara, por lo que prácticamente quedaban en el abandono.

El huasipunguero dependía del paternalismo latifundista, lo que significaba la existencia de una autoridad civil, moral y religiosa, además de un recurso económico, frente a los abusos de tenientes políticos y de curas. Es decir, ser un peón de la hacienda era un obstáculo que, en determinados casos, podía limitar los abusos procedentes de las autoridades. La ruptura de este vínculo llegó a ser algo desastroso porque el ex-huasipunguero se vio obligado a asumir la defensa de sus derechos; lo cual era una tarea difícil de realizar, ya que se trataba de un grupo que carecía de estudios y del acceso necesario a los medios que le permitieran obtener algún tipo de ayuda. ${ }^{980}$

En definitiva, la liquidación del huasipungo vino a cumplir el objetivo de dar acceso a la tierra a aquellos trabajadores que tenían derecho potencial. Ahora bien, estas entregas esporádicas, a las que el propietario tuvo que vincularse como resultado de las circunstancias y la evolución de las ideas de los políticos de la época, presentaban su lado más débil. ${ }^{981}$

\footnotetext{
${ }^{980}$ Ibíd. p. 117-120.

${ }^{981}$ Ibíd. p. 120.
} 
Vamos a pasar ahora a estudiar el proceso de entrega de huasipungos a partir de la implantación de la Ley de Reforma Agraria de 1964. Aquí, se ha de diferenciar entre las entregas anticipadas y las que se hicieron efectivas por mandato legal, y es importante estudiar ambos procesos conjuntamente para medir cuál fue su magnitud frente al problema global.

La tabla 19 (Liquidación de huasipungos desde 1959 a julio de 1967 por provincias) muestra la liquidación de huasipungos por entregas anticipadas y por mandato legal desde 1959 hasta el año 1967, con un total de 49.067 hectáreas repartidas entre 16.726 familias beneficiadas durante esos años en las diferentes provincias de la Sierra, a excepción de Loja. De estas cifras, la cantidad de 13.707 beneficiarios y 39.764 hectáreas correspondía a las entregas en base a la Ley de Reforma Agraria de $1964 .^{982}$

Gráfico 8: Entregas en base a la Ley de Reforma Agraria, 1964-1967:

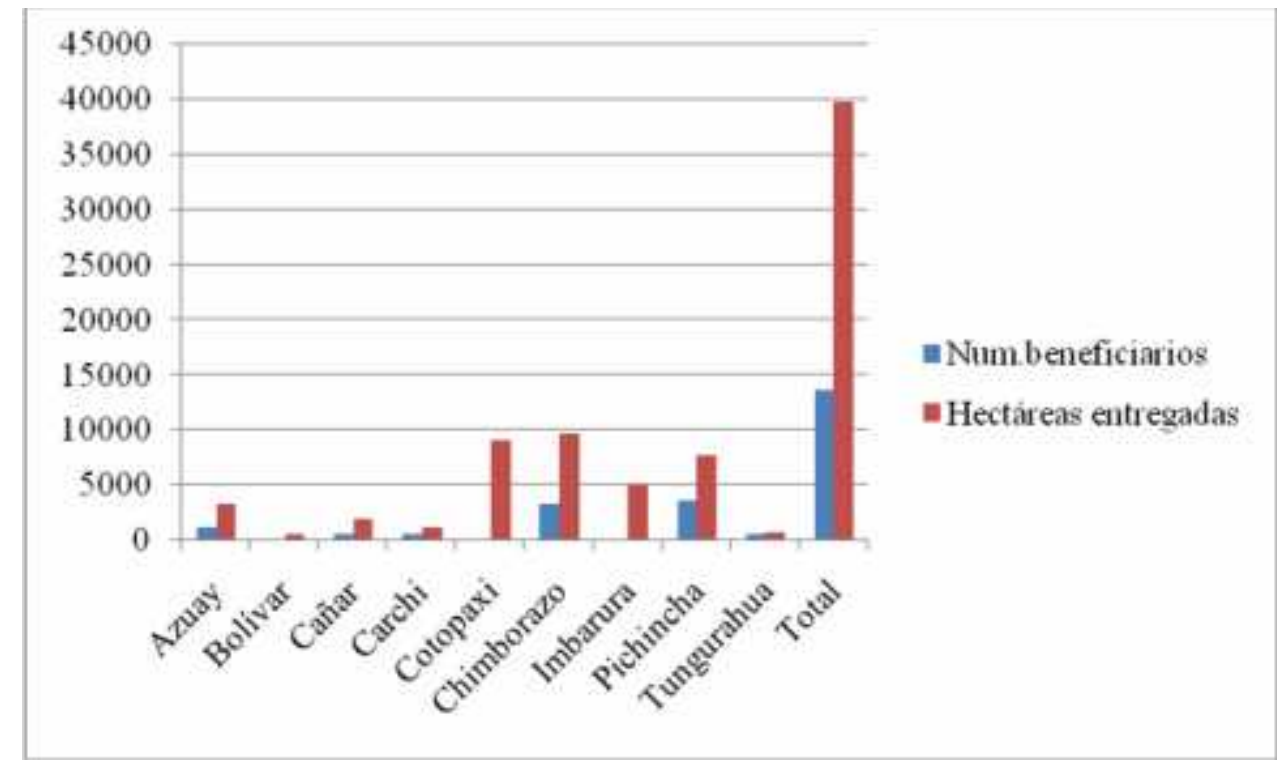

Elaboración propia a partir de los datos de la tabla 19.

Fuente: Ministerio de Previsión Social y Trabajo, Departamento de Cuestiones Sociales, Departamento de Liquidación de Huasipungos del IERAC. Elaboración: Instituto Ecuatoriano de Antropología y Geografía, Departamento de Antropología Social, agosto de 1967.

\footnotetext{
${ }^{982}$ Ministerio de Previsión Social y Trabajo, Departamento de Cuestiones Sociales, Departamento de Liquidación de Huasipungos del IERAC. Elaboración: Instituto Ecuatoriano de Antropología y Geografía, Departamento de Antropología Social, agosto de 1967.
} 
Si se cuentan las entregas de tierras según el número de beneficiarios y la superficie en hectáreas con la reforma agraria; se observa que Pichincha, Cotopaxi y Chimborazo contaban con el mayor número, mientras que en la parte inferior se encontraban Bolívar y Tungurahua, provincias donde lo mestizo y el minifundio limitaron estas posibilidades.

Pedro Saad afirma que, en el proceso de entrega de huasipungos, la política de la Junta Militar contribuyó a empeorar la situación del campesino, ya que mientras que la Junta Nacional de Planificación recomendaba la entrega de una extensión que no fuera inferior a las 12 hectáreas, los campesinos recibieron parcelas que apenas tenían una hectárea de superficie. ${ }^{983}$ Además, la ley concedía al terrateniente el derecho de reasentamiento de los antiguos huasipungueros, dejaba endeudados a los precaristas con menos de diez años de antigüedad, y solo proporcionaba el derecho al acceso de agua y leña a los trabajadores de la hacienda, además de privarlos a corto plazo de pastos fundamentales para la reproducción de su economía, obligándoles a pagar por las tierras adjudicadas. $^{984}$

A este respecto, al analizar el impacto de la liquidación de los huasipungos en el Ecuador, se ha de hacer alusión al cambio y la integración social de los diferentes grupos, que se vieron limitados por la falta de preparación de los huasipungueros a la hora de recibir la tierra, puesto que no tenían los conocimientos necesarios sobre el derecho de propiedad (salarios agrícolas, legalización de la posesión de la tierra, acceso a servidumbres, etc.), lo cual supuso el consiguiente desajuste social:

La consecuencia de esas políticas fue un incremento del minifundio, unidad inviable económicamente, de 93.000 en 1954 a 206.000 en 1968, mientras la mayor parte de la Sierra seguía concentrada en manos de los latifundistas”. Entre 1954 y 1974, el número de unidades menos de 5 hectáreas se incrementó en un 37\%, lo que llevó a que el tamaño

\footnotetext{
${ }^{983}$ Pedro Saad, La reforma..., op. cit. p. 27-110.

984 Osvaldo Barsky, Los terratenientes..., op. cit. p. 133-205, 1980, O. Barsky et al: El proceso de transformación de la producción lechera serrana y el aparato de generación- transferencia en Ecuador, Quito: FLACSOPROTAAL, 1980; Pedro Saad, La reforma..., op. cit. p. 27.
} 
promedio de las explotaciones menores a 5 hectáreas pasara de 1,71 en 1954 a 1.55 hectáreas en $1974 .{ }^{985}$

Estos bajos niveles de distribución de la tierra ponen de manifiesto las diferencias en el efecto de una política estatal formada por elementos regionales de larga duración.

De igual manera, Leon Zamosc indica a través de su estudio de la liquidación del huasipungo durante los años sesenta, la importancia de este proceso y la necesidad de apreciar sus dimensiones y evaluar el impacto de la reforma agraria sobre la estructura del agro en la Sierra ecuatoriana. ${ }^{986}$

Para ello, también lleva a cabo una comparativa en la distribución de tierras realizadas desde el inicio de las entregas anticipadas en 1959 hasta el año 1970, con el propósito de ver el efecto conseguido antes y después de la aplicación de la Ley de Reforma Agraria de 1964. En este caso, utiliza los datos proporcionados por las investigaciones de Oswaldo Barsky y Fernando Velasco con los que se vuelve a observar las entregas anticipadas de los huasipungos y los que correspondían a la actividad del IERAC (Tabla 14: La liquidación del huasipungo en la Sierra ecuatoriana 1959-1970). ${ }^{987}$

\footnotetext{
${ }^{985}$ Osvaldo Barsky et al, Políticas agrarias..., op. cit. p.77.

${ }^{986}$ Leon Zamosc, Luchas campesinas..., op. cit. p. 215-220.

${ }^{987}$ Esta tabla se encuentra en el apéndice de datos del capítulo 4. Fuente: Osvaldo Barsky, La reforma..., op. cit. p. 72; F. Velasco: Reforma agraria y movimiento indígena en la Sierra, Quito: Editorial El Conejo, 1983, p. 86.
} 
Gráfico 9: La liquidación del huasipungo en la Sierra ecuatoriana (1959-1970):

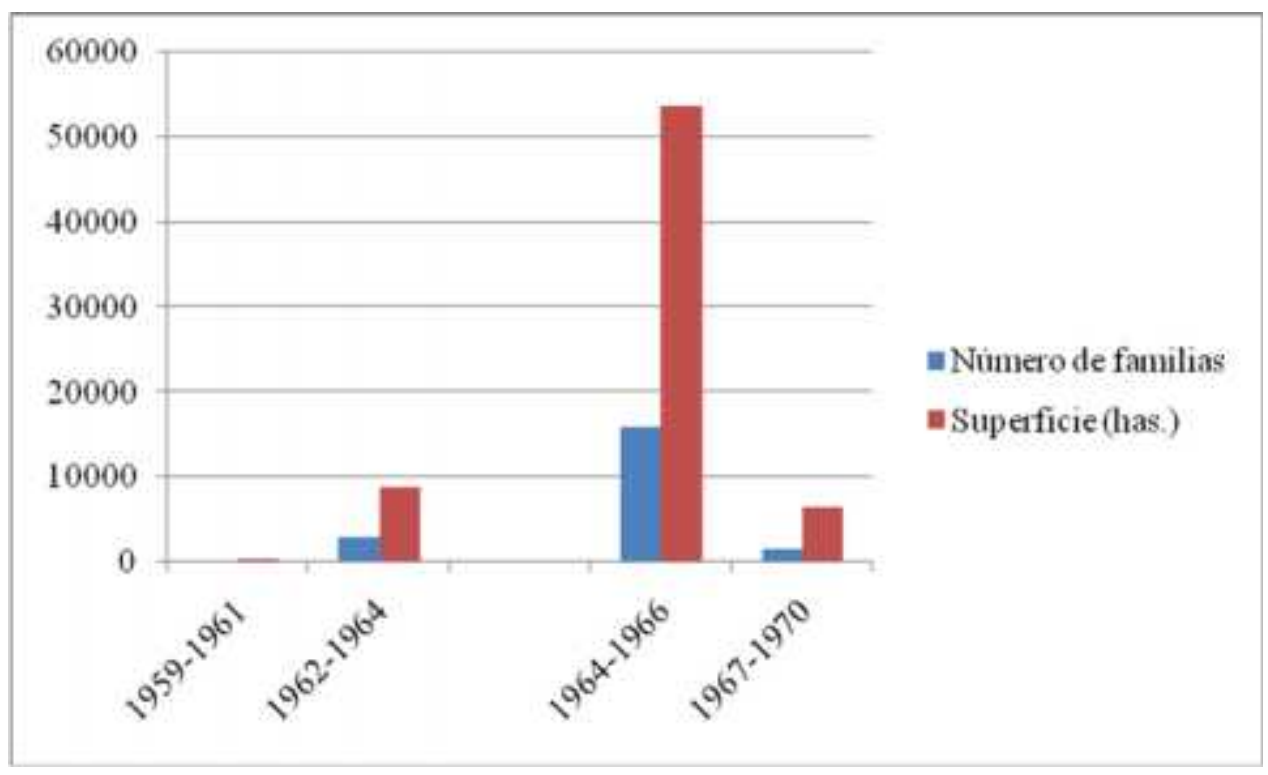

Entregas anticipadas de huasipungos: Periodos 1959-1961, 1962-1964. Entregas de huasipungos con la Reforma Agraria: Periodos 1964-1966, 1967-1970.

Elaboración propia a partir de los datos de la tabla 20.

Fuente: O. Barsky: La reforma agraria ecuatoriana, Quito: Corporación Editora Nacional, 1984, p. 72; F. Velasco: Reforma agraria y movimiento indígena en la Sierra, Quito: Editorial El Conejo, 1983 , p. 86.

Según Zamosc, las motivaciones políticas fueron un factor dominante en las entregas anticipadas, pues la mayoría de los repartos ocurrieron entre 1962-1964, debido a los debates iniciados en torno a la reforma agraria, además de tener lugar las grandes movilizaciones campesinas organizadas por la Federación Ecuatoriana de Indios (FEI), como ya se dijo antes. ${ }^{988}$ En relación a la actividad del IERAC, las estadísticas muestran que una parte considerable del programa de liquidación del huasipungo ocurrió durante el gobierno de la Junta Militar (19631966), ya que el tamaño promedio de los lotes adjudicados por dicho instituto fue de 3,4 hectáreas, cantidad que si bien era superior al promedio de 3,1 hectáreas en las entregas

\footnotetext{
${ }^{988}$ En este periodo, el número de familias beneficiadas y de hectáreas repartidas fue superior a las del periodo 19591961. Ver datos en Tabla 20: La liquidación del huasipungo en la Sierra ecuatoriana, 1959-1970 (en el apéndice de datos del capítulo 4). Fuente: O. Barsky, La reforma..., op. cit. p. 72; F. Velasco, Reforma..., op. cit. p. 86.
} 
anticipadas, no llegaba al mínimo necesario de cinco hectáreas para mantener a una familia en la Sierra. $^{989}$

De este modo, en el intervalo correspondiente a 1959-1964, el número de familias de antiguos huasipungueros ascendía a 3.019, mientras que en el periodo 1964-1970, esta cifra era de 17.391 familias beneficiadas por la reforma agraria en la Sierra:

Tomados en su conjunto, los datos del periodo 1964-1970 indican que las 27.087 familias incluidas en la reforma apenas equivalían a un 10,2\% del total de familias serranas y a un 37,4 de las familias que en 1960 carecían de acceso a tierras propias. Por otra parte, las 125.231 hectáreas adjudicadas y redistribuidas por el IERAC solo representaban un 8,5\% de la superficie ocupada por las haciendas mayores de 500 hectáreas y un 4,1\% del total de tierras censadas en $1954 .^{990}$

A partir de aquí, se vuelve a apreciar el impacto tan pequeño que la reforma agraria tuvo en los años sesenta en cuanto a la distribución de la tierra en la Sierra. De esta manera, la redistribución se redujo a un mínimo, a la vez que la liquidación del huasipungo solo llegó a suponer un cambio en el status oficial de las familias implicadas, siendo el efecto de la reforma, la eliminación de las relaciones pre-capitalistas. En este caso, los terratenientes tuvieron que olvidarse de las rentas y vincularse a la fuerza de trabajo mediante relaciones salariales.

Vamos a ver ahora cómo se produjo la eliminación de otra de las formas pre-capitalistas, los arrimados, que todavía existía en la Sierra en los años sesenta, y cuya erradicación se inició tras la promulgación de la Ley de 1964.

La Tabla 21 (Liquidación y ampliación de parcelas en la provincia de Loja 1965 -1967) muestra la desventaja a la que estuvo sometido el arrimado en la provincia de Loja, pues mientras se repartían 4.582 hectáreas entre 1.777 familias, se ampliaba mediante compra a 1.271 familias con 11.407 hectáreas. De acuerdo con la Ley de Reforma Agraria, los arrimados no tenían

\footnotetext{
${ }^{989}$ Leon Zamosc, Luchas campesinas..., op. cit, p. 222.

${ }^{990}$ Ibíd. p. 222.
} 
derecho a fondos de reserva y tampoco a vacaciones no gozadas, mientras que para ampliar su parcela familiar estaban obligados a comprar la tierra al propietario. ${ }^{991}$

Al calcular el promedio de hectáreas por familia en la liquidación del arrimazgo, se obtiene la cantidad de 2,58, cifra bastante pequeña para cada familia, la cual ascendió a 8,97 tras la ampliación de tierras. ${ }^{992}$ No en vano, en la mayor parte de los casos, dicho aumento se hizo con tierras temporales y lugares libres dedicados al pasto de animales, a la vez que el antiguo arrimado perdía el derecho de acceso al pasto, leña, caminos y agua. Esto último ocurrió porque la ley no reconocía el uso y disfrute de servidumbre, sino un pequeño porcentaje muy limitado para atender las exigencias de su vida agrícola.

Como consecuencia, las condiciones para la reproducción de una gran parte de los campesinos serranos eran insuficientes, de ahí la necesidad de vincularse al mercado de trabajo asalariado para obtener los ingresos necesarios que complementaran la producción para el autoconsumo.

En efecto, la reforma agraria no consiguió acabar con la relación entre la economía terrateniente y la economía campesina, sino que las separó y estableció un conflicto en torno al control de los medios de producción. Esta división creó las condiciones para que en los lugares de desarrollo de la agricultura capitalista apareciera el trabajo asalariado, el cual podría ocupar el lugar de las antiguas rentas de trabajo. Aquí, las investigaciones de Barsky muestran que tras la resolución del conflicto interno y la creación de una reserva externa de mano de obra, la eliminación de las antiguas relaciones de producción fue funcional a la consolidación del capitalismo agrario en las haciendas modernas del centro y norte de la Sierra. ${ }^{993}$ No obstante, esto no aclara los resultados del proceso en otras haciendas de la zona y del resto de la región andina.

Además, la reforma agraria como proyecto modernizante era una representación más amplia de intereses sociales, pues como se ha mencionado, sus motivaciones estaban relacionadas con el marco político y la necesidad de acabar con los conflictos en el campo, siendo la meta principal la liquidación del precarismo.

\footnotetext{
${ }^{991}$ Esta tabla se encuentra en el apéndice de datos del capítulo 4. Fuente: Sección de Evaluación y Estadística del IERAC, 1967, en: Piedad Peñaherrera, Alfredo Costales, op. cit. p. 147.

992 Para calcular la cifra 2,58 se divide el número de hectáreas entregadas entre las familias beneficiadas: 4.582/1.777=2,58 has/familia. La cantidad 8,97 se ha obtenido dividiendo el número de hectáreas entregadas entre las familias beneficiadas: 11.407/1.271=8,97 has/familia.

${ }^{993}$ O. Barsky, La reforma..., op. cit. p. 97-98; O. Barsky, G. Cosse, Tecnología..., op. cit. p. 54-56.
} 
En relación a las luchas campesinas durante el proceso de reforma agraria, en las que los protagonistas fundamentales fueron los huasipungueros, hay que recordar los efectos indirectos de las luchas, pues en ninguna región de la Sierra ocurrieron movilizaciones que produjeran cambios sustanciales. La principal forma de presión fue el asedio interno en las haciendas, cuya presencia tenía lugar a través de las respuestas de los terratenientes.

De igual forma, las protestas organizadas tuvieron resultados más visibles pero también indirectos, ya que su incidencia se dio mediante la repercusión que alcanzaban dichas movilizaciones en la escena política. Las luchas del campesinado no llegaron a consolidarse en un movimiento social capaz de asumir un papel fundamental en la reforma agraria, a pesar de que la FEI parecía ser una organización de este tipo. ${ }^{994}$

Finalmente, se ha de destacar la gran desconcentración en la distribución de la tierra (tabla 22: Número y superficie de las explotaciones en la Sierra ecuatoriana (por grupos de tamaño, 19541974) como resultado del carácter marginal de la actividad redistributiva de la reforma agraria, en la que algunos terratenientes vendieron parte de las propiedades para incrementar su capital o consolidar la producción empresarial sobre una superficie más pequeña. ${ }^{995}$

Aquí, se puede pensar que la eliminación de las relaciones de producción pre-capitalistas aceleró la crisis de las haciendas tradicionales, aumentando su diferenciación y la venta de aquellas tierras que poseían menos condiciones para adaptarse a los cambios. ${ }^{996}$ De este modo, puede afirmarse que la primera etapa de la reforma agraria no pudo implementar un modelo homogéneo de evolución capitalista por la vía junker, pues la eliminación del pre-capitalismo definió un marco positivo para una pauta combinada de desarrollo, cuyos elementos fundamentales fueron los terratenientes convertidos en empresarios, una nueva burguesía rural naciente y los sectores de economía campesina. ${ }^{997}$

\footnotetext{
${ }^{994}$ O. Barsky, La reforma..., op. cit. p. 32-40.

995 Esta tabla se encuentra en el apéndice de datos del capítulo 4. Fuente: E. Archetti: Burguesía rural y campesina en la Sierra ecuatoriana, en Ecuador Archetti, Campesinado y Estructuras agrarias en América Latina, Quito: CEPLAES editores, 1981, p. 302.

${ }^{996}$ Ibíd. p. 302; O. Barsky, La reforma..., op. cit. p. 35-387; G. Cosse, Estado y agro..., op. cit. p. 37-42.

${ }^{997}$ Para más información de la vía junker, ver el apéndice de notas del capítulo 4. Fuente: Rafael Quintero: El mito del populismo en el Ecuador. Análisis de los fundamentos del estado ecuatoriano moderno, 1895-1934, FLACSO, Quito, 1980, p. 92; René Báez: Ecuador: ¿Genocidio económico o vía democrática?”, Biblioteca de Ciencias Sociales, volumen 40, Corporación Editora Nacional, 1992, p. 15-20; D. F. Maza Zavala: Evaluación crítica de la
} 
Ante esta situación, la conexión entre los cambios de los años sesenta, la fase siguiente de la reforma agraria y las luchas campesinas, ponen de manifiesto que la falta de acceso a los recursos de las haciendas dejó a una gran parte de los antiguos huasipungueros en condiciones precarias de reproducción. La alternativa tenía como viabilidad los alrededores de Quito y otras zonas del norte de la Sierra, donde el mayor dinamismo económico podía absorber trabajo en la agricultura capitalista, la industria y otras actividades urbanas. ${ }^{998}$ En cambio, en el resto de la zona interandina, las características de la economía campesina establecieron una nueva etapa, en la que el campesino minifundista aparecía como agente reivindicativo principal y las presiones se ejercían desde afuera de la haciendas, siendo este, el contexto donde tuvo lugar la ley de reforma agraria del gobierno militar de Rodríguez Lara de 1973, el cual se vio obligado a modificar la normativa para incluir criterios de productividad y presión demográfica.

enseñanza de la economía en América Latina, Revista Economía, IIE-UC, Quito, número 63, 1990, p.78, en René Báez: Ecuador: ¿Genocidio económico o vía democrática?, Biblioteca de Ciencias Sociales, volumen 40, Corporación Editora Nacional, 1992, p. 16-17.

998 A. Sáenz: Expulsión de fuerza de trabajo agrícola y migración diferencial, en Miguel Murmis et al, Ecuador: Cambios en el agro serrano, Quito, FLACSO, 1980. 


\section{CAPÍTULO 5: EL SECTOR INDUSTRIAL Y SU VINCULACIÓN A LA ECONOMÍA ECUATORIANA: NUEVAS TENDENCIAS EN LA ACUMULACIÓN DEL CAPITAL (1960-1973):}

\section{1) La industrialización y su vinculación al sistema capitalista: El papel del estado y de la burguesía moderna en la conformación de un nuevo modo de desarrollo en la economía ecuatoriana (1963-1970).}

Hasta ahora, hemos visto cómo el agotamiento del modelo agro-exportador y la crisis política del gobierno de Carlos Arosemena, generaron las condiciones necesarias para que la Junta Militar asumiera el control político del estado en 1963 y estableciera un programa que favorecía el proceso de acumulación interno con un claro apoyo en el sector industrial. Del mismo modo, nos hemos referido a los estudios realizados por la CEPAL sobre el desarrollo de la economía de los países de América Latina y a su teoría centrada en las causas que propiciaban el subdesarrollo, la cual llegó a ejercer una gran influencia en la adopción del nuevo modelo de industrialización (vía sustitución de importaciones) para fomentar el desarrollo del país. ${ }^{999}$

El gobierno militar buscaba eliminar el desarrollo agrario tradicional mediante un modelo de reforma basado en los principios de la Alianza para el Progreso, el cual había sido implementado en la región latinoamericana durante estos años. Además, estas ideas proponían la expansión del aparato económico del estado y la centralización de la recaudación de impuestos a nivel nacional que, hasta el momento, era realizada por instituciones de carácter regional. Es decir, se perseguía una nueva orientación del proceso de acumulación de capital a través de una mayor contribución del sector industrial y la introducción de reformas que impulsaran el desarrollo económico, la modernización estatal y la modificación de las relaciones tradicionales con el poder político. ${ }^{1000}$ A partir de estas ideas, en este apartado, vamos a revisar cuáles fueron las políticas de desarrollo e industrialización en el Ecuador a mediados de los años sesenta y cómo se llevó a cabo la implantación del modelo de sustitución de importaciones. También, veremos cuál fue el papel del estado y de las clases sociales en la conformación de este proceso, además de analizar la contribución del sector industrial al crecimiento de la economía. Esto nos ayudará a determinar si

\footnotetext{
${ }^{999}$ Raúl Prebisch: Estudio económico de América Latina, Naciones Unidas, Nueva York, 1949, y Problemas teóricos y prácticos del crecimiento económico, CEPAL, primera edición, 1952.

1000 Gustavo Cosse: Aproximación al análisis del aparato institucional agrario y su relación con el proceso político social en el caso ecuatoriano, FLACSO, Mimeo, Quito, 1979, p.9.
} 
la industria, como patrón de desarrollo de la economía ecuatoriana, pudo ser considerada el nuevo eje de acumulación de capital de los años sesenta.

En principio, al referirnos al modelo de industrialización por sustitución de importaciones, es importante considerar las etapas establecidas por los diferentes estudios realizados. Así, una primera fase puede ser situada entre 1960 y 1972, en la que el proceso tuvo poca fuerza debido a la debilidad del estado central; mientras que la segunda fase, situada a partir de 1972, coincide con el inicio de la exportación de petróleo y por el fuerte ritmo de desarrollo que el estado le proporcionó a dicho modelo, y que continuó hasta su crisis, ya en los años ochenta. ${ }^{1001}$

Otros estudios sobre el desarrollo industrial ecuatoriano dividen el proceso de industrialización en tres etapas a partir del año 1950, con las que se pone de manifiesto la influencia ejercida por las investigaciones sobre el desarrollo de la CEPAL en el Ecuador, su posterior aplicación en los años sesenta y su mayor apogeo durante la década de los setenta. ${ }^{1002}$

En este apartado, si bien nos centraremos en el desarrollo del proceso de industrialización de la década de los sesenta, comenzaremos haciendo una breve revisión de lo acontecido a este respecto, en los años cincuenta.

En este sentido, la primera etapa del modelo de industrialización abarca el periodo comprendido entre 1950-1960, y tiene como base la teoría de la CEPAL, que como ya se ha indicado, pretendía fomentar el modelo de desarrollo hacia adentro o de sustitución de las importaciones como alternativa al modelo tradicional agro-exportador, fundamentado en las exportaciones de productos agrícolas y dependiente a su vez, de las fluctuaciones de los precios.

La tesis principal de la CEPAL, basada en las ideas del economista argentino Raúl Prebisch en cuanto al deterioro de los términos de intercambio de los productos primarios, cuestionaba la validez del esquema de división internacional del trabajo que asignaba a la periferia (países subdesarrollados) el papel de productor y exportador de productos primarios como mecanismo eficaz para alcanzar el desarrollo. ${ }^{1003}$ Esta teoría partía de los acontecimientos del periodo de entreguerras del siglo XX, que provocaron la crisis del modelo agro-exportador y pusieron en

\footnotetext{
${ }^{1001}$ Galo Valarezo, Víctor Torres Dávila: El desarrollo local en el Ecuador: Historia, actores y métodos, Ediciones Abya-Yala, Quito, 2004, p. 13-68.

1002 Guillermo Landázuri Carrillo: Proposiciones de cambio en el desarrollo industrial ecuatoriano, Libro del Sesquicentenario Economía Ecuador, primera parte, Corporación Editora Nacional, 1983, p. 361-372.

${ }^{1003}$ Raúl Prebisch: El desarrollo económico de América Latina y sus principales problemas, CEPAL, 1949.
} 
entredicho la división internacional de trabajo, basada en la exportación de productos primarios. Fue así, como Prebisch construyó su teoría del deterioro de los términos de intercambio de los productos primarios frente a los productos manufacturados.

La novedad de la teoría de la CEPAL consistía en la utilización del término "centro-periferia" y en explicar la desigualdad de las relaciones económicas internacionales, así como la heterogeneidad de las estructuras productivas internas. Es decir, para Prebisch, los países subdesarrollados o de la periferia no podían retener los beneficios del progreso técnico, los cuales se concentraban en los países desarrollados o del centro. Esta desigualdad se manifestaba a la hora de repartir los beneficios comerciales entre unos países y otros. ${ }^{1004}$

De igual manera, mientras que los salarios reales solían estancarse en los países subdesarrollados, limitando su capacidad para acumular capital, los salarios y las tasas de acumulación en los países centrales se iban incrementando. Esta misma relación, centro-periferia y concentración del progreso técnico, tenía lugar en las naciones latinoamericanas y favorecía a los sectores modernos, mientras que perjudicaba a los sectores más atrasados.

A su vez, la CEPAL encontró una gran disparidad en la demanda de importaciones de productos primarios por parte de los países desarrollados o del centro, y la demanda de productos industriales de las naciones subdesarrolladas o de la periferia, siendo la primera, menor que la segunda. Esta baja demanda de los productos importados por parte del centro afectaba de forma negativa la producción del sector exportador de la periferia, que tampoco se encontraba en condiciones para absorber el exceso de mano de obra desplazada del sector agrícola y contaba con numerosas limitaciones técnicas. ${ }^{1005}$ En este caso, además de la preocupación por el deterioro de los términos de intercambio y variaciones de los precios de productos agrícolas, era necesario buscar una solución para que la población desplazada por el sector primario pudiera acceder a un empleo productivo.

Como ya se mencionó en la introducción, las ideas de la CEPAL procedían de las condiciones de la economía internacional y de la visión que se tenía en aquellos años sobre el desarrollo. Es decir, en los años cincuenta, el orden internacional de la posguerra estaba marcado por la gran presión ejercida sobre los países latinoamericanos para que abrieran sus mercados, y por la

\footnotetext{
1004 Jorge Estrada: Industriales, estado, industrialización en el Ecuador, Corporación de promoción universitaria, Universidad de San Francisco de Quito, INSOTEC, 1990, p. 36-62.

${ }^{1005}$ Ibíd. p. 36-62.
} 
disminución de los aranceles y políticas internas de estas naciones, que eran contrarias a la apertura debido al efecto negativo que la crisis externa de la década de los treinta había provocado. ${ }^{1006}$

La crisis latinoamericana y el camino hacia un nuevo modelo orientado "hacia adentro" tuvieron su origen en el agotamiento del modelo agro-exportador y en la posición que los países de América Latina ocupaban a nivel mundial. El desequilibrio externo, que provocaba frecuentes crisis, recesión e inflación, tenía su origen en el deterioro de los términos de intercambio entre los productos primarios y los manufacturados, y en la incapacidad de la periferia para mantener los beneficios del progreso técnico.

Para superar estos problemas, era necesario impulsar la industrialización aprovechando las circunstancias ofrecidas por la depresión y la guerra a través del establecimiento de una estrategia, en la que la protección y la acción estatal desempeñaban un papel central. A partir de este momento, se podría conseguir una mayor autonomía frente al centro que permitiera la acumulación de capital interna.

De esta manera, el pensamiento de la CEPAL puso de manifiesto la necesidad de crear un conjunto de políticas que lograra mantener la autosuficiencia vía sustitución de importaciones y con la intervención estatal. Además, como el crecimiento económico se centraba en las exportaciones, se impulsó la industrialización mediante el control de las importaciones y la planificación. ${ }^{1007}$

En aquella época, los términos de intercambio evolucionaban a favor de los productos industriales y en contra de los primarios; no tenía sentido invertir en actividades sujetas

\footnotetext{
${ }^{1006}$ Alfredo Mancero Samán: Industrialización, desarrollo y democratización, en "Políticas de industrialización en América Latina”, compilador Rafael Urriola, CEPLAES-ILDIS, 1988, p. 163-164.

${ }^{1007}$ A. Hirschman: Ideologies of economic development in Latin America, en Latin American issues, editado por A. Hirschman, Nueva York: The 20th Century Fund, 1961, p. 16. Entre los estudios que tratan este tema, se encuentran los realizados por Raúl Prebisch: El desarrollo de América Latina y algunos de sus principales problemas, CEPAL, 1949; Interpretación del proceso de desarrollo latinoamericano en 1949, segunda edición, Santiago: CEPAL, 1973; Crecimiento, desequilibrio y disparidades: Interpretación del proceso de desarrollo económico, en N.U CEPAL: Estudio económico de América Latina, 1949, Nueva York, Naciones Unidas, 1950; La CEPAL y los problemas del desarrollo económico en América Latina, Santiago: CEPAL, 1960, en Raúl Prebisch: "Discursos, declaraciones y documentos 1952-1963", 3.v.
} 
a los ciclos del comercio exterior, y la industrialización se veía como un proceso que, además de impulsar la modernización, crearía empleos de manera directa e indirecta. ${ }^{1008}$

En el caso ecuatoriano, a partir de 1955, las fluctuaciones internacionales no solo provocaron el estancamiento del país e impidieron un desarrollo sostenido, sino que llevaron a crisis agudas debido a las dificultades para mantener un proceso de acumulación interna. Tampoco, se pudieron canalizar las exportaciones, al pasar a manos de los monopolios nacionales y empresas extranjeras situadas en las zonas más rentables:

La pérdida de importancia del comercio con los países desarrollados por un intercambio creciente entre estos, las repercusiones económicas y políticas de la Revolución Cubana, y la incapacidad de poner en marcha las reformas y programas de desarrollo iniciados con la dictadura de 1963, motivaron la aguda recesión de estos años. ${ }^{1009}$

Ante este panorama, se adoptó una estrategia para promover el crecimiento del sector industrial y acelerar el progreso económico conforme a las ideas propuestas por la CEPAL. Así, el modelo de sustitución de importaciones comenzó a formarse hacia finales de la década de los cincuenta, cuando se expidió la Ley de Fomento Industrial en 1957 para la protección y consolidación gradual de las industrias nacionales.

Aunque, ya en 1953 y 1954, se habían elaborado algunas leyes de protección a la pequeña industria y artesanía (la Ley de Fomento Industrial del Austro se emitió en 1954 para ayudar a la recuperación de las provincias que habían sido afectadas por la desaparición de la industria de paja toquilla), fue la Ley de 1957, la que estableció un conjunto de prioridades de una forma más concreta, concediendo la exoneración de impuestos a la importación de maquinarias, equipos, materias primas, repuestos, etc., que eran utilizados en las diferentes actividades industriales. ${ }^{1010}$ De acuerdo con César Augusto, el modelo de industrialización para sustituir importaciones adoptado por el Ecuador era consistente con el diseño de los modelos elaborados por Arthur Lewis en 1954 y perfeccionados por Ramis y Fei en 1961, es decir, estos modelos implicaban la

\footnotetext{
${ }^{1008}$ Alfredo Mancero Samán, op. cit. p. 164.

${ }^{1009}$ Luis Fierro Carrión: Revista Economía, Diario Hoy, Quito, 15 de julio de 1984, p. 7.

${ }^{1010}$ Consultar el apéndice de notas del capítulo 5 para más información sobre estas leyes. Fuente: Galo Abril Ojeda: Política monetaria y desarrollo industrial en el Ecuador, 1970-1983, Banco Central del Ecuador, Instituto de Estudios Latinoamericanos, monografía número 11, agosto 1985.
} 
existencia de una economía cerrada, donde la agricultura generaba un excedente que podía ser aplicado para mantener el crecimiento del sector industrial. ${ }^{1011}$

Junto a esto, las ideas de la CEPAL fueron recogidas por el estado ecuatoriano, que pronto comenzó a analizar la necesidad de llevar a cabo la industrialización vía sustitución de importaciones, ante el pesimismo generado por la caída de las exportaciones y como mecanismo para poder superar la dependencia que existía de las mismas. ${ }^{1012}$

A partir de la década de los años cincuenta, comenzó a desarrollarse un sistema de fomento industrial mediante la creación de organismos y de leyes protectoras de la incipiente industria, entre las que se encontraban la Junta de Planificación Nacional (1954), la Ley de Etiquetas y Marcas de productos nacionales (1957) para regular el incremento de las actividades relacionadas con marcas, inventos y con los problemas vinculados a la propiedad industrial, y la ya mencionada Ley de Fomento Industrial (1957), con la que se desarrolló un mecanismo de clasificación para establecer diferentes categorías de empresas según su contribución a la sustitución de importaciones, exportaciones y uso de materias primas nacionales. ${ }^{1013}$

Así, en estos años, la mayor parte de la industria manufacturera estaba concentrada en las provincias de Guayas, Pichincha, y también, en la Sierra, pues era el centro de la industria del cuero, zapatos, bebidas, tabaco y madera, siendo Quito, Ambato, Cuenca, Riobamba y Latacunga, los lugares de producción más importantes. ${ }^{1014}$

\footnotetext{
${ }^{1011} \mathrm{Si}$ bien estas teorías reconocían el potencial de la agricultura para producir dicho excedente, no dejaban claro cómo se podía producir y mantener. Además, estos modelos entorpecían las inversiones en la agricultura y estimulaban políticas enfocadas en la extracción de beneficios, creándose por consiguiente, una tendencia a descuidar el sector agrícola. Para más información, consultar la obra de César Augusto Bravo: Historia del Ecuador: De la década de 1950 a la década de los 70, Colegio de abogados del Azuay, Editorial Gráficas Hernández, Cuenca, 1995, p. 123.

1012 Hay que recordar cómo la crisis del modelo de acumulación agroexportador a finales de los cincuenta, fue debilitando a la burguesía comercial; a la vez que comenzaron a producirse divisiones internas entre fracciones tradicionales y modernizantes de la clase de terratenientes. En este contexto, la Junta Militar promulgó la Ley de Reforma Agraria de 1964 y su plan de desarrollo, basado en un esquema de industrialización a través de sustitución de importaciones.

1013 Germánico Salgado: Lo que fuimos y lo que somos, en G. Drekonja et al, Ecuador Hoy, (Bogotá: Siglo XXI) 1978, p. 50.

1014 Aquí, se ha de aclarar la importancia de los centros artesanales y su contribución al sector industrial, pues el número de establecimientos y absorción de fuerza de trabajo era bastante mayor que los proporcionados por la gran industria, como se verá a continuación. Así, por ejemplo, tanto el desarrollo de las actividades artesanales en la zona de la Sierra sur y su vinculación con los trabajos agrícolas como las actividades artesanales con la paja toquilla, el cuero, el hierro, el barro y la orfebrería, constituyeron una forma de sustento para una gran cantidad de campesinos
} 
Además, la planificación llevaba asociada el impulso de la sustitución de importaciones, que fue bastante simple y estaba basada en industrias de bienes de consumo inmediato, (bebidas y alimentos) como muestra la tabla 1 (Valor bruto de la producción y valor agregado de las industrias, 1957-1960), al implicar procesos de tecnología relativamente simples y presentar una moderada contribución al producto interior bruto en comparación con la agricultura (ver las tablas 2 y 3 Producto interior bruto por clase de actividad económica 1950-1954, 19551959). ${ }^{1015}$ En el año 1953, la capitalización de la industria era baja; el total de activos fijos usados en la producción tenía un valor de 16.400 sucres por trabajador. ${ }^{1016}$

del austro ecuatoriano y dieron gran dinamismo a la región, creándose a su vez, una clase de intermediarios con mentalidad empresarial. Fuente: Marco Restrepo Guzmán: Estado, actores y conflicto social en la Amazonía: El caso de Morona Santiago (1940-1992), FLACSO, Quito, 1992, p. 54; Jorge Estrada, Industriales..., op. cit. p. 3662.

${ }^{1015}$ Las tablas 1, 2 y 3 se encuentran en el apéndice de datos del capítulo 5. Fuente: Francisco X. Swett: Modelos de desarrollo del Ecuador, Libro del Sesquicentenario Economía Ecuador, segunda parte, Corporación Editora Nacional, 1983, p. 73-81; Catherine Conaghan: Industrialists and the reformists interregnum: Dominant class behaviour and ideology in Ecuador, 1972-1979, 1983, p. 84.

${ }^{1016}$ César Augusto Bravo: Historia del Ecuador: De la década de 1950 a la década de los 70, Colegio de Abogados de Azuay, Editorial Gráficas Hernández, Cuenca, 1995, p. 131. 
Gráfico 1: Producto interior bruto por clase de actividad económica 1950-1959

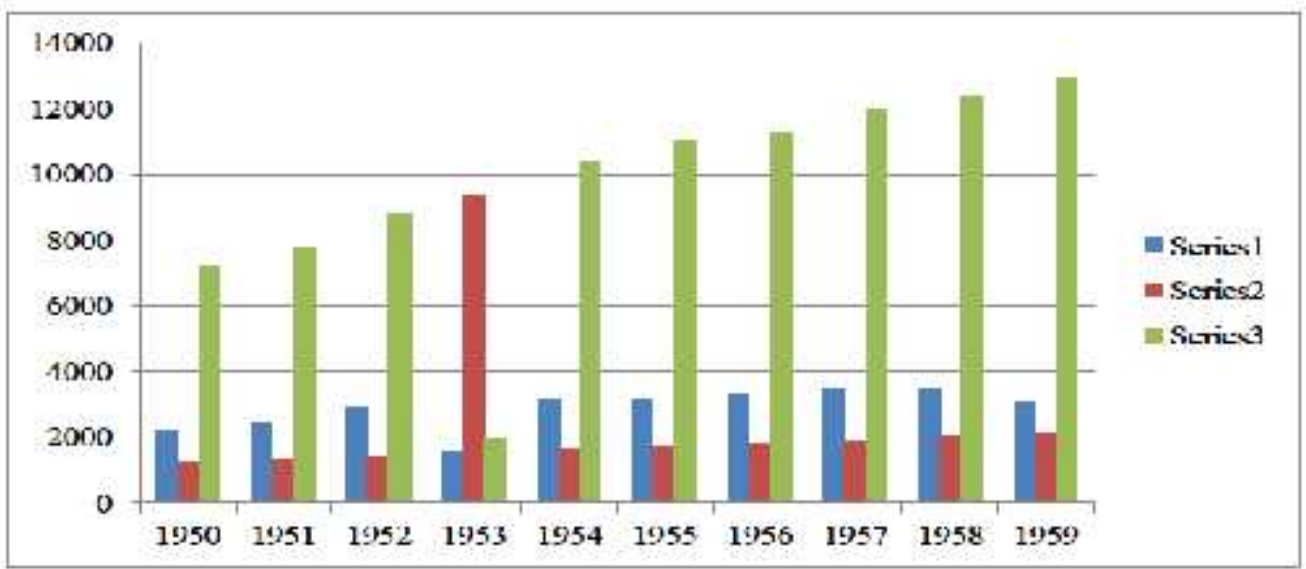

Elaboración propia a partir de los datos de las tablas 2 y 3.

Series 1: Agricultura, caza, silvicultura y pesca

Series 2: Industria Manufacturera

Series 3: Producto Interior Bruto (PIB)

Fuente: Patricio Almeida Guzmán, Rebeca Almeida Arroba: Estadísticas Económicas Históricas 1948-1983, Fuentes para la Historia Económica del Ecuador, serie estadísticas históricas, vol. 1, Banco Central del Ecuador, 1988, p. 137-138.

Por otro lado, aunque en la segunda etapa de la industrialización se hablará más del papel de la artesanía y pequeña industria en comparación con el de la gran industria, es necesario destacar la importancia de la artesanía en el Ecuador, que ya en los años cincuenta, constituía el grueso de establecimientos que conformaban el sector manufacturero y absorbía una parte importante de mano de obra. ${ }^{1017}$

\footnotetext{
${ }^{1017}$ En relación a la artesanía, el primer artículo de la Ley de Defensa del Artesano de 1953, definía al artesano como el trabajador manual que hubiere invertido en sus talleres para maquinarias o materias primas, una cantidad no mayor de 20.000 sucres, que tuviere a sus órdenes, no más de seis operarios y que realizare negocios de venta de los
} 
En 1950, el peso de la artesanía en el total del empleo del sector manufacturero alcanzaba más del 90\%, es decir, con 211.700 trabajadores vinculados a la artesanía, mientras que de la industria fabril dependían apenas 23.000 trabajadores, equivalente al porcentaje restante (9.8\%). La industria ha ido evolucionando año tras año, pero manteniendo básicamente la misma tendencia... ${ }^{1018}$

Un ejemplo de esto, fue la industria y artesanía de la Hoya de Quito que, en 1955, poseía un total de 23.754 personas ocupadas, de las que 11.827 pertenecían a la artesanía urbana, 2.711 a la artesanía rural y 9.216 a la industria. Asimismo, la artesanía urbana contaba con 4.170 establecimientos, mientras que la rural tenía 1.282 establecimientos, a diferencia de la gran industria, que únicamente tenía 406 establecimientos (ver la tabla 4: Establecimientos industriales y artesanales en la Hoya de Quito 1955 y la tabla 5: Personal ocupado en las industrias y artesanías de la Hoya de Quito en 1955). ${ }^{1019}$

artículos que producen, que no excediere de 15.000 sucres mensuales... Fuente: CONADE, CENAPIA, ILDIS: La situación económica de la artesanía en el Ecuador. Conclusiones y Recomendaciones", Quito, Ecuador, 1982, p. 10. ${ }^{1018}$ Ibíd. p. 26.

${ }^{1019}$ Las tablas 4 y 5 se encuentran en el apéndice de datos del capítulo 5. Fuente: Junta Nacional de Planificación: $L a$ industria y la artesanía de la Hoya de Quito en 1955, en Instituto Panamericano de Geografía e Historia, Plan Piloto del Ecuador, Sección de Economía, México, D.F, 1960, p. 43 y 51. 
Gráfico 2: Personal ocupado en las industrias y artesanías de la Hoya de Quito en 1955

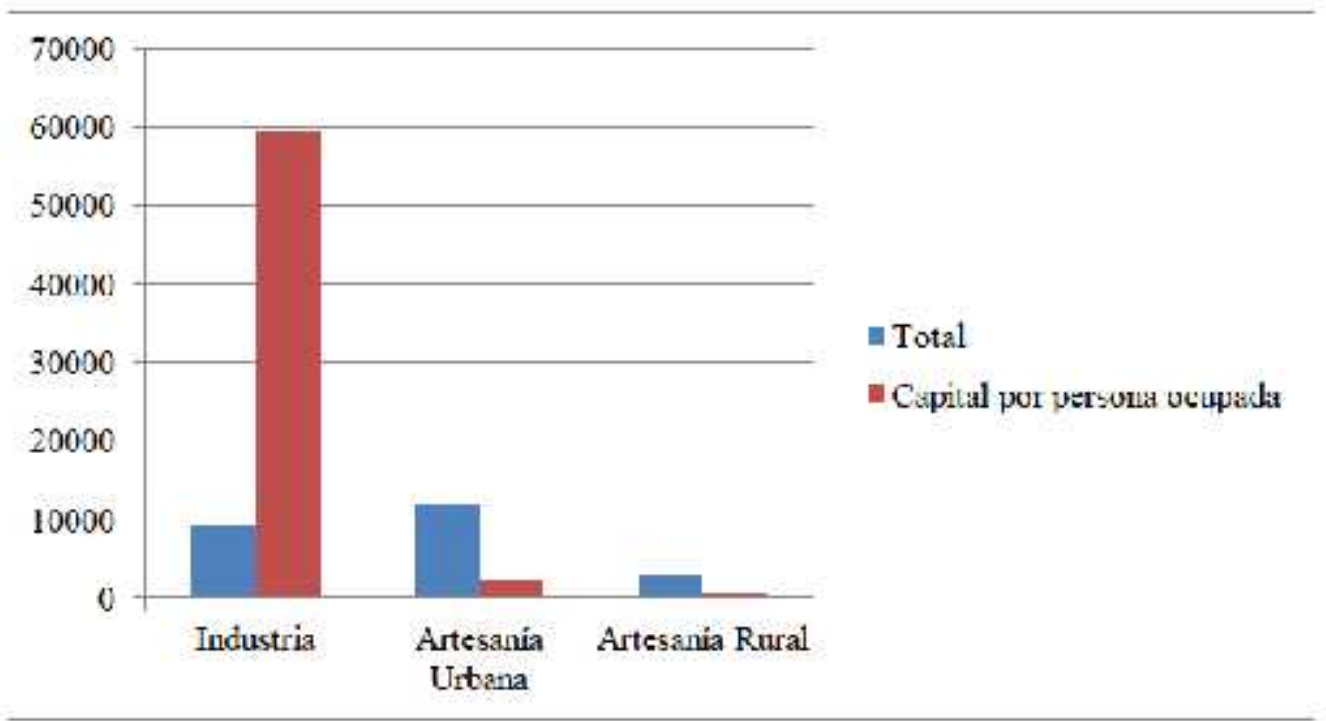

Elaboración propia a partir de los datos de la tabla 5.

Fuente: Junta Nacional de Planificación: La industria y la artesanía de la Hoya de Quito en 1955, en Instituto Panamericano de Geografía e Historia, Plan Piloto del Ecuador, Sección de Economía, México, D.F, 1960, p. 51.

Con estos datos, se aprecia el carácter dominante de la artesanía frente a la gran industria de los años cincuenta, la cual no logró modificar su estructura de forma radical durante los años sesenta, periodo en el que se inicia la segunda etapa del proceso de industrialización.

En esta nueva fase, se ha de señalar el papel del estado y cómo su discurso fue adquiriendo un carácter desarrollista que favorecía el cambio en las relaciones agrarias y la industrialización; de ahí que nos preguntemos cuáles fueron las características principales de la política de desarrollo en cuanto a la industrialización por sustitución de importaciones, el tipo de instituciones que se 
crearon y cuáles fueron las leyes aplicadas durante el régimen militar para contribuir a este objetivo.

De esta forma, el estado, con su nuevo papel protector, estaba encargado de orientar algunas inversiones hacia la agroindustria y diversas ramas de la industria manufacturera (textiles, alimentos, bebidas, y madera principalmente). ${ }^{1020}$ Las tablas 6-8 (Valor bruto de la producción y valor agregado de las industrias, 1961-1964, 1965-1968, 1969-1972) muestran el valor de la producción y valor agregado de las industrias, siendo los máximos valores, los correspondientes a las actividades indicadas. ${ }^{1021}$

Además, se ha de matizar que el desarrollo industrial se caracterizaba por su orientación hacia el mercado interno y la sustitución de importaciones por productos nacionales, lo que explica la producción de bienes simples de consumo final (alimentos, bebidas, calzado, vestuario, etc.) y productos intermedios (telas y cemento). A esto, posteriormente, se le habría de unir la elaboración de materias primas (refinación de petróleo) y la adopción de las etapas finales de producción en la fabricación de bienes de consumo más complejos (electrodomésticos y vehículos). ${ }^{1022}$

En lo que respecta a la legislación general aplicada en esta época, se ha de destacar la importancia de la estructura arancelaria, con la que se estableció un conjunto de barreras arancelarias y no arancelarias para proteger la producción nacional de consumo, a la vez que se aplicaban aranceles relativamente bajos a las importaciones de materia prima, insumos intermedios y bienes de capital que eran utilizados por las industrias protegidas. ${ }^{1023}$

Para la política monetaria, los incentivos de protección a la industria se hicieron efectivos mediante el sistema de crédito y la política de depósitos previos para la importación de productos

\footnotetext{
${ }^{1020}$ Guillermo Landázuri Carrillo, Proposiciones de cambio..., op. cit. p. 361-372.

${ }^{1021}$ Las tablas 6-8 se encuentran en el apéndice de datos del capítulo 5. Fuente: Patricio Almeida Guzmán, Rebeca Almeida Arroba, Estadísticas..., op. cit. p. 148-151.

${ }^{1022}$ Es importante destacar cómo en los años sesenta, cuando las políticas de sustitución de importaciones fueron ganando importancia, algunos importadores sintieron que sus negocios estaban amenazados, oponiéndose algunos de ellos a la creación de nuevas industrias, mientras que los importadores enfrentados a la competencia local, ante la posibilidad de obtener beneficios con la Ley de Desarrollo Industrial, crearon sus propias empresas o participaron como accionistas para defender sus propios intereses. Fuente: Jorge A. Hidrobo Estrada, Industriales..., op. cit. p. 40 .

${ }^{1023}$ César Verduga, op. cit. p. 124.
} 
industriales competitivos. De igual forma, se consolidó la estructura financiera estatal gracias a las actividades desempeñadas por organismos especializados como el Banco Nacional de Fomento y la Corporación Financiera Nacional (1964), cuyo objetivo consistía en la canalización de recursos y apoyo a la ejecución de proyectos industriales de diferentes tipos.

La tabla 9 muestra el crédito industrial aprobado por la Corporación Financiera Nacional por rama de actividad en el periodo 1962-1972, al igual que la tabla 10 (Volumen de crédito otorgado por el Banco Nacional de Fomento, por destino 1962-1972), en la que se puede ver el volumen de crédito otorgado por el Banco Nacional de Fomento para el mismo periodo de tiempo). ${ }^{1024}$

Además del propósito de disminuir el volumen de importaciones para acabar con el déficit de la balanza de pagos (ver tabla 13: Balanza de pagos 1960-1973), el resto de las prioridades establecidas pretendían aumentar la eficiencia y productividad industrial, lograr un mayor desplazamiento de recursos hacia las actividades manufactureras, crear empleo a partir del desarrollo industrial intensivo en el uso de mano de obra, aumentar la utilización de materia prima nacional y elevar el nivel de vida del país a través de la disminución de las desigualdades existentes en el ingreso. ${ }^{1025}$

En relación a los organismos creados para este fin, durante 1963-1966, se estableció un marco legal e institucional más amplio para el desarrollo de la industria. Así, se creó el Ministerio de Finanzas (1963) encargado de la administración tributaria y del control de aduanas, el Centro de Ejecutivos de Quito (1964) para la formación de empresarios, el Ministerio de Industrias y Comercio (1965) que tenía la misión de llevar a cabo el desarrollo industrial, el Centro Ejecutivo de Guayaquil (1965) y la Corporación Financiera Ecuatoriana (1966), cuyos objetivos eran los mismos que los de la Financiera Nacional. ${ }^{1026}$

Con estos organismos, se pretendía modernizar la estructura legal y administrativa estatal, además de realizar programas de infraestructura que proporcionaran servicios y facilitaran el

\footnotetext{
${ }^{1024}$ Las tablas 9 y 10 se encuentran en el apéndice de datos del capítulo 5. También, las tablas 11 y 12 reflejan el volumen de crédito otorgado por el Sistema Bancario Nacional y por el Banco Central para el periodo 1962-1972. Fuente: Patricio Almeida Guzmán, Rebeca Almeida Arroba, Estadísticas..., op. cit. p.258 y 261.

${ }^{1025}$ Las tablas 11-13 se encuentran en el apéndice de datos del capítulo 5. Fuente: Galo Abril Ojeda: Política monetaria y desarrollo industrial en el Ecuador, 1970-1983, Banco Central del Ecuador, Instituto de Estudios Latinoamericanos, monografía número 11, agosto 1985.

${ }^{1026}$ Rafael Quintero, Erika Silva, op. cit. p. 273.
} 
intercambio comercial, y buscar la incorporación del estado en las actividades económicas vinculadas a los capitales privados. ${ }^{1027}$

Aquí, Rafael Quintero y Erika Silva señalan que la creación de estas instituciones legales, financieras, de planificación estatal y promoción industrial, supuso una forma de aumentar el gasto público, a la vez que constituían un mecanismo con el que el estado podía ejercer su control y estimular una actividad industrial dependiente del capital extranjero, lo cual no fue de gran beneficio para el desarrollo nacional a largo plazo:

A partir de 1963, el estado no solo participa en la actividad económica, sino que se pone a tono con aquellas condiciones antes inexistentes en la dinámica del capital monopólico internacional, erigiéndose en la comadrona de una política de fomento industrial dependiente. ${ }^{1028}$

La ampliación del marco institucional se produjo en un contexto de rechazo social que ya se había manifestado en los años cincuenta y que, al volver a aparecer durante el gobierno de la Junta Militar, contribuyó a agudizar la crisis política del momento. Así, un ejemplo de esto, fue la reforma a la Ley de Fomento Industrial de 1963, mediante la cual, se beneficiaba directamente a las nuevas ramas industriales que comenzaron sus actividades en el Ecuador en este periodo y que estaban constituidas por grandes aportaciones de capital extranjero, pues no estaban obligadas a pagar impuestos por concepto de importación de materias y medios de producción. $^{1029}$

Un caso concreto fue el Centro Nacional de Desarrollo (CENDES), organismo creado para fomentar el desarrollo industrial y que tenía como objetivo, entre otros, la elaboración de estudios para llevar a cabo la inversión de capitales extranjeros. En tal sentido, Quintero y Silva afirman que este organismo expresaba de forma clara su función política de mediación entre el capital monopólico y el estado, pues su origen, establecimiento de actividades y vinculación con

\footnotetext{
${ }^{1027}$ Ibíd. p. 276.

${ }^{1028}$ Ibíd. p. 277.

${ }^{1029}$ Ley de Fomento Industrial de 1963, decreto 348, 28 de agosto de 1963, Banco Central del Ecuador, Memoria 1963.
} 
Estados Unidos fueron una expresión de la modernización estatal del gobierno de la Junta Militar. $^{1030}$

También, José Moncada habla de las instituciones creadas durante el gobierno de la Junta Militar de 1963 y de cómo las medidas desarrollistas aplicadas en esta época no lograron contribuir al desarrollo de la industria nacional:

Las medidas probadas y experimentadas en esa década, tales como el aumento de aranceles de aduanas, las reiteradas políticas de austeridad fiscal, el aumento de impuestos, la ampliación relativa de la infraestructura vial, las múltiples reorganizaciones gubernamentales y la ejecución de una planificación económica, no dieron los resultados anunciados y la economía ecuatoriana ponderada siempre por la oligarquía de la tierra como eminentemente agrícola, cerraba el año 1967, con la importación de 350 millones de sucres en productos agropecuarios. ${ }^{1031}$

Continuando con el tema de la modernización del aparato gubernamental, se ha de hacer alusión al desarrollo del sector bancario, el cual adquirió un papel fundamental en la financiación industrial de los años posteriores al régimen de la Junta Militar.

No obstante, se ha de señalar que la ampliación de estos sistemas no contó con el apoyo de los partidos de la oposición, lo cual se hizo evidente en la aplicación de la Ley de Fomento Industrial, mecanismo fundamental para impulsar el desarrollo industrial teniendo en cuenta su clasificación de prioridades. Así, la Ley de Fomento Industrial de 1957 fue reformada dos veces durante el gobierno militar (en 1963 y en 1964), emitiéndose finalmente la Ley de Fomento a la Pequeña Industria y Artesanía en $1965 .^{1032}$

Puede que de estas reformas, la más importante fuese la de 1963, al ser aplicada a las empresas industriales de armadura y montaje, mientras se establecía una clasificación más estricta de dichas empresas. También, se eliminaba la obligación de pagar impuestos por concepto de importación de materias primas y medios de producción a las empresas que estaban clasificadas siguiendo este criterio.

\footnotetext{
${ }^{1030}$ Rafael Quintero, Erika Silva, op. cit. p. 277.

${ }^{1031}$ José Moncada: La economía ecuatoriana en el siglo XX, Quito, IIE-UCE, 1980, p. 50.

${ }^{1032}$ G. Montaño, E. Wygard: Visión sobre la industria ecuatoriana, s/f, p. 204-295.
} 
En este caso, dicha reforma beneficiaba a las nuevas ramas industriales que habían comenzado o reforzado sus actividades en el país durante esta época y que contaban con una participación dominante de capitales extranjeros, como ya se ha visto (ver tabla 14: Inversión extranjera en el Ecuador 1964-1972). ${ }^{1033}$

Gráfico 3: Inversión extranjera en el Ecuador (miles de dólares) (1964-1972):

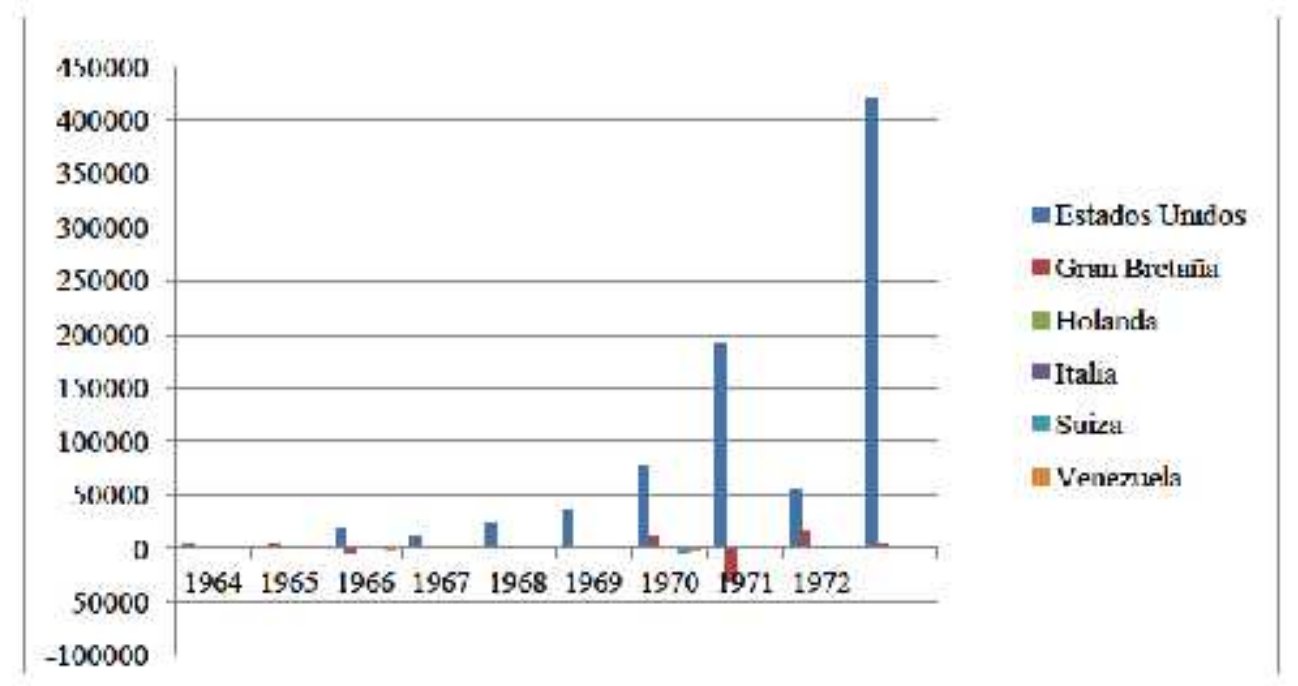

Elaboración propia a partir de los datos de la tabla 14

Fuente: Patricio Almeida Guzmán, Rebeca Almeida Arroba: Estadísticas Económicas Históricas 1948-1983, Fuentes para la Historia Económica del Ecuador, serie estadísticas históricas, vol. 1, Banco Central del Ecuador, 1988, p. 292-294.

De igual modo, la nueva situación institucional y legal hizo que la actividad industrial en el Ecuador, se viera influenciada por el estado, ya que pasó a convertirse en la mayor entidad organizadora de la economía ecuatoriana, a diferencia de otras épocas, en las que no había contribuido a la elaboración de las condiciones jurídicas y administrativas que impulsaban la

${ }^{1033}$ La tabla 14 se encuentra en el apéndice de datos del capítulo 5. Fuente: Patricio Almeida Guzmán, Rebeca Almeida Arroba, Estadísticas..., op. cit. p. 292-294. 
industrialización. En este caso, el régimen de la Junta Militar comenzó a participar de forma regular en la actividad económica, además de elaborar una política de fomento industrial dependiente, cuyo objetivo era la modernización de la estructura legal, la realización de programas de infraestructura que favorecieran la explotación de recursos naturales, el intercambio comercial y la participación del estado en determinadas actividades económicas asociadas a capitales privados. ${ }^{1034}$

La Junta Militar plasmó estas ideas mediante la modernización de organismos financieros y de instituciones especializadas en la promoción industrial como fue el Centro de Desarrollo Industrial (CENDES), creado en 1962, como entidad orientada a la realización de estudios de proyectos industriales nuevos, y a través de la consolidación de organismos como el Instituto Ecuatoriano de Electrificación (INECEL). ${ }^{1035}$

De forma paralela, con las reformas realizadas en la política fiscal del estado para impulsar el desarrollo del capitalismo dependiente, se aumentó el presupuesto destinado a las obras públicas y las inversiones en la construcción de carreteras, puentes, puertos, aeropuertos y diversos medios de comunicación (ver tabla 15: Inversión real en obras de infraestructura y transporte 1963-1972). ${ }^{1036}$

De todo lo dicho, se ha de destacar que aún cuando la participación del estado fue fundamental para el desarrollo de la industria, fueron las grandes aportaciones de capital privado, las que desempeñaron el papel más importante, al constituirse como el gran motor del estímulo industrial dependiente. Es decir, el desarrollo industrial ecuatoriano se caracterizó por su gran dependencia, la cual se fue consolidando tras el incremento de la brecha tecnológica y por la tendencia imperialista de integración de los sistemas productivos, que era reforzada por la creciente ideología de la Junta Militar.

\footnotetext{
${ }^{1034}$ Osvaldo Hurtado, El poder..., op. cit. p. 192.
}

${ }^{1035}$ En el año 1961, se fundó el Instituto Ecuatoriano de Electrificación (INECEL) para el control del sector eléctrico del Ecuador, incluyendo su generación y distribución en asocio con los municipios de cada región. Pese a que su actividad fundamental fue la construcción de un sistema de abastecimiento de energía; en la década de los ochenta, inició algunos proyectos de investigación de recursos energéticos no convencionales y de recursos hídricos, instalando algunas estaciones hidrométricas en varias cuencas del país. Fuente: Alfredo Mena Pachano: $L a$ investigación y desarrollo de energías renovables en el Ecuador. Análisis crítico, Corporación para la Investigación Energética, Quito, Ecuador, 2002.

${ }^{1036}$ La tabla 15 se encuentra en el apéndice de datos del capítulo 5. Fuente: Patricio Almeida Guzmán, Rebeca Almeida Arroba, Estadísticas..., op. cit. p.333. 
Al hilo de la idea planteada, además del aumento de participación del estado en el proceso de industrialización de la economía ecuatoriana, es importante llevar a cabo una valoración de la actuación de las clases sociales a la hora de promocionar la actividad industrial de estos años.

Recordemos que la ampliación de la base social tras la bonanza bananera, permitió la consolidación de un mercado interno, la cual sirvió para justificar el esfuerzo de sustitución de importaciones con el estancamiento de las exportaciones. Junto a esto, se encontraban los industriales que buscaban una cierta expresión política y los exportadores que querían encontrar un sector productivo al que transferir sus inversiones y mostrar su apoyo al régimen militar.

De este modo, representando a los exportadores, los intereses desarrollistas de los industriales y de los sectores medios, la Junta Militar trató de fomentar la competitividad de la industria mediante los mecanismos antes mencionados. ${ }^{1037}$

Asimismo, para que el proceso de industrialización tuviera éxito, la burguesía industrial debía mostrar capacidad suficiente para buscar una solución a los problemas relacionados con la ampliación del mercado interno, el abastecimiento del capital y la orientación de la inversión a la infraestructura, según sus objetivos y los de otros grupos. En este caso, si la burguesía industrial lograba desplazar el eje en manos de los sectores tradicionales de la clase dominante (terratenientes y exportadores), entonces, se podía dar la posibilidad de crear las condiciones políticas y económicas que permitieran obtener beneficios para el sector industrial. ${ }^{1038}$

De esta forma, la Junta Militar fue organizando las medidas mencionadas para hacer viable el proceso de sustitución de importaciones, mientras se pretendía realizar la ampliación del mercado interno a través de la Ley de Reforma Agraria de 1964 y con el aumento del poder de compra de los sectores medios urbanos, pues el mercado con mayores posibilidades de crecimiento era el urbano a diferencia del mercado rural, que contaba con menos recursos.

En relación a esto, hemos de recordar la incapacidad del estado para acabar con los problemas socio-económicos existentes, puesto que no logró poner fin a la dominación económica tradicional, caracterizada por las grandes diferencias entre el campo y la ciudad y la elevada concentración del ingreso en manos de las clases altas, situación que acabó con diversos levantamientos populares a los que el estado respondió haciendo uso de la fuerza.

\footnotetext{
${ }^{1037}$ Rafael Quintero, Erika Silva, op. cit. p. 273-325.

${ }^{1038}$ Fernando Velasco, op. cit. p. 201-230.
} 
En tal sentido, los diferentes intereses económicos propios de las clases dominantes de esta época muestran la escasa capacidad de la burguesía para establecer reformas sociales, lo cual explica el origen de nuevas movilizaciones. Así, en 1969, unos treinta estudiantes fueron asesinados en Guayaquil cuando exigían la democratización de la enseñanza, mientras que en 1970, el presidente de la Federación de Estudiantes Universitarios de Quito, Milton Reyes, fue también asesinado por el gobierno oligárquico.

Como vemos, las movilizaciones del pueblo, las cuales estuvieron acompañadas por huelgas obreras que exigían una mejora de las condiciones de trabajo, eran resueltas por el gobierno con la pena de cárcel o como se ha indicado previamente:

Las movilizaciones populares se daban en todo el país, acompañadas de huelgas obreras que demandaban mejores salarios, reducción de la jornada de trabajo, mejora en las condiciones de trabajo. Toda protesta, manifestación o huelga era acallada con bala y cárcel y amparada por un marco legal reaccionario. El 24 de mayo de 1971, se produjo un levantamiento popular en la fronteriza provincia del Carchi que exigía la supresión de un impuesto sobre cada persona y vehículo que viajaba a Colombia. Las fuerzas populares dieron un combate armado en Tulcán y la provincia fue ocupada por dos mil efectivos militares. Numerosos heridos, muertos y presos fue el saldo de un enfrentamiento que duró varios días. ${ }^{1039}$

No pasaba desapercibida para ciertos intelectuales orgánicos de la burguesía la polarización económica, social y política que vivía el país. En octubre de 1971, en un seminario organizado por el diario El Universo en Guayaquil se señalaba que la estratificación social marcada y la falta de cohesión nacional caracterizan nuestro sistema añadiéndose que el país está en manos de élites económico-sociales que disfrutan de los beneficios de la cultura, la economía y el poder político, en tanto que una clase media, ilustrada y técnica se marchita al margen del proceso de decisiones nacionales; y una inmensa clase popular, dispersa en las ciudades y en los campos sufre la falta de medios para llevar una vida digna ... ${ }^{1040}$

\footnotetext{
${ }^{1039}$ Rafael Quintero, Erika Silva, p. 322.

${ }^{1040}$ Ibíd. p. 322.
} 
Esta situación pone de manifiesto la existencia de un complejo conjunto de clases dominantes a finales de los sesenta, ya que estas se reproducían y se modernizaban a través de mecanismos tradicionales, en los que el peso de la clase terrateniente era el elemento principal de las fuerzas oligárquicas, reflejándose la precariedad de la clase burguesa y su baja capacidad para emprender una reforma social.

Ante este panorama, caracterizado por el estancamiento de las exportaciones y la crisis económica, la burguesía comercial bancaria de Guayaquil extendió sus inversiones a otras actividades, entre las que se encontraba una incipiente industria, con el desarrollo de grupos económicos y de empresas dirigidas por pequeños grupos de familias. ${ }^{1041}$

De forma paralela, mientras se producían estas inversiones industriales, algunos importadores sintieron que las nuevas industrias eran una amenaza para sus negocios y se opusieron a su creación. Este hecho no implicaba que los importadores no crearan firmas industriales, pues algunos de los importadores enfrentados a la competencia local y a la posibilidad de adquirir ventaja de los beneficios obtenidos por la Ley de Desarrollo Industrial, establecieron compañías industriales o participaron como accionistas. ${ }^{1042}$

De igual forma, las políticas de sustitución de importaciones orientadas a obtener un mayor beneficio, no solo despertaron el interés de los importadores para aceptar el riesgo asociado a la construcción de fábricas, sino que también provocaron que otros grupos se interesaran en el mercado y en los beneficios ofrecidos por dichas políticas de sustitución de importaciones. Se trataba de los terratenientes de la Sierra y las multinacionales, los cuales se unieron a los grupos nacionales. $^{1043}$

A este respecto, aún cuando en la década de los cincuenta, algunas de estas multinacionales comenzaron la producción de químicos y farmacéuticos, fue durante los sesenta, cuando se produjo un incremento importante de las inversiones extranjeras en la manufactura. ${ }^{1044}$ Así, en el periodo comprendido entre 1963-1969, la inversión extranjera aumentó de forma considerable

\footnotetext{
${ }^{1041}$ Catherine Conaghan, Industrialists..., op. cit. p. 70, en Lisa North: "Implementación de la política económica y la estructura del político en el Ecuador", 1985, p. 429.

1042 Jorge Estrada, Industriales..., op.cit. p. 36-62.

${ }^{1043}$ Ibíd. p. 36-62.

${ }^{1044}$ Coca-Cola y Standard Brands constituyen un ejemplo de las pocas multinacionales interesadas en el Ecuador en los años cincuenta.
} 
debido a las restricciones impuestas a las importaciones de productos industriales y a la existencia de un mercado protegido.

En lugar de vender sus productos al mercado ecuatoriano, estas multinacionales decidieron establecer la producción local y beneficiarse de los incentivos estatales. Además, la Ley de Promoción Industrial exigía que las operaciones industriales de inversionistas extranjeros tuvieran lugar en asociación con empresarios nacionales, lo cual explica el hecho de que las multinacionales se unieran a ellos (ver tabla 16: Inversión de la industria clasificada en las leyes de fomento industrial y de fomento a la pequeña industria y artesanía, por ramas de actividad 1963-1972). ${ }^{1045}$

De esta forma, durante los años sesenta, se produjo un aumento destacado de inversiones extranjeras en la manufactura y en la agro-industria. Para ello, en 1963, se realizó un viaje de promoción industrial a los Estados Unidos, mediante el cual, se establecieron vínculos con unas veinte compañías norteamericanas interesadas en invertir en dichos campos.

De acuerdo con Rafael Quintero y Erika Silva, estas fueron algunas de las industrias interesadas y los proyectos de inversión ${ }^{1046}$ :

- Levin Sargent Tand: Ingenio Aztra, envases de vidrio, ácido sulfúrico, acero estructural, con una inversión del $50 \%$ de capital.

- Global Corporation de California: Ingenio Aztra, herramientas manuales, extracción de aceite de higuerilla, pasta y salsa de tomate, alambre de hierro y acero, entre otros.

- Empresas Washington: Fábrica deshidratadora de banano.

- Morton Sal Co: Sal solar

- Cañaveral Utility and Developing Co.: Planta procesadora de frutas cítricas.

- Haddad \& Sons: Fábrica de elaboración de ropa.

- Trygue Hoff and Associates de California: Planta de producción de papel.

- Marcus Sittenfield and Associaters: Insecticidas y fertilizantes.

\footnotetext{
${ }^{1045}$ La tabla 16 se encuentra en el apéndice de datos del capítulo 5. Fuente: Patricio Almeida Guzmán, Rebeca Almeida Arroba, op. cit. p. 311-315.

${ }^{1046}$ Rafael Quintero, Erika Silva, op. cit. p. 311-312. La tabla 17 (Inversiones directas de capital norteamericano en la industria ecuatoriana 1963-1966) en el apéndice de datos del capítulo 5, muestra también otras inversiones directas de capital norteamericano en la industria ecuatoriana en el periodo 1963-1966.
} 
- Certain Teend Products Co: Tubería de cemento, asbestos y otros productos.

- Internacional Ingineers de New York: Alcohol de Durán

- Inter-Rolling Mills de California: Hierro estructural

- Ariguanado Co. de Jamaica: Pilas eléctricas.

En general, este tipo de acciones que perseguía la ampliación del mercado interno y una mayor rentabilidad e inversión en el sector, no fue sino una forma de reforzar la Ley de Protección Industrial, la cual proporcionaba al sector manufacturero una serie de privilegios y exenciones tributarias, y que junto a la asistencia técnica de CENDES, tenían la función de aumentar las ganancias (ver tablas 18 y 19: Nuevas inversiones en la industria manufacturera, por ramas de actividad, 1963-1967 y 1968-1972). ${ }^{1047}$

La Ley de Fomento Industrial, que permitió la asociación de capitales extranjeros, fue utilizada para conseguir la asistencia norteamericana en forma de empréstitos para cumplir con el Plan de Desarrollo, mientras que la asistencia y la tecnología tenían como objetivo fomentar el desarrollo de la industria vía sustitución de importaciones. ${ }^{1048}$ Así, la tabla 14 (Inversión extranjera en el Ecuador 1964-1972) refleja el volumen de inversiones extranjeras, siendo Estados Unidos, el país que más capital invirtió en el Ecuador con una cantidad de 419.777.000 dólares entre 19641972, seguido de Inglaterra, que contaba con un promedio de 4.598 .000 dólares para el mismo periodo. $^{1049}$

Esta dependencia del capital extranjero puede ser explicada a partir del desarrollo de las fuerzas productivas, el aumento de internacionalización del mercado y la importancia de la tecnología, elementos que requerían una importante acumulación de capital y fueron los responsables de que la industria pasara a ser el sector en que se concentraba dicho capital. ${ }^{1050}$

A este respecto, las tablas 20 y 21 (Importaciones totales por tipo de bienes: materias primas, bienes de capital y bienes de consumo 1963-1968, 1969-1974) reflejan la dependencia del capital

\footnotetext{
${ }^{1047}$ Las tablas 18 y 19 se encuentran en el apéndice de datos del capítulo 5. Fuente: Patricio Almeida Guzmán, Rebeca Almeida Arroba, op. cit. p.327.

1048 Alberto Moreno Cornejo: Ecuador: Capitalismo y dependencia, Guayaquil, Ediciones Amanecer, 1973, p. 1516.

1049 La tabla 14 se encuentra en el apéndice de datos del capítulo 5. Fuente: Patricio Almeida Guzmán, Rebeca Almeida Arroba, op. cit, p. 292-294.

${ }^{1050}$ Fernando Velasco, op. cit. p. 201-230.
} 
internacional mediante las variaciones en el ritmo de crecimiento de las importaciones destinadas a la industria (materias primas, combustibles, lubricantes, bienes intermedios, bienes de capital, etc.) siendo la cifra alcanzada de 164.407 dólares para 1965 y de 273.849 dólares en 1970, llegando a rondar el millón de dólares en $1974 .^{1051}$

Gráfico 4: Importaciones totales por tipo de bienes: materias primas, bienes de capital y bienes de consumo 1963-1968.

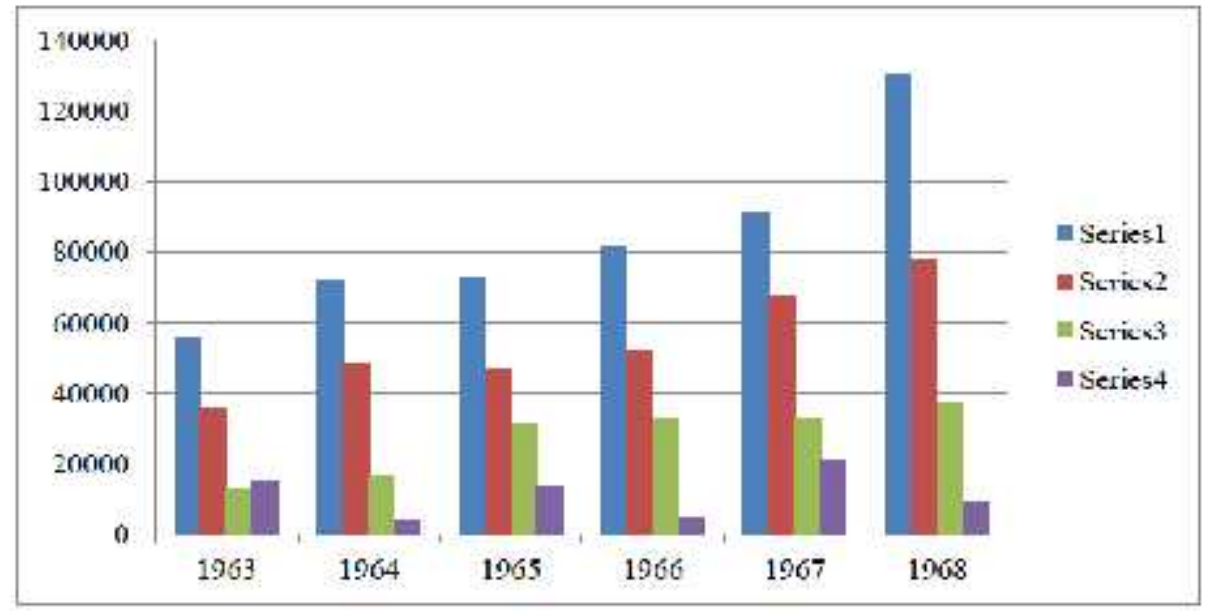

Elaboración propia a partir de los datos de la tabla 20.

Series 1: Materia prima y productos intermedios

Series 2: Bienes de capital

Series 3: Bienes de consumo

Series 4: Combustibles y lubricantes

Fuente: Patricio Almeida Guzmán, Rebeca Almeida Arroba: Estadísticas Económicas Históricas 1948-1983, Fuentes para la Historia Económica del Ecuador, serie estadísticas históricas, vol. 1, Banco Central del Ecuador, 1988, p. 488.

${ }^{1051}$ Las tablas 20 y 21 se encuentran en el apéndice de datos del capítulo 5. Fuente: Patricio Almeida Guzmán, Rebeca Almeida Arroba, op. cit. p.448-449. 
Gráfico 5: Importaciones totales por tipo de bienes: materias primas, bienes de capital y bienes de consumo 1969-1974.

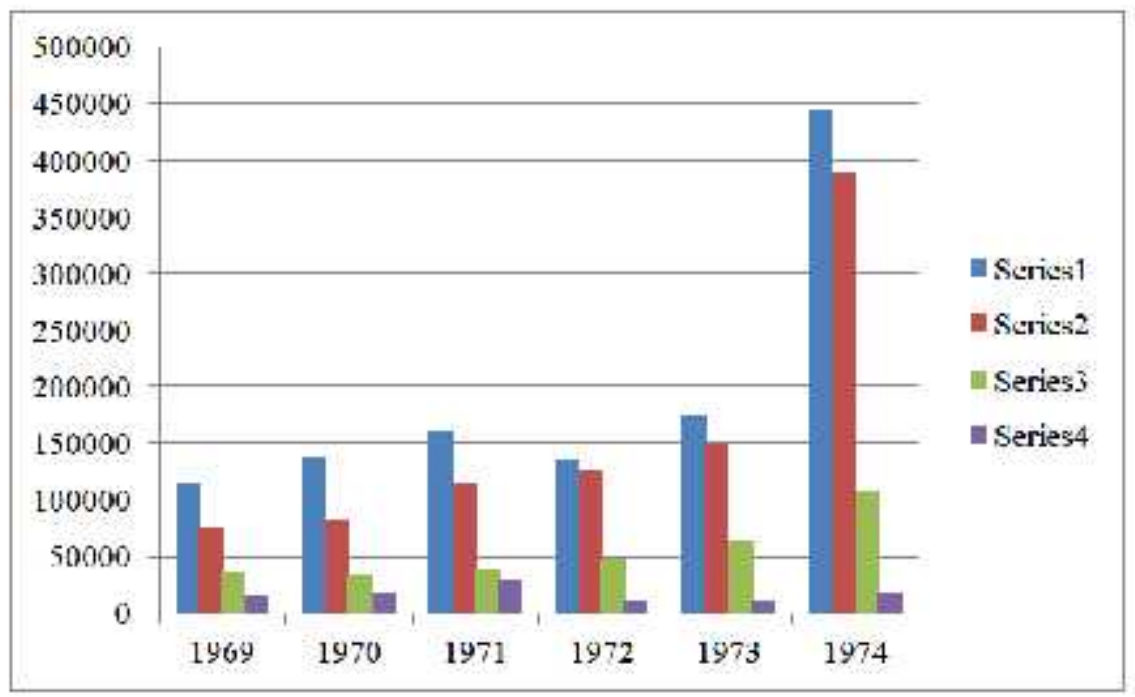

Elaboración propia a partir de los datos de la tabla 21.

Series 1: Materia prima y productos intermedios

Series 2: Bienes de capital

Series 3: Bienes de consumo

Series 4: Combustibles y lubricantes

Fuente: Patricio Almeida Guzmán, Rebeca Almeida Arroba: Estadísticas Económicas Históricas 1948-1983, Fuentes para la Historia Económica del Ecuador, serie estadísticas históricas, vol. 1, Banco Central del Ecuador, 1988, p. 449.

También, la tabla 22 (Importaciones por principales grupos de mercancías 1963-1973) muestra la dependencia de las ramas de maquinaria eléctrica, productos metálicos y de la industria química, siendo bastante elevadas las cantidades importadas, en particular, a partir de la década de los setenta, lo cual es un indicador de la escasa autonomía de la producción industrial con 
relación al capital comercial importador. ${ }^{1052}$ Además, este aumento de importaciones pone de relieve que el incipiente crecimiento industrial ecuatoriano no siguió en esos años el mecanismo de sustitución de importaciones que se había pretendido, siendo esto, una característica típica del fenómeno industrial ecuatoriano en cuanto a su vínculo con los intereses monopolistas.

En relación a los intereses de los monopolios, vamos a revisar ahora la política arancelaria impuesta por la Junta Militar y el conjunto de reformas que intentó establecer, a pesar de su impacto negativo en los intereses de los grupos de Guayaquil, ya que dichas reformas tenían como objeto la redistribución del excedente a favor de los monopolios vinculados a la política desarrollista de la Junta.

Los problemas mencionados fueron creando un ambiente de rechazo hacia la Junta por parte de los grupos regionales de Guayaquil, lo cual puso de manifiesto una nueva lucha regional entre los políticos de Quito y los productores de la Costa, a la vez que volvía a aparecer el problema de la cuestión nacional y del regionalismo como obstáculo a la unidad del país. Efectivamente, el elemento regional pasó a ser un elemento político de gran importancia cuando el gobierno militar hizo uso de una política centralizadora del aparato estatal, a la que se oponían las clases dominantes locales. Es decir, con esta política centralizadora, se pretendía concentrar los recursos y eliminar la autonomía financiera de las entidades descentralizadas, hecho que causó numerosos problemas entre las diversas agrupaciones. ${ }^{1053}$

Ante el descontento de los grupos de Guayaquil, la Junta decidió dejar a un lado la centralización de recursos y negociar el mantenimiento de sus privilegios. Esta situación provocó grandes protestas de los sectores populares en contra del régimen dictatorial, al reclamar también su propia autonomía, mientras que la política de centralización volvía a manifestar el problema de la cuestión regional, pues las clases dominantes locales habían sido favorecidas.

Este problema volvería a producirse en el año 1965, cuando el gobierno militar, para atender su compromiso con los capitales estadounidenses, anunció reformas a la Ley del Arancel de Aduanas, considerada como una herramienta necesaria para la protección estatal. ${ }^{1054}$

\footnotetext{
${ }^{1052}$ La tabla 22 se encuentra en el apéndice de datos del capítulo 5. Fuente: Patricio Almeida Guzmán, Rebeca Almeida Arroba, op. cit. p.495.

${ }^{1053}$ Gonzalo Abad, op. cit. p. 148.

${ }^{1054}$ Para más información sobre la Ley del Arancel de Aduanas, ver el apéndice de notas del capítulo 5.
} 
En mayo de 1965, faltando un año para que ocurrieran las protestas en Guayaquil por la centralización, la Junta Militar estableció su plan para revisar las tarifas arancelarias de numerosos artículos de producción y de consumo, haciéndolo público justo cuando se rompió la alianza que la mantenía en el poder. ${ }^{1055}$

El anuncio de la reforma arancelaria afectó directamente a los importadores de la Costa, cuyos beneficios ya habían sufrido el impacto de la crisis con la caída de los precios de los productos de exportación y la disminución de divisas en el mercado; por lo que decidieron crear una alianza entre fracciones de la burguesía de la Costa y de la clase terrateniente serrana (importadores y terratenientes). Los terratenientes serranos optaron por dicha alianza, ya que la Junta Militar pretendía aceptar ayuda financiera, lo cual significaba un impulso definitivo para la Reforma Agraria, mientras que para los importadores implicaba una política proteccionista que ponía en peligro sus intereses. Esto explica que la primera región en oponerse al arancel fuese Guayaquil, seguida de diversos sectores dominantes de la Sierra.

En relación a la política pública y la reforma arancelaria, Gonzalo Abad destaca la existencia de varios problemas como el manejo de la política industrial y el tema de la cuestión regional. Así, la crítica de la clase dominante de Guayaquil que rechazaba la reforma arancelaria, se centraba en la política industrial promocionada por la Junta, pues creía que las industrias creadas por el gobierno establecían desniveles tributarios injustos. Por su parte, los terratenientes serranos exigían la protección de las industrias que consumían materia prima nacional, así como la protección a plazos fijos y de forma decreciente para aquellas industrias que usaran materias primas importadas. ${ }^{1056}$

Además, algunos importadores criticaban las inversiones extranjeras (sobre todo en la industria química, al ser la rama que más inversiones extranjeras recibía), ya que afectaban a sus artículos, chocando sus intereses con los de los defensores de monopolios e inversionistas extranjeros, los cuales habían invertido su capital en la industria y querían obtener grandes beneficios.

\footnotetext{
1055 Recordemos que el pacto conservador entre el placismo y poncismo, representaba los intereses de las clases terratenientes en transición a burguesía terrateniente. Ante el descontento por parte de las fracciones atrasadas de los terratenientes serranos debido a la aprobación de la Ley de Reforma Agraria, estos decidieron retirar su apoyo a la Junta, rompiendo dicho pacto en julio de 1964.

${ }^{1056}$ Gonzalo Abad, op. cit. p. 102-151.
} 
Estas críticas explican la movilización que tuvo lugar en mayo de 1965, en la que la alianza entre las clases dominantes regionales y los sectores populares de Guayaquil se enfrentaron a la Junta Militar, siendo los conflictos por la eliminación del arancel superados por objetivos nacionales cuando se acabó con la dictadura y se inició una lucha contra el capital extranjero: ${ }^{1057}$

La articulación interclasista regional no asumió, sin embargo, características tan compactas como aquella analizada para 1959, ni persistió el tiempo que duró la crisis, por cuanto la lucha por la derogatoria del arancel claramente regional fue superada por objetivos más nacionales: el derrocamiento de la dictadura y la lucha contra el imperialismo. $^{1058}$

Además, la alianza entre clases organizó una huelga general, en la que la Cámara de Comercio de Guayaquil con la ayuda de los sindicatos, utilizó el tema del aumento de los costes con la nueva política del gobierno. ${ }^{1059}$ También, se han de mencionar las acciones de los comerciantes que se negaron a retirar los productos importados hasta que la Junta Militar realizara una reforma de la Ley de Arancel, hecho que provocó una elevada disminución de los ingresos recaudados. Por su parte, la lucha de la burguesía comercial tenía algunas limitaciones, pues no tenía el poder suficiente para afrontar la política antinacional y las acciones represivas del gobierno y tampoco podía acaparar el movimiento popular. Esto explica que la burguesía y los sectores populares iniciaran movilizaciones independientes, los cuales luchaban por la misma causa:

La lucha contra el arancel de aduanas se inició con el paro decretado por una asamblea de masas en la que participó también la Federación Provincial de Trabajadores del Guayas y que se inició el día 10 de este mes. Durante los dos primeros días, la acción se limitó al sector de la burguesía comercial. Pero a partir del día 12 de mayo la lucha

\footnotetext{
${ }^{1057}$ En la lucha en contra de las políticas públicas de la Junta Militar de 1963, existió un movimiento oligárquico y pro-imperialista, que rechazaba la modernización del estado y la sociedad, y un movimiento anti-imperialista y de carácter popular que defendía la democracia y se oponía a las acciones militares represivas. Fuente: Rafael Quintero, Erika Silva, op., cit. p. 297.

${ }^{1058}$ Ibíd. p. 293.

1059 George Pope Atkins: La Junta Militar ecuatoriana 1963-1966, Revista Economía, Quito, UCE, Tercera época, 1974, p. 108-109.
} 
excedió los marcos de la burguesía y fueron involucrándose en ella sectores cada vez más amplios. ${ }^{1060}$

De igual forma, en la huelga de mayo, participaron otros profesionales de la industria de la construcción, empresas fumigadoras del banano, aviadores civiles, la sociedad de ingenieros, el pueblo no organizado y algunos miembros del ejército, que fueron acusados de conspiración en contra de la Junta Militar y enviados a prisión. De este modo, ante la presión de diversos sectores sociales, la Junta Militar se vio obligada a abandonar sus ideas de reforma del arancel, disponiendo que los comerciantes retiraran las mercaderías conforme al antiguo arancel y estableciendo el plazo de un mes para que una comisión se encargara de las modificaciones a la reforma. ${ }^{1061}$

La lucha continuó hasta adquirir un carácter nacional y prepararse una nueva huelga unos meses después:

Hacia el verano de 1965, la oposición llamó al pueblo del Ecuador a unirse contra la dictadura militar. Guayaquil siguió siendo el centro de la agitación pero ya no era el último escenario de las manifestaciones. A la Cámara de Comercio del Guayas y a su vacilante aliada, la clase obrera, se unieron los comerciantes, trabajadores, políticos y estudiantes de diversas ciudades. ${ }^{1062}$

Todas estas contradicciones y problemas sociales acabaron en numerosas protestas y huelgas en las zonas de producción, las cuales contribuyeron al aumento del número de organizaciones populares apoyadas por los partidos de izquierda que luchaban por el cambio y la renuncia de la Junta Militar. ${ }^{1063}$

De forma paralela, las negociaciones entre la burguesía y la Junta acabaron con la renuncia de esta última tras el violento desalojo de estudiantes de la Universidad Central de Quito. Asimismo, la fragmentación del ejército, el pacto entre los grupos de Guayaquil y terratenientes

\footnotetext{
${ }^{1060}$ Diario El Pueblo, número 445, Guayaquil, 21 mayo 1964, en Rafael Quintero, Erika Silva, op. cit.p. 293.

${ }^{1061}$ Rafael Quintero, Erika Silva, op. cit. p. 288.

${ }^{1062}$ George Pope Atkins, op. cit. p. 109.

${ }^{1063}$ En el Municipio de Guayaquil se despidieron a 186 empleados y tuvo lugar la huelga en Atuntaqui, provincia de Imbarura, que acabó con un despido de 200 obreros. Fuente: Rafael Quintero, Erika Silva, op. cit. p. 317.
} 
serranos y el gran movimiento de masas en las zonas urbanas y rurales, fueron elementos que provocaron la resignación de los militares ante el descontento de dichos grupos por la política arancelaria y agraria.

Llegados a este punto, si bien antes se ha comentado que con el estancamiento de las exportaciones, los diferentes grupos iniciaron nuevas actividades, es importante aclarar a qué se dedicaron y cómo fue posible este proceso.

En este marco, se ha de hablar de los denominados "imperios costeños" o agrupaciones de exportadores e importadores de Guayaquil, que decidieron ampliar sus intereses y dedicarse a actividades relacionadas con las finanzas, la banca, tierra y la industria. ${ }^{1064}$ En el caso de la Sierra, sabemos que la transformación de las haciendas en unidades empresariales, llevó a que los terratenientes más modernos distribuyeran la renta capitalizada entre otros sectores de la producción como las finanzas, la industria y la construcción inmobiliaria. ${ }^{1065}$

Estos procesos fueron posibles gracias a la existencia de relaciones de parentesco, integración económica de familias y uniones matrimoniales que se daban en la Sierra y en la Costa. ${ }^{1066}$ Así, entre las mayores fortunas del país o clase dominante de la Sierra centro-sur, se encontraban los denominados "nobles de Cuenca", quienes lograron monopolizar en los años setenta, una gran variedad de actividades en las ciudades al ser los propietarios de las mayores empresas comerciales del país, industriales, dueños o directores de los bancos locales o sucursales de otros bancos y tener el monopolio en algunos trabajos, mantener vínculos especiales con la iglesia y controlar el poder político de la región. ${ }^{1067}$

Así pues, el efecto de la crisis pone de relieve que todavía, a finales de los años sesenta, existía un conjunto complejo de clases dominantes que se iba modernizando a través de los medios tradicionales, y en los que el peso de la clase terrateniente era un elemento fundamental que logró sobrevivir durante esta época.

\footnotetext{
1064 David Hanson: Political decision making in Ecuador: The influence of business groups, tesis, Universidad de Florida, 1971, en Rafael Quintero y Erika Silva, op. cit. p. 321.

1065 Andrés Guerrero, Ensayo sobre la acumulación..., op. cit. p. 55.

${ }^{1066}$ Lisa North: Implementación de la política económica y la estructura del poder político en el Ecuador, en L. Lefeber, ed. Economía Política del Ecuador, Campo, Región, Nación, Quito: CEN-CERLAC-FLACSO, 1985, p. 430.

${ }^{1067}$ Leslie A. Brownrigg: The nobles of Cuenca: The agrarian elite of Southern Ecuador, tesis, Public. Nueva York s.n, 1972.
} 
Por su parte, ya a comienzos de los setenta, la extrema desigualdad de la sociedad ecuatoriana se vio agudizada por la falta de acuerdo entre los grupos políticos para llevar a cabo la reforma agraria y el manejo de la producción petrolera, lo cual estuvo marcado por la campaña presidencial de 1972, a pesar de que no se elaboró un plan común para solucionar los principales problemas del país. Es decir, con los gobiernos de Clemente Yerovi (presidente interino desde 30/03/1966-16/11/1966) y Otto Arosemena Gómez (1966-1968), el estado se dedicó a representar los intereses de los grupos oligárquicos como fue el caso de los "imperios costeños", llegando a ser un agente de las empresas multinacionales. ${ }^{1068}$ Así, en el caso de Arosemena Gómez (1966-1968), se sabe que además de ser el presidente del país, representó a la empresa multinacional Grace Une. ${ }^{1069}$

En este caso, tras la caída de la Junta Militar, los gobiernos posteriores estuvieron representados por miembros de algunas de las familias más influyentes y poderosas de Guayaquil que, como se ha dicho antes, solían tener vínculos familiares.

En efecto, no por casualidad la Junta de Notables designó en 1966 a Clemente Yerovi Indaburu, terrateniente ligado al poderoso grupo San Carlos de Guayaquil y emparentado directamente con familias aristocráticas con amplios intereses en el comercio, la banca y la industria, como Presidente Interino. En agosto de ese mismo año, la Asamblea Constituyente reunida eligió un nuevo Presidente Constitucional, escogió del mismo grupo San Carlos a Otto Arosemena Gómez, primo de Victoria Gómez Ycaza, esposa del interino Yerovi Indaburu. ${ }^{1070}$

En definitiva, se puede observar cómo las políticas aplicadas en las formas capitalistas y precapitalistas tenían como objetivo beneficiar a los grandes terratenientes de la Costa y de la Sierra, además de ayudarles a mantener sus privilegios, rechazando las medidas para solucionar los problemas del país.

\footnotetext{
${ }^{1068}$ Para más información sobre Clemente Yerovi y Otto Arosemena, ver el apéndice de notas del capítulo 6. Fuente: Efrén Avilés: Enciclopedia del Ecuador, Academia Nacional de Historia del Ecuador, 2012 www.enciclopediadelecuador.com.

${ }^{1069}$ Lisa North, Implementación..., op. cit. p. 487 en Rafael Quintero, Erika Silva, op. cit. p. 326.

${ }^{1070}$ Ibíd. p. 327.
} 
Continuando con el tema de las actividades realizadas para impulsar la industrialización, vamos a pasar a analizar con más detalle el papel de la artesanía y pequeña industria y cómo el estado llegó a imponer sus deseos, ya que la gran industria absorbía la mayor parte de los excedentes procedentes de la agricultura. Aquí, se ha aclarar que a pesar de la existencia de algunos intentos para reclamar los intereses de artesanos y pequeños industriales a través de ajustes salariales y la Ley de Fomento de la Pequeña Industria y Artesanía, (15-01-1965), estos grupos quedaron al margen del modelo de industrialización, centrado en la industria moderna de gran escala y capital intensivo.

Además, la inclusión de estos grupos en la Ley de Fomento de la Pequeña Industria y Artesanía de 1965, sin que previamente se hubiera transformado la Ley de Defensa del Artesano de 1953, creó un conflicto entre los mismos y no eliminó la confusión que existía a la hora de diferenciar estas actividades. En este caso, el grupo artesanal defendió su antigua ley, oponiéndose a los intentos de unificación de los estatutos legales, pues las diferencias entre estas dos formas de producción eran tan importantes que requerían leyes diferentes: El artesano trabaja solo o con sus familiares y a veces, con algunos trabajadores (operarios y aprendices) donde predomina el trabajo humano sobre la maquinaria. Además, la mayor parte del tiempo estaba dedicado al trabajo relacionado con la manufactura, siendo esta característica primordial para diferenciarlo del pequeño industrial, pues este último se dedicaba a la administración de su negocio, contaba con varios obreros y utilizaba maquinaria con frecuencia. ${ }^{1071}$

Por su parte, la artesanía utilizaba materias primas de carácter nacional a diferencia de la pequeña y gran industria, lo que generaba posibilidades de empleo y fuentes de ingreso para un destacado número de proveedores de otros sectores económicos (campesinos, pequeña y mediana industria, comerciantes, etc.), además de proporcionar artículos manufacturados y servicios para los consumidores. La tabla 23 (Materias Primas utilizadas por las industrias y artesanías de la Hoya de Quito) refleja un mayor uso de materias primas nacionales en relación con las de carácter extranjero. ${ }^{1072}$

${ }^{1071}$ CONADA, CENAPIA, ILDIS, La situación socio-económica..., op. cit. p. 12.

${ }^{1072}$ Esta tabla se encuentra en el apéndice de datos del capítulo 5. Fuente: Junta Nacional de Planificación: La industria y la artesanía de la Hoya de Quito en 1955, en Instituto Panamericano de Geografía e Historia, Plan Piloto del Ecuador, Sección de Economía, México, D.F, 1960, p. 55. 
No en vano, algunos de los problemas que los artesanos debían de afrontar estaban relacionados con el abastecimiento de insumos y materias primas, pues al consumir cantidades bastante pequeñas y al no disponer de mecanismos de acceso al crédito y técnicas de comercialización, se veían obligados a depender de los intermediarios, teniendo que pagar con frecuencia, altos precios por esos materiales. 1073

Es importante tener en cuenta esta última consideración con respecto al papel de la artesanía y de la pequeña industria en el proceso de industrialización del Ecuador de los años sesenta, pues aún cuando se suele decir que el modelo de acumulación en esta época tuvo como eje a la industria manufacturera, es necesario aclarar el papel desempeñado por la gran industria, si llegó a ser el pilar de la acumulación de capital y cuáles fueron los mecanismos utilizados para financiar dicho proceso de industrialización.

Según Iván Fernández, el sector industrial en los años sesenta, comenzó a captar una parte del excedente agro-exportador, llegando a convertirse en una nueva forma de acumulación de capital a nivel interno, a la vez que promocionaba la urbanización, la formación del proletariado urbano y varias formas de consumo y comercialización en la economía nacional. ${ }^{1074}$

El excedente generado a través del comercio de productos agrícolas tenía como destino la financiación del déficit de la balanza comercial y de acumulación (inversiones-ahorros) del sector industrial para que la industria pudiera dinamizarse, mientras que otros sectores como la agricultura tradicional tendieron a estancarse (ver tabla 24: Balanza comercial 1963-1972). ${ }^{1075}$

\footnotetext{
1073 Ver el apéndice de notas del capítulo 5 para más información. Fuente: Junta Nacional de Planificación: Programa de artesanía y pequeñas industrias 1969-1973, número 02-14, 1969, p. 27-29.

${ }^{1074}$ Iván Fernández Espinosa, Patricio Tobar Robalino, op. cit. p. 126.

1075 Esta tabla se encuentra en el apéndice de datos del capítulo 5. Fuente: Patricio Almeida Guzmán, Rebeca Almeida Arroba, op. cit. p.459.
} 
Gráfico 6: Balanza comercial (millones de sucres) (1963-1972):

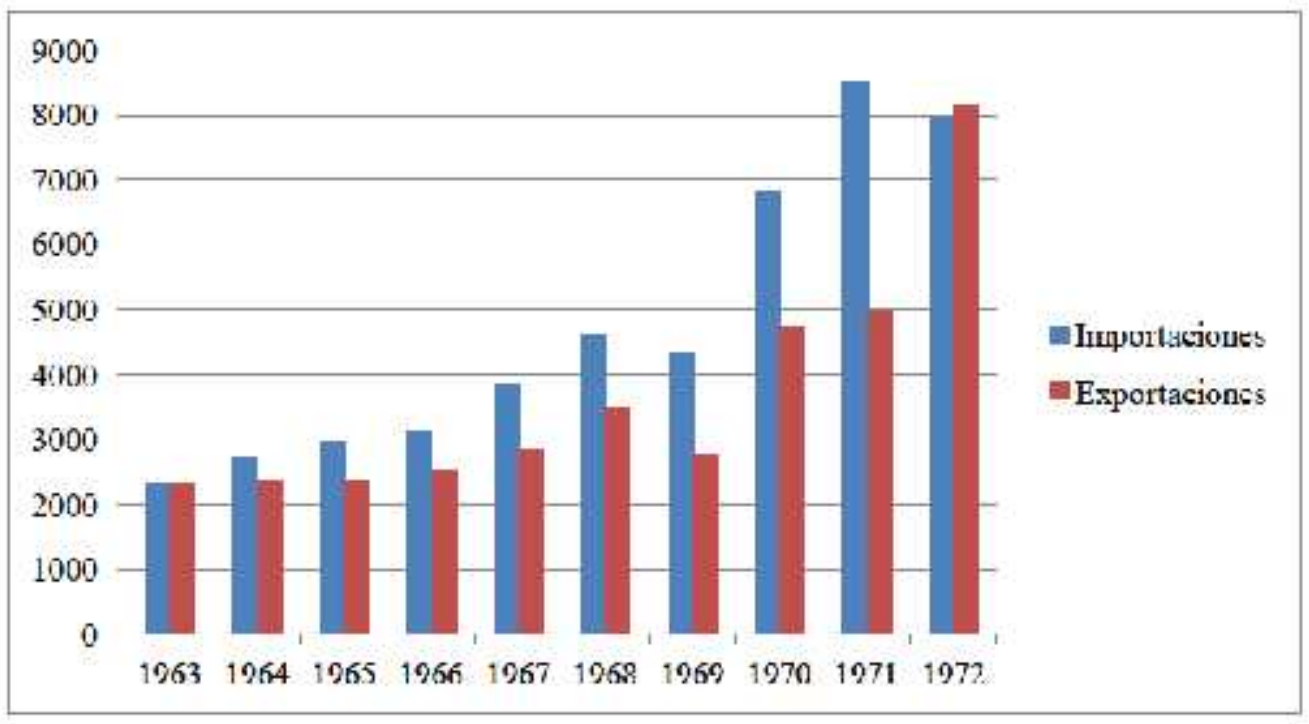

Elaboración propia a partir de la tabla 24

Fuente: Patricio Almeida Guzmán, Rebeca Almeida Arroba: Estadísticas Económicas Históricas 1948-1983, Fuentes para la Historia Económica del Ecuador, serie estadísticas históricas, vol. 1, Banco Central del Ecuador, 1988, p. 459.

Así, el sector agrícola se vio afectado por la falta de atención del estado, lo cual se tradujo en una escasez de inversiones para crear una estructura básica rural, una distribución desigual en favor de los grandes productores y en una tendencia decreciente de los términos internos de intercambio para los campesinos, hecho que ponía de manifiesto el escaso desarrollo rural a favor de la industria. ${ }^{1076}$ Como consecuencia, este hecho provocó una serie de obstáculos al

\footnotetext{
1076 En general, los incentivos para la agricultura se vieron disminuidos por las políticas sectoriales negativas aplicadas desde los años cincuenta hasta los ochenta. Los impuestos sobre las exportaciones de productos agrícolas se mantuvieron durante la mayor parte de este periodo, incluso después del auge petrolero de 1973, ya que las exportaciones agrícolas constituían la principal fuente de ingreso fiscal. Fuente: César Augusto Bravo: Historia del
} 
desarrollo de la industria manufacturera debido a la escasa ampliación del mercado interno que mantuvo los bajos ingresos de los campesinos, así como una limitada oferta de bienes agrícolas para la industria doméstica:

La política cambiaria resultó en precios subvalorados de las exportaciones y de los sustitutos de las importaciones (productos comerciables) en términos de sucres y que claramente discriminaban a los productores agrícolas. También, se proporcionaron subsidios implícitos a las importaciones, especialmente a las que favorecían los insumos industriales, que por lo general, estaban libres de barreras arancelarias y no arancelarias. $^{1077}$

Las tablas 25-27 (PIB por clase de actividad económica) muestran la evolución y contribución de la industria manufacturera al total del producto interior bruto para la primera y segunda fase de industrialización (1950-1960, 1961-1971), la cual fue aumentando de forma progresiva durante estas dos décadas. Así, para 1950, la aportación de la industria de manufactura al PIB fue de 1.235 millones de sucres, siendo el PIB de ese año de 7.229 millones de sucres. En 1955, se obtuvo la cantidad de 1.744 millones de sucres para un PIB de 11.017 millones de sucres, mientras que en 1959, su aportación fue de 2.129 millones de sucres para un PIB de 12.695 millones de sucres. ${ }^{1078}$

Ya, en la década de los sesenta, durante el régimen militar, nos encontramos en 1964, con una contribución de 3.054 millones de sucres y un PIB de 19.357 millones de sucres; para 1965, tenemos 3.359 millones de sucres y un PIB de 20.721 millones de sucres; y para 1966, la aportación de la industria manufacturera fue de 3.988 millones de sucres y un PIB de 22.596. La década termina con una cifra de 5.145 millones de sucres y un PIB de 30.144 millones de sucres para $1969 .^{1079}$

Ecuador: De la década de 1950 a la década de los 70, Colegio de abogados del Azuay, Editorial Gráficas Hernández, Cuenca, 1995.

${ }^{1077}$ Ibíd. p. 124.

${ }^{1078}$ Estas tablas se encuentran en el apéndice de datos del capítulo 5. Fuente: Patricio Almeida Guzmán, Rebeca Almeida Arroba, op. cit. p. 137-138.

${ }^{1079}$ Ibíd. p. 137-138. 
Gráfico 7: Producto Interior Bruto por clase de actividad económica 1960-1969

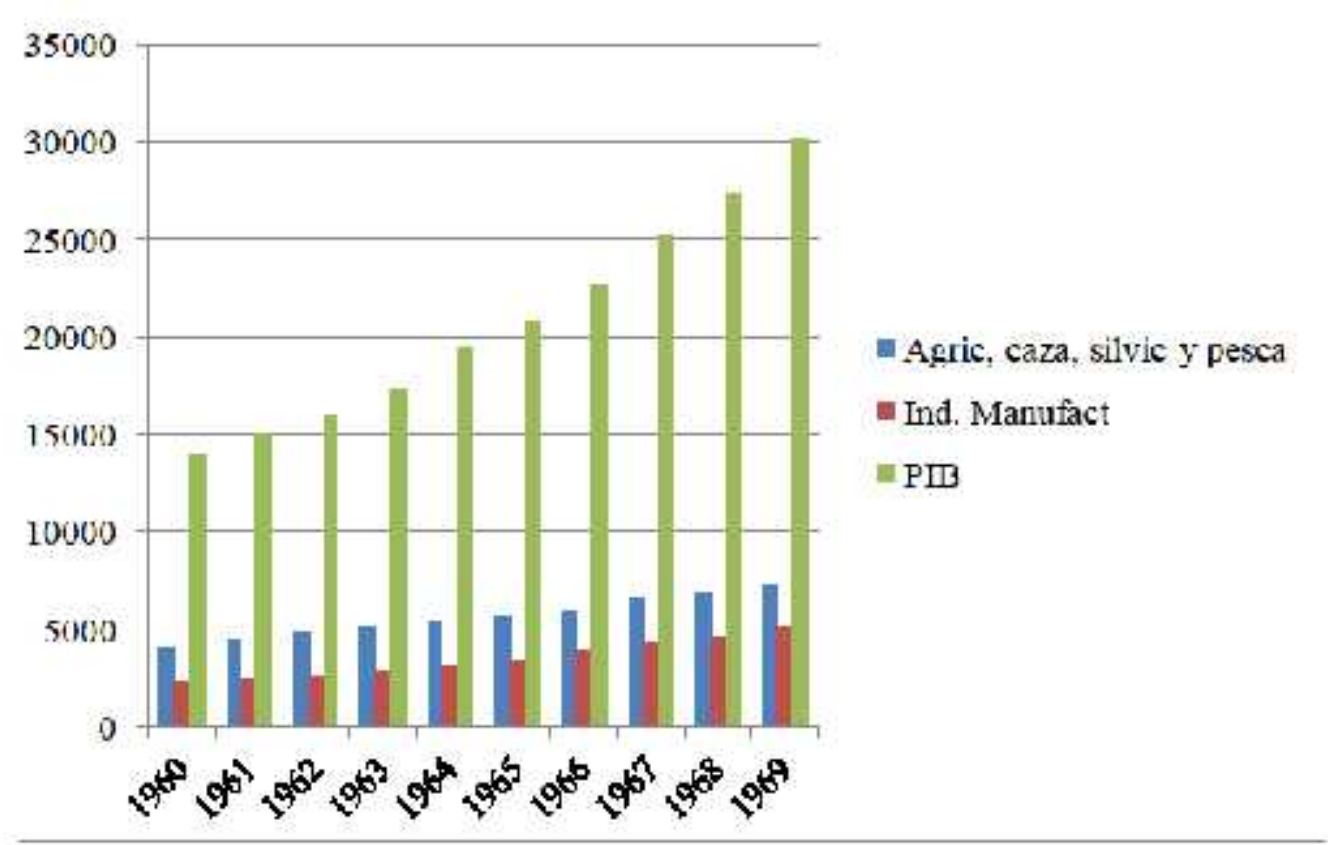

Elaboración propia a partir de los datos de las tablas 26 y 27

Fuente: Patricio Almeida Guzmán, Rebeca Almeida Arroba: Estadísticas Económicas Históricas 1948-1983, Fuentes para la Historia Económica del Ecuador, serie estadísticas históricas, vol. 1, Banco Central del Ecuador, 1988, p. 137-138.

Por otro lado, si nos fijamos en las tablas 28 y 29 (PIB por clase de actividad económica 19651969, 1970-1974) veremos la contribución desglosada de las diferentes ramas de la industria manufacturera al total del producto interior bruto, y cómo esta fue incrementándose a partir de los años setenta, sobre todo con los beneficios derivados del petróleo. Así, para 1970, la contribución de la manufactura al PIB fue de 6.372 millones de sucres; en 1971, fue de 7.546 millones de sucres; en 1972, tenemos la cifra 8.763 millones de sucres; en 1973, la cantidad fue de 10.828 millones de sucres; y finalmente, el año 1974, con una aportación de 14.292 millones de sucres al PIB. Aquí, nuevamente, se observa que las mayores cantidades corresponden a las 
ramas de productos alimenticios, bebidas, tabaco, textiles, prendas de vestir y la industria del cuero, siendo menor el aporte realizado por las otras actividades manufactureras (productos minerales, maquinaria y material de transporte). ${ }^{1080}$

Si bien es verdad que el desarrollo industrial de los setenta estuvo influenciado por los beneficios obtenidos de la explotación petrolera, como veremos posteriormente, se puede plantear la pregunta de si el proceso de industrialización de los sesenta, llegó a constituir un objetivo de los gobiernos de esta década, o si en realidad, fue una herramienta para continuar dando prioridad a las exportaciones, y con ello, al modelo de desarrollo hacia afuera como auténtico centro de acumulación de capital. ${ }^{1081}$

A este respecto, Rafael Quintero y Erika Silva indican que el proceso de industrialización tiene lugar en una sociedad cuando la industria se convierte en uno de los ejes fundamentales de la acumulación de capital. En este caso, dicho proceso corresponde a una etapa de desarrollo del capitalismo, en el que la gran industria mecanizada aparece (la industria fabril) y se constituye el capital industrial como generador de valor y ganancia capitalista. ${ }^{1082}$

Además, pese a que el vínculo entre la industrialización y el desarrollo del capitalismo estaba presente en algunos estudios dedicados a la industria; la cuestión que hay que determinar, guarda relación con el momento en que se establece la industria como eje de acumulación del capital en el Ecuador. ${ }^{1083}$

En nuestro análisis, nos encontramos con un problema, y es que los datos del Banco Central utilizados para establecer la contribución de la industria manufacturera al PIB, no muestran un desglose del sector manufacturero en cuanto a la industria fabril, artesanía y pequeña industria, lo

\footnotetext{
${ }^{1080}$ Estas tablas se encuentran en el apéndice de datos del capítulo 5. Fuente: Ibid. p. 57.

${ }^{1081}$ El desarrollo industrial de los setenta se correspondería con la tercera etapa del proceso de industrialización que analizaremos en el epígrafe 5.2.

1082 Estos autores parten de la obra de Lenin "el Desarrollo del Capitalismo en Rusia", con la que se pone de manifiesto que en el capitalismo, el grado superior de desarrollo de la industria viene dado por el "empleo de un sistema de máquinas para la producción". Las distintas fases del desarrollo industrial en un país son la pequeña producción mercantil, la manufactura y la fábrica, las cuales alcanzan su plenitud capitalista únicamente mediante esta última, pues es la que se constituye en su fase más avanzada de desarrollo. Fuente: V. Lenin: El desarrollo del capitalismo en Rusia, Moscú: Editorial Progreso, 1969: Moscú: Cartago, 1974, p. 418-505; Rafael Quintero, Erika Silva, op. cit., p. 270-317.

1083 César Verduga: El proceso económico contemporáneo, (análisis del periodo 1972-1975), en Drekonja et al, Ecuador Hoy, Bogotá: Siglo XXX, 1978, p. 54.
} 
cual, como Rafael Quintero y Erika Silva indican, presenta el problema de una heterogénea estructura industrial. ${ }^{1084}$

Volviendo al tema de la importancia de la artesanía y de cómo esta constituía el grueso de establecimientos que conformaban el sector manufacturero, se aprecia este problema a la hora de evaluar el crecimiento propiamente industrial, es decir, se puede asumir de forma errónea como producción industrial, la pequeña producción mercantil de la artesanía. En este sentido, la idea de un sector manufacturero que incluya distintas etapas de la producción, puede ser un obstáculo al desarrollo real de la industria y su peso en la estructura productiva del país.

El peso de la artesanía y la pequeña industria en el conjunto del sector manufacturero determinó que entre 1963 y 1973 la productividad industrial creciera solo a un promedio del 2\% anual... Si la artesanía y pequeña industria ocupaban para 1963, el $87 \%$ de la fuerza laboral del sector, no es sorprendente que la baja productividad de estos dos estratos diluyera totalmente el aumento de la productividad de la industria moderna. ${ }^{1085}$

Para analizar este punto con más detalle, hay que usar algunos factores como el número de personas ocupado, el volumen de producción y venta, el uso de maquinaria, y la legislación del momento en cuanto a la industria y artesanía; lo cual nos ayudará a diferenciar entre artesanía e industria fabril.

De este modo, la Ley promulgada en 1964, definía al sector artesanal como:

El pequeño industrial o pequeño artesano es la persona dedicada a cualquiera de estas actividades, de reducida capacidad económica, cuyos activos fijos, consistentes en maquinaria, equipos y herramientas, no excedan de 50.000 sucres y cuya producción bruta anual no sobrepase de un valor de 150.000 sucres. ${ }^{1086}$

Por su parte, la Ley dictada en enero de 1965, definía al artesanado como una labor fundamentalmente manual, realizada con o sin la ayuda de maquinaria y destinada a producir,

\footnotetext{
${ }^{1084}$ G. Montaño, E. Wygard: Visión sobre la industria ecuatoriana s/f, p. 170; Rafael Quintero, Erika Silva, op. cit. p. $270-317$.

1085 Ibíd. p. 29.

1086 Junta Nacional de Planificación Programa de artesanía y pequeñas industrias 1969-1973, documento, número. 02-14, 1969, p. 7.
} 
mientras que la pequeña industria se caracterizaba por su predominio del uso de maquinaria, y su dedicación a actividades de transformación, inclusive en la forma, de material prima o de productos semielaborados, en artículos finales o intermedios, y siempre que su activo fijo, no sea mayor de 200.000 sucres (excluyendo edificios y terrenos). ${ }^{1087}$

Posteriormente, en 1966, se estableció una nueva base para determinar quienes debían ser considerados como pequeños industriales y artesanos, fijando un activo fijo no superior a 200.000 sucres (excluyendo edificios y terrenos). De igual forma, la Junta utilizó varias definiciones para establecer los sectores que debían ser incluidos en la industria manufacturera. Así, consideraba como industrias de tipo fabril a las empresas que empleaban a siete o más personas y tenían un valor de producción anual superior a 180.000 sucres, mientras que en la artesanía, la Junta establecía que un taller artesanal ocupaba hasta seis personas y tenía un valor bruto de la producción no superior a 180.000 sucres. ${ }^{1088}$

Para determinar el número de establecimientos que conformaban el artesanado en la década de los sesenta, se ha utilizado la Encuesta Industrial de 1963 y 1964 y el Directorio Nacional de Establecimientos de 1964. La Encuesta Industrial de 1963, establece la existencia de 639 establecimientos industriales con siete o más trabajadores, una producción anual de 180.000 sucres o más, y 31.482 personas ocupadas, mientras que la Encuesta de 1964, refleja 635 establecimientos y 33.482 personas ocupadas. Por su parte, el Directorio de Establecimientos, establece que el total de establecimientos en el sector manufacturero era de 24.157 con 91.442 trabajadores para 1964 (ver tabla 30: Personal ocupado en artesanía). ${ }^{1089}$

También, se ha consultado el Censo de Manufactura y Minería de 1965, en el que se observa la existencia de 22.295 establecimientos grandes y pequeños registrados durante dicho año (ver tabla 31: Número de establecimientos, personal ocupado, producción 1965), con 88.598 personas ocupadas, de los que 21.493 establecimientos y 51.349 personas pertenecían al sector artesanal, y 802 establecimientos y 37.195 personas correspondían al sector fabril. ${ }^{1090}$

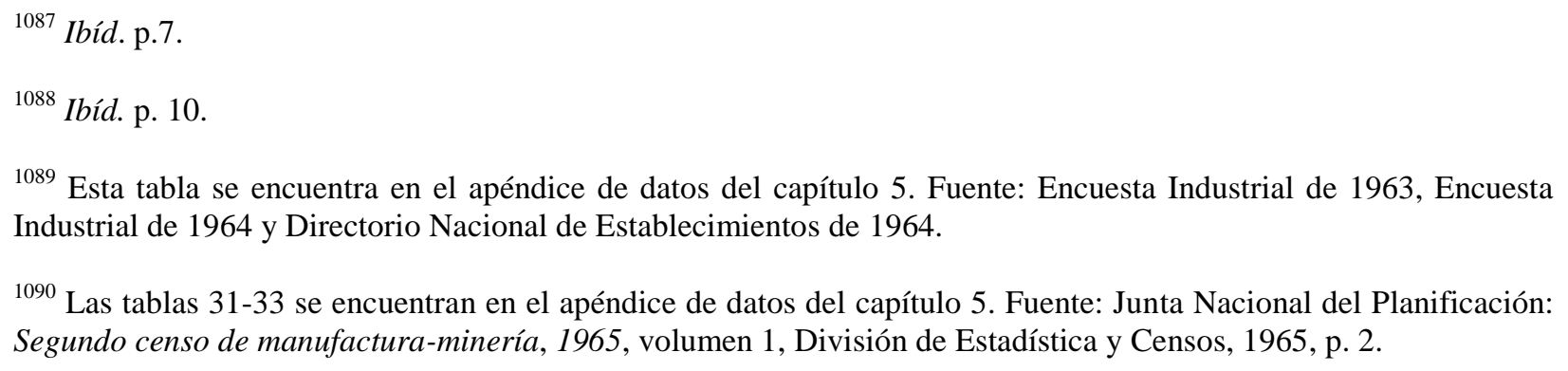


La tabla 32 (Distribución del sector artesanal por rama de actividad 1965) muestra los principales sectores del artesanado, siendo uno de los más importantes el del "calzado y vestuario" con 10.436 establecimientos y 19.110 trabajadores, seguido de la actividad "muebles" que contaba con 1.884 establecimientos y 4.112 personas ocupadas; "alimentos" con 1.567 establecimientos y 4.383 trabajadores; "material de transporte" con 1.410 establecimientos y 4.571 empleados, y la rama "productos metálicos" con 1.304 establecimientos y 3.033 empleados. ${ }^{1091}$

Asimismo, la tabla 33 (Sector artesanal 1965) muestra el valor bruto de la producción total para 1965, siendo los principales productos artesanales las prendas de vestir, calzado, muebles, instalación de oficinas y tiendas, productos metálicos, fabricación de pan, tortas, pastas y otros productos de panadería, además de servicios de reparación de calzado, trabajos de herrería y soldadura y reparación de vehículos motorizados. ${ }^{1092}$

Según las cifras del Censo Industrial de 1965, le correspondería al sector artesanal aproximadamente el $13.6 \%$ del total de la producción manufacturera sin considerar en estos cálculos, los valores correspondientes a la manufactura casera, lo que demuestra la importancia que tiene este sector en la economía nacional. ${ }^{1093}$

También, Rafael Quintero y Erika Silva afirman que de 22.295 establecimientos registrados... el 90\% (20.487) constituían talleres con menos de cinco personas ocupadas (dos personas promedio por establecimiento) y aportaban el 14\% del valor de la producción del sector; y concluyen que durante el régimen militar, la artesanía y la pequeña industria tuvieron un peso bastante grande en cuanto al número de establecimientos y número de empleados, siendo estos, el verdadero motor de la industria manufacturera en conjunto. ${ }^{1094}$

En definitiva, si bien se puede decir que la industria manufacturera llegó a experimentar un ligero crecimiento durante de la década de los sesenta, los datos examinados ponen de manifiesto que no se produjo de la manera programada para los años sesenta. Es más, si se examina esta

\footnotetext{
${ }^{1091}$ Estadísticas y censos, Directorio 1964 y Censo Industrial 1965, JUNAPLA.

${ }^{1092}$ División de estadística y Censos, Junta Nacional de Planificación, Censo 1965. Elaboración: Unidad de artesanía

${ }^{1093}$ Junta Nacional de Planificación, Programa de artesanía..., op. cit. p. 11.

${ }^{1094}$ Rafael Quintero, Erika Silva, op. cit. p. 271.
} 
cuestión con mayor detenimiento, vemos que durante la dictadura militar se incrementó el número de establecimientos industriales acogidos a la Ley de Fomento Industrial que había sido reformada durante esta época.

Las estadísticas del Banco Central (tablas 34 y 35: Industrias acogidas a la Ley de Fomento Industrial: Nuevas y existentes, 1957-1964, 1964-1970) muestran que en el periodo 1957-1963, se acogieron a la Ley de Fomento Industrial, 89 establecimientos nuevos y 65 establecimientos que ya existían, mientras que durante 1964-1970, se acogieron a la ley 206 establecimientos nuevos y 109 existentes, es decir, se produjo un aumento de las cifras para los dos tipos de industrias. $^{1095}$

Por otra parte, se aprecia cómo algunas de las ramas más débiles se fueron fortaleciendo a partir de 1963, como ocurrió con la fabricación de productos metálicos, la construcción de maquinaria eléctrica y fabricación de material de transporte como se refleja en las tablas 6-8 (Valor bruto de la producción y valor agregado de las industrias). Estas ramas, cuya producción era prácticamente inexistente en los años anteriores, irrumpieron precisamente durante la dictadura militar, notándose una leve disminución en algunas de las ramas tradicionales (producción de cuero, bebidas, etc.). ${ }^{1096}$

Por otra parte, una de las consecuencias de clasificar la industria y la artesanía como parte del sector de manufacturas, fue el establecimiento de una mayor aportación de la industria al producto interior bruto y, por tanto, al desarrollo y crecimiento de la economía ecuatoriana. Esto explica que se defendiera la idea del comienzo del proceso de industrialización en el Ecuador a partir de los años sesenta.

Los datos sobre el aporte del llamado sector manufacturero al PIB, indican que este heterogéneo conglomerado económico, oscila entre 1963 y 1966 alrededor de un 17\%, cifra nada desdeñable en un país en el que aún subsistían relaciones de producción precapitalistas. Pero, como sabemos, dentro de este sector se hallan incluidas artesanías, pequeña industria e industria, por lo que con estos datos no se puede establecer con precisión la participación de la industria fabril en el PIB. No obstante, la participación

\footnotetext{
1095 Estas tablas se encuentran en el apéndice de datos del capítulo 5. Fuente Patricio Almeida Guzmán, Rebeca Almeida Arroba, op. cit. p. 137-138.

${ }^{1096}$ Estas tablas se encuentran en el apéndice de datos del capítulo 5. Fuente: Ibíd. p. 148-151.
} 
de la industria fabril en el PIB para 1963-1966, según los cálculos, revela que esta es infima girando alrededor de un 9,6\%. Este dato hace ostensible que la industria fabril estaba lejos de convertirse en eje de acumulación de capital y por ende, se puede afirmar que el país no había entrado en un proceso de industrialización tal como lo hemos conceptualizado. ${ }^{1097}$

Las ideas expresadas junto con las estadísticas analizadas del Banco Central del Ecuador y del Censo de manufactura, muestran la dificultad para analizar la participación de la industria en el producto interior, y para establecer si la industria fue realmente el eje de acumulación de capital de esta época, ya que la fase principal de su desarrollo en el capitalismo, fue la manufactura asociada a la pequeña producción mercantil.

De forma paralela, hemos visto cómo la cifra de exportaciones comenzó a mostrar su incapacidad para mantener una economía que se había ido complicando con el paso del tiempo, pues el incipiente esfuerzo de industrialización había provocado una mayor dependencia del exterior con la adquisición de materias primas, maquinaria y otros productos.

En particular, esta situación puede ser observada hacia finales de los años sesenta y comienzos de los setenta, cuando ya se entra en lo que Guillermo Landázuri considera como "la tercera fase del proceso de industrialización", en la que las importaciones fueron mayores que las exportaciones y el déficit alcanzó niveles desmesurados (ver tabla 24: Balanza comercial 19631972), a pesar del impulso que recibió la industria derivado de los beneficios del petróleo, como veremos a continuación. ${ }^{1098}$

\section{2) Una nueva etapa imperialista: El auge del petróleo, el impulso de la industrialización y la subordinación financiera, comercial y tecnológica (1968-1973).}

En este apartado, vamos a analizar la última etapa correspondiente al proceso de industrialización ecuatoriano, la cual comenzó hacia finales de los años sesenta, al tiempo que el país se iniciaba en un nuevo periodo de desarrollo capitalista y acumulación de capital caracterizado por el auge petrolero y el papel desempeñado por el estado, la burguesía y el

\footnotetext{
${ }^{1097}$ Rafael Quintero, Erika Silva, op. cit. p. 273.

${ }^{1098}$ Esta tabla se encuentra en el apéndice de datos del capítulo 5. Fuente Guillermo Landázuri Carrillo, op. cit. p. 361-367.
} 
capital extranjero. Así, la planificación de los años setenta, basada en el modelo de industrialización a través de la sustitución de importaciones, orientó el proceso de acumulación hacia la generación y fortalecimiento de una estructura productiva de tipo industrial centrada en la ampliación del mercado interno, mediante la afluencia de recursos financieros procedentes de la producción y exportación del petróleo. ${ }^{1099}$

Con esta nueva etapa, y a diferencia de los procesos anteriores, las actividades ligadas a la exportación de productos agrícolas dejaron de ser el eje fundamental de riqueza en el país, siendo este lugar ocupado por la producción y exportación del petróleo, de cuyo control se encargaba el estado ecuatoriano y los capitales extranjeros. Por consiguiente, ¿cómo se llevó a cabo este nuevo periodo de acumulación de capital impulsado por el petróleo? ¿cómo afectó al proceso de industrialización del país? ¿cuáles fueron sus contribuciones al desarrollo de la economía ecuatoriana? ¿cuál fue el papel del estado y de las clases sociales?

Antes de dar respuesta a estas preguntas, es necesario revisar cómo y cuándo surgió el interés del estado ecuatoriano y de los capitales extranjeros en la explotación del petróleo. En principio, se podría decir que esta actividad tuvo lugar durante el siglo XIX, pero no fue hasta la segunda década del siglo XX, en que la compañía de petróleo inglesa Anglo Ecuadorean Oilfields, subsidiaria de Burmah Oil Co., se instaló en el Ecuador para explorar los yacimientos de la Península de Santa Elena en la Provincia del Guayas. ${ }^{1100}$

Esta primera etapa de explotación en la Costa finalizó a mediados de la década de los cincuenta, debido a la disminución de producción y agotamiento de los yacimientos de petróleo. ${ }^{1101}$

De igual manera, en lo que respecta a la región amazónica, las compañías inglesas y norteamericanas mostraron su interés en la búsqueda de petróleo en las primeras décadas del siglo XX. Así, la compañía inglesa Shell comenzó sus operaciones en el oriente central en 1937,

\footnotetext{
1099 A diferencia de las experiencias tradicionales de los países periféricos latinoamericanos, el proceso de industrialización a través de la sustitución de importaciones en el Ecuador, ha de ser concebido en el marco de un modelo combinado de sustitución de importaciones y de producción para la exportación. Fuente: Arnoldo Bocco: La economía política del petróleo ecuatoriano, FLACSO, Quito, 1980.

${ }^{1100}$ Para más información sobre estas compañías, ver el apéndice de notas del capítulo 5. Fuente: Jaime Galarza: El festín del petróleo, Quito, Solitierra, 1972, p. 22-248; Ana M.Varae: Marea negra en la Amazonía, ABYA-YALA, Quito, 1995; Boletín $\mathrm{N}^{\circ}$ 3, 2002, en Teresa Jimbicti Pandama: El petróleo en la región amazónica: El bloque 24 y los derechos colectivos en la nacionalidad Shuar, FLACSO, 2004, p. 3-5.

${ }^{1101}$ La producción de petróleo de la Anglo Ecuadorean Oilfields en 1953, fue de 2.430 .380 barriles, disminuyendo a 2.336.879 barriles en 1955. Fuente: Erika Silva, Rafael Quintero, op. cit. 340-341.
} 
mientras que la estadounidense Standard Oil se unió a la exploración en 1947, abandonando ambas compañías esta actividad dos décadas después, tras el fracaso de sus inversiones. ${ }^{1102}$ A pesar de estas pérdidas, las empresas norteamericanas continuaron buscando oportunidades para explorar en la región oriental ecuatoriana, consiguiendo el grupo Texaco-Gulf, un contrato de exploración para la zona sureste de la Amazonía que comprendía Aguarico, Santa Rosa de Sucumbios, Santa Cecilia, y territorios de Quichuas y Cofán:

La Texaco obtuvo en 1963 una concesión de 1.431 .450 hectáreas en el nororiente, por 40 años prorrogables por otros 10, con 8 años previos de exploración. En marzo de 1967, brotaba petróleo oriental y entre 1967-1968, se descubrían los primeros filones de petróleo en el noreste ecuatoriano. Para 1971, las compañías extranjeras habían completado la construcción de los pozos petroleros. En 1967-1972, las inversiones en el Oriente, incluida la construcción del oleoducto, alcanzaron a unos 350 millones de dólares. ${ }^{1103}$

El descubrimiento de petróleo en esta parte del país atrajo a numerosas compañías extranjeras a finales de los años sesenta, las cuales lograron beneficiarse a costa de la soberanía nacional, ya que para 1966, el número de hectáreas entregadas ascendía a la cantidad de 2.706.932,96. ${ }^{1104}$ Entre las concesiones de tierras que los gobiernos ecuatorianos hicieron, se encontraban la del Golfo de Guayaquil, que fue cedido durante el gobierno de Otto Arosemena al grupo de la Standard Oil, mientras que durante el quinto gobierno de Velasco Ibarra se creó una Ley de Hidrocarburos (decreto 1459, 1/10/1971) que impulsaba las entregas de tierra y favorecía la entrada de compañías extranjeras, a las que se les proporcionaban las máximas ventajas

\footnotetext{
${ }^{1102}$ Para más información de otras firmas extranjeras interesadas en el petróleo ecuatoriano, ver el apéndice de notas del capítulo 5. Fuente: Cyrano Tama Paz: Petróleo, drama ecuatoriano, Departamento de publicaciones de la Universidad de Guayaquil, Julio 1975, p. 83-84; Guillaume Fontaine: Petróleo y desarrollo sostenible en Ecuador, FLACSO, Ecuador, 2004, p. 47.

${ }^{1103}$ Rafael Quintero, Erika Silva, op. cit. p. 341.

${ }^{1104}$ Ibíd. p. 341.
} 
(renovación de sus contratos, transferencias de concesiones a terceras compañías, etc.) en perjuicio de los intereses ecuatorianos. ${ }^{1105}$

Esto explica que la Anglo Ecuadorian Oilfield y la Texaco-Gulf se convirtieran en las compañías petroleras más importantes en el Ecuador (poseían el 65\% de las concesiones), siendo la cantidad total de 9.400.776,40 hectáreas para 1970 (ver tabla 36: Concesiones territoriales para la exploración y explotación de petróleo 1966-1970): El territorio entregado en concesión a las compañías extranjeras era superior a todo el territorio de la Costa (67.930 km2), de la Sierra (64.248 km2) y equivalía a 3/4 partes de la territorialidad amazónica (130.578 km2). ${ }^{1106}$

Gráfico 8: Concesiones territoriales para la exploración y explotación de petróleo 1966-1970

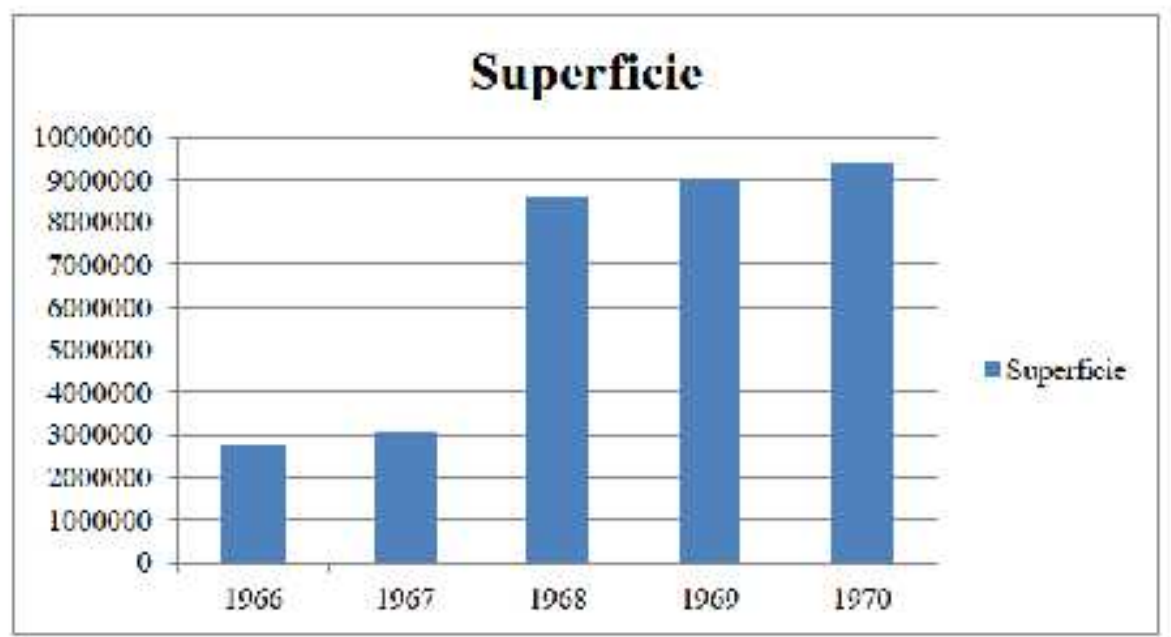

Elaboración propia a partir de los datos de la tabla 36.

Fuente: Rafael Quintero, Erika Silva: Ecuador: Una nación en ciernes, FLACSO, Abya-Yala, Tomo III, 1991, p. 340.

\footnotetext{
1105 Para más información de Otto Arosemena, ver el apéndice de notas del capítulo 5. Efrén Avilés: Enciclopedia del Ecuador, Academia Nacional de Historia del Ecuador, 2012; Cyrano Tama Paz, op. cit. p.22.

${ }^{1106}$ Esta tabla se encuentra en el apéndice de datos del capítulo 5. Fuente: Rafael Quintero, Erika Silva, op. cit. p. 340.
} 
A su vez, la entrada de compañías extranjeras implicaba la presencia de grandes inversiones realizadas para aumentar la extracción de petróleo ${ }^{1107}$. Así, en 1969, la Texaco-Gulf planeó la construcción de un oleoducto durante el gobierno de Velasco Ibarra, cuya ruta abarcaba los territorios de Quito, Baeza, Santo Domingo de los Colorados, el Lago Agrio y el litoral de la provincia de Esmeraldas. ${ }^{1108}$

El planteamiento básico de este proyecto, presentado por los asesores al gobierno de Velasco, tenía como propósito que el oleoducto fuera de propiedad exclusiva del estado ecuatoriano, a lo que el mandatario se opuso y cedió todas las ventajas a la Texaco-Gulf, que pasó a ser la dueña del mismo. ${ }^{1109}$

El abuso de las compañías petroleras y la actitud del gobierno de Velasco Ibarra, motivaron la lucha anti-imperialista y numerosas protestas en contra de dichas empresas monopolistas por su elevado lucro en la explotación del petróleo ecuatoriano, que además tenía lugar sin una compensación apropiada. Las quejas llevaron a la intervención de las Fuerzas Armadas que, para responder a tales denuncias, presentaron diversos obstáculos contra la política petrolera del gobierno de Velasco, el cual se negaba a modificar los contratos de las multinacionales. El primer resultado revolucionario favorable, tras el alejamiento de este político, fue el Decreto 430 (6-61972) que implicaba la aplicación de la Ley de Hidrocarburos para que el país se beneficiara de sus ventajas. ${ }^{1110}$

Además, el gobierno de Rodríguez Lara obligó a las compañías a ajustar retrospectivamente sus contratos a la nueva ley, como fue el caso de la Texaco-Gulf, que tras la suscripción del nuevo contrato en 1973, solo pudo acceder a 491.355 hectáreas petroleras.

\footnotetext{
${ }^{1107} \mathrm{El}$ aumento de la inversión extranjera se refleja en la tabla 14 (Inversión extranjera en el Ecuador 1964-1972) siendo las cifras más altas, las correspondientes a los capitales estadounidenses, como ya se dijo con anterioridad. Esta tabla se encuentra en el apéndice de datos del capítulo 5.

${ }^{1108}$ Ver el mapa del oleoducto en el apéndice de mapas del capítulo 5.

${ }^{1109}$ Ver el apéndice de notas del capítulo 5 para más información. Fuente: Cyrano Tama Paz, op. cit. p. 55; Rodrigo Cabezas: Política petrolera ecuatoriana, Nueva Sociedad, Número 14, septiembre-octubre 1974, p. 30-33.

${ }^{1110}$ Cyrano Tama Paz, op. cit. p.80.
} 
Posteriormente, en 1974, se hicieron otras modificaciones mediante las cuales, el gobierno militar aceleró la nacionalización parcial de este consorcio, autorizando la compra del $25 \%$ de sus acciones. ${ }^{1111}$

Por su parte, la producción de petróleo llevada a cabo por la Texaco-Gulf a comienzos de los años setenta, provocó grandes cambios e impulsó el desarrollo de la estructura económica del Ecuador, sobre todo al término de la dictadura de Velasco Ibarra, ya que los continuos problemas fiscales, económicos y políticos, llevaron a buscar una solución inmediata en la exportación petrolera. A este respecto, el estado se vio favorecido por el incremento de la producción (ver la evolución de la producción en la tabla 37: Volumen de la producción de petróleo crudo, 19681975) y de los ingresos proporcionados por las exportaciones de petróleo, los cuales fueron destinados a la financiación de proyectos industriales, mientras se impulsaba el crecimiento general del país. ${ }^{1112}$

\footnotetext{
${ }^{1111}$ Jorge Estrada, op cit. p. 36-62.

1112 Esta tabla se encuentra en el apéndice de datos del capítulo 5. Fuente: Patricio Almeida Guzmán, Rebeca Almeida Arroba, op. cit. p. 122.
} 
Gráfico 9: Volumen de la producción de petróleo crudo (1968-1975)

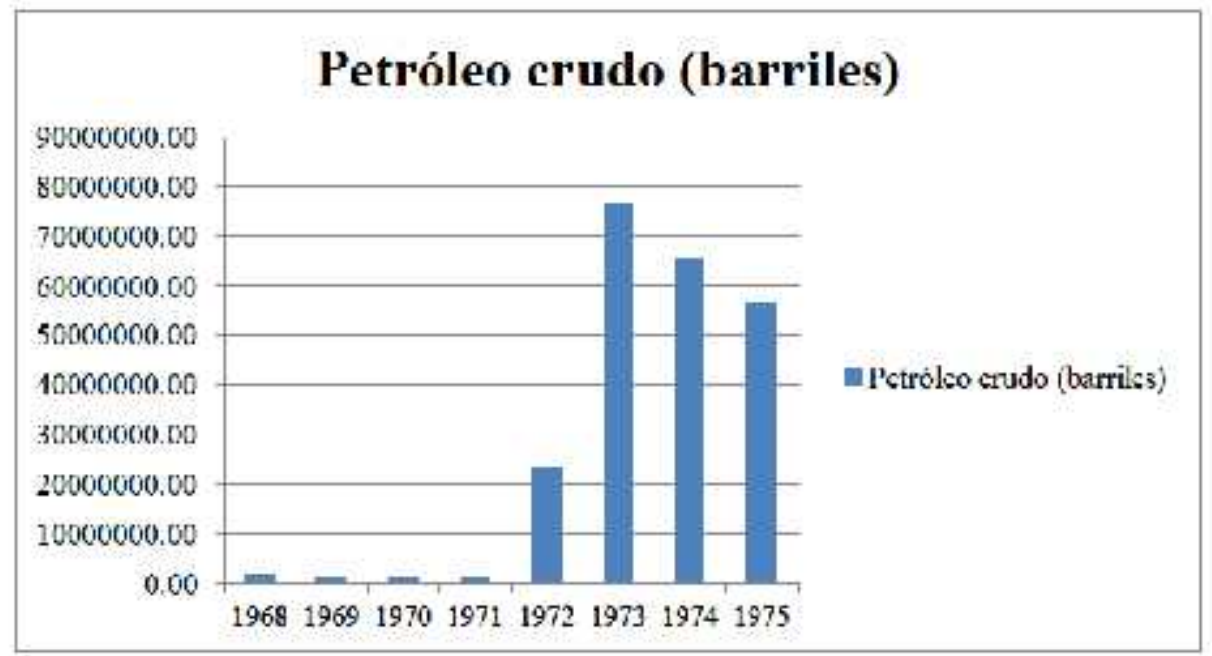

Elaboración propia a partir de los datos de la tabla 37.

Fuente: Patricio Almeida Guzmán, Rebeca Almeida Arroba: Estadísticas Económicas Históricas 1948-1983, Fuentes para la Historia Económica del Ecuador, serie estadísticas históricas, vol. 1, Banco Central del Ecuador, 1988, p. 122.

Al disponer de nuevos recursos económicos y al convertirse en el eje del nuevo modelo de acumulación, el estado fue configurándose como ente capitalista, desarrollando su estructura administrativa, institucional y jurídica, permitiendo modificaciones agrarias, arancelarias y monetarias y aumentando su ámbito de acción, pues pasó a ser la forma de representación de la burguesía. ${ }^{1113}$ Además, numerosos sectores se sumaron a la participación de la riqueza petrolera

\footnotetext{
${ }^{1113} \mathrm{Al}$ aumentar el ingreso estatal y el margen de los precios de petróleo, los sectores económicos pudieron gozar de un mayor beneficio. En Quito, Guayaquil y otras ciudades, se favoreció la construcción de edificios y se incrementó la producción agrícola como consecuencia de los créditos de fomento proporcionados. Así, lo indica Cyrano Tama en su obra: subieron precios agrícolas internos y de exportaciones en determinados productos, hubo ganancias por importaciones, prosperando algunos empresarios y contratistas con mayor movimiento de negocios. Fuente: Cyrano Tama Paz, op. cit. p.86.
} 
y de las oportunidades de inversión generadas en este periodo, siendo la oligarquía, los altos cargos de la burocracia y algunos segmentos del ejército, los que recibieron mayores beneficios:

La exportación petrolera se inició en 1972, inaugurando una nueva fase en el país. Era la primera vez que se trataba de un boom minero, no agrícola, manejado básicamente por el estado. La producción del crudo se incrementó 54 veces entre 1970 y 1973, al pasar de 1,4 a 76,2 millones de barriles por año. El precio del petróleo se multiplicó por 14 veces, de 2.50 dólares el barril en 1972 llegó a 35 dólares en 1980. Entre 1970 y 1979, el PIB creció al 9\%, se profundizó el modelo de industrialización sustitutiva, crecieron las capas medias, se consolidó un sector financiero e industrial, creció el sector servicios en medio de una urbanización constante que alteró definitivamente las características rurales que tenía el Ecuador hasta la década del sesenta. ${ }^{114}$

La política petrolera del estado estaba basada en un conjunto de intereses entre los que se encontraban la explotación racional, el mantenimiento de las reservas para futuras generaciones sin olvidar la rentabilidad de las inversiones de las compañías petroleras, la revisión de contratos, precios de referencias y nuevas refinerías, la construcción de una red de transporte marítimo y la entrada del país en la Organización de Países Exportadores de Petróleo (OPEP). ${ }^{1115}$

Recordemos que antes del auge de las exportaciones de petróleo, el impulso de la industrialización fue posible gracias al uso de los excedentes procedentes de las exportaciones de productos agrícolas. La tabla 38 (Exportación total por rama de actividad 1969-1974) refleja cómo todavía en el año 1969, existía una gran dependencia de las exportaciones de los productos tradicionales (banano, plátano, café y cacao), tendencia que comienza a cambiar, como se ha dicho, en 1973, en el que por primera vez las exportaciones de petróleo superaron a estas con la cantidad de 282.057.000 dólares, en comparación con los 74.126.000 dólares procedentes del banano y plátano, 26.016.000 del cacao y 65.427.000 del café. ${ }^{1116}$

\footnotetext{
1114 Galo Ramón Valarezo, Víctor Torres Dávila: El desarrollo local en el Ecuador: Historia, actores y métodos, Editorial Abya-Yala, 2004, p. 195.

1115 Para más información de la Organización de Países Exportadores de Petróleo, ver el apéndice de notas del capítulo 5. Fuente: Organización de Países Exportadores de Petróleo www.opep.org.

${ }^{1116}$ La importancia de las actividades agrícolas puede ser observada en la tabla 40: Producto interno bruto por clase de actividad económica 1970-1974, que muestra cómo su contribución al producto interior bruto fue mayor que la
} 
No obstante, si bien las exportaciones de petróleo pasaron a ser el componente central del sector externo con resultados bastante elevados, se ha de seguir teniendo en cuenta la importante contribución de dichos productos agrícolas dentro de la categoría de productos primarios (ver tabla 39: Valor de las exportaciones de productos primarios principales 1965-1975) y también, las exportaciones de bienes secundarios como productos farmacéuticos, azúcar, elaborados de cacao, sombreros y derivados del petróleo (ver tabla 40: Valor de las exportaciones de productos secundarios principales 1965-1975). ${ }^{117}$

Con la dictadura de Rodríguez Lara (1972-1976), el Ecuador inició algunas modificaciones en cuanto a su política económica, social y de energía, como consecuencia de su nuevo status de país productor y exportador de petróleo. En tal sentido, las ideas de los gobernantes del país, como fue el caso de Gustavo Jarrín Ampudia, Ministro de Recursos Naturales y Energéticos (1972-1974), estableció las bases para reformar las políticas del momento y favorecer al sector privado transnacional:

El gobierno militar procedió en seguida a administrar el país, con base en la nueva riqueza brotada del petróleo del petróleo, empeñándose en cambiar las estructuras fundamentales, erradicar la corrupción administrativa, elevar el nivel de vida de todos los ecuatorianos, eliminar los privilegios e impulsar la educación y la salud. Con esos buenos propósitos fue preparado el primer plan quinquenal para 1973-1977, cuyos pernos tenían que ser: (1) nacionalización del petróleo y (2) reforma agraria. ${ }^{1118}$

Pese a que el Ecuador pasó a ser uno de los países productores de petróleo, su nivel de producción a nivel internacional era bastante inferior al de los grandes productores. Así, en 1973, la producción anual de este recurso fue alrededor de 1,5 millones de barriles, con un promedio de 4.000 barriles al día, mientras que algunos de los grandes países, como era el caso de Arabia Saudí, proporcionaban cerca de 3,850.000 barriles al día. ${ }^{1119}$

del resto de las industrias todavía en la década de los setenta. Estas tablas se encuentran en el apéndice de datos del capítulo 5.

${ }^{1117}$ Estas tablas se encuentran en el apéndice de datos del capítulo 5. Fuente: Patricio Almeida Guzmán, Rebeca Almeida Arroba, op. cit. p. 482.

${ }^{1118}$ Ugo Stornaiolo: Ecuador: Anatomía de un país en transición, Ediciones Abya-Yala, 1999, p. 206.

${ }^{1119}$ OLADE, Base de datos, Histórico producción petrolera de Ecuador. 
El interés del ministro Jarrín por la incorporación del Ecuador a la OPEP consistía en el establecimiento de una política nacionalista, que lo situara más cerca de las grandes naciones productoras de un recurso tan importante como el petróleo:

$\mathrm{Su}$ objetivo era recibir el reconocimiento y prestigio internacional para la posición negociadora del Ecuador con las compañías multinacionales. Después de un extenso debate, el gobierno fue persuadido para buscar su afiliación... ${ }^{1120}$

De esta forma, el gobierno ecuatoriano comenzó una serie de conversaciones con los miembros de la Organización y logró asistir como observador a la 31 Reunión Ordinaria de la OPEP en Lagos, Nigeria (29-30 de noviembre de 1972), formalizando su ingreso como miembro, siete meses después en la 34 Reunión Ordinaria (27/06/1973) en Viena, Austria. ${ }^{1121}$

El Ecuador se incorporó a la OPEP con una producción de 209.000 barriles al día, representando el 0,6\% de la producción total mundial en aquel año. Aquí, se ha de añadir que aún cuando la producción de petróleo ecuatoriana era bastante inferior a la de los grandes países productores, los análisis nacionales hablaban de la entrada en la denominada "época de oro" de la producción petrolera. ${ }^{1122}$

Paralelamente, también en 1973, se acordó la construcción del oleoducto ecuatoriano de más de quinientos kilómetros que llegaba al Puerto del Balao, en la provincia de Esmeraldas, partiendo desde el Lago Agrio y atravesando los Andes. Además, se adquirió una flota petrolera para disponer de más autonomía, a la vez que se empezaron a nacionalizar los pozos mediante la creación de la ya mencionada Corporación Estatal Petrolera Ecuatoriana (CEPE). ${ }^{1123}$

Por el contrario, la oposición a nivel nacional, los empresarios de la Costa y las empresas petroleras privadas rechazaban abiertamente la política nacionalista del gobierno, cuyos intereses

\footnotetext{
${ }^{1120}$ John Martz: Politics and petroleum in Ecuador, Transaction, Inc. New Jersey, 1987, p. 111.

${ }^{1121}$ Resolución XXXIV-154 proclamada el 10 de noviembre del mismo año186, en Luis Aparicio: El ingreso de Ecuador en la OPEP, Tesis. PUCE, Quito, Ecuador, 1978 s/p.

${ }^{1122}$ Luis F. Rodríguez: El reingreso del Ecuador en la OPEP: Motivaciones y expectativas, Quito, PUCE, 2011, p. 89.

${ }^{1123}$ Ugo Stornaiolo, op. cit. p. 206.
} 
estaban ubicados en el gran negocio petrolero y buscaban mantener los privilegios de los que habían estado gozando. ${ }^{1124}$

Agustín Cueva habla de la entrada del Ecuador a la OPEP y la respuesta de Estados Unidos a la misma:

El imperialismo, por su parte, no vio con buenos ojos la política nacionalista del gobierno, y sobre todo, la integración activa del Ecuador a la OPEP, organización a la que visiblemente buscaba romper por su eslabón más débil, que por razones diversas resultaba ser nuestro país. ${ }^{1125}$

En este sentido, las acciones de las empresas extranjeras, que comenzaron a reducir la producción nacional y las ventas de petróleo, y la marcha de Jarrín Ampudia, acabaron perjudicando los intereses nacionales, lo cual hizo que algunos de los nuevos ministros encargados de la política energética reconocieran la ineficacia de la pertenencia a la OPEP, o aumentaran los precios del barril en contraposición a las decisiones establecidas en dicha Organización internacional. ${ }^{1126}$

\footnotetext{
${ }^{1124}$ Guillaume Fountaine: Geopolítica del petróleo en América Latina, Ecuador Debate, Vol. 58, Tema Central, p. 49-76, CAAP. Quito, Ecuador, 2003, p. 71.

${ }^{1125}$ Agustín Cueva, El proceso de dominación..., op. cit. p. 86.

1126 Gustavo Jarrín Ampudia: Política petrolera ecuatoriana, Ponencia, Departamento de publicaciones de la Universidad Estatal, Guayaquil, Ecuador, 1977, p. 40.
} 
Gráfico 10: Valor de las exportaciones de productos primarios principales (1965-1975)

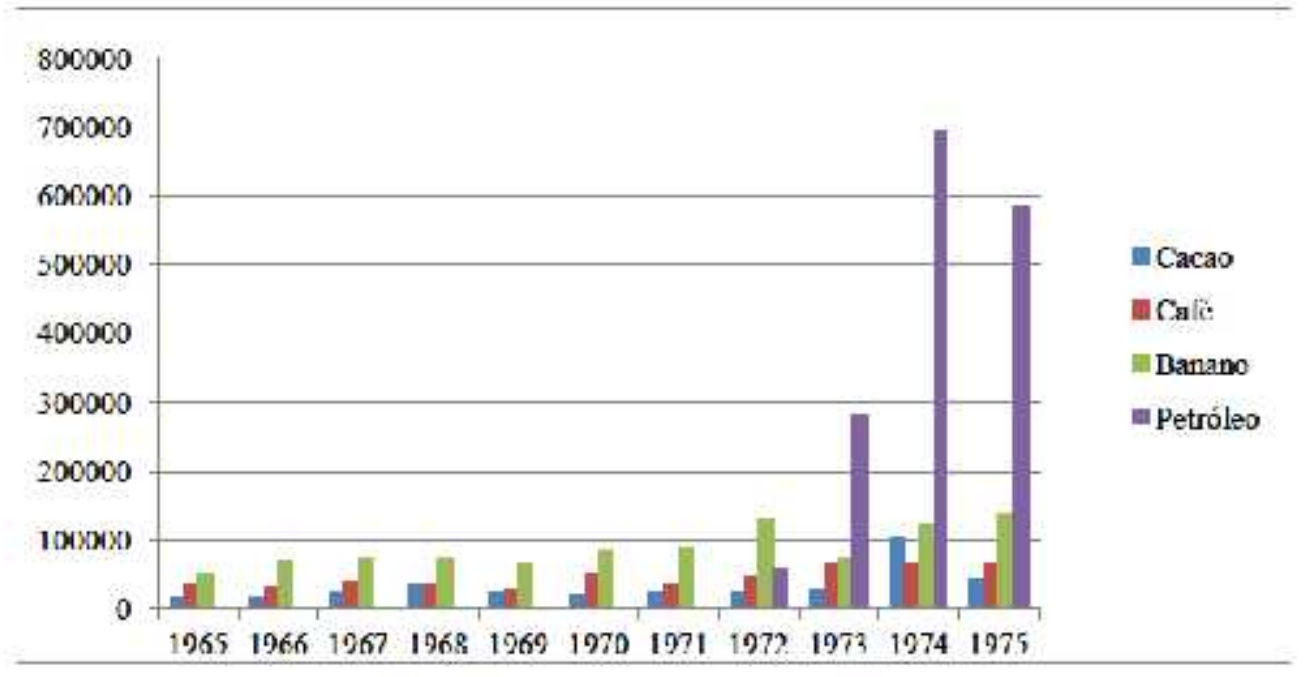

Elaboración propia a partir de los datos de la tabla 39.

Fuente: Patricio Almeida Guzmán, Rebeca Almeida Arroba: Estadísticas Económicas Históricas 1948-1983, Fuentes para la Historia Económica del Ecuador, serie estadísticas históricas, vol. 1, Banco Central del Ecuador, 1988, p. 482. 
Gráfico 11: Valor de las exportaciones de productos secundarios principales (miles de dólares FOB) (1965-1975):

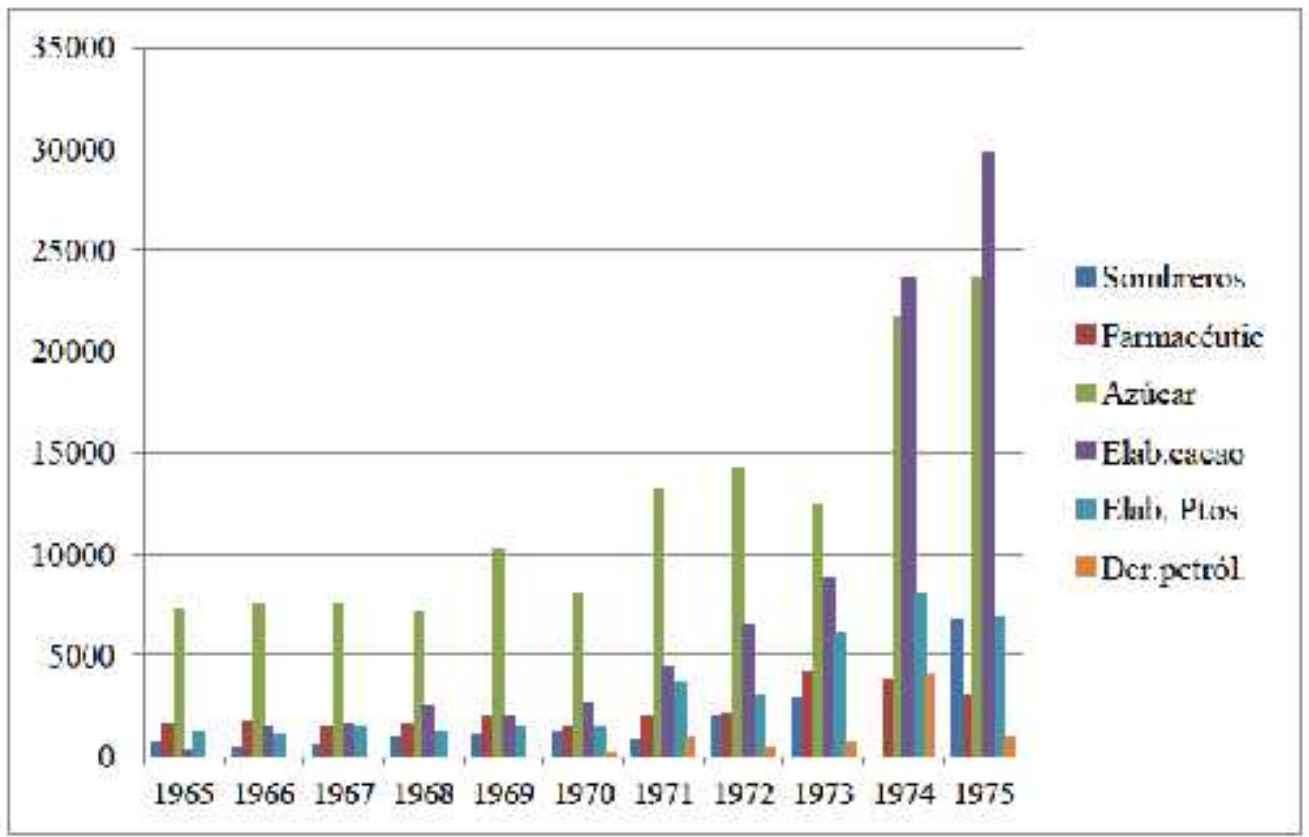

Elaboración propia a partir de los datos de la tabla 40.

Fuente: Patricio Almeida Guzmán, Rebeca Almeida Arroba: Estadísticas Económicas Históricas 1948-1983, Fuentes para la Historia Económica del Ecuador, serie estadísticas históricas, vol. 1, Banco Central del Ecuador, p. 484.

Por otro lado, el creciente peso de las exportaciones de hidrocarburos comenzó a originar un cambio positivo en el índice de precios de intercambio, provocando el fortalecimiento del sector externo y de la capacidad financiera estatal. No obstante, esta situación presentaba algunos problemas propios del crecimiento acelerado, pues la misma modificación de los precios de los principales bienes exportables podía provocar problemas en el sector exterior.

Así, por ejemplo, si analizamos la evolución del índice de precios al consumidor y la cotización del dólar en los años setenta, se puede apreciar la existencia de un desfase que favoreció a los 
importadores y perjudicó a los exportadores como aparece en la tabla 42: Tasas de cambio nominales y reales e indicadores de comercio exterior (1975-1983). ${ }^{1127}$

En este caso, la pérdida de importancia del dólar con respecto a los precios internos contribuyó al aumento de las importaciones comerciales y bienes de capital (ver tabla 43: Importaciones por principales grupos de mercancías 1969-1974), siendo este tipo de política cambiaria negativa para el desarrollo de la industrialización, al crearse un obstáculo a la sustitución de importaciones que intentó ser compensado con la aplicación de subsidios, estímulos y beneficios, como se verá después. ${ }^{1128} \mathrm{Si}$ bien el mantenimiento relativamente bajo de los tipos de cambio beneficiaba a los importadores, la existencia de excepciones impositivas a los industriales, permitió el aumento de la ganancia privada.

Por otra parte, las modificaciones de los precios de las exportaciones tradicionales en el mercado internacional favorecieron los intereses de los exportadores, ya que lograron elevados beneficios sin gran presión en el precio de la moneda.

Aquí, es importante aclarar que pese a la bonanza de las exportaciones, se observa un aumento constante en la deuda externa, sobre todo a partir de la segunda mitad de los setenta como se refleja en la tabla 44: Deuda externa directa a final de año 1969-1976, siendo la cantidad adeudada de unos doscientos millones de dólares para 1969, mientras que en 1976, ascendía a más de seiscientos millones de dólares. ${ }^{1129}$

\footnotetext{
${ }^{1127}$ Banco Central, Boletines Anuarios; Banco Central, Cuentas Nacionales; IMP, International Financial Statistics.

${ }^{1128}$ Estas tablas se encuentran en el apéndice de datos del capítulo 5. Fuente: Patricio Almeida Guzmán, Rebeca Almeida Arroba, op. cit. p. 496.

${ }^{1129}$ Ibíd. p. 463.
} 
Gráfico 12: Deuda externa directa a final de año (millones de dólares) (1969-1976)

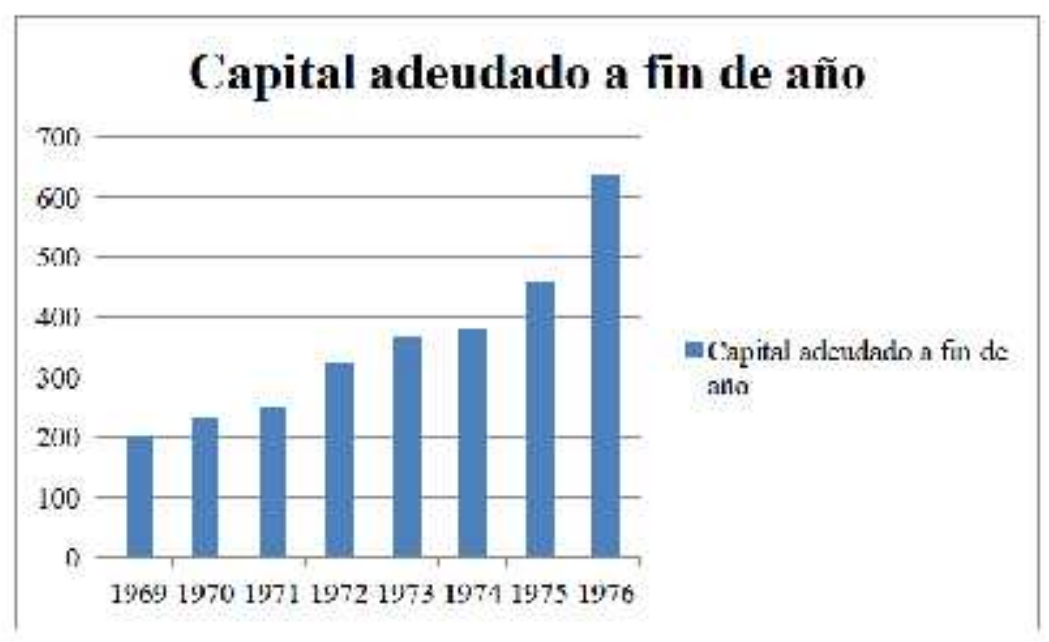

Elaboración propia a partir de los datos de la tabla 44.

Fuente: Patricio Almeida Guzmán, Rebeca Almeida Arroba: Estadísticas Económicas Históricas 1948-1983, Fuentes para la Historia Económica del Ecuador, serie estadísticas históricas, vol. 1, Banco Central del Ecuador, p. 463.

Esto puede explicarse a partir de la caída del volumen de exportaciones petroleras y el crecimiento del PIB (ver su evolución en la tabla 45: Producto Interior Bruto 1968-1975), siendo la magnitud de los proyectos de desarrollo llevados a cabo por el sector público, los que obligaron a un nivel de endeudamiento que permitiera satisfacer las demandas de una economía con un rápido crecimiento. ${ }^{1130}$

\footnotetext{
${ }^{1130}$ Esta tabla se encuentra en el apéndice de datos del capítulo 5. El Banco Mundial indica que conforme fueron aumentando los precios del petróleo, se produjo una disminución de los ingresos públicos debido a la menor presión fiscal generada, a la vez que el estado consolidaba un programa de inversiones de gran magnitud. El problema surgió cuando estos ingresos petroleros empezaron a disminuir, ya que fue imposible mantener la tendencia expansiva de la economía de los años setenta. Fuente: BCE, Memoria del Gerente General, Quito, 1978, p. 61.
} 
Gráfico 13: Producto Interior Bruto (millones de sucres) (1968-1975)

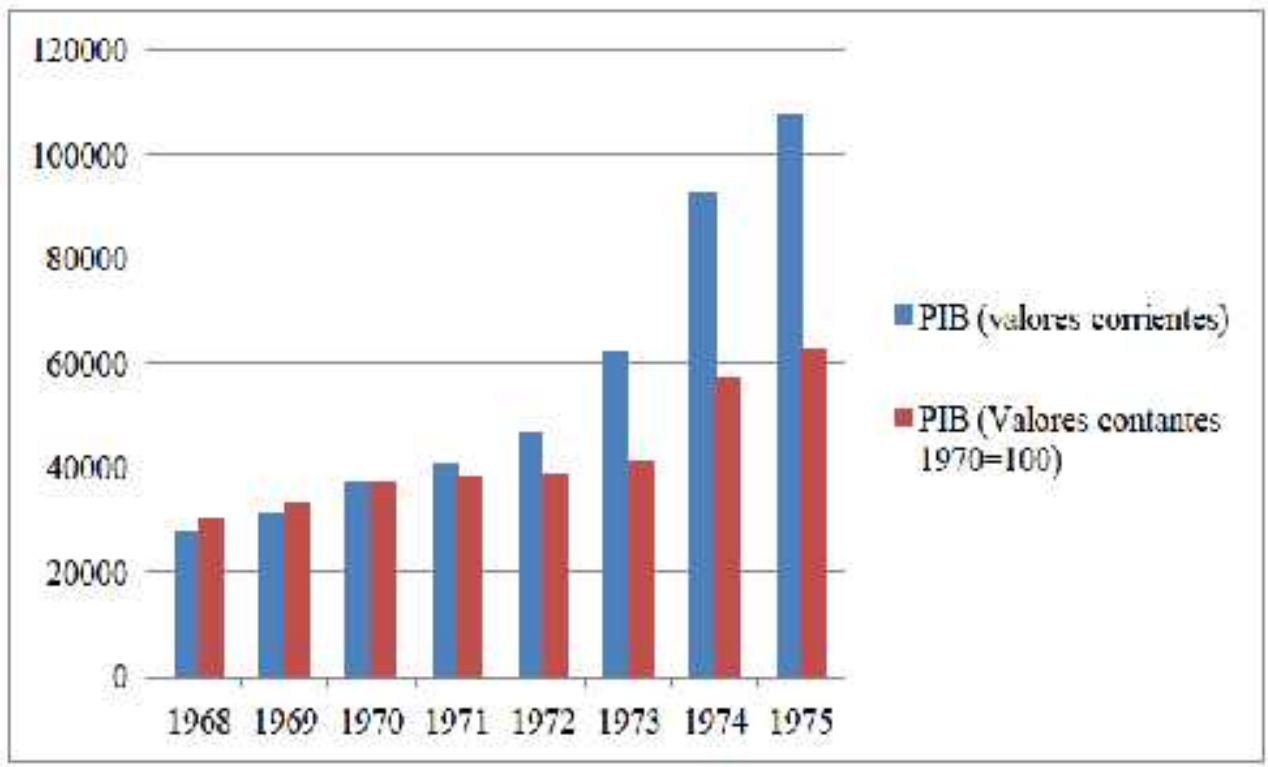

Elaboración propia a partir de la tabla 45.

Fuente: Patricio Almeida Guzmán, Rebeca Almeida Arroba: Estadísticas Económicas Históricas 1948-1983, Fuentes para la Historia Económica del Ecuador, serie estadísticas históricas, vol. 1, Banco Central del Ecuador, 1988, p. 51.

Además, se ha de mencionar que la inestable administración petrolera de gobiernos anteriores puso de manifiesto la necesidad de aumentar el nivel de tecnología en los programas gubernamentales del petróleo, obligando a buscar ayuda extranjera que pudiera aportar conocimientos científicos y técnicos y una mayor experiencia empresarial para administrar 
adecuadamente el petróleo. Fueron las intervenciones de expertos procedentes de Venezuela, México, Argentina, Francia y de otros países, las que ayudaron al Ecuador con este problema. ${ }^{1131}$ Volviendo al tema de la bonanza del petróleo, la situación de estabilidad de la economía ecuatoriana y las altas tasas de crecimiento obtenidas a partir de 1972, dieron lugar a la intensificación del ingreso de inversiones extranjeras, concentradas principalmente en los sectores de la industria, petróleo y minería, comercio y servicios públicos (ver tablas 46 y 47: Valor Inversión extranjera autorizada, por actividad económica según el CIIU, 1972-1975, 1976-1979). ${ }^{132}$

El descubrimiento de petróleo en el Oriente ecuatoriano y la promoción de las inversiones industriales emanadas de la reforma a la ley de 1964, son los factores más importantes que explican el crecimiento del flujo de capitales. El proceso de inversiones se localiza en los últimos años de la década de los sesenta en el sector petrolero y en la industria. Luego de 1972, no obstante las nacionalizaciones en el sector energético, las inversiones en hidrocarburos alcanzan al 35\%, mientras que aproximadamente el $30 \%$ del stock global se encuentra en la industria manufacturera. ${ }^{1133}$

El impulso adquirido por el modelo de industrialización estaba basado en la existencia de factores externos, entre los que se encontraban el ingreso de divisas procedentes de dichas inversiones, la coyuntura internacional y las exportaciones, y también, factores de carácter interno como la continua intervención estatal en la formulación de políticas que estimulaban la industrialización (política de subsidios, créditos, aranceles, etc.).

Con respecto al primero de estos factores, se ha de aclarar que una primera aproximación de la estrategia industrial a seguir en el Ecuador, incluía políticas de sustitución de importaciones o de

\footnotetext{
${ }^{1131}$ Para más información relacionada con la búsqueda de tecnología extranjera para desarrollar petróleo, ver el apéndice de notas del capítulo 5. Fuente: Cyrano Tama Paz, op. cit. p. 80-82; Susana Yazbek: La participación de ARPEL en la integración latinoamericana del sector petrolero, 1965-2011, III Congreso Latinoamericano de Historia Económica y XXIII Jornadas de Historia Económica, Simposio 9: Políticas petroleras en Américas (19452011), San Carlos de Bariloche, 23-27 de Octubre de 2012.

${ }^{1132}$ Estas tablas se encuentran en el apéndice de datos del capítulo 5. Fuente: Patricio Almeida Guzmán, Rebeca Almeida Arroba, op. cit. p. 280.

${ }^{1133}$ E. Gana; M. Mortimore: La programación andina y sus resultados en el Ecuador: El papel de las empresas transnacionales, CEPAL-CET documento de trabajo, No. 15, febrero 1979, p. 29.
} 
generación de exportaciones, debido a que las limitaciones del mercado interno constituían un obstáculo a la industrialización, por lo que la política de exportaciones era más realista. ${ }^{1134}$ Entre los factores internos, ya hablamos antes de las leyes utilizadas para fomentar dicho proceso, como fue el caso de la Ley de Fomento a la Pequeña Industria y Artesanía y la Ley de Fomento Industrial, con la que se establecieron diversas categorías ("Especial", "A" y "B") para clasificar las distintas empresas. Para esto, el estado debía de elaborar una lista de proyectos industriales cada año, los cuales tenían un carácter prioritario y eran clasificados en la categoría "especial" o "A"; mientras que el resto recibió la denominación "B", además de aplicarse diferentes exenciones a cada una. Dichas exenciones tributarias abarcaban la exoneración del pago de aranceles para la importación de equipos, maquinaria y repuestos, y una liberación parcial para las materias importadas que no se producían en el país. ${ }^{1135}$

Otra forma en que el estado impulsó la industrialización fue mediante la protección arancelaria, orientada a asegurar a los industriales el aprovechamiento del mercado interno. Así, se fue cambiando la estructura arancelaria para crear un arancel de tipo asimétrico, caracterizado por implementar una tasa bastante elevada para los bienes de consumo e intermedios que podían ser fabricados en el país, a la vez que se disminuía el arancel aplicado a los insumos y bienes de capital que la industria necesitaba para su funcionamiento.

En el año 1974, la estructura de protección efectiva para las diferentes ramas de la industria variaba entre un $130 \%$ y $185 \%$ para los textiles, prendas de vestir e industria de cuero, productos alimenticios, bebidas y tabaco, industrias de madera y productos de madera, mientras que las ramas productoras de bienes intermedios y de capital poseían un nivel de protección inferior al

\footnotetext{
${ }^{1134}$ El Ecuador pudo beneficiarse de las transformaciones de la estructura de precios del mercado de hidrocarburos, ya que con su entrada a la OPEP se benefició de la redistribución de ingresos mundiales tras el incremento en el precio del petróleo a nivel internacional. Esta decisión explica el auge económico de los años setenta, a diferencia de otros países de América Latina, los cuales sufrían los impactos de la desestabilización de la economía capitalista internacional. Fuente: Galo Montaño, Eduardo Wygard: Visión sobre la industria ecuatoriana, editado por COFIEC, 1976, p. 34.

${ }^{1135}$ La Ley de Fomento a la Pequeña Industria y Artesanía era parecida a la Ley de Fomento Industrial, al incluir el mismo tipo de beneficios para las actividades de artesanía y pequeña industria. Fuente: Jorge Fernández: Un decenio de industrialización en el Ecuador: Un balance crítico, en: "El proceso de industrialización ecuatoriano", IIEPUCE, 1983.
} 
100\%, como era el caso del sector metal-mecánico (ver tabla 48: Protección efectiva por ramas industriales 1974). ${ }^{1136}$

También, se ha de señalar que el impulso del estado a la inversión fomentó un desarrollo capitalintensivo en el sector industrial. El caso de la inversión en las ramas de alimentos, derivados de petróleo, cemento, metal-mecánica y otros, vino acompañado de una fuerte entrada de progreso tecnológico, que fue formando un grupo de pequeñas empresas que acabaron usando las mismas ventajas procedentes de los grandes capitales a diferencia del sector atrasado de la industria.

Por su parte, el aumento de las inversiones externas en el sector industrial (ver tabla 49: Inversión extranjera autorizada, dirigida a la industria manufacturera 1972-1976), tenía como objetivo estimular la capacidad del empresario para hacer frente a la competencia regional y cambiar el dinamismo de la economía del sector externo (conformado por las exportaciones agrícolas hasta el momento) por un proceso de sustitución de importaciones vía protección industrial para ampliar el mercado interno y favorecer el crecimiento y la productividad de otros sectores. De igual forma, se pretendía generar empleo en el sector rural, cuya mano de obra se encontraba desempleada como consecuencia de los problemas de la distribución de la tierra. ${ }^{1137}$ Dentro del sector manufacturero, las ramas que recibieron mayores inversiones de capital extranjero fueron las de alimentos y bebidas, productos químicos, plásticos y cauchos, productos minerales no metálicos y productos metálicos, maquinaria y equipos para el periodo 1972-1976, como refleja dicha tabla.

La importancia de la inversión extranjera en la formación bruta de capital de los tres últimos tres sectores, se debió al establecimiento de nuevas empresas en estas actividades industriales incipientes.

La inversión extranjera acumulada en la industria era de 27,8 millones de dólares en 1964; en 1978 el monto de activos propiedad de las empresas internacionales, alcanzaba la suma de 220 millones de dólares; creciendo en ese periodo de 12 años en 691,4\%. Este desproporcionado incremento del stock de la inversión extranjera, tiene su explicación en el persistente ingreso de capitales del exterior que se va a localizar en la

\footnotetext{
${ }^{1136}$ Las tabla 48 y 49 se encuentran en el apéndice de datos del capítulo 5. Fuente: INEC, Encuestas de manufactura y minería, MICEI, Anuarios de Comercio Exterior y Ley de Aranceles. Elaboración: Area industrial, IIE-PUCE.

${ }^{1137}$ Guillermo Landázuri Carrillo, op. cit. p. 361-372.
} 
industria manufacturera. El flujo anual de inversión extranjera neta hacia la industria, se elevó de un millón de dólares en $1976 .{ }^{1138}$

De esta forma, se puede apreciar cómo la bonanza generada por el petróleo facilitó el aumento de las inversiones internas y externas a partir de 1973, generando dicho movimiento de capital, un aumento de la tasa de crecimiento del sector industrial y del PIB en esos años (la tabla 28 refleja la contribución al producto interno bruto de la industria para el periodo 1970-1974). ${ }^{1139}$ Asimismo, la modernización de la industria se llevó a cabo con la colaboración del estado, el cual destinaba el excedente de divisas a la importación de tecnología extranjera y bienes de capital necesarios para su aplicación, convirtiéndose la industria manufacturera en uno de los sectores de mayor rentabilidad junto con la construcción y los servicios financieros.

Pese a la división de las clases tradicionales hegemónicas, la cual permitió que el estado contara con un mayor espacio en el control de la planificación, el modelo de industrialización se mantuvo bajo la presión de la nueva clase de industriales modernos que apoyaba el desarrollo de la industria moderna de gran escala y capital intensivo, frente a los intereses de pequeños industriales y artesanos, como ya se dijo en el apartado anterior.

Aquí, es importante analizar quiénes fueron estos industriales modernos, cuáles fueron algunos de los factores que contribuyeron a su surgimiento y sus objetivos.

En principio, hay que recordar que el modelo de sustitución de importaciones y la etapa de auge del sector exportador constituyeron una oportunidad para que diversos individuos, entre los que se encontraban inmigrantes extranjeros, importadores y terratenientes, entre otros, llevaran a cabo inversiones de carácter industrial en el Ecuador. Estos grupos gozaban de una posición privilegiada que les permitía acceder a una combinación de recursos económicos y sociales (familiares, educación superior) y dedicarse a las inversiones industriales. Así, mientras que las posesiones familiares constituyeron una parte del capital necesario para abrir una fábrica, los estudios superiores les proporcionaban los conocimientos necesarios para desempeñar las funciones de organización y administración de la empresa.

\footnotetext{
1138 Jorge Fernández, op. cit. p. 98.

1139 Esta tabla se encuentra en el apéndice de datos del capítulo 5. Fuente: Patricio Almeida Guzmán, Rebeca Almeida Arroba, op. cit. p. 137-138.
} 
Las políticas desarrollistas y el auge petrolero fueron elementos que impulsaron el interés por la industria y crearon una fuerte dependencia por parte de las industrias de insumos procedentes del exterior. $^{1140}$

De este modo, dentro del grupo de industriales se encontraban los ecuatorianos que aparecieron gracias al estímulo de medidas de sustitución de exportaciones y seguían una tendencia de devaluación de la moneda. Por otro lado, surgieron algunos industriales que defendían las políticas de sustitución de importaciones y dirigían sus productos al mercado doméstico de grupos con ingresos altos y medios. Además, este grupo apoyó el establecimiento de altas tarifas en manufacturas, que podían ser producidas en el mercado interno, una moneda sobrevaluada y la aplicación de impuestos moderados a las mercancías importadas.

En el caso ecuatoriano, las exportaciones de petróleo resultaron en una profundización de esa consecuencia de la sustitución de importaciones. En primer lugar, esas exportaciones dieron al gobierno de Rodríguez Lara la oportunidad de transformar las tarifas de un mecanismo de rentas públicas a un mecanismo de desarrollo. ${ }^{1141}$

Antes del auge de desarrollo los gobiernos habían dependido para financiar sus presupuestos de los impuestos en las aduanas que ofrecían del $50 \%$ al $60 \%$ de sus ingresos. Solamente durante el periodo del auge petrolero, el gobierno fue capaz de depender menos de los impuestos de aduanas y, por lo mismo, pudo revisarlos y retirar algunos para ofrecer protección y fortalecer los incentivos a la inversión. ${ }^{1142}$

Las políticas del gobierno en cuanto a la disminución de tarifas, liberalización de importaciones de insumos industriales y tasa de cambio nominal, aumentaron la dependencia de los industriales con respecto de las materias primas importadas, a la vez que se impulsó la creación de industrias que necesitaban de dichos bienes: Después de 1974, las tarifas tendieron a favorecer la creación

\footnotetext{
1140 Albert Hirschman: The political economy of import-substituting industrialization in Latin America, en "Latin America: Problems in Economic Development”, Ed. Charles T. Nisbet, New York, the Free Press, 1969, p. $242-245$.

${ }^{1141}$ Pontificia Universidad Católica del Ecuador: Ficha de información socio-política (6 abril), Quito, Departamento de Ciencias Políticas Sociales, 1974, p. 67.

1142 Jorge A. Hidrobo, op. cit. p.75.
} 
de industrias de bienes de consumo durables no esenciales, en lugar de industrias de bienes de consumo durables. ${ }^{1143}$

Una de las quejas con respecto al papel de los industriales y la industria en el Ecuador ha girado en torno a su carácter artificial. Es decir, durante los primeros años de la bonanza petrolera, se aplicaron políticas con las que el nivel de tasas tributarias era más alto para los productos acabados y no se incluía un impuesto a los componentes.

Como consecuencia, la política de tarifas diferenciales acabó teniendo un nivel más alto de protección para la industria ecuatoriana en comparación con otros aranceles aplicados, como ocurrió con el Arancel Externo Común propuesto por los miembros del Pacto Andino. Así, a la vez que la estructura ecuatoriana aseguraba la imposición a bienes de consumo acabados, el Arancel Externo Común garantizaba un impuesto a los insumos y bienes de capital para promocionar el consumo de recursos nacionales.

La industria ecuatoriana fue protegida efectivamente no solo por las tarifas altas impuestas a los productos acabados, sino también por las tarifas bajas aplicadas a los materiales usados en la producción. Además, unos 1.032 artículos de la nomenclatura Bruselas/Andina no se incluyeron en las listas de importaciones, por lo cual estuvieron bajo la prohibición implícita de ser importados. La mayoría de estos artículos eran bienes terminados o insumos disponibles en el país. ${ }^{1144}$

Esto provocó que las empresas acabaran dedicándose únicamente al ensamblaje del producto final, pero aún cuando este contaba con la ayuda de equipos importados, no se pudo reducir el coste de los productos industriales, creándose un mínimo de puestos de trabajo para la población. ${ }^{1145}$

El auge petrolero favoreció tales industrias artificiales..., no solo no se estimuló el procesamiento de materia prima local sino que, al contrario, este se desestimuló a través

\footnotetext{
1143 Janet Cevallos: La protección arancelaria del estado ecuatoriano a las actividades productivas en el periodo 1965-1980, Tesis de máster, FLACSO, 1984, p. 38-39.

${ }^{1144}$ Banco Mundial: Ecuador: An agenda for recovery and sustained growth country study, Washington DC, 1984, p. 1968; Jorge A. Hidrobo, op. cit. p. 83.

${ }^{1145}$ Rodrigo Malo: Esquema de la experiencia industrial ecuatoriana, en Economía, Ecuador: 1830-1980, III, Quito: Corporación Editora Nacional, 1983, p. 339.
} 
del subsidio implícito que la tasa de cambio dio a las importaciones. Además, algunos industriales aún importaron herramientas y acero para ensamblar, usando tecnología importada, refrigeradoras, cocinas, etc. ${ }^{1146}$

Estas medidas no solo no contribuyeron a la generación de tecnologías locales, sino que constituyeron un obstáculo a la organización de industrias intensivas en el uso de trabajo. Además, los industriales no estaban satisfechos con los beneficios obtenidos y prefirieron expandir sus industrias en lugar de invertir en otras actividades. ${ }^{1147}$

Por otra parte, la política monetaria y de créditos fue un factor que reforzó la tendencia hacia el uso de tecnologías capital-intensivas, pues el sistema de créditos apenas permitía que los pequeños industriales y artesanos tuvieran acceso a los mismos, existiendo mayores posibilidades para el sector moderno y la producción a gran escala (ver tabla 50: Crédito externo para la industria, pequeña industria, artesanía, agroindustria 1970-1975). ${ }^{1148}$

\footnotetext{
${ }^{1146}$ Jorge A. Hidrobo, op. cit. p. 83.

${ }^{1147}$ Ibíd. p. 97.

${ }^{1148}$ Esta tabla se encuentra en el apéndice de datos del capítulo 5. Fuente: Banco Central; CONADE, Sección Crédito Externo.
} 
Gráfico 14: Crédito externo para la industria, pequeña industria, artesanía, agroindustria (19701975) (millones de sucres)

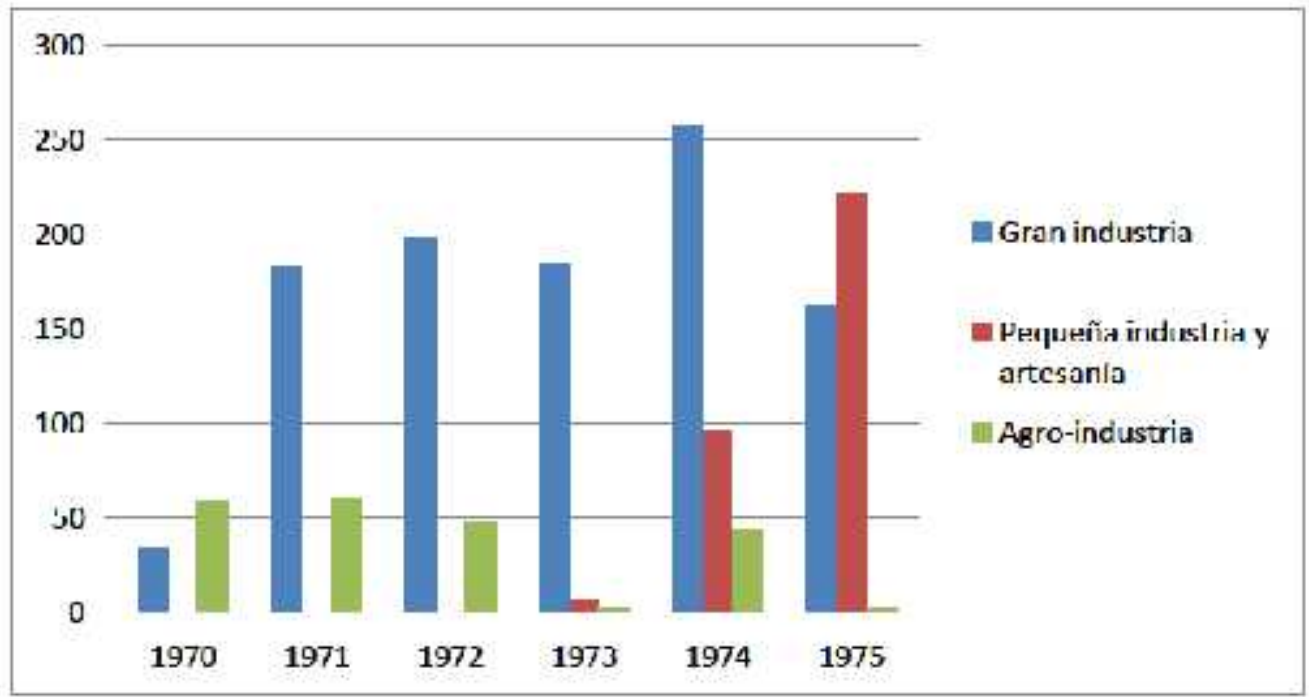

Elaboración propia a partir de la tabla 50.

Fuente: Banco Central; CONADE, Sección Crédito Externo.

Por su parte, el aumento de recursos financieros administrados por el estado provocó un cambio en su relación con la sociedad civil, ya que la expansión del mercado interno para los productores industriales y el mayor ingreso del estado, hicieron posible un aumento de los gastos en programas de educación y trabajos públicos (la tabla 51 refleja la inversión pública realizada en los sectores económicos para el periodo 1972-1976) y con ello, el crecimiento de las actividades administrativas y manuales en los centros urbanos. ${ }^{1149}$

Recordemos que el proceso de urbanización que había comenzado con el auge bananero a finales de la década de los cuarenta, llevaba asociado algunos cambios estructurales que ocasionaron un

1149 Esta tabla se encuentra en el apéndice de datos del capítulo 5. Fuente: Patricio Almeida Guzmán, Rebeca Almeida Arroba, op. cit. p. 288. 
proceso migratorio de mayores dimensiones con la consolidación del proceso de industrialización. Esta dinámica de expansión económica impulsó el proceso de urbanización y generó un aumento de las diferencias socio-económicas en el Ecuador.

También, la consolidación del ritmo de crecimiento de los centros industriales y modernización del país vino acompañada de modificaciones en el sector agropecuario, a raíz de la eliminación de las relaciones precarias de trabajo en las zonas rurales y el fortalecimiento de los sectores medios del campo. Con anterioridad, ya vimos algunos de los cambios que tuvieron lugar en la Sierra, al iniciarse la actividad ganadera y la producción de leche y cómo estos reemplazaron la producción de cereales, cebada y otros productos (al contrario de lo sucedido en la Sierra, la Costa siguió especializándose en los productos tradicionales como el arroz, la soja, el café, el cacao y el banano, los cuales eran demandados en el mercado internacional, mientras que los productos de la Sierra estaban destinados al consumo interno). ${ }^{1150}$

El inicio de estas actividades fue generando un conjunto de vínculos con la producción industrial, al mismo tiempo que este sector se iba modernizando y desarrollando gracias a las políticas de crédito, la incorporación de nuevos procesos tecnológicos y la eliminación de impuestos a la importación de bienes de capital e intermedios. Este fue el caso de las haciendas capitalistas con altos niveles de productividad y ganancias, a diferencia de la producción de las economías campesinas, las cuales estaban más atrasadas y por tanto, no tenían acceso a los mismos medios. ${ }^{1151}$

Asimismo, el crecimiento de la producción ganadera estaba vinculado a un mayor consumo de este tipo de productos por parte de los sectores con ingresos medios y altos, y también, a los estímulos proporcionados por el estado que favorecieron la modernización de las fuerzas productivas del sector agrícola. Como ejemplo se encuentra el aumento del comercio de importación de diversos productos agropecuarios (cebada y trigo), bienes de consumo (leche y manteca de cerdo) (ver tabla 52: Importaciones de alimentos y bebidas, 1969-1975) y bienes intermedios (fertilizantes, tractores y bienes de capital). ${ }^{1152}$

\footnotetext{
1150 Oswaldo Barsky: Iniciativa terrateniente en la reestructuración de las relaciones sociales en la Sierra ecuatoriana, 1956-64, en Revista de Ciencias Sociales, Volumen 11, No. 5, 1978.

${ }^{1151}$ Oswaldo Barsky, Gustavo Cosse, Tecnología..., op. cit. p. 40-75.

1152 Esta tabla se encuentra en el apéndice del capítulo 5. Fuente: Patricio Almeida Guzmán, Rebeca Almeida Arroba, op. cit. p. 492-493.
} 
Además del comercio de importación, las inversiones petroleras en la economía ecuatoriana y los ingresos obtenidos con la exportación de dicho recurso natural, permitieron el desarrollo y la ampliación de las actividades financieras y de aquellas actividades vinculadas a la construcción de infraestructura y vivienda, con el objetivo de incrementar la acumulación capitalista de la riqueza gracias a las políticas de protección implantadas por el gobierno. ${ }^{1153}$

Todo esto contribuyó a la ampliación de la producción industrial a través de la presencia de unidades de producción en el campo y en la ciudad, que junto con la importación de maquinaria, tecnología, materias primas y otros productos, logró favorecer la economía aumentando su capacidad de acumulación de capital, a la vez que se incrementaba la dependencia de la industria nacional con respecto a los acuerdos de las empresas extranjeras que controlaban los sectores más dinámicos de la economía. En la tabla 43 (Importaciones por principales grupos de mercancías 1969-1974) se aprecia cómo el mayor número de importaciones fue de bienes de capital y materias primas para la industria y equipos de transporte.

De este modo, la presencia de inversiones extranjeras directas, el comercio interno y mundial, el impulso del mercado interno y la ampliación de la producción industrial, fueron algunos de los factores que fomentaron el desarrollo de los sectores financieros vinculados a estas actividades, los cuales controlaban el capital extranjero y retenían una buena parte de las ganancias del petróleo.

Además, el auge de la industrialización gracias a la abundancia de recursos procedentes de las exportaciones de petróleo, tuvo lugar en las grandes ciudades como Guayaquil, Quito y Cuenca, sobre todo por la disposición de mano de obra y los estímulos de las leyes de fomento industrial:

A partir de los años setenta, el perfil del modelo global se altera y con ello, se consolida y reproduce el incipiente perfil de industrialización. La desconcentración progresiva de los ingresos a favor de las capas medias y la consecuente modernización de la sociedad, provocan un incremento sostenido de la demanda de bienes de consumo. La expansión de las actividades económicas del sector moderno y el crecimiento urbano repercuten sobre

${ }^{1153}$ Iván Fernández Espinosa, Patricio Tobar Robalino, op. cit. p. 117-131. 
la industria de la construcción. El desarrollo del estado y la acción que desenvuelve sobre la economía, lo convierten en un fuerte multiplicador de la actividad privada. ${ }^{1154}$

Esta fase afectó a la industrialización a través de los mercados externos, pues se aumentaron las inversiones en ramas que estaban vinculadas a otros sectores económicos como ocurrió con la industrialización de productos manufacturados del mar, originándose un nuevo interés industrial en el mercado exterior. ${ }^{1155}$ Asimismo, en el mercado interno, conforme se fueron sustituyendo las importaciones de productos orientados a los sectores de ingresos medios y altos, las industrias intentaron sustituir productos destinados a satisfacer la demanda de los grupos populares, dando lugar a la creación y diferenciación de un sector moderno grande y un sector de pequeñas empresas que operaban según el nivel de ingresos de las clases sociales.

En tal sentido, se puede hablar de la existencia de algunas restricciones en la expansión del mercado interno, ya que no vino acompañada de un gran aumento de la distribución del ingreso en el sector rural. Así, el impulso de la economía se caracterizó por un aumento de las diferencias regionales características de la sociedad ecuatoriana, consolidándose un estilo de desarrollo que daba prioridad al progreso técnico en el sector moderno, a diferencia del sector tradicional, que había limitado el estilo de desarrollo en las primeras fases de modernización.

Los sectores urbanos fueron los que lograron beneficiarse en mayor medida de la expansión de la economía, produciéndose cambios en la distribución del ingreso en áreas urbanas entre 1968 y 1975, como muestra la tabla 53 (Estructura del ingreso en áreas urbanas 1968 y 1975). ${ }^{1156}$ Por su parte, los sectores rurales, en particular, los sectores de campesinos, no pudieron beneficiarse de igual forma del proceso económico de modernización, pues los grandes centros urbanos absorbieron los beneficios de la fase de bonanza. ${ }^{1157}$

\footnotetext{
${ }^{1154}$ Arnoldo Bocco, op. cit. p. 69.

1155 Ver el apéndice de notas del capítulo 5 para más información. Fuente: Eva Aguayo, Saskia Portillo, Pilar Expósito: Perspectiva del crecimiento económico en laos países del Pacto Andino, Universidad Santiago de Compostela, Ministerio de Planificación Económica, CORDIPLAN, Venezuela, www.usc.es/economet.

${ }^{1156}$ Las tablas 53 y 54 se encuentran en el apéndice de notas del capítulo 5. Fuente: Patricio Almeida Guzmán, Rebeca Almeida Arroba, op. cit. p. 355.

1157 Gonzalo Crespo Ortíz: Estudio introductorio, en: "Economía, Ecuador: 1830-1980”, III, Quito, Corporación Editora Nacional, 1983, p. 42.
} 
Además, el estado dio prioridad a la aplicación de recursos hacia las zonas urbanas, siendo una de las consecuencias de estas políticas, la existencia de salarios menores en los sectores rurales en comparación con los de las ciudades (ver tabla 54: Salario mínimo vital nominal por actividades 1968-1977). ${ }^{1158}$

La década petrolera de los setenta acumula enormes excedentes que, de acuerdo a su destino, va a consolidar el modelo oligárquico y dependiente del desarrollo capitalista, con las consecuencias de ensanchamiento de la brecha de desigualdades económicas y sociales que se las visualiza, con mayor realismo en los periodos de crisis. ${ }^{1159}$

La industrialización, el ritmo de la actividad de la construcción en las ciudades y la mejora de servicios, expandieron el empleo urbano, ya que la estrategia de acumulación en las ciudades estaba basada en la mano de obra de las zonas rurales que se desplazó a las grandes ciudades, atraída por los mayores salarios y mejores condiciones de vida.

El crecimiento del mercado favoreció la instalación de una industria moderna orientada a sustituir importaciones y a eliminar determinados mercados de pequeñas industrias y artesanías, produciéndose de esta manera, un doble proceso de sustitución (de importaciones y de artesanías y pequeñas industrias). ${ }^{1160}$

La sustitución de la producción artesanal se llevó a cabo en las ramas donde se encontraba de forma mayoritaria la artesanía. Se trataba de sectores que fabricaban bienes que no se comercializaban en el exterior o donde, como consecuencia del tamaño del mercado, este se dividía en dos segmentos: uno abastecido con importaciones para satisfacer las necesidades de los grupos con ingresos más altos, y otro, que dependía de la producción artesanal y correspondía a los niveles con ingresos medios y bajos. En el primero se encontraban las ramas de alimentos, bebidas y tabaco y la de industria de madera, mientras que en el segundo segmento, estaba la

\footnotetext{
${ }^{1158}$ Patricio Almeida Guzmán, Rebeca Almeida Arroba, op. cit. p. 355.

1159 Leonardo Espinoza: Vías de integración de la formación espacial y el desarrollo regional en el Ecuador 18301980, Libro del Sesquicentenario Economía Ecuador, segunda parte, corporación editora nacional, 1983 , p. 35.

${ }^{1160}$ Jorge Fernández: Un decenio de industrialización en el Ecuador: Un balance crítico, en Cristian Sepúlveda: El proceso de industrialización ecuatoriano, IIE-PUCE, Quito, 1983, p. 115.
} 
rama de textiles, vestidos, confecciones y calzado, grupo en el que existía cierto nivel de especialización. $^{1161}$

La pérdida de importancia fue diferente para las diversas ramas artesanales, pues las que producían artesanía utilitaria tuvieron que hacer frente a la competencia del sector fabril, provocando la desaparición de algunas de ellas, mientras que las que sobrevivieron, se vieron obligadas a abastecer un mercado marginal, a diferencia de aquellas que elaboraban artesanías artísticas y que lograron mejorar su situación convirtiéndose en pequeñas industrias.

No obstante, todavía se ha de indicar la gran importancia de la artesanía durante los sesenta, ya que seguía siendo la actividad que absorbía una mayor fuerza de trabajo:

Daba empleo al $78 \%$ de la mano de obra clasificada oficialmente como manufacturera y contribuía con un 38\% al PIB. Además, su productividad en 1973, al igual que en el año de 1963, era equivalente a un sexto de la industria fabril. ${ }^{1162}$

De igual manera, el sector manufacturero no experimentó grandes diferencias con respecto a los años sesenta, predominando en su conformación industrial, la producción de bienes de consumo no duraderos (productos alimenticios, bebidas y tabaco, textiles, prendas de vestir e industrias del cuero, fabricación de papel, imprentas y editoriales) como se refleja en las tablas 55 y 56 (Valor bruto de la producción y valor agregado de las industrias clasificadas en las leyes de fomento industrial, pequeña industria, artesanía, por ramas de actividad 1969-1972 y 1973-1975). ${ }^{1163}$ En estas tablas, también se observa la baja participación de los bienes intermedios (exceptuando la de productos químicos) y la de bienes de capital en el valor agregado del sector fabril, así como la escasa existencia de una industria de bienes de consumo duradero, lo cual indicaba que pese a los esfuerzos realizados, el Ecuador estaba todavía en la fase inicial de industrialización.

\footnotetext{
${ }^{1161}$ Rafael Quintero, Erika Silva, op. cit. p.381.

1162 Ibíd. p.381.

${ }^{1163}$ Estas tablas se encuentran en el apéndice de datos del capítulo 5. Fuente: Patricio Almeida Guzmán, Rebeca Almeida Arroba, op. cit. p. 151-152.
} 
Esto se debía a la gran fragmentación de la estructura industrial, al encontrarse todavía bastante concentrada en pocas divisiones, siendo la mayor parte de ellas, bienes de consumo no duradero. $^{1164}$

El análisis de la composición del valor agregado a mediados de los setenta, muestra que la estructura industrial siguió sin cambiar de forma radical, sobre todo en cuanto a las ramas de productos alimenticios, bebidas y tabaco, textiles, prendas de vestir e industrias del cuero y fabricación de sustancias y productos químicos, produciéndose un aumento en la aportación del sector metal-mecánico (ver tabla 57: Valor bruto de la producción y valor agregado de las industrias clasificadas en las leyes de fomento industrial, pequeña industria, artesanía, por ramas de actividad 1976-1977). Si comparamos estos valores con los anteriores, se observa un incremento en la participación del sector de bienes intermedios y una disminución en los productos de consumo final, siendo bastante moderado este cambio a la hora de determinar una alteración importante del perfil de industrialización del país. ${ }^{1165}$

De igual forma, aún cuando la planificación estatal de los setenta tenía como objetivo orientar la riqueza obtenida del petróleo hacia el fortalecimiento de la estructura industrial para remediar los obstáculos externos y obtener más independencia, uno de los problemas asociados a la acumulación de capital, fue el del alto nivel de dependencia del capital extranjero y de tecnología desarrollada. Así pues, el estado confiaba en que la industrialización podría estimular una creciente dinámica de inversiones que, a través de políticas de protección progresivamente decrecientes, haría posible un aumento de exportaciones manufactureras y un mayor impulso al proceso de acumulación y de progreso técnico:

La interacción del enclave petrolero y la industria asociada, si bien en cierto sentido contribuirá a cubrir ciertos desequilibrios de la economía nacional, fundamentalmente agudizará las distorsiones que ha generado el proceso histórico de desarrollo. Por una parte, consolidará la dependencia estructural del país a un nivel más alto y por otra, acentuará contradicciones propias del capitalismo dependiente, como son la

\footnotetext{
${ }^{1164}$ Jorge Fernández, op. cit. p. 74.

1165 Esta tabla se encuentra en el apéndice de datos del capítulo 5. Fuente: Patricio Almeida Guzmán, Rebeca Almeida Arroba, op. cit. p. 153.
} 
polarización del ingreso, el desempleo tecnológico y la mala asignación de los recursos disponibles. ${ }^{1166}$

La subordinación política del sector agro-exportador en esta nueva economía industrial no implicó la eliminación de su papel estratégico, ya que adquirió una nueva faceta. Esto se aprecia en el hecho de que la industria, incapacitada para desarrollar la producción de bienes de capital y de insumos más complejos tecnológicamente, mostrara su dependencia con respecto de la oferta mundial de dichos bienes. Esto justifica que la industrialización se caracterizara por ser un proceso bastante vulnerable y sensible al ciclo primario exportador. ${ }^{1167}$

De forma paralela, se fueron presentando algunos rasgos negativos que actuaron como límite al crecimiento de periodos anteriores. Es decir, a pesar del avance de la industrialización, la participación en el comercio mundial siguió realizándose mediante las exportaciones primarias de recursos naturales, implicando que el estímulo externo continuaba dependiendo de dichas exportaciones y de la incertidumbre de los precios, que era precisamente el problema que había presentado el modelo agro-exportador.

En este caso, la disminución posterior de las exportaciones de petróleo jugó un papel importante en el deterioro industrial, pues si la industria hubiera generado una dinámica interna, habría podido seguir con su crecimiento y haber ampliado el mercado de su propia producción, a pesar del comportamiento negativo del sector externo.

Por otra parte, la dinámica interna de la economía ecuatoriana tenía como fundamento la expansión del consumo estatal y privado, debido al repentino aumento de los ingresos internos y a la transformación de los patrones de consumo que pasaron a ser bastante parecidos a los de los países más avanzados. Esta situación ha de ser interpretada de forma negativa debido a que la incorporación del progreso técnico no se produjo de forma paralela a estos cambios, al existir una gran dependencia de la tecnología y capitales de los países desarrollados.

Este hecho guarda una gran relación con el tipo de política aplicada, al centrarse en un sistema de incentivos fiscales y de crédito para el desarrollo de una industria moderna intensiva en el uso de bienes importados y de gran escala, quedando al margen del modelo de industrialización las

\footnotetext{
${ }^{1166}$ Fernando Velasco, op. cit. p. 226.

${ }^{1167}$ Ibíd. p. 225-229.
} 
políticas de fomento de exportaciones manufactureras y apoyo a la pequeña industria y artesanía. Además, al estar la industrialización ligada al mercado interno, se mantuvo dicha protección más allá de cualquier periodo que permitiera el aprendizaje tecnológico, llevando dicho proteccionismo y el carácter imitativo de los patrones de consumo a la incorporación de técnicas costosas y poco afianzadas. En otras palabras, a pesar de la contribución de la industria manufacturera al crecimiento de la economía en la década de los años setenta, no se pudo establecer una clara tendencia hacia una mayor integración de las diferentes ramas de actividad, ni reducir la dependencia externa de importaciones y capital extranjero. ${ }^{1168}$

Asimismo, la alta dependencia de tecnología provocó la falta de articulación industrial, condición necesaria para lograr niveles estables de competitividad que superaran los estímulos temporales de las devaluaciones a los que estaba sometido el modelo agro-exportador. A esto, se le ha de unir la fragilidad empresarial para llevar a cabo un proceso sostenido de acumulación y procurar una incorporación constante de innovaciones, como consecuencia de la débil relación entre el estado y el empresario. ${ }^{1169}$

Por su parte, los problemas del sector agrícola, que todavía en los años setenta era el sector más atrasado, ponían de manifiesto la necesidad de reformar las rudimentarias técnicas del campo, el sistema de precios, costes, almacenamiento y distribución de la cosecha. La aplicación de los ingresos derivados del petróleo habría permitido aumentar la producción de alimentos, orientándola como eje de desarrollo y generador de mayores fuentes de trabajo.

En definitiva, aún cuando el proceso de modernización y desarrollo del capitalismo ecuatoriano en los años setenta, logró impulsar la industrialización, las variaciones en el comercio exterior, la urbanización y el crecimiento del capital financiero, también se caracterizó por un conjunto de contradicciones que fueron manifestándose con el progresivo endeudamiento externo, una industria dependiente y protegida, la concentración del ingreso, tendencias monopolistas en la estructura de la propiedad y penetración del capital extranjero en las principales ramas de actividad que provocaron frecuentes desequilibrios en la economía del país. ${ }^{1170}$

\footnotetext{
1168 Oscar Altimir: La encrucijada de la industrialización en América Latina, en "Políticas de industrialización en América Latina”, compilador Rafael Urriola, CEPLAES-ILDIS, p. 23, Promesas y realidades del proceso de industrialización en la posguerra, 1988, p.21-35.

${ }^{1169}$ Ibíd. p. 21-35.

${ }^{1170}$ Iván Fernández Espinosa, Patricio Tobar Robalino, op. cit. p. 117-131.
} 


\section{CAPÍTULO 6: ESTUDIO DE CASO Y METODOLOGÍA: EL DESARROLLO Y CRECIMIENTO ECONÓMICO DEL ECUADOR (1950-1975):}

\section{1) Antecedentes teóricos y principales enfoques del desarrollo económico y humano de una sociedad: El desarrollo y modernización en el Ecuador.}

Hasta el momento, para analizar el proceso de modernización y crecimiento económico del Ecuador, hemos estudiado los diferentes modelos de desarrollo (el modelo agro-exportador y el modelo de industrialización vía sustitución de importaciones) y su impacto en la sociedad, además de englobar la problemática en cuanto a la decadencia del comercio exterior agrícola a finales de los años cincuenta, el consecuente agotamiento de la agro-exportación, las reformas de tipo agrario en la década de los sesenta, la posterior transición hacia la industrialización y el auge del petróleo.

Teniendo en cuenta todas estas ideas, el objetivo de este capítulo se va a centrar por un lado, en el análisis del desarrollo y modernización de este país, y por otro, en los factores que han ejercido una mayor influencia en el crecimiento económico a partir de la base de datos económicos disponible. Todo esto, combinado con los elementos históricos que ya conocemos, nos permitirá lograr una visión algo más profunda del avance capitalista del Ecuador para nuestro periodo de estudio.

Vamos a empezar recordando algunas de las principales teorías de la economía del desarrollo que vimos en la introducción, las cuales nos servirán como punto de apoyo para analizar las implicaciones en torno al proceso de modernización y evolución del Ecuador de 1950-1975. ${ }^{1171}$ Posteriormente, se revisarán otras teorías más recientes, entre las que se encuentra la del desarrollo humano de una sociedad, que será utilizada en nuestro análisis para establecer cuál es el papel desempeñado por algunos factores como el capital humano y económico en el desarrollo de la sociedad ecuatoriana. ${ }^{1172}$

\footnotetext{
${ }^{1171}$ En la primera parte de la introducción, estudiamos algunas de las principales corrientes teóricas del pensamiento social de América Latina como el nacionalismo, el marxismo ortodoxo, la teoría de la modernización, la teoría de la CEPAL y la teoría de la dependencia. En este apartado, se utilizarán estas tres últimas para aplicarlas a la experiencia ecuatoriana.

${ }^{1172}$ Entre los autores que han dedicado especial atención al desarrollo humano se encuentra el Premio de Nobel de Economía de 1998, Amartya Sen, con obras como: Desarrollo como libertad, GeoPlaneta, Editorial, S.A., 2000; Economía y derecho de alimentación, Food Economics and Entitlements, Helsinki, Wider Working Paper 1, 1986; Desarrollo y crisis global, 2011; La idea de la justicia, Santillana Ediciones Generales, 2012.
} 
En términos generales, cuando hablamos del concepto de desarrollo de una sociedad, nos referimos al nivel de crecimiento que tiene lugar en una economía y que comprende una serie de cambios estructurales conducentes al incremento del nivel de vida de un país. Así, en las sociedades capitalistas, este proceso se identifica con el acceso a la modernización y la acumulación del capital necesario para aumentar la producción de bienes y servicios y generar un mayor bienestar en la población. ${ }^{1173}$ A su vez, el crecimiento económico se corresponde con la asociación de la producción industrial y de la innovación técnico-científica, por lo que este concepto suele constituirse como el eje central del proceso de desarrollo de un país.

Al estudiar el fenómeno del desarrollo y la razón por la cual, unos países son ricos y otros pobres, hay que remontarse al interés surgido en las naciones subdesarrolladas después del fin de la Segunda Guerra Mundial (1939-1945), a raíz de los problemas provocados por la descolonización y el panorama económico de las diferentes sociedades: $:^{1174}$

El contexto económico en el que se construye el paradigma del desarrollo es el de la posguerra, cuando los países proveedores de materias primas pierden mercado, lo que afecta sus economías nacionales. ${ }^{1175}$

Ante estas circunstancias, el concepto de desarrollo aparece cuando se descubre el alto nivel de pobreza en algunas regiones de Asia, África y América Latina y tras reconocer la gran amenaza que este puede suponer para los países industrializados. ${ }^{1176}$

En este marco, se crearon algunas expectativas para impulsar el desarrollo en las nuevas naciones independientes y en aquellas regiones que tenían un elevado nivel de retraso económico, dándose una gran importancia al tema del crecimiento económico, que con la ayuda de la acumulación de trabajo y capital, podría ser el mecanismo adecuado para poner fin a la pobreza en el mundo:

\footnotetext{
${ }^{1173}$ Banco Mundial: Más allá del crecimiento, Grupo del Banco Mundial, www.worldbank.org, 2002.

${ }^{1174}$ Gonzalo Escribano: Introducción a las teorías del desarrollo, Facultad de Ciencias Económicas y Empresariales, UNED, 2012, p. 5-42.

${ }^{1175}$ Mireya Salgado, Carlos de la Torre: Galo Plaza y su época, Fundación Galo Plaza Lasso, FLACSO, 2008, p. 121.

${ }^{1176}$ Arturo Escobar: Antropología y desarrollo, Maguaré 14, Universidad de Massachussetts, 1999, p. 43.
} 
Dentro de la ideología del desarrollo se construye un modelo de estado, cuya función esencial es la de promover y orientar el crecimiento económico, a partir de la producción. A su vez, el crecimiento económico se veía como directamente relacionado con la estabilidad social. ${ }^{1177}$

La elaboración de este enfoque, en relación a las políticas de América Latina, contó con las aportaciones de Prebisch sobre las desigualdades en el intercambio, las cuales ponían en duda las ventajas de la vinculación al mercado mundial a partir de las exportaciones de materias primas como motor del crecimiento de la economía. ${ }^{1178}$ Recordemos que el desarrollismo consideraba que las economías atrasadas no podían estar sometidas a los vaivenes del mercado libre, siendo necesaria la intervención del estado en los sectores estratégicos, con el propósito de favorecer un proceso de modernización económica y de consolidación de la democracia.

Por su parte, a mediados del siglo XX, la explicación en relación al desarrollo y crecimiento a largo plazo logró ocupar un puesto destacado en el debate económico, conformándose dicho esfuerzo en torno a dos teorías conocidas como la teoría del desarrollo y la del crecimiento.

La teoría del desarrollo puso su empeño en la elaboración de una base teórica para analizar los elementos que permitían el progreso de los países en desarrollo, usando para ello, los elementos que causaban problemas estructurales en estos países; mientras que el segundo enfoque intentó crear una teoría universal relacionada con el crecimiento económico: La primera recurrió a una forma de hacer economía preferentemente argumentativa y verbalizada y la segunda optó por traducir en modelos matemáticos sus intuiciones básicas. ${ }^{1179}$

Con el paso del tiempo, la vía por la que la teoría del crecimiento optó, acabó convirtiéndose en la interpretación central de la dinámica económica, hecho que contribuyó a que ambas teorías siguieran caminos separados. Así, la teoría del desarrollo consideraba que las propuestas del

${ }^{1177}$ Mireya Salgado, Carlos de la Torre, op. cit. p.122.

1178 J.A. Ocampo, M.A. Parra: Los términos de intercambio de los productos básicos en el siglo XX, Revista de la CEPAL No. 7, 2003. Entre las aportaciones de Raúl Prebisch a este campo figuran: El desarrollo económico de la América Latina y algunos de sus principales problemas, Santiago, CEPAL, Mimeografiado, 1949; Hacia una dinámica del desarrollo latinoamericano, Santiago de Chile, CEPAL, 1963; Crecimiento, desequilibrio y disparidades: interpretación del proceso de desarrollo económico, en NU. CEPAL: Estudio económico de América Latina, 1949, Naciones Unidas, 1950, p. 3-89; Problemas del desarrollo económico en América Latina, Conferencia número 1, 23 de octubre de 1951, p. 12.

${ }^{1179}$ Jose Antonio Alonso: En defensa de la teoría del desarrollo, Cuadernos económicos de ICE, número 78, 2009, p. 10. 
crecimiento tenían un carácter más simple y alejado de la realidad, mientras que la teoría del crecimiento pensaba que el desarrollo ofrecía una visión sociológica de poca consistencia analítica y, por tanto, de limitada validez empírica. ${ }^{1180}$

Pese a las diferencias existentes entre ambos enfoques, hay que decir que en la actualidad, en el desarrollo, se valora la importancia para incorporar sus propuestas a los modelos económicos consistentes, mientras que en los estudios del crecimiento se han buscado explicaciones más complejas y se han incluido algunos aspectos institucionales y sociales que en una época anterior, no habrían sido considerados. ${ }^{1181}$

Antes de continuar con la interrelación existente entre desarrollo y crecimiento económico y cómo la consecución de uno puede llevar al otro y viceversa, vamos a repasar la evolución del proceso de desarrollo en el Ecuador y cuál ha sido la influencia de las diferentes escuelas de pensamiento en el mismo.

En el caso específico de América Latina, ya vimos cómo la teoría dominante fue el estructuralismo de la Comisión Económica para América Latina y el Caribe (CEPAL), que abogaba por la intervención estatal y por el proteccionismo necesario para evitar la explotación de los países industrializados. Esta organización afirmaba que la causa principal de la crisis y el atraso de los países latinoamericanos estaba en el desarrollo hacia afuera de dichas economías, es decir, habían basado su crecimiento económico en la exportación de bienes primarios agropecuarios o mineros, dejando a un lado la producción industrial. ${ }^{1182}$

En este marco, la crisis solo podría ser superada a través de un desarrollo hacia adentro que tuviera como finalidad diversificar la estructura productiva, sustentándose en inversiones nacionales de bienes de consumo y de capital, para lo cual era necesario abandonar los

\footnotetext{
${ }^{1180}$ Gonzalo Escribano, op. cit. p. 5-42

${ }^{1181}$ Ibíd. p. 5-42.

${ }^{1182}$ Raúl Prebisch: El desarrollo económico de la América Latina y algunos de sus principales problemas, Santiago, CEPAL, Mimeografiado, 1949; Hacia una dinámica del desarrollo latinoamericano, Santiago de Chile, CEPAL, 1963; Crecimiento, desequilibrio y disparidades: interpretación del proceso de desarrollo económico, en NU. CEPAL: Estudio económico de América Latina, 1949, Naciones Unidas, pp. 3-89, 1950, p. 3-89; Problemas del desarrollo económico en América Latina, Conferencia número 1, 23 de octubre de 1951, p. 12.
} 
anacronismos del campo y ampliar la inversión (incluida la extranjera), en tanto se adecuaran los objetivos del desarrollo industrial nacional. ${ }^{1183}$

Recordemos cómo la creación de la Alianza para el Progreso, fue el instrumento utilizado por la burguesía, cuya respuesta económica y política fue la implantación de un conjunto de medidas para modernizar el capitalismo atrasado del Ecuador. Entre estas medidas, figuraban el proceso de industrialización, una reforma agraria que impulsara el capitalismo e incorporara a las masas campesinas al consumo industrial, la integración regional, y la diversificación de la economía, siendo el desarrollo industrial y las nuevas producciones agrícolas la base del comercio.

Para que los países en vías de desarrollo pudieran salir de este estado de subdesarrollo, tanto el estructuralismo como la economía del desarrollo estaban centrados en el impulso de la industria doméstica y la modernización de los sectores. Para ello, el estado debía de llevar a cabo dicho proceso modernizador a través de la construcción de infraestructuras, con el apoyo a la educación y sanidad y la creación de instituciones que desempeñaran estas actividades. ${ }^{1184}$

Aún cuando este proceso parecía una buena idea para alcanzar el desarrollo, en el Ecuador, el desarrollismo se vio afectado en numerosas ocasiones por las políticas implantadas por gobiernos dictatoriales, en los que la burocracia carecía de preparación y motivación y el sistema político apenas representaba al pueblo en su totalidad.

A su vez, si bien las políticas desarrollistas estuvieron vinculadas plenamente al Ecuador durante los años setenta, fue durante la presidencia de Galo Plazo (1948-1952), con quien se establecieron las bases para la construcción de un estado con esas características.

Con anterioridad, vimos cómo Galo Plaza fue uno de los dirigentes que mostró una gran preocupación por la particular situación de los países en vías de desarrollo y participó en las tareas que dieron lugar al surgimiento del pensamiento desarrollista. ${ }^{1185}$

A partir de la segunda mitad del siglo XX y con el gobierno de Galo Plaza como punto de partida, la política económica del gobierno se tornó mucho más compleja y variada dentro de una concepción desarrollista de la acción del estado. Se apuntó a la modernización del aparato de gobierno, al ejercicio de la planificación, a la

\footnotetext{
${ }^{1183}$ Gonzalo Escribano, op. cit., p. 5-42.

${ }^{1184}$ Jose Antonio Alonso, op. cit. p.10.

${ }^{1185}$ Mireya Salgado, Carlos de la Torre, op. cit. p.122.
} 
construcción de infraestructura física y al fomento de una agricultura más tecnificada. Para impulsar estos cambios se recurrió a la cooperación internacional, pero el paso inicial fue el despegue de la producción y exportación bananera. ${ }^{1186}$

Mientras que en otros países de América Latina se consideró a la industrialización y la urbanización como los mecanismos para alcanzar el desarrollo, Galo Plaza elaboró una política enfocada en el potencial agrícola del país, decisión que pudo estar influenciada por su condición de terrateniente y la complejidad asociada a la existencia de relaciones precarias en el campo. ${ }^{1187}$ Así pues, en el año 1949, una misión especial enviada por la Corporación Internacional de Economía Básica, entidad dirigida por Nelson Rockefeller, presentó ante el gobierno de Plaza un informe denominado "el Desarrollo Económico del Ecuador", en el que se establecía el modelo de desarrollo que definía a este país. ${ }^{1188}$ Este modelo estaba basado en la consolidación y diversificación del sector exportador de productos agrícolas, así como en la dinamización del sector agropecuario que producía para el mercado interno, y del sector industrial. Esto llevaba aparejada la absorción de nuevas técnicas en la agricultura (ayuda técnica externa, sistemas de irrigación, etc.), mientras que para la industria, se perseguía una mejora de los costes a través de la modernización de mecanismos y maquinaria. ${ }^{1189}$

En este sentido, se empezó a entender el desarrollo como un proceso de crecimiento, en el que tenía lugar un conjunto de modificaciones estructurales de la economía, mediante las cuales, se pasaba de las actividades primarias (agricultura y minería) a las actividades industriales y de servicios.

\footnotetext{
${ }^{1186}$ Galo Plaza participó en la Conferencia de Chapultepec y en la de San Francisco, la cual dio comienzo a la Organización de las Naciones Unidas. También, contribuyó a la fundación de la Organización de los Estados Americanos, de la cual fue secretario general y participante activo de la CEPAL. Fuente: Mireya Salgado, Carlos de la Torre, op. cit. p.126.

${ }^{1187}$ Ibíd. p.131.

${ }^{1188}$ La Corporación Internacional de Economía Básica (IBEC) era una entidad adscrita a la Fundación Rockefeller, que, en el año 1947, anunció su asociación con otros países para promover el desarrollo económico, aumentar la producción y disponibilidad de ciertos productos y servicios para la mejorar los países en vías de desarrollo. Fuente: El Gobierno del Sr. Galo Plaza, Presidente Constitucional del Ecuador, 1948-1952, Economía Nacional, junio 1949, Ecuador: Talleres Gráficos Nacionales, en Mireya Salgado, Carlos de la Torre, op. cit. p.133.

${ }^{1189}$ Fernando Velasco Abad, op. cit. p. 194-195.
} 
Galo Plaza consideraba que la transferencia de capital y tecnología eran factores fundamentales para alcanzar el desarrollo, lo cual explica el énfasis en la reorganización y tecnificación de la producción agrícola y de las políticas fiscales, a la vez que también buscaba la difusión de los valores políticos vinculados a la democracia y la ampliación de la educación. Además, hay que señalar la importancia dada a la nación como elemento integrado, sobre todo, en cuanto a su planificación y creación de políticas de carácter nacional, lo que suponía dejar a un lado los problemas de fragmentación y luchas regionales que, hasta el momento, habían dividido al país. ${ }^{1190}$

De igual manera, Velasco Ibarra (1952-1956) y Camilo Ponce (1956-1960) centraron sus esfuerzos en la implantación de estrategias de desarrollo nacional, como las propuestas de la Alianza para el Progreso y de la CEPAL, además de fomentar la modernización del aparato estatal y organizar una reforma del agro y de la economía ecuatoriana.

Se da paso a la discusión en torno a la aplicación de la reforma agraria, se acelera la construcción de obras públicas: vías de comunicación, locales, escolares, medios de comunicación (...). Todas estas transformaciones dinamizan al sector de tecnócratas e intelectuales de clase media, segmento social que gana mayor peso y presencia en la conducción estatal. ${ }^{1191}$

A su vez, para las décadas de los sesenta y setenta, la adopción de medidas reformistas desde el punto de vista desarrollista, como ocurrió con el agro, fue vista como un medio para mejorar los niveles de eficiencia y productividad de la sociedad.

La primera Ley de Reforma Agraria (1964) pretendía erradicar las modalidades precarias de tenencia de la tierra y liberar mano de obra de la hacienda con el objetivo de proporcionar trabajadores a las empresas industriales, crear mercado interno e incorporar a la población del campo en el capitalismo. ${ }^{1192}$ En otras palabras:

\footnotetext{
${ }^{1190}$ Mireya Salgado, Carlos de la Torre, op. cit. p.122.

${ }^{1191}$ Agustín Cueva, El proceso de dominación..., op. cit. p. 68.

1192 A. Varas, F. Bustamante: Fuerzas Armadas y Política en Ecuador, Quito: Ediciones Latinoamérica, 1978, p. 63.
} 
Se buscaba establecer un sistema más dinámico y modificar las condiciones de vida de la población agraria mediante la creación de mayores oportunidades de ingreso, educación, salud y de su adaptación al sistema occidental, lo cual equivalía a su modernización. ${ }^{1193}$

Con el apoyo de la Alianza para el Progreso, se mostraba el interés norteamericano de contribuir al desarrollo, defensa y seguridad de los países latinoamericanos. En el caso del Ecuador, las élites locales, entre las que se encontraban los militares, aprovecharon esta última necesidad para aplicarla a sus intereses de carácter defensivo, ante las diferencias existentes entre la Costa y la Sierra, haciendo uso de las políticas para satisfacer sus propios intereses. ${ }^{1194}$

En los años sesenta, los militares apoyan al desarrollo desde una propuesta técnica, de ahí que la dictadura de los sesenta sea vista como un reformismo tecnocrático. ${ }^{195}$

Su acción posta la consigna clara de modernizar al país y de integrar a los habitantes del campo para conseguir la cohesión interna. En este objetivo, los militares confluyen con el resto de fuerzas sociales como una más, pero con una ventaja: la posibilidad de ejecutar su idea desde el amplio ámbito de acción que brinda el Poder Ejecutivo en un gobierno de facto, lo cual los libera de la presencia de un Legislativo inoperante. ${ }^{1196}$

Teniendo en cuenta estas ideas, la existencia de los gobiernos militares en el poder permitía la elaboración de la ley, pero esta debía adaptarse a sus intereses.

Tras el paso de la Junta Militar de 1963, tuvo lugar un breve periodo de administración civil entre 1966 y 1972, en el que se sucedieron dos gobiernos provisionales, el de Clemente Yerovi y el de Otto Arosemena Gómez; y luego, uno de tipo constitucional presidido por Velasco Ibarra en 1968, cuyo proyecto estaba basado en el desarrollo y consolidación del sector industrial.

\footnotetext{
${ }^{1193}$ Cecilia Ortíz: Indios, militares e imaginarios de nación en el Ecuador del siglo XX, Editorial Abya-Yala, 2006, p. 80 .

${ }^{1194}$ Ibíd. p.81.

${ }^{1195}$ A. Varas, F. Bustamante, op. cit. p. 63.

1196 Marcos Gándara: Los militares y la política en el Ecuador, en Luis Mora, coord, Política y Sociedad, Quito: Corporación Editora Nacional, 1980, p. 179.
} 
La posición anti-oligárquica mostrada por Velasco Ibarra y sus acciones para disminuir el poder de las élites tradicionales, así como la imposición de medidas fiscales para solucionar la crisis económica provocaron el descontento del pueblo. Con el apoyo de las fuerzas militares y algunos sectores sociales, Ibarra se proclamó dictador en 1970 y logró permanecer en el gobierno hasta 1972, año en que se produjo otro golpe de estado por parte de Rodríguez Lara.

A través del Plan Integral de Transformación y Desarrollo dictado por la nueva administración, se especificó el camino para modernizar el país desde un punto de vista político y socioeconómico, ya que de esta manera, se podía ampliar la participación política de los grupos que, por el momento, habían sido marginados:

Tales planes de acción constituyen la síntesis de un proyecto compartido entre fracciones de ciertos grupos de poder: un sector de los militares y otro de los civiles que cuestionan los viejos liderazgos desde una posición que aparece como cargada de objetividad democrática. $^{1197}$

Estos grupos, tecnócratas y militares, tenían en común la profesionalización de cada uno de sus miembros, es decir, el gobierno militar decidió enviarlos a centros para estudiar y tener un conocimiento más amplio de temas socio-económicos. De la misma forma, los militares afirmaban que las modificaciones necesarias para el desarrollo requerían de estabilidad interna, lo cual no podía conseguirse en un contexto de gobiernos civiles que no disponían de estudios de planificación, a la vez que existía una falta de continuidad en sus propuestas como consecuencia de la brevedad de sus administraciones. ${ }^{1198}$

Asimismo, el desinterés por parte de las clases privilegiadas en la nación, hizo que las fuerzas militares usaran el poder para conseguir el desarrollo siguiendo un plan de industrialización y centrándose en el auge del petróleo y en aquellos recursos naturales que podían ser estratégicos para la economía.

El nacionalismo en este horizonte es revolucionario porque pretende inducir a la nación en un proceso de cambio estructural desde los puntos de vista social, económico, político

\footnotetext{
${ }^{1197}$ Cecilia Ortíz, op. cit. p.83.

${ }^{1198}$ B. Loveman, T. Davies: The politics of antipolitics, en B. Loveman y T. Davies edit., the politics of antipolitics, the military in Latinamerica, Wilmington: Sr Books, 1997.
} 
y también cultural que difunde y hace prevalecer los valores democrático-liberales en lo político, social e ideológico. Confía en la movilización social a través de la organización de los actores del cambio. ${ }^{1199}$

Las fuerzas militares, a diferencia de la oligarquía, querían representar los intereses populares, para lo que abogaron por el uso de políticas de integración y desarrollo nacional que buscaran el beneficio del pueblo y la distribución de la riqueza. Además, se pretendía desplazar a los exportadores de productos agrícolas, al ser el grupo social que más se había enriquecido y había tenido acceso al control de la economía y política nacional.

Progreso y desarrollo continúan en la mira como fuentes de poder nacional, desde la perspectiva militar: el poder económico de un estado, su capacidad industrial y desarrollo tecnológico son determinantes para enfrentar las amenazas externas. ${ }^{1200} \mathrm{Se}$ considera que para acrecentar el poder económico es necesario crear condiciones de bienestar material adecuado para las mayorías nacionales, mediante la explotación de los recursos naturales... ${ }^{1201}$

Estas ideas ponen de manifiesto el interés por parte del gobierno a la hora de controlar el petróleo y sus inversiones, siendo las más importantes, las dedicadas al desarrollo de la industria para mantener las políticas desarrollistas y la modernización.

De igual forma, el régimen dictatorial de Rodríguez Lara tenía como objetivo constituirse como mediador entre la sociedad y el estado y contribuir a la implantación de mecanismos para que los sectores marginados pudieran acceder a la política. En otras palabras, se buscaba la incorporación de las comunidades indígenas a la realidad nacional y su modernización, mediante las estrategias de integración estatal, el fomento de la educación y la eliminación del analfabetismo. ${ }^{1202}$

\footnotetext{
${ }^{1199}$ Filosofía y Plan de Acción, Gobierno Revolucionario Nacionalista, 1972, en Cecilia Ortíz, op. cit. p.85.

${ }^{1200}$ M. Vallejo: Los roles de las Fuerzas Armadas en el post retorno, Quito: FLACSO, 1991, p. 8.

1201 Gral. EM (r) Luis Larrea Alba: El desarrollo económico y su ordenación técnica, Revista de las Fuerzas Armadas 42, Quito: Ministerio de Defensa Nacional, 1971, p. 16.

1202 Bertha García: Militares, economía y lucha política: Ecuador en los años 70, Tesis para la obtención de Maestría, Colegio de México) Quito: CONUEP/PUCE, 1987, p. 24.
} 
Otro aspecto de este gobierno fue la constante negociación y concesiones, pues la dictadura tuvo que hacer frente a los civiles y a los industriales nacionales que estaban favorecidos por la política de industrialización.

Si bien la dictadura no contó con una base de apoyo entre civiles, tampoco pudo hacerlo al interior de las Fuerzas Armadas, al estar estas igualmente divididas. ${ }^{1203}$ Los problemas entre estos grupos acabaron con un golpe de estado conducido por el general González Alvear, perteneciente al grupo autoritario, en septiembre de 1975, que a pesar de su fracaso, consiguió poner fin al gobierno de Rodríguez Lara en el año 1976.

A partir de entonces, el destino político del Ecuador pasó a manos de un triunvirato militar (1976-1979) organizado por el almirante Alfredo Poveda Burbano, el general Guillermo Durán Arcenales y el brigadier Luis Leoro Franco, jefes de la marina, el ejército y la aviación, los cuales implementarían un proceso de retorno al sistema constitucional democrático. ${ }^{1204}$

Durante los años del triunvirato, el auge del petróleo fue utilizado para promocionar el endeudamiento externo del país y así poder atender las nuevas demandas de la sociedad. En este contexto, se creó el acceso a créditos, los cuales no tenían las mejores condiciones de devolución para quienes asumían dicha deuda: La nueva política del triunvirato militar (1976-1979) deja sin vigencia algunos mecanismos importantes para el control del endeudamiento externo (como el comité de financiación externo). ${ }^{1205}$

Asimismo, la administración del triunvirato se llevó a cabo desde una posición autoritaria que pretendía acabar con cualquier reacción subversiva. Esto ocurrió en el momento en que la eliminación de la hacienda provocó daños entre la población del campo, y esta se vio obligada a reorientar su relación de dependencia con el estado.

\footnotetext{
1203 Por un lado, se encontraban los oficiales que apoyaban el proyecto reformista y por otro, el sector constitucionalista que se decantaba por un proyecto de subordinación de los militares a la conducción civil tradicional, especialmente liberal. Por último, estaba el grupo más reaccionario que respondía a la actividad ideológica de las Cámaras y de los grupos financieros internacionalizados. Fuente: Fernando Bustamante, Augusto Varas: Fuerzas Armadas y política en Ecuador, Quito, 1978, p. 126-131.

1204 Lucía Pazmiño Castro: Democracia tutelada en el Ecuador (cronología de una praxis), Informe final del concurso: El papel de la fuerzas armadas en América Latina y el Caribe, Programa Regional de Becas CLACSO, 2007, p. 14-15.

${ }^{1205}$ Bertha García, op. cit. p. 308.
} 
Paralelamente, la vuelta a la democracia tuvo lugar mediante la participación entre civiles y militares, elaborándose un mecanismo que orientara el nuevo sistema y la creación de una nueva Carta Constitucional, como resultado de la unión entre el ejército y el pueblo. Esta resolución concedía a la población analfabeta el derecho al voto, aumentándose así, el alcance de la ciudadanía a mayorías indígenas y campesinas que, hasta el momento, habían estado marginadas. En la administración del petróleo, el triunvirato puso a un grupo de las Fuerzas Armadas y a representantes de las clases civiles más importantes a su cargo, fortaleciéndose la nacionalización de este bien, con la creación del consorcio CEPE-TEXACO y con el impulso de la refinería de Esmeraldas. ${ }^{1206}$

En definitiva, en el intento de establecer políticas desarrollistas, se vuelve a observar la existencia de una diversidad de intereses y posiciones políticas en el triunvirato, que no impedía a sus miembros actuar conjuntamente con el resto de las élites económicas y políticas, según sus simpatías y antipatías ideológicas para satisfacer sus propios objetivos. ${ }^{1207}$

Tras este repaso de las políticas del desarrollo y estructuralismo en el Ecuador desde su inicio en la década de los cincuenta, es importante señalar que si bien los proyectos mencionados parecían estar dotados de gran potencial, la realidad de los acontecimientos analizados hasta la década de los setenta, momento de pleno apogeo del desarrollismo, muestran un país caracterizado por una profunda desigualdad, división política, gran dependencia del capital y tecnología extranjera y altos niveles de analfabetismo, entre otros problemas, lo cual lleva a preguntarnos el por qué de esta situación (la tabla 1: Población alfabeta y analfabeta (1950-1982) pone de manifiesto un elevado número de personas sin estudios, sobre todo durante el periodo 1950-1970, siendo las cifras más altas, las correspondientes a las mujeres. ${ }^{1208}$

Si se compara la situación del Ecuador con la de otros países de América Latina, se aprecia un resultado similar debido a la ausencia de medidas que pudieran asegurar la continuidad de un desarrollo independiente. En estos casos, tampoco la tasa de crecimiento económico fue suficiente para facilitar los sectores más retrasados de estas economías, a la vez que no podían hacer frente a la presión que implicaba el incremento de la población.

\footnotetext{
1206 Para más información de Cepe-Texaco, ver el apéndice de notas del capítulo 6. Fuente: Chevron: Guía de inspección judicial, 27 de julio, 2005, www.texaco.com, p. 3.

${ }^{1207}$ Bertha García, op. cit. p. 308-309.

1208 Esta tabla se encuentra en el apéndice de datos del capítulo 6. Fuente: Patricio Almeida Guzmán, Rebeca Almeida Arroba, op. cit. p. 395.
} 
En el caso de Brasil, pese a que el proceso sustitutivo de importaciones alcanzó la etapa de implantación de bienes de capital y creó una actitud positiva en torno a dicho sector, posteriormente, en los años sesenta, comenzó un periodo de estancamiento de su economía.

Más concretamente, durante el gobierno de Eurico Dutra (1946-1950) se llevó a cabo un tipo de política enfocada en la creación de algunas industrias básicas (energía eléctrica, acero, petróleo, etc.), siendo esta actitud adoptada por el gobierno de Vargas (1950-1954), pero con una mayor orientación al desarrollo estimulado por inversiones públicas en sectores estratégicos.

No obstante, aún cuando el remanente de la Segunda Guerra Mundial fue destinado a la remodelación del parque industrial, se mantuvo una política de fuertes importaciones de equipo, ya que existía un gran temor a una nueva guerra como consecuencia de la crisis en Corea, que a su vez, provocó un boom económico y un empuje de la industrialización procedentes de las fuerzas internas. $^{1209}$

El coste del proceso de industrialización tuvo como base las prácticas de control y tasas de cambio que favorecían al sector interno, público y privado; en perjuicio de los sectores exportadores que solían protestar en contra de las intervenciones del gobierno en el establecimiento de dichas tasas de cambio. ${ }^{1210}$

Aunque, en un principio, los precios internacionales fueron favorables y no afectaron demasiado a los sectores agrarios, a mediados de los cincuenta, se empieza a observar un efecto negativo que llevó a la elaboración de una política de contención basada en la capitalización mediante recursos externos para disminuir la presión producida por la inflación. A corto plazo, esta política permitiría reducir dicha presión, satisfacer las demandas de salarios y el fortalecimiento del sector industrial que, a partir de entonces, estaría vinculado al capital extranjero impulsando el desarrollo del país pese a la inestabilidad política y el endeudamiento. ${ }^{1211}$

Otro ejemplo a considerar, puede ser el de la economía mexicana, en la que el proceso de apertura del sistema productivo interno hacia el capital foráneo ocurrió sin las crisis políticas que caracterizaron al Ecuador y Brasil. En México, se estableció el papel del estado como inversor y regulador de la economía y el de la burguesía urbana, financiera e industrial, a la vez que se

\footnotetext{
${ }^{1209}$ Fernando Cardoso, Enzo Faletto: Dependencia y desarrollo en América Latina, Siglo XXI editores S.A., Buenos Aires, 1977, p 49-55.

${ }^{1210}$ Ibíd. p.53.

${ }^{1211}$ Ibíd. p.49-55.
} 
crearon los medios para que el movimiento obrero popular participara en la sociedad y su capacidad de expresión contara con cierta legitimidad.

Esta gran diferencia con respecto a los otros países, contribuyó a evitar conflictos entre la burguesía nacional y el estado, así como un choque de tipo populista, mientras que el paso hacia una política de participación del capital extranjero se realizó sin enfrentamientos de carácter serio. En estas condiciones, fue posible alcanzar un mayor grado de desarrollo y estabilidad, siendo el coste de estos objetivos, la consolidación de una nueva oligarquía que logró manipular al estado en beneficio propio y mantuvo el patrón de desarrollo asociado al capital extranjero:

Lo que pudo haber sido un desarrollo social y político modernizado, terminó por desembocar en el mismo callejón aparentemente sin salida del estado actual del desarrollo del capitalismo en Latinoamérica: la modernización se hace a costo de un autoritarismo creciente y sin que disminuya el cuadro de pobreza típico del desarrollo con marginalidad. ${ }^{1212}$

Fernando Cardoso y Enzo Faletto explican que la industrialización de las sociedades latinoamericanas, se caracterizó por su necesidad de acumulación, y por una fuerte diferenciación social. Es decir, este modelo se estableció partiendo de la base de una relación positiva en los términos de intercambio y en la limitada participación de la población en los beneficios obtenidos con el desarrollo. ${ }^{1213}$

En cierto modo, la explicación a este panorama en el Ecuador, ha de buscarse en la forma en que tuvo lugar su integración en el paradigma desarrollista y en cómo los grupos sociales fueron adoptando diferentes posiciones para resolver los conflictos internos, modificando las instituciones sociales y políticas según su capricho y transformando su propia condición a lo largo de dicho proceso de modernización.

Aquí, se pueden considerar otras teorías políticas y sociológicas del desarrollo que dan gran importancia a los efectos de los factores sociales y políticos mencionados, y que permiten explicar los desajustes que establecen la condición de desarrollo o subdesarrollo de un país.

\footnotetext{
${ }^{1212}$ Ibíd. p.53.

${ }^{1213}$ Ibíd. p.53-54.
} 
El problema planteado no se refiere a la exclusión de estos elementos, sino al hecho de que algunas veces se piensa en determinadas sociedades industrializadas y modernas, cuyo fracaso económico puede tener su raíz en la profunda división social y en la naturaleza dictatorial de sus regímenes políticos, como ocurrió en diferentes periodos de tiempo en el Ecuador. ${ }^{1214}$

En este sentido, dentro del campo del desarrollo, otras teorías que nos permiten analizar la evolución del desarrollo de este país y que incluyen las variables política y social, como es el caso de las instituciones y el papel que desempeñan dentro de una sociedad, son la teoría de la modernización y de la dependencia.

Al hablar de la escuela de la modernización, hay que recordar la importancia del análisis histórico en cuanto al establecimiento de los pasos que una nación tenía que seguir para alcanzar la modernización socio-política, que era la fase final en la que se encontraban los países desarrollados, caracterizados por ser sociedades abiertas con una democracia y una economía de mercado. $^{1215}$

$\mathrm{Su}$ fundamento teórico se basaba en las teorías funcionalistas y evolucionistas de principios del siglo XIX, que surgieron como respuesta a las modificaciones sociales producidas tras la Revolución Industrial, al buscar una transformación de la economía y mezclarse con las ideas de la Revolución Francesa (1789-1799), que pretendía implementar un nuevo orden político, basado en la democracia, la libertad y la igualdad. Todo esto implicaba una evolución de las sociedades, las cuales podrían salir de su estado de atraso hasta alcanzar el nivel de progreso de las naciones industriales de la época. Quizás, el aspecto más destacado de las teorías evolucionistas, fue el determinismo social, pues se partía de la idea de que una sociedad evolucionaba desde sus elementos más primitivos hasta su estado más avanzado, y en la que el valor moral de la humanidad y civilización estaba vinculado al progreso. ${ }^{1216}$

El periodo en que surge esta tendencia en el Ecuador es considerado como una etapa de progreso, en la que Europa se constituye como el modelo de desarrollo socio-económico y cultural, al que

\footnotetext{
${ }^{1214}$ A este respecto, North hace referencia a las instituciones que España impuso en América Latina durante la época colonial, las cuales se caracterizaron por el caciquismo, y a las carencias de una sociedad tradicional para estudiar el desarrollo económico. En este caso, el aislamiento de determinadas comunidades, el efecto de la religión, y el papel de la mujer en la sociedad, entre otros aspectos, pueden ser un obstáculo al desarrollo. Fuente: D.C. North: Instituciones, cambio institucional y desempeño económico, Fondo de Cultura Económica, México, 1993, p 5-170.

${ }^{1215}$ P.W. Preston: Una introducción a la teoría del desarrollo, Siglo Veintiuno Editores, 1999, p. 187-217.

${ }^{1216}$ Gonzalo Escribano, op. cit. p. 5-42.
} 
debían de referirse los países latinoamericanos. Por consiguiente, el positivismo en el Ecuador estaría basado en el pensamiento científico, en el darwinismo social y en la concepción de la evolución lineal de la historia hacia un progreso mayor. ${ }^{1217}$

Estas ideas permitieron que estudiosos como Espinosa Tamayo y Arturo Andrés, elaboraran su postura intelectual, configuraran algunos proyectos políticos para la sociedad ecuatoriana y defendieran la formación de nuevas estructuras socio-culturales fundamentadas en la diferenciación racial, en la diferencia evolutiva y en la necesidad de intervención para alcanzar un mayor progreso.

No estar a fin con el estado actual de civilización (...) y no vencer el título de deshonroso país ignorante y atrasado, debido a la existencia de una raza servil, menos apta, creada en la esclavitud, supone para estos autores, uno de los problemas más importantes que el Ecuador del siglo XX debía de solucionar. ${ }^{1218}$ Según Espinosa Tamayo y Andrés Roig, el indígena se encontraba en una posición de desventaja, al tener una mentalidad inferior y llena de defectos de la que solo podía salir con la ayuda de la educación para alcanzar un mayor desarrollo. En otras palabras, el proyecto educativo contribuiría a eliminar dichos obstáculos fomentando la moralidad política de las clases políticas con la creación de élites, en las que primaran los altos ideales. $^{1219}$

A partir de la teoría de la evolución y del funcionalismo, la teoría de la modernización explica que los países subdesarrollados podían salir de este estado si abandonaban sus prácticas tradicionales y seguían las mismas pautas de progreso que caracterizaban a los países occidentales (Inglaterra, Francia, Alemania, etc.). Sin embargo, esta teoría excluía los elementos diferenciales de otros países no europeos, a la vez que se ponía en duda que estas sociedades buscaran objetivos relacionados con la democracia, la instauración de leyes y el individualismo. De igual forma, se pensaba que el retraso político y económico no era consecuencia del colonialismo o del imperialismo, sino de su condición de país tradicional y su rechazo a la

\footnotetext{
${ }^{1217}$ Alicia Ibarra: Los indígenas y el estado en el Ecuador, editorial Abya-Yala, 1987, p. 19.

1218 Alfredo Espinosa Tamayo, Arturo Andrés Roig: Psicología y sociología del pueblo ecuatoriano, Banco Central del Ecuador, Corporación Editora Nacional, 1979 (1916), p. 167 y 349.

1219 Catalina Ribadeneira: El racismo en el Ecuador contemporáneo: Entre la modernidad y el fundamentalismo étnico. El discurso del otro, editorial Abya-Yala, 2001, p. 27-150.
} 
modernización, por lo que se debía de imitar a los países occidentales en cuanto a la modernización de las instituciones. ${ }^{1220}$

En este sentido, si se piensa en el desarrollo político como el establecimiento de democracias liberales parecidas a las de los países occidentales, el primer paso a seguir era modernizar las estructuras sociales, los valores de la cultura y el sistema económico, mediante el comercio, la inversión extranjera y la ayuda al desarrollo.

Como consecuencia, los países en desarrollo con sistemas políticos débiles se vieron obligados a hacer frente a tareas bastante complicadas, pues las élites políticas tenían la responsabilidad de crear gobiernos eficientes, en los que existiera una democracia con un sistema político que contribuyera al bienestar de la población, la educación y la adaptación de las tecnologías procedentes de los países occidentales. ${ }^{1221}$

En este caso, se ha de ver si el desarrollo económico y la modernización de un país pueden conducir a la democracia y viceversa, pues en países como el Ecuador, esto no siempre ha tenido lugar. Aquí, la teoría de la modernización critica la dificultad para aplicar la experiencia de las sociedades occidentales y la división existente entre países modernos y tradicionales.

Un ejemplo de esto, se encuentra en la permanencia en el Ecuador de instituciones de la etapa colonial, como ocurrió con el clientelismo, las divisiones étnicas caracterizadas por la manipulación política y el establecimiento del estado como patrimonio de una clase social con poder. $^{1222}$ Todos estos elementos constituyen un obstáculo al desarrollo económico y a la modernización, ya que los grupos en el poder acaban quedándose con los beneficios.

A este respecto, hay que recordar cómo una buena parte de los elementos pertenecientes a la herencia institucional de la colonia fue desapareciendo a lo largo del siglo XX. Este fue el caso del sistema de castas, monopolios estatales y fueros especiales para militares y eclesiásticos, a la vez que los sistemas de esclavitud se iban debilitando, se abandonaban los impuestos internos directos (como el tributo indígena) y se producía la separación entre la iglesia y el estado.

\footnotetext{
${ }^{1220}$ Gonzalo Escribano, op. cit. p. 5-42.

${ }^{1221}$ Ibíd. p. 5-42.

${ }^{1222}$ D.C. North, op. cit. p. 10-170.
} 
De igual manera, se llevó a cabo una reforma de los códigos legales, especialmente, los códigos civiles y comerciales, las leyes de los bancos, los temas fiscales y arancelarios y los relacionados con la deuda pública. ${ }^{1223}$

Sin embargo, en lugares como el Ecuador, donde las élites colonizadoras dominaron grandes poblaciones de indígenas, algunas instituciones coloniales lograron permanecer por más tiempo. Un ejemplo de esto, fue el latifundio y los problemas asociados de tenencia de la tierra, que todavía existían, tanto en la Sierra como en la Costa, a mediados del siglo XX.

Además, la concentración de riqueza de la colonia llevó a la creación de sociedades desiguales, en donde las élites colonizadoras explotaron a las poblaciones indígenas o esclavos importados.

Para hacer más fácil esta tarea, el régimen colonial creó instituciones que lograron permanecer en el siglo XX, y que estaban encargadas de proteger los derechos de propiedad de las élites, negándose tal protección a las clases subordinadas que no gozaban de dicho poder. ${ }^{1224}$

John Coatsworth indica que el problema principal de América Latina al término del colonialismo tenía como base la falta de interés por parte de España (y de Portugal) a la hora de modificar los derechos de propiedad con el advenimiento de la Revolución Industrial, pues:

la supervivencia de su imperio dependía del mantenimiento de un equilibrio frágil, en donde la autoridad de un monarca débil y distante se basaba en mantener inseguras a las élites de colonizadores en cuanto a sus derechos, y en mantener a raya el descontento de los de abajo. ${ }^{1225}$

La ausencia de una reforma en el régimen de los derechos de propiedad para fomentar la innovación afectó al proceso de modernización de los sistemas judiciales, los impuestos fiscales, las leyes comerciales y estructuras gubernamentales, siendo necesarias varias décadas de luchas civiles para que esto se hiciera realidad. Además, la modernización institucional coincidió con las demandas del pueblo cuando los movimientos liberales se enfrentaron al sistema de

\footnotetext{
${ }^{1223}$ Ibíd. p. 10-170.

${ }^{1224}$ S. Engerman, K. Sokoloff: Factor endowments, institutions and differential paths of growth among new world economics: A view from economic historians of the United States, en Stephen Haber (ed.), How Latin America Fell Behind: Essays on the Economic History of Brazil and Mexico 1800-1914, Stanford University Press, 1997, p. 260304.

1225 John H. Coatsworth: Desigualdad, instituciones y crecimiento económico en América Latina, Economía Vol. XXXV núm. 69, semestre enero-junio 2012, p. 217.
} 
relaciones precarias o movilizaron el apoyo de los agricultores y campesinos hacia finales de los cincuenta y durante los sesenta en el Ecuador.

No en vano, la reforma de las instituciones coloniales demandó un gran esfuerzo y resistencia por parte de las élites que rechazaban la idea de reparto de la propiedad y la reforma de los códigos civiles y comerciales. ${ }^{1226}$

Asimismo, en la etapa colonial, el estado destinaba sus recursos a la defensa del territorio, la represión de las revoluciones interiores y la recolección de impuestos, por lo que la atención prestada a los servicios públicos e infraestructura fue mínima.

En cierto modo, se puede decir que esta actitud fue mantenida después de la independencia, ya que los organismos estatales que tenían que llevar a cabo la modernización de las instituciones no fueron los demandados por la mayoría popular. Es decir, se consolidó tanto el poder como el dominio de las élites, excluyéndose a los campesinos e indígenas, a la vez que las clases altas y los inversionistas extranjeros gozaban de estabilidad y seguridad.

Por su parte, los regímenes dictatoriales también han servido para bloquear las posibles ventajas de la modernización, pues un sistema democrático puede terminar con el clientelismo, la corrupción y otros problemas, siempre y cuando este sea establecido como un factor ligado al desarrollo. En el Ecuador, los diferentes gobiernos se caracterizaron por beneficiar a los grupos sociales de mayor poder (oligarquía y burguesía) a costa del pueblo y del desarrollo de la sociedad.

Al hilo de la idea planteada y la relación entre desarrollo y democracia, Alejandro Moreano explica que la modernización del Ecuador y su proceso de acumulación de capital durante el siglo XX no siguió una vía democrática, sino que estuvo marcado por las constantes luchas por el poder entre la burguesía y la oligarquía y la manipulación de los gobiernos. Ya hemos analizado cómo el resultado de estas acciones condujo al fortalecimiento del aparato estatal, la consolidación imperialista y la represión de las masas populares. ${ }^{1227}$

Además, nuestro periodo de estudio tiene especial interés, pues los problemas socio-políticos que surgieron a partir de la década de los cincuenta, y en particular, a raíz de la Revolución Cubana de 1959, pusieron de manifiesto las contradicciones sociales existentes y la necesidad de

\footnotetext{
${ }^{1226}$ D.C. North, op. cit. p. $10-170$.

1227 Alejandro Moreano: El pensamiento y la acción política de Fernando Velasco, en Fernando Velasco Abad: "Ecuador: Subdesarrollo y dependencia", primera edición, Edit. El Conejo, 1981, p.11.
} 
reformar las estructuras pre-capitalistas en la producción agraria, siendo estas modificaciones realizadas bajo la presencia de la dominación imperialista y a partir de los rasgos déspotas del estado en las década posteriores.

La crisis del antiguo sistema semi-feudal fue un elemento más que se unió a los problemas generales del país, sobre todo en lo concerniente a la gran propiedad agraria y al capital comercial. Este régimen oligárquico, cuya base era el sistema de exportación de productos agrarios, tocó fondo con la crisis del banano en los años cincuenta, cuando este dejó de ser uno de los productos fundamentales para la acumulación de capital, de ahí, el giro político de los diferentes gobiernos de los sesenta que se habían propuesto modificar el sistema, impulsar el desarrollo de la economía y la profundizar las relaciones capitalistas. ${ }^{1228}$

Aquí, se puede apreciar cómo la influencia de la economía ecuatoriana, gobernada por el estructuralismo y la modernización, comenzó a declinar cuando la industrialización fallaba ya en los años sesenta.

En este campo, la influencia de intelectuales como Celso Furtado, hizo que la perspectiva de la formación histórica de los países de la región se uniera a la dimensión estructuralista, provocando el surgimiento de un método de análisis conocido como "históricoestructuralista."1229 Esto contribuyó a que el desarrollo de la CEPAL se produjera como una escuela de pensamiento encargada de examinar las transformaciones socio-económicas de los países latinoamericanos y del Caribe.

Dichas ideas pasaron a ser una referencia durante los primeros años del proceso de integración andina en los años sesenta, pues la necesidad de crear una base industrial con la protección de elevados aranceles, que permitieran especializar a los países andinos en producciones específicas para impulsar el crecimiento comercial mediante la vigencia de una zona de libre comercio cerrada, fue una teoría recogida por el pensamiento de la CEPAL. ${ }^{1230}$

${ }^{1228}$ Ibíd. p. 19.

${ }^{1229}$ Celso Furtado: La economía latinoamericana: formación histórica y problemas contemporáneos, Siglo XXI, 1991, p. 23-300; Aníbal Pinto: América Latina: Una visión estructuralista, Facultad de economía, Universidad Nacional Autónoma de México, 1991, 110-550.

1230 César Montaño Huerta: La integración comercial sudamericana: ¿Es realmente posible?, en "Comercio exterior: alternativas para Ecuador", editado por Javier Ponce, Abya-Yala, 2005, p. 216. 
El análisis de Furtado establecía que el subdesarrollo era un factor estructural específico, resultado de la evolución histórica del capitalismo como sistema internacional conformado por centros y periferias. De igual forma, según este autor, las características fundamentales de los países subdesarrollados eran la dependencia externa y la heterogeneidad estructural, las cuales tenían una tendencia a reproducirse.

Así, el crecimiento no tenía la capacidad para impulsar el desarrollo en economías vinculadas a la división mundial del trabajo, al considerarlas únicamente como productoras de bienes primarios. En dichas economías, el sector exportador no mantenía el resultado de su progreso técnico y tampoco lo difundía al resto del sistema de producción. ${ }^{1231}$

Asimismo, el desarrollo debía de ser el resultado de la transformación de estructuras para que, con la intervención del estado, permitiera el avance de la industrialización mediante políticas de fomento y la elaboración de planes que destinaran inversiones en cada etapa.

También, asignó un papel importante a la concentración del ingreso en manos de las élites, ya que se trataba de un factor con tendencia a la reproducción en los diferentes modelos de desarrollo de las economías latinoamericanas. Dicho comportamiento condicionaba la existencia de patrones de consumo de bienes de lujo que no se correspondían con el nivel de desarrollo obtenido por las fuerzas productivas, consolidando un sistema productivo que implicaba la desviación del excedente monetario hacia fines diferentes de la acumulación de capital. ${ }^{1232}$

Además, limitaba el crecimiento de los ingresos de los trabajadores y de una buena parte de la población e imponía obstáculos al crecimiento del mercado interno, generando el retraso de la economía. $^{1233}$

A partir de entonces, los estudiosos del tema comenzaron a interesarse en las consecuencias políticas más radicales del motivo estructuralista centro-periferia. Conforme el estructuralismo se iba renovando, surgió el enfoque conocido como teoría de la dependencia que mostraba cómo el

\footnotetext{
${ }^{1231}$ Celso Furtado, La economía latinoamericana..., op. cit. p. 23-300; Aníbal Pinto, op. cit. p. 110-500.

${ }^{1232}$ Ibíd. p. 23-300; Ibíd. p 110-500.

${ }^{1233}$ Gregorio Vidal, Arturo Guillén: Introducción. La necesidad de construir el desarrollo en América Latina, en Repensar la teoría del desarrollo en un contexto de globalización, Homenaje a Celso Furtado, CLACSO, 2007, p. 13-14.
} 
resultado de la experiencia histórica de los países de América Latina situaba a la región en una posición de subordinación en la economía global. ${ }^{1234}$

Recordemos que el sistema centro-periferia reconocía la existencia de dos polos económicos, cada uno con características diferentes. Por una parte, la periferia abarcaba aquellos países que eran productores y exportadores de bienes agrícolas, con una estructura productiva bastante especializada y heterogénea, mientras que los países del centro, estaban especializados en bienes industriales y contaban con una estructura productiva diversificada y homogénea.

Las consecuencias políticas de este modelo estaban relacionadas con el hecho de que en las economías periféricas, la industrialización tuvo lugar a partir de una escasa tecnología y un bajo nivel de acumulación de capital, lo cual implicaba poca capacidad de ahorro y, por tanto, una limitada capacidad de inversión. Este patrón de desarrollo generó grandes diferencias que acabaron mostrándose con un menor crecimiento de la productividad del trabajo y una mayor diferenciación en la distribución de los ingresos.

Asimismo, se ha de hablar de la heterogeneidad tecnológica como consecuencia de la concentración de progreso técnico en los países desarrollados, lo cual implicaba una mayor dependencia del centro, ante la incapacidad de la periferia para obtener y mantener dichos conocimientos tecnológicos. Aquí, se ha de destacar que las alianzas entre las clases más altas, vinculadas a la relación de dependencia y al capital externo, y la debilidad de las instituciones, fueron factores que no contribuyeron a la formulación de políticas eficaces de desarrollo.

Otro de los problemas estaba relacionado con el desequilibrio externo producido cuando las cantidades importadas superaban a las exportadas. Es decir, la especialización en productos agrícolas y la imposición de un crecimiento hacia adentro, provocaron un aumento de las importaciones de bienes de capital capaz de mantener ese proceso de industrialización, mientras que las exportaciones continuaban en los mismos niveles. ${ }^{1235}$

Por su parte, el objetivo de esta escuela consistía en la separación de los obstáculos internos que impedían el crecimiento de los países subdesarrollados, a la vez que destacaba el control político y económico de los países desarrollados como responsable del subdesarrollo.

\footnotetext{
${ }^{1234}$ P.W. Preston, op. cit. p. 187-217.

1235 Joaquín Bertinat, Alfonsina Calvette, María Inés Ignatczuk, María Sauval, Lucía Villamil: Acercamiento al sistema centro-periferia, Cátedra de Crecimiento y Desarrollo Económico, octubre 2012, p.3-10.
} 
La presencia de estos aspectos en el Ecuador se aprecia cuando se analiza el problema nacional del país, ya que se ha caracterizado por ser un país dependiente y dominado por el imperialismo. En cierta parte, el origen de estos problemas ocurrió en el momento en que el Ecuador se vinculó al mercado mundial a finales del siglo XIX, a partir del modelo de crecimiento hacia afuera. Fernando Velasco explica que la posición como país exportador de productos agrarios (cacao, banano y paja toquilla) llevaba asociada una situación de subordinación con respecto a los países centrales que estaban especializados en productos industriales. ${ }^{1236}$

Como hemos visto, esta relación se fue reproduciendo en distintos momentos hasta llegar al agotamiento del modelo agro-exportador en los años cincuenta, a raíz del deterioro de los términos de intercambio. Velasco atribuye esta decadencia al nivel de tecnología de los países centrales con respecto al Ecuador, a la imposición de precios por parte de monopolios y por supuesto, al exceso de oferta sobre la demanda.

Esta relación asimétrica permanecerá y dará lugar a su condición de país dependiente, provocando un desarrollo atrofiado de la estructura económica, además de determinar una sistemática descapitalización de la economía. ${ }^{1237}$

Dicha situación puede ser comparada con el caso argentino, ya que en el periodo de auge de la agroexportación, este país se centró en la producción y exportación de carne y cereales gracias a la explotación de sus abundantes recursos naturales, a la vez que importaba productos manufacturados y de capital. En el mercado internacional, las fluctuaciones de la economía argentina estaban vinculadas al ciclo económico de Gran Bretaña, que era su principal articulador a este nivel, y con las condiciones climáticas, ya que afectaban las cosechas. ${ }^{1238}$

De forma paralela a la agro-exportación, ya en los años treinta, se produjo un repentino proceso de industrialización centrado en el sector agroindustrial, con tendencia a dinamizar el mercado interno y eliminar los desequilibrios sociales.

Sin embargo, no fue hasta finales de dicha década, cuando la combinación de una serie de elementos (el final de la expansión de la frontera agrícola, la crisis de 1929 y las relaciones

\footnotetext{
${ }^{1236}$ Fernando Velasco Abad, op. cit. p. 177-178.

${ }^{1237}$ Ibíd. p. 178.

${ }^{1238}$ Bernardo Kosacoff: La industria argentina: Un proceso de reestructuración desarticulada, en "El desafio de la competitividad" CEPAL-ALIANZA Editorial-1993, p. 4-5.
} 
conflictivas entre Argentina, Inglaterra y EE.UU, principales mercados de exportación de los productos argentinos), permitió alcanzar la posterior etapa de industrialización mediante la sustitución de las importaciones. ${ }^{1239}$

En este caso, la nueva coyuntura internacional del mercado planteó crear un plan de disminución de salarios y gastos públicos a costa de la clase popular y campesina, y una reforma de la economía agroexportadora para aumentar la productividad y la financiación del sector industrial:

El control de cambios de 1931, la vigencia de los permisos previos de importación en 1933, el desdoblamiento del mercado cambiario con el exterior y la elevación de los aranceles de importación -inducido fundamentalmente por motivos fiscales- son ilustrativos del nuevo funcionamiento de la economía, que en su cierre con el exterior fue paulatinamente reduciendo la importancia del comercio internacional en el PIB. ${ }^{1240}$

Bajo estas condiciones, se desarrolló la primera etapa de la sustitución de importaciones en Argentina, siendo las industrias productoras de bienes de consumo (alimentos, textiles, confecciones), los electrodomésticos, maquinarias y la industria asociada a la construcción, las actividades más importantes, que continuaron hasta el primer gobierno de Perón en 1945.

A estas circunstancias internacionales, se unió la influencia de las ideas de la CEPAL en el periodo 1950-1970, cuya manifestación de políticas nacionales fue la orientación hacia un modelo de desarrollo hacia dentro mediante la estrategia de industrialización por sustitución de importaciones. De este modo, conforme se profundizaba en la sustitución de importaciones, la creciente intervención estatal incorporaba una gran variedad de políticas industriales y comerciales con el objetivo de superar la crisis de balanza de pagos que el modelo sustitutivo había provocado debido a un creciente sesgo antiexportador en su estructura productiva. ${ }^{1241}$ Volviendo al caso del Ecuador, Fernando Velasco hace alusión a los problemas mencionados cuando analiza esa relación caracterizada por el control directo que el capital financiero mundial ejerce en los procesos productivos más importantes y, también, por el desplazamiento de las inversiones del sector agro-exportador hacia la industria. En este sentido, la reorientación

\footnotetext{
${ }^{1239}$ Ibíd. p. 5.

${ }^{1240}$ Ibíd. p. 5.

1241 David Matesanz, Ángeles Sánchez: El desarrollo económico argentina a fines el siglo XX, en Agenda Internacional, número 3, 2010, p 100-117.
} 
implicaba un nuevo papel del imperialismo, pues ya no se ocupaba de estructurar las posibles alianzas con las fuerzas pre-capitalistas, sino que se constituía como un obstáculo al desarrollo del capitalismo en las formaciones sociales dependientes. ${ }^{1242}$

Así, la lucha por la soberanía nacional fue adquiriendo una nueva dimensión, puesto que el imperialismo no era solo una forma de opresión exterior, sino que se trataba de un proceso que había sido internalizado en diferentes niveles de la vida social. ${ }^{1243}$

Asimismo, Fernando Velasco alude a las nuevas formas jurídicas asumidas por el capitalismo internacional, es decir, la empresa transnacional y el significado político del proceso:

A otro nivel de relaciones políticas, tenemos que la presencia de la empresa transnacional afecta al conjunto de relaciones que mantiene el estado nación con las empresas inversoras de fuera. ¿Por qué? Partamos de un ejemplo simple: En 1974, el PIB del Ecuador era de 3,6 billones de dólares. Frente a eso, nosotros tenemos que las rentas, ese mismo año, o sea, la producción total de empresas como la Exxon, que es la transnacional más grande que existe, era de 42 billones de dólares. Esto significa que la transnacional como expresión de un tipo determinado de desarrollo, tiene a su vez, una gran capacidad de presión económica que la utiliza en su propio beneficio, lo cual supone que tiene posibilidad de imponernos un patrón de desarrollo que interese a las necesidades de acumulación de la empresa transnacional y no a las necesidades nacionales. $^{1244}$

Para este autor, el incremento del poder político de las multinacionales en un marco de creciente internacionalización capitalista, en el que el centro imperialista más importante era Estados Unidos, constituía una amenaza al desarrollo. Además, la articulación de la lucha por la democracia y la soberanía nacional debía de ser un objetivo prioritario para el país.

\footnotetext{
1242 Fernando Velasco Abad: La dependencia, el imperialismo y las empresas transnacionales, Quito, Edit. El Conejo, 1979.

1243 Alejandro Moreano: El pensamiento y la acción política de Fernando Velasco, en Fernando Velasco Abad: "Ecuador: Subdesarrollo y dependencia", primera edición, Edit. El Conejo, 1981, p. 29.

${ }^{1244}$ Fernando Velasco Abad, La dependencia..., op. cit. p. 63.
} 
También, Agustín Cueva se refiere a las concesiones realizadas a las multinacionales petroleras durante el gobierno del general Rodríguez Lara (1972-1976), no solo en cuanto a las extensiones de tierras, sino también a la exoneración de todo tipo de derechos arancelarios e impuestos, y a las regalías reducidas al mínimo, entre otras: Cuadro que se completaba con la entrega de todo el golfo de Guayaquil a las multinacionales, para la explotación del gas, mediante turbios negociados en los que intervinieron, perpetrando múltiples delitos... ${ }^{1245}$

Agustín Cueva afirma que el capitalismo dependiente característico de los países de América Latina se encontraba ligado al desarrollo del capitalismo imperial, siendo esta posición de subordinación bastante peligrosa, pues en épocas de crisis, los problemas se agudizan en estas sociedades: No es por eso, un azar el que la crisis del capitalismo haya arrastrado en su pendiente al mundo subdesarrollado, produciendo en él los efectos negativos por todos conocidos. $^{1246}$

En el caso ecuatoriano, hemos estudiado cómo la interacción del petróleo y la industria asociada contribuyó a aliviar algunas distorsiones de la economía, pero también sirvió para aumentar los desequilibrios ocasionados por el proceso histórico de desarrollo, ya que, a la vez que la dependencia estructural llegó a consolidarse, las contradicciones propias del capitalismo dependiente (mala asignación de los recursos, distribución del ingreso, etc.) fueron agudizándose. $^{1247}$

Fue entonces, a partir de este momento, en que los problemas de inestabilidad económica se extendían no solo en el Ecuador, sino en el resto de los países de América Latina, cuando se pusieron de manifiesto las debilidades del estructuralismo y de la economía del desarrollo, convirtiéndose la economía neoclásica, en la escuela de pensamiento dominante para resolver los problemas de desarrollo. ${ }^{1248}$

\footnotetext{
${ }^{1245}$ Agustín Cueva: Crisis del capitalismo y perspectivas del nacionalismo en América Latina (análisis del caso ecuatoriano, Revista mexicana de sociología, vol. 38, no. 4, Perspectivas del nacionalismo latinoamericano, Universidad Nacional Autónoma de México, Oct.-Dic. 1976, p. 833.

${ }^{1246}$ Ibíd. p. 829.

${ }^{1247}$ Fernando Velasco Abad, Ecuador..., op. cit. p. 230.

${ }^{1248}$ De igual forma, se pretendía disminuir las distorsiones de incentivos creados como consecuencia del control del estado o por la falta de mercados eficaces de economías tradicionales, por lo que se intentó terminar con el pensamiento que estaba en contra de las exportaciones y del sector agrícola. La otra parte del plan buscaba impulsar la productividad industrial, la inversión extranjera, privatizar las compañías públicas que no fueran rentables y
} 
A este respecto, a finales de los años ochenta, se empezaron a incorporar otros elementos al concepto de desarrollo como el aspecto humano, la educación y las políticas relacionadas con la libertad de los individuos, debido a la situación económica de los países africanos y latinoamericanos que atravesaban una profunda crisis, a pesar del esfuerzo de los planes de desarrollo mencionados en cuanto a estabilización y ajustes estructurales y que provocaron el estancamiento de la economía, recayendo el peso del ajuste en los grupos más desfavorecidos y pobres. $^{1249}$

Para este momento, la base intelectual del desarrollo humano ya había sido aceptada en los círculos académicos y solo faltaba su incorporación en otros ámbitos. El impulso recibido por la Mesa Redonda Norte-Sur y por el Comité de Naciones para la planificación del desarrollo fue fundamental, pues este último incorporó en su informe de 1988, el coste humano del ajuste estructural. $^{1250}$ Asimismo, se creó un grupo de trabajo y un seminario de investigación en Ginebra que estaba encargado de elaborar una edición especial del Informe sobre el desarrollo humano (Journal of Development Planning), además de crear la base de dicho informe destinado al Comité de las Naciones Unidas sobre planificación del desarrollo. ${ }^{1251}$

Por otro lado, el paradigma del desarrollo humano supuso un cambio radical en este campo, al cuestionar la idea fundamental que constituía la base de la economía del desarrollo. ${ }^{1252}$ Así, a partir de la obra de Amartya Sen, este concepto fue considerado como un proceso en el que se ampliaban las necesidades de las personas (tener una vida más larga, evitar enfermedades, acceso

mejorar la actividad de los mercados acomodando el sistema estructural de los países a sus ventajas comparativas. Fuente: Gonzalo Escribano, op. cit. p. 5-42.

1249 Keith Griffith: Desarrollo humano: Origen, evolución e impacto, Nosotros Latinoamericanos Organización, 2011, p. 1-11.

${ }^{1250}$ Para más información de la Mesa Redonda Norte-Sur, ver el apéndice de notas del capítulo 6. Fuente: Richard Jolly: Society for international development, the North-South Roundtable and the power of ideas, en "Development", Society for International Development, 2007, p. 47-58; North South Round Table, Human Development: The neglected dimension, 1985, Committee for Development Planning, Human Resources Development: A Neglected Dimension of Development Strategy, El desarrollo de recursos humanos: Una dimensión olvidada de la estrategia para el desarrollo), New York: United Nations, capítulo III, 1988.

1251 A partir de 1990, el Programa de las Naciones Unidas para el Desarrollo comenzó a publicar anualmente un Informe sobre Desarrollo Humano, en el que se establecía el concepto de desarrollo humano y mostraba cuáles podían ser las estrategias para diseñar las políticas de desarrollo correspondientes. Fuente: Keith Griffith: Desarrollo Humano: Origen, evolución e impacto, Nosotros Latinoamericanos Organización, 2011, p. 1-11.

${ }^{1252}$ Gonzalo Escribano, op. cit., p. 5-42. 
a conocimientos, etc.) y no únicamente como el incremento del bienestar y satisfacción económica o el aumento del producto interior bruto. ${ }^{1253}$

A su vez, el desarrollo humano pone en entredicho la idea de que la acumulación de capital físico, la inversión en infraestructura industrial y bienes de equipo, es el mecanismo para lograr el desarrollo, dándose prioridad a la acumulación de capital humano.

Algunos estudios han demostrado que el gasto en educación puede ocasionar rendimientos económicos más altos que los que se logran con la inversión de capital físico. ${ }^{1254}$ En este caso, el capital humano no se refiere únicamente al gasto en educación, sino también a la investigación y desarrollo, los gastos relacionados con los servicios sanitarios, programas de alimentación, etc. ${ }^{1255}$ Por tanto, independientemente de que se persiga un aumento del producto nacional o del potencial de los individuos, la inversión en educación puede ser igualmente beneficiosa. ${ }^{1256}$

El predominio del producto interior bruto en el campo del desarrollo llegó de la mano de autores como Meghnad Desai, Julio Boltvinik y Amartya Sen, entre otros, al inventar el índice de desarrollo humano (IDH) que fue incluido por las Naciones Unidas en su Informe sobre Desarrollo Humano anual, a la vez que pasó a ser un indicador alternativo de desarrollo aceptado a nivel mundial. ${ }^{1257}$

El enfoque de desarrollo humano nació, en parte, como resultado de las crecientes críticas al enfoque de desarrollo predominante en el decenio de 1980, el cual suponía un

\footnotetext{
1253 Amartya Sen: Development as capability expansion, en Keith Griffin y John Knight, eds., Human Development and the International Development strategy for the 1990s. Londres, MacMikllan, 1990.

1254 George Psacharopoulos: Education and development: A review, World Bank Research Observer, vol. 3, $\mathrm{n}^{\mathrm{a}} 1$, 1988; George Psacharopoulos: Return to investment in education: A global update", World development, vol. 22, 1994; Rati Ram: Level of development and returns to schooling: Some estimates from multicountry data, Economic Development and Cultural Change, vol. 44, n $\mathrm{n}^{\circ}$, 1996.

1255 John Strauss, Duncan Thomas: Health, nutrition and economic development, Journal of Economic Literature, vol. XXXVI, no 2, junio 1998.

1256 Keith Griffith: Desarrollo Humano: Origen, evolución e impacto, Nosotros Latinoamericanos Organización, 2011, p. 1-11.

1257 Desai Meghnad, Amartya Sen, Julio Boltvinik: Índice de progreso social: Una propuesta, Centro de Investigaciones Interdisciplinarias en Ciencias y Humanidades, UNAM, 1998, p. 25-100.
} 
vínculo estrecho entre el crecimiento económico nacional y la ampliación de las opciones individuales del ser humano. ${ }^{1258}$

No obstante, se ha de indicar que el índice de desarrollo humano y el producto interior bruto per cápita no pretenden cuantificar lo mismo, pues este último, es un indicador de bienestar económico, mientras que el índice de desarrollo humano busca medir el nivel de capacidad humana, las opciones de una persona y las libertades que posee. ${ }^{1259}$

A su vez, el índice de desarrollo humano está formado por una serie de componentes, entre los que figuran la esperanza de vida al nacer, la tasa de alfabetización adulta, la tasa de matriculación combinada en educación primaria, secundaria y terciaria, y la renta real medida en términos de paridad de poder adquisitivo. ${ }^{1260}$

El índice de desarrollo humano mide el progreso medio conseguido por un país en tres dimensiones básicas del desarrollo humano: Disfrutar de una vida larga y saludable, medida a través de la esperanza de vida al nacer. Disponer de educación, medida a través de la tasa de alfabetización de adultos (con una ponderación de dos terceras partes) y la tasa bruta combinada de matriculación en primaria, secundaria y terciaria (con una ponderación de una tercera parte). Disfrutar de un nivel de vida digno, medido a través del PIB per cápita en términos de la paridad del poder adquisitivo en dólares estadounidenses. ${ }^{1261}$

Aquí, es importante clarificar que el desarrollo humano no es un objetivo fácil de cuantificar y tampoco existe un criterio establecido en relación a los componentes cualitativos que dicho término comprende. Por otro lado, hay una tendencia a confundir los medios y los fines, es decir, el crecimiento económico, la modernización y el cambio tecnológico constituyen medios para el desarrollo, mientras que el fin del desarrollo es la ampliación de las libertades de los individuos.

\footnotetext{
${ }^{1258}$ Informes sobre desarrollo humano, orígenes del enfoque de Desarrollo Humano, hdr.unp.org

${ }^{1259}$ Gonzalo Escribano, op. cit., p. 5-42.

${ }^{1260}$ Keith Griffith, op.cit. p. 1-11.

${ }^{1261}$ Informe sobre el Desarrollo Humano: Cálculo de los índices de desarrollo humano, 2007-2008, p. 357-358.
} 
Estas libertades son de tipo político, civil (libertad de expresión, de participación, de elección, etc.) y social (eliminar el hambre, la mortalidad, la desnutrición, etc.). ${ }^{1262}$

De esta manera, el crecimiento deja de ser un fin para transformarse en un medio y así puede ayudar a que se consigan los dos componentes del desarrollo humano: la formación de capacidades humanas (una mejora de la salud, conocimientos y destrezas) y el uso que hace la población de esas capacidades adquiridas (el descanso, la producción y las actividades culturales, sociales y políticas. $^{1263}$

Teniendo como referente las ideas expuestas sobre el desarrollo humano, vamos a pasar ahora a calcular dicho índice para el Ecuador y a compararlo con el de otros países, para lo cual, se utilizarán los datos del Banco Mundial correspondientes al periodo 1960-1980. La escasez de datos de los años cincuenta ha impedido que se pueda calcular este índice para dicha década, problema que se plantea también en los sesenta, pese a que se puede calcular dicho índice, pero no incluye todas las variables seleccionadas.

Esto explica el por qué se ha aumentado el periodo de estudio al año 1980, ya que la disponibilidad de valores para todas las variables, nos permite comprender con mayor precisión la evolución del desarrollo humano en el Ecuador y el lugar que ocupa con respecto a los otros países elegidos.

En el cálculo del índice de desarrollo humano, es necesario crear un índice para cada uno de sus componentes (índice de esperanza de vida, educación y producto interior bruto), y se han escogido valores mínimos y máximos (valores límite) para dichos indicadores, tal y como muestra la tabla incluida en el apéndice del capítulo 6 (Tabla 2: Valores límite de los indicadores). ${ }^{1264}$

\footnotetext{
${ }^{1262}$ Falconi Benítez, Julio Oleas Montalvo: Antología de economía ecuatoriana 1992-2003, Crisis de pensamiento y desarticulación de la teoría del desarrollo económico, 14 de julio de 2004, p. 17-19.

${ }^{1263}$ Amartya Sen: Nuevo examen de la desigualdad, Alianza Editorial, Madrid, 1992; Sen, Amartya: Development as freedom, Oxford University Press, 1999, p. 50-175.

${ }^{1264}$ La fórmula para calcular el índice de desarrollo humano es la siguiente: IDH: 1/3 (índice de esperanza de vida) + 1/3 (índice de escolarización) + 1/3 (índice PIB per cápita). Fuente: Informe sobre el Desarrollo Humano, op. cit. p. 357-358.
} 
A continuación, se procede a calcular los siguientes índices usando la información proporcionada por el Informe de Desarrollo Humano. ${ }^{1265}$

- El índice de esperanza de vida, que mide los logros relativos de un país en cuanto a esperanza de vida al nacer.

- El índice de educación, que mide el progreso relativo de un país en cuanto al nivel de alfabetización de adultos y matriculación bruta combinada en educación primaria, secundaria y terciaria. En primer lugar, se calcula el índice de alfabetización de adultos y el índice de la tasa bruta combinada de matriculación. Luego, se combinan ambos índices para crear el índice de educación, en el que se da una ponderación de dos terceras partes a la alfabetización de adultos y una tercera parte a la tasa bruta combinada de matriculación ${ }^{1266}$.

- El índice del PIB, que se calcula utilizando el PIB per cápita ajustado. En el índice de desarrollo humano, los ingresos actúan como sustitutos de los demás componentes del desarrollo humano que no se reflejan en una vida larga y saludable ni en la educación adquirida. Los ingresos han de ser ajustados puesto que alcanzar un nivel respetable de desarrollo humano no requiere ingresos ilimitados, por lo que se usa el logaritmo de los ingresos.

- En último lugar, una vez que se han calculado los índices de cada componente, la determinación del índice de desarrollo humano consiste en el promedio simple de los índices de los tres componentes.

Como se puede observar en las tablas que incluyen el cálculo del índice de desarrollo humano (ver los cálculos realizados del IDH en el apéndice del capítulo 6), además del Ecuador, se han incluido cuarenta y cuatro países entre los que figuran, Alemania, Chile, Venezuela, Estados Unidos, Guatemala, China, Yemen, Nicaragua, Francia, México, Guinea, España, Sudán, Egipto, Nicaragua, México, etc., para los que también, se ha calculado dicho índice. Esto nos permitirá

\footnotetext{
${ }^{1265}$ Ibíd. p. 357-358.

${ }^{1266}$ En el segundo apartado de este capítulo, se analizará con más detalle el nivel de educación en el Ecuador.
} 
establecer una clasificación según el índice de desarrollo humano y ver cuál es el lugar ocupado por el Ecuador en el periodo 1960-1980. ${ }^{1267}$

Los cálculos realizados en la década de los sesenta muestran algunos de los países con un índice de desarrollo humano más alto como es el caso de Estados Unidos, Canadá, Suiza, Noruega, Reino Unido, Dinamarca, Francia, Finlandia y Japón, mientras que algunos de los países con menor valor son Guinea, Mozambique, Irán, Haití, Etiopía, El Salvador y Yemen. Por último, otros países como el Ecuador, Perú, Honduras, Colombia, Brasil y Nicaragua ocupan los valores correspondientes a la mitad de la clasificación de la tabla.

Aquí, hay que volver a destacar que la falta de disponibilidad de datos ha constituido un problema a la hora de calcular este índice, pues no se han podido obtener las cifras del nivel de educación y matriculación para la década de los sesenta, incorporándose únicamente, los valores de la tasa de esperanza de vida y del producto interior bruto, aunque no para todos los países.

Por otro lado, la relación del índice de desarrollo humano con sus componentes se explica aquí, a partir de sus valores, ya que cuantos mayores sean estos, más elevado será el índice y viceversa. En este caso, los países con mayor desarrollo humano son los que tienen valores más altos para el producto interior bruto y la esperanza de vida, es decir, una renta alta y unas buenas condiciones sanitarias han contribuido a alargar y mejorar la vida del pueblo, ocurriendo lo contrario en las naciones con un producto interior más bajo y peor nivel de esperanza de vida. Estos resultados son reflejo de ciertos indicadores mundiales como el producto interior bruto, la tasa de natalidad, mortalidad infantil y el analfabetismo, que permiten dividir a las naciones entre desarrolladas, en desarrollo o subdesarrolladas.

Mientras Estados Unidos posee más de 40 veces el ingreso per cápita de Tanzania, relación relativamente estable en el tiempo, otros países verificaron un ascenso meteórico en el “ranking” por producto interior bruto, como China, Japón, Taiwán. Por otro lado, regiones enteras del globo terráqueo parecen destinadas a la mediocridad: los

${ }^{1267}$ Elaboración propia a partir de la base de datos del Banco Mundial, periodo 1960-1980, data.worldbank.org. 
países de Latinoamérica luchan por revertir un estancamiento y en parte deterioro relativo de sus indicadores sociales y económicos durante décadas. ${ }^{1268}$

Por el contrario, para los cálculos de la década de los setenta, se ha podido contar con información de la escolarización y nivel de educación, pero no se dispone de la misma para todos los países. En este caso, vemos que nuevamente Estados Unidos, Canadá, Suiza, Noruega, Reino Unido, Dinamarca, Francia, Japón y Finlandia son los que tienen un índice de desarrollo humano más alto, ya que los altos valores del índice de escolarización contribuyen a afianzar su posición, junto con una alta tasa de esperanza de vida y del PIB. ${ }^{1269}$

Al final de la clasificación, también se vuelven a encontrar Guinea, Mozambique, Irán, Etiopía, El Salvador, Haití y Yemen, mientras que Perú, Honduras, Colombia, Brasil y Nicaragua se han mantenido en la mitad de la clasificación de una forma aproximada.

En el caso del Ecuador, si bien este pasó a situarse en el puesto número diecinueve a finales de los setenta, la tendencia fue la de mantenerse entre el número veintitrés y veintiséis de la clasificación. Esto pone de manifiesto que a pesar de la ligera mejora producida en los últimos años de dicha década, el bajo nivel de escolarización y educación de la población ecuatoriana ha contribuido de forma negativa al desarrollo humano, al igual que ha ocurrido con la tasa de esperanza de vida y el producto interior bruto.

Los resultados obtenidos del índice de desarrollo humano para el Ecuador no son ajenos a lo que se ha venido analizando en esta tesis, ya que teniendo en cuenta las reflexiones anteriores, las profundas y marcadas desigualdades a nivel social e institucional y la concentración de poder y riqueza han creado políticas sesgadas que han desfavorecido a los grupos de ingresos bajos y medios, cuyos intereses apenas han sido representados por sus gobernantes. A su vez, la desigualdad ha dificultado el propósito para disminuir la pobreza, pues la alta fragmentación social no ha contribuido a remediar las crisis, y por consiguiente, el desarrollo del país se ha visto mermado.

\footnotetext{
${ }^{1268}$ Silvia London, María M. Formichella: El concepto de desarrollo de Sen y su vinculación con la educación, Economía y Sociedad Volumen XI, n. 17, Editorial: Universidad Michoacana de San Nicolás de Hidalgo, México, 2006, p. 17-32.

${ }^{1269}$ Ver cálculos en el apéndice de datos del capítulo 6. Elaboración propia a partir de la base de datos del Banco Mundial, periodo 1960-1980, data.worldbank.org.
} 
Aquí, se pueden aplicar las ideas de Amartya Sen, ya que, para que un individuo pueda gozar de una buena vida, ha de tener la capacidad suficiente para hacer determinadas cosas que valorará por diferentes motivos. ${ }^{1270}$ Esta valoración puede ser directa según el tipo de elementos que le permitan tener mejor calidad de vida, como una buena salud, nutrición, y también, indirecta dependiendo de la posibilidad para contribuir más y mejor en la producción.

Asimismo, este autor se refiere a las capacidades como las libertades fundamentales que pueden poseer los individuos, entre las que se encuentran las instituciones sociales y económicas, como los servicios de educación y salud, o los derechos humanos y políticos, tales como la libertad de expresión y el derecho a elegir los gobernantes de una nación. ${ }^{1271}$

En esta dirección, Sen señala que la pobreza y el desempleo, desde el momento en que inhiben la manera en que los individuos pueden disfrutar de la vida, representan graves violaciones a la libertad $^{1272}$. Así pues, para que un país se desarrolle es necesario que se eliminen aquellos obstáculos que privan al hombre de su libertad, tales como la pobreza, las dictaduras, la falta de oportunidades económicas y las privaciones sociales, entre otras ${ }^{1273}$.

Al mismo tiempo, las libertades fundamentales que conforman el proceso de desarrollo no sólo son un objetivo primordial para Sen, sino que también forman parte de sus medios principales, están íntimamente relacionadas entre sí y pueden reforzarse unas a otras:

Las libertades políticas (en forma de libertad de expresión y elecciones libres) contribuyen a fomentar la seguridad económica. Las oportunidades sociales (en forma de servicios educativos y sanitarios) facilitan la participación económica. Los servicios económicos (en forma de oportunidades para participar en el comercio y la producción)

\footnotetext{
1270 Amartya Sen: Desarrollo y Libertad, Editorial Planeta, 1999; Capital humano y capacidad humana, Foro de economía política, en www.red-vertice.com/fep, 2004, p. 180-430.

${ }^{1271}$ Ibíd. p. 180-440.

1272 Amartya Sen: Desigualdad y desempleo en la Europa contemporánea, Revista Internacional del Trabajo Vol. 136, número 2, 1997.

${ }^{1273}$ Silvia London, María M. Formichella, op. cit.p.17-32.
} 
pueden contribuir a generar riqueza personal y general, así como recursos públicos para financiar servicios sociales. ${ }^{1274}$

Por otro lado, se observa cómo la evidencia empírica obtenida muestra importantes vínculos entre el crecimiento humano y el desarrollo humano, los cuales se manifiestan en los dos sentidos, por lo que para maximizar las posibilidades del círculo se necesitan políticas que puedan consolidar esos lazos.

Así pues, las medidas políticas implantadas deben asegurar que los mayores ingresos derivados del crecimiento económico tengan como destino la inversión en el capital humano, tanto a nivel del gobierno como de la población, a través del aumento de la eficiencia y eficacia del gasto social, sobre todo en cuanto a la calidad de la educación pública y la infraestructura educativa. ${ }^{1275}$ En este sentido, es preciso que estas políticas mantengan el crecimiento favorable al desarrollo humano a través del uso intensivo del trabajo para que la tasa de desempleo disminuya, se distribuyan las rentas generadas y mejore la educación y sanidad.

A partir de aquí, la obtención de un elevado índice de desarrollo humano dependerá del nivel de progreso de la sociedad, del crecimiento de la economía, la reducción de las desigualdades, el aumento de la participación, libertad, derechos civiles y políticos y en último lugar, de la eficiencia en términos de uso y disponibilidad de los recursos, ya que el desarrollo humano fomenta el crecimiento, siempre y cuando, este pueda favorecer de manera directa a las personas más pobres y grupos marginados. De esta forma, si el crecimiento económico se basa en la formación de capital humano, entonces, el desarrollo humano no solo será una meta de crecimiento a lograr, sino que también constituirá un medio para poder obtenerlo. ${ }^{1276}$

\section{2) Teorías del crecimiento y análisis empírico: Determinantes del crecimiento económico ecuatoriano.}

Tras la revisión de algunas de las teorías y factores que afectan el desarrollo de un país, vamos a pasar ahora a analizar el concepto de crecimiento económico y algunas de sus principales

\footnotetext{
${ }^{1274}$ Amartya Sen, Desarrollo..., op. cit. p.53.

${ }^{1275}$ Fernando Vázquez: La relación entre crecimiento económico y desarrollo humano en el Perú, Revista Moneda, Crecimiento económico y desarrollo, número 151, 2012, p. 12.

${ }^{1276}$ Gonzalo Escribano, op. cit. p. 5-42.
} 
escuelas, así como las variables a tener en cuenta en nuestro análisis empírico dependiendo de su mayor o menor impacto en una economía como la ecuatoriana.

En términos generales, se puede decir que la importancia dada al estudio del crecimiento económico ha aumentado en los últimos años, al constituir una medida y un objetivo del bienestar de un país y llevar asociado un mayor uso de bienes y servicios para satisfacer las necesidades de una población. ${ }^{1277}$

Con estas ideas, una primera definición del crecimiento económico se refiere al incremento sostenido del producto per cápita o por trabajador. ${ }^{1278}$ Es decir, el crecimiento se correspondería con un incremento del valor de los bienes y servicios producidos por un país durante un intervalo de tiempo, siendo la tasa de crecimiento del producto interior, la medida empleada, la cual es calculada en términos reales para eliminar los problemas ocasionados por la inflación. ${ }^{1279}$

Otros autores también consideran que el crecimiento económico se corresponde con un aumento de la renta, de la producción de bienes y servicios finales o del producto interior bruto (PIB). En este caso, las variables económicas fundamentales son el consumo de las familias, la inversión, el gasto del gobierno y las exportaciones netas (exportaciones menos importaciones). ${ }^{1280}$ Asimismo, la importancia del estudio del crecimiento económico se debe a que, en la mayoría de los casos, su aumento tiende a estar asociado con un resultado positivo del bienestar de la población. Sin embargo, si bien los habitantes de los países con altos niveles de producto interior bruto suelen disponer de una mejor calidad de vida, también puede ocurrir que el crecimiento económico venga acompañado por el incremento de la desigualdad, sobre todo en la distribución de los ingresos, como ocurrió en el Ecuador en los años setenta. ${ }^{1281}$

Además, los países con mayores índices de crecimiento normalmente experimentan una serie de cambios que se manifiestan en una disminución del peso del sector agrario, la concentración de

\footnotetext{
${ }^{1277}$ Miguel A. Galindo Martín: Crecimiento económico, ICE, Tendencias y nuevos desafíos de la teoría económica, no. 858, Universidad de Castilla La Mancha, enero-febrero 2011, p. 39-52.

${ }^{1278}$ S. Kuznets: Modern economic growth, Yale University Press, New Haven, Conn., 1966, p. 1.

${ }^{1279}$ Ibíd. p. 1.

${ }^{1280}$ Es necesario tratar el PIB en términos reales, es decir, sin el efecto de la inflación. Además para que el PIB real, como indicador del crecimiento económico, sea más acertado, se puede dividir entre el número de habitantes del país que es lo que se considera como el PIB real per cápita.

${ }^{1281}$ Gonzalo Escribano, op. cit. p. 5-42.
} 
la población en zonas urbanas y menores tasas de crecimiento demográfico, siendo estas características fundamentales para los economistas a la hora de identificar qué elementos pueden afectar en mayor medida al crecimiento. ${ }^{1282}$

Partiendo de la idea de que el crecimiento económico se encuentra vinculado a la mejora del bienestar de la población, es lógico que entonces, nos preguntemos cuáles son los factores que influyen y explican dicho crecimiento y que el objetivo sea elaborar políticas públicas adecuadas que contribuyan al mismo. Esta pregunta ha constituido un tema de debate que los estudiosos del crecimiento económico han intentado responder en numerosas ocasiones, por lo que en el estudio de los elementos que pueden impulsar el crecimiento de una economía a largo plazo, se han utilizado frecuentemente los modelos económicos que constituyen una representación matemática de la producción en función de un conjunto de variables. ${ }^{1283}$

La explicación de la naturaleza del crecimiento de los países fue llevada a cabo por los economistas clásicos pertenecientes a la escuela clásica del crecimiento como Adam Smith, Thomas Malthus, David Ricardo y las contribuciones de Keynes, quienes trataron de estudiar cuáles eran los elementos que impulsaban el crecimiento y el enriquecimiento económico cuando observaron los cambios que tuvieron lugar en Inglaterra durante los siglos XVIII y XIX. ${ }^{1284}$

Mediante La riqueza de las naciones, Adam Smith indica que la riqueza de los países depende del progreso técnico y de la distribución del factor trabajo entre las actividades productivas e improductivas. Estos factores están, a su vez, influenciados por la división del trabajo (especialización), el intercambio, el tamaño de los mercados y la acumulación de capital, que son elementos importantes para que ocurra el crecimiento económico de un país. Así, una economía podrá crecer debido a la acumulación de factores como el capital (maquinaria, herramientas, etc.), el trabajo y la producción, ya que cuanto más trabajo y capital existan en una sociedad, mayor será su nivel de crecimiento económico. ${ }^{1285}$

\footnotetext{
1282 Germán Chavarría, María Fonseca, Octavio Martínez, Deybi Morales: Manual introductorio a las teorías del crecimiento económico, editado por Edumetnet, Universidad de Málaga, 2010, p. 7-8.

${ }^{1283}$ Miguel Ángel Galindo Martín, op. cit. p. 39-52.

1284 Entre las obras pertenecientes a la escuela neoclásica se encuentran las de Adam Smith: La riqueza de las naciones, primera edición 1776; Thomas Malthus: Ensayo sobre el principio de la población, primera edición, 1798, p. 150-595; David Ricardo: Principios de economía política y tributación, edit. Pirámide, 2003 (1817).

${ }^{1285}$ Adam Smith: La riqueza de las naciones, primera edición 1776, en Miguel Ángel Galindo Martín, op. cit. p. 3952.
} 
Sin embargo, esta teoría afirma que una vez que los recursos disponibles han sido utilizados, se alcanza un punto estacionario en el que la economía no puede crecer más y tampoco se produce una mejora en la calidad de vida de las personas. Es decir, el crecimiento económico se encuentra limitado por los factores de producción y por el hecho de que las oportunidades de inversión van desapareciendo, siendo estos rendimientos decrecientes.

Esta situación explica la gran importancia dada a la acumulación de capital, ya que permite incrementar la cantidad de capital por trabajador y su productividad; y a la apertura de nuevos mercados e innovaciones que originen nuevas oportunidades de inversión. A su vez, se ha de considerar el conjunto de instituciones y leyes de un país, en el sentido de que pueden limitar el comercio y disminuir las posibilidades de inversión, lo cual acelerará la llegada a ese punto estacionario en el crecimiento. ${ }^{1286}$

También, David Ricardo se refirió a la etapa estacionaria e indicó que el incremento de capital y el avance técnico eran factores fundamentales con los que se podrían evitar los rendimientos decrecientes, mientras que para Malthus, los elementos que afectaban al crecimiento de forma negativa eran la falta de consumo, el exceso de ahorro y la población. ${ }^{1287}$ Según este autor, el crecimiento económico dependía de la demanda adicional, una mayor inversión y el incremento de la oferta, siendo la dinámica de la población la causante del estado estacionario, al originar los rendimientos decrecientes. ${ }^{1288}$

Las aportaciones de John Keynes a la teoría del crecimiento económico destacaban la existencia de factores como la actitud asociada a la hora de invertir y el ahorro que afecta a la riqueza dependiendo de lo que las personas hagan con él. Posteriormente, este mismo autor señaló que las modificaciones en la tecnología, población, distribución de la renta y ahorro, también generaban un impacto en el crecimiento económico. ${ }^{1289}$

Las teorías clásicas del crecimiento producidas entre 1750 y 1936, tenían en común una actitud negativa con respecto al futuro de los países industrializados de la época, a la vez que mostraban un gran optimismo con respecto a la situación de las economías menos desarrolladas, siempre y

\footnotetext{
${ }^{1286}$ Gonzalo Escribano, op. cit. p. 5-42.

${ }^{1287}$ David Ricardo, op. cit. p. 39-52.

${ }^{1288}$ Thomas Malthus, op. cit. p. 150-595; David Ricardo, op. cit. p. 39-52.

${ }^{1289}$ John Keynes: Teoría general del empleo, del interés y de la moneda, publ. Londres, 1936.
} 
cuando, estas siguieran los pasos de los países desarrollados. Sin embargo, la situación que las diferentes economías experimentaron tras el término de la Segunda Guerra Mundial (1939-1945) condujo a la aparición de nuevas teorías del crecimiento económico, entre las que se encontraban la teoría moderna del crecimiento. ${ }^{1290}$

Así pues, dicha teoría se caracterizó por un conjunto de estudios que comprendían un mayor interés en el análisis empírico que las teorías clásicas, debido al progreso realizado en el marco de la econometría y a la mejora de la información estadística, permitiendo la consideración de un número más amplio de países y la incorporación de más variables de tipo cuantitativo y cualitativo. Asimismo, las contribuciones realizadas por esta escuela han supuesto una mejora y modernización de las aportaciones clásicas, siendo el punto de partida los estudios de Harrod y Domar. $^{1291}$

Una de las características más importantes de estas investigaciones es su origen común, pues fueron realizadas para dinamizar el análisis económico de Keynes, al ampliar la dinámica a corto plazo introducida por dicho autor. ${ }^{1292}$ Este modelo se basaba en la búsqueda de las condiciones que tenían que darse en una economía de mercado para crear el volumen de demanda necesario y mantener de este modo, una situación de crecimiento equilibrado y de pleno empleo. Se trataba por tanto, de un análisis en el que la tasa de producción y su crecimiento estaban determinados por la demanda. ${ }^{1293}$

Las conclusiones desalentadoras sobre la estabilidad del crecimiento llevaron a la elaboración de un modelo básico de una economía dinámica, siendo Solow y Swan, los encargados de dicho modelo. ${ }^{1294}$ El elemento diferenciador de su aportación era una función de producción neoclásica con rendimientos constantes a escala, rendimientos decrecientes de los factores y una elasticidad de sustitución positiva entre ellos. De esta manera, en el modelo de crecimiento de Solow se

\footnotetext{
${ }^{1290}$ Gonzalo Escribano, op. cit. p. 5-42.

1291 E.D. Domar: Essays in the theory of economic growth, Oxford, New York: Oxford University Press, 1957, p. 100-250; R. F. Harrod: An essay in dynamic theory, Economic Journal, 49, 1939, Towards a dynamic economics, Londres, Macmillan, 1948, p. 19-33.

${ }^{1292}$ Ibíd. p. 100-250; Ibíd. p. 19-33.

1293 Miguel Ángel Galindo Martín, op. cit. p. 39-52; Marianela Gómez: Determinantes empíricos del crecimiento económico, Universidad Nacional de Río Cuarto, diciembre 2010, p. 1-23.

${ }^{1294}$ R. Solow: A contribution to the theory of economic growth, en The Quarterly Journal of Economics, Vol. 70, No. 1, Febr. 1956, p. 65-94; T. Swan: Economic growth and capital accumulation, vol. 32, num. 2, 1956 , p. 334-361.
} 
permitía la sustitución de un factor por otro (capital por trabajo) en la producción, admitiéndose la posibilidad del progreso técnico y, con ello, la movilidad de la función de la producción. ${ }^{1295}$ Las contribuciones de Solow y Swan (modelos neoclásicos de crecimiento exógenos) y las postkeynesianas, entre otras, intentaron buscar una solución a los problemas de estabilidad del modelo de Harrod y Domar. ${ }^{1296}$

Los modelos neoclásicos de crecimiento exógeno parten de los estudios de Solow y Swan, en los que se incorpora una función de producción con rendimientos constantes a escala y decrecientes para cada uno de los factores productivos y los mercados son perfectamente competitivos, generándose así, una situación de equilibrio sostenido a largo plazo con pleno empleo y con tasas nulas de crecimiento de la renta per cápita. ${ }^{1297}$

Estos resultados justifican la introducción del progreso tecnológico como el factor exógeno que determina la existencia de tasas de crecimiento positivas a largo plazo de la renta per cápita. La necesidad de incorporar mejores técnicas exógenas es la razón por la que estos modelos reciben el nombre de crecimiento exógeno, en los que las variables políticas no ejercen gran influencia. Por otra parte, el modelo neoclásico de Solow y Swan intentaba explicar el comportamiento del crecimiento de una economía desarrollada como la de los Estados Unidos, mostrando que los rendimientos decrecientes del capital suponen que la acumulación de capital físico no puede explicar el crecimiento económico a largo plazo. Solow considera la existencia de un conjunto de factores que afectan al crecimiento económico, como es el caso de la tasa de acumulación de capital humano y físico, el nivel de ingreso inicial y el crecimiento demográfico, a lo que se ha de añadir las variables macroeconómicas e institucionales. ${ }^{1298}$

A pesar de que el modelo proporciona un equilibrio estable, algunas de las críticas recalcan el hecho de no explicar el papel del progreso técnico, al ser determinado de forma exógena en el modelo. No obstante, los modelos de crecimiento endógenos coinciden en que el factor

\footnotetext{
1295 Germán Chavarría, María Fonseca, Octavio Martínez, Deybi Morales: Manual introductorio a las teorías del crecimiento económico, editado por Edumetnet, Universidad de Málaga, 2010, p. 7-8.

${ }^{1296}$ R. Solow, op. cit., p. 65-94.

${ }^{1297}$ Marianela Gómez, op. cit. p. 1-23.

${ }^{1298}$ R. Solow, op. cit. p. 65-94; T. Swan, op. cit. p. 334-361.
} 
tecnológico tiene una gran importancia al definir el crecimiento económico, pero esta es una variable difícil de definir.

Por su parte, las teorías post-keynesianas tienen como base las ideas de Keynes y señalan que la economía capitalista está caracterizada por su inestabilidad como consecuencia de la divergencia existente entre los incentivos públicos y privados, lo cual acaba provocando fallos en la demanda. En este caso, el estado es el agente que debe de hacerse cargo del desequilibrio generado a través del gasto, sirviendo como freno al poder de las grandes corporaciones y sector financiero. Aquí, la variable más importante es la acumulación de capital, ya que tiene un gran peso en el nivel de empleo y la inversión, produciéndose esta, en el momento en que los empresarios piensan que pueden lograr un aumento de sus beneficios futuros. ${ }^{1299}$

Posteriormente, en los años sesenta, el desarrollo teórico del crecimiento se llevó a cabo gracias a los estudios de Cass y Koopmans a partir de un modelo elaborado por Ramsey. ${ }^{1300}$ En el modelo de Ramsey-Cass-Koopmans, un agente establecía un patrón de consumo óptimo en una senda de crecimiento, completándose la teoría neoclásica a partir de la idea de que los consumidores eran optimizadores racionales.

En este sentido, dichos autores contribuyeron a la dinámica de la transición de un estado estacionario a otro, aunque respetando la mayor parte de las conclusiones del modelo neoclásico de Solow.

A pesar de esto, los rendimientos decrecientes también llevaban a un resultado en el que la economía dejaba de crecer a la larga, y al igual que los otros modelos neoclásicos, las predicciones de este enfoque no coincidían con la evidencia empírica.

Aquí, hay que aclarar que las contribuciones de Robert Solow crearon una creciente insatisfacción en este campo de la investigación, pues algunas predicciones teóricas, como el

\footnotetext{
${ }^{1299}$ Algunos de los autores que pertenecen a esta escuela son P. Davidson: Post Keynesian Macroeconomic Theory, Aldershot, UK: Edward Elgar, 1994; H.P. Minsky: The Legacy of Keynes, Metroeconómica, vol. XXXV, febrerojunio 1983.

${ }^{1300}$ F. Ramsey: A mathematical theory of saving, Economic Journal 38, 1928; D. Cass: Optimum growth in an aggregate model of capital accumulation, Review of Economic Studies 32, 1965; J. Koopmans: On the concept of optimal economic growth, en The Economic Approach to Development Planning, 1965.
} 
caso de la hipótesis de convergencia, no se verificaban claramente y existían algunos problemas en las investigaciones empíricas. ${ }^{1301}$

El escaso avance en esta materia durante tres décadas se debió, en gran medida, a que los modelos teóricos existentes imponían la restricción de exogeneidad al crecimiento de largo plazo, lo cual disminuía las posibilidades de interpretación de dichos modelos y minimizaba el papel de las políticas económicas en el crecimiento. ${ }^{1302}$ A su vez, la ausencia de series de datos comparables para un número significativo de países ha sido una restricción para la comprensión del crecimiento económico.

En los años ochenta, el interés de los economistas por este tema volvió a aparecer con los trabajos de Paul Romer y Robert Lucas, creándose modelos para superar los problemas de los enfoques neoclásicos ${ }^{1303}$. En este sentido, el elemento fundamental del crecimiento, el progreso técnico, era producido en el interior del modelo, lo cual dio origen a la teoría de crecimiento endógeno. Así, los países podían mostrar tasas de crecimiento mantenidas en el tiempo, cuya base era la capacidad para innovar, sin que se tuviera que producir la convergencia de la teoría neoclásica.

De forma paralela, Heston y Summers publicaron un panel de datos sobre las cuentas nacionales de más de 130 países con información desde 1960-1985, el cual permitía comparar los datos en la misma unidad a nivel internacional. ${ }^{1304}$

1301 La hipótesis de convergencia deriva del modelo de crecimiento neoclásico con rendimientos de capital decrecientes y predice que las economías menos productivas crecen más rápido que las de un nivel productivo y por tanto, en el largo plazo tienden al mismo nivel de ingreso. En contraste, los modelos de crecimiento endógeno suponen que cuando una economía presenta rendimientos de escala crecientes, se produce un crecimiento a largo plazo sostenido, cuya consecuencia podría ser un proceso de divergencia respecto de las economías caracterizadas por un crecimiento exógeno. Fuente: CEPAL: La República Dominicana en 2030: Hacia una nación cohesionada, Víctor Godínez y Jorge Máttar, coordinadores, sept. 2009, p. 79; Felipe Larraín, Rodrigo Vergara: Distribución del ingreso, inversión y crecimiento, Cuadernos de economía, año 29, número 87, agosto 1992, p. $207-228$.

${ }^{1302}$ Para más información del modelo de Solow, ver el apéndice de notas del capítulo 6. Fuente: Fernando Villarán: Política económica, planeamiento, desarrollo regional y local, Instituto para la Democracia y la Asistencia Electoral, IDEA Internacional, Asociación Civil Transparencia, coordinación general Pila Tello Rozas, marzo 2009, p. 19-25.

${ }^{1303}$ Paul Romer: Increasing returns and long-run growth, The Journal of Political Economy, Vol. 94, No. 5, octubre 1986, p. 1002-1037; Robert Lucas: On the mechanics of economic development, Universidad de Chicago, Journal of Monetary Economics 22, 1988, p. 3-42.

${ }^{1304}$ A. Heston, R. Summers: What we have learned about prices and quantities from international comparisons, The American Economic Review, vol. 78, No. 2, mayo 1988. 
El primer estudio conocido que hizo uso de dicha base de datos fue el de Robert Barro, mediante el cual, se creó lo que hoy día se conoce como literatura empírica del crecimiento, centrada en el establecimiento del enfoque adecuado (neoclásico o crecimiento endógeno), además de indicar cuáles son los determinantes o factores que influyen en el crecimiento económico. ${ }^{1305}$

Al referirse a los determinantes del crecimiento económico, la literatura empírica ha estado guiada por la siguiente cuestión: ¿por qué algunos países han crecido tanto y son ricos mientras que otros países son pobres e incluso tienen niveles próximos a los de subsistencia?

Si se parte de la idea de que las naciones desarrolladas tenían una situación similar a la de los países subdesarrollados antes de alcanzar dicho avance, el interés por esta situación consiste en saber cuáles son los factores que han posibilitado dicha divergencia con el propósito de que los gobiernos de los países pobres puedan planificar sus economías hacia el camino del progreso. ${ }^{1306}$ Como ya sabemos, la escasez de datos comparables entre países provocó la espera durante varias décadas para poder llevar a cabo dicha tarea, siendo el estudio de Barro, el comienzo de la misma. $^{1307}$

Este autor señalaba que el crecimiento del ingreso per cápita tenía una relación positiva con el nivel de escolaridad y la estabilidad política de un país, existiendo a su vez, una relación negativa con el consumo gubernamental. Por su parte, la muestra incluía datos promedios para el periodo 1960-1985 y un total de 98 países. ${ }^{1308}$

Años más tarde, Loayza y Soto propusieron un agrupamiento de los determinantes a partir de las siguientes categorías: capital físico e infraestructura, capital humano y educación, políticas estructurales, culturales e institucionales y características demográficas. ${ }^{1309}$

\footnotetext{
1305 Robert Barro: Economic growth in a cross section of countries, the Quarterly Journal of Economics, Vol. 106, no. 2, mayo, 1991.

1306 Raymundo Chirinos: Determinantes del crecimiento económico: Una revisión de la literatura existente y estimaciones para el periodo 1960-2000, Banco Central de Reserva del Perú, Serie de Documentos de Trabajo, Agosto, 2007, p. 4.

${ }^{1307}$ Robert Barro: Economic growth in a cross section of countries, The Quarterly Journal of Economics, Vol. 102, No. 2, 1991.

${ }^{1308}$ Marianela Gómez, op. cit. p. 1-23.

${ }^{1309}$ N. Loayza, R. Soto: The sources of economic growth: an overview, en Economic growth, trends and cycles, Central Bank of Chiel, 2002; Marianela Gómez: Determinantes empíricos del crecimiento económico, Universidad Nacional de Río Cuarto, diciembre 2010, p. 1-23.
} 
Igualmente, Durlauf, Johnson y Temple presentan una lista de diferentes grupos de variables que han sido consideradas en el estudio del crecimiento económico. ${ }^{1310}$ Dicha lista incluye algunas definiciones de conceptos como gobierno, apertura comercial, inversión, educación y democracia.

En esta línea, se han de destacar las contribuciones de Levine y Renelt en cuanto a la selección de las variables adecuadas, pues afirman que algunas de estas como el nivel inicial del PIB per cápita real, la tasa de matriculación en la escuela secundaria, la inversión como porcentaje del PIB y el promedio de una tasa anual de crecimiento de la población han de ser las principales variables a considerar, mientras que los estudios de Sala-i-Martin incorporan un número más amplio de variables en su estudio empírico. ${ }^{1311}$

Además, Levine y Renelt consideran que la tasa de inversión en capital físico y la cantidad de capital humano inicial son factores que pueden afectar de forma positiva al crecimiento, mientras que el ingreso per cápita inicial y el crecimiento de la población pueden ocasionar un impacto negativo. ${ }^{1312}$

También, tienen en cuenta el impacto de diversos factores de carácter socio-político (la disparidad del ingreso, las guerras de tipo civil y étnicas y la inestabilidad política) y económico (la composición del gasto, la inversión en capital humano y físico, el grado de apertura de la economía, etc.). Así pues, ya vimos cómo al medir el desarrollo económico de un país se han de incorporar otras variables como los efectos sociales y políticos, la desigualdad económica, el coste medioambiental, las modificaciones en la población y los problemas relacionados con la distribución de la renta. ${ }^{1313}$

La incorporación de estos factores se debe a que, en muchos casos, se piensa que un mayor crecimiento económico implica el uso de una política económica apropiada, por lo que los países

\footnotetext{
${ }^{1310}$ S. N. Durlauf, P. A. Johnson, J.R. Temple: Growths econometrics, en S.N. Durlauf, P. Aghion (Eds), Handbook of Economic Growth, Elsevier, 2005.

1311 R. Levine, D. Renelt: A sensitivity analysis of cross-country growth regressions, the American Economic Review, 82(4), 1992, p. 942-963; Sala-i-Martin: I just ran two million regressions, American economic review, 87(2), 1997; Marianela Gómez: Determinantes empíricos del crecimiento económico, Universidad Nacional de Río Cuarto, diciembre 2010, p. 1-23

1312 Carlos Dabús, Yanina Laumann: Determinantes del crecimiento: Evidencia comparada de países con diferente nivel de desarrollo, Universidad Nacional del Sur (Argentina), Vol. 24-1, 2006, p. 165-180.

${ }^{1313}$ Marianela Gómez, op. cit. p. 1-23.
} 
con una baja tasa crecimiento deberían de seguir medidas políticas similares a estos países para lograr un aumento de dicha tasa. Por esta razón, como ya se indicó con anterioridad, se han ido introduciendo diferentes indicadores para medir el desarrollo humano y progreso social como el índice de desarrollo humano (IDH) o el índice de salud social (Index of Social Health o ISH), entre otros.

En el estudio del crecimiento económico, algunos autores, como Maddison, observaron la evolución histórica de distintos países, mostrando diferencias en las tasas de crecimiento anual en cada una de estas economías. ${ }^{1314}$ El estudio de Maddison abarcaba un análisis del crecimiento a largo plazo desde el año 1820 y recogía un conjunto de países desarrollados y países en vías de desarrollo, siendo el crecimiento per cápita más rápido en las economías más avanzadas.

Al parecer, la evidencia empírica puso de manifiesto una serie de variables y pautas de crecimiento que, tanto los países industrializados, como los que se encontraban en vías de desarrollo debían seguir, y que únicamente las teorías del crecimiento económico podían explicar. $^{1315}$

En esta línea, Barro dice que dicha relación se cumple para el conjunto de países más pobres en una amplia muestra de países desarrollados y subdesarrollados. ${ }^{1316}$ Para ello, aplica una metodología en la que se explica la tasa de crecimiento del producto a partir de un conjunto de factores, siendo la variable dependiente en este tipo de regresiones, la tasa promedio de crecimiento del producto interior bruto per cápita para un momento determinado.

Los resultados obtenidos establecen que el nivel inicial de ingreso per cápita, la inestabilidad política (medida a partir del número de revoluciones, guerras y golpes de estado de un país) y la distorsión del mercado suelen tener un impacto negativo en el crecimiento de la economía, mientras que el capital humano, el porcentaje de producto destinado a la inversión y un mejor desarrollo de los mercados financieros suelen tener un efecto positivo en el crecimiento. ${ }^{1317}$

\footnotetext{
${ }^{1314}$ A. Maddison: Monitoring the World Economy, 1820-1992, public. OECD, enero 1995.

${ }^{1315}$ Por ejemplo, el PIB en Francia y Alemania aumentó 13 veces y en Estados Unidos hasta 17 veces. En cambio, en los países iberoamericanos solo se incrementó siete veces, mientras que la situación de África en el año 1992, era la misma que mostraban los países europeos en 1820. Fuente: Miguel Ángel Galindo Martín: Crecimiento económico, Tendencias y nuevos desarrollos de la teoría económica, pp. 39-52, nº 858 ICE, Enero-Febrero 2011.

${ }^{1316}$ Robert Barro: Inequality and growth in a panel of countries, Journal of Economic growth, vol. 5, 2000, p. 5-32.

${ }^{1317}$ Marianela Gómez, op. cit. p. 1-23.
} 
A continuación, vamos a revisar con más detalle algunos de los factores que influyen en el crecimiento, y para ello, empezaremos con las variables que Levine y Renelt consideraron como robustas a la hora de explicar el crecimiento de una economía: el nivel inicial de ingreso, el capital humano y la inversión en capital físico. ${ }^{1318}$ Asimismo, se han seleccionado otras variables que corresponden a un subconjunto de las identificadas por Durlauf, Johnson y Temple y que pueden influir en el crecimiento económico: las condiciones iniciales y variables exógenas, factores políticos, inputs intermedios y variables institucionales. ${ }^{1319}$

En nuestra clasificación, se incluye el valor inicial del producto, la esperanza de vida y la población urbana al inicio del periodo dentro de la primera categoría (condiciones iniciales y variables exógenas). Como parte de los inputs intermedios tenemos la acumulación de capital físico y humano, que están representados por la inversión como porcentaje del producto interior bruto, el stock de años de escolaridad y la tasa de crecimiento de la población. Por último, dentro de las variables políticas, incluiremos la medida de apertura de la economía, el consumo del gobierno y el precio de la inversión, mientras que en las variables institucionales, consideraremos un índice de derechos políticos y libertades civiles (ver la Tabla 4: Determinantes del crecimiento). ${ }^{1320}$

\section{Ingreso inicial per cápita}

Los estudios realizados por Levine y Renelt determinaron que el nivel de ingreso inicial era una de las variables más importantes para explicar el crecimiento promedio en una muestra de 119 países, siendo para el periodo seleccionado $1960-1985$. $^{1321}$

A este respecto, una de las primeras ideas establecidas en el modelo de crecimiento neoclásico se refiere a la dependencia de la tasa de crecimiento con respecto de la posición inicial de una economía. Algunos autores como Barro y Sala-i-Martin establecen la hipótesis de convergencia condicional, que implica que si todos los factores se mantienen constantes (ceteris paribus), los países pobres deberían de crecer de forma más rápida que los países ricos debido a los retornos

\footnotetext{
${ }^{1318}$ R. Levine, D. Renelt, op. cit. p. 942-963.

${ }^{1319}$ S. N. Durlauf, P. A. Johnson, J.R. Temple: Growths econometrics, en S.N. Durlauf, P. Aghion (Eds), Handbook of Economic Growth, Elsevier, 2005.

${ }^{1320}$ Esta tabla se encuentra en el apéndice de datos del capítulo 6. Fuente: Marianela Gómez, op.cit. p. 1-23.

${ }^{1321}$ Levine, D. Renelt, op. cit. p. 942-963.
} 
decrecientes en el factor capital. ${ }^{1322}$ Es decir, cada vez se obtendrá menos producción conforme se añadan cantidades adicionales de un bien, siempre y cuando, el resto de los factores se mantenga constante y se estime el signo del coeficiente del nivel inicial del PIB cápita en el año de partida (yi,o). ${ }^{1323}$

A su vez, las regresiones de corte transversal realizadas por estos autores muestran de forma constante la importancia de las condiciones iniciales, lo cual explica el uso del PIB inicial o el logaritmo del nivel inicial del PIB per cápita. ${ }^{1324}$

Por tanto, teniendo en cuenta que la incorporación de las condiciones iniciales para comprobar la convergencia condicional ha constituido un hecho de fuerte carácter en la literatura económica, se considerará el ingreso inicial per cápita como la variable dependiente de nuestro estudio empírico, la cual estará representada por Yt con un valor al inicio del periodo (ver la tabla 5: Descripción de las variables del estudio empírico, Ecuador 1950-1980). ${ }^{1325}$

\section{Inversión}

Aún cuando el modelo neoclásico indica que esta variable no puede ser considerada como parte fundamental del crecimiento, sino como un factor que explica la transición hacia el nivel del estado estacionario, la inversión como capital físico e infraestructura constituye el punto de partida en el análisis del crecimiento de una economía. ${ }^{1326}$ A este respecto, se ha de destacar el estudio de Levine y Renel que indica que esta variable junto con el nivel de ingreso inicial son algunos de los elementos más importantes a la hora de explicar el crecimiento promedio para una muestra de 119 países en el periodo 1960-1985. ${ }^{1327}$ Sin embargo, se ha de destacar que este estudio es bastante crítico en cuanto a los cambios de las variables, pues cualquier modificación

\footnotetext{
${ }^{1323}$ Marianela Gómez, op. cit. p. 1-23. 2002.

${ }^{1325}$ Esta tabla se encuentra en el apéndice de datos del capítulo 6.

${ }^{1326}$ Raymundo Chirinos, op. cit. p. 6.

${ }^{1327}$ R. Levine, D. Renelt, op. cit. p. 942-963.
}

${ }^{1322}$ R. Barro, Sala-i-Marti: Convergence, Journal of political economy, 100(2), 1992, p. 223.

${ }^{1324}$ R. Barro: Economic growth in a crow section of countries, The quarterly journal of economics, 106 (2), $1997, \mathrm{p}$. 407-443; R. Barro: Determinants of Economic Growth: A cross-country empirical study, The MIT Press, 1997 ; R. Barro: Inequality and growth in a panel of countries, Journal of Economic Growth 5(1), 2000, p 5-32; N. Loayza, R. Soto: The sources of economic growth: an overview, en Economic Growth, trends and cycles, Central Bank of Chile, 
puede presentar cambios de signo o resultar no significativa dependiendo del tipo de país que se analice. $^{1328}$

De igual forma, el impacto de la acumulación de capital en el crecimiento de una economía está relacionado con el modelo de Solow, pues la inversión puede hacer que la cantidad de capital aumente a un nivel que compensa el crecimiento de la población, la depreciación de capital y el progreso de la tecnología. En este caso, el efecto de la inversión en el potencial de crecimiento económico puede ser medido mediante el ratio de inversión con respecto al producto interior bruto. $^{1329}$

Asimismo, Barro habla sobre la estrecha relación existente entre la inversión y el crecimiento, ya que al usar regresiones de corte transversal para identificar los factores empíricos de la tasa de crecimiento de una economía, la inversión como porcentaje del PIB aparece como variable explicativa con signo positivo y significativo. ${ }^{1330}$ De igual manera, analiza la inversión como variable dependiente y establece que los determinantes son parecidos a los de la tasa de crecimiento del producto interior bruto per cápita.

En nuestro caso vamos a usar también la inversión como porcentaje del PIB, la cual parecerá representada como InverPIB (ver la tabla 5: Descripción de las variables del estudio empírico, Ecuador 1950-1980). ${ }^{1331}$

\section{Capital Humano}

El modelo neoclásico ponía de manifiesto que las desigualdades en los niveles de ingreso podían mejorar, al aumentar el peso del factor capital en la función de la producción. Esto suponía la elaboración de una nueva definición para el capital humano, a partir de la cual, la capacidad productiva de una persona puede aumentar mediante una mejora de la salud y educación.

Robert Barro afirma que el capital humano afecta de diferentes formas al crecimiento de una economía, pues un alto nivel de esta variable puede impulsar la acumulación de capital o

\footnotetext{
${ }^{1328}$ Marianela Gómez, op. cit. p. 1-23.

${ }^{1329}$ R. Solow, op. cit. p. 65-94.

${ }^{1330}$ R. Barro, Economic growth..., op. cit. p. 407-443.

${ }^{1331}$ Ver el apéndice de notas del capítulo 6 para más información. Fuente: R. Solow, op. cit. p. 65-94.
} 
incrementar el nivel de innovación tecnológica en aquellas naciones que produzcan tecnología, además de facilitar la absorción de la misma en países que traten de imitarla. ${ }^{1332}$

Barro, Levine y Renelt utilizan la tasa de matriculación de la mano de obra como variable para medir el capital humano. ${ }^{1333}$ Por su parte, Barro usa la tasa de matriculación en la escuela primaria y secundaria para el periodo 1950-1970 y habla sobre la existencia de una relación positiva con el crecimiento promedio.

Análisis posteriores de Barro vuelven a confirmar todos estos estudios y encuentran una relación positiva y significativa de la educación en el crecimiento, siendo la calidad de la educación más importante que la cantidad. ${ }^{1334}$ En este caso, la hipótesis que se establece se refiere a que cuanto mayor sea el capital humano, medido en términos de la tasa de matriculación en el colegio, más elevado será el crecimiento de una economía.

En nuestro estudio empírico, se usará el valor de la educación secundaria como capital humano y aparecerá representada como SecEdu (ver tabla 5: Descripción de las variables del estudio empírico, Ecuador 1950-1980). Este término incorpora las predicciones de la teoría del crecimiento en cuanto a la idea de que las sociedades desarrolladas suelen tener un nivel más alto de educación y estar más urbanizadas, produciéndose un cambio en el énfasis de la agricultura hacia la manufactura y servicios en la estructura económica. ${ }^{1335}$

\section{Apertura Comercial}

Al considerar la apertura como un factor del crecimiento, se tienen en cuenta los resultados obtenidos de la observación empírica que indican que las economías más abiertas son las más desarrolladas, entre las que se producen los intercambios comerciales a nivel mundial.

La literatura destaca cinco canales por los cuales el comercio exterior afecta el crecimiento económico de un país: ${ }^{1336}$ el aprovechamiento del uso de economías de escala al ampliar el mercado de las firmas nacionales, menores prácticas anticompetitivas al impulsar la competencia

\footnotetext{
${ }^{1332}$ R. Barro, Economic growth..., op. cit. p. 407-443.

${ }^{1333}$ Ibíd. p. 407-443, 1991; R. Levine, D. Renelt, A sensitivity..., op. cit.p. 942-963.

${ }^{1334}$ R. Barro: Human capital and growth, American Economic review 91, 2001, p. 12.

${ }^{1335}$ O. Galor: From stagnation to growth: Unified growth theory, en Handbook of Economic Growth, en P. Aghion y S.N. Durlauf (eds), Handbook of Economic Growth, Elsevier, vol. 1A, cap. 4, 2005, p. 171-293; S. Kuznets: Economic growth and income inequality, American Economic Review 45 (1), 1955, p. 1-28.

${ }^{1336}$ N. Loayza, R. Soto: The sources of economic growth: an overview, Banco Central de Chile, 2002, p. 2-29.
} 
exterior, mayor especialización que lleva a ganancias de eficiencia, disminución de actividades para buscar rentas y permitir la expansión de innovaciones tecnológicas y mejores prácticas empresariales que aparecen con el contacto con el mundo externo. Esta última razón lleva a un crecimiento sostenido, mientras que las cuatro primeras, serían equivalentes a las ganancias obtenidas en un momento dado, las cuales permitirían a la economía alcanzar un nuevo nivel pero no crecería más rápidamente. ${ }^{1337}$

Por otro lado, al hablar sobre los beneficios del comercio y de la apertura comercial en la economía de un país, se ha de hacer referencia a las investigaciones a nivel teórico de autores como Grossman y Helpman y, a las de tipo empírico, como los estudios de Dollar, Edwards, Sachs y Warner, que establecen un efecto positivo del comercio y apertura sobre la tasa de crecimiento a largo plazo, es decir, las economías más abiertas suelen tener mayores tasas de crecimiento. $^{1338}$

Estos autores, al igual que Levine y Renelt, usaron una medida de apertura real y una proxy (factor aproximado a la variable objeto de análisis) para indicar la apertura del producto interior bruto, llegando a la conclusión de que el efecto del comercio mundial en la productividad del trabajo y el ingreso per cápita era altamente significativo. En su estudio, establecieron la hipótesis de que una mayor apertura comercial, medida como la suma de exportaciones e importaciones como porcentaje del PIB, puede fomentar el conjunto de oportunidades de inversión y promover el crecimiento económico.

En nuestro estudio, se utilizará la relación de las exportaciones e importaciones sobre el producto interior bruto como variable que aproxima la apertura económica del Ecuador, la cual aparecerá representada como Apert (promedio de las importaciones y exportaciones como porcentaje del PIB) (ver tabla 5: Descripción de las variables del estudio empírico, Ecuador 1950-1980). ${ }^{1339}$

\footnotetext{
${ }^{1337}$ Raymundo Chirinos, op. cit. p. 8.

${ }^{1338}$ G. Grossman, E. Helpman: Comparative advantage and long run growth, The American Economic Review, vol. 80, num. 4, 1990; D. Dollar: Outward orientes developing economies really do grow more rapidly: Evidence from 95 LDCs, 1976-1985, Economic development and cultural change, 1992, p. 523-544; S. Edwards: Openness, productivity and growth: what do we really know?, Economic journal, 1998, p. 383-398; J. Sachs, A. Warner: Economic reform and the process of global integration, Brooking papers on economic activity 1, 1995, p. 1-95; Fundamental sources of long run growth, The American economic review, vol. 87, num. 21997.

${ }^{1339}$ R. Levine, D. Renelt, op. cit. p. 942-963.
} 


\section{Instituciones}

Para analizar el papel desempeñado por las instituciones en el desarrollo y crecimiento de un país, vamos a guiarnos por el trabajo de Douglas North en los años sesenta y setenta, que define a las instituciones como una serie de reglas de carácter formal y no formal que regulan la interacción entre los agentes de una sociedad, así como los mecanismos existentes para asegurar su cumplimiento. ${ }^{1340}$ De este modo, el aparato institucional contribuye a disminuir de forma significativa el coste de transacción e información de un mercado. ${ }^{1341}$

La inclusión de los elementos institucionales y culturales en las regresiones de crecimiento es cada vez mayor y con ello, parece ser que se ha reducido la parte que los factores físicos de producción no han explicado.

La figura 1 muestra algunos de los factores institucionales que afectan al crecimiento de una economía, como es el capital social, a partir del cual, la confianza y las normas de cooperación pueden mejorar el desempeño en una sociedad al disminuir los costes de transacción. En este caso, un individuo destinará menos recursos para protegerse en un intercambio comercial y los usará para obtener técnicas de innovación. ${ }^{1342}$

Otro elemento a considerar es la corrupción, ya que afecta negativamente al crecimiento alejando la inversión privada y desviando el uso de los recursos públicos a fines no productivos. A este respecto, Paolo Mauro ha empleado los índices de corrupción elaborados por The Economist y nueve medidas de control institucional y ha observado la existencia de una relación negativa y significativa entre corrupción, inversión y crecimiento. ${ }^{1343}$

También, hay que mencionar la calidad de las instituciones, siendo uno de los estudios utilizados el de Acemoglu, Johnson y Robinson. ${ }^{1344}$ Estos autores indican que los países con mejores

\footnotetext{
1340 Douglas North: Economic performance through time: The limits of knowledge, Washington University, mimeo, 1996, p. 1-21.

${ }^{1341}$ Raymundo Chirinos, op. cit. p. 12-13.

1342 Robert Putnam, Robert Leonardi, Raffaella Y. Nanetti: Making democracy work: Civic Traditions in Modern Italy, Princeton University Press, Mayo, 1994, p. 15-175.

${ }^{1343}$ P. Mauro: Corruption and growth, the quarterly journal of economics, vol. 110, no. 3, agosto 1995, p. 681-712.

1344 D. Acemoglu, S. Johnson, J. Robinson: The colonial origins of comparative development: An empirical investigation, The American economic review, vol. 91, no. 5, diciembre, 1991, p. 1361-1401.
} 
instituciones pueden garantizar los derechos de propiedad y evitar la implementación de políticas que provoquen una distorsión a la hora de invertir. ${ }^{1345}$

Con respecto al resto de factores que aparecen en la figura 1, Barro establece una relación en forma de "U invertida" en cuanto al crecimiento y democracia, pues, en principio, un país con una democracia es un entorno positivo para el desarrollo de las actividades privadas, pero puede ocurrir que exista algún tipo de presión redistributiva que ponga en peligro la estabilidad política del país. Asimismo, la división social es un elemento negativo para las perspectivas de crecimiento de un país, al igual que la ausencia política, variable que puede ser medida mediante el número de golpes de estado y asesinatos. A este respecto, Barro indica que el desarrollo económico suele estar acompañado de una mayor esperanza de vida, una menor tasa de fertilidad, una mayor inclinación a la democracia y mejores instituciones en la forma de un estado de derecho más fuerte y con menos corrupción. ${ }^{1346}$

Si bien la democracia en el proceso de crecimiento económico ha recibido una gran atención, no existe un acuerdo en cuanto a la forma en que el nivel de democracia en un país puede impactar el crecimiento económico. En este caso, un elevado nivel de los derechos políticos de una población (más democracia), llevará a impulsar los derechos económicos y fomentar de este modo, el crecimiento. Sin embargo, también puede ocurrir que la democracia disminuya el crecimiento como consecuencia de la preocupación por los programas sociales y el reparto del ingreso. $^{1347}$

Aquí, vamos a considerar las variables de los derechos políticos, libertades civiles y la esperanza de vida, las cuales aparecen representadas como DerPolit, LibCiv y EspVida (ver tabla 5: Descripción de las variables del estudio empírico, Ecuador 1950-1980).

\footnotetext{
${ }^{1345}$ Raymundo Chirinos, op. cit.p. 12-15.

${ }^{1346}$ R. Barro: Cantidad y calidad de crecimiento económico, Revista Economía Chilela 5 (2), 2002, p. 17-36.

${ }^{1347}$ R. Barro, Determinants of Economic... op. cit.p. 5-50; J. Tavares, R. Wacziarg: How democracy affects growth, European Economic review 45(8), 2001, p. 1341-1378.
} 
Figura 1: Factores institucionales que afectan al crecimiento económico:

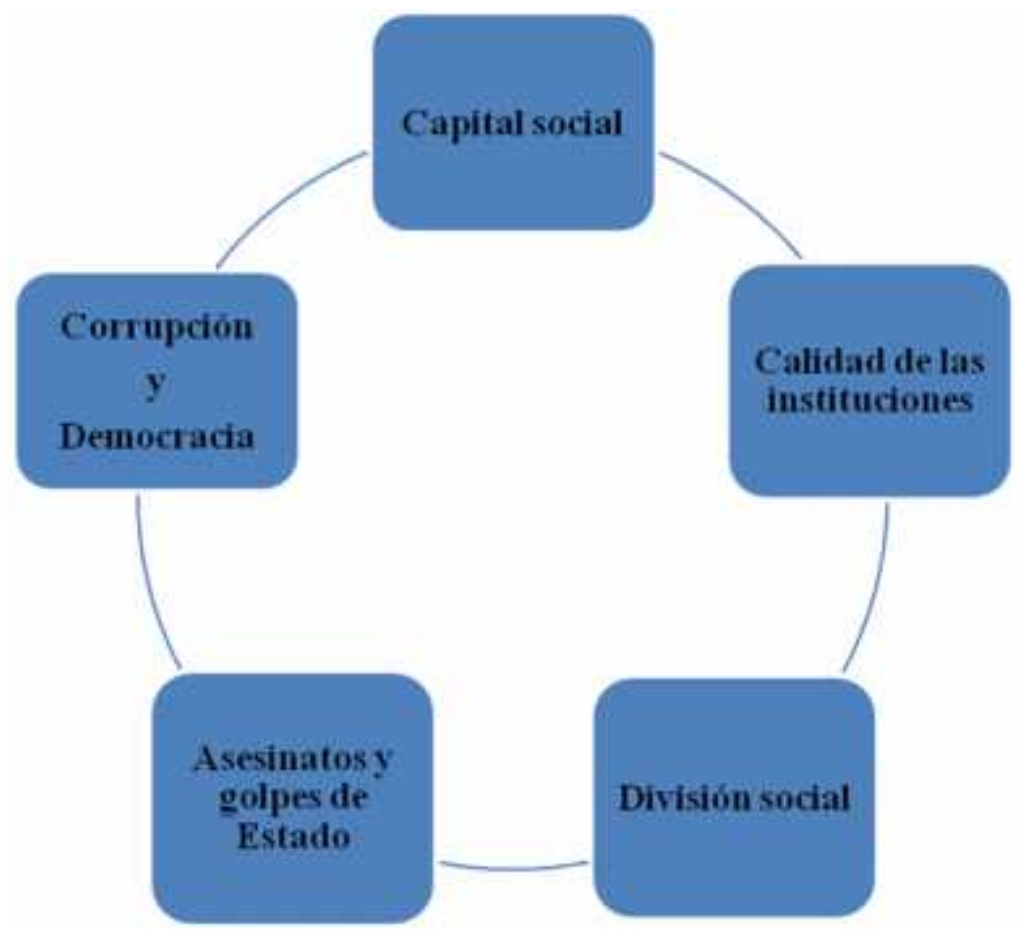

Fuente: Raymundo Chirinos: Determinantes del crecimiento económico: Una revisión de la literatura existente y estimaciones para el periodo 1960-2000, Banco Central de Reserva del Perú, Serie de Documentos de Trabajo, Agosto, 2007, p. 12-13.

\section{Geografía y población}

Algunos autores creen que las condiciones físicas y geográficas de un país y su impacto en las instituciones son elementos importantes para explicar las diferencias en el desarrollo de las naciones. Así, por ejemplo, Frankel y Romer señalan que algunas de las características más importantes a tener en cuenta son el área o tamaño de un país, en el sentido de que si este es más grande, puede tener mayores posibilidades de compartir su frontera con otros países, el acceso al mar, ya que podrá realizar más o menos actividades comerciales por vía marítima, y el tamaño de la fuerza laboral, al operar externalidades y efectos de escala. ${ }^{1348}$

1348 J. Frankel, D. Romel: Does trade cause growth, The American Economic Review, vol. 89, num. 3, 1999 en Marianela Gómez, op. cit. p. 1-23. 
Por su parte, Rodrick y Subramanian afirman que las características geográficas influyen en la creación de las instituciones y en el desarrollo a largo plazo de un país, pero no ejercen una influencia directa en su renta per cápita cuando se consideran las instituciones. ${ }^{1349}$

Henderson indica que el crecimiento y la urbanización son dos factores estrechamente relacionados, pues el desarrollo económico implicaría la evolución de un país desde una economía agrícola a una industrial y de servicios, en la que la producción de manufacturas es más eficaz y está concentrada en densas zonas industriales. ${ }^{1350}$ Además, la cercanía espacial puede fomentar la distribución de información entre productores, una mayor eficiencia en el funcionamiento de los mercados y un ahorro en los costes de transporte de los bienes.

Teniendo en cuenta estas últimas ideas, en nuestro estudio empírico se incorporará la tasa de crecimiento anual de la población o TCpob y la fracción de la población que vive en las zonas urbanas o UrbanPob para comprobar si existe una relación positiva entre el crecimiento económico y la urbanización (ver tabla 5: Descripción de las variables del estudio empírico, Ecuador 1950-1980).

\section{Inestabilidad macroeconómica}

De acuerdo con Hnatkovska y Loayza, la inestabilidad o volatilidad macroeconómica puede tener efectos positivos o negativos en el crecimiento de una economía. ${ }^{1351}$ Por ejemplo, si la inestabilidad procede del aumento del retorno asociado a un mayor riesgo, esto tendría un efecto positivo en el producto generado. Por el contrario, si no existen los medios institucionales que permitan disminuir el riesgo de una inversión, la incertidumbre sería negativa para el crecimiento. $^{1352}$

Por su parte, Barro y Easterly indican que las distorsiones de los precios de mercado causan un impacto negativo en el crecimiento económico, las cuales pueden ser medidas a través del nivel

\footnotetext{
${ }^{1349}$ D. Rodric, A. Subramanian et al: Institutions rule: The primacy of institutions over geography and integration in economic development, Journal of Economic Growth 9(2), 2004, p. 131-165.

${ }^{1350}$ J. Henderson: How urban concentration affects economic growth, World Bank Policy Research working paper num. 2326, 2000, p. 5-40.

${ }^{1351}$ V. Hnatkovska, N. Loayza: Volatility and growth, Mimeo, agosto 2003.

${ }^{1352}$ Raymundo Chirinos, op. cit. p. 10.
} 
de precios de inversión, al actuar como indicador del nivel de las distorsiones de los precios de mercado existente en una economía. ${ }^{1353}$

En este caso, cuanto mayor sea la distorsión de los precios de mercado, mayor será el impacto negativo generado en el crecimiento de la economía, siendo esta variable representada en nuestro estudio, como el promedio del nivel de precio de la inversión o PrecInv (ver tabla 5: Descripción de las variables del estudio empírico, Ecuador 1950-1980).

\section{Consumo del gobierno}

La última variable a tener en cuenta es el consumo del gobierno, pues una variante del modelo neoclásico incluye el gasto público como argumento en la función de producción. En este caso, el gasto en la provisión de los bienes públicos puede ser considerado como un factor positivo que estimula el crecimiento y mejora el bienestar de la sociedad, pero también, puede distorsionar la economía y afectar negativamente a su crecimiento si su financiación se realiza a través de los

impuestos. ${ }^{1354}$ Aquí, se utilizará el consumo del gobierno como porcentaje del PIB y aparecerá representado como GovConsPIB (ver tabla 5: Descripción de las variables del estudio empírico, Ecuador 1950-1980).

Una vez analizadas las diferentes variables y clasificaciones, vamos a usar un panel de datos económicos con el que se podrá llevar a cabo una estimación del modelo dinámico durante el periodo 1950-1980. La falta de disponibilidad de datos anuales para algunas de las variables a utilizar, sobre todo de la década de los cincuenta, nos ha obligado a ampliar el periodo de estudio hasta la década de los ochenta, para que de este modo, se pueda observar de una forma más completa el comportamiento de la economía ecuatoriana y determinar cuáles de los factores indicados han ejercido un mayor impacto en su crecimiento.

En nuestro modelo, se utilizará como variable dependiente el crecimiento del producto interior bruto real (CrecPIB), cuyos datos proceden de la base Penn World Table Version 6.2 (188 countries, 1950-2004), que está compuesta por datos de gasto denominados con un mismo conjunto de precios y una moneda común, lo que permite realizar un análisis de cantidades reales de los países en el tiempo.

En cuanto a las variables independientes, se utilizará la tasa de crecimiento de la población como

\footnotetext{
${ }^{1353}$ R. Barro, Economic growth... op. cit. p. 407-443; W. Easterly: How much do distortions affect growth, Journal of Monetary Economics 32(2), 1993, p. 187-212.

${ }^{1354}$ R. Barro, Sala-i-Martin: Crecimiento económico, Editorial Reverte, 1999, p. 152.
} 
promedio de la tasa de crecimiento anual de la población (TCPob), el precio de la inversión (PrecInv), una medida de apertura de la economía ecuatoriana, que es el promedio de importaciones más exportaciones como porcentaje del PIB (Apert), el consumo del gobierno como porcentaje del PIB (GovConsPIB), la inversión realizada como porcentaje del PIB (InverPIB), cuyos valores también han sido obtenidos de la Penn World Table Version 6.2.

Otras variables independientes son la esperanza de vida al nacer (EspVida) y la población urbana (UrbanPob), que han sido obtenidas de la base de datos World Development Data, 2013.

Por último, se usa el nivel de educación secundaria (SecEdu) que se obtiene del estudio de Barro y Lee y el índice de derechos políticos (DerPol) y libertades civiles (CivLib), que proporciona la Combined Freedom House Index 2013. ${ }^{1355}$ (Ver tabla Tabla 5: Descripción de las variables del estudio empírico, Ecuador 1950-1980).

A continuación, la Tabla 6 presenta las estadísticas descriptivas para los datos de la muestra e incluye la media y la desviación estándar, con un valor máximo y mínimo para todas las variables:

${ }^{1355}$ R. Barro, J. Lee: International data on educational attainment: Updates and implications, CID working paper, no. 42, abril 2000, p. 1-19. 
Tabla 6: Estadísticas descriptivas de las variables (Ecuador 1950-1980)

\begin{tabular}{|l|l|l|l|l|}
\hline Variable & Media & $\begin{array}{l}\text { Desviación } \\
\text { estándar }\end{array}$ & Mínimo & Máximo \\
\hline CrecPIB & 7.95 & 7.92 & -1.29 & 38.37 \\
\hline Yt & 6.75 & 0.62 & 6.00 & 8.15 \\
\hline Yt1 & 0.07 & 0.07 & -0.01 & 0.32 \\
\hline Tcpob & 2.89 & 0.13 & 2.62 & 3.03 \\
\hline Precinv & 21.15 & 8.66 & 13.51 & 40.10 \\
\hline Apert & 40.10 & 9.13 & 30.63 & 67.29 \\
\hline Govconspbi & 25.86 & 4.19 & 21.03 & 35.18 \\
\hline Inverpbi & 28.24 & 2.80 & 20.07 & 33.27 \\
\hline Espvida & 57.93 & 2.87 & 53.12 & 53.12 \\
\hline Urbanpob & 244655.14 & 684621.82 & 1505063.05 & 3743237.45 \\
\hline SecEdu & 3.85 & 2.33 & 1.60 & 7.90 \\
\hline Derpolit & 5.60 & 2.01 & 2.00 & 7.00 \\
\hline CivLib & 3.30 & 0.95 & 2.00 & 4.00 \\
\hline
\end{tabular}

Fuente: Elaboración propia a partir de los datos de Penn World Table 6.2; Freedom House, Freedom in the World 2012; R. Levine, D. Renelt: A sensitivity analysis of cross-country growth regressions, the American Economic Review, 82(4), 1992, p. 942-963; S. N. Durlauf, P. A. Johnson, J.R. Temple: Growths econometrics, en S.N. Durlauf, P. Aghion (Eds), Handbook of Economic Growth, Elsevier, 2005. 
Las estadísticas descriptivas de las variables muestran los valores mínimos y máximos de todas las variables con su respectiva media aritmética y desviación típica o estándar. ${ }^{1356}$ Así, por ejemplo, la tasa de crecimiento medio del PIB real es de 7,95 con una desviación estándar de 7.92, siendo su rango de variación de -1,29 y 38,37. El aumento de la población de Ecuador contribuye al PIB con una tasa media de crecimiento de 2,89 y una desviación estándar de 0,13. El valor medio de la participación del gobierno en el producto interno bruto per cápita es de 25,86 con una desviación estándar de 4,19 y un intervalo de variación de 21,03 de mínimo y un máximo de 35,18 . Por su parte, el precio de la inversión tiene un valor medio de 21,15 y una desviación estándar de 8,66 siendo el valor mínimo de 13,51 y el máximo de 40,10, y así sucesivamente.

Por su parte, la Tabla 7: Matriz de correlación de variables (Ecuador 1950-1980) (ver los cálculos en el apéndice del capítulo 6) muestra la matriz de correlación de variables, en la que se observa cómo la correlación entre la tasa de crecimiento del ingreso real per cápita y el ingreso al comienzo del periodo es positiva. Con el fin de investigar las relaciones entre las diferentes variables dadas, se utiliza el coeficiente de correlación de Pearson para diferentes pares de variables, tal y como se puede apreciar en dicha tabla. ${ }^{1357}$

Este cuadro indica que la mayor parte de los pares de variables tienen correlación positiva significativa, aunque también existe una correlación negativa significativa entre algunas de las variables como ocurre con el coeficiente de correlación entre la inversión como porcentaje del PIB y la tasa de crecimiento del PIB, que es de - 0.144. Esto significa que hay una correlación negativa significativa entre la participación en la inversión del PIB real per cápita y la tasa de crecimiento del PIB real, por lo que si la cuota de inversión del PIB real se incrementa, habrá una

\footnotetext{
${ }^{1356} \mathrm{Al}$ analizar un conjunto de datos, se tienen en cuenta dos objetivos: por una parte, se trata de descubrir las irregularidades que puedan existir en él y de resumirlas mediante un valor típico (un promedio); y por otra, se intenta establecer la medida en que los datos se concentran o dispersan alrededor de ese valor típico, es decir, la importancia de las desviaciones de los elementos individuales respecto a ese valor representativo escogido para caracterizar al grupo. Es importante conocer el promedio y también la variabilidad de los datos a su alrededor, pues cuanto más concentrados estén los datos alrededor del promedio aritmético, más confianza se tendrá en este valor para caracterizar un conjunto de datos. Para medir la variabilidad o dispersión de la información cuantitativa, se va a usar la desviación estándar, la cual nos indica cuánto se alejan, en promedio, las observaciones de la media aritmética del conjunto. Fuente: S. Lipschutz, J. Schiller: Introducción a la probabilidad y estadística, Editorial McGraw Hill, 2000.

${ }^{1357}$ Para la elaboración de la tabla 7, se han utilizado los datos de Penn World Table 6.2, Freedom House, Freedom in the World 2012; R. Levine, D. Renelt: A sensitivity analysis of cross-country growth regressions, the American Economic Review, 82(4), 1992, p. 942-963; S. N. Durlauf, P. A. Johnson, J.R. Temple: Growths econometrics, en S.N. Durlauf, P. Aghion (Eds), Handbook of Economic Growth, Elsevier, 2005.
} 
ligera disminución en la tasa de crecimiento del PIB real porque una parte del PIB se utilizará para invertir.

El coeficiente de Pearson para la relación entre la tasa de crecimiento de la población y la población urbana, educación secundaria, derechos políticos es negativo, siendo sus valores -0,63, $-0,71$ y -0,79. Estos valores negativos muestran que la tasa de crecimiento anual de la población disminuye al aumentar el nivel de educación y la sensibilización de los derechos políticos y civiles $^{1358}$. Por otro lado, se observa un alto nivel de correlación positiva entre la educación secundaria y la esperanza de vida, lo cual se explica a partir de que un aumento de la educación secundaria se traduce en una mayor esperanza de vida.

En general, se puede decir que en esta matriz, las variables de control presentan los signos esperados, pues las economías más abiertas, con mayor de nivel de educación, esperanza de vida, derechos y democracia tienden a crecer más rápido, siendo por tanto, su correlación positiva. ${ }^{1359}$ Sin embargo, como se ha visto, algunos estudios indican que la inversión suele estar positivamente correlacionada con el crecimiento, no siendo este nuestro caso. ${ }^{1360}$

Así pues, no necesariamente los países con mayores niveles de ingreso per cápita atraen mayores niveles de inversión ni presentan síntomas destacados de crecimiento. ${ }^{1361}$ Los flujos de la inversión pueden tener una relación positiva con el crecimiento económico cuando permitan una disminución en el costo de creación de nuevos bienes de capital y la transferencia de tecnología desde las empresas extranjeras a las nacionales mediante la realización de producciones complementarias.

No en vano, para que se produzca este fenómeno es necesario que la economía tenga un nivel mínimo de capital humano y físico que permita que este efecto positivo se propague en toda la

\footnotetext{
${ }^{1358}$ S. L. Jackson: Statistics: Plain and Simple, segunda edición, Cengage Learning, 2009, p. 10-380.

${ }^{1359}$ R. Wacziarg, K. Welch: Trade liberalization and growth: New evidence, World Bank Economic Review, 22 (2), 2008, p. 187-231.

${ }^{1360}$ S. Bond, A. Leblebibioglu, F. Schiantarelli: Capital accumulation and growth: A new look at the empirical evidence, Journal of Applied Econometrics, 25 (7), 2010, p. 1073-1099.

${ }^{1361}$ N. Campos, K. Yuco: Out of caveats: The impact of foreign direct investment in transitions economies, Dep. of Economics, University of Newcastel, 2004.
} 
economía y, como ya se ha visto con anterioridad, esto no ha ocurrido en el Ecuador como consecuencia de la gran dependencia externa del capital y tecnología extranjera. ${ }^{1362}$

Los resultados obtenidos del análisis de correlación sugieren la realización de un análisis de regresión múltiple para poder encontrar el mejor modelo con predictores significantes.

Análisis de Regresión (Ecuador 1950-1980):

Se procederá a realizar dicho análisis de regresión para poder detectar los predictores significantes, por lo que primero realizamos una regresión completa. ${ }^{1363}$

Como ya se ha dicho, la tasa de crecimiento del PIB (CrecPIB) será la variable dependiente a considerar, mientras las variables independientes incluidas en el modelo de regresión serán: ${ }^{1364}$

- Tasa de crecimiento de la población o TCPob,

- Precio de la inversión como \% del PIB o PrecInv,

- Medida de apertura o Apert,

- Consumo del gobierno como \% del PIB o GovConsPIB,

- Inversión como \% del PIB o InverPIB,

- Esperanza de vida al nacer o EspVida,

- Población urbana o UrbanPob,

- Educación secundaria o SecEdu,

- Derechos políticos o DerPolit,

- Libertades civiles o LibCiv.

A partir de aquí, se establecen las siguientes hipótesis de investigación:

Hipótesis nula: La variable dependiente (CrecPIB) no está influenciada por las variables independientes, es decir, la variabilidad observada en las respuestas es causada por el azar y no hay influencia de las variables independientes.

\footnotetext{
1362 Diego F. Baracaldo, Paola Garzón, Hernando Vásquez: Crecimiento económico y flujos de inversión extranjera directa, econpapers, Universidad de Colombia, Noviembre 2005.

${ }^{1363}$ S. L. Jackson, op. cit. p. 10-380; E. L. Lehmann, J. P. Romano: Testing Statistical Hypotheses, tercera edición, EE.UU, Springer, 2005, p. 7-375.

${ }^{1364}$ Los datos de las variables se encuentran en el apéndice del capítulo 6.
} 
Hipótesis alternativa: Existe algún tipo de evidencia de la contribución significativa de una o más variables independientes en la tasa de crecimiento del producto interior bruto real per cápita del Ecuador. En este caso, la significación del contraste se calcula haciendo un análisis de la varianza.

Figura 2: Diagrama de dispersión para la relación (Ecuador 1950-

1980)

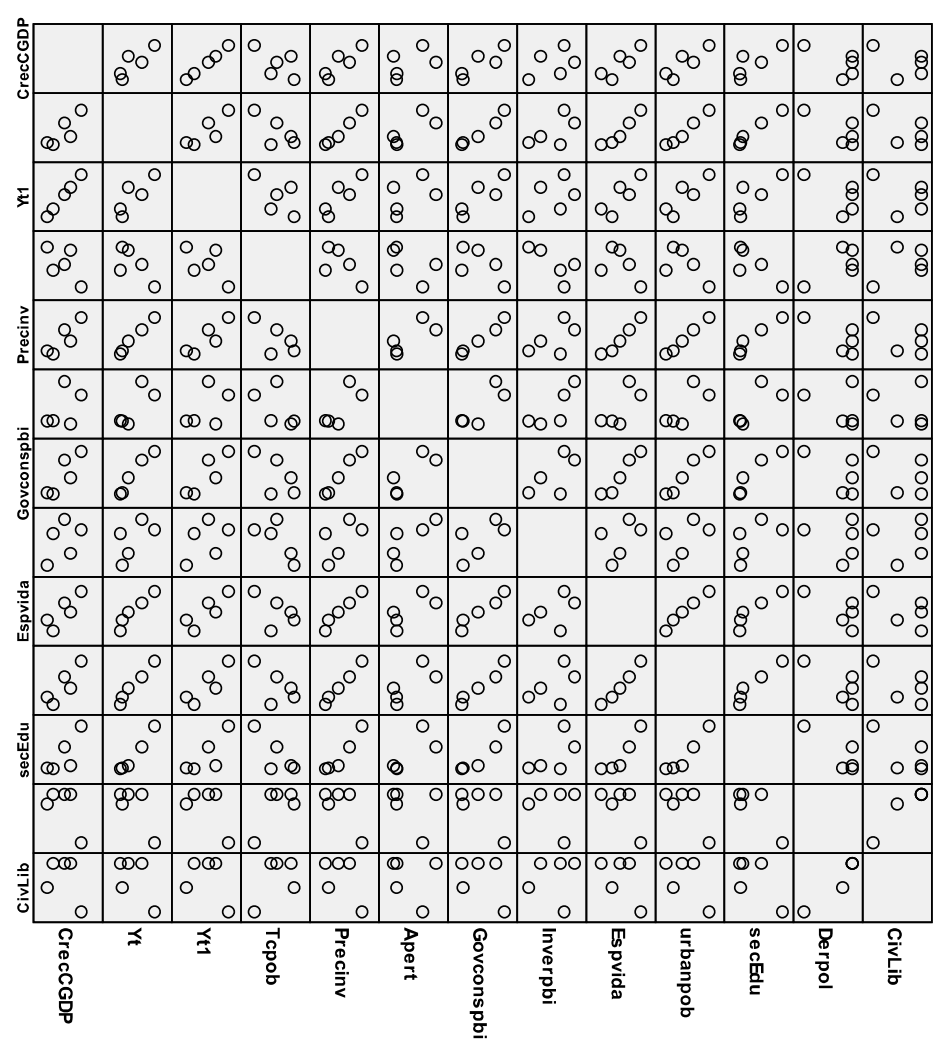

Fuente: Elaboración propia a partir de los datos de Penn World Table 6.2; Freedom House: Freedom in the World 2012; R. Levine, D. Renelt: A sensitivity analysis of cross-country growth regressions, the American Economic Review, 82(4), 1992, p. 942-963; S. N. Durlauf, P. A. Johnson, J.R. Temple: Growths econometrics, en S.N. Durlauf, P. Aghion (Eds), Handbook of Economic Growth, Elsevier, 2005.

En este gráfico de dispersión, se observa la relación significativa de la tasa de crecimiento del producto interior bruto real per cápita, ya que la primera fila de la matriz del gráfico muestra la relación de dicha variable con la tasa de crecimiento de la población (TCPob), el precio de inversión (PrecInv), la apertura de la economía (Apert), el consumo del gobierno como porcentaje del PIB (GovConsPIB), la inversión como porcentaje del PIB (InverPIB), la esperanza de vida (EspVida), la población urbana (UrbanPob), la educación secundaria 
(SecEdu), los derechos políticos (DerPolit) y las libertades civiles (CivLib). Es decir, existe un tipo de relación positiva de la tasa de crecimiento del producto interior bruto real per cápita (CrecPIB) con la esperanza de vida (EspVida), la población urbana (UrbanPob), la educación secundaria (SecEdu), y una correlación ligeramente negativa entre tasa de crecimiento del producto interior bruto real per cápita (CrecPIB) con las libertades civiles (CivLib).

No obstante, la tabla de correlación muestra que el valor del coeficiente de correlación de Pearson tiene un mayor valor para SecEdu, 0.797, siendo la educación secundaria, el factor que más influye de todas las variables independientes dadas. Esta variable ejerce un impacto en la tasa de crecimiento del PIB real per cápita, porque el nivel de educación secundaria y una mayor preparación de la población, puede aumentar directa o indirectamente la producción de una economía en el sector de servicios o de producción.

Por otro lado, el modelo de regresión se fija con la ayuda de la herramienta de regresión disponible en la hoja de cálculo, que sirve para evaluar el coeficiente de determinación y los valores de coeficiente beta para diferentes variables.

Las siguientes tablas (tablas 8 y 9: Ecuador 1950-1980) nos dan información sobre la precisión y la validez del modelo de regresión ajustada:

\begin{tabular}{|c|c|c|}
\hline \multicolumn{3}{|c|}{ Regression Statistics } \\
\hline Multiple R & & 1 \\
\hline R Square & & 0.93124 \\
\hline $\begin{array}{l}\text { Adjusted } \\
\text { Square }\end{array}$ & $\mathrm{R}$ & $\begin{array}{l}-1.9 \mathrm{E}- \\
09\end{array}$ \\
\hline Standard Error & & $\begin{array}{l}4.88 \mathrm{E}- \\
19\end{array}$ \\
\hline Observations & & 5 \\
\hline
\end{tabular}


ANOVA

\begin{tabular}{llllll}
\hline & $d f$ & $S S$ & $M S$ & $F$ & \multicolumn{2}{l}{ Significance } \\
& & & & & $F$ \\
\hline Regression & 12 & 126.5203 & 10.54336 & $4.4353 \mathrm{E}+37$ & 0.000 \\
Residual & $4.29 \mathrm{E}+09$ & $1.02 \mathrm{E}-27$ & $2.38 \mathrm{E}-37$ & & \\
Total & $4.29 \mathrm{E}+09$ & 126.5203 & & & \\
\hline
\end{tabular}

Fuente: Elaboración propia a partir de los datos de Penn World Table 6.2; Freedom House, Freedom in the World 2012; R. Levine, D. Renelt: A sensitivity analysis of cross-country growth regressions, the American Economic Review, 82(4), 1992, p. 942-963; S. N. Durlauf, P. A. Johnson, J.R. Temple: Growths econometrics, en S.N. Durlauf, P. Aghion (Eds), Handbook of Economic Growth, Elsevier, 2005.

Para determinar la bondad del ajuste, hay que fijarnos en el valor de la R-cuadrado ( $R$-square) que se interpreta del siguiente modo: La variable respuesta presenta cierta variabilidad, pero cuando se conoce el valor de las variables independientes, dicha variabilidad o incertidumbre disminuye. El término R-cuadrado es una cantidad que puede interpretarse como un porcentaje de reducción de la incertidumbre cuando se conocen las variables independientes. Cuanto más se acerque a uno, más poder explicativo tiene el modelo.

En este caso, la tabla estadística de la regresión indica que el valor R-cuadrado para el modelo de regresión ajustada es de 0,93124, es decir, este modelo ajustado explica el $93.12 \%$ de la variabilidad de la tasa de crecimiento del producto interior bruto real, teniendo en cuenta que su valor depende de varios factores exógenos y endógenos, a la vez que este alto porcentaje muestra la validez y precisión del modelo utilizado.

El valor de $\mathrm{p}$ significativo para la prueba $\mathrm{F}$ en la tabla de análisis de la varianza (ANOVA) es también menos de 0,05 , lo que conduce al rechazo de la hipótesis nula y se llega a la conclusión de que una o más de las variables independientes seleccionadas son responsables de la variabilidad de la variable dependiente o de la tasa de crecimiento del producto interior bruto real per cápita. 
Tabla 10: Evaluación de los coeficientes (Ecuador, periodo 1950-1980)

\begin{tabular}{|c|c|c|c|c|c|c|}
\hline & Coefficients & $\begin{array}{c}\text { Standard } \\
\text { Error }\end{array}$ & t Stat & $P$-value & Lower 95\% & Upper 95\% \\
\hline Intercept & 7.555493174 & $2.55411 \mathrm{E}-11$ & $2.96 \mathrm{E}+11$ & 0 & 7.555493174 & 7.555493174 \\
\hline & - & & & & - & \\
\hline Yt & 0.072674248 & 0 & 65535 & & 0.072674248 & 0.072674248 \\
\hline Yt1 & 83.04874574 & $5.19543 \mathrm{E}-11$ & $1.6 \mathrm{E}+12$ & 0 & 83.04874574 & 83.04874574 \\
\hline Tcpob & 2.678035551 & $6.10876 \mathrm{E}-12$ & $-4.4 \mathrm{E}+11$ & 0 & 2.678035551 & 2.678035551 \\
\hline Precinv & 0.110466561 & 0 & 65535 & & 0.110466561 & 0.110466561 \\
\hline Apert & 0.076853983 & $3.13671 \mathrm{E}-13$ & $-2.5 E+11$ & 0 & 0.076853983 & 0.076853983 \\
\hline Govconspbi & 0.139794644 & 0 & 65535 & & $0.139794644^{-}$ & 0.139794644 \\
\hline Inverpbi & 0.175180642 & $2.1938 \mathrm{E}-13$ & $7.99 \mathrm{E}+11$ & 0 & 0.175180642 & 0.175180642 \\
\hline Espvida & -0.06890332 & $2.63606 \mathrm{E}-14$ & $-2.6 \mathrm{E}+12$ & 0 & -0.06890332 & -0.06890332 \\
\hline urbanpob & $2.57265 \mathrm{E}-06$ & $2.36262 \mathrm{E}-18$ & $1.09 \mathrm{E}+12$ & 0 & $2.57265 \mathrm{E}-06$ & 2.57265E-06 \\
\hline secEdu & $0.412888189^{-}$ & $1.48439 \mathrm{E}-12$ & $-2.8 \mathrm{E}+11$ & 0 & $0.412888189^{-}$ & 0.412888189 \\
\hline Derpol & 0.224458279 & $8.73693 \mathrm{E}-13$ & $-2.6 \mathrm{E}+11$ & 0 & 0.224458279 & 0.224458279 \\
\hline CivLib & 0.771022948 & $2.24105 \mathrm{E}-12$ & $3.44 \mathrm{E}+11$ & 0 & 0.771022948 & 0.771022948 \\
\hline
\end{tabular}

Fuente: Elaboración propia a partir de los datos de Penn World Table 6.2; Freedom House, Freedom in the World 2012; R. Levine, D. Renelt: A sensitivity analysis of cross-country growth regressions, the American Economic Review, 82(4), 1992, p. 942-963; S. N. Durlauf, P. A. Johnson, J.R. Temple: Growths econometrics, en S.N. Durlauf, P. Aghion (Eds), Handbook of Economic Growth, Elsevier, 2005.

La evaluación de los coeficientes beta de las variables independientes seleccionadas y su contribución significativa a la tasa de crecimiento del PIB real se refleja en la tabla 10, aplicándose para ello, el método de regresión con el test-t para variables independientes. Esta 
tabla muestra que el valor de p para los test-t relacionados con todas las variables es menor que $0,05 .^{1365}$

En relación al coeficiente de la variable tasa de crecimiento de la población, se observa que es significativo ya que p es menor que el nivel de significación normal (0.05) y su valor es de 2.67, lo cual indica que una unidad adicional en el término población se traducirá en un aumento del 2.67 de la tasa de crecimiento del producto interior bruto real per cápita. También, el coeficiente de la variable población urbana es significativo, ya que p es menor que el nivel de significación normal (0.05) y su valor es de 2.57, lo cual indica que una unidad adicional en el término población urbana se traducirá en un aumento del 2.57 de la tasa de crecimiento del producto interior bruto real per cápita.

Otros coeficientes significativos, con p inferior al nivel de significación normal (0.05), son los de la educación secundaria con un valor de 0.41 , el de la inversión como porcentaje del producto interior bruto, siendo su valor de 0.18 , el de las libertades civiles con 0.77 , los derechos políticos con un coeficiente de 0.22 , y la apertura de la economía. Por su parte, el coeficiente de la esperanza de vida es significativo y equivale a -0.068 , lo cual indica que se dedica un mayor número de recursos para lograr la acumulación de capital y menos a los medios que hacen posible un aumento de la esperanza de vida de la población.

Teniendo en cuenta el análisis estadístico de los datos facilitados para las variables seleccionadas, se ha encontrado que la tasa de crecimiento de la población, la población urbana, la educación secundaria y la inversión como porcentaje del PIB y en menor medida la apertura de la economía, son las variables más importantes, que de una forma modesta han influido en la tasa de crecimiento de la economía ecuatoriana para el periodo 1950-1980.

En este caso, el aumento de la población urbana debe generar un aumento de bienes y servicios y crecimiento económico de la sociedad, ya que, por lo general, las personas que viven en las zonas urbanas contribuyen al incremento de la productividad, de las importaciones y exportaciones y de la inversión, produciendo más ingresos, y con ello, un aumento de la tasa de crecimiento del producto interior bruto real per cápita.

De la misma manera, cuanto mayor sea la inversión, los derechos políticos y libertades civiles, mayor será el nivel de vida y progreso de la nación, aumentando el nivel de satisfacción de los

\footnotetext{
${ }^{1365}$ E. L. Lehmann, J. P Romano, op. cit. p 7-375; F. J. Barón López, F. Téllez Montiel: Apuntes de estadística, Universidad de Málaga, 2009, p. 35-43.
} 
habitantes del país y su capacidad para tomar decisiones. A su vez, otro factor clave es la educación secundaria, pues es responsable de la aparición de las generaciones jóvenes que trabajan para alcanzar la prosperidad de la nación y el crecimiento del producto interior bruto real per cápita.

No obstante, hay que volver a recalcar que la contribución de estas variables al crecimiento de la economía ecuatoriana ha sido bastante modesta, como indican los valores de los coeficientes de la regresión, debido a los altibajos sufridos en dicha sociedad durante el periodo seleccionado, lo cual nos lleva a matizar algunos aspectos.

En primer lugar, al referirnos a la educación en el Ecuador, las variaciones en la evolución de los distintos aspectos de la realidad nacional (economía, educación, vivienda, situación de la democracia, etc.), que han sido fiel reflejo de los intereses políticos-ideológicos de los grupos sociales más poderosos, han afectado al nivel de estudios de la población.

Así, si bien el nivel de educación aumentó a partir de la década de los sesenta, produciéndose una ampliación en el número de matrículas de los niveles medio y superior, se ha de aclarar que desde el punto de vista de la calidad, esta variable ha sido un obstáculo para el desarrollo nacional y se ha caracterizado por sus conocimientos obsoletos-verbalistas y científicos, en todos sus niveles, alejados del conocimiento de la realidad y sin una preparación práctica del trabajo productivo. ${ }^{1366}$

Al parecer, el nivel de educación ha estado orientado a reforzar los grupos sociales con más poder y no ha sido un mecanismo para que el pueblo pueda ascender dentro de la sociedad. En este sentido, las clases sociales más altas han gozado de un número mayor de años de educación, mientras que los grupos de posición más baja, apenas han tenido acceso a esta, lo cual refleja las grandes desigualdades existentes.

El declive en la expansión de las instituciones públicas de educación, que logró una relativa cobertura pero de baja calidad, provocó el desgaste de la educación en las zonas marginadas (sobre todo en las áreas rurales) que poseían escasos mecanismos de presión política.

De igual forma, también contribuyó a un aumento notable de instituciones privadas que atendían a las demandas de las élites y de familias de ingresos altos y que posibilitaban la enseñanza de un mayor número de horas diarias con personal más competente, pero al no estar disponible para

\footnotetext{
1366 Edmundo Vera Manzo: Fuerza laboral, bienestar social y educación en el Ecuador, en Enfoque: Ecuador, estudios de la realidad nacional, Fundación Eugenio Espejo, 1983, p. 131.
} 
toda la población, acabó contribuyendo a agudizar las diferencias sociales (la tabla 11 muestra los datos de matrícula por niveles en colegios públicos y privados (1960-1961, 1965-1966, 19701971). ${ }^{1367}$

A este respecto, el estudio realizado por Milton Luna y Alfredo Astorga refleja un aumento de la matrícula en la escuela primaria, del número de colegios públicos (de 304 a 1.041) y de los profesores (de 5.521 a 23.316) durante los años 1950-1976 (ver tablas 12 y13: Datos educación en el Ecuador para una población 13-18 años, 1959-1960, 1975-1976). También, observan un incremento de la matrícula en la educación secundaria, la cual se triplicó, pero a la vez, indican una mayor intervención del gobierno en los colegios públicos y una menor presencia del sector privado:

Si en 1959-60 el 59,9\% correspondía a centros particulares, en 1976-77 este índice bajó a 49,1\%. Lo mismo ocurrió en el caso de los docentes: en 1959-60 el 48,8\% trabajaba en establecimientos particulares y en $1975-76$ el $38,8 \%{ }^{1368}$

Aún cuando uno de los objetivos programados fue la mejora de la educación rural, creándose un mayor número de colegios públicos en estas zonas, Luna y Astorga critican la falta de apoyo docente y la escasez de medidas de las que estos centros disponían, los cuales acabaron acogiendo a un menor número de niños de lo previsto. ${ }^{1369}$

En los años sesenta, se llevó a cabo un importante cambio en materia educativa que consistía en la enseñanza de seis años de estudio en las escuelas rurales para acabar con la medida discriminatoria que disminuía la educación en cuatro años, siendo esto un obstáculo, al impedir el acceso a estudios secundarios y universitarios.

En la primaria de 6 años, se establecen 3 ciclos de 2 años cada uno, con la finalidad de proponer formas de trabajo pedagógico que permitan mejorar los aprendizajes de los

\footnotetext{
${ }^{1367}$ Las tablas 11-13 se encuentran en el apéndice de datos del capítulo 6. Fuente: Carlos Iturralde Durán: Educación pública frente a educación privada en zonas urbano-marginales de Guayaquil. Estudio de caso en los Vergeles, programa de políticas públicas y gestión del desarrollo, Quito, mayo 2005, p. 15-120.

1368 Milton Luna Tamayo, Alfredo Astorga: Educación 1950-2010, Informe cero, Ecuador 1950-2010, FLACSO, 2011, p. 291-307.

${ }^{1369}$ Ibíd. p. 291-307.
} 
niños según los niveles psicológicos, y reducir el abandono escolar mediante el reemplazo de exámenes anuales por exámenes de ciclo. ${ }^{1370}$

De igual forma, la escuela secundaria fue dividida en dos ciclos (básico y diversificado) de tres años. El ciclo diversificado abarcaba especializaciones que permitían la entrada a la universidad o formación de obreros con una cualificación. También, se eliminaron los exámenes de ingreso para la secundaria como una medida de democratización y ampliación del acceso a los colegios, que, al no disponer de medidas integrales, acabó siendo negativa en lo referente al nivel de calidad.

Por norma general, en los países latinoamericanos, los trabajos a los que han aspirado los grupos con un nivel de estudios más alto no han aumentado con la misma velocidad que el número de candidatos. A esto, se ha de unir la dura competencia existente que se ha resuelto a favor de los que tienen más años de educación, produciéndose, por consiguiente, un incremento de la demanda social. ${ }^{1371}$

De este modo, las posibilidades para que la educación contribuya al cambio social de manera efectiva han tenido un carácter modesto. ${ }^{1372}$ Este ha sido el caso de las regiones del Ecuador con minifundios muy pequeños, en los que no se ha usado todo el potencial de la mano de obra, al no existir una gran preocupación para mejorar la educación o incorporar nuevos recursos tecnológicos, ya que todo esto habría supuesto un aumento del coste de la mecanización, del asesoramiento técnico y de los gastos asociados a la mejora cultural. En otras circunstancias, el estado ecuatoriano debería de haber permitido un incremento en la extensión de las parcelas mínimas para mejorar su productividad con la ayuda de nuevas técnicas, y así, eliminar los sistemas anacrónicos de producción y los problemas de analfabetismo.

En 1950, había 815.464 analfabetos de más de 15 años que representaban un porcentaje de 44.2\%; en 1962, el número de analfabetos ascendía a 799.535, cifra equivalente al $32.5 \%$ de la población; mientras que en 1974, esta cantidad era de 945.044 y representaba el $26.1 \%$ de la población. Sin embargo, tenemos que decir que los

\footnotetext{
${ }^{1370}$ Ibíd. p. 291-307.

${ }^{1371}$ Ibíd. p. 291-307.

${ }^{1372}$ Plan Nacional de Desarrollo, 1980-1984, Segunda Parte, Tomo IV, Cultura y Educación, p. 17-18.
} 
analfabetos son muchos más si incluimos los comprendidos entre las edades de 6 a 14 años que no aparecen en las estadísticas y forman parte de los 300.000 niños que desde hace treinta años no son absorbidos por la educación primaria, a pesar del notorio crecimiento de la educación primaria. ${ }^{1373}$

Estas cifras muestran que, si bien el analfabetismo pudo verse reducido en ciertas regiones del Ecuador, el fracaso a la hora de impulsar las reformas fue un obstáculo para acabar con dicho problema. Todo esto se complica más aún, si se tiene en cuenta que un gran número de niños de las áreas rurales dejaban de estudiar al terminar el segundo año de la escuela primaria y solo llegaban al tercer curso menos de la mitad, mientras que únicamente un cuarto de los niños del total inicial acababan el sexto grado. En las zonas urbanas, las tres cuartas partes pasaban al tercer curso y tres quintos de los alumnos terminaban la escuela primaria. ${ }^{1374}$

Resulta imperioso que llegue a comprenderse que para la mitad de los niños en las áreas rurales el sistema escolar no entrega absolutamente nada: lo poco que hubiese aprendido en dos años será rápidamente olvidado. Este es un cargo muy serio al sistema escolar, ya que, a causa de tales deficiencias, por lo menos la mitad de los niños en las zonas rurales del Ecuador, o sea, más de la cuarta parte de la población rural del país está condenada al analfabetismo. ${ }^{1375}$

En cuanto a la educación media, a finales de los años setenta, había alrededor de 130.000 alumnos matriculados en cursos de humanidades y unos 60.000 en asignaturas técnicas, siendo este bajo número, un indicativo del escaso interés con respecto a los estudios de tecnología industrial y agropecuaria.

A pesar de las dificultades en el mercado de trabajo a excepción de la modalidad de comercio, en el resto de los bachilleratos técnicos, de seguir la tasa de crecimiento histórica a partir de 1974 y contemplando que el 50\% de los mismos ingresarán en la

\footnotetext{
${ }^{1373}$ Edmundo Vera Manzo, op. cit. p. 132.

${ }^{1374}$ Ibíd. p. 133.

1375 PREALC: Situación y Perspectivas de empleo en el Ecuador, en Mimeógrafo editado por la Facultad de Economía de la Universidad Central, p. 222.
} 
universidad, existirá un déficit del 75\% en el sector agropecuario y del 79\% en el sector industrial. $^{1376}$

Estas cifras muestran la necesidad de una reforma del sistema de educación que, de haber tenido lugar, habría permitido la creación de una mano de obra preparada a nivel medio para el trabajo productivo. El aumento de los niveles de educación primaria y secundaria es un objetivo fundamental debido a su importancia para el desarrollo de la productividad y la integración de nuevas tecnologías, al facilitar el progreso de la economía ecuatoriana.

Así, la reforma de la educación en el nivel medio debería de haber abarcado diversas especializaciones en áreas de tipo cultural y científico que habrían permitido acceder a una formación de carácter superior y, también, impulsado una formación profesional de nivel medio en sectores de producción y servicios para satisfacer las necesidades del país. En este caso, la educación podría haber contribuido a un aumento de la productividad, al incrementarse el número de trabajadores preparados con una formación adecuada para desempeñar las actividades. $^{1377}$

Por otro lado, en relación al nivel de estudiantes matriculados en la universidad, se puede decir que ha existido un alto nivel de abandono de la educación superior (aproximadamente dos tercios de los estudiantes matriculados), ya que no existía la posibilidad de cursar carreras de dos o tres años. Esta situación también afectó a las universidades politécnicas, siendo el resultado, la falta de profesionales de carácter medio o superior que el país necesitaba para alcanzar su desarrollo y atender las necesidades básicas de la población ecuatoriana.

Del periodo 1957-1961 al periodo 1972-1976, la tasa de crecimiento de egresados de ingeniería pasa de 8,1\% anual al 18,5\%. Para 1974, había 5.400 ingenieros. Hasta 1951-1952, había en el país solo las ingenierías civil y eléctrica. Antes de terminar la década de los cincuenta se introdujeron las ingenierías química, agronómica e industrial y en la década de los sesenta, las de mecánica, naval zootécnica y forestal. En 1976-

\footnotetext{
${ }^{1376}$ Edmundo Vera Manzo, op. cit. p. 134.

${ }^{1377}$ Ibíd. p. 134-135.
} 
1977, los ingenieros mecánicos y eléctricos representaban el 13\% y $7 \%$ respectivamente del total de ingenieros, mientras que los civiles el $48 \%{ }^{1378}$

No en vano, aquí se ha de señalar el papel desempeñado por los bachilleratos, pertenecientes al ciclo diversificado del nivel de educación secundaria, con una duración de tres años y opción de hasta cinco años de estudio, que estaban destinados a preparar alumnos para estudios superiores o para el ejercicio de profesiones medias. Además, los bachilleratos formaban a profesionales de nivel medio según los requerimientos del desarrollo del país en cuanto a una preparación en humanidades, ciencias y tecnología.

En Ecuador, además de la educación superior en las especialidades correspondientes, es la educación técnica del ciclo diversificado la que tiene por responsabilidad la preparación y capacitación de los profesionales destinados a cumplir labores de nivel medio. Específicamente, dentro de las especialidades técnicas, se encuentran la agrícola y la industrial. Adicionalmente, la educación técnica es puente de enlace entre el ciclo básico y la educación superior de estas especialidades cuando el alumno, que tiene también la opción de incorporarse de inmediato al mercado de trabajo de nivel medio, continúa estudios universitarios. ${ }^{1379}$

Con el bachillerato técnico se desarrollaba un plan de estudios propio de acuerdo con las siguientes ramas: comercio, administración, ciencias agrícolas, mecánica general, agrícola y automotriz, y otras que fueron establecidas según los requerimientos de la sociedad. ${ }^{1380}$ A este respecto, se ha de hacer alusión a la labor realizada durante el breve gobierno de Carlos Julio Arosemena (7-11-1961-11-07-1963), pues la gestión del ministro de educación, Gonzalo Abad, fomentó la implementación de un programa serio de alfabetización y educación de adultos y la creación de colegios técnicos, así como un análisis total de la educación. ${ }^{1381}$

\footnotetext{
${ }^{1378}$ Informativo No. 237, Escuela Superior Politécnica del Litoral, agosto 1981, p. 11-12.

${ }^{1379}$ Consejo Ecuatoriano de Ciencias Sociales: Un experimento innovativo para reducir el desempleo y el subempleo juvenil en el Ecuador, Reunión de expertos sobre el desempleo juvenil, Paris 18-20 septiembre 1985, p. 32.

${ }^{1380}$ Organización de Estados Iberoamericanos: Sistema educativo del Ecuador, oei.es/quipu/ecuador/index.html

${ }^{1381}$ Para más información de los colegios con bachillerato técnico, ver el apéndice de notas del capítulo 6. Fuente: Julio Ayala Serra: Educación y política en el Ecuador 1830-1980, en Libro del Sesquicentenario I, Política y
} 
Otro problema que se presentaba con respecto a las carreras técnicas y al nivel de abandono del segundo o tercer curso, era la falta de preparación y orientación científica de los estudiantes, al no saber aplicar los conocimientos aprendidos en la realidad profesional. En este caso, la enseñanza debería de haberse centrado en aspectos teóricos durante los primeros cursos y luego, en los conocimientos prácticos, para después pasar a una combinación de teoría y práctica.

Además del nivel de educación, las políticas económicas y sociales desarrolladas por el estado ecuatoriano a lo largo del periodo seleccionado han tenido diferentes efectos en la acumulación de capital y, como consecuencia, en el gasto público realizado para lograr el progreso del país, que puede ser medido a través de indicadores del desarrollo social global, como la esperanza de vida.

Francisco Guerra se refiere a esto en su análisis del modelo económico y social del Ecuador:

La magnitud del excedente económico es fundamental, pues parte de este, llega al estado para ser gastado e invertido en el gasto social e infraestructura, la misma que servirá para ampliar la cobertura de los principales servicios sociales, como retribución del ingreso en términos sociales y para beneficio de la acumulación de capital. ${ }^{1382}$

Ya vimos cómo el dinamismo de la economía ecuatoriana que tuvo lugar durante la primera mitad del siglo XX, se encontraba ligado al sector externo y las exportaciones de productos agrícolas y cómo el estado dedicó una parte del excedente obtenido para financiar obras públicas y comenzó a mejorar algunos servicios sociales, como la educación, la salud, etc. ${ }^{1383}$ En este sentido, antes del auge del petróleo, las privaciones de las necesidades básicas afectaban a más de la mitad de la población, existiendo altos niveles de desnutrición y un bajo índice de esperanza de vida, lo cual explica el signo negativo del coeficiente de esta variable en nuestra regresión.

Sociedad Ecuador: 1830-1980, Corporación Editora Nacional, 1980, p. 307; Organización de la Naciones Unidas para la Educación, la Ciencia y la Cultura: Un experimento innovativo para reducir el desempleo y el subempleo juvenil en el Ecuador, Reunión de expertos sobre el desempleo juvenil, Paris, 18-20, 37-38, septiembre 1985, p. 5253.

${ }^{1382}$ Francisco Guerra: Análisis del modelo económico y social ecuatoriano. De los años setenta y ochenta en el marco de la globalización, FLACSO, Quito, 11 de abril 2001, p. 93.

1383 José Moncada: La economía ecuatoriana en el siglo XX: Algunos elementos relativos a la génesis, apropiación y utilización del excedente económico, Instituto de Investigaciones económicas, Universidad Central del Ecuador, 1980, p. 20. 
Carlos Larrea indica que las cifras de las privaciones de las necesidades básicas ponen de manifiesto una situación inferior al promedio latinoamericano. Así, en 1965-1975, la esperanza de vida al nacer, un indicador representativo del desarrollo social global:

Seguía siendo 57.18 años en el Ecuador, comparado con la media regional de 59.51. En 1964-1966, el consumo de proteína per cápita solo alcanzó el 72\% de los requerimientos mínimos. La cifra correspondiente para las calorías era del 74\%. En 1970, la mortalidad infantil para niños entre uno y cuatro se elevaba al 16.6 por mil. Esta cifra solo fue superada por Bolivia (27.6) en América Latina y seis veces superior a la de Argentina (2.7). La situación en el campo era hasta peor, las provincias predominantemente rurales de Cañar, Chimborazo y Cotopaxi donde se concentra la población indígena de la Sierra, indicaron niveles de mortalidad infantil aproximadamente dos veces más altos que el promedio nacional. ${ }^{1384}$

Si bien durante los años setenta se realizaron profundas transformaciones en la sociedad ecuatoriana (urbanización, industrialización protegida, modernización agrícola, aumento de la intervención del estado, crecientes presupuestos fiscales a raíz del auge del petróleo e importantes inversiones en infraestructura vial y salud) que llevaron a un aumento del producto interior bruto y a un intento de planificar el gasto mediante una redistribución social, las reformas de las políticas sociales tuvieron un carácter poco consistente. ${ }^{1385}$

En el caso de la Reforma Agraria de 1973 y otros programas, Carlos Larrea explica que estas medidas no tuvieron una buena planificación durante el gobierno de Rodríguez Lara. Luego, los gobiernos posteriores excluyeron políticas redistributivas significativas, a la vez que tampoco llegaron a contar con el apoyo necesario de la sociedad civil. Por una parte, las fracciones industriales modernas de las clases dominantes no apoyaron la redistribución social, sino que se opusieron a la misma con la ayuda de las fracciones tradicionales, mientras que por otra parte, la organización política de las clases subordinadas era demasiado débil para proveer un apoyo sostenible a las reformas.

\footnotetext{
${ }^{1384}$ Carlos Larrea: Pobreza y Políticas sociales en América Latina, Maestría Relaciones Internacionales, Capítulo III, FLACSO-Quito, diciembre 1988, p. 15.

${ }^{1385}$ Ver el apéndice de notas del capítulo 6 para más información. Fuente: Ibíd. p.14-15.
} 
Solo en ciertas regiones donde las organizaciones campesinas eran lo suficientemente fuertes, la Reforma Agraria fue implementada de modo significativo. Ese fue el caso en la zona arrocera en la Costa y también en algunas áreas de las provincias de Chimborazo y Cañar en la Sierra. ${ }^{1386}$

A pesar de los problemas de las reformas, los programas de desarrollo social se expandieron durante el periodo en cuestión, sobre todo en lo referente a la educación y salud. De hecho, alrededor del $40 \%$ del presupuesto estatal fue empleado en servicios sociales, incluyendo la educación (17\%), la salud (aproximadamente un 7\%), la vivienda (5\%) y el bienestar social. ${ }^{1387}$ Este hecho permite explicar el signo positivo del coeficiente de esta variable en nuestro estudio empírico, pues la prestación de servicios sociales (educación, seguridad social, etc.) y la construcción de infraestructura (vial, electricidad, agua potable, etc.), tienen una incidencia directa en las condiciones de vida de la mayoría de la población, al proveer servicios que mejoran el acceso a las necesidades básicas, aumentan la educación, reducen la mortalidad y aumentan la esperanza de vida.

Como ya se ha dicho, la esperanza de vida aparece con un coeficiente negativo, ya que al parecer, los valores más bajos de este índice han tenido un mayor peso en la regresión a pesar de la mejora de los mismos en los años setenta. También, esto puede deberse a que si bien dichos resultados beneficiaron a las zonas rurales, se mantuvo un pronunciado sesgo urbano en las políticas sociales. ${ }^{1388}$

Aquí, la variable que desempeña un papel muy importante es la del nivel de ingresos, sobre todo, si se tienen en cuenta las diferencias existentes entre la Costa y la Sierra en cuanto a la tenencia de la tierra y el destino de la producción. No en vano, pese a las diferencias estudiadas en ambas regiones, se observan rasgos parecidos en cuanto a la concentración del ingreso, originándose un modelo concentrador y excluyente, pues la mayor parte de los beneficios estaban en manos de un

\footnotetext{
${ }^{1386}$ Ibíd. p.8.

1387 Cornelio Marchán: Ecuador: Crisis, ajuste y política social en los años ochenta, Fundación Grupo Esquel, Ecuador, 1992, p. 6.

1388 Carlos Larrea, Rob Vos, Luis Ignacio Jácome: Políticas macroeconómicas, distribución y pobreza en el Ecuador, CORDES, Ecuador, 1998, p. 31, en Francisco Guerra: Análisis del modelo económico y social ecuatoriano. De los años setenta y ochenta en el marco de la globalización, FLACSO, Quito, 11 de abril 2001.
} 
pequeño grupo de personas, mientras que el resto de la población vivía con un ingreso mínimo con el que apenas podía satisfacer sus necesidades básicas.

Desde la época de la colonia se fue conformando este modelo de sociedad y más tarde en la República. En ausencia de políticas y acciones profundas, frente a las fuerzas concentradoras, hicieron que el fenómeno se fuera agudizando y acentuando el grado de la regresividad, descartándose la idea de que el crecimiento por sí solo impulsara una mejora en la distribución del ingreso. ${ }^{1389}$

La distribución del ingreso está altamente concentrada a favor de reducidos grupos de la población y esto, es la resultante más clara en lo social del funcionamiento de la economía en este marco. ${ }^{1390}$

Ya hemos estudiado cómo los problemas en la distribución del ingreso en el Ecuador, dificultaron el crecimiento industrial, puesto que el mercado interno estaba bastante limitado. En este caso, la falta de capacidad para producir suponía un obstáculo para atender la demanda existente, ocasionando altos costes de producción y la aparición de los monopolios. Además, la existencia de un mercado interno de carácter tan restringido, constituía un límite a las oportunidades de trabajo, pues existía una alta tasa de marginalidad de la población.

A su vez, la estructura de producción industrial tenía una gran dependencia de las inversiones extranjeras, ya que en la mayoría de los casos, los sectores sociales con un nivel de ingresos más alto demandaban productos más complicados y, para producirlos, era necesario importar bienes de capital y pagar licencias extranjeras, que a fin de cuentas, debilitaban aún más la posición de la balanza de pagos. ${ }^{1391}$

Junto con los problemas de tenencia de la tierra, la estrechez del mercado interno y la gran subordinación con respecto a los capitales foráneos, se ha mencionar la dependencia de las

1389 Lionel López Pinto: Distribución del ingreso en la economía ecuatoriana 1830-1980, en Libro del Sesquicentenario, Economía Ecuador, segunda parte, 1830-1980, Corporación Editora Nacional, 1983, p. 156; Enrique Ayala, Alberto Costa: IV Economía, Ecuador 1830-1989, vol. 2, Libro del Sesquicentenario, Corporación Editora Nacional, 1983, p. 156.

${ }^{1390}$ Leonardo Vicuña: Situación de la clase trabajadora en la economía ecuatoriana, en Economía Ecuador: 18301980, primera parte, Libro del Sesquicentenario, Corporación Editora Nacional, 1983, p. 144.

${ }^{1391}$ Lionel López Pinto, op. cit. p.162. 
exportaciones del sector primario, que, al estar ligadas a dicho sistema de tenencia y formas de producción, originaron efectos concentradores en el nivel de ingresos.

La producción de algunos de los principales productos de exportación (cacao, café, arroz y banano), permitieron obtener las divisas necesarias para pagar las importaciones de bienes de capital e insumos; y a su vez, ayudaron a consolidar la posición de los agroexportadores, dueños de las propiedades de la Costa, y de los comerciales-importadores. Estos grupos se quedaron con una buena parte del ingreso que se obtenía mediante estas actividades, dándoles a los trabajadores un salario mínimo, que facilitó a su vez la competencia del producto en el mercado internacional. $^{1392}$

Posteriormente, durante el auge del petróleo en los años setenta, se produjo una variación si se compara con el periodo anterior, y es que el estado pasó a ser el mayor beneficiario de los recursos generados por las exportaciones. Un estudio realizado por el Instituto Nacional de Estadísticas y Censos del Ecuador muestra la variación en la distribución del ingreso en esta etapa, en la que se registraron altas tasas de crecimiento de la economía, que no lograron ayudar a la clase más baja, mientras que la clase media pudo favorecerse en algunos casos, hecho que permite explicar el signo positivo del coeficiente del nivel de ingresos en nuestra regresión (y su moderada contribución). ${ }^{1393}$

Se observó que en el estrato inferior de ingreso no hubo mejoría y el promedio del ingreso real por persona se reduce en el periodo analizado. Los estratos medios de ingreso tuvieron una relativa mejoría con relación a la situación anterior, debido a las nuevas oportunidades de empleo creadas con la expansión económica, especialmente el emprendimiento de numerosas obras de infraestructura por parte del estado... ${ }^{1394}$

Los sectores más altos lograron fortalecer su posición y aumentar su capacidad de concentración de ingresos, provocando una mayor diferencia entre las clases y su poder adquisitivo en el periodo comprendido desde finales de los años sesenta y mediados de los setenta.

\footnotetext{
${ }^{1392}$ Leonardo Vicuña, op. cit. p. 144.

${ }^{1393}$ Encuestas de hogares de 1968, INEC, encuestas de población y ocupación, INEC, 1975.

${ }^{1394}$ Lionel López Pinto, op. cit. p.162.
} 
Así, a pesar de los pequeños cambios positivos producidos en la distribución de ingresos, salarios y necesidades básicas, estos logros, solo llegaron a representar un cambio limitado:

si los comparamos con la magnitud de desigualdad, pobreza e insatisfacción de las necesidades básicas. En términos de desarrollo social, el país permanecía a finales del auge petrolero, muy por debajo de los promedios latinoamericanos. ${ }^{1395}$

Vamos a pasar a analizar el papel de la variable inversión, la cual ha sido un elemento fundamental para el desarrollo de la economía ecuatoriana, pero su contribución al mismo, se ha visto limitada por la dependencia externa generada, lo cual explica el moderado valor del coeficiente de nuestra regresión.

Ya analizamos cómo durante los años cincuenta las inversiones fueron realizadas por el estado a través del Banco de Fomento en las plantaciones de banano y otros productos agrícolas, a la vez que se organizó un sistema de comercialización encargado de promocionar las exportaciones de estos bienes. Paralelamente, la inversión estatal se concentró en la construcción de una red de carreteras para satisfacer las necesidades fundamentales del país y en la ampliación del esfuerzo de los organismos encargados del desarrollo urbano.

En este sentido, el auge bananero supuso una mayor integración del país al sistema capitalista internacional, a la vez que el crecimiento económico se iba vinculando a un modelo exterior y se producían transformaciones sociales en un contexto, en el que el estado comenzaba a asumir un nuevo papel de agente dinamizador.

En efecto, el estado no se limitó a garantizar únicamente la estabilidad monetaria, sino que dedicó sus esfuerzos a la construcción de carreteras y otras obras de infraestructura para satisfacer las necesidades fundamentales del país, mientras mantenía un conjunto de organismos técnicos dedicados a la planificación económica, al control de los servicios fundamentales y al fomento de las inversiones. ${ }^{1396}$

En la década de los sesenta, con el estímulo de la Alianza para el Progreso, tuvo lugar una reorganización administrativa y legal importante que, en principio, parecía que iba a preparar al

\footnotetext{
${ }^{1395}$ Carlos Larrea, Pobreza y políticas..., op. cit. p.8.

${ }^{1396}$ Ver mapa de las carreteras en el apéndice de mapas del capítulo 6. Fuente: Enrique Ayala, Rafael Quintero: Teorías e ideologías sobre el estado en Ecuador 1948-1984, en "El estado en América Latina: Teoría y práctica", coordinador Pablo González Casanova, Biblioteca América Latina: actualidad y perspectivas, editorial Siglo XXI, 1990, p. 370.
} 
país para una mejora notable de su capacidad de inversión dentro de un esquema claramente capitalista. ${ }^{1397}$ No obstante, la pérdida de dinamismo de las exportaciones de banano limitó el proceso como consecuencia de la falta de recursos financieros.

La tabla 14 (Formación bruta de capital fijo, 1965-1973) muestra el crecimiento de la inversión privada en un 70\% durante un periodo de ocho años (1965-1973), mientras que la inversión pública no gozaba del mismo dinamismo y solo pudo alcanzar un $50 \%{ }^{1398}$

Sin embargo, José Gangotena indica que un análisis de estos datos en términos per cápita, pone de manifiesto que la capacidad de conversión de ahorro en capital fijo de cada individuo del país solo resultó en un aumento del $20 \%$ durante dicho periodo. ${ }^{1399}$

Posteriormente, en los años setenta, a pesar del auge petrolero, la capacidad para invertir no fue suficiente para absorber el flujo incrementado de recursos financieros. Hasta mediados de esta década, una buena parte de estos recursos eran mantenidos en depósito en el exterior, ya que su monetización fomentaba solo un consumo que la economía no podía satisfacer, lo que dio lugar a una elevada presión inflacionaria. ${ }^{1400}$

Como consecuencia, el estado tuvo que liberar importaciones de bienes de lujo para disminuir la presión sobre la producción interna. Aquí, es donde tuvo lugar el aumento del consumo, al que nos referimos antes, por parte de la clase media y alta de este tipo de bienes (televisiones en color, electrodomésticos, etc.), viéndose el gobierno obligado a realizar importantes inversiones urbanas para atender las nuevas necesidades de estas clases sociales.

Por su parte, el fomento del consumo de dichos productos procedía de la congelación de los precios de combustibles y bienes agrícolas, ya que se originó una amplia transferencia de ingresos hacia estos sectores. Esta situación hizo que se agotaran los recursos que podían haber sido destinados a la inversión productiva.

\footnotetext{
1397 José Raúl Gangotena: La inversión en el Ecuador 1830-1980, en Libro del Sesquicentenario, Economía Ecuador, segunda parte, 1830-1980, Corporación Editora Nacional, 1983, p. 146.

${ }^{1398}$ Esta tabla se encuentra en el apéndice de datos del capítulo 6. Fuente: Ibíd. p. 147.

${ }^{1399}$ Cuentas Nacionales, Banco Central del Ecuador, en Ibíd. p. 147.

${ }^{1400}$ Ibíd. p. 148.
} 
Además, el proceso de industrialización estuvo orientado a la producción de bienes demandados por consumidores con una alta capacidad adquisitiva, incrementándose por tanto, las importaciones de productos intermedios, y con ello, su peso en la balanza de pagos.

La crisis del petróleo a mediados de los setenta puso de manifiesto las restricciones de la economía ecuatoriana debido a la tendencia consumista y la creación de un ingreso permanente para las clases más privilegiadas. Así, en el año 1977, la inversión y el consumo existieron gracias al endeudamiento, que alcanzó altos niveles, mientras que la capacidad de inversión del Ecuador aumentó considerablemente, tal y como se aprecia en la tabla 15 (Formación bruta de capital fijo (1972-1980). En este periodo (1975-1980), la inversión privada se incrementó en un $140 \%$ siendo superada por la inversión pública que creció en un 170\%. ${ }^{1401}$

Asimismo, algunos de los estudios relacionados con el papel de la inversión foránea en el Ecuador, defienden que la afluencia de este tipo de capital ha sido beneficiosa para el país, ya que ha servido como complemento al ahorro interno y ha contribuido a la transferencia de tecnología; mientras que otras investigaciones sostienen que este tipo de actividad no ha ayudado al desarrollo nacional, pues al estar centrada en la rentabilidad, ha dejado a un lado la situación socio-económica de los países que la reciben. ${ }^{1402}$

En los años cincuenta y sesenta, el mercado ecuatoriano estaba caracterizado por su reducido tamaño y un bajo nivel de ingresos, lo cual era motivo suficiente para que los inversores de la época no estuviesen interesados en invertir grandes cantidades en este país. No en vano, ya sabemos que a partir de 1970, las modificaciones llevadas a cabo en la estructura económica tras el auge del petróleo, impulsaron las inversiones extranjeras y, con ello, se mejoró el nivel de ingreso de una buena parte de la población:

Hacia 1977, la inversión extranjera acumulada en el sector industrial representaba aproximadamente el $44 \%$ de las inversiones realizadas en todos los sectores, siguiéndole

\footnotetext{
${ }^{1401}$ Esta tabla se encuentra en el apéndice de datos del capítulo 6. Fuente: Ibid. p. 149.

${ }^{1402}$ Domingo Sánchez Caro: Consecuencias socioculturales de la transferencia de tecnología, Estudios Sociales, no. 7-CPU, 1975, Hugo Trivelli: Tecnología y crecimiento económico", Estudios Sociales, No. 7-CPU, 1975; Jorge Fernández: La transferencia de tecnología, Estudios Sociales, no.7, CPU-1975.
} 
en importancia la inversión realizada en el sector de hidrocarburos que alcanzó el $21 \%$ de las inversiones acumuladas totales hasta dicho año. ${ }^{1403}$

Pese a esto, el capital que ingresó en el Ecuador como inversión volvió a salir en mayor cantidad mediante la vía del mercado libre, dejando las actividades productivas vinculadas a una oferta de tecnología, recursos financieros y materia prima del exterior. En este contexto, es importante considerar el efecto de la contribución de la tecnología realizada por dichas inversiones.

Teniendo en cuenta la falta de preocupación del país por el desarrollo científico y tecnológico, no es de extrañar la ausencia de un mecanismo que permitiera generar nuevos conocimientos técnicos para innovar y desarrollar un conjunto de procesos propios. Esta falta de capacidad técnica se convirtió en un motivo esencial para buscar en el exterior la tecnología necesaria que el proceso productivo requería, siendo uno de los principales problemas, el exceso de dependencia externa a la hora de tomar decisiones y decidir sobre el desarrollo económico futuro.

En este contexto, el elemento fundamental para que un proceso tecnológico sea el motor de desarrollo de un país es que pueda responder a las necesidades de producción de bienes y servicios de acuerdo a la dotación de recursos humanos, financieros y técnicos de una sociedad. En el caso ecuatoriano, en lugar de considerar la inversión extranjera como un medio para solucionar los problemas productivos y financieros del país, se debió de haber establecido una función específica para la misma, ya que este capital acabó actuando de acuerdo a sus propios intereses económicos y políticos. Además, se debía de haber determinado la forma en que se daba uso a la tecnología externa y haber creado los mecanismos necesarios para captar y mejorar su uso. ${ }^{1404}$

El tema de las inversiones realizadas en el Ecuador se encuentra ligado a otro importante elemento, la apertura de la economía, sobre todo, si se tiene en cuenta el carácter dominante del modelo de crecimiento económico hacia el exterior en este país a lo largo del siglo XX.

Asimismo, las políticas adoptadas con la industrialización por sustitución de importaciones configuraron lo que sería el modelo de integración del Ecuador en la economía global generando

\footnotetext{
1403 Ángel Matovelle: Las inversiones extranjeras y la transferencia de tecnología en el Ecuador, en Libro del Sesquicentenario, Economía Ecuador, segunda parte, 1830-1980, Corporación Editora Nacional, 1983, p. 315.

${ }^{1404}$ Ibíd. p. 316.
} 
un impacto en el crecimiento, en el momento en que dicho modelo comenzó a desarrollar tendencias aperturistas.

Aquí, el estado aprovechó la apertura para consolidar su sector industrial mediante la inversión extranjera directa, a la vez que la atracción de capitales hacia su sector productivo le permitió incorporarse al mercado internacional. Sin embargo, hay que señalar el Ecuador no adoptó políticas de protección de sus sectores más sensibles obteniendo por tanto, un nivel bajo de beneficios.

Asimismo, la apertura generada no dio los beneficios esperados debido a los condicionantes ya mencionados, como la debilidad de la tasa de formación bruta de capital fijo, el destino de la creciente inversión extranjera, las bajas tasas de investigación y desarrollo y el bajo grado de sofisticación de las exportaciones. ${ }^{1405}$ Todo esto explica la moderada contribución del coeficiente de la apertura económica en nuestra regresión.

En relación a la tasa de crecimiento de la población y la población urbana y su contribución al crecimiento de la economía, hemos de recordar la importancia de la tierra y su papel como una de las principales fuentes de riqueza, pues la distribución de los derechos de propiedad determina por un lado, el nivel en que los grupos sociales pueden acceder a dichas fuentes de riqueza y, por otro, el nivel de población existente.

Ya sabemos que el Ecuador está constituido por economías regionales que poseen los rasgos básicos de las dos principales regiones del país, en las que los factores de producción no se encuentran distribuidos según su productividad. Es decir, nos estamos refiriendo a la región del litoral, tradicionalmente orientada hacia el exterior y caracterizada por su auge comercial, y, a la Sierra, con una tendencia de ritmo lento en el crecimiento interno de su economía. El nivel de desarrollo de dichas regiones permite explicar las diferencias en cuanto a la tasa de crecimiento de la población y su distribución alrededor de las zonas urbanas.

También, Gonzalo Correa se refiere a las regiones en que el país se encuentra dividido y a cómo el desarrollo de cada zona se ha producido de forma aislada, siendo bastante lenta su integración debido a la dificultad para establecer vías de comunicación que permitieran un aprovechamiento productivo:

\footnotetext{
1405 Pablo Andrade, Alicia Puyana: La pobreza en América Latina: ¿Una dimensión olvidada de la integración económica regional?, CLACSO, 2010, p. 31-32.
} 
En la Costa, se desarrolló la cuenca del río Guayas, que era el medio de comunicación disponible y el desarrollo costeño se proyectó al exterior. En la Sierra, Quito y Cuenca y otros centros tendían a una autosuficiencia. ${ }^{1406}$

En la región de la Costa se establecieron los elementos de una sociedad capitalista comercial, mientras que en la Sierra permanecieron las características de una economía tradicional, feudal y atrasada en cuanto a las relaciones de producción.

Este equilibrio socio-económico basado en la economía tradicional de la Sierra o en las plantaciones de la Costa, se vería alterado tras la aparición de un conjunto de factores percibidos durante los años cincuenta, los cuales vinieron a desequilibrar la situación. ${ }^{1407}$

En esta línea, la concentración de la tierra, el aumento de la población, la creciente demanda del sector urbano, la intensificación de las vinculaciones con la economía de la Costa y su relación con el mercado internacional fueron algunos de los elementos que ayudaron a eliminar las instituciones y el sistema latifundista tradicional para entrar en un proceso de adaptación a los requerimientos de las nuevas condiciones. ${ }^{1408}$

Como consecuencia, la distribución de la población entre las principales regiones del Ecuador cambió de forma sustancial desde 1950 en adelante, con grandes implicaciones políticas, sociales y económicas. La Costa se convirtió en el área más poblada, mientras que el Oriente había triplicado su población a pesar de que esta no era demasiado alta.

El porcentaje de la población que vive en la Costa se incrementó entre 1950 y 1990, de cerca del 40,5\% a aproximadamente el 49,7\% y del 1,5 al 3,5\% en el Oriente; mientras que la participación de la Sierra decayó del 58\% al 45,7\%. La Costa llegó a ser una región muy influyente políticamente y la más dominante en la economía del Ecuador.

\footnotetext{
${ }^{1406}$ Gonzalo Correa Escobar: La economía ecuatoriana de 1830 a 1980, en Economía Ecuador: 1830-1980, primera parte, Libro del Sesquicentenario, Corporación Editora Nacional, 1983, p. 76.

1407 Marco Jaramillo Pavón: La economía campesina y la reforma agraria en el Ecuador, en Economía Ecuador: 1830-1980, primera parte, Libro del Sesquicentenario, Corporación Editora Nacional, 1983, p. 159-183.

${ }^{1408}$ Ibíd. p. 167.
} 
Pese a que la Sierra es la sede del gobierno central, su importancia económica y política ha disminuido. ${ }^{1409}$

Las variaciones en la concentración de la población entre las principales regiones ecuatorianas, mostraban las diferencias en el crecimiento de la población. Así, por ejemplo, si bien en 1950, el Ecuador contaba con una población predominantemente agraria con el 71,5\% de sus 3,2 millones de habitantes viviendo en las áreas rurales, esta situación fue cambiando al incrementarse la población urbana más de seis veces entre 1950 y $1990{ }^{1410}$

Este rápido crecimiento de la población urbana supuso un mayor peso en los gobiernos para satisfacer los servicios públicos (salud, educación, electricidad, transporte, agua potable, etc.), lo cual explica el coeficiente positivo de nuestra regresión.

En 1950, la Sierra tenía la mayor proporción de habitantes urbanos de la población total de cualquier región con el 15,2\%, mientras que la población urbana en la Costa representaba el 13,2\% de la población total del Ecuador. ${ }^{1411}$

De este modo, el aumento de la población en la Costa se debió a las oportunidades de empleo e ingresos en las áreas urbanas, las cuales estaban vinculadas al auge del petróleo y a las políticas macroeconómicas que favorecían la industrialización para sustituir las importaciones.

En último lugar, al analizar las variables de derechos políticos y civiles en el Ecuador, se ha de hacer referencia al sistema político e institucional y recordar las diferencias entre una primera etapa caracterizada por una sociedad tradicional con un sistema de haciendas que dominaba la vida política, económica y social, y la etapa posterior a la década de los cincuenta, al entrar en crisis dicho modelo debido a los cambios que tuvieron lugar en la sociedad y organización política del país. Pese a esto, dichos periodos tienen en común la existencia de contradicciones, luchas y negociaciones entre las diferentes fuerzas sociales, que buscando imponer su hegemonía

\footnotetext{
${ }^{1409}$ Morris D. Whitaker, Dale Colyer, Jaime Alzamora: El rol de la agricultura en el desarrollo económico del Ecuador, Un diagnóstico del sector agrícola del Ecuador, Quito, Ecuador, 7 junio 1990, p. 129.

${ }^{1410}$ Ibíd. p. 131.

${ }^{1411}$ Ibíd. p. 131-132.
} 
al conjunto de la sociedad para acceder al poder político y beneficiarse, han obstaculizado el crecimiento económico del país. ${ }^{1412}$

De acuerdo con Fernando Maldonado, estas contradicciones, manifestadas en ámbitos y tiempos diversos, dieron forma a la sociedad ecuatoriana y a los elementos que configuraron la existencia de gobiernos controlados por militares o caudillos populares, determinando su papel político y sus intervenciones permanentes en el control del estado, de ahí que el nivel de derechos políticos o libertades civiles sea mínimo en este periodo. ${ }^{1413}$

Hemos visto cómo el progresivo carácter capitalista de la agricultura, el auge de exportaciones de banano en la Costa, la incorporación de capital, técnicas y contratación salarial de los trabajadores, junto con la introducción de nuevos cultivos en la Sierra y en el Oriente (té, piretro, etc.) y el desarrollo de la ganadería, fueron algunos de los factores que contribuyeron a la promoción del capitalismo ecuatoriano en los años cincuenta. De igual manera, el crecimiento de las ciudades se fue consolidando a partir del aumento de las migraciones de población, sobre todo en la Costa, las cuales llegaron a crecer a tasas del 10\% anual, esto es, tres veces más rápidamente que la población del país. ${ }^{1414}$ (La tabla 16 muestra un censo con las regiones y provincias más importantes y con mayor crecimiento de población para este periodo).

Osvaldo Hurtado habla sobre las consecuencias políticas de este fenómeno, pues ayudaron al proceso de descomposición de la hacienda tradicional, en el momento en que una amplia parte de la población pudo escapar de su dominio. En este caso, la ciudad pasó a ser el centro de la política nacional, siendo los intereses del pueblo el elemento de mayor influencia, cuando este comenzó a ser percibido como elemento político.

Según Hurtado, el pueblo no solo se integró con los marginados que eran las poblaciones que habitan los suburbios en las ciudades de la Costa y la Sierra, sino que supuso una ruptura con la sociedad tradicional dominada por la hacienda, en la que la presencia popular ocurría a través de las clientelas electorales de los caciques. ${ }^{1415}$

\footnotetext{
${ }^{1412}$ Osvaldo Hurtado, El proceso político..., op. cit. p.35-52.

${ }^{1413}$ Fernando Maldonado Donoso: Militares y política en e Ecuador de 1830-1980, en Libro del Sesquicentenario I, Política y Sociedad, Ecuador: 1830-1980, Corporación Editora Nacional, 1980, p. 390-399.

${ }^{1414}$ Esta tabla se encuentra en el apéndice de datos del capítulo 6. Fuente: Osvaldo Hurtado, El proceso político..., op. cit. p.36-37.

${ }^{1415}$ Ibíd. p.37.
} 
Aquí, los marginados, todavía bajo la influencia de los valores rurales tradicionales, buscaban en la ciudad un amo paternalista o caudillo populista que les solucionara los problemas y representara sus intereses en cuanto a política, como ocurrió con la figura de Velasco Ibarra, presidente del Ecuador en cinco ocasiones, y que no siempre supo estar a la altura de las circunstancias a la hora de representar al pueblo ecuatoriano. ${ }^{1416}$

Como ejemplo de esto, se puede hacer alusión a su ascenso al poder mediante un golpe de estado en el año 1946, implantando en el país una dictadura caracterizada por frecuentes antagonismos, resentimientos y persecuciones de estudiantes y obreros.

Al hablar de situaciones contradictorias, se ha de recordar cómo pese a que Velasco Ibarra presumía de su carácter liberal y atacaba a los oligarcas, la realidad muestra cómo defendía sus intereses al igual que la propiedad privada, llegando a convertirse en la figura ideal para dichos grupos dominantes, los cuales financiaban su campaña política:

Los gobiernos más agitados son los de Velasco, hombre contradictorio, populista, que en sus administraciones trató siempre de destruir a los partidos políticos. Rodeado de elementos en gran mayoría sin escrúpulos con los fondos, dejó al país en un estado de descomposición moral de espanto, en tanto que como un mal administrador arruinó la situación económica nacional. No se puede hablar mucho de su respeto a la Constitución, pues en sus gobiernos se clausuran periódicos, se destierra a ciudadanos, se rompen huelgas y se cometen tropelias e iniquidades. ${ }^{1417}$

Además de la presencia de los caudillos populistas, se ha de recordar la posición de los militares en el Ecuador, como la Junta Militar de 1963-1966, que llegó al gobierno en la década del desarrollo para promocionar la modernización y programación, recurriendo en su lucha contra el comunismo, a la persecución y represión política de la población. Posteriormente, el gobierno Nacionalista Revolucionario de las Fuerzas Armadas (1972-1976), al mando de Rodríguez Lara,

\footnotetext{
${ }^{1416}$ Velasco Ibarra fue presidente del Ecuador durante 1934-1935, 1944-1947, 1952-1955, 1960-1961 y $1968-1972$.

${ }^{1417}$ Camilo Mena: Evolución de la organización político-constitucional en América Latina (1950-1975). Situación del Ecuador, en "Evolución de la organización político-constitucional en América Latina", Vol. II, UNAM, 1979, p. 213-214.
} 
se hizo cargo del poder, tras acabar con la dictadura de Velasco Ibarra proclamada dos años antes, con el objetivo de controlar el petróleo y continuar su auge. ${ }^{1418}$

La crisis económica y política que el Ecuador vivía por aquel entonces con Velasco Ibarra, ponía de manifiesto una insurgencia de sectores industriales vinculados al capital industrial de las multinacionales y que necesitaban del estado para consolidar sus posiciones ante las fracciones tradicionales de la burguesía agroexportadora. ${ }^{1419}$

En este contexto, las Fuerzas Armadas tomaron el control del poder, y aún cuando la política petrolera del periodo 1972-1974, fue el elemento más importante en la lucha para conseguir mayores ingresos para el estado ante los monopolios petroleros, el resultado fue un empeoramiento de los problemas del país, una mayor concentración de la riqueza en pocas manos, un alto nivel de deuda externa y de corrupción generalizada.

Hemos analizado cómo años más tarde, en 1976, Rodríguez Lara fue derrocado por las Fuerzas Armadas y sustituido por un triunvirato formado por los oficiales más antiguos del ejército. El triunvirato militar impuso un tipo de política vinculada a los grupos tradicionales de la burguesía y a la derecha política, en particular, las dictaduras del Cono Sur, a la vez que emprendía una campaña de altos gastos militares, que contribuyeron a aumentar las ganancias de las multinacionales de la guerra. No en vano, dicho gobierno constitucional mantuvo las políticas económicas y sociales anteriores, produciéndose solo algunos cambios hacia el final de dicho mandato, siendo uno de ellos, el ocurrido en el ámbito político electoral, al convocarse elecciones y devolver el poder a los civiles para poder salvar a la institución militar, bastante deteriorada por sus conflictos internos, e integrarla en sus funciones específicas. ${ }^{1420}$

Esto ocurrió por la presión ejercida por Estados Unidos para promover la vuelta a la democracia parlamentaria, como consecuencia del fracaso de las dictaduras militares y el desgaste de sus ejércitos, lo cual explica el ligero aumento de las libertades civiles y derechos políticos en esta época. ${ }^{1421}$

\footnotetext{
${ }^{1418}$ Osvaldo Hurtado, El proceso político..., op. cit. p.43.

${ }^{1419}$ Fernando Maldonado Donoso, op. cit. p. 398.

${ }^{1420}$ Osvaldo Hurtado, El proceso político..., op. cit. p.44.

${ }^{1421}$ Fernando Maldonado Donoso, op. cit. p. 399.
} 
En definitiva, del análisis realizado se puede concluir que si bien los débiles efectos redistributivos llevados a cabo, produjeron cambios positivos moderados en la distribución de los ingresos, salarios y necesidades básicas, estos logros solo representaron un cambio limitado cuando se comparan con la magnitud de desigualdad, pobreza e insatisfacción de las necesidades básicas de la población ecuatoriana. ${ }^{1422}$ Como parte del proceso de modernización, el paso de una economía fundamentalmente agrícola a una industrial y la importancia dada a este modelo industrial-proteccionista, determinó cambios en el producto interior bruto, en donde el sector agropecuario se redujo de forma considerable.

Esta disminución contradice las ideas planteadas al principio en las reformas agrarias y en los planes de desarrollo, en cuanto al establecimiento de la actividad agropecuaria como apoyo de la industria manufacturera, creando bienes y servicios para la mayoría de la población.

Así pues, siguiendo la lógica de la acumulación de capital o de la búsqueda de la mayor rentabilidad, la modernización de la agricultura se desvió hacia la ganadería y se empezaron a crear productos agropecuarios industriales, que si bien satisfacían las necesidades de las capas sociales más altas de la población urbana, dejaban a un lado las de la mayoría de la población. Asimismo, la agricultura acabó orientándose hacia cultivos comerciales vinculados a la agroindustria y exportación, creando poco empleo para los campesinos y con un alto índice de dependencia del exterior en lo referente a insumos y maquinaria. Esta situación refleja un crecimiento económico concentrador y socialmente restringido y excluyente, pues en general, las políticas beneficiaron a los grupos más ricos de la sociedad, los dueños de las tierras y capital. ${ }^{1423}$

\footnotetext{
1422 Carlos Larrea: Pobreza y políticas sociales en América Latina, Maestría Relaciones Internacionales, Capítulo III, FLACSO-Quito, diciembre 1988.

${ }^{1423}$ Francisco Guerra: Análisis del modelo económico y social ecuatoriano. De los años setenta y ochenta en el el marco de la globalización, FLACSO, Quito, 11 de abril 2001, p. 3-190.
} 


\section{CONCLUSIONES: EVALUACIÓN DEL PROCESO DE MODERNIZACIÓN Y DESARROLLO DEL CAPITALISMO EN EL ECUADOR (1950-1970):}

En la introducción a esta tesis, se estableció un conjunto de objetivos para realizar el estudio de los principales cambios socio-económicos ocurridos en el Ecuador durante el desarrollo del capitalismo, así como su incidencia en el crecimiento de la economía en el periodo 1950-1970. La revisión del pensamiento social y de las obras de algunos de los autores predominantes de la historiografía ecuatoriana contemporánea, nos han permitido analizar las diversas etapas en las que se produjo la acumulación del capital, la inserción en el sistema capitalista como país agroexportador, los modelos de desarrollo utilizados por los diferentes gobiernos, las transformaciones de las estructuras agrarias tradicionales, el desarrollo de la industrialización y la contribución de estos sectores a la economía en su intento de modernización de la sociedad ecuatoriana. $^{1424}$

El estudio de estos factores pone de manifiesto la existencia de un sistema estructural, en el que la evolución del estado y de sus instituciones durante los siglos XIX y XX, la formación social y el papel de las clases dominantes, la importancia de la hacienda como eje articulador de la economía, la dependencia del capital extranjero, la cuestión nacional y los intereses en cuanto al regionalismo, han desempeñado un papel fundamental en el proceso del desarrollo histórico de este país, tal y como muestran las siguientes conclusiones.

Al hilo de la idea planteada, la PRIMERA CONCLUSIÓN obtenida, se refiere a la forma en que la transición postcolonial tuvo lugar en el siglo XIX, pues el marcado regionalismo de la sociedad pone de relieve la ausencia de unidad nacional, siendo esta, una característica permanente que ha dificultado la modernización del país. Estos aspectos, junto con los rasgos heredados de la colonia, las luchas regionales por la independencia y los diversos gobiernos republicanos, son algunos de los factores responsables de la formación de la sociedad ecuatoriana a lo largo del siglo XX.

\footnotetext{
${ }^{1424}$ Entre las obras analizadas se encuentran las de los siguientes autores: Enrique Ayala Mora: Resumen de historia del Ecuador, Independencia y etapa colombiana, tercera edición actualizada, Corporación editora nacional, Quito, 2008; Lucha política y origen de los partidos en Ecuador, Pontificia Universidad Católica del Ecuador, Editorial Publitécnica, Quito, Ecuador, 1978; Rafael Quintero y Erika Silva: Ecuador: Una nación en ciernes, Tomo I, II y III, FLACSO, 1991; Andrés Guerrero: Los oligarcas del cacao: Ensayo sobre la acumulación originaria en Ecuador: Hacendados, cacaoteros, banqueros, exportadores y comerciantes en Guayaquil (1890), Corporación editorial, primera edición, agosto, 1980; Gonzalo Ortíz Crespo: La incorporación del Ecuador al mercado mundial: La coyuntura socio- económica 1875-1895, Banco Central del Ecuador. Colección Isidro Ayora, volumen IV, 1981.
} 
Es importante matizar que la falta de integración se ha de buscar en el modo en que se llevó a cabo la configuración del país en diversas regiones desde una época temprana y en el proceso de formación social y fragmentación de clases, la ejecución del poder político en el marco de un nuevo estado, el creciente desarrollo de la hacienda como elemento fundamental de la economía y la incorporación de este país al sistema capitalista mundial a finales del siglo XIX. Es decir, la rapidez con la que ocurrieron todos estos acontecimientos durante los dos siglos mencionados, tuvo un gran impacto en el proceso de creación y consolidación del Ecuador como nación.

En este caso, se ha mostrado cómo la independencia puede ser interpretada como una etapa en la que comenzó a resurgir ese carácter regionalista, pues supuso un momento de transición y abandono del estatus colonial, en el que se planteó la constitución de la nación ecuatoriana, lo cual supuso un complicado reto después de tres siglos de colonialismo.

Otro aspecto que también contribuyó al regionalismo, fue la formación social y sus clases, que en el caso de la zona de la Sierra, sabemos que estaba formada por una clase dominante que había heredado una acumulación histórica colonial y cuyos intereses económicos estaban vinculados a la tenencia de la tierra. ${ }^{1425}$ Por su parte, en la Costa, la inserción del país en las relaciones capitalistas mundiales a través del mercado internacional, permitió el nacimiento de la burguesía costeña que, a finales del siglo XIX, logró convertirse en una clase nacional, a la vez que la serranía conservaba las estructuras sociales heredadas de la colonia y que apenas habían sido modificadas. ${ }^{1426}$

De esta combinación, se concluye que la cultura resultante acabó constituyéndose como un producto dividido que se encontraba unido a la cultura conquistadora de forma artificial y en el que no se prescindía de lo nacional por conveniencia propia.

$* * * * * *$

Volviendo a la idea de la incorporación del Ecuador al sistema capitalista hacia finales del siglo XIX, nuestra SEGUNDA CONCLUSIÓN hace alusión a la forma tan particular en que se desarrolló el capitalismo en el Ecuador y a cómo el capital y pre-capital lograron convivir durante tanto tiempo, ya que la transición de su economía pre-capitalista se produjo al crearse un espacio, en el que se mantenían las relaciones feudales y asalariadas.

\footnotetext{
${ }^{1425}$ Rafael Quintero, Erika Silva, op. cit, p. 29.

${ }^{1426}$ Andrés Guerrero, Los oligarcas del cacao: Ensayo sobre la acumulación..., op. cit. p. 20-75.
} 
La combinación de estos elementos nos lleva a concluir que el limitado desarrollo del capitalismo en el Ecuador tuvo un impacto negativo en el proceso de modernización del país. Además, llama la atención la lenta transformación de la economía latifundista mediante la vía junker con la que se mantuvo la gran propiedad agraria y los rasgos semifeudales según el interés de los terratenientes, los cuales irían perdiendo este carácter al convertirse en capitalistas agrarios.

A este respecto, recordemos cómo el análisis de las contradicciones existentes entre las formas pre-capitalistas y capitalistas, y la manera en que cada uno de estos modos llegó a convertirse en una condición necesaria para la existencia del otro, fueron utilizados para explicar la evolución de la hacienda y de las modalidades de trabajo y su inserción en las relaciones capitalistas en el siglo XX. ${ }^{1427}$ En dicho caso, la combinación de las relaciones de producción se caracterizaba porque el trabajo se encontraba subordinado al latifundio a través de la coerción extraeconómica y al capital mediante el salario.

La existencia de estos factores junto con la penetración imperialista durante las primeras décadas del siglo XX, que había sido impulsada por la alianza liberal conservadora, fueron los causantes fundamentales del retraso socio-económico de la región. No obstante, ya sabemos que pese a que ambos modos de producción constituyeron un negocio para el terrateniente, esto tuvo graves consecuencias para el país a la hora de establecer su modelo de desarrollo histórico, puesto que este proceso funcional para las necesidades de acumulación, tendría como eje al sector agro-exportador. ${ }^{1428}$

Lo que queda claro de este análisis, es que el paso para eliminar las relaciones precarias se produjo cuando el desarrollo capitalista creó las condiciones de mercado necesarias para estimular un tránsito acelerado de las unidades agrícolas hacia empresas agropecuarias. Por eso, el interés giró en torno a una mayor participación de la fracción moderna de terratenientes en la elaboración de los proyectos de reforma agraria, y en referencia a la entrega de huasipungos y eliminación de las relaciones pre-capitalistas, ya que compartir los recursos de la hacienda con los precaristas dejó de ser rentable para los terratenientes.

\footnotetext{
${ }^{1427}$ Gonzalo Ortíz Crespo, La incorporación del Ecuador al mercado mundial..., op. cit., p. 130.

1428 Alain de Janvry, Pablo Glikman: Encadenamientos de producción en la economía campesina del Ecuador, Publicado por el Fondo Internacional de Desarrollo Agrícola y el Instituto Interamericano de Cooperación para la Agricultura, 1991, p. 55-65.
} 
De este modo, en la década de los sesenta, se sigue observando que la economía ecuatoriana todavía estaba representada por la hacienda tradicional, la cual era la figura dominante de la producción agropecuaria en la Sierra y en gran parte de la Costa, pese a que en esta última zona se llevaron a cabo algunos cambios debido a las inversiones de la United Fruit Company en las plantaciones de banano y se extendieron las relaciones salariales. ${ }^{1429}$ En este sentido, uno de los problemas principales del proceso de modernización en el Ecuador de la década de los sesenta fue la cuestión agraria, a lo que se ha de añadir el papel desempeñado por el triunfo de la Revolución Cubana que marcó un momento de gran agitación social y política en este país. ${ }^{1430}$

De igual forma, el análisis de los datos nos indica que la aplicación de la reforma agraria como mecanismo de política pública para el desarrollo del campo, no tuvo el impacto esperado debido a su escaso carácter distributivo. La redistribución fue mínima y la liquidación del huasipungo solamente fue un cambio en el estatus formal de las familias implicadas, siendo el resultado de la reforma, la erradicación de las relaciones pre-capitalistas y la vinculación de los terratenientes a la mano de obra mediante relaciones salariales.

Esto nos lleva a concluir que la primera etapa de reforma agraria no logró implementar un modelo homogéneo de evolución capitalista por la vía junker, ya que la eliminación del precapitalismo creó un contexto favorable para un camino de desarrollo, cuyos elementos esenciales fueron los terratenientes transformados en empresarios, una nueva burguesía y los sectores campesinos. ${ }^{1431}$

$* * * * * *$

Siguiendo con el tema de las limitaciones al sistema capitalista en el Ecuador, la TERCERA CONCLUSIÓN establece como obstáculo al desarrollo, las restricciones impuestas a través del poder de la clase terrateniente y de la burguesía, las alianzas para mantener sus intereses y la intervención imperialista. Así, las políticas y prácticas regionalistas permitieron una formación capitalista deficitaria en el plano económico, institucional y estatal, que estaba caracterizada por un conjunto de etapas de acumulación incapaces de reproducir de forma sostenida el suministro

\footnotetext{
${ }^{1429}$ Leon Zamosc, Luchas campesinas y reforma agraria..., op. cit., p. 207.

${ }^{1430}$ Pedro Saad, Obras escogidas, op. cit., p. 3-27.

1431 Rafael Quintero: El mito del populismo en el Ecuador. Análisis de los fundamentos del estado ecuatoriano moderno, 1895-1934, FLACSO, Quito, 1980, p. 92.
} 
de capital.

En este sentido, a lo largo de esta tesis se han identificado distintos momentos históricos en el desarrollo del capitalismo y acumulación del capital en el Ecuador, cuyas diferencias se encuentran en las formas de generación del excedente económico, en los mecanismos de apropiación del mismo y en los beneficiarios y destino de la riqueza acumulada, entre otros factores.

A partir de aquí, se establecieron diferentes etapas en las que se analizó la evolución del proceso de acumulación del capital, así como la incidencia en el crecimiento económico mediante el estudio de los principales sectores de la economía ecuatoriana.

Recordemos cómo el estudio de la primera etapa de acumulación de capital, que tuvo lugar durante los últimos años del siglo XIX y primeras décadas del XX, puso de manifiesto la importancia del modelo de desarrollo agro-exportador, al facilitar el asentamiento del capitalismo en el país. ${ }^{1432}$

Los datos analizados muestran cómo, desde un principio, la orientación de la agricultura del litoral al mercado externo respondió a las fluctuaciones del sistema capitalista internacional, siendo el carácter dependiente de su producción y su gran especialización, los elementos cruciales en la estructuración y transformación de las relaciones productivas, las cuales serán dominantes durante las sucesivas etapas por las que ha transcurrido la economía de la Costa. ${ }^{1433}$ Un aspecto importante que afectó al limitado desarrollo del capitalismo fueron los sistemas de tenencia de la tierra y las relaciones entre las clases sociales ecuatorianas, al tener lugar en medio de la lucha de la clase terrateniente para ejercer su control, además de mostrar los enfrentamientos entre sus fracciones, cada vez más diferenciadas. ${ }^{1434}$

En consecuencia, aunque ambas fracciones llegaron a controlar la dirección de la sociedad mediante mecanismos relativamente parecidos, los antagonismos existentes entre ambas fueron creciendo paulatinamente, lo que explica el hecho de que esta etapa se caracterizara por su inestabilidad y por las frecuentes luchas internas y alianzas entre estas clases, siendo el resultado de todo esto, las limitaciones mencionadas en el desarrollo del capitalismo.

\footnotetext{
${ }^{1432}$ Iván Fernández Espinosa, Patricio Tobar Robalino, op. cit., p.117-131.

${ }^{1433}$ Francisco Pareja Cucalón, Comercio de exportación..., p. 386.

${ }^{1434}$ Enrique Ayala, Lucha politica y origen de los partidos..., op. cit. p. 50-200.
} 
En la segunda etapa de acumulación, se vuelve a observar la dependencia y subordinación de la economía ecuatoriana con respecto al dinamismo del mercado internacional, pero en esta ocasión, la dirección del desarrollo capitalista moderno se define a partir del crecimiento de las exportaciones de banano. A diferencia de la fase anterior, el auge del banano permitió a los diferentes gobiernos de la década de los cincuenta impulsar el desarrollo y dirigir una parte significativa de las divisas hacia el sistema productivo, además de aplicar una política caracterizada por la atracción del capital externo y otras medidas de tipo administrativo, acordes con las necesidades de modernización institucional reclamadas por la nueva situación en el país. ${ }^{1435}$

Sin embargo, los datos analizados indican que la tenencia de la tierra en la Costa no cambió demasiado, existiendo una alta presencia del latifundio, ya que el monopolio de la tierra estaba compartido por la propiedad imperialista y por los grandes hacendados. A esta concentración de la tierra, que muestra la plena vigencia del latifundio, se han de añadir un bajo desarrollo tecnológico agrícola, un gran porcentaje de la población indígena-campesina sometida a relaciones de producción pre-capitalistas y el frecuente abuso de las comunidades indígenas en beneficio del latifundio atrasado. ${ }^{1436}$

Posteriormente, ya vimos cómo la segunda crisis del modelo agro-exportador vuelve a poner de manifiesto el agotamiento de las estructuras tradicionales, y cómo los gobiernos de la época acudieron a los préstamos internacionales para enfrentar los retos planteados por las demandas de la sociedad, en lugar de aplicar medidas correctivas que hubieran afectado a la estructura de tenencia de la propiedad agrícola y a la todavía incipiente industria, así como a otras áreas de la economía.

Asimismo, la insuficiencia de estímulos externos y la inexistencia de una base tecnológica sólida que propiciara el despegue industrial autónomo, fueron algunos de los factores que limitaron las posibilidades para un crecimiento autosostenido, hecho que también se atribuye al fracaso de las reformas impuestas por los diferentes gobiernos. ${ }^{1437}$

$* * * * * *$

\footnotetext{
${ }^{1435}$ Iván Fernández Espinosa, Patricio Tobar Robalino, op. cit., p. 117-131.

${ }^{1436}$ Censo agropecuario de 1954.

${ }^{1437}$ José Moncada: La economía ecuatoriana en el siglo XX, Instituto de Investigaciones Económicas, Universidad Central del Ecuador, 1980, p. 58.
} 
Todas estas ideas en torno a los problemas y excesiva dependencia del modelo agro-exportador durante la primera y segunda etapa de acumulación, nos llevan a la CUARTA CONCLUSIÓN, la cual hace referencia a la dificultad para establecer un modelo global de desarrollo en el Ecuador que demuestre continuidad en el tiempo y que sea capaz de fijar una serie de objetivos coherentes de política económica para lograr la modernización de la sociedad.

En este sentido, ya se ha demostrado cómo la acumulación de capital ha estado condicionada por una diversidad de factores, entre los que se encuentran la inestabilidad política, los cuales han imposibilitado la formación de un modelo congruente de desarrollo. Como consecuencia, la economía ecuatoriana ha quedado a merced de las idas y venidas del modelo agro-exportador.

También, se ha analizado cómo la frecuente reinversión de capitales en las actividades agroexportadoras llegó a generar una tendencia permanente al monocultivo (como ocurrió con el cacao y el banano), ya que de acuerdo con la teoría de la especialización de la ventaja comparativa, la asignación de recursos naturales suele favorecer la actividad agrícola y generar sucesivas bonanzas. ${ }^{1438}$

De forma paralela, este modelo ha provocado que la economía ecuatoriana esté sometida a las decisiones de las principales ciudades capitalistas y a la subordinación mediante el endeudamiento externo, al deterioro en los términos de intercambio y a los bajos precios de los productos ecuatorianos, siendo la dependencia del capital foráneo, uno de los problemas más importantes a resolver, pues la elevada cifra de la deuda ha constituido una amenaza para el desarrollo.

Además, la rentabilidad obtenida por la burguesía con la agro-exportación, fue uno de los factores que mermó las posibilidades de desarrollo manufacturero y el lento progreso de las fuerzas productivas, pues la industrialización no tenía cabida en los esquemas de la burguesía como proyecto económico. Para los terratenientes serranos este proyecto tampoco fue posible, ya que para llevarlo adelante tenían que transformar la estructura latifundista y eliminar las relaciones precarias que constituían la fuente de su modelo de acumulación. ${ }^{1439}$

$* * * * * *$

\footnotetext{
${ }^{1438}$ Francisco X. Swett, Modelos de desarrollo del Ecuador, op. cit., p. 73-81.

${ }^{1439}$ Washington Macías, Ecuador: De la agro-exportación a la industrialización asociada..., op. cit., p. 12.
} 
Respecto al otro modelo de desarrollo, la industrialización vía sustitución de importaciones, se ha de establecer la QUINTA CONCLUSIÓN, la cual pone de relieve que pese a la implantación de las políticas desarrollistas y la contribución del auge petrolero a la industria, se observa un proceso de industrialización caracterizado por una gran vulnerabilidad y sensibilidad al ciclo primario exportador y una gran dependencia del capital y tecnología extranjeros. La precariedad en el desarrollo industrial alcanzado fue consecuencia de la falta de mecanización, de los escasos conocimientos tecnológicos y del reducido mercado interno, creándose una actividad industrial superficial en la que se utilizó una alta proporción de materias primas y bienes de capital importados.

De igual forma, la subordinación política del sector agro-exportador durante el establecimiento de la industrialización no implicó la eliminación de su papel estratégico, ya que este adquirió una nueva dimensión. Esto queda claro en el momento en que la industria, ante su incapacidad para asumir la producción de bienes de capital y otros de tecnología más compleja, mostró su dependencia de la oferta mundial de esos bienes, la cual recibía una importante parte de los ingresos obtenidos con el sector exportador. ${ }^{1440}$

Así, del análisis realizado de la primera etapa de industrialización (1950-1960), se puede concluir que pese al intento por llevar a cabo la consolidación de la gran industria mediante la creación de un sistema institucional de fomento y de leyes protectoras, solo se pudo lograr un desarrollo incipiente de la misma. Aquí, se ha de destacar el papel desempeñado por la pequeña industria y la artesanía, ya que durante los años cincuenta representaban la mayor parte de los establecimientos del denominado sector manufacturero y absorbían una parte importante de mano de obra. ${ }^{1441}$

En cuanto a la segunda etapa de industrialización (1960-1972), se sigue apreciando el carácter dominante de la artesanía frente a la gran industria, ya que a pesar de su evolución, no logró modificar su estructura de forma sustancial durante los años sesenta. No obstante, existe una mayor implicación estatal, centrándose sus políticas desarrollistas y reformadoras en el cambio de las relaciones agrarias y en la industrialización.

\footnotetext{
1440 Galo Ramón Valarezo, Víctor Torres Dávila: El desarrollo local en el Ecuador: Historia, actores y métodos, Ediciones Abya-Yala, Quito, 2004.

${ }^{1441}$ CONADE, CENAPIA, ILDIS: La situación económica de la artesanía en el Ecuador..., op. cit., p. 10.
} 
Es importante recordar cómo los diversos organismos creados para modernizar la estructura administrativa, contribuyeron al aumento del gasto público y del control estatal y estimularon una actividad industrial dependiente del capital extranjero, que acabó siendo bastante negativa para el desarrollo del país. ${ }^{142}$ Es decir, el desarrollo industrial ecuatoriano se caracterizó por su gran dependencia, la cual se fue consolidando tras el incremento de la brecha tecnológica y por la tendencia imperialista de integración de los sistemas productivos.

Asimismo, a través del análisis de las importaciones, se ha observado que el incipiente crecimiento industrial ecuatoriano no siguió en esos años el mecanismo de sustitución de importaciones que se había pretendido, siendo esto, una característica típica del fenómeno industrial ecuatoriano en cuanto a su vínculo con los intereses monopolistas. En este caso, las estadísticas revisadas constituyen una prueba de las grandes cantidades importadas de maquinaria eléctrica, productos metálicos y químicos, a la vez que ponen de manifiesto la escasa autonomía de la producción industrial en relación al capital comercial importador. ${ }^{1443}$

El análisis de la tercera etapa de industrialización en el Ecuador, comprendida desde finales de los sesenta hasta los años ochenta, nos indica que aunque el crecimiento del mercado favoreció la instalación de una industria moderna orientada a sustituir importaciones y a eliminar determinados mercados de pequeñas industrias y artesanías, el sector manufacturero no llegó a experimentar grandes diferencias con respecto a las etapas anteriores, predominando en su conformación industrial, la producción de bienes de consumo no duraderos (productos alimenticios, bebidas y tabaco, textiles, prendas de vestir e industrias del cuero, etc.). ${ }^{1444}$

A su vez, aún cuando la planificación estatal de los setenta tuvo como objetivo orientar la riqueza obtenida del petróleo hacia el fortalecimiento de la estructura productiva de tipo industrial para aliviar las restricciones externas y obtener una mayor independencia, es importante reiterar que uno de los problemas asociados a la acumulación de capital, fue el alto nivel de dependencia del capital extranjero, en particular con respecto de la tecnología altamente desarrollada de la cual carecía el país.

\footnotetext{
${ }^{1442}$ Rafael Quintero, Erika Silva, op. cit. p. 276.

${ }^{1443}$ Patricio Almeida Guzmán, Rebeca Almeida Arroba, Estadísticas económicas históricas..., op. cit., p. 495.

1444 Jorge Fernández, Un decenio de industrialización en el Ecuador...p. 115; Patricio Almeida Guzmán, Rebeca Almeida Arroba, op. cit., p. 151-152.
} 
En definitiva, a pesar de la contribución de la industria manufacturera al crecimiento de la economía en la década de los años setenta, no se pudo establecer una clara tendencia hacia una mayor integración de las diferentes ramas de actividad, ni reducir la dependencia externa de importaciones y capital extranjero. ${ }^{1445}$

$* * * * * *$

La SEXTA CONCLUSIÓN nos lleva a destacar la falta de organización de una clase política con capacidad suficiente para modernizar el país. Esto guarda relación con la evolución y los rasgos adquiridos por el estado ecuatoriano desde la independencia hasta los años setenta del siglo XX, modificándose su papel según su mayor o menor participación en el desarrollo socio-económico. En este proceso se han identificado varios tipos de estados (estado terrateniente, estado burgués y un estado con características burguesas y terratenientes) caracterizados por las continuas luchas por el poder entre las clases sociales.

A este respecto, en el siglo XIX y como continuación de la etapa de colonización, se observa un estado con las características de los terratenientes en cuanto a su capacidad de poder represivo, vinculado a la iglesia, con rasgos dictatoriales, marcado por la fragmentación regional y con base en el latifundio y por tanto, con capacidad para bloquear la unificación nacional.

Con el ascenso de la burguesía al poder a finales de este siglo, se logró crear el denominado estado burgués pero, al igual que el estado terrateniente, obstaculizó la unidad nacional. Las razones que explican la dificultad para constituir un estado nacional se han de buscar por un lado, en el mantenimiento de las relaciones pre-capitalistas, al impedir que la clase campesina creara sus propias bases sociales y, por otro, en la incapacidad de la burguesía a la hora de generar un modelo nacional, ya que no contaba con una base previa que hubiera sido elaborada durante la colonización o el estado terrateniente posterior a la independencia.

Ya se ha comentado cómo con las alianzas entre terratenientes y burguesía y su lucha por el poder político, se condicionó la creación de un estado capitalista al mantenimiento de las relaciones pre-capitalistas y al desarrollo de la agricultura mediante la denominada vía junker. Además, pese a la promoción de la burguesía, los terratenientes lograron mantener sus privilegios, creándose un aparato estatal con rasgos burgueses y oligárquicos determinado por

\footnotetext{
1445 Oscar Altimir: La encrucijada de la industrialización en América Latina, en "Políticas de industrialización en América Latina”, p. 21-55, compilador Rafael Urriola, CEPLAES-ILDIS, Promesas y realidades del proceso de industrialización en la posguerra, 1988, p. 23.
} 
sus relaciones antagónicas, lo cual sería un obstáculo a la creación de un estado nacional en el siglo $\mathrm{XX}$.

En nuestro periodo de estudio, esto ocurrió durante las décadas de los cincuenta y sesenta, cuando la existencia del patrón agro-exportador como modelo de desarrollo económico estableció una estructura social y cierta dinámica para la estructura de poder, pues en el ámbito político, lo habitual era el control del poder ejercido por los grupos vinculados a la agroexportación. ${ }^{1446}$ De este modo, las fluctuaciones del sector externo moldearon las diversas formas que la dominación política asumió en cada etapa del desarrollo de la sociedad ecuatoriana, de ahí que se piense en el auge bananero como el responsable de la estabilidad y funcionamiento de una democracia más o menos liberal entre 1948 y 1960.

También, la quiebra de este modelo, la intensificación del desarrollo industrial y el inicio de la producción y exportación del petróleo, generaron importantes modificaciones en el funcionamiento de la estructura de poder que, de igual forma, se vio afectada por la influencia de la Revolución Cubana de 1959.

De forma paralela, se ha de hacer alusión a las formas de gobierno dictatoriales que también lograron mermar los proyectos liberales de mediados del siglo XX. Este es el caso de la política de desarrollo adoptada por la Junta Militar de 1963, con rasgos represivos, autoritarios y antidemocráticos y que tenía como objetivo obstaculizar el estado burgués, en lugar de elaborar un contenido de tipo nacional. Aquí, se vuelve a observar cómo la vinculación de la clase terrateniente con el imperialismo y la relación de dependencia de la burguesía con el capital monopólico, constituyen un ejemplo de la precariedad estatal y de esa incapacidad que mencionamos anteriormente de las clases políticas a la hora de gobernar.

En definitiva, todos estos acontecimientos son un ejemplo de la evolución de la modernización llevada a cabo desde la independencia hasta los años setenta del siglo XX, a la vez que muestran los cambios en la estructura socio-política y la transición de un estado dominado por la oligarquía a un estado burgués. Como resultado de las diferentes estructuras políticas, se observa en el Ecuador de los años setenta, la combinación de fuerzas democráticas, autoritarias y nacionalistas, las cuales dieron forma al estado burgués.

$* * * * * *$

${ }^{1446}$ Agustín Cueva, El proceso de dominación política del Ecuador..., op. cit., p. 95-105. 
Para terminar, la ÚLTIMA CONCLUSIÓN guarda relación con el estudio empírico realizado a partir de los datos económicos disponibles y que nos ha servido para corroborar las ideas desarrolladas a lo largo de esta tesis en cuanto a los límites impuestos en el desarrollo del sistema capitalista ecuatoriano.

En primer lugar, en el análisis de la modernización, la revisión de las principales teorías del desarrollo, como ha sido el caso del estructuralismo de la CEPAL, nos indican que pese a que los proyectos mencionados parecían estar dotados de gran potencial, la realidad de los acontecimientos analizados hasta la década de los setenta, momento de pleno apogeo del desarrollismo, muestran un Ecuador caracterizado por una profunda desigualdad, una división política, dependencia del capital y de la tecnología extranjera y altos niveles de analfabetismo, entre otros problemas.

La explicación a este panorama ha de buscarse en la forma en que el Ecuador adoptó el desarrollismo y en cómo los grupos sociales fueron asumiendo diferentes posiciones para resolver los conflictos internos, modificando las instituciones sociales y políticas a su antojo y transformando su propia condición a lo largo del proceso de modernización.

Aquí, se han considerado otras teorías sociológicas del desarrollo que dan gran importancia a los efectos de los factores sociales y políticos mencionados, y que permiten explicar los desajustes que establecen la condición de desarrollo o subdesarrollo de un país. ${ }^{1447}$

En nuestro caso, los resultados obtenidos al calcular el índice de desarrollo humano para el Ecuador no son ajenos a lo que se ha venido analizando, ya que las profundas y marcadas desigualdades a nivel social e institucional y la concentración de poder y riqueza han creado políticas sesgadas, que no han ayudado a los grupos de ingresos medios y bajos, cuyos intereses apenas han sido representados por sus gobernantes. A su vez, la desigualdad ha dificultado el objetivo para disminuir la pobreza, pues al existir una alta división social han surgido nuevos problemas para hacer frente a las crisis, y por consiguiente, su desarrollo se ha visto afectado.

En segundo lugar, el análisis empírico del crecimiento económico vuelve a indicar la modesta contribución de las variables que influyen positivamente en la economía ecuatoriana debido a los altibajos sufridos durante el periodo 1950-1970.

\footnotetext{
1447 Keith Griffith: Desarrollo humano: Origen, evolución e impacto", Nosotros Latinoamericanos Organización, 2011, p. 1-11.
} 
De todas las variables consideradas, se ha de concluir que la desigualdad en la distribución de los ingresos ha sido uno de los elementos que ha limitado el crecimiento, ya que tanto en la Sierra como en la Costa, se ha originado un modelo concentrador y excluyente, al encontrarse la mayor parte de los beneficios en manos de un pequeño grupo de personas, mientras que el resto de la población ha vivido con un ingreso mínimo, con el que apenas ha podido satisfacer sus necesidades básicas.

Junto a los problemas de tenencia de la tierra, se ha de volver a mencionar la estrechez del mercado interno, la subordinación del capital externo y la dependencia de las exportaciones del sector primario, que al estar ligadas a dicho sistema de tenencia y formas de producción, originaron efectos concentradores en los ingresos.

Como parte del proceso de modernización del Ecuador, el paso de una economía agrícola a una industrial y la importancia concedida a este último modelo proteccionista, determinó cambios en el producto interior bruto, en donde el sector agropecuario se redujo de forma destacada. Esta disminución contradice las ideas planteadas inicialmente en las reformas agrarias y en los planes de desarrollo, en referencia al establecimiento de la actividad agropecuaria como modo de mantener una industria manufacturera, creando bienes y servicios para la mayoría de la población. ${ }^{1448}$

Finalmente, este análisis nos lleva a concluir que las limitaciones del sistema capitalista señaladas, tienen su raíz en el desarrollo histórico del sistema político e institucional del país, pues pese a las diferencias entre una primera etapa, caracterizada por una sociedad tradicional con un sistema de haciendas que dominaba los aspectos políticos y socio-económicos, y una segunda etapa posterior a la década de los cincuenta, en la que se impuso el desarrollismo y los cambios en la sociedad y organización del país, ambos periodos tienen en común la existencia de contradicciones, luchas y alianzas entre las clases sociales que, buscando imponer su hegemonía en la sociedad para tener el control del poder político y aplicarlo para su propio beneficio, no hicieron sino obstaculizar el crecimiento económico y la modernización del país. ${ }^{1449}$

\footnotetext{
${ }^{1448}$ Francisco Guerra: Análisis del modelo económico y social ecuatoriano. De los años setenta y ochenta en el el marco de la globalización, FLACSO, Quito, 11 de abril 2001.

${ }^{1449}$ Osvaldo Hurtado, El proceso político contemporáneo, op. cit., p. 35-52.
} 


\section{BIBLIOGRAFÍA:}

- Abad Ortíz, Gonzalo: El proceso de lucha por el poder en el Ecuador, Tesis de Maestría, El Colegio de México, 1970.

- Abril Ojeda, Galo: Política monetaria y desarrollo industrial en el Ecuador, 1970-1983, Banco Central del Ecuador, Instituto de Estudios Latinoamericanos, monografía número 11, agosto 1985.

- Abril-Ojeda, Galo: Auge exportador y desarrollo en Ecuador, en: Trayectorias divergentes: comparación de un siglo de desarrollo económico latinoamericano y escandinavo, Magnus Blomström, Patricio Meller Coordinadores, Santiago de Chile: Cieplan, 1990.

- Aceituno, Gerardo: La acumulación de capital en la formación social ecuatoriana, en Aceituno et al. Ecuador, Historia y Acumulación de Capital, Cuenca, F. de Ec., 1978.

- Acemoglu, D.; Johnson, S.; Robinson, J.: The colonial origins of comparative development: An empirical investigation, The American economic review, vol. 91, no. 5, diciembre, 1991.

- Acosta, Alberto: Breve historia económica del Ecuador, 2da. ed. Quito: Corporación Editora Nacional, 2006.

- Adoum, J. E.: Cronología del siglo XX: Cultura y política en Ecuador y el mundo, Quito, Ecuador: Eskeletra Editorial, 2000.

- Agge, P.: Inside the company: CIA diary, Gran Bretaña: Penguin Books LTD, 1975.

- Aguayo, Eva; Portillo, Saskia; Expósito, Pilar: Perspectiva del crecimiento económico en los países del Pacto Andino, Universidad Santiago de Compostela, Ministerio de Planificación Económica, CORDIPLAN, Venezuela, www.usc.es/economet.

- Aguilar, Pablo: Arquitectura y modernidad 1850-1950, Quito, Museo Municipal Alberto Mena Caamaño, 1995.

- Aguilera Peralta, Gabriel: Cuba y la OEA Apuntes de una larga y complicada relación, Revista Nueva Sociedad, No 223, septiembre-octubre de 2009.

- Aguirre Rojas, Carlos: Mercado interno, Guerra y revolución de México, 1870-1920, Revista mexicana de sociología, año 52, número 2, México, 1990;

- Aguirre Rojas, Carlos: El legado intelectual de los Annales braudelianos. 1956-1968, en el libro Braudel a debate, Coedición Fondo editorial Tropykos/Fondo editorial Buría, Caracas, 1998. 
- Aguirre Rojas, Carlos: El largo siglo XX de la historiografía latinoamericana contemporánea: 1870-2025. Puntos de partida para su reproducción, Historia Agenda, Año I, Nueva Época, número 3, México, CCH/UNAM, 2003.

- Aguirre, Orlando: La Alianza para el Progreso y la promoción del desarrollo en América Latina, historiadeamericalatina.files.wordpress.com/2011/07/clase-20_alianza-para-elprogreso.pdf

- Albornoz, Oswaldo: Del crimen de El Ejido a la Revolución del 9 de julio de 1925, Tall. Gráf. de Editorial Claridad, 1969.

- Albornoz, Oswaldo: Las luchas indígenas en el Ecuador, Editorial Claridad, S.A. Guayaquil, Ecuador, 1971.

- Albornoz Peralta, Oswaldo: Ecuador: Luces y sombras del liberalismo, Editorial El Duende, Quito, Ecuador, 1989.

- Albornoz Peralta, Osvaldo: Las compañías extranjeras en el Ecuador, Quito, Abya-Yala, 2001.

- Alcántara, Manuel: El origen de los partidos políticos en América Latina, Instituto de Ciencias Políticas y Sociales, WP, número 187, Barcelona, 2001.

- Almeida Guzmán, Patricio; Almeida Arroba, Rebeca: Estadísticas Económicas Históricas 1948-1983, Serie estadísticas históricas, Vol. 1, Banco Central del Ecuador, 1988.

- Alonso, Jose Antonio: En defensa de la teoría del desarrollo, Cuadernos económicos de ICE, número 78, 2009.

- Altamirano, Carlos: Introducción general, en Carlos Altamirano, dir., Historia de los intelectuales en América Latina. I. La ciudad letrada, de la conquista al modernismo, Buenos Aires, Katz Editores, p. 15, 2008.

- Altimir, Oscar: La encrucijada de la industrialización en América Latina, en "Políticas de industrialización en América Latina", compilador Rafael Urriola, CEPLAES-ILDIS, p. 23, Promesas y realidades del proceso de industrialización en la posguerra, 1988.

- Andrade, Pablo; Puyana, Alicia: La pobreza en América Latina: ¿Una dimensión olvidada de la integración económica regional?, CLACSO, 2010.

- Aníbal Minda, Pablo: La tenencia de la tierra en la provincia de Esmeraldas, en "Identidad y Conflicto: La Lucha por la tierra en la zona norte de la provincia de Esmeraldas", Escuela de Antropología Aplicada, UPS-Quito, Ediciones Abya-Yala, 2002. 
- Arcos, Carlos; Marchán, Carlos: Apuntes para una discusión sobre los cambios en la estructura serrana, Pontificia Universidad Católica del Ecuador, 1976.

- Arcos, Carlos: El espíritu del progreso: Los hacendados en el Ecuador del 1900, en "Clase y región en el agro ecuatoriano”, Biblioteca de Ciencias Sociales, Volumen 7, Corporación Editora Nacional, 1986.

- Arcos Cabrera, Carlos: La caja sin secreto: Dilemas y perspectivas de la literatura ecuatoriana contemporánea, Quorum, Revista de pensamiento iberoamericano, no. 14, primavera, Universidad de Alcalá, 2006.

- Archetti, Eduardo: Burguesía rural y campesinado en la Sierra ecuatoriana, en Ecuador Archetti, Campesinado y estructuras agrarias en América Latina, Quito, CEPLAES Editores, 1981.

- Arias, Pedro: La economía mundial del banano, 1985-2002.

- Arosemena, Guillermo: La Gran Bretaña en el desarrollo económico del Ecuador, 1820-1930, Selected Work, Embajada de Inglaterra en Ecuador, enero 1991.

- Arosemena, Guillermo: La Revolución Juliana: Evento ignominioso en la historia de Guayaquil, Archivo Histórico del Guayas, Guayaquil, 2002.

- Avilés Pino, Efrén: Enciclopedia del Ecuador, Academia Nacional de Historia del Ecuador, 2012.

- Ayala Mora, Enrique: Lucha política y origen de los partidos en Ecuador, Publicaciones Pontificia Universidad Católica Ecuador, Editado por Publitécnica, Quito, 1978.

- Ayala, Enrique; Costa, Alberto: IV Economía, Ecuador 1830-1989, vol. 2, Libro del Sesquicentenario, Corporación Editora Nacional, 1983.

- Ayala Mora, Enrique; Quintero, Rafael: Teorías e ideologías sobre el estado en Ecuador: 19481984, en “El estado en América Latina”, Edit. Siglo XXI, 1990.

- Ayala Mora, Enrique: La relación Iglesia-Estado en el Ecuador del siglo XIX, Procesos: Revista ecuatoriana de historia, II Semestre, 1994.

- Ayala Mora, Enrique; Fernández, Sonia: Ecuador: Las raíces del presente, compilación de los suplementos especiales del diario La Hora, Universidad Andina Simón Bolívar-Taller de Estudios Históricos-La Hora, Quito, 1995. 
- Ayala Mora, Enrique: Una relectura de El Poder Político en el Ecuador, El poder político en el Ecuador, Debates de Osvaldo Hurtado, vigésimo aniversario, Procesos, revista ecuatoriana de historia, no. 10, Corporación editora nacional, ouko, 1997.

- Ayala Mora, Enrique: Resumen de historia del Ecuador, Independencia y etapa colombiana, tercera edición actualizada, Corporación editora nacional, Quito, 2008.

- Ayala Mora, Enrique: Gabriel García Moreno y la gestación del estado nacional en Ecuador, Escenarios Alternativos, Crítica y Utopía, número 5. www.escenariosalternativos.org.

- Ayala Serra, Julio: Educación y política en el Ecuador 1830-1980, en Libro del Sesquicentenario I, Política y Sociedad Ecuador: 1830-1980, Corporación Editora Nacional, 1980.

- Báez, René: Teorías para el subdesarrollo, Editorial Diógenes S.A., México, primera edición, 1975.

- Báez, René: Apogeo y decadencia del modelo agro-exportador: Periodo de la segunda posguerra, Colección Isidro Ayora, vol. II, Banco Central del Ecuador, 1980.

- Báez, René: Ecuador: ¿Genocidio económico o vía democrática?, Biblioteca de Ciencias Sociales, volumen 40, Corporación Editora Nacional, 1992.

- Bain, J.: Barriers to new competition, Cambridge: Harvard University Press, 1956.

- Baracaldo, Diego; Garzón, Paola; Vásquez, Hernando: Crecimiento económico y flujos de inversión extranjera directa, econpapers, Universidad de Colombia, Noviembre 2005.

- Barsky, Oswaldo; Cosse, Gustavo: Tecnología y Cambio Social: Las haciendas lecheras del Ecuador, Facultad Latinoamericana de Ciencias Sociales (FLACSO), USDA, National Agricultural Library, 1981.

- Barsky, Osvaldo: La reforma agraria ecuatoriana, Biblioteca de Ciencias Sociales, Volumen 3, FLACSO, Corporación Editora Nacional, Quito, 1984, en Segovia, artículo en El Comercio, 5 de marzo de 1962.

- Barsky, Osvaldo: Ideologías terratenientes en los procesos de modernización de la Sierra ecuatoriana, en "Terratenientes y desarrollo capitalista en el agro" CEPLAES, Quito, 1978.

- Barsky, Osvaldo: Los terratenientes serranos y el debate político al dictado de la Ley de Reforma Agraria de 1964 en el Ecuador, en "Ecuador: Cambios en el agro serrano", FLACSOCEPLAES, Quito, Abril 1980. 
- Barsky, Osvaldo: Ecuador, cambios en el agro serrano, Facultad Latinoamericana de Ciencias Sociales, 1980.

- Barsky, Osvaldo: Políticas agrarias, colonización y desarrollo rural en el Ecuador, Quito, OEA-CEPLAE, 1982.

- Barsky, Osvaldo: Iniciativa terrateniente en la re-estructuración de las relaciones sociales en la Sierra ecuatoriana: 1959-1964, en: "El problema agrario en el Ecuador", Antología de las Ciencias Sociales, Publicación ILDIS, 1988.

- Barsky, Osvaldo; Barril, Alex; Cosse, Gustavo; Morandi, Jorge, Vinueza, Humberto: El proceso de transformación de la producción lechera serrana y el aparato de generación-transferencia en Ecuador, FLACSO, Proyecto Cooperativo de Investigación sobre tecnología agropecuaria en América Latina, Documento Protaal, núm. 40, 1990.

- Barahona, Rafael: Una tipología de haciendas en la Sierra ecuatoriana, en Oscar Delgado (comp.) Reforma Agraria en América Latina, proceso y perspectivas, Fondo de Cultura Económica, México, 1965.

- Barón López, F.J.; Téllez Montiel, F.: Apuntes de estadística, Universidad de Málaga, 2009.

- Barraclough, S.; Collarte, J.: Tenencia de la tierra y desarrollo socio-económico del sector agrícola, Ecuador, Resumen del Informe del CIDA, FLACSO, 1976.

- Barril, Alex: Desarrollo Tecnológico, producción agropecuaria y relaciones de producción en la Sierra ecuatoriana, Centro de Planificación y Estudios Sociales (CEPLAES), en "Ecuador: Cambios en el agro serrano", Quito, 1980.

- Barro, Robert: Economic growth in a cross section of countries, the Quarterly Journal of Economics, Vol. 106, no. 2, mayo, 1991.

- Barro, Robert: Determinants of Economic Growth: A cross-country empirical study, The MIT Press, 1997.

- Barro, Robert: Inequality and growth in a panel of countries, Journal of Economic Growth 5(1), pp 5-32, 2000.

- Barro, R.; Sala-i-Martin: Crecimiento económico, Editorial Reverte, 1999.

- Barro, R.; Lee, J.: International data on educational attainment: Updates and implications, CID working paper, no. 42, abril 2000.

- Becker, Marc; Tutillo, Silvia: "Historia agraria y social de Cayambe" FLACSO, Abya-Yala, 2009. 
- Benítez, Falconi; Oleas Montalvo, Julio: Antología de economía ecuatoriana 1992-2003, Crisis de pensamiento y desarticulación de la teoría del desarrollo económico, 14 de julio de 2004.

- Bertinat, Joaquín; Calvette, Alfonsina; Ignatczuk, María Inés; Sauval, María; Villamil, Lucía: Acercamiento al sistema centro-periferia, Cátedra de Crecimiento y Desarrollo Económico, octubre 2012.

- Bocco, Arnaldo: La economía política del petróleo ecuatoriano, FLACSO, Quito, 1980.

- Bond, S.; Leblebibioglu, A.; Schiantarelli, F.: Capital accumulation and growth: A new look at the empirical evidence, Journal of Applied Econometrics, 25 (7), 2010.

- Brassel, Frank; Herrera, S.; Laforge, M.: ¿Reforma agraria en el Ecuador? Viejos temas, nuevos argumentos, SIPAE, Quito, 2008.

- Brassel, Frank; Ruíz, Patricio; Zapatta, Alex: La estructura agraria en el Ecuador: Una aproximación a su problemática y tendencias, en: “¿Reforma Agraria en el Ecuador?, Viejos temas, nuevos argumentos”, Publ. Sipae, agosto 2008.

- Braudel, F.: Renacimiento, reforma, 1968: Revoluciones culturales de larga duración, en La Jornada Semanal, num. 226, México, 10 de octubre de 1993.

- Bravo, César A.: Historia del Ecuador: De la década de los 1950 a la década de los 70, Colegio de Abogados del Azuay, editorial Gráficas Hernández, Cuenca, 1995.

- Bromley, Raymond y Rosemary: Cambios de los días de feria en la Sierra central del Ecuador durante el siglo XIX, Revista del Archivo Histórico del Guayas, Guayaquil, 1976.

- Brownrigg, Leslie A.: The nobles of Cuenca: The agrarian elite of Southern Ecuador, tesis, Public, Nueva York s.n, 1972.

- Bustos, Guillermo: La producción historiográfica contemporánea sobre la independencia ecuatoriana (1980-2001): Una aproximación, Procesos, Revista ecuatoriana de Historia, No. 20, Corporación Editora Nacional, 2004.

- Cabezas, Rodrigo: Política petrolera ecuatoriana, Nueva Sociedad, Número 14, septiembreoctubre 1974.

- Campos, N.; Yuco, K.: Out of caveats: The impact of foreign direct investment in transitions economies, Dep. of Economics, University of Newcastle, 2004.

- Canelos, Franklin: Colonización y vías de desarrollo: El caso de la parroquia Pedro Vicente Maldonado, FLACSO, Ecuador, 1980. 
- Canessa Oneto, Mario: La Banca del Ecuador: Una explicación histórica, Escuela Superior Politécnica del Litoral, 1958.

- Carbo, Luis: Historia Monetaria y Cambiaria del Ecuador, Banco Central del Ecuador p. 4478, 1953.

- Cardoso, F.; Faletto E.: Dependencia y desarrollo en América Latina, México DF: Siglo XXI, 1969.

- Carlyle, T.: Los héroes (1840), Madrid: Globus, 1995.

- Carrasco, Hernán: Democratización de los poderes locales y levantamiento indígena, Dirección de Organizaciones Populares, MAG, en "Sismo étnico en el Ecuador, Varias perspectivas", CEDIME, 1993.

- Cass, D.: Optimum growth in an aggregate model of capital accumulation, Review of Economic Studies 32, 1965.

- Cevallos, Janet: La protección arancelaria del estado ecuatoriano a las actividades productivas en el periodo 1965-1980, Tesis de máster, FLACSO, 1984.

- Chavarría, Germán; Fonseca, María; Martínez, Octavio; Morales, Deiby: Manual introductorio a las teorías del crecimiento económico, editado por Edumetnet, Universidad de Málaga, 2010.

- Checa Cobo, Marco: Régimen de la propiedad de la tierra en el Ecuador, Universidad Católica del Ecuador, Quito Ecuador, 1973.

- Chiodi, Francisco: Ecuador, capítulo III, en La educación indígena en América Latina: México, Guatemala, Tomo I, P. Ebi-Abya Yala, UNESCO/OREALC, 1990.

- Chiriboga, Manuel: Las fuerzas del poder en 1830, Revista Cultura, Quito, BCE, Vol. II, 6, 1980.

- Chiriboga, Manuel: Los terratenientes costeños en la economía del Ecuador republicano, en Libro del Sesquicentenario: Economía', CEN, Quito, 1982.

- Chiriboga, Manuel: La pobreza rural y la producción agropecuaria, en: M. Chiriboga et al: El mito del desarrollo, Quito, Editorial El Conejo, 1982.

- Chiriboga, Manuel: El estado y las políticas hacia el sector rural (1979-1989), en: "Ecuador Agrario", Quito, ILDIS-El Conejo, 1984. 
- Chirinos, Raymundo: Determinantes del crecimiento económico: Una revisión de la literatura existente y estimaciones para el periodo 1960-2000, Banco Central de Reserva del Perú, Serie de Documentos de Trabajo, Agosto, 2007.

- Cifuentes E.: Los Annales y la historiografía centroamericana, en Eslabones, núm. 7, cit.; Marcia Mansor d'Alessio: Los Annales en Brasil. Algunas reflexiones, en Eslabones, núm. 7, cit.; Tulio Halperin Donghi: Un cuarto de siglo de historiografía argentina (1960-1985), en Desarrollo Económico, núm. 100, Buenos Aires, 1986.

- Czinkota, Michael; Ronkainen, Ilkka: Marketing Internacional, Ed. Cengage Learning, octava edición, 2007.

- Clayton, Lawrence: Los astilleros de Guayaquil Colonial, Guayaquil, Archivo Histórico del Guayas, 1978.

- Coatsworth, John H.: Desigualdad, instituciones y crecimiento económico en América Latina, Economía Vol. XXXV num. 69, semestre enero-junio 2012.

- Colmenares, Germán: Análisis referido a la estructura agraria de la Sierra norte-central, Quito: FLACSO, 1979.

- Conaghan, Catherine: Industrialists and the reformist's interregnum: Dominant class behavior and ideology in Ecuador, 1972-1979, 1983.

- Cornejo-Polar, Antonio: Escribir en el aire: Ensayo sobre la heterogeneidad socio-cultural en las literaturas andinas, Editorial Horizonte, Lima, 1994.

- Corsino Cárdenas, José: Ensayo histórico de la economía ecuatoriana, Biblioteca de Historia Económica, Banco Central del Ecuador, 1995.

- Correa Escobar, Gonzalo: La economía ecuatoriana de 1830 a 1980, Libro del Sesquicentenario, Corporación editora nacional, III Economía/Ecuador 1830-1980 primera parte, 1983.

- Cosse, Gustavo: Aproximación al análisis del aparato institucional agrario y su relación con el proceso político social en el caso ecuatoriano, FLACSO, Mimeo, Quito, 1979.

- Cosse, Gustavo: Reflexiones acerca del estado, el proceso político y la política agraria en el caso ecuatoriano 1964-1977, en "Ecuador, cambios en el agro serrano", CEPLAES,-FLACSO, 1980.

- Costales, Alfredo; Peñaherrera Costales, Piedad: Historia social del Ecuador, Reforma agraria, Tomo IV, Editorial Casa de la Cultura Ecuatoriana, Quito, 1971. 
- Cowan, B.: The social life of coffee: The emergence of the British Coffeehouse, New Haven: Yale University Press, 2005.

- Crespo Ortíz: Gonzalo: Estudio introductorio, en: “Economía, Ecuador: 1830-1980”, III, Quito, Corporación Editora Nacional, 1983.

- Crissman, Charles C.: La agricultura en los páramos: Estrategias para el uso del espacio, Consorcio para el Desarrollo Sostenible de la Ecorregión Andina, Num. 1, 2003.

- Cueva, J.: Comercialización del banano ecuatoriano, Quito, AECA, 1964.

- Cueva, Agustín: Reflexiones sobre la novela indigenista, Indoamérica, año I, No 2, marzo- abril, Quito, Ecuador, 1965.

- Cueva, Agustín: El proceso de dominación política en el Ecuador, Quito, Editorial Universitaria, 1967.

- Cueva, Agustín: Crisis del capitalismo y perspectivas del nacionalismo en América Latina: Análisis del caso ecuatoriano, en Revista mexicana de sociología, vol. 38, no. 4), Perspectivas del nacionalismo latinoamericano, Universidad Nacional Autónoma de México, Oct.-Dic. 1976.

- Cuvi, Pablo: Velasco Ibarra: El último caudillo de la oligarquía, Instituto de Investigaciones Económicas, p. 230-233, 1977.

- Cuvi, María: Oferta tecnológica en la producción de banano en el Ecuador, Quito, FLACSO, 1984.

- Cuvi, María; Urriola, Rafael: Oleaginosas, cereales y agroindustria en la Costa ecuatoriana, en "Transformaciones agrarias en el Ecuador", p. 95-107, CEDIG, 1988.

- Dabús, Carlos; Laumann, Yanina: Determinantes del crecimiento: Evidencia comparada de países con diferente nivel de desarrollo, p. 165-180, Universidad Nacional del Sur (Argentina), Vol. 24-1, 2006.

- Dahrendorf, Ralph: Class and Class Conflict in Industrial Society, Stanford University Press, Stanford, CA, 1959.

- David, H.; Thurston: Enfermedades de cultivos en el Trópico, Turrialba, Costa Rica, 1989.

- Davidson, A.: Europeans. Wary encounter with potatoes, tomatoes and other New World foods, en: N. Foster y L. Cordell (Eds), Chilies to chocolate: Food the Americas gave the world, Tucson: University of Arizona Press, 1992. 
- De Janvry, Alain; Glikman, Pablo: Encadenamientos de producción en la economía campesina del Ecuador, Publicado por el Fondo Internacional de Desarrollo Agrícola y el Instituto Interamericano de Cooperación para la Agricultura, 1991.

- De Jesús Velásquez, E.: Historia de la Doctrina de la Seguridad Nacional, Universidad Autónoma del Estado de México, Convergencia, enero-abril, año 9, número 27, Toluca, México, 2002.

- De la Pena, Sergio: La formación del capitalismo en México, Instituto de investigaciones sociales UNAM. pp. 103-135, Siglo veintiuno editores, 1975.

- De la Torre, Carlos; Salgado, Mireya: Galo Plaza y su época, Introducción, FLACSO, Ecuador, 2008.

- Deler, J. P.: Ecuador: del espacio al estado nacional, Centro de Investigación y Cultura, Banco Central del Ecuador, 1987.

- Deves Valdés, Eduardo: El Pensamiento latinoamericano a comienzos del siglo XX: La reivindicación de la identidad, CUYO, Anuario de filosofía argentina y americana, número, 14, p. 11-75, 1997.

- De Vries, J.: The economy of Europe in an Age of crisis, 1600-1750, Cambridge: Cambridge University Press, 1976.

- De Vries, J.: Between purchasing power and the world of goods: Understanding the household economy in Early Modern Europe, p. 85-132 en J. Brewer y R. Porter (Eds.) "Consumption and the World of Goods" London: Routledge, 1993.

- Dollar, D.: Outward orientes developing economies really do grow more rapidly: Evidence from 95 LDCs, 1976-1985, Economic development and cultural change, p. 523-544, 1992.

- Domar, E.D.: Essays in the theory of economic growth, Oxford, New York: Oxford University Press, 1957; R. F. Harrod: An essay in dynamic theory, Economic Journal, 49, 1939, Towards a dynamic economics, Londres, Macmillan, 1948.

- Domínguez, Jorge: Disputas fronterizas en América Latina, Foro Internacional 177, p. 357-391, jul-sept. 2004.

- Durlauf, S.N.; Aghion, P. (Eds): Handbook of Economic Growth, Elsevier, 2005.

- Durlauf, S.N.; Johnson, P.A.; Temple, J.R.: Growths econometrics, en S.N. Durlauf, P. Aghion (Eds), Handbook of Economic Growth, Elsevier, 2005. 
- Durán, Jaime: Movimientos sociales en Ecuador en 1970: Unidad y crisis de las centrales sindicales, en: Los movimientos populares en América Latina, Edit. Siglo XXI, Universidad de las Naciones Unidas, 1989.

- Edwards, S.: Openness, productivity and growth: what do we really know? Economic journal, 1998.

- Ellis, Frank: Las transnacionales del banano en Centroamérica, Educa, Costa Rica, 1983.

- Engerman, S.; Sokoloff, K.: Factor endowments, institutions and differential paths of growth among new world economics: A view from economic historians of the United States, en Stephen Haber (ed.), How Latin America Fell Behind: Essays on the Economic History of Brazil and Mexico 1800-1914, Stanford University Press, 1997.

- Escobar, Arturo: Antropología y desarrollo, Maguaré 14, Universidad de Massachusetts, 1999.

- Escribano, Gonzalo: Introducción a las teorías del desarrollo, Facultad de Ciencias Económicas y Empresariales, UNED, 2012.

- Espinosa, C: Historia del Ecuador en contexto regional y global, Editores España, 2010.

- Espinosa Tamayo, Alfredo; Andrés Roig, Arturo: Psicología y sociología del pueblo ecuatoriano, Banco Central del Ecuador, Corporación Editora Nacional, 1979 (1916).

- Espinoza, Leonardo: Vías de integración de la formación espacial y el desarrollo regional en el Ecuador 1830-1980, Libro del Sesquicentenario Economía Ecuador, segunda parte, Corporación editora nacional, 1983.

- Espinoza, Leonardo: Política fiscal de la Provincia de Cuenca: Reseña histórica presupuestaria 1779-1861, Segundo Encuentro de Historia y Realidad Económica y Social del Ecuador, Cuenca: s/e, Vol. I, 1978.

- Estrada, I.: El Hospital de Guayaquil, p. 13, 2a. ed. Archivo Histórico del Guayas, Guayaquil, 1974.

- Estrada, Jorge: Industriales, estado, industrialización en el Ecuador, Corporación de promoción universitaria, Universidad de San Francisco de Quito, INSOTEC, 1990.

- Falero, Alfredo: El paradigma renaciente de América Latina: Una aproximación sociológica a legados y desafíos de la visión centro-periferia, en "Crítica y teoría en el pensamiento social latinoamericano", Consejo Latinoamericano de Ciencias Sociales (CLACSO), Buenos Aires, agosto 2006 .

- Fernández, Jorge: La transferencia de tecnología, Estudios Sociales, no.7, CPU-1975. 
- Fernández Espinosa, Iván; Tobar Robalino, Patricio: Acumulación de Capital 1830-1980. Sus mecanismos de creación y apropiación, Libro del Sesquicentenario. Economía Ecuador, Segunda parte, 1830-1980, Corporación Editorial Nacional, Inter-Americal Defense College library, p.117-131, 1983.

- Fernández, Iván: Estado y desarrollo capitalista en el Ecuador, Nueva sociedad, Número 45, p. 12, Noviembre-Diciembre, 1979.

- Fernández, Jorge: Un decenio de industrialización en el Ecuador: Un balance crítico, en: "El proceso de industrialización ecuatoriano", IIE-PUCE, 1983.

- Fierro Carrión, Luis: Revista Economía, Diario Hoy, Quito, 15 de julio de 1984.

- Fiori, J.: Estados y modos de desenvolvimiento de las naciones, São Paulo: Vozes, 1999.

- Fitch, J. S.: The military coup d'état as a political process, Ecuador, 1948-1966, Universidad de Johns Hopkins, University Press, 1977.

- Fontaine, Guillaume: Petróleo y desarrollo sostenible en Ecuador, FLACSO, Ecuador, 2004.

- Frankel, J.; Romel, D.: Does trade cause growth, The American Economic Review, vol. 89, num. 3, 1999.

- Furtado, Celso: Subdesarrollo y estancamiento en América Latina", Buenos Aires: Editorial Universitaria, 1966.

- Furtado, Celso: Economic Development in Latin America, Cambridge, Cambridge University Press, p. 38, 1970.

- Furtado, Celso: La economía latinoamericana desde la conquista ibérica hasta la Revolución Cubana, México, Siglo XXI Editores, 1973.

- Furtado, Celso: La economía latinoamericana: formación histórica y problemas contemporáneos, Siglo XXI, 1991.

- Galarza, Jaime: El festín del petróleo, Quito, Solitierra, 1972.

- Galarza, Jaime: El yugo feudal, Edic. Solitierra, 1973.

- Galindo Martín, Miguel A.: Crecimiento económico, ICE, Tendencias y nuevos desafíos de la teoría económica, no. 858, Universidad de Castilla La Mancha, enero-febrero 2011.

- Galo, Ramón: Indios, crisis y proyecto popular alternativo, Centro Andino de Acción Popular, Quito, 1988. 
- Galor, O.: From stagnation to growth: Unified growth theory, en Handbook of Economic Growth, en P. Aghion y S.N. Durlauf (eds), Handbook of Economic Growth, Elsevier, vol. 1A, cap. 4, 2005.

- Gana, E.; Mortimore, M.: La programación andina y sus resultados en el Ecuador: El papel de las empresas transnacionales, CEPAL-CET documento de trabajo, No. 15, febrero 1979.

- Gandard, Pierre; Mazurek, Hubert: Treinta años de reforma agraria y colonización en el Ecuador (1964-1994): Dinámicas espaciales, en Dinámicas territoriales: Ecuador, Bolivia, Perú Venezuela, Estudios de Geografía, vol. 10, CGE/Corporación Editoria Nacional, Pontificia Universidad Católica del Ecuador, PUCE, Quito, 2001.

- Gándara, Marcos: Los militares y la política en el Ecuador, en Luis Mora, coord, Política y Sociedad, Quito: Corporación Editora Nacional, 1980.

- Gangotena, José Raúl: La inversión en el Ecuador 1830-1980, Libro del Sesquicentenario. Economía Ecuador, segunda parte, 1830-1980, Corporación Editorial Nacional, Inter Americal Defense College Library, 1983.

- García, María A.: Análisis estadístico de la producción bananera en el Ecuador, p. 52-86, Escuela Superior Politécnica del Litoral, Guayaquil, Ecuador, 2000.

- García Gallegos, Bertha: Militares, economía y lucha política: Ecuador en los años 70, en Tesis para la obtención de Maestría, Colegio de México) Quito: CONUEP/PUCE, 1987.

- García Gallegos, Bertha: Ecuador: Democratización y Fuerzas Armadas: "El contexto histórico, social y político de una relación ambivalente, en "La Administración de la defensa en América Latina. Análisis nacionales", Instituto Universitario General Gutiérrez Mellado-UNED, 2008.

- García Márquez, G.: El general en su laberinto, Madrid, 1989.

- García Navarro, Luis: El comercio interamericano por la mar del Sur en la Edad Moderna, Revista de Historia, vol. IV, número 23, Caracas, 1965.

- Godoy, Gastón: El caso cubano y la OEA, Madrid, Artes Gráficas, 1961.

- Gómez, Nelson: Organización del espacio ecuatoriano, en Nueva Historia del Ecuador, Vol. $12,1992$.

- Gómez, Marianela: Determinantes empíricos del crecimiento económico, Universidad Nacional de Río Cuarto, diciembre 2010. 
- González Suárez, F.: Historia general de la República del Ecuador, Imprenta del Clero, Quito, Ecuador, 1894.

- González, Víctor: Razas y clases en la colonia, Guayaquil: Casa de la Cultura Ecuatoriana, 1978.

- González Martínez, José Antonio: La enfiteusis: aspectos básicos de esta institución, Revista de la Facultad de Ciencias Sociales, Jurídicas de Elche, Volumen I, Número 4, 2009.

- González Prada, Manuel: Nuestros indios (1904), en Horas de lucha, n. 31-32, Quito, 1905.

- Gonzalo, Camilo: Aplicación del principio uti possidetis juris en América, Universidad Autónoma de Colombia, Facultad de Derecho, Bogotá, 2010.

- Goodman, J.: Excitantia: Or how Enlightment Europe took soft drugs, en: J. Goodman, P.E. Lovejoy y A. Sherrat (Eds.), "Consuming habits: Drugs in history and anthropology" London: Routledge, 1995.

- Griffith, Keith: Desarrollo humano: Origen, evolución e impacto, Nosotros Latinoamericanos Organización, 2011.

- Grossman, G.; Helpman, E.: Comparative advantage and long run growth, The American Economic Review, vol. 80, num. 4, 1990

- Guadarrama González, P.: Razones de confluencia y divergencia entre el pensamiento latinoamericano y el humanismo socialista, en "Islas", n. 110, 1995.

- Guaña, Pablo; Camino, Pedro, Ulco, Quibia: Inti Raymi Cayambi: La fiesta sagrada del sol en la mitad del mundo; la fiesta de San Pedro en Cayambe, Cayambe: CICAY/Museo Cayambe, 1992.

- Guerra, Guillemo: La planificación y el desarrollo agrícola e institucional en Ecuador, IICA, Dirección regional para la Zona Andina, apartado 478, Lima-Perú, junio, 1969.

- Guerrero Cazar, Fernando; Ospina Peralta, Pablo: El poder de la comunidad. Ajuste estructural y movimiento indígena en los Andes ecuatorianos, CLACSO, 2003.

- Gunder Frank, A.: Capitalism and underdevelopment in Latin America: Historical studies of Chile and Brazil, London: Monthly Review, 1967.

- Guerra, Francisco: Análisis del modelo económico y social ecuatoriano. De los años setenta y ochenta en el marco de la globalización, FLACSO, Quito, 11 de abril 2001. 
- Guerrero, Andrés: La hacienda pre-capitalista y la clase terrateniente en América Latina y su inserción en el modo de producción capitalista: El caso ecuatoriano, Ocasional Papers No. 23, Institute of Latin American Studies, University of the Sorbonne, París, 1977.

- Guerrero, Andrés: Ensayo sobre la acumulación originaria en el Ecuador: Hacendados cacaoteros, banqueros, exportadores y comerciantes de Guayaquil (1890-1910), s/l, s/e, Mimeo, 1977.

- Guerrero, Andrés: Renta diferencial y vías de disolución de la hacienda pre-capitalista en el Ecuador, Revista de Ciencias Sociales, Vol. II, número 5, p. 52, 1978.

- Guerrero, Andrés: Los oligarcas del cacao: Ensayo sobre la acumulación originaria en Ecuador: Hacendados, cacaoteros, banqueros, exportadores y comerciantes en Guayaquil (1890), Corporación editorial, primera edición, agosto, 1980.

- Guerrero, Andrés: Hacienda, Capital y Lucha de Clases Andina, Quito, Editorial, El Conejo, 1983.

- Hamerly, Michael: Historia Social y Económica de la antigua Provincia de Guayaquil 17631842, Guayaquil: Publicaciones del Archivo Histórico del Guayas, 1973.

- Hamerly T.; Carter, J.: Bibliografías ecuatorianas: Estado actual y últimos aportes, 20012005, p. 175, Iconos, 2006.

- Hamerly, M.: Más bibliografías ecuatorianas: las antologías de FLACSO, en publicación: Iconos, Revista de Ciencias Sociales no. 26, FLACSO, Facultad Latinoamericana de Ciencias Sociales, Sede Quito, Septiembre 2006.

- Hanson, David: Political decision making in Ecuador: The influence of business groups, tesis, Universidad de Florida, 1971, en Rafael Quintero y Erika Silva: "Ecuador: una nación en ciernes", pp. 321, Tomo III, FLACSO, Abya-Yala, 1991.

- Harnecker, Marta: Los conceptos elementales del materialismo histórico, Siglo XXI, 2007.

- Henderson, J.: How urban concentration affects economic growth, World Bank Policy Research working paper num. 2326, 2000.

- Hernández, Jesús: El fruto prohibido. El cacao de Guayaquil y el mercado novohispano, siglo XVI-XVIII, Universidad Autónoma de Tamaulipas, EHN 39, julio-diciembre 2008.

- Herrera Vascónez, C.: Algunos datos sobre la producción y comercialización de banano en el mundo y particularmente en el Ecuador, Guayaquil, REV-VAG, Doc. No. 021-ST, 1965. 
- Heston, A.; Summers, R.: What we have learned about prices and quantities from international comparisons", The American Economic Review, vol. 78, No. 2, mayo 1988.

- Hidalgo, A.: El aparecimiento del saber histórico en Guayaquil: El Centro de Investigaciones Históricas (1930-1962), Revista Ecuatoriana de Historia, 31, Quito, Ecuador, Universidad Andina Simón Bolívar, primer semestre 2010.

- Hidrobo Estrada, Jorge: Industriales, estado, industrialización en el Ecuador, Serie: Industrialización y Desarrollo, Universidad de San Francisco de Quito, Corporación de Promoción Universitaria, INSOTEC, 1990.

- Hirschman, Albert: Ideologies of economic development in Latin America, en Latin American issues, editado por A. Hirschman, Nueva York: The 20th Century Fund, 1961.

- Hirschman, Albert: The political economy of import-substituting industrialization in Latin America, en "Latin America: Problems in Economic Development", Ed. Charles T. Nisbet, New York, The Free Press, 1969.

- Hirschman, Albert: Enfoque generalizado del desarrollo por medio de enlaces, con referencia especial a los productos básicos, en El Trimestre económico, número 173, México, enero-marzo, 1977.

- Hirschman, Albert: Auge y ocaso de la teoría económica del desarrollo, en El Trimestre Económico. México DF, no 188, 1980.

- Hnatkovska, V.; Loayza, N.: Volatility and growth, Mimeo, agosto 2003.

- Hopkins T, Wallerstein I.: The age of transition. Trajectory of the World system 1945-2025, Editorial Zed Books, New Jersey, 1998.

- Horan, B.; Mee, J.F.; Rath, M.; O'Connor, P.; Dillon, P.: The effect of strain of HolsteinFriesian cow and feed system on reproductive performance in seasonal-calving milk production systems, Animal Science 79, 2004.

- Hurtado, Osvaldo: Dos mundos superpuestos, p. 111, Quito, INEDES, 1969.

- Hurtado, Osvaldo: El poder político en el Ecuador, Quito: PUCE, Barcelona: Ariel, Ed. actualizada, 1981.

- Ibarra, Alicia: Los indígenas y el estado en el Ecuador, editorial Abya-Yala, 1987.

- Icaza, Jorge: Huasipungo, Cátedra, Madrid, 1934.

- Icaza, Jorge: Seis relatos, Quito, Casa de la Cultura Ecuatoriana, 1952. 
- Icaza, Jorge: Mama Pacha, en Seis veces la muerte”, Buenos Aires, Editora Alpes, 1954.

- Icaza, Jorge: Atrapados: tríptico, vol. 1: El Juramento, Editorial Losada, 1972.

- Ianni, Octavio: Los Estados Unidos y el militarismo latinoamericano, Revista Mexicana de Sociología, Vol, 30, No 3, p. 522-524, Universidad Nacional Autónoma de México, Jul-Sept, 1968.

- Jackson, S.L: Statistics: Plain and Simple, segunda edición, EE.UU., Cengage Learning, 2009.

- Jaramillo Pavón, Marco: La economía campesina y la reforma agraria en el Ecuador, en Economía/Ecuador: 1830-1980, Libro del Sesquicentenario, Tomo III, Corporación Editora Nacional, 1983.

- Jarrín Ampudia, Gustavo: Política petrolera ecuatoriana, Ponencia, Departamento de publicaciones de la Universidad Estatal, Guayaquil, Ecuador, 1977.

- Jeifets, Lazar; Jeifets, Víctor: Los orígenes del Partido Comunista del Ecuador y la Tercera Internacional, Revista Izquierdas, año 3, número 6, 2010

- Jijón y Caamaño, Jacinto: Política conservadora", Segundo volumen, Riobamba, Edit. La Buena Prensa del Chimborazo, 1929.

- Jolly, Richard: Society for international development, the North-South Roundtable and the power of ideas, en "Development", Society for International Development, 2007.

- Jordán, Fausto: Reforma agraria en el Ecuador, en Proceso agrario en Bolivia y América Latina, Edit. CIDES-UMSA, Biblioteca virtual CLACSO, 2003.

- Kany, C.: Life and manners in Madrid 1750-1800, Berkeley: University of California Press, 1932.

- Kay, Cristóbal: Reforma agraria, industrialización y desarrollo: ¿Por qué Asia Oriental superó a América Latina?, Debate agrario: análisis y alternativas; publicación trim. del Centro Peruano de Estudios Sociales, Lima, 2002.

- Keynes, John: Teoría general del empleo, del interés y de la moneda, publ. Londres, 1936.

- Koopmans, J.: On the concept of optimal economic growth, en The Economic Approach to Development Planning, 1965.

- Kosacoff, Bernardo: La industria argentina: Un proceso de reestructuración desarticulada, en "El desafio de la competitividad" CEPAL-ALIANZA Editorial-1993. 
- Kuznets, S.: Economic growth and income inequality, American Economic Review 45 (1), 1955.

- Kuznets, S.: Modern economic growth, Yale University Press, New Haven, Conn., 1966.

- Labini, Sylor: Oligopoly and technical progress, p. 158, Cambridge: Harvard University Press, 1962.

- Laclau, Ernesto: Feudalismo y capitalismo en América Latina, de la publicación del Centro de Estudios de Economía Política, Buenos Aires, 1971.

- Landázuri Carrillo, Guillermo: Proposiciones de cambio en el desarrollo industrial ecuatoriano, Libro del Sesquicentenario Economía Ecuador, primera parte, Corporación Editora Nacional, 1983.

- Larraín, Felipe; Vergara, Rodrigo: Distribución del ingreso, inversión y crecimiento, cuadernos de economía, año 29, número 87, agosto 1992.

- Larrain, J.: Theories of development, London: Polity, 1998.

- Larrea, Carlos: Federico González Suárez, Quito, Ecuador, Estudio y Selecciones Biblioteca Virtual Miguel de Cervantes, 1960.

- Larrea Alba, Luis (Gral. EM (r): El desarrollo económico y su ordenación técnica, en Revista de las Fuerzas Armadas 42, Quito: Ministerio de Defensa Nacional, 1971.

- Larrea, Carlos: Estructura social, apropiación del excedente y desarrollo desigual en el Ecuador. Una primera aproximación, Mimeo, Quito, 1978.

- Larrea Maldonado, Carlos: Las empresas transnacionales y la economía ecuatoriana durante el periodo bananero, III Economía/Ecuador 1830-1980, primera parte, Libro de Sesquicentenario, Corporación Editora Nacional, 1983.

- Larrea, Carlos: El sector agroexportador y su articulación con la economía ecuatoriana durante la etapa bananera (1948-1972), en Louis Lefeber, ed. Economía Política del Ecuador. Campo, Región, Nación, Quito: CEN-CERLAC- FLACSO, p. 35-90, 1985.

- Larrea, Carlos; Espinosa, Malva; Charbe, Paolat: El banano en el Ecuador: Transnacionales, modernización y subdesarrollo, FLACSO, Biblioteca de Ciencias Sociales, volumen 16. Quito, Corporación Editorial Nacional, 1987.

- Larrea, Carlos: Pobreza y políticas sociales en América Latina, Maestría Relaciones Internacionales, Capítulo III, pp.15, FLACSO-Quito, diciembre 1988. 
- Larrea, Carlos; Vos, Rob; Jácome, Luis Ignacio: Políticas macroeconómicas, distribución y pobreza en el Ecuador, p. 31, CORDES, Ecuador, 1998, en Francisco Guerra: Análisis del modelo económico y social ecuatoriano. De los años setenta y ochenta en el marco de la globalización, FLACSO, Quito, 11 de abril 2001.

- Larrea, Carlos: Hacia una historia ecológica del Ecuador, Quito: Corporación Editora Nacional, Universidad Andina Simón Bolívar, Eco-Ciencia, 2006.

- Larrea Stacey, Eduardo: Evolución de la política del Banco Central del Ecuador 1927-1987, Quito, Banco Central del Ecuador, 1990.

- Laviana, M. Luisa: Guayaquil en el siglo XVIII: Recursos naturales y desarrollo económico, Escuela de estudios hispano-americanos de Sevilla, 1987.

- Leal, Francisco: La doctrina de Seguridad Nacional: Materialización de la Guerra Fría en América del Sur, Revista de Estudios Sociales, número 15, p. 74-87, junio 2003.

- Lehmann, E.L.; Romano, J.P.: Testing Statistical Hypotheses, tercera edición, EE.UU, Springer, 2005.

- Lenin, V. I.: El desarrollo del capitalismo en Rusia, en Obras Completas, tomo 3, en: Marta Harnecker: "Los conceptos elementales del Materialismo Histórico", Siglo XXI, 2007.

- Lenski, Gerard: Power and privilege: A theory of social stratification, New York: McGrawHill book Company, 1966.

- Levine, R.; Renelt, D.: A sensitivity analysis of cross-country growth regressions, the American Economic Review, 82(4), p. 942-963, 1992

- Levinson, Jerome; De Onís, Juan: The Alliance that lost its way: A critical report on the Alliance for Progress, en Michael Larosa y Frank O. Mora: Neighborly Adversaries: Readings in U.S. Latin American Relations, Lanham: Rowman \& Littlefield Publishers, In., 1999.

- Leys, C.: The rise and fall of development theory, London: James Currey, 1996.

- Linke, L.: Ecuador's politics: President Velasco's Fourth Exit, The World Today, Vol. 18, 2, p. $65-75,1962$.

- Lipschutz, S.; Schiller, J.: Introducción a la probabilidad y estadística, Editorial McGraw Hill, 2000.

- Loayza, N.; Soto, R.: The sources of economic growth: an overview, en Economic growth, trends and cycles, Central Bank of Chile, 2002. 
- London, Silvia; Formichella, María M.: El concepto de desarrollo de Sen y su vinculación con la educación, Facultad de Economía Vasco de Quiroga, 2006, www.economia.umich.mx.

- López Albújar, Enrique: Matalaché, Biblioteca Peruana, Peisa, Lima, 1983.

- López, Patricio: La normalidad excepcional: Una panorámica de la política económica del Gobierno Plaza Lasso (1948-1952), en “Galo Plaza y su época”, FLACSO, p. 86-89, 2008.

- López Pinto, Lionel: Distribución del ingreso en la economía ecuatoriana 1830-1980, p. 155164, Libro del Sesquicentenario. Economía Ecuador, segunda parte, 1830-1980, Corporación Editora Nacional, 1983.

- Loveman, B.; Davies, T.: The politics of antipolitics, en B. Loveman y T. Davies edit., The politics of antipolitics, the military in Latinamerica, Wilmington: Sr Books, 1997.

- Lowry, Michael: El pensamiento del Che Guevara, Editorial Siglo XXI, 1985.

- Lucas, Robert: On the mechanics of economic development, Universidad de Chicago, Journal of Monetary Economics 22, 1988.

- Luna Tamayo, Milton; Astorga, Alfredo: Educación 1950-2010, Informe cero, Ecuador 19502010, FLACSO, 2011.

- Maca, Luis: La tierra para los pueblos indígenas en el Ecuador, p. 1, Boletín ICCI-ARY Rimay, Año 6, No. 58, enero del 2004, en Galo Viteri Díaz: Reforma Agraria en el Ecuador editado por eumed.net, www.eumed.net/libros/2007b/298, 2007.

- Macías, Washington: Ecuador: De la agro- exportación a la industrialización asociada 18301986, Colección problemas socio económicos del Ecuador, 1983.

- Maddison, A.: Monitoring the World Economy, 1820-1992, public. OECD, enero 1995.

- Maiguashca; North L.: Orígenes y significado del velasquismo: Lucha de clases y participación política en el Ecuador, 1920-1972, en Rafael Quintero, edit. La cuestión regional y el poder, Quito, Corporación Editora Nacional/CERLAC-York University/FLACSO, p. 100, 1991.

- Malo, Rodrigo: Esquema de la experiencia industrial ecuatoriana, p. 339, en Economía, Ecuador: 1830-1980, III, Quito: Corporación Editora Nacional, 1983.

- Maldonado Donoso, Fernando: Militares y política en el Ecuador de 1830-1980, en Libro del Sesquicentenario, Política y Sociedad, Ecuador: 1830-1980, Corporación Editora Nacional, 1980.

- Maltus, Thomas: Ensayo sobre el principio de la población, primera edición, 1798; David Ricardo: Principios de economía política y tributación, edit. Pirámide, 2003 (1817), en Miguel 
Ángel Galindo Martín: Crecimiento económico, Tendencias y nuevos desarrollos de la teoría económica, pp. 39-52, nº 858 ICE, Enero-Febrero 2011.

- Mancero Samán, Alfredo: Industrialización, desarrollo y democratización, en "Políticas de industrialización en América Latina”, compilador Rafael Urriola, CEPLAES-ILDIS, 1988.

- Marchán Romero, Carlos: Guaytama y Cusubamba: dos modalidades de desarrollo de la agricultura serrana, Revista Ciencias Sociales, Quito, UCE, Vol. II, 5, p. 13-51, 1978.

- Marchán Romero, Carlos: El panorama agrario de la Sierra centro-norte 1550-1982, III Economía / Ecuador: 1830-1980, primera parte, Libro del Sesquicentenario, Corporación Editora Nacional, 1983.

- Marchán, Cornelio: Ecuador: Crisis, ajuste y política social en los años ochenta, Fundación Grupo Esquel, Ecuador, 1992.

- Mariátegui, Jose Carlos: Invitación a la vida heroica, Textos esenciales, Lima, Fondo Editorial del Congreso del Perú, 2005.

- Marqués de Lozoya: Historia de España, Tomo V, Salvat Editores, S.A. Barcelona, 1973.

- Martínez, Astrid: Planes de desarrollo y política agraria en Colombia: 1940-1978, Ed. Universidad Nacional de Colombia, 1986.

- Martínez, L.A.: A la Costa, reedición sin fecha, ed. Andes, p. 170-171, 1904, en Andrés Guerrero: Los oligarcas del cacao: Ensayo sobre la acumulación originaria en el Ecuador: Hacendados cacaoteros, banqueros, exportadores y comerciantes en Guayaquil, Quito, Ecuador: Editorial El Conejo, 1980.

- Martínez Valle, Luciano: Las organizaciones de segundo grado como nuevas formas de organización de la población rural, en "La construcción de la democracia en el campo latinoamericano", CLACSO, Consejo Latinoamericano de Ciencias Sociales, 2006.

- Martz, John: Politics and petroleum in Ecuador, Transaction, Inc. New Jersey, 1987.

- Marx, Karl: El Capital, México, F.C, 4a.edic, 1966.

- Matesanz, David; Sánchez, Ángeles: El desarrollo económico argentina a fines el siglo XX, en Agenda Internacional, número 3, 2010.

- Matovelle, Ángel: Las inversiones extranjeras y la transferencia de tecnología en el Ecuador, en Libro del Sesquicentenario, Economía Ecuador, segunda parte, 1830-1980, Corporación Editora Nacional, 1983. 
- Mauro, P.: Corruption and growth, The quarterly journal of economics, vol. 110, no. 3, agosto 1995.

- May, S.; Plaza, G.: The United Fruit Company in Latin America, p. 170 Washington, National Planning Association, 1958.

- Maza Zavala, D.F.: Evaluación crítica de la enseñanza de la economía en América Latina, Revista Economía, IIE-UC, Quito, número 63, p.78, 1990, en René Báez: "Ecuador: ¿Genocidio económico o vía democrática?”, p.16-17, Biblioteca de Ciencias Sociales, volumen 40, Corporación Editora Nacional, 1992.

- Meghnad, Desai; Sen, Amartya; Boltvinik, Julio: Índice de progreso social: Una propuesta, Centro de Investigaciones Interdisciplinarias en Ciencias y Humanidades, UNAM, 1998.

- Mena, Camilo: Evolución de la organización político-constitucional en América Latina (19501975). Situación del Ecuador, en "Evolución de la organización político-constitucional en América Latina”, Vol. II, UNAM, 1979.

- Mills, Nick; Ortíz, Gonzalo: Economía y sociedad en el Ecuador postcolonial, Cultura, Revista del Banco Central del Ecuador, vol, II, núm. 6, Quito, 1980.

- Mintz, Sidney: The sweetness and power: The place of sugar in modern history, New York: Penguin Books, 1985.

- Miño, Wilson: Breve historia bancaria del Ecuador, Quito: Corporación Editora Nacional, 2008.

- Moncada, José: La economía ecuatoriana en el siglo XX. Algunos elementos relativos a la génesis, apropiación y utilización del excedente económico, Primera edición, Quito, Ed. III.UC. 1980.

- Moncada, José: Panorama general de la economía en el Ecuador republicano, Libro del Sesquicentenario, Corporación editora nacional, III Economía/Ecuador 1830-1980 primera parte, 1983.

- Moncada Sánchez, José: Historia económica, planificación y socialismo en el Ecuador, Pensamiento Socialista, Ediciones La Tierra, Quito, 2008.

- Moncayo, Pedro: El Ecuador de 1825 a 1875: Sus hombres, sus instituciones y sus leyes, Segunda Edición corregida, anotada y documentada por C.E.M. y L.F. V., Quito, Imprenta Nacional, 1906. 
- Montalvo, César: La estructura vertical del mercado bananero para el Ecuador y el carácter limitado de las reformas de comercio internacional, en Revista Tecnológica Espol, vol. 21 Número1, p. 165-179, 2008.

- Montaño, G.; Wygard, E.: Visión sobre la industria ecuatoriana, s/f, p. 204-295.

- Montaño Huerta, César: La integración comercial sudamericana: ¿Es realmente posible?, en “Comercio exterior: alternativas para Ecuador", editado por Javier Ponce, Abya-Yala, 2005.

- Morales Martín, Juan J.: José Medina Echavarría y la sociología del desarrollo, Íconos, Revista de Ciencias Sociales, Núm. 36, Quito, p. 133-146, Facultad Latinoamericana de Ciencias Sociales-Sede Académica de Ecuador, enero 2010.

- Moreano, Alejandro: Los presentes. Tzántzicos, en La bufanda del sol, N², Quito, agosto, 1965.

- Moreano, Alejandro: El pensamiento y la acción política de Fernando Velasco, en Fernando Velasco Abad: "Ecuador: Subdesarrollo y dependencia", p. 11, primera edición, Edit. El Conejo, 1981.

- Moreano, Alejandro: El discurso historiográfico ecuatoriano como forma narrativa (periodo 1920-50), Proyecto de investigación Historia de la narrativa y narrativa de la historia, Universidad Andina Simón Bolívar, 2003; Introducción -Ecuador: Subdesarrollo y dependencia, Fernando Velasco Abad. Ed. El Conejo, 1983.

- Moreano, Alejandro: El escritor, la sociedad y el poder, en "La literatura ecuatoriana en los últimos treinta años (1950-1980)", Quito, El Conejo, 1983.

- Moreno Cornejo, Alberto: Ecuador: Capitalismo y dependencia, Guayaquil, Ediciones Amanecer, 1973.

- Moreno Luzón, J.: Teoría del clientelismo y estudios de la política caciquil, Revista de Estudios Políticos (Nueva Época) Núm. 89, Julio-Septiembre, 1995.

- Morner M.: Ensayos sobre historia latinoamericana: Enfoques, conceptos y métodos, Capítulo 1: Historiografía europea occidental y norteamericana: Algunas tendencias recientes, Biblioteca de Ciencias Sociales, Volumen 37, Corporación Editora Nacional, Universidad Andina Simón Bolívar, 1992.

- Mortimore, Gana; Mortimore, M.: La programación andina y sus resultados en el Ecuador: El papel de las empresas transnacionales, CEPAL-CET documento de trabajo, No. 15, febrero 1979. 
- Moya, A.: Instituciones de salud en el Ecuador. La beneficencia, en: Geografía de la Salud en el Ecuador. Tomo II, volumen 2, CEDIG, 1995.

- Murillo Jiménez, Hugo: La intervención norteamericana en Guatemala en 1954. Dos interpretaciones recientes, Escuela de Historia y Geografía, Universidad de Costa Rica, Anuario de Estudios Centroamericanos, 11 (2): 149-155, 1985.

- Murmis, Miguel: Sobre la emergencia de una burguesía terrateniente capitalista en la Sierra ecuatoriana como condicionamiento de la acción estatal, en Revista de Ciencias Sociales, Volumen II, número 5, Quito, 1978.

- Murmis, Miguel: El agro serrano y la vía prusiana de desarrollo capitalista, en Miguel Murmis et al, Ecuador: Cambios en el agro serrano, Quito, FLACSO, 1980.

- Murmis, Miguel; Bengoa, Jose; Barsky, Osvaldo: Terratenientes y desarrollo capitalista en el agro, ediciones CEPLAES, 1982.

- Myrdal, G.: Economic Theory and Underdevelopment, London: Duckworth, 1957; A. Hirschman: "The Strategy of Economic Development". Yale: Yale University Press, 1958.

- Nahón Corina, Cecilia; Rodríguez Enríquez, Martín Schorr: El pensamiento latinoamericano en el campo del desarrollo del subdesarrollo: Trayectoria, rupturas y continuidades, en "Crítica y teoría en el pensamiento social latinoamericano", Consejo Latinoamericano de Ciencias Sociales (CLACSO), 2006.

- Naranjo Chiribog, Marco: Dolarización oficial y regímenes monetarios en el Ecuador, Colegio de Economistas de Pichincha, Quito, 2005.

- Norero, A.: El cacao y su cultivo, Madrid, 1910.

- Norero, .A: Equatore Moderno, vol. 1, Roma, 1908, en: Andrés Guerrero: "Los oligarcas del cacao", pp. 73, Corporación Editorial, agosto, 1980.

- North, Lisa: Implementación de la política económica y la estructura del poder político en el Ecuador, en L. Lefeber, ed. Economía Política del Ecuador, Campo, Región, Nación, Quito: CEN-CERLAC-FLACSO, 1985.

- North, D.C.: Instituciones, cambio institucional y desempeño económico, Fondo de Cultura Económica, México, 1993.

- North, Douglas: Economic performance through time: The limits of knowledge, Washington University, Mimeo, 1996. 
- Novoa Monreal, Eduardo: La evolución del derecho de propiedad ante los actuales textos constitucionales latinoamericanos, De Estudios de Derecho económico, serie I, número 1, Instituto de Investigaciones Jurídicas de la UNAM, p.41-73, México, 1980.

- Núñez Rivero, Cayetano; Núñez Martínez, María: Los orígenes de las grandes corrientes ideológicas latinoamericanas: El socialismo, el nacionalismo y el populismo, UNED, Boletín de la Facultad de Derecho, núm. 26, 2005.

- Núñez Sánchez, J.: Historia. Antología" Estudio introductorio: La actual historiografía ecuatoriana y ecuatorianista, FLACSO/ ILDIS, Sede Ecuador, Quito, Ecuador, 2000; en La historiografía ecuatoriana contemporánea (1970-1994), Ediciones de la FAU, Universidad Central del Ecuador, Quito, 1984.

- Ocampo, J: Cincuenta años de la CEPAL, en Revista de la CEPAL (Santiago de Chile), Número extraordinario, 1998.

- Ocampo, J.A.; Parra, M.A.: Los términos de intercambio de los productos básicos en el siglo XX, Revista de la CEPAL No. 7, 2003.

- Ojeda, Ramón: Efectos del ferrocarril en la agricultura y la ganadería, Revista de la Sociedad Nacional de Agricultura, Vol. IX, Nil 66, Quito, p. 35, 1925.

- Ojeda, Ramón: Efectos del ferrocarril en la agricultura y ganadería, en Revista de la SNA, año IX, octubre de 1927, Citado en "Apuntes para una discusión sobre los cambios en la estructura agraria serrana”, Universidad Católica, Quito, 1976, Arcos y Marchán.

- Orlove, Benjamin: Living importance to imports, en: Arnold J. Bauer (ed), The allure of the foreign: Imported goods in postcolonial Latin America, Ann Arbor, University of Michigan Pres, 1997.

- Ortíz, Jose Luis: Formas de organización rural en el Ecuador. Marco histórico (la comunidad campesina), en "Enfoque: Ecuador, Estudios de la realidad nacional", Fundación Eugenio Espejo, Guayaquil, mayo 1983.

- Ortíz Crespo, Gonzalo: La incorporación del Ecuador al mercado mundial: La coyuntura socio-económica 1875-1895, Colección Ayora, Volumen IV, Banco Central del Ecuador, 1988.

- Ortíz, Cecilia: Indios, militares e imaginarios de nación en el Ecuador del siglo XX, Editorial Abya-Yala, 2006.

- Osorio Urbina, Jaime: El marxismo latinoamericano y la dependencia, Cuadernos políticos, número 38, Ediciones Era, México, D.F., enero-marzo 1984.

- Ospina, Pablo: Obras completas, Editorial Universidad de Costa Rica, 2000. 
- Ospina, Pablo: Esquemas para una breve historia del espacio ecuatoriano, en Sara Báez, Pablo Ospina y Galo Ramón: "Una breve historia del espacio ecuatoriano", Quito, Camaren-IEE, 2004.

- Pacari, Nina: La tenencia de tierras y rublos indígenas, en Latinoamérica agraria hacia el siglo XXI, CEPLAES, Quito, 1993.

- Pacheco, Lucas: La política económica en el Ecuador Republicano, Libro del Sesquicentenario, segunda parte, 1830-1980, Corporación Editora Nacional, 1983.

- Pachano, Simón: Sobrepoblación relativa: Un acercamiento al caso del campesinado serrano, Revista Ciencias Sociales, número 12, Universidad Central, Quito, 1979.

- Palma, G.: Dependency and development: A critical overview, en Seers, D. Dependency, 1981.

- Paniagua Pérez, Jesús: Noticias socioeconómicas del Austro Ecuatoriano en el proceso de la nunca construida catedral de la colonia de Cuenca, Separata del anuario Jurídico y Económico Escurialense, XXVI, Vol. I, San Lorenzo del Escorial, 1993.

- Pareja Cucalón, Francisco: Comercio de exportación en la economía pre-petrolera, Libro del Sesquicentenario, Corporación editora nacional, III Economía/Ecuador 1830-1980, primera parte, 1983.

- Pareja, Alfredo: La lucha por la democracia en el Ecuador, Quito, Ed. Ruminahui, 1956.

- Pareja Díezcanseco, Alfredo: Don Balón de Baba, Quito, Casa de la Cultura Ecuatoriana, 1960.

- Pareja Diezcanseco, A: Ecuador: La República de 1830 hasta nuestros días, Ed. Universitaria, Quito, 1979.

- Parodi, E.: La decadencia del cacao en Ecuador, Le materiel colonial, junio 1937.

- Parsons, Talcott: El sistema social, Madrid: Alianza, 1966.

-Parsons, Talcott: Sociological Theory and Modern Society, New York, Free Press, 1967.

- Paz Juan J.; Cepeda, Miño: Historiografía económica del Ecuador sobre el siglo XIX y XX en los últimos 25 años, Revista Procesos, Corporación Editora Nacional, 1993; Asociación de historiadores ecuatorianos, Taller de Historia Económica, Facultad de Economía. The.pazymino.com/manifiesto.html.

- Paz, Juan J, Cepeda, Miño: La economía en los gobiernos de José María Velasco Ibarra (19601961) y Carlos Julio Arosemena (1961-1963), Monografías, Archivo Histórico del Taller de Historia Económica, No. 01, PUCE, 2006. 
- Paz, J.; Cepeda, M.: La Revolución Juliana: Nación, Ejército y bancocracia, Abya-Yala, Quito, Ecuador, 2002.

- Paz, Juan J.; Cepeda, Miño: La fundación del Banco Central del Ecuador y su significado histórico a los 75 años, capítulo V, Taller de Historia Económica, número 2, Noviembre 2002,

- Paz, Juan J.; Cepeda, Miño: Ecuador: Una democracia inestable, Pontificia Universidad Católica de Ecuador, HAOL, Núm. 11, 2006.

- Paz, Juan J.; Cepeda Miño: La época cacaotera en Ecuador, p.2-3, Boletín del Taller de Historia Económica, Pontificia Universidad Católica del Ecuador, Facultad de Economía, Quito, no. 3, marzo/abril de 2011.

- Pazmiño Castro, Lucía: Democracia tutelada en el Ecuador (cronología de una praxis), en Informe final del concurso: El papel de la fuerzas armadas en América Latina y el Caribe, Programa Regional de Becas CLACSO, 2007.

- Peñaherrera de Costales, Piedad; Costales Samaniego, Alfredo: Historia social del Ecuador: Reforma agraria, vol. 4, Editorial Casa de la Cultura Ecuatoriana, 1971.

- Pérez Concha, Jorge: Ensayo histórico-crítico de las relaciones diplomáticas del Ecuador con los estados limítrofes, Quito, Banco Central del Ecuador (ed. Orig. 1958-1959), 1979.

- Pérez, Pilar: Cuando los montes se vuelven carbón: La transformación del paisaje en los alrededores de Quito, Tesis de maestría, Quito, FLACSO, 1995.

- Pineo, Ronn: Ecuador: Relaciones exteriores a la luz del bicentenario, Quito, FLACSO, Colección Bicentenario, 2009.

- Pinto, Aníbal: Naturaleza e implicaciones de la heterogeneidad estructural, en El Trimestre Económico (México DF) No 145, 1970.

- Pinto, Aníbal: América Latina: Una visión estructuralista, Facultad de economía, Universidad Nacional Autónoma de México, 1991.

- Pizano, Lariza: Caudillismo y clientelismo: Expresiones de una misma lógica. El fracaso del modelo liberal en Latinoamérica, en Revista Estudios Sociales, Junio, 2001.

- Polo, Rafael: Los intelectuales y la narrativa de la nación mestiza en el Ecuador en la década de 1950, Universidad Andina Simón Bolívar, 1998.

- Pomeranz, Kenneth: The Great Divergence: China, Europe and the making of the modern world economy, p. 194, Princeton: Princeton University Press, 2000. 
- Pope Atkins, George: La Junta Militar ecuatoriana 1963-1966, Revista Economía, Quito, UCE, Tercera época, 1974.

- Porras, María E.: La Gobernación y el Obispado de Mainas, Quito, Abya-Yala/TEHIS, 1987.

- Post, Ken: Problems of transition to socialism in underdeveloped capitalist countries", Notes on Lectures, Institute of Social Studies, The Hague, 1976.

- Poulantzas, N.: Classes in contemporary Capitalism, London, New Left Books, 1975.

- Pozas, Mario: El liberalismo hispanoamericano en el siglo XIX, Universidad Centroamericana, José Simeón Cañas, Realidad, Revista de Ciencias Sociales y Humanidades, número 108, abriljunio, 2006.

- Prebisch, Raúl: El desarrollo económico de América Latina y algunos de sus principales problemas, Nueva York: Naciones Unidas, 1949.

- Prebisch, Raúl: Crecimiento, desequilibrio y disparidades: interpretación del proceso de desarrollo económico, en NU. CEPAL: Estudio económico de América Latina, 1949, Naciones Unidas, p. 3-89, 1950.

- Prebisch, Raúl: Problemas del desarrollo económico en América Latina, conferencia número 1, p. 12, 23 de octubre de 1951.

- Prebisch, Raúl: Problemas teóricos y prácticos del crecimiento económico, CEPAL, primera edición, 1952.

- Prebisch, Raúl: Hacia una dinámica del desarrollo latinoamericano, Santiago de Chile, CEPAL, 1963.

- Preston, P.W.: Una introducción a la teoría del desarrollo, Siglo Veintiuno Editores, 1999.

- Prieto, Mercedes: Liberalismo y temor: Imaginando los sujetos indígenas en el Ecuador postcolonial, 1895-1950, Abya-Yala, Quito, 2004.

- Proudhon, Pierre: ¿Qué es la propiedad: Investigaciones sobre el principio del derecho y del gobierno,Título del original en francés: Qu'est-ce que la propriété?, Traducción directa de A. Gómez Pinilla, Primera edición, Buenos Aires, 2005.

- Putnam, Robert; Leonardi, Robert; Nanetti, Raffaella: Making democracy work: Civic Traditions in Modern Italy, Princeton University Press, Mayo, 1994.

- Quintero, Rafael: La cuestión regional y el poder, Facultad Latinoamericana Ciencias Sociales (FLACSO), Biblioteca de Ciencias Sociales, volumen 29, Corporación Editora 
Nacional. Quito, Ecuador, 1991.

- Quintero, Rafael: El mito del populismo: Análisis de los fundamentales del estado ecuatoriano moderno (1895-1934), FLACSO, Quito, 1980.

- Quintero, Rafael; Silva, Erika: Ecuador: Una nación en ciernes, Tomo I, II, III, Abya-Yala, FLACSO, 1991.

- Ramsey, F.: A mathematical theory of saving, Economic Journal 38, 1928.

- Redclift, M.R.: Agrarian reform and peasant organization on the Ecuadorian Coast, Universidad de Londres, The AthoIonc Press, 1978.

- Restrepo Guzmán, Marco: Estado, actores y conflicto social en la Amazonía: El caso de Morona Santiago (1940-11992), FLACSO, Quito, 1992.

- Ribadeneira, Catalina: El racismo en el Ecuador contemporáneo: Entre la modernidad y el fundamentalismo étnico. El discurso del otro, editorial Abya-Yala, 2001.

- Ricardo, David: Principios de economía política y tributación, editorial Pirámide, 2003 (1817).

- Rodas Chaves, Germán: La izquierda ecuatoriana. Aproximación Histórica, segunda edición, Edic. Abya-Yala, 2000.

- Rodas, Germán: J. de Morainville y el primer dibujo universal de la quina o cascarilla, Boletín del Instituto Francés de Estudios Andinos, año/vol. 32, número 3, Instituto francés de estudios andinos, Lima, Perú, 2003.

- Rodric, D.; Subramanian, A. et al: Institutions rule: The primacy of institutions over geography and integration in economic development, Journal of Economic Growth 9(2), 2004.

- Rodríguez Campomanes, Pedro: Reflexiones sobre el comercio español a Indias (1762), reeditada por Llombart Roca, V. Madrid, 1988.

- Rodríguez, L.A.: The search for public policy: Regional politics and government finances in Ecuador, 1830-1940, University of California Press, Bekerley, 1985.

- Rodríguez, Luis F.: El reingreso del Ecuador en la OPEP: Motivaciones y expectativas, Quito, PUCE, 2011.

- Romer, Paul: Increasing returns and long-run growth, The Journal of Political Economy, Vol. 94, No. 5, pp. 1002-1037, octubre 1986.

- Rostow, W.: The stages of economic growth, Cambridge University Press, 1980. 
- Saad, Pedro: La cuestión agraria, en obras escogidas, tomo IV Guayaquil, Editorial Claridad, 1971.

- Saad, Pedro: Obras escogidas, Tomo IV, Edit. Claridad, 1971.

- Saad, Pedro: Obras Escogidas, Tomo V, Comisión de Propaganda, Comité Central del Partido Comunista del Ecuador (eds.), EEICA, Guayaquil, 1977.

- Sachs, J.; Warner, A.: Economic reform and the process of global integration, Brooking papers on economic activity 1, p. 1-95, 1995;

- Sachs, J.; Warner, A.: Fundamental sources of long run growth, The American economic review, vol. 87, num. 21997.

- Sáenz, A.: Expulsión de fuerza de trabajo agrícola y migración diferencial, en Miguel Murmis et al, Ecuador: Cambios en el agro serrano, Quito, FLACSO, 1980.

- Salamea, Lucía: La transformación de la hacienda y los cambios en la condición campesina, p.251-300, en "Ecuador, cambios en el agro serrano", FLACSO, CEPLAES, 1980.

- Salas, Pedro: El Tratado Interamericano de Asistencia Recíproca de Río de Janeiro (1947), Editorial Jurídica de Chile, 1962 y Pan American Union: "IX Conferencia Internacional Americana, Bogotá, 1948: Convención Interamericana sobre concesión de los derechos políticos a la mujer", Washington, D.C, Unión Panamericana, 1948.

- Salgado, Germánico: El Ecuador y la Integración Subregional, Exportaciones, Quito, UNTAL, 1969.

- Salgado, Germánico: La economía del Ecuador en los últimos setenta años, Libro del Sesquicentenario, Economía Ecuador, segunda parte, 1830-1980, Corporación Editora Nacional, 1983.

- Sánchez Caro, Domingo: Consecuencias socioculturales de la transferencia de tecnología, Estudios Sociales, no. 7-CPU, 1971.

- Sandoval Moreano, Fabián: La fuerza de trabajo en el Ecuador Republicano, Libro del Sesquicentenario, Corporación editora nacional, III Economía/Ecuador 1830-1980 primera parte, 1983.

- Sala-i-Martin: I just ran two million regressions, American economic review, 87(2), 1997.

-Salgado, Mireya; De la Torre, Carlos: Galo Plaza y su época, p.121, Fundación Galo Plaza Lasso, FLACSO, 2008. 
- Sarlo, Beatriz: Una modernidad periférica, Buenos Aires 1920 y 1930, Buenos Aires, Nueva Visión, 1999.

- Schoultz, Lars: National Security and United States Policy toward Latin America, Princeton University Press, 1987.

- Sen, Amartya: Development as capability expansion, en Keith Griffin y John Knight, eds., Human Development and the International Development strategy for the 1990s, Londres, MacMikllan, 1990.

- Sen, Amartya: Desarrollo como libertad, GeoPlaneta, Editorial, S.A., 2000.

- Sepúlveda, Cristian: Estado y fases de acumulación dependiente en el desarrollo capitalista chileno, Berlín Occ. Mimeo, 1978.

- Sepúlveda, Cristian et al: Estrategias de desarrollo rural y economías campesinas: Hacia la formación de una nueva política tecnológico-ocupacional, en Estructuras agrarias y reproducción campesina, Lecturas sobre transformaciones capitalistas en el agro ecuatoriano, Ed. IIE-PUCE, 1982.

- Silva Charvet, E.: Identidad nacional y poder, Quito, Abya-Yala, 2004.

- Silverman, Marilyn: Variabilidad agraria en la Costa ecuatoriana, en Clase y región en el agro ecuatoriano, Proyecto FLACSO-CERLAC II, Corporación Nacional Editora, Quito, 1986.

- Strauss, John; Thomas, Duncan: Health, nutrition and economic development, Journal of Economic Literature, vol. XXXVI, nº 2, junio 1998.

- Striffler, Steve: In the shadows of state and capital. The United Fruit Company, Popular struggle and agrarian restructuring in Ecuador, 1900-1995, Duke University Press, Durham \& London, 2002.

- Solow, Robert: A contribution to the theory of economic growth, en The Quarterly Journal of Economics, Vol. 70, No. 1, Febr. 1956, T. Swan: "Economic growth and capital accumulation", volumen 32, num. 2, p. 334-361, 1956.

- Suárez, Rubén: El sector eléctrico ecuatoriano como fuente de bienestar social, FLACSO, Quito, 2010.

- Sunkel O.; Paz P.: El subdesarrollo latinoamericano y la teoría del desarrollo, México DF: Siglo XXI, 1980.

- Stornaiolo, Ugo: Ecuador: Anatomía de un país en transición, Ediciones Abya-Yala, 1999. 
- Swett, Francisco: Modelos de desarrollo del Ecuador, Libro del Sesquicentenario, Economía Ecuador, segunda parte, 1830-1980, Corporación Editora Nacional, 1983.

- Sylva, Paola: Los productos de banano, en: El banano en Ecuador: Transnacionales, modernización y subdesarrollo, FLACSO, volumen 16, 1987.

- Sylva, Paola: La organización rural en el Ecuador, Quito, Cepp - Abya Yala, 1991.

- Tapia Valdés, Jorge: La doctrina de la seguridad nacional y el rol político de las fuerzas armadas, en Juan Carlos Rubinstein (comp.), El estado periférico latinoamericano, Buenos Aires, Eudeba, 1988.

- Tama Paz, Cyrano: Petróleo, drama ecuatoriano, Departamento de publicaciones de la Universidad de Guayaquil, Julio 1975;

- Terain Najas, R.: La historia económica y social sobre la época colonial ecuatoriana. Balance de la producción historiográfica en los últimos 25 años, Revista ecuatoriana de historia No. 5, Corporación Editora Nacional, Quito, 1994.

- Thomas, Jack: The Role of private libraries and public archives in nineteenth century Spanish American Historiography, Journal of Library History, 9:4, Oct. 1974.

- Tobar, Bayardo; Cisneros, Ramiro: Industrialización dependiente del Ecuador, Revista Economía, Quito, (IIE-UCE) 68, 1968.

- Torres Caicedo, Reinaldo: Los estratos socio-económicos del Ecuador, Quito, JUNAPLA, Proyecciones de Torres Caicedo, p. 30, Quito, JUNAPLA, 1960.

- Trivelli, Hugo: Tecnología y crecimiento económico, Estudios Sociales, No. 7-CPU, 1975.

- Trujillo, Jorge: Los obscuros designios de Dios y del Imperio, Quito, CIESE, 1981.

- Tuaza, Luis A.: Cansancio Organizativo, en "Repensando los movimientos indígenas", FLACSO, Ministerio de Cultura del Ecuador, 2009

- Uggen, J.F.: Peasant Mobilization in Ecuador: A Case Study of the Guayas Province, Tesis doctoral, Universidad de Miami, 1975.

- Valarezo, Galo; Torres, Víctor: El desarrollo local en el Ecuador: Historia, actores y métodos, Ediciones Abya-Yala, Quito Ecuador, 2004.

- Valenzuela, Armando: El Perú y sus fronteras geopolíticas, tensiones territoriales y guerra con Ecuador, Centro de Estudios Histórico-Militares del Perú, Lima, Perú, 1998. 
- Villarán, Fernando: Política económica, planeamiento, desarrollo regional y local, Instituto para la Democracia y la Asistencia Electoral, IDEA Internacional, Asociación Civil Transparencia, coordinación general Pila Tello Rozas, marzo 2009.

- Vallejo, M.: Los roles de las Fuerzas Armadas en el post retorno, Quito: FLACSO, 1991.

- Varas, Augusto; Bustamante, Fernando: Fuerzas Armadas y Política en Ecuador, Quito: Ediciones Latinoamérica, 1978.

- Varae, Ana M.: Marea negra en la Amazonía, ABYA-YALA, Quito, 1995; Boletín N 3, 2002, en Teresa Jimbicti Pandama: El petróleo en la región amazónica: El bloque 24 y los derechos colectivos en la nacionalidad Shuar, p.3-5, FLACSO, 2004.

- Vázquez, Fernando: La relación entre crecimiento económico y desarrollo humano en el Perú, en Revista Moneda, Crecimiento económico y desarrollo, número 151, 2012.

- Velasco, Fernando: La estructura economía de la Real Audiencia de Quito: Notas para su análisis, Publicado en "Ecuador: pasado y presente", Instituto de Investigaciones Económicas de la Universidad Central, 1976.

- Velasco Abad, Fernando: Ecuador: Subdesarrollo y dependencia, Ed. El Conejo, 1983.

- Velasco Abad, Fernando: Reforma agraria y movimiento campesino indígena de la Sierra, segunda ed. Quito: Editorial El Conejo, 1983.

- Vera Manzo, Edmundo: Fuerza laboral, bienestar social y educación en el Ecuador, en Enfoque: Ecuador, estudios de la realidad nacional, Fundación Eugenio Espejo, 1983.

- Verdesoto, Luis F.: El análisis de algunas características sobresalientes de la evolución en los últimos treinta años del sistema político ecuatoriano, en "Enfoque: Ecuador. Estudios de la realidad nacional" Fundación Eugenio Espejo, Guayaquil, 1983.

- Verduga, César: Política económica y desarrollo capitalista en el Ecuador contemporáneo, Quito: Escuela de Sociología, UCE-Quito, segunda edición, 1977.

- Verduga, César: Ecuador contemporáneo: Modelos de desarrollo o recomposiciones hegemónicas, Libro del Sesquicentenario Economía Ecuador, segunda parte, Corporación Editora Nacional, 1983.

- Verduga, César; Cosse, Gustavo: Algunas consideraciones sobre las políticas estatales para el agro ecuatoriano (1964-1970), en Proyecto Cooperativo de Investigación sobre Tecnología Agropecuaria en América Latina (PROTAAL), Facultad Latinoamericana de Ciencias Sociales (FLACSO), documento número 29, 1978. 
- Verduga, César: El proceso económico contemporáneo (análisis del periodo 1972-1975). en Drekonja et al, Ecuador Hoy, Bogotá: Siglo XXX, 1978.

- Verduga, César: Desarrollo del capitalismo en el agro ecuatoriano e intervenci6n estatal: Un esbozo preliminar, en "El problema agrario", ILDIS, 1988.

- Vicuña, Leonardo: Situación de la clase trabajadora en la economía ecuatoriana, en Economía Ecuador: 1830-1980, primera parte, Libro del Sesquicentenario, Corporación Editora Nacional, 1983.

- Vidal, Gregorio; Guillén, Arturo: Introducción. La necesidad de construir el desarrollo en América Latina, en Repensar la teoría del desarrollo en un contexto de globalización, Homenaje a Celso Furtado, CLACSO, 2007.

- Vitale, Luis: Introducción a una teoría de la Historia para América Latina, Edit. Planeta, Buenos Aires Argentina, 1992.

- Viteri Díaz, Galo: Reforma agraria en el Ecuador, p. 12, editado por eumed.net, www.eumed.net/libros/2007b/298, 2007.

- Wacziarg, R.; Welch, K.: Trade liberalization and growth: New evidence, World Bank Economic Review, 22 (2), 2008.

- Wallerstein, Immanuel: 1968: Revolución en el sistema-mundo. Tesis e Interrogantes, en revista Estudios sociológicos, num. 20, México, 1989.

- Weber, Max: Essays in Sociology, traducción e introducción de H. H. Gerth and C. Wright Mills, New York, Oxford University Press, 1970.

- Weinman, L.J: Ecuador and cacao: Domestic responses to the boom-collapse monoexport cycle, University of California, Los Angeles, 1970;

- Wiener, Carlos: 1879-1882: Viaje al río de las Amazonas y a las Cordilleras, en "El Ecuador visto por los extranjeros", Biblioteca Ecuatoriana Mínima, México, 1950.

- Wiener, Carlos: Un francés en Guayaquil, Biblioteca ecuatoriana mínima en "El Ecuador visto por los extranjeros", Viajeros de los siglos XVIII y XIX, Ed. Cajica, Puebla, México, 1960.

- Whitaker, Morris D.; Colyer, Dave; Alzamora, Jaime: El rol de la agricultura en el desarrollo económico del Ecuador, Un diagnóstico del sector agrícola del Ecuador, U. S. Department of Agriculture, National Agriculture Library, 1990.

- White, Hayden: Historiography and historiophoty, en The American Historical Review, Vol. 93, No. 5, p. 181, Washington, 1988. 
- Wolf, Eric: Pueblos y culturas de Mesoamérica, Traducción de Felipe Sarabia, México, Editorial Era, 1985.

- Wolf, Theodor: Geografía y geología del Ecuador, Geografía botánica y zoológica, capítulo I, Public. Gobierno de la República, 1892.

- Yazbek, Susana: La participación de ARPEL en la integración latinoamericana del sector petrolero, 1965-2011, III Congreso Latinoamericano de Historia Económica y XXIII Jornadas de Historia Económica, Simposio 9: Políticas petroleras en Américas (1945-2011), San Carlos de Bariloche, 23-27 de Octubre de 2012.

- Ycaza, Patricio: Movimiento obrero, estado y modernización capitalista en el Ecuador (19601983), p. 13, Editorial Rafael Perugachi, 1985.

-Yépez, J.; Rodríguez Rojas, P.: América latina y la visión de los otros: Breve revisión crítica de la historiografía latinoamericana, Universidad Simón Rodríguez, Venezuela, 2006.

- Zamosc, Leon: Luchas campesinas y reforma agraria: Un análisis comparado de la Sierra ecuatoriana y la Costa atlántica colombiana, Publicación: Agricultura y Sociedad, 1990;

- Zea, Leopoldo: El positivismo en Hispanoamérica. El positivismo como filosofía para un nuevo orden, Edición digital basada en la tercera edición (Ariel,Barcelona, 1976), diciembre 2003.

- Zeuske, M.: Los negros hicimos la independencia: Aspectos de la movilización afrocubana en el hinterland cuban", Cienfuegos entre colonia y república, en Espacios, silencios y los sentidos de la libertad, Cuba entre 1878 y 1912, p. 193-234, Editorial de Ciencias Sociales, 2002.

\section{Leyes:}

-Ley de Fomento Industrial de 1963, decreto 348, 28 de agosto de 1963, Banco Central del Ecuador, Memoria 1963.

\section{Encuestas, Boletines, Juntas, Directorios, Censos y otras publicaciones:}

- Archivo de Providencias de adjudicación de tierras. Sección de evaluación y estadísticas, 1968, en Alfredo Costales y Piedad Costales: Historia Social del Ecuador: Reforma Agraria, Edit. Casa de la Cultura Ecuatoriana, Quito, 1971.

- Banco Central, Boletines Anuarios; Banco Central, Cuentas Nacionales; IMP, International Financial Statistics.

- Banco Central del Ecuador, Ministerios de Economía, Banco Nacional de Fomento: Primer Censo Agropecuario Nacional, 1954, Impreso en los talleres gráficos de la Dirección General de Estadística y Censos, Ministerio de Economía, Quito, Julio 1956. 
- Banco del Ecuador: Crónica comercial e Industrial de Guayaquil en el primer siglo de la independencia, 1820- 1920, en La economía del Ecuador en los últimos setenta años (19061976), Biblioteca ecuatoriana, 1977.

- Banco Mundial: Ecuador: An agenda for recovery and sustained growth country study, Washington DC, 1984.

-Banco Mundial: Más allá del crecimiento, Grupo del Banco Mundial, 2002, www.worldbank.org

- Banco Nacional de Fomento: Historia del Banco Nacional de Fomento, www.bnf.fin.ec.

- BCE, Memoria del Gerente General, p. 61, Quito, 1978.

- Bretton Woods Project: Asociación Internacional de Desarrollo, Índice de instituciones, 2008.

- Censo Industrial de 1965.

- CEPAL: Estudio económico de América Latina, 1949, Nueva York: Naciones Unidas, 1951.

- CEPAL: El desarrollo económico del Ecuador, México, N.U., 1954.

- CEPEP: Las luchas campesinas 1950-1983. Movilización Campesina e historia de la FENOC, Quito, Centro de Educación Superior Popular (CEPED), Serie Movimiento Social, 1985.

- CEPAL: La República Dominicana en 2030: hacia una nación cohesionada, p.79, Víctor Godínez y Jorge Máttar, coordinadores, sept. 2009.

- CIH: El iniciador de la historia patria, cap.I: 1, 1931.

- Comité Interamericano de Desarrollo Agrícola (CIDA): Tenencia de la tierra y desarrollo socio-económico del sector agrícola Ecuador, Secretaría General de la Organización de los Estados Americanos-Washington D.C. Publicado por Unión Panamericana, 1965.

- CONADE: La situación socio-económica de la artesanía en el Ecuador, Conclusiones y recomendaciones del seminario organizado por CONADE, CENAPIA, ILDIS en Quito, 23-26 noviembre de 1981, segunda edición, 1982.

- CONDESAN: Problemática en zonas ganaderas alto andinas, p. 2-3, en Instrumentación de políticas con influencia en la ganadería y la pobreza en zonas alto andina en Perú, Ecuador y Bolivia. Análisis de las condiciones en Ecuador, Pablo López Buitrón, apéndice I del Informe final del proyecto Andean Hub of the pro-poor livestock policy initiative, PR number 24333, 23 de febrero 2003. 
- Consejo Ecuatoriano de Ciencias Sociales: Un experimento innovativo para reducir el desempleo y el subempleo juvenil en el Ecuador, p. 32, Reunión de expertos sobre el desempleo juvenil, Paris 18-20 septiembre 1985.

- Departamento Estimaciones Agrarias, Dirección Nacional de Agricultura y Ministerio de Fomento, 1963.

- Directorio Nacional de Establecimientos de 1964.

- Encuesta Industrial de 1963, Encuesta Industrial de 1964.

- Encuestas de hogares de 1968, INEC, encuestas de población y ocupación, INEC, 1975.

- Estadísticas y censos, Directorio 1964.

- Enciclopedia Salvat, Países de América Latina, Salvat Ediciones Ecuatoriana S.A., Tomo VIII, Barcelona, 1980.

- Estadística del MHC: Extracto Estadístico del Perú, 1931-1933. Anuario Estadístico del Perú, 1948-1949, 1951.

- FAO: La economía mundial del banano 1985-2002, Organización de las Naciones Unidas para la agricultura y la alimentación, Roma, 2004.

- Federación Ecuatoriana de Indios: III Congreso de la Federación Ecuatoriana de Indios y Gran Concentración de la Sierra para exigir la Reforma Agraria Radical y Democrática, e-archivo ecuatoriano, www.yachana.org/earchivo/fei/ , en: El Comité Ejecutivo Nacional, La Comisión Nacional Campesina de la CTE, "III Congreso de la Federación Ecuatoriana de Indios y Gran Concentración de la Sierra para exigir la Reforma Agraria Radical y Democrática," Mañana 2, no. 96 (December 7, 1961).

- Fondo Monetario Internacional: Estadísticas Financieras Internacionales, vol. XXIX, no. 5, Washington D.C, mayo de 1976.

- GUIA: Ecuador, guía comercial, agrícola e industrial de la República, 1909, Guayaquil, 1909.

- INEC, Encuestas de manufactura y minería, MICEI, Anuarios de Comercio Exterior y Ley de Aranceles. Elaboración: Area industrial, IIE-PUCE.

- Informativo No. 237, p. 11-12, Escuela Superior Politécnica del Litoral, agosto 1981.

- Instituto Interamericano de Ciencias Agrícolas: La planificación y el desarrollo agrícola e institucional en Ecuador, Dirección Regional para la zona Andina, apartado 478, Lima-Perú, 1969. 
- Instituto Nacional de Colonización, p. 29-43; 65-66, 1963-1964.

- Instituto Nacional de Colonización, p. 41, 1936-194, Ley de Reforma Agraria y Colonización de 1964.

- Instituto Nacional Autónomo de Investigaciones agropecuarias: Tecnología para el desarrollo agropecuario, Corpoiniap, 1995.

- Junta Nacional de Planificación: Censo Agropecuario de 1954.

- Junta Nacional de Planificación: La industria y la artesanía de la Hoya de Quito en 1955, en Instituto Panamericano de Geografía e Historia, Plan Piloto del Ecuador, Sección de Economía, pp. 51, México, D.F, 1960.

- Junta Nacional de Planificación: Plan General de Desarrollo Económico y Social, T.I. Lb.I, Quito, 1963.

- Junta Nacional de Planificación: 25 Años de Planificación, Selección y Notas: Dr. Germánico Salgado. Director Técnico de JUNAPLA. Econ. Eduardo Santos Alvite 1979, Secretaría Nacional de Planificación y Desarrollo, www.planificacion.gob.ec.

- Junta Nacional de Planificación y Coordinación Económica: Desarrollo y perspectivas de la economía ecuatoriana, en Plan general de desarrollo económico y social, Quito, Citado por Miño, p. 120, 1963.

- Junta Nacional de Planificación: Programa de artesanía y pequeñas industrias 1969-1973, p. 27-29, número 02-14, 1969.

- Junta Nacional de Planificación: Evolución histórica del comercio exterior ecuatoriano 19501970, Oficina de Publicaciones, Ecuador, 1975.

- Ministerio Coordinador del Desarrollo Social: Eloy Alfaro: Pensamiento y políticas sociales, Cassolutions Publicidad, Quito, 2012.

- Ministerio de Economía, Dirección General de Estadística y Censos: Censo Agropecuario Nacional 1954, Quito, 1956.

- Ministerio de Previsión Social y Trabajo, Departamento de Cuestiones Sociales, Departamento de Liquidación de Huasipungos del IERAC. Elaboración: Instituto Ecuatoriano de Antropología y Geografía, Departamento de Antropología Social, agosto de 1967.

- North South Round Table: Human Development: The neglected dimension, 1985, Committee for Development Planning, Human Resources Development: A Neglected Dimension of 
Development Strategy, El desarrollo de recursos humanos: una dimensión olvidada de la estrategia para el desarrollo), New York: United Nations, capítulo III, 1988.

- OLADE: Base de datos. Histórico producción petrolera de Ecuador.

- Organización de la Naciones Unidas para la Educación, la Ciencia y la Cultura: Un experimento innovativo para reducir el desempleo y el subempleo juvenil en el Ecuador, p. 5253, Reunión de expertos sobre el desempleo juvenil, Paris, 18-20 septiembre 1985.

- Penn World Table 6.2; Freedom House: Freedom in the World 2012.

- Plan Integral de Transformación y Desarrollo 1973-1977; Plan Nacional de Desarrollo 19801984; Plan Nacional de Desarrollo Económico y Social 1989-1992, en Galo Viteri Díaz: Reforma Agraria en el Ecuador, p. 8, editado por eumed.net, www.eumed.net/libros/2007b/298, 2007.

- Plan Nacional de Desarrollo, 1980-1984, Segunda Parte, Tomo IV, Cultura y Educación, p. 1718.

- Pontificia Universidad Católica del Ecuador: Ficha de información socio-política (6 abril), p. 67, Quito, Departamento de Ciencias Políticas Sociales, 1974.

- PREALC: Situación y Perspectivas de empleo en el Ecuador, p. 222, en Mimeógrafo editado por la Facultad de Economía de la Universidad Central.

- Primer Congreso del Partido Comunista Cubano, Informe Central, p. 12, La Habana: Editorial Pueblo y Educación, 1978.

- Resolución XXXIV-154 proclamada el 10 de noviembre del mismo año186, en Luis Aparicio: El ingreso de Ecuador en la OPEP, Tesis. PUCE, Quito, Ecuador, $1978 \mathrm{~s} / \mathrm{p}$.

- Secretaría de la Comisión Económica para América Latina: El desarrollo económico del Ecuador, p. 88, Naciones Unidas, México, enero de 1954.

- Secretaría General de Planeación y Económica de la Junta Nacional de Planificación y Coordinación: El crédito agropecuario en el periodo 1964-1967, p.3, documento num. 08-03, 1968.

- Universidad de Georgetown: República del Ecuador, Political database of the Americas, Center for Latin American Studies, 2009. 


\section{Diarios:}

- Diario El Comercio, años 1959-1964, 3 de enero de 1962, en Osvaldo Barsky: La Reforma agraria ecuatoriana, Corporación Editora Nacional, Biblioteca de Ciencias Sociales, Volumen 3, p. 123-160, 1984.

- Diario El Militante: La Revolución Cubana: Pasado, presente y futuro, p. 16-22, noviembre 2004.

-Diario El Pueblo, número 445, Guayaquil, 21 mayo 1964, en Rafael Quintero, Erika Silva: Ecuador: Una nación en ciernes, p. 293, Tomo III, FLACSO, Abya-Yala, 1991.

\section{Páginas de internet:}

- ALI: Movimiento campesino, alainet.org/publica/diversidad/movcampesino.html

- Base de datos del Banco Mundial (1960-1980) data.worldbank.org

- Chevron: Guía de inspección judicial, 27 de julio, 2005, www.texaco.com

-Informes sobre desarrollo humano, orígenes del enfoque de Desarrollo Humano, hdr.unp.org

- Organización de Países Exportadores de Petróleo www.opep.org.

- Organización de Estados Iberoamericanos: Sistema educativo del Ecuador, www.oei.es/quipu/ecuador/index.html 


\section{APÉNDICE DE NOTAS A PIE DE PÁGINA}

\section{INTRODUCCIÓN}

Nota 16: El periodo comprendido entre 1925 y 1950, época de desarrollo de las ideas nacionales-populares, de influjo del marxismo y de inicio del pensamiento de la CEPAL en América Latina, se caracteriza por la existencia de los siguientes partidos políticos: la Alianza Popular Revolucionaria Americana (PAP), el Partido Revolucionario institucional (PRI), Acción Democrática (AD), el Movimiento Nacionalista Revolucionario (MNR), el Partido Justicialista (PJ) y el Partido Socialista (PS), continuador del legado marxista, entre otros. Este último partido asumió el impulso de diferentes agrupaciones socialistas muy activas a principios de la década de 1930 y proyectos sobre la vida política chilena en el horizonte de la revolución socialista.

Posteriormente, durante el periodo de la modernización desarrollista (1950-1975), algunos partidos lograron mantener los niveles regulares de éxito en su presencia política, debido a su capacidad de acceder al poder o por su influencia significativa en el mismo. Entre estos, se encuentran los partidos de proximidad demócrata cristiana como el Partido Demócrata Cristiano (PDC) en Chile, el Partido Reformista Social Cristiano (PRSC) de la República Dominicana y Democracia Popular (DP) en el Ecuador. También, figuran los de carácter socialdemócrata como Izquierda Democrática (ID) en el Ecuador (se creó por la convergencia de grupos procedentes del liberalismo y militantes socialistas ecuatorianos), el Movimiento de Izquierda Revolucionaria (MIR) en Bolivia, y la derecha ecuatoriana (Partido Social Cristiano o PSC). Fuente: Manuel Alcántara: El origen de los partidos políticos en América Latina, Instituto de Ciencias Políticas y Sociales, WP, número 187, Barcelona, 2001.

Nota 63: Se ha de diferenciar el uso del término "ilustrado" para referirnos a la época mencionada y no a la de los pensadores ilustrados del siglo XVIII. La Ilustración fue un movimiento cultural, social, político y espiritual europeo del siglo XVIII, centrado en Francia, y cuyas raíces específicas intelectuales se vinculan con la ciencia moderna, el protestantismo y el racionalismo filosófico. Esta etapa constituye un periodo fundamental en la historia del pensamiento burgués, pues permitió a esta clase tomar conciencia de sí misma y del papel político que debía desempeñar conforme a su poder económico y su importancia social. La Ilustración dejó una herencia perdurable en los siglos XIX y XX, ya que supuso un paso clave en la declinación de la Iglesia y en el crecimiento del secularismo, además de servir como modelo 
para el liberalismo político y económico que tuvo lugar en América Latina durante el siglo XIX. Así, la causa independentista del nuevo orden postcolonial se vio favorecida por la incorporación de las ideas de algunos de los principales pensadores de la Ilustración, como fue el caso de Rousseau, del cual se extrajo su visión positiva de la libertad, Montesquieu, con sus aportaciones con respecto a la división de poderes y Voltaire, con sus ideas fundamentadas en el sentido del progreso y perfección humana. Estas ideas, junto con las diferentes relaciones y sentimientos de los criollos hacia su herencia española, fueron las que proporcionaron una identidad al movimiento liberal hispanoamericano. Fuente: Mario Pozas: El liberalismo hispanoamericano en el siglo XIX, Universidad Centroamericana, José Simeón Cañas, Realidad, Revista de Ciencias Sociales y Humanidades, número 108, abril-junio, 2006.

Nota 84: La obra de González Suárez es bastante amplia, ya que publicó cuatro volúmenes sobre ciencias eclesiásticas y cuestiones religiosas, como los Estudios bíblicos, en los que analiza los primeros capítulos del Génesis. También, destacan sus obras sobre prehistoria y arqueología y sus escritos históricos, entre los que sobresalen la Historia eclesiástica del Ecuador desde los tiempos de la conquista hasta nuestros días de 1881; La Memoria histórica sobre Mutis y La Expedición botánica de Bogotá en el siglo décimo octavo, editada por primera vez en 1888, y la ya mencionada Historia general de la República del Ecuador.

Para la elaboración de algunas de sus obras, González Suárez tomó como referencia la Historia del Reino de Quito del padre Juan de Velasco (1841-44) y el Resumen de la historia del Ecuador de Pedro Fermín Cevallos (1870), en la que a pesar de su admiración, halló grandes vacíos y deficiencias notables, sobre todo, en lo que respecta a los tiempos de la conquista y a las épocas prehistóricas; de ahí su empeño para completar y rectificar el Resumen de la historia con notas y apéndices.

Así, González Suárez dedicó una buena parte de su tiempo a la investigación y a la búsqueda de fuentes y documentos en los archivos de Quito, Cuenca, Loja, Riobamba e Ibarra, a la vez que también se desplazó a España, Uruguay, Argentina, Chile, Perú y otros países, para consultar y recoger algunos datos complementarios y documentos útiles. Si bien esta labor ha tenido una gran importancia en la historia ecuatoriana, no obstante, se ha de señalar que la falta de fuentes de consulta, recursos económicos y una atmósfera adecuada para elaborar trabajos positivistas, fueron algunos de los obstáculos que, con frecuencia, impedirían la investigación histórica de esta época, poniendo de manifiesto una escasa producción de carácter científico. Fuente: Carlos 
M. Larrea: Federico González Suárez, Estudio y Selecciones, Biblioteca Virtual Miguel de Cervantes, Quito, Ecuador, 1960.

\section{CAPÍTULO 1}

Nota 169: Esta orden fue dictada por la Cédula del 15 de julio de 1802. Puede verse la obra de María E. Porras: La Gobernación y el Obispado de Mainas, en la que se analiza la situación de Mainas en los siglos XVII y XVIII y se exponen las razones que condujeron a la emisión de la Cédula de 1802. Además, esta cédula supuso el traspaso de la soberanía de Mainas al Virreinato peruano, siendo una de las principales bases jurídicas de la demanda territorial del Perú en el conflicto de límites con el Ecuador durante el siglo XIX. La interpretación ecuatoriana indica que la Cédula de 1802, otorgaba la jurisdicción religiosa y militar sobre Mainas al Virreinato del Perú, pero no la jurisdicción administrativa, que seguía perteneciendo a la Real Audiencia de Quito. Otros estudios indican que el establecimiento del Virreinato de Nueva Granada o Santafé y del Río de la Plata o Buenos Aires, tuvo lugar en el siglo XVIII, siendo ambos territorios segregados del Virreinato del Perú. Fuente: María E. Porras: La Gobernación y el Obispado de Mainas, Quito, Abya-Yala/TEHIS, 1987.

Por su parte, el Virreinato de Nueva Granada fue creado mediante la Real Cédula del 27 de mayo de 1717, y aunque, en un principio, estuvo integrado por las provincias de Mainas y Guayaquil, estas fueron devueltas al Virreinato del Perú en 1802 (ver mapa 4 en apéndice de mapas). La imposibilidad del Virreinato de Nueva Granada para administrar adecuadamente la extensa región de Mainas (actualmente Amazonas), llevó a la subscripción de la Real Cédula del 15 de julio de 1802, en virtud de la cual regresaron a la jurisdicción del Virreinato del Perú, las regiones de Mainas y Quijos. Sin embargo, un año después, el virrey Fernando de Abascal, mediante la Real Cédula del 7 de Julio de 1803, decretaba el reintegro de la gobernación de Guayaquil al Virreinato del Perú, lo que sería confirmado de manera absoluta con otra Real Cédula firmada en 1809. Fuente: Armando Valenzuela: El Perú y sus fronteras geopolíticas, tensiones territoriales y guerra con Ecuador, Centro de Estudios Histórico-Militares del Perú, Lima, Perú, 1998.

Nota 398: Por razones económicas y clasistas, García Moreno logró fundir los intereses de las clases dominantes en un proyecto coyuntural para la consolidación del estado nacional. Así, con respecto a la burguesía comercial, las actividades bancarias y los propios banqueros llegaron 
a consolidarse en un único cuerpo con los comerciantes. Por otro lado, sus relaciones con los terratenientes se caracterizaban por la influencia de la ideología católica, cuya fe era compartida por los terratenientes serranos. Como la Iglesia era el principal terrateniente del país, sus dirigentes defendían la explotación de la mano de obra campesina, de ahí que el proyecto de García Moreno se basara en la explotación de los trabajadores mediante el concertaje o la imposición de trabajos obligatorios y el pago de diezmos y primicias.

La finalización del gobierno de García Moreno coincidió con el periodo de mayor integración al mercado capitalista, durante el cual, el poder político no se encontraba en manos de la burguesía costeña: Veintimilla (1876-1883), Caamaño (1884-1888), Flores (1888- 1891) y Cordero (1892-1895) no fueron representantes típicos del gamonalismo tradicional serrano, pero tampoco representaban a la burguesía costeña y a la fracción radical del general Alfaro. Este grupo progresista puede ser calificado de centrista, al propugnar un lento proceso de modernización del país, que no llegó a afectar los intereses básicos de los terratenientes serranos y tampoco llegó a entregar el poder político a la burguesía comercial costeña. Fuente: Enrique Ayala Mora: Lucha política y origen de los partidos en Ecuador, Pontificia Universidad Católica, Editado por Publitécnica, Quito, 1978.

Nota 430: En el Ecuador, la influencia de Marta Harnecker se refleja en su trabajo de reconstrucción de la memoria crítica del proceso socio-político transformador que ha tenido lugar en este país. Desde un primer momento, esta autora chilena se ha comprometido con los procesos populares de cambio social ocurridos en América Latina, expresando su opinión sobre las prácticas revolucionarias colectivas. Para ella, los procesos actuales revolucionarios son el resultado de las acciones de los pueblos que, en su diversidad, van articulándose y tomando el control de sus vidas, y a través de su resistencia, lucha y transformación se constituyen en agentes políticos colectivos capaces de protagonizar su historia.

En su obra, Ecuador: una nueva izquierda en busca de la vida en plenitud, habla de la importancia de la base popular y observa un debilitamiento de este proceso con motivo de la consulta popular que enfrentó a la izquierda entre sí (el gobierno y el movimiento indígena) con posturas prácticamente opuestas.

Harnecker intenta ayudar a la reconciliación de la izquierda ecuatoriana, recogiendo distintas opiniones sobre esa relación, con el fin de solucionar el problema. Asimismo, habla de la dificultad y complejidad de la transición del Ecuador, pues no se trata de un proceso 
caracterizado por las revoluciones pasadas en torno al aparato estatal, sino de la conquista de los espacios de institucionalidad frente a los problemas que presenta la oposición de los poderes económicos y mediáticos. Esto explica la necesidad de fortalecer un gobierno basado en la organización popular, pues es el pueblo (y no el estado), el que puede construir una nueva sociedad. Fuente: Marta Harnecker: Ecuador: Una nueva izquierda en busca de la vida de plenitud, Editorial Intervención Cultural, Barcelona, 2011.

Nota 449: La Revolución Juliana comenzó con el golpe militar llevado a cabo por el ejército ecuatoriano el 9 de Julio de 1925, en contra de la hegemonía bancaria y oligárquica de dicha época, a la vez que se iniciaba un nuevo ciclo histórico-político. De esta manera, se establecieron las bases para superar el sistema oligárquico-terrateniente, se puso freno a los abusos y controles de la banca privada sobre el estado, se impuso el interés nacional sobre la plutocracia regionalista de Guayaquil, se institucionalizó la preocupación estatal sobre las clases trabajadoras y comenzó un proceso de modernización de las instituciones públicas.

Con esta Revolución surgieron dos políticas decisivas para la vida futura del país, marcando la superación del aparato estatal del siglo XIX:

- La imposición de los intereses nacionales en materia monetario-financiera contra la hegemonía de los intereses privados;

- La institucionalización de la "cuestión social" ecuatoriana como política de estado y no únicamente como política de gobierno.

La Revolución Juliana expresó una reacción nacional contra lo que se consideraba como dominio de la "bancocracia", consolidado por los que fueron calificados como gobiernos liberales "plutocráticos" (1912-1925). En aquella época, los grandes bancos privados de emisión dominaban las finanzas del país, no sólo porque de sus créditos dependía el desarrollo empresarial, sino porque también el propio estado se hallaba sujeto, como deudor, a la determinante influencia económica y política de los banqueros.

Durante el ciclo juliano (1925-1931) se sucedieron dos Juntas de Gobierno provisionales: la primera, que duró seis meses, estaba integrada por Modesto Larrea Jijón, José Rafael Bustamante, Pedro Pablo Garaicoa, Francisco Boloña, Luis N. Dillon, Francisco Arízaga Luque y el general Francisco Gómez de la Torre. La segunda, que duró tres meses, estaba integrada por Julio E. Moreno, Homero Viteri Lafronte, Isidro Ayora, Humberto Albornoz, Adolfo Hidalgo, Nevares, José Antonio Gómez Gault. Posteriormente, en 1926, la Junta Militar acabó con los 
gobiernos plurales, designando a Isidro Ayora, Presidente Provisional de la República, que se convirtió en Presidente Constitucional en 1929. En agosto de 1931, Ayora fue forzado a concluir su mandato, poniéndose fin a esta etapa de gobiernos julianos. Fuente: Juan J. Paz y Miño Cepeda: La fundación del Banco Central del Ecuador y su significado histórico a los 75 años, Taller de Historia Económica, Noviembre 2002- Año II- Número 2, 2002; Juan J. Paz y Miño Cepeda: La Revolución Juliana: Nación, ejército y bancocracia, Abya-Yala, Quito, Ecuador, 2002; Guillermo Arosemena: La Revolución Juliana: Evento ignominioso en la historia de Guayaquil, Archivo Histórico del Guayas, Guayaquil, 2002; Rafael Quintero: El mito del populismo. Análisis de los fundamentales del estado ecuatoriano Moderno (1895-1934), FLACSO, Quito, 1980, p. 242.

Nota 452: A principios del siglo XX, a la vez que se producían levantamientos en el campo se fueron consolidando diversas organizaciones urbanas a partir de los gremios artesanales que existían desde la época de la colonia, bajo la influencia de la Iglesia, y que fueron mantenidos tras la independencia. En este sentido, hemos visto cómo Alfaro apoyó la formación de asociaciones e instituciones de beneficencia que estuvieron orientadas por la ideología liberal y el anarquismo, las cuales con la influencia de las ideas socialistas adquirieron un carácter clasista.

Hacia 1920, fueron surgiendo organizaciones con capacidad de convocatoria como la Confederación de Obreros del Guayas (COG) y más tarde la Federación de Trabajadores Regional Ecuatoriana (FETRE), que fue bastante importante para el movimiento popular en 1922. Más tarde, a partir de 1926, año en que se fundó el Partido Socialista, la mayor parte del movimiento popular estuvo influenciado por su actividad y por el apoyo que sus miembros prestaron a las luchas de los trabajadores de la ciudad y el campo. De este modo, gracias al respaldo de este partido y del Partido Comunista, se empezaron a formar los primeros sindicatos campesinos con una base mayoritaria de indígenas. Fuente: CONAIE: Las nacionalidades indígenas en el Ecuador, Quito, Ecuador, 1988.

Nota 453: En relación a la industria textil, durante un periodo más o menos largo, a partir de la conquista, tanto la Sierra como la Costa permanecieron prácticamente aisladas la una de la otra. Esto planteaba a la Sierra la necesidad de obtener recursos en un medio internacional de pago que le permitiese mantener sus vínculos no solamente con la metrópoli, sino también con los 
mercados de ultramar, a fin de obtener bienes y servicios indispensables. En el caso de Quito y la Sierra, la actividad de minería de oro y plata estaba limitada, lo que llevó a la idea de organizar una actividad que, partiendo de un principio de ventaja comparativa, le permitiese obtener esos recursos. La selección recayó en la industria textil, para la que existían mercados potenciales en otras zonas coloniales y en la propia Sierra. No había ocurrido todavía la Revolución Industrial y era posible explotar los nuevos mercados que se abrían en la colonia a medida que esta incrementaba su población, actividades y poder de compra. La industria textil fue creada en Quito sobre la base de tres elementos de ventaja natural: la producción agrícola en tierras de buena calidad, páramos para la cría de ganado lanar y la abundancia de mano de obra que, a finales del siglo XVIII, se concentraba en la zona centro-norte del país.

A finales del siglo XVIII, la industria textil de la Sierra había declinado debido a los efectos de la Revolución industrial (que colocó a Inglaterra y a Francia a la cabeza de la competencia mundial) y al excesivo proteccionismo y cierre a la competencia externa. Tras la independencia, con el desarrollo de los bancos y el ciclo de prosperidad del cacao, la industria textil de la Sierra logró avanzar desde el punto de vista tecnológico y económico, usando los incentivos creados por el régimen liberal a favor del incipiente desarrollo industrial del país. Fuente: José Corsino Cárdenas: Ensayo histórico de la economía ecuatoriana, Capítulo 2: El ciclo del cacao, Banco Central del Ecuador, Biblioteca de Historia Económica. Volumen VI, Quito, 1995, p. 33-59.

Nota 459: Durante las últimas décadas del siglo XIX, los artesanos reestructuraron sus organizaciones tradicionales, los gremios, siendo su presencia cada vez más activa en la escena pública hasta su consolidación como agente social y político de primer orden en los primeros años del siglo XX. Según Milton Lunas, fueron los artesanos, los que, por el débil desarrollo industrial del país y la casi inexistente presencia de obreros industriales, se apropiaron del concepto obrero en un proceso lento y consistente de formación de su conciencia de clase y de su identidad social. A este respecto, la década de los veinte, vino marcada por la profunda crisis de cacao, la toma obrera de Guayaquil y la masacre de una gran cantidad de artesanos y trabajadores del puerto. Este acontecimiento, que tuvo lugar en 1922, marcó el fin de un periodo de organización, toma de conciencia y afirmación de la identidad de los trabajadores, en el que tuvieron lugar varias acciones organizativas que darían lugar a dos congresos obreros nacionales. Además, los artesanos de la Sierra y de la Costa, inspirados en la Doctrina Social de la Iglesia o en el socialismo, aunaron criterios y empezaron a exponer sus reivindicaciones al estado, entre 
las que figuraban, la reducción de la jornada de trabajo a ocho horas diarias, el descanso dominical, la indemnización por accidentes de trabajo, la limitación de las importaciones, y otras. Fuente: Milton Luna: Trabajo infantil y educación en el primer Código de menores en el Ecuador, 1900-1940, Procesos Revista ecuatoriana de Historia, 28, II semestre, Quito, 2008, p. 3. En el caso de Colombia, de acuerdo con David Sowell, durante el periodo comprendido desde la Independencia hasta la década de 1910, Bogotá fue una ciudad de claro predominio artesanal, pues se trataba de la clase subalterna fundamental del momento en términos demográficos, económicos y culturales. A su vez, estos grupos artesanales fueron los protagonistas de algunos de los acontecimientos más importantes de protesta urbana del siglo XIX, entre los que encuentra la agitación social y política producida entre 1847 y 1854, la insurrección artesanal de 1893 y las movilizaciones que culminaron con las masacres en 1911 y 1919. Cabe destacar que todas estas acciones tenían en común el impacto de disposiciones de tipo económico que afectaban de manera directa las posibilidades de subsistencia material de los artesanos y del pueblo, como era el caso de la adopción del librecambio a mediados de la década del siglo XIX, o las medidas de importación de mercancías extranjeras en 1919. Fuente: David Sowell: Artesanos y política en Bogotá, Trad. Isidro Vanegas, Ediciones Pensamiento Crítico, Editorial Círculo de Lectura Alternativa, Bogotá, 2006.

\section{CAPÍTULO 2}

Nota 471: Este proceso se interrumpe a raíz del término de la Primera Guerra Mundial y del desplazamiento del centro hegemónico de Inglaterra a Estados Unidos y la depresión de los años 1929-1932, a la vez que los países de la periferia ven disminuir sus exportaciones y su poder adquisitivo, hecho que trajo consigo serias restricciones a su crecimiento. Frente a este fenómeno, los países más avanzados del área latinoamericana encontraron una respuesta a la crisis en la activación del proceso de sustitución de importaciones, por lo que algunos países como el Ecuador, tuvieron que hacer frente a estos fenómenos a través de sistemas encaminados a encontrar un equilibrio bajo situaciones de inestabilidad social, económica y política. Solamente en la década de los cuarenta, cuando las economías de "crecimiento hacia afuera" volvieron a encontrar condiciones favorables en el mercado mundial, impulsaron la economía hacia un crecimiento más o menos sostenido que, sin embargo, se caracterizaría por ser fluctuante e inestable. Fuente: Junta Nacional de Planificación: Evolución histórica del comercio 
exterior ecuatoriano 1950-1970, Oficina de Publicaciones, Ecuador, 1975; F. H. Cardosso, E. Faletto: Dependencia y desarrollo en América Latina, Siglo XXI, Editores, México 1972, p. 4-5 y ss.

Nota 487: José María Velasco Ibarra (1893-1979) fue presidente de la República del Ecuador durante 1934-1935, 1944-1947, 1952-1956, 1960-1961 y 1968-1972. De todos estos periodos, únicamente logró terminar su mandato de 1952-1956, ya que en el resto, fue derrocado por diversos golpes de estado dirigidos por militares aliados con distintos grupos de oposición y movilizaciones populares originadas en el campo y en la ciudad.

Durante la crisis económica, agudizada en el Ecuador tras el fin del boom cacaotero y la Gran Depresión, los partidos conservador y liberal fueron incapaces de controlar los nuevos conflictos, que surgieron en los años veinte y treinta. En estas circunstancias, el velasquismo apareció como un movimiento que ofrecía una respuesta a las idas y venidas de la transición capitalista, al tiempo que parecía establecer el orden y las oportunidades de ascenso social a los sectores medios. Su figura de caudillo logró aunar fuerzas, especialmente, sectores populares que los políticos de la aristocracia terrateniente no podían movilizar, llegándose a convertir en el eje de una alianza del latifundismo serrano con sectores terratenientes de la Costa que abandonaron el viejo liberalismo. Así, su primer triunfo en las elecciones de 1933, condujo al nacimiento del denominado velasquismo, uno de los fenómenos políticos más destacados del siglo XX de la política ecuatoriana, al ser considerado como una fórmula caudillista que expresa una alianza oligárquica contradictoria a partir de la necesidad de controlar la movilización de los sectores populares.

Sobre el velasquismo se han elaborado numerosos trabajos, entre los que se encuentran: Agustín Cueva: El proceso de dominación política en el Ecuador, Planeta, Quito, 1997; Rafael Quintero: El mito del populismo en el Ecuador, FLACSO, Quito, 1980; Juan Maiguashca, Lisa North: Orígenes y significado del velasquismo: Lucha de clases y participación política en el Ecuador, en Rafael Quintero (comp.), La cuestión regional y el poder, Corporación Editora Nacional, FLACSO, CERLAC, Quito, 1991.

Nota 495: La figura de Galo Plaza (1906-1987) representa el encuentro de los poderes más influyentes en la política ecuatoriana de principios del siglo XX. Nacido en Nueva York, era hijo de Leónidas Plaza, presidente de la República de Ecuador (1901-1905 y 1912-1916) y promotor 
de las bases de la secularización y el estado, y de Avelina Lasso, descendiente de encomenderos de tiempos de la Conquista e hija de uno de los principales terratenientes conservadores de la Sierra centro-norte del Ecuador.

Galo Plaza fue elegido presidente de la República entre 1948-1952, periodo en el que inició al país en la racionalidad desarrollista, mediante la cual, el estado debía centrarse, a través de políticas planificadas y de largo plazo, en la lucha contra la pobreza, la modernización y el crecimiento económico del país. Fuente: Carlos de la Torre, Mireya Salgado: Galo Plaza y su época, Introducción, FLACSO, Ecuador, 2008, p. 11-26.

Nota 534: La International Basic Economy Corporation o IBEC fue creada por Nelson A. Rockefeller en 1946, con el objetivo de promover el desarrollo económico en los países de América Latina. La idea fundamental de esta compañía tenía como base la combinación de metas filantrópicas en el desarrollo de los sectores básicos de la economía local para obtener una ganancia adecuada sobre la inversión. La búsqueda de un compromiso con la creación de una empresa podría contribuir al desarrollo del país anfitrión en el largo plazo y establecer operaciones que fueran rentables.

IBEC inició sus operaciones en Venezuela y Brasil en los campos de la agricultura, la pesca, las finanzas y la producción industrial. Después de diez años de funcionamiento, IBEC decidió ampliar sus actividades a otros países y, siguiendo su política de empresa, se estableció en otras regiones con problemas económicos. Después de un estudio detallado de la situación del comercio en Europa, estableció una cadena de cinco supermercados en Italia ("Supermercados Italiani”) con una inversión inicial de aproximadamente de 300.000 dólares. Fuente: Emmanuella Scarpellini: Nelson A. Rockefeller's International Basic Economy Corporation and the Introduction of Supermarkets to Italy, Researcher in Contemporary History University of Milan, Italy, 2001.

Nota 559: Según Pablo Aníbal, la gran propiedad en el Ecuador se constituyó con la acumulación resultante de la etapa de recolección y exportación de los productos demandados durante este periodo de tiempo en el mercado internacional. En este caso, la acumulación de capital se produjo gracias a estas actividades y a una mayor concentración de tierra, utilizada en su gran mayoría para el desarrollo ganadero, siendo las principales fuentes de poder, la concentración y explotación de la tierra y la actividad comercial. 
Teniendo en cuenta que la concentración de la tierra actuaba como elemento de poder económico y político, es importante distinguir dentro de la gran propiedad entre la hacienda tradicional y la plantación.

La hacienda tradicional, presente en casi todos los cantones de la provincia de Esmeraldas, estaba dedicada a la producción extensiva de ganadería con baja tecnología, a la vez que suponía una amenaza para los medianos y pequeños propietarios cercanos a dichas propiedades, al verse presionados por la necesidad de la hacienda por extender su dominio.

La gran propiedad tipo plantación llegó a consolidarse en la provincia a partir de la década de los cuarenta, cuando se presenta en Esmeraldas el boom económico de la exportación de banano. Así pues, dicha bonanza fue para los grandes y medianos productores, los cuales pudieron articularse en torno al enclave que formó la Fruit Trading Corporation, que tenía su compañía comercializadora, la Astral, y también con la empresa Estrella Fruit Shipping que demandaba fruta en Nueva Orleans.

Además, dicho enclave bananero creó su propio astillero, donde se fabricaban las embarcaciones necesarias para llevar a cabo sus actividades. Pese a esto, las áreas más fructíferas para el cultivo del banano fueron Esmeraldas, Muisne y Quinindé, siendo en esta última, donde llegó a consolidarse la gran propiedad tipo plantación, pues tras la crisis se introdujo el cultivo de palma africana. Fuente: Pablo Aníbal Minda: La tenencia de la tierra en la provincia de Esmeraldas, en "Identidad y Conflicto: La Lucha por la tierra en la zona norte de la provincia de Esmeraldas", Escuela de Antropología Aplicada, UPS-Quito, Ediciones Abya-Yala, 2002, p. 23-30.

Nota 562: En el Ecuador, a diferencia de los enclaves bananeros centroamericanos, el estado tuvo una importante participación desde el comienzo del auge. El impulso inicial se produjo a partir de un acuerdo establecido entre algunas de las compañías y la administración de Galo Plaza, siendo decisiva la influencia de poderosos empresarios nacionales involucrados en el negocio bananero y en la definición de las políticas estatales en cuanto a la exportación de banano.

Como se dijo con anterioridad, la política estatal se caracterizó por una posición mediadora entre los intereses y demandas de las compañías compradoras y las necesidades de los empresarios del banano. Esto justifica que su participación se orientara en varias direcciones básicas: las inversiones en carreteras, canales de riego, flota de barcos, construcción y adecuación de puertos, apertura de líneas de crédito, creación de organismos oficiales encargados de realizar acciones 
para la mejora de la calidad, el aumento de la productividad y el control de las plagas, y la formulación de organizaciones que regularan la producción y comercialización del producto.

En la ejecución de estas líneas del aparato institucional participó una gran variedad de organismos públicos como el Banco de Fomento, el Ministerio de Fomento, el Ministerio de Obras Públicas y, a partir de 1955, los entes creados para regular la comercialización, fijar precios mínimos, ofrecer asistencia técnica y otras actividades a los agentes ligados a la producción de banano, entre los que se encontraban la Asociación Nacional de Bananeros del Ecuador (ANBE) de 1955 a 1964; la Campaña de Defensa del Banano de 1957 a 1964; la Dirección Nacional del Banano de 1964 a 1971, la cual se convertiría en el Programa Nacional del Banano y Frutas Tropicales de 1971 a 1977 y en el Programa Nacional del Banano de 1977. Algunos de los objetivos y funciones de la Dirección General del Banano consistían en atender los problemas inherentes a la producción, comercialización, exportación e industrialización del banano producido en el país, además de estimular la mejora de la calidad de la producción bananera facilitando su industrialización; fomentar nuevos cultivos en áreas marginales y de producción de otras variedades de acuerdo con las características de las zonas bananeras. Fuente: Instituto Interamericano de Ciencias Agrícolas: La planificación y el desarrollo agrícola e institucional en Ecuador, Dirección Regional para la zona Andina, apartado 478, Lima-Perú, 1969, p. 54; M. Cuvi, Carrión: Oferta tecnológica en la producción de banano en el Ecuador, Quito, FLACSO, 1984. (Mecanografiado); Paola Sylva: Los productos de banano, en: El banano en Ecuador: Transnacionales, modernización y subdesarrollo, FLACSO, volumen 16, 1987.

Nota 581: Relacionado con el fomento agrícola en el Ecuador de los años cincuenta, se han mencionado las obras de infraestructura y los créditos empleados por Galo Plaza para promocionar la producción y exportación del banano. Aquí, es importante destacar que las políticas de desarrollo agrícola en el resto de América Latina, también se caracterizaron por una fuerte intervención estatal que, en el ámbito de la financiación agrícola y rural, se tradujeron en la creación de instituciones financieras de fomento para atender las necesidades de financiación de los productores del campo. En este contexto, se puede afirmar que la necesidad de una estructura crediticia adecuada a los requerimientos del sector agropecuario, ha estado presente en los planes y propuestas de desarrollo, a pesar de que su articulación en el marco de la política agraria global haya sufrido algunos cambios a través del tiempo. 
Esto contribuyó a que el instrumento crediticio se convirtiera en el principal mecanismo de fomento agrícola en numerosos países latinoamericanos en el periodo 1940-1950. En el caso de Colombia, en los primeros estudios (Plan de Fomento Económico de 1940) el crédito fue propuesto como el mecanismo de fomento más importante del gobierno, lo que explica que en 1950, apareciera la idea de ligar la concesión de créditos a la contratación de asistencia técnica. Posteriormente, en 1961, los documentos enfatizaban la necesidad de complementar la política de tierras con un programa de crédito encaminado a garantizar la explotación productiva de las tierras expropiadas.

Por otra parte, el estado en Colombia se caracterizó por estimular financieramente la actividad agropecuaria de tipo moderno, ofreciendo abundantes recursos en condiciones preferenciales a tasas de interés subsidiadas y a plazos generalmente adecuados al tipo de cultivo financiado. Un ejemplo de esto, fue la creación en la década de los cuarenta del Fondo Rotatorio adscrito al Ministerio de Economía con amplias funciones de fomento y promoción de la producción agrícola. Fuente: Astrid Martínez: Planes de desarrollo y política agraria en Colombia: 19401978, Ed. Universidad Nacional de Colombia, 1986.

Nota 582: Entre las movilizaciones campesinas se puede citar la que tuvo lugar en 1954 en Guachalá, antiguo latifundio de la provincia Pichincha, como consecuencia de la demanda salarial por parte de los campesinos que estaban siendo explotados: El conflicto se origina en un reclamo de salario, pues los indios piden que se les pague la suma que corresponde a los tres meses de trabajo adeudado. El jornal diario, que antes se había señalado en 1,50 sucres, se rebaja a solo 1.00 sucre. La resistencia presentada por los terratenientes a la hora de pagar los salarios correspondientes, acabó en un levantamiento que se cobró la vida de varios campesinos, mientras que otros fueron heridos o terminaron en la cárcel.

Tras la masacre de Guachalá, el teniente político de la parroquia de Pungalá (provincia del Chimborazo) y algunos policías atacaron a los indios de la Comuna de San Antonio de Minas, con el objetivo de que los hacendados vecinos pudieran hacerse cargo de las tierras. Esto mismo ocurrió en enero de 1959 en la Comuna Pucará Baja de Velázquez, situada a orillas del lago de San Pablo, cuando los latifundistas decidieron expropiar las tierras de algunos de los miembros de la Comuna para construir un hotel de turismo para los visitantes de la XI Conferencia Interamericana. La respuesta a esto fue la firme protesta por parte de los campesinos, lo que 
acabó en el uso de la fuerza bruta por parte del estado y la muerte de varios comuneros, resultando en más de una veintena herida y otros tantos apresados.

Por último, se encuentra la protesta de la Hacienda El Molino de Guamote en 1960, siendo el tema de disputa, el impago de los salarios y con ello, la huelga de los trabajadores. Ante esta situación, los terratenientes intentaron acabar con el paro de los indígenas utilizando para ello, cualquier medio disponible. Fuente: Oswaldo Albornoz: Las luchas indígenas en el Ecuador, Editorial Claridad, S.A. Guayaquil, Ecuador, 1971, p. 80-85.

Nota 589: El Partido Demócrata Cristiano fue fundado por un grupo de jóvenes católicos, procedentes de la juventud social cristiana. La democracia cristiana ecuatoriana se vinculó a los organismos de coordinación internacional de esa tendencia, identificándose su declaración de principios y plan de gobierno con los postulados que la democracia cristiana internacional había elaborado hasta el momento.

Desde su declaración inicial de principios, la democracia cristiana ecuatoriana estableció el pensamiento "personista comunitario" como el centro de su propuesta política, rechazó el capitalismo individualista como alternativa, y manifestó la necesidad de implantación del socialismo que, a diferencia del socialismo marxista, debía de ser de tipo comunitario y no totalitario.

En definitiva, se planteaba una forma de organización gubernamental que garantizaba otras formas de propiedad diversas a la privada, a la vez que se basaba en la descentralización del poder mediante el establecimiento de un estado integrado por una comunidad de comunidades.

La existencia de una comunidad de comunidades no solo supone el reconocimiento legal de los derechos de sociedades menores dentro de la sociedad global, sino la promoción activa desde el poder central de formas de propiedad intermedia o comunitaria. Además, se propuso la creación de una empresa con gestión propia, la cual era manejada por sus propios trabajadores de acuerdo con la propuesta indicada. Fuente: Enrique Ayala, Rafael Quintero: Teorías e ideologías sobre el estado en Ecuador: 1948-1984, en "El estado en América Latina", Edit. Siglo XXI, 1990, p. 400402.

Nota 599: El gobierno velasquista de 1935 redujo el precio del dólar de 12 sucres a 10,50, medida que acabó con la caída de Velasco ante el rechazo de la Banca de Guayaquil. Luis Carbo (defensor de los intereses de los exportadores) demostró en su exposición al Congreso, que las 
importaciones se incrementaron entre enero y agosto de 1935 y que la balanza arrojó un saldo negativo.

Pablo Cuvi habla sobre la existencia de otros elementos que refuerzan la hipótesis acerca de la existencia de elementos comunes entre exportadores e industriales. Así, Carbo señaló que el desarrollo de las industrias nacionales debía de ser uno de los medios más importantes y convenientes para reducir la importación, junto con la creación de un Plan Económico que destinara la mayor parte del crédito y del dinero en efectivo al estímulo de la producción exportable y a la industria.

Durante sus primeras presidencias, Velasco llegó siempre a situarse en contra de la tendencia histórica del sistema, pues en 1946, por ejemplo, tras haberse declarado dictador con el apoyo de los terratenientes conservadores y cuando la crisis económica era definitiva, estableció una medida de acuerdo con la política del FMI de apertura de las importaciones.

El hecho de tomar el problema del cambio monetario como base para llevar a cabo una diferenciación social de la clase dominante en ese periodo, no responde a una decisión arbitraria, pues el tema de la moneda ocasionó frecuentes conflictos entre las fracciones dominantes. Esto explica que las medidas tomadas en referencia a las importaciones, al crédito público y privado, a la emisión de circulante, etc. giraran en torno a los efectos que tenían en el movimiento de divisas, la depreciación del sucre y la inflación interna. En suma, se puede decir que la política monetaria y cambiaria reflejaba los intereses económicos de los grupos en disputa, hasta la creación del FMI, al transferir el centro de decisión al capital norteamericano. Fuente: Pablo Cuvi: Velasco Ibarra: El último caudillo de la oligarquía, Instituto de Investigaciones Económicas, 1977, p. 230-233.

Nota 600: Carlos Julio Arosemena Monroy nació en Guayaquil el 24 de agosto de 1919. Hijo del ex presidente Carlos Julio Arosemena Tola, fue vicepresidente durante el periodo de gobierno de Velasco Ibarra (1960-1961), pero durante esta administración, ambos mandatarios fueron distanciándose hasta llegar al punto de nunca coincidir en actos oficiales. La tensa relación llegó a su límite cuando el presidente declaró su desacuerdo con un viaje a Rusia por parte de Arosemena, lo que acabó con la ruptura de su relación. El pronunciamiento militar favorable a la sucesión constitucional hizo que Arosemena tomara posesión y se convirtiera en el Presidente Constitucional del Ecuador desde el 9 de noviembre de 1961 hasta el 11 de julio de 1963, momento en que fue derrocado por una Junta Militar de Gobierno. Fuente: Juan J. Paz y Miño 
Cepeda: La economía en los gobiernos de José María Velasco Ibarra (1960-1961) y Carlos Julio Arosemena (1961-1963), Monografías, Archivo Histórico del Taller de Historia Económica, No. 01, PUCE, 2006.

Nota 610: En las circunstancias de la época, el anticomunismo fue uno de los rasgos que caracterizó a la Junta Militar, influida por las estrategias continentales norteamericanas orientadas con una política similar. La dictadura acogió el programa norteamericano "Alianza para el Progreso" e inició las reformas estructurales que proporcionaban al estado un papel activo en la economía. Así, hizo público un Decreto Supremo con el que dictaba la Ley de aranceles, que gravaba con más impuestos a las importaciones de mercaderías, a la vez que esta medida económica tenía como objetivo financiar el presupuesto general estatal, provocando la inmediata reacción de los comerciantes de Guayaquil agrupados en la Cámara de Comercio.

Además, este hecho desencadenó la resistencia de las oligarquías tradicionales y la de los terratenientes heridos con la reforma agraria. En abril de 1965, la reacción del gran comercio de Guayaquil produjo la "guerra del arancel", agudizándose el problema al año siguiente cuando los comerciantes decidieron no pagar impuestos, detener importaciones, no sacar sus mercaderías de la aduana y realizar un paro que coincidió con la agitación generalizada. Posteriormente, en marzo del 1966, cuando se produjo la incursión de fuerzas especiales en la Universidad Central y la indignación general llegó a sus límites, los militares se vieron obligados a dejar el gobierno. Fuente: Carlos Larrea: El sector agro-exportador y su articulación a la economía ecuatoriana entre 1948 y 1972: Subdesarrollo y crecimiento desigual, en Economía política del Ecuador, editado por Louis Lefeber, Quito, Corporación Editora Nacional, CERLAC-FLACSO Series, 1985.

En relación a la Junta Militar, se ha indicar su iniciación el 11 de julio de 1963, cuando los jefes de las tres ramas militares, Ramón Castro Jijón, Luis Cabrera Sevilla y Guillermo Freile Posso, junto con el Senador Funcional por las Fuerzas Armadas, Marcos Gándara Enríquez, destituyeron al presidente del gobierno constitucional Carlos Julio Arosemena Monroy y proclamaron una dictadura bajo el nombre de Junta Militar de Gobierno. Fuente: Efrén Avilés Pino: La Junta Militar de Gobierno, en Enciclopedia del Ecuador, 2012.

Nota 611: Clemente Yerovi asumió el poder el 30 de marzo de 1966, después de la caída de la Junta Militar de 1963, siendo presidente de la República del Ecuador hasta el 16 de noviembre 
de 1966. Su prestigio de hombre progresista y de amplia visión hizo que ocupara importantes cargos públicos y privados en el campo de la industria y la banca. Fue Ministro de Economía durante el gobierno de Galo Plaza Lasso, entre 1948 y 1950, contribuyendo a estimular y orientar la producción bananera hasta convertir al Ecuador en el primer país productor y exportador de banano del mundo. Fue Senador de la República entre 1951 y 1955 y desde el Congreso inspiró leyes orientadas a solucionar los grandes problemas de la economía del país. También, desempeñó el cargo de Presidente de la Junta Monetaria, elaborando una política económica y cambiaria beneficiosa para todos los sectores de la producción. Fuente: Efrén Avilés Pino: Clemente Yerovi, en Enciclopedia del Ecuador, 2012.

Nota 614: La variedad inicialmente sembrada fue la Gros Michel, dominante en la exportación mundial hasta bien entrada la década de los sesenta. Se la denominó así "por ser una variedad que produce racimos gruesos, simétricos, de considerable peso, cuyo promedio se calcula en alrededor de 80 libras, aunque su límite superior llega a 130 y hasta 140 libras. Es un árbol que consiste de un seudo tallo compuesto por fundas o vainas muy compactas, rematado por un penacho de grandes hojas que caen a su alrededor. El tronco tiene una altura promedio de 5 metros y produce un racimo duradero más resistente que otras variedades a la manipulación del manejo y el transporte". Esta cualidad hizo que se mantuviera en el primer lugar del mercado durante muchas décadas, hasta que fue desplazada debido a sus defectos (poca resistencia al mal de Panamá, baja densidad de siembra (menos de mil plantas por hectáreas) y fragilidad ante la acción de fuertes vientos por la altura del tallo).

En 1957, cuando se inició la Campaña en Defensa del Banano por los alarmantes avances de la Sigatoka Amarilla, se organizó el Primer Registro de Productores para facilitar el combate de la plaga. La política de selección rigurosa de barreras a la entrada cobró fuerza e importancia a mediados de los sesenta por los severos reajustes que las ventas externas estancadas y la alta productividad de la nueva variedad Cavendish obligaron a hacer.

Algunas de las características del banano Gros Michel y su diferencia con las variedades Cavendish, han influido en las estructuras económicas del sector exportador mediante su desarrollo histórico. La variedad Gros Michel produce un racimo de bananos grande y bastante duradero y puede resistir mejor que otras variedades el manejo y el transporte. La resistencia de la fruta y el porcentaje relativamente bajo de pérdidas al llegar al mercado son las razones por las 
que dicha variedad de banano fue mantenida durante más de medio siglo. Sin embargo, la planta tenía un defecto muy grande, al ser bastante vulnerable a la enfermedad de Panamá.

Por su parte, el Cavendish es resistente a dicha enfermedad, aunque no tiene tanta durabilidad como la variedad Gros Michel, siendo su fruta parecida pero puede dañarse si se maltrata. Además, el banano Cavendish es muy delicado y no puede ser transportado en racimos, por lo que es necesario empaquetarlo para protegerlo antes de su embarque. Fuente Frank Ellis: Las transnacionales del banano en Centroamérica, Editorial Universitaria Centroamericana, 1983, p. 80-82; J. Cueva: Comercialización del banano ecuatoriano, Quito, AECA, 1964.

Nota 619: En 1954, el gobierno de los Estados Unidos bajo la presidencia de Eisenhower, provocó la caída del gobierno de Guatemala, presidido por Jacobo Arbenz, mediante una acción encubierta organizada por la Agencia Central de Inteligencia (CIA). Arbenz era el sucesor de Juan José Arévalo Bermejo, profesor universitario y exiliado político, electo en 1945, después del derrocamiento de la dictadura del general Jorge Ubico.

Con el ascenso al poder de Arévalo se inauguró una época de reformas que incluían el restablecimiento de la democracia política y la transformación de las condiciones económicas del país a través de la reforma agraria, la legislación laboral y la mejora de las oportunidades educativas, siendo este proceso continuado por Arbenz.

La política socialista llevada a cabo por Arévalo y Arbenz, desafiaba los poderosos intereses de la oligarquía local, la Iglesia Católica y las compañías extranjeras, por lo que diez años después del inicio del programa de reformas, la reacción de los grupos de oposición locales, incluyendo los militares, la United Fruit Company y la administración del presidente Eisenhower, provocaron la caída de Arbenz en 1954.

En agosto de 1953, el presidente Eisenhower aprobó el plan elaborado por la CIA y el Departamento de estado para el derrocamiento de Arbenz y su reemplazo por el Coronel Carlos Castillo a través de una ofensiva diplomática contra su gobierno y de la denominada "Operation Success". Mediante esta operación, el 18 de junio de 1954, el Ejército de Liberación Nacional de Carlos Castillo invadió Guatemala, a la vez que los agentes de la CIA y del Departamento de estado provocaron un levantamiento popular y una gran presión, que finalmente llevó al ejército de Guatemala a forzar la renuncia de Arbenz. Fuente: Hugo Murillo Jiménez: La intervención norteamericana en Guatemala en 1954. Dos interpretaciones recientes, Escuela de Historia y 
Geografía, Universidad de Costa Rica, Anuario de Estudios Centroamericanos, 11 (2), 1985, p. 149-155.

Nota 622: Para comprender la ruptura que representa la Revolución Cubana en cuanto al patrón político y económico entre Cuba y Estados Unidos, es necesario analizar los efectos de estas relaciones en la conformación de un modelo neocolonial para Cuba. En lo económico, contribuyó a la formación en Cuba de una economía, cuya función principal consistía en la producción de azúcar para el mercado dominado por este país. Esto permitía su inserción en el sistema como país mono-productor y mono-exportador de azúcar y como importador de mercancías norteamericanas.

Al encontrarse obstaculizados tanto el desarrollo industrial como la diversificación agrícola, la reproducción del sistema económico cubano dependía del sector externo, que era el punto vulnerable de este proceso. La supeditación de la economía cubana a los intereses norteamericanos se basaba en la inversión directa norteamericana desde finales del siglo XIX.

Así, puede comprobarse que las inversiones de Estados Unidos en Cuba que, en 1896, ascendían a 50 millones de dólares, se elevaron a 160 en 1906, a 205 en 1911 y a 1.200 en 1923, e incluían el control de las tres cuartas partes de la industria azucarera. Fuente: Primer Congreso del Partido Comunista Cubano, Informe Central, La Habana: Editorial Pueblo y Educación, 1978, p.12.

En el año 1958, después de un descenso de las inversiones estadounidenses en los años treinta, la inversión total en Cuba ascendía a un volumen de 1.001 millones de dólares, siendo dicho nivel de inversiones, uno de los mayores de Latinoamérica, ya que significaba el dominio del $42 \%$ de la producción azucarera, el 47,2\% de las tierras dedicadas a este cultivo, el $90 \%$ de los servicios eléctricos y telefónicos, el 50\% de los ferrocarriles y el 23\% de las industrias no azucareras. Otro de los rasgos característicos de esta dependencia, era la alta concentración del comercio exterior dominado por Estados Unidos, pues el $72 \%$ de las exportaciones y el $71 \%$ de las importaciones se concentraban en ese país.

De esta manera, a través de sus inversiones, los tratados impuestos y las leyes comerciales, Estados Unidos logró un control absoluto de la situación económica, política y social cubana, lo cual posibilitó la dificultad para llevar a cabo un desarrollo económico autónomo de corte nacional.

La intromisión norteamericana en los asuntos internos de Cuba llegó a sobrepasar el plano económico, político, social, ideológico y militar como último recurso de control, estableciéndose 
en 1942, nueve acuerdos militares entre Cuba y Estados Unidos durante el primer Gobierno de Batista.

El triunfo de la Revolución Cubana significó la ruptura de la política neocolonial norteamericana hacia Cuba y de los lazos de dependencia, pues se pretendía desarrollar un programa encaminado a la solución de los problemas socio-económicos fundamentales del país, que implicaba abordar la estructura económica y las relaciones de dependencia con Estados Unidos.

Por una parte, era necesario eliminar la estructura agraria latifundista que impedía el desarrollo nacional, por lo que la primera gran transformación en esta etapa, fue la Ley de Reforma Agraria de mayo de 1959. A partir de aquí, la oposición del gobierno de los Estados Unidos a esta ley se hizo sentir a través de una fuerte campaña de prensa que tenía como propósito limitar las ventas y los negocios en Cuba. Entre julio y octubre de 1960, tuvo lugar una serie de nacionalizaciones, en parte como respuesta a la actitud hostil del gobierno norteamericano y frente a la oposición al proceso que las clases propietarias habían asumido, lo cual impidió un proceso negociador de las propiedades nacionalizadas.

A mediados de julio de 1960, la negativa de las empresas petroleras norteamericanas de no enviar más combustible a Cuba y prohibir el uso de sus refinerías para procesar el petróleo soviético, fue seguida de la intervención y posterior nacionalización de estas industrias y por la reducción de las compras de azúcar por parte del gobierno de Estados Unidos, que ordenó rebajar la cuota azucarera cubana y rechazar la compra de 700.000 toneladas ya producidas.

Tres meses más tarde, declaró el embargo parcial sobre Cuba, al prohibir todas las exportaciones a la isla, excepto medicinas y alimentos no subsidiados, mientras que en 1961, acabaría suspendiendo la cuota azucarera, siendo total el bloqueo a Cuba para 1964. Además, el bloqueo económico, comercial y financiero establecía la prohibición de las transacciones comerciales y de operaciones monetario-financieras entre EE.UU. y Cuba y sus nacionales y disponía la congelación de todos los valores propiedad de nacionales cubanos.

Fuente: D. Rich, M. Kaplowitz, Michael: New opportunities for US-Cuban trade, Universidad de John Hopkins, abril, 1992, p. 1; J. Luis Rodríguez, G. Carriazo, George: La erradicación de la pobreza en Cuba, La Habana: Editorial Ciencias Sociales, 1990, p. 3; F. López Segrera: Cuba: Capitalismo dependiente y subdesarrollo (1510-1959), La Habana: Editorial Ciencias Sociales, 1981, pp. 187; José Acosta: Cuba: de la neocolonia a la construcción del socialismo, Economía y Desarrollo, Núm. 19, La Habana, 1973, p. 64; F. López Segrera: Dependencia y subdesarrollo, 
Revista de la Biblioteca Nacional José Martí, septiembre-diciembre 1969, Núm. 3, p. 110; Leo Hubennan, Paul Sweezy: Cuba, anatomía de una revolución, Anuario Azucarero de Cuba 1960, (La Habana: 1961), p. 59.

Nota 623: Con la elección de John Kennedy en noviembre de 1960, la invasión de EEUU a Cuba era inminente, pues su campaña electoral se había centrado en la intervención militar de la isla, al considerarse insuficientes las medidas de nacionalización de empresas impuestas por Eisenhower. Así, el gobierno norteamericano confiaba en que una invasión animaría a una movilización interna que derrocaría a Fidel Castro. Según su cálculo, la contrarrevolución contaba con 2.500 militantes activos en el ejército, 20.000 partidarios en las ciudades y una cuarta parte de la población cubana. Políticamente, la lucha estaba representada por los sectores de la ultraderecha y otros que no habían combatido con Castro, pero que no estaban de acuerdo con el camino que había tomado la revolución.

La invasión empezó durante las primeras horas de la mañana del 15 de abril de 1961, con el vuelo de bombarderos americanos pintados con la bandera cubana para que pareciese un movimiento de carácter interno. Pero, pronto se demostró que los aviones eran realmente americanos, por lo que Kennedy, por el temor a las implicaciones que esto podía tener, suspendió el apoyo aéreo a la invasión.

Dicha invasión fue un fracaso completo y acabó por cimentar el poder y el apoyo popular de los dirigentes guerrilleros y eliminó el capitalismo en la isla. Fuente: Revista el Militante: La Revolución Cubana: Pasado, presente y futuro, noviembre 2004, p. 16-22.

Nota 626: La Conferencia Interamericana de carácter especial y oficialmente denominada de "Mantenimiento de la Paz y la Seguridad del Continente", tuvo lugar en Brasil en el periodo comprendido entre el 15 de agosto y el 2 de septiembre de 1947. Aún cuando sus sesiones se efectuaron en las vecindades de Petrópolis, esta reunión fue clausurada en Río de Janeiro, donde diecinueve repúblicas americanas firmaron el Tratado de Asistencia Recíproca, creándose una alianza defensiva contra las agresiones del exterior.

Durante la Conferencia Interamericana celebrada en Bogotá, Colombia, el 30 de abril de 1948, la Organización de Estados Americanos (OEA) fue fundada por veintiún países latinoamericanos. Esta organización es de la Unión Internacional de las Repúblicas Americanas, fundada en 1890, durante la primera Conferencia Internacional de Estados Americanos y llevada a cabo en 
Washington D.C, Estados Unidos. Los miembros fundadores de la OEA son: Argentina, Bolivia, Brasil, Chile, Colombia, Costa Rica, Cuba, República Dominicana, Ecuador, El Salvador, Guatemala, Haití, Honduras, México, Nicaragua, Panamá, Paraguay, Perú, Estados Unidos, Uruguay y Venezuela. Más tarde, se unieron los siguientes miembros: Antigua y Barbuda (1981), República de Bahamas (1982), Barbados (1967), Belice (1991), Canadá (1989), Dominica (1979), Granada (1975), Guyana (1991), Jamaica (1969), Santa Lucía (1979), San Vicente y las Granadinas (1981), Saint Kitts y Nevis (1984), Surinam (1977) y Trinidad y Tobago (1967). Fuente: Pedro F. Salas: El Tratado Interamericano de Asistencia Recíproca de Río de Janeiro (1947), Editorial Jurídica de Chile, 1962 y Pan American Union: "IX Conferencia Internacional Americana, Bogotá, 1948: Convención Interamericana sobre concesión de los derechos políticos a la mujer", Washington, D.C, Unión Panamericana, 1948.

Nota 632: Camilo Ponce Enríquez fue presidente de la República del Ecuador durante el periodo constitucional de 1956-1960, siendo la primera figura conservadora después de varias décadas de regímenes liberales, socialistas y populistas.

Entre sus logros, se encuentran la realización de numerosas obras públicas como la construcción del Palacio del Congreso, la Cancillería, la Caja del Seguro, las residencias estudiantiles de las universidades Central y Católica, las terminales de los aeropuertos de Quito y de Guayaquil y otras más.

Durante los cuatro años que duró su gobierno, tuvo que afrontar una triple oposición que trató de desestabilizar la paz y la tranquilidad nacional: la del Frente Democrático Nacional que no se resignaba a aceptar que el poder hubiera pasado a la derecha; la del Marxismo Socialista y Comunista, que no cesó en sus actos de agitación; y la del velasquismo, dispuesto a romper la Constitución de la República. Estas tres fuerzas crearon una grave situación de descontento popular que, junto con los crecientes problemas de la economía, acabaron con la derrota de su gobierno, al que le sucedió por cuarta vez Velasco Ibarra en 1960. Fuente: Efrén Avilés: Camilo Ponce Enríquez, en Enciclopedia del Ecuador, 2012.

Nota 649: Entre los movimientos armados en América Latina se encuentran: el Movimiento de Liberación Nacional Tupamaros en Uruguay, que se identificó inicialmente con la Revolución Cubana y actuó como guerrilla urbana de izquierda marxista durante los años sesenta hasta que fue derrotado militarmente y desarticulado en 1972; el movimiento Unidad Revolucionaria 
Nacional, formado por un grupo de dirigentes campesinos y oficiales del ejército en 1960, partidarios de Arbenz, jefe de un gobierno socialista en Guatemala, el cual fue derrocado en 1954 con el apoyo de EEUU; el movimiento de las Fuerzas Armadas Revolucionarias, grupo guerrillero de base marxista-leninista, creado en 1964, que operaba en Colombia y en las regiones fronterizas de Venezuela, Ecuador, Panamá y Perú; y el Frente Sandinista de Liberación Nacional, formado en 1961, tras el ejemplo de la Revolución Cubana. Fuente: Michael Lowry: El pensamiento del Che Guevara, Editorial Siglo XXI, 1985.

Nota 656: La mayoría de los golpes militares latinoamericanos en el siglo XX recibió el apoyo de los gobiernos norteamericanos. Con la aparición de la Doctrina de Seguridad Nacional, la intervención de los Estados Unidos se hizo más agresiva en esta parte del continente como ocurrió con las intervenciones en los golpes militares de Brasil en 1964 y Chile en 1973. En 1969, el informe Rockefeller recomendaba las dictaduras temporales como medida para garantizar la seguridad continental, aplicando la teoría de la "construcción nacional" como ayuda o sustituto para regímenes considerados débiles o no-operativos para contrarrestar el comunismo y consolidar el poder nacional. Todo esto concordaba con las teorías de la ciencia política norteamericana que planteaban que no se trataba de un ataque a la democracia en sí, sino a la "falta de preparación" de las nuevas naciones para el gobierno democrático. Fuente: Jorge Tapia Valdés: La doctrina de la seguridad nacional y el rol político de las fuerzas armadas, en Juan Carlos Rubinstein (comp.), El estado periférico latinoamericano, Buenos Aires, Eudeba, 1988, p. 241.

\section{CAPÍTULO 3}

Nota 663: Las leyes de regulación de la tierra en el Ecuador se resumen a continuación: La Ley de Tierras Baldías y Colonización, dictada el 12 de mayo de 1936, limitaba la extensión de las entregas y contribuía a la colonización basada en la pequeña propiedad como medio para acabar con el latifundio.

El proyecto de colonización en tierras baldías requería la centralización de las políticas estatales y el reconocimiento de iniciativas privadas de colonización de tierras por parte de los organismos públicos. Esta práctica hizo que el gobierno de Velasco Ibarra (1952-1956) promulgara el Decreto $\mathrm{N}^{\circ} 455$ del 3 de marzo de 1954, introduciendo varias disposiciones a la Ley de Tierras 
Baldías y Colonización que permitían impulsar la colonización para mantener las formas precapitalistas de las haciendas de la Sierra.

Posteriormente, durante el gobierno de Camilo Ponce Enríquez (1956-1960) se establece la ley para la creación del Instituto Nacional de Colonización (6 de junio de 1957), con el objetivo de llevar a cabo una colonización de forma más estructurada y que permitiera el desarrollo de la producción y el incremento de la productividad para el avance de la economía ecuatoriana. Fuente: Jorge E. Grijalva, Venus Arévalo, Charles H. Wood: Expansión y trayectorias de la ganadería en la Amazonía, Ecuador, INIPIAP, 2004, p. 19.

Nota 664: En relación al concertaje, se ha de recordar que con la crisis de 1700 y el establecimiento de las reformas borbónicas, se creó un nuevo pacto colonial mediante el cual, se consolidó el latifundio como eje del sistema económico a costa de las propiedades de las comunidades indígenas que fueron tomadas por la fuerza. La necesidad de pagar tributos y de atender los compromisos religiosos, obligó a los indígenas a trabajar más tiempo para los propietarios, hecho que propició el surgimiento de un nuevo tipo de relación: el concertaje. Con esta forma de trabajo, el campesino se comprometía a trabajar en la hacienda a cambio de un salario que, en la mayoría de los casos, se veía obligado a pedirlo por adelantado, quedando por tanto, permanentemente endeudado con el patrono. Fuente: Enrique Ayala Mora: Resumen de Historia del Ecuador, Tercera edición actualizada, Corporación Editora Nacional, Quito, Biblioteca General de Cultura, 2008, p. 19.

También, hemos de recordar que la sembraduría era un sistema de trabajo precario de la Costa ecuatoriana, mediante el cual, el propietario vendía a crédito una parcela al campesino. La sembraduría, junto al peonaje y la redención, incluía la posibilidad de saldar las deudas y el pago de salarios. Fuente: Juan J. Paz, Miño Cepeda: La época cacaotera en Ecuador, Boletín del Taller de Historia Económica, Pontificia Universidad Católica del Ecuador, Facultad de Economía, Quito, no. 3, marzo/abril de 2011, p. 2-3.

Nota 665: Entre los levantamientos que se produjeron, se pueden citar los siguientes:

- En 1927, en la Hacienda Tigua, los levantamientos se produjeron por una lucha por las tierras, el pago de salarios y demandas por malos tratos.

- En 1929, en las comunidades de Columbe y Colta, tuvo lugar un levantamiento indígena porque sus casas fueron quemadas, acabando con la muerte de 3.000 indígenas. 
- En 1931, tuvo lugar el levantamiento indígena en la hacienda Quinua-Corral, propiedad de la Asistencia Pública.

- En 1932, levantamiento de los indígenas de Palmira-Chimborazo, pues sus tierras fueron expropiadas debido al desvío del ferrocarril.

- En 1933, se produjo una lucha por las tierras entre la Asociación Agrícola de Sanancajas y la hacienda Mochapata.

- En 1934, tuvo lugar un enfrentamiento entre la comunidad de Salinas, Provincia de Bolívar y la Iglesia de Guaranda, pues a pesar de la expropiación establecida por la Ley de Beneficiencia con la Revolución Liberal de 1895, para esta época, era otra vez latifundista.

- En 1935, los conflictos tuvieron lugar entre los peones y jornaleros de la hacienda Licto y los terratenientes que contaban con el apoyo de la fuerza pública y pretendían mantener las relaciones pre-capitalistas.

- En 1941, el conflicto volvió a producirse entre el terrateniente Restrepo, dueño de la hacienda Leito y los comuneros que trataban de recuperar las tierras arrebatadas.

Fuente: Oswaldo Albornoz: Las luchas indígenas en el Ecuador, editorial Claridad, 1976, p. 8496.

Nota 667: Entre 1945 y 1950, aparecen los primeros intentos para modernizar el campo por parte de las haciendas estatales y de algunos latifundistas privados que planteaban la generalización del trabajo asalariado, la conversión de las actividades pecuarias y la disminución de las áreas entregadas a los precaristas. Esta situación dio lugar a frecuentes protestas de los campesinos para mantener sus parcelas precarias y sus reclamos como trabajadores agrícolas por la ley. En 1953, los trabajadores de la hacienda Galte (Chimborazo) reclamaron a los hacendados el pago de un salario justo y a tiempo, ya que siempre se les estaba adeudando. En la hacienda "El Molino" del cantón Guamote (Chimborazo), los trabajadores indígenas paralizaron sus tareas y demandaron salarios justos. Ante estas incidencias y otras más, algunos sectores de las élites dominantes pensaron que este malestar de campesinos e indígenas debía ser asumido mediante reformas en el campo. Fuente: Osvaldo Barsky: Iniciativa terrateniente en la reestructuración de las relaciones sociales en la Sierra ecuatoriana: 1959.1964, en Revista Ciencias Sociales, Vol. II-No.5, Quito, 1978. 
Nota 668: En el Ecuador, en la década de los veinte, durante la época de crisis del sistema financiero, se llevaron a cabo importantes transformaciones en el manejo de la economía y del estado, como fue el caso de la creación del Banco Central del Ecuador en 1927 y otros organismos de control. A partir de este momento, el sector comercial e industrial contó con mayores posibilidades de acceso a operaciones crediticias.

No se puede decir lo mismo del sector agropecuario, el cual atravesaba una situación difícil por falta de recursos y de apoyo a sus iniciativas y esfuerzos. En estas circunstancias, el gobierno de Isidro Ayora (1926-1931), mediante Decreto Ejecutivo del 27 de enero de 1928, creó el Banco Hipotecario del Ecuador, que mantuvo su condición de sociedad anónima hasta 1937. Desde entonces, se transformó en una institución privada con finalidad social y pública, autónoma y sujeta a su propia Ley y Estatutos. Posteriormente, se llevaron a cabo sucesivas reformas que fueron cambiando su estructura hasta que, el 14 de octubre de 1943, se expidió la ley que transformó al Banco Hipotecario en el Banco Nacional de Fomento Provincial. Luego, mediante Decreto No. 327 del 28 de marzo de 1974, publicado en el Registro Oficial No. 526 del 3 de abril del mismo año, se expidió una nueva Ley Orgánica del Banco Nacional de Fomento. Fuente: Banco Nacional de Fomento: Historia del Banco Nacional de Fomento, www.bnf.fin.ec.

Nota 673: Emilio Bonifaz, latifundista descendiente de la familia propietaria de la hacienda Guachalá en Cayambe, se convirtió en el portavoz de la Cámara de Agricultura de la Primera Zona, tras reiterar con notable perseverancia sus opiniones sobre la situación del agro serrano. Fuente: Osvaldo Barsky: La reforma agraria ecuatoriana, Corporación Editora Nacional, Biblioteca de Ciencias Sociales, Volumen 3, 1984, p. 106.

Por su parte, Galo Plaza Lasso, presidente del Ecuador durante el periodo 1948-1952, era el hijo del presidente liberal Leónidas Plaza (1901-1905/1912-1916) y de Avelina Lasso, hija de uno de los principales terratenientes conservadores de la Sierra norte del Ecuador. Galo Plaza heredó y administró las numerosas haciendas de la familia, llegando a convertirse en patrón de grandes comunidades de huasipungueros y arrimados en el sistema precarista de producción que imperaba en el campo ecuatoriano. Fuente: Carlos de la Torre, Mireya Salgado, Introducción. Galo Plaza y su época, FLACSO, Fundación Galo Plaza, 2008.

Nota 684: Junto a la gran agitación política a nivel nacional e internacional, el modelo de desarrollo económico, cuyo eje de acumulación era la producción bananera, comenzó a fallar, 
agudizándose las malas condiciones de vida de gran parte de la población. Además, las manifestaciones contra el gobierno conservador de Camilo Ponce, las huelgas estudiantiles y obreras de 1961, que hicieron que Velasco perdiera el control de la situación, la posterior presidencia de Carlos Arosemena Monroy y, finalmente, la Junta Militar de Gobierno de 1963, presidida por Ramón Castro Jijón, con el pretexto de evitar un triunfo de la conspiración comunista, pusieron de manifiesto la crisis del régimen político de la época. A nivel internacional, el triunfo de la Revolución Cubana produjo un decisivo influjo a lo largo del continente: No solo estimuló un excepcional auge revolucionario [...] sino que produjo una profunda conmoción cultural e ideológica en los distintos estados latinoamericanos, y sirvió para despertar a la juventud a fin de que cuestionen su pasado cultural y la condición de países “subdesarrollados". Fuente: Alejandro Moreano: El escritor, la sociedad y el poder, en "La literatura ecuatoriana en los últimos treinta años (1950-1980)”, Quito, El Conejo, 1983, p. 112. En el campo intelectual, la agitación política revolucionaria se constituyó como una lucha interna, surgiendo el ya mencionado tzantzismo. La fuerza de este movimiento vanguardista se caracterizaba por su renovación, que afectaba al conjunto de las relaciones intelectuales. También, la presencia de los tzántzicos significó un cambio en la dinámica interna del campo y en sus relaciones con la sociedad, además de crear las líneas de su enfrentamiento: el concepto de cultura nacional y la narrativa de la nación mestiza, la función del intelectual y su relación con la sociedad, el sentido de la crítica y la interpretación del mundo social.

Sin embargo, la problemática central característica del campo intelectual, el cuerpo de la nación o la nacionalidad ecuatoriana logró permanecer, pero se empezará a hablar de la búsqueda de una auténtica cultura nacional. El nuevo punto de vista se desplaza a la perspectiva que de ella hicieron los sectores "subalternos" de la sociedad ecuatoriana, especialmente de la pequeña burguesía identificada políticamente con los sectores obreros y campesinos. Fuente: Rafael Polo: Los intelectuales y la narrativa de la nación mestiza en el Ecuador en la década de 1950, Universidad Andina Simón Bolívar, 1998.

Nota 685: En relación a las movilizaciones, hay que señalar que en los años cincuenta y principios de los sesenta, algunas organizaciones como la Confederación de Pueblos y Organizaciones Indígenas-Campesinas del Ecuador (FEI), convocaron al campesinado para luchar por la reforma agraria, una mejora en las condiciones de vida y de trabajo y la erradicación de las formas pre-capitalistas de producción de las haciendas. 
De este modo, las movilizaciones campesinas fueron consolidándose en los sesenta, tras el establecimiento de la primera Ley de Reforma Agraria en 1964, a la vez que se fueron creando las federaciones campesinas que comenzaron a organizar a los campesinos y huasipungueros de la Sierra y de la Costa en su lucha por el reparto de las tierras.

En este marco, en 1965, apareció la Federación Ecuatoriana de Trabajadores Agropecuarios (FETAP), que tras una larga lucha para la eliminación del huasipungo y del trabajo precario, consiguió un importante incremento de sus organizaciones afiliadas. En 1968, se creó la Federación Nacional de Organizaciones Campesinas (FENOC), cuyo propósito era lograr un contexto más amplio que permitiera la participación de las organizaciones campesinas. Además, la FENOC orientó la movilización campesina para la reforma agraria, a la vez que se fueron creando federaciones de segundo grado y la estructura organizativa se extendía por el país.

En referencia a las movilizaciones del campesinado arrocero de la Costa, se ha de mencionar la creación de la Asociación de Cooperativas Agropecuarias del Ecuador (ACAE) en 1969, que reunió a 500 cooperativas dedicadas al cultivo de arroz en las provincias de Guayas y Los Ríos y extendió su organización a cooperativas de vivienda y asociaciones de pequeños comerciantes. También, en 1969, se creó la Federación Nacional de Campesinos Libres del Ecuador (FENACLE), como institución de la Confederación Ecuatoriana de Organizaciones Sindicales Libres, cuyo objetivo fue el de reunir a finqueros, arroceros y sembradores de ciclo permanente, aunque años más tarde, la FENACLE diversificó su base social, abarcando otros sectores del campo. Fuente: Agencia Latinoamericana de Información: Movimiento campesino, alainet.org/publica/diversidad/movcampesino.html

Nota 695: El Primer Congreso Nacional de Indios del Ecuador celebrado en la ciudad de Quito, tuvo como objetivo la creación de la Federación Ecuatoriana de Indios (FEI) en 1945. Los fines de la Federación Ecuatoriana de Indios se resumen a continuación: a) Llevar a cabo la emancipación económica de los indios ecuatorianos; b) elevar su nivel cultural y moral, conservando lo bueno de sus costumbres e instituciones; c) contribuir a la realización de la unidad nacional; y, d) establecer vínculos de solidaridad con todos los indios americanos (FEI, 1945:3).

El primer objetivo ponía de manifiesto que la FEI continuaría con la modalidad de lucha de clases de base económica establecidas previamente. Asimismo, algunas de sus demandas y programas posteriores giraron en torno al incremento de salarios, recorte de la semana laboral y 
abolición del trabajo femenino forzado. Muchos de estos objetivos estaban en línea con los de la clase obrera o los sindicatos, siendo una de las acciones más significativas, la consolidación e institucionalización de la lucha indígena. Fuente: M. Becker, S. Tutillo: Historia agraria y social de Cayambe, FLACSO, Abya-Yala, 2009, p. 138-139.

Nota 696: El Tercer Congreso de la Federación Ecuatoriana de Indios tuvo lugar en Quito durante el 16, 17 y 18 de diciembre de 1961, mientras que la gran concentración de la Sierra para exigir la reforma agraria fue celebrada en la capital ecuatoriana el 16 de diciembre en ese mismo año. Mediante estos eventos, se buscaba un aumento de los salarios para los huasipungueros, la construcción de colegios en las áreas rurales, el derecho al voto universal, la eliminación de las cargas feudales y deudas impuestas a los indios, la propiedad gratuita e inmediata de los huasipungos, la nacionalización de las aguas para el riego de los campesinos y la eliminación de las tasas a campesinos, así como la entrega de las tierras que previamente habían sido confiscadas. Fuente: Federación Ecuatoriana de Indios: III Congreso de la Federación Ecuatoriana de Indios y Gran Concentración de la Sierra para exigir la Reforma Agraria Radical y Democrática, e-archivo ecuatoriano, www.yachana.org/earchivo/fei/, en: El Comité Ejecutivo Nacional, La Comisión Nacional Campesina de la CTE, "III Congreso de la Federación Ecuatoriana de Indios y Gran Concentración de la Sierra para exigir la Reforma Agraria Radical y Democrática," Mañana 2, no. 96 (December 7, 1961).

Nota 702: Alfredo Pérez Guerrero ejerció como profesor en el Instituto Nacional Mejía y como profesor y decano de la Facultad de Jurisprudencia de la Universidad Central, de la que también fue rector en tres ocasiones. Su labor abarcó el campo de la política como miembro del Partido Socialista, además de ser Ministro de Previsión Social y de Trabajo (1947-1948), Senador por la Educación Pública (1951 y 1958), Diputado al Congreso (1962) y varias veces Concejal del Ilustre Municipio de Quito. Entre las obras que se han escrito sobre Alfredo Pérez Guerrero figuran:

- Gil Vela: Perfil de Alfredo Pérez Guerrero, Editorial Universitaria, 1967.

- Carlos Pérez Patiño: La aventura de su espíritu: Biografía de Alfredo Pérez Guerrero, Casa de la Cultura Ecuatoriana, Benjamín Carrión, 2001.

- A la memoria de Alfredo Pérez Guerrero, CCE Benjamín Carrión, 2003. 
- Patricio Viteri Paredes, Patricio Herrera Crespo: Ideario Alfredo Pérez Guerrero (19011966), Quito, UNAO, 2007.

Fuente: Efrén Avilés: www.enciclopediadelecuador.com, miembro de la Academia Nacional de Historia del Ecuador, 2012.

Nota 704: Las relaciones feudales existentes en las haciendas tradicionales causaron frecuentes movimientos reivindicativos entre 1958 y 1963 contra los abusos de los terratenientes. Osvaldo Albornoz muestra las luchas campesinas que tuvieron lugar en estos años e indica algunas de las razones como la retención de los salarios a los huasipungueros, la defensa de tierras y de huasipungos, una reducción de las tareas y horas de trabajo, eliminación de trabajos gratuitos, asignación de herramientas y erradicación de los malos tratos. Fuente: Oswaldo Albornoz: Las luchas indígenas en el Ecuador, Guayaquil, Editorial Claridad, 1971, pp. 117-123.

Por su parte, en relación al aumento de los salarios el diario El Comercio establecía: Se han solucionado tres conflictos colectivos en las haciendas de la Asistencia Social: San Vicente de Pusir, Yascón y Turnbatur en la provincia del Carchi. Aumento de salarios obtenidos: SI. 4 diarios a huasipungueros y SI. 6,50 a jornaleros. Pago de vacaciones, pago de horas extras y suplementarias con recargo del 500/0 y 1000/0, jubilación para los trabajadores, mejoramiento de los huasipunqos, etc.: Fuente: Diario El Comercio, 10 de diciembre de 1960.

Nota 752: En el año 1953, un grupo de ganaderos liderados por Galo Plaza, creó la Asociación Nacional de Criadores de Ovejas (ANCO) como una institución privada sin fines de lucro (Acuerdo Ministerial No. 142, 27 de abril de 1953). Dicha organización tenía un fondo destinado a la adquisición de implementos, medicamentos para la industria ovejera, que se vendían a los agricultores a bajo costo. Fuente: Miguel Murmis, Jose Bengoa, Osvaldo Barsky: Terratenientes y Desarrollo Capitalista en el Agro, ediciones CEPLAES, 1982.

También, Barsky hace referencia a esta asociación e indica que los Plaza impulsaron su creación para que la calidad de la lana fuese mejor, siendo el objetivo fundamental, la importación de animales de pedigrí, ya que estos poseían lana de calidad superior a la del ganado de la Sierra. Esto fue posible gracias a la financiación nacional e internacional, a la que tuvieron acceso los Plaza y otros ganaderos de ANCO, mediante la cual, llevaron a cabo operaciones de embarque de ovejas a cargo del Banco de Fomento. Fuente: O. Barsky: La Reforma agraria ecuatoriana, 
FLACSO, Biblioteca de Ciencias Sociales, volumen 3, Corporación Editora Nacional, 1984, p. 100.

Nota 773: El concepto de eslabonamiento productivo se refiere al conjunto de fuerzas que generan inversiones y se accionan cuando la capacidad productiva de los sectores es insuficiente o inexistente. La presencia de eslabonamientos se asocia con las relaciones tecno-productivas, cuya importancia económica radica en sus efectos positivos sobre la capacidad para estimular la inversión, el crecimiento y el fortalecimiento productivo. Según Hirschman, los eslabonamientos hacia delante aparecen cuando una rama produce bienes y servicios que serán utilizados por otras ramas como inputs intermedios. Fuente: A. Hirschman: Enfoque generalizado del desarrollo por medio de enlaces, con referencia especial a los productos básicos, en El Trimestre económico, número 173, México, enero-marzo, 1977.

Nota 780: En los países andinos existen diferencias notables en cuanto al nivel altitud de las diferentes regiones, variando la elevación de las zonas en producción de los 2.000 a 5.000 metros sobre el nivel del mar. Esto es lo que determina los distintos pisos ecológicos, cultivos y especies animales de crianza. Un ejemplo de esto, se encuentra en el Ecuador y el norte del Perú, en los que la ganadería suele ser bovina y la producción de leche es fundamental, a diferencia de la región del sur peruana, que se caracteriza por la existencia de alpacas (mamíferos parecidos a las llamas empleados en la industria textil), mientras que en varias zonas de Bolivia hay ganado ovino y llamas.

Las regiones alto-andinas están formadas por tres ecosistemas (los valles interandinos, las zonas altas de pastizales y las punas) y las precipitaciones suelen ser escasas y concentradas en periodos reducidos de tiempo. Como consecuencia de las condiciones de altura y baja precipitación, la mayor parte de la región suele caracterizarse por heladas y granizadas, lo cual limita el tipo de cultivos y favorece los pastos naturales de altura.

En el piso andino más bajo suele haber cultivos de alfalfa y se caracteriza por la lechería, siendo la leche fresca vendida a las plantas industriales o centros de consumo. En las áreas de pastizales, la lechería no tiene tanta importancia y se crían ovejas para la producción de lana y carne y ganado ovino para la producción de queso y otras actividades. Fuente: CONDESAN Problemática en zonas ganaderas alto andinas, p. 2-3, en Instrumentación de políticas con influencia en la ganadería y la pobreza en zonas alto andina en Perú, Ecuador y Bolivia. 
Análisis de las condiciones en Ecuador, Pablo López Buitrón, apéndice I del Informe final del proyecto Andean Hub of the pro-poor livestock policy initiative, PR number 24333, 23 de febrero 2003.

Nota 806: Arcos y Marchán explican que la temprana eliminación de relaciones pre-capitalistas por iniciativa terrateniente generó un aumento del minifundio en la mayor parte de las cuencas lecheras. La zona de Guaytacama, pionera en la transformación de la hacienda en empresa ganadera, representa un ejemplo de ello. Estos autores indican que las pequeñas propiedades que conforman las áreas de minifundio... se originaron en el proceso de transformación de las haciendas en empresas ganaderas. Fuente: Carlos Arcos, Carlos Marchán: Guaytama y Cusubamba: dos modalidades de desarrollo de la agricultura serrana, Revista Ciencias Sociales, Quito, UCE, Vol. II, 5, 1978, p. 26.

Esta transformación ocurrió en la década de los veinte y fue ocasionada por la necesidad de los terratenientes de garantizar una reserva estable de fuerza de trabajo. Otro proceso similar fue el de la parroquia de Cutuglahua (de 3.514 hectáreas), en el cantón Mejía de la provincia de Pichincha, en donde el pasaje de la hacienda a la producción lechera en los años sesenta, provocó una aguda situación de los minifundios campesinos. Así, para 1974, el 76.1\% de las UPAS entre 1 y 5 hectáreas poseían el $0,7 \%$ de la superficie agrícola de la parroquia, mientras que apenas ocho haciendas $(9,1 \%$ de las UPAS) abarcaban una superficie de 3.110 hectáreas correspondientes al 80,26\% de la tierra. El crecimiento de la gran propiedad a expensas del campesino, se puso de manifiesto en la entrega de tierras, pues los precaristas no huasipungueros (como los arrendatarios) fueron despojados de sus tierras, mientras que en otros casos, se negó el derecho al acceso de la tierra de algunos husipungueros o estos recibieron menos tierra de la que poseían con anterioridad. Fuente: Rafael Quintero, Erika Silva: Ecuador: Una nación en ciernes, Tomo III, FLACSO, Abya-Yala, 1991, p. 202; Carlos Arcos, Carlos Marchán: Guaytama y Cusubamba: dos modalidades de desarrollo de la agricultura serrana, Revista Ciencias Sociales, Quito, UCE, Vol. II, 5, 1978, p. 13-51.

Nota 819: En el caso del partido de izquierdas del Ecuador, se produjo una confrontación de tipo ideológica entre 1960 y 1961, quedando establecidas dos líneas socialistas en dicha ruptura: el Partido Socialista Ecuatoriano (PSE) y el Partido Socialista Revolucionario Ecuatoriano (PSRE), el cual definió su deseo de tomar el poder a partir de la represión ejercida por las fuerzas de 
seguridad del estado, que asesinaron a algunos militantes del PSRE. Por su parte, en el Partido Comunista se produjo también una lucha ideológica que fue en aumento, hasta el punto en que militantes de este partido y del PSRE ensayaron un proyecto guerrillero (las guerrillas del Toachi) que acabó fracasando en 1961, tras haber sido detectado por la Agencia de Inteligencia Central de Estados Unidos (CIA).

El tema de las guerrillas provocó un distanciamiento político en el Partido Comunista, al ser detenidos algunos de los participantes del Toachi, ya que habían transgredido la línea política oficial del partido. Así, en 1960 dos agentes (Mario Cárdenas y Luis Vargas) se infiltraron en el Partido Comunista para poder controlar a Rafael Echevarría, dirigente comunista (y uno de los encargados de iniciar la Guerrilla del Toachi) e informar a la CIA de sus actividades políticas. Algo parecido ocurrió con el PSE, cuando un agente de la CIA, Manuel Naranjo Toro, llegó a ser el secretario general del dicho partido. Fuente: Germán Rodas Chaves: La izquierda ecuatoriana. Aproximación histórica, segunda edición, Edic. Abya-Yala, 2000, p. 73-74.

Nota 832: Aquí, es importante recordar la trayectoria política ecuatoriana y su estructura básica, en cuanto al establecimiento de un estado liberal o sistema de representación y participación basado en un proceso de ciudadanía. Los problemas de la economía, su extrema dependencia de las exportaciones de productos agrícolas, la división social y geográfica, así como las luchas por el poder político, son algunos de los factores que explican la falta de organización de una clase política con capacidad para modernizar el país. En este contexto, las clases progresistas utilizaron formas de mediación como las fuerzas armadas, los militares y el populismo para imponer su liderazgo.

La crisis del banano y la implantación de la estrategia norteamericana "Alianza para el Progreso" como respuesta a la misma, marcarán una época caracterizada por la consolidación de las dictaduras militares desarrollistas en el Ecuador y en el resto de los países latinoamericanos. Con este programa, se pretendía impulsar el crecimiento del mercado interno mediante la reforma agraria y el establecimiento del primer Plan decenal de desarrollo (1964-1973) como mecanismo para fomentar la industria y distribuir los recursos entre los sectores productivos.

Fuente: Bertha García Gallegos: Ecuador: Democratización y Fuerzas Armadas: El contexto histórico, social y político de una relación ambivalente, en "La Administración de la defensa en América Latina. Análisis nacionales", Instituto Universitario General Gutiérrez Mellado-UNED, 2008, p. 1-2. 
Nota 853: Ya se ha hablado de cómo en este periodo, fueron apareciendo movimientos campesinos que lograron consolidarse tras la promulgación de la Ley de Reforma Agraria de 1964. Así, en 1965, surgió la Federación Ecuatoriana de Trabajadores Agropecuarios y, en 1968, la Federación Nacional de Organizaciones Campesinas (FENOC), con el objetivo de que el sector campesino tuviera un ámbito de participación más amplio. A estas organizaciones se les unieron la Federación Nacional de Campesinos Libres del Ecuador (FENACLE) y la Asociación de Cooperativas Agropecuarias del Ecuador (ACAE), cuyas reivindicaciones giraron en torno al reparto de la tierra y reconocimiento de su identidad, tradiciones y lengua.

El fracaso de la dictadura militar a la hora de abordar los problemas socio-económicos ecuatorianos, como fue el caso de la reforma agraria y la eliminación de los huasipungos, permitió reforzar las organizaciones indígenas, como la Federación Ecuatoriana, cuyo papel fue en aumento durante esta época, llegando a provocar una serie de protestas que acabaron con la retirada del poder de la Junta Militar. Fuente: Ramón Galo: Indios, crisis y proyecto popular alternativo, Centro Andino de Acción Popular, Quito, 1988.

- La Confederación de Trabajadores del Ecuador (CTE) comenzó su actividad sindical y de lucha organizada en el año 1926, con la conformación de los primeros sindicatos agrarios en el litoral ecuatoriano, siendo legalmente reconocida por el Ministerio de Previsión Social y Trabajo el 9 de julio de 1944. Desde su fundación, la CTE se ha venido caracterizando por la unidad sindical desde una orientación política y clasista y por el fortalecimiento y ampliación de la unidad de todos los trabajadores del campo y la ciudad. Fuente: www.cte-ecuador.org

- La Confederación Ecuatoriana de Obreros Católicos (CEDOC), actualmente denominada Central Ecuatoriana de Organizaciones Clasistas o CEDOC-CLAT, fue fundada en la ciudad de Quito por un Congreso de Sociedades, Mutualidades, Corporaciones y Centros Culturales de Artesanos y Obreros, entre el 28 de septiembre y el 2 de octubre de 1938. Sus principios y valores, inspirados en el humanismo integral, consisten en la implementación de cambios dirigidos a la construcción de una sociedad humanista y solidaria en el marco de una democracia participativa y responsable. Fuente: www.cedoc-clat.org.

- Clemente Yerovi fue designado como presidente interino del Ecuador el 30 de marzo de 1966, tras una reunión mantenida en Quito, en la que algunos de los ciudadanos con más influencia, destacados militares y representantes de los partidos políticos, acordaron llamarlo para que asumiera el poder y condujera al país hacia la constitucionalidad. Durante su corto gobierno 
(acabó el 16 de noviembre de 1966), su labor se centró en la realización de numerosas obras públicas y educativas, entre las que se destacan, la construcción de treinta colegios y la remodelación de diversas carreteras y puentes. Fuente: www.enciclopediadelecuador.com.

\section{CAPÍTULO 4}

Nota 873: La Federación Ecuatoriana de Indios (FEI) fue creada en 1944, durante el Primer Congreso Nacional de Indios del Ecuador. Esta organización nacional fue el primer intento político con éxito, que surgió de los esfuerzos de sindicatos y partidos políticos de izquierda en su lucha de representación y defensa de los indígenas. Entre los objetivos de la FEI se destacan la emancipación económica de los indios ecuatorianos, el aumento de su nivel cultural y mantenimiento de sus costumbres e instituciones; y la creación de vínculos de solidaridad con otros indios americanos. Fuente: Marc Becker, Silvia Tutillo: Historia agraria y social de Cayambe, FLACSO, Abya-Yala, 2009, p. 132-133.

Nota 874: Rafael Quintero y Erika Silva dicen que aún cuando el movimiento campesino en el Ecuador no tuvo gran fuerza, no puede olvidarse su incidencia en la sociedad y a nivel de estado. Fuente: Rafael Quintero, Erika Silva: Ecuador: Una nación en ciernes, Tomo II, Abya-Yala, FLACSO, 1991.

Si se comparan estos movimientos campesinos con los de otras naciones, como es el caso de México, se ha de hacer referencia a los que surgieron a finales de la segunda década del siglo XX, cuando el líder del Partido Socialista del Sudeste, Carrillo Puerto, estableció una reforma agraria y ofrecía a los peones de la hacienda y semi-esclavos un desarrollo del agro con base en el maíz, eliminando con ello, su dependencia alimenticia de la hacienda. A partir de los años cuarenta, los pueblos autóctonos vinculados al indigenismo buscaron defender sus necesidades políticas, económicas y sociales con la ayuda del Instituto Nacional Indigenista (INI) y aunque su lucha se caracterizó por su lentitud, logró adquirir un sentido más profundo. Así, los conflictos políticos y económicos y sus efectos recesivos fueron movilizando a los campesinos y obreros como resultado de las contradicciones estructurales generadas por un crecimiento fuertemente concentrado y monopolizado en los sectores de la economía.

En el sector agrario, dicho crecimiento se produjo por la aplicación de políticas agrarias que consolidaron una estructura bastante polarizada y diferenciada en su composición de clase y que vinculaba el desarrollo agrario del país a las necesidades de crecimiento industrial. En este 
sentido, los problemas de reparto de propiedades y la lucha campesina por la tierra provocaron el surgimiento de importantes organizaciones campesinas en todo el país en el periodo 1940-1970. Por su parte, el factor político que permitió el avance del modelo de desarrollo agrario sin numerosos conflictos, fue el control ejercido por la Confederación Nacional Campesina (CNC) sobre los sectores campesinos del país.

A pesar de esto, a finales de los años cuarenta, a raíz de la contrarreforma agraria llevada a cabo por el gobierno de Manuel Ávila Camacho (1940-1946) y la adhesión por parte de esta organización a las políticas gubernamentales, tuvo lugar una división importante entre sus miembros. Así, en 1948, dicho sector pasó a ser parte de la recién creada Alianza de Obreros y Campesinos (AOC), la cual se unió posteriormente con la Central Única de Trabajadores (CUT), dando lugar a la creación de la Unión General de Obreros y Campesinos de México (UGOCM). Esta organización se constituyó como una alternativa de representación de obreros y campesinos que querían reunirse independientemente de los grandes centros de obreros y campesinos.

También, dentro de las reivindicaciones de campesinos, se puede hablar del movimiento “jaramillista" de la década de los cincuenta, que reflejaba los problemas presentados a la CNC para establecer el control sobre el conjunto del sector campesino. Este movimiento fue iniciado en los años cuarenta por Rubén Jaramillo, militar y político que participó en la Revolución Mexicana de 1910, para conseguir un mejor salario para los campesinos.

Posteriormente, en 1961, el Movimiento de Liberación Nacional con la ayuda de la Central Campesina Independiente (CCI), creada en 1963, logró concentrar a una gran cantidad de trabajadores del campo representados por dos mil delegados en su lucha por sus derechos y un reparto equitativo de la tierra. Fuente: Graciela Flores, Luisa Paré, Sergio Sarmiento: Las voces del campo: Movimiento campesino y política agraria, 1976-1984, Instituto de Investigaciones Sociales, UNAM, Siglo Veintiuno editores, 1988, p. 30-34; y A. Bartra, G. Otero: Movimientos indígenas campesinos en México: La lucha por la tierra, la autonomía y la democracia, en "Publicación: Recuperando la tierra, El resurgimiento de movimientos rurales en África, Asia y América Latina", Sam Moyo y Paris Yeros (coord.) Buenos Aires: CLACSO, Consejo Latinoamericano de Ciencias Sociales, 2008.

Nota 877: El Instituto Ecuatoriano de Reforma Agraria y Colonización (IERAC) era un organismo autónomo con personería jurídica de Derecho Público, perteneciente al Ministerio de Agricultura y Ganadería e integrado por tierras baldías, predios de la Asistencia Social y diversas 
asignaciones recibidas. La trayectoria del IERAC ha sido caracterizada por su inestabilidad, pues hasta 1978, hubo 13 directores ejecutivos (prácticamente uno por año), cada uno de los cuales hizo su propia reestructuración (Cf. Evaluación de Reforma Agraria, MAG, segunda parte A, 88). Fuente: Osvaldo Barsky, Gustavo Cosse: Tecnología y cambio social. Las haciendas lecheras del Ecuador, FLACSO, 1981.

Nota 878: El IERAC desapareció en 1994, creándose en ese mismo año, el Instituto Nacional de Desarrollo Agrario (INDA) mediante la Ley de Desarrollo Agrario de 1994. Entre los objetivos del INDA, se puede citar la promoción del desarrollo del sector agrario, la implantación de programas de capacitación para pequeños agricultores y comunidades indígenas y el aumento de la exportación de excedentes. Fuente: Patricio Martínez Jaime: Ecuador en la OMC. Hacia una política de apoyo a la competitividad a la competitividad agropecuaria, Oficina del IICA en Ecuador, 1995.

Nota 886: Recordemos que la colonización en el Ecuador presentaba varias etapas: La primera, que se corresponde con la expansión colonizadora en torno a la producción de cacao a mediados del siglo XIX. La segunda etapa, que se produce con la disolución de las haciendas cacaoteras con la crisis y el desarrollo de la producción de arroz en base a las relaciones precarias. La tercera etapa, que se reinicia con el flujo colonizador ligado a la producción bananera en la década de los cuarenta. Por último, la cuarta etapa, que comenzó en los años cuarenta y abarcaba las áreas correspondientes al Oriente y ciertas zonas tropicales y del litoral ubicadas entre el Pacífico y la cordillera occidental. El régimen de colonización que se acelera a partir de 1964, fue el predominante hasta mediados de los años ochenta y se concentró en la Sierra, Costa y Oriente como política alternativa frente a la Reforma Agraria por las Cámaras de Agricultura y los partidos de la burocracia desde finales de los cincuenta. Fuente: O. Barsky et al: Políticas agrarias, colonización y desarrollo rural en el Ecuador, Quito, OEA-CEPLAE, 1982, p. 63-65.

Nota 890: En referencia al programa industrial de la Junta Militar, hay que destacar que durante esta época de industrialización en América Latina, las desventajas de la agricultura se fueron haciendo más notorias, en tanto que la producción agrícola era incapaz de mantener el ritmo de crecimiento de las necesidades de la industria. Así, mientras la presión sobre la agricultura aumentaba, las políticas gubernamentales favorecían a la industria a costa de la agricultura, 
negándole a esta última, los recursos necesarios para su modernización. Esto explica el surgimiento de peticiones para efectuar reformas agrarias durante los años cincuenta y sesenta. Además, los gobiernos de América Latina vieron la reforma agraria como un medio de extender el mercado interno para la industria nacional, dándole vigor debido a los efectos de distribución de los ingresos a favor de los campesinos beneficiarios. Asimismo, esperaban que la producción total de alimentos aumentara, evitando de esta forma, el incremento de sus precios y la presión de los trabajadores industriales por salarios más altos. El incremento de la producción de alimentos podría contribuir al mantenimiento del control de las importaciones agrícolas, liberando las escasas divisas para las importaciones esenciales requeridas por la industria nacional.

En el Ecuador, a diferencia de otros países en América Latina, el modelo de industrialización cobró mayor auge en la década de los sesenta gracias a los ingresos procedentes del petróleo, como veremos en el capítulo siguiente. Por su parte, los bajos resultados obtenidos con la primera reforma agraria, junto con la potenciación socio-organizativa en las zonas rurales, llevaron a que la presión por una segunda reforma agraria fuera en aumento. La aplicación de esta segunda reforma en el año 1973, tuvo una fuerte influencia de la ideología desarrollista de la CEPAL, que seguía enmarcada en una concepción modernizante y veía la industrialización como única vía para el desarrollo. Fuente: Cristóbal Kay: Reforma agraria, industrialización y desarrollo: ¿Por qué Asia Oriental superó a América Latina?, Debate agrario: análisis y alternativas; publicación trimestral del Centro Peruano de Estudios Sociales, Lima, 2002, p. 4594.

Nota 891: El Partido Comunista (PC) surgió tras la separación de algunos de los militantes del Partido Socialista en el año 1927. Algunos de los planteamientos de este partido se basaban en una mejora de la incorporación de las ideas del Marxismo-Leninismo, en la promoción de la clase obrera y en la reivindicación de tipo político y económico para lograr una influencia en el sector popular. Fuente: Lazar Jeifets, Víctor Jeifets: Los orígenes del Partido Comunista del Ecuador y la Tercera Internacional, Revista Izquierdas, año 3, número 6, 2010

- La Confederación de Trabajadores del Ecuador (CTE) fue creada en 1944, momento en que la agitación social revolucionaria puso fin al gobierno de Arroyo del Río (1940-1944). Esta organización reunió a grupos de maestros, artesanos, estudiantes, campesinos, comités de empresa y sindicatos que habían ido surgiendo desde la expedición del Código de Trabajo en 
1938. Los objetivos de la CTE se basaban en la mejora económica y social de los trabajadores y en la defensa de sus derechos de clase (derecho de huelga, reducción de la jornada de trabajo, etc.). Fuente: América Latina en movimiento: Movimiento sindical, La Riqueza de la Diversidad, alainet.org/publica/diversidad/sindicalismo.html.

- Carlos Arroyo del Río fue presidente de la República del Ecuador durante el periodo 19401944. A pesar de que su gobierno es conocido por la firma del controvertido Protocolo de Río de Janeiro en 1942, tras la invasión peruana de 1941, y los continuos problemas territoriales con este país, también se llevó a cabo la reforma de la Ley del Seguro Social, a la vez que redujo el déficit presupuestario y se intentó solucionar los problemas económicos.

Asimismo, se impulsó la educación pública con la creación de colegios nacionales como Aguirre Abad de Guayaquil y el Nacional de Señoritas de Riobamba; se aportó dinero a los talleres de la Escuela Central Técnica de Quito, se crearon más de treinta establecimientos de educación primaria en diferentes lugares del país y la Universidad de Loja, además de destinar la cifra de 1.500.000 sucres para la construcción de escuelas rurales.

También, durante la presidencia de Arroyo del Río se construyeron puentes y caminos y se fomentó el servicio radiofónico internacional, a la vez que se creó en 1943, el Banco Nacional de Fomento para contribuir al desarrollo económico del país, sobre todo en el campo de la industria y la agricultura. Fuente: Efrén Avilés: Dr. Carlos Alberto Arroyo del Río, Enciclopedia del Ecuador, www.enciclopediadelecuador.com, 2012.

Nota 895: Los propósitos establecidos en la Ley de Reforma Agraria de 1964 se resumen a continuación:

1. Promover un cambio adecuado en la estructura de la tenencia y utilización de la tierra;

2. Asegurar la justa distribución de los ingresos generados en el sector agropecuario entre los factores de producción;

3. Garantizar los derechos del trabajador agrícola;

4. Estimular el uso productivo de la tierra y eliminar las formas antieconómicas de explotación;

5. Garantizar el libre desenvolvimiento de las actividades del productor agrícola y su derecho de asistencia técnica, social y crediticia por parte de las entidades de derecho público y privado;

6. Incorporar las tierras baldías a la producción agropecuaria;

7. Promover la mejor utilización de las tierras en poder de la Asistencia Social y de otros organismos de derecho público o privado con finalidad social; 
8. Estimular la tecnificación de la agricultura;

9. Asegurar la conservación, recuperación y defensa de los recursos naturales;

10. Evitar el acaparamiento de la tierra.

Para la mejora de las condiciones del campesino y del trabajador agrícola la ley establecía:

1. La abolición de modalidades defectuosas de tenencia y trabajo de la tierra como el huasipungo, la yanapa o ayuda, el arrimado, el finquero, y otras similares.

2. La progresiva eliminación de sistemas absentistas de explotación como el arrendamiento, la aparcería y otras similares; y su sustitución por formas directas y modernas de explotación como empresas y cooperativas agropecuarias;

3. La elevación del nivel de vida del trabajador agrícola que carece de tierra y del campesinado mediante el acceso a la propiedad de la tierra, el establecimiento de un salario mínimo adecuado, la participación en las utilidades de la empresa agrícola, la asistencia técnica y su incorporación a la Seguridad Social.

Fuente: Marco Jaramillo Pavón: La economía campesina y la reforma agraria en el Ecuador, en Economía/Ecuador: 1830-1980, Libro del Sesquicentenario, Tomo III, Corporación Editora Nacional, 1983, p. 159-185.

Nota 903: La Ley de Reforma Agraria de 1964 dinamizó las exigencias de lucha por la tierra, lo que dio lugar al nacimiento de nuevas organizaciones como la Federación Nacional de Organizaciones Campesinas (FENOC). Esta organización, creada en el año 1968, con el objetivo de lograr un espacio de participación más amplio de las organizaciones campesinas, canalizó la movilización campesina por la reforma agraria; conformándose federaciones de segundo grado y extendiéndose la estructura organizativa en una parte considerable del país. Fuente: Agencia Latinoamericana de Información: Movimiento campesino, alainet.org; J.F. Uggen: Peasant Mobilization in Ecuador: A Case Study of the Guayas Province, Tesis doctoral, Universidad de Miami, 1975, p. 204.

En cuanto a la formación de cooperativas, el artículo 5 (apartado g) de la Ley de Reforma Agraria establecía lo siguiente: Promover la formación de cooperativas y otras organizaciones, especialmente aquellas que estimulen la mejor utilización de la tierra y de su producción y que faciliten la acción crediticia y asistencia técnica del estado.

Asimismo, pretendía incorporar a la producción las tierras baldías, garantizar derechos del trabajador agrícola, estimular la tecnificación del agro (artículo 4) y la progresiva eliminación 
de sistemas absentistas de explotación como el arrendamiento y la aparcería y su sustitución por formas directas y modernas de explotación, como empresas y cooperativas agropecuarias (artículo 5, apartado b).

La Ley propuso dos casos en los cuales, las tierras eran afectables: el primero estaba comprendido en el artículo 28, y establecía:

a) Las tierras que no son aprovechadas por ninguna explotación organizada durante tres años,

b) Las tierras cuya explotación se hace en contravención de las normas jurídicas que regulan el trabajo agrícola y la tenencia de la tierra,

c) Las tierras laboradas por más de tres años y por quien no tenga ningún vínculo contractual con el dueño,

d) Las tierras cuya explotación se realice en contravención de los literales b y c del artículo 3 (explotación ausentista).

Para el segundo caso, el artículo 29 establecía: Las tierras, cuyo rendimiento sea notoriamente inferior al promedio de la zona, tomando en cuenta la capacidad productiva de la tierra; o cuando la explotación contravenga los derechos del trabajador agrícola. También aquí, se concede un plazo de tres años.

En este caso, había dos excepciones, una a favor de los terratenientes que hubiesen planificado inversiones con el Banco de Fomento, y la otra, en contra de ellos, en el sentido de que se podían expropiar predios eficientes en las situaciones de exceso de población (artículo 31).

Por lo demás, la Ley establecía la extinción de la propiedad, siempre y cuando una parcela no hubiese sido explotada en un plazo superior a los ocho años (artículo 38):

Existen tres regímenes básicos para implementar la Ley: Primero, el de colonización. Segundo, el de Reforma Agraria que se subdivide en tres: el de erradicación de huasipungos y otras formas precarias, el de negociaciones, reversiones y expropiaciones, y las parcelaciones en haciendas de la Asistencia Pública.

También, la Ley prohibía el fraccionamiento de la propiedad y establecía los siguientes límites: Los máximos de tamaño permitidos son: 2.500 hectáreas en la Costa y 800 hectáreas en la Sierra a lo cual se puede agregar 1.00 hectáreas de sabanas y páramos respectivamente (artículo 42). 
Fuente: César Verduga, Gustavo Cosse: Algunas consideraciones sobre las políticas estatales para el agro ecuatoriano (1964-1970), en Proyecto Cooperativo de Investigación sobre Tecnología Agropecuaria en América Latina (PROTAAL), Facultad Latinoamericana de Ciencias Sociales (FLACSO), documento número 29, 1978, p. 5-9. También, se ha consultado el Informe del Instituto Nacional y Colonización, 1963-196, p. 29-43.

Nota 919: En este contexto, Gustavo Cosse habla de la colonización, ya que solía sustituir a la política de reforma agraria y fue una línea de consenso entre los diversos gobiernos que se sucedieron desde 1963. El régimen de colonización que se acelera a partir de 1964, y que dominaba en la Sierra, Costa y Oriente, fue planteado como política alternativa frente a la reforma agraria por las Cámaras de Agricultura y los partidos de la burguesía desde finales de los años cincuenta. A pesar de esto, con el régimen de colonización, el campesinado no pudo lograr el apoyo del estado en relación a los créditos y asesoramiento técnico, factores que imposibilitaron en la mayoría de los casos un ciclo de acumulación.

Este proceso tiene gran importancia para Cosse, puesto que logró generar una considerable masa de productores ligados al mercado, con un tipo de articulación al sistema de haciendas diferente al del antiguo huasipunguero, al tiempo que provocó una transformación en la estructura de clases en el campo y constituyó un dato central en la conformación de alianzas y movilizaciones sociales. Fuente: Gustavo Cosse: Reflexiones acerca del estado, el proceso político y la política agraria en el caso ecuatoriano 1964-1977, en: "Ecuador, cambios en el agro serrano", CEPLAES,-FLACSO, 1980; S. Barraclough, J. C. Collarte: Tenencia de la tierra y desarrollo socio-económico del sector agrícola, Ecuador, Resumen del Informe del CIDA, Quito, FLACSO, 1976, p. 356.

Nota 924: La Confederación Ecuatoriana de Obreros Católicos (CEDOC) nació en 1938, bajo el amparo de la Iglesia católica, y estaba formada por sectores artesanales y campesinos. Pese a que esta organización tenía un carácter sindical frente a los problemas laborales y sociales ecuatorianos, al iniciarse la década de los sesenta, la CEDOC dio un giro cuando decidió concentrar sus esfuerzos en la ampliación de su base social incluyendo también a organizaciones campesinas. Esta tendencia, que se vio reforzada a causa de la dictadura militar de 1963, estaba en contra de las organizaciones de izquierdas. Fuente: Jaime Durán: Movimientos sociales en 
Ecuador en 1970: Unidad y crisis de las centrales sindicales, en: Los movimientos populares en América Latina, Edit. Siglo XXI, Universidad de las Naciones Unidas, 1989.

Aquí, se ha de hablar de la tensión vivida en el campo ecuatoriano, ya que con la Ley de Reforma Agraria de 1964, se produjo un reparto de los huasipungos inferior al estipulado, quedando numerosos campesinos fuera del reparto o recibiendo tierras marginales de escaso valor productivo. A esto, se ha de añadir la creación de la Ley de Abolición del Trabajo Precario en Agricultura en 1970, que debía de poner fin a todas las formas de trabajo precarias, de ahí que en este intervalo de tiempo, se agudizaran las demandas de los campesinos para obtener las tierras que cultivaban.

Posteriormente, en 1973, la nueva Ley de Reforma Agraria tenía como objetivo analizar el alcance de la ley anterior, a la vez que imponía condiciones más estrictas que permitían el mantenimiento de la hacienda (eliminación de las relaciones pre-capitalistas, niveles mínimos de productividad, etc.). De forma paralela, la bonanza de las exportaciones de petróleo hizo que la reforma buscara el establecimiento de un nuevo modelo económico, el de la moderna empresa, que permitiera realizar un ajuste de la propiedad al proceso de industrialización del país. Así, en 1979, para acabar con la movilización campesina y sus demandas de tierra, el gobierno militar creó la Ley de Fomento y Desarrollo Agropecuario, cuyo objetivo, según la CEDOC, era: desterrar todo nuevo intento de reforma agraria, consolidar la gran propiedad modernizada, canalizar el crédito hacia las empresas y grandes propiedades y contener al movimiento campesino a través de disposiciones punitivas.

Fuente: CEPEP: Las luchas campesinas 1950-1983. Movilización Campesina e historia de la FENOC, Quito, Centro de Educación Superior Popular (CEPED), Serie Movimiento Social, 1985, pp. 8; Francisco Chiodi: Ecuador, capítulo III, en La educación indígena en América Latina: México, Guatemala, Tomo I, P. Ebi-Abya Yala, UNESCO/OREALC, 1990, p. 354.

Nota 932: Recordemos que la Junta Nacional de Planificación (JUNAPLA), creada en 1954, era el organismo encargado de la planificación y desarrollo del país, convirtiéndose posteriormente, en un organismo asesor del poder público.

A este respecto, la tarea de planificación nacional obligó a la creación del Instituto Nacional de Estadísticas y Censos (INEC), que se encontraba ligado a la Junta para consolidar la perspectiva de una visión integral del primer diagnóstico del país. De este modo, JUNAPLA, con la participación de las dependencias gubernamentales y otras entidades competentes, pudo abordar 
una planificación general de la economía ecuatoriana, siendo el resultado de ese esfuerzo, el Plan de Desarrollo que combinaba una programación detallada de los primeros cinco años (19641968) con una visión de perspectiva para 1969-1973. Fuente: 25 Años de Planificación. JUNAPLA, Edición, Selección y Notas: Dr. Germánico Salgado. Director Técnico de JUNAPLA. Econ. Eduardo Santos Alvite 1979, Secretaría Nacional de Planificación y Desarrollo, www.planificacion.gob.ec.

Nota 934: Recordemos que el Banco Central fue creado para que el país tuviera una institución u organismo de emisión, giro, depósito y descuento del estado. A raíz de la Revolución Juliana (9 de julio de 1925), se inició el proceso de fundación de este banco nacional emisor, siendo Luis Napoleón Dillon, Ministro de hacienda de la época, quien impulsó este proyecto. Posteriormente, el 11 de febrero de 1927, la Misión Kemmerer presentó al gobierno, el Proyecto de Ley Orgánica del Banco Central del Ecuador, y el 12 de marzo de 1927, el Presidente Isidro Ayora decretó la Ley Orgánica del Banco Central del Ecuador (Registro Oficial N. 283). Finalmente, tras la aprobación de los estatutos, el 10 de agosto de 1927, el Banco Central del Ecuador fue constituido. Fuente: Juan J. Paz, Miño Cepeda: La fundación del Banco Central del Ecuador y su significado histórico a los 75 años, capítulo V, Taller de Historia Económica, número 2, Noviembre 2002.

En relación al Banco Nacional de Fomento, el gobierno del Doctor Isidro Ayora, mediante Decreto Ejecutivo del 27 de enero de 1928, publicado en el Registro Oficial No. 552 del mismo mes y año, creó el Banco Hipotecario del Ecuador. La condición de sociedad anónima la mantuvo hasta 1937, año en que se transformó en institución privada con finalidad social y pública, autónoma y sujeta a su propia Ley y Estatutos.

Varias reformas posteriores fueron cambiando su estructura hasta que, el 14 de octubre de 1943, se expidió la ley que transformó al Banco Hipotecario en el Banco Nacional de Fomento Provincial, la misma que fue publicada en el registro Oficial No. 942 con fecha 20 de octubre de 1943, durante la administración del Doctor Carlos Alberto Arroyo del Río, presidente Constitucional de la República del Ecuador.

Luego, mediante Decreto No. 327 del 28 de marzo de 1974, publicado en el Registro Oficial No. 526 del 3 de abril del mismo año, se expidió la nueva Ley Orgánica del Banco Nacional de Fomento. Con esta Ley, el Banco Nacional de Fomento adquirió autonomía económica, financiera y técnica. Fuente: Banco Nacional de Fomento, Historia, www.bnf.fin.ec 
En este sentido, los bancos destinaron menos dinero a la agricultura, ya que preferían destinar sus créditos a las actividades más rentables (como el comercio) con las que podían obtener mayores beneficios. Si bien los créditos fueron más bajos en la época anterior a la reforma de 1964, estos se vieron modificados y siguieron una tendencia constante en su aplicación. Así, se muestra en el artículo 113 de la Ley: la obligación para los Bancos Privados (en general) de conceder créditos al sector agropecuario en un porcentaje igual al 15\% de los depósitos a la vista y a plazo.

Fuente: Guillermo Guerra: La Planificación y el Desarrollo Agrícola e institucional en Ecuador, IICA, Dirección regional para la Zona Andina, apartado 478, Lima-Perú, junio, 1969, p. 64-65.

Nota 942: Desde finales de los cincuenta, se empezó a crear una serie de instituciones nacionales y regionales para el fin mencionado. Entre 1958 y 1962, se crearon algunos importantes organismos de desarrollo: el Centro de Reconversión Económica del Austro (CREA), el 7 de noviembre de 1958; el 11 de julio de 1959 se creó el Instituto Nacional de Investigaciones Agropecuarias (INIAP); y el 12 de mayo de 1960, el Instituto Ecuatoriano de Electrificación (INECEL). Fuente: M. Chiriboga: El estado y las políticas hacia el sector rural (1979-1989), en: "Ecuador Agrario", Quito, ILDIS-El Conejo, 1984, p.94-141.

- Centro de Reconversión Económica del Austro (CREA): En 1958, el presidente Camilo Ponce Enríquez creó el Centro de Reconversión Económica del Austro para propulsar el desarrollo de las provincias de Azuay y Cañar, siendo incorporada la provincia de Morona Santiago a la esfera político-administrativa de la institución. Fuente: M. Chiriboga: El estado y las políticas hacia el sector rural (1979-1989), en: "Ecuador Agrario”, Quito, ILDIS-El Conejo, 1984, p.94-141.

- Instituto Nacional de Investigaciones Agropecuarias (INIAP): Los problemas que afectaban a los cultivos agrícolas en el año 1959, indujeron al gobierno ecuatoriano a crear el Instituto Nacional de Investigaciones Agropecuarias, con lo cual se dio permanencia a las actividades de investigación agropecuaria, que hasta el momento habían sido ejecutadas con el apoyo de los Estados Unidos. El INIAP nació como entidad autónoma, pasando a ser parte del Ministerio de Agricultura y Ganadería años después. Fuente: Instituto Nacional Autónomo de Investigaciones agropecuarias: Tecnología para el desarrollo agropecuario, Corpoiniap, 1995.

- Instituto Ecuatoriano de Electrificación (INECEL): El 23 de mayo de 1961, el estado asumió la responsabilidad del servicio eléctrico mediante la creación del Instituto Ecuatoriano de Electrificación para optimizar la utilización de los recursos naturales y mejorar las condiciones 
técnicas y económicas del suministro de energía. Fuente: Rubén Suárez: El sector eléctrico ecuatoriano como fuente de bienestar social, FLACSO, Quito, 2010.

Nota 943: Ministerio de Agricultura y Ganadería (MAG): En el año de 1911, al asumir la Presidencia de la República el Dr. Manuel Enrique Araujo, en el Decreto de Organización del Gabinete de Gobierno (D.E. $1^{\circ}$ de marzo de 1911. D.O. No 50 del 2 de marzo de 1911), creó la Secretaría de Agricultura. Posteriormente, la Asamblea Nacional Legislativa, por Decreto de fecha 30 de marzo de 1911, definió las atribuciones de la Secretaría de Agricultura, atribuyéndole el régimen y gobierno de la industria agrícola, que consignaba el Art. $1^{\circ}$ de la Ley Agraria del momento, la inspección de los caminos vecinales y municipales, lo relativo a los impuestos sobre los productos agrícolas; la importación de maquinaria agrícola y otros (D.L. del 20 de marzo de 1911. D.O. $\mathrm{N}^{\mathrm{o}} 78$ del 4 de abril de 1911).

Entre las funciones del Ministerio de Agricultura se encuentra el levantamiento de catastros que establece el estado civil de cada propiedad; la construcción de una gran red de canales para convertir las tierras de secano en tierras de regadío; la introducción de máquinas auxiliares de los cultivos, y el establecimiento de fábricas de abono para fertilizar los terrenos ya agotados. Fuente: Ministerio de Agricultura y Ganadería, Historia, www.mag.gob.sv

- Instituto Ecuatoriano de Recursos Hidráulicos (INERHI): El Instituto ecuatoriano de recursos hidráulicos fue creado en 1966, como entidad de Derecho Público con personería jurídica y adscrita al Ministerio de Agricultura y Ganadería. Este instituto era el organismo ejecutor de Ministerio de Agricultura para el cumplimiento de las funciones que a este confiere la Ley de Riego y Saneamiento del suelo. Su finalidad fundamental era procurar el mejor aprovechamiento y protección de los recursos hídricos del país, como condición esencial para el desarrollo económico de este. Fuente: Ley de creación del Instituto Ecuatoriano de Recursos Hidráulicos, capítulo 1: Finalidades y funciones, artículo 1, faolex.fao.org, M. Chiriboga: El estado y las políticas hacia el sector rural, 1979-1982, en: Ecuador Agrario, Quito, ILDIS-El Conejo, 1984 p. 94-141; O. Barsky: Los terratenientes serranos y el debate político previo al dictado de la Ley de Reforma Agraria de 1964 en el Ecuador, en: O. Barsky et al, Ecuador: Cambios en el agro serrano, Quito: CEPLAES-FLACSO, 1980. 
- Comisión Ecuatoriana para el Desarrollo de la Cuenca del Río Guayas (CEDEGE): Es una entidad con personería jurídica, patrimonio propio y sede en la ciudad de Guayaquil, creada mediante Decreto Supremo No. 2672 del 2 de diciembre de 1965. CEDEGE tiene como finalidad realizar las investigaciones, estudios, obras y ejecutar programas y proyectos necesarios para el Desarrollo Integral de la Cuenca del Río Guayas y de la Península de Santa Elena. Fuente: Ley de Creación de la Comisión de Estudios CEDEGE, Decreto Supremo No. 2672, RO/ 645 de 13 de Diciembre de 1965.

Nota 962: Los proyectos de reforma de los años sesenta para la distribución de la tierra y la eliminación de las relaciones pre-capitalistas, provocaron la descomposición de las bases de los poderes locales. Así, algunas de las iglesias locales, como ocurrió en la provincia del Chimborazo, además de entregar a los campesinos parte de sus haciendas, fomentaron procesos de educación y contribuyeron a la creación de organizaciones de campesinos en torno al acceso de la tierra.

Según la información aportada por la Dirección de Organizaciones Populares del Ministerio de Agricultura y Ganadería, para el periodo 1938-1964, se habían creado 186 comunidades campesinas en esta zona, mientras que en 1965-1969, se constituyeron 71, y entre 1970-1975, aparecieron otras 63 comunidades, coincidiendo con la imposición de las dos leyes de reforma agraria (1963 y 1973). Fuente: Dirección de Organizaciones Populares, MAG, en Hernán Carrasco: Democratización de los poderes locales y levantamiento indígena, en "Sismo étnico en el Ecuador. Varias perspectivas, CEDIME, 1993, p. 134.

Aquí, se ha de aclarar que la base organizativa de los indígenas ha sido la comuna, la cual, a pesar de haber existido durante siglos, sólo fue reconocida de forma legal a partir de 1937, momento en que fue impulsada por las organizaciones de izquierda, surgiendo entonces, uniones de comunas parroquiales o cantonales. En este caso, se puede hablar de Columbe, que fue la Parroquia de Chimborazo con mayor número de organizaciones consolidadas y que protagonizaron frecuentes luchas por el acceso a la tierra.

La aparición de organizaciones comunitarias y Organizaciones de Segundo Grado (OSG) de Columbe, está asociada con la intervención del estado en el campo y el apoyo de la Federación Ecuatoriana de Indios. En este sentido, con la Ley de Comunas de 1937, los indígenas huasipungueros de la hacienda Columbe Grande constituyeron en 1948, las comunas de Columbe Grande Lote 1 y 2, Columbe Grande Lote 3 y 4, San Francisco y Columbe alto. Fuente: 
Luis A. Tuaza: Cansancio Organizativo, en "Repensando los movimientos indígenas", FLACSO, Ministerio de Cultura del Ecuador, 2009, p. 126.

Por otro lado, se ha de aclarar que las Organizaciones de Segundo Grado (OSG) son organizaciones de base que han adquirido un estatuto de representatividad local o regional y buscan establecer una serie de demandas. En el caso ecuatoriano, algunas de las OSG surgieron ligadas a la lucha por la tierra y a reivindicaciones políticas, mientras que otras fueron creadas como respuesta a los proyectos establecidos por parte del estado. Fuente: Luciano Martínez Valle: Las organizaciones de segundo grado como nuevas formas de organización de la población rural, en "La construcción de la democracia en el campo latinoamericano", CLACSO, Consejo Latinoamericano de Ciencias Sociales, 2006, p. 109.

Nota 997: Para explicar el tema de la vía junker o prusiana, Rafael Quintero hace alusión al tema de la burguesía y a cómo después de la Revolución Liberal de 1895, la clase terrateniente logró mantener su poder político, económico e ideológico, pues las relaciones pre-capitalistas de las haciendas no fueron eliminadas. Este camino de transición, denominado por Lenin como "camino prusiano", fue desfavorable para el surgimiento de la sociedad burguesa y es aplicado por Quintero al caso ecuatoriano.

Para Lenin, el desarrollo capitalista puede adquirir dos modalidades: Por un lado, las características de una sociedad capitalista, que desaparecen a raíz de las modificaciones en la economía latifundista, y por otro, dichos rasgos son eliminados con la desaparición de los latifundios. De este modo, el desarrollo de la burguesía puede realizarse a partir de las transformaciones de la economía terrateniente y la sustitución de los métodos pre-capitalistas de explotación por los burgueses. También, una pequeña economía campesina puede alcanzar el libre desarrollo capitalista y acabar con los rezagos típicos del feudalismo mediante la vía revolucionaria:

En el primer caso, la economía feudal del terrateniente se transforma lentamente en una economía burguesa, junker que condena a los campesinos a décadas enteras de la más dolorosa expropiación y servidumbre.... En el segundo caso, no existe economía terrateniente o ha sido liquidada por la revolución, que confisca y divide las haciendas feudales... Fuente: V. Lenin: Obras completas, Tomo XIII, Akal/Ayuso, 1975, p. 223224. 
Aquí, Quintero explica que las ideas de Lenin han de ser aplicadas a la cuestión agraria y a la sociedad burguesa. En el caso ecuatoriano, la vía prusiana de creación del estado burgués y el tema de la Revolución Liberal de 1895 no contribuyeron al desarrollo de la sociedad burguesa, pero sí ayudaron a mantener los privilegios de la clase terrateniente que, con el paso del tiempo, fue transformándose en burguesía, a la vez que pudo conservar su nivel de poder en el estado. Es decir, se ha de hablar de un estado burgués-terrateniente. Rafael Quintero: El mito del populismo en el Ecuador. Análisis de los fundamentos del estado ecuatoriano moderno, 1895-1934, FLACSO, Quito, 1980, p. 92

Por otra parte, Quintero hace referencia al tema del imperialismo para explicar el cambio de estado feudal a estado burgués-terrateniente que tuvo lugar en el Ecuador a finales del siglo XIX, tras el intervencionismo por parte de países como Inglaterra, Estados Unidos, Francia y Alemania. En el caso estadounidense, el impacto de su intervención fue mayor, pues tuvo lugar cuando el desarrollo del capitalismo norteamericano ya había generado una base industrial y financiera que le permitió constituirse bajo la forma de una nueva etapa, la del imperialismo. El comienzo de esta fase coincidió con la Revolución Liberal de1895 en el Ecuador, hecho que ejerció una influencia en la formación social ecuatoriana y en el desarrollo del estado burguésterrateniente, al crearse una nueva vía dependiente del imperialismo. Es decir, el imperialismo generó la implantación de técnicas represivas de los países imperialistas en los aparatos estatales del Ecuador:

Ello significa que se genera un abultamiento e hipertrofia de los aparatos estrictamente represivos del estado (policía, ejército, centrales de inteligencia) destinados a velar por los intereses económicos extranjeros en la semi-colonia. Esto produce un debilitamiento de los proyectos democráticos del estado nacional a la vez que fomenta la adopción de formas de estado que respondan incondicionalmente a los mandatos del capital monopólico. Fuente: Rafael Quintero: El mito del populismo en el Ecuador. Análisis de los fundamentos del estado ecuatoriano moderno, 1895-1934, FLACSO, Quito, 1980, p. 93.

Esta explicación sobre la vía específica de constitución del estado, a la que Quintero denomina “el camino prusiano-dependiente”, nos aclara la razón por la cual, el estado ecuatoriano no pudo convertirse en un estado moderno, democrático-burgués desarrollado, ya que desde el año 1895, muestra formas inferiores a las típicas, lo cual se debe a la constancia del poder de la clase 
terrateniente en el proceso de cambio del estado. Con esta idea, Quintero destaca el complicado camino atravesado por el Ecuador después de la Revolución Liberal de 1895, caracterizado por una combinación de retrocesos históricos y pequeños avances:

Es, en este contexto, que debe ser comprendido el tardío surgimiento de un régimen de partidos políticos, en especial como organismos actuantes en calidad de instrumentos de control y participación democrática en el Estado burgués. De igual manera, la no constitución de un partido jacobino de la burguesía debe ser entendido en el contexto de esta debilidad de la burguesía ecuatoriana y la vía dependiente de constitución del estado capitalista en el país. Rafael Quintero: El mito del populismo en el Ecuador Análisis de los fundamentos del estado ecuatoriano moderno, 1895-1934, FLACSO, Quito, 1980, p. 94.

Teniendo en cuenta que una de las principales características del estado ecuatoriano ha sido el de su permanente atraso, y el hecho de que sus formas políticas no se correspondan con las de una sociedad capitalista, es lógico que se explique la constitución del estado burgués a partir de la vía prusiana-dependiente planteada por este autor.

Por su parte, René Báez afirma que la vía clásica de desarrollo económico es el capitalismo, siendo sus características diferentes en América Latina con respecto a las de los países europeos, debido a la complejidad y heterogeneidad de sus sociedades y estructuras feudales. En este caso, el crecimiento económico de estos países no debe ser considerado como un proceso inexistente, sino que su problema radica en un conjunto de condiciones específicas, dentro de las cuales, se instauró el capitalismo. Fuente: René Báez: Ecuador: ¿Genocidio económico o vía democrática?, Biblioteca de Ciencias Sociales, volumen 40, Corporación Editora Nacional, 1992, p. 15-20.

Para explicar este proceso, Báez hace alusión a las ideas de Maza Zavala, e indica que en los países desarrollados, las relaciones de producción capitalistas tienen lugar entre productores y trabajadores asalariados, mientras que en los países subdesarrollados, las relaciones capitalistas conviven con las pre-capitalistas, dando lugar a un "complejo estructural", en el que las formas capitalistas son las dominantes y por ello, caracterizan al conjunto.

A este complejo estructural que se ha formado en los países latinoamericanos... puede calificarse como una formación económico/social periférica o dependiente. Este último calificativo obedece a la característica de subordinación respecto a los países capitalistas 
desarrollados. Fuente: D. F. Maza Zavala: Evaluación crítica de la enseñanza de la economía en América Latina, Revista Economía, IIE-UC, Quito, número 63, 1990, p. 78, en René Báez: Ecuador: ¿Genocidio económico o vía democrática?, Biblioteca de Ciencias Sociales, volumen 40, Corporación Editora Nacional, 1992, p. 16-17.

Asimismo, para Báez el fenómeno del subdesarrollo en estos países no se origina en la inexistencia de vínculos entre los sectores productivos capitalistas y modernos con los tradicionales, y tampoco considera al desarrollo económico como un problema tecnológico, puesto que no se puede sustituir un proceso productivo feudal por uno con tecnología moderna. En el primero de los casos, se produce una articulación entre los sectores modernos y tradicionales a favor de los primeros, mientras que en segundo lugar, el problema consiste en la identificación de los factores políticos y económicos que limitan la modernización de estos países. También, el mecanismo de acumulación y crecimiento de esta región se encontraba limitado por ciertas restricciones de tipo interno que impedían la expansión del excedente económico y por relaciones externas negativas que implicaban la transferencia al exterior de capital generado localmente. Fuente: René Báez: Ecuador: ¿Genocidio económico o vía democrática?, Biblioteca de Ciencias Sociales, volumen 40, Corporación Editora Nacional, 1992, p. 19.

\section{CAPÍTULO 5}

Nota 1010: La Ley de Defensa del Artesano fue aprobada el 5 de noviembre de 1953, creándose al mismo tiempo, la Junta Nacional de Defensa del Artesano para administrar dicha ley y proporcionar a los artesanos de los medios necesarios para que pudieran acogerse a los beneficios correspondientes. Con esta Ley, también se reconocieron legalmente las organizaciones, gremios, sociedades, asociaciones y federaciones de artesanos para que participaran en la elección de los vocales artesanos que integraban la Junta, de acuerdo a las disposiciones aprobadas.

El establecimiento de esta Ley permitió a los artesanos de las ciudades, pequeños industriales y comerciantes evitar legalmente los reglamentos del Código de Trabajo, pues los dueños de un taller, de acuerdo con lo establecido en la Ley, no eran considerados como patrones.

A este respecto, se ha de señalar las divisiones y contradicciones que existían a principios del siglo XX en el sector artesanal en cuanto a la distinción entre maestro artesano o patrón 
industrial, y oficial, operario o trabajador asalariado. Con la creación del Código del Trabajo en 1938, se delimitó el trabajo del maestro como empleador y del obrero como empleado, marcándose así, la distancia entre artesanos y obreros y, como consecuencia, la primacía de los segundos en las organizaciones sindicales.

De esta forma, en la Ley de Defensa del Artesano, la condición necesaria de calificación beneficiaba solamente a los artesanos establecidos en las ciudades y permitía la incorporación de comerciantes y aprendices, con lo que se dejaba al margen a una gran cantidad de artesanos pobres, operarios y aprendices.

Fuente: María Cuvi: Políticas de Fomento Artesanal en el Ecuador, edición de los trabajos y discusiones del Seminario "Políticas de Desarrollo, Promoción y Comercialización de las Artesanías y Artes Populares, Quito 24-26 de septiembre de 1985, Instituto Latinoamericano de Investigaciones Sociales, ILDIS y de la Subsecretaria de Artesanías del Ministerio de Industrias, Comercio, Integración y Pesca.

En cuanto a la ley de Fomento Industrial del Austro de 1954, hay que indicar que el austro ecuatoriano está formado fundamentalmente por las provincias de Azuay y Cañar, las cuales se han caracterizado por su relativo aislamiento geográfico, así como por ser zonas de alto nivel de migración, debido a la rígida estructura de propiedad, la existencia de numerosos minifundios y suelos erosionados que han dificultado la realización de las tareas agrícolas.

La Sierra sur del Ecuador se ha caracterizado por el desarrollo de la artesanía ligada a los trabajos agrícolas, es decir, las actividades artesanales con paja toquilla, cuero, hierro, barro y orfebrería, constituían el medio de vida de una gran cantidad de campesinos del austro ecuatoriano. La expansión de la actividad artesanal hizo que una buena parte de la población rural abandonara la producción de las haciendas por la producción artesanal, entre las que se encontraba la confección y exportación de los sombreros de paja toquilla, actividad que dio gran dinamismo a la región.

La relación existente entre los campesinos y los terratenientes de esta zona en la industria de sombrero de paja toquilla, generó una clase de intermediarios con una mentalidad empresarial poco frecuente debido al control ejercido por parte de una élite agraria cerrada, que se dedicada a cultivar la caña de azúcar en los valles de río Gualaceo y Paute.

La disminución de los precios de sombreros de paja toquilla a nivel mundial, produjo una gran crisis en la sociedad y economía del austro, pues dicha actividad empleaba entre 60.000 y 
80.000 personas, para lo cual, diferentes sectores de la región elaboraron un conjunto de políticas en el año 1952. En este caso, las Cámaras locales de producción, los bancos, la Federación de Artesanos y Trabajadores del Azuay organizaron una Asamblea Popular, en la que se analizó la situación de la economía regional y se creó el Centro de Recuperación Económica del Austro (CREA) encargado de la reconstrucción de la economía Sierra-sur.

Por otro lado, la estrategia elaborada para hacer frente a la crisis tenía como objetivo presionar al estado desde la sociedad regional, para que este atendiera las demandas de la clase dominante y lograra el establecimiento de una política económica que ayudara a la región y favoreciese a estos poderes a través de la denominada Ley de Fomento Industrial del Azuay de 1954. Es decir, la estrategia fue elaborada mediante la participación de los sectores sociales (organizaciones de trabajadores y artesanos del austro), las pretensiones hegemónicas de los nobles de Cuenca y las Cámaras de Industria y de Agricultura que buscaban consolidar su poder regional en el austro ecuatoriano. Fuente: Marco Tulio Restrepo Guzmán Estado, actores y conflicto social en la Amazonía: El caso de Morona Santiago (1940-1992), FLACSO, Quito, 1992, p. 52-55.

Por último, en referencia a la Ley de Fomento Industrial de 1957, se ha de indicar que, a partir de los años cincuenta, las aportaciones de la CEPAL en cuanto a la necesidad de acelerar el proceso de sustitución de importaciones, fueron incorporadas por la Junta Nacional de Planificación, pues el pesimismo generado en torno al crecimiento económico basado en las exportaciones de productos primarios, provocó una mayor inclinación hacia la industrialización por sustitución de importaciones para superar el carácter de dependencia del país.

La Junta Nacional de Planificación no estaba completamente a favor de la supremacía de la industrialización, ya que pretendía incrementar la producción agrícola para fortalecer la economía exportadora mediante la expansión de la industria, y recomendó el estímulo a las inversiones industriales. De este modo, el gobierno de Camilo Ponce (1956-1960) se acogió a este programa y aprobó la Ley de Desarrollo Industrial de 1957, caracterizada por dos factores que desempeñaron un papel importante en su formulación:

El primer factor era el fortalecimiento del poder ejecutivo en el proceso de modernización estatal, con una tendencia a sesgar el equilibrio de las relaciones jerárquico-funcionales entre los poderes estatales a favor del Ejecutivo, mientras que el segundo factor, estaba relacionado con el papel del estado como dinamizador empresarial. 
A su vez, esta nueva Ley permitió la incorporación de un sistema de clasificación para que las empresas pudieran agruparse por categorías según su contribución a la sustitución de importaciones, exportaciones y uso de materias primas nacionales:

- La primera categoría o "Categoría A", abarcaba a las empresas encargadas de producir materia prima y productos semielaborados dedicados a la sustitución de mercancías que habían sido objeto de importación.

- La segunda categoría o "Categoría B”, protegía a las industrias productoras de bienes que tenían como objeto satisfacer las necesidades relacionadas con la salud y subsistencia de la población y cuya importación podía ser sustituida por los productos locales. También, se podían exportar los productos sobrantes una vez cubierta las necesidades de la población.

- La tercera categoría o "Categoría C", proporcionaba beneficios a las industrias que transformaban la materia prima o semielaborada y que defendían el desarrollo nacional, pero no habían sido incluidas en otras categorías.

Fuente: Catherine Mary Conaghan: Industrialists and Reformist Interregnum: Dominant Class Behaviour and Ideology in Ecuador, 1972-1979, Tesis de doctorado, Universidad de Yale, 1983, pp. 74; Víctor Hugo Torres: Estado e industrialización en Ecuador, Universidad Politécnica Salesiana, Abya-Yala, 2012, p. 59-61; Ley de Fomento Industrial, 1961, p. 24-28, en Víctor Hugo Torres: Estado e industrialización en Ecuador, Universidad Politécnica Salesiana, AbyaYala, 2012, p. 64.

Nota 1054: En el año 1965, el gobierno de la Junta Militar anunció la revisión de las tarifas arancelarias de numerosos artículos de consumo y producción mediante la imposición de una nueva Ley de Arancel de Aduanas. Esta medida afectaba en mayor medida a los importadores de la Costa, cuyos beneficios se vieron mermados con la crisis económica, al disminuir los precios de los productos de exportación y la disponibilidad de divisas, ya que la Ley de Aranceles gravaba con más impuestos a dichos importadores de mercaderías.

En un principio, Guayaquil fue la primera ciudad que presentó quejas en contra del arancel, seguida de los sectores dominantes de la Sierra. Así, los comerciantes de la Costa pensaban que estas medidas favorecían la creación de industrias ficticias, a las que se aplicaban niveles tributarios diferentes, mientras que los terratenientes de la Sierra querían que el estado 
defendiera los intereses de la industria nacional y que las industrias que importaran materias primas, recibieran protección a plazos fijos y en escala decreciente.

De igual manera, los importadores rechazaron estas medidas, ya que sus partidas de productos correspondientes a la industria química, que era la que más recursos extranjeros recibía, fueron las más perjudicadas. Aquí, se producía un conflicto de intereses entre los importadores, fieles defensores de los monopolios, y el capital foráneo invertido en la industria creada durante esos años: Esta contradicción se potenciaba al ser una región y no solo una fracción burguesa la afectada por el trato preferencial dado al capital monopólico por parte del gobierno.

Fuente: Rafael Quintero, Erika Silva: Ecuador: Una nación en ciernes, Tomo III, FLACSO, Abya-Yala, 1991, p. 292; Diario Hoy: La historia se repite 34 años después, Texto tomado de El Expreso, Noticias del Ecuador y el mundo, 1999; Joaquín Mena-Soto: Enfoques universitarios: De la dictadura militar al quinto Velasquismo, Ed. Fray Jodoco Ricke, 1968, p. 128.

Nota 1068: Clemente Yerovi fue designado como presidente interino del Ecuador el 30 de marzo de 1966 tras una reunión mantenida en Quito, en la que los ciudadanos más destacados, destacados militares y representantes de los partidos políticos, acordaron llamarlo para que asumiera el poder y condujera al país hacia la constitucionalidad. Durante su corto gobierno (acabó el 16 de noviembre de 1966), su labor se centró en la realización de numerosas obras públicas y educativas, entre las que se destacan la construcción de treinta colegios y la remodelación de diversas carreteras y puentes. Fuente: www.enciclopediadelecuador.com.

- Otto Arosemena fue presidente del Ecuador durante el periodo comprendido entre 1966-1968. Aunque su gobierno fue de corta duración, este logró impulsar el desarrollo del país mediante la creación del Ministerio de Salud Pública, la construcción del Puente de la Unidad Nacional, la ampliación de las obras portuarias de Manta, las carreteras Ambato-Riobamba y El EmpalmeQuevedo, la electrificación de Manabí y la Península de Santa Elena, la rehabilitación del ferrocarril Quito-Guayaquil y el fomento a las telecomunicaciones, entre otras obras. Su gobierno acabó en el año 1968, como consecuencia de los continuos ataques y acusaciones por parte de sus adversarios políticos en cuanto a su gestión del petróleo y las numerosas concesiones realizadas que otorgaban preferencias a determinados contratistas. Fuente: Efren Avilés: Enciclopedia del Ecuador, Academia Nacional de Historia del Ecuador, 2012. 
Nota 1073: A este respecto, la Junta Nacional de Planificación establece varios factores que afectaron tanto a la artesanía como a la pequeña industria: factores externos (estrechez del mercado interno, dificultades de expansión del comercio exterior y escasez de obras de infraestructura, entre otros); factores internos (deficiente calidad de productos finales debido al bajo nivel de tecnología, conocimientos de producción y materias primas inapropiadas, escasa mano de obra cualificada, falta de capital de trabajo, comercialización deficiente y dependiente en numerosos casos de la venta a plazo y que limitaba la posibilidad de expansión y adaptación de los productos a las necesidades del productor, etc.) y factores intangibles (salud física, educación, tradición científica, capacidad de investigación y de adaptación a las innovaciones tecnológicas, estructura social y cultural del país, y todos aquellos factores que podían variar las condiciones para un mejor aprovechamiento de los recursos disponibles del sector). Fuente: JUNAPLA: Programa de artesanía y pequeñas industrias 1969-1973, número 02-14, 1969, p. 27-29.

Nota 1100: En 1919, la Anglo Ecuadorian Oil Fields estableció en Ancón, Península de Santa Elena, provincia del Guayas, sus actividades de explotación petrolera, creándose en 1925, la primera refinería del Ecuador. Fuente: Cepsa S.A.: Historia de la Empresa, www.cepsa.com.ec. Por su parte, Texaco comenzó las exploraciones de petróleo en el norte del Oriente de Ecuador, alrededor de la ciudad Lago Agrio, en el año 1964. En 1967, a través de la Texaco de petróleos del Ecuador C.A. y Gulf Ecuatoriana de petróleos S. A., la producción de petróleo en el pozo de Lago Agrio alcanzó una profundidad de 10.171 pies cúbicos, arrojando aproximadamente unos 2.640 barriles diarios. Fuente: Ana M.Varae: Marea negra en la Amazonía, ABYA-YALA, Quito, 1995.

Texaco operó en el Ecuador en el periodo 1964-1990, durante el cual se construyó la vía Auca y el Sistema de Oleoducto Transecuatoriano, se extrajeron 1.434.000 barriles de petróleo y se tuvo acceso a 491.355 hectáreas en la Amazonía ecuatoriana. Fuente: Boletín $\mathrm{N}^{\circ}$ 3, 2002, en Teresa Jimbicti Pandama: El petróleo en la región amazónica: El bloque 24 y los derechos colectivos en la nacionalidad Shuar, FLACSO, 2004, p. 3-5.

Nota 1102: De acuerdo con la obra de Cyrano Tama Paz, en treinta y cinco años de exploración, nueve firmas extranjeras gastaron alrededor de 400 millones de dólares en el Ecuador. Entre estas se encontraban: Shell-Standard of New Jersey que obtuvo una concesión de 4.776 .110 
hectáreas, gastando la cantidad de 44 millones de dólares; Minas y Petróleo S.A., 1961-1973, con 4.350.000 hectáreas en el periodo 1961-1973 y un gasto de 18 millones de dólares; TexacoGulf (1964-1975) que inicialmente contaba con 1.431 .450 hectáreas, las cuales pasaron a 491.355 hectáreas, y un gasto superior a 260 millones de dólares; Anglo-Union-Superior con una concesión inicial de 2.373.739 en 1968, que pasó a 230.700 posteriormente, y un gasto de 37 millones de dólares. De igual forma, otras compañías interesadas en el petróleo ecuatoriano fueron: Amoco, con 400.000 hectáreas, Shenandoh, con 135.072 hectáreas, $O K C$, con 282.693 hectáreas; y Cayman, con 325.000 hectáreas. Fuente: Cyrano Tama Paz: Petróleo, drama ecuatoriano, Departamento de publicaciones de la Universidad de Guayaquil, Julio 1975, p. 8384.

También, en el año 1937, con la Ley de Petróleos, aprobada durante la dictadura de Federico Páez (1935-1937), se crearon las concesiones como modelo contractual petrolero, con las que se permitía el establecimiento de compañías extranjeras sin restricciones. Fuente: Guillaume Fontaine: Petróleo y desarrollo sostenible en Ecuador, FLACSO, Ecuador, 2004, p. 47.

Nota 1105: Recordemos que Otto Arosemena fue presidente del Ecuador durante el periodo comprendido entre 1966-1968. Sabemos que su gobierno acabó en el año 1968 como consecuencia de los continuos ataques y acusaciones por parte de sus adversarios políticos, en cuanto a su gestión del petróleo y las numerosas concesiones realizadas que otorgaban preferencias a determinados contratistas. Fuente: Efrén Avilés: Enciclopedia del Ecuador, Academia Nacional de Historia del Ecuador, 2012.

Así, durante las elecciones de 1968, las compañías petroleras, con la ayuda de la Agencia de Inteligencia Central (CIA) y sus intermediarios, apoyaron la candidatura de Velasco Ibarra que logró mantenerse en el poder por quinta vez desde 1968-1972. Resultaba entonces, el más adecuado presidente electo, para contratar el petróleo y garantizar confianza a Texaco-Gulf, para su explotación petrolera. Fuente: Cyrano Tama Paz: Petróleo, drama ecuatoriano, Departamento de publicaciones de la Universidad de Guayaquil, Julio 1975, p. 22.

La crisis fiscal, los problemas socio-económicos y los enfrentamientos cada vez más violentos entre los estudiantes universitarios y el ejército, fueron algunos de los aspectos fundamentales que le llevaron a disolver el Congreso y a proclamar una dictadura a partir del 22 de julio de 1970, con el pretexto de reorganizar el país. Estos dos años de gobierno dictatorial se caracterizaron por múltiples conflictos de orden social, económico, político y militar, hasta que 
en 1972, el General Rodríguez Lara mediante un golpe militar, puso fin al quinto y último gobierno de Velasco Ibarra. Fuente: Efrén Avilés: Enciclopedia del Ecuador, Academia Nacional de Historia del Ecuador, 2012.

Nota 1109: Los problemas repercutieron en la amortización del oleoducto y en otros aspectos económicos. Así, la Corporación Estatal Petrolera Ecuatoriana (CEPE) se vio forzada a comprar en 1975 una parte del oleoducto, pagando a la Texaco-Gulf la cantidad de 25 millones de dólares procedentes de obras de desarrollo y mejora del país.

Por otro lado, los perjuicios de este cambio de posición gubernamental pueden ser resumidos en el aumento del precio total de la obra, cuyo precio inicial era de 86 millones y que se incrementó en más de 180 millones, alargándose con ello, el plazo de amortización y transferencia del oleoducto al estado; la falta de control estatal sobre el trazado del oleoducto, planos de construcción, calidad de los materiales empleados, presupuestos de equipos y servicios, etc. Fuente: Cyrano Tama Paz: Petróleo, drama ecuatoriano, Departamento de publicaciones de la Universidad de Guayaquil, Julio 1975, p. 55.

- CEPE: El 23 de junio de 1972, mediante decreto suscrito por el Gobierno de la Fuerzas Armadas, se creó la Corporación Estatal Petrolera Ecuatoriana (CEPE), entidad encargada de desarrollar las actividades asignadas por la Ley de Hidrocarburos; explorar, industrializar, y comercializar otros productos necesarios de la actividad petrolera y petroquímica. Con la creación de CEPE, el estado podía administrar y controlar por su propia cuenta el petróleo en beneficio del país, además de iniciar actividades de exploración y comercialización, pese a la resistencia de intereses locales y extranjeros. Fuente: Rodrigo Cabezas: Política petrolera ecuatoriana, Nueva Sociedad, Número 14, septiembre-octubre 1974, p. 30-33.

Nota 1115: La Organización de Países Exportadores de Petróleo (OPEP) es una organización intergubernamental creada en 1960, a la que pertenecen actualmente doce países productores de petróleo. Uno de los principales objetivos de la organización es el establecimiento de mecanismos para salvaguardar los intereses de la organización y de sus miembros, tanto de forma individual como colectiva. También, persigue la estabilización de los precios del petróleo en los mercados internacionales con el fin de eliminar altas fluctuaciones y volatilidad, teniendo en cuenta los intereses y necesidades de los países productores de petróleo para poder asegurar 
un ingreso estable, un suministro regular de petróleo a los países consumidores y una rentabilidad justa para los inversores en petróleo y su industria. El Ecuador se incorporó a la OPEP el 27 de junio de 1973, bajo la presidencia del General Rodríguez Lara, siendo miembro hasta 1993. Posteriormente, volvió a unirse a esta organización en el año 2007. Fuente: Organización de Países Exportadores de Petróleo www.opep.org.

Nota 1131: Con la búsqueda de tecnología extranjera para desarrollar petróleo, se estableció la necesidad de obtener cooperación internacional para resolver los problemas en el Ecuador. Los primeros pasos del gobierno consistieron en asociarse con el organismo de Asistencia Recíproca Petrolera Estatal Latinoamericana (ARPEL), convocándose diversas reuniones en 1972, para su ingreso en dicha asociación. Fuente: Cyrano Tama Paz: Petróleo, drama ecuatoriano, Departamento de publicaciones de la Universidad de Guayaquil, Julio 1975.

La organización institucional ARPEL fue creada específicamente para el sector petrolero en el año 1965, como resultado de la integración regional en América Latina. Así, varias empresas petroleras estatales de estos países decidieron constituir una asociación de asistencia recíproca con el objetivo de defender y fomentar sus intereses, además de propiciar el desarrollo de la industria latinoamericana a través de acciones estratégicas comunes.

De igual forma, esta organización pasó a llamarse Asistencia Recíproca Petrolera Empresarial Latinoamericana en 1993, mientras que en 1998, adoptó el nombre de Asociación Regional de Empresas de Petróleo y Gas Natural en Latinoamérica y el Caribe. En la actualidad, desde el año 2011, esta organización tiene el nombre de Asociación Regional de Empresas de Petróleo, Gas y Biocombustibles en Latinoamérica y el Caribe. Fuente: Susana Yazbek: La participación de ARPEL en la integración latinoamericana del sector petrolero, 1965-2011, III Congreso Latinoamericano de Historia Económica y XXIII Jornadas de Historia Económica, Simposio 9: Políticas petroleras en Américas (1945-2011), San Carlos de Bariloche, 23-27 de Octubre de 2012.

Nota 1155: Ya sabemos que el estado ecuatoriano trató de acelerar la industrialización utilizando los recursos procedentes de la agricultura y del comercio, lo que unido a la sustitución de importaciones y las exportaciones de manufacturas, permitiría generar más empleo y una mayor integración de la economía. El propósito de incrementar las exportaciones estaba relacionado con el deseo de incentivar de forma especial las industrias, cuya producción tenía como destino el 
Pacto Andino, es decir, los objetivos del estado en el proceso de industrialización, no solo incluían la sustitución de importaciones, sino que perseguían la incorporación al mercado subregional andino. Como ejemplo, se puede citar el crecimiento de la industria metal-mecánica como consecuencia de las decisiones del acuerdo de integración andina y los programas de inversiones de empresas extranjeras.

En referencia al acuerdo de integración andina y su creación, el 26 de mayo de 1969, cinco países de América Latina (Bolivia, Colombia, Ecuador, Chile y Perú) firmaron el Acuerdo de Cartagena con el objetivo de mejorar el nivel de vida de sus pueblos mediante la integración y cooperación socio-económica. De esa manera, se puso en marcha el proceso andino de integración conocido como Pacto Andino o Acuerdo de Cartagena.

Algunas de las herramientas más importantes para alcanzar los objetivos de integración y crecimiento económico eran el Programa de Liberación automático de los intercambios entre las diversas regiones; el arancel externo común que se adoptaría de manera paulatina, el proceso de industrialización vía sustitución de importaciones, cuya planificación se realizaría con programas sectoriales de desarrollo industrial y la armonización de políticas económicas.

En la actualidad, el Grupo Andino recibe el nombre de Comunidad Andina de Naciones (CAN), siendo su composición la siguiente: los países miembros son Bolivia, Colombia, Ecuador y Perú, mientras que Brasil, Argentina, Chile, Paraguay y Uruguay figuran como países asociados, y Panamá y México, son países observadores. Fuente: Eva Aguayo, Saskia Portillo, Pilar Expósito: Perspectiva del crecimiento económico en los países del Pacto Andino, Universidad Santiago de Compostela, Ministerio de Planificación Económica, CORDIPLAN, Venezuela, www.usc.es/economet.

\section{CAPÍTULO 6}

Nota 1206: En 1964, se adjudicó a Texaco-Petroleum Company (Texpet) y Ecuadorian Gulf Oil Company (Gulf) una concesión para explorar y producir petróleo en un área de 400.000 hectáreas en la región Oriental del Ecuador. Texpet fue seleccionada como operadora, ejecutando las decisiones de operaciones tomadas por los dueños del consorcio. Cuando la producción se inició en 1972, el gobierno del Ecuador exigió una participación del 25\% en el consorcio.

En consecuencia, tanto Texpet como Gulf, tuvieron que ceder a CEPE (predecesora de la compañía estatal Petroecuador) un $12.5 \%$ de su propio $50 \%$ de participación en el consorcio. 
Cuatro años después, CEPE adquirió el 37.5\% restante de participación de la Gulf, quedándose de este modo, con el control mayoritario del consorcio con el 62.5\% de acciones. Texpet era dueña minoritaria del 37.5\% restante, mientras que Petroecuador asumió las operaciones del campo petrolero en 1990 y la concesión de Texpet expiró en 1992, terminando así, toda su participación en el consorcio. Fuente: Chevron: Guía de inspección judicial, 27 de julio, 2005, www.texaco.com, p. 3 .

Nota 1250: La Mesa Redonda Norte-Sur, más conocida como North-South Roundtable, fue fundada en el año 1977, y desde entonces, ha desempeñado un papel destacado en el trabajo de la Sociedad para el Desarrollo Internacional. Durante este tiempo, ha mantenido más de cuarenta reuniones internacionales y ha publicado numerosos estudios, convirtiéndose en una parte importante de las formas no oficiales de debate de la política de desarrollo y acciones de la Organización de Naciones Unidas. Fuente: Richard Jolly: Society for international development, the North-South Roundtable and the power of ideas, en "Development", Society for International Development, 2007, pp. 47-58; North South Round Table, Human Development: The neglected dimension, 1985, Committee for Development Planning, Human Resources Development: A Neglected Dimension of Development Strategy, El desarrollo de recursos humanos: Una dimensión olvidada de la estrategia para el desarrollo), New York: United Nations, capítulo III, 1988.

Nota 1302: El modelo de crecimiento de Solow, conocido como el modelo exógeno de crecimiento o modelo de crecimiento neoclásico, consiste en un modelo macroeconómico que explica el crecimiento económico y las variables que influyen a largo plazo en el mismo. Este modelo establece un conjunto de variables relevantes de carácter exógeno que inciden en el crecimiento de una economía y pueden ayudar a mejorar la situación en un periodo determinado. Por esta razón, en este modelo neoclásico, el crecimiento es exógeno y se habla de exogeneidad, ya que dicho factor queda fuera del modelo, es decir, no se explica mediante el modelo sino que se parte de la idea de que tiene un valor concreto. Pese a que esta idea contribuye a simplificar el modelo, no se ofrece una explicación de cómo o por qué crecen las economías.

De forma paralela, la teoría del crecimiento endógeno intenta interiorizar el crecimiento y explicar el crecimiento en un modelo de la economía. Los estudios realizados en este campo se 
han centrado en los aumentos del capital humano (la educación) o del cambio tecnológico (la modernización o innovación).

La crítica a los modelos neoclásicos se realiza a la existencia de una función de producción compuesta por dos factores, el capital y el trabajo, con rendimientos constantes a escala y rendimientos decrecientes en cada factor. Hay que señalar que cuando falta el progreso técnico, la tasa de crecimiento del producto interior bruto por habitante tenderá a cero en el largo plazo. En este caso, el cambio tecnológico es considerado como exógeno al sistema, siendo tal exogeneidad, el factor que implica que el progreso tecnológico se produzca sin la intervención de agentes económicos. Por su parte, los modelos de crecimiento endógeno niegan la exogeneidad del progreso tecnológico, lo que permite cuestionar el carácter decreciente de los rendimientos marginales de los factores como el capital físico y humano. Fuente: Fernando Villarán: Política económica, planeamiento, desarrollo regional y local, Instituto para la Democracia y la Asistencia Electoral, IDEA Internacional, Asociación Civil Transparencia, coordinación general Pila Tello Rozas, marzo 2009, p. 19-25.

Nota 1331: El modelo de Solow explica el crecimiento de la producción nacional de bienes y servicios mediante un modelo cuantitativo. El modelo está compuesto por la producción nacional $(Y)$, la tasa de ahorro $(s)$ y la dotación de capital fijo $(K)$ y establece que el producto interior bruto nacional es igual a la renta nacional, es decir, supone la existencia de una economía cerrada, en la que no hay importaciones o exportaciones. La producción depende de la cantidad de mano de obra empleada $(L)$, la cantidad de capital fijo $(K)$ (maquinaria, instalaciones y otros recursos usados en la producción) y de la tecnología disponible.

Por otro lado, el modelo presupone que la manera de incrementar el producto interior bruto es con la mejora de la dotación de capital $(K)$, es decir, de lo producido en un año, se invierte una parte en acumular más bienes de capital o capital fijo (instalaciones, maquinaria), por lo que se podrá producir una cantidad mayor de bienes al año siguiente porque habrá más maquinaria disponible para la producción.

En este modelo, el crecimiento económico tiene lugar gracias a la acumulación constante de capital, ya que si cada año aumenta la maquinaria y las instalaciones disponibles (capital fijo) para producir, se podrá obtener una mayor producción, cuyo efecto acumulado a largo plazo, dará como resultado un aumento de la producción y, por tanto, un crecimiento económico 
destacado. Fuente: R. Solow: A contribution to the theory of economic growth, The quarterly journal of economics, 70(1), 1956, p. 65-94.

Nota 1381: Entre los colegios con bachillerato técnico en el Ecuador, se encuentran el Colegio Técnico Salesiano y el Agronómico Salesiano en Cuenca con orientación industrial y agropecuaria, el Colegio Técnico Guayaquil en Ambato con una orientación industrial, el de Carlos Cisneros en Riobamba con enfoque en la rama industrial, etc. Fuente: Organización de la Naciones Unidas para la Educación, la Ciencia y la Cultura: Un experimento innovativo para reducir el desempleo y el subempleo juvenil en el Ecuador, Reunión de expertos sobre el desempleo juvenil, Paris, 18-20 septiembre 1985, p. 52-53.

El sistema de enseñanza del Ecuador está dividido en los siguientes niveles: educación preprimaria, educación primaria, educación media o secundaria, el cual comprende un ciclo básico con una duración de tres años lectivos comunes para toda la educación media, prepara a los estudiantes para estudios de bachillerato o carreras cortas, amplía la cultura de la educación primaria y ofrece conocimientos técnicos, y un ciclo diversificado, mencionado con anterioridad, y con el que se puede acceder a la educación superior impartida por las universidades y escuelas politécnicas del país. Fuente: Organización de la Naciones Unidas para la Educación, la Ciencia y la Cultura: Un experimento innovativo para reducir el desempleo y el subempleo juvenil en el Ecuador, Reunión de expertos sobre el desempleo juvenil, Paris, 18-20 septiembre 1985, p. 3738.

Nota 1385: Carlos Larrea dice que el papel tradicional del Ecuador como exportador de productos agrícolas (cacao, banano, etc.) era un elemento fundamental en el análisis de la estructura de clases, es decir, constituía un vínculo de los intereses entre los nuevos industriales y las clases tradicionales y el mercado interno, lo cual pone de manifiesto el comportamiento político conservador de esas nuevas élites industriales. De hecho, rechazaron abiertamente las políticas de redistribución, aún cuando la gran mayoría de la población estaba excluida del mercado doméstico de productos manufacturados.

Así, durante los primeros años del auge, el gobierno militar reformista de Rodríguez Lara apoyado por la tecnocracia civil, intentó aplicar medidas redistributivas, incluyendo una reforma agraria. No obstante, este proyecto fracasó debido a la fuerte oposición de las clases dominantes, que incluían una gran mayoría de industriales. En ese momento, las organizaciones populares no 
eran demasiado fuertes como para llevar a cabo una redistribución social real, por lo que las clases tradicionales consiguieron mantener el control de las medidas públicas a favor de sus propios intereses, consolidando el patrón de desarrollo del país con sus características excluyentes. Fuente: Carlos Larrea: Pobreza y Políticas sociales en América Latina, Maestría Relaciones Internacionales, Capítulo I, FLACSO-Quito, diciembre 1988, p. 14-15, en Francisco Guerra: Análisis del modelo económico y social ecuatoriano. De los años setenta y ochenta en el marco de la globalización, FLACSO, Quito, 11 de abril 2001. 


\section{APÉNDICE DE DATOS Y ESTADÍSTICAS: INTRODUCCIÓN}

Tabla 1: Dictaduras en América Latina (1945-1965):

\begin{tabular}{|c|l|}
\hline Países & Dictaduras / Periodos \\
\hline Perú & Manuel Odria (1948-1956) \\
\hline Cuba & Fulgencio Batista (1952-1959) \\
\hline Nicaragua & $\begin{array}{l}\text { Anastasio Somoza García (1937-1947, 1950- } \\
\text { 1956), Luis Somoza Debayle (1956-1963) }\end{array}$ \\
\hline República Dominicana & Rafael Leónidas Trujillo (presidente 1952-1958) \\
\hline Argentina & Pedro Eugenio Aramburu (1955-1958) \\
\hline Venezuela & Marcos Pérez Jiménez (1948-1958) \\
\hline Paraguay & Alfredo Stroessner (1954-1989) \\
\hline Colombia & Gustavo Rojas Pinilla (1953-1957) \\
\hline Chile & $\begin{array}{l}\text { Carlos Ibáñez del Campo (1952-1958), A. } \\
\text { Pinochet (1973-1990) }\end{array}$ \\
\hline Bolivia & Gualberto Villarroel (1952-1958) \\
\hline Ecuador & $\begin{array}{l}\text { Gilberto Enrique Gallo (1937-1938), la Junta } \\
\text { Militar (1963-1966), Velasco Ibarra (1970-1972), } \\
\text { Guillermo Rodríguez Lara (1972-1976), el } \\
\text { Triunvirato Militar (1976-1979) }\end{array}$ \\
\hline &
\end{tabular}

Fuente: Regímenes dictatoriales desde 1930, en Historia General de América Latina, Tomo VIII, América Latina desde 1930 (UNESCO/Trotta. 2008), Cap. 13, p. 355. 


\section{APÉNDICE DE DATOS Y ESTADÍSTICAS: CAPÍTULO 1}

Tabla 1: Estructura de poder en una sociedad latinoamericana ficticia:

\begin{tabular}{|c|c|c|c|c|}
\hline \multicolumn{5}{|c|}{ Sistema distributivo } \\
\hline $\begin{array}{l}\text { Sistema político de } \\
\text { clase } \mathrm{W}^{*}=10\end{array}$ & $\begin{array}{l}\text { Sistema propiedad } \\
\text { de clase }\left(\mathrm{W}^{*}=5\right)\end{array}$ & \multicolumn{2}{|c|}{$\begin{array}{l}\text { Sistema ocupacional de } \\
\text { clase }\left(\mathrm{W}^{*}=3\right)\end{array}$} & $\begin{array}{l}\text { Sistema étnico de } \\
\text { clase }\left(\mathrm{W}^{*}=2\right)\end{array}$ \\
\hline Élites (X) & Riqueza (X) & \multicolumn{2}{|c|}{ Latifundistas (X) } & Españoles (X) \\
\hline Burocracia & Clase media $(\mathrm{Y})$ & \multicolumn{2}{|c|}{$\begin{array}{ll}\text { 1. } & \text { Labradores } \\
\text { independientes } \\
\text { 2. } \\
\text { 3. } & \text { Comerócratas } \\
\end{array}$} & Mestizos (Y) \\
\hline Clase apolítica & Pobres & Campesinos & Artesanos & \multirow[t]{2}{*}{ Indios } \\
\hline $\begin{array}{c}\text { Supuestos enemigos } \\
\text { del régimen }\end{array}$ & Indigentes & $\begin{array}{r}\text { Men } \\
\text { Desempl }\end{array}$ & $\begin{array}{l}\text { gos } \\
\text { dos, etc. }\end{array}$ & \\
\hline
\end{tabular}

\section{*peso equivalente a}

En el sistema de Lenski, "los españoles" han sido reemplazados por el concepto "blancos" dentro de la columna de etnicidad.

Fuente: Gerhard Lenski: Power and Privilege: A Theory of Social Stratification, New York: McGraw-Hill book Company, 1966, p. 80. 
Tabla 2: Concentración de la propiedad de las haciendas cacaoteras (1909):

\begin{tabular}{|c|c|c|c|}
\hline $\begin{array}{c}\text { Número de } \\
\text { propiedades poseidas }\end{array}$ & $\begin{array}{c}\text { Total de propietarios } \\
\text { anunciando }\end{array}$ & $\begin{array}{c}\text { Total de haciendas } \\
\text { (se excluyen las } \\
\text { haciendas no } \\
\text { cacaoteras) }\end{array}$ & $\begin{array}{c}\text { Promedio de } \\
\text { propiedades por } \\
\text { anunciante }\end{array}$ \\
\hline 1 & 30 & 30 & 1,0 \\
\hline 2 a 4 & 13 & 32 & 6,4 \\
\hline 5 a 8 & 3 & 20 & 1,7 \\
\hline Total & 46 & 82 & 6,6 \\
\hline
\end{tabular}

Fuente: GUIA: Ecuador, Guía comercial, agrícola e industrial de la República, 1909, Guayaquil, 1909. 
Tabla 3: Producción anual de cacao en el Ecuador (1871-1900):

\begin{tabular}{|c|c|c|c|}
\hline Ã̃o & $\begin{array}{l}\text { Producción } \\
\text { (quintales) }\end{array}$ & Ã̃o & $\begin{array}{l}\text { Producción } \\
\text { (quintales) }\end{array}$ \\
\hline 1871 & 172.422 & 1886 & 416.523 \\
\hline 1872 & 187.238 & 1887 & 354.571 \\
\hline 1873 & 245.969 & 1888 & 288.841 \\
\hline 1874 & 247.493 & 1889 & 256.777 \\
\hline 1875 & 163.508 & 1890 & 392.433 \\
\hline 1876 & 220.993 & 1891 & 227.070 \\
\hline 1877 & 214.103 & 1892 & 350.024 \\
\hline 1878 & 105.734 & 1893 & 433.851 \\
\hline 1879 & 322.578 & 1894 & 413.632 \\
\hline 1880 & 347.220 & 1895 & 385.349 \\
\hline 1881 & 223.981 & 1896 & 377.036 \\
\hline 1882 & 211.806 & 1897 & 358.198 \\
\hline 1883 & 156.721 & 1898 & 453.192 \\
\hline 1884 & 182.933 & 1899 & 578.426 \\
\hline 1885 & 257.221 & 1900 & 411.349 \\
\hline
\end{tabular}

Fuente: Informe de la Junta de la Asociación de Agricultores del Ecuador (periodo 1871-1876). Informe Anual de las Cámaras de Comercio y Agricultura de Guayaquil (periodo 1877-1900), 1925 . 
Tabla 4: Valor declarado de importaciones y exportaciones ecuatorianas (1871-1900) (en millones de dólares):

\begin{tabular}{|c|c|c|c|c|c|}
\hline Año & Importaciones & Exportaciones & Año & Importaciones & Exportaciones \\
\hline 1871 & 2.931 .500 & 3.807 .100 & 1886 & 6.027 .700 & 8.576 .800 \\
\hline 1872 & 3.289 .100 & 4.271 .600 & 1887 & 5.917 .300 & 8.897 .400 \\
\hline 1873 & 2.331 .700 & 3.028 .200 & 1888 & 6.396 .600 & 9.009 .300 \\
\hline 1874 & 3.013 .400 & 3.913 .500 & 1889 & 9.220 .400 & 7.910 .200 \\
\hline 1875 & 2.032 .000 & 2.639 .000 & 1890 & 9.105 .800 & 9.761 .600 \\
\hline 1876 & 2.609 .900 & 3.389 .600 & 1891 & 6.896 .300 & 7.351 .800 \\
\hline 1877 & 3.260 .600 & 3.928 .400 & 1892 & 6.205 .800 & 7.688 .700 \\
\hline 1878 & 2.993 .000 & 3.365 .100 & 1893 & 6.377 .100 & 7.600 .100 \\
\hline 1879 & 5.415 .100 & 8.684 .300 & 1894 & 5.928 .100 & 7.600 .100 \\
\hline 1880 & 4.981 .600 & 8.207 .100 & 1895 & 5.078 .400 & 5.640 .300 \\
\hline 1881 & 4.351 .500 & 4.995 .700 & 1896 & No disponible & 5.843 .000 \\
\hline 1882 & 3.384 .800 & 5.469 .800 & 1897 & 7.575 .000 & 4.392 .500 \\
\hline 1883 & 3.873 .200 & 4.923 .300 & 1898 & 4.814 .500 & 7.187 .900 \\
\hline 1884 & 5.556 .300 & 5.915 .100 & 1899 & No disponible & 9.147 .600 \\
\hline 1885 & 3.384 .800 & 5.344 .700 & 1900 & 6.546 .800 & 7.521 .400 \\
\hline
\end{tabular}

Fuente: Informes del Ministerio de Finanzas. Tomado de Luis Carbo: Historia Monetaria y Cambiaria del Ecuador, Banco Central del Ecuador, 1953, p. 447-448. 
Tabla 5: Ingresos por cacao, 1884-1884 y 1888-1898 (en miles de libras esterlinas):

\begin{tabular}{|c|c|c|c|}
\hline Año & $\begin{array}{l}\text { Exportaciones de } \\
\text { cacao (X cacao) }\end{array}$ & $\begin{array}{l}\text { Total de exportaciones } \\
\qquad(\text { Total } \mathbf{X})\end{array}$ & $\begin{array}{c}\text { Porcentaje } \\
\text { (Xcacao/Total } X * \\
\text { 100) }\end{array}$ \\
\hline 1880 & 834 & 1.159 & $71.95 \%$ \\
\hline 1881 & 542 & 769 & $70.33 \%$ \\
\hline 1882 & 505 & 750 & $67.33 \%$ \\
\hline 1883 & 458 & 734 & $62.39 \%$ \\
\hline 1884 & 554 & 816 & $67.89 \%$ \\
\hline \multicolumn{4}{|c|}{ No se ha encontrado información disponible del período 1885-1887 } \\
\hline 1888 & 845 & 1.287 & $65.65 \%$ \\
\hline 1889 & 761 & 1.134 & $67.10 \%$ \\
\hline 1890 & 1.073 & 1.125 & $80.98 \%$ \\
\hline 1891 & 682 & 981 & $69.52 \%$ \\
\hline 1892 & 964 & 1.355 & $71.14 \%$ \\
\hline 1893 & 1.215 & 1.564 & $77.68 \%$ \\
\hline 1894 & 1.024 & 1.393 & $73.51 \%$ \\
\hline 1895 & 768 & 1.156 & $66.43 \%$ \\
\hline 1896 & 787 & 1.089 & $72.26 \%$ \\
\hline 1897 & 960 & 1.218 & $78.81 \%$ \\
\hline 1898 & 1.320 & 1.679 & $78.61 \%$ \\
\hline
\end{tabular}

Fuente: Parliamentary Papers, Consular Reports, Ecuador.

* Las diferencias en el valor total de las exportaciones entre esta tabla y la anterior, pueden deberse a diferentes fuentes de donde se han tomado los datos. Mientras L. Carbo usa los informes de los ministros de hacienda, los cónsules británicos que mandaban estos datos, recogían su información en las casas comerciales o en la oficina de aduanas de Guayaquil. Pese a las diferencias, la tendencia es similar. Fuente: Luis Carbo: Historia Monetaria y Cambiaria del Ecuador, Banco Central del Ecuador, 1953, p. 447-448. 
Tabla 6: Cacao (1900-1909):

\begin{tabular}{|c|c|c|}
\hline Año & Producción (en Kg) & Valor(en dólares) \\
\hline $\mathbf{1 9 0 0}$ & 18.825 .000 & 10.700 .582 \\
\hline $\mathbf{1 9 0 1}$ & 23.179 .000 & 12.255 .015 \\
\hline $\mathbf{1 9 0 2}$ & 24.398 .000 & 13.230 .561 \\
\hline $\mathbf{1 9 0 3}$ & 23.005 .000 & 12.194 .537 \\
\hline $\mathbf{1 9 0 4}$ & 28.564 .000 & 15.248 .691 \\
\hline $\mathbf{1 9 0 5}$ & 21.127 .000 & 10.916 .086 \\
\hline $\mathbf{1 9 0 6}$ & 23.426 .000 & 12.198 .484 \\
\hline $\mathbf{1 9 0 7}$ & 19.703 .000 & 13.477 .656 \\
\hline $\mathbf{1 9 0 8}$ & 32.119 .000 & 17.737 .040 \\
\hline $\mathbf{1 9 0 9}$ & 31.569 .000 & 14.522 .617 \\
\hline
\end{tabular}

Fuente: Banco del Ecuador: Crónica comercial e industrial de Guayaquil en el primer siglo de la independencia, 1820-1920, La economía del Ecuador en los últimos setenta años (1906-1976), Biblioteca ecuatoriana, 1977.

Tabla 7: Cacao (1910-1919):

\begin{tabular}{|c|c|c|}
\hline Año & Producción (en Kg) & Valor (en dólares) \\
\hline $\mathbf{1 9 1 0}$ & 36.305 .192 & 16.213 .670 \\
\hline $\mathbf{1 9 1 1}$ & 38.802 .951 & 16.095 .248 \\
\hline $\mathbf{1 9 1 2}$ & 38.224 .698 & 15.715 .616 \\
\hline $\mathbf{1 9 1 3}$ & 41.869 .235 & 20.524 .340 \\
\hline $\mathbf{1 9 1 4}$ & 47.210 .017 & 20.769 .322 \\
\hline $\mathbf{1 9 1 5}$ & 37.018 .639 & 19.938 .092 \\
\hline $\mathbf{1 9 1 6}$ & 42.666 .525 & 26.235 .824 \\
\hline $\mathbf{1 9 1 7}$ & 45.123 .421 & 21.947 .234 \\
\hline $\mathbf{1 9 1 8}$ & 38.415 .640 & 17.116 .585 \\
\hline $\mathbf{1 9 1 9}$ & 44.680 .041 & 29.491 .040 \\
\hline
\end{tabular}

Fuente: Banco del Ecuador: Crónica comercial e Industrial de Guayaquil en el primer siglo de la independencia, 1820-1920, La economía del Ecuador en los últimos setenta años (1906-1976), Biblioteca ecuatoriana, 1977. 
Tabla 8: Producción café (1880-1909):

\begin{tabular}{|c|c|c|}
\hline Año & Producción (en quintales) & Valor (en dólares) \\
\hline $\mathbf{1 8 8 0}$ & 19.597 & 313.562 \\
\hline $\mathbf{1 8 8 1}$ & 14.138 & 190.862 \\
\hline $\mathbf{1 8 8 2}$ & 11.747 & 129.217 \\
\hline $\mathbf{1 8 8 3}$ & 14.694 & 161.634 \\
\hline $\mathbf{1 8 8 4}$ & 13.381 & 173.953 \\
\hline $\mathbf{1 8 8 5}$ & 18.501 & 199.809 \\
\hline $\mathbf{1 8 8 6}$ & 29.733 & 321.121 \\
\hline $\mathbf{1 8 8 7}$ & No disponible & No disponible \\
\hline $\mathbf{1 8 8 8}$ & No disponible & No disponible \\
\hline $\mathbf{1 8 8 9}$ & 23.180 & 510.848 \\
\hline
\end{tabular}

\begin{tabular}{|c|c|c|}
\hline Año & Producción (en quintales) & Valor (en dólares) \\
\hline $\mathbf{1 8 9 0}$ & 27.060 & 511.922 \\
\hline $\mathbf{1 8 9 1}$ & 28.980 & 609.061 \\
\hline $\mathbf{1 8 9 2}$ & 38.267 & 915.707 \\
\hline $\mathbf{1 8 9 3}$ & 39.640 & 1.154 .936 \\
\hline $\mathbf{1 8 9 4}$ & No disponible & No disponible \\
\hline $\mathbf{1 8 9 5}$ & 50.560 & 1.1466 .800 \\
\hline $\mathbf{1 8 9 6}$ & 40.680 & 935.640 \\
\hline $\mathbf{1 8 9 7}$ & 33.511 & 672.381 \\
\hline $\mathbf{1 8 9 8}$ & 50.620 & 656.564 \\
\hline $\mathbf{1 8 9 9}$ & 35.790 & 426.572 \\
\hline
\end{tabular}

\begin{tabular}{|c|c|c|}
\hline Año & Producción (en quintales) & Valor (en dólares) \\
\hline $\mathbf{1 9 0 0}$ & 45.999 & 474.911 \\
\hline $\mathbf{1 9 0 1}$ & 43.041 & 648.829 \\
\hline $\mathbf{1 9 0 2}$ & 69.063 & 900.867 \\
\hline $\mathbf{1 9 0 3}$ & 52.844 & 672.868 \\
\hline $\mathbf{1 9 0 4}$ & 69.793 & 1.014 .596 \\
\hline $\mathbf{1 9 0 5}$ & 44.153 & 792.040 \\
\hline
\end{tabular}




\begin{tabular}{|c|c|c|}
\hline $\mathbf{1 9 0 6}$ & 53.140 & 931.369 \\
\hline $\mathbf{1 9 0 7}$ & 22.866 & 390.740 \\
\hline $\mathbf{1 9 0 8}$ & 74.438 & 1.041 .839 \\
\hline $\mathbf{1 9 0 9}$ & 73.470 & 1.056 .949 \\
\hline
\end{tabular}

Fuente: Banco del Ecuador: Crónica comercial e Industrial de Guayaquil en el primer siglo de la independencia, 1820-1920, La economía del Ecuador en los últimos setenta años (1906-1976), Biblioteca ecuatoriana, 1977. 
Tabla 9: Producción Caucho (1880-1909):

\begin{tabular}{|c|c|c|}
\hline Año & Producción (en quintales) & Valor (en dólares) \\
\hline $\mathbf{1 8 8 0}$ & 7.996 & 439.758 \\
\hline $\mathbf{1 8 8 1}$ & 8.715 & 488.054 \\
\hline $\mathbf{1 8 8 2}$ & 9.034 & 632.380 \\
\hline $\mathbf{1 8 8 3}$ & 6.126 & 428.820 \\
\hline $\mathbf{1 8 8 4}$ & 3.995 & 199.750 \\
\hline $\mathbf{1 8 8 5}$ & 4.272 & 82.033 \\
\hline $\mathbf{1 8 8 6}$ & 8.730 & 387.066 \\
\hline $\mathbf{1 8 8 7}$ & No disponible & No disponible \\
\hline $\mathbf{1 8 8 8}$ & No disponible & No disponible \\
\hline $\mathbf{1 8 8 9}$ & 5.600 & 262.207 \\
\hline
\end{tabular}

\begin{tabular}{|c|c|c|}
\hline Año & Producción (en quintales) & Valor (en dólares) \\
\hline $\mathbf{1 8 9 0}$ & 7.700 & 382.435 \\
\hline $\mathbf{1 8 9 1}$ & 8.320 & 415.767 \\
\hline $\mathbf{1 8 9 2}$ & 8.340 & 220.403 \\
\hline $\mathbf{1 8 9 3}$ & 7.080 & 200.770 \\
\hline $\mathbf{1 8 9 4}$ & No disponible & No disponible \\
\hline $\mathbf{1 8 9 5}$ & No disponible & No disponible \\
\hline $\mathbf{1 8 9 6}$ & No disponible & No disponible \\
\hline $\mathbf{1 8 9 7}$ & 10.160 & 867.439 \\
\hline $\mathbf{1 8 9 8}$ & 8.800 & 772.919 \\
\hline $\mathbf{1 8 9 9}$ & 13.151 & 133.369 \\
\hline
\end{tabular}

\begin{tabular}{|c|c|c|}
\hline Año & Producción (en quintales) & Valor (en dólares) \\
\hline $\mathbf{1 9 0 0}$ & 10.031 & 1.076 .068 \\
\hline $\mathbf{1 9 0 1}$ & 6.477 & 571.192 \\
\hline $\mathbf{1 9 0 2}$ & 7.896 & 695.690 \\
\hline $\mathbf{1 9 0 3}$ & 9.896 & 1.073 .061 \\
\hline $\mathbf{1 9 0 4}$ & 10.381 & 1.125 .075 \\
\hline $\mathbf{1 9 0 5}$ & 10.733 & 1.500 .473 \\
\hline
\end{tabular}




\begin{tabular}{|c|c|c|}
\hline $\mathbf{1 9 0 6}$ & 12.650 & 1.546 .189 \\
\hline $\mathbf{1 9 0 7}$ & 9.579 & 1.306 .024 \\
\hline $\mathbf{1 9 0 8}$ & 8.046 & 843.522 \\
\hline $\mathbf{1 9 0 9}$ & 11.046 & 1.540 .668 \\
\hline
\end{tabular}

Fuente: Banco del Ecuador: Crónica comercial e Industrial de Guayaquil en el primer siglo de la independencia, 1820-1920, La economía del Ecuador en los últimos setenta años (1906-1976), Biblioteca ecuatoriana, 1977. 
Tabla 10: Exportaciones generales (1900-1909):

\begin{tabular}{|c|c|}
\hline Año & Exportaciones (en dólares) \\
\hline $\mathbf{1 9 0 0}$ & 15.419 .220 \\
\hline $\mathbf{1 9 0 1}$ & 16.393 .155 \\
\hline $\mathbf{1 9 0 2}$ & 18.106 .038 \\
\hline $\mathbf{1 9 0 3}$ & 18.626 .354 \\
\hline $\mathbf{1 9 0 4}$ & 23.284 .193 \\
\hline $\mathbf{1 9 0 5}$ & 18.565 .668 \\
\hline $\mathbf{1 9 0 6}$ & 21.964 .714 \\
\hline $\mathbf{1 9 0 7}$ & 22.906954 \\
\hline $\mathbf{1 9 0 8}$ & 26.559 .207 \\
\hline
\end{tabular}

Fuente: Banco del Ecuador: Crónica comercial e Industrial de Guayaquil en el primer siglo de la independencia, 1820-1920, La economía del Ecuador en los últimos setenta años (1906-1976), Biblioteca ecuatoriana, 1977.

Tabla 11: Exportaciones generales (1910-1919):

\begin{tabular}{|c|c|}
\hline Año & Exportaciones (en dólares) \\
\hline $\mathbf{1 9 1 0}$ & 28.062 .363 \\
\hline $\mathbf{1 9 1 1}$ & 26.115 .714 \\
\hline $\mathbf{1 9 1 2}$ & 28.168 .099 \\
\hline $\mathbf{1 9 1 3}$ & 32.488 .410 \\
\hline $\mathbf{1 9 1 4}$ & 26.875 .650 \\
\hline $\mathbf{1 9 1 5}$ & 26.533 .064 \\
\hline $\mathbf{1 9 1 6}$ & 36.151 .629 \\
\hline $\mathbf{1 9 1 7}$ & 33.558 .014 \\
\hline $\mathbf{1 9 1 8}$ & 27.499 .535 \\
\hline $\mathbf{1 9 1 9}$ & 43.220 .558 \\
\hline
\end{tabular}

Fuente: Banco del Ecuador: Crónica comercial e Industrial de Guayaquil en el primer siglo de la independencia, 1820-1920, La economía del Ecuador en los últimos setenta años (1906-1976), Biblioteca ecuatoriana, 1977. 
Tabla 12: Principales socios comerciales del Ecuador: Importaciones y exportaciones (1889):

\begin{tabular}{|c|c|c|c|c|}
\hline \multirow{2}{*}{ PAIS } & \multicolumn{2}{|c|}{ IMPORTACIONES } & \multicolumn{2}{c|}{ EXPORTACIONES } \\
\cline { 2 - 5 } & Valor declarado & Derechos & Valor declarado & Derechos \\
\hline Alemania & $1.331 .248,66$ & $285.998,17$ & $1.222 .969,62$ & $40.266,26$ \\
\hline Colombia & $423.679,61$ & $17.105,20$ & $351.063,40$ & $4.064,93$ \\
\hline Chile & $845.277,84$ & $106.706,88$ & $349.096,21$ & $2.922,16$ \\
\hline España & $273.270,97$ & $76.044,03$ & $1.671 .829,50$ & $26.995,01$ \\
\hline Francia & $1.989 .426,26$ & $445.249,69$ & $1.944 .534,79$ & $20.896,75$ \\
\hline Inglaterra & $2.350 .500,71$ & $435.877,71$ & $1.275 .145,79$ & $21.304,62$ \\
\hline N. América & $377.522,73$ & $384.389,71$ & $731.097,36$ & $20.091,68$ \\
\hline Perú & $740.331,56$ & $75.292,29$ & $173.074,58$ & $3.943,71$ \\
\hline Otros (*) & $250.127,47$ & $50.298,28$ & $191.798,96$ & $2.081,73$ \\
\hline Total & $\mathbf{9 . 6 8 1 . 4 5 5 , 8 1}$ & $\mathbf{1 . 8 7 6 . 9 6 1 , 7 9}$ & $\mathbf{7 . 9 1 0 . 2 1 0 , 2 1}$ & $\mathbf{1 4 2 . 5 6 6 , 8 5}$ \\
\hline & & & & \\
\hline
\end{tabular}

(*) Esta partida incluye Bélgica, Cuba, China, Holanda, Italia, Suiza, Argentina, Centroamérica, México y Uruguay.

Fuente: La Nación, Guayaquil, 25 de septiembre de 1890, no. 3382. 
Tabla 13: Exportaciones de cacao (1900-1925):

\begin{tabular}{|c|c|c|c|c|}
\hline Año & Kilos & Valor (sucres) & Valor (dólares) & $\begin{array}{c}\% \text { Total } \\
\text { exportaciones }\end{array}$ \\
\hline 1900 & 18.791 & 10.908 & 5.321 & 70,7 \\
\hline 1901 & 23.179 & 12.255 & 6.007 & 74,8 \\
\hline 1902 & 24.398 & 13.231 & 6.583 & 73,1 \\
\hline 1903 & 23.005 & 12.195 & 6.128 & 65,5 \\
\hline 1904 & 28.564 & 15.249 & 7.780 & 65,5 \\
\hline 1905 & 21.127 & 10.916 & 5.656 & 58,7 \\
\hline 1906 & 23.426 & 12.198 & 6.386 & 55,5 \\
\hline 1907 & 19.703 & 13.478 & 6.543 & 58,8 \\
\hline 1908 & 32.119 & 17.737 & 8.250 & 66,8 \\
\hline 1909 & 31.570 & 14.523 & 6.982 & 58,4 \\
\hline 1910 & 36.305 & 16.214 & 7.721 & 57,8 \\
\hline 1911 & 38.803 & 16.095 & 8.088 & 61,3 \\
\hline 1912 & 38.225 & 15.716 & 7.413 & 55,8 \\
\hline 1913 & 41.869 & 20.524 & 9.546 & 63,2 \\
\hline 1914 & 47.210 & 20.769 & 9.985 & 77,3 \\
\hline 1915 & 37.019 & 19.938 & 8.981 & 75,1 \\
\hline 1916 & 42.667 & 26.236 & 11.301 & 72,6 \\
\hline 1917 & 45.193 & 21.947 & 8.779 & 65,4 \\
\hline 1918 & 38.416 & 17.116 & 7.102 & 62,2 \\
\hline 1919 & 44.680 & 29.491 & 13.911 & 68,2 \\
\hline 1920 & 39.790 & 35.573 & 15.810 & 71,3 \\
\hline
\end{tabular}




\begin{tabular}{|c|c|c|c|c|}
\hline $\mathbf{1 9 2 1}$ & 40.709 & 20.363 & 5.518 & 60,0 \\
\hline $\mathbf{1 9 2 2}$ & 40.361 & 30.241 & 7.287 & 65,6 \\
\hline $\mathbf{1 9 2 3}$ & $\mathbf{2 9 . 5 6 4}$ & $\mathbf{1 8 . 8 9 0}$ & $\mathbf{4 . 9 7 1}$ & 49,2 \\
\hline $\mathbf{1 9 2 4}$ & 30.505 & 32.240 & 6.072 & 49,4 \\
\hline $\mathbf{1 9 2 5}$ & 32.281 & 33.986 & 7.742 & 46,2 \\
\hline
\end{tabular}

Fuente: L. A. Rodríguez: The search for public policy. Regional politics and government finances in Ecuador, 1830-1940, University of California Press, Bekerley, 1985, p.191.

L. J. Weinman: Ecuador and cacao: domestic responses to the boom-collapse monoexport cycle, University of California, Los Angeles, 1970, p. 360.

L. A. Carbo: Historia monetaria y cambiaria del Ecuador, Banco Central del Ecuador, Quito, 1953, p. 68. 
Tabla 14: Casas exportadoras más importantes (1905):

\begin{tabular}{|c|c|}
\hline NOMBRE DE LA FIRMA & HACENDADOS \\
\hline Aspiazu y Hnos. & Sí \\
\hline Caamaño Jijón Cia. & Sí \\
\hline Higgins Calderón & Sí \\
\hline López y Guzmán & $?$ \\
\hline Orrantia y Cia. & Sí \\
\hline Pareja y Vernaza & $?$ \\
\hline Reyre Hnos y Cia. & $?$ \\
\hline Rhode y Cia. & $?$ \\
\hline Sánchez Bruno & \\
\hline San Lucas y Cia. & \\
\hline Seminario, M.E. & \\
\hline Zeballos e Icaza & \\
\hline
\end{tabular}

Fuente: A. Norero: Equatore Moderno, vol. 1, Roma, 1908, en: Andrés Guerrero: "Los oligarcas del cacao" Corporación Editorial, agosto, 1980, p. 73. 
Tabla 15: Exportaciones desde 1900 a 1969. Promedios quinquenales en dólares precios corrientes:

\begin{tabular}{|c|c|}
\hline Quinquenio & Cantidad (millones de dólares) \\
\hline $\mathbf{1 9 0 0 - 1 9 0 4}$ & 8,9 \\
\hline $\mathbf{1 9 0 5 - 1 9 0 9}$ & 10,9 \\
\hline $\mathbf{1 9 1 0 - 1 9 1 4}$ & $\mathbf{1 3 , 9}$ \\
\hline $\mathbf{1 9 1 5 - 1 9 1 9}$ & $\mathbf{1 1 , 9}$ \\
\hline $\mathbf{1 9 2 0 - 1 9 2 4}$ & $\mathbf{1 3 , 9}$ \\
\hline $\mathbf{1 9 2 5}-1929$ & $\mathbf{7 , 1}$ \\
\hline $\mathbf{1 9 3 0 - 1 9 3 4}$ & $\mathbf{7 , 7}$ \\
\hline $\mathbf{1 9 3 5}-1939$ & 17,2 \\
\hline $\mathbf{1 9 4 0 - 1 9 4 4}$ & 35,4 \\
\hline $\mathbf{1 9 4 5 - 1 9 4 9}$ & 89 \\
\hline $\mathbf{1 9 5 0 - 1 9 5 4}$ & 127,3 \\
\hline $\mathbf{1 9 5 5 - 1 9 5 9}$ & 147,9 \\
\hline $\mathbf{1 9 6 0 - 1 9 6 4}$ & 188,4 \\
\hline $\mathbf{1 9 6 5 - 1 9 6 9}$ & \\
\hline
\end{tabular}

Fuente: Carlos Larrea: Estructura social, apropiación del excedente y desarrollo desigual en el Ecuador. Una primera aproximación, Mimeo, Quito, 1978. 
Tabla 16: Exportación de cacao (en quintales) (1877-1932):

\begin{tabular}{|c|c|}
\hline Año & Miles de quintales \\
\hline $\mathbf{1 8 7 7}$ & 214 \\
\hline $\mathbf{1 8 9 0}$ & 347 \\
\hline $\mathbf{1 8 8 6}$ & 416,5 \\
\hline $\mathbf{1 8 9 3}$ & 433,8 \\
\hline $\mathbf{1 9 0 4}$ & 613,4 \\
\hline $\mathbf{1 9 1 4}$ & 971,7 \\
\hline $\mathbf{1 9 1 6}$ & 1.079 \\
\hline $\mathbf{1 9 1 7}$ & 1098 \\
\hline $\mathbf{1 9 1 8}$ & 819,1 \\
\hline $\mathbf{1 9 1 9}$ & 826 \\
\hline $\mathbf{1 9 2 0}$ & 865 \\
\hline $\mathbf{1 9 2 1}$ & 884 \\
\hline $\mathbf{1 9 2 2}$ & 877 \\
\hline $\mathbf{1 9 3 2}$ & 247 \\
\hline
\end{tabular}

Fuente: Leopoldo Benites: Ecuador: Drama y Paradoja, edit. Libresa, 1995, p. 237 y 249. 
Tabla 17: Evolución de las importaciones por grupos de artículos (Importaciones por habitante en sucres a precios de 1937):

\begin{tabular}{|c|c|c|}
\hline Grupos de artículos & 1928-1930 & 1948-1950 \\
\hline Alimentos, bebidas, tabaco & 10.0 & 10.1 \\
\hline Productos químicos & 4.22 & 12.58 \\
\hline Piedras, vidrios y similares & 0.68 & 1.24 \\
\hline Metales y sus artefactos & 2.45 & 3.63 \\
\hline Combustibles y lubricantes & 1.84 & 2.31 \\
\hline $\begin{array}{l}\text { Papel, Cartón y sus } \\
\text { manufacturas }\end{array}$ & 18.17 & 10.61 \\
\hline Bienes duraderos de consumo & 2.09 & 2.48 \\
\hline $\begin{array}{l}\text { Aceites y grasas no } \\
\text { comestibles }\end{array}$ & 1.68 & 1.03 \\
\hline Textiles y sus manufacturas & 18.17 & 10.61 \\
\hline Cauchos y sus manufacturas & 0.74 & 0.16 \\
\hline Madera y sus manufacturas & 0.50 & 0.04 \\
\hline $\begin{array}{l}\text { Pieles, cueros y sus } \\
\text { manufacturas }\end{array}$ & 1.03 & 0.03 \\
\hline
\end{tabular}

Fuente: CEPAL: El desarrollo económico del Ecuador, México, N.U., 1954, p, 27. 
Tabla 18: Variaciones en las importaciones de textiles (en miles de sucres, a precios de 1937):

\begin{tabular}{|l|l|l|l|}
\hline & $\mathbf{1 9 2 8 - 1 9 3 0}$ & $\mathbf{1 9 4 8 - 1 9 5 0}$ & Variación \% \\
\hline Materias Primas & 2.4 & 6.2 & 158.3 \\
\hline Hilados & 2.3 & 5.3 & 130.4 \\
\hline Tejidos y cintas & 22.7 & 18.4 & -19.0 \\
\hline Confecciones & 7.1 & 3.1 & -56.3 \\
\hline Total & 34.5 & 33.0 & -4.4 \\
\hline
\end{tabular}

Fuente: CEPAL: El desarrollo económico del Ecuador, México, N.U., 1954, p. 28. 


\section{APÉNDICE DE DATOS Y ESTADÍSTICAS: CAPÍTULO 2}

Tabla 1: Diferencias en el ingreso mensual por clases sociales (1950 y 1956) (en sucres):

\begin{tabular}{|c|c|c|c|}
\hline Años & Clases propietarias & Pequeño burguesía & Clases trabajadoras \\
\hline $\mathbf{1 9 5 0}$ & $2.226,75$ & 217,20 & 111,16 \\
\hline $\mathbf{1 9 5 6}$ & $2.930,55$ & 276,98 & 142,62 \\
\hline
\end{tabular}

Fuente: Rafael Quintero, Erika Silva: Ecuador: Una nación en ciernes, Tomo II, FLACSO, Abya-Yala, 1991, p. 59.

Tabla 2: Relación de precios de intercambio y capacidad del Ecuador para importar (19281949):

\begin{tabular}{|l|l|l|l|l|l|}
\hline Periodos & $\begin{array}{l}\text { Precios de } \\
\text { exportación }\end{array}$ & $\begin{array}{l}\text { Precios de } \\
\text { importación }\end{array}$ & $\begin{array}{l}\text { Relación de } \\
\text { precios del } \\
\text { intercambio }\end{array}$ & \multicolumn{2}{|l|}{$\begin{array}{l}\text { Capacidad para importar } \\
\text { Total por habitante }\end{array}$} \\
\hline $1928-1929$ & 100.0 & 100.0 & 100.0 & 100.0 & 100.0 \\
\hline $1930-1934$ & 78.2 & 98.8 & 79.3 & 68.6 & 62.9 \\
\hline $1935-1939$ & 128.7 & 202.8 & 63.2 & 70.6 & 57.4 \\
\hline $1940-1944$ & 264.0 & 334.7 & 77.6 & 96.1 & 69.1 \\
\hline $1945-1949$ & 491.9 & 478.5 & 102.6 & 127.5 & 81.3 \\
\hline
\end{tabular}

Fuente: CEPAL: El desarrollo económico del Ecuador, México, Naciones Unidas, 1954, p. 23. 
Tabla 3: Índices de precios de productos de exportación (1927-1940):

\begin{tabular}{|c|c|c|}
\hline Años & Precios (Sucres) & Precios (Dólares) \\
\hline $\mathbf{1 9 2 7}$ & 100.0 & 100.0 \\
\hline $\mathbf{1 9 2 8}$ & 90.2 & 90.2 \\
\hline $\mathbf{1 9 2 9}$ & 87.7 & 86.9 \\
\hline $\mathbf{1 9 3 0}$ & 65.8 & 65.2 \\
\hline $\mathbf{1 9 3 1}$ & 51.7 & 51.1 \\
\hline $\mathbf{1 9 3 2}$ & 47.4 & 40.8 \\
\hline $\mathbf{1 9 3 3}$ & 49.7 & 42.8 \\
\hline $\mathbf{1 9 3 4}$ & 84.7 & 39.5 \\
\hline $\mathbf{1 9 3 5}$ & 76.9 & 36.4 \\
\hline $\mathbf{1 9 3 6}$ & 108.9 & 51.9 \\
\hline $\mathbf{1 9 3 7}$ & 148.3 & 65.6 \\
\hline $\mathbf{1 9 3 8}$ & 123.0 & 45.6 \\
\hline $\mathbf{1 9 3 9}$ & 141.3 & 52.0 \\
\hline $\mathbf{1 9 4 0}$ & 141.2 & 44.0 \\
\hline & & \\
\hline & & \\
\hline
\end{tabular}

Fuente: H. Heiman: Estadísticas de las exportaciones del Ecuador, 1940-1942 (con series históricas anteriores), Tabla 78, Quito, Ministerio de Economía, 1943-1945. 
Tabla 4: Cronología de presidencias Ecuador (1931-1948):

\begin{tabular}{|c|c|}
\hline Años & Presidentes \\
\hline 1931-1932 & $\begin{array}{l}\text { Alfredo Baquerizo } \\
\text { Moreno }\end{array}$ \\
\hline 1932 & Carlos Freile Larrea \\
\hline 1932 & $\begin{array}{l}\text { Alberto Guerrero } \\
\text { Martínez }\end{array}$ \\
\hline 1932-1933 & $\begin{array}{l}\text { Juan de Dios Martínez } \\
\text { Mera }\end{array}$ \\
\hline 1934-1935 & $\begin{array}{l}\text { José María Velasco } \\
\text { Ibarra }\end{array}$ \\
\hline $1935-1937$ & $\begin{array}{l}\text { Antonio Pons } \\
\text { Campusano }\end{array}$ \\
\hline $1937-1938$ & $\begin{array}{l}\text { Gil Alberto Enríquez } \\
\text { Gallo }\end{array}$ \\
\hline 1938-1939 & $\begin{array}{l}\text { Aurelio Mosquera } \\
\text { Narváez }\end{array}$ \\
\hline 1939 & $\begin{array}{l}\text { Carlos Alberto Arroyo } \\
\text { del Río }\end{array}$ \\
\hline 1939 & $\begin{array}{l}\text { Manuel María Borrero } \\
\text { González }\end{array}$ \\
\hline 1939-1940 & Andrés F. Córdoba \\
\hline 1940 & $\begin{array}{l}\text { Julio Enrique Moreno } \\
\text { Peñaherrera }\end{array}$ \\
\hline
\end{tabular}




\begin{tabular}{|l|l|}
\hline 1940-1944 & $\begin{array}{l}\text { Carlos Alberto Arroyo } \\
\text { del Río }\end{array}$ \\
\hline 1944 & $\begin{array}{l}\text { José María Velasco } \\
\text { Ibarra }\end{array}$ \\
\hline $1944-1947$ & $\begin{array}{l}\text { José María Velasco } \\
\text { Ibarra }\end{array}$ \\
\hline 1947 & $\begin{array}{l}\text { Cnel. Carlos } \\
\text { Mancheno Cajas }\end{array}$ \\
\hline 1947 & $\begin{array}{l}\text { Mariano Suárez } \\
\text { Veintimilla }\end{array}$ \\
\hline $1947-1948$ & $\begin{array}{l}\text { Carlos Julio } \\
\text { Arosemena Tola }\end{array}$ \\
\hline
\end{tabular}

Fuente: Universidad de Georgetown: República del Ecuador, Political database of the Americas, Center for Latin American Studies, 2009. 
Tabla 5: Exportaciones de banano, cacao y café y su participación en el total exportado (en miles de sucres):

\begin{tabular}{|c|c|c|c|c|c|c|}
\hline \multicolumn{3}{|c|}{ Banano } & \multicolumn{2}{|c|}{ Cacao } & \multicolumn{2}{|c|}{ Café } \\
\hline Años & Valor & Porcentaje & Valor & Porcentaje & Valor & Porcentaje \\
\hline 195 & 107.3 & 19.9 & 267.4 & 31.2 & 237.2 & 27.2 \\
\hline 1952 & 320.7 & 26.7 & 255.6 & 21.3 & 302.2 & 25.2 \\
\hline 1953 & 355.0 & 31.3 & 233.4 & 20.6 & 282.9 & 24.9 \\
\hline 1954 & 415.1 & 27.2 & 512,0 & 33.5 & 413.6 & 27.1 \\
\hline 1955 & 551.6 & 41.4 & 281.2 & 21.1 & 345.8 & 26.0 \\
\hline 1956 & 547.6 & 39.3 & 261.4 & 18.8 & 439.9 & 31.6 \\
\hline 1957 & 517.8 & 35.0 & 279.2 & 18.9 & 448.6 & 30.3 \\
\hline 1958 & 507.7 & 35.7 & 305.7 & 21.5 & 394.1 & 27.7 \\
\hline 1959 & 663.9 & 45.6 & 326.5 & 22.5 & 262.5 & 18.0 \\
\hline 1960 & 679.0 & 44.1 & 321.6 & 20.0 & 329.2 & 21.4 \\
\hline
\end{tabular}

Fuente: Junta Nacional de Planificación: Plan General de Desarrollo, T.I. Libro 1, Quito, 1963, p. 66 . 
Tabla 6: Ecuador: Exportaciones de banano 1948-1960 (Dólares a precios corrientes):

\begin{tabular}{|l|l|l|l|}
\hline Año & $\begin{array}{l}\text { Valor (millones de } \\
\text { \$US) }\end{array}$ & Año & $\begin{array}{l}\text { Valor (millones de } \\
\text { \$US) }\end{array}$ \\
\hline 1948 & 8.1 & $\mathbf{1 9 5 5}$ & 62.0 \\
\hline 1949 & 12.6 & $\mathbf{1 9 5 6}$ & 60.0 \\
\hline 1950 & 17.0 & $\mathbf{1 9 5 7}$ & 69.0 \\
\hline 1951 & 25.0 & $\mathbf{1 9 5 8}$ & 73.0 \\
\hline $\mathbf{1 9 5 2}$ & 44.0 & $\mathbf{1 9 5 9}$ & 90.0 \\
\hline $\mathbf{1 9 5 3}$ & 41.0 & $\mathbf{1 9 6 0}$ & 90.0 \\
\hline 1954 & 51.0 & & \\
\hline
\end{tabular}

Fuente: Carlos Larrea: Estructura social, apropiación del excedente y desarrollo desigual en el Ecuador. Una primera aproximación, Mimeo, Quito, 1978. 
Tabla 7: Composición de las exportaciones 1950-1970 (porcentajes a precios corrientes):

\begin{tabular}{|c|c|c|c|c|c|c|c|c|}
\hline Años & Agropecuario & Alimentos & Minería & Químicos & $\begin{array}{c}\text { Calzado } \\
\mathbf{y} \\
\text { vestidos }\end{array}$ & $\begin{array}{c}\text { Madera } \\
\mathbf{y} \\
\text { corcho }\end{array}$ & Otros & $\begin{array}{c}\text { Total } \\
\text { General }\end{array}$ \\
\hline $\mathbf{1 9 5 0}$ & 82,5 & 0,6 & 7,1 & 0,7 & 5,5 & 1,1 & 2,5 & 100 \\
\hline $\mathbf{1 9 5 5}$ & 93,5 & 0,2 & 2,6 & 1,0 & 1,1 & 1,1 & 0,3 & 100 \\
\hline $\mathbf{1 9 6 0}$ & 93,6 & 1,9 & 0,8 & 1,1 & 1,1 & 1,1 & 0,2 & 100 \\
\hline $\mathbf{1 9 6 5}$ & 84,5 & 8,0 & 2,2 & 2,3 & 0,5 & 1,9 & 0,6 & 100 \\
\hline $\mathbf{1 9 6 6}$ & 86,3 & 7,6 & 0,5 & 2,4 & 0,3 & 2,4 & 0,5 & 100 \\
\hline $\mathbf{1 9 6 7}$ & 87,0 & 7,3 & 0,4 & 1,8 & 0,4 & 2,7 & 0,4 & 100 \\
\hline $\mathbf{1 9 6 8}$ & 88,5 & 6,2 & 0,8 & 1,6 & 0,5 & 2,1 & 0,3 & 100 \\
\hline $\mathbf{1 9 6 9}$ & 83,5 & 9,9 & 0,9 & 2,1 & 0,7 & 2,5 & 0,4 & 100 \\
\hline $\mathbf{1 9 7 0}$ & 87,4 & 7,2 & 0,5 & 1,8 & 0,7 & 1,7 & 0,7 & 100 \\
\hline
\end{tabular}

Fuente: Anuario de Comercio Exterior y Boletines del Banco Central, tomado de: Evolución Histórica del Comercio Exterior Ecuatoriano 1950-1970, JNP. 
Tabla 8: Destino de las exportaciones (Composición Porcentual a Precios corrientes):

\begin{tabular}{|l|l|l|l|l|l|l|l|}
\hline $\begin{array}{l}\text { Países- } \\
\text { grupos } \\
\text { económicos }\end{array}$ & $\mathbf{1 9 5 0}$ & $\mathbf{1 9 5 5}$ & $\mathbf{1 9 6 0}$ & $\mathbf{1 9 6 5}$ & $\mathbf{1 9 6 8}$ & $\mathbf{1 9 6 9}$ & $\mathbf{1 9 7 0}$ \\
\hline EE.UU & 52,3 & 60,9 & 64,5 & 56,3 & 37,8 & 38,3 & 41,6 \\
\hline Japón & 0,1 & 0,1 & 1,1 & 2,1 & 12,1 & 12,4 & 17,8 \\
\hline CEE & 17,2 & 20,6 & 22,9 & 27,2 & 25,4 & 24,4 & 20,1 \\
\hline AELC & 1,01 & 3,5 & 2,2 & 2,0 & 0,6 & 0,8 & 0,8 \\
\hline ALALC $\left.*^{*}\right)$ & 19,5 & 9,3 & 7,5 & 10,2 & 8,4 & 10,4 & 10,6 \\
\hline $\begin{array}{l}\text { Otros } \\
\text { países }\left(^{* *}\right)\end{array}$ & 9,9 & 5,6 & 1,9 & 2,2 & 15,7 & 13,7 & 9,1 \\
\hline $\begin{array}{l}\text { Total } \\
\text { exportado }\end{array}$ & 100,0 & 100,0 & 100,0 & 100,0 & 100,0 & 100,0 & 100,0 \\
\hline
\end{tabular}

(*) incluye Reino Unido

(**) incluye los países socialistas

Fuente: Boletines del Banco Central y Comercio Exterior. 
Tabla 9: Principales productos de las exportaciones peruanas 1927-1950 (\% dentro del valor total):

\begin{tabular}{|l|l|l|l|l|l|l|l|l|}
\hline Productos & $\mathbf{1 9 2 7 - 2 9}$ & $\mathbf{1 9 3 0 - 3 2}$ & $\mathbf{1 9 3 3 - 3 5}$ & $\mathbf{1 9 3 6 - 3 8}$ & $\mathbf{1 9 3 9 - 4 1}$ & $\mathbf{1 9 4 2 - 4 4}$ & $\mathbf{1 9 4 5 - 4 7}$ & $\mathbf{1 9 4 8 - 5 0}$ \\
\hline $\begin{array}{l}\text { Petróleo y } \\
\text { derivados }\end{array}$ & 28,2 & 32,8 & 38,2 & 34,1 & 25,3 & 20,7 & 10,9 & 13,9 \\
\hline Algodón & 20,7 & 17,4 & 25,6 & 23,1 & 21,2 & 12,1 & 26,1 & 31,8 \\
\hline Cobre & 20,1 & 16,3 & 11,7 & 15,4 & 17,9 & 15 & 8,8 & 6 \\
\hline $\begin{array}{l}\text { Azúcar y } \\
\text { derivados }\end{array}$ & 13,5 & 13 & 9,9 & 7,9 & 11,3 & 23,7 & 30,4 & 16,8 \\
\hline Lanas & 3,5 & 3 & 3,1 & 3,8 & 4,3 & 3 & 1,8 & 3 \\
\hline Plomo & & & & & & 4,8 & 5,3 & 9,1 \\
\hline Plata & & & & & & & & 2,9 \\
\hline Zinc & & & & & & & 2,6 & 5,1 \\
\hline Pesca & & & & & & & & 2,4 \\
\hline Otros & 14 & 17,5 & 11,5 & 15,7 & 20 & 20,7 & 14,1 & 9 \\
\hline
\end{tabular}

Fuente: Dirección de Estadística del MHC, Extracto Estadístico del Perú, 1931-1933, p. 67 y 117; Anuario Estadístico del Perú 1948-1949 y Anuario Estadístico del Perú 1951. Elaboración propia. Cuando los casilleros están en blanco quiere decir que el porcentaje representado era menor al del último producto que figura en el cuadro o no figuraba en los Anuarios Estadísticos oficiales. 
Tabla 10: Exportaciones del Perú (1927-1950):

\begin{tabular}{|c|c|c|}
\hline Años & $\begin{array}{l}\text { Valor exportado (millones } \\
\text { de dólares corrientes) }\end{array}$ & $\begin{array}{l}\text { Volumen exportado (miles } \\
\text { de toneladas métricas) }\end{array}$ \\
\hline 1927 & 116,4 & 1713 \\
\hline 1928 & 315,9 & 1799 \\
\hline 1929 & 335,1 & 2157 \\
\hline 1930 & 236 & 2021 \\
\hline 1931 & 197,4 & 1708 \\
\hline 1932 & 178,5 & 1610 \\
\hline 1933 & 257 & 2124 \\
\hline 1934 & 305,1 & 2526 \\
\hline 1935 & 308,4 & 2631 \\
\hline 1936 & 335,8 & 2758 \\
\hline 1937 & 365,4 & 2776 \\
\hline 1938 & 342,1 & 2343 \\
\hline 1939 & 381,4 & 2088 \\
\hline 1940 & 405,1 & 1770 \\
\hline 1941 & 494,1 & 1977 \\
\hline 1942 & 495 & 2019 \\
\hline 1943 & 460,3 & 1957 \\
\hline 1944 & 547,3 & 1903 \\
\hline
\end{tabular}




\begin{tabular}{|c|c|c|}
\hline 1945 & 674,5 & 1893 \\
\hline 1946 & 983,6 & 1762 \\
\hline 1947 & 1002,9 & 1583 \\
\hline 1948 & 1055,8 & 1726 \\
\hline 1949 & 2107,5 & 1751 \\
\hline 1950 & 2886,8 & 1801 \\
\hline
\end{tabular}

Fuente: Ministerio de Hacienda y Comercio (1951) Anuario Estadístico del Perú 1948-1949, Lima y Ministerio de Hacienda y Comercio (1957) Anuario Estadístico del Perú 1954, Lima. 
Tabla 11: Productos principales de exportación a los EE.UU (miles de dólares corrientes):

\begin{tabular}{|c|c|c|c|c|c|c|c|}
\hline Productos & 1950 & 1955 & 1960 & 1965 & 1968 & 1969 & 1970 \\
\hline Banano & 6.174 & 25.382 & 34.244 & 29.370 & 29.694 & 19.987 & 21.919 \\
\hline Café & 10.631 & 15.730 & 13.960 & 22.625 & 17.715 & 15.790 & 33.550 \\
\hline Cacao & 12.524 & 8.820 & 12.947 & 6.599 & 9.934 & 4.276 & 7.896 \\
\hline Balsa & 619 & 804 & 931 & 1.054 & 2.466 & 2.083 & 1.277 \\
\hline $\begin{array}{l}\text { Sombreros } \\
\text { paja toquilla }\end{array}$ & 3.394 & 1.615 & 758 & 173 & 395 & 266 & 174 \\
\hline Petróleo & & 417 & & & & & \\
\hline $\begin{array}{l}\text { Ptos } \\
\text { farmacéuticos }\end{array}$ & 16 & & 2 & 10 & 33 & & \\
\hline Azúcar & & & & 7.358 & 7.111 & 10.372 & 8.036 \\
\hline Otros ptos & 2.194 & 1.906 & 3.314 & 7.085 & 6.528 & 5.711 & 6.287 \\
\hline TOTAL & 35.552 & 54.674 & 66.156 & 74.274 & 73.876 & 58.485 & 79.139 \\
\hline
\end{tabular}

Fuente: Junta Nacional de Planificación: Evolución histórica del comercio exterior ecuatoriano 1950-1970, Oficina de Publicaciones, Ecuador, 1975. 
Tabla 12: Inversión real en obras de infraestructuras y transporte 1948-1965 (millones de sucres):

\begin{tabular}{|c|c|c|c|c|c|c|}
\hline Años & $\begin{array}{c}\text { Carreteras } \\
\text { y puentes }\end{array}$ & Telecomunicaciones & $\begin{array}{c}\text { Puertos y } \\
\text { muelles }\end{array}$ & Aeropuertos & Ferrocarriles & $\begin{array}{l}\text { Vehículos } \\
\text { y equipo } \\
\text { caminero }\end{array}$ \\
\hline 1948 & 9,2 & & & & & \\
\hline 1949 & 9,4 & & & & & \\
\hline 1950 & 6,9 & 2,0 & 1,0 & 1,0 & 18,0 & 6 \\
\hline 1951 & & & & & & \\
\hline 1952 & & & & & & \\
\hline 1953 & & & & & & \\
\hline 1954 & & & & & & \\
\hline 1955 & 209,4 & 12,0 & 4,0 & 27,0 & 26,0 & 21 \\
\hline 1956 & 220,0 & & 19,0 & 26,0 & 19,0 & \\
\hline 1957 & 207,5 & & 10,0 & 14,0 & 17,0 & \\
\hline 1958 & 194,0 & 2096,0 & 10,0 & 2,0 & 9,0 & 9374 \\
\hline 1959 & 219,0 & & 35,0 & 5,0 & 2,0 & \\
\hline 1960 & 228,0 & 34,0 & 67,0 & 27,0 & 11,0 & 9 \\
\hline 1961 & 223,0 & 8,0 & 38,0 & 24,0 & 7,0 & 2 \\
\hline
\end{tabular}




\begin{tabular}{|c|c|c|c|c|c|c|}
\hline 1962 & 202,0 & 6,0 & 11,0 & & 2,0 & \\
\hline 1963 & 117,0 & 82,3 & 23,0 & 8,0 & 1,0 & 2 \\
\hline 1964 & 161,0 & 86,4 & 21,0 & 7,0 & 3,0 & 8 \\
\hline 1965 & 234,0 & 138,7 & 27,0 & 19,0 & & 11 \\
\hline
\end{tabular}

Fuente: Patricio Almeida Guzmán y Rebeca Almeida Arroba: Estadísticas económicas históricas (1948-1983), Fuentes para la Historia Económica del Ecuador. Serie Estadísticas Históricas Vol. 1. Banco Central del Ecuador, Quito, 1988, p. 333. 
Tablas 13: Socios comerciales del Ecuador (1950-1965):

Exportaciones por paises compradores 1950-1965 (Miles de dólares FOB)

\begin{tabular}{|r|r|r|r|r|r|}
\hline Aíos & $\begin{array}{l}\text { Estados } \\
\text { Unidos }\end{array}$ & Canadí & \multicolumn{1}{l|}{ Colombia } & \multicolumn{1}{l|}{ Crile } & Venerzela \\
\hline 1950 & 38559 & 590 & 4083 & 928 & 1949 \\
\hline 1951 & 33881 & 585 & 3955 & 1471 & 317 \\
\hline 1952 & 43146 & 520 & 4688 & 1013 & 159 \\
\hline 1953 & 47244 & 505 & 5175 & 1287 & 108 \\
\hline 1954 & 64345 & 472 & 7980 & 1630 & 235 \\
\hline 1955 & 52969 & 173 & 5885 & 1252 & 108 \\
\hline 1956 & 55460 & 367 & 4762 & 1210 & 53 \\
\hline 1957 & 56544 & 275 & 6581 & 1623 & 79 \\
\hline 1958 & 55231 & 222 & 4379 & 2206 & 3268 \\
\hline 1959 & 58044 & 76 & 5016 & 2124 & 1847 \\
\hline 1960 & 66157 & 195 & 2416 & 2008 & 2885 \\
\hline 1961 & 57258 & 124 & 4313 & 2493 & 613 \\
\hline 1962 & 76196 & 142 & 3107 & 2263 & 36 \\
\hline 1963 & 72909 & 128 & 4242 & 2087 & 37 \\
\hline 1964 & 59814 & 665 & 6965 & 2224 & 31 \\
\hline 1965 & 67425 & 51 & 5875 & 3526 & 36 \\
\hline
\end{tabular}

Fuente: Patricio Almeida y Rebeca Almeida: "Estadisticas económicas históricas (1948-1983)". Banco Central, 1984 
Tabla 14: Socios comerciales del Ecuador (1950-1965)

Exportaciones por paises compradores 1950-1965 (Miles de doblares FOB)

\begin{tabular}{|r|r|r|l|r|r|r|}
\hline \multicolumn{1}{|l|}{ Años } & \multicolumn{1}{|l|}{ Suiza } & Italia & Anstria & \multicolumn{1}{c|}{ Suecia } & Holanda & España \\
\hline 1950 & 26 & 5556 & & 33 & 1022 & 184 \\
\hline 1951 & 71 & 3235 & & 54 & 395 & 91 \\
\hline 1952 & 124 & 8237 & & 220 & 309 & 10 \\
\hline 1953 & 102 & 2532 & & 485 & 918 & 72 \\
\hline 1954 & 93 & 3124 & & 1299 & 1884 & 67 \\
\hline 1955 & 174 & 3221 & & 2439 & & 560 \\
\hline 1956 & 193 & 4252 & & 1289 & 2061 & 54 \\
\hline 1957 & 448 & 4749 & & 1097 & 1213 & 237 \\
\hline 1958 & 716 & 3972 & & 1783 & 1103 & 891 \\
\hline 1959 & 945 & 3988 & & 344 & 2243 & 29 \\
\hline 1960 & 677 & 2950 & 178 & 752 & 3140 & 60 \\
\hline 1961 & 1090 & 2414 & 35 & 890 & 2937 & 86 \\
\hline 1962 & 1011 & 2558 & 291 & 709 & 2856 & 75 \\
\hline 1963 & 486 & 2517 & 132 & 1366 & 4018 & 349 \\
\hline 1964 & 172 & 2666 & 3 & 729 & 4916 & 556 \\
\hline 1965 & 576 & 3876 & 204 & 816 & 5702 & 628 \\
\hline
\end{tabular}

Fuente: Patricio Almeida y Rebeca Almeida: "Estadisticas económicas históricas (1948-1983) "(1948-1983)". Banco Central, 1984. 
Tabla 15: Socios comerciales del Ecuador (1950-1965)

Exportaciones por paises compradores 1950-1965

(Miles de dólares FOB)

\begin{tabular}{|r|r|r|r|r|r|r|}
\hline \multicolumn{1}{|l|}{ Aiios } & Hongria & Yogoslania & Bélgica & Francia & Pinamarca & Finlandia \\
\hline 1950 & & & 2181 & 468 & 15 & \\
\hline 1951 & & & 2132 & 1309 & 22 & 3 \\
\hline 1952 & 54 & & 2883 & 937 & 20 & 4 \\
\hline 1953 & & & 1901 & 807 & 300 & \\
\hline 1954 & & & 4515 & 1483 & 9 & \\
\hline 1955 & & & 3795 & 1965 & 107 & \\
\hline 1956 & & & 3694 & 1366 & 156 & 13 \\
\hline 1957 & & & 4217 & 1595 & 117 & 1 \\
\hline 1958 & & & 4448 & 1499 & 74 & \\
\hline 1959 & 10 & 28 & 4330 & 1343 & 162 & 25 \\
\hline 1960 & & & 4013 & 2561 & 212 & 54 \\
\hline 1961 & & & 4018 & 2637 & 194 & 38 \\
\hline 1962 & & & 5432 & 2160 & 237 & 60 \\
\hline 1963 & & & 5709 & 2469 & 156 & 63 \\
\hline 1964 & & & 7038 & 2633 & 156 & 91 \\
\hline 1965 & & & 6078 & 2715 & 186 & 104 \\
\hline
\end{tabular}

Fuente: Patricio Almeida y Rebeca Almeida: "Estadisticas económicas

históricas (1948-1983)". Banco Central, 1984. 
Tabla 16: Deuda externa por sector público (millones de dólares):

\begin{tabular}{|c|c|c|c|c|c|}
\hline Años & $\begin{array}{c}\text { Total sector } \\
\text { público }\end{array}$ & Años & $\begin{array}{c}\text { Total sector } \\
\text { público }\end{array}$ & Años & $\begin{array}{c}\text { Total sector } \\
\text { público }\end{array}$ \\
\hline $\mathbf{1 9 4 8}$ & 39,3 & $\mathbf{1 9 5 8}$ & 34,1 & $\mathbf{1 9 6 8}$ & \\
\hline $\mathbf{1 9 4 9}$ & 39,3 & $\mathbf{1 9 5 9}$ & 31,2 & $\mathbf{1 9 6 9}$ & 200,7 \\
\hline $\mathbf{1 9 5 0}$ & 41,6 & $\mathbf{1 9 6 0}$ & 28,1 & $\mathbf{1 9 7 0}$ & 230,0 \\
\hline $\mathbf{1 9 5 1}$ & 41,9 & $\mathbf{1 9 6 1}$ & 103,4 & $\mathbf{1 9 7 1}$ & 249,8 \\
\hline $\mathbf{1 9 5 2}$ & 43,0 & $\mathbf{1 9 6 2}$ & 114,7 & $\mathbf{1 9 7 2}$ & 328,0 \\
\hline $\mathbf{1 9 5 3}$ & 38,6 & $\mathbf{1 9 6 3}$ & 114,3 & $\mathbf{1 9 7 3}$ & 363,0 \\
\hline $\mathbf{1 9 5 4}$ & 39,7 & $\mathbf{1 9 6 4}$ & 119,0 & $\mathbf{1 9 7 4}$ & 376,0 \\
\hline $\mathbf{1 9 5 5}$ & 40,5 & $\mathbf{1 9 6 5}$ & 130,7 & $\mathbf{1 9 7 5}$ & 365,0 \\
\hline $\mathbf{1 9 5 6}$ & 38,6 & $\mathbf{1 9 6 6}$ & 149,7 & $\mathbf{1 9 7 6}$ & 540,0 \\
\hline $\mathbf{1 9 5 7}$ & 36,5 & $\mathbf{1 9 6 7}$ & 171,1 & $\mathbf{1 9 7 7}$ & 1237,0 \\
\hline & & & & & \\
\hline
\end{tabular}

Fuente: Patricio Almeida Guzmán y Rebeca Almeida Arroba: Estadísticas económicas históricas (1948-1983), Fuentes para la Historia Económica del Ecuador, Serie Estadísticas Históricas Vol. 1. Banco Central del Ecuador, Quito, 1988, p 466. 
Tabla 17: Exportaciones de banano y plátano en el Ecuador (1927-1947) (Miles de dólares FOB):

\begin{tabular}{|c|c|c|c|c|c|}
\hline Años & $\begin{array}{c}\text { Miles de } \\
\text { dólares FOB }\end{array}$ & Años & $\begin{array}{c}\text { Miles de } \\
\text { dólares FOB }\end{array}$ & Años & $\begin{array}{c}\text { Miles de } \\
\text { dólares FOB }\end{array}$ \\
\hline $\mathbf{1 9 2 7}$ & 144 & $\mathbf{1 9 3 4}$ & 258 & $\mathbf{1 9 4 1}$ & 291 \\
\hline $\mathbf{1 9 2 8}$ & 143 & $\mathbf{1 9 3 5}$ & 303 & $\mathbf{1 9 4 2}$ & 208 \\
\hline $\mathbf{1 9 2 9}$ & 133 & $\mathbf{1 9 3 6}$ & 186 & $\mathbf{1 9 4 3}$ & 154 \\
\hline $\mathbf{1 9 3 0}$ & 154 & $\mathbf{1 9 3 7}$ & 517 & $\mathbf{1 9 4 4}$ & 135 \\
\hline $\mathbf{1 9 3 1}$ & 91 & $\mathbf{1 9 3 8}$ & 563 & $\mathbf{1 9 4 5}$ & 211 \\
\hline $\mathbf{1 9 3 2}$ & 40 & $\mathbf{1 9 3 9}$ & 483 & $\mathbf{1 9 4 6}$ & 551 \\
\hline $\mathbf{1 9 3 3}$ & 55 & $\mathbf{1 9 4 0}$ & 413 & $\mathbf{1 9 4 7}$ & 1730 \\
\hline
\end{tabular}

Fuente: Carlos Larrea: El banano en el Ecuador, Corporación Editora Nacional, 1997

Tabla 18: Producto interior bruto del Ecuador (1927-1947):

\begin{tabular}{|c|c|c|c|c|c|}
\hline Años & $\begin{array}{c}\text { Millones de } \\
\text { dólares }\end{array}$ & Años & $\begin{array}{c}\text { Millones de } \\
\text { dólares }\end{array}$ & Años & $\begin{array}{c}\text { Millones de } \\
\text { dólares }\end{array}$ \\
\hline $\mathbf{1 9 2 7}$ & 79 & $\mathbf{1 9 3 4}$ & 96 & $\mathbf{1 9 4 1}$ & 168 \\
\hline $\mathbf{1 9 2 8}$ & 83 & $\mathbf{1 9 3 5}$ & 98 & $\mathbf{1 9 4 2}$ & 183 \\
\hline $\mathbf{1 9 2 9}$ & 87 & $\mathbf{1 9 3 6}$ & 102 & $\mathbf{1 9 4 3}$ & 228 \\
\hline $\mathbf{1 9 3 0}$ & 91 & $\mathbf{1 9 3 7}$ & 105 & $\mathbf{1 9 4 4}$ & 273 \\
\hline $\mathbf{1 9 3 1}$ & 91 & $\mathbf{1 9 3 8}$ & 109 & $\mathbf{1 9 4 5}$ & 280 \\
\hline $\mathbf{1 9 3 2}$ & 92 & $\mathbf{1 9 3 9}$ & 113 & $\mathbf{1 9 4 6}$ & 323 \\
\hline $\mathbf{1 9 3 3}$ & 94 & $\mathbf{1 9 4 0}$ & 148 & $\mathbf{1 9 4 7}$ & 360 \\
\hline
\end{tabular}

Fuente: Banco Central del Ecuador: Setenta años de información estadística 1927-1997, 1997. 
Tabla 19: Producto Interior Bruto del Ecuador (1948-1965):

\begin{tabular}{|c|c|c|c|c|c|}
\hline Años & $\begin{array}{c}\text { Millones de } \\
\text { dólares }\end{array}$ & Años & $\begin{array}{c}\text { Millones de } \\
\text { dólares }\end{array}$ & Años & $\begin{array}{c}\text { Millones de } \\
\text { dólares }\end{array}$ \\
\hline $\mathbf{1 9 4 8}$ & 460 & $\mathbf{1 9 5 4}$ & 692 & $\mathbf{1 9 6 0}$ & 938 \\
\hline $\mathbf{1 9 4 9}$ & 492 & $\mathbf{1 9 5 5}$ & 734 & $\mathbf{1 9 6 1}$ & 907 \\
\hline $\mathbf{1 9 5 0}$ & 535 & $\mathbf{1 9 5 6}$ & 749 & $\mathbf{1 9 6 2}$ & 888 \\
\hline $\mathbf{1 9 5 1}$ & 517 & $\mathbf{1 9 5 7}$ & 799 & $\mathbf{1 9 6 3}$ & 966 \\
\hline $\mathbf{1 9 5 2}$ & 588 & $\mathbf{1 9 5 8}$ & 826 & $\mathbf{1 9 6 4}$ & 1075 \\
\hline $\mathbf{1 9 5 3}$ & 623 & $\mathbf{1 9 5 9}$ & 864 & $\mathbf{1 9 6 5}$ & 1151 \\
\hline
\end{tabular}

Fuente: Banco Central del Ecuador: Setenta años de información estadística 1927-1997,1997. 
Tabla 20: PIB por clase de actividad económica (1950-1954):

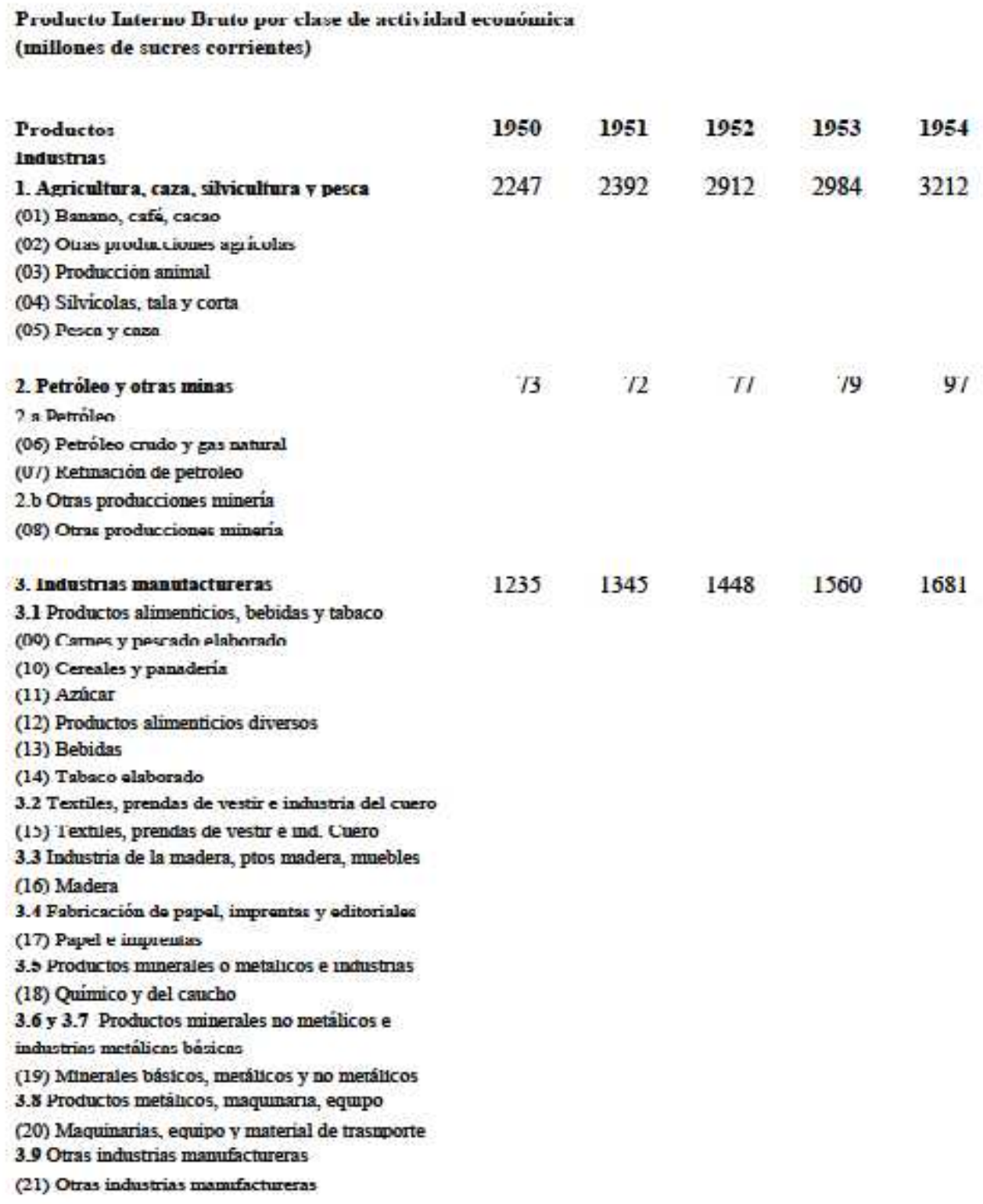

Fuente: Patricio Almeida Guzmán y Rebeca Almeida Arroba: Estadísticas económicas históricas (1948-1983), Fuentes para la Historia Económica del Ecuador, Serie Estadísticas Históricas Vol. 1. Banco Central del Ecuador, Quito, 1988, p. 53-70. 
Tabla 21: PIB por clase de actividad económica (1955-1959):

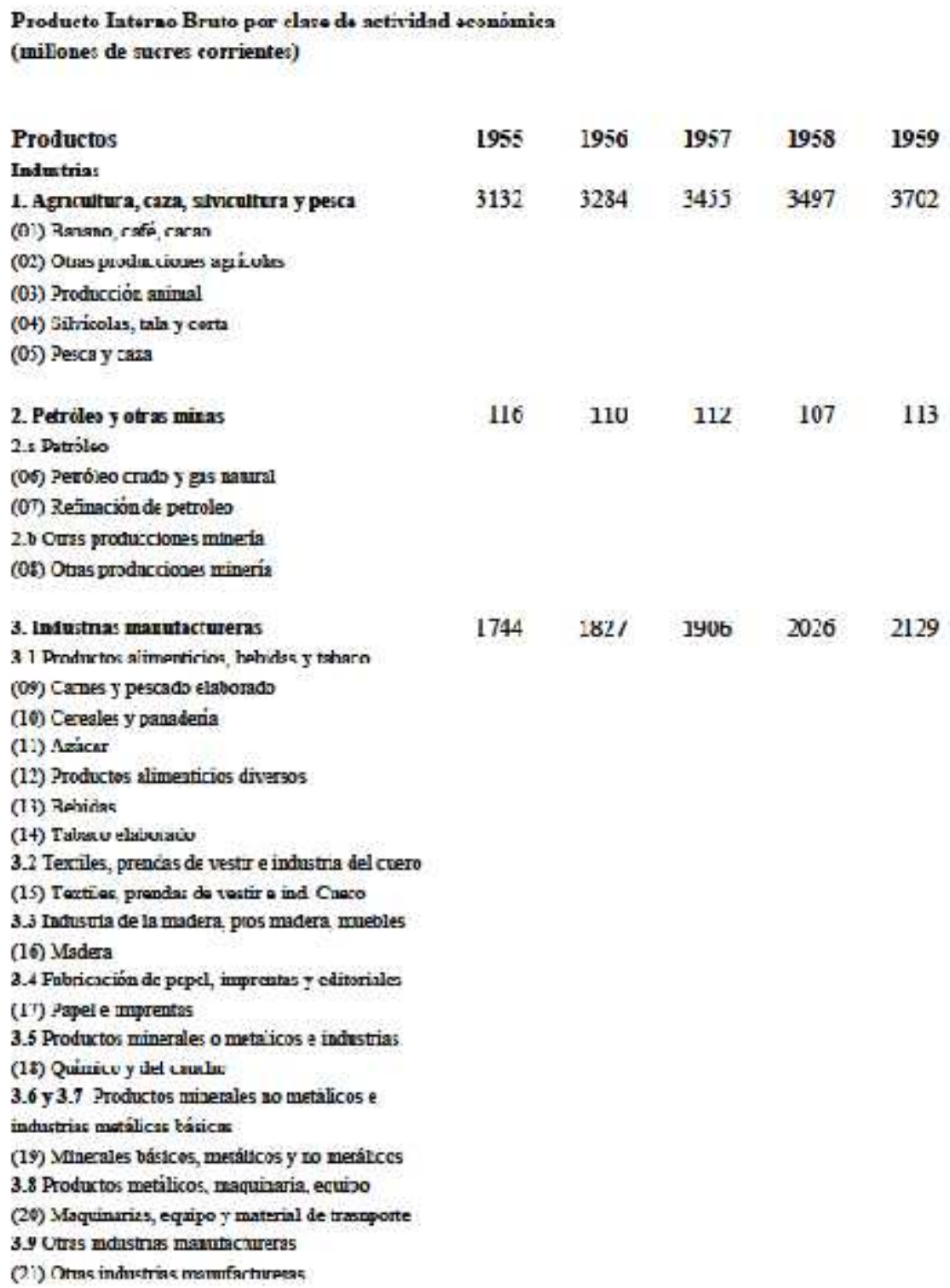

$\begin{array}{lllll}116 & 110 \quad 112 & 107 & 113\end{array}$

1906

Fuente: Patricio Almeida Guzmán y Rebeca Almeida Arroba: Estadísticas económicas históricas (1948-1983), Fuentes para la Historia Económica del Ecuador, Serie Estadísticas Históricas Vol. 1, Banco Central del Ecuador, Quito, 1988, p. 53-70. 
Tabla 22: PIB por clase de actividad económica (1960-1964):

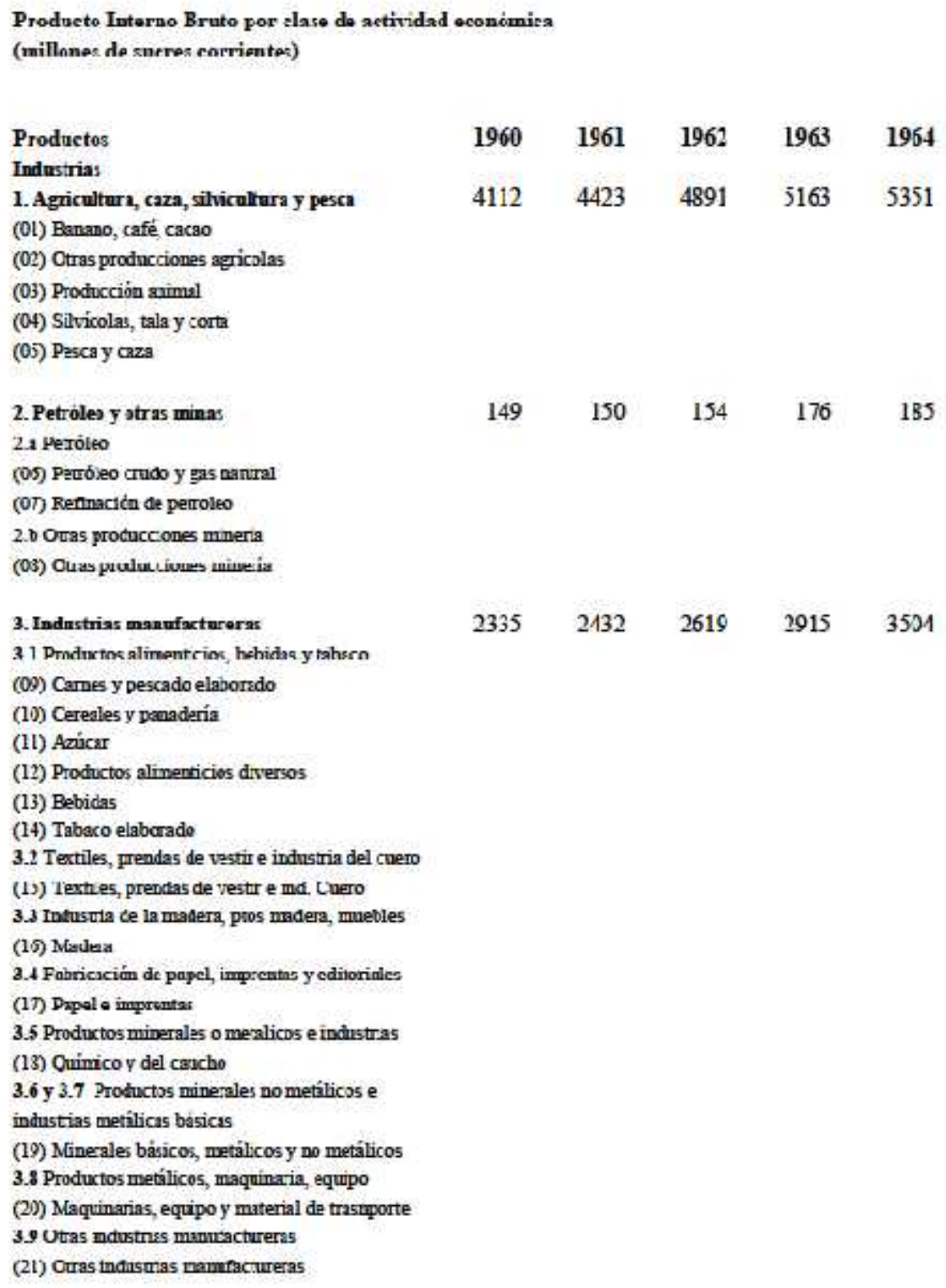

Fuente: Patricio Almeida Guzmán y Rebeca Almeida Arroba: Estadísticas económicas históricas (1948-1983), Fuentes para la Historia Económica del Ecuador, Serie Estadísticas Históricas Vol. 1, Banco Central del Ecuador, Quito, 1988, p. 53-70. 
Tabla 23: Valor de las exportaciones del banano (1948- 1965) (miles de dólares):

\begin{tabular}{|c|c|c|c|}
\hline Años & $\begin{array}{c}\text { Banano (miles de } \\
\text { dólares FOB) }\end{array}$ & Años & $\begin{array}{c}\text { Banano (miles de } \\
\text { dólares FOB) }\end{array}$ \\
\hline 1948 & $2.761,2$ & 1957 & $34.520,2$ \\
\hline 1949 & $4.944,2$ & 1958 & $33.848,3$ \\
\hline 1950 & $7.854,3$ & 1959 & $44.260,9$ \\
\hline 1951 & $11.252,0$ & 1960 & $45.266,7$ \\
\hline 1952 & $21.379,5$ & 1961 & $48.005,0$ \\
\hline 1953 & $23.674,0$ & 1962 & $62.305,5$ \\
\hline 1954 & $27.671,1$ & 1963 & $67.833,0$ \\
\hline 1955 & $36.760,5$ & 1964 & $68.951,0$ \\
\hline 1956 & $36.505,3$ & 1965 & $51.000,0$ \\
\hline
\end{tabular}

Fuente: Patricio Almeida Guzmán, Rebeca Almeida Arroba: Estadísticas económicas históricas (1948-1983), Fuentes para la Historia Económica del Ecuador. Serie Estadísticas Históricas Vol. 1, Banco Central del Ecuador, Quito, 1988, p.482. 
Tabla 24: Estimaciones de la producción, exportación del banano (1948-1965) (miles de toneladas métricas):

\begin{tabular}{|c|c|c|}
\hline \multirow[t]{2}{*}{ Años } & \multicolumn{2}{|c|}{ Banano } \\
\hline & Producción & Exportación \\
\hline 1948 & & 99,6 \\
\hline 1949 & & 138,8 \\
\hline 1950 & 571,4 & 197,7 \\
\hline 1951 & 595,5 & 287,2 \\
\hline 1952 & 676,9 & 500,8 \\
\hline 1953 & 706 & 473,5 \\
\hline 1954 & $1.686,3$ & 585,4 \\
\hline 1955 & $1.872,8$ & 716,6 \\
\hline 1956 & 1953 & 687,8 \\
\hline 1957 & $1.668,7$ & 793,8 \\
\hline 1958 & $1.754,7$ & 829,1 \\
\hline 1959 & $1.897,5$ & 1051 \\
\hline 1960 & $2.075,2$ & $1.062,3$ \\
\hline 1961 & $2.050,4$ & 997,0 \\
\hline 1962 & $2.114,9$ & 897,8 \\
\hline 1963 & 2544 & 1.342 \\
\hline 1964 & & \\
\hline 1965 & $2.220,99$ & 822,8 \\
\hline
\end{tabular}

Fuente: Patricio Almeida Guzmán, Rebeca Almeida Arroba: Estadísticas económicas históricas (1948-1983), Fuentes para la Historia Económica del Ecuador, Serie Estadísticas Históricas Vol. 1. Banco Central del Ecuador, Quito, 1988, p. 482. 
Tabla 25: Ecuador: Entradas de capital extranjero. Promedios y cifras anuales en millones de dólares estadounidenses (1951-1965):

\begin{tabular}{|c|c|c|c|}
\hline Períodos y años & Préstamos recibidos & Inversiones directas & Total entradas \\
\hline $1951-1955$ & 6.5 & 3.1 & 9.6 \\
\hline $1956-1960$ & 14.3 & 7.3 & 21.6 \\
\hline $1961-1965$ & 18.7 & 6.6 & 25.3 \\
\hline
\end{tabular}

Fuente: Fondo Monetario Internacional: Balance of Payments Yearbooks (grabación en cinta magnética), Estudios e Informes de la CEPAL: "La presencia de las empresas transnacionales en la economía ecuatoriana", Naciones Unidas, Santiago de Chile, 1984, p. 13. 
Tabla 26: Exportación total por rama de actividad (1948-1955) (miles de dólares F.O.B):

\begin{tabular}{|c|c|c|c|c|c|c|c|c|}
\hline Bienes & 1948 & 1949 & 1950 & 1951 & 1952 & 1953 & 1954 & 1955 \\
\hline \multicolumn{9}{|l|}{ PRIMARIOS } \\
\hline Arroz & $13.324,0$ & $5.354,2$ & $8.209,0$ & $1.073,0$ & $11.310,9$ & $6.003,1$ & $3.300,9$ & $2.611,8$ \\
\hline Banano y plátanos & $2.761,2$ & $4.944,2$ & $7.854,3$ & $11.252,0$ & $21.379,5$ & $23.674,0$ & 27.671,1 & $36.760,5$ \\
\hline Cacao en grano & 13.327,1 & $8.831,2$ & $18.376,5$ & $17.829,0$ & $17.042,8$ & $15.557,4$ & 34.136,7 & $18.745,8$ \\
\hline Café en grano & $7.138,1$ & $5.439,0$ & $18.872,0$ & $15.810,3$ & $20.147,2$ & $18.861,5$ & $27.571,3$ & 23.053,1 \\
\hline \multicolumn{9}{|l|}{ Higuerilla } \\
\hline \multicolumn{9}{|l|}{ Abacá } \\
\hline \multicolumn{9}{|l|}{ Otros ptos agr. } \\
\hline Balsa & 310,4 & 383,2 & 678,0 & $1.168,0$ & 980,4 & 985,2 & 942,3 & $1.050,2$ \\
\hline \multicolumn{9}{|l|}{ Otras maderas } \\
\hline \multicolumn{9}{|l|}{ Pecuarios } \\
\hline \multicolumn{9}{|l|}{ Atún y pescado } \\
\hline \multicolumn{9}{|l|}{ Camarones } \\
\hline \multicolumn{9}{|l|}{ Langosta y otros } \\
\hline \multicolumn{9}{|l|}{ Petróleo crudo } \\
\hline \multicolumn{9}{|l|}{ Otos ptos mineros } \\
\hline \multicolumn{9}{|l|}{ Tierra mineral } \\
\hline \multicolumn{9}{|l|}{ Lana de ceibo } \\
\hline Caucho & & & 99,0 & 361,5 & 58,9 & & & \\
\hline Tagua & 613,0 & 583,0 & 667,5 & 581,3 & 372,3 & 510,3 & 466,1 & 383,5 \\
\hline \multicolumn{9}{|l|}{ SECUNDARIOS } \\
\hline $\begin{array}{l}\text { Químicos y } \\
\text { farmacéuticos }\end{array}$ & 361,4 & 306,1 & 375,2 & 581,6 & 808,5 & 727,6 & 960,7 & 839,0 \\
\hline \multicolumn{9}{|l|}{ Azúcar } \\
\hline Melazas y panelas & & & & & & & & \\
\hline
\end{tabular}




\begin{tabular}{|c|c|c|c|c|c|c|c|c|}
\hline $\begin{array}{l}\text { Café } \\
\text { industrializad }\end{array}$ & & & & & & & & \\
\hline $\begin{array}{l}\text { Elaborados d } \\
\text { cacao }\end{array}$ & & & & & & & & \\
\hline $\begin{array}{l}\text { Elaborados d } \\
\text { banano }\end{array}$ & & & & & & & & \\
\hline Elab. ptos de & & & & & & & & \\
\hline $\begin{array}{l}\text { Otros ptos } \\
\text { alimenticios }\end{array}$ & & & & & & & & \\
\hline $\begin{array}{l}\text { Alim. para } \\
\text { animales }\end{array}$ & & & & & & & & \\
\hline Extracto de $\mathrm{p}$ & & & & & & & & \\
\hline $\begin{array}{l}\text { Madera tercia } \\
\text { prens. }\end{array}$ & & & & & & & & \\
\hline Deriv. petróle & & & & & & & & \\
\hline Manuf. metal & & & & & & & & \\
\hline Art. electrodo & & & & & & & & \\
\hline $\begin{array}{l}\text { Sombr. paja y } \\
\text { mocora }\end{array}$ & $3.846,1$ & $3.854,5$ & $3.751,1$ & $3.236,0$ & $2.767,8$ & $3.165,1$ & $1.607,8$ & 992,4 \\
\hline Art. fibras tex & & & & & & & & \\
\hline $\begin{array}{l}\text { Manuf. cuero } \\
\text { plástico }\end{array}$ & & & & & & & & \\
\hline Cerámica & & & & & & & & \\
\hline Velas esteáric & & & & & & & & \\
\hline Otros & & & & & & & & \\
\hline Otros & $2.071,0$ & $1.523,1$ & $4.226,0$ & $3.502,3$ & $4.154,3$ & $4.638,0$ & $3.708,3$ & $2.716,1$ \\
\hline $\begin{array}{l}\text { TOTAL } \\
\text { GENERAL }\end{array}$ & $43.752,3$ & $31.218,5$ & $63.108,6$ & $55.395,0$ & $79.022,6$ & $74.122,2$ & $100.365,2$ & $87.152,4$ \\
\hline
\end{tabular}

Fuente: Patricio Almeida Guzmán, Rebeca Almeida Arroba: Estadísticas económicas históricas (1948-1983), Fuentes para la Historia Económica del Ecuador, Serie Estadísticas Históricas Vol. 1, Banco Central del Ecuador, Quito, 1988, p. 472-476. 
Tabla 27: Exportación total por rama de actividad (1956-1963) (Miles de dólares F.O.B):

\begin{tabular}{|c|c|c|c|c|c|c|c|c|}
\hline Bienes & 1956 & 1957 & 1958 & 1959 & 1960 & 1961 & 1962 & 1963 \\
\hline \multicolumn{9}{|l|}{ PRIMARIOS } \\
\hline Arroz & $1.581,6$ & $4.860,8$ & $3.532,5$ & $2.328,6$ & $3.717,0$ & $2.921,0$ & 658,5 & $3.691,0$ \\
\hline Banano y plátanos & $36.505,3$ & $34.520,2$ & $33.848,3$ & $44.260,9$ & $45.266,7$ & $48.005,0$ & $62.305,5$ & $67.833,0$ \\
\hline Cacao en grano & $17.424,2$ & $18.612,6$ & $20.379,0$ & $21.765,0$ & $21.414,0$ & $15.180,0$ & $15.913,1$ & $19.795,0$ \\
\hline Café en grano & $29.328,2$ & $29.907,8$ & $26.273,8$ & $17.502,0$ & $21.946,0$ & $14.602,0$ & $20.953,4$ & $18.255,0$ \\
\hline \multicolumn{9}{|l|}{ Higuerilla } \\
\hline \multicolumn{9}{|l|}{ Abacá } \\
\hline \multicolumn{9}{|l|}{ Otros ptos agr. } \\
\hline Balsa & $1.037,7$ & $1.949,9$ & $1.533,0$ & $1.547,9$ & $1.351,0$ & $1.242,0$ & $1.197,8$ & $1.485,0$ \\
\hline \multicolumn{9}{|l|}{ Otras maderas } \\
\hline \multicolumn{9}{|l|}{ Pecuarios } \\
\hline \multicolumn{9}{|l|}{ Atún y pescado } \\
\hline \multicolumn{9}{|l|}{ Camarones } \\
\hline \multicolumn{9}{|l|}{ Langosta y otros } \\
\hline \multicolumn{9}{|l|}{ Petróleo crudo } \\
\hline \multicolumn{9}{|l|}{$\begin{array}{l}\text { Otros ptos } \\
\text { mineros }\end{array}$} \\
\hline \multicolumn{9}{|l|}{ Tierra mineral } \\
\hline \multicolumn{9}{|l|}{ Lana de ceibo } \\
\hline Caucho & & & & 24,2 & 5,6 & & 6,3 & \\
\hline Tagua & 274,0 & 297,0 & 154,8 & 92,2 & 91,4 & 88,0 & 94,6 & 91,0 \\
\hline \multicolumn{9}{|l|}{ SECUNDARIOS } \\
\hline $\begin{array}{l}\text { Químicos y } \\
\text { farmacéuticos }\end{array}$ & 726,0 & 392,7 & 690,6 & 713,9 & 911,0 & $1.117,0$ & $1.040,6$ & 962,0 \\
\hline \multicolumn{9}{|l|}{ Azúcar } \\
\hline Melazas y panelas & & & & & & & & \\
\hline
\end{tabular}




\begin{tabular}{|c|c|c|c|c|c|c|c|c|}
\hline $\begin{array}{l}\text { Café } \\
\text { industrializad }\end{array}$ & & & & & & & & \\
\hline $\begin{array}{l}\text { Elaborados de } \\
\text { cacao }\end{array}$ & & & & & & & & \\
\hline $\begin{array}{l}\text { Elaborados de } \\
\text { banano }\end{array}$ & & & & & & & & \\
\hline Elab. ptos de & & & & & & & & \\
\hline $\begin{array}{l}\text { Otros ptos } \\
\text { alimenticios }\end{array}$ & & & & & & & & \\
\hline $\begin{array}{l}\text { Alim. para } \\
\text { animales }\end{array}$ & & & & & & & & \\
\hline Extracto de pi & & & & & & & & \\
\hline $\begin{array}{l}\text { Madera tercia } \\
\text { prens. }\end{array}$ & & & & & & & & \\
\hline Deriv. petróle & & & & & & & & \\
\hline Manuf. metale & & & & & & & & \\
\hline Art. electrodo & & & & & & & & \\
\hline $\begin{array}{l}\text { Sombr. paja y } \\
\text { mocora }\end{array}$ & $1.466,7$ & $1.73,7$ & 864,2 & 791,2 & $1.105,0$ & 487,0 & 466,6 & 384,0 \\
\hline Art. fibras tex & & & & & & & & \\
\hline $\begin{array}{l}\text { Manuf. cuero } \\
\text { plástico }\end{array}$ & & & & & & & & \\
\hline Cerámica & & & & & & & & \\
\hline Velas esteáric & & & & & & & & \\
\hline Otros & & & & & & & & \\
\hline Otros & $3.667,1$ & $5.824,5$ & $7.624,5$ & $8.020,5$ & $6.753,3$ & $11.030,0$ & $14.793,1$ & $15.941,0$ \\
\hline $\begin{array}{l}\text { TOTAL } \\
\text { GENERAL }\end{array}$ & 92.012,2 & $97.439,2$ & $94.900,7$ & $97.046,6$ & $102.561,0$ & $94.672,0$ & $117.429,5$ & $128.437,0$ \\
\hline
\end{tabular}

Fuente: Patricio Almeida Guzmán y Rebeca Almeida Arroba: Estadísticas económicas históricas (19481983), Fuentes para la Historia Económica del Ecuador. Serie Estadísticas Históricas Vol. 1, Banco Central del Ecuador, Quito, 1988, p. 472-476. 
Tabla 28: Exportaciones totales (1948-1965) (Miles de dólares FOB):

\begin{tabular}{|c|c|c|c|}
\hline Años & Total exportaciones & Años & Total exportaciones \\
\hline $\mathbf{1 9 4 8}$ & $43.752,3$ & $\mathbf{1 9 5 7}$ & $97.439,2$ \\
\hline $\mathbf{1 9 4 9}$ & $31.218,5$ & $\mathbf{1 9 5 8}$ & $94.900,7$ \\
\hline $\mathbf{1 9 5 0}$ & $63.108,6$ & $\mathbf{1 9 5 9}$ & $97.046,6$ \\
\hline $\mathbf{1 9 5 1}$ & $55.395,0$ & $\mathbf{1 9 6 0}$ & $102.561,0$ \\
\hline $\mathbf{1 9 5 2}$ & $79.022,6$ & $\mathbf{1 9 6 1}$ & $94.672,0$ \\
\hline $\mathbf{1 9 5 3}$ & $74.122,2$ & $\mathbf{1 9 6 2}$ & $117.429,5$ \\
\hline $\mathbf{1 9 5 4}$ & $100.365,2$ & $\mathbf{1 9 6 3}$ & $128.437,0$ \\
\hline $\mathbf{1 9 5 5}$ & $87.152,4$ & $\mathbf{1 9 6 4}$ & $131.084,0$ \\
\hline $\mathbf{1 9 5 6}$ & $92.012,2$ & $\mathbf{1 9 6 5}$ & 131.975 \\
\hline
\end{tabular}

Fuente: Patricio Almeida Guzmán, Rebeca Almeida Arroba: Estadísticas económicas históricas (1948-1983), Fuentes para la Historia Económica del Ecuador, Serie Estadísticas Históricas Vol. 1, Banco Central del Ecuador, Quito, 1988, p. 471. 
Tabla 29: Importaciones totales (Tipos de bienes: materias primas, bienes de capital y bienes de consumo) (miles de dólares CIF):

\begin{tabular}{|c|c|c|c|}
\hline Años & Total Importaciones & Años & Total Importaciones \\
\hline 1952 & 58.500 & $\mathbf{1 9 5 9}$ & 97.265 \\
\hline 1953 & 63.700 & $\mathbf{1 9 6 0}$ & 115.183 \\
\hline $\mathbf{1 9 5 4}$ & 100.200 & $\mathbf{1 9 6 1}$ & 106.439 \\
\hline $\mathbf{1 9 5 5}$ & 96.900 & $\mathbf{1 9 6 2}$ & 97.148 \\
\hline $\mathbf{1 9 5 6}$ & 88.800 & $\mathbf{1 9 6 3}$ & 128.009 \\
\hline $\mathbf{1 9 5 8}$ & 97.825 & $\mathbf{1 9 6 4}$ & 161.916 \\
\hline
\end{tabular}

Fuente: Patricio Almeida Guzmán, Rebeca Almeida Arroba: Estadísticas económicas históricas (1948-1983), Fuentes para la Historia Económica del Ecuador, Serie Estadísticas Históricas Vol. 1, Banco Central del Ecuador, Quito, 1988, p. 491. 
Tabla 30: Población del Ecuador según regiones y provincias (censo de 1950 y 1962):

\begin{tabular}{|c|c|c|}
\hline Regiones y Provincias & $\begin{array}{c}\text { Censo de } 1950 \\
\text { Total }\end{array}$ & $\begin{array}{c}\text { Censo de } 1962 \\
\text { Total }\end{array}$ \\
\hline Total nacional & 3.202 .757 & 4.721 .100 \\
\hline Costa & 1.298 .495 & 2.178 .601 \\
\hline Esmeraldas & 75.407 & 127.847 \\
\hline Manabí & 401.378 & 627.235 \\
\hline Los Ríos & 150.260 & 255.942 \\
\hline Guayas & 582.144 & 1.002 .9752 \\
\hline El Oro & 89.306 & 164.602 \\
\hline Sierra & 1.856 .445 & 2.461 .024 \\
\hline Carchi & 76.595 & 98.712 \\
\hline Imbabura & 146.893 & 181.096 \\
\hline Pichincha & 386.520 & 612.366 \\
\hline Cotopaxi & 165.602 & 202.412 \\
\hline Tangarahua & 187.942 & 224.739 \\
\hline Bolívar & 109.305 & 144.397 \\
\hline Chimborazo & 218.130 & 296.080 \\
\hline Cañar & 97.681 & 117.409 \\
\hline Azuay & 250.975 & 286.226 \\
\hline Loja & 216.802 & 297.587 \\
\hline Oriente (1) & 46.471 & 79.007 \\
\hline Napo & 25.425 & 25.582 \\
\hline Pastaza & & 14.442 \\
\hline
\end{tabular}




\begin{tabular}{|l|c|c|}
\hline Morona Santiago & 21.046 & 26.894 \\
\cline { 2 - 3 } Zamora Chinchipe & & 12.089 \\
\cline { 2 - 3 } Archipiélago de Colón & 1.346 & 2.468 \\
\hline
\end{tabular}

(1) En 1950 la Región Oriental comprendía dos provincias: Napo, Pastaza y Zamora.

Fuente: 1950 Primer Censo de Población, 1962 Segundo Censo de Población y Per. Censo de Vivienda, p. 3.

Tabla 31: Ecuador: Salarios de los trabajadores bananeros (1952-1976):

\begin{tabular}{|c|c|c|}
\hline Año & $\begin{array}{c}\text { Capacidad adquisitiva } \\
\text { (sucres de 1965) }\end{array}$ & Índice (Base: 1952=100) \\
\hline 1952 & 770 & 100,0 \\
\hline 1961 & 735 & 95,5 \\
\hline 1964 & 620 & 80,5 \\
\hline 1968 & 525 & 68,2 \\
\hline 1969 & 595 & 77,3 \\
\hline 1974 & 440 & 57,1 \\
\hline 1976 & 415 & 53,9 \\
\hline
\end{tabular}

Fuente: Carlos Larrea: El sector agroexportador y su articulación en la economía ecuatoriana (1948-1972): Subdesarrollo y crecimiento desigual, en Lefeber (ed.) Economía política del Ecuador: Campo, región, nación, Quito, Corporación Editora Nacional, 1985. 
Tabla 32: Panamá: Valor promedio de los salarios anuales en la exportación bananera (19501974):

\begin{tabular}{|c|c|c|c|}
\hline $\begin{array}{c}\text { Promedio del } \\
\text { quinquenio }\end{array}$ & $\begin{array}{c}\text { Salarios anuales por } \\
\text { persona (en dólares) }\end{array}$ & $\begin{array}{c}\text { Valor total } \\
\text { (en miles de dólares) }\end{array}$ & $\begin{array}{c}\text { Valor promedio del } \\
\text { producto por persona } \\
\text { (en dólares) }\end{array}$ \\
\hline $1950-1954$ & 836,4 & $15.907,0$ & $1.436,7$ \\
\hline $1955-1959$ & $1.179,6$ & $21.886,3$ & $2.064,2$ \\
\hline $1960-1964$ & $1.372,8$ & $22.440,4$ & $2.418,7$ \\
\hline $1965-1969$ & $1.562,4$ & $49.141,1$ & $4.008,2$ \\
\hline $1970-1974$ & $1.869,6$ & $61.864,6$ & $4.820,0$ \\
\hline
\end{tabular}

Fuente: Fondo Monetario Internacional: Estadísticas Financieras Internacionales, vol. XXIX, no. 5, Washington D.C, mayo de 1976; Chiriquí Land Co., Informe, Op. cit. (Panamá), Contraloría General de la República, op. cit., cuadro Mimeo.

Tabla 33: Salarios mensuales de los trabajadores del banano en distintos países (1975):

\begin{tabular}{|c|c|c|c|}
\hline País & Compañía & $\begin{array}{c}\text { Salario mensual (en } \\
\text { dólares) }\end{array}$ & Índice \\
\hline Panamá & United Brands & 72,50 & 100,0 \\
\hline Costa Rica & United Brands & 56,20 & 77,5 \\
\hline Honduras & Standard Fruit & 51,20 & 70,6 \\
\hline Honduras & United Fruit & 47,50 & 65,5 \\
\hline Guatemala & Del Monte & 43,70 & 60,3 \\
\hline Ecuador & & 36,00 & 49,7 \\
\hline
\end{tabular}

Fuente: Frank Ellis, cit. Banco Central del Ecuador, Boletín Anuario no. 5, Quito, 1982. 
Tabla 34: Créditos concedidos por los bancos de fomento para el cultivo del banano (19441951):

\begin{tabular}{|c|c|}
\hline Años & Miles de sucres \\
\hline $\mathbf{1 9 4 4}$ & 330.6 \\
\hline $\mathbf{1 9 4 5}$ & 501.8 \\
\hline $\mathbf{1 9 4 6}$ & 2.433 .7 \\
\hline $\mathbf{1 9 4 7}$ & 3.397 .9 \\
\hline $\mathbf{1 9 4 8}$ & 8.942 .3 \\
\hline $\mathbf{1 9 4 9}$ & 17.853 .4 \\
\hline $\mathbf{1 9 5 0}$ & 4.625 .0 \\
\hline
\end{tabular}

Fuente: CEPAL: El desarrollo económico del Ecuador, México, 1954, p. 170. 
Tabla 35: Distribución de la superficie bananera según la clasificación por tamaño de las explotaciones:

\begin{tabular}{|c|c|c|c|c|}
\hline \multirow[b]{2}{*}{$\begin{array}{c}\text { Clase de } \\
\text { explotaciones }\end{array}$} & \multicolumn{2}{|c|}{ Explotaciones } & \multicolumn{2}{|c|}{ Superficie } \\
\hline & Número & Porcentaje & Hectáreas & Porcentaje \\
\hline $\begin{array}{l}\text { Familiar: muy } \\
\text { pequeña y } \\
\text { pequeña (hasta } \\
25 \text { hectáreas) }\end{array}$ & 871 & 47,9 & 11.024 & 10,9 \\
\hline $\begin{array}{l}\text { Mediana (26-100 } \\
\text { hectáreas) }\end{array}$ & 740 & 40,7 & 38.559 & 38,1 \\
\hline $\begin{array}{c}\text { Grande (101-500 } \\
\text { hectáreas) }\end{array}$ & 192 & 10,5 & 36.606 & 36,2 \\
\hline $\begin{array}{c}\text { Semi-industrial } \\
\text { (501-1000 } \\
\text { hectáreas) }\end{array}$ & 11 & 0,6 & 7.701 & 7,6 \\
\hline $\begin{array}{c}\text { Industrial (más } \\
\text { de } 1000 \\
\text { hectáreas) }\end{array}$ & 5 & 0,3 & 7.313 & 7,2 \\
\hline TOTAL & 1.819 & 100 & 101.203 & 100 \\
\hline
\end{tabular}

Fuente: Comité Interamericano de Desarrollo Agrícola (CIDA): Tenencia de la tierra y desarrollo socio-económico del sector agrícola, publicado por Unión Panamericana. Secretaría General de la Organización de los Estados Americanos-Washington D.C, 1965, p. 412. 
Tabla 36: Emigración e inmigración en el Ecuador por provincias (años 1950 y 1962):

\begin{tabular}{|c|c|c|c|c|}
\hline \multirow[t]{2}{*}{ Región } & \multicolumn{2}{|c|}{$\begin{array}{l}\text { Año } 1950 \\
\text { Población }\end{array}$} & \multicolumn{2}{|c|}{$\begin{array}{l}\text { Año } 1962 \\
\text { Población }\end{array}$} \\
\hline & Inmigrante & Emigrante & Inmigrante & Emigrante \\
\hline Costa & 311.773 & 213.923 & 278.530 & 190.063 \\
\hline Esmeraldas & 17.328 & 12560 & 12.103 & 11.064 \\
\hline Manabí & 11.274 & 63.729 & 9.994 & 62.784 \\
\hline Los Ríos & 43.483 & 46.024 & 39.263 & 42.305 \\
\hline Guayas & 196.621 & 69.716 & 178.199 & 56.386 \\
\hline El Oro & 43.072 & 21.894 & 38.571 & 17.524 \\
\hline Sierra & 237.004 & 327.355 & 211.178 & 316.226 \\
\hline Carchi & 10.779 & 21.150 & 5.258 & 20.428 \\
\hline Imbabura & 18.913 & 28.144 & 15.740 & 26.424 \\
\hline Pichincha & 135.621 & 44.489 & 23.816 & 39.714 \\
\hline Cotopaxi & 7.782 & 33.677 & 7.284 & 33.285 \\
\hline Tungurahua & 14.984 & 40.385 & 14.072 & 39.688 \\
\hline Chimborazo & 14.176 & 42.357 & 12.966 & 41.315 \\
\hline Bolívar & 6.188 & 17.976 & 5.787 & 17.674 \\
\hline Cañar & 8.840 & 18.165 & 8.384 & 17.742 \\
\hline Azuay & 12.718 & 49.058 & 12.033 & 48.660 \\
\hline Loja & 7.003 & 31.954 & 5.838 & 31.296 \\
\hline Oriente & 23.372 & 6.753 & 20.852 & 4.957 \\
\hline Napo & 3.931 & 1.728 & 3.134 & 1.495 \\
\hline Pastaza & 6.196 & 2.286 & 5.580 & 1.730 \\
\hline
\end{tabular}




\begin{tabular}{|c|c|c|c|c|}
\hline Morona S. & 7.741 & 1.897 & 6.865 & 1.062 \\
\hline Zamora Ch. & 5.504 & 842 & 5.273 & 670 \\
\hline Archipiélago & 1.157 & 422 & 1.107 & 421 \\
\hline & & & & \\
\hline Total & $\mathbf{5 7 3 . 3 1 1}$ & $\mathbf{5 4 8 . 4 5 3}$ & $\mathbf{5 1 1 . 6 6 7}$ & $\mathbf{5 1 1 . 6 6 7}$ \\
\hline
\end{tabular}

Fuente: Patricio Almeida Guzmán, Rebeca Almeida Arroba: Estadísticas Económicas Históricas 1948-1983, Fuentes para la historia económica del Ecuador, Serie Estadísticas Históricas, vol. 1, Banco Central del Ecuador, 1988, p. 444-447.

Tabla 37: Ingreso mensual por clases sociales (1950 y 1956) (en sucres):

\begin{tabular}{|c|c|c|c|}
\hline Años & Clases propietarias & Pequeño burguesía & Clases trabajadoras \\
\hline $1950(1)$ & $2.226,75$ & 217,20 & 111,16 \\
\hline $1956(2)$ & $2.930,55$ & 276,98 & 142,62 \\
\hline
\end{tabular}

Fuente: (1) Reinaldo Torres Caicedo: Los estratos socio-económicos del Ecuador, Quito, JUNAPLA, 1960, pp. 30. (2) Proyecciones de Torres Caicedo, Quito, JUNAPLA, 1960, p. 30. 
Tabla 38: Exportaciones de banano y relación de intercambio (1951-1960):

\begin{tabular}{|c|c|c|c|}
\hline \multirow{2}{*}{ Año } & \multicolumn{2}{|c|}{ Exportaciones } & \multirow{2}{*}{$\begin{array}{c}\text { Relación de } \\
\text { intercambio }\end{array}$} \\
\cline { 2 - 3 } & $\begin{array}{c}\text { Volumen } \\
\text { (miles de Tm) }\end{array}$ & $\begin{array}{c}\text { Valor (millones de } \\
\text { sucres) }\end{array}$ & 105.6 \\
\hline 1951 & 246.5 & 107.3 & 105.4 \\
\hline 1952 & 429.8 & 320.7 & 105.8 \\
\hline 1953 & 406.4 & 355.0 & 120.8 \\
\hline 1954 & 492.2 & 415.1 & 100.0 \\
\hline 1955 & 612.6 & 551.4 & 100.5 \\
\hline 1956 & 578.9 & 547.6 & 96.5 \\
\hline 1957 & 669.1 & 517.8 & 90.7 \\
\hline 1958 & 742.7 & 507.7 & 80.4 \\
\hline 1959 & 885.6 & 663.9 & 679.0 \\
\hline 1960 & 895.1 & & \\
\hline
\end{tabular}

Fuente: Germánico Salgado: El Ecuador y la Integración Subregional, Exportaciones, Volumen, Quito, UNTAL, 1969, p. 64. Junta Nacional de Planificación: "Plan General de Desarrollo", Valor y relación de intercambio, Libro I, Volumen I, Quito, 1963, p. 62 y 66. 
Tabla 39: Crecimiento de los principales centros urbanos (1950-1960):

\begin{tabular}{|c|c|c|c|}
\hline Ciudad & $\mathbf{1 9 5 0}$ & $\mathbf{1 9 6 2}$ & $\begin{array}{c}\text { Tasa de crecimiento } \\
\text { anual }\end{array}$ \\
\hline Guayaquil & 268.908 & 510.804 & 5,5 \\
\hline Quito & 209.932 & 354.764 & 4,5 \\
\hline Cuenca & 39.983 & 60.402 & 3,5 \\
\hline Ambato & 31.312 & 53.372 & 4,5 \\
\hline Riobamba & 29.830 & 41.625 & 2,8 \\
\hline Manta & 19.028 & 33.622 & 4,9 \\
\hline Portoviejo & 16.330 & 32.228 & 5,8 \\
\hline Milagro & 13.736 & 28.148 & 6,2 \\
\hline Esmeraldas & 13.169 & 33.403 & 8,1 \\
\hline Loja & 13.399 & 26.785 & 5,9 \\
\hline Machala & 7.549 & 29.036 & 11,9 \\
\hline Quevedo & 4.166 & 20.602 & 14,2 \\
\hline Santo Domingo & 1.499 & 6.951 & 13,6 \\
\hline
\end{tabular}

Fuente: Censos nacionales 1950 y 1962 (en Carlos Larrea y Renato Landín: Estructura Social, Crecimiento Económico y Desequilibrios Internos en el Ecuador: El caso de las exportaciones de banana y cacao en la Costa Sur, Centro de cómputo de FLACSO, 1987. 
Tabla 40: Ecuador: Evolución de la Deuda Externa (1950-1970) (millones de dólares):

\begin{tabular}{|c|c|c|c|}
\hline Años & Deuda Pública & Deuda Privada & Deuda Total \\
\hline 1950 & 24,0 & 0,5 & 24,5 \\
\hline 1951 & 24,7 & 0,5 & 25,2 \\
\hline 1952 & 28,4 & 0,5 & 28,9 \\
\hline 1953 & 28,5 & 0,5 & 29,0 \\
\hline 1954 & 38,5 & 0,5 & 39,0 \\
\hline 1955 & 47,6 & 0,5 & 48,1 \\
\hline 1956 & 61,1 & 0,5 & 61,6 \\
\hline 1957 & 62,8 & 1,4 & 64,2 \\
\hline 1958 & 62,4 & 0,6 & 63,0 \\
\hline 1959 & 67,9 & 0,4 & 68,3 \\
\hline 1960 & 83,1 & 0,3 & 83,4 \\
\hline 1961 & 92,6 & 0,4 & 93,0 \\
\hline 1962 & 102,4 & 0,3 & 102,7 \\
\hline 1963 & 103,0 & 0,2 & 103,2 \\
\hline 1964 & 109,0 & 0,1 & 110,0 \\
\hline 1965 & 120,5 & 0,8 & 121,3 \\
\hline 1966 & 138,2 & 2,5 & 140,7 \\
\hline 1967 & 159,7 & 3,6 & 163,3 \\
\hline
\end{tabular}




\begin{tabular}{|c|c|c|c|}
\hline 1968 & 188,4 & 7,8 & 196,2 \\
\hline 1969 & 202,9 & 10,2 & 213,1 \\
\hline 1970 & 229,3 & 12,2 & 241,5 \\
\hline
\end{tabular}

Fuente: Banco Central del Ecuador: Setenta Años de Información Estadística, Boletín Deuda Externa, 1987-1996. Banco Central del Ecuador, en: Betty Silva, Marina Mero: "Series estadísticas históricas de Ecuador, América Latina y el mundo 1927-2008", Universidad de Guayaquil, Facultad de Ciencias Económicas, 2008. 
Tabla 41: Latifundios en el Ecuador (Censo de 1954):

\begin{tabular}{|c|c|c|}
\hline $\begin{array}{c}\text { Tamaño de las explotaciones } \\
(\mathbf{2 . 5 0 0} \text { hectáreas y más })\end{array}$ & $\begin{array}{c}\text { No. estimado de } \\
\text { explotaciones }\end{array}$ & $\begin{array}{c}\text { Superficie total censada } \\
\text { Total Sierra }\end{array}$ \\
\hline Provincia de Azuay & 138 & 880,2 \\
\hline Provincia de Bolívar & 7 & 75,6 \\
\hline Provincia de Cañar & 3 & 36,3 \\
\hline Provincia de Carchi & 9 & 53,2 \\
\hline Provincia Cotopaxi & 22 & 194,0 \\
\hline Provincia Chimborazo & 17 & 80,8 \\
\hline Provincia Imbabura & 10 & 55,3 \\
\hline Provincia Loja & 27 & 136,7 \\
\hline Provincia Pichincha & 28 & 158,4 \\
\hline Provincia Tunguragua & 5 & 39,4 \\
\hline
\end{tabular}

\begin{tabular}{|c|c|c|}
\hline $\begin{array}{c}\text { Tamaño de las explotaciones } \\
(\mathbf{2 . 5 0 0} \text { hectáreas y más) }\end{array}$ & $\begin{array}{c}\text { No. estimado de } \\
\text { explotaciones }\end{array}$ & \begin{tabular}{c} 
Superficie total censada \\
\hline Total Costa
\end{tabular} \\
\hline Provincia El Oro & $\mathbf{1 0 3}$ & 30,4 \\
\hline Provincia Esmeraldas & 3 & 16,6 \\
\hline Provincia del Guayas & 54 & 401,8 \\
\hline Provincia Los Ríos & 28 & 159,1 \\
\hline Provincia Manabi & 15 & 68,6 \\
\hline
\end{tabular}


Fuente: Banco Central del Ecuador, Ministerios de Economía, Banco Nacional de Fomento: Primer Censo Agropecuario Nacional, 1954, Impreso en los talleres gráficos de la Dirección General de Estadística y Censos, Ministerio de Economía, Quito, Julio 1956.

Tabla 42: Población total estimada (miles de personas) (1950-1969):

\begin{tabular}{|c|c|c|c|}
\hline Ã̃o & Población & Año & Población \\
\hline 1950 & 3.225 & 1960 & 4.325 \\
\hline 1951 & 3.317 & 1961 & 4.461 \\
\hline 1952 & 3.412 & 1962 & 4.602 \\
\hline 1953 & 3.511 & 1963 & 4.749 \\
\hline 1954 & 3.615 & 1964 & 4.902 \\
\hline 1955 & 3.722 & 1965 & 5.061 \\
\hline 1956 & 3.833 & 1966 & 5.227 \\
\hline 1957 & 3.949 & 1967 & 5.399 \\
\hline 1958 & 4.070 & 1968 & 5.579 \\
\hline 1959 & 4.195 & 1969 & 5.766 \\
\hline
\end{tabular}

Fuente: Patricio Almeida Guzmán, Rebeca Almeida Arroba: Estadísticas Económicas Históricas 1948-1983, Fuentes para la historia económica del Ecuador, Serie Estadísticas Históricas, vol. 1. Banco Central del Ecuador, 1988, p. 4. 
Tabla 43: Superficie de bananos Gros Michel y Cavendish en el Ecuador (1965-1976):

\begin{tabular}{|c|c|c|c|c|}
\hline $\mathbf{A n ̃ o}$ & $\begin{array}{c}\text { Gros Michel } \\
\text { (hectáreas) }\end{array}$ & Porcentaje & $\begin{array}{c}\text { Cavendish } \\
\text { (hectáreas) }\end{array}$ & Porcentaje \\
\hline $\mathbf{1 9 6 5}$ & 144.088 & 100 & & \\
\hline $\mathbf{1 9 6 6}$ & 163.772 & 100 & & 9,7 \\
\hline $\mathbf{1 9 6 7}$ & 146.233 & 91,3 & 13.995 & 15,9 \\
\hline $\mathbf{1 9 6 8}$ & 131.898 & 84,1 & 24.978 & 26,6 \\
\hline $\mathbf{1 9 6 9}$ & 108.280 & 73,4 & 32.249 & 40,4 \\
\hline $\mathbf{1 9 7 0}$ & 74.045 & 59,6 & 50.200 & 47,9 \\
\hline $\mathbf{1 9 7 1}$ & 59.665 & 52,1 & 54.921 & 53,4 \\
\hline $\mathbf{1 9 7 2}$ & 47.067 & 46,6 & 53.927 & 54,2 \\
\hline $\mathbf{1 9 7 3}$ & 42.399 & 45,8 & 50.107 & 60,7 \\
\hline $\mathbf{1 9 7 4}$ & $35.545,5$ & 39,3 & $54.955,5$ & 61,7 \\
\hline $\mathbf{1 9 7 5}$ & $33.464,5$ & 38,3 & $53.938,5$ & 72,7 \\
\hline $\mathbf{1 9 7 6}$ & 23.432 & 27,3 & $62.472,5$ & \\
\hline
\end{tabular}

Fuente: Listados de Sistemas Mecanizados del P.N.B., 1977. 
Tabla 44: Salarios mensuales de los trabajadores bananeros deflactados respecto al índice de precios del banano (1952-1976):

\begin{tabular}{|c|c|c|}
\hline Año & $\begin{array}{c}\text { Salario mensual } \\
\text { (dólares de 1965) }\end{array}$ & Índice (Base: 1952=100) \\
\hline 1952 & 39,00 & 100,0 \\
\hline 1961 & 39,50 & 101,3 \\
\hline 1964 & 31,00 & 79,5 \\
\hline 1968 & 34,30 & 97,9 \\
\hline 1969 & 38,60 & 78,2 \\
\hline 1974 & 30,50 & 68,2 \\
\hline 1976 & 26,60 & \\
\hline
\end{tabular}

Fuente: Carlos Larrea: El sector agroexportador y su articulación a la economía ecuatoriana entre 1948 y 1972: Subdesarrollo y crecimiento desigual, en Economía política del Ecuador, editado por Louis Lefeber, Quito, Corporación Editora Nacional, CERLAC-FLACSO Series, 1985. 
Tabla 45: Presidentes en los países latinoamericanos (1950-1960):

\begin{tabular}{|c|c|c|c|}
\hline País & Presidente & Periodo & $\begin{array}{l}\text { Partido político } \\
\text { (ideología) }\end{array}$ \\
\hline Guatemala & Carlos Castillo Armas & 1954-1957 & $\begin{array}{l}\text { Ideología } \\
\text { conservadora }\end{array}$ \\
\hline Paraguay & Alfredo Stroessner & 1954-1989 & $\begin{array}{l}\text { Asociación Nacional } \\
\text { Republicana-Partido } \\
\text { Colorado } \\
\text { (conservador y } \\
\text { nacionalista) }\end{array}$ \\
\hline Colombia & Gustavo Rojas Pinilla & $1953-1957$ & $\begin{array}{l}\text { Movimiento de } \\
\text { Acción Nacional } \\
\text { (populismo, } \\
\text { nacionalismo) }\end{array}$ \\
\hline Nicaragua & Anastasio Somoza & $\begin{array}{l}\text { 1937-1947; 1950- } \\
1956\end{array}$ & $\begin{array}{l}\text { Partido Liberal } \\
\text { Nacionalista }\end{array}$ \\
\hline Cuba & $\begin{array}{l}\text { Fulgencio Bautista y } \\
\text { Zaldívar }\end{array}$ & 1952-1959 & $\begin{array}{l}\text { Ideología } \\
\text { conservadora }\end{array}$ \\
\hline Argentina & $\begin{array}{l}\text { Juan Domingo Perón } \\
\text { Pedro Aramburu }\end{array}$ & 1946-1955 & $\begin{array}{l}\text { Partido Laborista } \\
\text { La Unión del Pueblo } \\
\text { Argentino } \\
\text { (conservador) }\end{array}$ \\
\hline Perú & $\begin{array}{l}\text { Manuel Odria } \\
\text { Amoretti } \\
\text { Manuel Prado } \\
\text { Ugarteche }\end{array}$ & $\begin{array}{c}1948-1950 ; 1950- \\
1956 \\
\\
1939-1945 ; 1956- \\
1962\end{array}$ & $\begin{array}{l}\text { Unión Nacional } \\
\text { Odriísta (conservador) }\end{array}$ \\
\hline & J. Velasco Ibarra & 1952-1956 & Conservador \\
\hline
\end{tabular}




\begin{tabular}{|c|c|c|c|}
\hline Ecuador & Camilo Ponce & $1956-1960$ & Liberal \\
\hline Costa Rica & $\begin{array}{l}\text { Otilio Ulate Blanco } \\
\text { Mario Echandi } \\
\text { Jiménez }\end{array}$ & $\begin{array}{r}1949-1953 \\
1958-1962\end{array}$ & $\begin{array}{l}\text { Partido Unión } \\
\text { Nacional } \\
\text { (conservador) }\end{array}$ \\
\hline Honduras & $\begin{array}{l}\text { Julio Lozano Díaz } \\
\text { Junta Militar }\end{array}$ & $\begin{array}{r}1954-1956 \\
1956-1957\end{array}$ & $\begin{array}{l}\text { Partido Nacional } \\
\text { (orientación centro) } \\
\text { Ideología } \\
\text { conservadora }\end{array}$ \\
\hline Bolivia & $\begin{array}{l}\text { Víctor Paz Estenssoro } \\
\text { Hernán Siles Zuazo }\end{array}$ & $\begin{array}{l}1952-1956 \\
1956-1960\end{array}$ & $\begin{array}{l}\text { Movim. Nacionalista } \\
\text { Revolucionario } \\
\text { (nacionalista, } \\
\text { populista) }\end{array}$ \\
\hline Venezuela & Marcos Pérez Jiménez & $1952-1958$ & $\begin{array}{l}\text { Frente electoral } \\
\text { Independiente } \\
\text { (nacionalista } \\
\text { militarista) }\end{array}$ \\
\hline Chile & $\begin{array}{l}\text { Carlos Ibáñez del } \\
\text { Campo }\end{array}$ & $1952-1958$ & $\begin{array}{l}\text { Partido Independiente } \\
\text { (nacionalista, } \\
\text { populista) }\end{array}$ \\
\hline
\end{tabular}

Fuente: Enciclopedia Salvat, Países de América Latina, Salvat Ediciones Ecuatoriana S.A., Tomo VIII, Barcelona, 1980. 


\section{APÉNDICE DE DATOS Y ESTADÍSTICAS: CAPÍTULO 3}

Tabla 1: Concesión de tierras baldías realizadas por el estado (1948-1959):

\begin{tabular}{|c|c|c|c|c|c|c|c|c|c|c|c|c|c|c|c|c|}
\hline \multirow[t]{3}{*}{ Provincias } & \multicolumn{16}{|c|}{ Adjudicación definitiva de tierras baldías (Santo Domingo-Quinindé-Quevado-Chone) } \\
\hline & \multicolumn{2}{|c|}{1948} & \multicolumn{2}{|c|}{1949} & \multicolumn{2}{|c|}{1950} & \multicolumn{2}{|c|}{1955} & \multicolumn{2}{|c|}{1956} & \multicolumn{2}{|c|}{1957} & \multicolumn{2}{|c|}{1958} & \multicolumn{2}{|c|}{1959} \\
\hline & $\mathbf{A}$ & $\mathbf{S}$ & $\mathbf{A}$ & $\mathbf{S}$ & A & $\mathbf{S}$ & A & $\mathbf{S}$ & $\mathbf{A}$ & $\mathbf{S}$ & $\mathbf{A}$ & $\mathbf{S}$ & $\mathbf{A}$ & $\mathbf{S}$ & $\mathbf{A}$ & $\mathbf{S}$ \\
\hline Carchi & & & & & & & & & & & & & & & & \\
\hline \multicolumn{17}{|l|}{ Imbabura } \\
\hline Pichincha & & & & & & & 52 & 2.787 & 55 & 3.071 & 60 & 6.463 & 19 & 1.348 & 34 & 1.998 \\
\hline Cotopaxi & & & & & & & & & & & & & & & & \\
\hline Tungurahua & & & & & & & & & & & & & & & & \\
\hline Bolívar & & & & & & & & & & & & & & & & \\
\hline Azuay & & & & & & & & & & & & & & & & \\
\hline Loja & & & & & & & & & & & & & & & & \\
\hline El Oro & & & & & & & & & & & & & & & & \\
\hline & & & & & & & 1 & 98 & 6 & 497 & 16 & 1.004 & 7 & 418 & 5 & 192 \\
\hline
\end{tabular}




\begin{tabular}{|c|c|c|c|c|c|c|c|c|c|c|c|c|c|}
\hline Guayas & & & & & & & & & & & & & \\
\hline Los Ríos & & & & 2 & 105 & 20 & 24.500 & 35 & 13.923 & 15 & 1.375 & 33 & 626 \\
\hline Manabí & & & & 1 & 200 & 2 & 250 & 3 & 350 & 1 & 100 & & \\
\hline Esmeraldas & & & & 10 & 840 & 19 & 3.082 & 3 & 26 & 1 & 150 & 4 & 800 \\
\hline $\begin{array}{l}\text { Napo- } \\
\text { Pastaza }\end{array}$ & & & & & & & & & & & & & \\
\hline Total & 20.000 & 10.500 & 9.900 & 66 & 4.030 & 100 & 31.400 & 117 & 2.945 & 43 & 3.391 & 46 & 3.616 \\
\hline
\end{tabular}

A: Adjudicatarios

S: Superficie (hectáreas)

Fuente: Patricio Almeida Guzmán, Rebeca Almedia Arroba: Estadísticas Económicas Históricas 1948-1983, en Fuentes para la Historia Económica del Ecuador, serie estadísticas históricas, vol. 1, Banco Central del Ecuador, 1988, p. 32. 
Tabla 2: Composición de la población agrícola de las provincias de la Sierra (año 1960) (miles de familias):

\begin{tabular}{|c|c|c|}
\hline Tipos de familias & Número & Porcentaje \\
\hline Propietarias de tierras & 174 & 66 \\
\hline Tenedoras mixtas de tierras & 27,3 & 10 \\
\hline Colonas y otras & 12,8 & 5 \\
\hline Huasipungueras & 19,7 & 7 \\
\hline Arrendatarias & 8,0 & 3 \\
\hline Partidarias o aparceras & 12,9 & 5 \\
\hline Comuneras agrícolas & 4,9 & 2 \\
\hline $\begin{array}{l}\text { Con nexo de posesión de } \\
\text { tierras }\end{array}$ & 259,6 & 98 \\
\hline $\begin{array}{l}\text { Trabajadores y peones } \\
\text { independientes }\end{array}$ & 4,4 & 2 \\
\hline Total & 264 & 100 \\
\hline
\end{tabular}

Fuente: Comité Interamericano de Desarrollo Agrícola (CIDA): Tenencia de la tierra y desarrollo socio-económico del sector agrícola del Ecuador, Secretaría General de la Organización de los Estados Americanos-Washington D.C. Publicado por Unión Panamericana, 1965, p. 17. 
Tabla 3: Clasificación por tamaño de la superficie total y de labranza de los huasipungueros en el total de la Sierra ecuatoriana:

\begin{tabular}{|l|c|c|c|c|}
\hline Tamaño & No. de unidad & Superf. Total & $\begin{array}{l}\text { Superf. } \\
\text { labranza }\end{array}$ & $\begin{array}{l}\text { Superf. Tierras } \\
\text { de labranza por } \\
\text { explotación }\end{array}$ \\
\hline -de 1 ha. & 2.130 & 1.100 & 1.100 & 0,5 \\
\hline 1-de 4,9 ha. & 15.000 & 37.000 & 32.900 & 2,2 \\
\hline 5- de 9,9 ha. & 2.020 & 12.800 & 9.800 & 7,1 \\
\hline 10- de 19,9 ha. & 435 & 5.400 & 3.100 & 7,5 \\
\hline 20- de 49,9 ha. & 160 & 4.100 & 1.200 & \\
\hline 50- de 99,9 ha. & & & & 100 \\
\hline 100- de 199,9 ha. & 1 & 100 & & \\
\hline 200 y más ha. & 1 & 60.800 & 48.200 & 2,4 \\
\hline Total & 19.747 & & & \\
\hline
\end{tabular}

Elaboración: Osvaldo Barsky: La reforma agraria ecuatoriana, Biblioteca de Ciencias Sociales, Volumen 3, FLACSO, Corporación Editora Nacional, Quito, 1984.

Fuente: Segovia, artículo en El Comercio, 5 de marzo de 1962. 
Tabla 4: Entrega de huasipungos (1959-1964):

\begin{tabular}{|c|c|c|c|c|}
\hline Años & $\begin{array}{c}\text { No. } \\
\text { Beneficiarios }\end{array}$ & $\begin{array}{c}\text { No. hectáreas } \\
\text { entregadas }\end{array}$ & Porcentaje & $\begin{array}{c}\text { Valor total en } \\
\text { sucres }\end{array}$ \\
\hline 1959 & 88 & 404,80 & 4,4 & \\
\hline 1962 & 899 & $3.661,20$ & 39,4 & $12.542 .341,53$ \\
\hline $\begin{array}{c}1963(01 / 01- \\
11 / 07)\end{array}$ & 447 & 917,21 & 9,8 & $4.747 .206,83$ \\
\hline $\begin{array}{c}1963(12 / 07- \\
31 / 12)\end{array}$ & 863 & $2.391,46$ & 25,7 & $7.067 .960,75$ \\
\hline $\begin{array}{c}1964(01 / 0- \\
15 / 07)\end{array}$ & 722 & $1.929,76$ & 20,7 & $9.139 .34,15$ \\
\hline Total & 3.019 & $9.303,43$ & 100 & $33.496 .850,26$ \\
\hline
\end{tabular}

Fuente: Departamento de Cuestiones Sociales del Ministerio de Previsión Social y Trabajo, en Osvaldo Barsky: La reforma agraria ecuatoriana, Biblioteca de Ciencias Sociales, Volumen 3, FLACSO, Corporación Editora Nacional, Quito, 1984. 
Tabla 5: Entrega de huasipungos por provincias:

\begin{tabular}{|c|c|c|c|c|c|}
\hline Provincias & $\begin{array}{c}\text { No. } \\
\text { beneficiarios }\end{array}$ & Porcentaje & $\begin{array}{c}\text { No. } \\
\text { hectáreas }\end{array}$ & Porcentaje & $\begin{array}{l}\text { Valor total } \\
\text { en sucres }\end{array}$ \\
\hline Pichincha & 1.760 & 58,3 & $4.954,86$ & 53,2 & 15.698 .447 \\
\hline Carchi & 498 & 16,5 & $2.672,21$ & 28,7 & 9.880 .302 \\
\hline Imbabura & 452 & 15,1 & $1.072,47$ & 11,5 & 5.386 .485 \\
\hline Cotopaxi & 158 & 5,2 & 473,63 & 5,2 & 1.946 .851 \\
\hline Chimborazo & 134 & 4,4 & 116,16 & 1,2 & 531.100 \\
\hline Bolívar & 17 & 0,5 & 14,00 & 0,2 & 53.665 \\
\hline Total & 3.019 & 100,0 & $9.303,33$ & 100,0 & 33.496 .850 \\
\hline & & & & & \\
\hline
\end{tabular}

Fuente: Departamento de Cuestiones Sociales del Ministerio de Previsión Social y Trabajo, en Osvaldo Barsky: La reforma agraria ecuatoriana, Biblioteca de Ciencias Sociales, Volumen 3, FLACSO, Corporación Editora Nacional, Quito, 1984. 
Tabla 6: Tipos de haciendas (tipología Barahona, 1963):

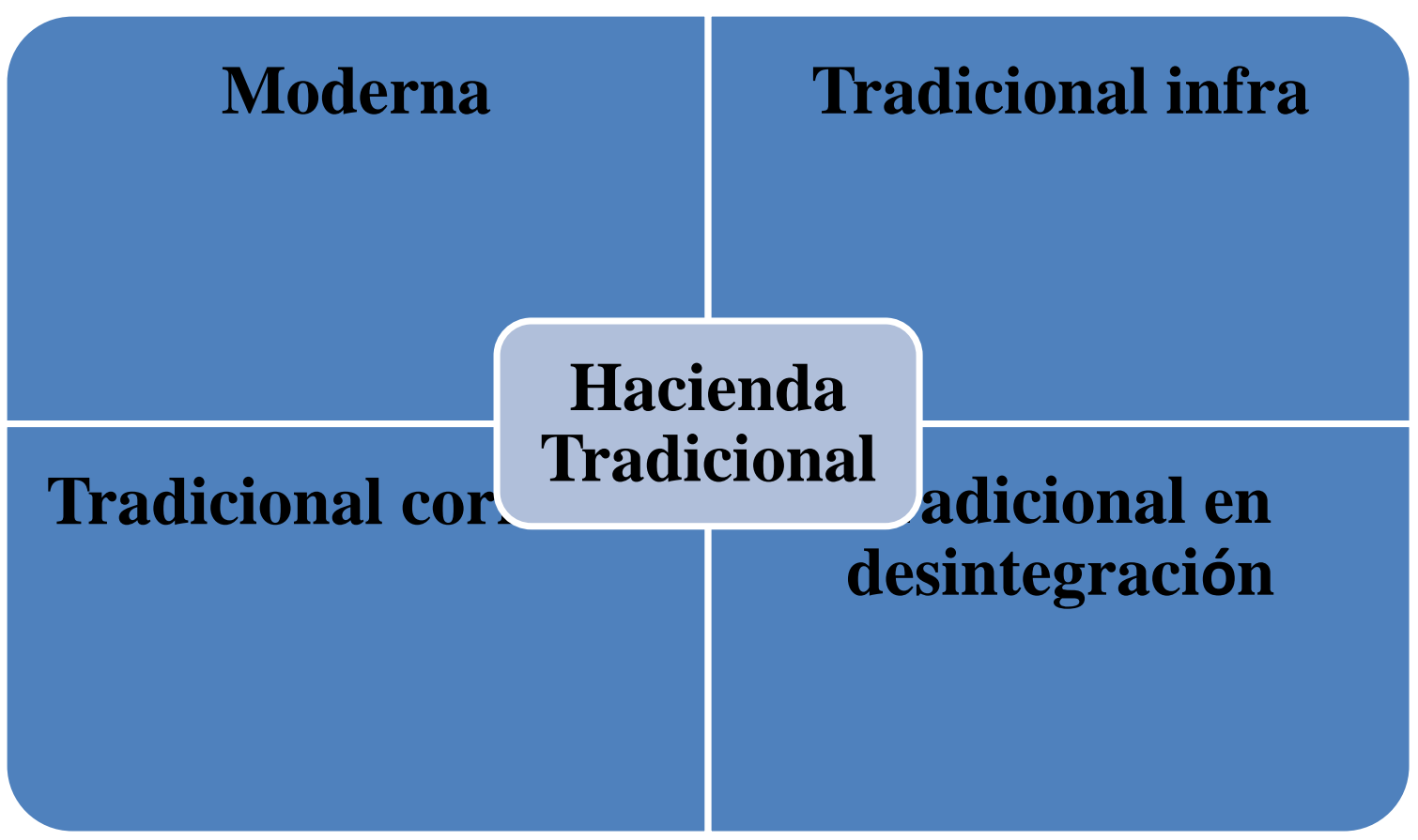

Fuente: Osvaldo Barsky: Iniciativa terrateniente en la estructuración de las relaciones sociales en la Sierra ecuatoriana: 1959-1964, Revista Ciencias Sociales, Volumen II, Número 5, Quito, 1978. 
Tabla 7: Hacienda tradicional infra (tipología Barahona):

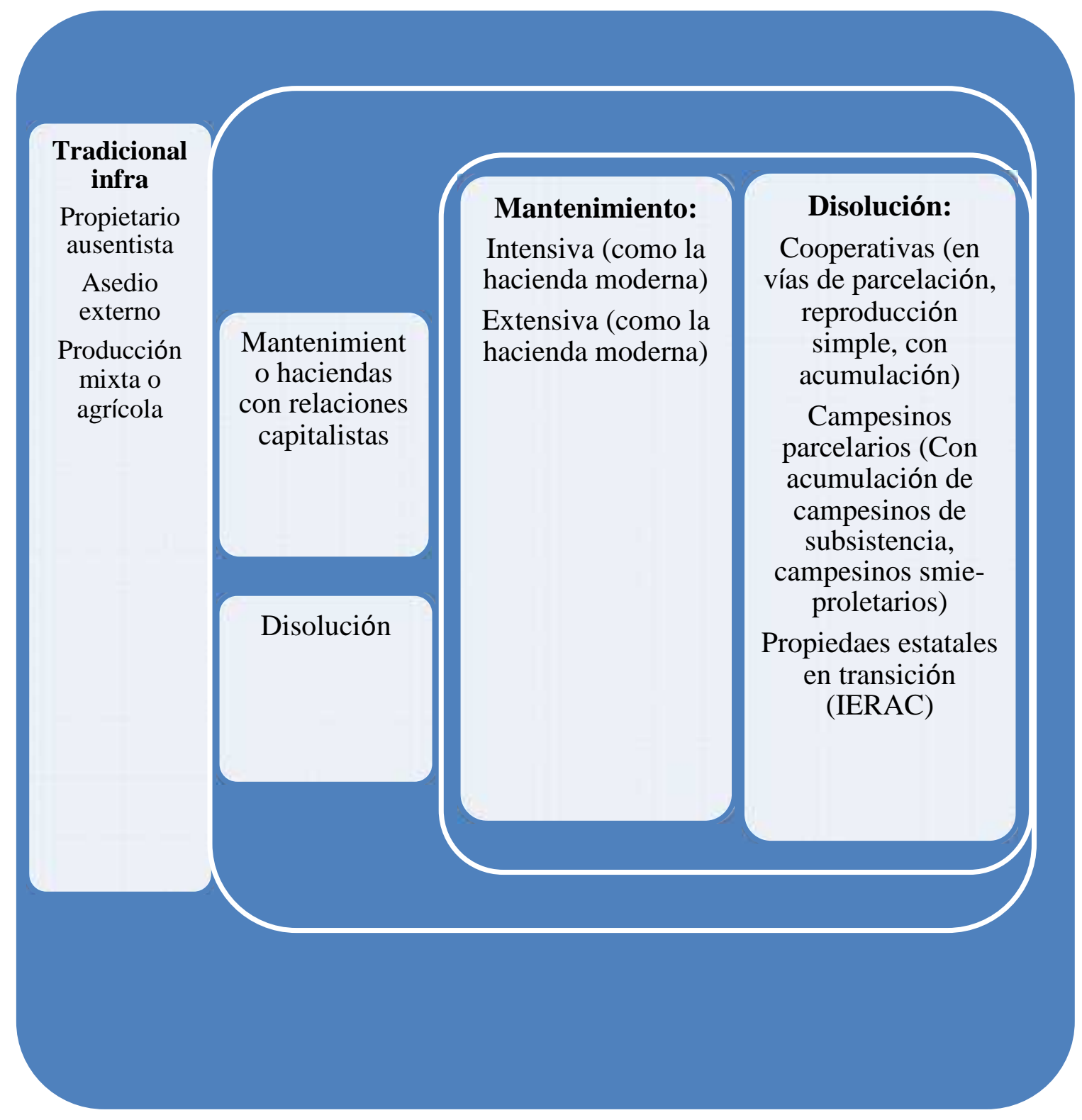

Fuente: Osvaldo Barsky: Iniciativa terrateniente en la estructuración de las relaciones sociales en la Sierra ecuatoriana: 1959-1964, Revista Ciencias Sociales, Volumen II, Número 5, Quito, 1978. 
Tabla 8: Hacienda tradicional en desintegración (tipología Barahona):

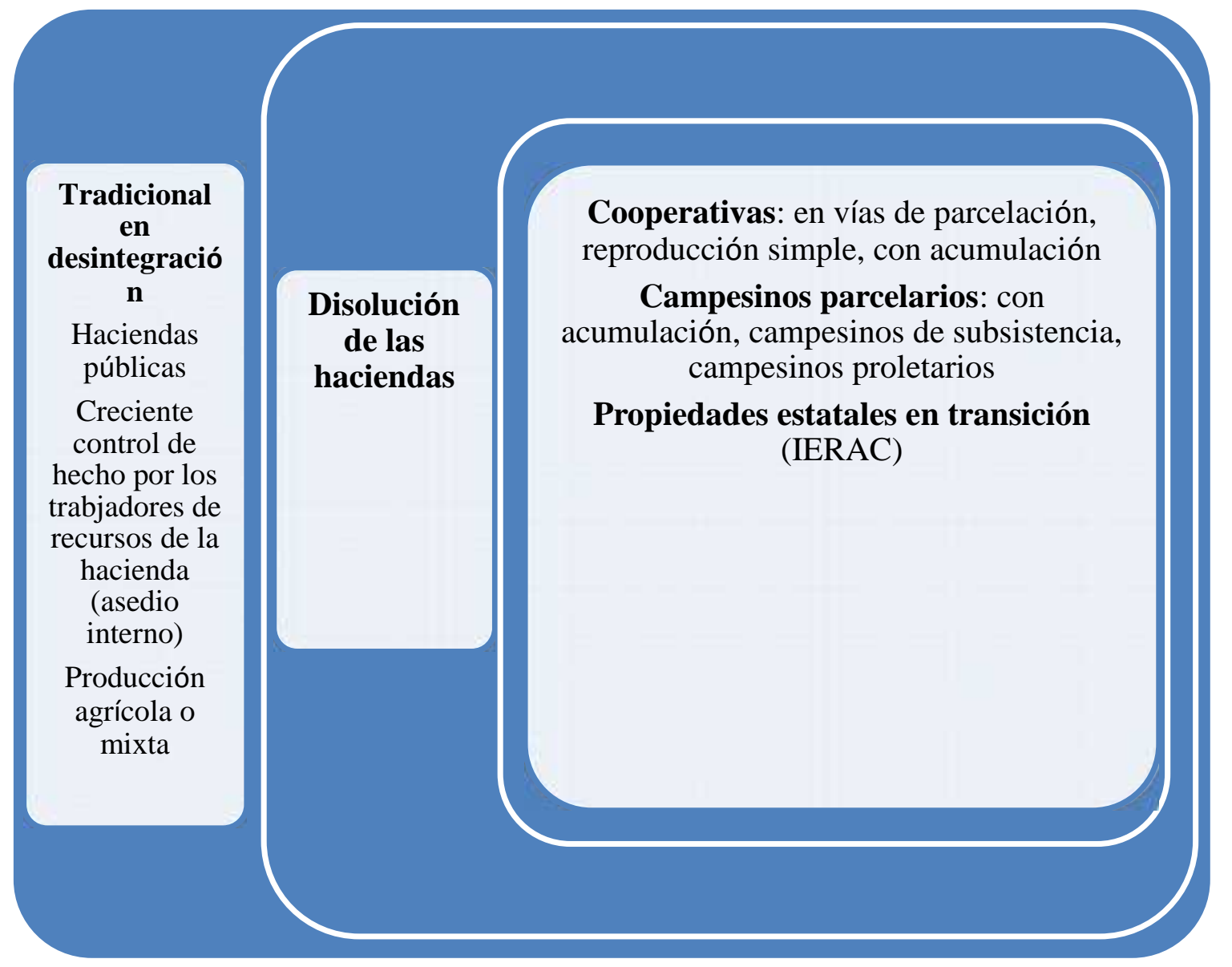

Fuente: Osvaldo Barsky: Iniciativa terrateniente en la estructuración de las relaciones sociales en la Sierra ecuatoriana: 1959-1964, Revista Ciencias Sociales, Volumen II, Número 5, Quito, 1978. 
Tabla 9: Hacienda tradicional corriente (tipología Barahona):

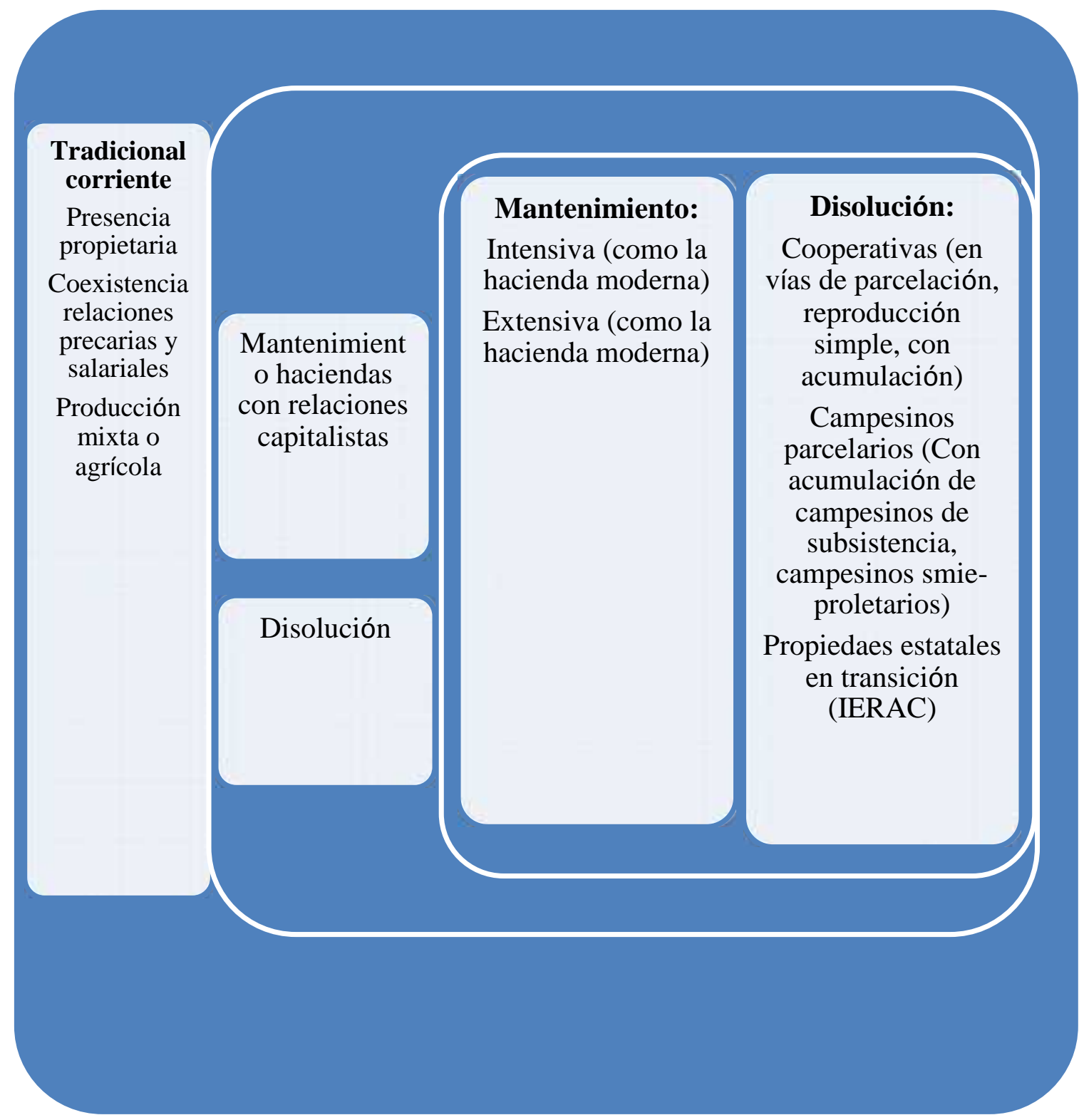

Fuente: Osvaldo Barsky: Iniciativa terrateniente en la estructuración de las relaciones sociales en la Sierra ecuatoriana: 1959-1964, Revista Ciencias Sociales, Volumen II, Número 5, Quito, 1978. 
Tabla 10: Hacienda moderna (tipología Barahona):

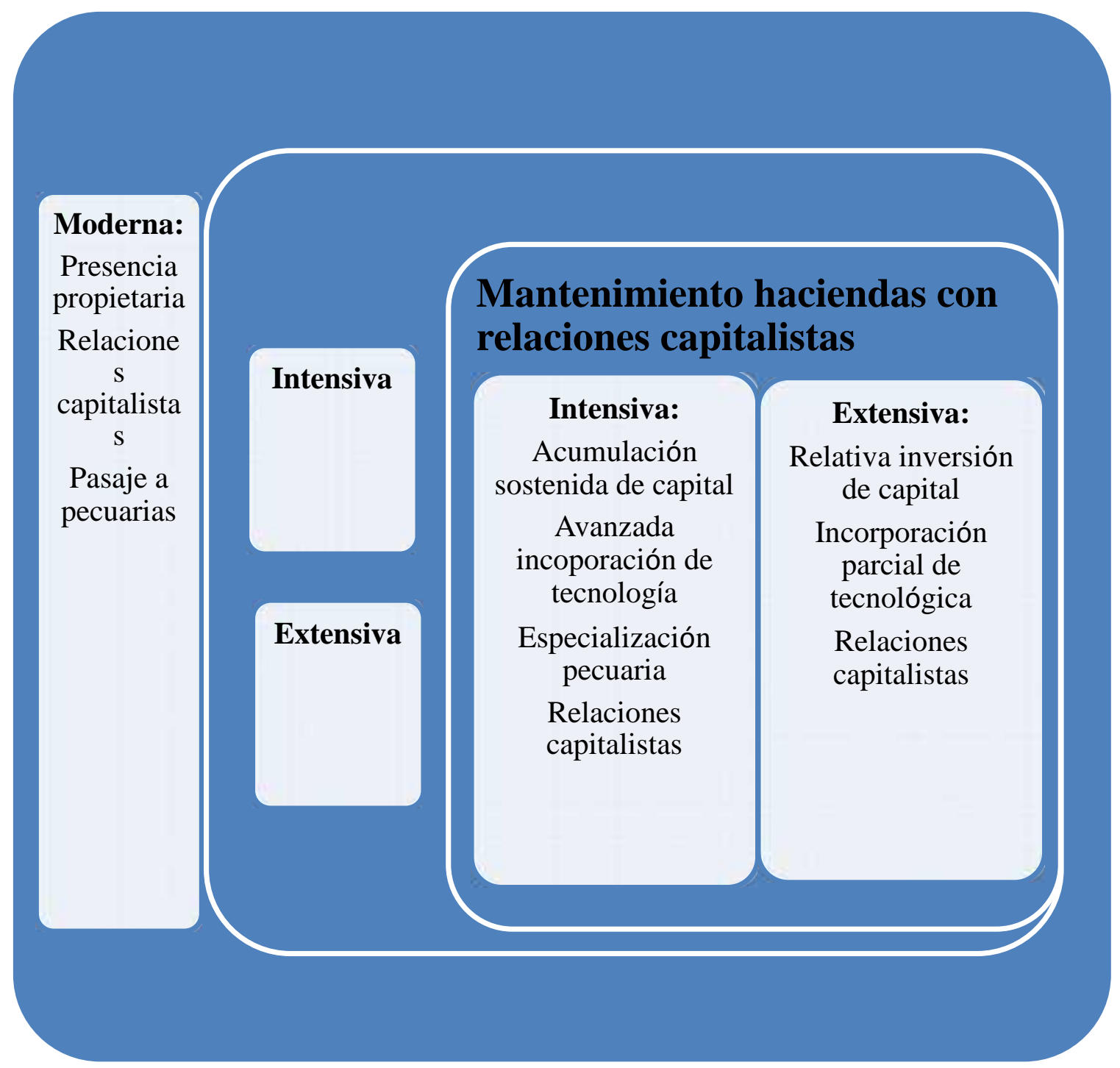

Fuente: Osvaldo Barsky: Iniciativa terrateniente en la estructuración de las relaciones sociales en la Sierra ecuatoriana: 1959-1964, Revista Ciencias Sociales, Volumen II, Número 5, Quito, 1978. 
Tabla 11: Tipos de haciendas y procesos en la Sierra ecuatoriana (Baharona, Barsky y Cosse):

\begin{tabular}{|c|c|c|}
\hline $\begin{array}{l}\text { Tipología de Barahona } 1963 \text { de } \\
\text { Hacienda Tradicional }\end{array}$ & Pasos de transición & Tipología de Barsky y Cosse \\
\hline $\begin{array}{l}\text { Moderna Intensiva y } \\
\text { Extensiva: } \\
\text { Presencia propietaria, relaciones } \\
\text { capitalistas, pasaje a pecuarias. }\end{array}$ & $\begin{array}{l}\text { Mantenimiento haciendas con } \\
\text { relaciones capitalistas. }\end{array}$ & $\begin{array}{l}\text { Mantenimiento: } \\
\text { Intensiva: Acumulación } \\
\text { sostenida de capital, avanzada } \\
\text { incorporación de tecnología, } \\
\text { especialización pecuaria, } \\
\text { relaciones capitalistas. }\end{array}$ \\
\hline $\begin{array}{l}\text { Tradicional Corriente: } \\
\text { Presencia propietaria, relaciones } \\
\text { mixtas precarias y salariales, } \\
\text { producción agrícola o mixta. }\end{array}$ & $\begin{array}{l}\text { Mantenimiento haciendas con } \\
\text { relaciones capitalistas o } \\
\text { disolución. }\end{array}$ & $\begin{array}{l}\text { Mantenimiento: } \\
\text { Extensiva: Relativa inversión de } \\
\text { capital, incorporación parcial de } \\
\text { tecnología, relaciones } \\
\text { capitalistas. }\end{array}$ \\
\hline $\begin{array}{l}\text { Tradicional Infra: } \\
\text { Propietario ausentista, asedio } \\
\text { externo, producción agrícola o } \\
\text { mixta. }\end{array}$ & $\begin{array}{l}\text { Mantenimiento haciendas con } \\
\text { relaciones capitalista disolución. }\end{array}$ & $\begin{array}{l}\text { Disolución: } \\
\text { Cooperativas: En vías de } \\
\text { parcelación, reproducción simple } \\
\text { con acumulación. }\end{array}$ \\
\hline $\begin{array}{l}\text { Tradicional en } \\
\text { desintegración: } \\
\text { Haciendas públicas, creciente } \\
\text { control de los trabajadores, } \\
\text { asedio interno, producción } \\
\text { agrícola mixta. }\end{array}$ & Disolución de las haciendas. & $\begin{array}{l}\text { Campesinos parcelarios: } \\
\text { Con acumulación, campesinos de } \\
\text { subsistencia, campesinos semi- } \\
\text { proletarios. } \\
\text { Propiedades estatales en } \\
\text { transición. }\end{array}$ \\
\hline
\end{tabular}

Fuente: Adaptada de Barsky, Osvaldo: Iniciativa terrateniente en la reestructuración de las relaciones sociales en la Sierra Ecuatoriana: 1959-1964, Revista Ciencias Sociales, Volumen II, Numero 5, Quito, 1978. 
Tabla 12: Número de explotaciones y superficie de la Sierra ecuatoriana por estratos de tamaños, año 1954 (en valores absolutos):

\begin{tabular}{|l|c|c|}
\hline \multicolumn{1}{|c|}{ Tamaños } & Número de explotaciones & Superficie Total \\
\hline Menores de 1 há. & 33.714 & 40.400 \\
\hline De 1 a 5 hás. & 128.439 & 301.300 \\
\hline De 5 a 10 hás. & 22.443 & 154.700 \\
\hline De 10 a 20 hás. & 10.570 & 220.000 \\
\hline De 20 a 50 hás. & 7.722 & 218.700 \\
\hline De 50 a 100 hás. & 3.594 & 471.100 \\
\hline De 100 a 500 hás. & 2.368 & 228.300 \\
\hline De 500 a 1000 hás. & 330 & 362.700 \\
\hline De 1000 a 2500 hás. & 251 & 880.200 \\
\hline De 2500 y más hás. & 138 & 3.020 .400 \\
\hline TOTAL & 259.169 & \\
\hline
\end{tabular}

Fuente: Ministerio de Economía, Dirección General de Estadística y Censos: Censo Agropecuario Nacional 1954, Quito, 1956.

Elaboración: Osvaldo Barsky: Iniciativa terrateniente en la estructuración de las relaciones sociales en la Sierra ecuatoriana: 1959-1964, Revista Ciencias Sociales, Volumen II, Número 5, Quito, 1978. 
Tabla 13: Número estimado de explotaciones y superficie según el uso de la tierra (superficie en 1.000 hectáreas):

\begin{tabular}{|c|c|c|c|c|c|c|c|c|c|c|}
\hline & & & \multicolumn{5}{|c|}{ Tierras de labranza } & \multicolumn{3}{|c|}{ Otras tierras } \\
\hline & $\begin{array}{l}\text { No. estimado } \\
\text { explotaciones }\end{array}$ & $\begin{array}{l}\text { Superficie } \\
\text { total } \\
\text { censada }\end{array}$ & Total & $\begin{array}{l}\text { Cultivos } \\
\text { transitorios }\end{array}$ & $\begin{array}{l}\text { Pastos } \\
\text { artificiales }\end{array}$ & $\begin{array}{c}\text { Barbecho } \\
\text { o } \\
\text { descanso }\end{array}$ & $\begin{array}{l}\text { Cultivos } \\
\text { permanentes }\end{array}$ & $\begin{array}{l}\text { Pastos } \\
\text { naturales }\end{array}$ & Bosque & Maleza \\
\hline $\begin{array}{l}\text { Total } \\
\text { República }\end{array}$ & 344.234 & $5.999,7$ & 2.081 & 896,6 & 520,8 & 348,3 & 315,3 & $1.254,5$ & $1.136,4$ & $1.527,8$ \\
\hline Total Sierra & 259.569 & $3.020,4$ & 847 & 577,6 & 137,8 & 107,1 & 24,9 & 954,9 & 448 & 770,1 \\
\hline Total Costa & 84.665 & $2.979,3$ & 1.234 & 319 & 383 & 241,2 & 290,4 & 299,6 & 688,4 & 757,7 \\
\hline
\end{tabular}

Fuente: Ministerio de Economía, Dirección General de Estadística y Censos: Censo Agropecuario Nacional 1954, Quito, 1956. 
Tabla 14: Producción agrícola (1954):

\begin{tabular}{|c|c|c|c|}
\hline $\begin{array}{c}\text { Producto } \\
\text { Superficie cosechada } \\
\text { y producción }\end{array}$ & Total República & Total Sierra & Total Costa \\
\hline Maíz & $\begin{array}{c}182.800 \text { ha. } \\
2.415 .800 \text { quintales }\end{array}$ & $\begin{array}{c}164.040 \\
2.027 .500\end{array}$ & $\begin{array}{l}18.760 \\
388.300\end{array}$ \\
\hline Fréjol & $\begin{array}{l}22.260 \text { ha. } \\
140.700 \text { qq. }\end{array}$ & $\begin{array}{l}21.690 \\
136.500\end{array}$ & $\begin{array}{c}4.200 \\
320\end{array}$ \\
\hline Cebada & $\begin{array}{l}119.330 \text { ha. } \\
1.289 .000 \text { qq. }\end{array}$ & $\begin{array}{r}119.010 \\
1.286 .700\end{array}$ & $\begin{array}{r}320 \\
2.300\end{array}$ \\
\hline Trigo & $\begin{array}{l}56.770 \text { ha. } \\
729.100 \text { qq. }\end{array}$ & $\begin{array}{r}56.660 \\
728.300\end{array}$ & $\begin{array}{l}110 \\
800\end{array}$ \\
\hline Patatas & $\begin{array}{l}37.290 \text { ha. } \\
3.101 .400 \text { qq. }\end{array}$ & $\begin{array}{c}37.170 \\
3.100 .400\end{array}$ & $\begin{array}{c}120 \\
1.000\end{array}$ \\
\hline Arroz invierno & $\begin{array}{c}44.300 \text { ha. } \\
1.482 .900 \text { qq. }\end{array}$ & $\begin{array}{r}1.840 \\
41.200\end{array}$ & $\begin{array}{c}42.460 \\
1.441 .700\end{array}$ \\
\hline
\end{tabular}




\begin{tabular}{|c|c|c|c|}
\hline Arroz verano & $\begin{array}{l}7.050 \text { ha. } \\
356.700 \text { qq. }\end{array}$ & $\begin{array}{l}40 \\
300\end{array}$ & $\begin{array}{c}7.010 \\
356.400\end{array}$ \\
\hline Banano & $\begin{array}{c}115.080 \text { ha. } \\
62.085 .000 \text { racimos }\end{array}$ & $\begin{array}{c}17.690 \\
10.413 .000\end{array}$ & $\begin{array}{c}97.390 \\
51.672 .000\end{array}$ \\
\hline Plátano & $\begin{array}{l}39.260 \text { ha. } \\
27.029 .000 \text { racimos }\end{array}$ & $\begin{array}{c}9.030 \\
5.165 .000\end{array}$ & $\begin{array}{c}30.230 \\
21.864 .000\end{array}$ \\
\hline Cacao & $\begin{array}{c}114.830 .000 \text { árboles } \\
621.400 \mathrm{qq} .\end{array}$ & $\begin{array}{c}4.670 .000 \\
33.500\end{array}$ & $\begin{array}{r}11.160 .000 \\
587.900\end{array}$ \\
\hline Café & $\begin{array}{c}83.400 .000 \text { árboles } \\
766.500 \mathrm{qq} .\end{array}$ & $\begin{array}{c}11.930 .000 \\
61.700\end{array}$ & $\begin{array}{r}71.470 .000 \\
704.800\end{array}$ \\
\hline Caña & 41.310 ha. & 19.900 & 21.410 \\
\hline
\end{tabular}

Fuente: Ministerio de Economía, Dirección General de Estadística y Censos: Censo Agropecuario Nacional 1954, Quito, 1956. 
Tabla 15: Ganado vacuno. Existencia por provincias (1954):

\begin{tabular}{|c|c|c|}
\hline Provincias & $\begin{array}{c}\text { No. estimado de } \\
\text { explotaciones informantes }\end{array}$ & Total \\
\hline Total República & 163.019 & $1.215,9$ \\
\hline Total Sierra & 136.020 & 786,3 \\
\hline Azuay & 24.550 & 105,0 \\
\hline Bolívar & 10.947 & 49,0 \\
\hline Cañar & 8.551 & 39,1 \\
\hline Carchí & 4.473 & 49,1 \\
\hline Cotopaxi & 12.019 & 63,1 \\
\hline Chimborazo & 18.075 & 79,3 \\
\hline Imbabura & 8.908 & 46,2 \\
\hline Loja & 19.107 & 147,7 \\
\hline Pichincha & 13.366 & 153,7 \\
\hline
\end{tabular}




\begin{tabular}{|l|l|l|}
\hline Tunguragua & 16.024 & 54,1 \\
\hline
\end{tabular}

Fuente: Ministerio de Economía, Dirección General de Estadística y Censos: Censo Agropecuario Nacional 1954, Quito, 1956.

Tabla 16: Ganado vacuno. Existencia por provincias (1954):

\begin{tabular}{|c|c|c|}
\hline Provincias & $\begin{array}{c}\text { No. estimado de } \\
\text { explotaciones informantes }\end{array}$ & Total \\
\hline Total Costa & $\mathbf{2 6 . 9 9 9}$ & $\mathbf{4 2 9 , 6}$ \\
\hline El Oro & 2.206 & 25,6 \\
\hline Esmeraldas & 2.107 & 37,9 \\
\hline Guayas & 7.051 & 141,3 \\
\hline Los Ríos & 2.312 & 52,0 \\
\hline Manabí & & 172,8 \\
\hline
\end{tabular}

Fuente: Ministerio de Economía, Dirección General de Estadística y Censos: Censo Agropecuario Nacional 1954, Quito, 1956. 
Tabla 17: Ganado Vacuno: Existencias de ganado por tamaño de explotaciones (1.000 cabezas):

\begin{tabular}{|c|c|c|}
\hline Tamaño de las explotaciones & $\begin{array}{c}\text { No. estimado de } \\
\text { explotaciones informantes }\end{array}$ & Total \\
\hline Total República & 163.019 & $1.215,9$ \\
\hline Menores de 1 ha. & 24.075 & 48,0 \\
\hline De 1 a 4,9 ha. & 74.482 & 236,6 \\
\hline De 5 a 9,9 ha. & 28.768 & 125,0 \\
\hline De 10 a 19,9 ha. & 13.008 & 94,9 \\
\hline De 20 a 49,9 ha. & 12.418 & 148,8 \\
\hline De 50 a 99,9 ha. & 4.921 & 102,0 \\
\hline De 100 a 199,9 ha. & 2.555 & 103,7 \\
\hline De 200 a 499,9 ha. & 1.726 & 126,5 \\
\hline De 500 a 999,9 ha. & 517 & 74,2 \\
\hline De 1.000 a $2.499,9$ ha. & 375 & 85,2 \\
\hline
\end{tabular}


De 2.500 o más ha.

Fuente: Ministerio de Economía, Dirección General de Estadística y Censos: Censo Agropecuario Nacional 1954, Quito, 1956.

Tabla 18: Ganado Vacuno: Existencias de ganado por tamaño de explotaciones (1.000 cabezas):

\begin{tabular}{|c|c|c|}
\hline Tamaño de las explotaciones & $\begin{array}{c}\text { No. estimado de } \\
\text { explotaciones informantes }\end{array}$ & Total \\
\hline Total Sierra & 136.020 & 786,3 \\
\hline Menores de 1 ha. & 23.469 & 45,4 \\
\hline De 1 a 4,9 ha. & 70.040 & 216,3 \\
\hline De 5 a 9,9 ha. & 24.735 & 103,7 \\
\hline De 10 a 19,9 ha. & 8.041 & 63,0 \\
\hline De 20 a 49,9 ha. & 5.531 & 73,7 \\
\hline De 50 a 99,9 ha. & 1.765 & 42,1 \\
\hline De 100 a 199,9 ha. & 1.060 & 46,5 \\
\hline
\end{tabular}




\begin{tabular}{|c|c|c|}
\hline De 200 a 499,9 ha. & 777 & 63,2 \\
\hline De 500 a 999,9 ha. & 270 & 43,5 \\
\hline De 1.000 a 2.499,9 ha. & 224 & 50,4 \\
\hline & & \\
\hline De 2.500 o más ha. & 108 & 38,5 \\
\hline
\end{tabular}

Fuente: Ministerio de Economía, Dirección General de Estadística y Censos: Censo Agropecuario Nacional 1954, Quito, 1956. 
Tabla 19: Ganado Vacuno: Existencias de ganado por tamaño de explotaciones (1.000 cabezas):

\begin{tabular}{|c|c|c|}
\hline Tamaño de las explotaciones & $\begin{array}{c}\text { No. estimado de } \\
\text { explotaciones informantes }\end{array}$ & Total \\
\hline Total Costa & 26.999 & 426,6 \\
\hline Menores de 1 ha. & 606 & 2,6 \\
\hline De 1 a 4,9 ha. & 4.442 & 20,3 \\
\hline De 5 a 9,9 ha. & 4.033 & 21,3 \\
\hline De 10 a 19,9 ha. & 4.967 & 31,9 \\
\hline De 20 a 49,9 ha. & 6.887 & 75,1 \\
\hline De 50 a 99,9 ha. & 3.156 & 59,9 \\
\hline De 100 a 199,9 ha. & 1.495 & 57,2 \\
\hline De 200 a 499,9 ha. & 949 & 63,3 \\
\hline De 500 a 999,9 ha. & 247 & 30,7 \\
\hline De 1.000 a $2.499,9$ ha. & 151 & 34,8 \\
\hline
\end{tabular}




\begin{tabular}{|l|c|c|}
\hline De 2.500 o más ha. & 66 & 32,5 \\
\hline
\end{tabular}

Fuente: Ministerio de Economía, Dirección General de Estadística y Censos: Censo Agropecuario Nacional 1954, Quito, 1956. 
Tabla 20: Producción pecuaria: vacas lechando, leche producida y huevos obtenidos el día anterior a la enumeración y ovejas esquiladas y lana producida durante 1954 (por provincias):

\begin{tabular}{|c|c|c|c|c|c|}
\hline Provincias & $\begin{array}{c}\text { No. de vacas } \\
\text { ordeñadas }\end{array}$ & $\begin{array}{c}\text { Leche } \\
\text { producida } \\
\text { (en 1.000 } \\
\text { litros) }\end{array}$ & $\begin{array}{c}\text { Ovejas } \\
\text { esquiladas }\end{array}$ & $\begin{array}{c}\text { Lana } \\
\text { producida } \\
\text { (en qq.) }\end{array}$ & $\begin{array}{c}\text { Huevos } \\
\text { puestos (en } \\
1.000)\end{array}$ \\
\hline $\begin{array}{c}\text { Total } \\
\text { República }\end{array}$ & 220,2 & 718,4 & 871,8 & 16.772 & 466,7 \\
\hline Total Sierra & 134,7 & 511,2 & 863,7 & 16.724 & 275,2 \\
\hline Azuay & 20,4 & 65,4 & 103,8 & 1.948 & 38,2 \\
\hline Bolívar & 9,6 & 29,6 & 111,6 & 2.7166 & 38,6 \\
\hline Cañar & 6,2 & 17,0 & 36,7 & 766 & 19,0 \\
\hline Carchi & 9,1 & 34,3 & 13,8 & 293 & 7,8 \\
\hline Cotopaxi & 13,8 & 61,2 & 165,1 & 2.704 & 14,7 \\
\hline Chimborazo & 12,6 & 41,9 & 143,7 & 3.224 & 30,8 \\
\hline Imbabura & 8,1 & 31,6 & 73,8 & 1.116 & 22,3 \\
\hline & & & & & \\
\hline
\end{tabular}




\begin{tabular}{|c|c|c|c|c|c|}
\hline Loja & 12,6 & 30,6 & 41,2 & 591 & 54,5 \\
\hline Pichincha & 31,8 & 165,1 & 107,0 & 1.956 & 35,8 \\
\hline Tunguragua & 10,5 & 34,5 & 67,0 & 1.410 & 13,5 \\
\hline
\end{tabular}

Fuente: Ministerio de Economía, Dirección General de Estadística y Censos: Censo Agropecuario Nacional 1954, Quito, 1956. 
Tabla 21: Producción pecuaria: vacas lechando, leche producida y huevos obtenidos el día anterior a la enumeración y ovejas esquiladas y lana producida durante 1954 (provincias):

\begin{tabular}{|c|c|c|c|c|c|}
\hline Provincias & $\begin{array}{c}\text { No. de vacas } \\
\text { ordeñadas }\end{array}$ & $\begin{array}{c}\text { Leche } \\
\text { producida } \\
\text { (en 1.000 } \\
\text { litros) }\end{array}$ & $\begin{array}{c}\text { Ovejas } \\
\text { esquiladas }\end{array}$ & $\begin{array}{c}\text { Lana } \\
\text { producida } \\
\text { (en qq.) }\end{array}$ & $\begin{array}{c}\text { Huevos } \\
\text { puestos (en } \\
1.000)\end{array}$ \\
\hline Total Costa & 85,5 & 207,2 & 8,1 & 48 & 191,5 \\
\hline El Oro & 3,2 & 9,2 & 8,0 & 46 & 11,6 \\
\hline Esmeraldas & 4,5 & 9,9 & - & - & 10,4 \\
\hline Guayas & 33,0 & 83,2 & 0,1 & 2 & 27,3 \\
\hline Los Ríos & 9,0 & 22,1 & - & - & 20,3 \\
\hline Manabí & 35,8 & 82,8 & - & - & 121,9 \\
\hline
\end{tabular}

Fuente: Ministerio de Economía, Dirección General de Estadística y Censos: Censo Agropecuario Nacional 1954, Quito, 1956. 
Tabla 22: Producción pecuaria (1954):

\begin{tabular}{|c|c|c|c|}
\hline $\begin{array}{c}\text { Concepto } \\
\text { (cabezas) }\end{array}$ & Total República & Total Sierra & Total Costa \\
\hline Ganado Vacuno & 1.215 .900 & 786.300 & 429.600 \\
\hline Ovejas & 1.330 .600 & 1.338 .000 & 12.600 \\
\hline Porcinos & 683.100 & 429.800 & 253.300 \\
\hline $\begin{array}{c}\text { Gallos, gallinas y } \\
\text { pollos }\end{array}$ & 2.856 .200 & 1.674 .500 & 1.181 .700 \\
\hline
\end{tabular}

Fuente: Ministerio de Economía, Dirección General de Estadística y Censos: Censo Agropecuario Nacional 1954, Quito, 1956. 
Tabla 23: Tipo de tracción usada en las actividades agrícolas según tamaño de las explotaciones (1954):

\begin{tabular}{|c|c|c|c|c|c|c|}
\hline $\begin{array}{l}\text { Tamaño } \\
\text { explotaciones }\end{array}$ & $\begin{array}{l}\text { No. } \\
\text { explotaciones }\end{array}$ & $\begin{array}{l}\text { Tracción } \\
\text { animal }\end{array}$ & $\begin{array}{l}\text { Tracción } \\
\text { mecánica }\end{array}$ & $\begin{array}{l}\text { Tracción } \\
\text { mixta }\end{array}$ & $\begin{array}{l}\text { Ninguna } \\
\text { tracción }\end{array}$ & $\begin{array}{l}\text { Sin } \\
\text { información }\end{array}$ \\
\hline De 0 a 4,9 ha. & 215.250 & 160.262 & - & 60 & 81.372 & 9.556 \\
\hline $\begin{array}{c}\text { De 5 a 9,9 ha. } \\
\text { De 10 a 49,9 } \\
\text { ha. }\end{array}$ & 46.117 & 16.477 & - & 40 & 18.399 & 1.201 \\
\hline $\begin{array}{c}\text { De 50 a 199,9 } \\
\text { ha. }\end{array}$ & 11.957 & 1.777 & 102 & 295 & 9.466 & 1.378 \\
\hline $\begin{array}{c}\text { Más de 200 } \\
\text { ha. }\end{array}$ & 3.697 & 762 & 207 & 381 & 2.271 & \\
\hline
\end{tabular}

Fuente: Censo Agropecuario de 1954, JUNAPLA y FAO, 1960. 
Tabla 24: Maquinaria agrícola en el Ecuador entre 1959-1962 (en unidades acumulativas):

\begin{tabular}{|c|c|c|c|c|}
\hline $\begin{array}{c}\text { Tipo de } \\
\text { maquinaria }\end{array}$ & 1959 & 1960 & 1961 & 1962 \\
\hline $\begin{array}{c}\text { Tractores de } \\
\text { rueda }\end{array}$ & 677 & 690 & 695 & 700 \\
\hline Tractores oruga & 855 & 860 & 863 & 865 \\
\hline Motocultivadoras & 285 & 290 & 295 & 310 \\
\hline $\begin{array}{l}\text { Trilladoras- } \\
\text { cosechadoras }\end{array}$ & 129 & 134 & 142 & 144 \\
\hline Sembradoras & 360 & 370 & 385 & 400 \\
\hline
\end{tabular}

Fuente: Departamento Estimaciones Agrarias, Dirección Nacional de Agricultura y Ministerio de Fomento, 1963. 
Tabla 25: Porcentaje de huasipungos entregados y de superficie entregada en 1959:

\begin{tabular}{|c|c|c|}
\hline Provincia & \% de huasipungos & Superficie (\%) \\
\hline Carchi & 92,1 & 4,4 \\
\hline Imbabura & 24,3 & 23,9 \\
\hline Pichincha & 26,9 & 27,3 \\
\hline En contraste con Cotopaxi & 4,3 & 6,6 \\
\hline
\end{tabular}

Fuente: Rafael Quintero, Erika Silva: Ecuador: Una nación en ciernes, Tomo III, FLACSO, Abya-Yala, 1991, p. 201. 
Tabla 26: Población total del Ecuador estimada por regiones (1955-1965) (miles de personas):

\begin{tabular}{|c|c|c|c|c|c|}
\hline Años & Población & Sierra & Costa & Oriente & $\begin{array}{l}\text { Archipiélago } \\
\text { de Colón }\end{array}$ \\
\hline 1955 & 3.722 & 2.144 & 1.526 & 50 & 2 \\
\hline 1956 & 3.833 & 2.167 & 1.612 & 52 & 2 \\
\hline 1957 & 3.949 & 2.277 & 1.671 & 55 & 2 \\
\hline 1958 & 4.070 & 2.277 & 1.734 & 57 & 2 \\
\hline 1959 & 4.195 & 2.336 & 1.797 & 60 & 2 \\
\hline 1960 & 4.325 & 2.419 & 1.843 & 61 & 2 \\
\hline 1961 & 4.461 & 2.480 & 1.918 & 61 & 2 \\
\hline 1962 & 4.602 & 2.515 & 2.020 & 65 & 2 \\
\hline 1963 & 4.749 & 2.473 & 2.192 & 81 & 3 \\
\hline 1964 & 4.902 & 2.535 & 2.278 & 86 & 3 \\
\hline 1965 & 5.061 & 2.599 & 2.367 & 92 & 3 \\
\hline
\end{tabular}

Fuente: Patricio Almeida Guzmán, Rebeca Almeida Arroba: Estadísticas Económicas Históricas 1948-1983, en Fuentes para la Historia Económica del Ecuador, serie estadísticas históricas, vol. 1, Banco Central del Ecuador, 1988, p. 5. 
Tabla 27: Población alfabeta y analfabeta (población de 15 años y más):

\begin{tabular}{|c|c|c|c|c|c|c|}
\hline \multirow{2}{*}{ Años } & \multicolumn{3}{|c|}{ Población Alfabeta } & \multicolumn{3}{|c|}{ Población analfabeta } \\
\hline & Hombres & Mujeres & Total & Hombres & Mujeres & Total \\
\hline 1950 & 557.891 & 468.822 & 1.026 .713 & 341.188 & 474.276 & 85.464 \\
\hline 1951 & & & & & & \\
\hline 1952 & & & & & & \\
\hline 1953 & & & & & & \\
\hline 1954 & & & & & & \\
\hline 1955 & & & & & & \\
\hline 1956 & & & & & & \\
\hline 1957 & & & & & & \\
\hline 1958 & & & & & & \\
\hline 1959 & & & & & & \\
\hline 1960 & & & & & & \\
\hline 1961 & & & & & & \\
\hline 1962 & 872.690 & 789.277 & 1.661 .967 & 337.849 & 461.686 & 799.563 \\
\hline 1963 & & & & & & \\
\hline
\end{tabular}




\begin{tabular}{|l|l|l|l|l|l|l|}
\hline 1964 & & & & & & \\
\hline 1965 & & & & & & \\
\hline
\end{tabular}

Fuente: Patricio Almeida Guzmán, Rebeca Almeida Arroba: Estadísticas Económicas Históricas 1948-1983, en Fuentes para la Historia Económica del Ecuador, serie estadísticas históricas, vol. 1, Banco Central del Ecuador, 1988, p. 395-396. 
Tabla 28: Número de alfabetizados 1948-1956 (por provincias):

\begin{tabular}{|c|c|c|c|c|c|c|c|c|c|}
\hline Provincia & 1948 & 1949 & 1950 & 1951 & 1952 & 1953 & 1954 & 1955 & 1956 \\
\hline Carchi & 1.845 & 1.162 & 932 & 579 & 54 & 102 & & & \\
\hline Imbabura & 2.274 & 1.833 & 1.560 & 636 & 239 & 476 & & & \\
\hline Pichincha & 2.268 & 2.695 & 1.395 & 747 & 119 & 121 & & & \\
\hline Cotopaxi & 707 & 722 & 1.185 & 507 & 142 & 175 & & & \\
\hline Tungurahua & 4.018 & 4.739 & 880 & 424 & 180 & 209 & & & \\
\hline Chimborazo & 954 & 1.132 & 2.192 & 987 & 873 & 448 & & & \\
\hline Bolívar & 1.386 & 901 & 936 & 534 & 328 & 265 & & & \\
\hline Cañar & 2.001 & 2.690 & 1.675 & 1.525 & 541 & 165 & & & \\
\hline Azuay & 2.628 & 1.930 & 1.937 & 1.416 & 487 & 797 & & & \\
\hline Loja & 1.754 & 1.501 & 1.586 & 597 & 162 & 360 & & & \\
\hline El Oro & & & & & & & & & \\
\hline Guayas & & & & & & & & & \\
\hline Los Ríos & & & & & & & & & \\
\hline Manabí & & & & & & & & & \\
\hline Esmeraldas & & & & & & & & & \\
\hline Napo & 529 & 340 & 757 & 318 & 38 & 34 & & & \\
\hline Pastaza & & & & & & & & & \\
\hline Zamora & 558 & 418 & 981 & 439 & 31 & 72 & & & \\
\hline Morona & & & & & & & & & \\
\hline Galápagos & & & & & & & & & \\
\hline Total & 20.932 & 20.063 & 16.016 & 8.703 & 3.194 & 3.324 & 3.605 & 3.361 & 2.929 \\
\hline
\end{tabular}




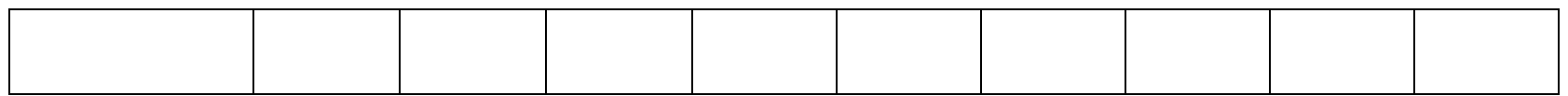

Fuente: Patricio Almeida Guzmán, Rebeca Almeida Arroba: Estadísticas Económicas Históricas 1948-1983, en Fuentes para la Historia Económica del Ecuador, serie estadísticas históricas, vol. 1, Banco Central del Ecuador, 1988, p. 397-398.

Tabla 28: Número de alfabetizados (1957-1965) (por provincia):

\begin{tabular}{|c|c|c|c|c|c|c|c|c|c|}
\hline Provincia & 1957 & 1958 & 1959 & 1960 & 1961 & 1962 & 1963 & 1964 & 1965 \\
\hline Carchi & & & & & & & & & \\
\hline Imbabura & & & & & & & & & \\
\hline Pichincha & & & & & & & & & \\
\hline Cotopaxi & & & & & & & & & \\
\hline Tungurahu & & & & & & & & & \\
\hline Chimboraz & & & & & & & & & \\
\hline Bolívar & & & & & & & & & \\
\hline Cañar & & & & & & & & & \\
\hline Azuay & & & & & & & & & \\
\hline Loja & & & & & & & & & \\
\hline El Oro & & & & & & & & & \\
\hline Guayas & & & & & & & & & \\
\hline Los Ríos & & & & & & & & & \\
\hline Manabí & & & & & & & & & \\
\hline Esmeraldas & & & & & & & & & \\
\hline Napo & & & & & & & & & \\
\hline Pastaza & & & & & & & & & \\
\hline Zamora & & & & & & & & & \\
\hline
\end{tabular}




\begin{tabular}{|l|l|l|l|l|l|l|l|l|l|}
\hline Morona & & & & & & & & & \\
\hline Galápagos & & & & & & & & & \\
\hline Total & 4.509 & 2.989 & & & & & & & \\
\hline
\end{tabular}

Fuente: Patricio Almeida Guzmán, Rebeca Almeida Arroba: Estadísticas Económicas Históricas 1948-1983, en Fuentes para la Historia Económica del Ecuador, serie estadísticas históricas, vol. 1, Banco Central del Ecuador, 1988, p. 397-398. 


\section{APÉNDICE DE DATOS Y ESTADÍSTICAS: CAPÍTULO 4}

Tabla 1: Adjudicación de tierras, del sector privado, la Asistencia Social, el estado y otros organismos a diciembre de 1967 (por provincias):

\begin{tabular}{|c|c|c|c|c|}
\hline Provincias & $\begin{array}{c}\text { Num. Has o } \\
\text { zonas }\end{array}$ & Num. hectáreas & $\begin{array}{c}\text { Num. familias } \\
\text { beneficiadas }\end{array}$ & $\begin{array}{c}\text { Promedio } \\
\text { provincial }\end{array}$ \\
\hline Azuay & 3 & $2.689,85$ & 48 & 56,04 \\
\hline Cañar & 4 & $9.052,72$ & 485 & 18,67 \\
\hline Carchi & 2 & $4.497,42$ & 413 & 10,89 \\
\hline Cotopaxi & 2 & $3.062,12$ & 808 & 2,69 \\
\hline Chimborazo & 1 & 785,98 & 292 & 16,65 \\
\hline El Oro & 10 & $5.077,65$ & 305 & 11,52 \\
\hline Guayas & 5 & $9.077,65$ & 782 & 2,00 \\
\hline Imbarura & 1 & 222,47 & 111 & 29,39 \\
\hline Los Ríos & 1 & $5.318,89$ & 181 & 6,93 \\
\hline Pichincha & 11 & $4.495,48$ & 649 & 158,57 \\
\hline Total & 40 & $44.210,06$ & 4.074 & \\
\hline
\end{tabular}

Fuente y elaboración: Archivo de Providencias de adjudicación de tierras. Sección de evaluación y Estadísticas, 1968. En Alfredo Costales y Piedad Peñaherrera Costales: Historia Social del Ecuador: Reforma Agraria, Edit. Casa de la Cultura Ecuatoriana, Quito, 1971. 
Tabla 2: Crédito del sistema bancario por actividades (1960-1967):

\begin{tabular}{|c|c|c|c|c|c|c|c|c|c|c|}
\hline \multirow[t]{2}{*}{ Años } & \multicolumn{2}{|c|}{ Agricultura } & \multicolumn{2}{|c|}{ Comercio } & \multicolumn{2}{|c|}{ Industria } & \multicolumn{2}{|c|}{ Otros } & \multicolumn{2}{|c|}{ Total } \\
\hline & Valor & $\%$ & Valor & $\%$ & Valor & $\%$ & Valor & $\%$ & Valor & $\%$ \\
\hline 1960 & 334,5 & 7,6 & $3.071,8$ & 70,1 & 598,6 & 13,7 & 379,3 & 8,6 & $4.384,2$ & 100 \\
\hline 1961 & 438,5 & 9,1 & $3.426,5$ & 70,9 & 574,4 & 11,9 & 390 & 8,1 & $4.829,4$ & 100 \\
\hline 1962 & 386,3 & 7,6 & $3.862,3$ & 75,6 & 569,5 & 11,1 & 293,4 & 5,7 & $5.111,5$ & 100 \\
\hline 1963 & 424,1 & 7,3 & $4.294,3$ & 74,1 & 714,4 & 12,3 & 362,9 & 6,3 & $5.795,7$ & 100 \\
\hline 1964 & 525,4 & 6,9 & $5.655,9$ & 74,1 & 913,8 & 11,9 & 54,1 & 7,1 & $7.636,2$ & 100 \\
\hline 1965 & 733,1 & 9,6 & $5.276,7$ & 69,3 & $1.188,8$ & 15,6 & 412 & 5,4 & $7.610,6$ & 100 \\
\hline 1966 & 917 & 11,9 & $5.103,5$ & 66 & $1.186,7$ & 15,4 & 522,2 & 6,7 & $7.729,4$ & 100 \\
\hline 1967 & 979,7 & 10,6 & $6.316,1$ & 68,5 & $1.166,7$ & 12,7 & 752.9 & 8,2 & $9.215,4$ & 100 \\
\hline
\end{tabular}

Nota: El comercio incluye crédito para futuras exportaciones concedido por el Banco Central.

Fuente: Sección Programación Financiera y Banco Nacional de Fomento, en: Secretaría General de Planeación y Económica de la Junta Nacional de Planificación y Coordinación: El crédito agropecuario en el periodo 1964-1967, documento num. 08-03, 1968, p. 3. 
Tabla 3: Crédito otorgado por el sistema bancario para la agricultura (1960-1967):

\begin{tabular}{|c|c|c|c|c|c|c|c|c|}
\hline \multirow{2}{*}{ Años } & \multicolumn{2}{|c|}{ Banco Central } & \multicolumn{2}{|c|}{$\begin{array}{c}\text { Banco Nacional } \\
\text { Fomento }\end{array}$} & \multicolumn{2}{c|}{ Bancos Privados } & \multicolumn{2}{|c|}{ Total } \\
\cline { 2 - 10 } & Valor & \% & Valor & $\%$ & Valor & \% & Valor & $\%$ \\
\hline $\mathbf{1 9 6 0}$ & 36,8 & 10,8 & 189,1 & 56,5 & 109,1 & 32,6 & 334,5 & 100 \\
\hline $\mathbf{1 9 6 1}$ & 101,7 & 23,2 & 234,2 & 53,4 & 102,5 & 23,4 & 438,5 & 100 \\
\hline $\mathbf{1 9 6 2}$ & 108,5 & 28,1 & 183,9 & 47,6 & 93,9 & 24,3 & 386,3 & 100 \\
\hline $\mathbf{1 9 6 3}$ & 102,4 & 24,1 & 222,9 & 52,6 & 98,8 & 23,3 & 424,1 & 100 \\
\hline $\mathbf{1 9 6 4}$ & 98 & 18,6 & 266,2 & 50,7 & 161,2 & 30,7 & 525,4 & 100 \\
\hline $\mathbf{1 9 6 5}$ & 133,1 & 18,1 & 258 & 35,2 & 342 & 46,7 & 733,1 & 100 \\
\hline $\mathbf{1 9 6 6}$ & 153,2 & 16,7 & 281,4 & 30,7 & 482,4 & 52,6 & 917 & 100 \\
\hline $\mathbf{1 9 6 7}$ & 186,2 & 19 & 323,7 & 33,0 & 469,8 & 48,0 & 979,7 & 100 \\
\hline
\end{tabular}

Fuente: Sección Programación Financiera y Banco Nacional de Fomento, en: Secretaría General de Planeación y Económica de la Junta Nacional de Planificación y Coordinación: El crédito agropecuario en el periodo 1964-1967, documento num. 08-03, 1968, p. 4. 
Tabla 4: Metas del Plan de Desarrollo y Crédito Agropecuario concedido por el sistema bancario, 1964-1967 (en millones de sucres):

\begin{tabular}{|c|c|c|c|}
\hline Años & Crédito planeado (a) & $\begin{array}{c}\text { Crédito concedido } \\
(\mathbf{b})\end{array}$ & $\begin{array}{c}\text { Porcentaje (b/a } \\
* \mathbf{1 0 0})\end{array}$ \\
\hline $\mathbf{1 9 6 4}$ & 396,2 & 525,4 & 132,6 \\
\hline $\mathbf{1 9 6 5}$ & 489,1 & 733,1 & 149,9 \\
\hline $\mathbf{1 9 6 6}$ & 569,6 & 917,0 & 161,0 \\
\hline $\mathbf{1 9 6 7}$ & 628,0 & 979,7 & 155,7 \\
\hline
\end{tabular}

Fuente: Plan de Desarrollo y Sección Programación Financiera, en: Secretaría General de Planeación y Económica de la Junta Nacional de Planificación y Coordinación: El crédito agropecuario en el periodo 1964-1967, documento num. 08-03, 1968, p. 11. 
Tabla 5: Comparación de las metas del Plan con el crédito concedido por el Banco Nacional de Fomento, 1964-1967 (millones de sucres):

\begin{tabular}{|c|c|c|c|}
\hline Años & Crédito planeado (a) & $\begin{array}{l}\text { Crédito concedido } \\
\text { por Banco Nac. } \\
\text { Fomento }(b)\end{array}$ & $\begin{array}{c}\text { Porcentaje } \\
\left(\mathbf{c}=\mathbf{b} / \mathbf{a}^{*} 100\right)\end{array}$ \\
\hline & 1.Corto plazo & & \\
\hline 1964 & 208,0 & 197,4 & 94,9 \\
\hline 1965 & 253,3 & 158,5 & 62,6 \\
\hline 1966 & 278,1 & 163,2 & 58,7 \\
\hline \multirow[t]{2}{*}{1967} & 308,4 & 187,2 & 60,7 \\
\hline & 2. Mediano plazo & & \\
\hline 1964 & 74,7 & 45,0 & 60,2 \\
\hline 1965 & 97,2 & 79,7 & 82,0 \\
\hline 1966 & 130,4 & 95,8 & 73,5 \\
\hline \multirow[t]{2}{*}{1967} & 151,1 & 97,4 & 64,5 \\
\hline & 3. Largo plazo & & \\
\hline 1964 & 113,5 & 23,9 & 21,0 \\
\hline 1965 & 138,6 & 19,9 & 14,3 \\
\hline 1966 & 161,1 & 22,4 & 13,9 \\
\hline 1967 & 173,5 & 39,1 & 22,5 \\
\hline
\end{tabular}

Fuente: Programa de Desarrollo Agropecuario y Banco Nacional de Fomento, en: Secretaría General de Planeación y Económica de la Junta Nacional de Planificación y Coordinación: El crédito agropecuario en el periodo 1964-1967, documento num. 08-03, 1968, p. 12. 
Tabla 6: Necesidades según el Plan de Desarrollo y nuevos créditos concedidos por el Banco Nacional de Fomento, 1964-1967 (en millones de sucres):

\begin{tabular}{|c|c|c|c|}
\hline \multirow{2}{*}{ Años } & $\begin{array}{c}\text { Necesidades según } \\
\text { Plan (a) }\end{array}$ & $\begin{array}{c}\text { Créditos originales } \\
\text { concedidos por el } \\
\text { Bco Nac. Fomento } \\
\text { (b) }\end{array}$ & $\begin{array}{c}\text { Porcentaje (b/a * } \\
\mathbf{1 0 0})\end{array}$ \\
\hline 1964 & 396,2 & 175,7 & 44,3 \\
\hline 1965 & 489,1 & 180,4 & 36,9 \\
\hline 1966 & 569,4 & 204,4 & 35,9 \\
\hline 1967 & 625,9 & 255,8 & 40,9 \\
\hline
\end{tabular}

Fuente: Plan de Desarrollo y Banco Nacional de Fomento, en: Secretaría General de Planeación y Económica de la Junta Nacional de Planificación y Coordinación: El crédito agropecuario en el periodo 1964-1967, documento num. 08-03, 1968, p. 13. 
Tabla 7: Distribución de las hectáreas adjudicadas por periodo, régimen y región (porcentajes) (1964-1977):

\begin{tabular}{|c|c|c|c|c|c|c|c|c|}
\hline \multicolumn{4}{|c|}{ Reforma Agraria } & \multicolumn{6}{c|}{ Colonización } \\
\hline & Sierra & Costa & Subtotal & Sierra & Costa & Oriente & Subtotal & $\begin{array}{c}\text { Total } \\
\text { hectáreas }\end{array}$ \\
\hline $\mathbf{1 9 6 4 - 6 6}$ & 23,3 & 5,7 & $\mathbf{2 9 , 0}$ & 40,0 & 15,0 & 16,0 & $\mathbf{7 1 , 0}$ & $\mathbf{2 9 2 . 8 6 7}$ \\
\hline $\mathbf{1 9 6 7 - 7 1}$ & 19,0 & 5,5 & $\mathbf{2 4 , 5}$ & 31,2 & 27,4 & 16,9 & $\mathbf{7 5 , 5}$ & $\mathbf{3 8 0 . 2 3 8}$ \\
\hline $1972-75$ & 13,7 & 8,1 & 21,8 & 14,5 & 17,4 & 46,3 & 78,2 & 530.086 \\
\hline $1976-77$ & 22,6 & 8,6 & 31,2 & 12,8 & 16,5 & 39,5 & 68,9 & 434.697 \\
\hline $1972-77$ & 17,7 & 8,3 & 26 & 13,7 & 17,0 & 43,3 & 74,0 & 964.783 \\
\hline
\end{tabular}

Fuente: Estadísticas de Adjudicaciones IERAC, en Gustavo Cosse: Reflexiones acerca del estado, el proceso político y la política agraria en el caso ecuatoriano 1964-1977, en Ecuador, cambios en el agro serrano, CEPLAES-FLACSO, 1980, p. 424

Tabla 8: Promedio de hectáreas por familia adjudicadas por tipo de afectación. Año y región (1964-1970):

\begin{tabular}{|c|c|c|c|c|c|}
\hline \multirow{2}{*}{ Años } & \multicolumn{2}{|c|}{ Reforma Agraria } & \multicolumn{3}{c|}{ Colonización } \\
\cline { 2 - 6 } & Sierra & Costa & Sierra & Costa & Oriente \\
\hline 1964 & 2,64 & 0 & 20,1 & 52,0 & 0 \\
\hline 1965 & 4,03 & 21,6 & 38,4 & 44,0 & 0 \\
\hline 1966 & 4,26 & 12,4 & 35,5 & 34,0 & 0 \\
\hline 1967 & 5,43 & 12,9 & 43,6 & 25,5 & 0 \\
\hline 1968 & 9,9 & 28,4 & 33,9 & 25,9 & 0 \\
\hline 1969 & 4,2 & 22,0 & 36,4 & 46,5 & 0 \\
\hline 1970 & 2,7 & 17,6 & 37,4 & 38,2 & 0 \\
\hline
\end{tabular}

Fuente: Estadísticas Adjudicaciones IERAC, en Gustavo Cosse: Reflexiones acerca del estado, el proceso político y la política agraria en el caso ecuatoriano 1964-1977, en Ecuador, cambios en el agro serrano, CEPLAES-FLACSO, 1980, p. 425. 
Tabla 9: Número de familias beneficiadas y hectáreas adjudicadas en Colonización y Reforma Agraria (1964-1971):

\begin{tabular}{|c|c|c|c|c|}
\hline Años & Concepto & Colonización & $\begin{array}{c}\text { Reforma } \\
\text { Agraria }\end{array}$ & Total General \\
\hline \multirow[t]{2}{*}{1964} & Familias & 728 & 831 & 1.559 \\
\hline & Hectáreas & 17.614 & 2.194 & 19.808 \\
\hline \multirow[t]{2}{*}{1965} & Familias & 2.686 & 12.617 & 15.303 \\
\hline & Hectáreas & 97.821 & 56.614 & 154.435 \\
\hline \multirow[t]{2}{*}{1966} & Familias & 2.708 & 4.712 & 7.420 \\
\hline & Hectáreas & 92.123 & 26.795 & 118.918 \\
\hline \multirow[t]{2}{*}{1967} & Familias & 1.567 & 4.452 & 6.019 \\
\hline & Hectáreas & 58.416 & 25.154 & 83.570 \\
\hline \multirow[t]{2}{*}{1968} & Familias & 1.408 & 1.884 & 3.292 \\
\hline & Hectáreas & 43.043 & 20.983 & 64.026 \\
\hline \multirow[t]{2}{*}{1969} & Familias & 1.535 & 3.463 & 4.998 \\
\hline & Hectáreas & 59.623 & 20.739 & 80.359 \\
\hline \multirow[t]{2}{*}{1970} & Familias & 2.295 & 1.110 & 3.405 \\
\hline & Hectáreas & 92.629 & 6.903 & 99.532 \\
\hline \multirow[t]{2}{*}{1971} & Familias & 1.505 & 2.391 & 3.896 \\
\hline & Hectáreas & 56.735 & 19.520 & 76.252 \\
\hline
\end{tabular}

Nota: Los datos del año 1964, aparecen a partir del mes de septiembre.

Fuente: Patricio Almeida Guzmán, Rebeca Almeida Arroba: Estadísticas Económicas Históricas 1948-1983, Serie estadísticas históricas, Vol. 1, Banco Central del Ecuador, 1988, p. 33. 
Tabla 10: Adjudicación legalizada de tierras en Colonización, por provincias (1964-1967):

\begin{tabular}{|c|c|c|c|c|c|c|c|c|}
\hline \multirow{2}{*}{$\begin{array}{l}\text { Regiones } \\
\text { Provincias }\end{array}$} & \multicolumn{2}{|c|}{1964} & \multicolumn{2}{|c|}{1965} & \multicolumn{2}{|c|}{1966} & \multicolumn{2}{|c|}{1967} \\
\hline & Hectár. & $\begin{array}{l}\text { Fam. } \\
\text { Benef. }\end{array}$ & Hectár. & $\begin{array}{l}\text { Fam. } \\
\text { Benef. }\end{array}$ & Hectár. & $\begin{array}{l}\text { Fam. } \\
\text { Benef. }\end{array}$ & Hectár. & $\begin{array}{l}\text { Fam. } \\
\text { Benef. }\end{array}$ \\
\hline Costa & $1.458,20$ & 28 & $15.465,4$ & 349 & $26.520,9$ & 779 & $13.899,6$ & 417 \\
\hline Esmeraldas & 885,35 & 19 & $6.558,03$ & 156 & $11.251,3$ & 334 & $2.076,84$ & 73 \\
\hline Manabí & & & & & & & & \\
\hline Los Ríos & 132,76 & 2 & 330,25 & 4 & $1.935,92$ & 36 & $2.086,20$ & 46 \\
\hline \multirow{3}{*}{$\begin{array}{l}\text { Guayas } \\
\text { El Oro }\end{array}$} & 374,44 & 6 & $5.053,32$ & 77 & $6.435,69$ & 190 & $1.664,08$ & 36 \\
\hline & 65,65 & 1 & $1.270,54$ & 6 & $2.062,49$ & 50 & $8.032,43$ & 258 \\
\hline & - & - & $2.253,27$ & 106 & $4.835,49$ & 169 & 40,10 & 4 \\
\hline Sierra & $11.786,2$ & 585 & $60.230,3$ & 1.567 & $44.534,3$ & 1251 & $35.106,6$ & 804 \\
\hline \multirow{2}{*}{$\begin{array}{c}\text { Carchi } \\
\text { Imbabura }\end{array}$} & 833,16 & 222 & 4,00 & 2 & 83,66 & 20 & 48,06 & 9 \\
\hline & 160,00 & 4 & 315,0 & 4 & 56,0 & 1 & - & - \\
\hline Cotopaxi & $10.793,0$ & 359 & $53.592,3$ & 1.373 & $43.834,6$ & 1.218 & $31.714,3$ & 745 \\
\hline \multirow{2}{*}{$\begin{array}{l}\text { Tungurahua } \\
\text { Chimborazo }\end{array}$} & - & - & 36,50 & 62 & - & - & - & - \\
\hline & - & - & $1.555,87$ & 28 & 42,00 & 1 & 45,80 & 1 \\
\hline Bolívar & - & - & - & - & - & - & - & - \\
\hline
\end{tabular}




\begin{tabular}{|c|c|c|c|c|c|c|c|c|}
\hline Cañar & - & - & - & - & - & - & - & - \\
\hline Loia & - & - & $4.726,57$ & 98 & 517,99 & 11 & $3.298,47$ & 49 \\
\hline & - & - & - & - & - & - & - & - \\
\hline & - & - & - & - & - & - & - & - \\
\hline Oriente & $4.369,17$ & 115 & $22.104,3$ & 769 & $20.800,6$ & 663 & $9.078,99$ & 276 \\
\hline Napo & $1.832,67$ & 71 & $6.985,50$ & 251 & $5.507,69$ & 156 & $1.023,90$ & 18 \\
\hline Pastaza & 816,43 & 16 & $7.248,22$ & 189 & $2.472,19$ & 131 & $3.863,16$ & 102 \\
\hline Santiago & $1.027,57$ & 16 & $5.930,61$ & 286 & $10.745,8$ & 334 & $4.031,93$ & 154 \\
\hline $\begin{array}{c}\text { Zamora } \\
\text { Chinchipe }\end{array}$ & & & $1.940,00$ & 43 & $2.074,93$ & 42 & 160,00 & 2 \\
\hline $\begin{array}{l}\text { Archipiélag } \\
\text { o de Colón }\end{array}$ & - & - & 20,76 & 1 & 266,62 & 15 & 331,02 & 70 \\
\hline Total & $17.613,6$ & 728 & $97.820,8$ & 2.686 & $92.122,5$ & 2.708 & $58.416,3$ & 1.567 \\
\hline
\end{tabular}

Fuente: Patricio Almeida Guzmán, Rebeca Almeida Arroba: Estadísticas Económicas Históricas 1948-1983, Serie estadísticas históricas, Vol. 1, Banco Central del Ecuador, 1988, p. 34. 
Tabla 11: Adjudicación legalizada de tierras en Colonización, por provincias (1968-1971):

\begin{tabular}{|c|c|c|c|c|c|c|c|c|}
\hline \multirow{2}{*}{$\begin{array}{l}\text { Regiones } \\
\text { Provincias }\end{array}$} & \multicolumn{2}{|c|}{1968} & \multicolumn{2}{|c|}{1969} & \multicolumn{2}{|c|}{1970} & \multicolumn{2}{|c|}{1971} \\
\hline & Hectár/ & $\begin{array}{l}\text { Fam. } \\
\text { Benef. }\end{array}$ & Hectár. & $\begin{array}{l}\text { Fam. } \\
\text { Benef. }\end{array}$ & Hectár. & $\begin{array}{l}\text { Fam. } \\
\text { Benef. }\end{array}$ & Hectár. & $\begin{array}{l}\text { Fam. } \\
\text { Benef. }\end{array}$ \\
\hline Costa & $13.283,9$ & 511 & $20.832,9$ & 619 & $28.107,0$ & 735 & $19.044,2$ & 557 \\
\hline \multirow{2}{*}{$\begin{array}{l}\text { Esmerald. } \\
\text { Manabí }\end{array}$} & $2.978,54$ & 169 & $8.623,51$ & 249 & $6.910,97$ & 196 & $3.702,91$ & 104 \\
\hline & $3.780,24$ & 123 & $2.011,49$ & 45 & $8.555,59$ & 190 & $6.538,46$ & 172 \\
\hline \multirow{3}{*}{$\begin{array}{l}\text { Guayas } \\
\text { El Oro }\end{array}$} & $4.820,09$ & 143 & $5.986,87$ & 178 & $4.581,83$ & 167 & $3.070,62$ & 128 \\
\hline & 707,55 & 19 & $3.220,14$ & 100 & $6.833,76$ & 172 & $3.937,59$ & 125 \\
\hline & 997,55 & 57 & 990,98 & 47 & $1.224,93$ & 10 & $1.794,69$ & 28 \\
\hline Sierra & $20.526,2$ & 605 & $18.721,7$ & 53 & $25.342,6$ & 677 & $19.206,6$ & 552 \\
\hline \multirow{2}{*}{$\begin{array}{l}\text { Carchi } \\
\text { Imbabura }\end{array}$} & - & - & - & - & - & - & - & - \\
\hline & 268,50 & 16 & - & - & - & - & 62,93 & 3 \\
\hline $\begin{array}{l}\text { Pichincha } \\
\text { Cotopaxi }\end{array}$ & $13.991,6$ & 454 & $18.121,1$ & 473 & $22.485,4$ & 612 & $16.754,4$ & 518 \\
\hline \multirow{3}{*}{$\begin{array}{l}\text { Tungurah. } \\
\text { Chimbor. } \\
\text { Bolívar }\end{array}$} & $4.828,94$ & 109 & - & - & 779,73 & 17 & 242,83 & 11 \\
\hline & 72,65 & 4 & 23,44 & 2 & 23,43 & 3 & - & - \\
\hline & - & - & - & - & - & - & - & - \\
\hline
\end{tabular}




\begin{tabular}{|c|c|c|c|c|c|c|c|c|}
\hline \multirow{4}{*}{$\begin{array}{l}\text { Cañar } \\
\text { Azuay } \\
\text { Loja }\end{array}$} & - & - & - & - & 56,87 & 2 & - & - \\
\hline & $1.364,56$ & 22 & 577,09 & 38 & $1.997,12$ & 43 & $2.146,51$ & 20 \\
\hline & - & - & - & - & - & - & - & - \\
\hline & - & - & - & - & - & - & - & - \\
\hline Oriente & $9.182,41$ & 291 & $20.068,0$ & 403 & $39.171,9$ & 855 & $18.481,1$ & 395 \\
\hline Napo & $2.332,69$ & 104 & $4.624,21$ & 56 & $8.940,18$ & 253 & $6.206,88$ & 146 \\
\hline Pastaza & $3.681,38$ & 90 & $8.879,49$ & 187 & $9.069,79$ & 200 & $3.604,13$ & 92 \\
\hline $\begin{array}{l}\text { Morona } \\
\text { Santiago }\end{array}$ & $3.005,80$ & 94 & $6.534,20$ & 159 & $20.907,7$ & 396 & $7.649,59$ & 141 \\
\hline $\begin{array}{l}\text { Zamora } \\
\text { Chinchipe }\end{array}$ & 162,54 & 3 & 30,15 & 1 & 254,25 & 6 & $1.020,54$ & 16 \\
\hline $\begin{array}{l}\text { Archipiéla } \\
\text { go de } \\
\text { Colón }\end{array}$ & 50,0 & 1 & - & - & 6,78 & 28 & 0,05 & 1 \\
\hline Total & $43.042,6$ & 1.408 & $59.622,7$ & 1.535 & $92.628,4$ & 2.295 & $56.732,1$ & 1.505 \\
\hline
\end{tabular}

Fuente: Patricio Almeida Guzmán, Rebeca Almeida Arroba: Estadísticas Económicas Históricas 1948-1983, Serie estadísticas históricas, Vol. 1, Banco Central del Ecuador, 1988, p.34-35. 
Tabla 12: Adjudicación legalizada de tierras en Reforma Agraria, por provincias (1964-1967):

\begin{tabular}{|c|c|c|c|c|c|c|c|c|}
\hline \multirow{2}{*}{$\begin{array}{l}\text { Regiones } \\
\text { Provincias }\end{array}$} & \multicolumn{2}{|c|}{1964} & \multicolumn{2}{|c|}{1965} & \multicolumn{2}{|c|}{1966} & \multicolumn{2}{|c|}{1967} \\
\hline & Hectáreas & $\begin{array}{l}\text { Fam. } \\
\text { Benef. }\end{array}$ & Hectáreas & $\begin{array}{l}\text { Fam. } \\
\text { Benef. }\end{array}$ & Hectáreas & $\begin{array}{l}\text { Fam. } \\
\text { Benef. }\end{array}$ & Hectáreas & $\begin{array}{l}\text { Fam. } \\
\text { Benef. }\end{array}$ \\
\hline Costa & - & - & $6.964,2$ & 321 & $10.190,2$ & 821 & $1.635,93$ & 126 \\
\hline \multirow{2}{*}{$\begin{array}{l}\text { Esmerald. } \\
\text { Manabí }\end{array}$} & - & - & - & - & - & - & - & - \\
\hline & - & - & - & - & - & - & - & - \\
\hline Guayas & - & - & $2.970,99$ & 88 & $2.317,49$ & 91 & 50,48 & 2 \\
\hline \multirow[t]{2}{*}{ El Oro } & - & - & 1.600 & 119 & $7.214,65$ & 710 & $1.312,08$ & 114 \\
\hline & - & - & $2.393,21$ & 114 & 658,78 & 20 & 273,37 & 10 \\
\hline Sierra & $2.194,14$ & 831 & $49.649,4$ & 12.296 & $16.604,0$ & 3.891 & $23.418,3$ & 4.326 \\
\hline Carchi & - & - & $1.598,24$ & 714 & 538,69 & 122 & 274,88 & 327 \\
\hline Imbabura & 629,27 & 141 & $4.281,75$ & 717 & 406,09 & 226 & $4.631,87$ & 80 \\
\hline Cotopaxi & 344,43 & 246 & $10.190,27$ & 3.189 & $1.910,97$ & 701 & $3.738,57$ & 784 \\
\hline Tungurahua & 388,82 & 70 & $7.201,46$ & 1.951 & $2.734,97$ & 431 & 2,33 & 693 \\
\hline Bolívar & 246,90 & 149 & 547,25 & 402 & - & - & 869,18 & 2 \\
\hline Cañar & 574,72 & 215 & $6.961,22$ & 2.643 & $2.660,20$ & 1.177 & - & 418 \\
\hline & - & - & 433,75 & 166 & 145 & 30 & $4.213,59$ & - \\
\hline & - & - & $4.073,38$ & 647 & $1.428,87$ & 436 & $1.387,14$ & 444 \\
\hline
\end{tabular}




\begin{tabular}{|l|c|c|c|c|c|c|c|c|}
\hline & 10,0 & 10 & $3.925,14$ & 1.046 & 798,34 & 195 & $5.990,69$ & 155 \\
\cline { 2 - 9 } & - & - & $10.437,0$ & 821 & $5.981,05$ & 573 & & 1.423 \\
\hline \multirow{2}{*}{ Oriente } & - & - & - & - & - & - & - & - \\
\hline \multirow{2}{*}{$\begin{array}{l}\text { Napo } \\
\text { Pastaza }\end{array}$} & - & - & - & - & - & - & - & - \\
\hline $\begin{array}{l}\text { Morona } \\
\text { Santiago }\end{array}$ & - & - & - & - & - & - & - & - \\
\hline $\begin{array}{l}\text { Zamora } \\
\text { Chinchipe }\end{array}$ & - & - & - & - & - & - & - & - \\
\hline $\begin{array}{l}\text { Archipiélago } \\
\text { de Colón }\end{array}$
\end{tabular}

Fuente: Patricio Almeida Guzmán, Rebeca Almeida Arroba: Estadísticas Económicas Históricas 1948-1983, Serie estadísticas históricas, Vol. 1, Banco Central del Ecuador, 1988, p. 38. 
Tabla 13: Adjudicación legalizada de tierras en Reforma Agraria, por provincias (1967-1971):

\begin{tabular}{|c|c|c|c|c|c|c|c|c|}
\hline \multirow{2}{*}{$\begin{array}{l}\text { Regiones } \\
\text { Provincias }\end{array}$} & \multicolumn{2}{|c|}{1968} & \multicolumn{2}{|c|}{1969} & \multicolumn{2}{|c|}{1970} & \multicolumn{2}{|c|}{1971} \\
\hline & Hectáreas & $\begin{array}{l}\text { Fam. } \\
\text { Benef. }\end{array}$ & Hectáreas & $\begin{array}{l}\text { Fam. } \\
\text { Benef. }\end{array}$ & Hectáreas & $\begin{array}{l}\text { Fam. } \\
\text { Benef. }\end{array}$ & Hectáreas & $\begin{array}{l}\text { Fam. } \\
\text { Benef. }\end{array}$ \\
\hline Costa & $3.355,27$ & 118 & $7.470,53$ & 339 & $4.530,67$ & 257 & $4.112,65$ & 358 \\
\hline \multirow{2}{*}{$\begin{array}{l}\text { Esmeraldas } \\
\text { Manabí }\end{array}$} & 184 & 1 & - & - & - & -- & - & - \\
\hline & - & - & - & - & - & - & 4,23 & 3 \\
\hline Guayas & 78,13 & 2 & $1.455,43$ & 49 & $2.461,98$ & 107 & 472,89 & 15 \\
\hline \multirow[t]{2}{*}{ El Oro } & $2.838,43$ & 112 & $5.850,81$ & 263 & $2.051,99$ & 149 & $2.953,96$ & 308 \\
\hline & 254,71 & 3 & 164,29 & 27 & 16,70 & 1 & 681,57 & 32 \\
\hline Sierra & $17.628,20$ & 1.766 & $13.265,87$ & 3.124 & 2.371,95 & 853 & $15.407,13$ & 2.033 \\
\hline Carchi & 847,50 & 198 & $2.031,41$ & 78 & 16,90 & 6 & $1.731,39$ & 289 \\
\hline & 366,63 & 124 & 832,92 & 142 & 123,32 & 133 & 484,64 & 102 \\
\hline Cotopaxi & $2.256,49$ & 245 & 394,73 & 988 & 502,64 & 123 & $1.859,38$ & 377 \\
\hline Tungurahua & $2.758,82$ & 419 & 706,98 & 184 & $1.131,36$ & 481 & $3.622,51$ & 493 \\
\hline Bolívar & - & - & - & - & - & - & 26,95 & 7 \\
\hline Cañar & $1.872,55$ & 281 & $7.066,79$ & 1.470 & 121,60 & 31 & 894,03 & 55 \\
\hline Azuay & 10,79 & 8 & - & - & 1,10 & 1 & 400,00 & 40 \\
\hline
\end{tabular}




\begin{tabular}{|l|c|c|c|c|c|c|c|c|}
\hline Loja & $4.626,50$ & 315 & 601,56 & 86 & 29,39 & 5 & 394,37 & 60 \\
\cline { 2 - 10 } & 5,40 & 1 & 3,63 & 4 & 159,03 & 29 & 61,86 & 8 \\
\cline { 2 - 9 } & $4.883,52$ & 175 & 627,85 & 172 & 286,61 & 44 & $5.932,00$ & 602 \\
\hline \multirow{2}{*}{$\begin{array}{l}\text { Oriente } \\
\text { Napo }\end{array}$} & - & - & - & - & - & - & - & - \\
\hline $\begin{array}{l}\text { Pastaza } \\
\text { Morona } \\
\text { Santiago }\end{array}$ & - & - & - & - & - & - & - & - \\
\hline $\begin{array}{l}\text { Zamora } \\
\text { Chinchipe }\end{array}$ & - & - & - & - & - & - & - & - \\
\hline
\end{tabular}

Fuente: Patricio Almeida Guzmán, Rebeca Almeida Arroba: Estadísticas Económicas Históricas 1948-1983, Serie estadísticas históricas, Vol. 1, Banco Central del Ecuador, 1988, p.38-39. 
Tabla 14: Volumen de hectáreas adjudicadas por año, subperiodo y región (1964-1971):

\begin{tabular}{|c|c|c|c|c|c|c|c|}
\hline \multirow{2}{*}{ Años } & \multicolumn{3}{|c|}{ Reforma Agraria } & \multicolumn{3}{c|}{ Colonización } \\
\cline { 2 - 8 } & Sierra & Costa & Total & Sierra & Costa & Oriente & Total \\
\hline 1964 & 2.194 & - & 2.194 & 11.786 & 1.458 & 4.369 & 17.613 \\
\hline 1965 & 49.649 & 6.964 & 56.613 & 60.230 & 15.465 & 22.104 & 97.799 \\
\hline 1966 & 16.604 & 10.190 & 26.794 & 44.530 & 26.520 & 20.800 & 91.850 \\
\hline $\begin{array}{c}\text { Subtotal } \\
\mathbf{1 9 6 4 - 6 6}\end{array}$ & 68.447 & 17.154 & $\mathbf{8 5 . 6 0 1}$ & 116.550 & 43.443 & 47.273 & $\mathbf{2 0 7 . 2 6 6}$ \\
\hline 1967 & 23.518 & 1.635 & 25.153 & 35.106 & 13.899 & 9.079 & 58.084 \\
\hline 1968 & 17.628 & 3.355 & 20.983 & 20.526 & 13.283 & 9.182 & 42.991 \\
\hline 1969 & 13.265 & 7.450 & 20.735 & 18.721 & 29.832 & 20.068 & 68.621 \\
\hline 1970 & 2.371 & 4.530 & 6.901 & 25.342 & 28.107 & 12.776 & 66.225 \\
\hline 1971 & 15.407 & 4.112 & 19.519 & 19.206 & 19.044 & 12.776 & 51.026 \\
\hline Subtotal & 72.189 & 21.102 & $\mathbf{9 3 . 2 9 1}$ & 118.901 & 104.165 & 63.881 & $\mathbf{2 8 6 . 9 4 7}$ \\
\hline $\mathbf{1 9 6 7 - 7 1}$ & & & & & & & \\
\hline
\end{tabular}

Fuente: Estadísticas Adjudicaciones IERAC en Gustavo Cosse: Reflexiones acerca del estado, el proceso político y la política agraria en el caso ecuatoriano 1964-1977, en Ecuador, cambios en el agro serrano, CEPLAES-FLACSO, 1980, p. 426. 
Tabla 15: Número y superficie de las explotaciones de la Sierra, Costa y Oriente (1954 y 1968):

\begin{tabular}{|c|c|c|c|c|}
\hline \multirow{2}{*}{$\begin{array}{c}\text { Tamaño } \\
\text { explotación }\end{array}$} & \multicolumn{2}{|c|}{1954} & \multicolumn{2}{c|}{1968} \\
\cline { 2 - 5 } Explotaciones & Área (has.) & $\begin{array}{c}\text { No. } \\
\text { Explotaciones }\end{array}$ & Área (has.) \\
\hline Menos de 1 & 92.387 & 46.000 & 206.085 & 92.851 \\
\hline $1-5$ & 159.299 & 386.200 & 263.293 & 613.380 \\
\hline $5-10$ & 36.250 & 271.500 & 67.387 & 458.532 \\
\hline $10-20$ & 21.400 & 294.300 & 34.525 & 461.640 \\
\hline $20-50$ & 19.415 & 591.500 & 29.972 & 927.955 \\
\hline $50-100$ & 8.327 & 547.200 & 13.682 & 867.867 \\
\hline $100-500$ & 5.787 & 1.156 .300 & 7.877 & 1.551 .584 \\
\hline $500-1.000$ & 664 & 464.700 & 863 & 596.958 \\
\hline Más de 1.000 & 705 & 2.242 .000 & 354 & 971.366 \\
\hline Total & 344.234 & 5.999 .700 & 624.038 & 6.542 .133 \\
\hline
\end{tabular}

Fuente: Patricio Almeida Guzmán, Rebeca Almeida Arroba: Estadísticas Económicas Históricas 1948-1983, Serie estadísticas históricas, Vol. 1, Banco Central del Ecuador, 1988, p. 47. 
Tabla 16: Relación entre la población huasipunguera y la superficie ocupada en hectáreas con la entrega de huasipungos (1959-1964):

\begin{tabular}{|c|c|c|c|c|c|c|c|c|}
\hline Provincias & $\begin{array}{c}\text { Num. } \\
\text { huasipungueros }\end{array}$ & $\%$ & Superf.has. & $\%$ & $\begin{array}{c}\text { Entrega a } \\
\text { Huasipung. }\end{array}$ & $\%$ & $\begin{array}{c}\text { Superf. } \\
\text { Has. }\end{array}$ & $\%$ \\
\hline Azuay & 1.050 & 5,4 & 3.900 & 6,5 & & & & \\
\hline Bolívar & 230 & 1,2 & 1.700 & 3 & 17 & 0 & 14 & 0,2 \\
\hline Cañar & 690 & 3,5 & 1.900 & 3,2 & & & & \\
\hline Carchi & 1.110 & 5,6 & 2.900 & 4,9 & 460 & 15,1 & 2672 & 28,7 \\
\hline Cotopaxi & 2.380 & 12 & 11.000 & 18,1 & 158 & 5,3 & 473,63 & 5,2 \\
\hline Chimborazo & 3.975 & 20,2 & 11.100 & 18,2 & 134 & 4,4 & 116,16 & 1,2 \\
\hline Pichincha & 6.440 & 32,7 & 18.400 & 30,4 & 1.760 & 60 & $4.954,86$ & 53,2 \\
\hline Tungurahua & 550 & 2,8 & 1.200 & 2,2 & & & & \\
\hline Imbarura & 1.890 & 9,6 & 4.400 & 7,3 & 452 & 15,3 & $1.072,47$ & 11,5 \\
\hline Loja & 1.350 & 6,8 & 3.700 & 6,2 & & & & \\
\hline Total & 19.665 & 100 & 60.800 & 100 & 3.119 & 10 & $9.303,33$ & 10 \\
\hline
\end{tabular}

Fuente: Censo Agropecuario de 1954 actualizado a 1959, por el IEAG. Departamento de Cuestiones Sociales del Ministerio de Previsión Social y Trabajo, 1964.

Elaboración: Instituto Ecuatoriano de Antropología y Geografía, División Antropología Social y Cultural, 1964. 
Tabla 17: Entrega de huasipungos por provincias (1959-1964):

\begin{tabular}{|c|c|c|c|c|}
\hline Provincias & $\begin{array}{c}\text { Num. } \\
\text { beneficiarios }\end{array}$ & Num. hectáreas & Porcentaje & Valor total en \$ \\
\hline Carchí & 498 & $2.672,21$ & 28,7 & $9.880 .302,10$ \\
\hline Imbarura & 452 & $1.072,47$ & 11,5 & $5.386 .484,78$ \\
\hline Pichincha & 1.760 & $4.954,86$ & 53,2 & $15.698 .447,78$ \\
\hline Cotopaxi & 158 & 473,63 & 5,2 & $1.946 .850,60$ \\
\hline Chimborazo & 134 & 116,16 & 1,2 & $531.100,00$ \\
\hline Bolívar & 17 & 14,00 & 0,2 & $53.665,00$ \\
\hline Total & $\mathbf{3 . 0 1 9}$ & $\mathbf{9 . 3 0 3 , 3 3}$ & $\mathbf{1 0 0 , 0 0}$ & $\mathbf{3 3 . 4 9 6 . 8 5 0 , 2 6}$ \\
\hline
\end{tabular}

Fuente y elaboración: Departamento de Cuestiones Sociales del Ministerio de Previsión Social y Trabajo, 1964, en: Piedad y Alfredo Costales: Historia Social del Ecuador, Reforma Agraria, edit. Casa de la Cultura Ecuatoriana, Quito, 1971, p. 117. 
Tabla 18: Entrega de los huasipungos por provincias, según los espacios de tenencia. Número de beneficiarios y valor en sucres (1959-1964):

\begin{tabular}{|c|c|c|c|c|c|c|c|}
\hline \multirow[t]{2}{*}{ Provincias } & \multirow{2}{*}{$\begin{array}{c}\text { Num. } \\
\text { beneficiarios }\end{array}$} & \multicolumn{5}{|c|}{ Hectáreas entregadas } & \multirow[t]{2}{*}{ Total en \$ } \\
\hline & & $0-5$ & $5-10$ & $10-20$ & $20-50$ & 50 o más & \\
\hline Carchi & $\begin{array}{l}17 \\
41 \\
85 \\
317\end{array}$ & & 15,70 & 52,36 & 147,02 & $2.457,13$ & $\begin{array}{c}114.270,40 \\
87.486,40 \\
1.101 .507,30 \\
8.577 .038\end{array}$ \\
\hline Imbabura & $\begin{array}{l}3 \\
14 \\
25 \\
44 \\
366\end{array}$ & 1,82 & 9,88 & 29,11 & 62,50 & 969,16 & $\begin{array}{c}13.368 \\
34.549 \\
295.483 \\
675.875 \\
4.369 .269,78\end{array}$ \\
\hline Pichincha & $\begin{array}{l}252 \\
234 \\
297 \\
211 \\
804\end{array}$ & 69,38 & 155,75 & 262,81 & 277,93 & $4.188,99$ & $\begin{array}{c}1.492 .073 \\
1.714 .321 \\
2.699 .561 \\
3.195 .000 \\
6.597 .490,55\end{array}$ \\
\hline Cotopaxi & $\begin{array}{c}21 \\
8 \\
8 \\
121\end{array}$ & 12,31 & 8,0 & 11,28 & 442,04 & & $\begin{array}{c}106.199 \\
50.915 \\
128.000 \\
1.661 .736\end{array}$ \\
\hline
\end{tabular}




\begin{tabular}{|c|c|c|c|c|c|c|c|}
\hline Chimborazo & $\begin{array}{l}23 \\
31 \\
80 \\
80\end{array}$ & 3,59 & & 25,95 & $\begin{array}{l}86,61 \\
86,61\end{array}$ & & $\begin{array}{l}13.660 \\
163.939 \\
364.501 \\
364.501\end{array}$ \\
\hline Bolívar & 17 & & & 14,00 & & & 53.665 \\
\hline $\begin{array}{l}\text { Total } \\
\text { Porcentaje }\end{array}$ & 3.019 & $\begin{array}{c}87,10 \\
0,9\end{array}$ & $\begin{array}{c}189,33 \\
2,1\end{array}$ & $\begin{array}{c}395,52 \\
4,3\end{array}$ & $\begin{array}{c}474,06 \\
5,1\end{array}$ & $\begin{array}{c}8.057,32 \\
87,7\end{array}$ & 33.496 .850 \\
\hline
\end{tabular}

Fuente: Departamento de Cuestiones Sociales del Ministerio de Previsión Social y Trabajo. Elaboración: Instituto Ecuatoriano de Antropología y Geografía, en: en: Piedad Peñaherrera y Alfredo Costales: Historia Social del Ecuador. Reforma Agraria" edit. Casa de la Cultura Ecuatoriana, Quito, 1971, p. 119-120. 
Tabla 19: Liquidación de huasipungos desde 1959 a julio de 1967 (por provincias):

\begin{tabular}{|c|c|c|c|c|c|}
\hline \multicolumn{3}{|c|}{ Entregas anticipadas } & \multicolumn{3}{|c|}{$\begin{array}{c}\text { Entregas en base a la Ley de Reforma } \\
\text { Agraria }\end{array}$} \\
\hline Provincias & Num.beneficiarios & $\begin{array}{c}\text { Hectáreas } \\
\text { entregadas }\end{array}$ & Provincias & Num.beneficiarios & $\begin{array}{c}\text { Hectáreas } \\
\text { entregadas }\end{array}$ \\
\hline Azuay & & & Azuay & 1.196 & 3.399 \\
\hline Bolívar & 17 & 14,00 & Bolívar & 196 & 578 \\
\hline Cañar & & & Cañar & 655 & 2.024 \\
\hline Carchi & 498 & $2.672,21$ & Carchi & 676 & 1.273 \\
\hline Cotopaxi & 158 & 473,63 & Cotopaxi & 2.326 & 9.092 \\
\hline Chimborazo & 134 & 116,16 & Chimborazo & 3.374 & 9.684 \\
\hline Imbarura & 452 & $1.072,47$ & Imbarura & 1.025 & 5.233 \\
\hline Pichincha & 1.760 & $4.954,86$ & Pichincha & 3.706 & 7.685 \\
\hline Tungurahua & & & Tungurahua & 553 & 796 \\
\hline Total & 3.019 & $9.303,33$ & Total & 13.707 & 39.764 \\
\hline
\end{tabular}

Fuente: Ministerio de Previsión Social y Trabajo, Departamento de Cuestiones Sociales, Departamento de Liquidación de Huasipungos del IERAC. Elaboración: Instituto Ecuatoriano de Antropología y Geografía, Departamento de Antropología Social, agosto de 1967. 
Tabla 20: La liquidación del huasipungo en la Sierra ecuatoriana (1959-1970):

\begin{tabular}{|c|c|c|c|c|}
\hline & Años & $\begin{array}{c}\text { Número de } \\
\text { familias }\end{array}$ & Superficie (has.) & $\begin{array}{c}\text { Promedio } \\
\text { has./familia }\end{array}$ \\
\hline $\begin{array}{c}\text { Entregas } \\
\text { anticipadas }\end{array}$ & $1959-1961$ & 88 & 404 & 4,6 \\
\hline $\begin{array}{c}\text { Adjudicaciones } \\
\text { IERAC }\end{array}$ & $1962-1964$ & 2.931 & 8.899 & 3,0 \\
\hline & $1967-1970$ & 1.515 & 6.586 & 3,4 \\
\hline TOTAL & $1959-1970$ & 20.410 & 69.574 & 3,4 \\
\hline
\end{tabular}

Fuente: O. Barsky: La reforma agraria ecuatoriana, Quito: Corporación Editora Nacional, p. 72, 1984 y F. Velasco: Reforma Agraria y Movimiento Indígena en la Sierra, Quito: Editorial El Conejo, 1983, p. 86. 
Tabla 21: Liquidación y ampliación de parcelas en la provincia de Loja (enero de 1965 a 31 de diciembre de 1967):

\begin{tabular}{|c|c|c|}
\hline Forma de liquidación & Familias beneficiadas & Hectáreas entregadas \\
\hline $\begin{array}{c}\text { Liquidación de arrimazgos } \\
\text { Aplicación a favor de } \\
\text { arrimados }\end{array}$ & 1.777 & 4.582 \\
\hline $\begin{array}{c}\text { Parcelaciones de iniciativa } \\
\text { privada }\end{array}$ & 1.271 & 41.407 \\
\hline Total & 745 & 4.988 \\
\hline
\end{tabular}

Fuente: Sección de Evaluación y Estadística del IERAC, 1967, en: Piedad Peñaherrera y Alfredo Costales: Historia Social del Ecuador. Reforma Agraria, edit. Casa de la Cultura Ecuatoriana, Quito, 1971, p. 147. 
Tabla 22: Número y superficie de las explotaciones en la Sierra ecuatoriana (por grupos de tamaño, 1954-1974):

\begin{tabular}{|c|c|c|c|c|c|c|c|c|}
\hline \multirow{3}{*}{ Tamaño } & \multicolumn{4}{|c|}{ Número } & \multicolumn{4}{|c|}{ Área (has.) } \\
\hline & \multicolumn{2}{|c|}{1954} & \multicolumn{2}{|c|}{1974} & \multicolumn{2}{|c|}{1954} & \multicolumn{2}{|c|}{1974} \\
\hline & Total & $\%$ & Total & $\%$ & Total & $\%$ & Total & $\%$ \\
\hline $0-10$ & 234.596 & 90,37 & 280.974 & 87,10 & 496.400 & 16,43 & 560.800 & 18,24 \\
\hline $10,1-50$ & 18.292 & 7,04 & 32.064 & 9,93 & 362.200 & 11,99 & 663.092 & 21,56 \\
\hline $\begin{array}{c}50,1- \\
100\end{array}$ & 3.594 & 1,38 & 6.014 & 1,86 & 218.700 & 7,24 & 368.043 & 11,97 \\
\hline $\begin{array}{c}100,1- \\
500\end{array}$ & 2.368 & 0,91 & 2.935 & 0,90 & 471.100 & 15,59 & 504.702 & 16,41 \\
\hline+ de 500 & 720 & 0,30 & 599 & 0,21 & 1.472 .200 & 48,75 & 977.637 & 31,82 \\
\hline TOTAL & 259.570 & 100 & 322.586 & 100 & 3.020 .600 & 100 & 3.0740274 & 100 \\
\hline
\end{tabular}

Fuente: E. Archetti: Burguesía rural y campesina en la Sierra ecuatoriana, en Ecuador Archetti, Campesinado y Estructuras agrarias en América Latina, Quito: CEPLAES editores, 1981, p. 302. 


\section{APÉNDICE DE DATOS Y ESTADÍSTICAS: CAPÍTULO 5}

Tabla 1: Valor bruto de la producción y valor agregado de las industrias clasificadas en las leyes de fomento industrial, pequeña industria, artesanía, por ramas de actividad (1957-1960) (sucres):

\begin{tabular}{|c|c|c|c|c|c|c|c|c|}
\hline \multirow{3}{*}{$\begin{array}{l}\text { Ramas de } \\
\text { actividad }\end{array}$} & \multicolumn{2}{|c|}{1957} & \multicolumn{2}{|c|}{1958} & \multicolumn{2}{|c|}{1959} & \multicolumn{2}{|c|}{1960} \\
\hline & \multicolumn{2}{|c|}{ Gran industria } & \multicolumn{2}{|c|}{ Gran industria } & \multicolumn{2}{|c|}{ Gran industria } & \multicolumn{2}{|c|}{ Gran industria } \\
\hline & V.B.P & V.agreg. & V.B.P & V.agreg. & V.B.P. & V.agreg. & V.B.P. & V.agreg. \\
\hline Alimentos & & & 9.133 .000 & 885.250 & 70.623 .400 & & 2.736 .100 & 471.400 \\
\hline $\begin{array}{c}\text { Alimentos } \\
\text { diversos }\end{array}$ & & & & & 20.520 .500 & & & \\
\hline Bebidas & & & & & & & 48.011 .500 & 18.207 .500 \\
\hline Textiles & & & 4.387 .700 & 1.889 .428 & 45.923 .894 & 19.439 .042 & 53.787 .587 & 13.525 .687 \\
\hline $\begin{array}{c}\text { Prendas de } \\
\text { vestir }\end{array}$ & & & & & & & & \\
\hline Calzado & & & & & & & & \\
\hline $\begin{array}{c}\text { Cueros y } \\
\text { otros }\end{array}$ & & & & & & & & \\
\hline Madera & & & & & & & & \\
\hline $\begin{array}{l}\text { Muebles y } \\
\text { accesorios }\end{array}$ & & & & & & & & \\
\hline $\begin{array}{c}\text { Papel y ptos } \\
\text { papel }\end{array}$ & & & & & & & & \\
\hline
\end{tabular}




\begin{tabular}{|c|c|c|c|c|c|c|c|c|}
\hline $\begin{array}{c}\text { Imprentas y } \\
\text { editorial }\end{array}$ & & & & & & & 14.647 .800 & 3.862 .100 \\
\hline Ind.Química & & & 2.356 .021 & 503.700 & & & & \\
\hline $\begin{array}{l}\text { Otros ptos } \\
\text { químicos }\end{array}$ & 5.454 .248 & 2.139 .696 & & & & & 11.880 .000 & 462.000 \\
\hline $\begin{array}{l}\text { Deriv. } \\
\text { petróleo y } \\
\text { carbón }\end{array}$ & 63.231 .600 & 8.687 .600 & & & 2.942 .673 & 1.398 .305 & 1.680 .250 & 298.909 \\
\hline Ind. Plástic. & & & & & & & & \\
\hline $\begin{array}{l}\text { Vidrio y ptos } \\
\text { vidrio }\end{array}$ & & & & & & & & \\
\hline $\begin{array}{c}\text { Loza y } \\
\text { porcelana }\end{array}$ & & & & & & & & \\
\hline Ind. Caucho & & & & & 49.629 .000 & 12.852 .000 & 8.410 .300 & 1.515 .300 \\
\hline $\begin{array}{l}\text { Min.no } \\
\text { metálicos }\end{array}$ & & & & & 3.375 .037 & 1.137 .600 & & \\
\hline $\begin{array}{c}\text { Básicos } \\
\text { hierro/acero }\end{array}$ & & & & & & & & \\
\hline $\begin{array}{l}\text { Ptos met. } \\
\text { Exc. Maquin } \\
\text { y eq. electric }\end{array}$ & & & & & & & 1.776 .266 & 550.632 \\
\hline $\begin{array}{l}\text { Básicas } \\
\text { met.noferros }\end{array}$ & & & & & & & & \\
\hline
\end{tabular}




\begin{tabular}{|c|c|c|c|c|c|c|c|c|}
\hline os & & & & & & & & \\
\hline $\begin{array}{l}\text { Constr. Ma } \\
\text { Eléctrica }\end{array}$ & & & & & & & & \\
\hline $\begin{array}{c}\text { Maq. Excep } \\
\text { eléctrica }\end{array}$ & & & & & & & & \\
\hline $\begin{array}{c}\text { Mat. } \\
\text { Transporte }\end{array}$ & & & & & & & & \\
\hline $\begin{array}{c}\text { Ind.manuf } \\
\text { N.E.P. }\end{array}$ & & & & & 5.046 .000 & 2.529 .373 & & \\
\hline $\begin{array}{l}\text { Otros ptos } \\
\text { minerales }\end{array}$ & & & & & & & & \\
\hline $\begin{array}{l}\text { Equipo pro } \\
\text { y científicc }\end{array}$ & & & & & & & & \\
\hline Varios & 5.700 .000 & 2.225 .586 & 5.610 .000 & 2.308 .250 & & & & \\
\hline TOTAL & 74.385 .848 & 13.052 .882 & 32.985 .957 & 11.040 .984 & $\begin{array}{c}198.060 .50 \\
4\end{array}$ & 52.274 .520 & 142.929 .803 & 38.893 .528 \\
\hline
\end{tabular}

V.B.P.: Valor bruto de la producción

Fuente: Patricio Almeida Guzmán, Rebeca Almeida Arroba: Estadísticas Económicas Históricas 1948-1983, Fuentes para la Historia Económica del Ecuador, serie estadísticas históricas, vol. 1, Banco Central del Ecuador, 1988, p. 148-151. 
Tabla 2: Producto interior bruto por clase de actividad económica (millones de sucres corrientes) (1950-1954):

\begin{tabular}{|c|c|c|c|c|c|}
\hline Actividad & 1950 & 1951 & 1952 & 1953 & 1954 \\
\hline $\begin{array}{l}\text { 1.Agricultura, } \\
\text { caza, silvicultura y } \\
\text { pesca }\end{array}$ & 2.247 & 2.392 & 2.912 & 2.984 & 3.212 \\
\hline $\begin{array}{l}\text { 2. Petróleo y otras } \\
\text { minas }\end{array}$ & 73 & 72 & 77 & 79 & 97 \\
\hline $\begin{array}{l}\text { 3. Ind. } \\
\text { Manufactureras }\end{array}$ & 1.235 & 1.345 & 1.448 & 1.560 & 1.681 \\
\hline $\begin{array}{l}\text { 4. Electricidad, gas } \\
\text { y agua. }\end{array}$ & 24 & 29 & 39 & 52 & 61 \\
\hline 5. Construcción & 99 & 100 & 122 & 138 & 154 \\
\hline $\begin{array}{l}\text { 6. Comercio al por } \\
\text { mayor, al por } \\
\text { menor restaurantes } \\
\text { y hoteles. }\end{array}$ & 1.017 & 1.086 & 1.290 & 1.342 & 1.510 \\
\hline $\begin{array}{l}\text { 7. Transporte, } \\
\text { almacen. y comun. }\end{array}$ & 372 & 431 & 474 & 501 & 568 \\
\hline $\begin{array}{l}\text { 8. Establ. Finan., } \\
\text { segueor, b. inm., } \\
\text { serv a empresas }\end{array}$ & 953 & 996 & 1.047 & 1.113 & 1.314 \\
\hline -alquiler vivienda & 673 & 692 & 730 & 767 & 885 \\
\hline -Otros & 280 & 304 & 317 & 346 & 429 \\
\hline $\begin{array}{l}\text { 9. Serv. } \\
\text { Comunales soc. Y } \\
\text { personales }\end{array}$ & 616 & 641 & 691 & 731 & 832 \\
\hline (-)Servic. & -58 & -67 & -72 & -77 & -86 \\
\hline
\end{tabular}




\begin{tabular}{|l|c|c|c|c|c|}
\hline Bancarios & & & & \\
\hline $\begin{array}{l}\text { Subtotal valor } \\
\text { agregado } \\
\text { industrias }\end{array}$ & 6.578 & 7.025 & 8.028 & 8.423 & 9.343 \\
\hline Serv. Gubern. & 382 & 390 & 428 & 477 & 559 \\
\hline $\begin{array}{l}\text { Servicio domést. } \\
\text { Total Valor } \\
\text { agregado bruto }\end{array}$ & 6.960 & 7.415 & 8.456 & 8.900 & \\
\hline $\begin{array}{l}\text { Otros elementos } \\
\text { del PIB }\end{array}$ & 269 & 339 & & & \\
\hline $\begin{array}{l}\text { Producto Interior } \\
\text { Bruto (PIB) }\end{array}$ & $\mathbf{7 . 2 2 9}$ & $\mathbf{7 . 7 5 4}$ & $\mathbf{8 . 8 2 4}$ & $\mathbf{9 . 3 4 4}$ & $\mathbf{1 0 . 3 7 9}$ \\
\hline
\end{tabular}

Fuente: Patricio Almeida Guzmán, Rebeca Almeida Arroba: Estadísticas Económicas Históricas 1948-1983, Fuentes para la Historia Económica del Ecuador, serie estadísticas históricas, vol. 1, Banco Central del Ecuador, 1988, p. 137-138. 
Tabla 3: Producto interior bruto por clase de actividad económica (millones de sucres corrientes) (1955-1959):

\begin{tabular}{|c|c|c|c|c|c|}
\hline Actividad & 1955 & 1956 & 1957 & 1958 & 1959 \\
\hline $\begin{array}{l}\text { 1.Agricultura, } \\
\text { caza, silvicultura y } \\
\text { pesca }\end{array}$ & 3.132 & 3.284 & 3.455 & 3.497 & 3.072 \\
\hline $\begin{array}{l}\text { 2. Petróleo y otras } \\
\text { minas }\end{array}$ & 116 & 110 & 112 & 107 & 113 \\
\hline $\begin{array}{l}\text { 3. Ind. } \\
\text { Manufactureras }\end{array}$ & 1.744 & 1.827 & 1.906 & 2.026 & 2.129 \\
\hline $\begin{array}{l}\text { 4. Electricidad, gas } \\
\text { y agua. }\end{array}$ & 78 & 77 & 87 & 91 & 100 \\
\hline 5. Construcción & 171 & 195 & 210 & 213 & 254 \\
\hline $\begin{array}{l}\text { 6. Comercio al por } \\
\text { mayor, al por } \\
\text { menor restaurants } \\
\text { y hoteles. }\end{array}$ & 1.879 & 1.908 & 1.969 & 2.007 & 2.031 \\
\hline $\begin{array}{l}\text { 7. Transporte, } \\
\text { almacen. y comun. }\end{array}$ & 590 & 574 & 611 & 617 & 634 \\
\hline $\begin{array}{l}\text { 8. Establ. Finan., } \\
\text { segueor, b. inm., } \\
\text { serv a empresas }\end{array}$ & 1.432 & 1.479 & 1.615 & 1.704 & 1.801 \\
\hline -alquiler vivienda & 969 & 980 & 1.015 & 1.042 & 1.065 \\
\hline -Otros & 463 & 499 & 600 & 662 & 736 \\
\hline $\begin{array}{l}\text { 9. Serv. } \\
\text { Comunales soc. Y } \\
\text { personales }\end{array}$ & 883 & 810 & 970 & 1.034 & 1.076 \\
\hline
\end{tabular}




\begin{tabular}{|l|c|c|c|c|c|}
\hline $\begin{array}{l}\text { (-)Servic. } \\
\text { Bancarios }\end{array}$ & -97 & -107 & -119 & -124 \\
\hline $\begin{array}{l}\text { Subtotal valor } \\
\text { agregado } \\
\text { industrias }\end{array}$ & 9.928 & 10.157 & 10.816 & 11.172 & 11.704 \\
\hline $\begin{array}{l}\text { Serv. Gubern. } \\
\text { Servicio domést. }\end{array}$ & 605 & 627 & 632 & 650 & 682 \\
\hline $\begin{array}{l}\text { Total Valor } \\
\text { agregado bruto }\end{array}$ & 10.533 & 10.784 & 11.448 & 11.822 & 12.386 \\
\hline $\begin{array}{l}\text { Producto Interior } \\
\text { Bruto (PIB) }\end{array}$ & $\mathbf{1 1 . 0 1 7}$ & $\mathbf{1 1 . 2 3 1}$ & $\mathbf{1 1 . 9 9 2}$ & & \\
\hline
\end{tabular}

Fuente: Patricio Almeida Guzmán, Rebeca Almeida Arroba: Estadísticas Económicas Históricas 1948-1983, Fuentes para la Historia Económica del Ecuador, serie estadísticas históricas, vol. 1, Banco Central del Ecuador, 1988, p. 137-138. 
Tabla 4: Establecimientos industriales y artesanales en la Hoya de Quito (1955):

\begin{tabular}{|c|c|c|c|c|}
\hline \multirow{2}{*}{$\begin{array}{c}\text { Rama de } \\
\text { actividad }\end{array}$} & \multirow{2}{*}{ Industria } & \multicolumn{2}{|c|}{ Artesanía } & \multirow{2}{*}{ Total } \\
\cline { 2 - 4 } & & Urbana & Rural & \\
\hline Extractivas & 2 & 24 & & 26 \\
\hline Alimenticias & 64 & 110 & 41 & 215 \\
\hline Bebidas & 12 & 9 & & 2 \\
\hline Tabasco & 2 & & 64 & 160 \\
\hline Textiles & 63 & 33 & 751 & 2.938 \\
\hline $\begin{array}{c}\text { Calzado y } \\
\text { confecciones }\end{array}$ & 91 & 2.096 & 205 & 320 \\
\hline Madera & 22 & 93 & 50 & 567 \\
\hline $\begin{array}{c}\text { Muebles de } \\
\text { Madera }\end{array}$ & 11 & 506 & & 20 \\
\hline Papel y carton & 5 & 15 & & 72 \\
\hline Imprentas & 37 & 35 & & 34 \\
\hline Cuero & 4 & 27 & 3 & 42 \\
\hline Caucho & 6 & 29 & & 342 \\
\hline Ptos químicos & 23 & 19 & & 15 \\
\hline $\begin{array}{c}\text { Minerales no } \\
\text { metálicos }\end{array}$ & 15 & 245 & 82 & 504 \\
\hline Metálicas básicas & 15 & & & 409 \\
\hline $\begin{array}{c}\text { Mecánicas y } \\
\text { metalúrgicas }\end{array}$ & 25 & 408 & & 138 \\
\hline Radiotecnia & & 408 & 1.282 & 5.858 \\
\hline Metales finos & 11 & 113 & & \\
\hline Total & 406 & 4.170 & & \\
\hline
\end{tabular}

Fuente: Junta Nacional de Planificación: La industria y la artesanía de la Hoya de Quito en 1955, en Instituto Panamericano de Geografía e Historia, Plan Piloto del Ecuador, Sección de Economía, México, D.F, 1960, p. 43. 
Tabla 5: Personal ocupado en las industrias y artesanías de la Hoya de Quito en 1955 (promedio mensual):

\begin{tabular}{|c|c|c|c|c|}
\hline $\begin{array}{c}\text { Personal } \\
\text { ocupado }\end{array}$ & Total & $\begin{array}{c}\text { Porcentaje del } \\
\text { total }\end{array}$ & Por empresas & $\begin{array}{c}\text { Capital por } \\
\text { persona } \\
\text { ocupada }\end{array}$ \\
\hline Industria & 9.216 & 38,79 & 24 & $59.531,1$ \\
\hline Artesanía Urbana & 11.827 & 49,78 & 3 & 2.171 \\
\hline Artesanía Rural & 2.711 & 11,43 & 2 & 414 \\
\hline Totales & 23.754 & 100 & & \\
\hline
\end{tabular}

Fuente: Junta Nacional de Planificación: La industria y la artesanía de la Hoya de Quito en 1955, en Instituto Panamericano de Geografía e Historia, Plan Piloto del Ecuador, Sección de Economía, México, D.F, 1960, p. 51. 
Tabla 6: Valor bruto de la producción y valor agregado de las industrias clasificadas en las leyes de fomento industrial, pequeña industria, artesanía, por ramas de actividad (1961-1964) (sucres):

\begin{tabular}{|c|c|c|c|c|c|c|c|c|}
\hline \multirow{3}{*}{$\begin{array}{l}\text { Ramas de } \\
\text { actividad }\end{array}$} & \multicolumn{2}{|c|}{1961} & \multicolumn{2}{|c|}{1962} & \multicolumn{2}{|c|}{1963} & \multicolumn{2}{|c|}{1964} \\
\hline & \multicolumn{2}{|c|}{ Gran industria } & \multicolumn{2}{|c|}{ Gran industria } & \multicolumn{2}{|c|}{ Gran industria } & \multicolumn{2}{|c|}{ Gran industria } \\
\hline & V.B.P & V.agreg. & V.B.P & V.agreg. & V.B.P. & V.agreg. & V.B.P. & V.agreg. \\
\hline Alimentos & 136.781 .000 & 35.234 .400 & 222.614 .877 & 48.213 .869 & 99.812 .630 & 20.123 .128 & 65.468 .046 & 8.418 .654 \\
\hline $\begin{array}{l}\text { Alimentos } \\
\text { diversos }\end{array}$ & 3.633 .500 & 1.302 .700 & 180.000 & 120.000 & 12.521 .877 & 4.175 .416 & 24.084 .212 & 13.335 .640 \\
\hline Bebidas & 35.979 .000 & 7.598 .600 & 7.509 .887 & 1.682 .046 & 90.224 .999 & 40.011 .851 & 33.122 .890 & 11.971 .106 \\
\hline Textiles & 26.874 .500 & 8.397 .700 & 31.390 .174 & 10.552 .174 & 64.335 .669 & 18.113 .556 & 123.113 .556 & 40.545 .057 \\
\hline \multicolumn{9}{|l|}{$\begin{array}{l}\text { Prendas de } \\
\text { vestir }\end{array}$} \\
\hline \multicolumn{9}{|l|}{ Calzado } \\
\hline Cueros y otros & 862.100 & 430.800 & & & & & 1.752 .847 & 569.787 \\
\hline Madera & & & 21.620 .200 & 6.271 .200 & 3.114 .944 & 817.344 & 528.500 & 220.500 \\
\hline $\begin{array}{l}\text { Muebles y } \\
\text { accesorios }\end{array}$ & & & & & & & 2.835 .944 & 1.535 .374 \\
\hline $\begin{array}{l}\text { Papel y ptos } \\
\text { papel }\end{array}$ & 77.021 .420 & 21.728 .300 & & & 215.526 .000 & 23.580 .000 & & \\
\hline $\begin{array}{c}\text { Imprentas y } \\
\text { editorial }\end{array}$ & & & & & 5.001 .132 & 3.474 .900 & 4.042 .797 & 961.000 \\
\hline Ind.Química & 1.010 .420 & 455.224 & 844.938 & 360.807 & & & 30.312 .905 & 4.615 .435 \\
\hline $\begin{array}{l}\text { Otros ptos } \\
\text { químicos }\end{array}$ & 26.108 .672 & 3.388 .553 & 15.103 .390 & 3.025 .079 & 64.277 .761 & 27.526 .000 & 43.887 .546 & 10.046 .484 \\
\hline $\begin{array}{c}\text { Deriv. } \\
\text { petróleo y } \\
\text { carbón }\end{array}$ & & & & & & & 4.534 .875 & 2.436 .975 \\
\hline Ind. Plástic. & & & & & 8.681 .852 & 3.933 .217 & 49.925 .232 & 18.743 .278 \\
\hline \multicolumn{9}{|l|}{$\begin{array}{l}\text { Vidrio y ptos } \\
\text { vidrio }\end{array}$} \\
\hline $\begin{array}{c}\text { Loza y } \\
\text { porcelana }\end{array}$ & & & & & & & 12.965 .810 & 6.945 .136 \\
\hline Ind. Caucho & & & & & & & 2.342 .775 & 1.041 .845 \\
\hline
\end{tabular}




\begin{tabular}{|c|c|c|c|c|c|c|c|c|}
\hline $\begin{array}{l}\text { Min.no } \\
\text { metálicos }\end{array}$ & 51.756 .769 & 15.333 .302 & 37.071 .194 & 9.076 .094 & 1.119 .304 & 155.586 & 21.700 .419 & 4.457 .733 \\
\hline $\begin{array}{c}\text { Básicos } \\
\text { hierro/acero }\end{array}$ & & & & & & & 26.000 .000 & 4.248 .000 \\
\hline $\begin{array}{l}\text { Ptos met. Exc. } \\
\text { Maquin y eq. } \\
\text { electric }\end{array}$ & 9.910 .000 & 1.769 .622 & 9.360 .676 & 3.748 .125 & 14.577 .393 & 3.274 .781 & 26.024 .724 & 7.308 .818 \\
\hline $\begin{array}{c}\text { Básicas } \\
\text { met.noferrosos }\end{array}$ & & & & & & & & \\
\hline $\begin{array}{l}\text { Constr. Maq. } \\
\text { Eléctrica }\end{array}$ & 8.977 .300 & 1.588 .600 & 2.275 .000 & 1.232 .132 & 29.036 .162 & 9.223 .801 & 24.426 .587 & 4.308 .818 \\
\hline $\begin{array}{l}\text { Maq. Except } \\
\text { eléctrica }\end{array}$ & & & & & & & & \\
\hline $\begin{array}{c}\text { Mat. } \\
\text { Transporte }\end{array}$ & & & & & 21.574 .475 & 5.241 .709 & 4.417 .111 & 1.396 .300 \\
\hline $\begin{array}{l}\text { Ind.manuf. } \\
\text { N.E.P. }\end{array}$ & & & 6.571 .368 & 2.114 .470 & 5.838 .940 & 3.439 .539 & 9.032 .725 & 3.398 .610 \\
\hline $\begin{array}{l}\text { Otros ptos } \\
\text { minerales }\end{array}$ & & & & & & & & \\
\hline $\begin{array}{l}\text { Equipo prof. y } \\
\text { científico }\end{array}$ & & & & & & & & \\
\hline Varios & & & & & & & & \\
\hline TOTAL & 378.914 .661 & 97.227 .801 & 344.541 .704 & 86.396 .756 & 635.643 .138 & 163.091 .127 & 510.864 .970 & 147.133 .617 \\
\hline
\end{tabular}

V.B.P.: Valor bruto de la producción

Fuente: Patricio Almeida Guzmán, Rebeca Almeida Arroba: Estadísticas Económicas Históricas 1948-1983, Fuentes para la Historia Económica del Ecuador, serie estadísticas históricas, vol. 1, Banco Central del Ecuador, 1988, p. 148-151. 
Tabla 7: Valor bruto de la producción y valor agregado de las industrias clasificadas en las leyes de fomento industrial, pequeña industria, artesanía, por ramas de actividad (1965-1968) (sucres):

\begin{tabular}{|c|c|c|c|c|c|c|c|c|}
\hline \multirow{3}{*}{$\begin{array}{l}\text { Ramas de } \\
\text { actividad }\end{array}$} & \multicolumn{2}{|c|}{1965} & \multicolumn{2}{|c|}{1966} & \multicolumn{2}{|c|}{1967} & \multicolumn{2}{|c|}{1968} \\
\hline & \multicolumn{2}{|c|}{ Gran industria } & \multicolumn{2}{|c|}{ Gran industria } & \multicolumn{2}{|c|}{ Gran industria } & \multicolumn{2}{|c|}{ Gran industria } \\
\hline & V.B.P & V.agreg. & V.B.P & V.agreg. & V.B.P. & V.agreg. & V.B.P. & V.agreg. \\
\hline Alimentos & 263.323 .589 & 62.744 .047 & 19.695 .769 & 3.077 .328 & 277.883 .965 & 38.197 .412 & 191.898 .350 & 28.088.297 \\
\hline $\begin{array}{l}\text { Alimentos } \\
\text { diversos }\end{array}$ & 37.513 .560 & 8.910 .269 & 23.437 .763 & 9.149 .271 & 12.053 .425 & 2.036 .460 & & \\
\hline Bebidas & 9.101 .966 & 4.612 .642 & 15.359 .970 & 4.091 .124 & 24.064 .336 & 12.662 .684 & 10.794 .000 & 2.575 .750 \\
\hline Textiles & 114.756 .463 & 45.396 .230 & 8.029 .478 & 2.943 .618 & 14.716 .276 & 4.735 .871 & 32.818 .770 & 6.974 .385 \\
\hline $\begin{array}{l}\text { Prendas de } \\
\text { vestir }\end{array}$ & & & 2.170 .080 & 568.335 & & & & \\
\hline Calzado & 1.098 .804 & 659.980 & & & & & & \\
\hline Cueros y otros & 6.386 .358 & 2.500 .864 & & & & & & \\
\hline Madera & & & & & 9.824 .515 & 3.954 .993 & 1.522 .500 & 339.359 \\
\hline $\begin{array}{l}\text { Muebles y } \\
\text { accesorios }\end{array}$ & & & & & & & 10.810 .000 & 3.291 .261 \\
\hline $\begin{array}{l}\text { Papel y ptos } \\
\text { papel }\end{array}$ & 61.321 .360 & 11.451 .812 & & & & & 120.381 .600 & 31.462 .251 \\
\hline $\begin{array}{c}\text { Imprentas y } \\
\text { editorial }\end{array}$ & 4.100 .000 & & 38.259 .111 & 12.857 .290 & 3.143 .080 & 513.153 & 10.065 .038 & 1.431 .887 \\
\hline Ind.Química & 6.373 .500 & 2.696 .360 & & & & & & \\
\hline $\begin{array}{l}\text { Otros ptos } \\
\text { químicos }\end{array}$ & 29.697 .143 & 4.365 .740 & 18.865 .595 & 6.212 .854 & & & 18.653 .177 & 5.581 .633 \\
\hline $\begin{array}{c}\text { Deriv. } \\
\text { petróleo y } \\
\text { carbón }\end{array}$ & & & 45.849 .360 & 10.389 .360 & & & 22.455 .563 & 5.712 .834 \\
\hline Ind. Plástic. & 18.974 .713 & 5.215 .357 & 3.743 .000 & 1.201 .849 & & & 9.850 .000 & 3.419 .351 \\
\hline $\begin{array}{l}\text { Vidrio y ptos } \\
\text { vidrio }\end{array}$ & & & 12.250 .000 & 5.356 .350 & & & & \\
\hline $\begin{array}{c}\text { Loza y } \\
\text { porcelana }\end{array}$ & & & & & & & 6.403 .113 & 3.306 .755 \\
\hline
\end{tabular}




\begin{tabular}{|c|c|c|c|c|c|c|c|c|}
\hline Ind. Caucho & 10.615 .000 & 3.078 .560 & & & 1.438 .000 & 543.898 & & \\
\hline $\begin{array}{c}\text { Min.no } \\
\text { metálicos }\end{array}$ & 4.495 .250 & 1.607 .148 & 10.519 .010 & 4.326 .685 & 4.196 .274 & 2.143 .084 & 45.364 .220 & 11.473 .594 \\
\hline $\begin{array}{c}\text { Básicos } \\
\text { hierro/acero }\end{array}$ & 2.326 .800 & 7.904 .500 & 48.091 .650 & 10.487 .210 & 2.720 .000 & 1.047 .780 & & \\
\hline $\begin{array}{l}\text { Ptos met. Exc. } \\
\text { Maquin y eq. } \\
\text { electric }\end{array}$ & 17.029 .459 & 5.266 .770 & 17.288 .691 & 4.308 .952 & 16.488 .787 & 5.065 .450 & 51.369 .602 & 15.279 .977 \\
\hline $\begin{array}{c}\text { Básicas } \\
\text { met.noferrosos }\end{array}$ & & & & & 4.520 .000 & 652.893 & & \\
\hline $\begin{array}{l}\text { Constr. Maq. } \\
\text { Eléctrica }\end{array}$ & 8.850 .399 & 3.843 .140 & & & 28.729 .980 & 4.858 .665 & 3.052 .650 & 847.330 \\
\hline $\begin{array}{l}\text { Maq. Except } \\
\text { eléctrica }\end{array}$ & & & & & & & & \\
\hline $\begin{array}{c}\text { Mat. } \\
\text { Transporte }\end{array}$ & & & 1.334 .400 & 802.595 & & & & \\
\hline $\begin{array}{c}\text { Ind.manuf. } \\
\text { N.E.P. }\end{array}$ & 20.877 .166 & 10.036 .273 & & & & & & \\
\hline $\begin{array}{l}\text { Otros ptos } \\
\text { minerales }\end{array}$ & & & & & & & & \\
\hline $\begin{array}{l}\text { Equipo prof. y } \\
\text { científico }\end{array}$ & 3.150 .000 & $1.133,00$ & 1.190 .898 & 805.206 & & & & \\
\hline \multicolumn{9}{|l|}{ Varios } \\
\hline TOTAL & 619.991 .530 & 181.422 .692 & 266.084 .755 & 76.578 .027 & 399.778 .638 & 76.412 .343 & 535.438 .583 & 119.784 .664 \\
\hline
\end{tabular}

V.B.P.: Valor bruto de la producción

Fuente: Patricio Almeida Guzmán, Rebeca Almeida Arroba: Estadísticas Económicas Históricas 1948-1983, Fuentes para la Historia Económica del Ecuador, serie estadísticas históricas, vol. 1, Banco Central del Ecuador, 1988, p. 148-151. 
Tabla 8: Valor bruto de la producción y valor agregado de las industrias clasificadas en las leyes de fomento industrial, pequeña industria, artesanía, por ramas de actividad (1969-1972) (sucres):

\begin{tabular}{|c|c|c|c|c|c|c|c|c|}
\hline \multirow{3}{*}{$\begin{array}{l}\text { Ramas de } \\
\text { actividad }\end{array}$} & \multicolumn{2}{|c|}{1969} & \multicolumn{2}{|c|}{1970} & \multicolumn{2}{|c|}{1971} & \multicolumn{2}{|c|}{1972} \\
\hline & \multicolumn{2}{|c|}{ Gran industria } & \multicolumn{2}{|c|}{ Gran industria } & \multicolumn{2}{|c|}{ Gran industria } & \multicolumn{2}{|c|}{ Gran industria } \\
\hline & V.B.P & V.agreg. & V.B.P & V.agreg. & V.B.P. & V.agreg. & V.B.P. & V.agreg. \\
\hline Alimentos & 180.183 .734 & 46.099 .708 & 21.230 .473 & 7.579 .110 & 310.423 .212 & 160.802 .719 & 290.847 .880 & 134.543 .634 \\
\hline $\begin{array}{l}\text { Alimentos } \\
\text { diversos }\end{array}$ & 761.866 & 335.164 & & & & & 18.180 .000 & 4.074 .852 \\
\hline Bebidas & & & 29.700 .000 & 8.897 .939 & & & 54.000 .000 & 6.106 .800 \\
\hline Textiles & 31.761 .387 & 9.175 .330 & 50.467 .500 & 16.132 .552 & 88.559 .244 & 37.233 .518 & 44.481 .023 & 15.953 .544 \\
\hline $\begin{array}{c}\text { Prendas de } \\
\text { vestir }\end{array}$ & & & & & 7.200 .000 & 1.396 .560 & 8.237 .600 & 2.607 .322 \\
\hline Calzado & & & & & 3.300 .000 & 1.248 .340 & & \\
\hline Cueros y otros & & & & & 16.250 .000 & 4.849 .036 & & \\
\hline Madera & 16.800 .000 & 5.884 .500 & & & 91.943 .230 & 39.473 .254 & 74.649 .490 & 29.607 .690 \\
\hline $\begin{array}{l}\text { Muebles y } \\
\text { accesorios }\end{array}$ & 29.988 .600 & 8.962 .450 & 7.950 .000 & 2.632 .610 & & & 14.680 .000 & 4.519 .994 \\
\hline $\begin{array}{c}\text { Papel y ptos } \\
\text { papel }\end{array}$ & 17.907 .114 & 2.177 .573 & 4.200 .000 & 1.984 .045 & 19.377 .000 & 8.533 .011 & 47.206 .000 & 9.293 .419 \\
\hline $\begin{array}{c}\text { Imprentas y } \\
\text { editorial }\end{array}$ & & & & & & & 13.500 .000 & 2.436 .632 \\
\hline Ind.Química & 13.519 .600 & 2.788 .720 & 5.077 .800 & 1.339 .220 & 5.700 .000 & 3.862 .850 & & \\
\hline $\begin{array}{l}\text { Otros ptos } \\
\text { químicos }\end{array}$ & 11.725 .700 & 5.065 .421 & 5.225 .000 & 1.241 .011 & 10.400 .000 & 1.753 .296 & 4.200 .000 & 1.983 .702 \\
\hline $\begin{array}{c}\text { Deriv. } \\
\text { petróleo y } \\
\text { carbón }\end{array}$ & & & & & & & & \\
\hline Ind. Plástic. & 33.071 .492 & 9.408 .515 & & & 63.408 .000 & 16.280 .834 & 52.019 .517 & 15.018 .269 \\
\hline $\begin{array}{l}\text { Vidrio y ptos } \\
\text { vidrio }\end{array}$ & 13.393 .359 & 6.117 .182 & 3.240 .000 & 890.273 & & & 8.884 .960 & 2.377 .095 \\
\hline $\begin{array}{c}\text { Loza y } \\
\text { porcelana }\end{array}$ & & & & & & & & \\
\hline Ind. Caucho & & & & & & & & \\
\hline
\end{tabular}




\begin{tabular}{|c|c|c|c|c|c|c|c|c|}
\hline $\begin{array}{l}\text { Min.no } \\
\text { metálicos }\end{array}$ & 66.026 .980 & 14.823 .108 & 35.853 .096 & 11.269 .215 & 3.612 .000 & 1.562 .734 & 918.000 & 592.720 \\
\hline $\begin{array}{c}\text { Básicos } \\
\text { hierro/acero }\end{array}$ & 32.350 .594 & 10.794 .232 & & & 91.300 .000 & 6.628 .360 & & \\
\hline $\begin{array}{l}\text { Ptos met. Exc. } \\
\text { Maquin y eq. } \\
\text { electric }\end{array}$ & 20.615 .963 & 4.660 .967 & 30.189 .125 & 10.435 .319 & 7.820 .000 & 1.968 .744 & 26.943 .900 & 10.588 .942 \\
\hline $\begin{array}{c}\text { Básicas } \\
\text { met.noferrosos }\end{array}$ & 32.399 .349 & 2.975 .036 & & & & & & \\
\hline $\begin{array}{l}\text { Constr. Maq. } \\
\text { Eléctrica }\end{array}$ & 14.443 .000 & 4.523 .250 & 50.886 .446 & 6.122 .858 & 12.694 .311 & 3.352 .469 & 32.412 .320 & 7.760 .213 \\
\hline $\begin{array}{l}\text { Maq. except } \\
\text { eléctrica }\end{array}$ & & & 11.860 .000 & 4.198 .170 & & & & \\
\hline $\begin{array}{c}\text { Mat. } \\
\text { Transporte }\end{array}$ & & & 16.591 .000 & 3.192 .879 & 10.561 .876 & 4.586 .116 & 37.958 .217 & 12.024 .897 \\
\hline $\begin{array}{l}\text { Ind.manuf. } \\
\text { N.E.P. }\end{array}$ & & & 7.841 .097 & 2.358 .062 & 4.636 .910 & 3.161 .498 & 11.906 .000 & 6.243 .514 \\
\hline $\begin{array}{l}\text { Otros ptos } \\
\text { minerales }\end{array}$ & & & & & & & & \\
\hline $\begin{array}{l}\text { Equipo prof. y } \\
\text { científico }\end{array}$ & 2.712 .000 & 1.373 .733 & & & & & 3.538 .900 & 1.324 .014 \\
\hline \multicolumn{9}{|l|}{ Varios } \\
\hline TOTAL & 517.720 .738 & 135.164 .889 & 280.311 .537 & 78.263 .263 & 747.185 .873 & 296.693 .339 & 744.563 .807 & 276.057 .253 \\
\hline
\end{tabular}

V.B.P.: Valor bruto de la producción

Fuente: Patricio Almeida Guzmán, Rebeca Almeida Arroba: Estadísticas Económicas Históricas 1948-1983, Fuentes para la Historia Económica del Ecuador, serie estadísticas históricas, vol. 1, Banco Central del Ecuador, 1988, p. 148-151. 
Tabla 9: Crédito industrial aprobado por la Corporación Financiera Nacional por rama de actividad (miles de sucres) (1962-1972):

\begin{tabular}{|c|c|c|c|c|}
\hline $\begin{array}{l}\text { Rama de } \\
\text { actividad }\end{array}$ & 1962 & 1963 & 1963-1967 & 1968-1972 \\
\hline $\begin{array}{l}\text { Agricultura,silvic., } \\
\text { caza y pesca }\end{array}$ & 1.967 & 2.171 & 2.050 & 64.936 \\
\hline $\begin{array}{l}\text { Explot. Minas y } \\
\text { canteras }\end{array}$ & & & & 3.900 \\
\hline $\begin{array}{l}\text { Industrias } \\
\text { manufactureras }\end{array}$ & & & $332.492,8$ & $954.588,3$ \\
\hline $\begin{array}{l}\text { Alimentos, } \\
\text { bebidas y tabaco }\end{array}$ & 1.800 & & 155.709 & 229.252 \\
\hline $\begin{array}{l}\text { Textiles, vestido y } \\
\text { calzado }\end{array}$ & 5.555 & 326 & $51.043,5$ & $183.350,7$ \\
\hline Madera y sus ptos & & 427 & $1.199,8$ & 72.400 \\
\hline Papel e impresión & & & $16.603,5$ & $88.938,6$ \\
\hline Ptos químicos & 700 & 3.080 & $33.117,8$ & 58.100 \\
\hline Min. no metálicos & & & $9.905,4$ & 92.905 \\
\hline Metales básicos & & & 8.323 & 34.900 \\
\hline $\begin{array}{l}\text { Ptos metálicos, } \\
\text { maquinaria y } \\
\text { equipo }\end{array}$ & 600 & 1.118 & $33.096,7$ & $115.635,4$ \\
\hline Otros & & & $23.494,1$ & 79.106 \\
\hline $\begin{array}{l}\text { Electric., gas y } \\
\text { agua }\end{array}$ & & & & 104.184 \\
\hline $\begin{array}{l}\text { Comercio, restaur. } \\
\text { Y hoteles }\end{array}$ & & & $40.398,4$ & $84.584,1$ \\
\hline Servicios & 1.842 & & & \\
\hline Transporte & & & & \\
\hline
\end{tabular}




\begin{tabular}{|l|l|l|l|l|}
\hline Caucho & 10.000 & & & \\
\hline Total & & & $374.941,2$ & $1.212 .192,4$ \\
\hline
\end{tabular}

Fuente: Patricio Almeida Guzmán, Rebeca Almeida Arroba: Estadísticas Económicas Históricas 1948-1983, Fuentes para la Historia Económica del Ecuador, serie estadísticas históricas, vol. 1, Banco Central del Ecuador, 1988, p. 261.

Tabla 10: Volumen de crédito otorgado por el Banco Nacional de Fomento, por destino (millones de sucres) (1962-1972):

\begin{tabular}{|c|c|c|c|c|c|}
\hline Años & Agropecuario & Industrial & Comercial & Otros & Total \\
\hline 1962 & 183,9 & 41,7 & 19,4 & 18,3 & 263,3 \\
\hline 1963 & 201,9 & 44,3 & 20,8 & 27,6 & 294,6 \\
\hline 1964 & 246,9 & 81,4 & 20,7 & 27,1 & 376,1 \\
\hline 1965 & 253,4 & 42 & 13,3 & 27 & 335,7 \\
\hline 1966 & 304,8 & 39,7 & 16,7 & 17,2 & 378,4 \\
\hline 1967 & 354 & 47 & 19 & 46 & 466 \\
\hline 1968 & 439 & 40 & 23 & 47 & 549 \\
\hline 1969 & 470 & 49 & 23 & 61 & 603 \\
\hline 1970 & 544 & 104 & 26 & 4 & 678 \\
\hline 1971 & 593 & 127 & 37 & 6 & 763 \\
\hline 1972 & 587 & 150 & 66 & 5 & \\
\hline
\end{tabular}

Fuente: Patricio Almeida Guzmán, Rebeca Almeida Arroba: Estadísticas Económicas Históricas 1948-1983, Fuentes para la Historia Económica del Ecuador, serie estadísticas históricas, vol. 1, Banco Central del Ecuador, 1988, p. 258. 
Tabla 11: Volumen de crédito otorgado por el Sistema Bancario Nacional, por destino (millones de sucres) (1962-1972):

\begin{tabular}{|c|c|c|c|c|c|}
\hline Años & Agropecuario & Comercio & Industria & Otros & Total \\
\hline 1962 & 487 & 2.758 & 620 & 337 & 4.202 \\
\hline 1963 & 492 & 2.874 & 745 & 410 & 4.521 \\
\hline 1964 & 632 & 4.255 & 972 & 590 & 6.449 \\
\hline 1965 & 904 & 3.998 & 1.236 & 481 & 6.619 \\
\hline 1966 & 1.111 & 3.854 & 1.230 & 673 & 6.868 \\
\hline 1967 & 1.229 & 4.737 & 1.237 & 868 & 8.071 \\
\hline 1968 & 1.311 & 5.736 & 1.482 & 998 & 9.527 \\
\hline 1969 & 1.529 & 5.564 & 1.806 & 1.358 & 10.257 \\
\hline 1970 & 1.805 & 6.528 & 2.240 & 1.339 & 11.912 \\
\hline 1971 & 1.648 & 7.329 & 2.370 & 1.257 & 12.604 \\
\hline 1972 & 2.044 & 8.344 & 2.443 & 1.609 & 14.440 \\
\hline
\end{tabular}

Fuente: Patricio Almeida Guzmán, Rebeca Almeida Arroba: Estadísticas Económicas Históricas 1948-1983, Fuentes para la Historia Económica del Ecuador, serie estadísticas históricas, vol. 1, Banco Central del Ecuador, 1988, p. 243. 
Tabla 12: Volumen de crédito otorgado por el Banco Central, por destino (millones de sucres) (1962-1972):

\begin{tabular}{|c|c|c|c|c|c|}
\hline Años & Agropecuario & Industrial & Comercial & Otros & Total \\
\hline 1962 & 108,5 & 252 & 826,3 & 46,2 & 1.233 \\
\hline 1963 & 104,4 & 290,6 & 729,5 & 68,6 & $1.193,1$ \\
\hline 1964 & 101,0 & 420,9 & 946,6 & 19,2 & $1.487,7$ \\
\hline 1965 & 133,1 & 647,4 & 517 & 13,2 & $1.311,1$ \\
\hline 1966 & 153,2 & 554,7 & 570 & 105 & $1.382,9$ \\
\hline 1967 & 186,3 & 454 & 447 & 112 & $1.199,5$ \\
\hline 1968 & 148 & 623 & 559 & 343 & 1.673 \\
\hline 1969 & 198 & 692 & 830 & 470 & 2.190 \\
\hline 1970 & 215 & 905 & 797 & 661 & 2.578 \\
\hline 1971 & 159 & 970 & 728 & 506 & 2.363 \\
\hline 1972 & 109 & 789 & 1.159 & 493 & 2.550 \\
\hline
\end{tabular}

Fuente: Patricio Almeida Guzmán, Rebeca Almeida Arroba: Estadísticas Económicas Históricas 1948-1983, Fuentes para la Historia Económica del Ecuador, serie estadísticas históricas, vol. 1, Banco Central del Ecuador, 1988, p. 248. 
Tabla 13: Balanza de pagos; saldos de balanzas: comercial, servicios y de capital (millones de dólares) (1960-1973):

\begin{tabular}{|c|c|c|c|c|c|c|}
\hline Años & $\begin{array}{c}\text { Balanza } \\
\text { comercial }\end{array}$ & $\begin{array}{c}\text { Balanza } \\
\text { de } \\
\text { servicios }\end{array}$ & Transferencias & $\begin{array}{c}\text { Saldo en } \\
\text { cuenta } \\
\text { corriente }\end{array}$ & $\begin{array}{c}\text { Balanza } \\
\text { de capital }\end{array}$ & $\begin{array}{l}\text { Reservas } \\
\text { errores y } \\
\text { omisiones }\end{array}$ \\
\hline 1960 & 38,5 & $-56,7$ & 7,2 & $-11,0$ & 9,3 & 1,7 \\
\hline 1961 & 23,3 & $-51,5$ & 7,1 & $-21,0$ & 5,7 & 15,4 \\
\hline 1962 & 37,0 & $-47,5$ & 9,3 & $-1,2$ & 12,8 & $-11,6$ \\
\hline 1963 & 32,2 & $-41,9$ & 6,9 & $-2,8$ & 14,9 & $-12,1$ \\
\hline 1964 & 21,9 & $-52,5$ & 11,9 & $-18,7$ & 22,4 & $-3,7$ \\
\hline 1965 & 29,2 & $-57,2$ & 9,7 & $-18,3$ & 4,9 & 12,8 \\
\hline 1966 & 27,0 & $-60,5$ & 9,4 & $-24,1$ & 34,8 & $-10,7$ \\
\hline 1967 & 3,2 & $-69,8$ & 12,7 & $-53,9$ & 63,0 & $-9,1$ \\
\hline 1968 & $-20,9$ & $-83,3$ & 13,2 & $-91,0$ & 77,4 & 13,6 \\
\hline 1969 & $-25,3$ & $-82,5$ & 12,3 & $-95,5$ & 99,2 & $-3,7$ \\
\hline 1970 & $-14,7$ & $-115,2$ & 17,0 & $-112,9$ & 118,6 & $-6,0$ \\
\hline 1971 & $-68,8$ & $-103,1$ & 16,0 & $-155,9$ & 125,1 & 31,0 \\
\hline 1972 & 39,0 & $-131,7$ & 15,0 & $-77,7$ & 176,8 & $-99,0$ \\
\hline 1973 & 185,8 & $-207,5$ & 27,0 & 5,3 & 78,3 & $-85,0$ \\
\hline
\end{tabular}

Fuente: Patricio Almeida Guzmán, Rebeca Almeida Arroba: Estadísticas Económicas Históricas 1948-1983, Fuentes para la Historia Económica del Ecuador, serie estadísticas históricas, vol. 1, Banco Central del Ecuador, 1988, p. 457. 
Tabla 14: Inversión extranjera en el Ecuador (miles de dólares) (1964-1972):

\begin{tabular}{|c|c|c|c|c|c|c|}
\hline Años & $\begin{array}{c}\text { Estados } \\
\text { Unidos }\end{array}$ & $\begin{array}{c}\text { Gran } \\
\text { Bretaña }\end{array}$ & Holanda & Italia & Suiza & Venezuela \\
\hline 1964 & 4.536 & 2.774 & 385 & -32 & 197 & 381 \\
\hline 1965 & 2.925 & 3.406 & 400 & 97 & 100 & 223 \\
\hline 1966 & 19.784 & -4.213 & 163 & 935 & -460 & -1.111 \\
\hline 1967 & 11.236 & 2.274 & 139 & -77 & 407 & 305 \\
\hline 1968 & 22.680 & 610 & 69 & 880 & 3.425 & 136 \\
\hline 1969 & 34.761 & 742 & 348 & 329 & 629 & 1.022 \\
\hline 1970 & 77.008 & 12.298 & 856 & -550 & -3.270 & -1.057 \\
\hline 1971 & 192.094 & -29.984 & 48 & 434 & -18 & 88 \\
\hline 1972 & 54.753 & 16.691 & 399 & 1.002 & 1.801 & 334 \\
\hline Total & $\mathbf{4 1 9 . 7 7 7}$ & $\mathbf{4 . 5 9 8}$ & $\mathbf{2 . 8 0 7}$ & $\mathbf{3 . 0 1 8}$ & $\mathbf{2 . 8 1 1}$ & $\mathbf{3 2 1}$ \\
\hline
\end{tabular}

Fuente: Patricio Almeida Guzmán, Rebeca Almeida Arroba: Estadísticas Económicas Históricas 1948-1983, Fuentes para la Historia Económica del Ecuador, serie estadísticas históricas, vol. 1, Banco Central del Ecuador, 1988, p. 292-294. 
Tabla 15: Inversión real en obras de infraestructura y transporte (millones de sucres) (19631972):

\begin{tabular}{|c|c|c|c|c|c|}
\hline Años & $\begin{array}{c}\text { Carreteras } \\
\text { y puentes }\end{array}$ & Telecomunicaciones & $\begin{array}{c}\text { Puertos y } \\
\text { muelles }\end{array}$ & Aeropuertos & Ferrocarriles \\
\hline 1963 & 202 & 6,0 & 11 & & 2 \\
\hline 1964 & 117 & 82,3 & 23 & 8 & 1 \\
\hline 1965 & 161 & 86,4 & 21 & 11 & 3 \\
\hline 1966 & 234 & 138,7 & 15 & 11 & \\
\hline 1967 & 235 & 150,2 & & & \\
\hline 1968 & & 181,8 & & & \\
\hline 1969 & & 201,1 & & & \\
\hline 1970 & & & & & \\
\hline 1971 & & & & & \\
\hline
\end{tabular}

Fuente: Patricio Almeida Guzmán, Rebeca Almeida Arroba: Estadísticas Económicas Históricas 1948-1983, Fuentes para la Historia Económica del Ecuador, serie estadísticas históricas, vol. 1, Banco Central del Ecuador, 1988, p. 333. 
Tabla 16: Inversión de la industria clasificada en las leyes de fomento industrial y de fomento a la pequeña industria y artesanía, por ramas de actividad (sucres) (1963-1972):

\begin{tabular}{|c|c|c|}
\hline Año & Gran industria (nuevas) & Gran industria (existentes) \\
\hline 1963 & $89,544.393$ & 519.520 .843 \\
\hline 1964 & 265.372 .598 & 305.027 .396 \\
\hline 1965 & 200.306 .218 & 277.982 .962 \\
\hline 1966 & 136.423 .062 & 95.836 .811 \\
\hline 1967 & 70.592 .840 & 165.149 .402 \\
\hline 1968 & 172.652 .980 & 120.379 .661 \\
\hline 1969 & 204.504 .750 & 94.200 .941 \\
\hline 1970 & 118.775 .577 & 57.007 .960 \\
\hline 1971 & 678.465 .222 & 183.592 .671 \\
\hline 1972 & 482.254 .941 & \\
\hline
\end{tabular}

Fuente: Patricio Almeida Guzmán, Rebeca Almeida Arroba: Estadísticas Económicas Históricas 1948-1983, Fuentes para la Historia Económica del Ecuador, serie estadísticas históricas, vol. 1, Banco Central del Ecuador, 1988, p. 311-315. 
Tabla 17: Inversiones directas de capital norteamericano en la industria ecuatoriana (1963-1966) (La perforación y explotación de petróleo se encuentran excluidas):

\begin{tabular}{|c|c|c|c|}
\hline Años & $\begin{array}{l}\text { Compañías y líneas } \\
\text { de producción }\end{array}$ & $\begin{array}{c}\text { Inversiones (en } \\
\text { millones de US\$) }\end{array}$ & $\begin{array}{l}\text { \% acciones de la } \\
\text { compañía }\end{array}$ \\
\hline 1963 & $\begin{array}{c}\text { Ralston Purina: atún } \\
\text { enlatado }\end{array}$ & 0.4 & 100 \\
\hline 1963 & $\begin{array}{c}\text { Gulfoil: Plásticos para } \\
\text { uso domestic }\end{array}$ & 0.3 & 100 \\
\hline 1965 & $\begin{array}{c}\text { St. Revis Paper: } \\
\text { recipientes }\end{array}$ & 1.5 & 35 \\
\hline 1965 & $\begin{array}{l}\text { Sterling Drugs: } \\
\text { farmacéuticos }\end{array}$ & 0.2 & 100 \\
\hline 1965 & $\begin{array}{c}\text { Crown Cork and Seal: } \\
\text { tazas }\end{array}$ & 0.5 & 100 \\
\hline 1965 & $\begin{array}{c}\text { Continental } \\
\text { Grain/Seaboard Allifa }\end{array}$ & 1.2 & 100 \\
\hline 1966 & $\begin{array}{l}\text { Del Monte: atún } \\
\text { congelado }\end{array}$ & 2.7 & 100 \\
\hline 1966 & $\begin{array}{c}\text { Texaco Corp: } \\
\text { Lubricantes, aceites }\end{array}$ & 2.0 & 100 \\
\hline
\end{tabular}

Fuente y Elaboración: NACLA, p. 21, 1975, en Rafael Quintero y Erika Silva: Ecuador: Una nación en ciernes, Tomo III, FLACSO, Abya-Yala, 1991, p. 306. 
Tabla 18: Nuevas inversiones en la industria manufacturera, por ramas de actividad (miles de sucres) (1963-1967):

\begin{tabular}{|c|c|c|c|c|c|}
\hline $\begin{array}{l}\text { Ramas de } \\
\text { actividad }\end{array}$ & 1963 & 1964 & 1965 & 1966 & 1967 \\
\hline $\begin{array}{l}\text { Alimentos, } \\
\text { bebidas y } \\
\text { tabaco }\end{array}$ & 15.170 & 112.530 & 22.470 & 27.500 & 573.140 \\
\hline $\begin{array}{l}\text { Textiles, } \\
\text { prendas de } \\
\text { vestir, cuero }\end{array}$ & 12.250 & 12.200 & 43.290 & 11.140 & 13.350 \\
\hline $\begin{array}{l}\text { Industria de } \\
\text { Madera y sus } \\
\text { ptos }\end{array}$ & 11.910 & 11.360 & & 3.310 & \\
\hline $\begin{array}{l}\text { Fab. Papel, } \\
\text { imprenta y } \\
\text { editorials }\end{array}$ & & 22.000 & 4.210 & 30.800 & \\
\hline $\begin{array}{l}\text { Fab. Químicos } \\
\text { y derive, } \\
\text { petróleo }\end{array}$ & 51.120 & 33.340 & 18.700 & 17.020 & 50.248 \\
\hline $\begin{array}{l}\text { Mine. No } \\
\text { metálicos }\end{array}$ & & 1.690 & 4.930 & 121.000 & 6.775 \\
\hline $\begin{array}{l}\text { Ind. Metálicas } \\
\text { básicas }\end{array}$ & & & & 22.500 & \\
\hline $\begin{array}{l}\text { Fab. Ptos } \\
\text { metálicos, maq. } \\
\text { Y equipo }\end{array}$ & 5.780 & 17.200 & 6.600 & 20.150 & 8.395 \\
\hline $\begin{array}{l}\text { Otros ptos } \\
\text { manufacturados }\end{array}$ & 5.400 & 1.950 & 4.980 & 6.150 & 2.520 \\
\hline Total & 101.630 & 212.270 & 105.180 & 259.570 & 454.428 \\
\hline
\end{tabular}

Fuente: Patricio Almeida Guzmán, Rebeca Almeida Arroba: Estadísticas Económicas Históricas 1948-1983, Fuentes para la Historia Económica del Ecuador, serie estadísticas históricas, vol. 1, Banco Central del Ecuador, 1988, p. 327. 
Tabla 19: Nuevas inversiones en la industria manufacturera, por ramas de actividad (miles de sucres) (1968-1972):

\begin{tabular}{|c|c|c|c|c|c|}
\hline $\begin{array}{l}\text { Ramas de } \\
\text { actividad }\end{array}$ & 1968 & 1969 & 1970 & 1971 & 1972 \\
\hline $\begin{array}{l}\text { Alimentos, } \\
\text { bebidas y } \\
\text { tabaco }\end{array}$ & 107.580 & & & & 42.390 \\
\hline $\begin{array}{l}\text { Textiles, } \\
\text { prendas de } \\
\text { vestir, cuero }\end{array}$ & 10.738 & & & & 4.970 \\
\hline $\begin{array}{l}\text { Industria de } \\
\text { Madera y sus } \\
\text { ptos }\end{array}$ & 2.150 & & & & 2.580 \\
\hline $\begin{array}{l}\text { Fab. Papel, } \\
\text { imprenta y } \\
\text { editorials }\end{array}$ & 75.000 & & & & 360 \\
\hline $\begin{array}{l}\text { Fab. Químicos } \\
\text { y derive, } \\
\text { petróleo }\end{array}$ & 50.000 & & & & 5.680 \\
\hline $\begin{array}{l}\text { Mine. No } \\
\text { metálicos }\end{array}$ & 25.000 & & & & 1.020 \\
\hline $\begin{array}{l}\text { Ind. Metálicas } \\
\text { básicas }\end{array}$ & 2.000 & & & & 1.970 \\
\hline $\begin{array}{l}\text { Fab. Ptos } \\
\text { metálicos, maq. } \\
\text { Y equipo }\end{array}$ & 14.300 & & & & 29.900 \\
\hline $\begin{array}{l}\text { Otros ptos } \\
\text { manufacturados }\end{array}$ & & & & & \\
\hline Total & 286.768 & & & 606.300 & 88.880 \\
\hline
\end{tabular}

Fuente: Patricio Almeida Guzmán, Rebeca Almeida Arroba: Estadísticas Económicas Históricas 1948-1983, Fuentes para la Historia Económica del Ecuador, serie estadísticas históricas, vol. 1, Banco Central del Ecuador, 1988, p. 327. 
Tabla 20: Importaciones totales por tipo de bienes: materias primas, bienes de capital y bienes de consumo (miles de dólares) (1963-1968):

\begin{tabular}{|c|c|c|c|c|c|c|}
\hline Bienes & 1963 & 1964 & 1965 & 1966 & 1967 & 1968 \\
\hline $\begin{array}{l}\text { Materia prima } \\
\text { y ptos } \\
\text { intermedios }\end{array}$ & 55.804 & 71.680 & 72.568 & 81.365 & 91.365 & 130.058 \\
\hline Agricultura & 2.075 & 3.219 & 4.346 & 3.734 & 3.770 & 4.302 \\
\hline Industria & 49.744 & 64.155 & 59.220 & 65.402 & 75.763 & 101.312 \\
\hline Construcción & 3.985 & 4.306 & 9.002 & 12.229 & 11.832 & 24.444 \\
\hline $\begin{array}{l}\text { Bienes de } \\
\text { capital }\end{array}$ & 36.063 & 48.480 & 46.741 & 52.297 & 67.875 & 77.700 \\
\hline Agricultura & 2.771 & 3.699 & 4.542 & 4.057 & 4.637 & 6.643 \\
\hline Industria & 16.995 & 23.832 & 24.606 & 29.889 & 40.536 & 41.446 \\
\hline $\begin{array}{l}\text { Equipo } \\
\text { transporte }\end{array}$ & 16.297 & 20.949 & 17.593 & 18.351 & 22.702 & 29.611 \\
\hline $\begin{array}{l}\text { Bienes de } \\
\text { consumo }\end{array}$ & 12.842 & 16.512 & 31.258 & 33.07 & 33.022 & 37.041 \\
\hline $\begin{array}{l}\text { Ptos } \\
\text { alimenticios }\end{array}$ & 3.004 & 4.776 & 3.856 & 3.475 & 3.443 & 4.298 \\
\hline $\begin{array}{l}\text { Ptos } \\
\text { farmacéuticos }\end{array}$ & 7.140 & 8.362 & 10.209 & 9.990 & 10.769 & 12.181 \\
\hline $\begin{array}{l}\text { Vestuarios y } \\
\text { textiles }\end{array}$ & 787 & 1.125 & 1.044 & 654 & 872 & 680 \\
\hline Otros & 1.911 & 2.249 & 16.149 & 18.952 & 17.938 & 19.682 \\
\hline $\begin{array}{l}\text { Combustibles } \\
\text { y lubricantes }\end{array}$ & 15.262 & 4.134 & 13.495 & 4.873 & 20.825 & 9.323 \\
\hline \multicolumn{7}{|l|}{ Aceites } \\
\hline \multicolumn{7}{|l|}{ Grasas } \\
\hline \multicolumn{7}{|l|}{ Gasolina } \\
\hline Otros & 8.038 & 11.110 & 345 & 2.523 & 1.123 & 1.343 \\
\hline Total & 128.009 & 151.916 & 164.407 & 174.129 & 214.210 & 255.465 \\
\hline
\end{tabular}

Fuente: Patricio Almeida Guzmán, Rebeca Almeida Arroba: Estadísticas Económicas Históricas 1948-1983, Fuentes para la Historia Económica del Ecuador, serie estadísticas históricas, vol. 1, Banco Central del Ecuador, 1988, p. 448. 
Tabla 21: Importaciones totales por tipo de bienes: materias primas, bienes de capital y bienes de consumo (miles de dólares) (1969-1974):

\begin{tabular}{|c|c|c|c|c|c|c|}
\hline Bienes & 1969 & 1970 & 1971 & 1972 & 1973 & 1974 \\
\hline $\begin{array}{l}\text { Materia } \\
\text { prima y ptos } \\
\text { intermedios }\end{array}$ & 113.972 & 137.070 & 158.592 & 135.042 & 173.829 & 443.125 \\
\hline Agricultura & 4.729 & 5.552 & 3.695 & 4.557 & 5.746 & 61.041 \\
\hline Industria & 96.110 & 116.084 & 118.163 & 105.595 & 149.349 & 316.240 \\
\hline Construcción & 13.133 & 15.434 & 36.734 & 24.890 & 18.734 & 65.844 \\
\hline $\begin{array}{l}\text { Bienes de } \\
\text { capital }\end{array}$ & 75.558 & 82.047 & 114.349 & 125.687 & 147.856 & 388.570 \\
\hline Agricultura & 6.135 & 7.557 & 6.670 & 4.370 & 5.695 & 16.686 \\
\hline Industria & 37.161 & 41.904 & 63.120 & 76.316 & 83.992 & 239.588 \\
\hline $\begin{array}{l}\text { Equipo } \\
\text { transporte }\end{array}$ & 32.262 & 32.586 & 44.559 & 45.001 & 58.169 & 132.296 \\
\hline $\begin{array}{l}\text { Bienes de } \\
\text { consumo }\end{array}$ & 34.866 & 32.198 & 38.234 & 46.228 & 64.064 & 108.246 \\
\hline $\begin{array}{l}\text { Ptos } \\
\text { alimenticios }\end{array}$ & 4.256 & 3.639 & 3.182 & 3.894 & 4.706 & 19.780 \\
\hline $\begin{array}{l}\text { Ptos } \\
\text { farmacéuticos }\end{array}$ & 14.766 & 14.606 & 14.949 & 20.248 & 30.805 & 30.805 \\
\hline $\begin{array}{l}\text { Vestuarios y } \\
\text { textiles }\end{array}$ & 664 & 766 & 471 & 413 & 563 & 833 \\
\hline Otros & 15.180 & 17.187 & 19.632 & 24.872 & 38.547 & 56.828 \\
\hline $\begin{array}{l}\text { Combustibles } \\
\text { y lubricantes }\end{array}$ & 15.893 & 17.193 & 27.688 & 10.602 & 11.183 & 16.284 \\
\hline \multicolumn{7}{|l|}{ Aceites } \\
\hline Grasas & & & & & & \\
\hline
\end{tabular}




\begin{tabular}{|l|c|c|c|c|c|c|}
\hline Gasolina & & & & & & \\
\hline Otros & 1.549 & 1.341 & 1.240 & 1.040 & 350 & 2.263 \\
\hline Total & 241.838 & 273.849 & 340.103 & 318.599 & 397.282 & 958.488 \\
\hline
\end{tabular}

Fuente: Patricio Almeida Guzmán, Rebeca Almeida Arroba: Estadísticas Económicas Históricas 1948-1983, Fuentes para la Historia Económica del Ecuador, serie estadísticas históricas, vol. 1, Banco Central del Ecuador, 1988, p. 449. 
Tabla 22: Importaciones por principales grupos de mercancías (miles de sucres) (1963-1973):

\begin{tabular}{|c|c|c|c|c|c|c|}
\hline Productos & 1963 & 1964-1969 & 1970 & 1971 & 1972 & 1973 \\
\hline Alimentos & 8.000 & & $125.178,9$ & $231.738,6$ & $269.009,8$ & $306.079,7$ \\
\hline Bebidas & 3.200 & & $8.571,6$ & 22.817 & $70.699,6$ & $111.139,5$ \\
\hline Cigarrillos & & & $10.901,7$ & $53.328,8$ & $36.776,3$ & $5.457,5$ \\
\hline Textiles & & & $180.849,9$ & $318.018,3$ & $293.547,1$ & $479.034,9$ \\
\hline $\begin{array}{l}\text { Calzado y } \\
\text { vestuario }\end{array}$ & & & $8.560,9$ & $7.957,3$ & $9.107,3$ & $10.818,9$ \\
\hline $\begin{array}{l}\text { Madera y } \\
\text { corcho }\end{array}$ & & & $5.245,7$ & $8.085,1$ & $4.705,2$ & $7.174,9$ \\
\hline $\begin{array}{l}\text { Muebles de } \\
\text { Madera }\end{array}$ & & & 472,6 & & & \\
\hline $\begin{array}{l}\text { Papel y } \\
\text { carbón }\end{array}$ & & & 161.700 & $565.885,7$ & $198.150,5$ & 377.433 \\
\hline $\begin{array}{l}\text { Industria } \\
\text { impresora }\end{array}$ & & & $26.774,4$ & $34.681,4$ & 82.010 & $115.452,7$ \\
\hline $\begin{array}{l}\text { Cuero y } \\
\text { pieles }\end{array}$ & & & $1.344,9$ & $1.298,8$ & $1.528,1$ & $2.117,7$ \\
\hline $\begin{array}{l}\text { Industria de } \\
\text { caucho }\end{array}$ & & & $46.521,9$ & $74.00,5$ & $75.922,3$ & $101.255,7$ \\
\hline $\begin{array}{l}\text { Industria } \\
\text { química }\end{array}$ & 13.900 & & 958.184,7 & $1.210 .943,1$ & 1.442 .025 & 1.651.306,7 \\
\hline $\begin{array}{l}\text { Petróleo y } \\
\text { carbon }\end{array}$ & 5.400 & & $67.991,4$ & $131.941,5$ & 392.137 & $245.504,8$ \\
\hline $\begin{array}{l}\text { Minerales no } \\
\text { metálicos }\end{array}$ & & & $110.386,1$ & $122.919,6$ & 115.828 & $206.031,2$ \\
\hline $\begin{array}{l}\text { Metálicas } \\
\text { básicas }\end{array}$ & & & 477.371,8 & $1.098 .880,1$ & 873.531,6 & 1.001.249,2 \\
\hline
\end{tabular}




\begin{tabular}{|l|l|l|l|l|l|l|}
\hline $\begin{array}{l}\text { Maquinaria } \\
\text { no eléctrica }\end{array}$ & & & 203.397 & $346.890,7$ & $324.971,6$ & $390.497,5$ \\
\hline $\begin{array}{l}\text { Maquinaria } \\
\text { eléctrica }\end{array}$ & & & $\mathbf{8 3 1 . 8 6 5 , 6}$ & $\mathbf{1 . 2 3 2 . 2 2 8 , 2}$ & $\mathbf{1 . 4 0 8 . 7 3 1 , 2}$ & $\mathbf{1 . 6 2 9 . 5 6 8 , 8}$ \\
\hline $\begin{array}{l}\text { Material de } \\
\text { transporte }\end{array}$ & 35.200 & & $381.470,6$ & $634.240,6$ & $639.778,1$ & $888.598,2$ \\
\hline $\begin{array}{l}\text { Manufacturas } \\
\text { diversas }\end{array}$ & 47.300 & & $617.216,2$ & $1.144 .917,2$ & $1.163 .639,4$ & $1.566 .026,7$ \\
\hline Total & 113.000 & & 157.501 & $205.062,2$ & 273.835 & $281.515,4$ \\
\hline & & & $4.381 .506,9$ & $7.445 .844,7$ & $7.675 .933,1$ & 9.376 .263 \\
\hline
\end{tabular}

Fuente: Patricio Almeida Guzmán, Rebeca Almeida Arroba: Estadísticas Económicas Históricas 1948-1983, Fuentes para la Historia Económica del Ecuador, serie estadísticas históricas, vol. 1, Banco Central del Ecuador, 1988, p. 495. 
Tabla 23: Materias Primas utilizadas por las industrias y artesanías de la Hoya de Quito (1955):

\begin{tabular}{|l|l|l|l|l|l|l|l|l|l|}
\hline & \multicolumn{3}{|c|}{ Industria } & \multicolumn{3}{c|}{ Artesanía Urbana } & \multicolumn{3}{c|}{ Artesanía Rural } \\
\hline $\begin{array}{l}\text { Mat. } \\
\text { Primas }\end{array}$ & $\begin{array}{l}\text { Total } \\
\text { (sucres) }\end{array}$ & $\begin{array}{l}\text { Promedio } \\
\text { empresa }\end{array}$ & $\%$ & $\begin{array}{l}\text { Total } \\
\text { (sucres) }\end{array}$ & $\begin{array}{l}\text { Promedio } \\
\text { empresa }\end{array}$ & $\%$ & $\begin{array}{l}\text { Total } \\
\text { sucres }\end{array}$ & $\begin{array}{l}\text { Promedio } \\
\text { Empresa }\end{array}$ & $\%$ \\
\hline Nacionales & 96.101 .300 & 254.900 & 44,85 & 33.840 .000 & 9.500 & 63,33 & 3.862 .800 & $3.015,48$ & 91,14 \\
\hline Importadas & 118.157 .400 & 313.400 & 55,15 & 19.501 .800 & 5.500 & 26,67 & 375.600 & 293,16 & 8,86 \\
\hline Total & 214.258 .700 & 568.300 & 100 & 53.341 .800 & 15.000 & 100 & 4.238 .400 & $3.308,64$ & 100 \\
& & & & & & & & & \\
\hline
\end{tabular}

Fuente: Junta Nacional de Planificación: La industria y la artesanía de la Hoya de Quito en 1955, en Instituto Panamericano de Geografía e Historia, Plan Piloto del Ecuador, Sección de Economía, México, D.F, 1960, p. 55. 
Tabla 24: Balanza comercial (millones de sucres) (1963-1972):

\begin{tabular}{|c|c|c|c|}
\hline Años & Importaciones & Exportaciones & Saldo \\
\hline 1963 & 2.320 & 2.312 & $-8,0$ \\
\hline 1964 & 2.734 & 2.347 & $-387,0$ \\
\hline 1965 & 2.959 & 2.375 & $-584,0$ \\
\hline 1966 & 3.134 & 2.515 & $-619,0$ \\
\hline 1967 & 3.856 & 2.845 & $-1.011,0$ \\
\hline 1968 & 4.598 & 3.513 & $-1.085,0$ \\
\hline 1969 & 4.353 & 2.745 & $-1.608,0$ \\
\hline 1970 & 6.846 & 4.748 & $-2.098,0$ \\
\hline 1971 & 8.503 & 4.977 & $-3.526,0$ \\
\hline 1972 & 7.965 & 8.157 & 192,0 \\
\hline
\end{tabular}

Fuente: Patricio Almeida Guzmán, Rebeca Almeida Arroba: Estadísticas Económicas Históricas 1948-1983, Fuentes para la Historia Económica del Ecuador, serie estadísticas históricas, vol. 1, Banco Central del Ecuador, 1988, p. 459. 
Tabla 25: Producto interior bruto por clase de actividad económica (millones de sucres corrientes) (1950-1954):

\begin{tabular}{|c|c|c|c|c|c|}
\hline Actividad & 1950 & 1951 & 1952 & 1953 & 1954 \\
\hline $\begin{array}{l}\text { 1.Agricultura, } \\
\text { caza, silvicultura y } \\
\text { pesca }\end{array}$ & 2.247 & 2.392 & 2.912 & 2.984 & 3.212 \\
\hline $\begin{array}{l}\text { 2. Petróleo y otras } \\
\text { minas }\end{array}$ & 73 & 72 & 77 & 79 & 97 \\
\hline $\begin{array}{l}\text { 3. Ind. } \\
\text { Manufactureras }\end{array}$ & 1.235 & 1.345 & 1.448 & 1.560 & 1.681 \\
\hline $\begin{array}{l}\text { 4. Electricidad, gas } \\
\text { y agua. }\end{array}$ & 24 & 29 & 39 & 52 & 61 \\
\hline 5. Construcción & 99 & 100 & 122 & 138 & 154 \\
\hline $\begin{array}{l}\text { 6. Comercio al por } \\
\text { mayor, al por } \\
\text { menor restaurantes } \\
\text { y hoteles. }\end{array}$ & 1.017 & 1.086 & 1.290 & 1.342 & 1.510 \\
\hline $\begin{array}{l}\text { 7. Transporte, } \\
\text { almacen. y comun. }\end{array}$ & 372 & 431 & 474 & 501 & 568 \\
\hline $\begin{array}{l}\text { 8. Establ. Finan., } \\
\text { segueor, b. inm., } \\
\text { serv a empresas }\end{array}$ & 953 & 996 & 1.047 & 1.113 & 1.314 \\
\hline -alquiler vivienda & 673 & 692 & 730 & 767 & 885 \\
\hline -Otros & 280 & 304 & 317 & 346 & 429 \\
\hline $\begin{array}{l}\text { 9. Serv. } \\
\text { Comunales soc. Y } \\
\text { personales }\end{array}$ & 616 & 641 & 691 & 731 & 832 \\
\hline
\end{tabular}




\begin{tabular}{|c|c|c|c|c|c|}
\hline $\begin{array}{l}\text { (-)Servic. } \\
\text { Bancarios }\end{array}$ & -58 & -67 & -72 & -77 & -86 \\
\hline $\begin{array}{l}\text { Subtotal valor } \\
\text { agregado } \\
\text { industrias }\end{array}$ & 6.578 & 7.025 & 8.028 & 8.423 & 9.343 \\
\hline Serv. Gubern. & 382 & 390 & 428 & 477 & 559 \\
\hline Servicio domést. & & & & & \\
\hline $\begin{array}{l}\text { Total Valor } \\
\text { agregado bruto }\end{array}$ & 6.960 & 7.415 & 8.456 & 8.900 & 9.902 \\
\hline $\begin{array}{l}\text { Otros elementos } \\
\text { del PIB }\end{array}$ & 269 & 339 & 368 & 444 & 477 \\
\hline $\begin{array}{l}\text { Producto Interior } \\
\text { Bruto (PIB) }\end{array}$ & 7.229 & 7.754 & 8.824 & 9.344 & 10.379 \\
\hline
\end{tabular}

Fuente: Patricio Almeida Guzmán, Rebeca Almeida Arroba: Estadísticas Económicas Históricas 1948-1983, Fuentes para la Historia Económica del Ecuador, serie estadísticas históricas, vol. 1, Banco Central del Ecuador, 1988, p. 137-138. 
Tabla 26: Producto interior bruto por clase de actividad económica (millones de sucres corrientes) (1955-1959):

\begin{tabular}{|c|c|c|c|c|c|}
\hline Actividad & 1955 & 1956 & 1957 & 1958 & 1959 \\
\hline $\begin{array}{l}\text { 1.Agricultura, } \\
\text { caza, silvicultura y } \\
\text { pesca }\end{array}$ & 3.132 & 3.284 & 3.455 & 3.497 & 3.072 \\
\hline $\begin{array}{l}\text { 2. Petróleo y otras } \\
\text { minas }\end{array}$ & 116 & 110 & 112 & 107 & 113 \\
\hline $\begin{array}{l}\text { 3. Ind. } \\
\text { Manufactureras }\end{array}$ & 1.744 & 1.827 & 1.906 & 2.026 & 2.129 \\
\hline $\begin{array}{l}\text { 4. Electricidad, gas } \\
\text { y agua. }\end{array}$ & 78 & 77 & 87 & 91 & 100 \\
\hline 5. Construcción & 171 & 195 & 210 & 213 & 254 \\
\hline $\begin{array}{l}\text { 6. Comercio al por } \\
\text { mayor, al por } \\
\text { menor restaurants } \\
\text { y hoteles. }\end{array}$ & 1.879 & 1.908 & 1.969 & 2.007 & 2.031 \\
\hline $\begin{array}{l}\text { 7. Transporte, } \\
\text { almacen. y comun. }\end{array}$ & 590 & 574 & 611 & 617 & 634 \\
\hline $\begin{array}{l}\text { 8. Establ. Finan., } \\
\text { segueor, b. inm., } \\
\text { serv a empresas }\end{array}$ & 1.432 & 1.479 & 1.615 & 1.704 & 1.801 \\
\hline -alquiler vivienda & 969 & 980 & 1.015 & 1.042 & 1.065 \\
\hline -Otros & 463 & 499 & 600 & 662 & 736 \\
\hline $\begin{array}{l}\text { 9. Serv. } \\
\text { Comunales soc. Y } \\
\text { personales }\end{array}$ & 883 & 810 & 970 & 1.034 & 1.076 \\
\hline
\end{tabular}




\begin{tabular}{|l|c|c|c|c|c|}
\hline $\begin{array}{l}\text { (-)Servic. } \\
\text { Bancarios }\end{array}$ & -97 & -107 & -119 & -124 \\
\hline $\begin{array}{l}\text { Subtotal valor } \\
\text { agregado } \\
\text { industrias }\end{array}$ & 9.928 & 10.157 & 10.816 & 11.172 & 11.704 \\
\hline $\begin{array}{l}\text { Serv. Gubern. } \\
\text { Servicio domést. }\end{array}$ & 605 & 627 & 632 & 650 & 682 \\
\hline $\begin{array}{l}\text { Total Valor } \\
\text { agregado bruto }\end{array}$ & 10.533 & 10.784 & 11.448 & 11.822 & 12.386 \\
\hline $\begin{array}{l}\text { Producto Interior } \\
\text { Bruto (PIB) }\end{array}$ & $\mathbf{1 1 . 0 1 7}$ & $\mathbf{1 1 . 2 3 1}$ & $\mathbf{1 1 . 9 9 2}$ & & \\
\hline
\end{tabular}

Fuente: Patricio Almeida Guzmán, Rebeca Almeida Arroba: Estadísticas Económicas Históricas 1948-1983, Fuentes para la Historia Económica del Ecuador, serie estadísticas históricas, vol. 1, Banco Central del Ecuador, 1988, p. 137-138. 
Tabla 27: Producto interior bruto por clase de actividad económica (millones de sucres corrientes) (1960-1964):

\begin{tabular}{|c|c|c|c|c|c|}
\hline Actividad & 1960 & 1961 & 1962 & 1963 & 1964 \\
\hline $\begin{array}{l}\text { 1.Agricultura, } \\
\text { caza, silvicultura y } \\
\text { pesca }\end{array}$ & 4.112 & 4.423 & 4.891 & 5.163 & 5.351 \\
\hline $\begin{array}{l}\text { 2. Petróleo y otras } \\
\text { minas }\end{array}$ & 149 & 150 & 154 & 176 & 186 \\
\hline $\begin{array}{l}\text { 3. Ind. } \\
\text { Manufactureras }\end{array}$ & 2.335 & 2.432 & 2.619 & 2.915 & 3.054 \\
\hline $\begin{array}{l}\text { 4. Electricidad, gas } \\
\text { y agua. }\end{array}$ & 109 & 126 & 139 & 159 & 174 \\
\hline 5. Construcción & 273 & 312 & 304 & 323 & 380 \\
\hline $\begin{array}{l}\text { 6. Comercio al por } \\
\text { mayor, al por } \\
\text { menor restaurants } \\
\text { y hoteles. }\end{array}$ & 2.213 & 2.303 & 2.390 & 2.634 & 2.848 \\
\hline $\begin{array}{l}\text { 7. Transporte, } \\
\text { almacen. y comun. }\end{array}$ & 635 & 685 & 687 & 749 & 807 \\
\hline $\begin{array}{l}\text { 8. Establ. Finan., } \\
\text { segueor, b. inm., } \\
\text { serv a empresas }\end{array}$ & 1.866 & 2.042 & 2.140 & 2.331 & 2.594 \\
\hline -alquiler vivienda & 1.106 & 1.198 & 1.264 & 1.363 & 1.457 \\
\hline -Otros & 760 & 844 & 876 & 968 & 1.137 \\
\hline $\begin{array}{l}\text { 9. Serv. } \\
\text { Comunales soc. Y } \\
\text { personales }\end{array}$ & 1.124 & 1.137 & 1.238 & 1.273 & 1.519 \\
\hline
\end{tabular}




\begin{tabular}{|l|c|c|c|c|c|}
\hline $\begin{array}{l}\text { (-)Servic. } \\
\text { Bancarios }\end{array}$ & -140 & -164 & -170 & -184 & \\
\hline $\begin{array}{l}\text { Subtotal valor } \\
\text { agregado } \\
\text { industrias }\end{array}$ & 12.676 & 13.446 & 14.392 & 15.539 & 17.146 \\
\hline $\begin{array}{l}\text { Serv. Gubern. } \\
\text { Servicio domést. }\end{array}$ & 753 & 865 & 917 & 987 & 1.151 \\
\hline $\begin{array}{l}\text { Total Valor } \\
\text { agregado bruto }\end{array}$ & 13.429 & 14.311 & 15.309 & 16.526 & 18.297 \\
\hline $\begin{array}{l}\text { Producto Interior } \\
\text { Bruto (PIB) }\end{array}$ & $\mathbf{1 4 . 0 7 1}$ & $\mathbf{1 4 . 9 6 6}$ & $\mathbf{1 5 . 9 7 8}$ & & \\
\hline
\end{tabular}

Fuente: Patricio Almeida Guzmán, Rebeca Almeida Arroba: Estadísticas Económicas Históricas 1948-1983, Fuentes para la Historia Económica del Ecuador, serie estadísticas históricas, vol. 1, Banco Central del Ecuador, 1988, p. 137-138. 
Tabla 28: Producto interior bruto por clase de actividad económica (millones de sucres corrientes) (1965-1969):

\begin{tabular}{|c|c|c|c|c|c|}
\hline Actividad & 1965 & 1966 & 1967 & 1968 & 1969 \\
\hline $\begin{array}{l}\text { 1.Agricultura, } \\
\text { caza, silvicultura y } \\
\text { pesca }\end{array}$ & 5.634 & 5.961 & 6.574 & 6.847 & 7.268 \\
\hline $\begin{array}{l}\text { 2. Petróleo y otras } \\
\text { minas }\end{array}$ & 456 & 461 & 475 & 537 & 631 \\
\hline $\begin{array}{l}\text { 3. Ind. } \\
\text { Manufactureras }\end{array}$ & 3.359 & 3.988 & 4.302 & 4.571 & 5.145 \\
\hline $\begin{array}{l}\text { 4. Electricidad, gas } \\
\text { y agua. }\end{array}$ & 193 & 203 & 225 & 252 & 282 \\
\hline 5. Construcción & 431 & 524 & 727 & 847 & 1.076 \\
\hline $\begin{array}{l}\text { 6. Comercio al por } \\
\text { mayor, al por } \\
\text { menor restaurants } \\
\text { y hoteles. }\end{array}$ & 3.102 & 3.374 & 3.878 & 4.311 & 4.533 \\
\hline $\begin{array}{l}\text { 7. Transporte, } \\
\text { almacen. y comun. }\end{array}$ & 839 & 1.022 & 1.228 & 1.483 & 1.761 \\
\hline $\begin{array}{l}\text { 8. Establ. Finan., } \\
\text { segueor, b. inm., } \\
\text { serv a empresas }\end{array}$ & 2.520 & 2.666 & 2.912 & 3.125 & 3.399 \\
\hline -alquiler vivienda & 1.563 & 1.619 & 1.716 & 1.86 & 1.888 \\
\hline -Otros & 957 & 1.047 & 1.196 & 1.309 & 1.511 \\
\hline $\begin{array}{l}\text { 9. Serv. } \\
\text { Comunales soc. Y } \\
\text { personales }\end{array}$ & 1.606 & 1.647 & 1.796 & 1.804 & 1.970 \\
\hline
\end{tabular}




\begin{tabular}{|l|c|c|c|c|c|}
\hline $\begin{array}{l}\text { (-)Servic. } \\
\text { Bancarios }\end{array}$ & -303 & -324 & -374 & -428 & -500 \\
\hline $\begin{array}{l}\text { Subtotal valor } \\
\text { agregado } \\
\text { industrias }\end{array}$ & 18.037 & 19.522 & 21.743 & 23.339 & 25.565 \\
\hline $\begin{array}{l}\text { Serv. Gubern. } \\
\text { Servicio domést. }\end{array}$ & 1.425 & 1.551 & 1.637 & 2.125 & 2.563 \\
\hline $\begin{array}{l}\text { Total Valor } \\
\text { agregado bruto }\end{array}$ & 19.688 & 21.307 & 23.621 & & \\
\hline $\begin{array}{l}\text { Producto Interior } \\
\text { Bruto (PIB) }\end{array}$ & $\mathbf{2 0 . 7 2 1}$ & $\mathbf{2 2 . 5 9 6}$ & $\mathbf{2 5 . 2 3 8}$ & & \\
\hline
\end{tabular}

Fuente: Patricio Almeida Guzmán, Rebeca Almeida Arroba: Estadísticas Económicas Históricas 1948-1983, Fuentes para la Historia Económica del Ecuador, serie estadísticas históricas, vol. 1, Banco Central del Ecuador, 1988, p. 137-138. 
Tabla 29: Producto interior bruto por clase de actividad económica (millones de sucres corrientes) (1970-1974):

\begin{tabular}{|c|c|c|c|c|c|}
\hline Productos & 1970 & 1971 & 1972 & 1973 & 1974 \\
\hline $\begin{array}{l}\text { 1.Agricultura, } \\
\text { caza, silvic., } \\
\text { pesca }\end{array}$ & 8.386 & 9.180 & 10.535 & 12.241 & 17.377 \\
\hline $\begin{array}{l}\text { 01.Banano, café, } \\
\text { cacao }\end{array}$ & 2.222 & 2.504 & 2.866 & 3.030 & 4.563 \\
\hline $\begin{array}{l}\text { 02.Otras } \\
\text { producciones } \\
\text { Agrícolas }\end{array}$ & 3.161 & 3.201 & 3.577 & 4.559 & 6.367 \\
\hline 03. Prod. Animal & 2.519 & 2.783 & 3.207 & 3.572 & 4.983 \\
\hline $\begin{array}{l}\text { 04. Silvícolas, tala } \\
\text { y corta }\end{array}$ & 286 & 346 & 426 & 535 & 801 \\
\hline 05. Pesca y caza & 198 & 346 & 459 & 545 & 663 \\
\hline $\begin{array}{l}\text { 2. Petróleo y } \\
\text { otras minas }\end{array}$ & 543 & 622 & 1.543 & 6.172 & 16.320 \\
\hline 2a. Petróleo & 457 & 514 & 1.430 & 5.982 & 16.064 \\
\hline $\begin{array}{l}\text { 06. Petróleo crudo } \\
\text { y gas natural }\end{array}$ & -12 & -45 & 824 & 5.821 & 21.373 \\
\hline $\begin{array}{l}\text { 07. Refinac. } \\
\text { Petróleo }\end{array}$ & 469 & 559 & 606 & 101 & -5.309 \\
\hline
\end{tabular}




\begin{tabular}{|c|c|c|c|c|c|}
\hline $\begin{array}{l}\text { 2b. Otras } \\
\text { producc. Minería }\end{array}$ & 86 & 108 & 113 & 190 & 256 \\
\hline $\begin{array}{l}\text { 08. Otras producc. } \\
\text { Minería }\end{array}$ & 86 & 108 & & 190 & 256 \\
\hline $\begin{array}{l}\text { 3.Industria } \\
\text { Manufacturera } \\
\text { (ex. refinación } \\
\text { petróleo) }\end{array}$ & 6.372 & 7.546 & 8.763 & 10.828 & 14.292 \\
\hline $\begin{array}{l}\text { 3.1 Ptos } \\
\text { alimenticios, } \\
\text { bebidas, tabaco }\end{array}$ & 3.289 & 3.736 & 4.203 & 4.989 & 6.551 \\
\hline $\begin{array}{l}\text { 09. Carnes, } \\
\text { pescado elaborado }\end{array}$ & 464 & 570 & 659 & 818 & 1.170 \\
\hline $\begin{array}{l}\text { 10. Cereales, } \\
\text { panadería }\end{array}$ & 531 & 559 & 648 & 619 & 728 \\
\hline 11. Azúcar & 477 & 661 & 618 & 693 & 1.318 \\
\hline $\begin{array}{l}12 \text { Ptos } \\
\text { alimenticios diver. }\end{array}$ & 959 & 971 & 1.131 & 1.572 & 1.847 \\
\hline 13. Bebidas & 762 & 864 & 1.043 & 1.169 & 1.319 \\
\hline $\begin{array}{l}\text { 14. Tabaco } \\
\text { Elaborado }\end{array}$ & 96 & 111 & 104 & 118 & 169 \\
\hline $\begin{array}{l}3.2 \text { Textiles, } \\
\text { prendas vestir, }\end{array}$ & 1.127 & 1.425 & 1.816 & 2.216 & 2.838 \\
\hline
\end{tabular}




\begin{tabular}{|c|c|c|c|c|c|}
\hline industria cuero & & & & & \\
\hline $\begin{array}{l}\text { 15. Textiles, } \\
\text { prendas vestir, ind. } \\
\text { Cuero }\end{array}$ & 1.127 & 1.425 & 1.816 & 2.216 & 2.838 \\
\hline $\begin{array}{l}\text { 3.3 Ind. Madera, } \\
\text { ptos Madera, } \\
\text { muebles }\end{array}$ & 293 & 352 & 478 & 614 & 953 \\
\hline 16. Madera & 293 & 352 & 478 & 614 & 953 \\
\hline $\begin{array}{l}\text { 3.4 Fabric. Papel, } \\
\text { imprentas y } \\
\text { editor. }\end{array}$ & 378 & 446 & 504 & 589 & 767 \\
\hline $\begin{array}{l}\text { 17. Papel e } \\
\text { imprentas }\end{array}$ & 378 & 446 & 504 & 589 & 767 \\
\hline $\begin{array}{l}\text { 3.5 Ptos químicos } \\
\text { del carbón y } \\
\text { plásticos }\end{array}$ & 553 & 704 & 644 & 868 & 974 \\
\hline $\begin{array}{l}\text { 18. Químico y del } \\
\text { caucho }\end{array}$ & 553 & 704 & 644 & 868 & 974 \\
\hline $\begin{array}{l}\text { 3.6 y 3.7 Ptos } \\
\text { minerales no } \\
\text { metálicos e ind. } \\
\text { Metálicas básicas }\end{array}$ & 552 & 663 & 839 & 1.029 & 1.485 \\
\hline $\begin{array}{l}\text { 19. Minerales } \\
\text { básicos, metálicos } \\
\text { y no metálicos }\end{array}$ & 552 & 663 & 839 & 1.029 & 1.485 \\
\hline $\begin{array}{l}3.8 \text { Ptos metálicos, } \\
\text { maquinaria, } \\
\text { equipo }\end{array}$ & 180 & 220 & 279 & 523 & 724 \\
\hline
\end{tabular}




\begin{tabular}{|l|l|l|l|l|l|}
\hline & & & & & \\
\hline $\begin{array}{l}\text { 20. Maquin., } \\
\text { equipo y material } \\
\text { transporte }\end{array}$ & 180 & 220 & 279 & 523 & 724 \\
\hline $\begin{array}{l}\text { 3.9 Otras } \\
\text { industrias } \\
\text { manufactureras }\end{array}$ & & & & & \\
\hline $\begin{array}{l}\text { 21. Otras } \\
\text { industrias } \\
\text { manufactureras }\end{array}$ & & & & & \\
\hline
\end{tabular}

Fuente: Patricio Almeida Guzmán, Rebeca Almeida Arroba: Estadísticas Económicas Históricas 1948-1983, Fuentes para la Historia Económica del Ecuador, serie estadísticas históricas, vol. 1, Banco Central del Ecuador, 1988, p. 57. 
Tabla 30: Personal ocupado en artesanía (1961-1965):

\begin{tabular}{|l|l|l|l|l|}
\hline Rama actividad & $\mathbf{1 9 6 1}(\mathbf{1})$ & $\mathbf{1 9 6 2}(\mathbf{2})$ & $\mathbf{1 9 6 4 - 1 9 6 5}(\mathbf{3})$ & $\mathbf{1 9 6 5}(\mathbf{4})$ \\
\hline Alimentos & 3.540 & - & 4.383 & 4.742 \\
\hline Bebidas & 0 & - & 365 & 749 \\
\hline Tabaco & 0 & - & 11 & - \\
\hline Textiles & 4.325 & $\begin{array}{l}\text { (incluido en calzado } \\
\text { y vestidos })\end{array}$ & 2.515 & 2.556 \\
\hline $\begin{array}{l}\text { Calzado y } \\
\text { vestidos }\end{array}$ & 40.151 & 46.214 & 19.110 & 20.236 \\
\hline $\begin{array}{l}\text { Madera y } \\
\text { muebles }\end{array}$ & 12.060 & 12.060 & 6.432 & 6.561 \\
\hline Papel y cartón & 0 & - & 30 & 26 \\
\hline $\begin{array}{l}\text { Imprentas } \\
\text { Cuero y piel }\end{array}$ & 1.738 & 525 & 816 & 851 \\
\hline $\begin{array}{l}\text { Ptos caucho y } \\
\text { químicos }\end{array}$ & 790 & y vestidos) & 821 & 805 \\
\hline $\begin{array}{l}\text { Minerales no } \\
\text { metálicos }\end{array}$ & 5.726 & - & 738 & 767 \\
\hline Metal-mecánicas & 10.701 & 2.163 & 1.764 & 1.768 \\
\hline $\begin{array}{l}\text { Manufacturas } \\
\text { diversas }\end{array}$ & 8.445 & 10.701 & 9.137 & 8.192 \\
\hline Total & 88.001 & 93.201 & 2.494 & 2.600 \\
\hline
\end{tabular}

\section{Fuente:}

(1) y (2) Datos tomados de Industria Fabril, p. 23 y de la artesanía, p. 20, JUNAPLA.

(3) Estadísticas y Censos, Directorio 1964 y Censo Industrial, 1965.

(4) Estadísticas y censos, Censo Industrial 1965 con expansión muestra artesanal. 
Tabla 31: Establecimientos grandes y pequeños y Personal ocupado (Resumen nacional, 1965) (miles de sucres):

\begin{tabular}{|c|c|c|}
\hline Rama de actividad & No. establecimientos & Personal ocupado \\
\hline TOTAL & $\mathbf{2 2 . 2 9 5}$ & $\mathbf{8 8 . 5 9 8}$ \\
\hline Ptos alimenticios & 1.665 & 15.202 \\
\hline Industrias bebidas & 215 & 2.716 \\
\hline Industrias de tabaco & - & 258 \\
\hline Fabric. Textiles & 885 & 11.759 \\
\hline Calzado, vestuario & 10.482 & 21.578 \\
\hline Madera y corcho & 1.109 & 3.962 \\
\hline Muebles y accesorios & 2.060 & 5.282 \\
\hline Papel y ptos papel & 22 & 773 \\
\hline Imprentas, editorials & 289 & 2.889 \\
\hline Industrias cuero & 377 & 1.303 \\
\hline Ptos caucho & 215 & 1.120 \\
\hline Ptos químicos & 148 & 2.534 \\
\hline Deriv. petróleo, carbon & - & 1.549 \\
\hline Min. no metálicos & 612 & 3.352 \\
\hline Metales básicos & 20 & 97 \\
\hline Ptos metálicos & 1.268 & 3.669 \\
\hline Maquin. No eléctrica & 124 & 329 \\
\hline Maquin. Eléctrica & 507 & 1.288 \\
\hline Mat. Transporte & 1.192 & 5.369 \\
\hline Ind. diversas & 1.099 & 3.569 \\
\hline
\end{tabular}

Fuente: Junta Nacional del Planificación: Segundo Censo de manufactura-minería, 1965, volumen 1, División de Estadística y Censos, 1965, p. 2. 
Tabla 32: Distribución del sector artesanal por rama de actividad (1965):

\begin{tabular}{|l|l|l|}
\hline Rama de actividad & Establecimientos & Personal ocupado \\
\hline 20. Alimentos & 1.567 & 4.383 \\
\hline 21. Bebidas & 125 & 365 \\
\hline 22.Tabaco & 3 & 11 \\
\hline 23. Textiles & 925 & 2.515 \\
\hline 24. Calzado y vestuario & 10.436 & 19.110 \\
\hline 25. Madera y corcho & 1.095 & 2.320 \\
\hline 26. Muebles & 1.884 & 4.112 \\
\hline 27. Papel y cartón & 15 & 30 \\
\hline 28. Imprentas & 213 & 816 \\
\hline 29. Cuero y piel & 379 & 821 \\
\hline 30. Productos de caucho & 200 & 464 \\
\hline 31. Productos químicos & 88 & 274 \\
\hline 33. Minerales no metálicos & 627 & 1.764 \\
\hline 34. Metálicas básicas & 23 & 48 \\
\hline 35. Productos metálicos & 1.304 & 3.033 \\
\hline 36. Maquinaria no eléctrica & 133 & 398 \\
\hline $\begin{array}{l}\text { 37. Maquinaria y accesorios } \\
\text { eléctricos }\end{array}$ & 539 & 1.087 \\
\hline 38. Material de transporte & 1.410 & 4.571 \\
\hline 39. Manufacturas diversas & 1.199 & 2.494 \\
\hline Total & $\mathbf{2 2 . 1 6 5}$ & $\mathbf{4 8 . 6 1 6}$ \\
\hline
\end{tabular}

Fuente: Estadísticas y censos, Directorio 1964 y Censo Industrial 1965, JUNAPLA. 
Tabla 33: Sector artesanal (hasta 6 personas y 180.000 sucres venta anual) (1965):

\begin{tabular}{|l|l|}
\hline \multicolumn{1}{|c|}{ Rama actividad } & Valor bruto producción (miles sucres) \\
\hline Alimentos & 137.107 \\
\hline Bebidas & 3167 \\
\hline Tabaco & - \\
\hline Textiles & 37.855 \\
\hline Calzado y vestidos & 236.004 \\
\hline Madera y muebles & 103.897 \\
\hline Papel y cartón & 1.842 \\
\hline Imprentas & 15.209 \\
\hline Cuero y piel & 14.978 \\
\hline Ptos caucho y químicos & 15.616 \\
\hline Minerales no metálicos & 23.228 \\
\hline Metálicas básicas & 621 \\
\hline Ptos metálicos & 39.886 \\
\hline Maquinaria no eléctrica & 6.054 \\
\hline Maquinaria eléctrica & 20.071 \\
\hline Material transporte & 116.799 \\
\hline Manufacturas diversas & 40.446 \\
\hline Total & 812.780 \\
\hline
\end{tabular}

Fuente: División de estadística y Censos, Junta Nacional de Planificación, Censo 1965. Elaboración: Unidad de artesanía. 
Tabla 34: Industrias acogidas a la Ley de Fomento Industrial: nuevas y existentes; número de establecimientos por regiones y provincias (número de empresas) (1957-1963):

\begin{tabular}{|c|c|c|c|c|c|c|c|c|c|c|c|c|c|c|}
\hline Provincias & \multicolumn{2}{|c|}{1957} & \multicolumn{2}{|c|}{1958} & \multicolumn{2}{|c|}{1959} & \multicolumn{2}{|c|}{1960} & \multicolumn{2}{|c|}{1961} & \multicolumn{2}{|c|}{1962} & \multicolumn{2}{|c|}{1963} \\
\hline Costa & $\mathrm{N}$ & $\mathrm{E}$ & $\mathrm{N}$ & $\mathrm{E}$ & $\mathrm{N}$ & $\mathrm{E}$ & $\mathrm{N}$ & $\mathrm{E}$ & $\mathrm{N}$ & $E$ & $\mathrm{~N}$ & $\mathrm{E}$ & $\mathrm{N}$ & $\mathrm{E}$ \\
\hline Esmeraldas & 4 & & & & & & & & & & & & 1 & \\
\hline Manabí & & & & & & & & & & & & 1 & & 1 \\
\hline Guayas & & & 2 & 1 & 2 & & 2 & 1 & 2 & 7 & 4 & 8 & 15 & 9 \\
\hline El Oro & & & & & & & & & & & & & 2 & \\
\hline Los Ríos & & & & & & & & & & & & & & \\
\hline Sierra & & & & & & & & & & & & & & \\
\hline Carchi & & & & & & & & & & 1 & & 1 & 1 & \\
\hline Imbabura & & & & & & 1 & 2 & & & & 1 & & 1 & \\
\hline Pichincha & & & 6 & & 2 & 4 & 5 & 4 & 2 & 6 & 7 & 5 & 10 & 12 \\
\hline Cotopaxi & & & & & 1 & & & & 1 & & & & 1 & \\
\hline Tungurahua & & & & & & & & & & & 2 & & & 1 \\
\hline Chimborazo & & & & & & & & & 2 & & & & & \\
\hline Bolívar & & & & & & & & & & & & & & \\
\hline Cañar & & & & & & & & & & & 1 & & 1 & \\
\hline Azuay & & & & & 1 & & & 1 & 1 & & 2 & & 1 & \\
\hline Loja & & & & & 1 & & & & & & 1 & 1 & & \\
\hline & & & & & & & & & & & & & & \\
\hline
\end{tabular}




\begin{tabular}{|c|c|c|c|c|c|c|c|c|c|c|c|c|c|c|}
\hline Oriente & & & & & & & & & & & & & \\
\hline Napo & & & & & & & & & & & & & & \\
\hline Pastaza & & & & & & & & & 1 & & 1 & & & \\
\hline Zamora Ch. & & & & & & & & & & & & & \\
\hline Morona S. & & & & & & & & & & & & & & \\
\hline Archipiélago & & & & & & & & & & & & & & \\
\hline Total & & - & 8 & 1 & 7 & 5 & 9 & 6 & 9 & 14 & 19 & 16 & 33 & 23 \\
\hline
\end{tabular}

*N: Nuevas / E: Existentes

Fuente: Patricio Almeida Guzmán, Rebeca Almeida Arroba: Estadísticas Económicas Históricas 1948-1983, Fuentes para la Historia Económica del Ecuador, serie estadísticas históricas, vol. 1, Banco Central del Ecuador, 1988, p. 137-138. 
Tabla 35: Industrias acogidas a la Ley de Fomento Industrial: nuevas y existentes; número de establecimientos por regiones y provincias (número de empresas) (1964-1970):

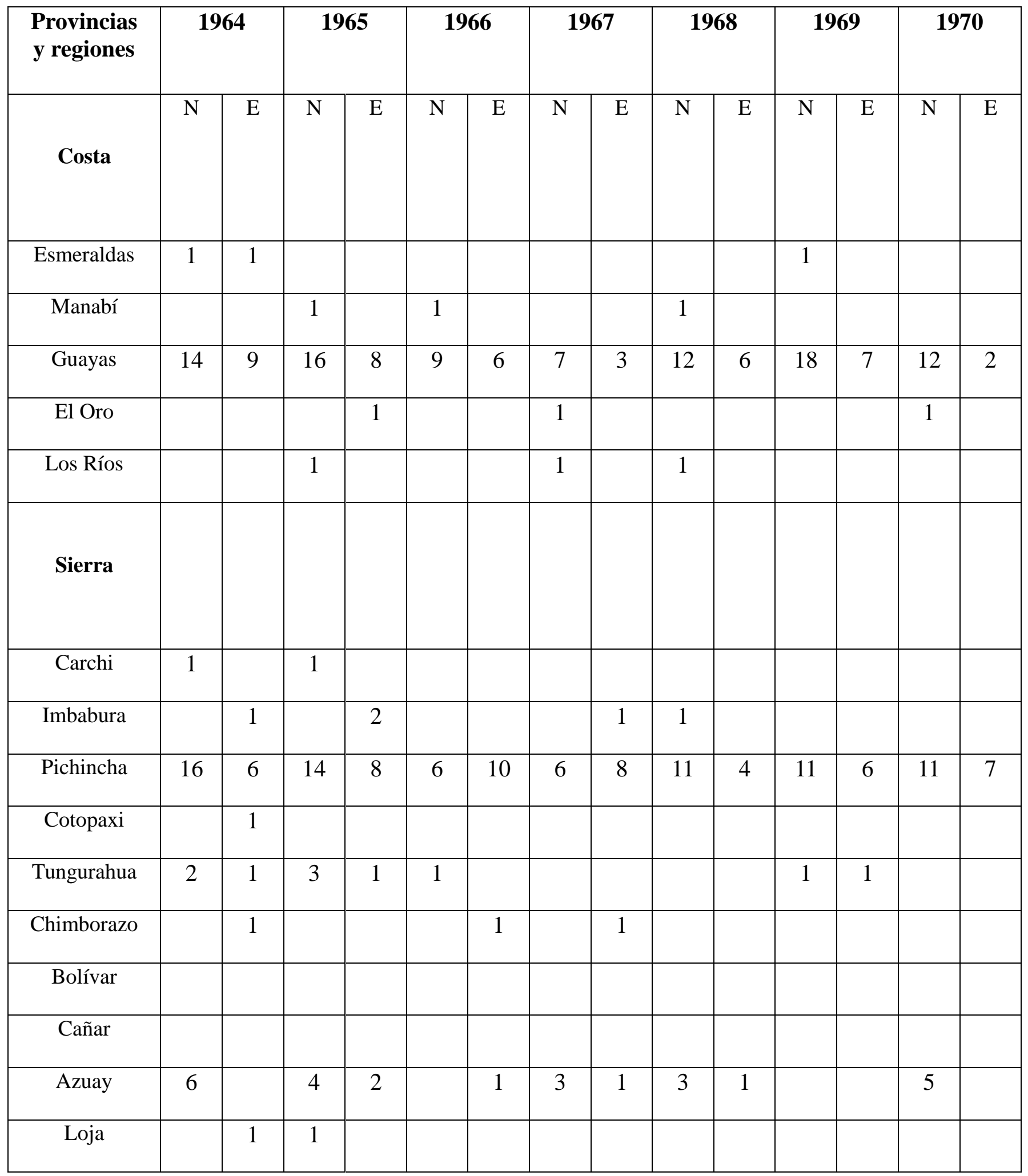




\begin{tabular}{|c|c|c|c|c|c|c|c|c|c|c|c|c|c|c|}
\hline Oriente & & & & & & & & & & & & & & \\
\hline Napo & & & & & & & & & & & & & & \\
\hline Pastaza & & & & & & & & & & & & & & \\
\hline Zamora Ch. & & & & & & & & & & & & & & \\
\hline Morona S. & & & 1 & & & & & & & & & & & \\
\hline Archipiélago & & & & & & & & & & & & & & \\
\hline Total & 40 & 21 & 42 & 22 & 17 & 18 & 18 & 14 & 29 & 11 & 31 & 14 & 29 & 9 \\
\hline
\end{tabular}

$* \mathrm{~N}$ : Nuevas / E: Existentes

Fuente: Patricio Almeida Guzmán, Rebeca Almeida Arroba: Estadísticas Económicas Históricas 1948-1983, Fuentes para la Historia Económica del Ecuador, serie estadísticas históricas, vol. 1, Banco Central del Ecuador, 1988, p. 137-138. 
Tabla 36: Concesiones territoriales para la exploración y explotación de petróleo (en hectáreas) (1966-1970):

\begin{tabular}{|c|c|}
\hline Año & Superficie \\
\hline 1966 & $2.706 .932,96$ \\
\hline 1967 & $3.064 .368,78$ \\
\hline 1968 & $8.592 .911,96$ \\
\hline 1969 & $9.000 .776,40$ \\
\hline 1970 & $9.400 .776,40$ \\
\hline
\end{tabular}

Fuente: Rafael Quintero, Erika Silva: Ecuador: Una nación en ciernes, FLACSO, Abya-Yala, Tomo III, 1991, p. 361.

Tabla 37: Volumen de la producción de petróleo crudo (barriles) (1968-1975):

\begin{tabular}{|c|c|}
\hline Años & Petróleo crudo (barriles) \\
\hline 1968 & $1.815 .083,0$ \\
\hline 1969 & $1.607 .617,9$ \\
\hline 1970 & $1.480 .036,87$ \\
\hline 1971 & $1.354 .389,0$ \\
\hline 1972 & $23.230 .644,0$ \\
\hline 1973 & $76.220 .978,9$ \\
\hline 1974 & $65.134 .180,0$ \\
\hline 1975 & $56.706 .164,0$ \\
\hline
\end{tabular}

Fuente: Patricio Almeida Guzmán, Rebeca Almeida Arroba: Estadísticas Económicas Históricas 1948-1983, Fuentes para la Historia Económica del Ecuador, serie estadísticas históricas, vol. 1, Banco Central del Ecuador, 1988, p. 122. 
Tabla 38: Exportación total por rama de actividad (miles de dólares F.O.B.) (1969-1974):

\begin{tabular}{|c|c|c|c|c|c|c|}
\hline Años & 1969 & 1970 & 1971 & 1972 & 1973 & 1974 \\
\hline $\begin{array}{l}\text { Bienes } \\
\text { Primarios }\end{array}$ & 132.274 & 170.949 & 170.091 & 291.235 & 482.903 & 1.032 .429 \\
\hline \multicolumn{7}{|l|}{ Arroz } \\
\hline $\begin{array}{l}\text { Banano y } \\
\text { plátanos }\end{array}$ & 68.175 & 83.299 & 88.157 & 130.991 & 74.126 & 126.723 \\
\hline $\begin{array}{l}\text { Cacao en } \\
\text { grano }\end{array}$ & 24.240 & 22.182 & 24.332 & 23.628 & 26.016 & 102.613 \\
\hline $\begin{array}{l}\text { Café en } \\
\text { grano }\end{array}$ & 26.045 & 50.002 & 36.100 & 46.990 & 65.427 & 67.756 \\
\hline Higuerilla & 1.732 & 1.659 & 1.774 & 3.694 & 7.746 & 5.617 \\
\hline $\begin{array}{l}\text { Otros ptos } \\
\text { agrícolas }\end{array}$ & 1.123 & 2.278 & 2.196 & 3.262 & 3.767 & 4.252 \\
\hline Balsa & 3.342 & 2.869 & 3.214 & 3.809 & 4.827 & 6.283 \\
\hline $\begin{array}{l}\text { Otras } \\
\text { maderas }\end{array}$ & 26 & 31 & 123 & 792 & 582 & 874 \\
\hline Pecuarios & 1.391 & 2.702 & 1.581 & 307 & 178 & 116 \\
\hline $\begin{array}{l}\text { Atún y } \\
\text { pescado }\end{array}$ & 2.053 & 2.274 & 5.100 & 2.365 & 5.063 & 5.556 \\
\hline Camarones & 2.688 & 1.706 & 4.363 & 13.024 & 9.172 & 11.390 \\
\hline $\begin{array}{l}\text { Langosta y } \\
\text { otros }\end{array}$ & 93 & 66 & 121 & 923 & 764 & 1.615 \\
\hline $\begin{array}{l}\text { Petróleo } \\
\text { crudo }\end{array}$ & 615 & 834 & 1.154 & 59.452 & 282.057 & 692.769 \\
\hline $\begin{array}{l}\text { Otros ptos } \\
\text { mineros }\end{array}$ & 751 & 1.047 & 1.254 & 1.077 & 1.490 & 1.724 \\
\hline \multicolumn{7}{|l|}{$\begin{array}{l}\text { Tierra } \\
\text { mineral }\end{array}$} \\
\hline \multicolumn{7}{|l|}{$\begin{array}{l}\text { Lana de } \\
\text { ceibo }\end{array}$} \\
\hline \multicolumn{7}{|l|}{ Caucho } \\
\hline Tagua & & & & & & \\
\hline & & & & & & \\
\hline
\end{tabular}

Exportación total por rama de actividad (miles de dólares F.O.B.) (1969-1974) (continuación)

\begin{tabular}{|l|l|l|l|l|l|l|}
\hline Años & $\mathbf{1 9 6 9}$ & $\mathbf{1 9 7 0}$ & $\mathbf{1 9 7 1}$ & $\mathbf{1 9 7 2}$ & $\mathbf{1 9 7 3}$ & $\mathbf{1 9 7 4}$ \\
\hline $\begin{array}{l}\text { Bienes } \\
\text { secundarios }\end{array}$ & 20.077 & 18.609 & 28.708 & 34.711 & 48.411 & 90.829 \\
\hline $\begin{array}{l}\text { Químicos y } \\
\text { farmacéuticos }\end{array}$ & 2.001 & 1.457 & 1.881 & 2.146 & 4.179 & 3.828 \\
\hline Azúcar & 10.373 & 8.036 & 13.216 & 14.240 & 12.461 & 21.709 \\
\hline
\end{tabular}




\begin{tabular}{|c|c|c|c|c|c|c|}
\hline $\begin{array}{l}\text { Melazas y } \\
\text { panelas }\end{array}$ & & & 601 & 290 & 1.591 & 2.041 \\
\hline $\begin{array}{l}\text { Café } \\
\text { industrializado }\end{array}$ & & & 0 & 592 & 739 & 1.074 \\
\hline Elab. Cacao & 2.018 & 2.642 & 4.471 & 6.486 & 8.801 & 23.617 \\
\hline Elab. Banana & & & 6 & 4 & 2 & 0 \\
\hline Elab. Ptos mar & 1.411 & 1.468 & 2.584 & 2.097 & 6.138 & 8.067 \\
\hline $\begin{array}{l}\text { Otros ptos } \\
\text { alimenticios }\end{array}$ & 1.211 & 1.762 & 1.205 & 1.849 & 3.459 & 3.469 \\
\hline $\begin{array}{l}\text { Alimento para } \\
\text { animals }\end{array}$ & 11 & 76 & 14 & 63 & 821 & 4.487 \\
\hline $\begin{array}{l}\text { Extracto de } \\
\text { piretro }\end{array}$ & & & 677 & 572 & 766 & 700 \\
\hline $\begin{array}{l}\text { Madera } \\
\text { terciaria } \\
\text { prensada }\end{array}$ & & & 219 & 474 & & 805 \\
\hline $\begin{array}{l}\text { Deriv. } \\
\text { petróleo }\end{array}$ & & 101 & 889 & 448 & 689 & 3.951 \\
\hline $\begin{array}{l}\text { Manuf. } \\
\text { Metales }\end{array}$ & & & 153 & 562 & 629 & 789 \\
\hline $\begin{array}{l}\text { Art. } \\
\text { Electrodom. }\end{array}$ & & & 160 & 641 & 550 & 3.479 \\
\hline $\begin{array}{l}\text { Somb. Paja } \\
\text { toq. Y mocora }\end{array}$ & 1.085 & 1.314 & 829 & 1.983 & 2.830 & 4.966 \\
\hline $\begin{array}{l}\text { Art. Fibras } \\
\text { textiles }\end{array}$ & 3 & 41 & 197 & 531 & 2.437 & 2.953 \\
\hline $\begin{array}{l}\text { Manuf. Cuero } \\
\text { y plastic }\end{array}$ & 12 & 5 & 3 & 8 & 932 & 1.641 \\
\hline \multicolumn{7}{|l|}{ Cerámica } \\
\hline \multicolumn{7}{|l|}{$\begin{array}{l}\text { Velas } \\
\text { esteáricas }\end{array}$} \\
\hline Otros & 1.952 & 1.707 & 603 & 1.725 & 1.387 & 3.253 \\
\hline Otros bienes & 176 & 371 & 276 & 346 & 734 & 290 \\
\hline Total general & 152.527 & 189.929 & 199.075 & 326.292 & 532.048 & 1.123 .548 \\
\hline
\end{tabular}

Fuente: Patricio Almeida Guzmán, Rebeca Almeida Arroba: Estadísticas Económicas Históricas 1948-1983, Fuentes para la Historia Económica del Ecuador, serie estadísticas históricas, vol. 1, Banco Central del Ecuador, 1988, p. 475. 
Tabla 39: Valor de las exportaciones de productos primarios principales (miles de dólares FOB) (1965-1975):

\begin{tabular}{|c|c|c|c|c|}
\hline Años & Cacao & Café & Banano & Petróleo \\
\hline 1965 & 19.100 & 38.200 & 51.000 & 2.140 \\
\hline 1966 & 17.200 & 32.100 & 68.700 & - \\
\hline 1967 & 24.900 & 39.800 & 73.100 & - \\
\hline 1968 & 38.900 & 34.200 & 73.600 & 1.079 \\
\hline 1969 & 24.500 & 26.600 & 66.700 & 615 \\
\hline 1970 & 22.200 & 50.000 & 83.300 & 834 \\
\hline 1971 & 24.300 & 36.100 & 88.157 & 1.154 \\
\hline 1972 & 23.628 & 46.990 & 130.991 & 59.452 \\
\hline 1973 & 26.016 & 65.427 & 74.126 & 282.057 \\
\hline 1974 & 102.613 & 67.756 & 124.723 & 692.769 \\
\hline 1975 & 41.766 & 65.532 & 138.652 & 587.118 \\
\hline
\end{tabular}

Fuente: Patricio Almeida Guzmán, Rebeca Almeida Arroba: Estadísticas Económicas Históricas 1948-1983, Fuentes para la Historia Económica del Ecuador, serie estadísticas históricas, vol. 1, Banco Central del Ecuador, 1988, p. 482.

Tabla 40: Valor de las exportaciones de productos secundarios principales (miles de dólares FOB) (1965-1975):

\begin{tabular}{|l|l|l|l|l|l|l|}
\hline Años & Sombreros & Farmacéuticos & Azúcar & $\begin{array}{l}\text { Elaborados } \\
\text { De cacao }\end{array}$ & Elab. Ptos & $\begin{array}{l}\text { Derivados } \\
\text { petróleo }\end{array}$ \\
\hline 1965 & 689,0 & $1.564,8$ & 7.300 & 355 & 1.224 & \\
\hline 1966 & 425,0 & $1.709,2$ & 8.500 & 1.494 & 1.060 & \\
\hline 1967 & 563,0 & $1.456,8$ & 7.500 & 1.547 & 1.428 & \\
\hline 1968 & 954,0 & $1.518,2$ & 7.100 & 2.528 & 1.208 & \\
\hline 1969 & $1.085,0$ & $1.976,0$ & 10.300 & 2.018 & 1.411 & \\
\hline 1970 & $1.314,0$ & $1.457,0$ & 8.000 & 2.642 & 1.468 & 101 \\
\hline 1971 & 829,0 & $1.881,0$ & 13.216 & 4.471 & 3.584 & 889 \\
\hline 1972 & $1.983,0$ & $2.146,0$ & 14.240 & 6.486 & 3.097 & 448 \\
\hline 1973 & $2.830,0$ & $4.179,0$ & 12.416 & 8.801 & 6.138 & 689 \\
\hline 1974 & $4.966,0$ & $3.828,0$ & 21.709 & 23.617 & 8.067 & 3.951 \\
\hline 1975 & $6.782,0$ & $2.988,0$ & 23.636 & 29.782 & 6.873 & 890 \\
\hline & & & & & & \\
\hline
\end{tabular}

Fuente: Patricio Almeida Guzmán, Rebeca Almeida Arroba: Estadísticas Económicas Históricas 1948-1983, Fuentes para la Historia Económica del Ecuador, serie estadísticas históricas, vol. 1, Banco Central del Ecuador, 1988, p. 484. 
Tabla 41: Producto interno bruto por clase de actividad económica (millones de sucres corrientes) (1970-1974):

\begin{tabular}{|c|c|c|c|c|c|}
\hline & 1970 & 1971 & 1972 & 1973 & 1974 \\
\hline $\begin{array}{l}\text { 1.Agricultura, } \\
\text { caza, } \\
\text { silvicultura y } \\
\text { pesca }\end{array}$ & 8.386 & 9.180 & 10.535 & 12.241 & 17.377 \\
\hline $\begin{array}{l}\text { Banano, café, } \\
\text { cacao }\end{array}$ & 2.222 & 2.504 & 2.866 & 3.030 & 4.563 \\
\hline $\begin{array}{l}\text { Otras } \\
\text { producciones } \\
\text { agrícolas }\end{array}$ & 3.161 & 3.201 & 3.577 & 4.559 & 6.367 \\
\hline $\begin{array}{l}\text { Producción } \\
\text { animal }\end{array}$ & 2.519 & 2.783 & 3.207 & 3.572 & 4.983 \\
\hline $\begin{array}{l}\text { Silvícolas, tala y } \\
\text { corta }\end{array}$ & 286 & 346 & 426 & 535 & 801 \\
\hline Pesca y caza & 198 & 346 & 459 & 545 & 663 \\
\hline $\begin{array}{l}\text { 2.Petróleo y } \\
\text { otras minas }\end{array}$ & 543 & 622 & 1.543 & 6.172 & 16.320 \\
\hline 2a.Petróleo & 457 & 514 & 1.430 & 5.982 & 16.064 \\
\hline $\begin{array}{l}\text { Petróleo crudo y } \\
\text { gas natural }\end{array}$ & -12 & -45 & 824 & 5.821 & 21.373 \\
\hline $\begin{array}{l}\text { Refinación de } \\
\text { petróleo }\end{array}$ & 469 & 559 & 606 & 101 & -5.309 \\
\hline $\begin{array}{l}\text { 2b.Otras } \\
\text { producciones } \\
\text { minería }\end{array}$ & 86 & 108 & 113 & 190 & 256 \\
\hline $\begin{array}{l}\text { Otras } \\
\text { producciones } \\
\text { minería }\end{array}$ & 86 & 108 & & 190 & 256 \\
\hline $\begin{array}{l}\text { 3.Industrias } \\
\text { manufactureras } \\
\text { (excluye } \\
\text { refinación } \\
\text { petróleo) }\end{array}$ & 6.372 & 7.546 & 8.763 & 10.828 & 14.292 \\
\hline $\begin{array}{l}\text { 3.1Ptos } \\
\text { alimenticios, } \\
\text { bebidas, tabaco }\end{array}$ & 3.289 & 3.736 & 4.203 & 4.989 & 6.551 \\
\hline $\begin{array}{l}\text { Carnes, pescado } \\
\text { elaborado }\end{array}$ & 464 & 570 & 659 & 818 & 1.170 \\
\hline $\begin{array}{l}\text { Cereales y } \\
\text { panadería }\end{array}$ & 531 & 559 & 648 & 619 & 728 \\
\hline Azúcar & 477 & 661 & 618 & 693 & 1.318 \\
\hline $\begin{array}{l}\text { Ptos alimenticios } \\
\text { diversos }\end{array}$ & 959 & 971 & 1.131 & 1.572 & 1.847 \\
\hline Bebidas & 762 & 864 & 1.043 & 1.169 & 1.319 \\
\hline $\begin{array}{l}\text { Tabaco } \\
\text { elaborado }\end{array}$ & 96 & 111 & 104 & 118 & 169 \\
\hline $\begin{array}{l}3.2 \text { Textiles, } \\
\text { prendas vestir, } \\
\text { industria cuero }\end{array}$ & 1.127 & 1.425 & 1.816 & 2.216 & 2.838 \\
\hline
\end{tabular}




\begin{tabular}{|c|c|c|c|c|c|}
\hline $\begin{array}{l}\text { 3.3 Industria } \\
\text { Madera, ptos } \\
\text { madera y } \\
\text { muebles }\end{array}$ & 293 & 352 & 478 & 614 & 953 \\
\hline Madera & 293 & 352 & 478 & 614 & 953 \\
\hline $\begin{array}{l}\text { 3.4 Fabric. } \\
\text { papel, } \\
\text { imprentas y } \\
\text { editoriales }\end{array}$ & 378 & 446 & 504 & 589 & 767 \\
\hline $\begin{array}{l}\text { Papel e } \\
\text { imprentas }\end{array}$ & 378 & 446 & 504 & 589 & 767 \\
\hline $\begin{array}{l}\text { 3.5Ptos } \\
\text { químicos del } \\
\text { carbón y } \\
\text { plásticos }\end{array}$ & 553 & 704 & 644 & 868 & 974 \\
\hline $\begin{array}{l}\text { Químico y del } \\
\text { caucho }\end{array}$ & 553 & 704 & 644 & 868 & 974 \\
\hline $\begin{array}{l}\text { 3.6 y } 3.7 \text { Ptos } \\
\text { minerales no } \\
\text { metálicos e } \\
\text { industrias } \\
\text { metálicas } \\
\text { básicas }\end{array}$ & 552 & 663 & 839 & 1.029 & 1.485 \\
\hline $\begin{array}{l}\text { Minerales } \\
\text { básicos, } \\
\text { metálicos y no } \\
\text { metálicos }\end{array}$ & 552 & 663 & 839 & 1.029 & 1.485 \\
\hline $\begin{array}{l}\text { 3.8 Ptos } \\
\text { metálicos, } \\
\text { metálicos y no } \\
\text { metálicos }\end{array}$ & 180 & 220 & 279 & 523 & 724 \\
\hline $\begin{array}{l}\text { Maquinarias, } \\
\text { equipo y } \\
\text { material } \\
\text { transporte }\end{array}$ & 180 & 220 & 279 & 523 & 724 \\
\hline \multicolumn{6}{|l|}{$\begin{array}{l}3.9 \text { Otras } \\
\text { industrias } \\
\text { manufactureras }\end{array}$} \\
\hline $\begin{array}{l}\text { Otras industrias } \\
\text { manufactureras }\end{array}$ & & & & & \\
\hline
\end{tabular}

Fuente: Patricio Almeida Guzmán, Rebeca Almeida Arroba: Estadísticas Económicas Históricas 1948-1983, Fuentes para la Historia Económica del Ecuador, serie estadísticas históricas, vol. 1, Banco Central del Ecuador, 1988, p. 57. 
Tabla 42: Tasas de cambio nominales y reales e indicadores de comercio exterior (1975-1983):

\begin{tabular}{|l|c|c|c|c|c|c|c|c|}
\hline Años & $\begin{array}{c}\text { (1)Tipo } \\
\text { cambio } \\
\text { nominal } \\
\text { (s/. por } \\
\text { dólar) }\end{array}$ & $\begin{array}{c}\text { (2)Tipo } \\
\text { cambio } \\
\text { real } \\
\text { similado }\end{array}$ & $\begin{array}{c}\text { (3) Indice } \\
\text { Vol.export. }\end{array}$ & $\begin{array}{c}\text { (4)Indice } \\
\text { Vol. } \\
\text { Import. }\end{array}$ & $\begin{array}{c}\text { (5)Indice } \\
\text { precios } \\
\text { Exportac. }\end{array}$ & $\begin{array}{c}\text { (6)Indice } \\
\text { Precios } \\
\text { Import. }\end{array}$ & $\begin{array}{c}\text { (7)Términos } \\
\text { Intercambio } \\
\text { (5)/(6). }\end{array}$ & $\begin{array}{c}\text { (8)Indice } \\
\text { tipo } \\
\text { cambio } \\
\text { fficial }\end{array}$ \\
\hline 1975 & 25,0 & 25,0 & 100 & 100 & 100 & 100,0 & 100 & 100 \\
\hline 1976 & 25,0 & 22,4 & 108,5 & 97,0 & 111,6 & 105,4 & 105,9 & 100 \\
\hline 1977 & 25,0 & 22,0 & 103,0 & 114,1 & 142,0 & 115,3 & 123,2 & 100 \\
\hline 1978 & 25,0 & 20,3 & 106,3 & 117,9 & 136,0 & 124,3 & 109,4 & 100 \\
\hline 1979 & 25,0 & 20,6 & 111,7 & 117,8 & 192,2 & 143,0 & 134,4 & 100 \\
\hline
\end{tabular}

\begin{tabular}{|l|l|l|l|l|l|}
\hline Años & $\begin{array}{l}\text { (9)Indice } \\
\text { Precios } \\
\text { intercambio } \\
\text { Exportación } \\
\mathbf{( 5 ) * ( 8 )}\end{array}$ & $\begin{array}{l}\text { (10)Indice } \\
\text { Precios } \\
\text { Intercambio } \\
\text { Importación } \\
\mathbf{( 6 ) * ( 8 )}\end{array}$ & $\begin{array}{l}\text { (11)Indice } \\
\text { Precios } \\
\text { Al por } \\
\text { mayor }\end{array}$ & $\begin{array}{l}\text { (12)Precios } \\
\text { Relativos } \\
\text { Exportación } \\
\mathbf{( 9 ) / ( 1 1 )}\end{array}$ & $\begin{array}{l}\text { (13)Precios } \\
\text { relativos } \\
\text { importación } \\
(\mathbf{1 0}) /(11)\end{array}$ \\
\hline 1975 & 100 & 100 & 100 & 100 & 100 \\
\hline 1976 & 111,6 & 105,4 & 116,7 & 95,6 & 90,3 \\
\hline 1977 & 142 & 115,3 & 126,2 & 112,5 & 102,5 \\
\hline 1978 & 136,0 & 124,3 & 147,4 & 92,2 & 84,3 \\
\hline 1979 & 192,2 & 143,0 & 163,2 & 117,8 & 87,6 \\
\hline
\end{tabular}

Fuente: Banco Central, Boletines Anuarios; Banco Central, Cuentas Nacionales; IMP, International Financial Statistics. 
Tabla 43: Importaciones por principales grupos de mercancías (miles dólares C.I.F) (19691974):

\begin{tabular}{|c|c|c|c|c|c|c|}
\hline & 1969 & 1970 & 1971 & 1972 & 1973 & 1974 \\
\hline $\begin{array}{l}\text { Bienes } \\
\text { consumo no } \\
\text { duradero }\end{array}$ & 23.762 & 22.289 & 24.629 & 30.057 & 37.589 & 50.014 \\
\hline $\begin{array}{l}\text { Ptos } \\
\text { alimenticios }\end{array}$ & 4.256 & 3.636 & 3.182 & 3.894 & 4.706 & 7.343 \\
\hline Bebidas & 284 & 273 & 786 & 2.341 & 3.807 & 4.873 \\
\hline Tabaco & 1.025 & 602 & 2.499 & 1.386 & 218 & 468 \\
\hline $\begin{array}{l}\text { Farmac. Y de } \\
\text { tocador }\end{array}$ & 14.766 & 14.606 & 14.949 & 17.049 & 20.248 & 25.092 \\
\hline $\begin{array}{l}\text { Vestuar. Y } \\
\text { otras confecc. }\end{array}$ & 644 & 766 & 471 & 413 & 563 & 1.569 \\
\hline Otros & 2.767 & 2.403 & 2.742 & 4.974 & 8.047 & 10.669 \\
\hline $\begin{array}{l}\text { Bienes } \\
\text { consumo } \\
\text { duradero } \\
\end{array}$ & 11.294 & 13.902 & 13.605 & 16.171 & 26.476 & 51.691 \\
\hline $\begin{array}{l}\text { Utensil. } \\
\text { Domésticos }\end{array}$ & 2.659 & 2.336 & 2.382 & 1.969 & 3.105 & 3.309 \\
\hline $\begin{array}{l}\text { Obj. adorno y } \\
\text { musicales }\end{array}$ & 881 & 1.334 & 2.218 & 1.711 & 2.410 & 5.542 \\
\hline $\begin{array}{l}\text { Mueblas y } \\
\text { equipo hogar }\end{array}$ & 894 & 1.207 & 1.077 & 1.297 & 1.895 & 2.649 \\
\hline $\begin{array}{l}\text { Apartos uso } \\
\text { domestic }\end{array}$ & 4.705 & 4.799 & 4.515 & 6.420 & 9.335 & 14.621 \\
\hline $\begin{array}{l}\text { Vehíc. Transp. } \\
\text { Particular }\end{array}$ & 2.122 & 4.231 & 3.389 & 4.697 & 9.726 & 25.564 \\
\hline Otros & 33 & 2 & 24 & 77 & 4 & 6 \\
\hline $\begin{array}{l}\text { Combustibles, } \\
\text { lubric. Y } \\
\text { conexos }\end{array}$ & 15.894 & 17.193 & 27.688 & 10.602 & 11.183 & 29.894 \\
\hline Combustibles & 14.007 & 15.195 & 25.586 & 8.529 & 8.394 & 25.951 \\
\hline Lubricantes & 1.887 & 1.998 & 2.102 & 2.073 & 2.789 & 3.943 \\
\hline $\begin{array}{l}\text { Mat. Primas } \\
\text { para } \\
\text { agricultura }\end{array}$ & 5.078 & 5.552 & 3.695 & 4.557 & 5.746 & 26.024 \\
\hline $\begin{array}{l}\text { Alim. para } \\
\text { animales }\end{array}$ & 138 & 60 & 72 & 97 & 61 & 105 \\
\hline $\begin{array}{l}\text { Otras mat. } \\
\text { Primas }\end{array}$ & 4.940 & 5.492 & 3.623 & 4.460 & 5.685 & 25.919 \\
\hline $\begin{array}{l}\text { Mat. Primas } \\
\text { para } \\
\text { industria }\end{array}$ & 96.110 & 116.084 & 118.163 & 105.595 & 149.349 & 254.025 \\
\hline $\begin{array}{l}\text { Ptos } \\
\text { alimenticios }\end{array}$ & 10.326 & 10.917 & 11.109 & 17.812 & 25.525 & 43.592 \\
\hline $\begin{array}{l}\text { Agropec. No } \\
\text { alimenticios }\end{array}$ & 37.163 & 41.212 & 36.390 & 22.502 & 30.910 & 44.113 \\
\hline Mineros & 25.956 & 30.507 & 36.960 & 32.546 & 45.734 & 85.439 \\
\hline Químicos & 22.665 & 33.448 & 33.704 & 32.735 & 47.180 & 80.881 \\
\hline Materiales de & 13.133 & 15.434 & 36.734 & 24.890 & 18.734 & 30.435 \\
\hline
\end{tabular}




\begin{tabular}{|c|c|c|c|c|c|c|}
\hline construcción & & & & & & \\
\hline $\begin{array}{l}\text { Bienes capital } \\
\text { para } \\
\text { agricultura }\end{array}$ & 6.172 & 7.557 & 6.670 & 4.370 & 5.695 & 13.940 \\
\hline $\begin{array}{l}\text { Maq. Y } \\
\text { herramientas }\end{array}$ & 2.016 & 2.817 & 1.794 & 1.979 & 2.677 & 5.026 \\
\hline Otro equipo & 476 & 436 & 485 & 517 & 264 & 51 \\
\hline $\begin{array}{l}\text { Mat. } \\
\text { Transporte y } \\
\text { tracción }\end{array}$ & 3.680 & 4.304 & 4.391 & 1.874 & 2.754 & 8.863 \\
\hline $\begin{array}{l}\text { Bienes capital } \\
\text { para la } \\
\text { industria }\end{array}$ & 37.491 & 41.904 & 63.120 & 76.316 & 83.992 & 122.968 \\
\hline $\begin{array}{l}\text { Aparatos para } \\
\text { oficina }\end{array}$ & 4.502 & 4.660 & 5.641 & 9.585 & 11.369 & 12.307 \\
\hline Herramientas & 1.614 & 2.080 & 3.505 & 2.353 & 3.285 & 5.454 \\
\hline $\begin{array}{l}\text { Partes y } \\
\text { accesorios } \\
\text { para maquin. }\end{array}$ & 5.441 & 6.056 & 4.460 & 5.794 & 7.949 & 22.595 \\
\hline $\begin{array}{l}\text { Maquin. } \\
\text { Industrial }\end{array}$ & 21.252 & 24.852 & 44.654 & 48.654 & 53.336 & 70.313 \\
\hline $\begin{array}{l}\text { Otro equipo } \\
\text { fijo }\end{array}$ & 4.682 & 4.256 & 4.860 & 9.930 & 8.053 & 12.299 \\
\hline $\begin{array}{l}\text { Equipos de } \\
\text { transporte }\end{array}$ & 32.262 & 32.586 & 44.559 & 45.001 & 58.169 & 97.972 \\
\hline $\begin{array}{l}\text { Partes y } \\
\text { accesorios }\end{array}$ & 13.325 & 13.683 & 15.460 & 18.326 & 20.699 & 29.371 \\
\hline $\begin{array}{l}\text { Equipo } \\
\text { rodante de } \\
\text { transporte }\end{array}$ & 18.739 & 18.726 & 29.014 & 23.994 & 34.401 & 68.438 \\
\hline $\begin{array}{l}\text { Equipo fijo de } \\
\text { transporte }\end{array}$ & 198 & 177 & 85 & 2.681 & 3.069 & 163 \\
\hline Diversos & 632 & 1.341 & 1.241 & 1.040 & 350 & 1.239 \\
\hline Total & 241.838 & 273.849 & 340.104 & 318.599 & 397.282 & 678.202 \\
\hline
\end{tabular}

Fuente: Patricio Almeida Guzmán, Rebeca Almeida Arroba: Estadísticas Económicas Históricas 1948-1983, Fuentes para la Historia Económica del Ecuador, serie estadísticas históricas, vol. 1, Banco Central del Ecuador, 1988, p. 496. 
Tabla 44: Deuda externa directa a final de año (millones de dólares) (1969-1976):

\begin{tabular}{|c|c|}
\hline Año & Capital adeudado a fin de año \\
\hline 1969 & 202,9 \\
\hline 1970 & 229,3 \\
\hline 1971 & 248,0 \\
\hline 1972 & 324,6 \\
\hline 1973 & 366,2 \\
\hline 1974 & 377,2 \\
\hline 1975 & 456,5 \\
\hline 1976 & 635,8 \\
\hline
\end{tabular}

Fuente: Patricio Almeida Guzmán, Rebeca Almeida Arroba: Estadísticas Económicas Históricas 1948-1983, Fuentes para la Historia Económica del Ecuador, serie estadísticas históricas, vol. 1, Banco Central del Ecuador, 1988, p. 463. 
Tabla 45: Producto Interior Bruto (millones de sucres) (1968-1975):

\begin{tabular}{|c|c|c|}
\hline Año & PIB (valores corrientes) & $\begin{array}{c}\text { PIB (Valores Constantes } \\
\mathbf{1 9 7 0 = 1 0 0})\end{array}$ \\
\hline 1968 & 27.830 & 30.318 \\
\hline 1969 & 31.173 & 33.186 \\
\hline 1970 & 37.064 & 37.064 \\
\hline 1971 & 40.569 & 38.178 \\
\hline 1972 & 46.859 & 38.539 \\
\hline 1973 & 62.229 & 40.837 \\
\hline 1974 & 92.763 & 57.189 \\
\hline 1975 & 107.740 & 62.912 \\
\hline
\end{tabular}

Fuente: Patricio Almeida Guzmán, Rebeca Almeida Arroba: Estadísticas Económicas Históricas 1948-1983, Fuentes para la Historia Económica del Ecuador, serie estadísticas históricas, vol. 1, Banco Central del Ecuador, 1988, p. 51. 
Tabla 46: Valor Inversión extranjera autorizada, por actividad económica según el CIIU (sucres) (1972-1975):

\begin{tabular}{|c|c|c|c|c|}
\hline $\begin{array}{l}\text { Ramas de } \\
\text { actividad }\end{array}$ & 1972 & 1973 & 1974 & 1975 \\
\hline $\begin{array}{l}\text { Agricultura, silv., } \\
\text { caza y pesca }\end{array}$ & 580.000 & 15.747 .766 & 8.279 .141 & 33.775 .667 \\
\hline $\begin{array}{l}\text { Explotación, } \\
\text { minas y canteras }\end{array}$ & 865.081 & 8.543 .727 & 45.390 .388 & 31.823 .322 \\
\hline $\begin{array}{l}\text { Industria } \\
\text { manufactureras }\end{array}$ & 88.699.704 & 588.124 .110 & 384.787 .545 & 754.664.425 \\
\hline $\begin{array}{l}\text { Electricidad, gas } \\
\text { y agua }\end{array}$ & 564.000 & 4.893 .280 & 27.885 .292 & 0 \\
\hline Construcción & 3.804 .697 & 745.050 & 15.739 .202 & 9.639 .000 \\
\hline $\begin{array}{l}\text { Comercio, } \\
\text { restaur., hoteles }\end{array}$ & 8.128 .112 & 44.055 .735 & 132.609 .798 & 68.020 .900 \\
\hline $\begin{array}{l}\text { Transporte, } \\
\text { almacen. y } \\
\text { comunic. }\end{array}$ & 4.745 .455 & 728.221 & 1.446 .000 & 2.626 .000 \\
\hline $\begin{array}{l}\text { Establec. } \\
\text { Financieros, } \\
\text { seguros }\end{array}$ & 19.234 .000 & 119.296 .343 & 16.858 .532 & 65.935 .280 \\
\hline $\begin{array}{l}\text { Serv. } \\
\text { Comunales, } \\
\text { sociales y } \\
\text { personales }\end{array}$ & 202.020 & 3.857 .000 & 5.240 .000 & 100.000 \\
\hline $\begin{array}{l}\text { Inversión sin } \\
\text { derecho a giro }\end{array}$ & 0 & 22.553 .213 & 28.742 .049 & 10.050 .000 \\
\hline Inversión neutral & 0 & 0 & 0 & 0 \\
\hline $\begin{array}{l}\text { Transferencia en } \\
\text { acciones }\end{array}$ & - & - & - & - \\
\hline $\begin{array}{l}\text { Activid sin } \\
\text { especificar }\end{array}$ & - & - & - & - \\
\hline Total & 126.823 .069 & 808.545 .445 & 666.977 .947 & 976.634 .594 \\
\hline
\end{tabular}

Fuente: Patricio Almeida Guzmán, Rebeca Almeida Arroba: Estadísticas Económicas Históricas 1948-1983, Fuentes para la Historia Económica del Ecuador, serie estadísticas históricas, vol. 1, Banco Central del Ecuador, 1988, p. 280. 
Tabla 47: Valor Inversión extranjera autorizada, por actividad económica según el CIIU (sucres) (1976-1979):

\begin{tabular}{|c|c|c|c|c|}
\hline $\begin{array}{l}\text { Ramas de } \\
\text { actividad }\end{array}$ & 1976 & 1977 & 1978 & 1979 \\
\hline $\begin{array}{l}\text { Agricultura, silv., } \\
\text { caza y pesca }\end{array}$ & 93.640 .000 & 106.600 .080 & 116.456 .000 & 130.123 .000 \\
\hline $\begin{array}{l}\text { Explotación, } \\
\text { minas y canteras }\end{array}$ & 36.85 .000 & 2.795 .000 & 23.353 .500 & 46.607 .950 \\
\hline $\begin{array}{l}\text { Industria } \\
\text { manufactureras }\end{array}$ & 1.026 .160 .551 & 821.706.497 & 1.300 .047 .098 & 1.060.531.034 \\
\hline $\begin{array}{l}\text { Electricidad, gas } \\
\text { y agua }\end{array}$ & 200.000 & 200.000 & 827.000 & 67.763 .000 \\
\hline Construcción & 51.922 .500 & 18.639 .800 & 14.620 .000 & 14.347 .000 \\
\hline $\begin{array}{l}\text { Comercio, } \\
\text { restaur., hoteles }\end{array}$ & 213.546 .034 & 231.242 .029 & 99.235 .266 & 327.918 .100 \\
\hline $\begin{array}{l}\text { Transporte, } \\
\text { almacen. y } \\
\text { comunic. }\end{array}$ & 16.001 .000 & 8.369 .100 & 9.585 .000 & 13.110 .000 \\
\hline $\begin{array}{l}\text { Establec. } \\
\text { Financieros, } \\
\text { seguros }\end{array}$ & 327.033 .783 & 308.333 .961 & 444.939 .332 & 271.929 .825 \\
\hline $\begin{array}{l}\text { Serv. } \\
\text { Comunales, } \\
\text { sociales y } \\
\text { personales }\end{array}$ & 44.235 .000 & 2.753 .500 & 3.404 .000 & 600.000 \\
\hline $\begin{array}{l}\text { Inversión sin } \\
\text { derecho a giro }\end{array}$ & 37.442 .700 & 117.071 .700 & 38.419 .717 & 71.351 .203 \\
\hline Inversión neutral & 0 & 0 & 0 & 129.322 .000 \\
\hline $\begin{array}{l}\text { Transferencia en } \\
\text { acciones }\end{array}$ & - & - & - & 196.357 .770 \\
\hline $\begin{array}{l}\text { Activid sin } \\
\text { especificar }\end{array}$ & - & - & - & - \\
\hline Total & 1.846 .996 .568 & 1.617 .712 .267 & 2.050 .886 .913 & 2.329 .960 .882 \\
\hline
\end{tabular}

Fuente: Patricio Almeida Guzmán, Rebeca Almeida Arroba: Estadísticas Económicas Históricas 1948-1983, Fuentes para la Historia Económica del Ecuador, serie estadísticas históricas, vol. 1, Banco Central del Ecuador, 1988, p. 280. 
Tabla 48: Protección efectiva por ramas industriales (1974):

\begin{tabular}{|c|c|}
\hline Ramas de actividad & $\mathbf{1 9 7 4}$ \\
\hline Productos alimenticios, bebidas y tabaco & $136 \%$ \\
\hline Textiles, prendas de vestir, industrias del cuero & $185 \%$ \\
\hline Industrias de la Madera y productos de & $133 \%$ \\
\hline Madera, incluídos muebles & $82 \%$ \\
\hline Papel y productos de papel, imprentas y & \\
\hline editoriales & $25 \%$ \\
\hline Fábrica de sustancias químicas y derivados del & \\
\hline petróleo & $78 \%$ \\
\hline Minerales no metálicos & $79 \%$ \\
\hline Industrias metálicas básicas & $68 \%$ \\
\hline
\end{tabular}

Fuente: INEC, Encuestas de manufactura y minería, MICEI, Anuarios de Comercio Exterior y Ley de Aranceles. Elaboración: Area industrial, IIE-PUCE. 
Tabla 49: Inversión extranjera autorizada, dirigida a la industria manufacturera (sucres) (1972-1976):

\begin{tabular}{|c|c|c|c|c|c|}
\hline $\begin{array}{l}\text { Ramas de } \\
\text { actividad }\end{array}$ & 1972 & 1973 & 1974 & 1975 & 1976 \\
\hline $\begin{array}{l}\text { Ptos alimenticios, } \\
\text { bebidas y tabaco }\end{array}$ & 42.306.550 & 275.403.309 & 68.634.418 & 127.326.100 & 373.854 .866 \\
\hline $\begin{array}{l}\text { Textiles, prendas } \\
\text { de vestir, ind. } \\
\text { Cuero }\end{array}$ & 4.961 .626 & 39.350 .485 & 30.246 .667 & 22.869 .030 & 281.846 .500 \\
\hline $\begin{array}{l}\text { Industria Madera y } \\
\text { sus ptos }\end{array}$ & 2.576 .229 & 2.055 .555 & 18.508 .000 & 25.591 .500 & 43.650 .900 \\
\hline $\begin{array}{l}\text { Fabric. papel, } \\
\text { imprenta, editorials }\end{array}$ & 360.000 & 2.867 .677 & 11.300 .000 & 5.555 .165 & 61.751 .000 \\
\hline $\begin{array}{l}\text { Fabr. ptos } \\
\text { químicos, } \\
\text { derivados Petróleo, } \\
\text { carbon, caucho y } \\
\text { plástico }\end{array}$ & 5.668 .572 & 71.004.351 & 150.973.163 & 275.519.260 & 264.524 .400 \\
\hline $\begin{array}{l}\text { Fabric. Ptos } \\
\text { minerales no } \\
\text { metálicos excepto } \\
\text { derivados Petróleo } \\
\text { y carbón }\end{array}$ & 1.014.949 & 129.438.089 & 30.757 .125 & 163.294 .900 & 16.941 .400 \\
\hline $\begin{array}{l}\text { Industrias } \\
\text { metálicas básicas }\end{array}$ & 1.969.192 & 19.540.364 & 21.807.646 & 19.825.000 & 45.463.000 \\
\hline $\begin{array}{l}\text { Fabr. Ptos } \\
\text { metálicos, maquin. } \\
\text { Y equipo }\end{array}$ & 29.842.586 & 48.646.280 & 52.560 .525 & 113.567 .470 & 168.940 .485 \\
\hline $\begin{array}{l}\text { Otras ind. } \\
\text { Manufactureras }\end{array}$ & - & - & - & 1.116 .000 & 22.188 .000 \\
\hline Total & 88.699 .704 & 588.124 .110 & 384.787 .544 & 754.664 .425 & 1.026 .160 .551 \\
\hline
\end{tabular}

Fuente: Patricio Almeida Guzmán, Rebeca Almeida Arroba: Estadísticas Económicas Históricas 1948-1983, Fuentes para la Historia Económica del Ecuador, serie estadísticas históricas, vol. 1, Banco Central del Ecuador, 1988, p. 280. 
Tabla 50: Crédito externo para la industria, pequeña industria, artesanía, agroindustria (19701975) (millones de sucres):

\begin{tabular}{|c|c|c|c|}
\hline Años & Gran industria & $\begin{array}{c}\text { Pequeña industria y } \\
\text { artesanía }\end{array}$ & Agro-industria \\
\hline 1970 & 34,2 & & 58,9 \\
\hline 1971 & 183,1 & & 60,3 \\
\hline 1972 & 198,6 & & 47,1 \\
\hline 1973 & 184,2 & 7,2 & 2,9 \\
\hline 1974 & 258,1 & 96,5 & 43,9 \\
\hline 1975 & 161,6 & 221,5 & 2,8 \\
\hline
\end{tabular}

Fuente: Banco Central; CONADE, Sección Crédito Externo. 
Tabla 51: Inversión pública real por sectores económicos (sucres corrientes) (1972-1976):

\begin{tabular}{|l|l|l|l|l|l|}
\hline $\begin{array}{l}\text { Sectores } \\
\text { económicos }\end{array}$ & \multicolumn{1}{|c|}{$\mathbf{1 9 7 2}$} & $\mathbf{1 9 7 3}$ & $\mathbf{1 9 7 4}$ & $\mathbf{1 9 7 5}$ & \\
\hline $\begin{array}{l}\text { I. Inversión real } \\
\text { directa }\end{array}$ & & & & & \\
\hline 1.Educación & 8.100 .000 & 5.900 .000 & 7.300 .000 & 5.300 .000 & 5.700 .000 \\
\hline 2.Seguro social & 400.000 & 100.000 & & & \\
\hline 3.Serv. comunales & & & & & \\
\hline \begin{tabular}{l} 
4.Agropecuario \\
\hline 5.Regadío
\end{tabular} & 800.000 & 2.200 .000 & 5.400 .000 & 9.100 .000 & 4.200 .000 \\
\hline $\begin{array}{l}\text { 6.Energía y } \\
\text { combustibles }\end{array}$ & 2.200 .000 & 2.000 .000 & 2.200 .000 & 2.900 .000 & 5.800 .000 \\
\hline $\begin{array}{l}\text { 7.Industrias y } \\
\text { artesanías }\end{array}$ & & & & & \\
\hline $\begin{array}{l}8 . \text { Transporte } \\
\text { 9.Comunicaciones }\end{array}$ & & 1.900 .000 & 1.200 .000 & 1.500 .000 & 1.400 .000 \\
\hline $\begin{array}{l}\text { 10.Minería } \\
\text { público) }\end{array}$ & & & & & \\
\hline $\begin{array}{l}\text { 1..Salud y otros } \\
\text { serv. Económicos }\end{array}$ & 3.100 .000 & 5.200 .000 & 2.100 .000 & 1.500 .000 & 1.900 .000 \\
\hline $\begin{array}{l}\text { 12.Estudio } \\
\text { Cuenca Río } \\
\text { Guayas }\end{array}$ & & & & & \\
\hline $\begin{array}{l}\text { 13.Reforma } \\
\text { Agraria y desarr. } \\
\text { rural }\end{array}$ & 3.500 .000 & & & & \\
\hline $\begin{array}{l}\text { II. Inv. Indirect } \\
\text { 2. Segur. social }\end{array}$ & & & & & \\
\hline $\begin{array}{l}\text { 3.Serv. comunales } \\
\text { d. }\end{array}$ & & & & & \\
\hline
\end{tabular}




\begin{tabular}{|l|l|l|l|l|l|}
\hline 4.Agropecuario & & & & & \\
\hline 5.Regadío & & & & & \\
\hline $\begin{array}{l}\text { 6. Energ. y } \\
\text { combustible }\end{array}$ & & & & & \\
\hline $\begin{array}{l}\text { 7. Industria y } \\
\text { artesanía }\end{array}$ & & & & & \\
\hline 8. Transportes & & & & & \\
\hline 9.Comunicaciones & & & & & \\
\hline 10. Minería & & & & & \\
\hline $\begin{array}{l}\text { 11. Otros serv. } \\
\text { Económicos }\end{array}$ & & & & & \\
\hline $\begin{array}{l}\text { III. Transf. al } \\
\text { sector privado }\end{array}$ & & & & & \\
\hline $\begin{array}{l}\text { IV. Trasnf. Al } \\
\text { Sector financier } \\
\text { público }\end{array}$ & & & & & \\
\hline
\end{tabular}

Fuente: Patricio Almeida Guzmán, Rebeca Almeida Arroba: Estadísticas Económicas Históricas 1948-1983, Fuentes para la Historia Económica del Ecuador, serie estadísticas históricas, vol. 1, Banco Central del Ecuador, 1988, p. 288. 
Tabla 52: Importación de alimentos y bebidas (miles de sucres) (1969-1975):

\begin{tabular}{|c|c|c|c|c|c|}
\hline Año & Leche & $\begin{array}{c}\text { Aceites } \\
\text { comestibles } \\
\text { vegetales }\end{array}$ & Avena & Trigo & $\begin{array}{c}\text { Harina de } \\
\text { trigo }\end{array}$ \\
\hline 1969 & & & & & \\
\hline 1970 & & $195.282,55$ & & & \\
\hline 1971 & & $237.954,32$ & & $752.441,05$ & $44.132,14$ \\
\hline 1972 & & $220.871,0$ & $8.412,57$ & & \\
\hline 1973 & 2.100 .031 & $202.738,5$ & & & \\
\hline 1974 & & $412.176,13$ & & & \\
\hline 1975 & & & & & \\
\hline
\end{tabular}

Fuente: Patricio Almeida Guzmán, Rebeca Almeida Arroba: Estadísticas Económicas Históricas 1948-1983, Fuentes para la Historia Económica del Ecuador, serie estadísticas históricas, vol. 1, Banco Central del Ecuador, 1988, p. 492-493. 
Tabla 53: Estructura del ingreso en áreas urbanas 1968 y 1975 (precios en sucres de 1972):

\begin{tabular}{|c|c|c|c|c|}
\hline \multicolumn{5}{|c|}{1968} \\
\hline Ingreso anual & Num. Personas & Porcentaje & Ingreso & $\begin{array}{c}\text { Promedio \$ por } \\
\text { año }\end{array}$ \\
\hline $0-10.000$ & 246.319 & 42,8 & 12,1 & 5.903 \\
\hline $10.500-40.000$ & 262.187 & 45,5 & 44,1 & 20.287 \\
\hline $40.000-90.000$ & 48.895 & 8,5 & 22,6 & 55.936 \\
\hline $90.000-200.000$ & 17.868 & 3,1 & 19,8 & 133.703 \\
\hline $200.000-$ & 818 & 0,1 & 1,4 & 202.934 \\
\hline Total & 576.087 & 100,1 & 100 & 20.940 \\
\hline
\end{tabular}

\begin{tabular}{|c|c|c|c|c|}
\hline \multicolumn{5}{|c|}{1975} \\
\hline Ingreso anual & Num. Personas & Porcentaje & Ingreso & $\begin{array}{c}\text { Promedio \$ por } \\
\text { año }\end{array}$ \\
\hline $0-10.000$ & 225.200 & 26,7 & 5,5 & 5.293 \\
\hline $10.500-40.000$ & 473.880 & 56,2 & 48,1 & 21.968 \\
\hline $40.000-90.000$ & 122.292 & 14,5 & 30,4 & 53.814 \\
\hline $90.000-200.000$ & 17.445 & 2,1 & 11,1 & 137.518 \\
\hline $200.000-$ & 4.147 & 0,5 & 4,9 & 258.500 \\
\hline Total & 842.964 & 100 & 100,0 & 25.688 \\
\hline
\end{tabular}

Fuente: Gonzalo Crespo Ortíz: Estudio introductorio, en: "Economía, Ecuador: 1830-1980", III, Quito, Corporación Editora Nacional, 1983, p. 42. 
Tabla 54: Salario mínimo vital nominal, por actividades (1968-1977):

\begin{tabular}{|l|c|c|c|c|c|}
\hline \multicolumn{1}{|c|}{ Años } & \multirow{2}{*}{$\begin{array}{c}\text { Salario } \\
\text { mínimo vital }\end{array}$} & \multirow{2}{*}{ Artesanos } & \multicolumn{3}{c|}{ Trabajadores agrícolas } \\
\cline { 4 - 6 } & & & Sierra & Costa & Oriente \\
\hline $\mathbf{1 9 6 8}$ (29 oct) & & & & & \\
\hline $\mathbf{1 9 6 9}(\mathbf{1 5}$ enero) & & & & & \\
\hline $\mathbf{1 9 6 9}$ (7 mayo) & & & 100,0 & 100,0 & 100,0 \\
\hline $\mathbf{1 9 7 0}$ & 100,0 & 100,0 & 100,0 & 100,0 & 100,0 \\
\hline $\mathbf{1 9 7 1}(\mathbf{1}$ enero) & 125,0 & 100,0 & 100,0 & 100,0 & 100,0 \\
\hline $\mathbf{1 9 7 2}$ & 125,0 & 100,0 & 100,0 & 100,0 & 100,0 \\
\hline $\mathbf{1 9 7 3}$ & 125,0 & 100,0 & 133,3 & 125,0 & 125,0 \\
\hline $\mathbf{1 9 7 4}(\mathbf{1}$ enero) & 166,6 & 116,6 & 166,6 & 150,0 & 150,0 \\
\hline $\mathbf{1 9 7 4}(\mathbf{1}$ abril) & 166,6 & 141,6 & 166,6 & 150,0 & 150,0 \\
\hline $\mathbf{1 9 7 5}(\mathbf{1}$ mayo) & 208,3 & 158,3 & 213,3 & 180,0 & 180,0 \\
\hline $\mathbf{1 9 7 6}$ (31 dic) & 250,0 & 190,0 & 213,3 & 180,0 & 180,0 \\
\hline $\mathbf{1 9 7 7}$ & 250,0 & 190,0 & & & \\
\hline
\end{tabular}

Fuente: Patricio Almeida Guzmán, Rebeca Almeida Arroba: Estadísticas Económicas Históricas 1948-1983, Fuentes para la Historia Económica del Ecuador, serie estadísticas históricas, vol. 1, Banco Central del Ecuador, 1988, p. 355. 
Tabla 55: Valor bruto de la producción y valor agregado de las industrias clasificadas en las leyes de fomento industrial, pequeña industria, artesanía, por ramas de actividad (1969-1972) (sucres):

\begin{tabular}{|c|c|c|c|c|c|c|c|c|}
\hline \multirow{3}{*}{$\begin{array}{l}\text { Ramas de } \\
\text { actividad }\end{array}$} & \multicolumn{2}{|c|}{1969} & \multicolumn{2}{|c|}{1970} & \multicolumn{2}{|c|}{1971} & \multicolumn{2}{|c|}{1972} \\
\hline & \multicolumn{2}{|c|}{ Gran industria } & \multicolumn{2}{|c|}{ Gran industria } & \multicolumn{2}{|c|}{ Gran industria } & \multicolumn{2}{|c|}{ Gran industria } \\
\hline & V.B.P & V.agreg. & V.B.P & V.agreg. & V.B.P. & V.agreg. & V.B.P. & V.agreg. \\
\hline Alimentos & 180.183 .734 & 46.099 .708 & 21.230 .473 & 7.579 .110 & 310.423 .212 & 160.802 .719 & 290.847 .880 & 134.543 .634 \\
\hline $\begin{array}{l}\text { Alimentos } \\
\text { diversos }\end{array}$ & 761.866 & 335.164 & & - & & -- & 18.180 .000 & 4.074 .852 \\
\hline Bebidas & & & 29.700 .000 & 8.897 .939 & & - & 54.000 .000 & 6.106 .800 \\
\hline Textiles & 31.761 .387 & 9.175 .330 & 50.467 .500 & 16.132 .552 & 88.559 .244 & 37.233 .518 & 44.481 .023 & 15.953 .544 \\
\hline $\begin{array}{l}\text { Prendas de } \\
\text { vestir }\end{array}$ & & & & & 7.200 .000 & 1.396 .560 & 8.237 .600 & 2.607 .322 \\
\hline Calzado & & & & & 3.300 .000 & 1.248 .340 & & \\
\hline Cueros y otros & & & & & 16.250 .000 & 4.849 .036 & & \\
\hline Madera & 16.800 .000 & 5.884 .500 & & & 91.943 .230 & 39.473 .254 & 74.649 .490 & 29.607 .690 \\
\hline $\begin{array}{l}\text { Muebles y } \\
\text { accesorios }\end{array}$ & 29.988 .600 & 8.962 .450 & 7.950 .000 & 2.632 .610 & & & 14.680 .000 & 4.519 .994 \\
\hline $\begin{array}{c}\text { Papel y ptos } \\
\text { papel }\end{array}$ & 17.907 .114 & 2.177 .573 & 4.200 .000 & 1.984 .045 & 19.377 .000 & 8.533 .011 & 47.206 .000 & 9.293 .419 \\
\hline $\begin{array}{l}\text { Imprentas y } \\
\text { editorial }\end{array}$ & & & & & & & 13.500 .000 & 2.436 .632 \\
\hline
\end{tabular}




\begin{tabular}{|c|c|c|c|c|c|c|c|c|}
\hline Ind.Química & 13.519 .600 & 2.788 .720 & 5.077 .800 & 1.339 .220 & 5.700 .000 & 3.862 .850 & & \\
\hline $\begin{array}{l}\text { Otros ptos } \\
\text { químicos }\end{array}$ & 11.725 .700 & 5.065 .421 & 5.225 .000 & 1.241 .011 & 10.400 .000 & 1.753 .296 & 4.200 .000 & 1.983 .702 \\
\hline $\begin{array}{l}\text { Deriv. } \\
\text { petróleo y } \\
\text { carbón }\end{array}$ & & & & & & & & \\
\hline Ind. Plástic. & 33.071 .492 & 9.408 .515 & & & 63.408 .000 & 16.280 .834 & 52.019 .517 & 15.018 .269 \\
\hline $\begin{array}{l}\text { Vidrio y ptos } \\
\text { vidrio }\end{array}$ & 13.393 .359 & 6.117 .182 & 3.240 .000 & 890.273 & & & 8.884 .960 & 2.377 .095 \\
\hline $\begin{array}{c}\text { Loza y } \\
\text { porcelana }\end{array}$ & & & & & & & & \\
\hline Ind. Caucho & & & & & & & & \\
\hline $\begin{array}{l}\text { Min.no } \\
\text { metálicos }\end{array}$ & 66.026 .980 & 14.823 .108 & 35.853 .096 & 11.269 .215 & 3.612 .000 & 1.562 .734 & 918.000 & 592.720 \\
\hline $\begin{array}{l}\text { Básicos } \\
\text { hierro/acero }\end{array}$ & 32.350 .594 & 10.794 .232 & & & 91.300 .000 & 6.628 .360 & & \\
\hline $\begin{array}{l}\text { Ptos met. Exc. } \\
\text { Maquin y eq. } \\
\text { electric }\end{array}$ & 20.615 .963 & 4.660 .967 & 30.189 .125 & 10.435 .319 & 7.820 .000 & 1.968 .744 & 26.943 .900 & 10.588 .942 \\
\hline $\begin{array}{c}\text { Básicas } \\
\text { met.noferrosos }\end{array}$ & 32.399 .349 & 2.975 .036 & & & & & & \\
\hline
\end{tabular}




\begin{tabular}{|c|c|c|c|c|c|c|c|c|}
\hline $\begin{array}{l}\text { Constr. Maq. } \\
\text { Eléctrica }\end{array}$ & 14.443 .000 & 4.523 .250 & 50.886 .446 & 6.122 .858 & 12.694 .311 & 3.352 .469 & 32.412 .320 & 7.760 .213 \\
\hline $\begin{array}{l}\text { Maq. except } \\
\text { eléctrica }\end{array}$ & & & 11.860 .000 & 4.198 .170 & & & & \\
\hline $\begin{array}{c}\text { Mat. } \\
\text { Transporte }\end{array}$ & & & 16.591 .000 & 3.192 .879 & 10.561 .876 & 4.586 .116 & 37.958 .217 & 12.024 .897 \\
\hline $\begin{array}{l}\text { Ind.manuf. } \\
\text { N.E.P. }\end{array}$ & & & 7.841 .097 & 2.358 .062 & 4.636 .910 & 3.161 .498 & 11.906 .000 & 6.243 .514 \\
\hline $\begin{array}{l}\text { Otros ptos } \\
\text { minerales }\end{array}$ & & & & & & & & \\
\hline $\begin{array}{l}\text { Equipo prof. y } \\
\text { científico }\end{array}$ & 2.712 .000 & 1.373 .733 & & & & & 3.538 .900 & 1.324 .014 \\
\hline Varios & & & & & & & & \\
\hline TOTAL & 517.720 .738 & 135.164 .889 & 280.311 .537 & 78.263 .263 & 747.185 .873 & 296.693 .339 & 744.563 .807 & 276.057 .253 \\
\hline
\end{tabular}

V.B.P.: Valor bruto de la producción

Fuente: Patricio Almeida Guzmán, Rebeca Almeida Arroba: Estadísticas Económicas Históricas 1948-1983, Fuentes para la Historia Económica del Ecuador, serie estadísticas históricas, vol. 1, Banco Central del Ecuador, 1988, p. 151. 
Tabla 56: Valor bruto de la producción y valor agregado de las industrias clasificadas en las leyes de fomento industrial, pequeña industria, artesanía, por ramas de actividad (1973-1975) (sucres):

\begin{tabular}{|c|c|c|c|c|c|c|}
\hline \multirow[t]{2}{*}{$\begin{array}{l}\text { Rama } \\
\text { actividad }\end{array}$} & \multicolumn{2}{|c|}{$\begin{array}{c}1973 \\
\text { Gran industria }\end{array}$} & \multicolumn{2}{|c|}{$\begin{array}{c}1974 \\
\text { Gran industria }\end{array}$} & \multicolumn{2}{|c|}{$\begin{array}{c}1975 \\
\text { Gran industria }\end{array}$} \\
\hline & V.B.P. & V.agregado & V.B.P. & V. agregado & V.B.P. & V. agregado \\
\hline Alimentos & 614.808 .180 & 106.331 .763 & 514.677 .495 & 84.324 .891 & 538.945 .073 & 127.116 .754 \\
\hline $\begin{array}{l}\text { Alimentos } \\
\text { diversos }\end{array}$ & 21.018 .505 & 1.723 .144 & 27.721 .555 & 20.729 .282 & 4.082 .040 & 2.802 .396 \\
\hline Bebidas & 156.930 .895 & 59.965 .295 & 5.490 .000 & 2.435 .808 & 17.087 .805 & 7.188 .204 \\
\hline Textiles & 227.080 .110 & 63.157 .344 & 613.649 .866 & 239.753 .191 & 189.839 .981 & 71.305 .652 \\
\hline $\begin{array}{l}\text { Prendas de } \\
\text { vestir }\end{array}$ & 10.792 .795 & 2.775 .453 & & & 31.507 .768 & 9.449 .325 \\
\hline Calzado & & & 30.595 .000 & 8.229 .515 & 27.648 .000 & 7.918 .883 \\
\hline Cueros & 7.488 .000 & 3.239 .515 & 16.933 .200 & 5.662 .909 & 24.659 .000 & 10.191 .781 \\
\hline Madera & 52.344 .650 & 21.230 .997 & 102.096 .012 & 27.621 .474 & 128.542 .649 & 51.569 .473 \\
\hline $\begin{array}{l}\text { Muebles y } \\
\text { acces madera }\end{array}$ & & & & & 19.202 .000 & 10.680 .900 \\
\hline $\begin{array}{l}\text { Papel y ptos } \\
\text { papel }\end{array}$ & 7.102 .070 & 2.958 .885 & 100.726 .878 & 21.316 .386 & 166.776 .000 & 67.021 .065 \\
\hline $\begin{array}{l}\text { Imprentas, } \\
\text { edit y } \\
\text { conexas }\end{array}$ & 25.581 .040 & 10.696 .045 & 5.520 .000 & 2.767 .013 & 3.773 .0000 & 1.783 .888 \\
\hline $\begin{array}{l}\text { Industria } \\
\text { quimica }\end{array}$ & & & 25.446 .657 & 7.818 .154 & 110.400 .000 & 24.317 .189 \\
\hline $\begin{array}{l}\text { Otros ptos } \\
\text { quimicos }\end{array}$ & 164.839 .052 & 65.339 .425 & 487.691 .185 & 107.469 .092 & 141.266 .180 & 49.206 .536 \\
\hline $\begin{array}{l}\text { Derivados } \\
\text { petróleo y } \\
\text { carbón }\end{array}$ & & & & & & \\
\hline Ind plástica & 53.257 .168 & 15.522 .505 & 31.666 .025 & 10.596 .076 & 117.438 .437 & 37.125 .534 \\
\hline $\begin{array}{l}\text { Vidrio y ptos } \\
\text { vidrio }\end{array}$ & & & & & 19.423 .192 & 9.707 .394 \\
\hline $\begin{array}{l}\text { Objetos loza y } \\
\text { porcelana }\end{array}$ & & & 40.056 .000 & 19.606 .830 & & \\
\hline Ind caucho & 7.285 .200 & 1.640 .062 & 13.928 .040 & 4.270 .506 & & \\
\hline $\begin{array}{l}\text { Miner no } \\
\text { metalicos }\end{array}$ & 69.575 .900 & 18.835 .578 & 72.802 .100 & 35.185 .689 & 363.865 .342 & 185.729 .747 \\
\hline $\begin{array}{l}\text { Basicos de } \\
\text { hierro y acero }\end{array}$ & 137.801 .240 & 49.958 .146 & 157.317 .415 & 19.370 .675 & 133.998 .839 & 43.903 .869 \\
\hline $\begin{array}{l}\text { Ptos metal, } \\
\text { exc. maquin y } \\
\text { equipo }\end{array}$ & 131.801 .240 & 39.613 .704 & 42.056 .660 & 19.295 .009 & 20.079 .500 & 4.194 .825 \\
\hline
\end{tabular}




\begin{tabular}{|l|l|l|l|l|l|l|}
\hline electric & & & & & & \\
\hline $\begin{array}{l}\text { Básicas } \\
\text { metales no } \\
\text { ferrosos }\end{array}$ & 16.419 .156 & 4.468 .912 & 16.500 .000 & 5.197 .446 & 64.270 .000 & 16.906 .000 \\
\hline $\begin{array}{l}\text { Construcc } \\
\text { maquinaria } \\
\text { eléctrica }\end{array}$ & 54.980 .500 & 13.674 .787 & 9.800 .000 & 6.015 .640 & 214.719 .350 & 43.585 .079 \\
\hline $\begin{array}{l}\text { Maquin, } \\
\text { except } \\
\text { eléctrica }\end{array}$ & 36.815 .000 & 10.345 .011 & 31.746 .500 & 10.758 .124 & & \\
\hline $\begin{array}{l}\text { Material } \\
\text { transporte }\end{array}$ & 45.362 .070 & 14.891 .551 & 6.150 .144 & 2.704 .397 & 7.858 .000 & 2.663 .484 \\
\hline $\begin{array}{l}\text { Ind manufact } \\
\text { N.E.P }\end{array}$ & & 54.145 .100 & 17.787 .188 & & \\
\hline $\begin{array}{l}\text { Otros ptos } \\
\text { minerals }\end{array}$ & & & 38.400 .000 & 10.300 .914 & 223.730 .000 & 58.225 .205 \\
\hline $\begin{array}{l}\text { Equipo } \\
\text { profesional y } \\
\text { ciéntifico }\end{array}$ & & & & & & \\
\hline Varios & 1.841 .109 .556 & 506.368 .122 & 2.445 .215 .832 & 689.216 .209 & 2.569 .112 .156 & 842.593 .183 \\
\hline Total & & & & & & \\
\hline
\end{tabular}

V.B.P.: Valor bruto de la producción

Fuente: Patricio Almeida Guzmán, Rebeca Almeida Arroba: Estadísticas Económicas Históricas 1948-1983, Fuentes para la Historia Económica del Ecuador, serie estadísticas históricas, vol. 1, Banco Central del Ecuador, 1988, p. 152. 
Tabla 57: Valor bruto de la producción y valor agregado de las industrias clasificadas en las leyes de fomento industrial, pequeña industria, artesanía, por ramas de actividad (1976-1977) (sucres):

\begin{tabular}{|c|c|c|c|c|}
\hline \multirow{3}{*}{$\begin{array}{c}\text { Rama } \\
\text { actividad }\end{array}$} & \multirow{2}{*}{\multicolumn{2}{|c|}{$\begin{array}{c}1976 \\
\text { Gran industria }\end{array}$}} & \multirow{2}{*}{\multicolumn{2}{|c|}{$\begin{array}{c}1977 \\
\text { Gran industria }\end{array}$}} \\
\hline & & & & \\
\hline & V.B.P. & V.agregado & V.B.P. & V. agregado \\
\hline Alimentos & 886.365 .168 & 121.044 .491 & 415.098 .515 & 68.141 .342 \\
\hline $\begin{array}{c}\text { Alimentos } \\
\text { diversos }\end{array}$ & 4.322 .160 & 3.149 .570 & 358.608 .850 & 38.805 .694 \\
\hline Bebidas & 129.904 .499 & 29.493 .085 & 33.244 .400 & 12.674 .476 \\
\hline Textiles & 106.426 .000 & 57.088 .942 & 176.085 .000 & 34.591 .394 \\
\hline \multicolumn{5}{|l|}{$\begin{array}{c}\text { Prendas de } \\
\text { vestir }\end{array}$} \\
\hline \multicolumn{5}{|l|}{ Calzado } \\
\hline Cueros & 59.792 .000 & 18.947 .135 & & \\
\hline Madera & 70.188 .000 & 31.734 .151 & 72.314 .640 & 33.073 .329 \\
\hline \multicolumn{5}{|l|}{$\begin{array}{c}\text { Muebles y } \\
\text { acces madera }\end{array}$} \\
\hline $\begin{array}{l}\text { Papel y ptos } \\
\text { papel }\end{array}$ & 9.158 .400 & 5.104 .300 & 549.697 .900 & 181.549 .305 \\
\hline $\begin{array}{l}\text { Imprentas, } \\
\text { edit y } \\
\text { conexas }\end{array}$ & 99.001 .176 & 26.976 .563 & 80.040 .000 & 31.172 .540 \\
\hline $\begin{array}{c}\text { Industria } \\
\text { quimica }\end{array}$ & 96.890 .000 & 43.035 .649 & & \\
\hline $\begin{array}{l}\text { Otros ptos } \\
\text { quimicos }\end{array}$ & 156.043 .630 & 51.558 .179 & 88.732 .900 & 33.818 .750 \\
\hline $\begin{array}{l}\text { Derivados } \\
\text { petróleo y }\end{array}$ & & & 130.519 .500 & 25.010 .300 \\
\hline
\end{tabular}




\begin{tabular}{|c|c|c|c|c|}
\hline carbón & & & & \\
\hline Ind plástica & 27.550 .896 & 7.992 .159 & 131.150 .390 & 42.154 .775 \\
\hline $\begin{array}{l}\text { Vidrio y ptos } \\
\text { vidrio }\end{array}$ & & & 32.163 .170 & 16.704 .634 \\
\hline \multicolumn{5}{|l|}{$\begin{array}{l}\text { Objetos loza y } \\
\text { porcelana }\end{array}$} \\
\hline \multicolumn{5}{|l|}{ Ind caucho } \\
\hline $\begin{array}{l}\text { Miner no } \\
\text { metalicos }\end{array}$ & & & 459.407 .898 & 186.715 .812 \\
\hline $\begin{array}{c}\text { Basicos de } \\
\text { hierro y acero }\end{array}$ & & & 136.550 .087 & 27.889 .036 \\
\hline $\begin{array}{c}\text { Ptos metal, } \\
\text { exc. maquin y } \\
\text { equipo } \\
\text { electric }\end{array}$ & 136.388 .000 & 64.232 .539 & 6.600 .000 & 3.112 .142 \\
\hline $\begin{array}{l}\text { Básicas } \\
\text { metales no } \\
\text { ferrosos }\end{array}$ & 38.880 .000 & 8.233 .983 & & \\
\hline $\begin{array}{l}\text { Construcc } \\
\text { maquinaria } \\
\text { eléctrica }\end{array}$ & 572.049 .550 & 216.937 .481 & 25.059 .550 & 3.911 .160 \\
\hline $\begin{array}{l}\text { Maquin, } \\
\text { except } \\
\text { eléctrica }\end{array}$ & 25.260 .000 & 7.739 .200 & & \\
\hline $\begin{array}{l}\text { Material } \\
\text { transporte }\end{array}$ & 340.458 .400 & 72.281 .575 & 18.540 .000 & 3.175 .006 \\
\hline $\begin{array}{c}\text { Ind manufact } \\
\text { N.E.P }\end{array}$ & 27.207 .640 & 10.872 .587 & & \\
\hline \multicolumn{5}{|l|}{$\begin{array}{l}\text { Otros ptos } \\
\text { minerals }\end{array}$} \\
\hline \multicolumn{5}{|l|}{$\begin{array}{c}\text { Equipo } \\
\text { profesional y } \\
\text { ciéntifico }\end{array}$} \\
\hline Varios & & & & \\
\hline
\end{tabular}




\begin{tabular}{|l|l|l|l|l|}
\hline Total & 2.960 .293 .659 & 831.451 .459 & 2.713 .813 .340 & 742.499 .695 \\
\hline
\end{tabular}

V.B.P.: Valor bruto de la producción

Fuente: Patricio Almeida Guzmán, Rebeca Almeida Arroba: Estadísticas Económicas Históricas 1948-1983, Fuentes para la Historia Económica del Ecuador, serie estadísticas históricas, vol. 1, Banco Central del Ecuador, 1988, p. 153. 


\section{APÉNDICE DE DATOS Y ESTADÍSTICAS: CAPÍTULO 6}

Tabla 1: Población alfabeta y analfabeta (población de 15 años y más) (1950-1982):

\begin{tabular}{|c|c|c|c|c|c|c|}
\hline \multirow{2}{*}{ Años } & \multicolumn{3}{|c|}{ Alfabetos } & \multicolumn{3}{c|}{ Analfabetos } \\
\cline { 2 - 7 } & Hombres & Mujeres & Total & Hombres & Mujeres & Total \\
\hline 1950 & 557.891 & 468.822 & 1.026 .713 & 341.188 & 474.276 & 815.464 \\
\hline 1962 & 872.690 & 789.277 & 1.661 .967 & 337.849 & 461.686 & 799.563 \\
\hline 1968 & 1.044 .261 & 955.059 & 1.999 .320 & 388.195 & 535.866 & 924.061 \\
\hline 1974 & 1.179 .029 & 246.072 & 1.425 .101 & 368.823 & 66.067 & 434.890 \\
\hline 1982 & 2.005 .455 & 1.909 .239 & 3.914 .694 & 305.324 & 465.282 & 770.606 \\
\hline
\end{tabular}

Fuente: Patricio Almeida Guzmán, rebeca Almeida Arroba: Estadísticas económicas históricas 1948-1983, Fuentes para la historia económica del Ecuador, Serie estadísticas históricas vol.1, Banco Central del Ecuador, Quito, 1988, p. 395. 


\section{CÁLCULO DEL ÍNDICE DE DESARROLLO HUMANO (Ecuador, 1960-1980)}

Tabla 2: Valores límite de los indicadores:

\begin{tabular}{|c|c|c|}
\hline Indicador & Máximo valor & Mínimo valor \\
\hline $\begin{array}{c}\text { Esperanza de vida al nacer } \\
\text { (años) }\end{array}$ & 85 & 25 \\
\hline $\begin{array}{c}\text { Tasa de alfabetización de } \\
\text { adultos (\% personas de 15 } \\
\text { años o más) }\end{array}$ & 100 & 0 \\
\hline $\begin{array}{c}\text { Tasa bruta combinada de } \\
\text { matriculación (\%) }\end{array}$ & 100 & 0 \\
\hline $\begin{array}{c}\text { PIB per cápita (US\$ a precios } \\
\text { actuales) }\end{array}$ & 40.000 & 100 \\
\hline
\end{tabular}

Fuente: Informe sobre el Desarrollo Humano: Cálculo de los índices de desarrollo humano, 2007-2008, p. 357-358. 
Tabla 3: Equivalencia índices (español-inglés):

\begin{tabular}{|l|}
\hline \multicolumn{1}{|c|}{ EQUIVALENCIA ÍNDICES (Español-Inglés) } \\
\hline Índice de desarrollo humano (IDH): Human Development Index \\
\hline Índice de esperanza de vida: Life Expectancy Index \\
\hline Índice de Escolarización: Schooling Index \\
\hline Tasa de alfabetización de adultos (\%): Adult Literacy Index (\%) \\
\hline $\begin{array}{l}\text { Tasa de matriculación combinada (primaria, secundaria y terciaria) (\%): Combined } \\
\text { Enrolment Rate (\%) }\end{array}$ \\
\hline Índice bruto de matriculación: Gross Enrolment Index \\
\hline Índice del PIB: GDCP Index \\
\hline Clasificación según IDH: Classification according to IDH \\
\hline
\end{tabular}

Fuente: Informe sobre el Desarrollo Humano: Cálculo de los índices de desarrollo humano, 2007-2008, p. 357-358. 
CALCULO DEL ÍNDICE DE DESARROLLO HUMANO (1960-1980) (Elaboración propia):

\begin{tabular}{|c|c|c|c|c|c|c|c|c|}
\hline \multicolumn{9}{|c|}{ Año 1960} \\
\hline País & $\begin{array}{c}\text { Human } \\
\text { Development } \\
\text { Index }\end{array}$ & $\begin{array}{c}\text { Life } \\
\text { Expectancy } \\
\text { Index }\end{array}$ & $\begin{array}{l}\text { Schooling } \\
\text { Index }\end{array}$ & $\begin{array}{c}\text { Adult } \\
\text { Literacy } \\
\text { Index } \\
(\%)\end{array}$ & $\begin{array}{c}\text { Combined } \\
\text { Enrolment } \\
\text { Rate }(\%)\end{array}$ & $\begin{array}{c}\text { Gross } \\
\text { Enrolment } \\
\text { Index }\end{array}$ & $\begin{array}{l}\text { GDCP } \\
\text { Index }\end{array}$ & $\begin{array}{l}\text { Classification } \\
\text { according to } \\
\text { IDH or Index } \\
\text { of Human } \\
\text { development }\end{array}$ \\
\hline Alemania & 0.247890515 & 0.74367154 & 0 & $0.00 \%$ & & $0.00 \%$ & & 35 \\
\hline Argentina & 0.223195257 & 0.66958577 & 0 & & 0 & $0.00 \%$ & & 37 \\
\hline Australia & 100.5921374 & 0.76361789 & 0 & & 0 & $0.00 \%$ & 301.012794 & 3 \\
\hline Bolivia & 9.1849229 & 0.29420081 & 0 & & 0 & $0.00 \%$ & 27.2605679 & 26 \\
\hline Brasil & 11.50120346 & 0.49153699 & 0 & $0.00 \%$ & 0 & $0.00 \%$ & 34.0120734 & 24 \\
\hline Canadá & 127.657736 & 0.76888618 & 0 & & 0 & $0.00 \%$ & 382.204322 & 2 \\
\hline Chile & 30.55564565 & 0.53360488 & 0 & & 0 & $0.00 \%$ & 91.1333321 & 11 \\
\hline China & 4.96535365 & 0.3076313 & 0 & & 0 & $0.00 \%$ & 14.5884296 & 32 \\
\hline Colombia & 13.96542107 & 0.52854878 & 0 & & 0 & $0.00 \%$ & 41.3677144 & 19 \\
\hline Costa Rica & 21.11251243 & 0.61004919 & 0 & & 0 & $0.00 \%$ & 62.7274881 & 15 \\
\hline Croacia & 0.227606233 & 0.6828187 & 0 & & & $0.00 \%$ & & 36 \\
\hline Cuba & 0.214792547 & 0.64437764 & 0 & & 0 & $0.00 \%$ & & 38 \\
\hline Dinamarca & 75.92038789 & 0.78627642 & 0 & & 0 & $0.00 \%$ & 226.974887 & 7 \\
\hline Ecuador & 12.35055792 & 0.46866748 & 0 & & 0 & $0.00 \%$ & 36.5830063 & 23 \\
\hline Egipto & 8.095174637 & 0.34889268 & 0 & & 0 & $0.00 \%$ & 23.9366312 & 27 \\
\hline El Salvador & 0.146063821 & 0.43819146 & 0 & & 0 & $0.00 \%$ & & 39 \\
\hline España & 22.04200837 & 0.73515447 & 0 & & 0 & $0.00 \%$ & 65.3908706 & 14 \\
\hline Estados Unidos & 160.2816423 & 0.74617886 & 0 & & 0 & $0.00 \%$ & 480.098748 & 1 \\
\hline Etiopía & 0.074476152 & 0.22342846 & 0 & & 0 & $0.00 \%$ & & 42 \\
\hline Finlandia & 65.60018692 & 0.73032927 & 0 & & 0 & $0.00 \%$ & 196.070232 & 9 \\
\hline Francia & 74.71506009 & 0.74780488 & 0 & & 0 & $0.00 \%$ & 223.397375 & 8 \\
\hline Guatemala & 13.88113408 & 0.34575488 & 0 & & 0 & $0.00 \%$ & 41.2976474 & 21 \\
\hline
\end{tabular}




\begin{tabular}{|c|c|c|c|c|c|c|c|c|}
\hline Guinea & 0.040911789 & 0.12273537 & 0 & & 0 & $0.00 \%$ & & 45 \\
\hline Haití & 0.094903794 & 0.28471138 & 0 & & 0 & $0.00 \%$ & & 41 \\
\hline Honduras & 9.187642139 & 0.35350528 & 0 & & 0 & $0.00 \%$ & 27.2094211 & 25 \\
\hline Irán & 0.10876355 & 0.32629065 & 0 & & 0 & $0.00 \%$ & & 40 \\
\hline Japón & 26.62958872 & 0.71110163 & 0 & & 0 & $0.00 \%$ & 79.1776645 & 13 \\
\hline Mozambique & 0.055576152 & 0.16672846 & 0 & $0.00 \%$ & 0 & $0.00 \%$ & & 44 \\
\hline México & 18.70234088 & 0.5339187 & 0 & $0.00 \%$ & 0 & $0.00 \%$ & 55.5731039 & 18 \\
\hline Nepal & 2.781694909 & 0.22490081 & 0 & & 0 & $0.00 \%$ & 8.12018391 & 34 \\
\hline Nicaragua & 6.98920254 & 0.36518252 & 0 & & 0 & $0.00 \%$ & 20.6024251 & 28 \\
\hline Nigeria & 4.982333705 & 0.22494146 & 0 & & 0 & $0.00 \%$ & 14.7220597 & 31 \\
\hline Noruega & 80.22515739 & 0.8091626 & 0 & & 0 & $0.00 \%$ & 239.86631 & 5 \\
\hline Panamá & 20.30448995 & 0.59649959 & 0 & $0.00 \%$ & 0 & $0.00 \%$ & 60.3169703 & 16 \\
\hline Perú & 13.89494414 & 0.3773874 & 0 & & 0 & $0.00 \%$ & 41.307445 & 20 \\
\hline Portugal & 20.01137747 & 0.63394309 & 0 & & 0 & $0.00 \%$ & 59.4001893 & 17 \\
\hline Reino Unido & 76.7929767 & 0.76878049 & 0 & & 0 & $0.00 \%$ & 229.61015 & 6 \\
\hline Senegal & 13.70169394 & 0.23221667 & 0 & & 0 & $0.00 \%$ & 40.8728652 & 22 \\
\hline Sudán & 5.813552767 & 0.27643211 & 0 & & 0 & $0.00 \%$ & 17.1642262 & 29 \\
\hline Suiza & 99.44034643 & 0.77189024 & 0 & & 0 & $0.00 \%$ & 297.549149 & 4 \\
\hline Tailandia & 5.525446992 & 0.50498659 & 0 & $0.00 \%$ & 0 & $0.00 \%$ & 16.0713544 & 30 \\
\hline Uganda & 3.31723917 & 0.31630935 & 0 & & 0 & $0.00 \%$ & 9.63540816 & 33 \\
\hline Uruguay & 27.24244768 & 0.71351667 & 0 & & 0 & $0.00 \%$ & 81.0138264 & 12 \\
\hline Venezuela & 63.1046114 & 0.55864472 & 0 & & 0 & $0.00 \%$ & 188.755189 & 10 \\
\hline Yemen & 0.07103645 & 0.21310935 & 0 & & & $0.00 \%$ & & 43 \\
\hline
\end{tabular}

Fuente: Elaboración propia a partir de la base de datos del Banco Mundial, periodo 1960-1980, (data.worldbank.org) 


\begin{tabular}{|c|c|c|c|c|c|c|c|c|}
\hline \multicolumn{9}{|c|}{ Año 1961} \\
\hline Country & $\begin{array}{c}\text { Human } \\
\text { Development } \\
\text { Index }\end{array}$ & $\begin{array}{c}\text { Life } \\
\text { Expectancy } \\
\text { Index }\end{array}$ & $\begin{array}{l}\text { Schooling } \\
\text { Index }\end{array}$ & $\begin{array}{c}\text { Adult } \\
\text { Literacy } \\
\text { Index } \\
(\%)\end{array}$ & $\begin{array}{c}\text { Combined } \\
\text { Enrolment } \\
\text { Rate }(\%)\end{array}$ & $\begin{array}{c}\text { Gross } \\
\text { Enrolment } \\
\text { Index }\end{array}$ & $\begin{array}{l}\text { GDCP } \\
\text { Index }\end{array}$ & $\begin{array}{c}\text { Classification } \\
\text { according to } \\
\text { IDH or Index } \\
\text { of Human } \\
\text { development }\end{array}$ \\
\hline Alemania & 0.249035501 & 0.7471065 & 0 & $0.00 \%$ & & $0.00 \%$ & & 35 \\
\hline Argentina & 0.22387019 & 0.67161057 & 0 & & 0 & $0.00 \%$ & & 37 \\
\hline Australia & 104.2755829 & 0.76621951 & 0 & & 0 & $0.00 \%$ & 312.060529 & 4 \\
\hline Bolivia & 9.783665763 & 0.29935488 & 0 & & 0 & $0.00 \%$ & 29.0516424 & 25 \\
\hline Brasil & 11.21467128 & 0.4993122 & 0 & $0.00 \%$ & 0 & $0.00 \%$ & 33.1447016 & 24 \\
\hline Canadá & 124.1386338 & 0.77243496 & 0 & & 0 & $0.00 \%$ & 371.643466 & 2 \\
\hline Chile & 33.28996882 & 0.54010569 & 0 & & 0 & $0.00 \%$ & 99.3298008 & 12 \\
\hline China & 4.069230996 & 0.31287154 & 0 & & 0 & $0.00 \%$ & 11.8948214 & 32 \\
\hline Colombia & 15.28468617 & 0.53739797 & 0 & & 0 & $0.00 \%$ & 45.3166606 & 19 \\
\hline Costa Rica & 19.69581909 & 0.61957154 & 0 & & 0 & $0.00 \%$ & 58.4678857 & 17 \\
\hline Croacia & $\mathbf{0 . 2 3 0 0 7 7 5 0 7}$ & 0.69023252 & 0 & & & $0.00 \%$ & & 36 \\
\hline Cuba & 0.218202439 & 0.65460732 & 0 & & 0 & $0.00 \%$ & & 38 \\
\hline Dinamarca & 83.65616966 & 0.79063821 & 0 & & 0 & $0.00 \%$ & 250.177871 & 6 \\
\hline Ecuador & 11.63146309 & 0.47927276 & 0 & & 0 & $0.00 \%$ & 34.4151165 & 23 \\
\hline Egipto & 8.238851783 & 0.35578943 & 0 & & 0 & $0.00 \%$ & 24.3607659 & 27 \\
\hline El Salvador & 0.15011477 & 0.45034431 & 0 & & 0 & $0.00 \%$ & & 39 \\
\hline España & 25.02948634 & 0.74134146 & 0 & & 0 & $0.00 \%$ & 74.3471176 & 14 \\
\hline Estados Unidos & 163.2582606 & 0.7545122 & 0 & & 0 & $0.00 \%$ & 489.020269 & 1 \\
\hline Etiopía & 0.078159079 & 0.23447724 & 0 & & 0 & $0.00 \%$ & & 42 \\
\hline Finlandia & 73.83838688 & 0.73073577 & 0 & & 0 & $0.00 \%$ & 220.784425 & 9 \\
\hline Francia & 80.39503652 & 0.75195122 & 0 & & 0 & $0.00 \%$ & 240.433158 & 8 \\
\hline Guatemala & 13.94562107 & 0.35459431 & 0 & & 0 & $0.00 \%$ & 41.4822689 & 22 \\
\hline Guinea & 0.041407317 & 0.12422195 & 0 & & 0 & $0.00 \%$ & & 45 \\
\hline
\end{tabular}




\begin{tabular}{|c|c|c|c|c|c|c|c|c|}
\hline Haití & 0.09808645 & 0.29425935 & 0 & & 0 & $0.00 \%$ & & 41 \\
\hline Honduras & 9.443181903 & 0.36506057 & 0 & & 0 & $0.00 \%$ & 27.9644851 & 26 \\
\hline Irán & 0.113004472 & 0.33901341 & 0 & & 0 & $0.00 \%$ & & 40 \\
\hline Japón & 31.33938422 & 0.72183333 & 0 & & 0 & $0.00 \%$ & 93.2963193 & 13 \\
\hline Mozambique & 0.058148645 & 0.17444593 & 0 & $0.00 \%$ & 0 & $0.00 \%$ & & 44 \\
\hline México & 19.64127754 & 0.54382805 & 0 & $0.00 \%$ & 0 & $0.00 \%$ & 58.3800046 & 18 \\
\hline Nepal & 2.868573786 & 0.23069106 & 0 & & 0 & $0.00 \%$ & 8.3750303 & 34 \\
\hline Nicaragua & 7.290312552 & 0.37622276 & 0 & & 0 & $0.00 \%$ & 21.4947149 & 28 \\
\hline Nigeria & 5.206945139 & 0.23121016 & 0 & & 0 & $0.00 \%$ & 15.3896253 & 31 \\
\hline Noruega & 86.8217273 & 0.8091748 & 0 & & 0 & $0.00 \%$ & 259.656007 & 5 \\
\hline Panamá & 21.98537986 & 0.6047248 & 0 & $0.00 \%$ & 0 & $0.00 \%$ & 65.3514148 & 15 \\
\hline Perú & 15.24166028 & 0.38644593 & 0 & & 0 & $0.00 \%$ & 45.3385349 & 20 \\
\hline Portugal & 21.25055613 & 0.64109268 & 0 & & 0 & $0.00 \%$ & 63.1105757 & 16 \\
\hline Reino Unido & 80.81056008 & 0.76463415 & 0 & & 0 & $0.00 \%$ & 241.667046 & 7 \\
\hline Senegal & 14.07234778 & 0.2343878 & 0 & & 0 & $0.00 \%$ & 41.9826555 & 21 \\
\hline Sudán & 6.160130673 & 0.28089837 & 0 & & 0 & $0.00 \%$ & 18.1994936 & 29 \\
\hline Suiza & 109.6765234 & 0.77741463 & 0 & & 0 & $0.00 \%$ & 328.252156 & 3 \\
\hline Tailandia & 5.90186213 & 0.51398049 & 0 & $0.00 \%$ & 0 & $0.00 \%$ & 17.1916059 & 30 \\
\hline Uganda & 3.359273358 & 0.32554228 & 0 & & 0 & $0.00 \%$ & 9.7522778 & 33 \\
\hline Uruguay & 33.5047458 & 0.71706626 & 0 & & 0 & $0.00 \%$ & 99.7971711 & 11 \\
\hline Venezuela & 62.9931486 & 0.56810732 & 0 & & 0 & $0.00 \%$ & 188.411338 & 10 \\
\hline Yemen & 0.072546477 & 0.21763943 & 0 & & & $0.00 \%$ & & 43 \\
\hline
\end{tabular}

Fuente: Elaboración propia a partir de la base de datos del Banco Mundial, periodo 1960-1980, (data.worldbank.org) 


\begin{tabular}{|c|c|c|c|c|c|c|c|c|}
\hline \multicolumn{9}{|c|}{ Año 1962} \\
\hline Country & $\begin{array}{c}\text { Human } \\
\text { Development } \\
\text { Index }\end{array}$ & $\begin{array}{c}\text { Life } \\
\text { Expectancy } \\
\text { Index }\end{array}$ & $\begin{array}{l}\text { Schooling } \\
\text { Index }\end{array}$ & $\begin{array}{c}\text { Adult } \\
\text { Literacy } \\
\text { Index } \\
(\%)\end{array}$ & $\begin{array}{c}\text { Combined } \\
\text { Enrolment } \\
\text { Rate }(\%)\end{array}$ & $\begin{array}{c}\text { Gross } \\
\text { Enrolment } \\
\text { Index }\end{array}$ & $\begin{array}{l}\text { GDCP } \\
\text { Index }\end{array}$ & $\begin{array}{c}\text { Classification } \\
\text { according to } \\
\text { IDH or Index } \\
\text { of Human } \\
\text { development }\end{array}$ \\
\hline Alemania & 0.250056098 & 0.75016829 & 0 & $0.00 \%$ & & $0.00 \%$ & & 36 \\
\hline Argentina & 63.84624953 & 0.67315407 & 0 & & 0 & $0.00 \%$ & 190.865595 & 11 \\
\hline Australia & 102.9270878 & 0.76570732 & 0 & & 0 & $0.00 \%$ & 308.015556 & 4 \\
\hline Bolivia & 10.4744863 & 0.30454228 & 0 & & 0 & $0.00 \%$ & 31.1189166 & 26 \\
\hline Brasil & 14.25666899 & 0.5068626 & 0 & $0.00 \%$ & 0 & $0.00 \%$ & 42.2631444 & 23 \\
\hline Canadá & 125.4704348 & 0.77278455 & 0 & & 0 & $0.00 \%$ & 375.63852 & 2 \\
\hline Chile & 37.96747835 & 0.54715935 & 0 & & 0 & $0.00 \%$ & 113.355276 & 12 \\
\hline China & 3.735999159 & 0.32840325 & 0 & & 0 & $0.00 \%$ & 10.8795942 & 33 \\
\hline Colombia & 16.19914095 & 0.54558089 & 0 & & 0 & $0.00 \%$ & 48.051842 & 21 \\
\hline Costa Rica & 18.58201023 & 0.62898252 & 0 & & 0 & $0.00 \%$ & 55.1170482 & 19 \\
\hline Croacia & 0.232261382 & 0.69678415 & 0 & & & $0.00 \%$ & & 37 \\
\hline Cuba & 0.221670461 & 0.66501138 & 0 & & 0 & $0.00 \%$ & & 38 \\
\hline Dinamarca & 93.53027537 & 0.7886626 & 0 & & 0 & $0.00 \%$ & 279.802163 & 5 \\
\hline Ecuador & 11.06505871 & 0.48916829 & 0 & & 0 & $0.00 \%$ & 32.7060078 & 25 \\
\hline Egipto & 7.391564087 & 0.36282846 & 0 & & 0 & $0.00 \%$ & 21.8118638 & 29 \\
\hline El Salvador & 0.153951762 & 0.46185528 & 0 & & 0 & $0.00 \%$ & & 39 \\
\hline España & 28.93263277 & 0.74198374 & 0 & & 0 & $0.00 \%$ & 86.0559146 & 15 \\
\hline Estados Unidos & 172.9036228 & 0.75199187 & 0 & & 0 & $0.00 \%$ & 517.958877 & 1 \\
\hline Etiopía & 0.081650813 & 0.24495244 & 0 & & 0 & $0.00 \%$ & & 42 \\
\hline Finlandia & 78.52553123 & 0.72629675 & 0 & & 0 & $0.00 \%$ & 234.850297 & 9 \\
\hline Francia & 88.46564538 & 0.7552439 & 0 & & 0 & $0.00 \%$ & 264.641692 & 7 \\
\hline Guatemala & 14.42707735 & 0.36369106 & 0 & & 0 & $0.00 \%$ & 42.917541 & 22 \\
\hline
\end{tabular}




\begin{tabular}{|c|c|c|c|c|c|c|c|c|}
\hline Guinea & 0.041856098 & 0.12556829 & 0 & & 0 & $0.00 \%$ & & 45 \\
\hline Haití & 0.101238618 & 0.30371585 & 0 & & 0 & $0.00 \%$ & & 41 \\
\hline Honduras & 9.953553736 & 0.37646626 & 0 & & 0 & $0.00 \%$ & 29.4841949 & 27 \\
\hline Irán & 0.117139295 & 0.35141789 & 0 & & 0 & $0.00 \%$ & & 40 \\
\hline Japón & 35.23837542 & 0.7265813 & 0 & & 0 & $0.00 \%$ & 104.988545 & 14 \\
\hline Mozambique & 0.060623713 & 0.18187114 & 0 & $0.00 \%$ & 0 & $0.00 \%$ & & 44 \\
\hline México & 20.46473036 & 0.55262154 & 0 & $0.00 \%$ & 0 & $0.00 \%$ & 60.8415695 & 18 \\
\hline Nepal & 3.054837635 & 0.23669024 & 0 & & 0 & $0.00 \%$ & 8.92782266 & 35 \\
\hline Nicaragua & 7.814304608 & 0.38727073 & 0 & & 0 & $0.00 \%$ & 23.0556431 & 28 \\
\hline Nigeria & 5.619738338 & 0.23742805 & 0 & & 0 & $0.00 \%$ & 16.621787 & 32 \\
\hline Noruega & 92.76975934 & 0.80746748 & 0 & & 0 & $0.00 \%$ & 277.501811 & 6 \\
\hline Panamá & 23.23295399 & 0.61257317 & 0 & $0.00 \%$ & 0 & $0.00 \%$ & 69.0862888 & 16 \\
\hline Perú & 16.80131179 & 0.39506463 & 0 & & 0 & $0.00 \%$ & 50.0088707 & 20 \\
\hline Portugal & 22.65062382 & 0.6481813 & 0 & & 0 & $0.00 \%$ & 67.3036902 & 17 \\
\hline Reino Unido & 84.21048621 & 0.76544715 & 0 & & 0 & $0.00 \%$ & 251.866011 & 8 \\
\hline Senegal & 14.03425284 & 0.23635081 & 0 & & 0 & $0.00 \%$ & 41.8664077 & 24 \\
\hline Sudán & 6.52601966 & 0.28579837 & 0 & & 0 & $0.00 \%$ & 19.2922606 & 30 \\
\hline Suiza & 118.5797731 & 0.76993496 & 0 & & 0 & $0.00 \%$ & 354.969384 & 3 \\
\hline Tailandia & 6.253089408 & 0.52250041 & 0 & $0.00 \%$ & 0 & $0.00 \%$ & 18.2367678 & 31 \\
\hline Uganda & 3.306789836 & 0.33474268 & $\overline{0}$ & & 0 & $0.00 \%$ & 9.58562683 & 34 \\
\hline Uruguay & 36.50090767 & 0.72009837 & 0 & & 0 & $0.00 \%$ & 108.782625 & 13 \\
\hline Venezuela & 67.15141171 & 0.57752439 & 0 & & 0 & $0.00 \%$ & 200.876711 & 10 \\
\hline Yemen & 0.074039837 & 0.22211951 & 0 & & & $0.00 \%$ & & 43 \\
\hline
\end{tabular}

Fuente: Elaboración propia a partir de la base de datos del Banco Mundial, periodo 1960-1980, (data.worldbank.org) 


\begin{tabular}{|c|c|c|c|c|c|c|c|c|}
\hline \multicolumn{9}{|c|}{ Año 1963} \\
\hline Country & $\begin{array}{c}\text { Human } \\
\text { Development } \\
\text { Index }\end{array}$ & $\begin{array}{c}\text { Life } \\
\text { Expectancy } \\
\text { Index }\end{array}$ & $\begin{array}{l}\text { Schooling } \\
\text { Index }\end{array}$ & $\begin{array}{c}\text { Adult } \\
\text { Literacy } \\
\text { Index } \\
(\%)\end{array}$ & $\begin{array}{c}\text { Combined } \\
\text { Enrolment } \\
\text { Rate }(\%)\end{array}$ & $\begin{array}{c}\text { Gross } \\
\text { Enrolment } \\
\text { Index }\end{array}$ & $\begin{array}{l}\text { GDCP } \\
\text { Index }\end{array}$ & $\begin{array}{c}\text { Classification } \\
\text { according to } \\
\text { IDH or Index } \\
\text { of Human } \\
\text { development }\end{array}$ \\
\hline Alemania & 0.250955285 & 0.75286585 & 0 & $0.00 \%$ & & $0.00 \%$ & - & 36 \\
\hline Argentina & 46.96462467 & 0.67442561 & 0 & & 0 & $0.00 \%$ & 140.219448 & 11 \\
\hline Australia & 109.2054975 & 0.76519512 & 0 & & 0 & $0.00 \%$ & 326.851297 & 4 \\
\hline Bolivia & 11.03896677 & 0.30977967 & 0 & & 0 & $0.00 \%$ & 32.8071206 & 26 \\
\hline Brasil & 15.99684524 & 0.5141374 & 0 & $0.00 \%$ & 0 & $0.00 \%$ & 47.4763983 & 21 \\
\hline Canadá & 131.0122318 & 0.7730122 & 0 & & 0 & $0.00 \%$ & 392.263683 & 2 \\
\hline Chile & 36.89324092 & 0.55480691 & 0 & & 0 & $0.00 \%$ & 110.124916 & 13 \\
\hline China & 3.961909094 & 0.35539187 & 0 & & 0 & $0.00 \%$ & 11.5303354 & 33 \\
\hline Colombia & 15.31351087 & 0.55326382 & 0 & & 0 & $0.00 \%$ & 45.3872688 & 23 \\
\hline Costa Rica & 19.17492502 & 0.63821504 & 0 & & 0 & $0.00 \%$ & 56.88656 & 19 \\
\hline Croacia & 0.234180081 & 0.70254024 & 0 & & & $0.00 \%$ & & 37 \\
\hline Cuba & 0.225199458 & 0.67559837 & 0 & & 0 & $0.00 \%$ & & 38 \\
\hline Dinamarca & 98.77932773 & 0.79000813 & 0 & & 0 & $0.00 \%$ & 295.547975 & 6 \\
\hline Ecuador & 11.65368118 & 0.49819593 & 0 & & 0 & $0.00 \%$ & 34.4628476 & 25 \\
\hline Egipto & 7.478659927 & 0.3700187 & 0 & & 0 & $0.00 \%$ & 22.0659611 & 29 \\
\hline El Salvador & 0.157549729 & 0.47264919 & 0 & & 0 & $0.00 \%$ & & 39 \\
\hline España & 33.90066957 & 0.74468699 & 0 & & 0 & $0.00 \%$ & 100.957322 & 14 \\
\hline Estados Unidos & 179.8162553 & 0.74861789 & 0 & & 0 & $0.00 \%$ & 538.700148 & 1 \\
\hline Etiopía & 0.084865447 & 0.25459634 & 0 & & 0 & $0.00 \%$ & & 42 \\
\hline Finlandia & 84.68208216 & 0.73354472 & 0 & & 0 & $0.00 \%$ & 253.312702 & 9 \\
\hline Francia & 97.73591898 & 0.75857724 & 0 & & 0 & $0.00 \%$ & 292.44918 & 7 \\
\hline Guatemala & 15.52141152 & 0.37302033 & 0 & & 0 & $0.00 \%$ & 46.1912142 & 22 \\
\hline
\end{tabular}




\begin{tabular}{|c|c|c|c|c|c|c|c|c|}
\hline Guinea & 0.042279946 & 0.12683984 & 0 & & 0 & $0.00 \%$ & & 45 \\
\hline Haití & 0.104357453 & 0.31307236 & 0 & & 0 & $0.00 \%$ & & 41 \\
\hline Honduras & 10.19405391 & 0.38759797 & 0 & & 0 & $0.00 \%$ & 30.1945638 & 27 \\
\hline Irán & 0.121173713 & 0.36352114 & $\overline{0}$ & & $\overline{0}$ & $0.00 \%$ & & 40 \\
\hline Japón & 39.93020356 & 0.74430081 & 0 & & 0 & $0.00 \%$ & 119.04631 & 12 \\
\hline Mozambique & 0.062993225 & 0.18897967 & 0 & $0.00 \%$ & 0 & $0.00 \%$ & & 44 \\
\hline México & 22.06776832 & 0.56036585 & $\overline{0}$ & $0.00 \%$ & $\overline{0}$ & $0.00 \%$ & 65.6429391 & 18 \\
\hline Nepal & 2.572848227 & 0.24291545 & 0 & & 0 & $0.00 \%$ & 7.47562923 & 35 \\
\hline Nicaragua & 8.387325345 & 0.39830163 & 0 & & 0 & $0.00 \%$ & 24.7636744 & 28 \\
\hline Nigeria & 5.796222902 & 0.24360407 & 0 & & 0 & $0.00 \%$ & 17.1450646 & 32 \\
\hline Noruega & 98.79489887 & 0.80129268 & 0 & & 0 & $0.00 \%$ & 295.583404 & 5 \\
\hline Panamá & 24.9957533 & 0.62018659 & 0 & $0.00 \%$ & 0 & $0.00 \%$ & 74.3670733 & 16 \\
\hline Perú & $\mathbf{1 7 . 8 9 2 0 1 8 1 5}$ & 0.40323496 & 0 & & 0 & $0.00 \%$ & 53.2728195 & 20 \\
\hline Portugal & 24.02484511 & 0.65517602 & 0 & & 0 & $0.00 \%$ & 71.4193593 & 17 \\
\hline Reino Unido & 88.60301504 & 0.76378049 & 0 & & 0 & $0.00 \%$ & 265.045265 & 8 \\
\hline Senegal & 14.11474186 & 0.23824715 & 0 & & 0 & $0.00 \%$ & 42.1059784 & 24 \\
\hline Sudán & 6.461770335 & 0.29114837 & 0 & & 0 & $0.00 \%$ & 19.0941626 & 31 \\
\hline Suiza & 127.636565 & 0.76979268 & 0 & & 0 & $0.00 \%$ & 382.139902 & 3 \\
\hline Tailandia & 6.496981145 & 0.53053821 & 0 & $0.00 \%$ & 0 & $0.00 \%$ & 18.9604052 & 30 \\
\hline Uganda & 3.694872122 & 0.34389431 & 0 & & 0 & $0.00 \%$ & 10.7407221 & 34 \\
\hline Uruguay & 32.47443372 & 0.7224626 & 0 & & 0 & $0.00 \%$ & 96.7008386 & 15 \\
\hline Venezuela & 69.91932802 & 0.58685407 & $\overline{0}$ & & $\overline{0}$ & $0.00 \%$ & 209.17113 & 10 \\
\hline Yemen & 0.075524797 & 0.22657439 & 0 & & & $0.00 \%$ & & 43 \\
\hline
\end{tabular}

Fuente: Elaboración propia a partir de la base de datos del Banco Mundial, periodo 1960-1980, (data.worldbank.org) 


\begin{tabular}{|c|c|c|c|c|c|c|c|c|}
\hline \multicolumn{9}{|c|}{ Año 1964} \\
\hline Country & $\begin{array}{c}\text { Human } \\
\text { Development } \\
\text { Index }\end{array}$ & $\begin{array}{c}\text { Life } \\
\text { Expectancy } \\
\text { Index }\end{array}$ & $\begin{array}{l}\text { Schooling } \\
\text { Index }\end{array}$ & $\begin{array}{c}\text { Adult } \\
\text { Literacy } \\
\text { Index } \\
(\%)\end{array}$ & $\begin{array}{c}\text { Combined } \\
\text { Enrolment } \\
\text { Rate }(\%)\end{array}$ & $\begin{array}{c}\text { Gross } \\
\text { Enrolment } \\
\text { Index }\end{array}$ & $\begin{array}{l}\text { GDCP } \\
\text { Index }\end{array}$ & $\begin{array}{l}\text { Classification } \\
\text { according to } \\
\text { IDH or Index } \\
\text { of Human } \\
\text { development }\end{array}$ \\
\hline Alemania & 0.251733062 & 0.75519919 & 0 & $0.00 \%$ & & $0.00 \%$ & & 36 \\
\hline Argentina & 64.8271178 & 0.67565122 & 0 & & 0 & $0.00 \%$ & 193.805702 & 10 \\
\hline Australia & 118.3484947 & 0.76468293 & 0 & & 0 & $0.00 \%$ & 354.280801 & 4 \\
\hline Bolivia & 12.17788755 & 0.31505854 & 0 & & 0 & $0.00 \%$ & 36.2186041 & 26 \\
\hline Brasil & 14.30618995 & 0.52112724 & 0 & $0.00 \%$ & 0 & $0.00 \%$ & 42.3974426 & 24 \\
\hline Canadá & 140.7326466 & 0.77960569 & 0 & & 0 & $0.00 \%$ & 421.418334 & 2 \\
\hline Chile & 38.0583412 & 0.56301585 & 0 & & 0 & $0.00 \%$ & 113.612008 & 14 \\
\hline China & 4.54420617 & 0.3929065 & 0 & & 0 & $0.00 \%$ & 13.239712 & 33 \\
\hline Colombia & 18.42828899 & 0.5605626 & 0 & & 0 & $0.00 \%$ & 54.7243044 & 21 \\
\hline Costa Rica & 19.65270087 & 0.64727764 & 0 & & 0 & $0.00 \%$ & 58.310825 & 20 \\
\hline Croacia & 0.235870054 & 0.70761016 & 0 & & & $0.00 \%$ & & 37 \\
\hline Cuba & $\mathbf{0 . 2 2 8 7 5 3 2 5 2}$ & 0.68625976 & 0 & & 0 & $0.00 \%$ & & 38 \\
\hline Dinamarca & 112.0137738 & 0.7914187 & 0 & & 0 & $0.00 \%$ & 335.249903 & 5 \\
\hline Ecuador & 12.61529784 & 0.50633049 & 0 & & 0 & $0.00 \%$ & 37.339563 & 25 \\
\hline Egipto & 8.384720333 & 0.37740122 & 0 & & 0 & $0.00 \%$ & 24.7767598 & 29 \\
\hline El Salvador & 0.160883333 & 0.48265 & 0 & & 0 & $0.00 \%$ & & 39 \\
\hline España & 37.5628797 & 0.7566626 & 0 & & 0 & $0.00 \%$ & 111.931977 & 15 \\
\hline Estados Unidos & 190.4543397 & 0.75276423 & 0 & & 0 & $0.00 \%$ & 570.610255 & 1 \\
\hline Etiopía & $\mathbf{0 . 0 8 7 7 5 2 9 8 1}$ & 0.26325894 & 0 & & 0 & $0.00 \%$ & & 42 \\
\hline Finlandia & $\mathbf{9 4 . 9 8 5 9 3 4 3 8}$ & 0.73701626 & 0 & & 0 & $0.00 \%$ & 284.220787 & 9 \\
\hline Francia & 106.9661827 & 0.76105691 & 0 & & 0 & $0.00 \%$ & 320.137491 & 7 \\
\hline Guatemala & 15.54752432 & 0.38258984 & 0 & & 0 & $0.00 \%$ & 46.2599831 & 22 \\
\hline
\end{tabular}




\begin{tabular}{|c|c|c|c|c|c|c|c|c|}
\hline Guinea & 0.042723171 & 0.12816951 & 0 & & 0 & $0.00 \%$ & & 45 \\
\hline Haití & 0.107415447 & 0.32224634 & 0 & & 0 & $0.00 \%$ & & 41 \\
\hline Honduras & 11.01441943 & 0.39836301 & 0 & & 0 & $0.00 \%$ & 32.6448953 & 27 \\
\hline Irán & 0.12510542 & 0.37531626 & 0 & & 0 & $0.00 \%$ & & 40 \\
\hline Japón & 46.48606915 & 0.75220732 & 0 & & 0 & $0.00 \%$ & 138.706 & 12 \\
\hline Mozambique & 0.065270867 & 0.1958126 & 0 & $0.00 \%$ & 0 & $0.00 \%$ & & 44 \\
\hline México & 25.34969346 & 0.56727683 & 0 & $0.00 \%$ & 0 & $0.00 \%$ & 75.4818035 & 18 \\
\hline Nepal & 2.520208297 & 0.24940081 & 0 & & 0 & $0.00 \%$ & 7.31122408 & 35 \\
\hline Nicaragua & 9.52536579 & 0.40931585 & 0 & & 0 & $0.00 \%$ & 28.1667815 & 28 \\
\hline Nigeria & 6.110083955 & 0.24977154 & 0 & & 0 & $0.00 \%$ & 18.0804803 & 32 \\
\hline Noruega & 107.8273991 & 0.80993089 & 0 & & 0 & $0.00 \%$ & 322.672266 & 6 \\
\hline Panamá & 26.05430468 & 0.62768984 & 0 & $0.00 \%$ & 0 & $0.00 \%$ & 77.5352242 & 16 \\
\hline Perú & 21.05523198 & 0.41109837 & 0 & & 0 & $0.00 \%$ & 62.7545976 & 19 \\
\hline Portugal & 26.04497205 & 0.66205325 & 0 & & 0 & $0.00 \%$ & 77.4728629 & 17 \\
\hline Reino Unido & 96.21746629 & 0.77707317 & 0 & & 0 & $0.00 \%$ & 287.875326 & 8 \\
\hline Senegal & 14.54989102 & 0.2402687 & 0 & & 0 & $0.00 \%$ & 43.4094044 & 23 \\
\hline Sudán & 6.460301774 & 0.29693211 & 0 & & 0 & $0.00 \%$ & 19.0839732 & 31 \\
\hline Suiza & 139.1640326 & 0.78463008 & 0 & & 0 & $0.00 \%$ & 416.707468 & 3 \\
\hline Tailandia & 6.932040489 & 0.53815325 & 0 & $0.00 \%$ & 0 & $0.00 \%$ & 20.2579682 & 30 \\
\hline Uganda & 4.093560404 & 0.35300528 & 0 & & 0 & $0.00 \%$ & 11.9276759 & 34 \\
\hline Uruguay & 41.19651413 & 0.72415 & 0 & & 0 & $0.00 \%$ & 122.865392 & 13 \\
\hline Venezuela & 57.653262 & 0.59608821 & 0 & & 0 & $0.00 \%$ & 172.363698 & 11 \\
\hline Yemen & 0.077004201 & 0.2310126 & 0 & & & $0.00 \%$ & & 43 \\
\hline
\end{tabular}

Fuente: Elaboración propia a partir de la base de datos del Banco Mundial, periodo 1960-1980, (data.worldbank.org) 


\begin{tabular}{|c|c|c|c|c|c|c|c|c|}
\hline \multicolumn{9}{|c|}{ Año 1965} \\
\hline Country & $\begin{array}{c}\text { Human } \\
\text { Development } \\
\text { Index }\end{array}$ & $\begin{array}{c}\text { Life } \\
\text { Expectancy } \\
\text { Index }\end{array}$ & $\begin{array}{l}\text { Schooling } \\
\text { Index }\end{array}$ & $\begin{array}{c}\text { Adult } \\
\text { Literacy } \\
\text { Index } \\
(\%)\end{array}$ & $\begin{array}{c}\text { Combined } \\
\text { Enrolment } \\
\text { Rate }(\%)\end{array}$ & $\begin{array}{c}\text { Gross } \\
\text { Enrolment } \\
\text { Index }\end{array}$ & $\begin{array}{l}\text { GDCP } \\
\text { Index }\end{array}$ & $\begin{array}{c}\text { Classification } \\
\text { according to } \\
\text { IDH or Index } \\
\text { of Human } \\
\text { development }\end{array}$ \\
\hline Alemania & 0.25236748 & 0.75710244 & 0 & $0.00 \%$ & & $0.00 \%$ & & 37 \\
\hline Argentina & 70.70431582 & 0.67709797 & 0 & & 0 & $0.00 \%$ & 211.435849 & 10 \\
\hline Australia & 126.682438 & 0.76417073 & 0 & & 0 & $0.00 \%$ & 379.283143 & 4 \\
\hline Bolivia & 13.33078688 & 0.32030366 & 0 & & 0 & $0.00 \%$ & 39.672057 & 28 \\
\hline Brasil & 14.28678533 & 0.52784715 & 0 & $0.00 \%$ & 0 & $0.00 \%$ & 42.3325088 & 26 \\
\hline Canadá & 152.420231 & 0.78120325 & 0 & & 0 & $0.00 \%$ & 456.47949 & 2 \\
\hline Chile & 38.85255757 & 0.57171138 & 0 & & 0 & $0.00 \%$ & 115.985961 & 15 \\
\hline China & 5.312550891 & 0.43811545 & 0 & & 0 & $0.00 \%$ & 15.4995372 & 35 \\
\hline Colombia & 17.29029573 & 0.56753415 & 0 & & 0 & $0.00 \%$ & 51.303353 & 22 \\
\hline Costa Rica & 20.80185172 & 0.65610366 & 0 & & 0 & $0.00 \%$ & 61.7494515 & 21 \\
\hline Croacia & 0.237376152 & 0.71212846 & 0 & & & $0.00 \%$ & & 38 \\
\hline Cuba & 0.232292954 & 0.69687886 & 0 & & 0 & $0.00 \%$ & & 39 \\
\hline Dinamarca & 124.8474248 & 0.7895122 & 0 & & 0 & $0.00 \%$ & 373.752762 & 5 \\
\hline Ecuador & 25.39148211 & 0.51366382 & 0 & & 0 & $0.00 \%$ & 75.6607825 & 19 \\
\hline Egipto & 8.735830995 & 0.38492602 & 0 & & 0 & $0.00 \%$ & 25.822567 & 30 \\
\hline El Salvador & 0.163944309 & 0.49183293 & 0 & & 0 & $0.00 \%$ & & 40 \\
\hline España & 43.10191847 & 0.7634878 & 0 & & 0 & $0.00 \%$ & 128.542268 & 13 \\
\hline Estados Unidos & 203.8851382 & 0.75357724 & 0 & & 0 & $0.00 \%$ & 610.901837 & 1 \\
\hline Etiopía & 0.090291328 & 0.27087398 & 0 & & 0 & $0.00 \%$ & & 42 \\
\hline Finlandia & 104.6974518 & 0.73296341 & 0 & & 0 & $0.00 \%$ & 313.359392 & 8 \\
\hline Francia & 113.7958654 & 0.76353659 & 0 & & 0 & $0.00 \%$ & 340.624059 & 7 \\
\hline Guatemala & 15.51498458 & 0.39255813 & 0 & & 0 & $0.00 \%$ & 46.1523956 & 23 \\
\hline
\end{tabular}




\begin{tabular}{|c|c|c|c|c|c|c|c|c|}
\hline Guinea & 0.043268157 & 0.12980447 & 0 & & 0 & $0.00 \%$ & & 45 \\
\hline Haití & 0.110376423 & 0.33112927 & 0 & & 0 & $0.00 \%$ & & 41 \\
\hline Honduras & 11.90848853 & 0.40871992 & 0 & & 0 & $0.00 \%$ & 35.3167457 & 29 \\
\hline Irán & 13.55647196 & 0.38670569 & 0 & & 0 & $0.00 \%$ & 40.2827102 & 27 \\
\hline Japón & 51.16641491 & 0.75336585 & 0 & & 0 & $0.00 \%$ & 152.745879 & 12 \\
\hline Mozambique & 0.067490108 & 0.20247033 & 0 & $0.00 \%$ & 0 & $0.00 \%$ & & 44 \\
\hline México & 26.72195278 & 0.57357886 & 0 & $0.00 \%$ & 0 & $0.00 \%$ & 79.5922795 & 18 \\
\hline Nepal & 3.745942698 & 0.25617317 & 0 & & 0 & $0.00 \%$ & 10.9816549 & 36 \\
\hline Nicaragua & 15.10211694 & 0.42038089 & 0 & & 0 & $0.00 \%$ & 44.8859699 & 24 \\
\hline Nigeria & 6.334517809 & 0.25599065 & 0 & & 0 & $0.00 \%$ & 18.7475628 & 33 \\
\hline Noruega & 120.4340509 & 0.81205285 & 0 & & 0 & $0.00 \%$ & 360.4901 & 6 \\
\hline Panamá & 27.78422565 & 0.63514919 & 0 & $0.00 \%$ & 0 & $0.00 \%$ & 82.7175278 & 17 \\
\hline Perú & 24.26648998 & 0.41902073 & 0 & & 0 & $0.00 \%$ & 72.3804492 & 20 \\
\hline Portugal & 28.94743913 & 0.66881423 & 0 & & 0 & $0.00 \%$ & 86.1735032 & 16 \\
\hline Reino Unido & 102.9801306 & 0.77707317 & 0 & & 0 & $0.00 \%$ & 308.163319 & 9 \\
\hline Senegal & 14.39601683 & 0.24255691 & 0 & & 0 & $0.00 \%$ & 42.9454936 & 25 \\
\hline Sudán & 6.551450201 & 0.30307439 & 0 & & 0 & $0.00 \%$ & 19.3512762 & 32 \\
\hline Suiza & 145.7953957 & 0.78669512 & 0 & & 0 & $0.00 \%$ & 436.599492 & 3 \\
\hline Tailandia & 7.600187265 & 0.54540244 & 0 & $0.00 \%$ & 0 & $0.00 \%$ & 22.2551594 & 31 \\
\hline Uganda & 6.004659142 & 0.36231707 & 0 & & 0 & $0.00 \%$ & 17.6516604 & 34 \\
\hline Uruguay & 38.98938068 & 0.72518659 & 0 & & 0 & $0.00 \%$ & 116.242955 & 14 \\
\hline Venezuela & 58.68254587 & 0.60514431 & 0 & & 0 & $0.00 \%$ & 175.442493 & 11 \\
\hline Yemen & 0.078422493 & 0.23526748 & 0 & & & $0.00 \%$ & & 43 \\
\hline
\end{tabular}

Fuente: Elaboración propia a partir de la base de datos del Banco Mundial, periodo 1960-1980, (data.worldbank.org) 


\begin{tabular}{|c|c|c|c|c|c|c|c|c|}
\hline \multicolumn{9}{|c|}{ Año 1966} \\
\hline Country & $\begin{array}{c}\text { Human } \\
\text { Development } \\
\text { Index }\end{array}$ & $\begin{array}{c}\text { Life } \\
\text { Expectancy } \\
\text { Index }\end{array}$ & $\begin{array}{l}\text { Schooling } \\
\text { Index }\end{array}$ & $\begin{array}{c}\text { Adult } \\
\text { Literacy } \\
\text { Index } \\
(\%)\end{array}$ & $\begin{array}{c}\text { Combined } \\
\text { Enrolment } \\
\text { Rate }(\%)\end{array}$ & $\begin{array}{c}\text { Gross } \\
\text { Enrolment } \\
\text { Index }\end{array}$ & $\begin{array}{l}\text { GDCP } \\
\text { Index }\end{array}$ & $\begin{array}{l}\text { Classification } \\
\text { according to } \\
\text { IDH or Index } \\
\text { of Human } \\
\text { development }\end{array}$ \\
\hline Alemania & 0.252825339 & 0.75847602 & 0 & $0.00 \%$ & & $0.00 \%$ & & 37 \\
\hline Argentina & 70.39127434 & 0.67901585 & 0 & & 0 & $0.00 \%$ & 210.494807 & 10 \\
\hline Australia & 130.1063407 & 0.76365854 & 0 & & 0 & $0.00 \%$ & 389.555363 & 5 \\
\hline Bolivia & 14.26109753 & 0.32539837 & 0 & & 0 & $0.00 \%$ & 42.4578942 & 28 \\
\hline Brasil & 17.28344905 & 0.53432073 & 0 & $0.00 \%$ & 0 & $0.00 \%$ & 51.3160264 & 22 \\
\hline Canadá & 167.5046485 & 0.7834065 & 0 & & 0 & $0.00 \%$ & 501.730539 & 2 \\
\hline Chile & 44.03877593 & 0.58076016 & 0 & & 0 & $0.00 \%$ & 131.535568 & 14 \\
\hline China & 5.646474728 & 0.48668537 & 0 & & 0 & $0.00 \%$ & 16.4527388 & 35 \\
\hline Colombia & 15.81059523 & 0.57413455 & 0 & & 0 & $0.00 \%$ & 46.8576511 & 23 \\
\hline Costa Rica & 22.02516821 & 0.66466911 & 0 & & 0 & $0.00 \%$ & 65.4108355 & 21 \\
\hline Croacia & 0.238757317 & 0.71627195 & 0 & & & $0.00 \%$ & & 38 \\
\hline Cuba & 0.235763144 & 0.70728943 & 0 & & 0 & $0.00 \%$ & & 39 \\
\hline Dinamarca & 135.9373971 & 0.79073577 & 0 & & 0 & $0.00 \%$ & 407.021456 & 4 \\
\hline Ecuador & 25.10172793 & 0.52034634 & 0 & & 0 & $0.00 \%$ & 74.7848374 & 20 \\
\hline Egipto & 8.893752783 & 0.39258496 & 0 & & 0 & $0.00 \%$ & 26.2886734 & 30 \\
\hline El Salvador & 0.166735095 & 0.50020528 & 0 & & 0 & $0.00 \%$ & & 40 \\
\hline España & 49.49561471 & 0.76758537 & 0 & & 0 & $0.00 \%$ & 147.719259 & 13 \\
\hline Estados Unidos & 220.9828485 & 0.75353659 & 0 & & 0 & $0.00 \%$ & 662.195009 & 1 \\
\hline Etiopía & 0.09250813 & 0.27752439 & 0 & & 0 & $0.00 \%$ & & 42 \\
\hline Finlandia & 111.8285104 & 0.74128455 & 0 & & 0 & $0.00 \%$ & 334.744247 & 8 \\
\hline Francia & 122.0094415 & 0.76601626 & 0 & & 0 & $0.00 \%$ & 365.262308 & 7 \\
\hline Guatemala & 15.78344966 & 0.40311585 & 0 & & 0 & $0.00 \%$ & 46.9472331 & 24 \\
\hline
\end{tabular}




\begin{tabular}{|c|c|c|c|c|c|c|c|c|}
\hline Guinea & 0.043997425 & 0.13199228 & 0 & & 0 & $0.00 \%$ & & 45 \\
\hline Haití & 0.113188076 & 0.33956423 & 0 & & 0 & $0.00 \%$ & & 41 \\
\hline Honduras & 12.52523007 & 0.41867642 & 0 & & 0 & $0.00 \%$ & 37.1570138 & 29 \\
\hline Irán & 14.39541324 & 0.39759268 & 0 & & 0 & $0.00 \%$ & 42.788647 & 27 \\
\hline Japón & 58.88880195 & 0.76644309 & 0 & & 0 & $0.00 \%$ & 175.899963 & 12 \\
\hline Mozambique & 0.069687127 & 0.20906138 & 0 & $0.00 \%$ & 0 & $0.00 \%$ & & 44 \\
\hline México & 28.87867103 & 0.57957033 & 0 & $0.00 \%$ & 0 & $0.00 \%$ & 86.0564428 & 18 \\
\hline Nepal & 4.568889227 & 0.26325122 & 0 & & 0 & $0.00 \%$ & 13.4434165 & 36 \\
\hline Nicaragua & 15.77741857 & 0.43155569 & 0 & & 0 & $0.00 \%$ & 46.9007 & 25 \\
\hline Nigeria & 6.731122526 & 0.26236301 & 0 & & 0 & $0.00 \%$ & 19.9310046 & 32 \\
\hline Noruega & 128.9324317 & 0.81658943 & 0 & & 0 & $0.00 \%$ & 385.980706 & 6 \\
\hline Panamá & 29.39751457 & 0.64256382 & 0 & $0.00 \%$ & 0 & $0.00 \%$ & 87.5499799 & 17 \\
\hline Perú & 27.93074424 & 0.42758374 & 0 & & 0 & $0.00 \%$ & 83.364649 & 19 \\
\hline Portugal & 31.95932085 & 0.67544472 & 0 & & 0 & $0.00 \%$ & 95.2025178 & 16 \\
\hline Reino Unido & 109.0258392 & 0.77621951 & 0 & & 0 & $0.00 \%$ & 326.301298 & 9 \\
\hline Senegal & 14.42083646 & 0.24524553 & 0 & & 0 & $0.00 \%$ & 43.0172639 & 26 \\
\hline Sudán & 6.535134755 & 0.30950041 & 0 & & 0 & $0.00 \%$ & 19.2959039 & 33 \\
\hline Suiza & 154.9345842 & 0.78892683 & 0 & & 0 & $0.00 \%$ & 464.014826 & 3 \\
\hline Tailandia & 8.886694266 & 0.55240894 & 0 & $0.00 \%$ & 0 & $0.00 \%$ & 26.1076739 & 31 \\
\hline Uganda & 6.076079103 & 0.3721626 & 0 & & 0 & $0.00 \%$ & 17.8560747 & 34 \\
\hline Uruguay & 36.9407564 & 0.72567195 & 0 & & 0 & $0.00 \%$ & 110.096597 & 15 \\
\hline Venezuela & 59.6639801 & 0.61399797 & 0 & & 0 & $0.00 \%$ & 178.377942 & 11 \\
\hline Yemen & 0.079715718 & 0.23914715 & 0 & & & $0.00 \%$ & & 43 \\
\hline
\end{tabular}

Fuente: Elaboración propia a partir de la base de datos del Banco Mundial, periodo 1960-1980, (data.worldbank.org) 


\begin{tabular}{|c|c|c|c|c|c|c|c|c|}
\hline \multicolumn{9}{|c|}{ Año 1967} \\
\hline Country & $\begin{array}{c}\text { Human } \\
\text { Development } \\
\text { Index }\end{array}$ & $\begin{array}{c}\text { Life } \\
\text { Expectancy } \\
\text { Index }\end{array}$ & $\begin{array}{l}\text { Schooling } \\
\text { Index }\end{array}$ & $\begin{array}{c}\text { Adult } \\
\text { Literacy } \\
\text { Index } \\
(\%)\end{array}$ & $\begin{array}{c}\text { Combined } \\
\text { Enrolment } \\
\text { Rate }(\%)\end{array}$ & $\begin{array}{c}\text { Gross } \\
\text { Enrolment } \\
\text { Index }\end{array}$ & $\begin{array}{l}\text { GDCP } \\
\text { Index }\end{array}$ & $\begin{array}{l}\text { Classification } \\
\text { according to } \\
\text { IDH or Index } \\
\text { of Human } \\
\text { development }\end{array}$ \\
\hline Alemania & 0.253123035 & 0.75936911 & 0 & $0.00 \%$ & & $0.00 \%$ & & 37 \\
\hline Argentina & 58.79507964 & 0.68147073 & 0 & & 0 & $0.00 \%$ & 175.703768 & 12 \\
\hline Australia & 143.2238225 & 0.7644878 & 0 & & 0 & $0.00 \%$ & 428.90698 & 5 \\
\hline Bolivia & 15.20827921 & 0.33036748 & 0 & & 0 & $0.00 \%$ & 45.2944701 & 27 \\
\hline Brasil & 19.03599892 & 0.5406561 & 0 & $0.00 \%$ & 0 & $0.00 \%$ & 56.5673407 & 22 \\
\hline Canadá & 176.5392008 & 0.78679675 & 0 & & 0 & $0.00 \%$ & 528.830806 & 2 \\
\hline Chile & 42.50619731 & 0.59005325 & 0 & & 0 & $0.00 \%$ & 126.928539 & 14 \\
\hline China & 5.234555006 & 0.53349797 & 0 & & 0 & $0.00 \%$ & 15.1701671 & 35 \\
\hline Colombia & 16.13622599 & 0.58032967 & 0 & & 0 & $0.00 \%$ & 47.8283483 & 24 \\
\hline Costa Rica & 23.11416408 & 0.67301585 & 0 & & 0 & $0.00 \%$ & 68.6694764 & 21 \\
\hline Croacia & 0.240055556 & 0.72016667 & 0 & & & $0.00 \%$ & & 38 \\
\hline Cuba & 0.239116531 & 0.71734959 & 0 & & 0 & $0.00 \%$ & & 39 \\
\hline Dinamarca & 147.1519391 & 0.79870325 & 0 & & 0 & $0.00 \%$ & 440.657114 & 4 \\
\hline Ecuador & 25.63344878 & 0.52669512 & 0 & & 0 & $0.00 \%$ & 76.3736512 & 20 \\
\hline Egipto & 9.060850615 & 0.40032724 & 0 & & 0 & $0.00 \%$ & 26.7822246 & 31 \\
\hline El Salvador & 0.169266531 & 0.50779959 & 0 & & 0 & $0.00 \%$ & & 40 \\
\hline España & 53.87221087 & 0.77088211 & 0 & & 0 & $0.00 \%$ & 160.84575 & 13 \\
\hline Estados Unidos & 230.9932878 & 0.75934959 & 0 & & 0 & $0.00 \%$ & 692.220514 & 1 \\
\hline Etiopía & 0.09448645 & 0.28345935 & 0 & & 0 & $0.00 \%$ & & 42 \\
\hline Finlandia & 113.1634382 & 0.74444309 & 0 & & 0 & $0.00 \%$ & 338.745871 & 8 \\
\hline Francia & 130.7609278 & 0.76934959 & 0 & & 0 & $0.00 \%$ & 391.513434 & 7 \\
\hline Guatemala & 16.06721709 & 0.4143378 & 0 & & 0 & $0.00 \%$ & 47.7873135 & 25 \\
\hline
\end{tabular}




\begin{tabular}{|c|c|c|c|c|c|c|c|c|}
\hline Guinea & 0.0449771 & 0.1349313 & 0 & & 0 & $0.00 \%$ & & 45 \\
\hline Haití & 0.115822493 & 0.34746748 & 0 & & 0 & $0.00 \%$ & & 41 \\
\hline Honduras & 13.27003776 & 0.42838252 & 0 & & 0 & $0.00 \%$ & 39.3817308 & 29 \\
\hline Irán & 15.53147544 & 0.40793699 & 0 & & 0 & $0.00 \%$ & 46.1864893 & 26 \\
\hline Japón & 68.37088027 & 0.77127642 & 0 & & 0 & $0.00 \%$ & 204.341364 & 10 \\
\hline Mozambique & 0.07190935 & 0.21572805 & 0 & $0.00 \%$ & 0 & $0.00 \%$ & & 44 \\
\hline México & 30.55061096 & 0.58550854 & 0 & $0.00 \%$ & 0 & $0.00 \%$ & 91.0663244 & 18 \\
\hline Nepal & 4.145605603 & 0.27062683 & 0 & & 0 & $0.00 \%$ & 12.16619 & 36 \\
\hline Nicaragua & 16.57989878 & 0.44283171 & 0 & & 0 & $0.00 \%$ & 49.2968646 & 23 \\
\hline Nigeria & 5.350547364 & 0.26893943 & 0 & & 0 & $0.00 \%$ & 15.7827027 & 34 \\
\hline Noruega & 139.8844562 & 0.81777642 & 0 & & 0 & $0.00 \%$ & 418.835592 & 6 \\
\hline Panamá & 31.80003845 & 0.6499 & 0 & $0.00 \%$ & 0 & $0.00 \%$ & 94.7502154 & 17 \\
\hline Perú & 27.53631912 & 0.43716179 & 0 & & 0 & $0.00 \%$ & 82.1717956 & 19 \\
\hline Portugal & 35.95690735 & 0.68197967 & 0 & & 0 & $0.00 \%$ & 107.188742 & 15 \\
\hline Reino Unido & 112.5895076 & 0.7854065 & 0 & & 0 & $0.00 \%$ & 336.983116 & 9 \\
\hline Senegal & 14.0069602 & 0.24842561 & 0 & & 0 & $0.00 \%$ & 41.772455 & 28 \\
\hline Sudán & 6.886047488 & 0.31606789 & 0 & & 0 & $0.00 \%$ & 20.3420746 & 32 \\
\hline Suiza & 164.7273536 & 0.79394309 & 0 & & 0 & $0.00 \%$ & 493.388118 & 3 \\
\hline Tailandia & 9.218241338 & 0.55930447 & 0 & $0.00 \%$ & 0 & $0.00 \%$ & 27.0954195 & 30 \\
\hline Uganda & 6.142670417 & 0.38261626 & 0 & & 0 & $0.00 \%$ & 18.045395 & 33 \\
\hline Uruguay & $\mathbf{3 2 . 3 1 4 3 7 3 7 5}$ & 0.72582358 & 0 & & 0 & $0.00 \%$ & 96.2172977 & 16 \\
\hline Venezuela & 59.8950255 & 0.62260854 & 0 & & 0 & $0.00 \%$ & 179.062468 & 11 \\
\hline Yemen & 0.080889566 & 0.2426687 & 0 & & & $0.00 \%$ & & 43 \\
\hline
\end{tabular}

Fuente: Elaboración propia a partir de la base de datos del Banco Mundial, periodo 1960-1980, (data.worldbank.org) 


\begin{tabular}{|c|c|c|c|c|c|c|c|c|}
\hline \multicolumn{9}{|c|}{ Año 1968} \\
\hline Country & $\begin{array}{c}\text { Human } \\
\text { Development } \\
\text { Index }\end{array}$ & $\begin{array}{c}\text { Life } \\
\text { Expectancy } \\
\text { Index }\end{array}$ & $\begin{array}{l}\text { Schooling } \\
\text { Index }\end{array}$ & $\begin{array}{c}\text { Adult } \\
\text { Literacy } \\
\text { Index } \\
(\%)\end{array}$ & $\begin{array}{c}\text { Combined } \\
\text { Enrolment } \\
\text { Rate }(\%)\end{array}$ & $\begin{array}{c}\text { Gross } \\
\text { Enrolment } \\
\text { Index }\end{array}$ & $\begin{array}{l}\text { GDCP } \\
\text { Index }\end{array}$ & $\begin{array}{l}\text { Classification } \\
\text { according to } \\
\text { IDH or Index } \\
\text { of Human } \\
\text { development }\end{array}$ \\
\hline Alemania & 0.253293767 & 0.7598813 & 0 & $0.00 \%$ & & $0.00 \%$ & & 37 \\
\hline Argentina & 63.17999684 & 0.68453699 & 0 & & 0 & $0.00 \%$ & 188.855454 & 12 \\
\hline Australia & 151.272806 & 0.76531707 & 0 & & 0 & $0.00 \%$ & 453.053101 & 4 \\
\hline Bolivia & 12.4313596 & 0.33530285 & 0 & & 0 & $0.00 \%$ & 36.958776 & 29 \\
\hline Brasil & 20.55124227 & 0.54689553 & 0 & $0.00 \%$ & 0 & $0.00 \%$ & 61.1068313 & 22 \\
\hline Canadá & 189.780176 & 0.78922358 & 0 & & 0 & $0.00 \%$ & 568.551305 & 2 \\
\hline Chile & 42.63348161 & 0.59951585 & 0 & & 0 & $0.00 \%$ & 127.300929 & 14 \\
\hline China & 4.963057145 & 0.57444756 & 0 & & 0 & $0.00 \%$ & 14.3147239 & 35 \\
\hline Colombia & 16.21162509 & 0.58614431 & 0 & & 0 & $0.00 \%$ & 48.048731 & 26 \\
\hline Costa Rica & 24.86911323 & 0.68120407 & 0 & & 0 & $0.00 \%$ & 73.9261356 & 20 \\
\hline Croacia & 0.241318699 & 0.7239561 & 0 & & & $0.00 \%$ & & 39 \\
\hline Cuba & 0.242316938 & 0.72695081 & 0 & & 0 & $0.00 \%$ & & 38 \\
\hline Dinamarca & 150.9265116 & 0.80202439 & 0 & & 0 & $0.00 \%$ & 451.97751 & 5 \\
\hline Ecuador & 25.17957573 & 0.53303537 & 0 & & 0 & $0.00 \%$ & 75.0056918 & 19 \\
\hline Egipto & 9.68580753 & 0.40815244 & 0 & & 0 & $0.00 \%$ & 28.6492702 & 30 \\
\hline El Salvador & 0.171549322 & 0.51464797 & 0 & & 0 & $0.00 \%$ & & 40 \\
\hline España & 52.88566332 & 0.77563008 & 0 & & 0 & $0.00 \%$ & 157.88136 & 13 \\
\hline Estados Unidos & 249.872566 & 0.74918699 & 0 & & 0 & $0.00 \%$ & 748.868511 & 1 \\
\hline Etiopía & 0.09630122 & 0.28890366 & 0 & & 0 & $0.00 \%$ & & 42 \\
\hline Finlandia & 106.0913334 & 0.74360569 & 0 & & 0 & $0.00 \%$ & 317.530395 & 8 \\
\hline Francia & 141.1637427 & 0.77182927 & 0 & & 0 & $0.00 \%$ & 422.719399 & 7 \\
\hline Guatemala & 17.34634863 & 0.42618252 & 0 & & 0 & $0.00 \%$ & 51.6128634 & 23 \\
\hline
\end{tabular}




\begin{tabular}{|c|c|c|c|c|c|c|c|c|}
\hline Guinea & 0.046251491 & 0.13875447 & 0 & & 0 & $0.00 \%$ & & 45 \\
\hline Haití & 0.118276965 & 0.35483089 & 0 & & 0 & $0.00 \%$ & & 41 \\
\hline Honduras & 13.98919745 & 0.43797154 & 0 & & 0 & $0.00 \%$ & 41.5296208 & 28 \\
\hline Irán & 17.21769819 & 0.41781382 & 0 & & 0 & $0.00 \%$ & 51.2352807 & 24 \\
\hline Japón & 80.7075333 & 0.77685366 & 0 & & 0 & $0.00 \%$ & 241.345746 & 10 \\
\hline Mozambique & 0.074187127 & 0.22256138 & 0 & $0.00 \%$ & 0 & $0.00 \%$ & & 44 \\
\hline México & 32.75313605 & 0.59167561 & 0 & $0.00 \%$ & 0 & $0.00 \%$ & 97.6677325 & 17 \\
\hline Nepal & 3.711193063 & 0.27829187 & 0 & & 0 & $0.00 \%$ & 10.8552873 & 36 \\
\hline Nicaragua & 16.96709657 & 0.45418252 & 0 & & 0 & $0.00 \%$ & 50.4471072 & 25 \\
\hline Nigeria & 5.229933869 & 0.27568699 & 0 & & 0 & $0.00 \%$ & 15.4141146 & 34 \\
\hline Noruega & 148.1218008 & 0.81569919 & 0 & & 0 & $0.00 \%$ & 443.549703 & 6 \\
\hline Panamá & 33.23599896 & 0.65714065 & 0 & $0.00 \%$ & 0 & $0.00 \%$ & 99.0508562 & 16 \\
\hline Perú & 24.79085361 & 0.44797033 & 0 & & 0 & $0.00 \%$ & 73.9245905 & 21 \\
\hline Portugal & 39.97910156 & 0.6884439 & 0 & & 0 & $0.00 \%$ & 119.248861 & 15 \\
\hline Reino Unido & 105.5082807 & 0.77873984 & 0 & & 0 & $0.00 \%$ & 315.746102 & 9 \\
\hline Senegal & 14.30100098 & 0.2522561 & 0 & & 0 & $0.00 \%$ & 42.6507468 & 27 \\
\hline Sudán & 6.985648982 & 0.32268577 & 0 & & 0 & $0.00 \%$ & 20.6342612 & 32 \\
\hline Suiza & 173.693543 & 0.79317073 & 0 & & 0 & $0.00 \%$ & 520.287458 & 3 \\
\hline Tailandia & 9.658236794 & 0.56625407 & 0 & $0.00 \%$ & 0 & $0.00 \%$ & 28.4084563 & 31 \\
\hline Uganda & 6.379510917 & 0.39346098 & 0 & & 0 & $0.00 \%$ & 18.7450718 & 33 \\
\hline Uruguay & 31.93773012 & 0.72590041 & 0 & & 0 & $0.00 \%$ & 95.08729 & 18 \\
\hline Venezuela & 63.51636142 & 0.63100244 & 0 & & 0 & $0.00 \%$ & 189.918082 & 11 \\
\hline Yemen & 0.082027236 & 0.24608171 & 0 & & & $0.00 \%$ & & 43 \\
\hline
\end{tabular}

Fuente: Elaboración propia a partir de la base de datos del Banco Mundial, periodo 1960-1980, (data.worldbank.org) 


\begin{tabular}{|c|c|c|c|c|c|c|c|c|}
\hline \multicolumn{9}{|c|}{ Año 1969} \\
\hline Country & $\begin{array}{c}\text { Human } \\
\text { Development } \\
\text { Index }\end{array}$ & $\begin{array}{c}\text { Life } \\
\text { Expectancy } \\
\text { Index }\end{array}$ & $\begin{array}{l}\text { Schooling } \\
\text { Index }\end{array}$ & $\begin{array}{c}\text { Adult } \\
\text { Literacy } \\
\text { Index } \\
(\%)\end{array}$ & $\begin{array}{c}\text { Combined } \\
\text { Enrolment } \\
\text { Rate }(\%)\end{array}$ & $\begin{array}{c}\text { Gross } \\
\text { Enrolment } \\
\text { Index }\end{array}$ & $\begin{array}{l}\text { GDCP } \\
\text { Index }\end{array}$ & $\begin{array}{l}\text { Classification } \\
\text { according to } \\
\text { IDH or Index } \\
\text { of Human } \\
\text { development }\end{array}$ \\
\hline Alemania & 0.253403659 & 0.76021098 & 0 & $0.00 \%$ & & $0.00 \%$ & & 37 \\
\hline Argentina & 73.61729236 & 0.68822195 & 0 & & 0 & $0.00 \%$ & 220.163655 & 11 \\
\hline Australia & 166.1111624 & 0.76614634 & 0 & & 0 & $0.00 \%$ & 497.567341 & 5 \\
\hline Bolivia & 12.89201376 & 0.34038008 & 0 & & 0 & $0.00 \%$ & 38.3356612 & 29 \\
\hline Brasil & 22.16715938 & 0.5531065 & 0 & $0.00 \%$ & 0 & $0.00 \%$ & 65.9483716 & 22 \\
\hline Canadá & 206.0780852 & 0.79169106 & 0 & & 0 & $0.00 \%$ & 617.442564 & 2 \\
\hline Chile & 48.35587483 & 0.60912154 & 0 & & 0 & $0.00 \%$ & 144.458503 & 14 \\
\hline China & 5.447994398 & 0.60747764 & 0 & & 0 & $0.00 \%$ & 15.7365056 & 35 \\
\hline Colombia & 17.07784753 & 0.5917122 & 0 & & 0 & $0.00 \%$ & 50.6418304 & 26 \\
\hline Costa Rica & 26.7131054 & 0.68930935 & 0 & & 0 & $0.00 \%$ & 79.4500069 & 21 \\
\hline Croacia & 0.242580352 & 0.72774106 & 0 & & & $0.00 \%$ & & 39 \\
\hline Cuba & 0.245342276 & 0.73602683 & 0 & & 0 & $0.00 \%$ & & 38 \\
\hline Dinamarca & 170.712118 & 0.80368293 & 0 & & 0 & $0.00 \%$ & 511.332671 & 4 \\
\hline Ecuador & 29.49904798 & 0.53950894 & 0 & & 0 & $0.00 \%$ & 87.957635 & 19 \\
\hline Egipto & 10.63284114 & 0.41609309 & 0 & & 0 & $0.00 \%$ & 31.4824303 & 30 \\
\hline El Salvador & 0.173572087 & 0.52071626 & 0 & & 0 & $0.00 \%$ & & 40 \\
\hline España & 59.95599937 & 0.76762602 & 0 & & 0 & $0.00 \%$ & 179.100372 & 13 \\
\hline Estados Unidos & 267.1901856 & 0.75845528 & 0 & & 0 & $0.00 \%$ & 800.812101 & 1 \\
\hline Etiopía & 0.097988347 & 0.29396504 & 0 & & 0 & $0.00 \%$ & & 42 \\
\hline Finlandia & 121.1653719 & 0.74172358 & 0 & & 0 & $0.00 \%$ & 362.754392 & 8 \\
\hline Francia & 151.970329 & 0.77430894 & 0 & & 0 & $0.00 \%$ & 455.136678 & 7 \\
\hline Guatemala & 17.99489811 & 0.43844146 & 0 & & 0 & $0.00 \%$ & 53.5462529 & 24 \\
\hline
\end{tabular}




\begin{tabular}{|c|c|c|c|c|c|c|c|c|}
\hline Guinea & 0.047845799 & 0.1435374 & 0 & & 0 & $0.00 \%$ & & 45 \\
\hline Haití & 0.120551084 & 0.36165325 & 0 & & 0 & $0.00 \%$ & & 41 \\
\hline Honduras & 14.07763768 & 0.44758496 & 0 & & 0 & $0.00 \%$ & 41.7853281 & 27 \\
\hline Irán & 18.82807385 & 0.42736504 & 0 & & 0 & $0.00 \%$ & 56.0568565 & 23 \\
\hline Japón & 92.863786 & 0.78064634 & 0 & & 0 & $0.00 \%$ & 277.810712 & 10 \\
\hline Mozambique & 0.076531843 & 0.22959553 & 0 & $0.00 \%$ & 0 & $0.00 \%$ & & 44 \\
\hline México & 35.16467875 & 0.59826301 & 0 & $0.00 \%$ & 0 & $0.00 \%$ & 104.895773 & 18 \\
\hline Nepal & 3.715127433 & 0.28622886 & 0 & & 0 & $0.00 \%$ & 10.8591534 & 36 \\
\hline Nicaragua & 17.82603612 & 0.46549837 & 0 & & 0 & $0.00 \%$ & 53.01261 & 25 \\
\hline Nigeria & 6.565949615 & 0.28256301 & 0 & & 0 & $0.00 \%$ & 19.4152858 & 34 \\
\hline Noruega & 159.977029 & 0.81105691 & 0 & & 0 & $0.00 \%$ & 479.12003 & 6 \\
\hline Panamá & 35.44397466 & 0.66434431 & 0 & $0.00 \%$ & 0 & $0.00 \%$ & 105.66758 & 17 \\
\hline Perú & 27.00033715 & 0.45994228 & 0 & & 0 & $0.00 \%$ & 80.5410692 & 20 \\
\hline Portugal & 44.24724746 & 0.6948622 & 0 & & 0 & $0.00 \%$ & 132.04688 & 15 \\
\hline Reino Unido & 113.0723755 & 0.77869919 & 0 & & 0 & $0.00 \%$ & 338.438427 & 9 \\
\hline Senegal & 13.19611175 & 0.25686992 & 0 & & 0 & $0.00 \%$ & 39.3314653 & 28 \\
\hline Sudán & 7.482425837 & 0.32930366 & 0 & & 0 & $0.00 \%$ & 22.1179739 & 32 \\
\hline Suiza & 186.0943403 & 0.79354472 & 0 & & 0 & $0.00 \%$ & 557.489476 & 3 \\
\hline Tailandia & 10.33372893 & 0.57335041 & 0 & $0.00 \%$ & 0 & $0.00 \%$ & 30.4278364 & 31 \\
\hline Uganda & 6.973809458 & 0.40430488 & 0 & & 0 & $0.00 \%$ & 20.5171235 & 33 \\
\hline Uruguay & 39.87923658 & 0.72606911 & 0 & & 0 & $0.00 \%$ & 118.911641 & 16 \\
\hline Venezuela & 63.92594654 & 0.63918902 & 0 & & 0 & $0.00 \%$ & 191.138651 & 12 \\
\hline Yemen & 0.083239973 & 0.24971992 & 0 & & & $0.00 \%$ & & 43 \\
\hline
\end{tabular}

Fuente: Elaboración propia a partir de la base de datos del Banco Mundial, periodo 1960-1980, (data.worldbank.org) 


\begin{tabular}{|c|c|c|c|c|c|c|c|c|}
\hline \multicolumn{9}{|c|}{ Año 1970} \\
\hline Country & $\begin{array}{c}\text { Human } \\
\text { Development } \\
\text { Index }\end{array}$ & $\begin{array}{c}\text { Life } \\
\text { Expectancy } \\
\text { Index }\end{array}$ & $\begin{array}{l}\text { Schooling } \\
\text { Index }\end{array}$ & $\begin{array}{c}\text { Adult } \\
\text { Literacy } \\
\text { Index } \\
(\%)\end{array}$ & $\begin{array}{c}\text { Combined } \\
\text { Enrolment } \\
\text { Rate }(\%)\end{array}$ & $\begin{array}{c}\text { Gross } \\
\text { Enrolment } \\
\text { Index }\end{array}$ & $\begin{array}{l}\text { GDCP } \\
\text { Index }\end{array}$ & $\begin{array}{l}\text { Classification } \\
\text { according to } \\
\text { IDH or Index } \\
\text { of Human } \\
\text { development }\end{array}$ \\
\hline Alemania & 148.6542904 & 0.76068171 & 0 & $0.00 \%$ & & $0.00 \%$ & 445.202189 & 7 \\
\hline Argentina & 91.41736204 & 0.6924752 & 54.48432 & & 163.453 & $163.45 \%$ & 219.075288 & 11 \\
\hline Australia & 185.3711848 & 0.76697561 & 5.342893 & & 16.02868 & $16.03 \%$ & 550.003685 & 4 \\
\hline Bolivia & 23.45068989 & 0.34585041 & 30.5187 & & 91.5561 & $91.56 \%$ & 39.4875193 & 28 \\
\hline Brasil & 38.25550259 & 0.55935 & 41.43192 & $0.00 \%$ & 124.2958 & $124.30 \%$ & 72.7752411 & 20 \\
\hline Canadá & 225.1773622 & 0.79500813 & 0 & & 0 & $0.00 \%$ & 674.737079 & 2 \\
\hline Chile & 70.82708997 & 0.61894512 & 56.14317 & & 168.4295 & $168.43 \%$ & 155.719155 & 12 \\
\hline China & 21.61800789 & 0.63170407 & 46.32727 & & 138.9818 & $138.98 \%$ & 17.8950496 & 29 \\
\hline Colombia & 33.66088239 & 0.59719472 & 44.86687 & & 134.6006 & $134.60 \%$ & 55.5185825 & 23 \\
\hline Costa Rica & 45.8057799 & 0.69748293 & 47.27847 & & 141.8354 & $141.84 \%$ & 89.4413834 & 19 \\
\hline Croacia & 0.243876965 & 0.73163089 & 0 & & & $0.00 \%$ & & 39 \\
\hline Cuba & 36.33469604 & 0.7445939 & 0 & & 0 & $0.00 \%$ & 108.259494 & 22 \\
\hline Dinamarca & 187.2825749 & 0.80572358 & 0 & & 0 & $0.00 \%$ & 561.042001 & 3 \\
\hline Ecuador & 26.35920891 & 0.54626545 & 0 & & 0 & $0.00 \%$ & 78.5313613 & 26 \\
\hline Egipto & 11.64596728 & 0.4242065 & 0 & & 0 & $0.00 \%$ & 34.5136953 & 34 \\
\hline El Salvador & 11.43804103 & 0.52592642 & 33.7882 & & 101.3646 & $101.36 \%$ & & 35 \\
\hline España & 65.49069522 & 0.78378862 & 0 & & 0 & $0.00 \%$ & 195.688297 & 14 \\
\hline Estados Unidos & 278.0469712 & 0.76345528 & 0 & & 0 & $0.00 \%$ & 833.377458 & 1 \\
\hline Etiopía & 0.099603252 & 0.29880976 & 0 & & 0 & $0.00 \%$ & & 41 \\
\hline Finlandia & 135.539929 & 0.75299187 & 0 & & 0 & $0.00 \%$ & 405.866795 & 8 \\
\hline Francia & 156.9946928 & 0.77764228 & 0 & & 0 & $0.00 \%$ & 470.206436 & 6 \\
\hline Guatemala & 27.06641569 & 0.45079837 & 22.83761 & & 68.51284 & $68.51 \%$ & 57.9108354 & 25 \\
\hline
\end{tabular}




\begin{tabular}{|c|c|c|c|c|c|c|c|c|}
\hline Guinea & 0.04976626 & 0.14929878 & 0 & & 0 & $0.00 \%$ & & 43 \\
\hline Haití & 0.122677642 & 0.36803293 & 0 & & 0 & $0.00 \%$ & & 40 \\
\hline Honduras & 25.67395646 & 0.45733171 & 32.49562 & & 97.48687 & $97.49 \%$ & 44.0689144 & 27 \\
\hline Irán & 20.48147422 & 0.43742805 & 0 & & 0 & $0.00 \%$ & 61.0069946 & 30 \\
\hline Japón & 111.47693 & 0.78250407 & 0 & & 0 & $0.00 \%$ & 333.648286 & 10 \\
\hline Mozambique & -0.177230433 & 0.23693049 & 0 & $0.00 \%$ & 0 & $0.00 \%$ & -0.7686218 & 45 \\
\hline México & 37.26249642 & 0.60544431 & 0 & $0.00 \%$ & 0 & $0.00 \%$ & 111.182045 & 21 \\
\hline Nepal & 6.870594854 & 0.2944439 & 8.58236 & & 25.74708 & $25.75 \%$ & 11.7349807 & 38 \\
\hline Nicaragua & 27.83934831 & 0.47663415 & 29.65836 & & 88.97509 & $88.98 \%$ & 53.3830475 & 24 \\
\hline Nigeria & 17.19784136 & 0.28949106 & 14.76845 & & 44.30536 & $44.31 \%$ & 36.5355797 & 31 \\
\hline Noruega & 182.7452323 & 0.81813415 & 0 & & 0 & $0.00 \%$ & 547.417563 & 5 \\
\hline Panamá & 53.30823278 & 0.67166016 & 48.84218 & $0.00 \%$ & 146.5265 & $146.53 \%$ & 110.410858 & 16 \\
\hline Perú & 47.55737607 & 0.47280325 & 51.4472 & & 154.3416 & $154.34 \%$ & 90.7521216 & 18 \\
\hline Portugal & 51.2516546 & 0.70121951 & 0 & & 0 & $0.00 \%$ & 153.053744 & 17 \\
\hline Reino Unido & 124.736161 & 0.78288618 & 0 & & 0 & $0.00 \%$ & 373.425597 & 9 \\
\hline Senegal & 13.34848013 & 0.26249228 & 0 & & 0 & $0.00 \%$ & 39.7829481 & 32 \\
\hline Sudán & 8.274129229 & 0.33592154 & 0 & & 0 & $0.00 \%$ & 24.4864661 & 37 \\
\hline Suiza & 0.010571871 & 0.8003374 & 0 & & 0 & $0.00 \%$ & -0.7686218 & 44 \\
\hline Tailandia & 10.62801902 & 0.58061098 & 0 & $0.00 \%$ & 0 & $0.00 \%$ & 31.3034461 & 36 \\
\hline Uganda & 12.19088656 & 0.41438984 & 14.67151 & & 44.01453 & $44.01 \%$ & 21.4867598 & 33 \\
\hline Uruguay & 54.76374118 & 0.72647886 & 37.38787 & & 112.1636 & $112.16 \%$ & 126.176878 & 15 \\
\hline Venezuela & 67.36404952 & 0.64724431 & 0 & & 0 & $0.00 \%$ & 201.444904 & 13 \\
\hline Yemen & 0.084749864 & 0.25424959 & 0 & & & \#REF! & & 42 \\
\hline
\end{tabular}

Fuente: Elaboración propia a partir de la base de datos del Banco Mundial, periodo 1960-1980, (data.worldbank.org) 


\begin{tabular}{|c|c|c|c|c|c|c|c|c|}
\hline \multicolumn{9}{|c|}{ Año 1971} \\
\hline Country & $\begin{array}{c}\text { Human } \\
\text { Development } \\
\text { Index }\end{array}$ & $\begin{array}{c}\text { Life } \\
\text { Expectancy } \\
\text { Index }\end{array}$ & $\begin{array}{l}\text { Schooling } \\
\text { Index }\end{array}$ & $\begin{array}{c}\text { Adult } \\
\text { Literacy } \\
\text { Index } \\
(\%)\end{array}$ & $\begin{array}{c}\text { Combined } \\
\text { Enrolment } \\
\text { Rate }(\%)\end{array}$ & $\begin{array}{c}\text { Gross } \\
\text { Enrolment } \\
\text { Index }\end{array}$ & $\begin{array}{l}\text { GDCP } \\
\text { Index }\end{array}$ & $\begin{array}{l}\text { Classification } \\
\text { according to } \\
\text { IDH or Index } \\
\text { of Human } \\
\text { development }\end{array}$ \\
\hline Alemania & 171.8571817 & 0.76160772 & 0 & $0.00 \%$ & & $0.00 \%$ & 514.809937 & 7 \\
\hline Argentina & 94.55200483 & 0.69717154 & 55.71676 & & 167.1503 & $167.15 \%$ & 227.242086 & 11 \\
\hline Australia & 208.4252192 & 0.76780488 & 42.78913 & & 128.3674 & $128.37 \%$ & 581.718726 & 5 \\
\hline Bolivia & 24.08496341 & 0.3520313 & 30.36133 & & 91.084 & $91.08 \%$ & 41.5415256 & 29 \\
\hline Brasil & 42.14471869 & 0.56564675 & 43.20116 & $0.00 \%$ & 129.6035 & $129.60 \%$ & 82.6673527 & 22 \\
\hline Canadá & 272.111779 & 0.8004878 & 64.70414 & & 194.1124 & $194.11 \%$ & 750.830709 & 2 \\
\hline Chile & 81.20710236 & 0.62911016 & 60.78767 & & 182.363 & $182.36 \%$ & 182.20453 & 14 \\
\hline China & 23.08399168 & 0.64777886 & 49.81473 & & 149.4442 & $149.44 \%$ & 18.7894662 & 31 \\
\hline Colombia & 35.37287032 & 0.6027374 & 46.63 & & 139.89 & $139.89 \%$ & 58.8858769 & 24 \\
\hline Costa Rica & 47.98836412 & 0.70585041 & 47.73595 & & 143.2079 & $143.21 \%$ & 95.5232886 & 21 \\
\hline Croacia & 0.24523103 & 0.73569309 & 0 & & & $0.00 \%$ & & 43 \\
\hline Cuba & 59.40782348 & 0.75276057 & 48.12719 & & 144.3816 & $144.38 \%$ & 129.343523 & 17 \\
\hline Dinamarca & 230.6514308 & 0.80691057 & 69.25993 & & 207.7798 & $207.78 \%$ & 621.887455 & 3 \\
\hline Ecuador & 39.43533243 & 0.55332967 & 44.36313 & & 133.0894 & $133.09 \%$ & 73.389541 & 23 \\
\hline Egipto & 23.28847169 & 0.4325752 & 33.06693 & & 99.20079 & $99.20 \%$ & 36.3659099 & 30 \\
\hline El Salvador & 11.56070797 & 0.53016057 & 34.15196 & & 102.4559 & $102.46 \%$ & & 37 \\
\hline España & 93.52758854 & 0.77717073 & 59.61736 & & 178.8521 & $178.85 \%$ & 220.188238 & 12 \\
\hline Estados Unidos & 322.5422161 & 0.76845528 & 72.99107 & & 218.9732 & $218.97 \%$ & 893.867126 & 1 \\
\hline Etiopía & 1.756395176 & 0.30357886 & 4.965607 & & 14.89682 & $14.90 \%$ & & 41 \\
\hline Finlandia & 171.1925003 & 0.75029268 & 65.64038 & & 196.9212 & $196.92 \%$ & 447.186825 & 8 \\
\hline Francia & 197.2535154 & 0.78178862 & 69.5481 & & 208.6443 & $208.64 \%$ & 521.430657 & 6 \\
\hline Guatemala & 27.31423924 & 0.46288699 & 22.7219 & & 68.16571 & $68.17 \%$ & 58.7579274 & 27 \\
\hline
\end{tabular}




\begin{tabular}{|c|c|c|c|c|c|c|c|c|}
\hline Guinea & 4.865401734 & 0.1559752 & 14.44023 & & 43.32069 & $43.32 \%$ & & 39 \\
\hline Haití & 5.685132629 & 0.37406789 & 16.68133 & & 50.04399 & $50.04 \%$ & & 38 \\
\hline Honduras & 25.62867416 & 0.4673622 & 33.08487 & & 99.25461 & $99.25 \%$ & 43.3337903 & 28 \\
\hline Irán & 32.84851524 & 0.44907764 & 23.86289 & & 71.58867 & $71.59 \%$ & 74.2335781 & 25 \\
\hline Japón & 147.0067179 & 0.79804878 & 68.08329 & & 204.2499 & $204.25 \%$ & 372.138811 & 10 \\
\hline Mozambique & 0.170734824 & 0.24466626 & 1.03616 & $0.00 \%$ & 3.10848 & $3.11 \%$ & -0.7686218 & 44 \\
\hline México & 54.08127671 & 0.6132939 & 42.7192 & $0.00 \%$ & 128.1576 & $128.16 \%$ & 118.911333 & 19 \\
\hline Nepal & 4.004613112 & 0.30291829 & 0 & & 0 & $0.00 \%$ & 11.710921 & 40 \\
\hline Nicaragua & 28.75571753 & 0.48741098 & 30.65738 & & 91.97215 & $91.97 \%$ & 55.1223583 & 26 \\
\hline Nigeria & 14.07340056 & 0.29635203 & 16.01927 & & 48.05781 & $48.06 \%$ & 25.9045796 & 34 \\
\hline Noruega & 228.9385498 & 0.81965447 & 67.72234 & & 203.167 & $203.17 \%$ & 618.273652 & 4 \\
\hline Panamá & 58.69673514 & 0.67921301 & 54.26644 & $0.00 \%$ & 162.7993 & $162.80 \%$ & 121.144556 & 18 \\
\hline Perú & 50.37881248 & 0.48606179 & 52.15836 & & 156.4751 & $156.48 \%$ & 98.4920123 & 20 \\
\hline Portugal & 75.90667456 & 0.69617886 & 52.48693 & & 157.4608 & $157.46 \%$ & 174.536911 & 15 \\
\hline Reino Unido & 162.1464663 & 0.78788618 & 64.88243 & & 194.6473 & $194.65 \%$ & 420.769083 & 9 \\
\hline Senegal & 19.21704199 & 0.26925691 & 17.54109 & & 52.62328 & $52.62 \%$ & 39.8407757 & 33 \\
\hline Sudán & 13.65053189 & 0.34257317 & 14.67519 & & 44.02557 & $44.03 \%$ & 25.9338325 & 35 \\
\hline Suiza & 1.126569025 & 0.80217886 & 3.34615 & & 10.03845 & $10.04 \%$ & -0.7686218 & 42 \\
\hline Tailandia & 22.24498749 & 0.58800488 & 34.48828 & $0.00 \%$ & 103.4648 & $103.46 \%$ & 31.6586809 & 32 \\
\hline Uganda & 12.69446908 & 0.42281626 & 14.0953 & & 42.28589 & $42.29 \%$ & 23.5652943 & 36 \\
\hline Uruguay & 68.01631594 & 0.7272378 & 37.84469 & & 113.5341 & $113.53 \%$ & 165.477017 & 16 \\
\hline Venezuela & 88.3866153 & 0.65528577 & 47.53693 & & 142.6108 & $142.61 \%$ & 216.967627 & 13 \\
\hline Yemen & 0.086781843 & 0.26034553 & 0 & & & $0.00 \%$ & & 45 \\
\hline
\end{tabular}

Fuente: Elaboración propia a partir de la base de datos del Banco Mundial, periodo 1960-1980, (data.worldbank.org) 


\begin{tabular}{|c|c|c|c|c|c|c|c|c|}
\hline \multicolumn{9}{|c|}{ Año 1972} \\
\hline Country & $\begin{array}{c}\text { Human } \\
\text { Development } \\
\text { Index }\end{array}$ & $\begin{array}{c}\text { Life } \\
\text { Expectancy } \\
\text { Index }\end{array}$ & $\begin{array}{l}\text { Schooling } \\
\text { Index }\end{array}$ & $\begin{array}{c}\text { Adult } \\
\text { Literacy } \\
\text { Index } \\
(\%)\end{array}$ & $\begin{array}{c}\text { Combined } \\
\text { Enrolment } \\
\text { Rate }(\%)\end{array}$ & $\begin{array}{c}\text { Gross } \\
\text { Enrolment } \\
\text { Index }\end{array}$ & $\begin{array}{l}\text { GDCP } \\
\text { Index }\end{array}$ & $\begin{array}{l}\text { Classification } \\
\text { according to } \\
\text { IDH or Index } \\
\text { of Human } \\
\text { development }\end{array}$ \\
\hline Alemania & 205.1216933 & 0.7632378 & 0 & $0.00 \%$ & & $0.00 \%$ & 614.601842 & 7 \\
\hline Argentina & 96.77584401 & 0.70207683 & 56.50721 & & 169.5216 & $169.52 \%$ & 233.118249 & 12 \\
\hline Australia & 233.6198985 & 0.77429268 & 42.84165 & & 128.525 & $128.52 \%$ & 657.24375 & 6 \\
\hline Bolivia & 25.92836822 & 0.35914837 & 30.80419 & & 92.41258 & $92.41 \%$ & 46.621763 & 29 \\
\hline Brasil & 46.53544055 & 0.5720065 & 42.88654 & $0.00 \%$ & 128.6596 & $128.66 \%$ & 96.1477718 & 22 \\
\hline Canadá & 302.1985634 & 0.79889837 & 63.95308 & & 191.8592 & $191.86 \%$ & 841.843715 & 2 \\
\hline Chile & 85.61992925 & 0.63971626 & 63.14078 & & 189.4223 & $189.42 \%$ & 193.079295 & 15 \\
\hline China & 25.05688763 & 0.65857398 & 53.56461 & & 160.6938 & $160.69 \%$ & 20.9474822 & 30 \\
\hline Colombia & 37.30682754 & 0.60849268 & 47.48193 & & 142.4458 & $142.45 \%$ & 63.8300599 & 25 \\
\hline Costa Rica & 52.44707726 & 0.71453699 & 49.26012 & & 147.7804 & $147.78 \%$ & 107.366571 & 21 \\
\hline Croacia & 0.246614634 & 0.7398439 & 0 & & & $0.00 \%$ & & 43 \\
\hline Cuba & 66.07818626 & 0.76060163 & 47.80066 & & 143.402 & $143.40 \%$ & 149.673294 & 16 \\
\hline Dinamarca & 264.9759223 & 0.80731707 & 39.51158 & & 118.5347 & $118.53 \%$ & 754.60887 & 4 \\
\hline Ecuador & 42.83440315 & 0.56066789 & 45.31616 & & 135.9485 & $135.95 \%$ & 82.6263849 & 23 \\
\hline Egipto & 24.11961402 & 0.44127358 & 34.13765 & & 102.4129 & $102.41 \%$ & 37.7799218 & 31 \\
\hline El Salvador & 11.79297187 & 0.53340894 & 34.84551 & & 104.5365 & $104.54 \%$ & & 37 \\
\hline España & 112.6517582 & 0.79696748 & 60.19007 & & 180.5702 & $180.57 \%$ & 276.968234 & 11 \\
\hline Estados Unidos & 349.1723038 & 0.76926829 & 73.42661 & & 220.2798 & $220.28 \%$ & 973.321037 & 1 \\
\hline Etiopía & 1.849890298 & 0.30826423 & 5.241407 & & 15.72422 & $15.72 \%$ & & 41 \\
\hline Finlandia & 197.008324 & 0.76178862 & 66.97287 & & 200.9186 & $200.92 \%$ & 523.29031 & 8 \\
\hline Francia & 235.2544124 & 0.78512195 & 70.23623 & & 210.7087 & $210.71 \%$ & 634.741882 & 5 \\
\hline Guatemala & 28.11491976 & 0.47434146 & 23.31778 & & 69.95335 & $69.95 \%$ & 60.5526345 & 27 \\
\hline
\end{tabular}




\begin{tabular}{|c|c|c|c|c|c|c|c|c|}
\hline Guinea & 3.002658103 & 0.16337764 & 8.844597 & & 26.53379 & $26.53 \%$ & & 40 \\
\hline Haití & 5.91713439 & 0.37992317 & 17.37148 & & 52.11444 & $52.11 \%$ & & 39 \\
\hline Honduras & 26.88520076 & 0.47773496 & 33.8422 & & 101.5266 & $101.53 \%$ & 46.335664 & 28 \\
\hline Irán & 38.68679408 & 0.46248415 & 25.97753 & & 77.93258 & $77.93 \%$ & 89.6203714 & 24 \\
\hline Japón & 185.3347315 & 0.80844309 & 68.99513 & & 206.9854 & $206.99 \%$ & 486.200625 & 9 \\
\hline Mozambique & 0.163484662 & 0.25268577 & 1.00639 & $0.00 \%$ & 3.01917 & $3.02 \%$ & -0.7686218 & 44 \\
\hline México & 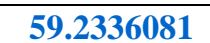 & 0.6216874 & 44.14254 & $0.00 \%$ & 132.4276 & $132.43 \%$ & 132.9366 & 18 \\
\hline Nepal & 10.25829098 & 0.31163252 & 17.05992 & & 51.17975 & $51.18 \%$ & 13.4033238 & 38 \\
\hline Nicaragua & 29.53825385 & 0.4976935 & 31.41312 & & 94.23937 & $94.24 \%$ & 56.7039447 & 26 \\
\hline Nigeria & 17.31773953 & 0.30301951 & 17.59519 & & 52.78558 & $52.79 \%$ & 34.0550057 & 34 \\
\hline Noruega & 266.438406 & 0.82241057 & 68.51137 & & 205.5341 & $205.53 \%$ & 729.981437 & 3 \\
\hline Panamá & 62.5357183 & 0.68704512 & 57.47132 & $0.00 \%$ & 172.414 & $172.41 \%$ & 129.44879 & 17 \\
\hline Perú & 53.27093778 & 0.49913577 & 53.07909 & & 159.2373 & $159.24 \%$ & 106.234588 & 20 \\
\hline Portugal & 89.44365916 & 0.72207317 & 53.9235 & & 161.7705 & $161.77 \%$ & 213.685408 & 14 \\
\hline Reino Unido & 182.6610873 & 0.7854065 & 65.28301 & & 195.849 & $195.85 \%$ & 481.914849 & 10 \\
\hline Senegal & 21.5885871 & 0.27718821 & 17.61949 & & 52.85848 & $52.86 \%$ & 46.8690797 & 33 \\
\hline Sudán & 14.69678349 & 0.34930813 & 16.39716 & & 49.19149 & $49.19 \%$ & 27.343879 & 35 \\
\hline Suiza & 1.188257128 & 0.81073984 & 3.522653 & & 10.56796 & $10.57 \%$ & -0.7686218 & 42 \\
\hline Tailandia & 23.37759364 & 0.59550122 & 35.35971 & $0.00 \%$ & 106.0791 & $106.08 \%$ & 34.1775664 & 32 \\
\hline Uganda & 12.69454703 & 0.42895935 & 13.5096 & & 40.5288 & $40.53 \%$ & 24.1450817 & 36 \\
\hline Uruguay & 55.53720446 & 0.72839512 & 37.1398 & & 111.4194 & $111.42 \%$ & 128.743415 & 19 \\
\hline Venezuela & 93.42216774 & 0.66336341 & 48.84622 & & 146.5387 & $146.54 \%$ & 230.756916 & 13 \\
\hline Yemen & 0.089494309 & 0.26848293 & 0 & & & $0.00 \%$ & & 45 \\
\hline
\end{tabular}

Fuente: Elaboración propia a partir de la base de datos del Banco Mundial, periodo 1960-1980, (data.worldbank.org) 


\begin{tabular}{|c|c|c|c|c|c|c|c|c|}
\hline \multicolumn{9}{|c|}{ Año 1973} \\
\hline Country & $\begin{array}{c}\text { Human } \\
\text { Development } \\
\text { Index }\end{array}$ & $\begin{array}{c}\text { Life } \\
\text { Expectancy } \\
\text { Index }\end{array}$ & $\begin{array}{l}\text { Schooling } \\
\text { Index }\end{array}$ & $\begin{array}{c}\text { Adult } \\
\text { Literacy } \\
\text { Index } \\
(\%)\end{array}$ & $\begin{array}{c}\text { Combined } \\
\text { Enrolment } \\
\text { Rate }(\%)\end{array}$ & $\begin{array}{c}\text { Gross } \\
\text { Enrolment } \\
\text { Index }\end{array}$ & $\begin{array}{l}\text { GDCP } \\
\text { Index }\end{array}$ & $\begin{array}{c}\text { Classification } \\
\text { according to } \\
\text { IDH or Index } \\
\text { of Human } \\
\text { development }\end{array}$ \\
\hline Alemania & 271.7084873 & 0.76569675 & 0 & $0.00 \%$ & & $0.00 \%$ & 814.359765 & 7 \\
\hline Argentina & 135.3024066 & 0.70700732 & 58.17209 & & 174.51626 & $174.52 \%$ & 347.028126 & 12 \\
\hline Australia & 279.354625 & 0.78078049 & 42.96662 & & 128.89987 & $128.90 \%$ & 794.316471 & 6 \\
\hline Bolivia & 25.8653984 & 0.3673439 & 31.56712 & & 94.70135 & $94.70 \%$ & 45.6617346 & 31 \\
\hline Brasil & 57.20099109 & 0.57841341 & 43.6117 & $0.00 \%$ & 130.83511 & $130.84 \%$ & 127.412857 & 22 \\
\hline Canadá & 341.7156246 & 0.80271138 & 63.03397 & & 189.10191 & $189.10 \%$ & 961.310192 & 3 \\
\hline Chile & 111.8948817 & 0.65082114 & 65.00797 & & 195.02391 & $195.02 \%$ & 270.025854 & 14 \\
\hline China & 28.16906858 & 0.66659634 & 58.726 & & 176.17801 & $176.18 \%$ & 25.1146061 & 28 \\
\hline Colombia & 41.80728846 & 0.6145939 & 50.47171 & & 151.41512 & $151.42 \%$ & 74.3355648 & 25 \\
\hline Costa Rica & 60.80781891 & 0.72356829 & 51.99316 & & 155.97949 & $155.98 \%$ & 129.706725 & 20 \\
\hline Croacia & 0.247982656 & 0.74394797 & 0 & & & $0.00 \%$ & & 44 \\
\hline Cuba & 77.14579373 & 0.76820894 & 49.77265 & & 149.31795 & $149.32 \%$ & 180.896522 & 17 \\
\hline Dinamarca & 345.7585415 & 0.81136992 & 41.43674 & & 124.31022 & $124.31 \%$ & 995.027515 & 2 \\
\hline Ecuador & 48.69334783 & 0.56824634 & 47.22224 & & 141.66671 & $141.67 \%$ & 98.2895605 & 24 \\
\hline Egipto & 25.41682643 & 0.45031829 & 35.13026 & & 105.39077 & $105.39 \%$ & 40.6699043 & 32 \\
\hline El Salvador & 12.26442092 & 0.53572276 & 36.25754 & & 108.77262 & $108.77 \%$ & & 37 \\
\hline España & 142.6055738 & 0.7935122 & 61.76772 & & 185.30315 & $185.30 \%$ & 365.255492 & 11 \\
\hline Estados Unidos & 374.855792 & 0.77260163 & 46.07317 & & 138.21952 & $138.22 \%$ & 1077.7216 & 1 \\
\hline Etiopía & 1.891130705 & 0.31276545 & 5.360627 & & 16.08188 & $16.08 \%$ & & 42 \\
\hline Finlandia & 251.9653451 & 0.77039431 & 67.65244 & & 202.95731 & $202.96 \%$ & 687.473204 & 8 \\
\hline Francia & 296.9331753 & 0.78926829 & 71.0531 & & 213.1593 & $213.16 \%$ & 818.957157 & 5 \\
\hline Guatemala & 31.9886006 & 0.48492886 & 23.28288 & & 69.84865 & $69.85 \%$ & 72.1979896 & 27 \\
\hline
\end{tabular}




\begin{tabular}{|c|c|c|c|c|c|c|c|c|}
\hline Guinea & 3.452040894 & 0.17127602 & 10.18485 & & 30.55454 & $30.55 \%$ & & 41 \\
\hline Haití & 6.075674038 & 0.38576545 & 17.84126 & & 53.52377 & $53.52 \%$ & & 40 \\
\hline Honduras & 26.59051009 & 0.48849228 & 28.04003 & & 84.12009 & $84.12 \%$ & 51.243008 & 30 \\
\hline Irán & 55.14736868 & 0.47711179 & 26.99473 & & 80.98418 & $80.98 \%$ & 137.970268 & 23 \\
\hline Japón & 242.0172196 & 0.81262602 & 69.85729 & & 209.57188 & $209.57 \%$ & 655.38174 & 9 \\
\hline Mozambique & 0.25023206 & 0.26079797 & 1.25852 & $0.00 \%$ & 3.77556 & $3.78 \%$ & -0.7686218 & 43 \\
\hline México & 67.42222099 & 0.63047642 & 43.77849 & $0.00 \%$ & 131.33547 & $131.34 \%$ & 157.857697 & 19 \\
\hline Nepal & 10.19362901 & 0.32055163 & 17.86289 & & 53.58868 & $53.59 \%$ & 12.3974421 & 39 \\
\hline Nicaragua & 33.60548828 & 0.50737236 & 31.74857 & & 95.2457 & $95.25 \%$ & 68.5605258 & 26 \\
\hline Nigeria & 19.94642244 & 0.30936626 & 18.31915 & & 54.95746 & $54.96 \%$ & 41.2107477 & 34 \\
\hline Noruega & 337.1476292 & 0.82403659 & 69.87721 & & 209.63164 & $209.63 \%$ & 940.741638 & 4 \\
\hline Panamá & 68.29227652 & 0.69515732 & 60.11612 & $0.00 \%$ & 180.34836 & $180.35 \%$ & 144.065552 & 18 \\
\hline Perú & 59.74709496 & 0.51159228 & 54.99573 & & 164.98719 & $164.99 \%$ & 123.733963 & 21 \\
\hline Portugal & 114.4033074 & 0.70873984 & 55.41516 & & 166.24549 & $166.25 \%$ & 287.086019 & 13 \\
\hline Reino Unido & 203.0538014 & 0.78873984 & 65.48359 & & 196.45076 & $196.45 \%$ & 542.889078 & 10 \\
\hline Senegal & 22.04525701 & 0.28622033 & 13.51074 & & 40.53221 & $40.53 \%$ & 52.338814 & 33 \\
\hline Sudán & 17.10807073 & 0.35615976 & 17.9497 & & 53.84911 & $53.85 \%$ & 33.0183491 & 35 \\
\hline Suiza & 11.64374482 & 0.81568293 & 34.88417 & & 104.65252 & $104.65 \%$ & -0.7686218 & 38 \\
\hline Tailandia & 26.9471772 & 0.60315041 & 35.96459 & $0.00 \%$ & 107.89378 & $107.89 \%$ & 44.2737879 & 29 \\
\hline Uganda & 14.02042101 & 0.43253577 & 14.7038 & & 44.11139 & $44.11 \%$ & 26.9249306 & 36 \\
\hline Uruguay & 90.6862373 & 0.72995081 & 37.65888 & & 112.97663 & $112.98 \%$ & 233.669884 & 16 \\
\hline Venezuela & 107.6154479 & 0.6714939 & 49.78035 & & 149.34105 & $149.34 \%$ & 272.3945 & 15 \\
\hline Yemen & 0.092978862 & 0.27893659 & 0 & & & $0.00 \%$ & & 45 \\
\hline
\end{tabular}

Fuente: Elaboración propia a partir de la base de datos del Banco Mundial, periodo 1960-1980, (data.worldbank.org) 


\begin{tabular}{|c|c|c|c|c|c|c|c|c|}
\hline \multicolumn{9}{|c|}{ Año 1974} \\
\hline Country & $\begin{array}{c}\text { Human } \\
\text { Development } \\
\text { Index }\end{array}$ & $\begin{array}{c}\text { Life } \\
\text { Expectancy } \\
\text { Index }\end{array}$ & $\begin{array}{l}\text { Schooling } \\
\text { Index }\end{array}$ & $\begin{array}{c}\text { Adult } \\
\text { Literacy } \\
\text { Index } \\
(\%)\end{array}$ & $\begin{array}{c}\text { Combined } \\
\text { Enrolment } \\
\text { Rate }(\%)\end{array}$ & $\begin{array}{c}\text { Gross } \\
\text { Enrolment } \\
\text { Index }\end{array}$ & $\begin{array}{l}\text { GDCP } \\
\text { Index }\end{array}$ & $\begin{array}{l}\text { Classification } \\
\text { according to } \\
\text { IDH or Index } \\
\text { of Human } \\
\text { development }\end{array}$ \\
\hline Alemania & 303.5993193 & 0.7690187 & 0 & $0.00 \%$ & & $0.00 \%$ & 910.028939 & 8 \\
\hline Argentina & 177.2376338 & 0.7118878 & 60.36108 & & 181.0832 & $181.08 \%$ & 470.639937 & 11 \\
\hline Australia & 374.2655193 & 0.78726829 & 42.12915 & & 126.3875 & $126.39 \%$ & 1079.88014 & 5 \\
\hline Bolivia & 35.72485932 & 0.37666789 & 32.23674 & & 96.71023 & $96.71 \%$ & 74.5611667 & 28 \\
\hline Brasil & 69.96673715 & 0.58490732 & 44.06008 & $0.00 \%$ & 132.1802 & $132.18 \%$ & 165.255227 & 21 \\
\hline Canadá & 405.5391733 & 0.80395935 & 62.29189 & & 186.8757 & $186.88 \%$ & 1153.52167 & 2 \\
\hline Chile & 105.9077902 & 0.66238333 & 65.26028 & & 195.7808 & $195.78 \%$ & 251.800707 & 15 \\
\hline China & 28.4800878 & 0.67285447 & 59.16529 & & 177.4959 & $177.50 \%$ & 25.6021223 & 31 \\
\hline Colombia & 46.38903553 & 0.6211565 & 51.28159 & & 153.8448 & $153.84 \%$ & 87.2643567 & 25 \\
\hline Costa Rica & 62.60212472 & 0.73294431 & 48.92925 & & 146.7878 & $146.79 \%$ & 138.14418 & 24 \\
\hline Croacia & 0.249306775 & 0.74792033 & 0 & & & $0.00 \%$ & & 43 \\
\hline Cuba & 85.371761 & 0.77553293 & 51.74901 & & 155.247 & $155.25 \%$ & 203.59074 & 18 \\
\hline Dinamarca & 382.1050876 & 0.81347154 & 43.12842 & & 129.3853 & $129.39 \%$ & 1102.37337 & 4 \\
\hline Ecuador & 69.69603633 & 0.57613984 & 45.89603 & & 137.6881 & $137.69 \%$ & 162.615939 & 22 \\
\hline Egipto & 24.29105879 & 0.45968496 & 35.122 & & 105.366 & $105.37 \%$ & 37.2914914 & 32 \\
\hline El Salvador & 12.89045401 & 0.53720203 & 38.13416 & & 114.4025 & $114.40 \%$ & & 37 \\
\hline España & 170.7684872 & 0.79949593 & 63.86085 & & 191.5825 & $191.58 \%$ & 447.645119 & 12 \\
\hline Estados Unidos & 411.3071589 & 0.78260163 & 74.22471 & & 222.6741 & $222.67 \%$ & 1158.91417 & 1 \\
\hline Etiopía & 2.060327019 & 0.31694106 & 5.86404 & & 17.59212 & $17.59 \%$ & & 42 \\
\hline Finlandia & 314.4399157 & 0.76891463 & 69.63527 & & 208.9058 & $208.91 \%$ & 872.915566 & 7 \\
\hline Francia & 316.7023292 & 0.79341463 & 72.54653 & & 217.6396 & $217.64 \%$ & 876.76704 & 6 \\
\hline Guatemala & 37.16339686 & 0.49454065 & 24.33771 & & 73.01313 & $73.01 \%$ & 86.6579399 & 27 \\
\hline
\end{tabular}




\begin{tabular}{|c|c|c|c|c|c|c|c|c|}
\hline Guinea & 3.528179268 & 0.17952114 & 10.40502 & & 31.21505 & $31.22 \%$ & & 41 \\
\hline Haití & 6.25218664 & 0.39170325 & 18.36486 & & 55.09457 & $55.09 \%$ & & 40 \\
\hline Honduras & 31.02844454 & 0.49966748 & 36.09806 & & 108.2942 & $108.29 \%$ & 56.4876095 & 29 \\
\hline Irán & 86.4715145 & 0.49185691 & 27.88034 & & 83.64101 & $83.64 \%$ & 231.04235 & 17 \\
\hline Japón & 261.7051423 & 0.82323171 & 70.48429 & & 211.4529 & $211.45 \%$ & 713.807905 & 9 \\
\hline Mozambique & -0.16661756 & 0.26876911 & 0 & $0.00 \%$ & 0 & $0.00 \%$ & -0.7686218 & 45 \\
\hline México & 82.82050791 & 0.6395626 & 48.14154 & $0.00 \%$ & 144.4246 & $144.42 \%$ & 199.680424 & 19 \\
\hline Nepal & 11.62420661 & 0.32964146 & 19.16947 & & 57.50841 & $57.51 \%$ & 15.3735084 & 39 \\
\hline Nicaragua & 41.91093912 & 0.51638984 & 32.39823 & & 97.19469 & $97.19 \%$ & 92.8181975 & 26 \\
\hline Nigeria & 22.19616234 & 0.31530854 & 0 & & 0 & $0.00 \%$ & 66.2731785 & 34 \\
\hline Noruega & 398.7174263 & 0.82922764 & 70.5221 & & 211.5663 & $211.57 \%$ & 1124.80095 & 3 \\
\hline Panamá & 74.20623399 & 0.70348374 & 61.64729 & $0.00 \%$ & 184.9419 & $184.94 \%$ & 160.267928 & 20 \\
\hline Perú & 69.55472187 & 0.52323252 & 56.26896 & & 168.8069 & $168.81 \%$ & 151.87197 & 23 \\
\hline Portugal & 128.8590776 & 0.71699187 & 57.20491 & & 171.6147 & $171.61 \%$ & 328.655334 & 14 \\
\hline Reino Unido & 218.0831795 & 0.79207317 & 67.32112 & & 201.9634 & $201.96 \%$ & 586.136342 & 10 \\
\hline Senegal & 23.74274236 & 0.29630244 & 13.61809 & & 40.85427 & $40.85 \%$ & 57.3138346 & 33 \\
\hline Sudán & 20.07488377 & 0.36311138 & 18.50139 & & 55.50418 & $55.50 \%$ & 41.3601466 & 35 \\
\hline Suiza & 11.69502092 & 0.82145122 & 35.03223 & & 105.0967 & $105.10 \%$ & -0.7686218 & 38 \\
\hline Tailandia & 30.6425107 & 0.61108659 & 36.65082 & $0.00 \%$ & 109.9525 & $109.95 \%$ & 54.6656255 & 30 \\
\hline Uganda & 16.13945996 & 0.43352033 & 15.49655 & & 46.48965 & $46.49 \%$ & 32.4883096 & 36 \\
\hline Uruguay & 93.86512996 & 0.73198862 & 39.91475 & & 119.7443 & $119.74 \%$ & 240.948648 & 16 \\
\hline Venezuela & 148.243231 & 0.67961057 & 50.19343 & & 150.5803 & $150.58 \%$ & 393.856649 & 13 \\
\hline Yemen & 0.097243902 & 0.29173171 & 0 & & & $0.00 \%$ & & 44 \\
\hline
\end{tabular}

Fuente: Elaboración propia a partir de la base de datos del Banco Mundial, periodo 1960-1980, (data.worldbank.org) 


\begin{tabular}{|c|c|c|c|c|c|c|c|c|}
\hline \multicolumn{9}{|c|}{ Año 1975} \\
\hline Country & $\begin{array}{c}\text { Human } \\
\text { Development } \\
\text { Index }\end{array}$ & $\begin{array}{c}\text { Life } \\
\text { Expectancy } \\
\text { Index }\end{array}$ & $\begin{array}{l}\text { Schooling } \\
\text { Index }\end{array}$ & $\begin{array}{c}\text { Adult } \\
\text { Literacy } \\
\text { Index } \\
(\%)\end{array}$ & $\begin{array}{c}\text { Combined } \\
\text { Enrolment } \\
\text { Rate }(\%)\end{array}$ & $\begin{array}{c}\text { Gross } \\
\text { Enrolment } \\
\text { Index }\end{array}$ & $\begin{array}{l}\text { GDCP } \\
\text { Index }\end{array}$ & $\begin{array}{l}\text { Classification } \\
\text { according to } \\
\text { IDH or Index } \\
\text { of Human } \\
\text { development }\end{array}$ \\
\hline Alemania & 335.7573805 & 0.77311301 & 0 & $0.00 \%$ & & $0.00 \%$ & 1006.49903 & 8 \\
\hline Argentina & 132.6319427 & 0.71671789 & 62.23325 & & 186.6997 & $186.70 \%$ & 334.945864 & 14 \\
\hline Australia & 403.5406456 & 0.7937561 & 43.579 & & 130.737 & $130.74 \%$ & 1166.24918 & 5 \\
\hline Bolivia & 39.18858964 & 0.38710285 & 33.77384 & & 101.3215 & $101.32 \%$ & 83.4048261 & 28 \\
\hline Brasil & 78.30742152 & 0.5914752 & 44.30596 & $0.00 \%$ & 132.9179 & $132.92 \%$ & 190.024833 & 22 \\
\hline Canadá & 430.0945435 & 0.80869512 & 62.78601 & & 188.358 & $188.36 \%$ & 1226.68892 & 4 \\
\hline Chile & 60.02432272 & 0.67436911 & 64.48732 & & 193.462 & $193.46 \%$ & 114.911279 & 24 \\
\hline China & 29.84139767 & 0.67819268 & 60.26191 & & 180.7857 & $180.79 \%$ & 28.5840937 & 31 \\
\hline Colombia & 47.83807076 & 0.62840041 & 52.54787 & & 157.6436 & $157.64 \%$ & 90.3379385 & 25 \\
\hline Costa Rica & 69.40441881 & 0.74265691 & 48.75382 & & 146.2615 & $146.26 \%$ & 158.71678 & 23 \\
\hline Croacia & 0.25001084 & 0.75003252 & 0 & & & $0.00 \%$ & & 43 \\
\hline Cuba & 95.09157899 & 0.78253211 & 54.88949 & & 164.6685 & $164.67 \%$ & 229.602718 & 16 \\
\hline Dinamarca & 449.9598094 & 0.8179187 & 43.80963 & & 131.4289 & $131.43 \%$ & 1305.25188 & 2 \\
\hline Ecuador & 80.00867717 & 0.5844061 & 53.96322 & & 161.8897 & $161.89 \%$ & 185.478402 & 19 \\
\hline Egipto & 27.96583441 & 0.46934106 & 36.89528 & & 110.6858 & $110.69 \%$ & 46.5328855 & 33 \\
\hline El Salvador & 13.32750295 & 0.53769553 & 39.44481 & & 118.3344 & $118.33 \%$ & & 38 \\
\hline España & 196.5251525 & 0.80531301 & 66.0444 & & 198.1332 & $198.13 \%$ & 522.725741 & 11 \\
\hline Estados Unidos & 443.1422456 & 0.79341463 & 74.83718 & & 224.5115 & $224.51 \%$ & 1253.79615 & 3 \\
\hline Etiopía & 2.198801111 & 0.32028333 & 6.27612 & & 18.82836 & $18.83 \%$ & & 42 \\
\hline Finlandia & 367.5846038 & 0.77789431 & 71.0769 & & 213.2307 & $213.23 \%$ & 1030.89902 & 7 \\
\hline Francia & 390.2076819 & 0.79756098 & 72.17015 & & 216.5104 & $216.51 \%$ & 1097.65534 & 6 \\
\hline Guatemala & 40.98559077 & 0.50316016 & 24.98293 & & 74.94879 & $74.95 \%$ & 97.4706822 & 27 \\
\hline
\end{tabular}




\begin{tabular}{|c|c|c|c|c|c|c|c|c|}
\hline Guinea & 3.625380732 & 0.18797886 & 10.68816 & & 32.06449 & $32.06 \%$ & & 41 \\
\hline Haití & 6.427286341 & 0.39782236 & 18.88404 & & 56.65211 & $56.65 \%$ & & 40 \\
\hline Honduras & 31.80641382 & 0.51128537 & 35.311 & & 105.933 & $105.93 \%$ & 59.5969528 & 30 \\
\hline Irán & 92.99622988 & 0.50377276 & 30.79854 & & 92.39561 & $92.40 \%$ & 247.68638 & 17 \\
\hline Japón & 278.8728906 & 0.83428862 & 71.86945 & & 215.6084 & $215.61 \%$ & 763.91493 & 9 \\
\hline Mozambique & -0.164123929 & 0.27625 & 0 & $0.00 \%$ & 0 & $0.00 \%$ & -0.7686218 & 45 \\
\hline México & 95.66797029 & 0.64881423 & 49.09724 & $0.00 \%$ & 147.2917 & $147.29 \%$ & 237.257853 & 15 \\
\hline Nepal & 13.7679933 & 0.33883537 & 21.29982 & & 63.89945 & $63.90 \%$ & 19.6653279 & 37 \\
\hline Nicaragua & 42.80761808 & 0.52467154 & 34.32406 & & 102.9722 & $102.97 \%$ & 93.5741194 & 26 \\
\hline Nigeria & 24.24366308 & 0.32078862 & 0.239717 & & 0.71915 & $0.72 \%$ & 72.1704839 & 34 \\
\hline Noruega & 475.7155904 & 0.83029268 & 70.71695 & & 212.1508 & $212.15 \%$ & 1355.59953 & 1 \\
\hline Panamá & 79.33356043 & 0.71188415 & 62.4837 & $0.00 \%$ & 187.4511 & $187.45 \%$ & 174.805097 & 21 \\
\hline Perú & 79.41421939 & 0.5340561 & 57.8247 & & 173.4741 & $173.47 \%$ & 179.883902 & 20 \\
\hline Portugal & 136.3473511 & 0.72182927 & 58.71465 & & 176.144 & $176.14 \%$ & 349.605571 & 13 \\
\hline Reino Unido & 256.6449385 & 0.7954065 & 68.0893 & & 204.2679 & $204.27 \%$ & 701.050109 & 10 \\
\hline Senegal & 29.76522891 & 0.30738455 & 13.61915 & & 40.85744 & $40.86 \%$ & 75.3691555 & 32 \\
\hline Sudán & 22.84721294 & 0.37015447 & 19.22953 & & 57.6886 & $57.69 \%$ & 48.941951 & 35 \\
\hline Suiza & 11.71074057 & 0.82776016 & 35.07308 & & 105.2193 & $105.22 \%$ & -0.7686218 & 39 \\
\hline Tailandia & 31.82611474 & 0.61953293 & 36.94931 & $0.00 \%$ & 110.8479 & $110.85 \%$ & 57.909498 & 29 \\
\hline Uganda & 17.53141079 & 0.43229634 & 16.55705 & & 49.67115 & $49.67 \%$ & 35.604886 & 36 \\
\hline Uruguay & 83.06924755 & 0.73454268 & 40.59284 & & 121.7785 & $121.78 \%$ & 207.88036 & 18 \\
\hline Venezuela & 154.2926787 & 0.68757195 & 51.41831 & & 154.2549 & $154.25 \%$ & 410.772158 & 12 \\
\hline Yemen & 0.102247696 & 0.30674309 & 0 & & & $0.00 \%$ & & 44 \\
\hline
\end{tabular}

Fuente: Elaboración propia a partir de la base de datos del Banco Mundial, periodo 1960-1980, (data.worldbank.org) 


\begin{tabular}{|c|c|c|c|c|c|c|c|c|}
\hline \multicolumn{9}{|c|}{ Año 1976} \\
\hline Country & $\begin{array}{c}\text { Human } \\
\text { Development } \\
\text { Index }\end{array}$ & $\begin{array}{c}\text { Life } \\
\text { Expectancy } \\
\text { Index }\end{array}$ & $\begin{array}{l}\text { Schooling } \\
\text { Index }\end{array}$ & $\begin{array}{c}\text { Adult } \\
\text { Literacy } \\
\text { Index } \\
(\%)\end{array}$ & $\begin{array}{c}\text { Combined } \\
\text { Enrolment } \\
\text { Rate }(\%)\end{array}$ & $\begin{array}{c}\text { Gross } \\
\text { Enrolment } \\
\text { Index }\end{array}$ & $\begin{array}{l}\text { GDCP } \\
\text { Index }\end{array}$ & $\begin{array}{l}\text { Classification } \\
\text { according to } \\
\text { IDH or Index } \\
\text { of Human } \\
\text { development }\end{array}$ \\
\hline Alemania & 357.2134489 & 0.77777439 & 0 & $0.00 \%$ & & $0.00 \%$ & 1070.86257 & 8 \\
\hline Argentina & 128.3611354 & 0.72153049 & 62.65457 & & 187.9637 & $187.96 \%$ & 321.707309 & 14 \\
\hline Australia & 430.7014407 & 0.8002439 & 44.09771 & & 132.2931 & $132.29 \%$ & 1247.20636 & 5 \\
\hline Bolivia & 42.45738259 & 0.39858089 & 34.38234 & & 103.147 & $103.15 \%$ & 92.5912269 & 28 \\
\hline Brasil & 90.95287595 & 0.59811098 & 43.05912 & $0.00 \%$ & 129.1774 & $129.18 \%$ & 229.2014 & 18 \\
\hline Canadá & 500.777313 & 0.81426829 & 62.80286 & & 188.4086 & $188.41 \%$ & 1438.71481 & 2 \\
\hline Chile & 72.88769319 & 0.68677886 & 63.24368 & & 189.7311 & $189.73 \%$ & 154.732617 & 24 \\
\hline China & 30.00190916 & 0.68307398 & 62.89917 & & 188.6975 & $188.70 \%$ & 26.4234802 & 33 \\
\hline Colombia & 52.4825128 & 0.6364935 & 53.31303 & & 159.9391 & $159.94 \%$ & 103.498012 & 25 \\
\hline Costa Rica & 80.26659343 & 0.7527061 & 49.55997 & & 148.6799 & $148.68 \%$ & 190.487104 & 22 \\
\hline Croacia & 0.25252981 & 0.75758943 & 0 & & & $0.00 \%$ & & 43 \\
\hline Cuba & 100.2798684 & 0.78909146 & 59.66384 & & 178.9915 & $178.99 \%$ & 240.386674 & 16 \\
\hline Dinamarca & 493.9624617 & 0.81232927 & 44.76501 & & 134.295 & $134.30 \%$ & 1436.31005 & 3 \\
\hline Ecuador & 90.09047678 & 0.59311992 & 57.29046 & & 171.8714 & $171.87 \%$ & 212.387847 & 19 \\
\hline Egipto & 30.62418324 & 0.47922114 & 38.05415 & & 114.1625 & $114.16 \%$ & 53.3391786 & 32 \\
\hline El Salvador & 13.81622041 & 0.53693455 & 40.91173 & & 122.7352 & $122.74 \%$ & & 38 \\
\hline España & 200.8849048 & 0.81071138 & 68.252 & & 204.756 & $204.76 \%$ & 533.592 & 11 \\
\hline Estados Unidos & 487.0891187 & 0.79760163 & 76.38637 & & 229.1591 & $229.16 \%$ & 1384.08339 & 4 \\
\hline Etiopía & 2.422234715 & 0.32215081 & 6.944553 & & 20.83366 & $20.83 \%$ & & 42 \\
\hline Finlandia & 394.7877378 & 0.78021545 & 72.83836 & & 218.5151 & $218.52 \%$ & 1110.74464 & 7 \\
\hline Francia & 400.021124 & 0.80170732 & 71.72064 & & 215.1619 & $215.16 \%$ & 1127.54103 & 6 \\
\hline Guatemala & 46.567234 & 0.51087073 & 25.25888 & & 75.77665 & $75.78 \%$ & 113.931948 & 27 \\
\hline
\end{tabular}




\begin{tabular}{|c|c|c|c|c|c|c|c|c|}
\hline Guinea & 3.541785285 & 0.19653252 & 10.42882 & & 31.28647 & $31.29 \%$ & & 41 \\
\hline Haití & 6.922812222 & 0.4042 & 20.36424 & & 61.09271 & $61.09 \%$ & & 40 \\
\hline Honduras & 35.4674971 & 0.52330447 & 36.44652 & & 109.3396 & $109.34 \%$ & 69.4326702 & 30 \\
\hline Irán & 115.2422609 & 0.50919919 & 32.73745 & & 98.21236 & $98.21 \%$ & 312.48013 & 15 \\
\hline Japón & 308.7863313 & 0.84094715 & 73.19055 & & 219.5717 & $219.57 \%$ & 852.327497 & 9 \\
\hline Mozambique & -0.16192962 & 0.28283293 & 0 & $0.00 \%$ & 0 & $0.00 \%$ & -0.7686218 & 45 \\
\hline México & 94.97508222 & 0.65809146 & 50.99346 & $0.00 \%$ & 152.9804 & $152.98 \%$ & 233.273699 & 17 \\
\hline Nepal & 13.87689031 & 0.34814228 & 23.6209 & & 70.8627 & $70.86 \%$ & 17.6616287 & 37 \\
\hline Nicaragua & 47.40600059 & 0.53216992 & 36.19578 & & 108.5873 & $108.59 \%$ & 105.490055 & 26 \\
\hline Nigeria & 36.14113662 & 0.32579878 & 16.24234 & & 48.72702 & $48.73 \%$ & 91.8552711 & 29 \\
\hline Noruega & 515.0591091 & 0.83399187 & 70.32012 & & 210.9604 & $210.96 \%$ & 1474.02322 & 1 \\
\hline Panamá & 81.73099863 & 0.72020935 & 63.61836 & $0.00 \%$ & 190.8551 & $190.86 \%$ & 180.854423 & 21 \\
\hline Perú & 75.15774796 & 0.54421301 & 59.5068 & & 178.5204 & $178.52 \%$ & 165.422231 & 23 \\
\hline Portugal & 140.0217174 & 0.73101626 & 62.2116 & & 186.6348 & $186.63 \%$ & 357.122536 & 13 \\
\hline Reino Unido & 247.6913042 & 0.79626016 & 68.58018 & & 205.7405 & $205.74 \%$ & 673.697476 & 10 \\
\hline Senegal & 29.37100286 & 0.31940041 & 13.37965 & & 40.13896 & $40.14 \%$ & 74.4139548 & 34 \\
\hline Sudán & 26.27744129 & 0.37725528 & 19.22883 & & 57.68649 & $57.69 \%$ & 59.2262386 & 35 \\
\hline Suiza & 11.71132921 & 0.8297561 & 35.07285 & & 105.2186 & $105.22 \%$ & -0.7686218 & 39 \\
\hline Tailandia & 34.15472158 & 0.62872033 & 37.25733 & $0.00 \%$ & 111.772 & $111.77 \%$ & 64.5781111 & 31 \\
\hline Uganda & 17.85227204 & 0.42952967 & 17.22823 & & 51.6847 & $51.68 \%$ & 35.8990531 & 36 \\
\hline Uruguay & 83.86915644 & 0.73768049 & 36.24441 & & 108.7332 & $108.73 \%$ & 214.625382 & 20 \\
\hline Venezuela & 171.0060961 & 0.6951939 & 54.32234 & & 162.967 & $162.97 \%$ & 458.000754 & 12 \\
\hline Yemen & 0.107887669 & 0.32366301 & 0 & & & $0.00 \%$ & & 44 \\
\hline
\end{tabular}

Fuente: Elaboración propia a partir de la base de datos del Banco Mundial, periodo 1960-1980, (data.worldbank.org) 


\begin{tabular}{|c|c|c|c|c|c|c|c|c|}
\hline \multicolumn{9}{|c|}{ Año 1977} \\
\hline Country & $\begin{array}{c}\text { Human } \\
\text { Development } \\
\text { Index }\end{array}$ & $\begin{array}{c}\text { Life } \\
\text { Expectancy } \\
\text { Index }\end{array}$ & $\begin{array}{l}\text { Schooling } \\
\text { Index }\end{array}$ & $\begin{array}{c}\text { Adult } \\
\text { Literacy } \\
\text { Index } \\
(\%)\end{array}$ & $\begin{array}{c}\text { Combined } \\
\text { Enrolment } \\
\text { Rate }(\%)\end{array}$ & $\begin{array}{c}\text { Gross } \\
\text { Enrolment } \\
\text { Index }\end{array}$ & $\begin{array}{l}\text { GDCP } \\
\text { Index }\end{array}$ & $\begin{array}{l}\text { Classification } \\
\text { according to } \\
\text { IDH or Index } \\
\text { of Human } \\
\text { development }\end{array}$ \\
\hline Alemania & 413.6429988 & 0.78269675 & 0 & $0.00 \%$ & & $0.00 \%$ & 1240.1463 & 7 \\
\hline Argentina & 138.1205676 & 0.72640081 & 61.96566 & & 185.89698 & $185.90 \%$ & 351.669642 & 14 \\
\hline Australia & 446.9040914 & 0.80573984 & 44.88237 & & 134.64711 & $134.65 \%$ & 1295.02416 & 5 \\
\hline Bolivia & 46.82001124 & 0.41080122 & 33.12584 & & 99.37751 & $99.38 \%$ & 106.923396 & 28 \\
\hline Brasil & 101.284672 & 0.60480976 & 44.85226 & $0.00 \%$ & 134.55677 & $134.56 \%$ & 258.39695 & 17 \\
\hline Canadá & 506.7926897 & 0.82026016 & 62.97342 & & 188.92025 & $188.92 \%$ & 1456.58439 & 4 \\
\hline Chile & 90.44762677 & 0.69943862 & 63.60716 & & 190.82147 & $190.82 \%$ & 207.036285 & 21 \\
\hline China & 30.47725271 & 0.68751789 & 61.02306 & & 183.06918 & $183.07 \%$ & 29.7211803 & 34 \\
\hline Colombia & 61.45825469 & 0.64537317 & 55.2029 & & 165.6087 & $165.61 \%$ & 128.526491 & 25 \\
\hline Costa Rica & 95.80808192 & 0.76292439 & 50.24699 & & 150.74098 & $150.74 \%$ & 236.414328 & 19 \\
\hline Croacia & 0.254135501 & 0.7624065 & 0 & & & $0.00 \%$ & & 43 \\
\hline Cuba & 103.1913039 & 0.79511057 & 63.42457 & & 190.2737 & $190.27 \%$ & 245.354234 & 16 \\
\hline Dinamarca & 548.7342797 & 0.82720732 & 43.66956 & & 131.00868 & $131.01 \%$ & 1601.70607 & 2 \\
\hline Ecuador & 100.5063758 & 0.60227317 & 50.01654 & & 150.04961 & $150.05 \%$ & 250.900318 & 18 \\
\hline Egipto & 32.41753358 & 0.48923496 & 39.49919 & & 118.49758 & $118.50 \%$ & 57.2641724 & 32 \\
\hline El Salvador & 14.06887829 & 0.53515488 & 41.67148 & & 125.01444 & $125.01 \%$ & & 38 \\
\hline España & 219.8450169 & 0.81886585 & 69.32894 & & 207.98682 & $207.99 \%$ & 589.387245 & 11 \\
\hline Estados Unidos & 533.9885365 & 0.80426829 & 75.96001 & & 227.88003 & $227.88 \%$ & 1525.20133 & 3 \\
\hline Etiopía & 2.601261924 & 0.32230244 & 7.481483 & & 22.44445 & $22.44 \%$ & & 42 \\
\hline Finlandia & 413.2785985 & 0.78917073 & 73.97472 & & 221.92415 & $221.92 \%$ & 1165.07191 & 8 \\
\hline Francia & 437.3364683 & 0.80585366 & 71.9773 & & 215.93191 & $215.93 \%$ & 1239.22625 & 6 \\
\hline Guatemala & 55.48563875 & 0.51801341 & 26.19263 & & 78.57789 & $78.58 \%$ & 139.746273 & 26 \\
\hline
\end{tabular}




\begin{tabular}{|c|c|c|c|c|c|c|c|c|}
\hline Guinea & 5.706971843 & 0.20512886 & 16.91579 & & 50.74736 & $50.75 \%$ & & 41 \\
\hline Haití & 7.040906829 & 0.41076382 & 20.71196 & & 62.13587 & $62.14 \%$ & & 40 \\
\hline Honduras & 40.9995013 & 0.53563252 & 38.97154 & & 116.91463 & $116.91 \%$ & 83.491328 & 29 \\
\hline Irán & 130.2239902 & 0.50635935 & 34.07887 & & 102.2366 & $102.24 \%$ & 356.086745 & 15 \\
\hline Japón & 371.3756087 & 0.84830488 & 74.17857 & & 222.53571 & $222.54 \%$ & 1039.09995 & 9 \\
\hline Mozambique & 0.136045854 & 0.28825935 & 0.8885 & $0.00 \%$ & 2.6655 & $2.67 \%$ & -0.7686218 & 44 \\
\hline México & 87.38336069 & 0.66723008 & 52.98412 & $0.00 \%$ & 158.95237 & $158.95 \%$ & 208.498729 & 22 \\
\hline Nepal & 14.6980303 & 0.35752276 & 27.35027 & & 82.0508 & $82.05 \%$ & 16.3863015 & 37 \\
\hline Nicaragua & 53.96591443 & 0.53901382 & 37.17566 & & 111.52699 & $111.53 \%$ & 124.183066 & 27 \\
\hline Nigeria & 37.05325663 & 0.33039106 & 22.3964 & & 67.18919 & $67.19 \%$ & 88.4329822 & 31 \\
\hline Noruega & 588.9139491 & 0.83978049 & 71.30389 & & 213.91168 & $213.91 \%$ & 1694.59817 & 1 \\
\hline Panamá & 83.96845568 & 0.72826057 & 64.27762 & $0.00 \%$ & 192.83286 & $192.83 \%$ & 186.899486 & 23 \\
\hline Perú & 69.63987066 & 0.55403618 & 60.82932 & & 182.48796 & $182.49 \%$ & 147.536256 & 24 \\
\hline Portugal & 145.6124938 & 0.75020325 & 63.47072 & & 190.41216 & $190.41 \%$ & 372.616558 & 13 \\
\hline Reino Unido & 276.9404327 & 0.80373984 & 68.79127 & & 206.37381 & $206.37 \%$ & 761.226288 & 10 \\
\hline Senegal & 29.87327328 & 0.33214959 & 15.00048 & & 45.00143 & $45.00 \%$ & 74.2871936 & 35 \\
\hline Sudán & 30.51933092 & 0.38437195 & 19.54607 & & 58.63821 & $58.64 \%$ & 71.6275508 & 33 \\
\hline Suiza & 10.97943079 & 0.83730081 & 32.86961 & & 98.60884 & $98.61 \%$ & -0.7686218 & 39 \\
\hline Tailandia & 37.36305627 & 0.63880488 & 37.88065 & $0.00 \%$ & 113.64194 & $113.64 \%$ & 73.5697173 & 30 \\
\hline Uganda & 20.21657052 & 0.42611179 & 18.26492 & & 54.79476 & $54.79 \%$ & 41.9586798 & 36 \\
\hline Uruguay & 94.27197835 & 0.74130244 & 42.48552 & & 127.45656 & $127.46 \%$ & 239.589113 & 20 \\
\hline Venezuela & 188.9353093 & 0.70232602 & 49.92142 & & 149.76427 & $149.76 \%$ & 516.182179 & 12 \\
\hline Yemen & 0.113933333 & 0.3418 & 0 & & & $0.00 \%$ & & 45 \\
\hline
\end{tabular}

Fuente: Elaboración propia a partir de la base de datos del Banco Mundial, periodo 1960-1980, (data.worldbank.org) 


\begin{tabular}{|c|c|c|c|c|c|c|c|c|}
\hline \multicolumn{9}{|c|}{ Año 1978} \\
\hline Country & $\begin{array}{c}\text { Human } \\
\text { Development } \\
\text { Index }\end{array}$ & $\begin{array}{c}\text { Life } \\
\text { Expectancy } \\
\text { Index }\end{array}$ & $\begin{array}{l}\text { Schooling } \\
\text { Index }\end{array}$ & $\begin{array}{c}\text { Adult } \\
\text { Literacy } \\
\text { Index } \\
(\%)\end{array}$ & $\begin{array}{c}\text { Combined } \\
\text { Enrolment } \\
\text { Rate }(\%)\end{array}$ & $\begin{array}{c}\text { Gross } \\
\text { Enrolment } \\
\text { Index }\end{array}$ & $\begin{array}{l}\text { GDCP } \\
\text { Index }\end{array}$ & $\begin{array}{c}\text { Classification } \\
\text { according to } \\
\text { IDH or Index } \\
\text { of Human } \\
\text { development }\end{array}$ \\
\hline Alemania & 510.5047961 & 0.78759878 & 0 & $0.00 \%$ & & $0.00 \%$ & 1530.72679 & 6 \\
\hline Argentina & 138.6928986 & 0.73135407 & 60.92466 & & 182.77399 & $182.77 \%$ & 354.422678 & 14 \\
\hline Australia & 473.5485008 & 0.81123577 & 45.37309 & & 136.11926 & $136.12 \%$ & 1374.46118 & 8 \\
\hline Bolivia & 51.76129419 & 0.42347967 & 33.15529 & & 99.46586 & $99.47 \%$ & 121.705116 & 27 \\
\hline Brasil & 111.6328687 & 0.61153618 & 46.53804 & $0.00 \%$ & 139.61413 & $139.61 \%$ & 287.749027 & 17 \\
\hline Canadá & 517.8609888 & 0.82549593 & 62.85659 & & 188.56978 & $188.57 \%$ & 1489.90088 & 5 \\
\hline Chile & 100.007795 & 0.71212439 & 63.80969 & & 191.42906 & $191.43 \%$ & 235.501574 & 22 \\
\hline China & 27.74111239 & 0.69159675 & 57.43489 & & 172.30467 & $172.30 \%$ & 25.0968504 & 35 \\
\hline Colombia & 69.03328986 & 0.65482886 & 56.2817 & & 168.84509 & $168.85 \%$ & 150.163344 & 24 \\
\hline Costa Rica & 102.4722625 & 0.77311138 & 42.7449 & & 128.23471 & $128.23 \%$ & 263.898773 & 21 \\
\hline Croacia & 0.252993225 & 0.75897967 & 0 & & & $0.00 \%$ & & 43 \\
\hline Cuba & 123.8280918 & 0.80051423 & 64.72203 & & 194.16609 & $194.17 \%$ & 305.961731 & 16 \\
\hline Dinamarca & 671.6155294 & 0.82321545 & 75.86108 & & 227.58325 & $227.58 \%$ & 1938.16229 & 1 \\
\hline Ecuador & 105.3469396 & 0.61184106 & 51.19011 & & 153.57032 & $153.57 \%$ & 264.238871 & 19 \\
\hline Egipto & 32.57235495 & 0.49926667 & 40.35437 & & 121.06312 & $121.06 \%$ & 56.8634249 & 33 \\
\hline El Salvador & 14.47577434 & 0.53289634 & 42.89443 & & 128.68328 & $128.68 \%$ & & 39 \\
\hline España & 258.7490818 & 0.8215935 & 70.35946 & & 211.07837 & $211.08 \%$ & 705.066195 & 11 \\
\hline Estados Unidos & 594.3204222 & 0.80593496 & 76.27826 & & 228.83477 & $228.83 \%$ & 1705.87707 & 3 \\
\hline Etiopía & 2.508100027 & 0.32086341 & 7.203437 & & 21.61031 & $21.61 \%$ & & 42 \\
\hline Finlandia & 444.2900402 & 0.79828455 & 74.69225 & & 224.07675 & $224.08 \%$ & 1257.37959 & 9 \\
\hline Francia & 532.17091 & 0.81004065 & 72.64865 & & 217.94596 & $217.95 \%$ & 1523.05404 & 4 \\
\hline Guatemala & 59.95657676 & 0.52487114 & 28.18488 & & 84.55463 & $84.55 \%$ & 151.159982 & 26 \\
\hline
\end{tabular}




\begin{tabular}{|c|c|c|c|c|c|c|c|c|}
\hline Guinea & 6.053209377 & 0.21370813 & 17.94592 & & 53.83776 & $53.84 \%$ & & 41 \\
\hline Haití & 7.075533198 & 0.41749959 & 20.8091 & & 62.4273 & $62.43 \%$ & & 40 \\
\hline Honduras & 45.11978724 & 0.54816138 & 41.23419 & & 123.70257 & $123.70 \%$ & 93.5770103 & 29 \\
\hline Irán & 123.9160536 & 0.49516667 & 35.03144 & & 105.09433 & $105.09 \%$ & 336.221551 & 15 \\
\hline Japón & 507.6635288 & 0.85063821 & 75.01316 & & 225.03949 & $225.04 \%$ & 1447.12678 & 7 \\
\hline Mozambique & 0.19141645 & 0.29240447 & 1.050467 & $0.00 \%$ & 3.1514 & $3.15 \%$ & -0.7686218 & 44 \\
\hline México & 103.0702003 & 0.67612317 & 53.97031 & $0.00 \%$ & 161.91093 & $161.91 \%$ & 254.564168 & 20 \\
\hline Nepal & 16.5356098 & 0.36694512 & 30.53857 & & 91.6157 & $91.62 \%$ & 18.7013176 & 38 \\
\hline Nicaragua & 49.65839519 & 0.54540732 & 33.36582 & & 100.09745 & $100.10 \%$ & 115.063962 & 28 \\
\hline Nigeria & 38.48578498 & 0.33455894 & 28.18528 & & 84.55583 & $84.56 \%$ & 86.9375193 & 31 \\
\hline Noruega & 654.508814 & 0.84030894 & 71.17474 & & 213.52422 & $213.52 \%$ & 1891.51139 & 2 \\
\hline Panamá & 93.71244254 & 0.73587195 & 64.21668 & $0.00 \%$ & 192.65005 & $192.65 \%$ & 216.184772 & 23 \\
\hline Perú & 60.28750396 & 0.56383374 & 57.67907 & & 173.03721 & $173.04 \%$ & 122.619608 & 25 \\
\hline Portugal & 156.118016 & 0.75528455 & 63.70304 & & 191.10911 & $191.11 \%$ & 403.895727 & 13 \\
\hline Reino Unido & 344.7408383 & 0.80292683 & 68.57092 & & 205.71277 & $205.71 \%$ & 964.848665 & 10 \\
\hline Senegal & 33.22624518 & 0.34536504 & 18.34605 & & 55.03816 & $55.04 \%$ & 80.9873172 & 32 \\
\hline Sudán & 31.90599972 & 0.39142967 & 20.18584 & & 60.55751 & $60.56 \%$ & 75.1407328 & 34 \\
\hline Suiza & 21.3897345 & 0.83645528 & 64.10137 & & 192.30411 & $192.30 \%$ & -0.7686218 & 36 \\
\hline Tailandia & 42.09349514 & 0.64985244 & 38.16761 & $0.00 \%$ & 114.50282 & $114.50 \%$ & 87.4630263 & 30 \\
\hline Uganda & 17.52141908 & 0.42280854 & 18.72943 & & 56.18828 & $56.19 \%$ & 33.412022 & 37 \\
\hline Uruguay & 107.1627746 & 0.74531789 & 36.55461 & & 109.66383 & $109.66 \%$ & 284.188396 & 18 \\
\hline Venezuela & 202.0433831 & 0.70888455 & 57.62497 & & 172.87492 & $172.87 \%$ & 547.796291 & 12 \\
\hline Yemen & 0.120145664 & 0.36043699 & 0 & & & $0.00 \%$ & & 45 \\
\hline
\end{tabular}

Fuente: Elaboración propia a partir de la base de datos del Banco Mundial, periodo 1960-1980, (data.worldbank.org) 


\begin{tabular}{|c|c|c|c|c|c|c|c|c|}
\hline \multicolumn{9}{|c|}{ Año 1979} \\
\hline Country & $\begin{array}{c}\text { Human } \\
\text { Development } \\
\text { Index }\end{array}$ & $\begin{array}{c}\text { Life } \\
\text { Expectancy } \\
\text { Index }\end{array}$ & $\begin{array}{l}\text { Schooling } \\
\text { Index }\end{array}$ & $\begin{array}{c}\text { Adult } \\
\text { Literacy } \\
\text { Index }(\%)\end{array}$ & $\begin{array}{c}\text { Combined } \\
\text { Enrolment } \\
\text { Rate }(\%)\end{array}$ & $\begin{array}{c}\text { Gross } \\
\text { Enrolment } \\
\text { Index }\end{array}$ & $\begin{array}{l}\text { GDCP } \\
\text { Index }\end{array}$ & $\begin{array}{l}\text { Classification } \\
\text { according to } \\
\text { IDH or Index } \\
\text { of Human } \\
\text { development }\end{array}$ \\
\hline Alemania & 607.3607042 & 0.79237276 & 0 & $0.00 \%$ & & $0.00 \%$ & 1821.29 & 5 \\
\hline Argentina & 159.5062578 & 0.73632398 & 61.29806 & & 183.89417 & $183.89 \%$ & 416.4844 & 14 \\
\hline Australia & 531.4936019 & 0.81673171 & 45.32145 & & 135.96436 & $135.96 \%$ & 1548.343 & 8 \\
\hline Bolivia & $\mathbf{5 7 . 9 3 0 4 3 8 2 5}$ & 0.43641545 & 33.39648 & & 100.18944 & $100.19 \%$ & 139.9584 & 27 \\
\hline Brasil & 121.4765894 & 0.61825732 & 48.84666 & $0.00 \%$ & 146.53998 & $146.54 \%$ & 314.9649 & 21 \\
\hline Canadá & $\mathbf{5 6 7 . 7 9 8 8 3 6 1}$ & 0.83110569 & 62.48657 & & 187.4597 & $187.46 \%$ & 1640.079 & 6 \\
\hline Chile & 125.952677 & 0.72459553 & 64.25904 & & 192.77711 & $192.78 \%$ & 312.8744 & 19 \\
\hline China & 28.56549032 & 0.69564878 & 55.34538 & & 166.03614 & $166.04 \%$ & 29.65544 & 35 \\
\hline Colombia & 78.21184383 & 0.66462033 & 57.60196 & & 172.80588 & $172.81 \%$ & 176.369 & 24 \\
\hline Costa Rica & 117.5451216 & 0.78306626 & 57.73373 & & 173.2012 & $173.20 \%$ & 294.1186 & 22 \\
\hline Croacia & 0.252373984 & 0.75712195 & 0 & & & $0.00 \%$ & & 44 \\
\hline Cuba & 133.3779991 & 0.8052687 & 65.73925 & & 197.21776 & $197.22 \%$ & 333.5895 & 17 \\
\hline Dinamarca & 776.9311009 & 0.82032114 & 74.79651 & & 224.38954 & $224.39 \%$ & 2255.176 & 1 \\
\hline Ecuador & 123.7182502 & 0.62176585 & 64.35745 & & 193.07235 & $193.07 \%$ & 306.1755 & 20 \\
\hline Egipto & 36.49559403 & 0.50927561 & 40.82198 & & 122.46593 & $122.47 \%$ & 68.15553 & 33 \\
\hline El Salvador & 14.9215132 & 0.53089959 & 44.23364 & & 132.70092 & $132.70 \%$ & & 39 \\
\hline España & 335.4448345 & 0.83031301 & 71.42985 & & 214.28954 & $214.29 \%$ & 934.0743 & 11 \\
\hline Estados Unidos & 653.3992682 & 0.81341463 & 73.85598 & & 221.56793 & $221.57 \%$ & 1885.528 & 3 \\
\hline Etiopía & 2.959512846 & 0.3182252 & 8.560313 & & 25.68094 & $25.68 \%$ & & 42 \\
\hline Finlandia & 538.2003147 & 0.80258943 & 75.48832 & & 226.46497 & $226.46 \%$ & 1538.31 & 7 \\
\hline Francia & 636.3565203 & 0.81418699 & 72.43419 & & 217.30257 & $217.30 \%$ & 1835.821 & 4 \\
\hline Guatemala & 65.75208056 & 0.53164431 & 28.86889 & & 86.60667 & $86.61 \%$ & 167.8557 & 26 \\
\hline
\end{tabular}




\begin{tabular}{|c|c|c|c|c|c|c|c|c|}
\hline Guinea & 6.280498103 & 0.22221098 & 18.61928 & & 55.85785 & $55.86 \%$ & & 41 \\
\hline Haití & 8.392203062 & 0.42436585 & 24.75224 & & 74.25673 & $74.26 \%$ & & 40 \\
\hline Honduras & 49.05747174 & 0.56082358 & 40.72259 & & 122.16776 & $122.17 \%$ & 105.889 & 28 \\
\hline Irán & 137.8486279 & 0.4770935 & 29.97124 & & 89.91373 & $89.91 \%$ & 383.0975 & 16 \\
\hline Japón & 523.2312039 & 0.85562602 & 75.21547 & & 225.64641 & $225.65 \%$ & 1493.623 & 9 \\
\hline Mozambique & 0.303523632 & 0.29522602 & 1.383967 & $0.00 \%$ & 4.1519 & $4.15 \%$ & -0.768622 & 43 \\
\hline México & 127.9184658 & 0.68468089 & 57.05208 & $0.00 \%$ & 171.15623 & $171.16 \%$ & 326.0186 & 18 \\
\hline Nepal & 18.7488707 & 0.37640976 & 34.66762 & & 104.00287 & $104.00 \%$ & 21.20258 & 37 \\
\hline Nicaragua & 40.51313253 & 0.55155407 & 38.90508 & & 116.71525 & $116.72 \%$ & 82.08276 & 31 \\
\hline Nigeria & 47.68003697 & 0.33827724 & 33.33419 & & 100.00258 & $100.00 \%$ & 109.3676 & 29 \\
\hline Noruega & 741.9094099 & 0.84023171 & 72.09092 & & 216.27275 & $216.27 \%$ & 2152.797 & 2 \\
\hline Panamá & 101.9629086 & 0.74293618 & 63.66637 & $0.00 \%$ & 190.99912 & $191.00 \%$ & 241.4794 & 23 \\
\hline Perú & 72.14818593 & 0.57367276 & 63.04714 & & 189.14143 & $189.14 \%$ & 152.8237 & 25 \\
\hline Portugal & 171.6535457 & 0.76947154 & 61.17023 & & 183.5107 & $183.51 \%$ & 453.0209 & 13 \\
\hline Reino Unido & 440.725745 & 0.8045935 & 68.50659 & & 205.51977 & $205.52 \%$ & 1252.866 & 10 \\
\hline Senegal & 38.86693619 & 0.35878049 & 17.73299 & & 53.19896 & $53.20 \%$ & 98.50904 & 32 \\
\hline Sudán & 32.05377314 & 0.39833659 & 20.51614 & & 61.54841 & $61.55 \%$ & 75.24685 & 34 \\
\hline Suiza & 21.49485106 & 0.84110163 & 64.41207 & & 193.23622 & $193.24 \%$ & -0.768622 & 36 \\
\hline Tailandia & 46.90523292 & 0.66185447 & 42.3604 & $0.00 \%$ & 127.0812 & $127.08 \%$ & 97.69344 & 30 \\
\hline Uganda & 15.79006644 & 0.41996951 & 18.40394 & & 55.21181 & $55.21 \%$ & 28.54629 & 38 \\
\hline Uruguay & 151.7798532 & 0.74963496 & 41.49052 & & 124.47157 & $124.47 \%$ & 413.0994 & 15 \\
\hline Venezuela & 231.5312957 & 0.71486992 & 58.56494 & & 175.69482 & $175.69 \%$ & 635.3141 & 12 \\
\hline Yemen & 0.12635271 & 0.37905813 & 0 & & & $0.00 \%$ & & 45 \\
\hline
\end{tabular}

Fuente: Elaboración propia a partir de la base de datos del Banco Mundial, periodo 1960-1980, (data.worldbank.org) 


\begin{tabular}{|c|c|c|c|c|c|c|c|c|}
\hline \multicolumn{9}{|c|}{ Año 1980} \\
\hline Country & $\begin{array}{c}\text { Human } \\
\text { Development } \\
\text { Index }\end{array}$ & $\begin{array}{c}\text { Life } \\
\text { Expectancy } \\
\text { Index }\end{array}$ & $\begin{array}{l}\text { Schooling } \\
\text { Index }\end{array}$ & $\begin{array}{c}\text { Adult } \\
\text { Literacy } \\
\text { Index (\%) }\end{array}$ & $\begin{array}{c}\text { Combined } \\
\text { Enrolment } \\
\text { Rate }(\%)\end{array}$ & $\begin{array}{c}\text { Gross } \\
\text { Enrolment } \\
\text { Index }\end{array}$ & $\begin{array}{l}\text { GDCP } \\
\text { Index }\end{array}$ & $\begin{array}{c}\text { Classification } \\
\text { according to } \\
\text { IDH or Index } \\
\text { of Human } \\
\text { development }\end{array}$ \\
\hline Alemania & 653.7258164 & 0.79697724 & 0.626086 & $93.91 \%$ & & & 1959.754 & 6 \\
\hline Argentina & 172.7338043 & 0.74116016 & 61.42948 & & 184.2884 & $184.29 \%$ & 456.0308 & 17 \\
\hline Australia & 582.4254218 & 0.82222764 & 45.10353 & & 135.3106 & $135.31 \%$ & 1701.351 & 9 \\
\hline Bolivia & $\mathbf{5 7 . 8 7 5 9 3 3 5 4}$ & 0.44939268 & 32.88924 & & 98.66771 & $98.67 \%$ & 140.2892 & 29 \\
\hline Brasil & 124.0020054 & 0.62494309 & 49.93491 & $74.59 \%$ & 148.313 & $148.31 \%$ & 321.4462 & 24 \\
\hline Canadá & 629.0489108 & 0.83463415 & 62.19609 & & 186.5883 & $186.59 \%$ & 1824.116 & 8 \\
\hline Chile & 158.2895324 & 0.73652886 & 63.73438 & & 191.2032 & $191.20 \%$ & 410.3977 & 18 \\
\hline China & 28.36913226 & 0.69989675 & 52.95995 & & 158.8799 & $158.88 \%$ & 31.44755 & 36 \\
\hline Colombia & 87.77031723 & 0.67435244 & 56.43286 & & 169.2986 & $169.30 \%$ & 206.2037 & 25 \\
\hline Costa Rica & 133.5764376 & 0.79251382 & 57.3316 & & 171.9948 & $171.99 \%$ & 342.6052 & 22 \\
\hline Croacia & 0.250974255 & 0.75292276 & 0 & & & & & 44 \\
\hline Cuba & 135.4651555 & 0.80937236 & 68.42749 & & 205.2825 & $205.28 \%$ & 337.1586 & 21 \\
\hline Dinamarca & 782.3793292 & 0.81836179 & 76.01325 & & 228.0397 & $228.04 \%$ & 2270.306 & 3 \\
\hline Ecuador & 147.7917537 & 0.63199878 & 66.17782 & & 198.5335 & $198.53 \%$ & 376.5654 & 19 \\
\hline Egipto & 42.18431378 & 0.51916992 & 41.69172 & & 125.0752 & $125.08 \%$ & 84.34205 & 33 \\
\hline El Salvador & 13.57218005 & 0.53046016 & 40.18608 & & 120.5582 & $120.56 \%$ & & 39 \\
\hline España & 360.0391421 & 0.83915447 & 72.51809 & & 217.5543 & $217.55 \%$ & 1006.76 & 12 \\
\hline Estados Unidos & 704.6914441 & 0.81097561 & 81.21386 & & 243.6416 & $243.64 \%$ & 2032.049 & 5 \\
\hline Etiopía & 3.792934688 & 0.3152374 & 11.06357 & & 33.1907 & $33.19 \%$ & & 43 \\
\hline Finlandia & 642.2898029 & 0.80733333 & 75.77317 & & 227.3195 & $227.32 \%$ & 1850.289 & 7 \\
\hline Francia & 719.7539586 & 0.81752033 & 72.86319 & & 218.5896 & $218.59 \%$ & 2085.581 & 4 \\
\hline Guatemala & 72.39417232 & 0.53853333 & 29.58681 & & 88.76044 & $88.76 \%$ & 187.0572 & 27 \\
\hline
\end{tabular}




\begin{tabular}{|c|c|c|c|c|c|c|c|c|}
\hline Guinea & 6.505466287 & 0.23057886 & 19.28582 & & 57.85746 & $57.86 \%$ & & 42 \\
\hline Haití & 9.075660732 & 0.43132886 & 26.79565 & & 80.38696 & $80.39 \%$ & & 41 \\
\hline Honduras & 54.12643741 & 0.57364472 & 44.78216 & & 134.3465 & $134.35 \%$ & 117.0235 & 30 \\
\hline Irán & 139.6605262 & 0.4557374 & 32.86001 & & 98.58004 & $98.58 \%$ & 385.6658 & 20 \\
\hline Japón & 542.9542212 & 0.85152846 & 75.26321 & & 225.7896 & $225.79 \%$ & 1552.748 & 11 \\
\hline Mozambique & 16.66495459 & 0.29676504 & 1.994749 & $27.10 \%$ & 5.44221 & $5.44 \%$ & 47.70335 & 38 \\
\hline México & 173.4613568 & 0.69286423 & 59.37153 & $82.99 \%$ & 176.4548 & $176.45 \%$ & 460.3197 & 16 \\
\hline Nepal & 19.45958052 & 0.38591016 & 36.18345 & & 108.5504 & $108.55 \%$ & 21.80938 & 37 \\
\hline Nicaragua & 51.59081577 & 0.55767398 & 44.87856 & & 134.6357 & $134.64 \%$ & 109.3362 & 32 \\
\hline Nigeria & 60.30713412 & 0.34147114 & 35.95075 & & 107.8523 & $107.85 \%$ & 144.6292 & 28 \\
\hline Noruega & 891.9194533 & 0.84452846 & 72.84884 & & 218.5465 & $218.55 \%$ & 2602.065 & 2 \\
\hline Panamá & 127.6499883 & 0.74934512 & 63.40397 & $88.07 \%$ & 188.4505 & $188.45 \%$ & 318.7966 & 23 \\
\hline Perú & 87.50815035 & 0.58360325 & 63.70586 & & 191.1176 & $191.12 \%$ & 198.235 & 26 \\
\hline Portugal & 205.5650294 & 0.7702439 & 61.999 & & 185.997 & $186.00 \%$ & 553.9258 & 15 \\
\hline Reino Unido & 558.1240347 & 0.81126016 & 68.21547 & & 204.6464 & $204.65 \%$ & 1605.345 & 10 \\
\hline Senegal & 41.21325563 & 0.37222114 & 19.04031 & & 57.12093 & $57.12 \%$ & 104.2272 & 34 \\
\hline Sudán & 28.93226087 & 0.40498415 & 20.66797 & & 62.00392 & $62.00 \%$ & 65.72383 & 35 \\
\hline Suiza & 1012.315406 & 0.8409878 & 64.75577 & & 194.2673 & $194.27 \%$ & 2971.349 & 1 \\
\hline Tailandia & 52.97723606 & 0.67496301 & 45.02848 & $87.98 \%$ & 133.3258 & $133.33 \%$ & 113.2283 & 31 \\
\hline Uganda & 11.75429397 & 0.41786016 & 19.06112 & & 57.18336 & $57.18 \%$ & 15.7839 & 40 \\
\hline Uruguay & 207.5381692 & 0.75413699 & 40.87183 & & 122.6155 & $122.62 \%$ & 580.9885 & 14 \\
\hline Venezuela & 267.2898556 & 0.7203748 & 59.68102 & & 179.0431 & $179.04 \%$ & 741.4682 & 13 \\
\hline Yemen & 0.132418157 & 0.39725447 & 0 & & & & & 45 \\
\hline
\end{tabular}

Fuente: Elaboración propia a partir de la base de datos del Banco Mundial, periodo 1960-1980, (data.worldbank.org) 
Tabla 4: Determinantes del crecimiento:

\begin{tabular}{|c|c|c|c|}
\hline $\begin{array}{c}\text { Condiciones iniciales } \\
\text { y variables exógenas }\end{array}$ & Inputs intermedios & Variables políticas & $\begin{array}{c}\text { Variables } \\
\text { institucionales }\end{array}$ \\
\hline Valor inicial del PIB & $\begin{array}{c}\text { Inversión como } \\
\text { porcentaje del PIB }\end{array}$ & $\begin{array}{c}\text { Medida de apertura de } \\
\text { la economía }\end{array}$ & $\begin{array}{c}\text { Índice de derechos } \\
\text { políticos }\end{array}$ \\
\hline Esperanza de vida & $\begin{array}{c}\text { Stock de años de } \\
\text { escolaridad }\end{array}$ & $\begin{array}{c}\text { Consumo del } \\
\text { gobierno }\end{array}$ & $\begin{array}{c}\text { Índice de libertades } \\
\text { civiles }\end{array}$ \\
\hline $\begin{array}{c}\text { Población urbana al } \\
\text { inicio del periodo }\end{array}$ & $\begin{array}{c}\text { Tasa de crecimiento } \\
\text { de la población }\end{array}$ & Precio de la inversión & \\
\hline
\end{tabular}

Fuente: Raymundo Chirinos: Determinantes del crecimiento económico: Una revisión de la literatura existente y estimaciones para el periodo 1960-2000, Banco Central de Reserva del Perú, Serie de Documentos de Trabajo, Agosto, 2007. 
Tabla 5: Descripción de las variables del estudio empírico (Ecuador 1950-1980):

\begin{tabular}{|c|c|c|c|c|}
\hline Variable & Símbolo & Descripción & Fuente & Periodo \\
\hline $\begin{array}{l}\text { Tasa de } \\
\text { crecimiento del } \\
\text { PIB real per } \\
\text { cápita ( } \$ 2000 \\
\text { en PPP) }\end{array}$ & Crec & $\begin{array}{l}\text { El PIB mide la } \\
\text { producción total } \\
\text { de bienes y } \\
\text { servicios de uso } \\
\text { final dentro del } \\
\text { territorio } \\
\text { doméstico de un } \\
\text { país dado. }\end{array}$ & $\begin{array}{l}\text { Penn World } \\
\text { Table } 6.2\end{array}$ & $1950-1980$ \\
\hline $\begin{array}{l}\text { Ln del PIB real } \\
\text { per cápita } \\
2000 \text { en ppp) }\end{array}$ & $\mathbf{Y t}$ & $\begin{array}{l}\text { Valor al principio } \\
\text { del periodo }\end{array}$ & $\begin{array}{l}\text { Penn World } \\
\text { Table } 6.2\end{array}$ & $1950-1980$ \\
\hline $\begin{array}{l}\text { Tasa de } \\
\text { crecimiento de la } \\
\text { población. }\end{array}$ & TCpob & $\begin{array}{l}\text { Promedio de la } \\
\text { tasa de } \\
\text { crecimiento } \\
\text { anual de la } \\
\text { población }\end{array}$ & $\begin{array}{l}\text { Penn World } \\
\text { Table } 6.2\end{array}$ & $1950-1980$ \\
\hline $\begin{array}{l}\text { Precio de la } \\
\text { inversión }\end{array}$ & PrecInv & $\begin{array}{l}\text { Promedio del } \\
\text { nivel de precio } \\
\text { de la inversion }\end{array}$ & $\begin{array}{l}\text { Penn World } \\
\text { Table } 6.2\end{array}$ & $1950-1980$ \\
\hline $\begin{array}{l}\text { Medida de } \\
\text { apertura }\end{array}$ & Apert & $\begin{array}{l}\text { Promedio de } \\
\text { importaciones } \\
\text { más } \\
\text { exportaciones } \\
\text { como porcentaje } \\
\text { del PIB }\end{array}$ & $\begin{array}{l}\text { Penn World } \\
\text { Table } 6.2\end{array}$ & $1950-1980$ \\
\hline $\begin{array}{l}\text { Consumo del } \\
\text { gobierno como } \\
\% \text { del PIB }\end{array}$ & GovConsPIB & $\begin{array}{l}\text { Promedio del } \\
\text { periodo del } \\
\text { consumo del } \\
\text { gobierno como } \\
\% \text { del PIB }\end{array}$ & $\begin{array}{l}\text { Penn World } \\
\text { Table } 6.2\end{array}$ & $1950-1980$ \\
\hline $\begin{array}{l}\text { Inversión como } \\
\% \text { del PIB }\end{array}$ & InverPIB & $\begin{array}{l}\text { Promedio del } \\
\text { periodo de la } \\
\text { inversión como } \\
\% \text { del PIB }\end{array}$ & $\begin{array}{l}\text { Penn World } \\
\text { Table } 6.2\end{array}$ & $1950-1980$ \\
\hline
\end{tabular}




\begin{tabular}{|c|c|c|c|c|}
\hline $\begin{array}{l}\text { Esperanza de } \\
\text { vida al nacer }\end{array}$ & EspVida & $\begin{array}{l}\text { Años de } \\
\text { esperanza de } \\
\text { vida, valor al } \\
\text { inicio del periodo }\end{array}$ & $\begin{array}{l}\text { World } \\
\text { Development } \\
\text { Data, } 2013\end{array}$ & $1960-1980$ \\
\hline Población urbana & UrbanPob & $\begin{array}{l}\text { Fracción de la } \\
\text { población que } \\
\text { vive en zonas } \\
\text { urbana, valor al } \\
\text { inicio del } \\
\text { periodo. }\end{array}$ & $\begin{array}{l}\text { World } \\
\text { Development } \\
\text { Data, } 2013\end{array}$ & $1960-1980$ \\
\hline $\begin{array}{l}\text { Educación } \\
\text { secundaria }\end{array}$ & SecEdu & $\begin{array}{l}\text { Stock de años de } \\
\text { educación } \\
\text { secundaria, valor } \\
\text { al inicio del } \\
\text { periodo. }\end{array}$ & $\begin{array}{l}\text { R. Barro, J. Lee: } \\
\text { International data } \\
\text { on educational } \\
\text { attainment: Updates } \\
\text { and implications } \\
\text { CID working paper, } \\
\text { no. } 42 \text {, abril } 2000 .\end{array}$ & $1950-1980$ \\
\hline $\begin{array}{l}\text { Índice de } \\
\text { derechos } \\
\text { políticos }\end{array}$ & DerPolit & $\begin{array}{l}\text { Derechos } \\
\text { políticos, Mayor } \\
\text { valor } 1 \text { menor } 7, \\
\text { valor al inicio del } \\
\text { periodo }\end{array}$ & $\begin{array}{l}\text { Freedom House, } \\
2012\end{array}$ & $1971-1980$ \\
\hline $\begin{array}{l}\text { Índice de } \\
\text { libertades civiles }\end{array}$ & LibCiv & $\begin{array}{l}\text { Libertades } \\
\text { Civiles, Mayor } \\
\text { valor } 1 \text { menor } 7, \\
\text { valor al inicio del } \\
\text { periodo }\end{array}$ & $\begin{array}{l}\text { Freedom House, } \\
2012\end{array}$ & $1971-1980$ \\
\hline
\end{tabular}

Fuente: Elaboración propia a partir de R. Levine, D. Renelt: A sensitivity analysis of crosscountry growth regressions, the American Economic Review, 82(4), p. 942-963, 1992; S. N. Durlauf, P. A. Johnson, J.R. Temple: Growths econometrics, en S.N. Durlauf, P. Aghion (Eds), Handbook of Economic Growth, Elsevier, 2005. 
Tabla 7: Matriz de correlación entre variables (Ecuador 1950-1980)

\begin{tabular}{|c|c|c|c|c|c|c|c|c|}
\hline 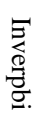 & 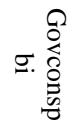 & 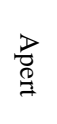 & 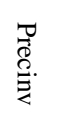 & $\overrightarrow{8}$ & $ほ$ & $\precsim$ & $\begin{array}{l}\hat{\sigma} \\
\overrightarrow{0} \\
\vec{\theta}\end{array}$ & \\
\hline & & & & & & & - & $\widetilde{乛}$ \\
\hline & & & & & & - & $\begin{array}{l}0 \\
\dot{N} \\
\infty \\
0\end{array}$ & $\precsim$ \\
\hline & & & & & - & 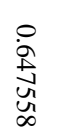 & 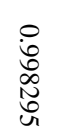 & $\Xi$ \\
\hline & & & & - & 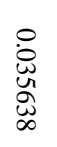 & 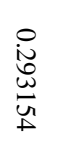 & 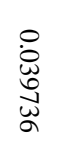 & $\overrightarrow{8}$ \\
\hline & & & - & 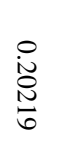 & $\begin{array}{l}\circ \\
\dot{N} \\
\text { 心 } \\
\infty \\
\infty \\
\text { N }\end{array}$ & 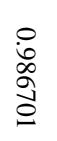 & $\begin{array}{l}\stackrel{\circ}{0} \\
\dot{W} \\
\stackrel{\circ}{\circ} \\
\infty\end{array}$ & 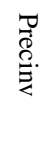 \\
\hline & & - & \begin{tabular}{l}
0 \\
$\dot{\infty}$ \\
\multirow{্}{*}{} \\
心̆
\end{tabular} & $\begin{array}{l}\stackrel{0}{0} \\
\stackrel{0}{0} \\
\stackrel{\infty}{\infty} \\
\infty\end{array}$ & 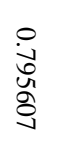 & 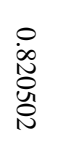 & $\begin{array}{l}\stackrel{0}{ \pm} \\
\dot{0} \\
\stackrel{0}{0} \\
\stackrel{N}{N}\end{array}$ & 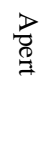 \\
\hline & - & $\begin{array}{l}\stackrel{0}{\Xi} \\
\underset{\nabla}{0} \\
\stackrel{+}{*}\end{array}$ & $\begin{array}{l}\dot{0} \\
\dot{8} \\
\stackrel{+}{+} \\
\dot{W} \\
+\end{array}$ & $\begin{array}{l}\stackrel{0}{0} \\
\stackrel{0}{0} \\
\stackrel{0}{\cup}\end{array}$ & 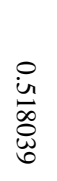 & $\begin{array}{l}0 \\
\infty \\
\infty \\
\infty \\
\infty \\
u\end{array}$ & \begin{tabular}{l}
0 \\
$\dot{t}$ \\
$\infty$ \\
$\infty$ \\
\multirow{\sigma}{*}{}
\end{tabular} & $\begin{array}{l}0 \\
0 \\
\delta \\
0 \\
0 \\
0 \\
0.0\end{array}$ \\
\hline- & 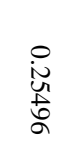 & $\begin{array}{l}\stackrel{0}{D} \\
\infty \\
\stackrel{+}{ \pm} \\
=\end{array}$ & $\begin{array}{l}\stackrel{0}{ \pm} \\
\stackrel{\Delta}{a} \\
\text { 心 }\end{array}$ & $\begin{array}{l}\stackrel{0}{0} \\
\tilde{N} \\
\dot{0} \\
0\end{array}$ & $\begin{array}{l}\dot{0} \\
\dot{\vec{u}} \\
\stackrel{\infty}{\sigma}\end{array}$ & $\begin{array}{l}0 \\
\stackrel{0}{0} \\
\stackrel{0}{U} \\
\mathbb{A}\end{array}$ & $\begin{array}{l}\dot{b} \\
\stackrel{+}{+} \\
\stackrel{+}{\sigma}\end{array}$ & 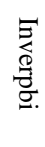 \\
\hline 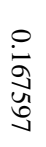 & \begin{tabular}{l}
$\stackrel{0}{\infty}$ \\
\multirow{\infty}{1}{} \\
$\delta$ \\
0
\end{tabular} & $\underset{\stackrel{O}{ \pm}}{\stackrel{0}{ \pm}}$ & 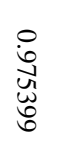 & 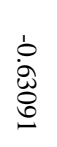 & $\begin{array}{l}\stackrel{\circ}{2} \\
\dot{\infty} \\
\infty \\
\infty \\
\infty\end{array}$ & 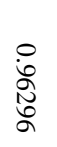 & $\begin{array}{l}\circ \\
\dot{O} \\
\dot{\infty} \\
\stackrel{1}{N} \\
\text { N }\end{array}$ & 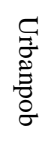 \\
\hline 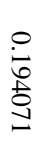 & 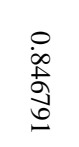 & 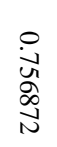 & $\begin{array}{l}0 \\
\dot{0} \\
\infty \\
0 \\
心 \\
\omega \\
\omega\end{array}$ & $\begin{array}{l}\dot{O} \\
\stackrel{j}{N} \\
N \\
\mathbb{D}\end{array}$ & $\begin{array}{l}\circ \\
\dot{\omega} \\
\frac{\sigma}{a} \\
\frac{1}{\sigma}\end{array}$ & $\begin{array}{l}0 \\
\dot{0} \\
\infty \\
\stackrel{1}{0} \\
\dot{U}\end{array}$ & 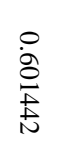 & 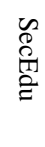 \\
\hline $\begin{array}{l}0 \\
\dot{\delta} \\
\infty \\
\infty \\
\infty \\
\infty\end{array}$ & $\begin{array}{l}\stackrel{0}{\dot{0}} \\
\dot{W} \\
\stackrel{ \pm}{\infty} \\
\dot{\sim}\end{array}$ & 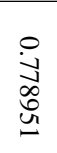 & $\begin{array}{l}\circ \\
\dot{0} \\
\stackrel{N}{0} \\
\stackrel{0}{0}\end{array}$ & 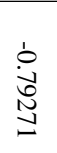 & 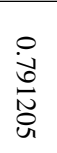 & $\begin{array}{l}\circ \\
\dot{0} \\
\infty \\
\infty \\
\stackrel{0}{0} \\
\dot{0}\end{array}$ & 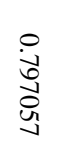 & 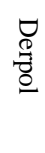 \\
\hline$\frac{b}{0}$ & $\begin{array}{l}\dot{b} \\
\dot{y} \\
0 \\
\stackrel{0}{0}\end{array}$ & $\begin{array}{l}\stackrel{0}{8} \\
\dot{\infty} \\
\dot{\omega}\end{array}$ & $\begin{array}{l}\dot{0} \\
\dot{a} \\
\stackrel{a}{0}\end{array}$ & 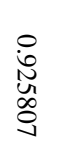 & $\begin{array}{l}\dot{0} \\
\dot{8} \\
\dot{0} \\
\mathscr{0} \\
\infty\end{array}$ & $\begin{array}{l}\dot{b} \\
\stackrel{\infty}{N}\end{array}$ & $\begin{array}{l}\stackrel{0}{0} \\
\dot{0} \\
\stackrel{\infty}{0} \\
\stackrel{0}{N}\end{array}$ & $\begin{array}{l}\Omega \\
\vdots \\
\sigma \\
\sigma\end{array}$ \\
\hline
\end{tabular}


Fuente: Elaboración propia a partir de los datos de Penn World Table 6.2; Freedom House, Freedom in the World 2012; R. Levine, D. Renelt: A sensitivity analysis of cross-country growth regressions, the American Economic Review, 82(4), p. 942-963, 1992; S. N. Durlauf, P. A. Johnson, J.R. Temple: Growths econometrics, en S.N. Durlauf, P. Aghion (Eds), Handbook of Economic Growth, Elsevier, 2005. 
Tabla 11: Matrícula por niveles y sexo en colegios públicos y privados (1960-1961, 1965-1966, 1970-1971):

\begin{tabular}{|c|c|c|c|c|c|c|c|c|c|}
\hline \multirow{2}{*}{$\begin{array}{l}\text { Nivel y } \\
\text { Sexo }\end{array}$} & \multicolumn{3}{|c|}{ 1960-1961 } & \multicolumn{3}{|c|}{ 1965-1966 } & \multicolumn{3}{|c|}{ 1970-1971 } \\
\hline & Total & Público & Privado & Total & Público & Privado & Total & Público & Privado \\
\hline \multirow{4}{*}{$\begin{array}{l}\text { Pre- } \\
\text { primaria } \\
\text { Total } \\
\text { Hombres } \\
\text { Mujeres }\end{array}$} & & & & & & & & & \\
\hline & 11.371 & 9.824 & 1.547 & 12.846 & 10.678 & 2.168 & 14.443 & 10.894 & 3.548 \\
\hline & 6.319 & 4.569 & 750 & 6.307 & 5.134 & 1.173 & 7.107 & 5.307 & 1.799 \\
\hline & 6.052 & 5.255 & 797 & 6.539 & 5.544 & 995 & 7.336 & 5.587 & 1.749 \\
\hline \multirow{4}{*}{$\begin{array}{l}\text { Primaria } \\
\text { Total } \\
\text { Hombres } \\
\text { Mujeres }\end{array}$} & & & & & & & & & \\
\hline & 596.019 & 472.573 & 123.446 & 800.507 & 658.297 & 142.210 & 1024.413 & 822.605 & 201.808 \\
\hline & 315.548 & 254.724 & 60.824 & 419.003 & 351.576 & 67.427 & 530.290 & 434.987 & 95.303 \\
\hline & 280.471 & 217.849 & 62.622 & 381.504 & 306.721 & 74.783 & 494.123 & 387.618 & 106.505 \\
\hline \multirow{4}{*}{$\begin{array}{l}\text { Media } \\
\text { Total } \\
\text { Hombres } \\
\text { Mujeres }\end{array}$} & & & & & & & & & \\
\hline & 69.087 & 43.501 & 25.586 & 117.268 & 69.593 & 47.675 & 219.394 & 132.947 & 81.447 \\
\hline & 39.581 & 25.774 & 13.807 & 64.406 & 39.846 & 24.560 & 119.283 & 78.048 & 41.235 \\
\hline & 29.506 & 17.727 & 11.779 & 52.862 & 29.747 & 23.115 & 100.111 & 59.899 & 40.212 \\
\hline \multirow{4}{*}{$\begin{array}{l}\text { Superior } \\
\text { Total } \\
\text { Hombres } \\
\text { Mujeres }\end{array}$} & & & & & & & & & \\
\hline & 9.361 & 9.651 & 710 & 15.395 & 12.426 & 2.969 & 21.363 & - & - \\
\hline & 7.615 & 7.125 & 490 & 11.828 & 10.003 & 1.825 & 14.291 & - & - \\
\hline & 1.746 & 1.526 & 220 & 8.567 & 2.423 & 1.144 & 7.072 & - & - \\
\hline
\end{tabular}

Fuente: O.E.A, 1974, en "Informaciones estadísticas", Organización de las Naciones Unidas para la educación, la ciencia y la cultura, Oficina Regional de Educación para América Latina y el Caribe, OREALC, Estadísticas, 12, Santiago de Chile, marzo 1978, p. 24. 
Tabla 12: Datos educación en el Ecuador (1959-1960, 1975-1976) población 6-12 años:

\begin{tabular}{|l|c|c|}
\hline & $\mathbf{1 9 5 9 - 1 9 6 0}$ & $\mathbf{1 9 7 5 - 1 9 7 6}$ \\
\hline Población 6-12 años & 796.907 & 1.360 .618 \\
\hline Niños matriculados & 566.805 & 1.254 .850 \\
\hline Tasa de matrícula & 71,1 & 92,2 \\
\hline \% matriculados en establecimientos privados & 20,7 & 16,7 \\
\hline Tasa de abandono & 22,9 & 6,4 \\
\hline No. profesores & 14.195 & 33.297 \\
\hline \% profesores en establecimientos privados & 25,6 & 48,0 \\
\hline No. establecimientos & 5.340 & 9.641 \\
\hline
\end{tabular}

Fuente: Luis F. Bilbao: Economía y educación en el Ecuador a partir de 1960, Quito, Banco Central, 1980.

Tabla 13: Datos educación en el Ecuador (1959-1960, 1975-1976) (población 13-18 años):

\begin{tabular}{|l|c|c|}
\hline & $\mathbf{1 9 5 9 - 1 9 6 0}$ & $\mathbf{1 9 7 5 - 1 9 7 6}$ \\
\hline Población 13-18 años & 546.788 & 943.765 \\
\hline Niños matriculados & 63.222 & 382.711 \\
\hline Tasa de matrícula & 11,6 & 40,5 \\
\hline \% matriculados en establecimientos privados & 39,1 & 30,8 \\
\hline Tasa de abandono & 19,9 & 8,7 \\
\hline No. profesores & 5.521 & 23.316 \\
\hline \% profesores en establecimientos privados & 48,8 & 38,8 \\
\hline No. establecimientos & 304 & 1.041 \\
\hline \% establecimientos particulares & 59,9 & 49,1 \\
\hline
\end{tabular}

Fuente: Luis F. Bilbao: Economía y educación en el Ecuador a partir de 1960, Quito, Banco Central, 1980. 
Tabla 14: Formación bruta de capital fijo (1965-1973) (millones de sucres, 1975):

\begin{tabular}{|l|c|c|c|c|}
\hline & $\mathbf{1 9 6 5}$ & Porcentaje & $\mathbf{1 9 7 3}$ & Porcentaje \\
\hline FBCFPrivada & 6.565 & 67 & 11.169 & 70 \\
\hline FBCFPública & 6.287 & 33 & 4.783 & 30 \\
\hline FBCFTotal & 9852 & 100 & 15.952 & 100 \\
\hline $\begin{array}{l}\text { FBCFper cápita } \\
\text { (sucres 1975) }\end{array}$ & 1.947 & & 2.417 & \\
\hline
\end{tabular}

Fuente: Cuentas Nacionales, Banco Central del Ecuador, en José Raúl Gangotena: La inversión en el Ecuador 1830-1980, en Libro del Seisquicentenario, Economía Ecuador, segunda parte, 1830-1980, Corporación Editora Nacional, 1983, p. 147.

Tabla 15: Formación bruta de capital fijo (1972-1980) (millones de sucres de 1975):

\begin{tabular}{|l|c|c|c|c|}
\hline & $\mathbf{1 9 7 2}$ & Porcentaje & $\mathbf{1 9 8 0}$ & Porcentaje \\
\hline FBCFPrivada & 10.804 & 77 & 26.461 & 75 \\
\hline FBCFPública & 3.298 & 23 & 8.811 & 25 \\
\hline FBCFTotal & 14.102 & 100 & 35.273 & 100 \\
\hline $\begin{array}{l}\text { FBCFper cápita } \\
\text { (sucres 1975) }\end{array}$ & 2.211 & & 4.222 & \\
\hline
\end{tabular}

Fuente: Cuentas Nacionales, Banco Central del Ecuador, en José Raúl Gangotena: La inversión en el Ecuador 1830-1980, en Libro del Sesquicentenario, Economía Ecuador, segunda parte, 1830-1980, Corporación Editora Nacional, 1983, p. 149. 
Tabla 16: Población por regiones y provincias de mayor crecimiento (1950-1982):

\begin{tabular}{|c|c|c|c|c|}
\hline $\begin{array}{c}\text { Regiones y } \\
\text { provincias }\end{array}$ & $\begin{array}{c}\text { Censo } \\
\text { Noviembre 1950 }\end{array}$ & $\begin{array}{c}\text { Censo } \\
\text { Noviembre 1962 }\end{array}$ & $\begin{array}{c}\text { Censo } \\
\text { Junio 1974 }\end{array}$ & $\begin{array}{c}\text { Censo } \\
\text { Noviembre 1982 }\end{array}$ \\
\cline { 1 - 3 } COSTA & & 512.542 & 817.966 & 868.598 \\
\hline Manabí & 401.378 & 250.062 & 383.432 & 455.869 \\
\hline Los Ríos & 150.260 & 979.223 & 1.512 .333 & 2.038 .454 \\
\hline Guayas & 582.144 & 587.835 & 988.306 & 1.382 .125 \\
\hline SIERRA & 386.520 & 276.668 & 304.316 & 316.948 \\
\hline Pichincha & 218.130 & 274.642 & 367.324 & 442.019 \\
\hline Chimborazo & 250.975 & 285.448 & 342.339 & 360.767 \\
\hline Azuay & 216.802 & & & \\
\hline Loja & &
\end{tabular}

Fuente: Patricio Almeida Guzmán, Rebeca Almeida Arroba: Estadísticas económicas históricas 1948-1983, en Fuentes para la historia económica del Ecuador, volumen 1, Banco Central del Ecuador, 1988, p. 3. 


\section{APÉNDICE DE MAPAS DEL ECUADOR}

\section{CAPÍTULO 1}

Mapa 1: La Real Audiencia de Quito (según la Real Cédula de 1563):

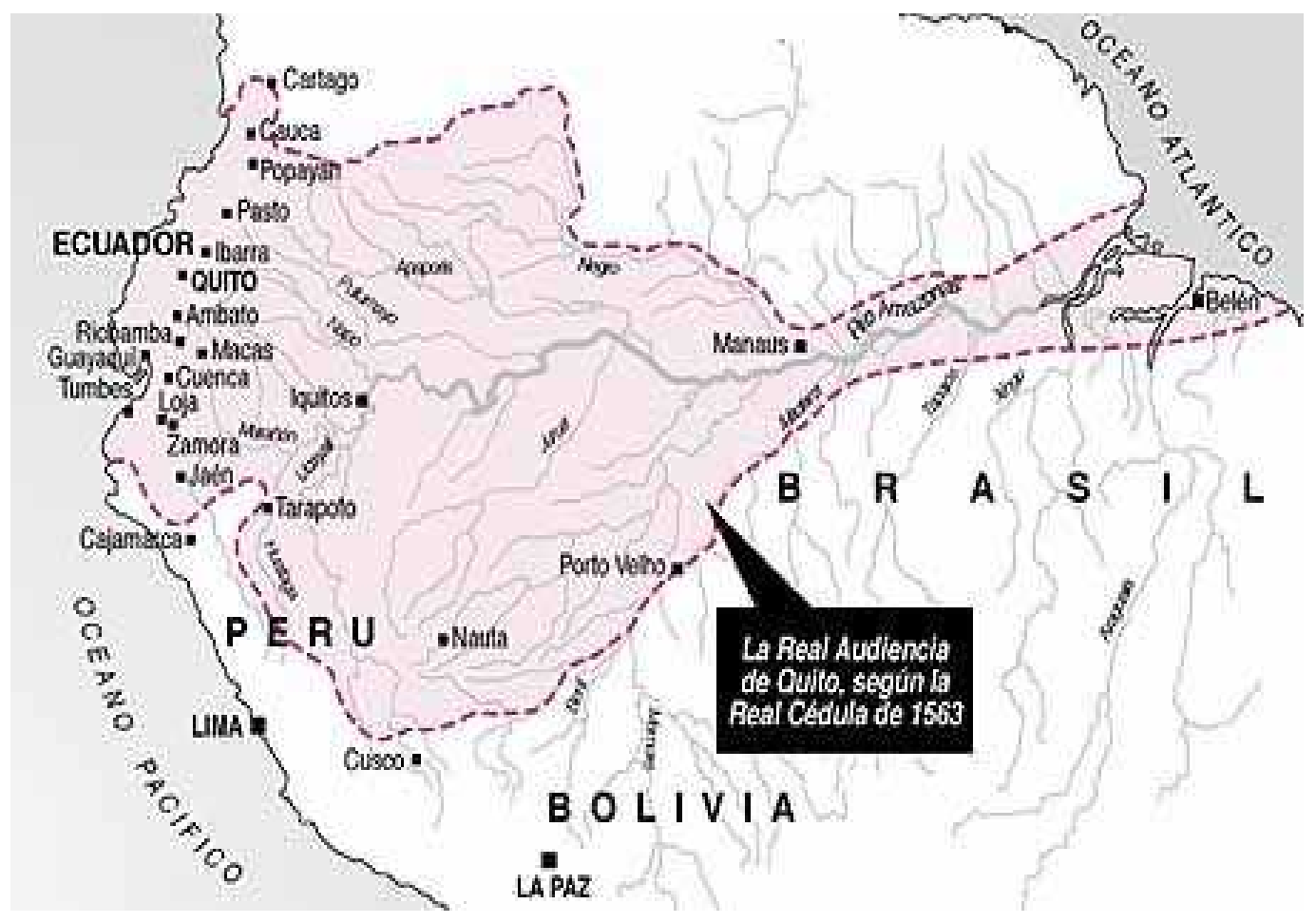

Según la Cédula Real del rey Felipe II de España, expedida en Guadalajara (España) el 29 de agosto de 1563, los territorios de Quito se extendían de la siguiente forma: por el norte hasta el Puerto de Buenaventura (inclusive) y por tierra adentro (actual República de Colombia) hasta Pasto, Popayán, Cali, Buga, Champachica y Guarchicona. Por el sur hasta el puerto de Paita (exclusive), y por tierra adentro (actual República del Perú), hasta Piura, Cajamarca, Chachapoyas, Moyobamba y Motilones; incluyendo Jaén Valladolid, Loja, Zamora, Cuenca, La Zarza y Guayaquil.

Fuente: Marqués de Lozoya: Historia de España, Tomo V, Salvat Editores, S.A. Barcelona, 1973. 
Mapa 2: Divisiones administrativas de la América hispana hacia 1700:

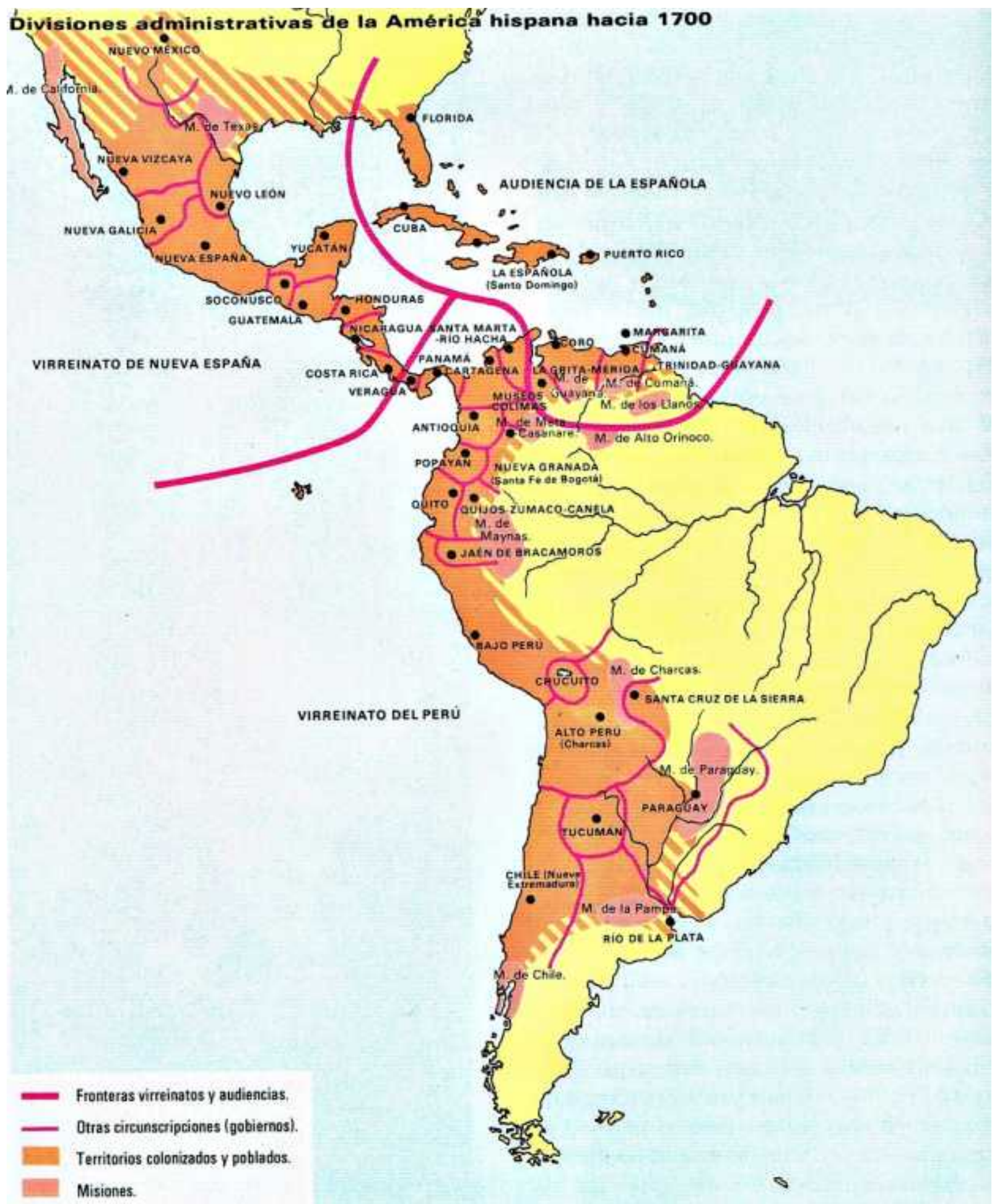

Fuente: Marqués de Lozoya: Historia de España, Tomo V, Salvat Editores, S.A. Barcelona, 1973. 
Mapa 3: América del Sur en el siglo XVIII. Posesiones españolas y portuguesas:

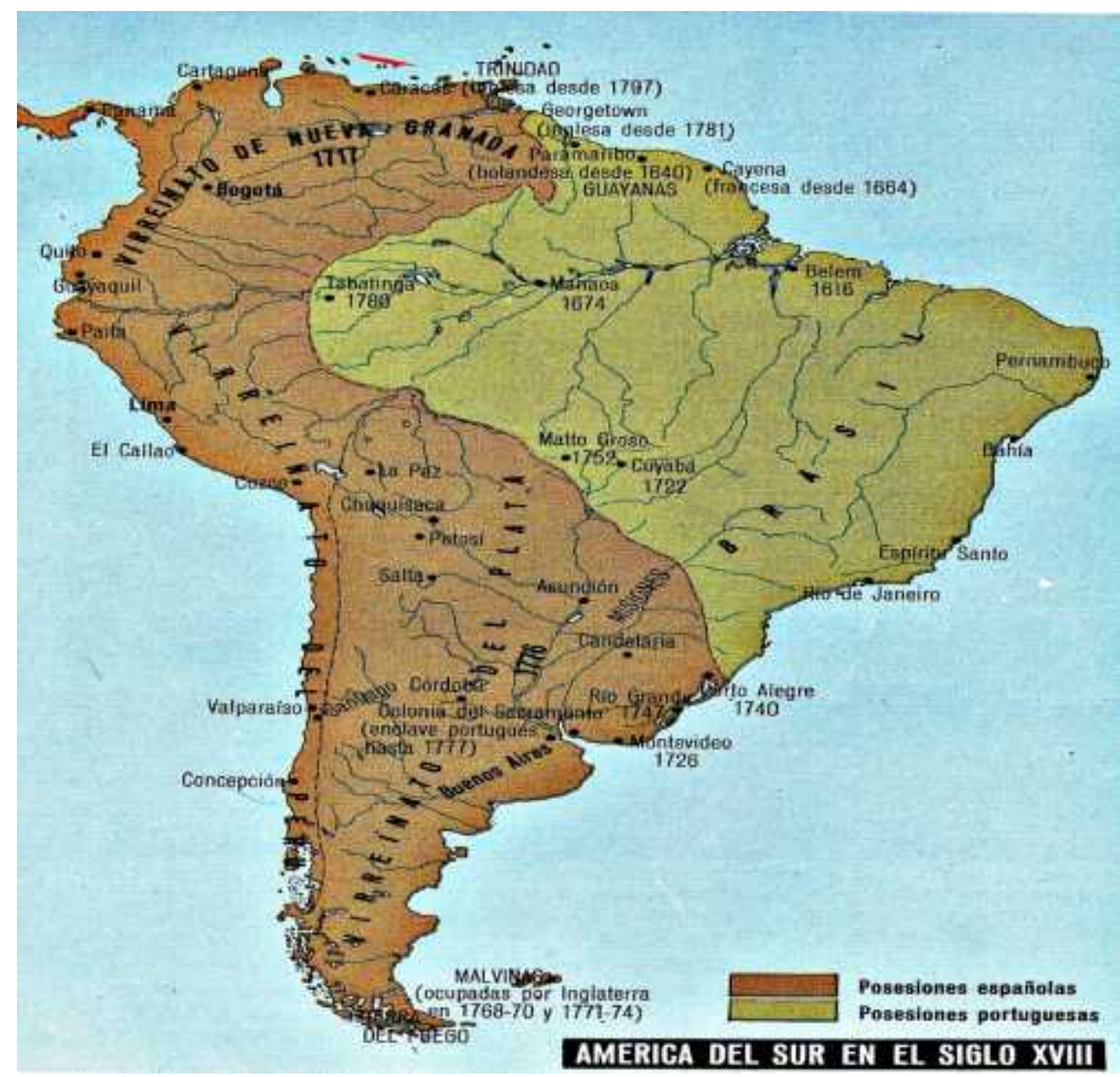

Fuente: Nueva Historia Universal, Siglos XVII y XVIII (Volumen IV). Editorial Marín, S.A 1969. 
Mapa 4: Virreinatos y Capitanías a principios del siglo XIX en América del Sur:

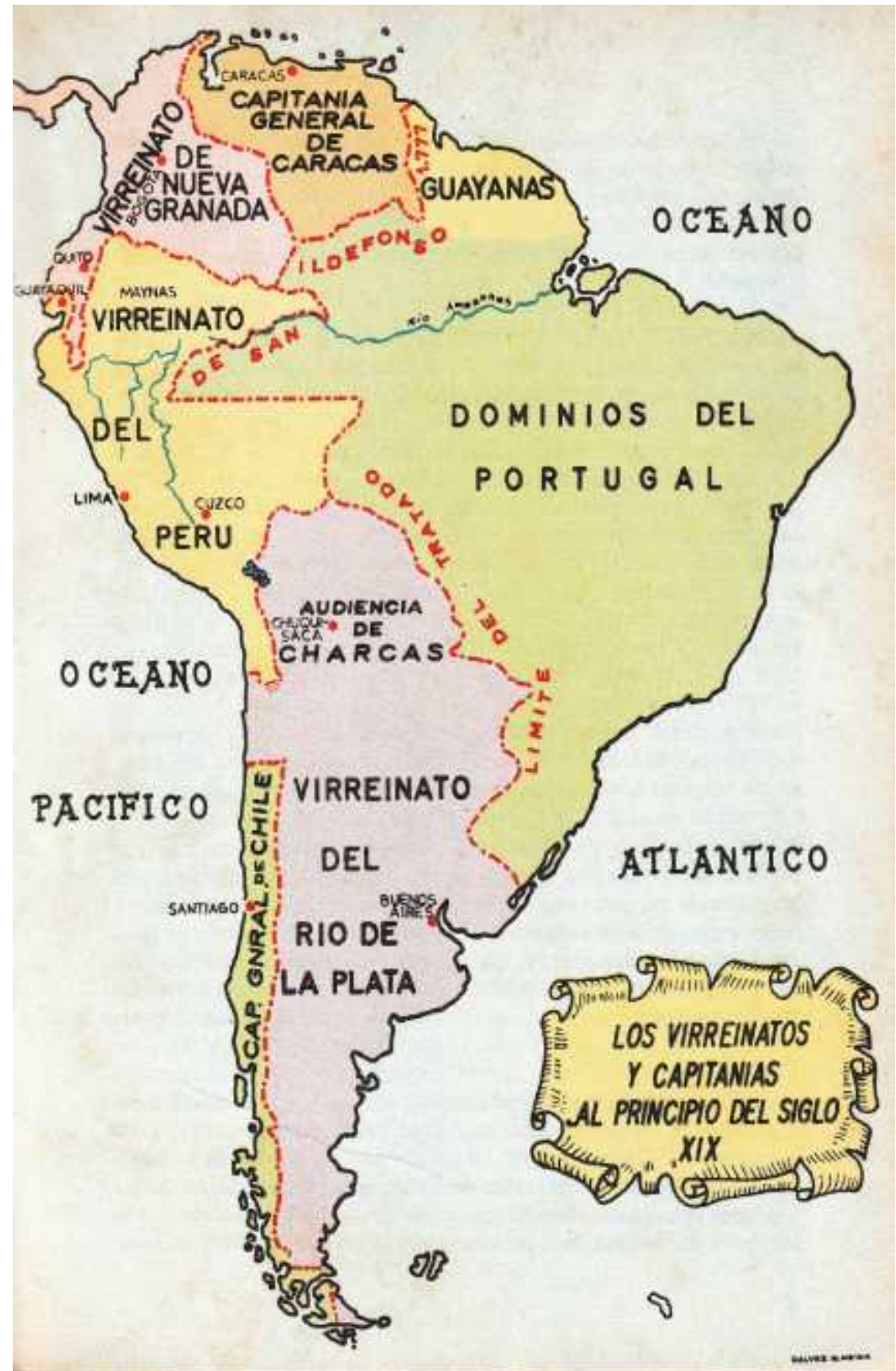

Fuente: Gustavo Pons Muzzo: Las fronteras del Perú: Estudio histórico, Lima: Talleres Gráficos Iberia, S. A., 1962, p. 39. 
Mapa 5: La Gran Colombia (1819-1830):

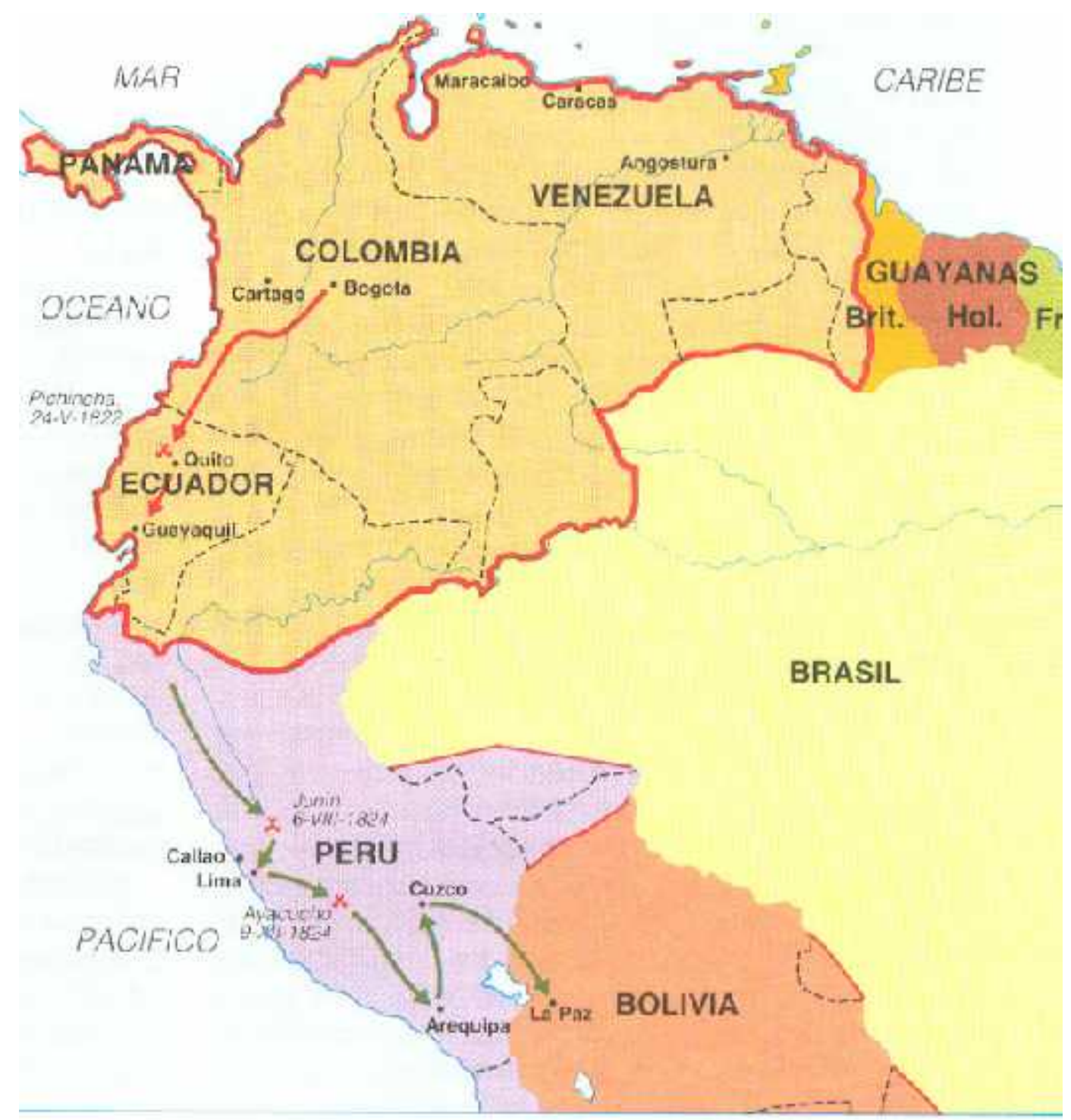

\section{LA GRAN COLOMBIA}
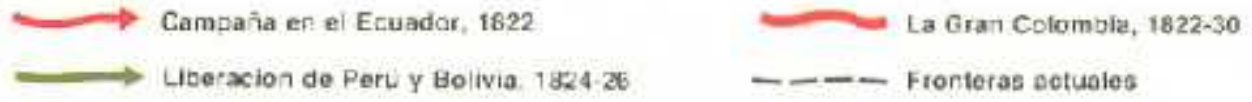

Fuente: www.lahistoriaconmapas.com/2010/01/la-gran-colombia-1819-1830. 
Mapa 6: Ecuador, siglo XX:

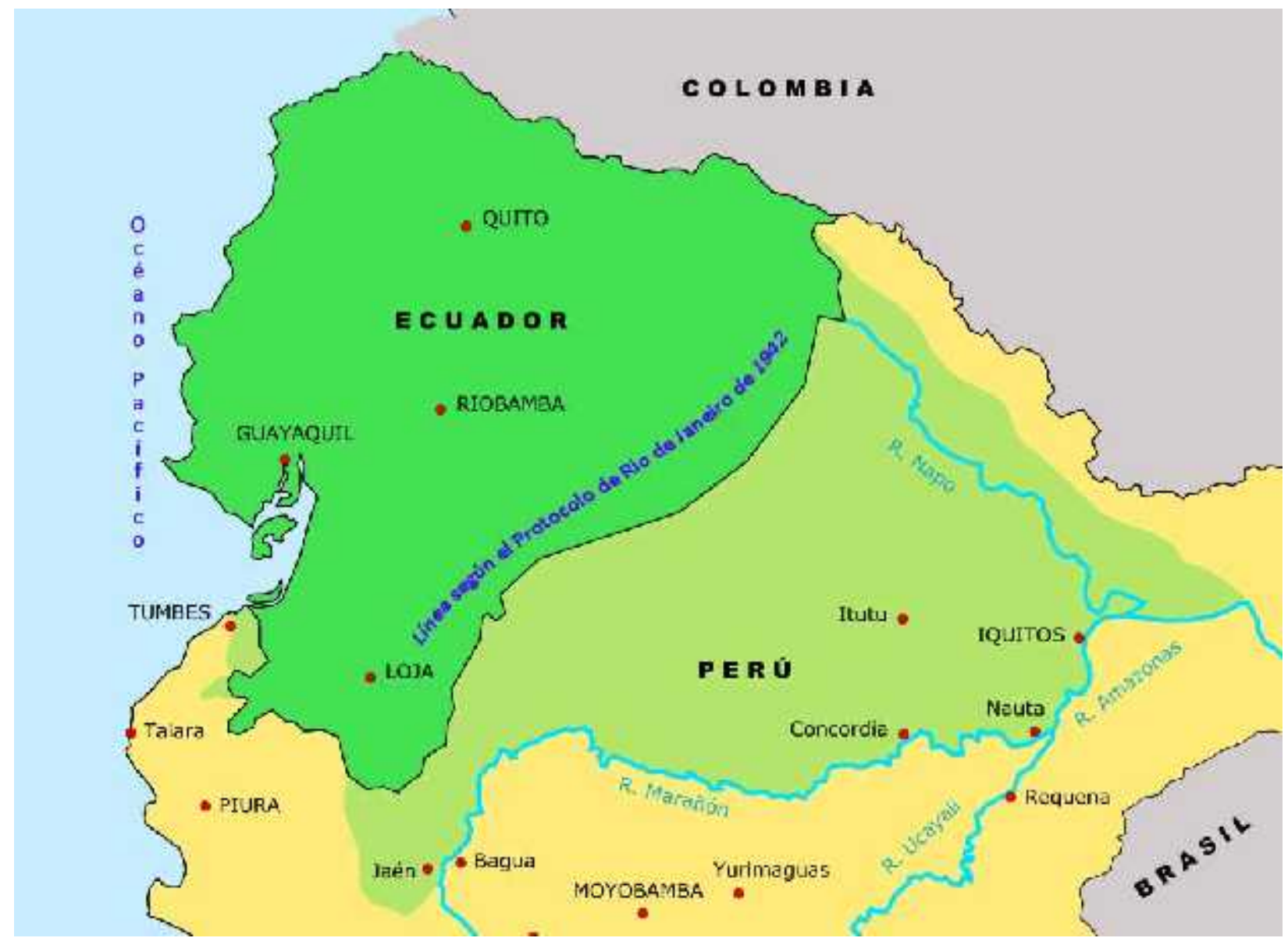

Fuente: Nueva Historia Universal, Siglos XVII y XVIII (Volumen IV). Editorial Marín, S.A 1969. 


\section{CAPÍTULO 2}

Mapa 1: Mapa Hacienda Tenguel-Balao en el Ecuador:

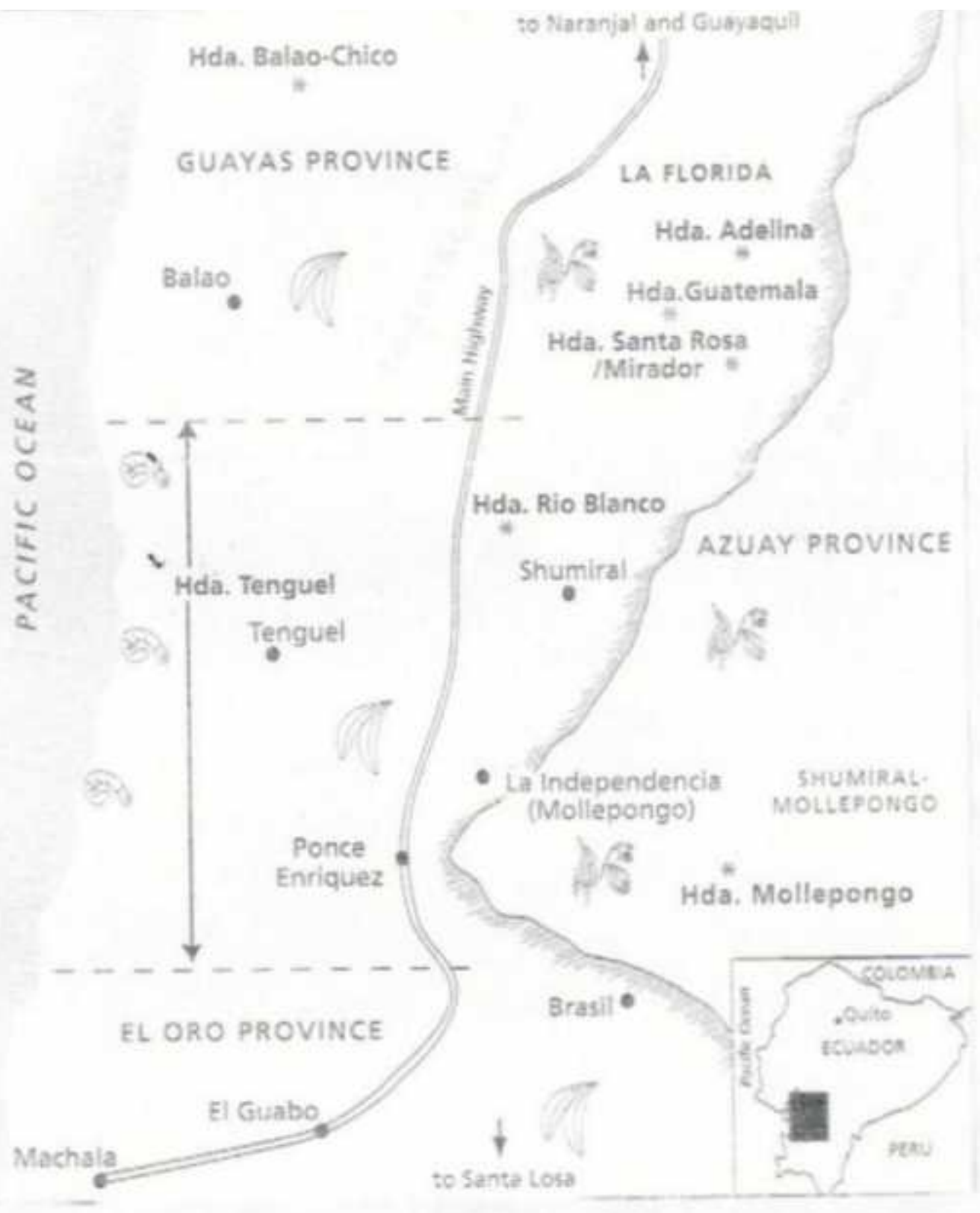

Fuente: Steve Striffler: In the Shadows of State and Capital. The United Fruit Company, Popular struggle and Agrarian restructuring in Ecuador, 1900-1995, Duke University Press, Durham \& London, 2002, p. 12. 
Mapa 2: Zonas bananeras en el Ecuador (década 1960):

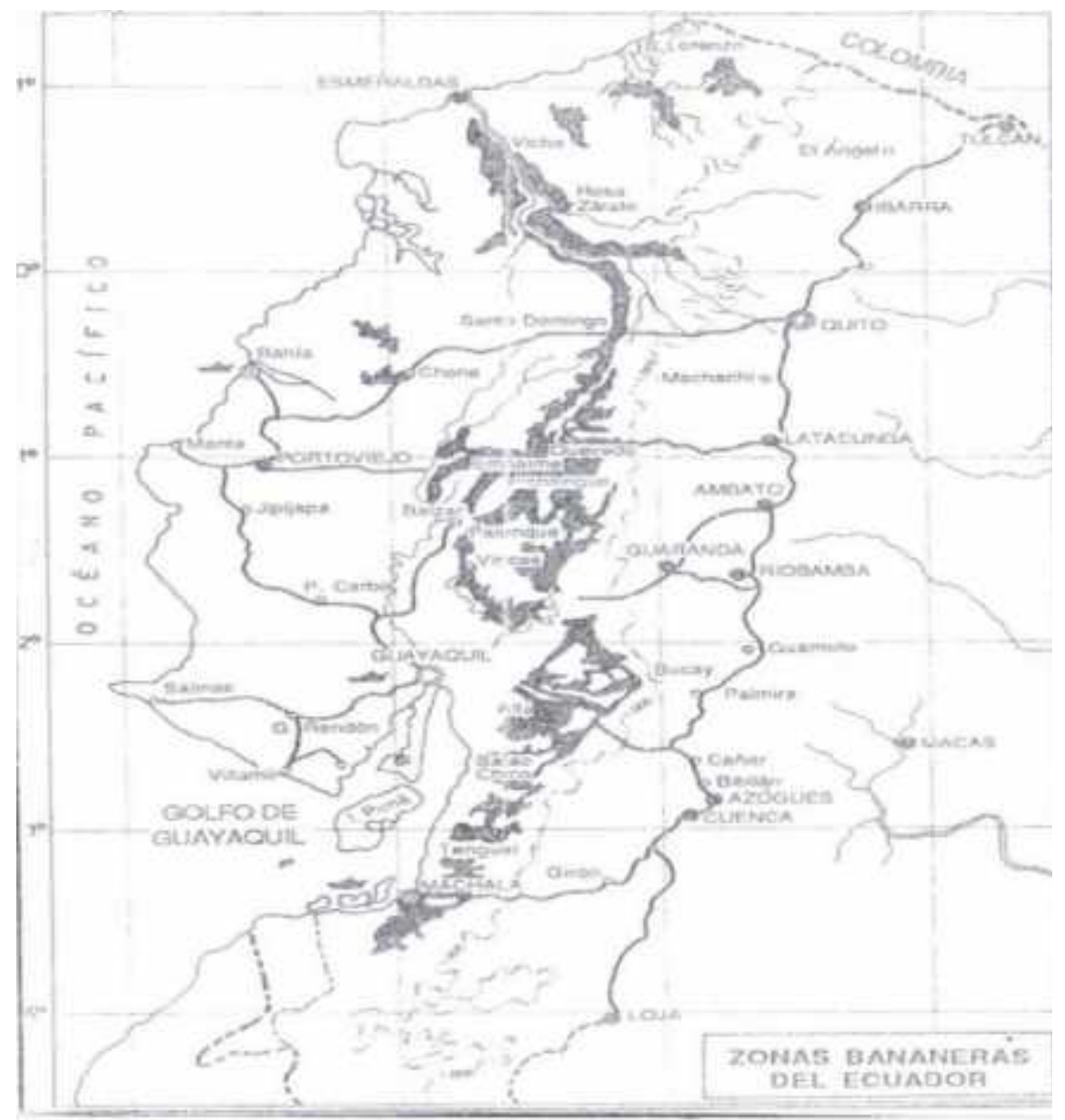

SHABOLOCIA:

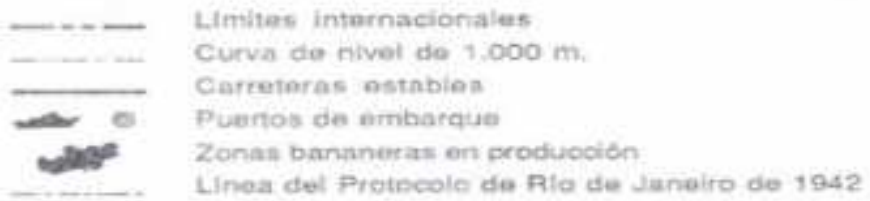

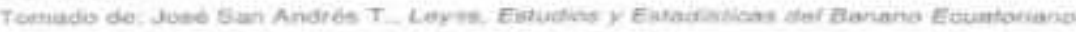

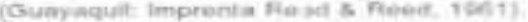

Fuente: R. Quintero, E. Silva: Ecuador: Una nación en ciernes, Tomo II, FLACSO, Abya-Yala, 1991, p. 29. 


\section{CAPÍTULO 3}

Mapa 1: División del Ecuador, Sierra centro-norte:
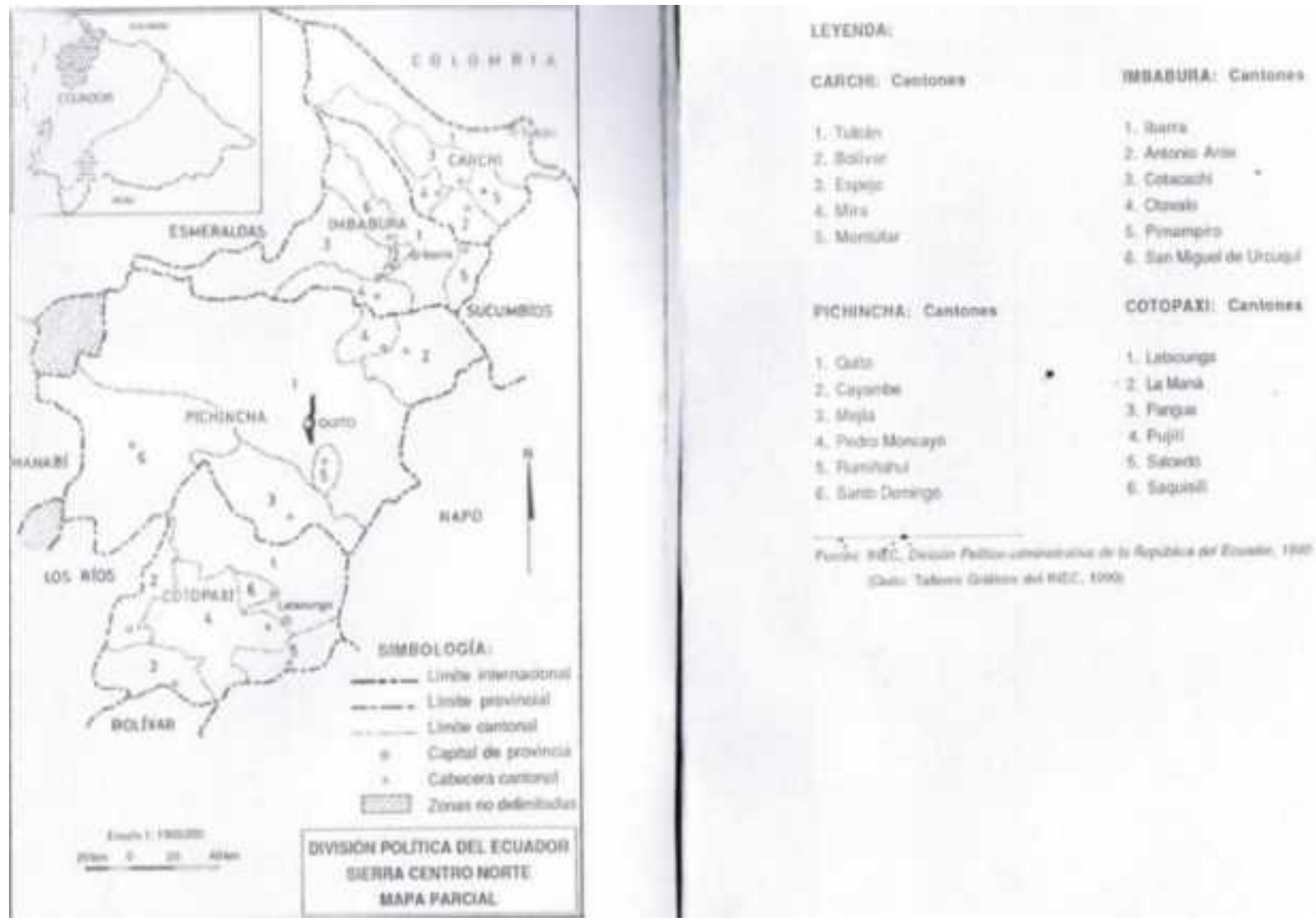

Fuente: Rafael Quintero, Erika Silva: Ecuador: Una nación en ciernes, Abya-Yala, FLACSO, 1991, p. 37. 


\section{CAPÍTULO 5}

Mapa Oleoducto en el Ecuador

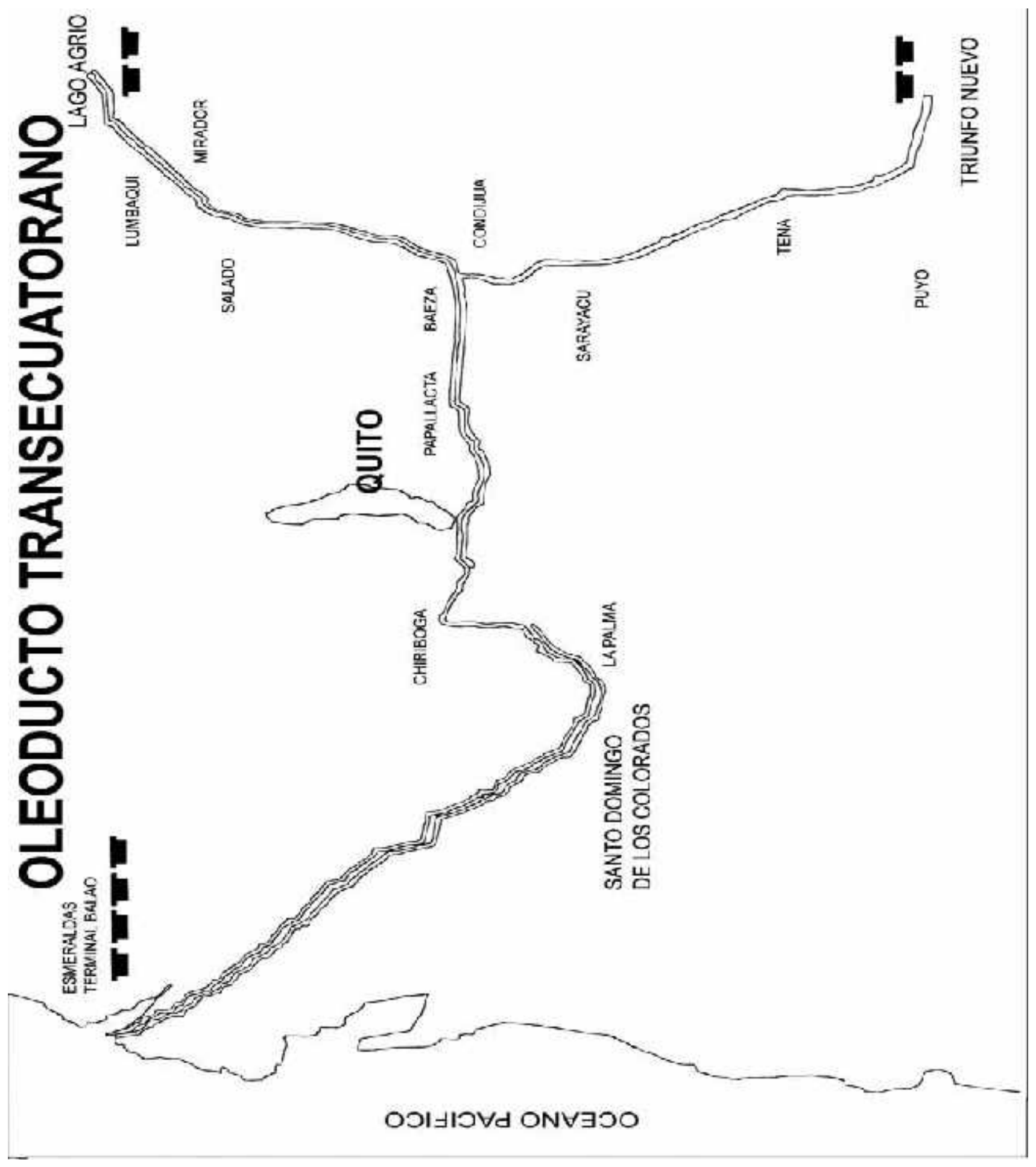

Fuente: Acción ecológica: ¿Qué es el petróleo? Fases e impactos de la actividad petrolera, Manuales de monitoreo ambiental comunitario, manual 1, 2002, p. 62. 


\section{CAPÍTULO 6}

Mapa de carreteras región litoral (1952)

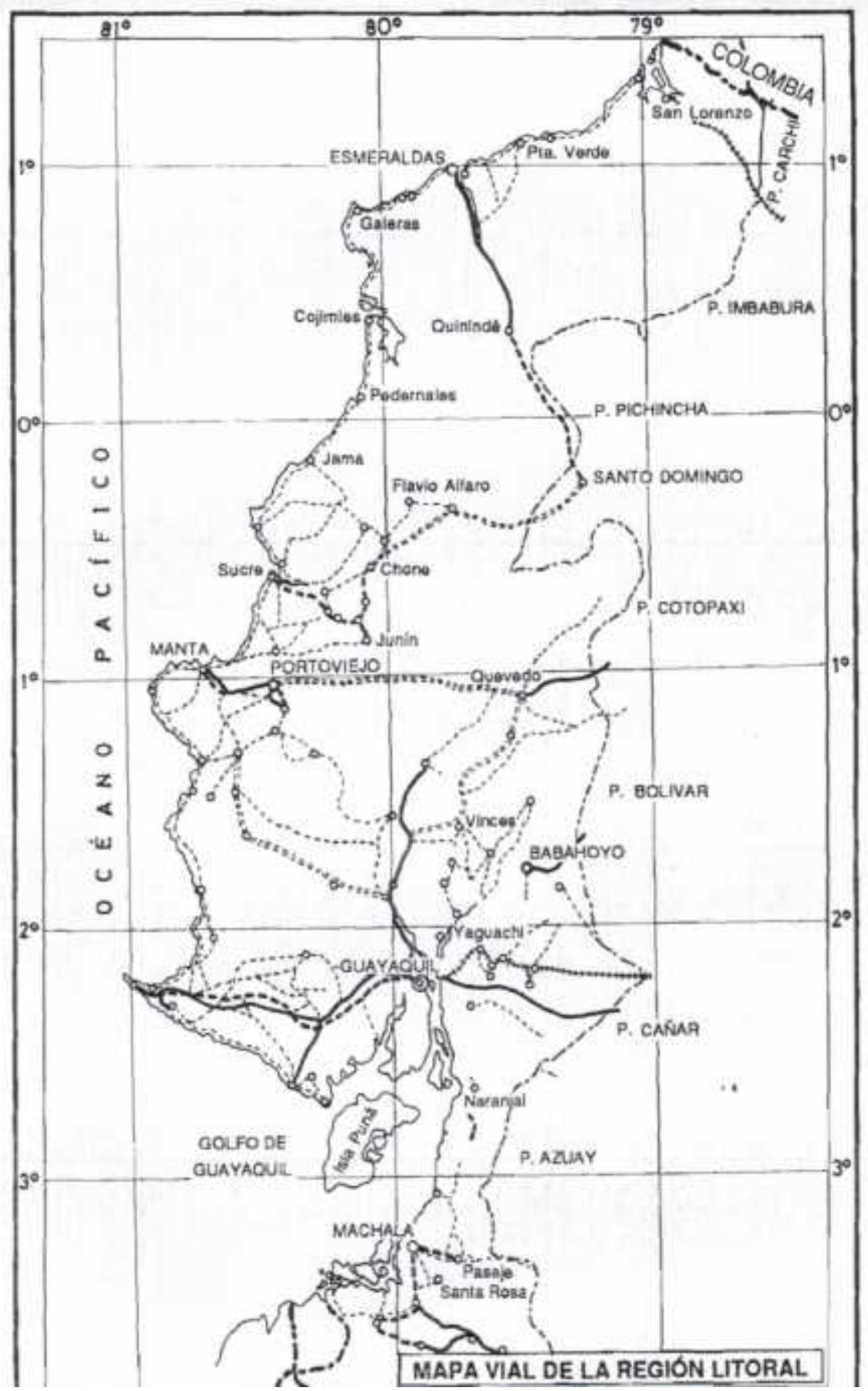


Simbología del mapa de carreteras región litoral (1952):

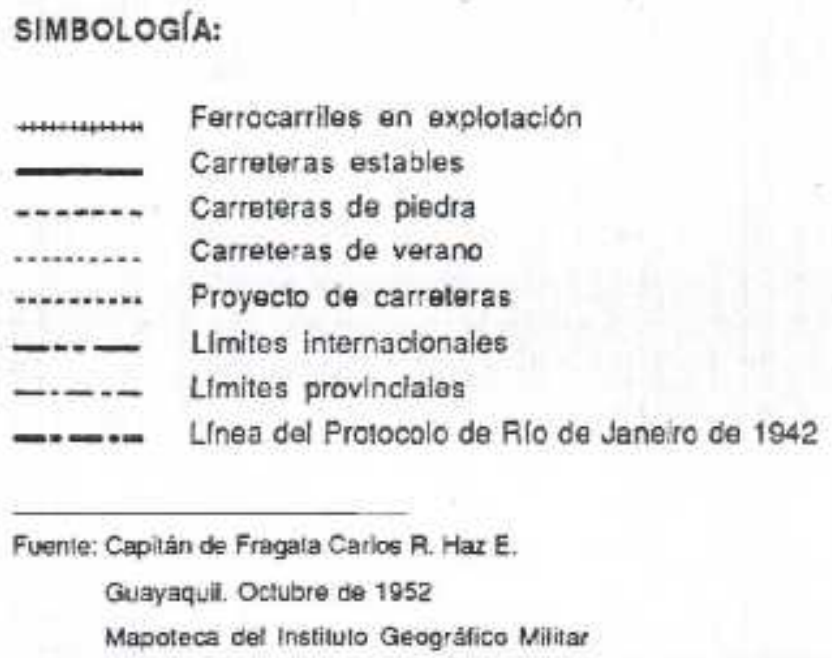

Fuente: Rafael Quintero, Érika Silva: Ecuador: Una nación en ciernes, Tomo II, FLACSO, Abya-Yala, 1991, p. 25-26. 
